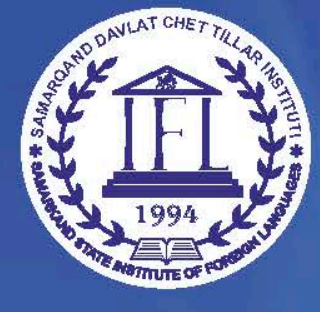

БУЮК ИПАК ЙЎЛИДА УМУМИНСОНИЙ ВА МИЛЛИЙ ҚАДРИЯТЛАР:

ТИЛ, ТАВЛИМ ВА МАДАНИЯТ

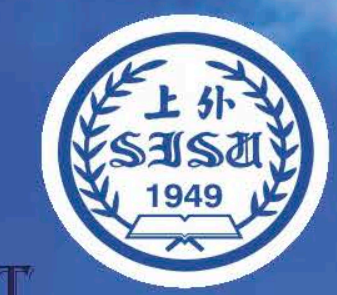

GLOBAL AND NATIONAL VALUES ALONG GREAT SILK ROAD:

LANGUAGE, EDUCATION AND CULTURE

伟大丝绸之路上的普世价值观与民族价值观：

语言、文化和教育学术研讨会

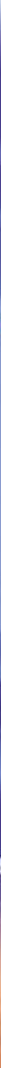

PROCIITIDINGS

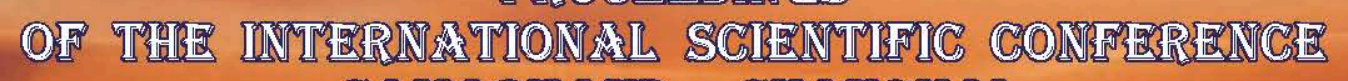

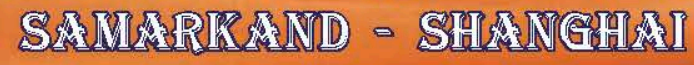

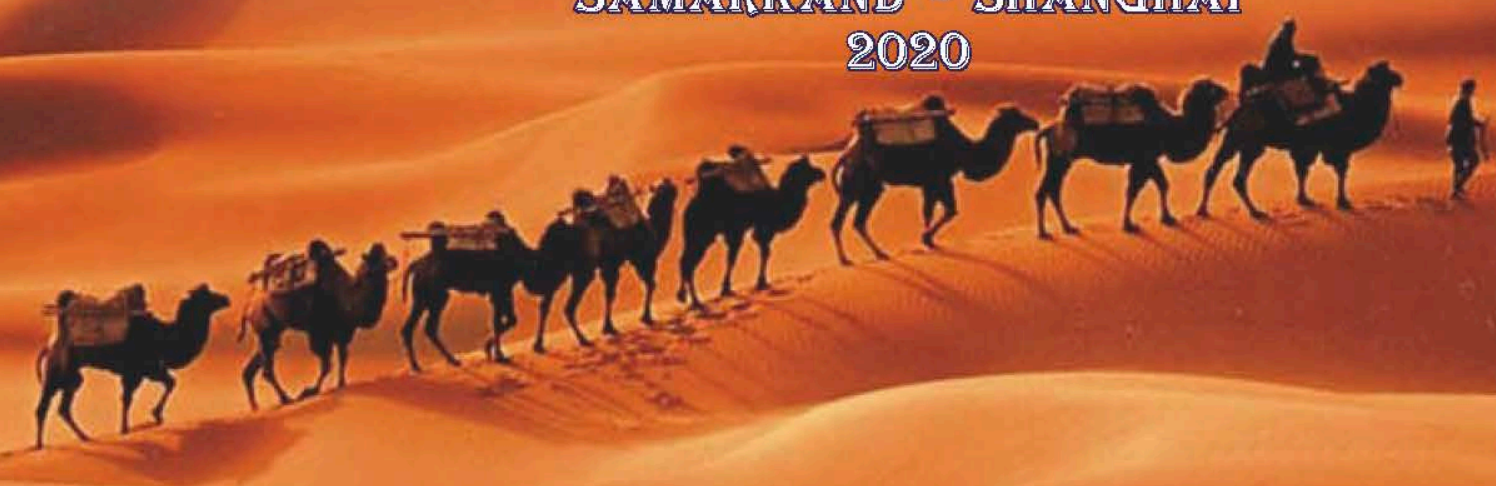


ЎЗБЕКИСТОН РЕСПУБЛИКАСИ

ОЛИЙ ВА ЎРТА МАХСУС ТАЪЛИМ ВАЗИРЛИГИ

MINISTRY OF HIGHER AND SECONDARY SPECIALIZED EDUCATION OF THE REPUBLIC OF UZBEKISTAN

САМАРҚАНД ДАВЛАТ ЧЕТ ТИЛЛАР ИНСТИТУТИ

SAMARKAND STATE INSTITUTE OF FOREIGN LANGUAGES

САМАРҚАНД КОНФУЦИЙ ИНСТИТУТИ

SAMARKAND CONFICIUS INSTITUTE

\section{БУЮК ИПАК ЙЎЛИДА УМУМИНСОНИЙ ВА МИЛЛИЙ ҚАДРИЯТЛАР: ТИЛ, ТАЪЛИМ ВА МАДАНИЯТ}

\section{GLOBAL AND NATIONAL VALUES ALONG GREAT SILK ROAD: LANGUAGE, EDUCATION AND CULTURE}

ХАЛҚАРО ИЛМИЙ-АМАЛИЙ КОНФЕРЕНЦИЯ МАТЕРИАЛЛАРИ

Самарқанд, 2020 йил 9-10 октябрь

PROCEEDINGS

OF THE INTERNATIONAL SCIENTIFIC CONFERENCE

Samarkand, 9-10 October 2020 


\section{Ў̆К 4И(075) \\ КБК $81.2(03)$ \\ Б 90}

\section{БУЮК ИПАК ЙЎЛИДА УМУМИНСОНИЙ ВА МИЛЛИЙ КАДРИЯТЛАР: ТИЛ,}

ТАЪЛИМ ВА МАДАНИЯТ. Халқаро илмий-амалий конференция материаллари. Самарқанд: СамДЧТИ, 2020. 542 бет.

Тўпламда Самарққанд давлат чет тиллар институти ва Шанхай чет тиллар университети хуамкорлигида уутказилган “Буюк Ипак Йўлида умуминсоннй ва миллий қ̧адриятлар: тил, таълим ва маданият” деб номланган халқаро конференщияда иштирок этган таниқли олимлар, ёш тадқұқотчиларнинг маърузалари жамланган. Ундан урин олган маърузалар уззбек, хитой, араб, турк, инглиз ва рус тилларида бўлгани каби, мавзу доираси хуам анча кенг ва хилма-хилдир. Хусусан, Буюк ипак йўли мамлакатлари тили ва адабиётининг назарий масалалари, таржсимашунослик, маданият ва тарих, таълим-тарбия назарияси, хорижий тиллар ўқитиш методикаси, манбашунослик каби сохуаларга оид долзарб масалалар ёритилган.

Тўплам тил ва адабиёт назарияси, таржимашунослик, маданият ва тарих, таълим тарбия назариялари, тиллар ўқутиш методикаси, манбашунослик сохаларида илмий изланиш олиб бораётган мутахассислар, тадқџқотчилар ва магистрларга мўлжалланган.

\section{Тахрир хайъати}

И.М.Тухтасинов (раис),

Ш.С.Ашуров (раис ўринбосари),

Ф.Ш.Рўзиқулов (масъул мухаррир),

Ш.С.Сафаров (масъул мухаррир),

С.Н.Бекниязова (масъул мухаррир),

Занг Йинг (Конфуций института директори)

И.Ё.Бекназарова (масъул котиб)

\section{Editorial board}

Tukhtasinov I.M. (chairman), Ashurov Sh.S. (vice chairman), Ruziqulov F.Sh. (chief editor), Safarov Sh.S. (chief editor), Bekniyazova S.N. (chief editor), Zang Ying (director of Conficius Institute),

Beknazarova I.

(executive secretary)

ISBN 978-9943-5193-5-0

Тўпламдан ўрин олган мақолаларнинг савияси, сифати ва илмий далилларнинг хқаққонийлиги хуамда мазмуни учун муаллифлар масъулдирлар. 


\title{
І ШЎЫБА
}

\section{ТИЛ ВА АДАБИЁТ НАЗАРИЯСИ}

\section{ТАРЖИМАШУНОСЛИКДА “КОМПЕТЕНЦИЯ” ВА “КОМПЕТЕНТЛИК” ТЕРМИНЛАРИНИНГ МОХИЯТИ}

\author{
И. М. Тухтасинов \\ (СамДЧТИ ректори, педагогика \\ фанлари доктори, проф)
}

Annotation: The thesis deals with the problem of the concepts as competence and competency in Translation studies. It reveals in detail differences and similarities between these two concepts. Moreover, it is described the importance of professional and communicative competence of interpreters.

Key words and expressions: Competence, competency, knowledge, skill, qualification, oral speech, translation

Мамлакатимизда сўнгги йилларда таълим сохасида, хусусан, олий таълим сохасида мисли кўрилмаган улкан ислохотлар амалга оширилмоқда. Ислохотлар самараси ўлароқ, олий таълим тизимида жуда кўплаб ўзгариш ва янгиликлар бўлмоқда. Жумладан, Ўзбекистон Республикаси Олий таълим тизимини 2030 йилгача ривожлантириш концепцияси орқали олий таълим тизимини ижтимоий соха ва иқтисодиёт тармоқлари эхтиёжларидан келиб чиққан холда, фан, таълим ва ишлаб чиқаришнинг мустахкам интеграциясини таъминлаш асосида таълим сифатини яхшилаш, рақобатбардош кадрлар тайёрлаш, илмий ва инновацион фаолиятни самарали ташкил этиш, халқаро хамкорликни ривожлантириш мақсадлари стратегия этиб белгиланган. Мазкур концепцияда илмийтадқиқот ва инновацион фаолият сохасида юқори малакали кадрлар тайёрлаш борасида олий таълим тизими олдида бугунги кунда ўз ечимини кутаётган бир қатор долзарб муаммо ва камчиликлар қаторида инновацион фаолият, тадқиқот натижаларини амалиётга кенг жорий этиш, илмий ишланмаларни тижоратлаштириш, илмий-тадқиқот ишларига иқтидорли ёшларни жалб этиш натижадорлигининг етарли эмаслиги, таълим, фан ва ишлаб чиқаришнинг мустахкам интеграцияси таъминланмаганлиги келтирилган.

Шу аснода, олий таълим муассасаларида ўкув жараёнини босқичма-босқич кредитмодул тизимига ўтказиш, халқаро тажрибалардан келиб чиқиб, олий таълимнинг илғор стандартларини жорий этиш, жумладан, ўқув дастурларида назарий билим олишга йўналтирилган таълимдан амалий кўникмаларни шакллантиришга йўналтирилган таълим тизимига босқичма-босқич ўтиш, олий таълим мазмунини сифат жихатидан янги босқичга кўтариш, ижтимоий соха ва иқтисодиёт тармоқларининг барқарор ривожланишига муносиб хисса қўшадиган, мехнат бозорида ўз ўрнини топа оладиган юқори малакали кадрлар тайёрлаш тизимини татбиқ этиш жараёнига янгича старт берилди.

Замонамизни янгиланиш босқичида ва талаблари каби таржимон касби ва мехнати жахон маданиятлари тараққиётида, уларнинг ўзаро хамкорлик қилишида алохида ўрин тутиб келмоқда.

Таржимонлик компетенцияси таржимоннинг касбий махорат ва имкониятларини характерловчи тушунча бўлиб, Европа Кенгаши томонидан ишлаб чиқилаётган таълим стандартларида, шунингдек, ўзбек ва чет эл мутахассисларининг илмий изланишларида кенг ёритиб келинмоқда. А.Биби ва Д.Энсингерлар томонидан таржимонлик компетенцияларига лингвистик (лексик, грамматик, дискурсив билим, малака ва кўникмалар), таржима назарияси, тил назарияси, маданиятга оид билимлар, таржиманинг махсус сохаларда фойдаланиладиган билимларни ўз ичига олувчи экстралингвистик компетенцияларни, матнни тушуниш, очиш, перефразалаш, шаклини ўзгартиришни ва таржима жараёнини ўз ичига олган замонавий технологияларни билишни, касбий компетенция, диққатни жамлаш, 
хотирани мустахкамлаш билан боғлиқ, психофизиологик сифатлар - когнитив қобилият, муайян психологик тавсиф, таржима компетенцияси ва бошқаларни киритиши зарурлигини қайд этганлар. Таржимонлик компетенцияси (Translation competence) билан боғлиқ масалаларни В.Монтальт Рессуррекьо, П.Эспелета Пиорно ва И.Гарсиа Искуэрдолар матн категорияларини, энг аввало, жанрни тушунишда асосий восита бўлиши керак деб ўйлайдилар ${ }^{1}$. Чунки таржимон тайёрлашда касбий фаолияни шакллантириш билан бирга зикр этилган ғоя жанр, стиль ва таржима методлари орасида боғлиқлиги мухим.

Таржимон турли маданиятларга мансуб бўлган ва турли тилларда гаплашадиган икки (ёки ундан ортиқ) коммуникантни ўз ичига олган ўзаро маданий мулоқотда воситачи вазифасини бажаради.

Таржима - ёзма ва оғзаки кўринишда бўлиб, ақлий фаолиятнинг ўта мураккаб тури хисобланади, шунинг учун таржимон ўз фаолияти ва тил шахсининг шартли ажратилган уч даражаси билан боғлиқ бутун бир компетенция, билим, кўникма ва малакаларга эга бўлиши керак.

Тил сохибининг лингводидактик тавсифи унинг тузилиши ва мазмунининг ривожланишига асосланади. Улар бир томондан нутқ фаолияти (гапириш, тинглаш, ёзиш ва ўқиш) турлари бўйича таснифланган “тил кўникмалари, махорати ва турли даражадаги мураккабликдаги нутқ харакатларини бажаришга тайёрлик” вазифасини акс эттиради ва бошқа томондан - тил сатхлари бўйича етук билимга эгаликни ифодалайди ${ }^{2}$.

Хозирги кунда турли фаолият турларини ўз ичига олган таржимани нутқини моделлаштириш нуқтаи назаридан мутахассислар “компетенция" хамда "билим, кўникма ва малака" каби терминлардан фаол фойдаланмоқдалар ${ }^{3}$. Аввало, биз ўхшаш ва бир-бири билан боғлиқ ва синоним бўлмаган бу тушунчаларни аниқлаш учун харакат қилишимиз.

Н. Н. Нечаев “компетентлик” терминини психология нуқтаи назаридан талқин қилади, яъни “компетентлик - касбий фаолиятни ривожлантиришнинг ушбу босқичида психологик жихатдан юзага келадиган ва ривожланадиган умумий ва касбий қобилиятларнинг тизими сифатида фаолият кўрсатадиган методларининг энг юқори даражасидир" . Бу талқин “касбий махорат" тушунчасига мос келади. Шу билан бирга, бу холатда малака, қобилият, табиий майл ёки инсоннинг муайян фаолиятга яроқлилиги сифатида эмас, балки тайёрлик синоними сифатида тил фаолиятини амалга ошириш деб талқин қилишимиз мумкин. Шундай қилиб, Н. Н. Нечаевнинг таърифини тахлил қилиб, компетентлик шахснинг касбий фаолиятга тайёрлигининг энг юқори даражаси деб айта оламиз. Бу тил шахси моделини янада кенгроқ ва айни пайтда ихчамроқ қилади. Шунингдек, у тил шахси даражалари бўйича тузилган асосий кўникмаларни аниқлайди.

Л. М. Орбодоева касбий фаолиятнинг муайян турини амалга ошириш учун зарур бўлган кўникма ва малакаларнинг энг юқори даражаси сифатида компетентликни тушунади. Унинг фикрича, “контент жихатидан компетентликни фаолиятнинг юқори даражаси сифатида муайян фаолиятнинг муваффақиятини белгилайдиган тегишли махсус билим, кўникма ва қобилиятлардан иборат бўлиб, унинг асосий функционал хусусияти касбга йўналтиришдир", . Бироқ, “компетентлик” тушунчаси хозирги кунда бошқа контекстларда, яъни билим, кўникма ва малакалар (шу маънода одатда кўплик - малакаларда кўлланилади), яъни ички ресурсларда кўлланилади. Терминнинг бундай ишлатилиши унинг чет тилига

\footnotetext{
${ }^{1}$ Montalt Ressurrecció V., Ezpeleta Piorno P., García Izquierdo I. The Acquisition of Translation Competence // The Translation, 2008. N 4, V 12.

2 Караулов Ю.Н. Русский язык и языковая личность. - М.: УРСС, 2004. - С.29

${ }^{3}$ Neubert A. Competence in Language, in Languages and in Translation // C.Schäffner, B.Adab. Developing Translation Competence. - Amsterdam: John Benjamins, 2000. - P. 3-18.

${ }^{4}$ Нечаев Н.Н. Психолого-педагогические основы формирования профессионального сознания специалистов в сфере межкультурной коммуникации // Сб. «Лингвауни-98». 3-я междунар. конференция ЮНЕСКО, 3 - 7 июня 1998. - М.: МГЛУ, 2000. - С. 154 - 164.

5 Орбодоева Л.М. Теоретические основы структуры и содержания учебника по практике межкультурного общения (языковой вуз, немецкий язык): дис. ... канд. пед. наук. - М.: 2003. - С.19
} 
компетентликка асосланган методикаларни ишлаб чиқувчи Европа тилшунослари ва методологлари томонидан тушунилиши билан боғлиқ. Шу сабабли, бу терминларни қўллашда маълум бир чалкашликлар мавжуд.

“Билим, кўникма ва малака” терминлари хам турли тадқиқотларда “компетентлик” ва “компетентлик ёндашуви” терминлари билан параллел равишда фаол қўлланилади, шунинг учун уларнинг лингводидактик ва психологик нуқтаи назардан талқинига мурожаат қилайлик.

Т.Цветкова кўникмаларни машқлар ва тренинглар орқали шаклланган онгли равишда амалга ошириладиган фаолиятнинг автоматлаштирилган таркибий қисмлари сифатида белгилайди ${ }^{6}$. Бу касбий фаолиятни амалга оширишга ёрдам берадиган яхши ривожланган автоматлаштирилган техникадир. Леонтиев нутқ махоратини қуйидагича таърифлайди:" нутқ кўникмалари аслида онгсизлик, тўлиқ автоматиклик, тил меъёрига риоя қилиш, ижро normal суръати (тезлиги), барқарорлик каби параметрларда фарқланувчи нутқ операцияларидир ${ }^{7}$. Қобилиятнинг кичик автоматлаштирилган операция сифатида психологик таърифи методологлар томонидан хам қўлланилади. Н.Галскова нутқ малакалари - “оғзаки ва ёзма шаклларда онгли нутқ фаолиятининг автоматлаштирилган компонентлари”, дея таъриф беради. Нутқ малакаларининг шаклланиши нутқ малакаларининг такомиллашишига олиб келади, яъни тил шахсининг ўзи ёзма ва оғзаки чет тили баёнларини тўғри тузиш ва турли лингвистик жамият вакилларининг баёнларини тушуниш қобилиятини акс эттиради. Шундай қилиб, ўз фикрларини тўғри ифодалаш, мулоқот холатини хисобга олган холда она тили фикрларини тушуниш нутқ кўникмаларини шакллантириш кўрсаткичларидир. Бундай кўникмаларга эга бўлиш нутқнинг тўғри услубини танлай олиш, нутқ шаклини алоқа мақсадларига бўйсундириш, энг самарали лингвистик воситалардан фойдаланиш демакдир. Кўникмалар фикрлаш, тасаввур ва хис-туйғулар билан боғлиқ ижодий фаолиятни ўз ичига олади.

Мулоқот шартлари хеч қачон такрорланмаганлиги сабабли, сўзловчи тил воситаларини хар сафар қайта танлаши керак. Кўникмалар нутқ малакаларини автоматлаштиришга асосланган холда шаклланади ва таълимнинг муайян босқичида ва амалга оширилган нутқ фаолияти турига мувофиқ - гапириш, тинглаш, ёзиш, ўқиш ва таржиманинг ўзига мос равишда тилга ўзлаштириш натижасидир.

Чет тили ва таржимани ўқитиш жараёнида олинган билимлар чет тилида ёзма ва оғзаки шаклларда нутқ фаолиятини амалга ошириш учун ишлатишга имкон берадиган кўникма ва малакаларни характерлайди.

Хулоса қилиб шуни айтишимиз мумкинки, нутқ фаолияти, жумладан, таржима учун зарур бўлган билим, кўникма ва малакаларнинг шаклланиш даражаси воситачи, яъни таржимоннинг касбий компетенцияси моделида тамал тоши тушунчаси бўлган коммуникатив компетенцияни қай даражада ўзлаштирганлигини кўрсатади. Фикримизча, коммпуникатив компетенция моделида коммуникатив компетентликнинг алохида ахамияти шундаки, таржимани ўз ичига олган нутқ фаолияти, аввало тил структураларини билиш даражасига ва уларни амалда қўллай олишга боғлиқ. Аммо коммуникатив компетенция анча мураккаб хусусиятга эга бўлиб, тил билимларини акс эттиради, ва бу эса таржима компетенциялари моделларини тахлил қилиш орқали исботланади.

\section{Фойдаланилган адабиётлар рўйхати}

1. Караулов Ю.Н. Русский язык и языковая личность. - М.: УРСС, 2004. - С.29

2. Леонтьев А.А. Язык, речь, речевая деятельность. - М.: URSS, 2008. - C.51.

\footnotetext{
${ }^{6}$ Цветкова Т.К. Проблема сознания в контексте обучения иностранному языку // Вопросы психологии. - 2001. № 4. $-69-82$ c.

${ }^{7}$ Леонтьев А.А. Язык, речь, речевая деятельность. - М.: URSS, 2008. - С.51.
} 
3.Нечаев Н.Н. Психолого-педагогические основы формирования профессионального сознания специалистов в сфере межкультурной коммуникации // Сб. «Лингвауни-98». 3-я междунар. конференция ЮНЕСКО, 3 - 7 июня 1998. - М.: МГЛУ, 2000. - С. 154 - 164.

4. Орбодоева Л.М. Теоретические основы структуры и содержания учебника по практике межкультурного общения (языковой вуз, немецкий язык): дис. ... канд. пед. наук. M.: 2003. - C.19

5. Цветкова Т.К. Проблема сознания в контексте обучения иностранному языку // Вопросы психологии. - 2001. № 4. -69- 82 с.

6. Montalt Ressurrecció V., Ezpeleta Piorno P., García Izquierdo I. The Acquisition of Translation Competence // The Translation, 2008. N 4, V 12.

7. Neubert A. Competence in Language, in Languages and in Translation // C.Schäffner, B.Adab. Developing Translation Competence. - Amsterdam: John Benjamins, 2000. - P. 3-18.

\section{КАТЕГОРИЗАЦИЯ И СОПОСТАВЛЕНИЕ ЯЗЫКОВ}

\section{Ш. Сафаров \\ (о.ф.н.проф.СамГИИЯ)}

Annotation: The thesis deals with the problem of categorization and comparison of languages. According to the author, special attention should be paid to the fact that categories are secondary, they stand out inductively from the facts of the language and are based on rational generalization and abstraction. The thesis describes in detail lexical, lexical-grammatical and Morphological-grammatical categories

Key words and expressions: Categorization, lexical categories, word formation

Категоризация в лингвистике предполагает как научный подход к обнаружению и определению категорий языка, так и практические измерения лингвистических явлений. Эти два процесса вполне совместимы, потому что категории не есть априорные концепции, прилагающиеся мышлением к чувственному миру. Они являются отражением в сознании материального мира, этапом его понимании, познании. Такие философские категории, как материя, движение, пространство, причинность и другие, имеют универсальное значение. Они передают свойства и отношения, присущие всем естественным и общественным явлениям. Категории частных наук выражают специфические аспекты объективной реальности, которые представляют самые широкие и общие понятия, в пределах данной научной области и извлекаются из фактического материала путём применения определённых научных методов.

Особое внимание следует обратить на то, что категории вторичны, они выделяются индуктивно из фактов языка и основаны на рациональном обобщении и абстракции. Вместе с тем теоретический подход неотделим от нормативного, а языковая реальность есть первичное и основное. О категории можно говорить только в случае, если неосуществима одновременная реализация всех категориальных форм данной оппозиции. Рассмотрим некоторые основные лингвистические категории.

Лексические категории. Для современного языкознания важно, с одной стороны, чётко различать лексику и грамматику, а с другой - не упускать из виду тесную связь, которая существует между ними. Вопрос о лексических категориях не отделим от проблемы продуктивности морфологических моделей. В словообразовательной системе выделяется некоторое число моделей, обладающих абстрактной продуктивностью. Идея о существовании в языке лексических морфологических категорий, наряду с грамматическими, принадлежит известному учёному А. И. Смирницкому, который обратил внимание на регулярно повторяющиеся противопоставление глаголов типа write - rewrite, read - reread и выдвинул положение о наличии в английском языке лексической категории первичности - повторности процесса [Смирницкий 1959]. А. И. Смирницкий дал следующее определение лексической категории: «Языковые единства наиболее общего характера, 
которые проявляются в семантическом противопоставлении по определённому признаку двух или более слов, при том условии, что такое же противопоставление наблюдается и в других парах или больших группах слов и имеет систематическое выражение» [Указ. раб. с. 205].

На более ранних этапах развития языкознания наблюдалась тенденция включать в систему грамматических закономерностей абсолютно продуктивное словообразование. Несмотря на отдельные различия между лексической морфологией и грамматической, они входили в один раздел языкознания - морфологию. Как бы не были научно обоснованы классификации и категоризации естественного языка, необходимо помнить, что между абсолютными выражениями и реализациями тех или иных категорий всегда обнаруживаются такие «участки» действительности, где количественное накопление тех или иных свойств ещё не дало качественного скачка, знаменующего переход в новую категорию.

Абсолютная продуктивность словообразования - это свойство грамматики, а для лексики основным является возможность индивидуального соотнесения слова с каким-либо предметом, находящимся за пределами лингвистической категоризации.

Лексико-грамматические категории. Эти понятия связаны с классификацией слов по частям речи, потому что каждая из последних непременно сочетает в себе отдельные лексические и грамматические свойства. Глагол, например, помимо свойственной только ему системы форм, имеет общее категориальное лексическое значение, определяющее какой-то фрагмент экстралингвистической действительности как явление, действие или своеобразное глагольное состояние.

Морфологические - грамматические категории. В английском языке они были исследованы достаточно подробно. Правила обнаружения и описания морфологических грамматических категорий были впервые разработаны А. И. Смирницким [Ук. соч.б с. 10].

При сопоставлении языков на категориальном уровне следует учитывать, что грамматическая система и её законы обязательны для всех пользующихся языком: владеющий данной системой не волен её изменять в соответствии с индивидуальными склонностями или потребностями, а выбор того или иного слова или словосочетания обуславливается тем, что человек хочет сказать. Сравним, скажем, категорию аспекта в английском, русском и узбекском языках. В этом случае несовершенный вид русского языка сопоставляется с формами длительного аспекта английского и узбекского языков.

Первым шагом в процессе сопоставления является прямое сравнение двух или более текстов. В этой связи необходимо тщательно проводить различие между первичным сопоставлением текстов, категориальным исследованием соотношений в них и прагматической проверкой выводов на соответствующем материале. Например, если в анализируемом тексте английское и узбекское аспектологическое значение длительности совпадает с русскими совершенными и несовершенными видами, то во избежание гиперграмматичности следует помнить, что каждая научная абстракция должна проверяться на практике.

Таким образом, первичное сопоставление текстов - это лишь начальный этап исследования, за которым идёт анализ на категориальном уровне. Вместе с тем не следует злоупотреблять системным принципом. Всякое обобщение, структура или отвлечённая система всегда гораздо беднее и примитивнее, чем объективная существующая реальность . Поэтому после подробного выяснения природы системных отношений необходимо переходить к углублённому исследованию, в частности, аутентических английских и узбекских текстов, так как овладеть грамматической системой любого языка можно только при постоянном и неустанном внимании к реальному функционированию существующих грамматических форм. 


\title{
MURAKKAB SINTAKTIK QURILMA VA GAPDA KAUZATIVLIKNING VOQELANISHI
}

\author{
Turniyazov Ne'mat Qayumovich, \\ (f.f.d., prof, SamDChTI ) \\ Turniyazov Behzod Nigmatovich, \\ (f. f.n., SamShTI dotsenti)
}

\begin{abstract}
Annotation: The article discusses the expression of causation in a complex syntactic construction with equal components and in a simple sentence, in particular, it describes some ideas about causasemantic derivation. When causation is studied on the basis of the law of semantic derivation, causality is not determined by the actual meaning of the sentence, but by the intrinsic meaning. When speaking about the semantic status of causality, it is important to pay attention to the general meaning of the situation. In addition, it is necessary to distinguish between predication and the function of the verb, since the core of the functional-semantic field of causality is not the causal verb, but the predicate, which is surrounded by predicativity. In the semantic structure of causative verbs there is a seme of state belonging to the object of action, which, in turn, generates a logical consequence and cause. Therefore, causative verbs represent actions and relationships that are specific to concepts such as state, event, etc.
\end{abstract}

Key words and expressions: causaderivation, operator, assertion, predication, presupposition.

Murakkab sintaktik qurilma mikromatn maqomiga ega bo'lib, uning kauzaderivatsiyasi real operatorga asoslanmasligi ham mumkin:

1. Iskandaroning rangi o'chib ketdi, qo'rqinch to 'la ko'zlari bilan eshikka qarab-qarab qo 'ydi (Oybek. Nur qidirib).

Mazkur misolda operandlari o'zaro semantik operator orqali munosabatga kirishayotgan teng komponentli murakkab sintaktik qurilma (MSQ) derivatsiyasi vujudga kelayotganini ko'ramiz. Bunda MSQning ikkala tarkibiy qismi ham tag hodisa mavqeyida keladi: birinchi komponent sirkonstativ tag hodisa hisoblansa (qo 'rqmoq), ikkinchisi esa aniq tag hodisa vazifasini bajaradi. Zotan, Iskandaroning qo'rqishi sababi asosiy hodisa bo'lib, bu vaziyatda u bizga ma'lum emas. Aniqrog'i, qo'rqish hissini uyg'otgan tashqi agensning roli ifodalanmayapti, shuning uchun MSQ birinchi komponenti $\left(\mathrm{P}_{1}\right)$ derivati dekauzativ tarzida voqelanayapti. Ta'sir amalga oshgan, biroq distantli ravishda qo' $\mathrm{zg}^{\text {' }}$ atish vujudga kelgan.

Ikkinchi komponentdagi oqibat ifodasiga (eshikka qaramoq) «qo 'rqinch» ta'sir qilgan, ya'ni u eshikka qarashga majbur qilgan. Shu bois biz undagi kauzal ma'noni kontaktli deb bilamiz: Iskandaroning rangi o 'chib ketdi (qo'rqdi=sabab), shuning uchun (U) qo 'rqinch to 'la ko 'zlari bilan eshikka qarab-qarab qo'ydi (oqibat). Bu vaziyatda ikkinchi operandning kauzaderivatsiyasida, kauzator ma'lum bo'lganligi uchun u kauzativ hisoblanadi.

Tahlil natijasidan ko'rinib turibdiki, MSQning derivatsion xususiyatini o'rganishda tub struktura g'oyat muhim ahamiyat kasb etadi, zotan, u sintaktik struktura shakllanishida asos vazifasini o'taydi, biroq kauzal ma'noning ifodalanishi esa so'nggi hosila strukturaga qarab aniqlanadi. MSQ tarkibiy qismlarining ikkalasida ham alohida kauzal ma'no yuzaga chiqayotganligining guvohi bo'lamiz. Lekin bunda real kauzatorning harakatni bajarishga undashi kuzatilmaydi. Shu bois MSQ operandlarining kauzal ma'no og'ushida ekanligi ularning mantiqiy presuppozitsiyasiga qarab aniqlanadi.

Presuppozitsiya mantiqiy kategoriya bo'lib, lingvistik tadqiqotlarda ham ko'p qo'llanadi. 1892-yilda nemis faylasufi G.Frege ilmiy qarashlarida mazkur tushunchaning izohini berib o'tadi. 1950-yilga kelib, Oksford maktabining vakili P.F.Stroson bu hodisani keng o'rganib, «presuppozitsiya» teminini iste'molga kiritadi[1.АрутюноваН. Д., ПадучеваЕ. В.1985. 40]. Presuppozitsiyadegandaesa, ma'lum bir sintaktik struktura ifodalayotgan real ma'nodan tashqari, uning ichki strukturasida anglashiladigan ma'no tushuniladi. 
2. Besh minutdan keyin adyutantnimau chundirog'zi qulog'iga yetib chiqdi(M.Ismoiliy. Farg'ona tong otguncha).

Ushbu misolimizda gapni taqozo etadi. Bu o'rinda shuni aytishimiz mumkinki, adyutantning xursand bo'lishi qandaydir sababga bog'liq holda ro'yobga chiqmoqda. Ushbu vaziyatda kauzativ ma'noni yuzaga keltiruvchi harakat sodir bo'layotganligining guvohi bo'lamiz. Boshqachaaytganda, bunday holatdagi kauzativ ma'no ham gapning real ma'nosi (assersiya) orqali emas, balki ichki tub ma'nosi asosida belgilanadi, chunki assersiya mazmuniy planda predikatsiyaning umumiy ko'rinishi, xolos. Tahlil etilayotgan misolning assertiv predikatsiyasi orqali ham faqatgina adyutantning xursangligi tasdiqlanmoqda. Aniqrog' $i$, uning xursandligi sababini assersiya belgilamaydi. Mazkur holat semantik majmuaning ma'no salmog'iga qarab aniqlanadi. Bu haqda Y.A.Daduyevaning «Общая характеристика каузативных глаголов» («Kauzativ fe’llarning umumiy tavsifi») nomli maqolasida aytgan fikri diqqatga sazovordir: «Kauzativ fe'llarning semantik tuzilishida harakat obyektiga tegishli bo'lgan holat semasi ajralib turadi, bu esa sababdan kelib chiqadigan mantiqiy oqibatni yuzaga chiqaradi. Shu bois kauzativ fe'llar holat, voqea-hodisa, sifat kabi tushunchalarga xos bo'lgan harakat va munosabatlarni ifodalaydi»[2. ДадуеваЕ.А. 2011.79].

Lekin shuni ham e'tiborga olish kerakki, kauzativlikning funksional-semantik maydoni yadrosini kauzativ fe'l tashkil etmagan holatlar ham uchraydi. Masalan, undov so'zlarni olaylik. Haydash-chaqirish undovlari ( $m a$, jim, tek, fisht, dirr, chuh, kisht kabi) semantik jihatdan to'g'ridan to 'g'ri kauzallik bilan bog'lanadi va bunda fe'l funksional vazifa bajarmaydi:

3. ...ot yana qay tomonga yurishini so 'rab to 'xtadi.

- Chuh(A.Qodiriy. O‘tkan kunlar).

4. «Tak», - dedi-yu, «chuvha», - dedijo 'nadi(Alpomish).

Keltirilgan ikki misolda ham kauzator jonivorga, otga, nisbatan kauzatsiyalashamalini oshirmoqda. Ko'rib turganimizdek, kauzativatsiya fe'lning ishtirokisiz ro'y bermoqda. Y.V.Fomicheva ham undash, buyurish ma'nosini beruvchi gaplarda mazkur ma'no ifodasi fe'lning ishtirokisiz ham voqelanishi mumkinligini to'g'ri ta'kidlaydi[4. ФомичеваE. В. 2009.156-162]. Shu bois, kauzativlikning semantic maqomi haqida so' $z$ yuritilganda situatsiyaning umumiy ma'no salmog'iga e'tibor berish kerak bo'ladi. Bundan tashqari, fe'l bajaradigan vazifa bilan predikatsiyani farqlash darkor, zero, kauzativlikning funksional-semantik maydoni yadrosini kauzativ fe'l emas, balki predikat tashkil etadi, u esa predikativlik qurshovida bo'ladi.

Prof. I.P.Susov predikatga: «Predikat dinamik va actual hisoblanadi. Shu bois u matnning dinamik perspektivasi shakllanishida eng zaruriy konstruktiv vazifasini bajaruvchi, ma'lumotlarning yangi kvantini beruvchi omil sifatida ishtirok etadi. Bundan tashqari, predikat semantic komponentlari yerarxiyasidagi hukmron a'zo hisoblanadi. U gap va matn semantikasining tub mohiyatini kengaytiradi», - deb to 'g'ri baho berganedi[3.СусовИ. П.1981. 97].

Shuni aytish kerakki, tahlilga tortilayotgan ikkinchi gapda, birinchi misoldagidan farqli ravishda, kauzasemantik derivatsiya operandlari «nima uchundir»so'roq olmoshi bilan ifodalangan real kauzaoperator orqali kauzativ ma'no ifodasini beruvchi derivatsion munosabatga kirishmoqda. Shu asosda kauzaderivat (kauzativli hosila struktura) shakllanmoqda. Lekin bu xildagi operatorlar gap tarkibida qo'llanmasligi ham mumkin, chunki bu nutq egasining o'z fikrini tinglovchiga qanday tartibda yetkazishiga bog'liq bo'ladi. Qiyoslang:

Besh minutdan keyin adyutant og 'zi qulog 'iga yetib chiqdi.

Qiyoslashnatijasida shunga aminbo'lamizki, jumladagarchi real semantik kauza operator qatnashmagan bo'lsa-da, sabab ma'nosini beruvchi kauzativ distributsiya munosabati borligi sezilib turibdi. Ushbu jarayonda nolifodali kauza operator muhim ahamiyat kasb etadi. Zero, derivatsion jarayon operatorsiz voqelanmaydi. Aytish kerakki, nolifodali operator umuman ifoda materialiga ega bo'lmaydi. Uni faqat nutqiy vaziyatda gap komponentlarining kauzativ qurshovda ekanligi orqali belgilash mumkin bo'ladi. Bu esa belgisiz operatorlardan shu jihati bilan farq qiladi. Belgisiz operator nutq ixchamligi uchun vaqtinchalik o'z o'rnini tark etadi, lekin u istalgan vaqtda yana sintagmatik komponentlar orasiga joylasha oladi. 


\title{
Список использованной литературы
}

1. Смирницкий А. И. Морфология английского языка. - М.: Успедгаз, 1959.

2. Глазунова О. И. Философия языка и проблемы современной лингвистики. - М.: URSS, 2014. - 400c.

\section{СИСТЕМНОСТЬ НЕОЛОГИИ СЛОВА}

\author{
T.А. Бушуй \\ (о.ф.н., проф. СамГИИЯ)
}

Annotation: The article raises the systematic problem of the relationship between motivating and motivated linguistic units, considers both the result of the derivation act and the phenomenon of nomination based on such featuresas: motivation, fragmentation, etc. The processes of formation of denominative collective nouns, their structural types of modification nature, mutational, i.e. the process of imposing an additional changed feature on the initial meaning is considered and the phenomenon of one conceptual category is called in relation to an element of another conceptual category. Word-formation processes are characterized in terms of a systematic approach. It was revealed that the main unit of the word-formation system is the word-formation pattern, as a structural diagram of derived words with an indication of the affixes and semantics of the original general basis. The basis for the appearance of occasional words in speech is the presence in the syntagmo-paradigmatic word-formation system of possibilities unrealized by the language.

Key words and expressions: neologism, motivating and motivated linguistic units, structural types of modificatory and mutational neologisms, derivational pattern, structural diagram of derived words.

На современном этапе актуальным представляется анализ производного слова с ономасиологических позиций. Подобное рассмотрение производного наименования предполагает учёт не только деривационного результата, но и самого процесса номинации [О.И. Титкова 2003: 70].

Характеризуя в конце XIX века состояние науки о языке, И. А. Бодуэн де Куртенэ[1963: 17] предсказывал: «Лексикология как наука о словах как отдельная ветвь грамматики будет творением XX века». Действительность сполна подтвердила его прогнозы. Так, например, изучение новых тенденций в развитии словарного состава языка сводится ко всё расширяющемуся выявлению неологизмов. Причём до сих пор этот лингвистический аспект не разработан ещё сколько-нибудь основательно. А между тем, например, англоязычная неология отличается [по данным толковых словарей академической значимости] заметной предрасположенностью к деривационной версификации.

Для производного наименования релевантными будут с точки зрения способа номинации следующие параметры: расчленённость, самостоятельность / несамостоятельность, мотивированность. Здесь изучению подлежат отношения, которые складываются между исходными [мотивирующими] словами и результативными [мотивированными], составляющими единицы соответствующего словообразовательного акта [A. Arlotto2008: 248].

Так, при образовании отымённых собирательных существительных в рамках категории субстанции происходит установление отношений к понятию предмета конкретного, исчисляемого. В этом случае в акте номинации складываются ономасиологические структуры типов: 1) модификационного, когда к содержанию исходного понятия прибавляется дополнительный модификационный признак, 2) мутационного, когда явление одной понятийной категории называется по отношению к элементу другой понятийной категории. При мутации между исходными и результативными единицами словообразовательного акта складываются более разнообразные связи, чем при модификации [A. Hill 2002: 402-403].

Основные аспекты номинации - взаимообусловлены, ибо язык есть «форма, которая находит выражение в последовательности категорий, составляющих его систему» [L. 
Hjelmslev 1928: 7]. Так, тип связи оказывается соотнесённым с системой не менее чем трёх координат: ономасиологической структурой производного, исходной единицей деривации и конкретным словообразовательным аффиксом.

На уровне лексической семантики в акте словообразовательной номинации учёту подлежат прежде всего следующие явления: 1) Вовлечение всей семантической сферы мотивирующего слова в процесс создания нового производного наименования - мотивировка всем содержанием. 2) Актуализация ряда компонентов семантической структуры мотивирующего слова, участвующих в акте номинации в качестве мотивирующего признака - мотивировка частью содержания. 3) Сохранение между исходными и результативными единицами словообразовательного акта отношений семантического тождества. 4) Семантическая модификация производного, сводящаяся к суждению или расширению значения.

Из новейших словообразовательных процессов в современных языках отметим следующие.

1. Заметно дифференцируется образование существительных способом

нулевой суффиксации, сопровождающее усечением производящей основы на морфемном шве [«профессионал», «оригинал», «нейтрал»], и образование усечением с произвольным сокращением производящей основы, не связанным с границами морфем как разновидность способа аббревиации [«спец», «фак»]. Причём источником усечений аббревиатурного типа [в отличие от аббревиатур как таковых] является не кодифицированный литературный язык [в котором аббревиатуры существуют в виде графических сокращений], а устная разговорная речь. Причина же продуктивности подобных образований заключается в их способности выступать в качестве способа экономии речевых средств. Такие усечения аббревиатурного типа сохраняют связь с полным именем. Однако новая форма отражает новые оттенки в значении - эмоциональные, семантические и стилистические. Разумеется, степень стилистического качества [сниженности и др.] у разных усечений неодинакова. Одни являются разговорными, употребляются в устной речи литературного языка [«зам», «фото», «лор» и др.]. Другие имеют бо́льшую степень стилистической сниженности будучи жаргонизмами [«абитура», «общага», «физия»] или арготизмами [«алкаш», «зэк», «дембиль»]. Впрочем, отмеченные границы между указанными типами подвижны.

2. Вышеотмеченные словообразовательные акты характеризуются в той или иной степени формированием системности, ибо любое явление входит в систему, если оно закономерно повторяется.

Основной единицей словообразовательной системы выступает словообразовательный образец. Эта структурная схема производных слов с указанием аффиксов и семантики исходной базовой основы.

К системным явлениям словообразования, например, относятся:

1) возникновение предметного значения в образцах, характеризующихся семантикой отвлечённого действия, ср.: «уборка» [отвлечённое значение] ↔ «покупка» [предметное значение];

2) закономерное отличие образцов со значением лица от образцов со значением предмета только системой флексий [подобное отличие проявляется в форме вин. падежа: «учитель» $\leftrightarrow$ «выключатель», «лжец» $\leftrightarrow$ «резец»].

Для выявления регулярных закономерных связей между образцами их следует классифицировать по модели внутреннего устройства, которая определяется как структурная схема, соединяющая базовую основу и дериват [безотносительно к наличию флексий].

Во внутреннем устройстве простых [производных] слов наличествуют компоненты: 1) префикс, 2) базовая основа [словоформа], 3) суффикс, 4) флексия, 5) постфиксальная частица [cp. pус. -ся]. Их различные комбинации дают всевозможные модели внутреннего устройства слова. Ср.: 1) префикс + основа + флексия [《без - голов-ый»] или же 2) основа + суффикс +

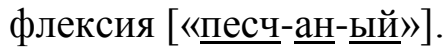


В моделях внутреннего устройства сложных слов регулярно используются следующие компоненты: 1) префикс первой основы, 2) первая базовая основа, 3) суффикс первой основы, 4) соединительный гласный, 5) префикс второй основы, 6) вторая базовая основа, 7) суффикс второй основы, 8) флексия второй основы. Ср. модели: 1) основа + соединительная гласная, основа + флексия: «широк-о-плеч-ий»; 2) основа +соединительная гласная +

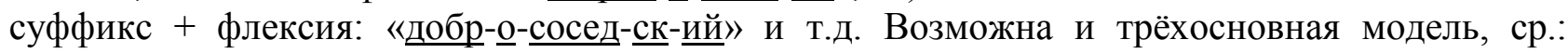
«плод-о-овош-е-

3. Активность лексической деривации языка следует усматривать в возникновении окказиональных слов [как единиц речи], отличающихся от слов канонических [как единиц языка]. Первые отличаются от вторых по таким признакам, как: 1) речевая принадлежность, 2) невоспроизводимость [так сказать, индивидуальная творимость], 3) словообразовательная производность, 4) ненормативность, 5) функциональная одноразовость, 6) экспрессивность, 7) номинативная факультативность, 8) синхронно-диахроническая диффузность.

Основой появления в речи окказиональных слов служит наличие в синтагмопарадигматической словообразовательной системе нереализованных языком возможностей. Эффект окказиональности возникает в результате формальных, семантических, стилистических и иных нарушений образцов соединения морфем в образуемое слово.

Свобода окказионального словотворчества ограничена системными словообразовательными отношениями, исторически сложившимися в языке, а также структурой канонических слов. Восприятие же окказиональных слов осуществляется на основе аналогии с канонизированными образцами слов как языковых единиц.

Итак, трансформации, влекущие за собой изменения в семантике слова, его морфологических и синтаксическихнормативных показателей, стилистической принадлежности, приводят к появлению новых слов в языке. Однако различного рода модификации имеют определённые границы, регулируемые сложившимися в языковой системе законами в области деривации, по принципу аналогии.

\section{Список использованной литературы}

1. Бодуэн де Куртенэ И. А. Избранные труды по общему языкознанию. - М.: Изд-во AH, 1963, т. 1. - 384 с.; т. 2. - 391 с.

2. Титкова О.И. О перспективах лингвистического исследования реккурентных единиц лексикона // Филологические науки. - М., 2003. - №2. - С. 70-86.

3. Arlotto, Anthony. Introduction to Historical Linguistics. - Boston: Houghton Mifflin, 2008. - 514 p.

4. Hill A. Introduction to Linguistic Structures. - New York: Holt, Rinehart and Windston, 2002.- 528 p.

5. Hjelmslev L. Principes de grammairegénérale. - København, 1928. - 312 p.

\section{ТВОРЧЕСКИЕ ПРИНЦИПЫ НИЗАМИ ГЯНДЖЕВИ И ФОРМИРОВАНИЕ РОМАНТИЗМА В ВОСТОЧНОЙ ПОЭЗИИ}

\section{Салохи Дилором Исамиддин кызы (о. ф. н., проф. СамГИИЯ)}

Annotation: This article is devoted to the study of the peculiarities of the artistic, aesthetic and ideological principles of Nizami Ganjavi in oriental poetry. The author of the article analyzes the relationship between the poet and his literary environment, the influence of his poetic style on the formation of romanticism in oriental poetry, in particular on the work of Alisher Navai. In the early Middle Ages, literature in Transcaucasia, created according to the mood of the rulers, became significantly outdated. It was monotonous and boring, despite the desire for innovation of such poets as Manuchehr, Farrukh, Unsuri, who recreated bright and cheerful images in their work. Under such literary conditions, the owner of 
exceptional talent Sheikh Nizami entered the creative environment and brought a new spirit into the literature of the era with his invaluable works. lyrics.

Key words and expressions: epos, psychologism, artistic traditions, composition, image, plot, "five",

Художественно-эстетические традиции персоязычных поэтов литературной среды Бухары, Самарканда и Северного Хорасана в ХП-ХШ веках начало оказывать своё влияние на литературу народов Закавказья. До этого периода в этом регионе существовали виды литературного искусства, соответствующие придворной жизни, но сведения о них почти не сохранились. Как отмечает Е.Э.Бертельс, первым поэтом, внесшим хорасанский стиль в литературную среду Азербайджана, был Катран ибн Мансур: «Можно поэтому с полной уверенностью утверждать, что Катран сознательно ориентировался на поэзию хорасанской школы и, может быть, даже принес этот стиль в Азербайджан» [Бертельс 1960:30]. Однако, новый творческий дух, внесенный Катраном в литературную среду Азербайджана, не послужил тематическому расширению и идейному обогащению местной поэзии. Катран создал удивительные образцы касыд, отвечающих требованиям традиционной восточной поэтики и имеющих идеальную форму. Его творческую традицию продолжили другие поэты, и в диванах, созданных ими, мы можем увидеть жанр касыды. В этой школе доминировали жанры касыды и сатиры, образцов мистической, дидактической литератур было очень мало, а суфийская лирика и эпические жанры ещё не были сформированы. Несмотря на стремление поэтов к новаторству в литературе, подражая представителям хорасанской литературной школы как Рудаки, Насыр Хосров, Манучехр, Фаррухи, Унсури, которые воссоздали яркие и весёлые образы, литература в Закавказье, создаваемая по настроению правителей, значительно устарела и была однообразной и скучной.

При таких литературных условиях в творческую среду вошёл обладатель исключительного таланта Низами и своими бесценными произведениями внёс в литературу новый дух.

Е.Э.Бертельс, просматривая в своей монографии «Низами и Физюли» изучение творчества поэта в русском и европейском востоковедении, отмечает, что мысли о взаимоотношениях Низами и его литературной среды излагаются односторонне и критикует их. В частности, указывая на недостатки автора первой монографии о творчестве Низами В. Бахера в том, что он не знает в совершенстве фарси и не умеет работать с источниками, особенно отмечает нижеприведенный идейный недостаток: «Ещё большая беда этой работы в том, что жизнь Низами рассматривается в ней в полном отрыве, как от исторической обстановки, так и от тех литературных связях, которые сближают его поэмы с литературами Переднего Востока. Низами предстает перед читателем изолированным, оторванным от живой среды. Это влечет за собой абстрактность изложения, и, что, конечно, печальнее всего, лишает работу исторической перспективы. Мы требуем от истории литературы показа всех связей поэта с его эпохой и предшествующей ему культурой. При огромном богатстве высказываний Низами это вполне осуществимо» [Бертельс 1962:24-25].

В чём же особенность литературно-эстетических и идейных принципов Низами в поэзии, почему его творчество вышло за рамки традиций? Поэт, в первую очередь, проявлял большую ответственность в выборе жанра и темы для художественного выражения своих социальных мыслей и идей. Известно, что его современник Хакани Ширвани, ещё за долго до Саади и Хафиза, стремился к тому, чтобы жанр газели обрела самостоятельную форму. Он писал совершенные по форме и содержанию газели, своеобразные касыды и этим самым обогатил лирику бытовыми темами.

Низами же обратился к эпосу, использованному очень мало в его литературной среде. До него в этом жанре была создана всего лишь одна поэма «Тухфат уль-ирокайн» Хакани. До этого времени в поэзии Ближнего Востока существовали два направления по написанию поэм, первое - героические эпосы типа «Шахнаме», второе направление - эпосы в духе рыцарских романов как «Вис и Ромин» Фахруддина Гургани. Произведение Гургани не имело большого успеха и уже в XV веке практически не упоминалось. В этот период даже 
известные поэты Хорасана и Хорезма не обращались к эпосу, самым активным литературным родом была лирика, и поэт, желающий создать эпическое произведение в таких условиях, должен был иметь ввиду, что он создаёт поэму не только для расширения возможностей данного жанра, чтобы он мог послужить требованиям социальной жизни и художественному наслаждению, но и для удовлетворения социально-духовных потребностей людей. Низами уже в своей первой поэме достиг решения всех этих требований. Он выразил свои социальные и просветительские мысли не в скучной дидактической форме, а посредством художественных бессмертных образов. С этой точки зрения его творческий художественный метод близок к стилю творцов европейского Ренессанса, которые стремились увидеть совершенство, великую красоту в человеке. В этом смысле так писал Бертельс: «... если формально поэмы Низами ещё носят все признаки Средневековой литературы, то в построении они уже значительно ближе к лучшим созданиям европейского Ренессанса» [Бертельс 1962:172]. Но, здесь необходимо отметить, что поэмы Низами резко отличаются от западных рыцарских романов, переполненных древними легендами, образами фей и привидений, различными фантастическими эпизодами, тем, что в них доминирует реалистический дух. Его творчество насыщено жизненностью и народностью. Даже малые лирические произведения он создаёт преследуя какую-либо идею. Лирическое творчество Низами отличается обилием сюжетных газелей на определенную тему и рядом образных систем. Внесение в газель эпических элементов, не ограничиваясь пустым восхвалением или комментарием, уже в ранних творениях Низами можно увидеть проявление специфики художественного метода поэта.

Изложение религиозно-мистических мыслей в творчестве Низами, в отличии от великого узбекского поэта Алишера Наваи, может оцениваться, исходя из особенностей той общественной жизни и времени. Эта проблема изучалось в узбекском литературоведении: «Статьи «Махзан уль-асрор» содержат такие религиозно-мистические моменты как «Изменчивость жизни», «Кары Судного дня». Наличие таких противоречивых мыслей вполне естественно для мировоззрения представителя XII века как Низами» [Маллаев 1985:17]. Сегодня же такие суждения должны изучаться по новым направлениям с точки зрения требований современной науки.

Низами окрашивает просветительские идеи, пронизанные благородством, очень интересными жизненными рассказами. Наваи же, выполняя именно эту задачу, ищет прототипы для героев своих притч. Выдвигая идею о том, что труд является основой жизни, Низами приводит притчу о старике, складывающего кирпичи в изнурительном труде и парне, предъявляющего ему претензию. Мораль этой притчи - восхваление труда. Для литературы романтизма достаточно писать о венце творения - Человеке. Низами обосновывает свою мысль посредством притчи. Но проницательный читатель Наваи обращает свое внимание больше на жизненную правду. Именно поэтому в главе, посвященной щедрости и благотворительности поэмы «Хайрат уль-аброр» («Смятение праведных») приводя «Рассказ о дровосеке и Хатеме Тайском», поэт создаёт художественный образ на основе какого-нибудь исторического события или личности. Как видно, романтические герои Низами находят своих прототипов в творчестве Наваи.

Исследователи Низами, в частности Бертельс, приходят к заключению, что поэмы, входящие в состав «Пандж гандж» («Пяти кладов»), объединяются одной общей идеей и составляют одно целостное монументальное произведение. Это суждение имеет глубокую научную основу. Но, как отмечает Е.Э. Бертельс, это явление происходит не по плану, а чисто «механически» [Бертельс 1947:282]. Создание «Хамсы» Низами в такой механической обстановке, освещение единой идеи в произведениях с разными темами и содержанием послужило почвой для социализации творческого метода Наваи в своей «Хамсе», для развития жанра эпоса как общественно активного жанра. Точнее говоря, великий Наваи, намереваясь создать «Пятерицу» старается наиболее полно выразить проблемы своего времени и общества, а также найти их решение в цикле произведений, объединенных одним целостным идейным содержанием. В поэме «Хайрат уль-аброр», восхваляя человека в 
двадцати статьях поэмы, поэт объясняет ему путь к совершенству, после чего он выдвигает идею о том «что человек в земной жизни обязательно должен быть счастливым».

Во второй своей поэме «Фархад и Ширин» поэт бросает взгляд на жизнь своего общества. В обществе, в котором он живет, есть такие парни как Фархад и девушки образцы совершенства как Ширин. Но почему же они не счастливы?

Ответ на этот вопрос поэт пытается дать в своей следующей поэме - «Лейли и Меджнун», потому что общество разделено на касты, имеет место социальное неравенство. В результате этого в обществе развиваются эгоизм, высокомерие, равнодушие к человеческим страданиям. Поэт ставит следующий вопрос: кто же в этом виноват?

В поэме «Сабъаи сайёр» («Семь планет») великий мыслитель отвечает на свой вопрос: «Виноваты эгоистичные правители подобно Бахраму».

После этого у читателя снова возникает вопрос: что же делать?

На этот вопрос в поэме «Садди Искандари» («Стена Искандера») Наваи дает такой ответ: «Гордость вселенной Человек может жить счастливо на земле в том случае, если государствами будут править такие достигшие совершенства правители, как Искандер!».

Такая законченная, совершенно разработанная композиция даёт возможность для представления «Хамсы» Наваи как целостного, монументального произведения. Это великое культурно-просветительское творение плод не только гения поэта, но и той эпохи, в котором он жил. Если бы Низами не создал «Пятерицу» до Наваи, то, возможно, что Наваи бы написал произведение, ставшим в его эпохе явлением для формирования романтического метода на примере Низами. Следовательно, если «Пятерица» Низами была плодом первоначального, только формирующегося романтизма, то «Хамса» Наваи является плодом достигшего высокого уровня романтизма, от которого веяло реалистическим духом.

\section{Список использованной литературы}

1. Бертельс Е.Э. История персидско-таджикской литературы. - М., 1960.

2. Бертельс Е.Э. Избранные труды. Низами и Физюли. - М.: ИВЛ, 1962.

3. Бертельс Е.Э. ЖЗЛ. Низами. - М., 1947.

4. Маллаев Н. Низомий Ганжавий мероси ва унинг маърифий-тарбиявий ахамияти. Т.: Укитувчи, 1985.

5. Мухаммад Хузарий. Нур ал-якийн. - Т., 1992.

6. Низами. Избранные произведения. - М., 1947.

7. Низами. Искандер-наме. - Баку, 1953.

8. Низами. Лейли и Меджнун. - М., 1966.

9. Низами. Пять поэм. - М., 1988.

10. Мустафаев Ж. Философские и этические воззрения Низами. - Баку, 1962.

\section{ИНКОР КОМПОНЕНТЛАР ИШТИРОКИДАГИ ФРАЗЕОЛОГИЗМЛАРНИНГ ЎЗБЕКЧА ТАЛКИНИДАГИ ЛЕКСИК-СЕМАНТИК ХУСУСИЯТЛАР}

\section{Ашуров Шахобиддин Саидович (ф.ф.н, доцент, СамДЧТИ)}

Annotation: The given article is devoted to analysing of phraseological units with negative elements. It has been analyzed lexical and semantic features of PhU with negative elements in the English and Uzbek languages.

Key words and expressions: phraseological unit, negative component, semantics, lexical.

Фразеологик бирликлар (ФБ) ифода хамда мазмун планига эгадирлар. Туб тил бирликларида, яъни лексемаларда ифода плани деб, тилнинг материал бирликлари, яъни товуш олинади. Таркибли тил бирликларида эса улар таркибидаги тил бирликлари кўзда тутилади. 
ФБлар хам йирик тил бирлиги бўлиб, камида иккита мустақил туркум лексемасидан, яъни сўзлардан таркиб топади. Шунга кўра ибораларнинг ифода плани деб лексемалар ва уларни боғлаш учун хизмат қиладиган грамматик элементлар назарда тутилади.

ФБлар хам таркибли тил бирлиги хисобланиб, унинг маъноси таркибидаги лексемаларга хос маъноларнинг оддий йиғиндисига тенг бўлмайди. Иборага хос маъно таркибидаги лексемаларнинг маъносига нисбатан махраж маъно, яъни устама маъно сифатида гавдаланади. Лекин бу маъно ибора таркибидаги лексемаларнинг маъносига таянилмаслиги хам мумкин. Иборанинг маъноси таркибидаги сўзларга хос маъноларнинг оддий йиғиндиси бўлмаслиги, хамда шу сўзлар устига қурилган янги бир маъно бўлиши сабабли ибораларда гуё ифода плани билан мазмун плани орасида қандайдир узилиш содир бўлади. Хусусан, сўзларда акс этаётган маънолар иборадан англашилаётган умумий маънони тўғридан-тўғри изохлаб турмайди. Шу сабабли иборалардаги ифода ва мазмун плани ўртасидаги боғланиш шартли бўлиб хисобланади. Бунда иккита ва ундан ортиқ сўз яхлитлигича маълум бир образ асосида кўчма маъно касб этади. Бу кўчма маъно фразеологик маъно деб аталади. Шундай экан, ФБ ифода плани билан мазмун планининг ўзига хос қарама- қаршилиги ва бирлиги асосида юзага келади.

Юқорида келтирилган мулохазаларни исботлаш учун биз мисол тариқасида инкор компонентлар иштирокидаги ФБлардан фойдаланамиз. Бундай ФБлар ўзбек тилига талқин қилинганда шу нарсанинг гувохи бўлинадики, инкор компонентлар иштирокидаги инглизча фразеологизмлар ўзбек тилига талқин қилинганда хам инкор компонентлар иштирокида амалга оширилади. Яна шуни алохида таъкидлаш жоизки, инкор компонентли ФБларнинг ўзбекча таржимаси инглизча вариантига деярли мос келиши билан хам ўзига хос. Мисол тариқасида тадқиқотимиз жараёнида энг кўп учраган nothing - инкор сўзи иштирокидаги фразеологик бирикмаларни олайлик. Масалан: the little nothing of life. Бу иборани ўзбек тилига таржима қилганимизда “хаёт ташвишлари, ёки майда-чуйдалари” деган ибора келиб чиқади. Кўриниб турибдики, ўзбекча вариант инглизча вариантга деярли мос тушяпти. Сўзимиз исботини қуйидаги мисолларда иккита тил вариантларининг сўзма-сўз мос келишида хам кўришимиз мумкин: want for nothing - хуеч нарсага мухттож бўлмаслик; couht for nothing - хуисобга олмаслик; leave nothing to chance - қулай имкониятга хуеч нарса қолдирмаслик; nothing in common - хуеч қ̧андай умумийлик йўқ; like nothing on earth - хуеч нарсага уухшамайди ёки, thank you for nothing иборасини олайлик. Агар бу иборани уцзбекчага сўзма сўз талқин қилсак, “хуеч нарсага рахммат”маъноси келиб чиқади. Айнан ўзбек тилидаги вариантини келтирсак, қандайдир киноя маъно яъни "шунисига хуам қуллуқ”" деган ибора хосил бўлади. Икки тилдаги вариантларни таққосласак улар деярли ўхшаш.

Nothing сўзи иштирок этган шундай иборалар хам борки, уларнинг ўзбек тилида учтўрт маъноси бор. Айрим маънолари ўзбек тилига сўзма-сўз талқин қилинса, айримлари умуман бошқача талқинга эга. Мисол тариқасида “make nothing of something” иборасини олайлик. Бу иборанинг биринчи маъноси иккала тилда ўхшаш. Масалан, “бирор нарсадан фойдаланмаслик”. Бу иборанинг навбатдаги ўзбекча вариантлари эса инглизча вариантларидан тамомила фарқ қилади. Масалан: 1.умуман англаб етмаслик; 2. бирор нарсани бемаъни хуисоблаш; 3.одатдагидек.

Агарда бу иборани ўзбек тилига таржима қилишга тўғри келса, унинг юқоридаги маъноларидан контекстга асосланган холда мосини танлашимизга тўғри келади.

Not - инкор сўзи иштирокидаги ибораларни кўриб чиқадиган бўлсак, бу сўз иштирокидаги ФБлар хам, инглиз тилидан ўзбек тилига талқин қилинганда, деярли ўзшаш эканлиги яққол кўзга ташланади. Масалан, "not to do a thing" ибораси. У ўзбек тилига “умуман хқеч нарса қ̧илмаслик”деб талқин қилинади. Ёки not - инкор сўзи иштирокидаги бошқа ибораларни олайлик. not to take no; not to be on speaking terms;not to hold of much account. Юқоридаги ибораларни ўзбек тилига сўзма-сўз таржима қилиш мумкин "рад жавобни қабул құлмаслик, уззаро гаплашмаслик, юқори бахуоламаслик”. ёки “nоt to think twice” иборасини олайлик, бу иборани ўзбек тилига тўғридан-тўғри таржима қилсак,"икки 
марта уй̆ламаслик” маъноси келиб чиқади. Лекин биз уни ўзбек тилидаги “бошқ̧а уйламаслик, унутиш” вариантлари билан хам алмаштириш мумкин.

Биз инглизча ФБларни ўзбек тилига талқин қилганда сўзма-сўз мос келиш холатларини кўп холларда мақолларда учратамиз. Масалан, “misfortunes never comes alone" мақолини “бахтсизлик хуеч құчон ёлzиз келмайди” деб талқин қилиш мумкин. Бу иборани халқимиз кўпинча “бахтсизлик бир келса куцша келади” тарзида ишлатади. Бу мақол замирида қанчалик хақиқат борлиги бизга маълум бўлмасада, халқимиз бунга ишонади.

Тадқиқотимиз жараёнида инкор маъно ифодаловчи сўзлардан without сўзидан хам кўп маротаба фразеологик ибораларни хосил қилишда ва тахлил қилишда фойдаландик. Шуни айтиш керакки, бу сўз иштирокидаги иборалар хам маъно жихатдан икки тилда сўзма-сўз мос келиши холатлари кўп учрайди. Масалан: without many words - opmиқ̧ча cy̆зсиз; without respect-эътиборга олмасдан; without a rap — бир чақұасиз.

Яна инкор маъно ифодаловчи сўзлардан out of - бирикмаси иштирокидаги ибораларнинг таржимасида кўпчилик холларда сўзма-сўз мос келишини айтиш керак. Сўзимиз далили сифатида "a word out of season" иборасини мисол қилиб келтирамиз. Бу иборани ўзбек тилига “ўз вақтида айтилмаган сўз, ёки уринсиз маслахат " тарзида келтиришимиз мумкин. Out of -бирикмаси иштирокидаги бошқа мисоларни келтирамиз: out of the ordinary - - вайриоддий; out of place - урринсиз; out of order - бетартиб; out of the question - гап булиши мумкин эмас; out of the wood-хавфдан холи.

Инкор компонентларни семантик жихатдан тахлил қилишда инкор компонентлар ўзбек тилига талқин қилинганда, маъно жихатдан мос келишини кўрдик. Хулоса тариқасида шуни таъкидлаш керакки, инглизча инкор компонентлар иштирокидаги ФБлар ўзбек тилига талқин қилинганда, уларда қуйидагича лексик-семантик хусусиятлар яққол кўзга ташланиши мумкин экан. Хусусан, бундай ибораларни лексик - семантик жихатдан икки катта гурухга ажратиш лозимдир, яъни:

1. Иборанинг сўзма-сўз маъноси ва фразеологик маъноси ўзаро боғлиқ бўлган ФБлар.

2. Иборанинг сўзма-сўз маъноси ва фразеологик маъноси қисман фарқ қиладиган ФБлар.

Умуман олганда, ФБлар икки тилда хам, бир-бирига хар томонлама яқин. Ибораларни ўрганиш жараёнида уларнинг ўзбек тилидаги вариантларидан унумли фойдаланиш алохида ахамият касб этади. Чунки, хар қандай тилни ўрганишда икки тилни қиёслаб ўрганиш самарали натижаларга олиб келади.

\section{Фойдаланилган адабиётлар рўйхати}

1.Амосова Н.Н. «Основы английского фразеологии» Л. ЛГУ, 1963г. -С.208.

2.Кунин А.В. «Курс фразеологии современного английского языка» М. В.Ш, 1986г. C.335.

3.Мюллер В.К. «Англо- русский словарь» Москва- 1969г. -С.912.

4.Рахматуллаев.Ш «Узбек тилининг фразеологик лугати» Тошкент-1992й. 6.378

\section{LINGVISTIK AREAL VA UNING TIPLARI TALQINIGA DOIR}

\section{Ashirbaev Samixan \\ (Alisher Navoiy nomidagi Toshkent davlat O'zbek tili va adabiyoti universiteti professori, f.f.d.)}

\footnotetext{
Annotation: Areal linguistics is an underdeveloped field in the Republic of Uzbekistan. Of course, much work has been done on linguistic geography as part of it. In this regard, A. B. Juraev's theoretical research is important. There is a need for research on the nationalization of applied linguistic concepts in world linguistics and its application. In this sense, this article
} 
explores the concept of linguistic area (territory) from the scientific literature and information system and discusses its application to Uzbek area linguistics.

Key words and expressions: area linguistics, linguistic geography, area, region, isogloss, hemogenic, heterogeneous, types and types of areas.

Areal lingvistika $\mathrm{O}^{\prime} z$ bekiston Respublikasida endigina rivojlantirilmoqda. Areal lingvistika termini dunyo amaliyotida keng qo'llansa-da, u o'zbek tilshunosligida dastlab A. Jo'raevning tadqiqotida nazariy talqinini topgan [Джураев 1991]. Ungacha bo'lgan davrda va undan keyin ham A. Shermatov, Q. Muhammadjonov, Y. Ibrohimov, N. Murodova, Z. Ibrohimovalar lingvistik geografiya termini ostida areal tadqiqotlar olib bordilar va ko'proq bu tadqiqotlarda o'zbek shevalarining ayrim hududlaridagi izoglossalarning tarqalishi kartalashtirildi. Ayni zamonda areal tadqiqotlar ham paydo bo'ldi [Муродова, Рахмонов 2017:148; Дарвешов 2019:148]. Areal lingvistika haqidagi ma'lumotlar o'zbek dialektologiyasiga oid darsliklarda ham yoritila boshlandi [Ashirboyev 2016: 76-84; Муродова 2019:126-134]. $\mathrm{Bu}$ ishlarda areal lingvistika dialektologiyaning bevosita davomi sifatida yoritildi. $\mathrm{Bu}$ fikrga, haqiqatan ham, areal lingvistikaning dialektologiya negizida yuzaga kelganligi [Qarang: Гаджиева 1975: 6], axborot tizimlarida uning lingvistik geografiya deb yuritilishi asos bo'ldi.

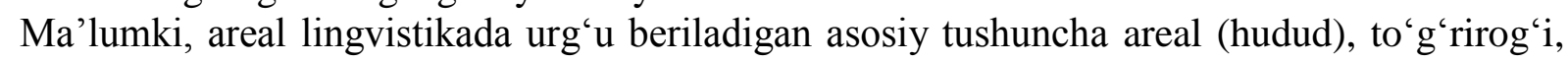
lingvistik arealdir. Albatta, bu tushuncha uning lotincha terminida $0^{6} z$ ma'nosini topgan, ya'ni area so'zi hudud, maydon, joy degan ma'noni anglatgan. Area so'zi sifat yasovchi -1 qo'shimchasi bilan birga qo'llanishi natijasida u endilikda lingvistika fanining bir yo'nalishini ifoda qiladi va areal lingvistikada areal tarzida qo'llanib (otlashib), taksonlarning, izoglossalarning joylashish hududini anglatadigan tushunchaga aylandi. Ushbu maqolada ana shu tushunchaning areal lingvistikada rivojlantirilishini o'zbek tili faktlari asosida talqin qilishga harakat qilamiz.

Area termini hudud degan ma'noni anglatsa ham, uning areal lingvistikada $\mathrm{o}^{6} \mathrm{z}$ ma'nosi bor. $\mathrm{O}^{\prime}$ zbek va rus tillarida u areal ko'rinishida qo'llanadi. Areal tushunchasi quyidagi o'rinlarda qo'llanadi:

1) areal so'zi til va dialektlarning turli hududlarda tarqalishiни anglatadi. Boshqacha aytganda, tilning yoki shevaning tarqalish o'rnini bildiradi. Masalan, ingliz tili turli qit'alarga tarqalgan, o'zbek lahjalari o'zbeklar massivining turli hududlarini egallagan, jumladan, o'g'uz lahjasiga oid shevalar Janubiy Qozog'iston, Forish, Qorako'1, Olot, Xorazm, Qoraqalpog'istonda muayyan hududlarni egallagan. Areal tushunchasi faqat til va dialektlarning emas, balki konkret bir izoglossaning tarqalishini, uning harakat yo'llarini, joylashgan o'rnini ham anglatadi, jumladan, “ā'lashish Toshkent, Farg'ona vodiysida alohida-alohida hududni egallagan. Demak, areal (hudud) tushunchasida tarqalish ma'nosi yetakchidir;

2) areal so'zi til va dialektlarning makon va vaqt birligi tushunchasini anglatadi. Bu til va shevalarning tarixiy taraqqiyoti bilan bog'liqdir. U yoki bu til va uning shevasi turli tarixiy davrlarda makonlarini almashtirishi mumkin, Masalan, turkiy xalqlardan bo'lgan qadimgi madyorlar (majorlar) hozirgi Volga daryosining quyi oqimlarida yashaganlar. Eramizning 830 yillarida ular quyi Dunay bo 'ylariga migratsiya bo'ladilar. Tili esa slavyan tillari ta'siriga uchraydi va (gibrid) vengr tili bo'lib shakllanadi [www. Worid-history.ru]. Madyorlarning tili to'g'risida gap ketganida, o'sha 830 yilgacha bo'lgan davr va quyi Volga bo'yi hududida tarqalganligi to'g'risida fikr yuritiladi. Tillar tarixida bunday o'lchov muhim rol o'ynaydi. Makon va vaqt birligi tushunchasini shevalarga nisbatan ham qo'llash mumkin. Qadimgi turkiy urug'-qabilalardan biri bo'lgan arg'ular Qozog'iston Respublikasining Taroz viloyati atrofida yashaganlar va ularning shevasi qarluq va chigil shevalariga yaqin bo'lgan. Keyinchalik ular qipchoqlar tarkibiga qo'shilib ketgan va hozirgi turkiy tillardan qozoq, qirg'iz, tatar, boshqird tillari tarkibidagi urug'larga aylangan. Demak, arg'ular shevasi to 'g'risida gap ketganida XI-XII asrlardagi holati bo'yicha fikr yuritilishi kerak bo'ladi. $\mathrm{Bu}$ urug'-qabilalar shevasi to'g'risida M. Koshg'ariyning ayrim ma'lumotlaridan boshqa jiddiy axborotlar yo'q.

3) areal so'zi til va shevalar ittifoqi tushunchalarini ifoda qiladi. Til va shevalar ittifoqi lingvistik kontaktologiyaning mahsuli ekanligi ma'lum. Til va shevalar ittifoqi tushunchasi N. S. Trubetskoy tomonidan kiritigan [Qarang: Гаджиева 1975: 7]. Har bir til va sheva o'zicha rivojlana 
olmaydi, balki unga chegaradosh bo'lgan til va shevalar bilan aloqada bo'ladi. Bu jarayon ikki til yoki shevaning chegarasida yuz beradi. O'zaro ta'sir doirasidagi bu tillar chegarasida har ikkala til yoki sheva kesishgan joyda oraliq sheva paydo bo'ladi. Bu lingvistik hodisa til yoki sheva ittifoqi tushunchasini oladi. O‘zbek tilidagi oraliq shevalar maxsus o'rganilgan [Кудратов 1976:39-45].

4) areal termini tillar guruhini (oilasini) ham anglatishi an'anada bor, ya'ni bir til oilasininig yoki katta til oilasidagi guruhlarning tarqalishini anglatadi. Bunga ko'ra, katta va kichik areallar haqida gapirish mumkin. Masalan, katta til arealiga Hind-Yevropa til oilasini misol sifqtida keltiradigan bo'lsak, kichik arealiga uning ichki bo'linishi - roman, german til guruhlari misol bo'la oladi. Shuningdek, turkiy tillar arealini katta areal, bulg`or, qarluq, qipchoq guruhlarini unung tarkibidagi kichik areal deb qarash mumkin va h.k.

Endi areallarning axborot tizimlarida qayd qilingan tiplariga to 'xtalamlz.

Oddiy areal. Bunday areallar muayyan hududlarga sidirg'a joylashgan bo'ladi, ular kuchli tashqi ta'sirga uchramaydi, balki shu hududda turg'un bo'ladi. Bunga kam sonli aholisi bo'lgan tillar (yaqut, yukagir) va atrofini boshqa til va shevalar o'rab olgan shevalar taalluqlidir. Afsuski, adabiyotlarda bazi shunday shevalar yo 'qolib ketayotganligi haqida fikrlar uchramoqda. Jumladan, J. Eltazarov shimoliy o'zbek shevalarining, xususan, u yerdagi o' $\mathrm{g}$ ' $\mathrm{uz}$ shevalarining yo'qolib borayotganligini yozadi [Eltazarov 2013]. Bizningcha, bu fikrda asos yo'q, chunki u nazariy jihatdan ham, amaliy jihatdan ham isbotlanmagan. Aksinch J. Eltazarov fikr yuritgan shevalar $\mathrm{o}^{\prime} \mathrm{z}$ mustaqilligini, tabiiyligini saqlab kelmoqda, chunki ularga boshqa til va shevalar sezilarli ta'sir etmagan. Aslida shevalarning yoqolishi g'oyasi o'zbek shevalariga emas, balki hozirgi Yevropaning yirik shahar shevalariga tegishli bo'lib, u migratsiyaning mahsulidir;

murakkab areal. U bo'laklarga ajratilishi mumkin bo'lgan areallardan tashkil topadi. Bu ko'p jihatdan yuqorida aytilgan katta areal tushunchasi bilan ham bog'lanadi. Jumladan, turkiy tillar o'z ichida bo'laklarga ajraladi, o'zbek tili ichki lahjalariga nisbatan murakkab arealdir.

keng areal. U katta hudud ichida areallarning to'siqlarsiz ko'chib yurishidir. Bunga qozoqlarning ko'chmanchilik davridagi tili misol bo'la oladi. Keng arealning boshqa talqini ham bor. Amerikalik lingvist J. Nikols keng (cho'zilgan) va tor areallarni qayd qiladi. Uningcha, keng (cho'zilgan) areallar genetik rang-barangligi kam bo'lgan tekisliklardagi areallardir, unga misol sifatida Yevroosiyo cho'l zonalarini keltiradi, tor areal esa tog'lik joylar va okeanlardagi areallar bo'lib, ularda xilma-xillik kuchli bo'ladi, unga misol sifatida Kavkaz keltiriladi [htpps//present5.com].

Shuningdek, areallarning quyidagi turlari to' $\mathrm{g}^{6}$ risida ham fikr yuritish mumkin:

bo 'lingan areal. Bu muayyan hududdagi til va shevalarning sharoiti o'zgarishi bilan yuz beradi. Professor E. D. Polivanov Iqon (Qozog'iston, Turkiston) aholisining bir qismi qachonlardir hozirgi Qorako'1 va Olot tumanlari hududiga ko'chganligi to'g'risidagi ma'lumotlarni (sheva vakillari axboroti) keltiradi (to'g'ri, bu fakt yana qo'shimcha o'rganilishi lozimligini ham uqtiradi) [Поливанов 1929: 527], V. V. Reshetov Markaziy Osiyodagi (Orol bo'yidagi) qatag'onlarning Afg'onistonga ko'chib ketishi tufayli u yerda qarluq shevalari shakllanganligini aytadi [Решетов,1966:5]. Bo'lingan arealning ikki turi qayd qilinadi: gemogen va geterogen. Gemogen areallar $o^{\prime} z$ chegarasiga ega bo'lmagan til va shevalardan iborat bo'ladi. " $\mathrm{O}{ }^{\prime} z$ chegarasiga ega bo 'Imagan til va shevalar" tushunchasi o'zbek tiliga tatbiq etilganida, uning lahjalari ko 'zda tutiladi, ya'ni lahjalarnimg dialektlarga va dialektlarning shevalarga bo'linishi tushuniladi, bunday bo'linishda aniq chegaralar yo'qligi ma'lum. Geterogen arealda muayyan til va shevalar chegaradosh til va shevalar bilan aralashadi. Qaysidir tillar qarindosh va qarindosh bo'Imagan tillar bilan chegadosh bo'lganligi uchun ham ular zich aloqada bo'ladi. Natijada kichik bir hudud paydo bo'ladiki, u boshqa-boshqa tillarning o'zaro ta'siri tufayli yuz beradi. Bu kichik hudud oraliq shevani hosil qiladi. Demak, geterogen areal tashqi aloqaning mahsulidan paydo bo'ladi.

tor local areal. Ular qisqa (kichik) hududga ega bo'ladi. Bunday areallar, deyarli, yopiq doirada ish ko'radi. Bunga Uzoq Sharqdagi yukagirlar tilini hamda Buxoro va Samarqand viloyatlaridagi ayrim qishloq $o^{\prime} g^{\prime} u z$ shevalarini misol sifatida keltirilish mumkin. Ularning tili va shevasi atrof shevalarga ta'sir eta olmaydi, aksincha, miqdor jihatdan yirik bo'lgan atrof tillar va shevalar ta'sirida bo'ladi; 
local areal. Ular nisbatan keng hududga ega bo'ladi. Bunga Qorako'l va Olot o'g'uz shevalarini keltirish mumkin. Bu shevalarning atrofi qarluq, qisman qipchoq va tojik shevalaridir;

subregional areal. Lokal areallardan katta hududlarni qamrab oladi. Ma'lumki, o'g'uz lahjasiga oid shevalar Markaziy Osioning katta qismida tarqoq holda joylashgan, lekin Xorazm hududi nisbatan katta hudud hisoblanadi. Demak, Xorazm o'g'uz lahjasining subregional arealidir; regional areal. $\mathrm{Bu}$ areal keng hududlarni qamrab oladi, masalan, turkiy tillar areali yoki turkiy tillarning o'g'uz areali;

poliregional areal. Bunda til va dialektlar bir necha qit'alarga tarqalgan bo'ladi. Ingliz, fransuz, ispan, potugal tillari shunday talalarga javob beradi, jumladan, ingliz tili Osiyo, Yevropa, Avstraliya qit'alariga, fransuz tili esa Yevropa, Afrikaga tarqalgan (davlat va milliy til sifatida) va h.k.

kosmopolitik areal. Turli iqlim sharoitlari tufayli til va dialektlarning tarqalishi hududlarini anglatadi. Ma'lumki, o'g'uzlar aslida Qozog'istonning Ile daryolari bo'yida shakllangan, lekin iqlim ularning yashash imkoniyatlarini qiyinlashtirgan, natijada ular g'arb tomon siljishga majbur bo'lgan va tillari ham ular yashagan o'lkalarda faoliyatda bo'lgan;

innovatsion areal (ona areal). Undan bir necha areallar paydo bo'ladi, ularni til oilalari bilan izohlash mumkin. Malumki, til oilalari tillarning bir manbadan tarqalganligi g'oyasiga asoslanadi. $\mathrm{Bu}$ fikr innovatsion markaz masalasi bilan ham bog'liq bo'lib, areallarning paydo bo'lish o'rnini bildiradi;

migratsion areal. Til va dialektlarning ko'chishi asosida paydo bo'ladi. Bunga misol turk tili, (ma'lumki, ular Markaziy Osiyodam migratsiya bo'lgan) O'zbekistondan tashqarid qavm bo'lib yashayotgan o'zbeklar tili, o'g'uzlarining Ile daryolari bo'ylaridan to Yevropa chegaralarigacha ko'chib borishi natijasida turkiy tillar o'g'uz guruhining paydo bo'lishi misol bo'la oladi.

vikarizm. Bu tushuncha areologiyada bir tur o'rnida boshqa turlarning paydo bo'lishi tushuniladi. Biologik turlar iqlim bilan bog'liq. Areologiyaga aloqador bu termindan areal lingvistika ham foydalanadi. Tillar va dialektlarda uni ijtimoiy jarayon bilan bog'lab tushuntirish mumkin. Xorazmda turkiylarning qaror topishi bilan bu hududda turkiy (o'zbek) shevalari rivojlanishni boshlagan.

Ko'rinadiki, tilshunoslikda lingvistik areal tushunchasi rang-barang bo'lib, ularni konkret tarixiy davr bilan bog'lab o'rganish maqsadga muvofiqdir.

\section{Foydalanilgan adabiyotlar ro'yxati}

1. Ashirboyev S. O‘zbek dialektologiyasi. - Toshkent: Navro`z, 2016, $150 \mathrm{~s}$.

2. Гаджиева Н.З. Проблемы тюркской ареальной лингвистики. - Москва: Наука, 1975, $304 \mathrm{c}$.

3. Дарвешов И. Ареал тилшунослик: жанубий-ғарбий Наманган шеваларининг фонетик-фонологик хусусиятлари. -Тошкент: Наврўз, 2019,148 с.

4. Джураев А. Б. Теоретические основы ареального исследования узбекоязычного массива. - Ташкент: Фан, 1991, 220 с.

5. Муродова Н. Ўзбек диалектологияси. -Тошкент:Barkamol fayz media, 2019, 180 c.

6. Муродова Н., Рахмонов Н. Ўзбек тили Навоий вилояти шеваларининг лингвоареал талқини. - Тошкент: Янги аср авлоди, 2017, 168 с.

7. Поливанов Е.Д. Образцы не-иранизованных (сингармонистических) говоров узбекского языка // Известия Академии наук...1929.

8. Решетов В.В. Ўзбек шеваларининг классификацияси // Ўзбек тили ва адабиёти, 1966, - №1.

9. Қудратов Т. Шевалар қандай аралашадилар // Ўзбек тилшунослиги масалалари, Қарши, 1976. 39-45-бет. 


\section{Foydalanilgan adabiyotlar ro'yxati}

1. Арутюнова Н. Д., Падучева Е. В. Истоки, проблемы и категории прагматики // Новое в зарубежной лингвистике.-М.,1985.-Вып.16. 2011.

2. Дадуева Е. А. Общая характеристика каузативных глаголов//Вестник СибГУТИ, №2,

3. Сусов И. П. Предикат и предикация // Семантика и прагматика синтаксических единств (Межвузовский тематический сборник).-Калинин: КГУ, 1981.

4. Фомичева Е .В. Средства выражения побудительности в английском языке в свете семантики и прагматики//Современные проблемы науки и образования, № 4, 2009.

\section{ВИДЫ ОБРАЩЕНИЙ В СТИХОТВОРЕНИЯХ}

\section{А. Ахматовой,Ёвкочева 3.М., (УзГУМЯ, Докторант)}

Annotation. Addresses as a separate intonational and grammatically independent component of the text attracted the interest of scientists for a long time. Recently, the pragmatic and methodological aspects of address have been investigated. As you know, in many works of art, adress is of great importance, since it serves to reveal the inner world of both the characters and the author himself. This article discusses the types of addresses in the works of Anna Akhmatova.

Key words and expressions: address, noun, adjective, syntax, function, role, repetition, construction.

Синтаксическая категория обращения издавна привлекает внимание российских лингвистов, которые отмечают его свойство не вступать в грамматические связи с другими словами в предложении и его особую интонационную оформленность, на письме нашедшую отражение в знаках препинания. Обращение - обособленный интонационно и грамматически самостоятельный компонент предложения или сложного синтаксического целого, служащий для обозначения лица или предмета, являющегося адресатом речи. Обращение обычно не относят к членам предложения и не включают в синтаксическое дерево зависимостей или составляющих. Примеры:

Приду, приду я вновь, мой милый домосед,

С тобою вспоминать беседы прежних лет (Пушкин) [8].

Термин «обращение» известно уже в античных теориях языка и стиля (Квинтилиан, Цицерон, Д.Галикарнаский) и рассматривается как фигура речи, используемая для большей убедительности и украшенности речи [2, с. 3-6].

В трудах М.В. Ломоносова [5], А.Х. Востокова [4] описывается звательный падеж, который в древнерусском языке являлся морфологическим средством выражения синтаксической функции господствующего слова того члена предложения («звательный, показывающий имя предмета, к коему речь обращается» [4, с. 21]. Звательный падеж в грамматике Ф.И. Буслаева получил название «обращение» [3]. Следует отметить, что термин «обращение» появляется впервые в работе Ф.И. Буслаева, однако ученый не дал четкого определения ему: под ним понимался то «звательный падеж», то «звательное слово», то «слововозвание», то «вставные члены предложения» [3].

В российском языкознании с XIX века обращение традиционно рассматривается в разделе синтаксиса как «грамматически независимый и интонационно обособленный компонент предложения или более сложного синтаксического целого, обозначающий лицо или предмет, к которому адресована речь» [6, с. 340-341].

Внимание исследователей привлекают такие проблемы, как синтаксический статус и функции обращения, его семантические и структурные типы, т.е. способы выражения, а также степень смысловой нагруженности, типы интонации при обращении, позиция обращения в структуре предложения, связи с остальным составом предложения. 
Обращение изучено в достаточной степени, однако, в силу сложности и противоречивости лингвистической природы самого объекта, многие вопросы, в том числе относящиеся к определению конститутивных признаков обращений, остаются пока нерешенными или решаются учеными по-разному. В частности, Н.Ю. Шведова справедливо отмечает, что обращение, будучи синтаксически независимым компонентом предложения, связано с остальным составом предложения не только семантически («вещественно»), но и синтаксически [7]. Недостаточно изучены обращения в прагматическом и стилистическом аспектах.

Рассмотрим структурно-семантические виды обращений в произведениях А. Ахматовой.

А. Ахматова - поэт-лирик, поскольку во всех ее произведениях присутствует явно выраженный лирический колорит. Значительная часть ее творчества - это диалог, в котором А. Ахматова использует обращения во всем многообразии его структурносемантических типов.

Среди обращений наиболее часто А. Ахматова использует формы нераспространенных обращений, выраженных именами существительными, обозначающими конкретные или абстрактные понятия.

В произведениях А. Ахматовой встречаются нераспространенные обращения, выраженные именами прилагательными, при этом они выносятся автором в отдельное предложение с восклицанием, и, чаще всего, с повтором, который делает адресата объектом повествования, являющимся центром происходящих событий. Такие обращения не только называют адресата, которым может быть как лицо, так и предмет, но и содержат в себе субъективную модальность, а также показывают интонацию, с которой автор обращается к адресату:

Я ответила: «Мильй, милььй!

Ия тоже. Умру с тобой...» [1].

Распространенные обращения - это тип обращений, содержащий в себе больше информации, в отличие от нераспространенных, и он также активно используется в лирике А. Ахматовой.

В следующем примере используется распространенное обращение, выраженное конструкцией «прилагательное + абстрактное существительное»:

Слава тебе, безысходная боль!

Умер вчера сероглазый король.

Вечер осенний был душен и ал,

Муж мой, вернувшись, спокойно сказал:

«Знаешь, с охоты его принесли,

Тело у старого дуба нашли.

Жаль королеву. Такой молодой!..

За ночь одну она стала седой...» [1].

Самой большой группой от общего числа рассмотренных стихотворений можно считать те произведения А. Ахматовой, в которых распространенное обращение, выраженное прилагательным + существительным, обозначает непосредственно личность:

Меня покинул в новолунье

Мой друг любимый. Ну так что ж!

Шутил: «Канатная плясунья!

Как ты до мая доживешь? [1].

Часто А. Ахматова использует обращения, в которых выражена субъективная оценка автора:

Высоко в небе облачко серело,

Как беличья расстеленная шкурка.

Он мне сказал: «Не жаль, что ваше тело

Растает в марте, хрупкая Снегурка!» [1]. 
Следует обратить внимание на частотность обращения друг, которое часто встречается в стихотворениях А. Ахматовой как в осложненном, так и в неосложненном виде:

И что память яростная мучит,

Пьткка сильных - огненный недуг! -

И в ночи бездонной сердие учит

Спрашивать: о, где ушедший друг? [1].

Довольно большую часть обращений этой группы составляют существительные, обозначающие конкретного адресата: литературных персонажей и персонажей, придуманных автором в контексте стихотворения, реальных личностей, богов:

В ярком блеске Тюилери,

Развеваются знамена.

— «Tы страдал! Теперь изари!

Здравствуй, сын Наполеона!» [1].

Присутствуют в лирике А. Ахматовой обращения с частицей $o$, как включенные в предложение, так и вынесенные в отдельное предложение.

Наиболее продуктивной в русском языке является такая форма распространенного обращения, как «существительное + прилагательное в позиции одиночного определения»: стихотворения с обращениями такого типа составляют достаточно большой пласт лирики А. Ахматовой, при этом частотны обращения к предметам и явлениям, что показывает, что адресат речи для автора или лирического героя стихотворения имеет особую важность и значимость, сам образ лирического адресата ему приятен и дорог.

Еще более ярко такая характеристика выражена в сочетании милый друг в качестве обращения типа «существительное + прилагательное в позиции согласованного определения», которое придает стихотворениям дружескую тональность, откровенность, характер личного, но в то же время открытого, доверительного разговора с адресатом. Употребление этого сочетания следует отметить как характерное для поэтической речи А. Ахматовой.

Распространенные обращения «существительное + местоимение в позиции одиночного определения» используются в проанализированных лирических произведениях А. Ахматовой, что позволяет определить этот прием как характерную черту ее творчества. Примечательно, что во всех случаях поэтесса использует притяжательное местоимение мой, что не только подчеркивает особое отношение к адресату, названному автором, состояние близости к поэту, но и причастность лирического героя к описываемой в стихотворении ситуации.

Необходимо отметить, что А. Ахматова при обращении к адресату часто использует «существительное + прилагательное в позиции одиночного определения + местоимение в позиции одиночного определения», усиливая тем самым передаваемые обращением чувства к адресату, его особую значимость, в некоторых случаях усиливая пафос сложного обращения частицей $o$ :

И тыл, мой юный, мой печальный,

Уходишь прочь!

По тебе томится вечер,

Черноокая моя!

Я буду здесь. Мы все горим:

Весь город мой, река, ия...

Крести крещеньем огневым,

О, милая моя! [1].

Необходимо отметить, что использование А. Ахматовой обращений рассмотренных типов в однородном ряду позволяет всесторонне охарактеризовать адресата, показать уровень своих с ним взаимоотношений, дать характеристику существующей между ними связи. 
Проведенный нами анализ типов обращений, используемых А. Ахматовой в стихотворениях, показывает, что поэтесса широко использует крупные распространенные конструкции. В частности, нередко встречаются примеры использования в качестве обращения существительного с причастным оборотом или существительного, выраженного причастием. В отличие от обращений с прилагательными, такие конструкции обладают большей эмоциональностью и экспрессивностью, речь приобретает различный характер, становясь в одних случаях более высокой, в других случаях - более торжественной, в третьих - более отчаянной. Такие обращения, по сравнению с обращениями, выраженными более простыми распространенными конструкциями, звучат гораздо ярче и способны гиперболизировать выражаемые по отношению к адресату чувства автора:

Косноязычно славивший меня

Еще топтался на краю эстрады [1].

Таким образом, подводя итоги, следует считать продуктивным в творчестве А. Ахматовой использование нераспространенных и распространенных обращений типа «субстантивированное прилагательное + местоимение в позиции одиночного определения», при этом используется исключительно притяжательное местоимение мой. Подводя итог анализа использования А. Ахматовой различных типов обращений в своих поэтических произведениях, необходимо подчеркнуть, что наиболее часто и преимущественно в конструкциях распространенного и нераспространенного типов используются главным образом существительные и субстантивированные прилагательные.

\section{Список использованной литературы}

1. Ахматова А. Собрание сочинений: В 6 т. - М., 1998.

2. Багна Ибрахим. Типы и функции русского обращения как наименования адресата в разных видах словесности: Автореф. дисс. ... канд.фил.наук. - М., 2004.

3. Буслаев Ф.И. Историческая грамматика русского языка, 1875.

4. Востоков А.Х. Русская грамматика, по начертанию его же сокращенной грамматики, полнее изложенная. - М.,1835.

5. Ломоносов Л.В. Полное собрание сочинений, т. 7, Труды по филологии. - 1739-1758.

6. Кручинина И.И. Обращение // Лингвистический энциклопедический словарь / Под ред. В.Н. Ярцевой - М., 1990.

7. Шведова Н.Ю. Распространение предложения включением обращения // Русская грамматика. Т. 2. - М., 1980.

8.https://ru.wikipedia.org/wiki/\%D0\%9E\%D0\%B1\%D1\%80\%D0\%B0\%D1\%89\%D0\%B5\% D0\%BD\%D0\%B8\%D0\%B5_(\%D0\%BB\%D0\%B8\%D0\%BD\%D0\%B3\%D0\%B2\%D0\%B8\%D1\% 81\%D1\%82\%D0\%B8\%D0\%BA\%D0\%B0)

\section{ЎЗБЕК ТИЛИ ТЕРМИНОЛОГИЯСИДА "НОН" ЛУҒАВИЙ БИРЛИГИНИНГ МАСАЛАЛАРИНИ ТАДКИҚ ЭТИШ}

\section{А.Ш.Ибатова \\ (СамДУ докторанти)}

Annotation: The article explores the issues of Uzbek language terminology, compiles glossaries on the industry, including the revival of today's endangered national handicrafts, and the urgent collection of words and terms related to them. It is a lexical unit related to products, which consists of lexemes collected in literary language, Uzbek dialects and dialects, dictionaries and ethnographic materials, as well as samples of oral and written literature, as well as in communication with bakers.

Key words and expressions: lexeme, term, dialect, dialect, lexical unit, field, language, bakery, methodological basis, national, historical, ethnographic, lexical.

Жахон тилшунослигида бугунги кунда лексик бирликларни система сифатида тадқиқ этишда тилшунослик билан бир қаторда этнография, лингвокультурология, 
маданиятшунослик ва санъатшунослик сингари фанлар билан бир қаторда табиий, техника, тиббиёт хамда қишлоқ хўжалиги каби фанлар интеграцияси устувор характерга эгадир.

Маълумки, маънавият кўзгуси бўлган тил хамиша эътиборга мухтож. $\quad$ Чунки усиз жамият ривожлана олмайди. Жамият хаётидаги хар қандай янгилик ва воқелар биринчи навбатда тилда акс этади. Президентимизнинг 2019 йил 21 декабрдаги “ Ўзбек тилининг давлат тили сифатида нуфузи ва мавқеини янада ошириш чора-тадбирлари тўғрисида"ги ПФ-5850 Фармон ижросини таъминлаш мақсадида 2020-2030 йилларда ўзбек тилини ривожлантириш хамда тил сиёсатини такомиллаштириш концепцияси лойихасининг эълон қилиниши ўзбек тилининг давлат тили сифатидаги мавқеини янада ошириш имкониятига асослаб бўла олади. Бу эса ўзбек тилининг хали тадқиқ этилмаган ва ўрганилмаган томонларини тадқиқ этишда хамда унинг амалий жихатдан кўлланиш кўламини янада оширишга хизмат қилиши шубхасиздир. Хусусан, ўзбек тили терминологияси масалаларини тадқиқ этиш, сохаларга доир изохли луғатлар тузиш, жумладан бугунги кундаги йўқолиш арафасида турган миллий хунармандчилик сохаларини қайта тиклаш баробарида зудлик билан уларга тегишли сўз ва терминларни йиғиб олиш миллийликнинг ўзига хос томонларини тиклашда ва бойитишда методологик асос бўлади. Бу эса ўзбек тилининг хали тадқиқ этилмаган ва ўрганилмаган томонларини тадқиқ этишда хамда унинг амалий жихатдан қўлланиш кўламини янада оширишга хизмат қилиши шубхасиздир.

Жахон тилшунослигида XX асрда лексика ва туркий тиллар сохавий лексикаси юзасидан тавсифий, қиёсий-тарихий ва тарихий-этимологик характердаги кўплаб тадқиқотлар яратилди. Рус тилшуносларидан В.В.Виноградов, Г.О.Винокур, Н.А.Баскаков, А.А.Реформатский, В.П.Даниленко, В.Г.Гак сингари олимларнинг асарларида лексиканинг назарий муаммолари, унинг таърифи ва бошқа мухим масалалар ўз ифодасини топган. Шунингдек, А.М.Шчербак, В.И.Литвинов ва бошқа олимлар лексиканинг айрим сохаларини ўрганиш бўйича мухим ишларни амалга оширганлар. Уларда асосий эътибор соха лексикасининг назарий, қиёсий, тарихий-этимологик тахлилларига эьтибор қаратилди. Ўзбек тилшуносларидан У.Турсунов, С.Иброхимов, А.Хожиев, Э.Бегматов, О.Усмонов, Х.Дониёров, Ғ.Абдурахмонов, С.Акобиров, Р.Дониёров, Х.Дадабоев, Х.Жамолхонов, Н.Махмудов, Н.Махкамов, Т.Турсунова, А.Мадвалиев, И.Йўлдошев, А.Собиров, М.Абдиев, $\mathrm{X}$. Жабборов ва бошқа олимларнинг ишларида ўзбек тили лексикасининг турли масалалари ёритилган. Аммо ўзбек тили лексикасида нон ва нон махсулотларининг шаклланиши, ясалиши ва бойиш манбалари махсус тадқиқ қилинмаган. Холбуки, озиқ-овқат саноатининг мухим тармоғи бўлган нон ва нон махсулотлари билан боғлиқ лексемалар жахон тилшунослигида махсус ўрганилмаган.

Ўзбек тилида нон ва нон махсулотлари билан боғлиқ луғавий бирлик бўлиб, уни адабий тилда, ўзбек тили лахжа ва шеваларида, луғатлар ва этнографик материалларда хамда оғзаки ва ёзма адабиёт намуналарида учровчи, шунингдек, нонвойлик билан шуғулланувчи кишилар билан мулоқотда тўпланган лексемалар ташкил этади ва нон махсулотлари билан боғлиқ лексемаларининг халқ оғзаки ижоди материаллари хамда бадиий, тарихий-илмий асарларда ифодаланиши аниқланиб, олинган хулосалар ўзбек тили тарихий лексик бирликлар тизимларини янада чукурроқ ўрганишга имкон бериши илмий-назарий жихатдан асосланади.

\section{Фойдаланилган адабиетлар рўйхати}

1.Азизов О. Тилшуносликка кириш.- Тошкент: Ўқитувчи, 1996

2.Воробьёв В.В. Лингвокультурология. - М.: РУДН, 2006. - 331 с.

3.Гумбольдт В. фон. Избранные труды по языкознанию / пер с нем. яз. под ред. и с предисл.

4.Г.В. Рамишвили. - М.: Прогресс, 1984. - 397 с.

5.Ирисқулов М. Тилшуносликка кириш.- Тошкент: Ўқитувчи,1998.

6.Маслова В.А. Лингвокультурология: Учеб. пособие для студ. высш. учеб. заведений. -М.: Академия, 2001. - 28-29 с. 
7.Ожегов С.И., Шведова Н.Ю. Толковый словарь русского языка. - М., 2009. - C. 403.

8. Рахматуллаев Ш., Ўзбек фразеологиясининг баъзи масалалари, Т., 1966; 9.Реформатский А. А., Введение в языковедение, М, 1998.

10.Турсунов У., Мухторов Ж., Рачматуллаев Ш., Хозирги ўзбек адабий тили [3нашр], T., 1992;

11.Ўзбек тилининг изохли луғати. Маъруфов 3.М. (мух) Икки томли. Москва: Русский язык. 1981. - т.1. А-Р. 632 б.; т.2. С-Х. 715 б.

12.Хожиев А. Лингвистик терминларнинг изохли луғати.- Тошкент: Ўқитувчи, 1985.

\section{МАТН ДЕРИВАЦИЯСИДА ЎРИН ВА ПАЙТ РАВИШЛАРИНИНГ ЎРНИ}

Турниёзов Н.К.

(Ф.ф.д., проф.)

Турниёзова Ш.Н.

(Ф.ф.н.)

Annotation: This article discusses the forms of place and time, which are one of the lexical tools that form the derivation of the text. In particular, the article analyzes that in traditional linguistics syntactic forms can be used as a case, but in functional syntax monema, and in terms of derivation can be activated as an operand or operator of a derivative, depending on the situation. As the forms in the text come as operators, we equate them to connectors. Therefore, we cannot deny that it is natural that they, like connectors, bind text components in space and time. Accordingly, we also associate the connection of text components through place and time forms with the concept of continuum.

Key words and expressions: macromat, connectors, place and time forms, derivation, operator, operand, continuum.

Равишларни макроматн таркибида унинг компонентларини боғловчи восита сифатида функцияга киришиши хозирда тилшуносликка оид тадқиқот ишлари олдида бир қатор мураккаб ва мунозарали муаммоларни қўймокда. Гап шундаки, равишлар ўзига хос сўз хусусиятларга эга бўлган сўз туркумидир. Уларда бир неча сўз туркумларининг (сифат, сон кабилар) лексик, морфологик ва синтактик хусусиятлари уйғунлашиб кетишини кузатиш мумкин. Хатто ёрдамчи сўз туркумлари қаторига кирувчи боғловчилар хам шулар жумласидандир.

Шу билан бирга, равишларнинг синтактик позицияси тилшуносликнинг турли йўналишларида турлича хусусиятларга эга десак янглишмаган бўламиз. Жумладан, анъанавий тилшуносликда синтактик жихатдан равишлар хол вазифасида келиши сир эмас. Бироқ функционал синтаксисда монема, деривацион нуқтаи назардан эса вазиятга қараб дериватнинг операнди ёки оператори сифатида фаоллашиши мумкин. Бизнинг ишимизда равишларнинг айнан мана шу охирги позицияси диққат марказимизда туради.

Таъкидлаш жоизки, рус тилшунослигида равишларнинг боғловчи вазифасида келиши фақат мураккаб синтактик курилмалар сатхида кўриб чиқилган: Я приду тогда, когда он мне разрешит.

Кўринадики, бундай холларда равиш хам боғловчи, хам маълум гап бўлаги вазифасида келмокда. Бошқача айтганда, равиш бу вазиятда хам мустақил, хам ёрдамчи сўз туркуми функциясини ўзида мужассамлаштираяпти.

Бизнингча, равишлар нафақат мураккаб синтактик курилма, балки абзац, хатто абзацлараро боғланишни хам таъминлай олади.

1. Тиллаев билан Қурбонбой ўртасида яқинлик пайдо бўлди. Бир куни гап орасида у руззворидан орттириб участкасининг томини ёполмаётганини айтиб қэолди...(С.Ахмад. Коплон)

2. Икромжон уларнинг гапига хуалал бермаслик учун ёнларидан тез уттиб кетди. Хозир у 
самоварга кириб битта чой ичмоқ̧чи. Клуб ичи дим булиб кетганидан терлаб чанқ̧аганди (С.Ахмад. Уфк).

3. Катта садақұайравочнинг тегида икки зўр самоворва ўт құлаб қ̧айнатардилар. Ундан нарироқুда бир-икки киши уч-тўрт қоп бодрингни бир-бирига суяб «Мирзақирон бодринг, касир-касир бодринг!»-деб мақташардилар (А. Қодирий. Улоқуа).

4. ... Албатта, буларга раис ўзи билиб муомала қүилди-ю, аммо район уут уучириш командасининг пенсияга чиқ̧ётган кекса ходимини табриклашни менга юклаб куйса бўладими. Бордим. Буларнинг тантанаси валати бўларкан. Ёлвондакам ўт кетди қүилиб, бирдан гупур-гупур құлишди. Бири сув сепаяпти, бири болта билан эски яшикларни парчалаб ташлаяпти. Роса одам йивилди. Мен учинчи бўлиб суизга чиқдим...

Ўша куни шамоллаб құлган эканман. Турт кун ётиб қолдим. Дармоним куриб ишга кетаётсам, раис қовоқ-димовини осилтириб самоварнинг сўрисида ўтирибди...(Х. Тўхтабоев. Сариқ девни миниб)

Келтирилган мисолларнинг биринчиси абзац қолипидаги макроматн бўлиб, у икки компонентдан иборатлиги кўзга ташланади. Ана шу компонентларнинг биринчисидаги Қурбонбой сўзи иккинчи компонентда у кишилик олмоши билан алмаштирилаяпти. Бу, албатта, матн компонентларининг синтактик боғланишини таъминлаяпти. Бироқ шу билан бирга мазкур матн компонентларини боғловчи яна бир восита - пайт равиши хам иштирок этаяпти. Бошқача айтганда, бир куни пайт равиши икки компонентни боғловчи восита вазифасини бажараяпти. Шунга кўра, биз мазкур деривацион жараён дубльоперторга таянган дейишимиз мумкин. Тўғри, у олмошининг бир куни равишига нисбатан салмоғи кучлироқ эканлиги бир қараганда сезилади. Аммо у олмоши икки компонентни масаланинг Курбобой тўғрисида кетаётганлигини хисобга олиб боғласа, бир куни равиши уларни замон ва макон сатхида боғлаб келаётганлигини кўриш мумкин.

Иккинчи мисол хам абзац қолипидаги макроматн бўлиб, у уч компонентдан иборат. Унда хам Икромжон сўзининг ўрнига иккинчи жумлада у олмоши қўлланилган. Бундан ташқари, мазкур мисолда хам кўш операторлик ходисасини кузатишимиз мумкин. Яъни у олмоши билан бирга хозир равиши оператор вазифасида келмоқда. Аммо шуни хам таъкидлаш лозимки, мазкур мисолда хозир равишиниг салмоғи у олмошига нисбатан кучлироқдир. Чунки гап Икромжон хақида бораётган бўлса-да, айни пайтда унинг айнан шу вақтдаги ахволи прагматик нуқтаи назардан хам биринчи ўринда турмоқда. Бошқача айтганда, Икромжон чанқаганлиги боис, унинг айнан хозир, иложи борича тезроқ чой ичмоқчи бўлганлиги матн мазмунидан хам ангилашилмоқда. Аша шунга асосланган холда, биз мазкур мисолда у олмоши эмас, балки хозир равиши кучлироқ салмоққа эга дея оламиз. Кўринадики, матн деривациясида кўш операторлик ходисаси кузатилса, операторлардан қайси бири каттароқ мавқега эга эканлигини матннинг семантик табиатига қараб аниқлаш мумкин.

Келтирилган мисолларнинг учинчиси икки компонентдан иборат. Лекин унда вазият юқоридаги икки мисолга нисбатан бирмунча бошқачароқ. Юқоридаги абзацларда жумлалар орасида бевосита боғланиш кузатилса, учинчи мисолда матн компонентлари ўртасида боғланиш нисбатан сустроқ эканлиги кўзга ташланади. Агар биз иккинчи жумла бошида келган ундан нарирокда ўрин равишини олиб ташласак, икки жумла ўртасида кескин узилиш хосил бўлганини сезишимиз мумкин. Ана шунда матн компонетлари ўртасида бевосита эмас, радиал муносабат яққол сезилади:

Катта садақ̧айравочнинг тегида икки зўр самоворва ўт құалаб құайнатардилар - Бирикки киши уч-туртт құоп бодрингни бир-бирига суяб «Мирзақирон бодринг, касир-касир бодринг!»- деб мақташардилар (А. Қодирий. Улоқ̧да).

Кўринадики, ундан нарироркда равиши матн компонентларини синтактик-семантик жихатдан боғлаб тургани изох талаб қилмайди. Бу эса унга синтактик деривация оператори мақомини беради.

Тўртинчи мисолда пайт равиши абзацлараро муносабатни шакллантираяпти. Иккинчи абзац бошида келган ўша куни равиши мазкур абзацни биринчисига боғловчи восита сифатида фаоллашаяпти. 
Мисолдан кўринадики, икки абзац мазмун жихатдан бир-бирига чамбарчас боғланмаган. Бошқача айтганда, абзацлар ўртасида бевосита семантик алоқа мавжудлиги кўзга ташланмайди. Биринчи абзацда, район ўт ўчириш командасининг пенсияга чиқаётган кекса ходимини табриклаш тантанаси тасвирланган бўлса, иккинчисида асар қахрамонининг умумий ахволи хақида ёзилган. Кўринадики, абзацларнинг хар бири алохида мустақил воқеалар тасвирини бермокда ва бири иккинчиси билан мазмунан боғланмаган. Бироқ шундай бўлса хам, улар ўртасида радиал муносабат мавжудлигини кўрамиз. Бундан ташқари, айнан ўша куни равиши ана шу мазмун жихатидан бир-бирига йироқ абзацларни боғлаб, уларнинг семантик хамда синтактик узвийлигини таъминлаяпти. Бу эса мазкур равишга оператор мақомини бераяпти.

Шуни хам айтиш жоизки, айрим холларда равишларнинг матн компонентларини синтактик жихатдан боғлаб келишида биз боғловчиларга хос бўлган элементларни яна хам яққол кузатишимиз мумкин:

Ўма куни мен кўринмай юрдим.Эртасига бой мени құидириб, чалпак құлиб куттартириб олиб келди. Аввал курттаккина қ̧илиб йигирма қ̧амчи бош-кўз аралаш едик. Сўнгра сурради... (Ғ.Ғулом. Шум бола).

Берилган абзац тўрт компонентли бўлиб, уларнинг хар тўрталаси хам бир-бири билан мазмунан ўта узвий боғланганини кўрамиз: биринчи компонентда тавсифи берилаётган фикр қолган компонентларда хам давом эттирилмоқда. Бу узвийликни эса хар тўртала компонентнинг бошида келаётган пайт равишлари таъминлаяпти. Биринчи жумладаги ўша куни, иккинчисида эртасига, кейигисида аввал ва нихоят, охиргисидаги сўнгра равишлари матн компонентларини кетма-кетликда бир-бири билан боғлаб келмокда. Шу билан бирга, биз мазкур абзацда хам қўш операторлик ходисасини кўрамиз. Бироқ бу матннинг синтактик деривациясида қўш операторлик ходисаси биз юқорида кузатган бошқа матнлардаги кўш операторлик ходисасидан бирмунча фарқ қилади. Юқоридаги холатларда биз операторлардан бирининг салмоғи бошқасига нисбатан кучлироқ эканлигини кузатган бўлсак, мазкур матнда биз операторларнинг хар тўрталасининг хам синтактик, хам семантик салмоғи бир хил мавқеда эканлигини гувохи бўламиз. Хатто бу вазиятда биз операторлар жуфтлашиб келаётганлигини кузатамиз: ўша куни - эртасига, аввал - сўнгра.

Прагматик нуқтаи назардан хам мазкур равишлар воқеа-ходисанинг кетма-кетлигини таъминлаяпти. Шунга ўхшаган кетма-кетликни қуйидаги мисолларда хам кўришимиз мукин:

1. ... Иссиқ кўрпага ўраб, құайноқ-қ̧айноқ чой ичиришди. Хар чой хўплаганимда журрттага бир инқ̧иллаб қўяман. Ичимга иссиқ кириши билан хузур құлиб ухлаб қуолибман.

Эртасига биринчи құилган ишим құитловимизда ямайдиган Сорахон фолбиннинг ишларини текшириб кўриш бўлди...(Х. Тўхтабоев. Сариқ девни миниб).

2. Биз куйларни бир саройга қ̧амаб, овқฺатланган бўлдик. Кейин бир оз ёнбошлаб дам олдик (Ғ. Ғулом. Шум бола).

3. Кампир беморнинг туззиган сочларини тузатди, у ёқ бу ёвини силади, суунгра...уттириб йивлади (А.Қаххор.Бемор).

Келтирилганлардан кўриш мумкинки, хар учала мисолда хам деривация операндлари синтактик боғланишини пайт равишлари таъминлаб келмокда. Табиийки, бу билан мазкур равишлар деривация операторлари мақомини олмоқда.

Шуни хам таъкидлаш керакки, пайт равиши биринчи мисолда икки абзацни, иккинчи мисолда абзац қолипидаги матн компонентларини, учинчи мисолда эса мураккаб синтактик қурилма компонентларини синтактик-семантик жихатдан боғлаб келмоқда. Эътиборлиси шундаки, хар учала вазиятда хам равишлар воқеа-ходисаларнинг кетма-кетлигини таъминлаяпти.

Матн компонентларини боғловчи лексик хамда морфологик воситалар таркибида ўзлари қўлланилаётган матнни олдинги матн билан боғлаш учун хам хизмат қилганда ва бу орқали таъсир доираси кенгайганда супероператор мақомини олади. Бошқача айтганда, мазкур воситалар абзацлараро боғланишни хосил қилганда супероператор вазифасини бажаради. 
Биз равишларни боғловчиларга тенглаштирар эканмиз, улар хам боғловчилар каби матн компонентларини макон ва замонда боғлаб туриши табиийлигини инкор эта олмаймиз. Шунга кўра матн компонентларининг ўрин ва пайт равишлари орқали боғланишини хам биз континуум тушунчаси билан боғласак бўлади.

Бадиий матннинг макон ва замон праметрлари бошқа матнлардан кескин фарқ қилади. Бадиий асарда ўз дунёсини яратар экан, муаллиф воқеалар кетма-кетлигини маълум асосмундарижасига эга бўлган ахборотлар чегарасидан чиқмаган холда, ўз ички хис туйғулари, хохиши, ўзига хос услубига кўра кенгайтириши, шиддатини ошириши, кескин узиши, хамда яна қайта тўхтаган жойидан давом эттириши мумкин. Бу, албатта, юқорида хам таъкидлаб ўтганимиздек, муаллифнинг прагматик кўрсаткичлари билан хам боғлиқ бўлади.

Таъкидлаш жоизки, бадиий матнда континуум хар доим хам воқеа-ходисаларнинг замон ва маконда узвий кетма-кетлигига асосланавермайди. Айрим холлада воқеаларнинг реал кетма-кетлиги бузилиши хам мумкин. Бундай вазиятларда бизнинг онгимиз вақт континуумини реал намоён бўлишига мухтож бўлади [1.87] . Чунки бадиий асарда воқеаларнинг макон ва замонда боғланиши қанчалик ўзгарувчан бўлса, асар орқали узатилаётган концептуал ахборотни қабул қилиш шунчалик қийинлашади. Негаки вақт ва маконнинг кескин алмашинуви ахборот қабул қилувчини бир оз шошириб кўяди. Ана шу кескин алмашув эса матн таркибида келган ўрин ва пайт равишлари (бугун, эртага, ўтган йили, хозир; яқинда, узоқда, олдинда, ортда ва х. к. ) орқали силлиқ амалга ошади хамда китобхоннинг тасаввурида бу алмашиниш у даражада кескин юз бермагандек туюлиб, воқеалар яхлитланиб кетади.

\section{Фойдаланилган адабиётлар руйхати}

1. Гальперин И.Р. Текст как объект лингвистического исследования. - М., 2006.

2. Храковский В.С. Трансформация и деривация // Проблемы структурной лингвистики -1972.- М.: Наука, 1973, 599 с. (489-507).

3. Ғуломов А., Асқарова М. Хозирги ўзбек адабий тили. - Тошкент : Ўқитувчи, 1987.

\section{“词语 $\Leftrightarrow$ 文本”的分析方法 МЕТОД АНАЛИЗА «ТЕКСТ СЛОВА»}

杨明天 博士 教授

上海外国语大学，上海 (Ян Минтянь Шанхай)

\section{摘要}

依据语言文化学的基本观点，归纳“词语 $\Leftrightarrow$ 文本”分析方法。“当人的规范感觉被培养起来以 后，他开始感到所有的有理由的偏离规范所带来的美妙（体验）”。计算机要达到诗人对语言的敏感 程度和使用能力, 然后才有可能进行分析。把文本分析模式化, 使用计算机进行诗歌文本分析的前 景遥远。

\section{关键词}

语言文化学，词语，文本，规范，计算机分析; Лингвокультурология, слово, текст, норма, компьютерный анализ; Linguoculturology, word, text, norm, computer analysis

Секция: Методика и теория дидактики в преподавании иностранных языков

Shangwaie@163.com; 1660@shisu.edu.cn

Тел. 13917860327

杰伊基娜（А.Д. Дейкина）等主编的俄语教材，通过摘引的形式，表达了 一定的语言文化观点，归纳了“词语 $\Leftrightarrow$ 文本”分析方法。这些内容对于语文教学 
具有借鉴意义,对借助计算机进行文本分析也具有启发作用。依据教材 8 , 归纳 如下（有些观点，不再具体指出教材具体页码）。

\section{引言}

我们关注的基本的语言文化观点包括：语言与思维的关系，语言与民族性 格、民族自我意识和文学表达的联系。陀思妥耶夫斯基对语言与思维的关系曾 经有过深刻论述:

“语言是什么......为什么需要词语? 毫无疑问, 语言是思维的形式、实体、外壳...... 由此, 很 清楚, 掌握的用以表达思想的材料和形式越是丰富, 个人的生活就会更幸福, 对自身、对别人来 说, 表达更为清晰, 更容易被理解, 更具有影响、更容易说服别人; 对自己更快说出想说的内容, 更深刻地说出, 更深刻理解曾想说出的内容, 个人的精神更加坚强和平静—— 当然, 他也就更聪 明。很清楚, 我们把愿意借助它进行思考的语言掌握得越灵活、越丰富, 通过语言表达我们的思想 就越多样和丰富”。“......语言, 民众, 在我们语言（俄语）里是同义词, 其中具有多么丰富、深刻 的思想! ”如果没有普希金（及其创作）, 可能也不会以这种无法战胜的力量（虽然不是在所有人 那里, 而是在少数人那里后来表现出来), 确定我们对我们俄罗斯的独立性的信任, 我们也不会有 意识地寄希望于我们民众的力量, 从而相信未来在欧洲民族家庭中的独立使命”。

语言与民族性格、民族自我意识和文学表达的联系，对大多数俄罗斯作家 而言, 是显而易见的。冈察洛夫曾说, 所有民族都应当为人类贡献他们最优秀 的成果, “为此, 需要俄罗斯人做俄罗斯人, 最能把我们和自己民族联系在一 起的, 就是语言” 。利哈乔夫说, “我们的言语, 不只是我们行为的重要部分, 还是我们的个性、灵魂和理智的重要部分”。

以上内容是俄语语言文化学认同的基本理论。值得注意的是, 这些内容出 现在俄语原版教材中, 是以俄语为母语的学生 (10-11 年级) 应该了解的内 容。这些观点对于消除片面强调语言“工具论”和“唯理论”的影响具有帮助。

\section{1 选辞的痛苦}

“任何词语都在概括”。只有人能够指明, 在他思想、情感和行为中, 隐藏 和展开了词语的多少色彩。如果语言是开放的系统, 那么, 人对词语的解释, 确实是无穷的 ${ }^{10}$ 。语法无法预先确定, 人应当选择什么词, 以何种组合与从属 的顺序排列这些词语, 使话语有力而准确。在每种具体情形下, 语言的使用者 应当自己, 也只有自己解决。考虑词语所有色彩、形式和组合的多样性, 全面 理解、感觉语言材料 ${ }^{11}$ 。

语言实践就是不断创造，寻求更接近真理的对思想、情感、体验的表达。 这一过程是无穷的。陀思妥耶夫斯基在《少年》中通过韦尔西洛夫说: “而 你，有时候会感到痛苦，思想没有通过言辞得到表达！这是崇高的痛苦，我的 朋友，只是赋予那些被选定的人; 俊人总是满足于他说过的话”。思想与言辞 紧密联系，使用词语表达思想并非易事，需要努力寻求更好的表达。思想（情 感，体验）可以“进入词语”的条件是，此人具有言语表达的修养，言语交流的 修养，自然应该具有思想修养12。

\footnotetext{
${ }^{8}$ Русский язык. 10-11-й кл. : учеб. для общеобразоват. учреждений : базовый и профильный уровни : в 2 ч. / А.Д. Дейкина, Т.М. Пахнова. - М.: АСТ : Астрель, 2011.

${ }^{9}$ 摘自本教材所收集的А.И. Горшков. Всё богатство, сила и гибкость нашего языка.

${ }^{10}$ 摘自本教材所婎的И. Горелов, В. Енгалычев. Безмолвный мысли знак.

${ }^{11}$ 摘自本教材所收集的M. Исаковский 语。

12 摘自本教材所收集的. Степанов语。
} 
创建文本的过程，既快乐，也痛苦。“选择言辞的痛苦”与此相关。特别是 选择文本的开端。高尔基说，“最困难的是开头，就是第一句话。就像在音乐 中, 赋予作品整体音调, 一般说来, 若要寻它, 非常费时......”。寻找能够帮 助作者“解开思维的线团, 成为小说开端”的词句 ${ }^{13}$ 。“思维的线团”的形象, 非常 准确。布宁就此写道:

“第一句话具有决定性的意义。它确定作品的整体方向。如果没有正确找到这个最初的声音, 那么肯定, 你或者搞乱、推迟已经开始的内容, 或者扔掉已经开始的内容, 就像不合适、不能用的 东西”。

作家，特别是诗人及其诗歌，追求全面“探求实质”，在外表下看到隐藏的 实质。“在可见的外壳下, 看到它的本质”。诗人追求认识自然、社会、自身, 达到根本、根基，他的技巧与此联系。技巧不独立存在，不脱离诗人寻求生死 的实质，不脱离诗人的体验与思想，不脱离他的哲学立场和公民的立场 ${ }^{14}$ 。

“诗歌草稿反映什么秘密? 诗人的手稿, 到处是修改。这说明什么? 说明沿着这些阶梯通往某 种真实, 这种诗歌的真实, 确实存在, 它被隐藏, ——即使不可测量, 无法看到, 但是, 可以感 觉, 它最为纯洁, 15 。

真正的阅读意味着深入作品，捕捉作者的思想和情感色彩。好的作品的共 同特点是它们的涵义韵味无穷。读者不管阅读多少遍，每次都有新的发现 ${ }^{16}$ 。

\section{2 词语 $\Leftrightarrow$ 文本}

读者分析文本时完成的工作，可以称为“从文本到词语”，或者“从词语到文 本”的分析。有时关注一个词, 有助于读者深入理解整部作品, 明确文体特 点。阐发文本词语秘密的同时, 也可能找到了解作家意图、文化和精神 (心 智) 源头的途径。金兹布尔格 (Л. Гинзбург) 在《论抒情诗》中的解析, 能够 说明“词语 $\Leftrightarrow$ 文本”的分析模式。

\section{1 从词语到文本}

例如，普希金《皇村回忆》的起句:

Навис покров угрюмой нощи 阴沉夜色的帷幕低垂 / На своде дремлющих небес; 在沉睡的天穹

汉语译文是这样的：睡意矇眬的苍穹上 / 挂起了阴沉的夜幕...... ${ }^{17}$

这首诗激情昂扬，有许多感叹号和限定语。这种崇高感情在诗歌的第一句 就产生了。第一句的主词是 нощь（旧词，诗歌用语）。熟悉莱蒙诺索夫“三种 语体”理论的人知道, 这是崇高语体的标记。虽然有人可能觉得, 使用 нощи, 而不使用 ночи, 只是针对下文的 рощи 的韵脚。在标准语中, ночь 和 нощь 平 行存在, 指同样的事物, 但是, 用在不同语体中: нощь 的词典标记是传统诗 歌用语。在古斯拉夫语中, 如果是原始俄语词, 典型的情况是, 在 $\mathrm{u}$ 的位置使 用 щ。 нощь 这个词就从世纪暗影走到现代读者面前：它是俄语从古斯拉夫语 引进的。很久以来, 它通过亲属词进入俄语, 保留至今, 虽然 нощь, еженощно（旧词, 每晚）, всенощная（东正教的晚䘠）这些词，对现代人而 言，具有特殊色彩，它们是旧词。但是，正是通过这些词，语言记忆把读者和

\footnotetext{
${ }^{13}$ 摘自本教材所收集的M. Осоргин语。

${ }^{14}$ 摘自本教材所收集的Л. Озеров语。

15 摘自本教材所收集的Юлиан Тувим语。

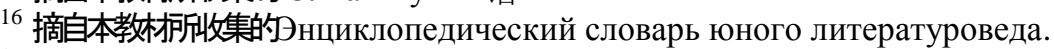

17 皇村回阳普希金 王士竖译 名作欣赏. 2011年第13期 第61-63页。
} 
语言的深层联系起来 (古斯拉夫语非常接近原始斯拉夫语, 是斯拉夫语的前 身），和文化、精神（心智）的源头联系。

这种时间印记, 使 нощь 这个词显得非常特别, 非常有意义, 在普希金诗 中, 就像调音器, 立刻把读者的心绪调到需要的位置 一 崇高、庄严。如果 在这行诗中使用 ночь, 经过对比可以看到, 许多涵义随着 нощь 失去。

总之，注意词语、语言、表达形式，它们在文本中不仅激起读者的语感， 而且赋予读者记忆—祖辈的记忆, 历史和文化记忆。这首诗的汉语译本, 结合整体的意思, 把 нощь 翻译成“夜幕”。可以看到, 这个词对以俄语为母语 的人而言激发的联想与情感, 这是以汉语为母语、不懂俄语的人所无法体会的 18。普希金说, 真正的品味, 不在于无意识拒绝某个词、词组, 而在于相称性 和合乎规则的感觉。

\section{2 从文本到词语}

金兹布尔格在《论抒情诗》中分析了普希金的《来自宾德蒙泰》（И3 Пиндемонти），她发现，固定的象征与“好像第一次看到的事物”之间存在强烈 互动, 这是非常有意义的现象。例如:

....Никому 不要为任何人 / Отчёта не давать, себе лишь самому 负责, 只对自身 / Служить и угождать; для власти, для ливреи 服侍和讨好; 对权力, 对制服 / Не гнуть ни совести, ни помыслов, ни шеи; 不要扭曲良心、意图, 还有脖子; / По прихоти своей скитаться здесь и там, 一时兴起到处游 荡, / Дивясь божественным природы красотам, 惊叹自然神奇美丽, / И пред созданьями искусств и вдохновенья 在艺术和灵感的创造前 / Трепеща радостно в восторгах умиленья... (Из Пиндемонти) 在柔情喜悦中快乐颤抖......

前两句句法结构明晰，散文特点明显，词语“赤裸”，达到极端。作者列 举、直接称名概念, 不作任何形象阐释, 词语用于概括意义。

在这样的上下文中, ливрея（华丽的仆役制服）是唯一的借喻，加强“服 侍”和“讨好”两个词的意思, 特别是“讨好”, 表现卑躬屈膝的特点。它对临近的 власть（权力）这个词产生强烈作用。在诗歌语言系统中，与“权力”相关的联 想是英雄主义的表征。但是, 因为与“制服”关联, “权力”从具有崇高色彩的序 列, 跌入官僚关系的领域。

在下一行 Не гнуть ни совести, ни помыслов, ни шеи... （既不扭曲良心、 意愿, 也不卑躬屈膝）, гнуть шею（卑躬屈膝）这个隐喻被纳入带有抽象词 语“意愿和良心”的统一句法表达公式而被激活。

在下面诗行中, 主题是自然与创作的对立。词汇氛围发生改变:

Дивясь божественным природы красотам, 惊奇于自然的神圣之美 / И пред созданьями искусств и вдохновенья 在艺术和灵感的创造面前 / Трепеща радостно в восторгах умиленья... 在柔情的喜悦中 快乐地颤抖.......

“自然”、“美好”、“艺术”、“灵感”，具有稳定的价值特征和传统的情感意 义, 对人而言, 都是主要现象, 只要称名它们, 就可以引起读者应有的联想和 情感。普希金在后期的抒情诗中, 创造出永恒的象征与那些好像第一次看到的 事物, 刚刚来自现实的事物之间的强烈互动19。

\footnotetext{
${ }^{18}$ 摘自本教材所收集的下. Злобина语。

${ }^{19}$ 摘自本教材所收集的片. Гинзбург. О лирике.
} 
与抒情体裁的诗歌表达公式（1810-1820）不同，普希金的“裸”词，就是没 有预先联想的词, 涵义潜力巨大，在新的未预见的转变中，具有认识事物的可 能。例如:

Люблю я пышное природы увяданье, 我热爱自然豪华的调零, / В багрец и в золото одетые леса, 森林穿着深红与金黄的衣裳, / В их сенях ветра шум, и свежее дыханье, 树影里风声喧器, 还有 清新的气息, / И мглой волнистою покрыты небеса... 天空覆盖浪涛般的雾靁........

“天空覆盖雾靄”，这是普通的诗歌表达，但是，普希金说：“浪涛般的雾 靄”, 这是已经看到的云朵的形状, 景色的细节。“自然的调零”这也是普遍 的，常用的说法，但是，通过使用“豪华”的定语，普希金打破固化的表达公 式，把它与下一句的主题糅合在一起，“森林穿着深红与金黄的衣裳”。

再如:

Ведут ко мне коня; в раздолии открытом, 为我牵马过来; 它在开阔无垠中, / Махая гривою, он всадника несет, 舞动鬃毛, 驮着骑手奔驰, / И звонко под его блистающим копытом 闪亮的马蹄下清 澈 / Звенит промерзлый дол и трескается лед. 鸣响冻彻的山谷, 冰块嘎吱作响。

“闪亮的马蹄”，这样的表达令人惊奇。普希金把“冰冻的山谷”，“嘎吱作响 的冰块”看作冬天的稳定形象, 马蹄带着雪花、闪亮的冰屑, 冰块嘎吱作响。 这样，马蹄也成为诗歌中的美景。

普希金一会儿是把词汇序列进行对比，一会儿把它们结合在一起，普通词 语带着它的原始特性，进入崇高美妙的氛围。具有诗歌光环的传统表达公式， 无法预见的散文表达, 不断来自现实的宝藏, 它们之间产生互动。重要、美丽 的领域, 吸引其他领域, 变革普通事物。诗歌文本的语境对词语产生影响。

промёрзлый（冻硬），трескается（爆裂），这些词可能不会被用于经典的 哀歌作品； копыто（蹄）这个词，更多属于口语语汇。在普希金的《秋天》这 首诗里, 这些表示事物意义的词, 同时也是思想的媒介, 指示自由的乡村生 活、俄罗斯的自然和具有灵感的劳动。

普希金从未没有理由地推翻传统。在抒情诗作中，他完全保留传统形象， 世代使用的诗歌表达公式, 它们能够立刻正确引发读者的情感反应和确定的表 征。在普希金的后期抒情诗中，传统的象征经常把普通词汇纳入自己的范围， 好像是通过周围环境的诗性感染它。或者相反，在“散文”上下文中提醒传统诗 学词语的出现。

别林斯基曾说，普希金具有惊人的能力，“把散文化的事物变得富有诗 意” 20 。众所周知，具有诗歌性质的，不一定是“神圣的语言”，也可以是普通 词，口语词，甚至是粗俗词。例如杰尔查文、普希金、尼古拉索夫、马雅科夫 斯基等人的抒情诗。显而易见，被纳入诗歌的词语，其中包括漂亮的词语，如 果没有言语的特殊结构, 没有可以把词语变为诗歌思维工具的内部转变, 使它 脱离散文用法，对诗歌来说，它还是外在材料。

词语的转变是在诗歌上下文中完成的。上下文是理解词语的钥匙, 它可能 改变词语的语义范围, 推动、促进它的一些特征的发展, 隐藏其他的一些特 征，扩展这个词，在它的上面培植联想层次。艺术上下文具有不同容量，远远

\footnotetext{
${ }^{20}$ 摘自本教材所收集的Л. Гинзбург语。
} 
超出一部作品的范围 ${ }^{21}$ 。诗歌上下文, 从一句话, 一个韵律-句法单位, 一部作 品，作家的创作周期，到文学流派和风格，这是可以扩展的概念。

真正的技能，其中包括语言创作的技能，很少表现为狂暴的词语创作，不像未来派所 做的事情, 而在于从已有的词语当中进行创造, 感觉语言的精神, 把它们细致联系起来, 准 确地说, 把它们的意思汇集为新的意思、新的形式, 例如浐语、俗语和表达。民众一直这样 实践, 当然没有意识到这一专门任务, 因此, 大多数新词和构词都是无名创作, 不是从书籍 进入语言的 22 。

\section{3 文本的词汇分析}

在这部教材中, 还总结了文本的词汇分析方法。我们做了一些补充。对文本进行词汇 分析, 需要分析以下内容:

\section{1 关键词（词组）;}

3.2 用作转义的词语;

3.3 同义词、反义词（其中包括上下文）和同音异义词;

3.4 具有修辞标记的词语（例如：崇高语体色彩、书面语体色彩、口语色彩、俗语色 彩、正式语体的色彩，等等）;

3.5 外来词、旧词、新词（包括作家使用的随机词语）、专业词、方言词和熟语;

以后需要完成的是:

3.6 解释这些词汇意义在文本中的作用、功能与效果;

3.7 确定 (查阅词典) 词语序列的意义。如果词语是多义的, 那么需要确定, 它在文中 用于哪种意义;

3.8 为词语序列选择同义词, 构成同义序列, 说明同义词的差别, 解释作者选词的合理 性;

3.9 观察文本使用的词汇重复 (使用同一个词, 同根词。此时需要对词语进行形态分 析）；特别注意那些用于不同意义的词语的重复;

3.10 说明作者借助什么词汇手段保证文本句际、段落之间的联系（注意相同主题的词 汇的作用，词汇重复、同义词、反义词，其中包括上下文形成的同义词、反义词的使用）。

3.11 对不同体裁的文本进行词汇分析, 具有自己的特点。在分析文学文本时, 应当指 明文学表达的手段, 指出文本如何实现词汇手段的修辞潜力。如果分析政论语体、文学语体 的文本, 那么, 词汇分析的层面应当包括对词汇手段使用的观察, 借助这些手段, 作者表达 自己的态度和评价（例如品评词汇、具有修辞色彩的词语、词汇重复、同义词、反义词，等 等)。

3.12 在分析文学文本关键词的使用特点时, 引入“更为广阔的上下文”, 并且说明, 在 作家的其他作品中, 这些词语是如何使用的。

一般所说的文本的词汇分析，指部分词汇分析。关于 3.9 所说的词语的形态分析，可以 根据教材的材料, 在此做些补充。在尚斯基（Н.М. Шанский）看来, 对词语进行形态分 析，类似一层层拆开俄罗斯套娃。例如:

从“词尾”开始层层分析, 分析顺序与构词过程相反。这样, 可以突出词中存在的有意 义的部分, 确定它们的实际意义, 区分相似的, 但不同的有意义的部分, 还有词语的结构类 型。同时, 可能在词语内部, 确定词素的相互关系和词语的结构公式。依据亲属关系, 在词 中有序区分词素, 最后区分词根。这一划分原则, 应该是确定的。就像套娃, 不可能立刻拿 出最后最小的套娃, 它无法进一步区分, 其中不再包括更小的套娃, 也不可能在所有情形下 都正确地“一下子”从词语的多个词素中析出词根。词语是具有组织的结构整体。

\section{4 创作的秘密}

\footnotetext{
${ }^{21}$ 摘自本教材所收集的Л. Гинзбург. О лирике.

22 摘自本教材所收集的A. Кондратович语。
} 
“语言是壮丽的系统，它的世界是和谐的”，需要“搞清语言系统的构造，它的完善和秘 密”。如果不思考语言系统的概念, “其构造的普遍规律, 也就是每个语言单位针对其他语言 单位的作用, 如果得不到研究, 整个壮丽的殿堂, 就会崩塌, 成为砖块、饰框、支柱、门廊 和圆顶，等等。”23词语就像语言系统的太阳。就像太阳内部，巨大的压力和温度使其内部成 分发生结合与分裂, 来自词语的辐射, 到达语言宇宙遥远的角落, 保障其中一切运动、和谐 与活力 ${ }^{24}$ 。诗人在大多数情况下并不创造新词, 使用现成的, 民众已经创造的词语的宝石, 传达不同的感情色彩。

文学创作，包括诗歌的所有秘密（它的涵义、意义）在于, 针对同样事物的同样词 语, 突然重组, 重新排列, 成为其他序列, 转变为其他性质。就像相同的砖块重组, 不再是 绿茵田园牧歌式的小屋, 变成阴郁的高塔或者哥特教堂的和声 ${ }^{25}$ 。

谢尔巴 (Л. Щерба) 说, 当人的规范感觉被培养起来以后, 他开始感到所有的有理由 的偏离规范所带来的美妙 ${ }^{26}$ 。仅从这一点来看, 把文本分析模式化, 使用计算机进行诗歌文 本分析的前景可能还是比较遥远的 ${ }^{27}$ 。计算机要达到诗人对语言的敏感程度和使用能力, 然 后才有可能进行分析。

\title{
结语
}

语言是文化的重要成分。人如果不依靠母语的记忆, 很快就失去自我, 变得只是外表 上的某一国家的人, 实则是某种世界现象, 因为失去自己整体历史。一个民族, 如果失去自 己的历史语言, 可能失去的就是自身的心理和精神, 与伟大的艺术作品绝交, 与祖先隔离, 自我遗忘。正是在语言中, 通过词语, 民众受到教育和培养 ${ }^{28}$ 。

\section{ТУРКИЙ ТИЛЛАРДАГИ МОРФОЛОГИК АНАЛИЗАТОРЛАР ХУСУСИДА}

\author{
Хамроева Шахло Мирджоновна \\ (Тошкент давлат узбек тили ва адабиёти университети \\ докторанти,ф. ф. фалсафа доктори (PhD) \\ Менглиев Бахтиёр Ражабович \\ (Тошкент давлат уззбек тили ва адабиёти университети \\ профессори, ф.ф.. .)
}

\begin{abstract}
Annotation: The article describes the morphological analyzers available in Turkic languages, their specific, general and different aspects. It is also recommended to use the experience of these morphoanalysts to create a morphological analyzer of the Uzbek language. Due to the fact that the Uzbek language has agglutinative features, there is a wide range of grammatical meanings. Therefore, the unification of grammatical forms is important in the construction of a morphological analyzer. Although there are different ways of constructing a morphological analyzer in the practice of computer linguistics, many analyzers created in Turkic languages exhibit the feature of a two-level morphological analyzer. Therefore, it is expedient to base the morphological analyzer of the Uzbek language on the theory of two-stage morphological analysis. The article analyzes these issues in detail.

Key words and expressions: Turkish, Uzbek, Tatar, morphological analyzer, linguistic support, automatic morphological analysis, information retrieval system.

Табиий тилга автоматик ишлов бериш масаласи жахон тилшунослигида кенг тадқиқ этилган. Масалан, рус тилшунослиги ва компьютер лингвистикасида морфологик анализатор, унинг умумий тавсифи, ишлаш принциплари, тилга оид грамматик категория,

\footnotetext{
${ }^{23}$ 摘自本教材所收集的次. Максимов语。

24 同上。

25 摘自本教材所收集的B. Солоухин. Большое Шахматово.

26 摘自本教材所收集的次. Щерба语。

27 刘金硕等. 文本情感倾向性分析方法：bfsmPMI-SVM. 武汉大学学报 (理学版). 2017年, 第63卷 第3期 259-264.

${ }^{28}$ 摘自本教材所收集的B. Колесов语。
} 
дастур учун лингвистик модулларлар тавсифи хақидаги ишлар сифатида О.В.Дереза, Д.А.Каютенко, А.С.Феногенова[Дереза; 9], М.Хакимов[Хакимов; 16]нинг ишларини келтириш мумкин. Туркий тилшуносликда хам табиий тилнинг компьютер ишлови, морфологик анализатор тузиш масалари кенг тадқиқ этилган. Бундай ишлар сирасига А.В.Дыбо, А.В.Шеймович [Дибо;10], А.Р.Гатиатуллин, А.М.Баширов [Гатиатуллин; 8], П.В.Желтов [Желтов; 12], Н.А.Исраилова, П.С.Бакасова [Исраилова; 13]ларнинг турли тадқиқотларини киритиш мумкин. Ўзбек тили морфологик анализаторини тузиш махсус тадқиқот предмети бўлмаган бўлса-да, айрим тадқиқотларда масаланинг баъзи қирралари хақида фикр билдирилган. Жумладан, М.Орхун [Орхун; 5,14], Н.Абдурахмонова [Абдурахмонова;1], М.Абжалова [Абжалова;7], У.Турсунов[Турсунов;15]нинг ишларини шундай тадқиқотлар сирасига киритиш жоиз. М.Орхун ўзбек тили отларини қидирув тизимида автоматик қайта ишлаш хамда морфологик анализаторнинг айрим хусусиятлари хақида тўхталар экан, ўзбек тили морфологик анализаторида бажарилиши мумкин бўлган жараёнлар хақида фикр билдиради. Табиий тилни қайта ишлашнинг биринчи босқичи морфологик тахлил ечими.

Маълумки, ўзбек тили агглютинатив хусусиятга эга, грамматик маънонинг кўшимча билан ифодаланиш имконияти кенг. Шу сабабли морфологик анализатор тузишда грамматик шаклларнинг унификация қилиниши мухим ахамият касб этади. Компьютер лингвистикаси тажрибасида морфологик анализатор тузишнинг турли усули мавжуд бўлса-да, туркий тилларда яратилган кўпгина анализатор икки даражали морфологик анализатор хусусиятини намоён қилади. Демак, ўзбек тили морфологик анализаторини тузишда хам икки босқичли морфологик анализ назариясига асосланиш мақсадга мувофиқ.

А.В.Дибо, А.В.Шеймович қадимги туркий тиллар ва хакас тили морфологик анализаторини яратишда дастлаб грамматик категориялар тавсифини ўрганишади. Олтой тилларини тавсифлашда қабул қилинган анъанага кўра, хакас тилида қуйидаги асосий грамматик синфлар ажраталади: номлар, феъллар. Гурухдаги дастлабки икки синф маълум расмий кўрсаткич (аффикс)лар билан ифодаланган грамматик тоифалар тўплами билан тавсифланади. Граммемалар тўплами сўзни сўзга тобелантириб боғлаш хамда синтактик шакл ясовчилар парадигмасини ажратади. Масалан, феъл учун шахс, сон, майл, замон, от учун сон, эгалик, келишик. Маълумки, туркий тилларда грамматик синфлар орасидаги дифференциациянинг ифодаланиши кучсиз. Хусусан, исмлар орасида бу хусусият кенг тарқалган: гапдаги вазифасига қараб бир сўз хам от, хам сифат сифатида қаралиш холатлари кузатилади [Дыбо;11; 20-26].

Шунингдек, морфологик анализатор тузишда сўз асослари луғати хам мухим лингвистик таъминот вазифасини ўтайди. Хакас тили морфологик анализаторини тузишда леммаларни гурухлашда юқорида тахлил қилинган масала алохида эътиборга олинган. Туркий тиллар морфологик тахлил тизими хамда уларнинг моделлари тавсифи, тахлилига бағишланган бир қанча тадқиқотлар [Oflazer; 4] мавжуд. Қуйида уларнинг айримлари билан танишамиз.

А.В.Дибо, А.В.Шеймовичнинг туркий тиллар автоматик морфологик анализи борасидаги фикрлари ахамиятга молик [Дибо; 11; 20-26]. Мақолада туркий тиллар учун автоматик морфологик анализаторнинг ишлаш тамойиллари тавсифланган. Унинг асосий таркибий қисми сифатида куйидагилар ажратилади:

1) тилнинг грамматик луғати;

2) сўз шаклининг тартибли модели (сўзшакл позициялар тўплами ва бу позициялар учун кўшимчаларнинг морфологик ифодалари);

3) сўзшакли чегарасида кўшимчанинг мувофиқлик қоидалари хамда маълум бир қўшимчанинг алломорфларини танлаш учун икки даражали фонетик қоидалар.

Парсернинг ишлаш алгоритми Ф.Крилов томонидан StarLing тизими базаси асосида ишлаб чиқилган қоидалар тизимига бўйсунади. Намуна сифатида қадимги турк тили морфологик анализатори версияси келтирилади. Туркий тиллар учун мўлжалланган анализатор рус ёки немис тиллари каби хинд-европа тилларига мўлжалланган Аbbуy 
Finereader, Abbyy Lingvo каби йирик дастурий махсулотларда ишлатиладиган автоматик морфологик анализаторлар билан бир хил тамойил асосида ишлаб чиқилади. Луғатдаги хар бир лемма парадигма индекси шаклини олади. Флектив тилда парадигмалар катта эмас, аммо уларнинг сони кўп. Анализатор хар бир сўз учун тўлиқ парадигмани шакллантиради, кейин матнда учраган сўзшаклни шу парадигма билан қиёслайди. А.В.Дибо, А.В.Шеймовичлар олтой гурухига кирувчи туркий тиллар морфологик анализатори хусусиятини ёритар экан, ушбу метод барча агглютинатив тиллар учун оптимал усул эмаслигига урғу беради.

А.В.Дибо, А.В.Шеймович агглютинатив тилларнинг хусусиятларини қуйидагича фарқлашади [Дибо; 11; 20-26]:

1) синтактик шакл ясовчи кўшимчалар тизими кенг ривожланган; бундай кўшимчаларнинг кўпчилик қисми грамматик жихатдан бир маъноли, яъни қўшимчанинг ўзи грамматик омонимияни хосил қилмайди (бир грамматик шакл битта грамматик маънони ифодалайди;

2) турланиш, тусланишнинг ягона усули мавжудлиги, яъни (флектив тилларга қараганда) исм ва феъллар орасида турланиш хамда тусланиш тизимида фарқ катта эмас;

3) мураккаб морфонологик ходисалар мавжуд эмас: алломорфлар қўлланишининг аниқ қоидалари мавжуд.

Агглютинатив сўзшакллар асосга стандарт грамматик шаклларнинг қатъий тартибда қўшилишидан хосил бўлади: морфеманинг чегараси аниқ, морфемалар кўшилишидан хосил бўладиган фонетик ходисалар қоидаси қатьий. Маълум бир сўзшаклнинг парадигмасини тузиш сўзшаклнинг фавқулодда мураккаб, кўптармоқли эканлигини кўрсатади. Бу мураккаблик синтактик шакл ясовчи шаклларнинг кўплиги билан изохланади. Бу эса туркий тиллар морфологик анализаторини тузишда морфемалар комбинациясининг ахамиятни катта эканлигидан далолат беради. Туркий тилларнинг мавжуд парсерлари битта сўзшаклнинг 300гача шаклнини қамраб олган парадигмасини тузган холатларни кўриш мумкин. Бу эса анализаторнинг иш сифатига таъсир кўрсатмай қолмайди.

Туркий сўзшаклларнинг компьютер моделини тузишда агглютинатив тилларга хос анъанавий “таснифланган грамматика"га асосланилади. Бу дастурий таъминот ахборот воситаси агглютинатив тилларни тавсифлашнинг қулай воситаси, унинг морфологияси қуйидаги талабларга жавоб бериши керак:

a) сўз ясовчи қўшимчалар кетма-кетлигининг белгилаб кўйилиши;

б) сўз ясовчиларнинг грамматик бир маънолилигига эришиш;

в) маълум бир граммеманинг бир сўзшаклда қандай шаклда учрашининг белгиланганлиги [Дибо; 11; 20-26].

Морфологик анализаторнинг асосий ташкил қилувчилари сифатида қуйидагиларни кўрсатиш мумкин:

1) тил луғати (сўзнинг туркумга мансублик белгиси хақидаги изох хамда фонологик қоидалар мавжуд луғат);

2) сўзшаклининг етарли грамматик тавсифига асосланган (тилнинг автоматик тахлилига йўналтирилган) компьютер модели;

3) маълум қўшимчанинг асосга қўшилиши учун фонетик қоидаларга бўйсунувчи алломорфларини танлаш қоидалари тўплами.

Ф.Крилов томонидан тахлил алгоритми юқорида санаб ўтилган материал билан исталган туркий тил материалини тўлдириш хамда ундан фойдаланиш имконини беради. У тузган алгоритм бўйича сўзшакл тахлили ўнгдан чапга йўналтирилади. Дастлаб, дастур асослар луғатидан сўзшаклнинг тўлиқ шаклини қидиради. Агар асослар луғатида бундай шакл (белгилар кетма-кетлиги) учрамаса, парсер сўзшаклнинг ўнг томонидаги қўшимча формантига мос шаклни излайди. Агар базада мавжуд қўшимчага мос белгилар кетмакетлиги топилса, кесиб олиниб, текширишга юборилади; сўзшаклнинг чап томони асослар луғат билан солиштирилади. Агар натижа мусбат бўлса, парсер шу шаклнинг тахлилини бошлайди. Натижа манфий бўлганда, парсер яна ўнг томондаги шаклга мурожаат қилади хамда қўшимчалар базасидан мос формантни қидиради. Бу қидирув асослар луғатидан мос 
асос топилгунча давом этади. Ушбу парсер хакас тили морфологик тахлили учун ишлаб чиқилган бўлса-да, маълумотлар базасини тўлдириш орқали шор, тува, ёқут ва қадимги турк тилини морфологик тахлил қилиш мумкин. Бу тилларнинг “асослар луғати” SUBD STARLING воситасида тузилган ва катта туркий-рус тили луғати билан текширилган.

Хулоса ўрнида айтиш лозимки, морфологик анализатор тузишда асосий иш лингвистик қоидалар тизимини ишлаб чиқиш, луғатдаги хатони бартараф этишда кўп мехнат ресурси талаб қилинади. Шундай мехнатни қисқартириш ва автоматик тахлилни амалга ошириш учун автоматик тахлил воситалари талаб қилинади. Морфологик анализаторга тил лексикасининг юқори частотали сўзлари, тилда мавжуд бўлган хар қандай сўзни қайта ишлашга оид қоидалар мажмуини ишлатадиган алгоритм киритилиши мақсадга мувофиқ. Бундан ташқари, морфоанализаторда турли тахминларни инобатга олган холда сўз тахлили хақидаги фаразларни яратишга имкон берадиган мослашувчан созлама бўлиши талаб этилади. Буларнинг барчачи ахборотни автоматик тахлил қилувчи тахлил воситалари томонидан амалга оширилади. Ўзбек тили сўзшаклларини автоматик тахлил қилувчи тахлил воситаси яратилса, тил корпуси, автоматик таржима, электрон луғатлар яратиш учун маълумотларни тахлил қилиш ва қайта ишлаш жараёни автоматлаштирилади.

\section{Фойдаланилган адабиётлар руйхати}

1. Abdurakhmonova N. Uzbek ontology of Uzbek language as example of adjective // Шестая Международная конференция по компьютерной обработке тюркских языков «TurkLang-2018». (Труды конференции) - Ташкент: Издательско-полиграфический дом «NAVOIY UNIVERSITETI», 2018. - $320 \mathrm{c}$.

2. Altintas K., Cicekli I. A morphological analyzer for Crimean Tatar //Proceedings of the 10th Turkish Symposium on Artifi cial Intelligence and Neural Networks (TAINN'2001). - 2001. - P. 180-189.;

3. Çağrı Çöltekin (2014) A Set of Open Source Tools for Turkish Natural Language Processing In: Proceedings of the Ninth International Conference on Language Resources and Evaluation (LREC'14) Ed. by N. Calzolari et al. 1079-1086.;

4. Kemal Oflazer. Two-level Description of Turkish Morphology. Literary and Linguistic Computing, - Vol. 9, No 2, - 1994.;

5. Orhun M., Tantug C., Adali E.. Rule Based Analysis of the Uyghur Nouns, International Journal of Asian Lang. Proc.,19(1), 33-44, 2009.

6. Tantug C., Adali E., Oflazer K.. Computer Analysis of the Turkmen Language Morphology, 5th International Conference on NLP(FinTAL 2006), Turku, Finland, 186-193, 2006.;

7. Абжалова М.Матнларга авто-лингвистик ишлов бериш тизимлари // Шестая Международная конференция по компьютерной обработке тюркских языков «TurkLang2018». (Труды конференции) - Ташкент: Издательско-полиграфический дом «NAVOIY UNIVERSITETI», 2018. $-320 \mathrm{c}$.

8. Гатиатуллин А.Р., Баширов А.М. Морфологический анализатор тюркских словоформ на базе структурно-функциональной модели тюркской морфемы // Пятая Международная конференция по компьютерной обработке тюркских языков «TurkLang 2017». - Труды конференции. В 2-х томах. Т 2. - Казань: Издательство Академиинаук Республики Татарстан, 2017. - 327 с.

9. Дереза О.В., Каютенко Д.А., Феногенова А.С. Автоматический морфологический анализ для русского языка сравнительный анализ систем // http://www.dialog21.ru/media/3473/dereza.pdf

10. Дыбо А.В., Шеймович А.В. Автоматический морфологический анализ для корпусов хакасского и древнетюркского языков / Научное обозрение саяно-алтая рецензируемый научный журнал Номер 2(08), 2014 (Периодичность -2 раза в год. серия: Филология.Выпуск 2). С. 9-31. 
11. Дыбо А.В., ШеймовичА.В.Автоматический морфологический анализ для корпусов тюркских языков / Филология и культура. Philology and culture. - 2014. №2(36). - С. 20-26.

12. Желтов П.В. Разработка морфологического анализатора чувашского языка // Пятая Международная конференция по компьютерной обработке тюркских языков «TurkLang 2017». - Труды конференции. В 2-х томах. Т 2. - Казань: Издательство Академии наук Республики Татарстан, 2017. - 327 с.

13. Исраилова Н.А., Бакасова П.С. Морфологический анализатор кыргызского языка // Пятая Международная конференция по компьютерной обработке тюркских языков «TurkLang 2017». - Труды конференции. В 2-х томах. T 2. - Казань: Издательство Академии наук Республики Татарстан, 2017. - 327 с.

14. Орхун M. Computationalanalysisofuzbeknouns / Шестая Международная конференция по компьютерной обработке тюркских языков «TurkLang-2018». (Труды конференции) - Ташкент: Издательско-полиграфический дом «NAVOIY UNIVERSITETI», 2018. - $320 \mathrm{c}$.

15. Турсунов А.Вопросы словообразования в формальных моделях тюркских языков (на примере узбекского языка) // Шестая Международная конференция по компьютерной обработке тюркских языков «TurkLang-2018». Труды конференции) - Ташкент: Издательско-полиграфический дом «NAVOIY UNIVERSITETI», 2018. - 320 с.

16. Хакимов М.Логико-лингвистические модели русского языка // Шестая Международная конференция по компьютерной обработке тюркских языков «TurkLang2018». (Труды конференции) - Ташкент: Издательско-полиграфический дом «NAVOIY UNIVERSITETI», 2018. $-320 \mathrm{c}$.

\section{文化翻译理据性研究 MADANIY TARJIMA MOTIVATSIYASI BO'YICHA TADQIQOTLAR}

\section{杨仕章, 博士，教授 上海外国语大学，中国上海(Yan Shizhang Shanhai)}

Annotation: The basic theory of cultranslatology includes the description and interpretation of cultural translation. After describing cultural translation methods and establishing cultural translation methodology, it is necessary to further study the motivation of cultural translation. Based on the theories of culturology, linguistic culturology, text linguistics and cognitive linguistics, this paper explains the reasons of cultural translation and the selection of relevant translation methods, so as to reveal the motivation of cultural translation and strengthen the interpretive study of cultranslatology.

Key words and expressions: cultural translation; motivation; cultural contact; linguistic world view; coherence; script

\section{1.引言}

文化翻译学既需要描写性研究，也需要阐释性研究。就文化翻译方法而言，既需要揭 示文化翻译方法本身以确立文化翻译方法论, 更需要解释各种文化翻译方法的实际应用问 题。对于“为什么需要进行文化翻译”这个问题，用“文化不同”来回答虽然简洁但并不充分。 至于文化翻译中具体翻译方法的选用的理据性问题，远非“文化不同”四个字所能解释清楚。

实践表明，同一文化素在不同文本中经常会有不同的翻译方法，即便在同一文本中， 不同译者也存在不同译法的情况。因此, 要科学阐释文化翻译实践中的各种情形, 不能停留 在感性认识上, 而应当深入其中，探寻规律。为此，需要运用多门相关学科理论，以便提高 阐释的全面性和系统性。本文将以文化学、语言文化学、篇章语言学、认知语言学等学科为 理论视角, 尝试揭示文化翻译的理据性。

\section{2.文化学视角}


共时地来看, 某一文化素的翻译常有不同的方法可供选择; 历时地来看, 同一文化素 的翻译方法可能会发生更迭。文化翻译方法的选择抑或变更, 都不仅仅是译者个体意志的结 果, 更多的是译语文化影响的结果。将源语文化素翻译成译语, 实际上是一个文化接触

(cultural contact) 的过程。在此过程中，文化多元性、我族中心主义、文化熟知度等方面 可以较好地阐释独立性普通文化素翻译方法的选择与变更缘由。

文化多元性（cultural pluralism）既是世界文化的特征，有时也是同一社会文化内部的 特征，如主文化与亚文化的不同，其中亚文化包括地域亚文化和社会亚文化。

就地域亚文化而言，俄语 брюква 这个词的纯音译形式“留克”或“布留克”只在中国东 北很少的地方使用（如呼伦贝尔市）。这个词在汉语主文化中采用了描述性翻译法译为“洋 大头菜”或使用纯意译方法译成“芜菁甘蓝”。

社会亚文化属于群体文化。网络文化作为社会亚文化的一种, 在文化翻译方法的选择 上与主文化不尽相同，比如 dollar 在网络文化中没有采用意译的“美元”, 而是使用半音译的 “美刀”甚至纯音译的“刀”。

我族中心主义（ethnocentrism）也称文化本位主义。我族中心主义的弱化减少了某些翻 译方法的使用机会。音译字形意化法的式微就是一个典型现象。传统上, 汉语在翻译外来事 物时即便只能音译, 也会努力使其汉化, 字形意化就是一个常用的手段, 也就是利用形旁表 示意义或类属的特点, 另造汉字来记音, “茉莉”“柠檬”“咖啡”等名称就是这样得来的。不 过，随着我族中心主义的减弱，这一方法如今在日常外来事物的翻译中基本不再使用了。

汉民族文化我族中心主义的弱化对描述性翻译法也不无影响。历史上，汉语在翻译外 来事物时, 常常“在多少可以比较的本地物件上加上“胡”, “洋”, “番”, “西”一类的字样” [罗 常培 1989: 30]，如“胡萝卜”、“洋油”、“番茄”、“西服”等。当然，这些修饰词具有一定的 时代性。随着我国对外交往不断扩大, 文化接触与文化交流日益频繁, 我族中心主义也有所 弱化。“现在中国虽然仍然不断从国外引入新事物, 却鲜见采用类似的修饰词来给新事物命 名了。”[高晓虹, 刘晓海 2008]

文化熟知度 (степень знакомости) 取决于文化接触的广度和深度。在外汉翻译过程 中, 随着中国读者对外国文化熟知度的提升, 译者会改变翻译方法来翻译某些外来事物。例 如, 过去采取音译加类名的方法翻译而来的“芭蕾舞”（ballet）, 如今改用纯音译, 译成了 “芭蕾”。而传统上意译成汉语的一些译名, 随着文化接触加深, 其含义不够确切的不足暴露 了出来，故而需要更换译法：意译被音译加类名替代，如“汤”（cy川）改译为“苏卜汤”; 近 似翻译变成纯音译, 如“别墅”（дача）改译为“达恰”; 描述性翻译变为音译加类名, 如“俄罗 斯式的发面煎饼”/“俄式煎饼”(блин）改译为“布林饼”。

\section{3.语言文化学视角}

语言具有文化属性。对此, 语言文化学中的语言世界图景（языковая картина мира） 理论有着更加深入的研究。语言世界图景是世界图景（картина мира）的一部分, 是指“捆 绑'在语言上并通过语言形式折射出来的那部分观念世界” [Кубрякова 1988: 142]，是“记录 在语言中并且为该语言集体所特有的理解现实的 图式” [Яковлева 1994: 9] 。语言是客观 世界与主观世界之间的“中间世界”。语言为个体创造了一个最为重要的文化环境。它直接影 响个体的文化心理。透过母语这块棱镜观察世界时, 个体眼里的世界就是母语所切割的世 界。不同语言所折射的世界图景虽然有相同之处, 但更多的是不同。这对跨语言交际以及翻 译活动构成一定的障碍。

每个民族都有自己的世界图景，并且都是个别性与普遍性的统一。世界图景的普遍性 特点是不同民族彼此沟通、不同语言相互翻译的前提, 而世界图景的个别性（民族性）特点 则会促使译者寻求变通方法。语言世界图景的非对称性是促成文化翻译中各类转换的一个重 要原因。 
当源语反映的世界图景在译语中阙如时, 译者就会调用独立性普通文化素的各种翻译 方法，具体包括：1）零译；2）纯音译；3）谐音译；4）音译字形意化；5）音译加类名； 6）半音半意译；7）音意兼译；8）仿译；9）纯意译；10）近似翻译；11）描述性翻译。

当源语和译语反映的世界图景存在差异或冲突时, 翻译中需要重新描绘源语的世界图 景, 以符合译语读者的认知习惯。

世界图景包括科学世界图景（научная картина мира）和素朴世界图景（наивная картина мира）。语言世界图景也有科学性与素朴性之分。翻译过程中, 无论译语的语言世 界图景是否科学, 都需按其要求, 选择恰当的表达手段。俄语 ночь 与汉语“夜”的所指是相 同的，但在具体的上下文中， ночь 与“夜”有时并不能简单地相互替换。例如， ночью 5 июля 就应该翻译成“在 7 月 5 日凌晨”, 而不是“在 7 月 5 日夜”。

每种语言都按自己的方式分割现实世界，它们在反映语言外现实（внеязыковая реальность）过程中形成的“世界图景”在细化程度上经常存在不对称性。这可以解释文化翻 译中的某些转换方法。如果源语文化素反映的是精细的世界图景, 那么当它作为非独立性文 化素, 并且翻译时不必传达那些被强调的区别性特征时, 就需要使用概括化法, 如把 студентка 译为“大学生”; 而当它作为独立性文化素时, 翻译时就需要保留那些被强调的区 别性特征, 因此有必要运用描述性翻译方法, 如把 студентка 译为“女大学生”。如果源语文 化素反映的是粗疏的世界图景, 那么为了补充译语所需要的区别性特征, 翻译时有必要使用 具体化法，如把俄语 держать 翻译成汉语“端”“捧”“背”等不同形式。

不同语言棱镜所折射的世界图景, 还存在清晰程度上的差异。这同样会导致翻译转换 的发生和相应翻译方法的选择。譬如, 俄罗斯文学作品中自然景色描写时常见到的 серёжка, 翻译成汉语时, 通常并没有使用它的学名“柔荑花序”, 而是根据汉语的认知习 惯, 采用概括化法, 变清晰的“柔荑花序”为模糊的“花”“花球”等。

\section{4.篇章语言学视角}

“文本是翻译的目标、客体与结果, 文本学问题在现代翻译学中占有重要地位。” [Комиссаров 1999: 62] 连贯（coherence, когерентность）作为文本特质（textuality）之 一, 也是检验译语文本的重要指标。在将源语文本转换成译语时, 需要重构译语文本的连贯 性。重构的原因既有语言因素, 也有文化因素。从重构译语文本连贯性的角度可以解释文化 翻译中的诸多转换。

源语文本的意向读者是源语读者, 因此可以缺省借以实现文化连贯的相关知识。翻译 时如果只传达源文字面意义, 译语读者通常难以获得相应的连贯效果。文化连贯的重构有赖 于文化连贯的结点—文化素的翻译。文本内的文化素作为直观的语言手段, 既与文本内其 他概念发生横向联系，也与文本外的概念发生纵向联系，是文本这块“织物”中“纬线”与“经 线”的结点, 是实现源文文化连贯和重构译文文化连贯的基点。为了帮助译语读者重构文化 连贯，有必要采取不同的方法来翻译文化素。这就是重构文化连贯对文化翻译的促动。

文化连贯重构对文化译法选用的影响主要同直接示意与间接示意有关。关联翻译理论 (relevance translation theory) 认为, 翻译过程包含两个示意一推理交际活动：1）源文作者 （示意）一译者（推理）；2）译者（示意）一译文读者（推理）。在第一个示意一推理交 际中, 译者需依据源文作者的示意行为, 推导其意图（信息意图与交际意图）。在第二个示 意一推理交际中, 译者需根据译语读者的认知语境（cognitive context）, 通过恰当的方式传 达源文作者的意图。一个语句有没有包含隐义, 其示意方式完全不同。如果没有隐义, 则属 于直接示意; 如果包含隐义, 则属于间接示意。就文化连贯而言, 有些文化素参与直接示 意, 有些文化素则参与间接示意。

对源语读者而言, 如果源语文化素参与直接示意, 那么译者在翻译该文化素时通常也 应采取直接示意, 以使译语读者能和源语读者大体相仿, 在认知与推理过程中无需付出太多 
努力（efforts）便可获得语境效果。这就为文化翻译中增益法、具体化法、概括化法、释义 法、注释法等方法的运用提供了理据。如果文化素在源文中参与间接示意, 那么翻译时需要 选用恰当的方法, 以使译语读者在认知与推理过程中必须付出相应努力才能获得语境效果。 这就为文化翻译中注释法的运用提供了理据。

\section{5.认知语言学视角}

“脚本”是指“为经常重现的事件序列而特别设计的知识结构” [Ungerer \& Schmid 2001: 213-214]，是框架或图式的一种，而行为文化具有规约性，“一个文化就是由这个文化所特 有的脚本 (和框架) 构成的” [冯晓虎 2004: 94] 。由此可以看出, 行为文化与脚本关系紧 密, 掌握必要的脚本对理解与翻译原作中的行为文化非常重要。然而, 文化脚本客观上的不 对应性, 必然要求译者选取相应的文化翻译方法来进行处理。

首先, 源语文化中有些脚本在译语文化中并不存在, 这给文本脚本的激活造成了较大 困难。譬如，俄罗斯历史上的“决斗”习俗在汉语文化中是没有的。“决斗”脚本在俄罗斯经典 文学作品中经常出现。脚本的空缺对原作解读与翻译都会构成较大的障碍。翻译时, 有必要 运用注释法作出适当的解释, 以便帮助读者建立相应的文化脚本。

其次, 对比两种文化可以发现, 许多脚本尽管有着相同的名称，如“就餐”、“购物”、 “看病”、“举行婚礼”等, 但是在结构上常常并不完全对应, 存在交错情形。有学者指出, 构 成脚本的要素包括一些确定的角色（roles）以及分配给这些角色的道具（props）、一系列 先后发生的活动（actions）及其评价（evaluation）。 [Hatch, Brown 1995/2001: 146-148] 只 要某一个要素不同, 两个脚本就会彼此不对应。

文化脚本的交错情形主要涉及常规脚本。常规脚本是指事件序列与定型情境完全匹配 而构成的脚本。如果在定型情境中, 相对固定的行为序列遭到打破, 则会导致脚本发生偏 离。有学者把这两种脚本分别称作无标记脚本 (unmarked script) 和标记脚本 (marked script）［陈安玲 2007］。在翻译引起文化脚本交错的次事件时, 应当准确表达次事件本 身, 揭示次事件在脚本中的含义, 建立事件序列的成因链（causal chain），以帮助译语读者 建立新的脚本，并通过脚本把握文化行为及其含义，理解不同次事件之间的联系。由此可以 解释文化翻译中经常运用的增益法、注释法等方法。

脚本要素的变化会引起脚本发生偏离, 使得常规的无标记脚本变成标记脚本。对于发 生偏离的脚本, 要使读者理解导致脚本偏离的次事件, 经常需要添加注释加以说明, 以便读 者意识到某个次事件已经破坏了脚本的规约性，并让读者理解由此可能带来的附加含义。

脚本的运用还存在嵌入情形。这是指在某个情境中嵌入了属于另一脚本的要素（如次 事件等) 。此时, 要想准确把握该要素在这个情境中的含义, 需要激活该要素所在的脚本, 然后结合当前的情境进行推理。译者的目标是保障读者能够理解实际含义。为此，可以将推 理结果, 即话语含义, 直接表达出来, 也可以通过补充相关脚本知识, 由读者进行推断, 从 而间接地表达出话语含义。前者可以说明增益法或意译法的理据性, 后者揭示了注释法的必 要性。

\section{6.结语}

文化翻译学需要在描写性研究的基础上作出阐释性研究。本文从文化学、语言文化 学、篇章语言学、认知语言学等学科理论视角, 阐释文化翻译得以进行的原因以及选择不同 文化译法的缘由, 以期部分揭示文化翻译的理据性。当然, 文化翻译理据性研究远非本文所 能完成的任务, 期待有更多的视角和研究, 最终形成文化翻译的系统性阐释。

\section{参考文献}

1. Hatch, E. \& C. Brown. Vocabulary, Semantics, and Language Education [M]. Beijing: Foreign Language Teaching and Research Press, 2001.

2. Ungerer, F. \& H. J. Schmid. An Introduction to Cognitive Linguistics [M]. Beijing: 
Foreign Language Teaching and Research Press, 2001.

3. Комиссаров В. Н. Современное переводоведение. Курс лекций [М]. М.: ЭТС, 1999.

4. Кубрякова Е. С. Роль словообразования в формировании языковой картины мира [А]. Серебренников Б. А. Роль человеческого фактора в языке: Язык и картина мира [C]. М.: Наука, 1988: 141-172.

5. Яковлева Е. С. Фрагменты русской языковой картины мира (модели пространства, времени и восприятия) [М]. М.: Гнозис, 1994.

6. 陈安玲. 脚本认知模式与语篇的解读 $[\mathrm{J}]$. 外语与外语教学. 2007, （5）：25$27+59$.

7. 冯晓虎. 隐喻一一思维的基础, 篇章的框架 $[\mathrm{M}]$. 北京: 对外经济贸易大学出版 社, 2004.

8. 高晓虹, 刘晓海. 汉语描写借词的地理变异 [J]. 世界汉语教学, 2008, （1）: 68-76.

9. 罗常培. 语言与文化 $[\mathrm{M}]$. 北京：语文出版社，1989.

\section{KAZAK TÜRKÇESINIIN SIRİ-DERYA BOYU AĞZINDA OĞUZCA UNSURLAR*}

\section{Zhumagali İBRAGIMOV (Semerkand Yabancı Diller Enstitüsü Ph.D. Dr.)}

Annotation: It is known that Oghuz Turks had massively migrated to the area of Sir Derya river after the second half of the 8th century. Oghuz Turks settled in the steppes from the entrence of the Sir Derya river to the middle of the steppes stretching from the Aral Lake to the Caspian Sea. Although the first settlement of the Sir Derya Oghuzes was formed in the YediSu regions, as a result of its progression to the west, the Oghuzes were developed by the nomadic and semi-nomadic communities in the territory of southern and western Kazakhstan. Oghuz Turks who came to this region merged with the tribes living in the size of Sir Derya and formed the Oghuzes of it. The dialects of the Ŏguz, Klpçak and Karluk elements living together in this region were influenced by one another. Later, although the Oghuz Turks tried to keep the Sir Derya tribes in their hands by struggling with the other Turkish tribes, Karluk, Pechenegs and Kipchaks, they started to leave this area by defeating the Kipchaks.

There are some differences between the dialect of the southern region of Kazakh Turkish and Standard Kazakh Turkish. There are some Oghuz elements in the dialect of the region in question and it suggests that the Oghuz ethnic structure had an effect on this region.

In this study, the Oghuz elements in the dialect of the southern region of Kazakh Turkish were examined in terms of "phonetics" and "morphology".

Key words and expressions: Kazakh Turkish, Dialect of the south region of Kazakh Turkish, Oguz elements

\section{Giriş}

Ötüken'deki Büyük Uygur devletinin 840'da Kırgızlar tarafından yıkılmasından sonra bu devlete bağlı olan boyların göçü başlayınca Oğuzlar Yedi $\mathrm{Su}$ havalisinde belli bir süre durakladıktan sonra, Karluklar'ın ve Yağmaların baskılarıya Sır Derya nehrinin orta ve aşağı yataklarına ve Karaçuk dağları bölgesine gelip yerleştiler. Bu topraklar daha önce Peçeneklerin elinde bulunuyordu. Oğuzlar Peçenekler'i asıl yurtlarından Emba nehrinin ötesine göçe zorlamışlardır. Böylece onlar daha da yayılarak, X. yüzyılda Hazar denizinin doğusundan, Aral Gölüne ve Sır Derya'nın orta sahasındaki Farab ve İsficab (Sayram) bölgesine kadar uzanan yerlerde ve bu nehrin kuzeyindeki bozkırlarda yaşadılar [Şalbayeva 2000: 23].

\footnotetext{
* Bu bildiri, Muğla Sıtkı Koçman Üniversitesi, Türk Dili ve Edebiyatı Bölümü’nde “Siri-Derya Boyu Kazak Ağızları (Kızılorda-Türkistan Arası)" doktora tez çalışmamın üzerinde yapılmıştır.
} 
Korkmaz(2013, 26), Oğuzların daha VIII. yüzyılın ikinci yarısından sonra başlayan (760-766) kitleler hâlinde yoğun göçlerle, Karluklar önünden çekilerek Siriderya bölgesine geldiklerini gösteriyor. Oğuzlar, IX-X. yüzyıllar içerisinde Seyhun Irmağı'nın aşağı kesimleri ile Aral Gölü küzeyindeki steplerde kısmen yerleşik hayata geçmiş, kısmen de göçebe yaşamlarını sürdürmüşlerdir. Oğuzların bu bölgede bazı şehirler kurdukları ve Yeni-Kent merkez olmak üzere bir Yabgu Devleti oluşturdukları da bilinmektedir. Bu bölgede, Oğuzlar dışında elbette Kıpçak, Yimek, Yabaku, Kalaç, Basmil, Çiğil, Yağma gibi başka Türk boyları da vardır.

Aynı şekilde X-XI. yüzyıllardan itibaren önce ecki Oğuzların Sirderya ve Aral gölü havzasındaki devletinin (Oğuz Yabgu devleti) Harezm'i siyasi, ekonomik ve kültürel açidan ekkilemesi, 1040 yılından itibaren ise Harezm'in önce Gazneviler, sonra Selçuklular ve Harezmşahlar gibi Oğuzların baskın etniste durumunda olduğu devletlerin topraklarında yer alması sonucunda buralarda Türk Oğuz nüfusunun hızla arttığı ve yerli toplulukların hızla Türkleştiği bilinmektedir [Eltazarov 2016: 84].

Oğuzların Sır Derya boyundaki maceraları Türk destanlarının en mühimlerinden biri olan Dede Korkut kitabında anlatılır. Dede Korkut kitabında geçen yer adlarının bir kısmı bugün de aynen veya bazı değişikliklerle Kazakistan'da yaşamaya devam etmektedir. Karaçuk Dağı bugün Karatau olarak anılmaktadır. Ayrıca Karaşık adlı bir kasaba da vardır. Dede Korkut kitabında destan kahramanlarından biri Karaçuk'un kaplanı diye anılmaktadır. Bir tarihî kaynakta Selçukluların çıktığı şehirler Karaçuk ve Sığnak olarak bildirilmektedir. Kaşgarlı Mahmud'un dünya haritasında da Karaçuk dağları etekleri Oğuzların yaşadıkları yerler olarak gösterilmektedir. Kaşgarlı Mahmud bu bölgelerdeki Oğuz şehirleri arasında Sütkend ve Karnak'ı da saymaktadır. Ahmed-i Yesevî'nin türbesinin bulunduğu Türkistan (Yesi) şehrine $70 \mathrm{~km}$. mesafede yer alan Şavuldir kasabası da Oğuz boylarından biri olan Çavuldur'un adını taşımaktadır. Farabî'nin doğduğu bu bölgenin en mühim şehri Otrar olmuştur. Otrar bölgesi veya şehrinden Orhun Âbidelerinde Kengü Tarban olarak bahsedilmektedir [Pala2019: 1].

O dönemin tarihî, siyasi ve sosyal koşulları dolayısıyla yer yer Karluk, Kıpçak, Peçenek, Basmil, Yabaku gibi öteki Türk boyları ile de temasları bulunduğu için lehçenin temel yapısında bir değişiklik olmamakla birlikte, kendi boyları arasındaki ağız ayrılıkları bir yana, yer yer öteki Türk kavimleri ile oluşan karşılıklı etkileşimlerin de etkisinde kalmışlardır [Korkmaz 2013: 41].

Bu bölgedeki Oğuzların önemli bir bölümü çeşitli sebeplere bağlı olarak batıya, İran, Irak ve Anadolu'ya, diğer bölümü ise Hazar'ın kuzeyinden Balkanlara göçmüşlerdir. Ata yurtta kalanlar ise bugünkü Türkmenistan ve Güney-batı Kazakistan'da Sırı Derya boylarında Kıpçaklarla karışık yaşamaya devam etmektedirler [Akar, 2018: 25].

Tarihî, sosyal ve siyasî olayların neticesinde bu coğrafiyda yaşayan Türk kavimlerin dil yapısına Oğuzcanın etkisi olduğu şüphesizdir. Bu bölgede kalan Türk boylarının kendi ağızlarına has lehçe özellikleri yanında burada oluşan karışık lehçe unsurlarını kullanmaya devam etmişlerdir.

\section{Ses Bilgisi}

\section{Kapalı /è/ ünlüsü}

Eski Türkçedeki kapalı /è/ ünlüsü ile bunun Oğuz-Türkmen lehçelerindeki devamı arasında bir bağlantı kurmak gerekirse, Oğuzların büyük bir çoğunluğunun ilk hecelerde kapalı /è/'yi benimsedikleri göz önüne bulundurarak, Eski Türkçede rastlanan kapal1, /è/'nin Oğuzcaya özgü bir belirti olduğunu kabul etmek yanlış olmaz kanısındayız [Korkmaz 2013: 45]. Kazak Türkçesi yazı dilinde bulunmayan Kapalı /è/ bölge incelenen ağızlarında rastlanmaktadır. Kapalı /è/ genellikle ilk hecede görülmektedir. Kapalı /e/ şeklinde konuşulan örnekler şunlardır:

$$
\begin{aligned}
& \text { bès "beş" (1-65) } \\
& \text { yéndi "şimdi" (1-69) } \\
& \text { jèr "yer" (1-81) } \\
& \text { yémes "değil" (2-55) } \\
& \text { déğen "diyen" (5-11) } \\
& \text { yégin "ekin" (5-196) } \\
& \text { kèyin "sonra" (6-49) } \\
& \text { yégiz "ikiz" (6-78) }
\end{aligned}
$$




\section{jëti “yedi" (7-65)}

\section{Uzun Ünlüler}

Oğuz Türkmen lehçelerindeki $\bar{a} c ̧, \bar{a} c ̧$ - "acıkmak", $\bar{a} d$, $\bar{a} t$ "at, isim”, $\bar{a} g u$ "ağ zehir" gibi birçok sözcügüun ilk hecelerindeki uzunlukların Eski Türkçe dönemi ile paralel olarak bu güne kadar sürdüregelmiş olması. Eski Türkçe dönemindeki bu uzunlukların Oğuzcayı da temsil etmekte olduğunun bir tanığıdır [Korkmaz 2013: 45].

Kazak Türkçesi yazı dilinde bulunmayan uzun ünlüler incelenen bölge ağzında ilk hecede rastlandığı görülmektedir. Uzun ünlülü örnekler şunlardır:

qālıqtiki < qalıqtiki "halka ait" (1-69)

bārımtaşılar < barımtaşılar "gaspçılar" (3-15)

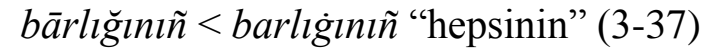

ārnayl < arnayl "özel" (4-32)

$\bar{a}$ day < aday "aday" (4-119)

bōrşımdl < borışımdl "vazifemi”" (2-17)

köbşülüğü < köpşiligi “çoğunluğu” (9-31)

\section{Ünsüz Değişmeleri}

\section{/t-/ > /d-/ değişmesi:}

$\mathrm{t}>\mathrm{d}$ değişimi Oğuzcanın diğer Türk lehçelerinden ayıran karakteristik özelliklerinden biridir. Korkmaz, sözcük başında /t-/ > /d-/ değişimi için: "Oğuzlarla onlara yakın olanlar kelimedeki /t-/ harfini /d-/ harfine çevirirler" demektedir [Korkmaz 2013: 57]. İncelediğimiz bölgede $t>d$ değişimi Oğuz lehçesinin etkisi olduğunu çeşitli Kazak bilim adamları kendi görüşlerini bildirmiştir. Tomonov, "Güney ve Batı bölgeleri Kazaklarının ağzındaki kelime başı /d/ ünsüzü Oğuz lehçeleriyle ilişki kurmasından olabilir" demektedir [1988: 73]. Omarbekov ve Junisov, "XI. yüzyıldan önceki devirlerde Siri Derya boyu, Küzey Hazar, Aral gölünün etrafı ve Karadağ, Jetisu bölgeleri Oğuz devletinin yaşadığı topraklar olduğu tarihten bellidir. Kazak toprağında Oğuz birliğinin dağılmasıyla bazı Oğuz uruk, taifeleri Kazaklarla karışmıştır” [1985: 86-87]. Jusipova ise, Kazak Türkçesinin diyalektoloji bilim uzmanları S. Amanjolov, J. Doskarayev tonsuz /t/ ünsüzünün /d/ ünsüzüne tonlulaşması Kazak toprağında IX-XI. yüzyılda yaşayan Türk dilinin Oğuz grubunun tesiri olarak değerlendirmiştir [2013: 18].

Kazak Türkçesi yazı dilinde genel olarak kelime başı/t-/'ler korunmaktadır. Kazak Türkçesinin güney bölgesi ağzında kelime başı /t-/ > /d-/ değişimine çok rastlamaktayız.

dürmöge < türmege "hapishaneye" (23-11)

doy < toy "düğün" (24-79)

durad < turadl "duracak" (24-160, 8-28)

deñizine < teñizine "denizine" (25-51)

duradın $<$ turatın "duracak olan" (25-17)

dalas < talas "tartışma, dalaş" (2-16)

dolıb $<$ tollp "dolup" (2-61)

darl $<$ tarl "dar1" (2-81)

damag்dl < tamaqtı "yemeğii" (4-97)

dam < tam "dam" (5-186)

dört < tört "dört" (7-98)

dizze < tize "diz" (1-108).

/k-/ > /g-/ değişmesi:

Oğuzca'nın Eski Türkçe ve onun devamı sayılabilecek Karahanlı, Harezm, Kıpçak ve Çağatay Türkçelerinden ayrılan en önemli özelliklerinin başında /k-/ > /g-/ tonlulaşması gelir. Oğuz ağızlarında ve Eski Anadolu Türkçesinde söz başındaki tonsuz damak ünsüzü /k-/ tonlulaşarak /g/'ye dönüşmüştür [Akar 2018: 121].

Kazak Türkçesi yazı dilinde kelime başı /k-/ ünsüzü korunmaktadır. Kazak Türkçesinin güney bölgesi ağzında ise, kelime başı /k-/ > /g-/ değişimine rastlamaktayız.

göl < köl "göl" (10-6)

gereg < kerek "gerek" (1-97) 
giyin < keyin "sonra" (2-37)

giyimderim < kiyimderim "elbiselerim" (3-49)

görsetsin < körsetsin "göstersin" (7-45)

gilemge < kilemge "kilime" (8-49)

\section{/-b-/ > /-v-/ değişmesi:}

Kâşgarlı, /b-/ > /v-/ değişimi bakımından, Karahanlı Türkçesindeki /b/ ile /f/ arasındaki boğumlanan /w/ ünsüzünün Oğuzlarca /v/'ye çevrildiğini kaydetmiştir. Ancak, Kâşgarlı'nın bu değişimi tanıklamak için verdiği örneklerdeki $v$-'ler yalnız sonses $v^{\prime} l e r d i r: e b>e v, a b>a v$ gibi. Eserin başka yerinde de yine Oğuzca kaydı ile tavar, savaş, savcl, yavlak sözcükleri vermiştir ki, bunlar da iç ses $-b$ - > $-v$ - değişimini tanıklayıcı örneklerdir. Bu duruma göre sözcüklerin içsesleri ile sonseslerinde $b>v$ değişimi gerçekleşmiştir [Korkmaz 2013: 57].

Kazak Türkçesi'nin güney bölgesi ağzında Kazak Türkçesinin yazı dilindeki patlayıcı /- $b-/$ ünsüzü sızılaşarak /-v-/ olmasına dayanan örnekler bulunmaktadır.

keyvir < keybir "baz1s1" (4-30)

jivergen < jibergen "göndermiş" (1-188)

balavahşa $<$ balabarşa "kreş" (1-197)

kövnese < köbnese "çoğunlukla" (3-3)

sevevi < sebebi "çünkü" (3-11)

javadı < jabadl "kapatır" (6-33)

şuvar adben < şubar atpen "ala atla" (6-133)

tavasiz < tabasız "bulursunuz" (6-153)

şövöre < şöbere "torunun çocuğu" (7-56)

Bununla birlikte Kazak Türkçesi'nin güney bölgesi ağzında /b-/ > /v-/ değişimi, iki ünlü arasında kalan /b/ ünsüzü /v/'ye dönüşmektedir. Bir ünlü ve akıcı ünsüz arasında kaldığı veya bir ünlü ve sızıcı ünsüzün arasında kaldığı durumlarda da süreklileşmektedir. Metinlerde /bar-/, /bol-/, /baq-/, /ber-/, /köp/kelimelerinde görülür.

suwı var < suwı bar "suyu var" (1-37)

jeKeşe vob < jekeşe bolıp "özel olup" (1-53)

jahsı vold < jaqsı bold "iyi oldu" (2-71)

dästüründe var < dästürinde var "âdetinde var" (4-137)

meKtebmiz var < mektebmiz bar "okulumuz var" (1-53)

dogdırımız var < dog்dırımız bar "doktoromuz var" (1-63)

qlz vosin < quz bolsin "k1z olsun" (24-18)

"oñay volad $<$ "oñay boladl "kolay olacak" (3-45)

mal vaqqan < mal baqqan "hayvan gütmüş" (5-86)

araldar var $<$ araldar bar "adalar var" (5-91)

qalay vered < qalay beredi "nas1l verecek" (3-78)

kövnese < köbnese "çoğunlukla" (3-3).

\section{/-ḳ-/ > /-h-h-/ değişmesi:}

Bu özellik daha çok Oğuzcanın özelliği olarak bilinir. Akar, Eski Anadolu Türkçesinde de kurallı olmamakla birlikte özellikle Azerbaycan bölgesine yakın yerlerde yazılmış metinlerde art sıradan ünlü taşıyan kelimelerde söz içi ve sonundaki / $/$ lar sızılaşarak /h/ya dönüşmüştür [Akar 2018: 120].

Kazak Türkçesi yazı dilinde kelime içi /-k-/ ünsüzü korunmaktadır. Kazak Türkçesinin güney bölgesi ağzında ise, iç seste /-ḳ-/ > /-ḩ-/ değişimine rastlamaktayız. Tonsuz, süreksiz /ḳ/ ünsüzü iki ünlü arasında kaldığında veya akıcı ve sızıcı ünsüzlerin yanında /h̆/ ünsüzüne değişmektedir. Bu değişmenin Oğuzcanın Kazak Türkçesinin güney bölgesi ağızlarına bir etkisi sonucu olduğunu düşünmekteyiz.

bashast < basqast "diğeri" (1-71)

jahında < jaqında "yakın zamanda" (1-98)

janjaha < jan jaqa "her tarafa" (2-80)

qazahıy < qazaqly "kazaklara mahsus" (4-8)

jılhınıñ < jılqınıñ “yılıkının” (4-53) 


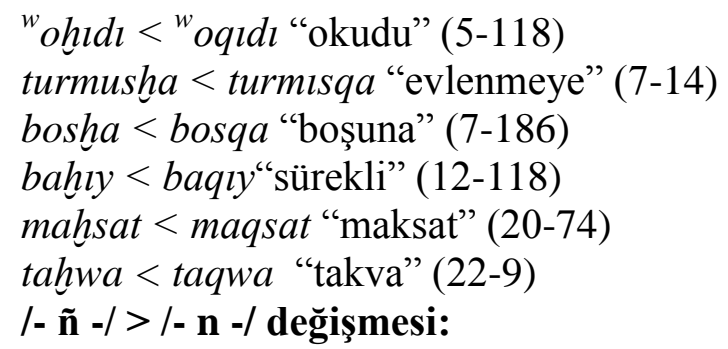

Eski Türkçedeki /ñn/ ünsüzü, Kazak Türkçesi yazı dilinde büyük ölçüde korumuştur. Oğuzcada ise, $\tilde{\mathrm{n}}>\mathrm{n}$ değişmesi en mühim özelliklerinden biridir [Ergin 2013: 92].

$\mathrm{Bu}$ değişim Kazak Türkçesinin güney bölgesi ağılarında genellikle / $\tilde{\mathrm{n}} />/ \mathrm{n} /$ şeklinde kullanıldığı görülmektedir.

a) II. teklik genizli /-ñ / şahıs ekinin genizsiz /-n/ şeklinde kullanıldığ görülmektedir.

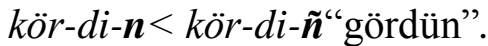

b) II. teklik şahıs nezaketlilik bildiren /-ñiz/ eki, genizsiz /-niz/ şeklinde kullanılmaktadır.

bil-di-niz< bil-di-ñiz"bildiniz".

/ş-/ /ç-/ değişmesi:

Kazak Türkçesi yazı dilinde /ç/ ünsüzüyle kullanılan kelimeler genellikle alıntı kelimelerde görülür. Ancak Kazak Türkçesinde kelime başı ve kelime sonu /ş/ ünsüzüyle söylenmesi gereken kelimeler incelediğimiz bölgede /ç/ ünsüzüyle telaffuz edildiği tespit edilmiştir. Eski Türkçedeki /ç/ ünsüzünü Oğuz lehçeleri ve Özbek, Kırgız, Uygur lehçeleri koruduğu ve bu lehçelerin incelediğimiz bölge ağzına etkisi olduğu bilinmektedir.

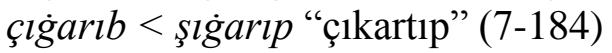

çamalı < şamalı "az, biraz" (11-209)

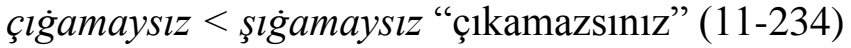

çayllgaylaw < şalgaylaw "biraz uzak" (9-25)

çarwa < şarwa "iş, çalışma" (9-31)

çoqparın < şoqparın "çomak, sopa" (12-62)

çawamayd $<$ şawamaydl "dörtnala gidemez" (3-111)

birinç gllasġa < birinşi kılasqa "birinci sınıfa" (25-25)

\section{ŞEKILL BILGISİ}

İlgi Hâli Eki

Uygur metinlerinde ilgi durumu (genetivus) eki, ünlü ve ünsüzlerden biten ad köklerinden sonra hep $+n I \tilde{n}$ biçimleri olduğu hâlde, Yazıtlarda ve kısmen $n$ lehçesi metinlerinde, ünsüzle biten adlardan sonra bu günkü Oğuz lehçelerinde olduğu gibi +In biçimindedir: moncuk-uñ, taşlar-ıñ, at$i \tilde{n}$, Kül Tigin-iñ gibi. - $n$ ilgi durumu ekinin yazıtlardaki ve bir kısım Mani metinlerindeki durumu ile Oğuzcayı temsil ettiği görülüyor [Korkmaz 2013: 49].

Kazak

Türkçesi yazı dilinde ilgi hâli eki şu şekildedir: -nıñ, -niñ, -diñ, -diñn, -tıñ, -tiñ. Kazak Türkçesinin güney bölgesi ağızlarında bazı kelimelerde ilgi hâli eki /-ın/, /-in/ olarak kullanıldığı görülmektedir. $\mathrm{Bu}$ durum, bu bölgeye Oğuz etnik yapısının etkisi olduğunu düşündürmektedir.

-ın, -in < KzT. -niñ, -niñ:

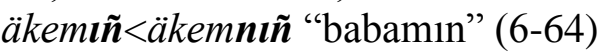

mekeniñ <mekenniñ "mekanın" (1-3)

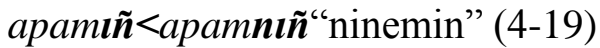

"sucuğun" (4-50)

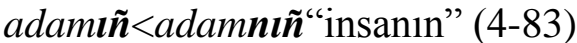

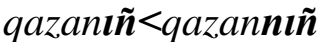

-In, -in < KzT. -diñ, -diñ:

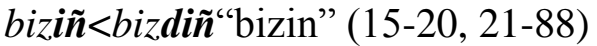

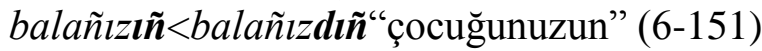

jastarımızın<jastarımızdın"gençlerimizin" (2-91) awlumızın<awlumızdın“köyümüzün” (3-

75)

jëriñ $<j e r d i \tilde{n} " y e r i n "(5-219)$

${ }^{w} \ddot{o z}$ zimiziñ $<{ }^{w} \ddot{o z i m i z d i \tilde{n} " k e n d i m i z i n " ~(15-46) ~}$

-in < KzT. -tiñ:

yërkekiñ <yérkektiñ “erkeğin" (8-137) 
Ağızlar, dildeki tabii seyri açısından değerlendiğinde, dilin kendine özgü belirgin özelliklerinin tespit edilmesi, dildeki gelişmenin ve değişmenin takip edilmesi ve dilin söz varlığının ortaya konulması açısından son derece önemlidir.

Oğuzca ile Kazak Türkçesinin güney bölgesi ağzının etkileşimi "ses bilgisi” ve "şekil bilgisi" yönünden ele alınmıştır. Yukarıda verdiğimiz ve çalışmnın tamamında incelenen örnekler ışığında Oğuzca dil özelliği incelediğimiz bölge ağzının bünyesinde barındırdığı, bunları işlevsel şekilde kullandığı görülmektedir.

\section{KAYNAKÇA}

1. Akar, Ali (2016), Sosyal Bilimlerin Veri Kaynağı Olarak Ağızlar, Gazi Akademik Bakış, cilt 10, say1 19. s. 169-182.

2. Akar, Ali (2018), Oğuzların Dili, İstanbul, Ötüken Yayınları.

3. Eltazarov, Juliboy (2016), Eski Orta Asya Oğuzcasının Kalıntısı: Harezm Oğuz Diyalekti Hakkında. Tehlikedeki Türk Dilleri II B, cilt 3. s. 81-115.

4. Ergin, Muharrem (2013), Türk Dil Bilgisi, İstanbul, Bayrak Yayınları.

5. Jusipova, Bibihadşa (2003), Türkistan Turgındarı Tiliniñ Erekşelikteri, Türkistan, Turan Yayınlar1.

6. Korkmaz, Zeynep.(2013), Oğuz Türkçesinin Gelişimi, Ankara, Türk Dil Kurumu.

7. Nakısbekov, Okas (2010), Qazaq Tiliniñ Oñtüstik Govorlar Tobı, Almatı, Gılım Yayınları.

8. Omarbekov, Sapargali ve Junisov, Nurlıbek (1985), Awızeki Tilimizdin Dıbıs Jüyesi, Almatı, Mektep Yayınları.

9. Pala, Ayhan (2019), "Oğuzların Ata Yurdu Kazakistan”, Erişim: https://www.fikircografyasi.com/makale/oguzlarin-ata-yurdu-kazakistan 19.04.2020.

10. Şalbayev, Aydos (2000), IX-XI Yüzyıllarda Sır Derya Oğuzları, (Gazi Üniversitesi. Sosyal Bilimler Enstitüsü Yayımlanmamış YLS Tezi), Ankara.

\section{О СЛОВООБРАЗОВАТЕЛЬНЫХ КАТЕГОРИЯХ В РУССКОМ И УЗБЕКСКОМ ЯЗЫКАХ}

\section{Бабакулов Исмаил Туркманович (ооц. СамГУ) Хамраева Дилором Азамовна (иреп.СамГУ)}

Annotation: The article considers the general system of the most productive word formation categories of verbs in Russian and Uzbek languages. Formative categories can form part of wider onomaseological categories or intersect with them.

Key words and expressions: System, word - formative category, productive verbs, verbs, verbal suffixes, verb formants, categories of the species, category of pledge, semantics, verbal causation.

Контраст морфемных систем русского и узбекского языков проявляется не в равной степени для именных и глагольных систем русского и узбекского словообразования: именно глагольная система русского языка проявляет многочисленные черты агглютинативности. Еще более это различие проявляется в контенсивном аспекте: если ряд именных СК русского и узбекского языка совпадают, закономерно различаясь в способах формантнего выражения, то совпадающих глаголных СК русского и узбекского языков всего две: СК каузации и СК становления.

Требует всестороннего изучения типологии мотивации при однородных способах словообразования в разносистемных языках. В программу дальнейшего сопоставительного изучения словообразовательных систем русского и узбекского языков должно войти выявление и описание способ нейтрализации и компенсации асимметрии 
словообразовательных категорий разносистемных языков - русского и узбекского на синтаксическом уровне.

В глагольных подсистемах русского и узбекского языков совпадают лишь две СК: “становление признака" (краснеть, прочнеть, деревенеть, крепчать, мельчать қизармоқ, қуюкламоқ, эскирмоқ) и “наделение признаком (каузация)" (жселтить, грязнить, выявить, источить, осиротить - янгиламоқ, яхииламоқ).

При этом морфонологические преобразования дериватов в узбекском языке могут быть не менее существенными, чем в русском: ср. сариқ-сарzаймоқ.

Таким образом, именные подсистемы словообразования русского и узбекского языков имеют гораздо больше изоморфных (в контенсивном плане) участков, чем глагольные, что объясняется прежде всего наличием в русском языке категории вида, а в узбекском языке последовательной и регулярной категории понудительного залога (также выражаемой рядом морфонологически распределенных аффиксов).

В то же время представляется существенным, что в русском языке техника присоединения глагольных суффиксов к основам приближена к агглютинативной: темн-еmb, бел-e-mb, черн-e-mb, грязн-и-ть, бел-и-тb. Глагольные суффиксы выделяются легче, чем большинство именных суффиксов. Однако о полной агглютинативности таких суффиксов говорить нельзя, так как они выражают не только деривационное, но видовое значение.

В русском языке глагольное словообразование в целом более агглютинативно, чем именное, несмотря на наличие ряда морфонологических преобразований при суффиксации и суффиксально-постфиксальном способе. Специфические глагольные форманты - префиксы и постфиксы - не сопровождаются морфонологическими преобразованиями.

По отношению к производной глагольной лексике русского языка особую актуальность приобретает глубинное исследование связей грамматических категорий вида и залога с лексико-грамматическими разрядами глаголов и их словообразовательными категориями. Это направление актуально как в сопоставительном аспекте, так и при изучении морфологических и словообразовательных систем отдельных языков, в том числе и русского. Актуальным представляется выявление взаимодействия морфологического яруса (категории вида и залога), лексического (способы глагольного действия) и словообразовательного (глагольные словообразовательные категории) русского языка.

В основе СК двух языков лежат следующие понятийные категории: «субъект, агенс» (СК «деятель»), «объект» (СК «результат действия»), «орудие» (СК «орудийность»), «локус (место)» (СК «локативность» и «вместилище»), «комитативность («совместность)» «СК «совместность») «пол живого существа» (СК «деятель», а также СК «женскость» и «невзрослость» в русском языке) и транспозиционные $\mathrm{C} 3$, отражающие взаимодействие между частями речи на самом абстрактном уровне, «отвлеченный процессуальный признак», (взаимодействие глагола и существительного)» и «отвлеченный непроцессуальный признак» (взаимодействие прилагательного и существительного).

Состав СК двух сопоставляемых наглядно демонстрирует систематизирующую роль словообразования по отношению к лексике, так как каждая СК служит средством пополнения тех ЛГР, которые наличествуют в каждом языке: абстрактных существительных (СК «отвлеченный процессуальный признак» и «отвлеченный непроцессуальный признак» для обоих языков), конкретно-предметных существительных (СК «орудийность», «локативность» и «вместилище» - для обоих языков; в русском языке к ним прибавляется также СК «единичность»), одушевленных существительных (СК «женскость», «невзрослость», «совместность» - для русского языка), личных существительных (СК «деятель» и «совместность» - для узбекского языка). ЛГР вещественных и собирательных существительные есть в обоих языках, но только в русском языке они находят словообразовательное «подтверждение».

Словообразовательные категории «совместность (комитативность)» русского и узбекского языков представляют собой наиболее изоморфные категории в системе 
субстантивного словообразования двух языков, причем проявляют частичный изоморфизм в аспекте формантного выражения, так как в узбекском языке для реализации С3 «совместность» используется своеобразный префиксальный морф хам- (наряду с исконным аффиксом -дош).

Словообразовательно оформленные глаголы каузации изучены в русистике хуже, чем глаголы становления. Если выделение словообразовательной категории (СК) «становление признака» подготовлено работами И.С. Улуханова, С.А. Емельяновой, И.Р. Хакимовой и др., то глаголы со значением «каузация признака» не объединены в какой-либо работе общего характера.

В отличие от СК «становление признака», которая в русском языке представляет собой цельную, компактную и в значительной мере агглютинативную категорию, СК «каузация» это более сложное комплексное явление. По мнению А.А. Азизова, «в русском языке есть лишь пережиточные явления каузатива (пить - поить, гнить - гноить), поэтому это залоговое значение является в русском языке мертвым и не выражается грамматическими средствами» . Можно согласиться с А.А. Азизовым в том, что в русском языке нет такой регулярной грамматической категории, как понудительный залог в узбекском языке, однако ни в коем случае нельзя согласиться с тем, что значение каузации представляет собой пережиточное явление.

С нашей точки зрения, продуктивность глагольной СК «каузации признака», парадигматически связанной с СК «становление признака» и в то же время противопоставленной ей, в русском языке частично компенсирует слабую «прорисовку» грамматической категории залога.

Соотношение собственного глагольных грамматических категорий (вида, залога, наклонения, времени, лица) сложно и, конечном итоге, определяется их вкладом в КЗ процессуальности, общего значения всех слов, относящихся к классу глаголов.

\title{
Список использованной литературы
}

1. Абдуллаева Ш.Д. Словообразовательные категории как фактор системности глагольной лексики в современном русском языке: Дисс... канд. филолог. наук. - Ташкент, 2011. - 153 c.

2. Азизов А.А. Сопоставительная морфология русского и узбекского языков. Ташкент: Ўқитувчи, 1983. - 240 с.

3. Виноградов В.В. Русский язык. Грамматическое учение о слове. - М.: Наука, 1986. $-640 \mathrm{c}$.

4. Улуханов И.С. Русская словообразовательная семантика и принципы ее описания. - М.: Наука, 1977. - 256 с.

5. Русская грамматика. Т. I. - М.: Наука, 1980. - 784 с.

\section{ИЗУЧЕНИЕ ФРАЗЕОЛОГИЗМОВ С ЗООНИМИЧЕСКИМ КОМПОНЕНТОМ В СОВРЕМЕННОЙ ЛИНГВИСТИКЕ (ИСТОРИЯ ВОПРОСА)}

\author{
Алиева Э.А. \\ (к.ф.н., доц.) \\ Хасанова П.Р. \\ (магистрант, Национальный университет Узбекистана, г. Таикент)
}

\begin{abstract}
Annotation: The article is devoted to an analytical review of modern linguistic works devoted to the study of phraseological units with a zoonym component. The scientific review allows you to orient yourself in the development of the main directions of the named scientific topic, on the basis of systematization and generalization of scattered information, to assess the state of this scientific problem, as well as the trends and prospects of its solution.
\end{abstract}


Key words and expression: phraseologism, zoonym, zoonymic component, zoomorphic phraseology, zoomorphisms.

Особенности фразеологизмов с зоонимическим компонентом неоднократно привлекаливнимание лингвистов (Е. Н. Ермакова, Г. Ч. Файзуллина; А. В. Алексеева; Баштабак Акиф Шинаси, ЛюБохань, Р.М. Вяткина, Г.Р. Рашидова, О.В. Галимова, С.А. Сасина, Соколова М. В., Ермакова Е. Н., Бичер Омер, Хабарова О.Г., Кудрявцева Е.В., Закирова Л.А., Яблонская О. Г., Солнцева Н.В., Аверина М.А., Гимадеева А.А., Мяклакова Е.М., Черникова Е. М., Шатровия Н. В. и др.). Большинство из этих работ имеют сопоставительный характер, так как материалом для анализа в этих работах послужили фразеологизмы с компонентом-зоонимом разных языков (русского и английского, русского и турецкого, русского и французского и т.д.), отличаются они тем, что материал исследования изучается в разных аспектах: функционально-прагматическом и когнитивном (Корман Е.А.), семантико-типологическом (Аверина М. А.), этно-семантическом (Солнцева Н. В.), лингвокультурологическом и лексикографическом (БичерОмер) и т.д.

Так, предметом изучения А.А. Киприяновой являются функциональные особенности зооморфизмов[Киприянова 1999]. Целью ее исследования является выявление и описание способов, при помощи которых проявляется национально-культурное своеобразие языковой личности во фразеологических единицах, пословицах, поговорках и прецедентных текстах с зооморфическим компонентом. А.А. Киприяновой были рассмотрены возможности передачи универсальных смыслов, а также проявлений этноспецифичности в толковании сходных сюжетов с помощью зооморфической фразеологии и паремиологии и анализируется национально-культурная специфика зооморфической фразеологии и паремиологии четырех языков (русского, английского, французского и новогреческого).

М.А. Аверина в одной из своей статье «Семантическая организация компонентовзоонимов в русских паремиях» выявила семантические особенности номинации компонентов-зоонимов в русских паремиях и определила их роль в формировании фрагментов фольклорной картины мира[Аверина 2013]. Материаломанализа послужили 600 языковых единиц из сборников русских пословиц В.И. Даля. М.А. Аверина выделяет семь семантических групп зоонимов, представленных в русских паремиях: 1) птицы (домашние, лесные, хищные); 2) домашние животные; 3) рыбы; 4) насекомые; 5) грызуны; 6) бесхвостые земноводные; 7) пресмыкающиеся.И делает вывод, что смысловой диапазон и языковая применяемость зоонимических компонентов в русских паремиях достаточно широкая, и они влияют на формирование фольклорной картины мира носителей русского языка, являются важнейшими компонентами русской культуры.

Одной из интересных работ в сопоставительном плане, на наш взгляд, является другая статья М.А. Авериной «Фразеологизмы с компонентом-зоонимом: семантикотипологический аспект (на материале русского и английского языков)»[Аверина 2015].Материалом для исследования послужили 192 фразеологизма из произведений русских, советских, английских и американских писателей XIX-XX веков, из научнопопулярной литературы и публицистики; данных современных словарей.В данной работе лингвист, проанализировав семантическую типологию русских и английских фразеологизмов с компонентом-зоонимом, пришла к выводу, что семантические свойства исследуемых фразеологических единиц имеют значительное сходство. Однако они различаются семантикой компонента-зоонима, в котором отражается национальный менталитет, своеобразие оценки окружающего мира.Все выявленные фразеологизмы М.А. Аверина, опираясь на предложенную классификацию А.М. Чепасовой[Чепасова 1998],подразделила на пять лексико-семантических классов: предметные, атрибутивнопредикативные, количественные, процессуальные, качественно-обстоятельственные фразеологизмы - и уточнила, что семантические свойства исследуемых фразеологизмов зависят от семантики зоонима[Аверина 2015].

Диссертация БичераОмера «Зооморфные образы в русских пословицах и поговорках: лингвокультурологический и лексикографический аспекты» посвящена зооморфным образам 
в русских и турецких паремиях[БичерОмер 2016]. Автор попытался выявить характеристики анималистических образов в русских пословицах и поговорках, установить особенности их национально-культурной семантики на фоне турецкого языка и предложить способ лексикографирования паремий с зооморфными образами в учебном лингвокультурологическом словаре. Материалом исследования послужили 274 русских и турецких пословиц и поговорок с образами восьми животных (верблюд, волк, ворон(а), конь (лошадь), лиса, осёл, свинья, собака (пёс)).Проведённый анализ фразеологического материала с компонентом-зоонимом позволили автору разработать проект учебного лингвокультурологического русско-турецкого словаря пословиц и поговорок с компонентомзоонимом.

Сопоставительному анализу фразеологических единиц с компонентом-зоонимом посвящены и работы Закирова Л.А. (на материале английского, русского, башкирского и татарского языков), БаштабакАкифШинаси (на материале русского и турецкого языков), Алексеевой А.В (на материале китайского, английсконо и русского языков), Яковлевой Е.С. (на материале китайского и английского языков), Сакаева Л.Р. (на материале русского и английского языков) и др.

Работа Л.А. Закировой «Эмоция страха в зоонимной фразеологии (на материале английского, русского, башкирского и татарского языков)» направлена на выявление фразеологизмов с зоонимами, имеющие фразеологическое значение «эмоция страха»[Закирова 2009]. Подобные фразеологизмы подобраны из четырех языков. Также в статье подчеркнуты особенности мировосприятия и миропредставления английского, русского, башкирского и татарского народов.

В статье Баштабак Акиф Шинаси «Отражение названий животных во фразеологизмах русского и турецкого языков» освещается вопрос сопоставления фразеологических единиц с названиями животных в двух языках: автор описывает сходства и различия фразеологизмов с зоонимным компонентов в русском и турецком языках[БаштабакАкифШинаси 2016].Баштабак Акиф Шинаси классифицирует названия животных на дикие и домашние, включая сюда же названия диких и домашних птиц. Исследователь приходит к выводу, что на многие слова очень влияет территория проживания народа и образ жизни.

А.В. Алексеева в своей работе «Особенности употребления фразеологических оборотов с названиями животных в китайском, английском и русском языках», распределив примеры фразеологизмов с компонентом анимализма в русском, английском и китайском языках по классификации В.В. Виноградова, пришла к выводу, что фразеологические обороты являются неотъемлемой частью рассматриваемых языков, применяются в определенных ситуациях и по своей структуре содержат культурологическую и историческую информацию, что делает их уникальным явлением[Алексеева 2019].

Сопоставление фразеологизмов с компонентами зоонимами, описывающие человека как объект, в русском и английском языках подробно изучает Л.Р. Сакаева[Сакаева 2008]. Она классифицирует их на 1) животные (домашние и дикие); 2) птицы (домашние и дикие); 3) рептилии; 4) рыбы, членистоногие; 5) насекомые. Проведя сопоставительный анализ, Л.Р. Сакаеваотметила сходство- единое происхождение, а различие - специфику жизни народа, географические условия, традиции, обычаи и т.д. Однако, в своей другой работе «Фразеологические единицы с компонентом-орнитонимом в русском, английском, татарском и таджикском языках»Л.Р. Сакаева названия домашних и диких птиц (курица, гусь, утка, лебедь, грач, сорока и др.) относит к орнитонимам[Сакаева 2008].

Некоторые языковеды уделяли особое внимание на отдельные компоненты-зоонимы в составе фразеологических единиц: собака (Кудрявцева Е.В.), свинья (Кудрявцева Е.В.), кот (Сидорова Ю.Е.), лошадь (Ермакова Е.Н., Файзуллина Г.Ч.) и др.

В статье Е.В. Кудрявцевой «Фразеологизмы с компонентом-зоонимом собака: лингвокультурологический комментарий» рассматривается зооним, который, будучи метафорически переосмысленным, используется для характеристики человека: его поведения, эмоций, физического состояния - или для характеристики типичных ситуаций, в 
которых действует человек[Кудрявцева 2015]. Анализ образа позволил автору выявить доминантные характеристики собаки как животного, которые используются для характеристики внутренних и внешних качеств человека, его образа жизни. Собранные в картотеку фразеологизмы с компонентом собака автор делит на три группы по степени мотивированности: 1) ФЕ с прозрачной мотивировкой; 2) ФЕ с непрозрачной мотивировкой; 3) ФЕ, в которых компонент собака является эвфемизмом. Кудрявцева Е.В. заметила, что во фразеологизмах с мотивированным значением зооморфный образ собаки не имеет прямого соотношения с характеристикой человека.

Е.Н. Ермакова и Г.Ч. Файзуллина в своей совместной работе «Анималистические фразеологизмы с компонентом лошадь как система образных эталонов в русском и татарском языках» предприняли попытку представить разнообразие семантики фразеологизмов с одним компонентом, выявить универсальные и специфические образные эталоны в русском и татарском языках, описать типы соотношений культурного компонента фразеологизмов с компонентом-зоонимом и рассмотреть этимологию отдельных единиц[Е.Н.Ермакова, Г.Ч. Файзуллина 2016]. Исследователи считают, что в состав русской анималистической фразеологии входит около четырехсот единиц, и выделяют 7 классов животного мира: 1) млекопитающие (звери); 2) птицы; 3) насекомые; 4) пресмыкающиеся; 5) рыбы; 6) ракообразные; 7) черви. Объектом их исследования являются анималистические фразеологизмы с компонентом-зоонимом лошадь (конь, кобыла, мерин, жеребец).

Таким образом, обзор научно-исследовательских источников по изучению особенностей фразеологизмов с компонентом-зоонимом показал актуальность изучения данной группы фразеологизмов и на сегодняшний день. В связи с тем, что несмотря на большое количество работ, посвященных анализу фразеологизмов с компонентом-зоонимом в различных аспектах и на материале разных языков, остается много спорных открытых вопросов. Например, выявляется необходимость уточнения содержания терминов «зооним», «зооморфизм», «зоологизм» и др., так как в вышеотмеченных работах данные термины используются либо как равноправные синонимы, либо согипонимы.

Обзор работ также показал, что материалом исследования в большинстве работ являются паремии (пословицы и поговорки), то есть многие лингвисты придерживаютсяширокого понимания «фразеологизма». Отдельной же работы, посвященной изучению особенностей фразеологизмов (в узком понимании: фразеологические сращения, фразеологические единства и фразеологические сочетания) с названным компонентом отсутствует.

Помимо этого, фразеологические единицы с компонентом-зоонимом изучаются в основном в сопоставительном плане (русского и английского, русского и татарского, русского и китайского и т.д.). Изучение фразеологизмов с зоонимическим компонентомпроводится в одном из аспектов: функционально-прагматическом и когнитивном, семантико-типологическом, этно-семантическом, лингвокультурологическом или лексикографическом.

В имеющихся исследованиях фразеологизмы с компонентом-зоонимом подвергаются либо структурной, либо лексико-тематической классификации.

В связи с этим считаем необходимым и актуальным провести структурносемантический и функциональный анализ фразеологизмов (в узком понимании) с компонентом-зоонимомна материале русского языка.

\section{Список использованной литературы}

1. Аверина М.А. Семантическая организация компонентов-зоонимов в русских паремиях // Инновации в науке. - 2013. - № 21. С. 29-34.

2. Аверина М.А. Фразеологизмы с компонентом-зоонимом: семантикотипологический аспект (на материале русского и английского языков) // Universum: Филология и искусствоведение: электрон.научн. журн. - 2015. - № 6 (19). 
3. Алексеева А.В. Особенности употребления фразеологических оборотов с названиями животных в китайском, английском и русском языках // Вестник науки и образования. Филологические науки. - 2019. - № 4(58). Часть 1.. С.45 - 49.

4. БаштабакАкифШинаси. Отражение названий животных во фразеологизмах русского и турецкого языков // Символ науки. - 2016. - № 3. С. 120-125.

5. БичерОмер. Зооморфные образы в русских пословицах и поговорках: лингвокультурологический и лексикографический аспекты. Дис. канд.филол.наук. Смоленск, 2016.

6. Ермакова Е.Н., Файзуллина Г.Ч. Анималистические фразеологизмы с компонентом лошадь как система образных эталонов в русском и татарском языках // Вестник Челябинского государственного педагогического университета. - 2016. - № 10. С. 164-168.

7. Закирова Л.А. Эмоция страха в зоонимной фразеологии (на материале английского, русского, башкирского и татарского языков) // Вестник ВГУ. Филология. Журналистика. 2009. - № 2. С.36-38.

8. Киприянова А.А. Функциональные особенности зооморфизмов (на материале фразеологии и паремиологии русского, английского, французского и новогреческого языков): автореф. дис. канд. филол. наук. - Краснодар, 1999.

9. Кудрявцева Е.В. Фразеологизмы с компонентом-зоонимом собака: лингвокультурологический комментарий // Вестник КГУ им. Н.А. Некрасова. - 2015. - № 2. C. 131-134.

10. Сакаева Л.Р. Фразеологизмы с компонентами зоонимами, описывающие человека как объект сопоставительного анализа русского и английского языков // Известия российского государственного педагогического университета им. А.И. Герцена. Языкознания. - 2008. С.43-47.

11. Сакаева Л.Р. Фразеологические единицы с компонентом-орнитонимом в русском, английском, татарском и таджикском языках // Известия российского государственного педагогического университета им. А.И. Герцена. Языкознания. - 2008. Языкознания. С. 162168.

12. Чепасова А.М. Мир русской фразеологии. - Челябинск: ЧГПУ, 1998. - 216 с.

\section{ФРАЗЕОЛОГИЧЕСКИЕ ЕДИНИЦЫ С ИМЕНАМИ СОБСТВЕННЫМИ КАЗАХСКОГО ЯЗЫКА КАК ОТРАЖЕНИЕ НАЦИОНАЛЬНОЙ КУЛЬТУРЫ}

\section{Омарбекова А. К. (к.ф.н., cm. npen. Казахский Национальный Педагогический Университет имени Абая)}

Annotation: This article is devoted to the analyses of cognitive-semantical and nationalcultural features of phraseological units with proper names. Phraseological units with proper names /PN/ of the Kazakh language are national and cultucal marking, they are connected with religion, mentality, history, social system of these people.

Key words and expressions: Phraseological units, phraseological image, proper name, derivation basis, the basic tendency deonimization of proper name, national-cultural features.

Фразеологические единицы с именами собственными казахского языка представляют собой большой интерес в лингвокультурологическом плане в первую очередь потому, что имя в их составе - прежде всего, казахского происхождения. Во - вторых, «культурный ореол» подобных фразеологизмов включает явления и понятия, не имеющие места в другой культуре. Иными словами, они не обладают денотативной соотнесенностью в иной культурной среде. Так, например, фразеологические единицы с именами собственными известных исторических деятелей представляют собой богатый иллюстративный материал по истории Казахстана, так как восходят к различным эпохам истории казахского народа, красноречиво отражают состояние общества, уровень его культуры, социальное положение 
их носителей в обществе, а вместе с тем и классовую структуру общества. Например: Алаштың азаматы «сын казахского народа», алты Алаш (букв. шесть народностей) «весь казахский народ», Есім салван ескі жол букв. Проторенная дорога Есим хана) «старый, утвердившийся закон»,Түгел сөздің түбі бір, түп атасы Майқы би используется тогда, когда нужно подчеркнуть, что каждое дело имеет свое начало, Асан құайвыza түсу (сальну), Қиналван Жамбыл жері осы, Абылай аспас асу (бел), Қаз дауысты Қазыбек; Шықбермес Шивайбай «скряга», Әзірет Әлінін күші - рел. очень сильный (букв. сила почтенного Али.), Әлидің кеуір қырған зүлперіндей (букв. словно меч Али) «сильное, острое оружие». Какие же знания активизируются в процессе образования фразеологической единицы с именем собственным данного рода, и какие когнитивно - семантические процессы и механизмы происходят на деривационной базе фразеологической единицы? Каким образом возникла фразеологическая единица этого рода деривационной базы? В своем буквальном значении деривационные базы означают конкретную, единичную ситуацию и выступают как внутренняя форма, фразеологический образ на базе, которого формируется фразеологическая единица. Фразеологическая единица Acaн қайzыза түсу (сальну) связана с именем Асана Сабитұлы, известного борца за независимость и свободу. Его отрицательное отношение к политике и действиям Джаныбек хана (XIV-XVI вв.) нашло отражение в деривационной базе данной фразеологической единицы. Прозвище «қайғы» связано с его раздумьями о будущем казахского народа, с его поисками земли обетованной. Именно этот положительный момент в имени собственном Асан Кайгы и служит тем основанием, на базе чего произошло возникновение нового семантического компонента «впадать в печаль; грустить». Надо отметить, что в основе деривационной базы образования актуализируются семы, отражающие определенные черты характера, профессиональной деятельности Асана Сабитулы.

Если буквальное значение можно употребить только в данной, единичной, конкретной ситуации, когда речь идет действительно о денотате, то новое значение ФЕ Асан қайғыға түсу можно употребить в любой ситуации, где есть этот факт - пессимистическое настроение. В процессе образного переосмысления имени собственного Асан кайгы приобрело качественно новое, абстрактное значение. В казахском языке существует и другая компаративная ФЕ Жер ұйық іздеген Асан Қайхылдай, буквальное значение которого «кто-либо ищет землю обетованную, как Асан Кайгы», фразеологическое значение «ктолибо ищет справедливость». ФЕ с ИС сохраняет определенную смысловую связь с соответствующими компонентами деривационной базы ФЕ. Исторические события связаны также с другой фразеологической единицей Қаз дауысты Қазыбек (букв. Қазыбек громкоголосый), так говорят о ком-либо, кто имеет громкий голос. Қазыбек вошел в историю как человек, сумевший добиться мира между казахским и калмыкским народами. Зная, что Казыбек отличался незаурядным даром оратора, становится понятной мотивированность данного фразеологизма. Возрождение Алаша после Актабан шубырынды, восстановление единой государственности связаны с именем Абылай-хана. Фразеологическая единица Абылайдай ақыльы (или Акылы Абылайдай) (буквально мудрый как Абылай) употребляется в значении «умный; мудрый». Имя собственное Аблай является также самым ярким компонентом в семантической структуре компаративного фразеологизма, отражающего своими корнями материальную и культурную жизнь народа. С именем Аблай хана имеются также фразеологизмы Абылай асnас асу; Құр Абылайлап дау ала алмайсын (букв. одним именем Абылай не победишь в споре). Семантика всего фразеологизма не выводится из смысла слов в его составе и приблизительно употребляется в значении «пустым гневом, криком до истины не дойти». Фразеологические единицы с именами собственными, которые ассоциируются с известными деятелями, историческими личностями казахского народа это имена реально существовавших личностей.

Национально- культурную окраску имеют также фразеологические единицы с именами собственными вошедшие в язык в виде литературных цитат, либо фразеологизмы, связанные с персонажами художественных персонажей. Широко известны такие ФЕ как 
Қиналван Жамбыл жері осы употребляется при каком-либо трудном,безвыходном положении; Судырлаван су жұқпас cyдыр Ахмет прозвище легкомысленного человека, лентяя, лгуна; даудын басы Дайрабайдың көк сиыры ( букв. Начало раздора- сизая корова Дайрабая) так говорят когда маленькая деталь, вещь становится причиной большого шума, спора; Кокан -локкы 1)ложная угроза 2) напугать кого -либо, и т.д.

Так, например,выражение Өлдін Мамай қор болдың употребляется в народе когда говорят о смерти великого человека.За первичным деривационным значением стоит образ конкретного человека, а именно, имя татарского хана Мамая по отношению которого данный словесный комплекс был употреблен. Это выражение взято из романа И. Есенберлина «Кочевники» и принадлежит герою романа хану Джанибеку «... Өлдін Мамай қор болдың!'деген міне осы!!... Қайсымыздың болса да бұл жалган дүниеденақырzы алар еншімізосы екі құлаш жер! Атақ, бақ ше!- Жәнібек ауыр күрсінді» - Умер Мамай, и пропало твое былое величие, как говорится в народе..Подобны золотымперстням власть и сила. При жизни мы носим эти перстни, стараясь удивить и затмить окружающих.Но кто после смерти отияа или деда хранит их перстни? Слава человека во всем подобна такому перстню. Потомки будут иенить ее лишь в том случае,если она способна служсить их интересам..Придя к такому выводу хан Джанибек встал и вышел из юрть. Знание литературных источников, знание ситуациии контекста, в которых впервые употреблено то или иное выражение ставшее впоследствии устойчивым, позволяет нам уточнить смысл фразеологизма, помогает правильному их употреблению.

С именами героев лирического эпоса связаны бытующие в казахском языке фразеологизмы Қыз Жібек пен Төлегендей,Қөзы Көрпеш-Баяндай, Ләйлі мен Мәжнундей, Жүсіп пен Зыльххадай образы которых являются олицетворением искренней любви [Қазақ халық әдебиеті 1990:14]. Эти имена стали нарицательными для обозначения верной, чистой любви супружеских пар. Духовная культура казахского народа с раннего периода бытовала и развивалась на основе фольклора (устной народной поэзии, сказках, загадках, эпосе, пословицах и т.д). ФЕ с ИС возникшие на основе фольклора не заимствуются другими языками, не получают интернационального распространения, они функционируют в рамках одного языка и являются исконно казахскими. Например: Төлебайдың төрт ұлы төбелесіп келеді, Егізбайдың екі ұлы ерегесіп келеді, Жавалбайдың жалгызы жаваласып келеді букв. Четыре сына Толебая идут и дерутся, два сына Егизбая идут и ссорятся, а единственный сын Жагалбая и тот не отстает. В этой загадке именами собственными обозначены отгадываемые предметы (Егизбай означают горбы верблюда, Толебай -ноги, Жагалбай хвост), жүзігі барда Сүлеймен, жүзігі жоқта сүмірейген ( букв.с перстнем Соломон, без перстня никому не нужен он), Аяз- би әлінді біл, құмырсқа жольлнды біл (ср.русс. Знай сверчок свой шесток), Шықбермес Шывайбай (Шыгайбай-герой казахских народных сказок ,олицетворяющий богатого,но скупого,жадного человека).

Своеобразная картина наблюдается во фразеологических единицах религиозного характера. Источником образования данных фразеологизмов служат религиозные мифы, легенды и предания ставшие общим достоянием для тюркского народа. Например: Қыљыьр туні, Қырықтың бірі Kылыьр, басына Қылыр дарыды, Сулейменнің жузігіндей (букв. как кольцо Сулеймена) «что-либо,имеющее чудотворное действие»,Пайгамбар жасына келу «почтенный возраст», Нух заманы «очень давно», Мын жасап Ульққпандай( Лукпандай) означает «прожить долго», Бибифатима пірімнің, колы « оберег рука». Фразеологическая единица Коркыттын кори(букв.могила Коркута) употребляется в значении « кому-либо кажется что его преследуют несчастье, плохое,нехорошее». Казахская легенда гласит, что в детстве Коркут увидел сон. Призрак смерти непокидал его ни днем, ни ночью. Всюду он встречал свежевырытые могилы, и каждый раз слышал «это могила Коркута». Сравните, употреблене данной единицы в контексте : Кемпі,кемпір анау адамды байқайсын ба? Көзін менен алмайды - Қойшы қайда барсаң Қорқыттың көрі.( ...Старуха, старуха, ты видишь того человека? Он с меня глаз не сводит. - Да полно, тебе везде мерещится не доброе). Согласно казахским преданиям и легендам Коркыт является создателем первого 
музыкального инструмента - кобыз. Коркыт не мог примириться с неизбежностью смерти, и ушел от людей к вечной природе, но горы, степи и леса поведали ему ожидающем их разрушении, везде перед ним представала могила. Тогда Коркыт выдолбил из дерева шыгай первый кобыз на земле и играл на нем, зачаровывая смерть. [Каскабасов С 1992:107]. Семантика ФЕ Қорқыыттың көрі передает чувство сильного страха и определяет значение всей фразообразующей базы. Адекватное восприятие описанных выше единиц представителем другой культуры возможно лишь в том случае, если человек имеет определенные фоновые знания. Освоение же фоновых знаний возможно лишь при ознакомлении с культурой данного народа. Все эти фоновые знания участвуют в формировании фразеологической семантики данных фразеологических единиц. Активное использование фразеологических единиц с именами собственными в современной речи говорит о том, что они живут в актуальном языковом сознании носителей языка до сих пор. Именно в языке того или иного народа находит отражение память и история народа, его культура и опыт познавательной деятельности, его мировоззрение и психология, передающийся из поколения в поколение.

Г. Бельгер [20016:111] справедливо замечает, что язык (любой) - это мировоззрение, миропонимание человека, племени, нации народа. Лишившись родного языка, человек теряет нечто большее, чем средство общения. Он теряет свои истоки, свою личностную субстанцию, свою изначальную суть, свое лицо, свою душу, которая если и не совсем утрачивается, улетучивается, испаряется, исчезает, то, по крайней мере, сильно деформируется, облачается в иную оболочку, обретает иную форму.

Отсюда следует, что язык народа это - главное его богатство, его символ, его пароль, его живая «душа».

\section{Список использованной литературы}

1. Қазақ халық әдебиеті. Қыз-Жібек-Төлеген 1990-14

2. Каскабасов С. Колыбель искусства. - А-Ата:Өнер, 1992- 95с.

3. Бельгер Г. Казахское слово. - Астана: Елорда, 2001.- 125c.

\section{QIPCHOQ LAHJASIGA XOS HARAKAT FE'LLARI}

\section{Suvonova R.A (SamDU O'zbek tilshunosligi kafedrasi dotsenti) Boymirzayev Alisher (2-kurs magistr SamDU)}

Annotation: This article collects and explains the history of the development of Uzbek dialects, the research of linguists, as well as examples in the field. Basically, action verbs have been shown to have different semantic properties in the events that take place in our lives and have been interpreted as examples. In Uzbekistan, due to the large scale of the Kipchak dialect in dialectal words, the examples are mostly taken from rural dialects. Analysis of all examples of verbs in the Kipchak dialect is done. A new study will be discovered in the study of their differences from the norms of literary language. In conclusion, as the science of dialectology has been declining for many years, it is one of the most pressing issues today to illuminate it and revive forgotten words.

Key words and expressions: Dialect, dialect, Kipchak, verbs of action, historical words, semantics, dialectics, verbs of action and state.

O’zbek adabiy tilining rivojlanish jarayonida dialektizmlar muhim o'rin egallaydi. O‘zbek tili uch lahjadan tashkil topgan ko'p komponentli dialekt bo'lib, uning shakllanishida qarluq, o'g'uz va qipchoq urug' uyushmalari barobar ishtirok etgan va yagona umum o'zbek tilini vujudga keltirgan.

Qipchoq lahjasidagi dialektizmlar xalqlarning hududiy joylashuvi ,shevalardagi darajalanish jarayoni va valentliklariga qarab so'z turkumlariga xos xususiyatlari o'rganiladi. 
Qipchoq lahjasidagi fe'l so'z turkumiga xos bo'lgan harakat fe'llarga xalq orasidan ko'plab misollar to'plashimiz mumkin. Ularning adabiy til normalaridan farqlanish xususiyatlari misollar tariqasida o'rganilsa maqsadga muvofiq bo'ladi va yangi bir tadqiqot maydonga keladi.

O'zbek adabiy tili xalq shevalaridan o'ziga kuch oladi va rivojlanadi, chunki sheva bo 'lmasa, adabiy tilimizning kelajagi bo'Imaydi. Hayotiy ozuqa olib turadigan asos bo'lmasa, har qanday adabiy til o'lik til hisoblanadi. Shuning uchun ham shevalar har qanday adabiy tilning asosini tashkil etadi, hamda rivojlanish poydevori hisoblanadi.

"Istiqlol yillarida o'zbek tilining qo'llanish doirasi amalda nihoyatda kengaygani, uni ilmiy asosda rivojlantirishga qaratilgan tadqiqotlar, tilimizning o'ziga xos xususiyatlariga bag'ishlangan ilmiy va ommabop kitoblar, o'quv qo'llanmalari, yangi-yangi lug'atlar ko'plab chop etilayotgani jamiyat tafakkurini yuksaltirishga o'z hissasini qo'shmoqda" 29 .

Shevashunosligimizning tarixi XI asrning mashhur tilshunosi Mahmud Koshg'ariyga borib taqaladi. Uning "Devonu lug'otit turk" asari turkiy xalqlar shevalarining so'zligini arab tilida izohlab, o'zida jamlagan mukammal va bebaho lug'atlardan biri sanaladi.

Ona tilimizning o'zagi -bo'lgan shevalarimizni o'rganish va yangi tadqiqotlar yaratish kun tartibimizning dolzarb muammolaridan biridir.

$\mathrm{O}^{\prime}$ zbek dialektalogiyasi sohasiga umrini baxshida etgan tilshunoslardan

I. I. Zarubin, K.K. Yudaxin, E. D. Polivanov, G‘ozi Olim, A. K. Borovkov, F. Abdullaev, V. V. Reshetov, Sh. Shoabdurahmonov, B. Jo'raev, S. Ibrohimov, M. Mirzaev, A. Ishaev, Q. Muhamedjanov, K. Nazarov, Yo. G'ulomov, A. Shermatov, A. Aliev, D. Abdurahmonov, N. Rajabov,X. Doniyorov, S.Ashirboev, B.To'ychiboev, K. Usmonov, A. Jo'raev, N. Murodova, T.Enazarov, N.Shoimova, M. Begaliev kabi olimlarimizning ilmiy tadqiqotlarini e’tirof etmaslik va ulardan bahramand bo 'Imaslik mumkin emas. Shu nuqtai nazardan shevashunosligimiz bo'yicha keng qamrovli yangi ilmiy tadqiqotlar olib borish zaruriyati sezilmoqda va tan olish kerakki, hozirgacha lahjalar va shevalararo dialektalogik lug'atlarning mukammal holda yaratish vaqti etdi.

$\mathrm{O}^{\prime} z$ bek xalq shevalarining lug'aviy boyligini o'zida jamlagan va umumiy holda ifodalaydigan bittagina "O'zbek xalq shevalari lug'ati” yaratilgan xalos.

Bizningcha, ular leksikografik nuqtai nazardan saralangan holda kelajakda yaratiladigan ko'p tomli “O'zbek xalq shevalari lug'ati”da qayd etilishi maqsadga muvofiqdir.

Xalq shevalari va dialektlarini ichki imkoniyat sifatida adabiy tilimiz bilan bog'lab o'rganish sohasida ham keyingi vaqtlarda jiddiy ishlar qilinmoqda. Tilshunosligimiz uchun bunday ishlarning ham benihoya zarurligi shubhasizdir. Chunki u yoki bu dialektning, u yoki bu guruh shevalarning adabiy tilimizga qo'shgan hissasi va unga beradigan imkoniyatlarini o'rganmasdan turib, shu shevalarning yoki, xususan, adabiy tilimizning istiqbolini belgilash, uning kelajagini ta'minlash sohasida biror jiddiy ish qilish qiyin.

$\mathrm{Bu}$ shevalarning vakillari hozirgi vaqtda Samarqand, Jizzax, Surxondaryo va Qashqadaryo viloyatlarining asosiy qismida, Toshkent, Sirdaryo viloyatlarining katta bir qismida, Farg'ona vodiysida, Xorazm viloyatining shimoliy qismida va Qoraqalpog'istonning bir qismida, shuningdek, Tojikistonning ko'pgina tumanlarida, Qozog'iston va Qirg'izistonning janubiy qismida, Turkmanistonning bir qismida yashaydilar. "O'zbek" nomi inqilobdan keyin hozirgi o'zbek millatining hamma a'zolari uchun umumiy nom bo'lib qolgach, ba'zi olimlar, jumladan akademiklar A.N.Samoylovich, V.M.Jirmunskiy, A.N.Kononov, professorlar N.A.Baskakov, V.V.Reshetov, M.Sh.Shiraliyev, F.A.Abdullayev, Sh.Shoabdurahmonov va boshqalar ilgari "o'zbek" nomi bilan atalib kelgan bu aholining shevalarini qipchoq shevalari deb atay boshladilar va bu nomni ilmiy muomalaga kiritdilar.

“O'zbek adabiy tili va shevashunosligi taraqqiyotiga ulkan hissa qo'shgan professor Xudoyberdi Doniyorov qipchoq shevalari,g'arbiy va sharqiy guruh leksikasining o'ziga xos leksik -

\footnotetext{
${ }^{29}$ И.Каримов. Юксак маънавият - енгилмас куч.Т.,Маънавият, 2008. 83-86-бетлар.
} 
semantik,morfologik va stilistik imkoniyatlarini boy faktik materiallar asosida bayon etib bergan atoqli lingvist hisoblandi". ${ }^{30}$

O‘zbek tilining qipchoq lahjasini uzoq yillar tahlil qilgan shevashunos olim Xudoyberdi Doniyorov edi.U adabiy tilda ham to'qqiz sof unli tovush mavjud, faqat uning harfiy belgisi yo'q degan fikrni bildirgan edi. Navbatdagi vazifa ana shu tovushlarning harfiy belgisini berish kerak, degan g'oyani olg'a surdi. Ikkinchidan, adabiy til xalq tili jozibasini o'zida mujassamlashtirardi. Uchinchidan, imlodagi chalkashlik birmuncha tugatilib, savodxonlik yaxshilanardi.

Xudoyberdi Doniyorov tarixiy-qiyosiy metod bilan o'zbek dialektlarini o'rganish asosida hozirgi o'zbek adabiy tili tarixiy taraqqiyoti va rivojlanishi bosqichlarini belgilashga harakat qildi. $\mathrm{Bu}$ boradagi nazariy qarashlarini doktorlik dissertatsiyasida bayon etdi. Ushbu tadqiqot samarasi bo"Igan "J-lovchi dialektlarni o'zbek adabiy tili bilan qiyoslab o'rganish tajribasidan" monografiyasi maydonga keldi. "Qipchoq dialektlarining leksikasi” nomli monografiyasida ham

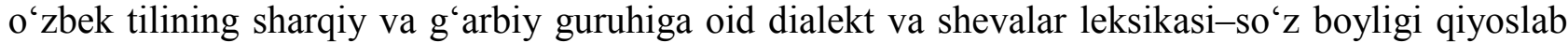
o'rganiladi.

Xudoyberdi Doniyorov qipchoq lahjalaridagi sof unli tovushlar haqida xulosalarini bayon etar ekan, ayni paytda grafemalar - yarim unlilar deb ataluvchi belgilarga ham o'z munosabatini bildiradi.

Biz ushbu o'rinda o'zbek xalq shevalarida, xususan, qipchoq shevalarida keng iste'molda bo'lgan harakat fe'llari xususida to'xtalmoqchimiz.

Harakat fe'llari qipchoq lahjasida so'zlashuvchi xalqlar tilining asosini tashkil etadi va har bir gapimiz harakat fe'llarisiz shakllanmaydi. Qipchoq lahjasidagi shevaga xos harakat fe'llari qiziqarli va sinonimik qatorga boydir. Harakat fe'llari turli ma'noda qo'llanish xususiyatlariga ega bo'lib, uni quyidagi semantik guruhlarga ajratish mumkin.

\section{Harakat fe'llarining semantik guruhlanishi:}

1. Inson kayfiyati bilan bog'liq harakat fe'llari;

2. Inson harakati bilan bog'liq holat fe'llari;

3. Ruhiy holat bilan bog'liq harakat fe'llari;

4. Inkor ma'noli harakat fe'llari;

5. Inson mehnatiga xos harakat fe'llari;

6. Kundalik hayotga xos harakat fe'llari;

7. Tafakkur bilan bog'liq holat fe'llari;

8. Ijobiy harakat fe'llari;

9. Salbiy harakat fe'llari;

10. Harakat, yarim holat fe'llari;

11. Nutqiy harakat fe'llari.

\section{Turli ma'no xususiyatiga ega bo'lgan harakat fe'llariga misollar:}

Chopti-yugurdi, enkaydi- engashdi, g'izziladi-tez keldi, iljaydi-tabassum qildi, shiqshaydimiyig'ida kuldi, jiladi-yig'ladi, allandi-aldandi, to'ng'illadi-norizo bo'ldi, jotti-yotdi, jonboshladiyonboshladi, jamg'ardi-yig'di, jashnadi-yashnadi, chupchima-sakrama, jo'g'otma-yo'qotma, javrama-vaysama, jilpilladi-qilpilladi, kulli-kuldi, cho'milli-cho'mildi, artinni-artindi, mo'radipoyladi, cho'zilli-cho'zildi, cho'milli-cho'mildi, jumshadi-yumshadi, sonnadi-ko'p gapirdi, bopladi-to'g'ri qildi, bezanni-bezandi, kiyinni-kiyindi, suqatti-sovqatdi, dam olli-dam oldi, qaqqayma-qotib qolmoq, qamalli-qamaldi, suxordi-sug'ordi, teshaladi-chopti, irjayma-kulma, ovnama-ag'nama, sang'ima-bekor yurma, jalpayma-yalpayma, baylama-bog'lama, chechinmayechinma, lallayma-bo'shashma, solishma-urushma, kaypanglama-o'zingdan ketma, bezraymayuzsiz bo'lma, to'rama-to'g'rama, quvlama-orqasidan yugurma, urma-do'pposlama, chechmayechinma, kechma-inkor qilma, zo'rlama-majburlama, kema-kelma, jog'otma-yo'qotma, suvuttisovutdi, jilitti-ilitdi, isitti-isitdi, shopirdi-qo'zg'adi, boshini chayqadi-ajablandi, juvutti-ivitdi,

${ }^{30}$ Karimov S.Sanaqulov U. “Ko’p qirrali ijod sohibi”.Istiqlol davri o'zbek dialektologiyasining dolzarb muammolari.Prof.X.Doniyorov tavalludining 90 yilligiga bag'ishlab o'tkazilgan Respublika ilmiy-nazariy konferensiya materiallari.Samarqand,2017-yil,18-18-may,18-19-betlar. 
quritti-quritdi, ko'pchitti-xamirni oshirdi, , sovdi-sog'di, juvdi-yuvdi, jildirdi-joyini o'zgartirdi, chaydi-chayqamoq, jaydi-yoydi, osti-ildi, sog'inni-sog'indi, kuydi-xato qildi, shipirdi-supurdi, kulli-kuldi, ovdardi-ag'dardi, jomadi-yamadi, kalladi-qo'lladi, zingraymoq-qotib qolmoq.

O’zbek dialektologiyasidagi shevaga xos so'zlarni XXI asrdan turib mukammal o'rganish va ilmiy asosda tadqiq etish bugungi kun talablaridan biri hisoblanadi.

Xulosa o'rnida shuni aytish lozimki o'zbek xalqi va uning adabiy tilining rivojlanishida qipchoq lahjasining o'rni beqiyosdir. Ilmga chanqoq yoshlarimiz bu sohada ham izlanishlar olib bormoqda.

Prezidentimiz Sh.M. Mirziyoyev "Yoshlarimiz qalbida Vatanga muhabbat va sadoqat tuyg'usini kamol toptirish, a'lo o'qishga da'vat etish, ularni sog'lom turmush tarzi ruhida tarbiyalashga qaratilgan targ'ibot ishlarini kuchaytiramiz. Bu boradagi siyosatimiz yangi qabul qilingan "Yoshlarga oid davlat siyosati to'g'risida "gi Qonun asosida qat'iy davom ettiriladi ${ }^{31}$ deb bejiz aytmagan.

Dialektologik olimlarimizning izdoshlari bo'lgan yosh tadqiqotchilar bugungi kunda shevaga xos so'zlarning yangi-yangi qirralarini kashf etmoqda.

\section{Foydalanilgan adabiyotlar ro'yxati}

1. Mirziyoev Sh . Buyuk kelajagimizni mard va olijanob xalqimiz bilan birga quramiz. Toshkent:,O`zbekiston ,2017,134 bet

2. Karimov I.A Yuksak ma’naviyat - yengilmas kuch. Toshkent: Ma'naviyat, 2008, 139 bet.

3. Istiqlol davri o'zbek dialektologiyasining dolzarb muammolari.

4. Samarqand,2017-yil,18-18-may,10-11-betlar.

5. Doniyorov X. O‘zbek xalqining shajara va shevalari. -. Toshkent :Navruz nashriyoti, 2017,108-109-betlar.

6. O'zbek dialektologiyasining dolzarb muammolari. Respublika ilmiy nazariy anjumani materiallari. Toshkent 2018, 38-40-betlar.

\section{ОСОБЕННОСТИ АББРЕВИАЦИИ В ОБРАЗОВАНИИ НОВЫХ ОБЩЕСТВЕННО- ПОЛИТИЧЕСКИХ ТЕРМИНОВ КИТАЙСКОГО ЯЗЫКА}

\section{Саодат Абдуллаевна Насирова (к.ф.н., доцент директор Узбекско-Китайского Института имени Конфуция при ТГУВ)}

Annotation: The use of abbreviations in the socio-political terms of the modern Chinese language depends on the era, time, environment and situation, which is why they differ from simple words. Abbreviated words are relatively common in negotiations, speeches, popular science books and magazines, in special fields (electronics, physics, computer science, economics, transport, communication, finance, banking, etc.), the media and terminology. It is in these areas that prudence and brevity are required. This article discusses some new socio-political terms in formation of which one of the abbreviation models 合成 is actively used.

Key words and expressions: abbreviation, model, cognition, social and political terms.

При создании сокращенных слов в китайском языке, особое внимание уделяется отражающим смысл иероглифам. Поэтому, сокращение неразрывно связано со словосочетанием. Превращение какого-либо словосочетания в аббревиатуру, во-первых, зависит от степени и частоты применения данного словосочетания. Например, НПСК, НОАК, ВСНП, ШОС и т.д.

\footnotetext{
31 Мирзиёев Ш . Буюк келажагимизни мард ва олижаноб халқимиз билан бирга курамиз. Тошкент:, Ўзбекистон ,2017,134 бет.
} 
А.Семенас разделяет китайские сокращения на два типа и каждый тип сокращений распределяет на несколько моделей [Семенас, 2000:57] ${ }^{32}$. Общественно-политические термины можно анализировать с помощью этих моделей.

В рамках данной статьи мы хотим проанализировать одну из моделей 合成 в составе которой активная роль уделяется числительным. В данной модели наблюдается образование, по большей мере, связанных с когнитивным методом или человеческой психологией новых терминов. Здесь главную роль играют связанные с числительными понятия китайцев. Например: если анализировать такие примеры, как “6+2 小组”, т.е. “группа 6+2”, или “中亚 五国” “Пять государств Центральной Азии”, примененные в данном термине числительные приобретают смысл только у знакомого с общественно-политической сферой читателя. Анализ термина 骨牌理论 теория домино сообщает о цепной реакции, когда построенные в ряд кости домино начинают падать, увлекая друг друга, как например, в экономике, когда какая-либо причина может потянуть за собой целый ряд других негативных событий. Например, начавшийся в 2008-2009 гг. в Соединенных Штатах Америки кризис финансовых и банковских компаний потянул за собой другие страны. Или ещё один неприятный пример: обнаруженный в декабре 2019 г. в китайском городе Ухань Covid-19 повлек за собой пандемию во всем мире.

При образовании новых терминов применение когнитивного метода можно увидеть на следующих примерах.

一个中心, 两个基本点 Один центр, два основных момента - это главное содержание основной линии КПК на начальном этапе социализма. «Один центр» означает, что упор будет делаться на экономическое строительство, а «два основных момента» - это необходимость отстаивать четыре основных принципа и проводить политику реформ и открытости.

一国两制 одна страна - два строя. Это научная концепция, выдвинутая КПК и правительством Китая для урегулирования тайваньского, сянганского и аомэньского вопросов в целях осуществления великого дела воссоединения Китая.Основное содержание данной концепции сводиться к следующему: при предпосылке единства Китая на основной части страны продолжает осуществляться социалистический строй; на Тайване, в Сянгане и Аомэне, являющихся неотъемлемыми частями Китая, длительное время сохраняются без изменений раннее существовавшие капиталистический строй и образ жизни; Тайване, Сянган и Аомэнь пользуются высокой степенью автономии. В свете этой концепции Сянган и Аомэнь вернулись в лоно Китая в 1997 и 1999 годах. Дослово термин 一国两制 следует переводить как две системь управления одного (иелостного) Китая, в документах он идёт в переводе один Китай.

两个一百年 два 100-летних юбилея. Цели, намеченные на «Два 100-летних юбилея», выдвинутые на XVIII съезда КПК предусматривают построение среднезажиточного общества К 100-летнему юбилею КПК и построение богатой, демократической, цивилизованной и гармоничной социалистической модернизованной страны к 100-летнему юбилею КНР.

В составе термина 三个代表 тройное представительство под числом 三 три подразумевается три основных положения: КПК должна всегда представлять потребности развития передовых производительных сил Китая, прогрессивное направление, в котором движется передовая культура Китая, и представлять коренные интересы самых широких народных масс Китая. Основоположник идеи - Цзян Цзэминь.

Идея о “тройном представительстве” является важной составной частью теоретической системы социализма с китайской спецификой, руководящей идеей КПК.

В составе термина 四项基本原则 четыре основных принципа мы видим число 四 четьре, которое в своей расшифровке подразумевает: придерживаться социалистического

\footnotetext{
${ }^{32}$ Семенас А.Л. Лексика китайского языка. -М.: Муравей, 2000. - С. 57
} 
пути, придерживаться демократической диктатуры народа, придерживаться руководства КПК и марксизма-ленинизма, идей Мао Цзэдуна. Эти четыре основных принципа являются основой китайского государства, политическим фундаментом существования и развития Партии и государства.

Число 五 пять в термине 五位一体 единство пяти аспектов подразумевает экономическое строительство, политической строительство, культурное строительство, социальное строительство и строительство экоцивилизации - это общая расстановка в деле социализма с китайской спецификой.

六个紧紧围绕 шестикратное повторение в «тесной увязке» - упомянуто в Постановлении ЦК КПК по некоторым важным вопросам всестороннего углубления реформ, принятого на 3-м пленуме ЦК КПК 18-го созыва, является дорожной картой по всестороннему углублению реформ. Её главное содержание: углубление реформы экономической модели должно быть тесно связано с предоставлением рынку возможности играть решающую роль в распределении ресурсов; укрепление партийного руководства, проведение политических реформ должно проходить в органичном сочетании с руководящей ролью партии и принципами «народ-хозяин страны» и управления государством на основе законов; реформирование культуры надо осуществлять в увязке с созданием системы базовых социалистических ценностей и строительства государства, обладающего мощной социалистической культурой; углубление реформы социальной системы должно проходить параллельно с улучшением народного благосостояния и обеспечением социального равноправия и справедливости; углубление реформы экологической системы в сочетании с реализацией концепции создания «прекрасного Китая»; реализация углубления реформы системы партийного строительства в сочетании с повышением уровня управления на основе научного подхода, демократии и закона.

中央八项规定 восемь установок ЦК КПК- восемь установок, выдвинутых Политбюро ЦК КПК на XVIII съезде об изменении стиля работы и укрепления связей с народом. Их основное содержание: улучшить исследования и опросы общественного мнения, сокращать количество совещаний, сокращать документации, стандартизировать визиты, модернизировать работы по охране, улучшить пресс-работу, строго издавать публикации и строго соблюдать принципы трудолюбия, бережливости и экономии.

Проанализированные примеры были взяты из выступлений главы КНР Си Цзиньпина с период с 2012-2019 гг.. В примерах терминов-аббревиатур не прослеживается употребление чисел 7 и 9.

Процесс проникновения аббревиатуры в китайский язык свидетельствует о необходимости пересмотра своеобразных традиций данного языка и обращение к новому направлению. При образовании аббревиатур, несомненно, следует учитывать национальные языковые традиции. В большинстве случаев образование аббревиатур связано с географическим фактором. Например, аббревиатура 上海组织/上合（上海合作组织 связана прежде всего с тем фактом, что организация зародилась именно в г. Шанхае. В лексическом слое китайского языка число возникших путем аббревиации новых терминов увеличивается. Причиной тому является, во-первых, влияние глобализации на человечество, экономику и культуру, науку, политическую и общественную жизнь, в том числе, языкознание, и вовторых, влияние самого языкознания на глобализацию. Рост международного авторитета Китая и все больше развивающиеся экономические и культурные отношение с другими государствами, конечно же, оказывают свое влияние на китайский язык.

\section{Список использованной литературы}

1. Семенас А.Л. Лексика китайского языка. -М.: Муравей, 2000. - С. 57

2. 习近平。谈治国理政。北京。2014。-469 页。

3. 习近平。谈治国理政 (第二卷)。北京。2017。-569 页。 
4. Си Цзиньпин. О государственном управлении. -Пекин: Издательство литературы на иностранных языках, 2014. -613 с.

5. Си Цзиньпин. О государственном управлении (II). -Пекин: Издательство литературы на иностранных языках, 2017. -787 с.

\title{
ОБ ЭФФЕКТИВНОСТИ ИСПОЛЬЗОВАНИЯ ПРИЕМОВ ИНТЕРАКТИВНОГО ОБУЧЕНИЯ В ПРЕПОДАВАНИИ РУССКОГО ЯЗЫКА (НА ПРИМЕРЕ ПРИЕМА «ОБУЧЕНИЕ В СОТРУДНИЧЕСТВЕ»)
}

Сидоркова Л.Р. (к.ф.н., доцент БГУ, Бухара) Тангриберганова Г.А. (cm. npen. УГУ, Ургенч)

\begin{abstract}
Annotation: Using the example of the "Learning in collaboration" technique, the paper considers the issue of the effectiveness of using the elements of interactive learning in teaching the Russian language when studying the topic "Expression of spatial relations in a simple sentence" in the discipline "Russian language" in bachelor's programs with Uzbek language of instruction. It is noted that the main advantage of using the technique when studying this topic is the relaxation nature, which helps to relieve nervous stress, switch attention, change the form of activity. A distinctive feature of the work is that the main pedagogical tasks have been studied, the solution of which is aimed at using the method "Learning in cooperation" in the process of studying at the university.
\end{abstract}

Key words and expressions: learning in collaboration; method; reception; interactivity; learning task; learning process.

Происходящие преобразования в системе высшего образования обусловлены движением в сторону инновационной личностно-развивающей парадигмы образования, необходимостью использования интеллектуально-творческого потенциала человека для созидательной деятельности во всех сферах жизни.

Интерактивные технологии в учебном процессе при обучении русскому языку связаны с использованием эффективных приемов и методов преподавания, активным включением студентов в образовательный процесс. Внедрению интерактивных методов в учебный процесс в своих трудах уделяли большое внимание С.И.Архангельский, Ю.К.Бабанский, В.П.Беспалько, И.Ильина, В.В.Краевский, И.Я.Лернер, Р.А.Низамов, В.А.Сластенин, Р.Х.Шаймарданов, отечественные ученые-педагоги Л.Т.Ахмедова, Е.А.Лагай, И.Х.Каримова, М.Лутфуллаев и другие.

Как отмечают Л.Т.Ахмедова, О.В.Кон вслед за А.В.Текучевым, и методы науки, и методы обучения являются категорией исторической, поскольку и возникают они, и разрабатываются в определенных исторических условиях, а уровень их развития в каждый исторический отрезок времени определяется уровнем развития цивилизации, социального устройства, социально-экономических условий, общественной формации [Ахмедова, Кон 2013: 27].

Суть интерактивных методов обучения состоит в том, что они ориентированы не только на широкое взаимодействие между педагогом и учащимися, но и на взаимодействие между самими учащимися. Особенность данных методов и приемов обучения заключается в том, что они предусматривают активное доминирование учащихся в процессе обучения, роль педагога сводится к направлению их деятельности на достижение поставленных целей занятия [https://spravochnick.ru...].

В отличие от коммуникативно-информационных стратегий интерактивные приемы связаны с умением воспринимать и принимать на себя роль другого человека. Они призваны обеспечивать регуляцию поведения участников общения, направлены на поиск оптимальных способов речевого взаимодействия, адекватную оценку и реакцию на 
поведение партнеров по общению. Для успешности интеракции собеседники могут прибегать к компенсаторным тактикам создания и поддержания положительной мотивации к общению в случае ее отсутствия, восстановления общения в случае прерывания, сбоя, смены темы разговора [Лебединский, Гербик 2011: 126].

Прием «Обучение в сотрудничестве» предполагает, что процесс совместного освоения обучающимися учебного материала проходит под руководством преподавателя. Данный прием разработан в университете штата Миннесота в 1987 году Дэвидом Джонсоном. В практике обучения его можно использовать в изучении темы при любом виде речевой деятельности. Данный вариант может быть использован как на отдельном этапе, так и на протяжении целого занятия. Рассмотрим особенности использования данного приема при изучении темы «Выражение пространственных отношений в простом предложении» по дисциплине «Русский язык» на направлениях бакалавриата с узбекским языком обучения.

Трудности, возникающие при изучении темы «Выражение пространственных отношений в простом предложении» посредством применения приема «Обучение в сотрудничестве», связаны, в первую очередь, с уровнем владения студентами русским языком, наличием множества речевых, лексических и грамматических ошибок в их речи.

Определенные трудности могут быть связаны также с наличием психологической скованности студентов, их стеснительностью, зачастую неумением свободно, открыто выражать свое мнение перед публикой. В этом отношении применение приема «Обучение в сотрудничестве» при изучении темы «Выражение пространственных отношений в простом предложении» позволит снять психологический барьер и позволит активно включиться в образовательный процесс. В целом, применение данного приема при изучении указанной темы способствует решению следующих педагогических задач:

- повышение образовательной мотивации студентов, их интереса к процессу обучения и активного восприятия грамматического материала по теме;

- формирование и развитие дискурсивной компетентности, навыков написания связного текста (сочинения на свободную тему) на основе рисунка;

- распознавание лингвистической, стилистической и композиционно-структурной специфики текста с целью адекватной интерпретации и продуцирования нового письменного, коллективного текста (групповое сочинение на основе сочинения членов группы);

- повышение информационной грамотности, развитие способности критически анализировать и оценивать сочинения членов группы на свободную тему;

- формирование и развитие социальной компетентности, толерантного отношения к членам своей группы.

Применение приема «Обучение в сотрудничестве» при изучении темы «Выражение пространственных отношений в простом предложении» дает возможность студентам удовлетворить следующие потребительские интересы:

- получить новые знания и стать более эрудированным;

- самоутвердиться в коллективе, утвердить свой социальный статус через собственную находчивость при решении поставленных проблем, получить признание членов группы;

- получать достойное вознаграждение за свой труд и способности, как со стороны преподавателя, так и членов группы;

- получить удовольствие от обучения, раскрыть свои скрытые способности и таланты;

- стремиться к самообразованию и самосовершенствованию;

- ориентация на способы добывания знаний, усвоение конкретного учебного материала;

- научиться принимать осознанные, самостоятельные решения на основе анализа проблемы, постановки вопросов и выработки аргументов.

Прием «Обучение в сотрудничестве» позволяет направить обучение на уровень понимания, а не просто воспроизведения той или иной информации и открывает возможности по организации различных видов деятельности студентов: одним предстоит 
прочитать текст и объяснить прочитанное, другим - прочитать текст и подготовить вопросы к нему. При этом всем студентам, независимо от задания, приходится глубоко осмысливать текст, перегруппировывать его, задавать вопросы и отвечать на них.

Главным достоинством применения приема при изучении указанной темы является релаксационный характер, помогающий снять нервную нагрузку, переключать внимание, сменить форму деятельности. Отличительной особенностью работы является то, что изучены основные педагогические задачи, на решение которых направлено применение приема «Обучение в сотрудничестве» в процессе занятия в вузе.

Все вышеизложенное свидетельствует о том, что применение методического приема «Обучение в сотрудничестве» при изучении темы «Выражение пространственных отношений в простом предложении» является одним из эффективных способов повышения интеракции студентов при помощи чтения и письма, что в свою очередь, способствует обеспечению высокого качества овладения изучаемой темы, развития умственных и творческих способностей, а также познавательной, самостоятельной и групповой деятельности студентов.

\section{Список использованной литературы}

1. https://spravochnick.ru/pedagogika/teoriya_obucheniya/interaktivnye_metody_obucheniy $\underline{\mathrm{a}}$

2. Ахмедова Л.Т., Кон О.В. Методика преподавания русского языка. - Ташкент: Fan va texnologiya, 2013.

3. Лебединский С.И., Гербик Л. Ф. Методика преподавания русского языка как иностранного: Учебное пособие. - Минск, 2011.

\section{ҚАДИМГИ ХИНД-ОРИЙ ТИЛЛАРИГА ХОС САНСКРИТ ТИЛИДАГИ ТАРТИБ СОНЛАР ДЕРИВАЦИЯСИ}

\section{Нурматов Сирожиддин Султанмуратович (ТДШУ, ф.ф.н.)}

Annotation: In this article derivation of ordinal numbers in the Sanskrit language were linguistic analysed. On the basis of scientific works of the linguists its linguistic features were carefully studied. prakrit.

Key words and expressions: word sequence, ordinal number, derivation lexeme, sanskrit,

Мақолада қадимги хинд-орий тилларига хос бўлган санскрит тилидаги тартиб сонлар деревациясининг ўзига хос жихатлари ўрганилиши билан бир қаторда хозирги янги хиндорий тилларига оид хиндий тилидаги тартиб сонларнинг қадимги шаклига хос лексемалар хам тахлил қилинади.

Хозирги янги хинд-орий тилларига хос бўлган барча тиллар санскрит тилидан келиб чиққанлиги илмий асарларда баён этилган. Қадимги хинд-орий тиллари эрамиздан аввалги 1500 йил аввал ривож топган бўлса-да, лекин улардаги баъзи лексемалар ханузгача хиндорий тилларида қўлланилиб келинмоқда. Айниқса, улар орасида сонларга хос лексик бирликлар кўпгина асарларда кўлланилиб келинаётганлигини кузатишимиз мумкин.

Хинд-орий тилларининг ривожланишида от, феъл, олмош, равиш, сифат сўз туркумларига хос лексемалар қаторида сон сўз туркумига хос лексик бирликлар хам ўзига хос жихатлари билан шаклланганлиги илмий асарларда тадқиқ этилган [भोलानाथ तिवारी 1972; हरदेव बहरी 1992; Кочергина 2007].

Маълумки, сонларга хос лексемалар орасида тартиб сонлар ўзига хос ясалиш жихатлари билан ажралиб туради. Хозирги янги хинд-орий тилларига оид хиндий тилидаги тартиб сонлар орасида पहला (pehlaa) - “биринчи”, दूसरा (dusraa) - “иккинчи”, तीसरा (tiisraa) “учинчи”,चौथा (chauthaa) - “турртинчи” ва छठт (chaThaа) -“олтинчи” тартиб сонлари бошқа 
тартиб сонлардан истисно шаклида ясалганлиги каби, қадимги хинд-орий тилларига хос бўлган санскрит тилида хам айнан ушбу сонлар истисно шаклида ясалганлиги кузатилади.

Қадимги хинд-орий тилларидаги сонларга хос лексик бирликлар хозирги хинд-орий тилларидаги сонлардан фарқли равишда шаклланган. Жумладан, санскрит тилида т्रथम (pratham) -“биринчи”, द्वितीय (dvityaa) -“иккинчи”, त्रितीय (tritiiya) -“учинчи”, चतुर्थक: (chaturthakah) “тўртинчи” ва षष्ठम ShaShTham) -“олтинчи” тартиб сонларга хос лексемалар флектив шаклда ясалган [Кочергина 1978: 663].

Санскрит тилидаги бошқа тартиб сонлар саноқ сонларга - -क аффиксини кўшиш орқали ясалади. Жумладан, чंचमक (panchamak) - “бешинчи”, सप्तमक (saptamak) - “еттинчи”, दशमक (dashamak) -“ўнинчи”, चत्वारिशतमक (chatvarinshatmak) - “қирқинчи”, अशीतिमक (ashiitimak) “саксонинчи” ва хоказо [Кочергина 1978: 82].

Санскрит тилидаги ушбу шакллар ўрта хинд-орий тилларидаги пракрит тилларига келиб секин-аста ўз шаклини ўзгартириб, янги хинд-орий тиллари давридаги тилларга хос лексемалар каби ривож топа бошлаган. Масалан, санскрит тилидаги पंचमक (panchamak) лексемасини олайлик. Ушбу сон тури ўрта-хинд орий тиллари даврига келиб пंचमिका (panchmikaa), पांचवाँ (paanchvaaN) шаклида ўз ифодасини топган. Янги хинд-орий тиллари даврининг дастлабки босқичида पіंचवाँ (paanchvaaN) ва पाँचवीं (paaNchviiN) шакллари хам қўлланила бошланган.

Таъкидлаш жоизки, санскрит тилидаги сонларга хос лексемалар орасида тартиб сонларга оид лексемалар аниқланмишнинг жинсига қараб ўз шаклини ўзгартирмайди. Хиндорий тилларига хос бўлган бошқа тилларда, хусусан, хиндий тилидаги тартиб сонларга оид лексемалар аниқланмишнинг жинс ва сонига қараб мослашади. Масалан: पहला कमरा (pehlaa kamraa) - “биринчи хона", तीसरी मंज़ल (tiisrii manzil) - “учинчи қават”, छठी क़तार (chaThii qataar) “олтинчи қатор”ва хоказо. Ушбу тартиб сонларга оид лексик бирликларда аниқланмишнинг жинсига қараб тартиб сонларга хос лексемалар ўз шаклини ўзгартиб келмокда. Айнан шу мисоллар таркибида қадимги хинд-орий тилларига хос бўлган санскрит тилидаги лексемалар иштирок этса, хеч қандай ўзгаришлар рўй бермайди. Жумладан: प्रथम कमरा (pratham kamraa) “биринчи хона", द्वितीय मंजिल(dvitiiya manzil) - “иккинчи қават”, षष्ठमपंक्ति (shahsTham pankti) “олтинчи қатор”. Санскрит тилидаги тартиб сонларга оид лексемалардан сўнг гарчи аниқланмиш муаннас жинсга хос бўлса-да, ушбу лексемалар ўз шаклини ўзгартирмаган холда ифодаланган. Демак, санскрит тилидаги барча тартиб сонларга оид лексик бирликлар янги хинд-орий тилларидаги сонлардан фарқли равишда шаклланганлиги билан ўзига хос жихатларга эга.

Юқоридаги тахлил натижаларига кўра қуйидаги хулосаларга келишимиз мумкин.

Қадимги хинд-орий тилларига хос бўлган санскрит тилидаги тартиб сонларга оид лексик бирликлар ўзига хос жихатлари билан бошқа сон турларидан ажралиб туради. Санскрит тилидаги бошқа сон турлари хам очиқ, хам ёпиқ бўғинларга тугаса, ушбу тилда тартиб сонларга хос лексемалар деярли ёпиқ бўғинларга тугайди.

Олиб борилган тахлил натижаларига кўра санскрит тилидаги тартиб сонларга хос лексемалар асосан -म (m), -य (y), -क: $(\mathrm{kaH})$, -क (k) каби ундош товушларга тугаса, хиндий тилидаги истисно холатига эга бўлган ушбу сонлар -आ (аa) унли товушига тугаши билан фарқланади. Эътиборли жихати шундаки, санскрит тилидаги тартиб сонларга оид лексемалар аниқланмишнинг жинсига қараб мослашмайди. Хиндий тилидаги тартиб сонларга оид лексемалар аниқаланмишнинг жинсига қараб ўз шаклини ўзгартиради.

Санскрит тилидаги тартиб сонларга оид лексемалар ўрта хинд-орий тилларига хос бўлган пракрит тилларига келиб ўз шаклини ўзгартирган ва янги хинд-орий тилларига келиб уларнинг шакли мутлоқ ўзгарган. Таъкидлаш жоизки, хозирги адабий хиндий тилида санскрит тилига хос бўлган тартиб сонлар хам қўлланилади ва ушбу лексемалар асосан санскритча шаклга эга бўлган отлар билан ифодаланиши етакчи ўринни эгаллайди. 


\section{Фойдаланилган адабиётлар руйхати}

1. Кочергина В.А. Санскрит. -М.: Академической Проект, 2007.

2. Кочергина В.А. Санскритско-русский словарь. Под ред. В.И. Кальянова. -М.: Изд. Русский язык, 1978.

3. Хинди-русский словарь. Составители А.С.Бархударов, В.М.Вескровный, Г.А. Зограф, В.М.Липеровский. Под ред. В.М.Бескровного. Т І. -М.: Советская Энциклопедия, 1972.

4. भोलानाथ तिवारी -हिन्दी भाषा। -इलाहाबाद, 1972.

5. हरदेव बहरी। भाषा का विकास। -दिल्ली, 1992.

6. रामचन्द्र वर्म्मा। मानक हिन्दी कोष। पहला खंड। हिन्दी साहित्य सम्मेलन, प्रयाग, 1977.

\section{语言观念学视角下“ДРУЖБА”观念域研究——以俄语谛俗语为例 Lingvistik tushunchalar nuqtai nazaridan " дружба" ning kontseptual sohasi bo'yicha tadqiqotlar - rus maqollari misolida}

\section{Liu Yuxin} (PhD student Shanghai International Studies University)

Annotation: The study of the concept by Russian scholars has their own characteristics. With the deepening of the study, an independent discipline, Linguistic conceptology, has gradually formed. Linguistic conceptology is a research direction in cognitive linguistics, in which concepts, as fragments of knowledge for understanding the world, can be combined into a conceptual sphere in a certain relationship. In this article, from the perspective of Linguistic conceptology and the analysis of the presentation of these concepts in Russian proverbs and idioms with examples .

Key words and expressions: Linguistic conceptology; concept; conceptual sphere, the conceptual sphere of Dzyuba.

\section{一、语言观念学及观念域相关概念}

语言观念学 (лингвоконцептология) 是俄罗斯认知语言学中的一个研究方向, 集中研 究认知的其中一个方面——观念化 (концептуализация) 进程, 其研究对象为观念化的结果

观念本身。（Дзюба, 2018: 155）

观念是语言观念学理论中的关键概念。依据观念研究的不同层面和方法, 以及观念含 义表征的不同方式，可以划分出研究观念结构的不同方法。（Дзюба, 2018：116）季霍诺娃

( Тихонова В.Я.) 在其论文《俄语语言世界图景中的 борьба 观念》 («Концепт борьба в русской языковой картине мира »)(Тихонова 2005)一文中, 区分出了研究观念的不同方法: 心理学方法(психологический)（代表人物：阿斯科利多夫 Аскольдов С.А.、利哈乔夫 Лихочев Д.С. 等) 、逻辑学方法(логический) (代表人物：阿鲁久诺娃 Арутюнова Н.Д. 等）、哲学方法（философский）（代表人物：科列索夫 Колесов В.В. 等）、语言文化学方 法（лингвокультурологический）（代表人物：斯捷潘诺夫 Стерпанов Ю.С.、玛斯洛娃 Маслова В.А. 、沃罗比耶夫 Воробьев В.В.、捷利娅 Телия В.Н. 等) 、整合方法 （интегративный）（代表人物：利亚平 Ляпин C.X.、斯雷什金 Слышкин Г.Г.、沃尔卡切夫 Воркачев С.Г. 等) 、语言人类学方法（лингвоантропологический）（代表人物：奥金措娃 Одинцова М.П. 、伊谢尔斯 Иссерс О.С. 、尼基季娜 Никитина Л.Б. 等) 、认知学方法 （когнитивный）（代表人物：库布里亚科娃 Кубрякова Е.С.、斯捷尔宁 Стернин И.А.、博 尔德列夫 Болдырев Н.Н. 等)。(Тихонова 2005) 久巴（Дзюба Е.В.）赞成季霍诺娃

( Тихонова В.Я. ) 的分类方法, 然而在其著作《认知语言学》（《Когнитивная лингвистика») 中, 概括了热门的研究观念结构的方法, 分别是: 逻辑学、认知语义学、认 知话语分析、语言文化学。(Дзюба, 2018: 116-120)

在语言观念学中，观念一方面被理解为一种思维操作的单位，另一方面被理解为一种 结构复杂的现象，概括了个人、社会团体和整个人类的认识经验。（Дзюба, 2018: 155）这 
样一来，观念整合了人通过不同的渠道获知的信息，归纳了抽象以及具体感知的形象，从而 与概念 (понятие) 、语言意义(языковое значение)等其他的心智单位相区别。观念是离散的 单位, 包括一系列有等级区分 (核心和边缘) 的认知符号。依据信息的结构和容量, 观念可 以区分为不同的类型：思维图景 ( мыслительная картинка) 、框架概念 (рамочное понятие)、带密核的概念(понятие с плотным ядром)、框架(фрейм)、脚本(сценарий)等。观 念内容结构中普遍的、民族的以及个人的组成要素使得我们可以通过对比不同的语言文化共 同体来揭示观念的民族文化特点，或者通过比较不同的艺术世界图景（художественная картина мира），进而发现不同的作家或诗人表征世界的独特之处。（Дзюба, 2018: 155）

观念作为认识世界的知识片段, 能够以一定的关系进行组合, 相互联系的观念组成了 观念域（концептосфера），或称心智空间（ментальное пространство）。观念域是由观念 构成的知识域, 是民族观念的总和, 由操某种语言者意识中的一切潜在观念组成。（刘佐艳 2019）。利哈乔夫（Лихачев Д.С. ) 在其论文《俄语观念域》 (《Концептосфера русского языка») 中提出了观念域这一术语。研究者们很快开始讨论这一学术术语, 并指出其意义的 细微差别。玛斯洛娃 (Маслова В.А.) 将观念域理解为: 观念的集合, 就像是马赛克方块那 样, 可以组合出操某种语言者的世界观画面。(Маслова 2007: 34) 作为例证, 她举出了俄 罗斯东正教意识观念域（концептосфера православного русского сознания）的例子, 指出: 那些进入到俄罗斯民族意识中、进入到民族心智和精神经验中的遗传基因，可以由 Слово （词）、Творец（造物主）、Истина（真）、Добро（善）、Благо（福祉）、Мир（和 平)、Свобода (自由)、Польза（益处）、Человек（人）等观念来表征，这其中的每一个 观念在俄罗斯东正教意识观念域中都具有宗教性的含义。（Маслова 2007: 34）使用认知语 义的方法研究观念的代表者波波娃（Попова 3.Д.）和斯捷尔宁(Стернин И.А.)将观念域这一 术语用作如下意义：观念域是民族观念的有序集合，是思维的构拟基础。（Попова, Стернин 2006: 26) 他们指出, 观念域不是由偶然集合的观念组成, 并强调, 它是观念的有 序集合，是彼此处于一定系统关系里的单位的集合。（Попова, Стернин 2006: 26)

学者们同样谈及了观念本身和整个观念域的同构性特征。玛斯洛娃 (Маслова В.А.) 赞成观念域场结构的观点, 即: 在观念的结构中有核心区（观念的认知命题结构）、近核心 区（观念的其他词汇表征、同义词等）、边缘区（联想-形象表征）。核心和近核心区主要 表征了普遍的以及民族性的意义，而边缘区表征了个人的意义。(Маслова 2007: 35)

由系统性关系所联结的观念，在一个观念域的框架内形成了几个心智空间。心智空间 这一术语在福科尼耶 (Ж. Фоконье) 和捷尔涅尔 (М. Тернер) 的著作中得到使用, 然而戈 利德别尔格 (Гольдберг В.Г.) 在《心智空间：反映人的生物存在》 («Ментальные пространства, отражающие биологическое существование человека») 一文中，指出他们对 这一术语的解释得过于狭义, 将心智空间理解为 “某些观念集合” ( небольшие концептуальные объединения）或是容纳我们的所想和所讲的“包裹”(пакеты)。此外, 戈利 德别尔格 (Гольдберг В.Г.) 认为, 福科尼耶 (Ж. Фоконье) 和捷尔涅尔 (М. Тернер) 只集 中研究构成心智空间基础的那些观念之间的理据-目的关系。他坚持，构成心智空间基础的 观念之间不仅是理据-目的关系，还存在着其他类型的观念联系，据此可以区分出心智空间 的不同类型。(Гольдберг 2004: 7) 此外, 他也区分出了不同类型的观念联系: 包蕴关系

( меронимическая связь / отношения включения) 、整体与部分关系（ меронимодинамическая связь / отношения части и целого )、项谓关系（фазовые связи）、吸引关系 (связи《тяготение») 、借用关系（реминисцентные связи）、反义关系（антонимические связи）、渐进关系（градуарные связи）、极性对立关系（полярные связи）、理据-目的关 系 (мотивирующе-целевые связи) 等。(Гольдберт 2004: 8-20)

从结构与系统性原则的角度来看, 观念既是观念域的一部分, 也是构成观念域的单 位。由于观念形成的连续性或者说观念体系的整体性, 每一个属于一定含义空间的观念都处 在不断变化的过程中，也就是处在同其他观念相互作用的过程中。(Пищальникова 1991: 58) 
观念域中的观念根据各自与其他观念的相似、相关、相异特征组成有序的层级系统, 重要 的、有价值的观念都会得到语言表达。（刘佐艳 2019）在现存观念相互作用以及新生观念 不断产生的基础上形成了心智空间, 也就是说, 将观念集合到一个含义场中，因而心智空间 的实质是关于世界的全部知识和表征的观念体系，也就是观念域。（Дзюба, 2018: 152-153)

通过对具体语言单位（词汇、成语、浐语、俗语，乃至篇章及语法结构、语用）的观 念分析, 深入到人的观念域, 可以形成对观念域中观念结构和内容的认识。（刘佐艳 2019）本文拟从语言观念学的视角出发，采用“从语言到思维、意识（观念）的方向, 即通 过语言揭示作为民族观念域单位、民族文化单位观念的模式化”（刘佐艳 2019），对构成 “дружба”观念域的观念进行分析，研究该观念域内观念的构成以及观念间的相互关系。

\section{二、“дружба”观念域分析}

“Дружба”一词常对应为汉语的“友谊”, 在《俄语详解大词典》(«Большой толковый словарь русского языка») 中解释为: 1. Отношения, основанные на взаимной привязанности, доверии, духовной близости, общности интересов и т.п. 2. Отношения между народами, странами, государствами, основанные на доверии, взаимопонимании и невмешательстве во внутренние дела друг друга. (БТС 1998)（1.建立在相互联结、相互信任、心灵相通、共同兴 趣等基础上的关系; 2. 建立在互相信任、互相理解、互不干涉内政基础上的民族及国家间的 关系)。在《哲学百科词典》 (《Философия: Энциклопедический словарь») 中解释为: разновидность избирательно-личностных отношений между людьми, характеризующихся взаимным признанием, доверительностью, доброжелательностью, заботой. (Философия: Энциклопедический словарь 2004)（一种有选择性的人际间关系，其 特点是：相互认可、相互信赖、心怀善意、相互关怀）。

从“дружба”一词的相关释义出发, 笔者尝试简要归纳了构成“дружба”观念域的几个层 面, 分别是：一、这是两个及多个个体之间的一种关系, 其主体是人或者是团体、乃至国家 民族等，这些有关“个体”的观念，可以构成“дружба”观念域的其中一个维度，可以称为“人 的层面”; 二、“дружба”关系的形成, 需要建立在很多要素的基础上, 这些要素是“дружба” 不可或缺的一部分, 换句话说, 满足了这些条件的关系, 才能称其为“дружба”, 我们也可以 将这些要素视为一个个的观念, 这些观念组成了“дружба”观念域的“成分层面”; 三、 “дружба”的这种关系具有一定的区分度，即有一定的亲疏远近程度，因而既有“хорошая дружба”（好的友谊）, 也存在“плохая дружба” (坏的友谊), 以及其他的区分更为仔细的 “дружба”类型，这些由程度度量而区分出的不同类型的“дружба”也是“дружба”观念域的一部 分，构成“类型层面”。

依据上文对“дружба”观念域不同层面的划分，以下将分别对这几个层面进行具体分 析, 采用从部分到整体、定量统计与定性分析相结合的方法, 分析其中较为代表性的观念。 下文将首先分别分析各个层面中代表性观念的词典释义, 根据观念不同类型的联结关系, 找 出与其相关的观念, 初步构建各个层面的观念体系, 进而结合俄语浐语和俗语, 描写这些观 念在浐俗语中的呈现, 力求完整地展现出“дружба”观念域的结构和内容。

\section{1“дружба”观念域中人的层面}

20 世纪 80 年代至 90 年代, 随着“人类中心论范式” (антропоцентрическая парадигма ) 的兴起, 学者们在研究语言现象时, 开始更多地关注到“人”的因素。通过上文的分析, 可 以知晓“дружба”这是一种个体间的关系，在构建“дружба”观念域时，应该考虑到其中有关个 体的观念。本文中，在描写有关个体的观念时，只选取了有关“人”的观念，而有关“民族、 国家”的观念则不在分析范围内。与“дружба”相关的“人”，本文选取了“друг”一词作为中心 词进行分析。在《俄语详解大词典》(《Большой толковый словарь русского языка»)中“друг” 主要的解释为: человек, связанный с кем-л. отношениями дружбы (由友谊关系联结起来的 人)。

通过查询近义词词典 (本文所用的词典为: «Словарь русских синонимов и сходных по смыслу выражений» 1999 ) , 可知 “друг” 的近义词有 : доброжелатель, приятель, 
благоприятель, наперсник, побратим, побратанец, товарищ 等。依据吸引关系, 这些观念词 也进入到“дружба”观念域中。通过查询反义词典（本文所用词典： “Словарь антонимов русского языка» 1984), “друг”的反义词主要有: враг, недруг, противник等。与此同时, “друг”的同义词对应的反义词也可视作“друг”的反义词。这些观念词是依据反义关系而成为 “друг”观念域的一部分。

该观念域中“人的层面”的这些观念在俄语浐俗语中也有所体现： не имей (не держи) сто рублей, а имей (держи) сто друзей (不要一百卢布, 而要一百个朋友) ; из-за нового приятеля не теряй и старого (不因新友失旧友); пеший конному не товарищ (步行的与骑马 的做不了朋友) ; ищи товарища лучше себя, а не хуже себя (寻找比自己更好而非更差的朋 友）; где враг, где друг, не узнаешь вдруг (朋友还是敌人, 不能很快分辨出); ищи друзей, а враги сами найдутся (寻找朋友, 敌人自会出现) ; лучше один приятель, чем десять врагов（一个朋友胜于十个敌人）; с другом дружись, а как недруга берегись (与朋 友交好, 提防敌人) ; раздружится друг - хуже недруга（与朋友绝交比用敌人绝交更糟） ; бедный знает и друга и недруга（人穷识敌友）等。

\section{2 “дружба””观念域中成分层面}

笔者将构成“дружба”关系的诸多要素以及“дружба”一词的同义词、反义词等归入 “дружба”观念域的“成分层面”。这些观念是从观念域名称“дружба”一词本身出发, 将围绕在 该词周围的一些重要的观念进行归类，将它们归入“成分层面”，从而使得观念域的构成更加 完整, 内容更加充实。

依据上文中“дружба”一词的字典释义，大致可以归结出，“дружба”关系的基础，也就 是其构成要素, 这些观念依据包蕴关系相联结, 主要有: доверие, привязанность, близость, признание, правда, забота, честь 等, 这些观念词构成了“成分层面”中有关“дружба”一词的组 成要素部分。在部分俄语浐俗语中就反映了这一点, 例如: дружба заботой да подмогой крепка (关心和帮助能巩固友谊) ; дружба крепка не лестью, а правдой и честью（友谊的 牢固不是依靠奉承, 而是依靠正义和真诚) ; дружба та лестна, которая честна (真诚的友 谊值得称赞）等。由“дружба”的同义词构成的观念之间是吸引关系, 依据同义词词典（同上 文) 有: дружество, содружество, дружелюбие, знакомство, братание, братство 等, 相关浐 语俗语: военное содружество крепко отвагой и мужеством (战斗友谊的巩固依靠勇敢和无 畏) ; шапочное знакомство не в потомство (点头之交, 不会持久) ; залез в богатство забыл и братство（发了财, 忘了兄弟情, 指见利忘义）。依据观念域观念间的反义关系, 从反义词词典 (同上文) 中, 可知这些词主要有: вражда, враждебность 等, 浐俗语中也体 现了这部分观念, 例如: дружба от недружбы близко живут（友好和敌对相邻而居）; дружная жизнь длительна, недружная жизнь коротка (友好的生活是长久的, 不友好的生活 是短暂的）; вражда с дураком не умнее дружбы（与俊瓜敌对，不如与之交朋友）等。

\section{3 “дружба”观念域中类型层面}

该观念域中的这一层面, 主要依据程度与类别度量来进行划分。“类型层面”中既包含 “дружба”的不同程度, 如上文所说的, 用表示程度的性质形容词来修饰, 依据渐进关系、吸 引关系及反义关系联结; 也包含“дружба”的不同类别, 主要用表示所属关系的关系形容词来 修饰，这里观念间的联结所依据的则是吸引关系。此外，“дружба”一词对应的表人的词 “друг”的不同程度和类别, 也归入该层面。

用来表示“дружба”程度的形容词主要有： настоящий (настоящая дружба), верный (верная дружба), крепкий (крепкая дружба), надежный (надежная дружба), милый (милая дружба), добрый (добрая дружба), хороший (хорошая дружба), маленький (маленькая дружба), плохой (плохая дружба), старый (старая дружба), новый (новая дружба) 等。在俄语 浐俗语中也有相关体现, 例如: настоящая дружба беспристрастна (真正的友谊是公正的 ) ; крепкую дружбу и топором не разрубишь (牢固的友谊斧头也砍不断) ; хорошая дружба что укрепленный дзот（好的友谊是坚固的堡垒）; маленькая дружба лучше 
большой ссоры（小的友谊胜过大的不和睦）; старая дружба не ржавеет（古老的友谊不会 生锈，指旧情难忘）等。

这些形容词同样也可以用来修饰“друг”，例如： настоящий друг, верный друг, надежный друг, милый друг, добрый друг, хороший друг, плохой друг, старый друг, новый друг 等, 在浐俗语中的体现有: для настоящих друзей и вода сладка（对于真正的朋友来说 ，喝水也甜）; верный друг и через век будет другом（忠诚的朋友过了一个世纪也还是朋 友）; для милого дружка и серёжку из ушка（为了好朋友, 什么都舍得）; добрый друг лучше ста родственников (一个好友胜过一百个亲戚) ; для хорошего друга не жаль ни хлеба, ни досуга（对好朋友不文惜面包和时间）; плохой друг - что тень: в солнечный день не отвяжешься, а в ненастный не найдёшь（坏朋友如同影子，晴天甩不掉，阴天见不着）; старый друг лучше новых двух（一个故交胜过两个新友）等。

至于修饰“дружба”和“друг”，用来表示所属关系的关系形容词，如： солдатская дружба, советская дружба 等，在俄语浐俗语中也有所体现，本文不再具体论述。

\section{三、结语}

本文通过对“дружба”观念域的三个层面：人的层面、成分层面、类型层面，分别对其 构成及内容研究, 总体上基本呈现了该观念域的框架及其中观念间的组合方式。在现有的研 究中, 通常只是将“дружба”视为一种观念, 多角度研究其语言与文化的特点。在本文中，将 “дружба”视为一个观念域, 对其中的观念进行研究, 研究该观念域内观念的构成以及观念间 的相互关系，从而能够为同类型观念域的研究提供一个新的视角。

\section{参考文献}

1. Абрамов Н. Словарь русских синонимов и сходных по смыслу выражений[М]. М.: Русские словари, 1999.

2. Большой толковый словарь русского языка[М]. гл. ред. С. А. Кузнецов. СПб.: Норинт, 1998.

3. Гольдберг В.Б. Ментальные пространства, отражающие биологическое существование человека[С]. // Концепт. Образ. Понятие. Символ: коллективная монография / отв. ред. Пименов Е.А., Пименова М.В. Кемерово: ИПК «Графика», 2004.

4. Даль В.И. Пословицы и поговорки русского народа[М]. М.: Эксмо-пресс, 2000.

5. Дзюба Е.В. Когнитивная лингвистика[М]. Екатеринбург: УрГПУ, 2018.

6. Львов М.Р. Словарь антонимов русского языка[М]. под ред. Новикова Л.А. М.: Русский язык, 1984.

7. Маслова В.А. Введение в когнитивную лингвистику[М]. М.: Флинта: Наука, 2007.

8. Пищальникова В.А. Концептуальный анализ художественного текста: учебное пособие[М]. Барнаул: Алтайский гос. ун-т., 1991.

9. Попова 3.Д., Стернин И.А. Семантико-когнитивный анализ языка[М]. Воронеж: Истоки, 2006.

10. Тихонова В.Я. Концепт борьба в русской языковой картине мира: дис... канд. филол. наук[D]. Новосибирск, 2005.

11. Философия: Энциклопедический словарь[М]. под. ред. А.А. Ивина. М.: Гардарики, 2004.

12. 白旭. 神话原型视阈中的俄语身体观念域研究[D]. 上海外国语大学，2017.

13. 刘佐艳. 俄罗斯认知语言学研究概览[J]. 解放军外国语学院学报, 2019(3): 93-100.

14. 王丽娟. Свой/Чужой 的语言文化与认知研究[D]. 上海外国语大学, 2018.

15. 杨明天. 观念的对比分析 [M]. 上海：上海译文出版社，2009.

16. 赵爱国. 当前俄语“观念”研究中的几个理论问题[J]. 中国俄语教学, 2016(3): 51-57. 


\title{
СОПОСТАВЛЕНИЕ РЕЧЕВОГО ЭТИКЕТА В СОВРЕМЕННОМ СОЦИАЛЬНОМ ВЗАИМОДЕЙСТВИИ НА РУССКОМ И КИТАЙСКОМ ЯЗЫКАХ
}

\section{Лю Юэлинь (Шанхайский университет иностранных языков г. Шанхай)}

\begin{abstract}
Annotation: Speech etiquette is one of the most important aspects of the study of communicative linguistics. It serves as a rule of behavior that rise from the influence of tradition in the process of social interaction. Both Russia and China are countries with the maximum use of etiquette in communication actions related to politeness. Comparison shows the cultural differences and similarities between the two countries for a better understanding of the national characteristics of the Chinese and Russian peoples. With the development of globalization, intercultural communication is becoming increasingly important. Russian Russian speech etiquette comparison shows the cultural differences and similarities between the two countries for a better understanding of the national characteristics of the Chinese and Russian peoples.
\end{abstract}

Key words and expressions: speech etiquette, modern social interaction, comparison, Chinese, Russian

\section{1. Понятие речевого этикета и его функции}

Известно, что русский лингвист Н. И. Формановская впервые обратила внимание на речевой этикет. Она утверждает, что тематические группы речевого этикета образуют семантические поля, представляющие собой «систему тематически объединенных синонимических единиц», в которых обнаруживаются центральные и периферийные единицы, различающиеся как по оттенкам значения, так и по стилистической маркированности.[Формановская 1982: 193]

В зависимости от формы речевой этикет также можно подразделяется на этикет устного общения и этикет письменного общения.[Стернин 1996: 73] Речевой этикет постепенно становится основной частью поведения человека.

В настоящее время, когда весь мир тесно связан друг с другом, речевой этикет имеет ряд важных функций, как установление и поддержание людских контактов, демонстрирование вежливости и уважения к собеседнику, регуляция поведения людей, предотвращение нежеланных конфликтов и т.д. С психологической точки зрения, человек с нормой этикета вызывает доверие от других, и этикетная речь успокоит собеседника, делает его более вежливым и спокойным.

2. Ситуативность речевого этикета в современном социальном взаимодействии Речевой этикет должен использоваться в определенной речевой ситуации, и в одной речевой ситуации должен примениться соответствующий речевой этикет. Ситуативность представляет собой одну из важных черт речевого этикета. Она выражает какие-то отношения между собеседниками в конкретный момент, на какую-то тему, и в каком-то месте общения. Формула речевого этикета изменяется в зависимости от ситуаций общения. Именно поэтому перед тем, как человек начинает общение, ему нужно разобраться в своей социальной позиции, ролевых признаках, и важнее всего, речевой ситуации.

3.Различия и сходства между китайским речевым этикетом и русским речевым этикетом 3.1 Различия:

(1) В сопоставлении использования обращения выявлены прагматические различия с точки зрения межличностных отношений, от сравнения наименований родных и близких к незнакомцам.

Имя+ отчество - это наиболее характерный способ наименования в русской культуре. В основном это используется в ситуации "младший к старшему". В китайском языке младший к старшему обращается по "фамилии+ должности", чтобы выразить уважение.

В России система обращения междуродственникамиочень простая, брат и сестра, как правило, называют друг друга по именам или ласкательным именам, такие как Александр Саша, Алексей - Алеша, Иван - Ваня и т.д. Однако, в Китае система родственных названий 
намного сложнее, чем в России. Китайцы не могут называть родственников старше себя по именам, а называть их в соответствии с родственными отношениями.

И в русском, и в китайском языках существует обращение к незнакомцам по родственным именам для устранения чувства незнакомства как можно скорее. Китайцы иногда предпочитают назвать незнакомых старше себя по наименованию родственника, чтобы выразить свои любезность и уважение. А в России такое обращение только использовано детьми к незнакомыми взрослыми. Кроме того, в России пожилых людей, живущих в сельской местности, можно назвать "бабушка" и "дедушка".

В китайском языке названия продавцов, официантов и водителей могут использоваться как отдельно, так и в сочетании с фамилией или именем. В русском языке нет такой привычки. Однако, в России для женщин, работающих в сфере услуг существует особое обращение - девушка. К тому же, в русскомязыке и китайском языке существует непочтительный и, можно сказать, грубый способ обращения.

(2) В сопоставлении приветствия две страны также существует множество различий. Русское приветствие часто используется в восклицательной форме, а редко в сомнительном выражении. Оно имеет относительно фиксированные формулы и краткое содержание. А китайское приветствие богато вопросительной формой, оно имеет богатое содержание, нефиксированный формат, тяжелую эмоциональную передачу и много информации. Русские в приветствии обычно просто говорят о работе, жизни, здоровье, хобби и национальных событиях, а в китайском приветствии часто задают личные вопросы, такие, как еда и проживание, физическое состояние, брак, возраст, работа и т.д. И китайцы говорят более подробно, тема вопросительного приветствия часто является коммуникативным субъектом с деятельностью при встрече.

(3) В связи с тем, что прощание функционально единично, и его семантическое выражение относительно легко понятно. Есть универсальные прощальные слова, которые можно использовать в большинстве случаев общения и носят нейтральную окраску. При прощании также используются благословенные прощальные слова, чтобы пожелать друг другу счастья и здоровья, счастливого путешествия и т.д.

\section{2 Сходства:}

(1) Что касается сходства речевого этикета обоих языков, то три параадекватных слов"Вы"（您） и "Ты"（你）, "Здравствуйте"（您好） и "Здравствуй/ Привет"（你好）, "До свидания" (再见) и "Пока" (拜拜) ясно показывают то, что оба китайцев и русских обращают особое внимание на ситуативность речевого этикета.

(2) Кроме того, под влиянием истории, культуры и традиции в названиях должностей и профессий обычно подразумеваются мужчины в этих двух языках.

(3) Русские иногда называют женщин мужскими названиями, такими, как "свой парень", которое имеет ярко одобрительное значение. И они иногда называют мужчин женскими названиями, включая "красную девицу" (застенчивых маленьких парней), "бабу" (трусливых, слабых мужчин) и другие. В Китае тоже употребяляются такие слова. Например, некоторых девушек называют "сорванцами", слабых мужчин - "очень девичьими" и т. д. С психологической точки зрения нет чисто мужских или женских черт, у каждого человека имеются свои особенности, "смешивающиеся" между самим полом и гетеросексуальным полом ".[Чжоу Миньцюань 2014: 178]

\section{4.Национальные особенности речевого этикета и причиныих формирования}

Из-за различий в культуре, способ, содержание и цель речевого этикета сильно различаются.Ниже перечислены некоторые особенности речевого этикета, отображаемые изза различий в китайском и русском мышлении.

\section{1 Русские во время общения:}

1) Русские редко показывают негативные эмоции. При первой встрече и установлении контакта русские обычно не говорят о том, что заставляет себя или участника быть неблагоприятным и неприятным. Этот гостеприимный способ отражается в русских пословицах: "Кому мир не дорог, тот нам и ворог", "Худой мир доброй войны". 
2) Русские не хотят напрямую говорить о своем личном секрете или о секрете собеседника. Это связано с тем, что Россия подражала европейскому поведению в речевом этикете.

3) Тема общения с незнакомыми редко относится к личным мелочам, а обращается к социальной жизни, общественным проблемам и др. Одной из причин является недоверие к собеседнику.

4) Русские хотят преодолеть препятствия незнакомства в кратчайшие сроки, а затем они могут обсудить более интимную тему. Исходя из этого характера видно стремление русских к духовной свободе, которая в значительной степени находится под влиянием православия.

5) Русские стремятся к равенству, человеческим правам, самовыражению и самоутверждения. Независимо от того, когда русские разговаривают с знакомыми или незнакомыми, они обращают большое внимание на равенство и простоту общения. По сравнению со сложной системой китайского речевого этикета, русские используют более короткие выражения.

\section{2 Китайцы во время общения:}

1) При первой встрече китайцы спрашивают собеседникав максимальной степени о личной информации. Например: возраст, должность профессии, зарплата, семейная ситуация, родной город и т.д. Говорить о такой приватности при первой встрече с русскими кажется неуместным.

2) Китайцы уважают свои "лица" или репутации в общении. Поэтому они часто обсуждают положительные темы, которые повышают свой социальный статус. В нашей стране культура "лица" оказывает огромное влияние на наше поведение, включая речевой этикет. Нет ничего большего, чем потеря лица, потому что это означает снижение социального статуса и разъединение с обществом.

3) Китайцы неукоснительно соблюдают правила речевого этикета при выборе коммуникативной темы, способа общения в связи с социальным статусом участников общения. В структуре китайского общества существуют различные классы и иерархическая лестница, которые уважают моральные принципы для поддержания социального порядка.

4) Этическая культура и моральные нормы конфуцианской идеологии заставляют людей в общении поклоняться коллективу, унижать индивида. В культурных связях обширность и приволье китайцев часто вызывают панику среди иностранных участников. Например, россияне не задают слишком много личных вопросов при первой встрече, а китайцы спрашивают о возрасте, профессии, зарплате, семейном положении, мнении о политике и т.д. И эти вопросы имеют свои основания, таким образом, мы знаем социальный статус собеседника и можем найти оптимальный способ общения. Это также сильно зависит от культуры "лица".

\section{Список использованной литературы} 1982.

1. Формановская Н. И. Употребление русского речевого этикета. М.: Русский язык,

2. Стернин И. А. Русский речевой этикет. Воронеж: Воронежского университета,

3. Судаков Г. В. Эволюция устного речевого этикета в Московском Руси в XIV-XVII вв. // Вестник Томского Государственного университета. 2018.

4. Конищева Н. С, Гундяева О. В. Русский речевой этикет. Н. Новгород: Учебно-метод. пособие / НГТУ, 2005.

5. Гольдин В. Е. Речь и этикет. М.: Просвещение, 1983.

6. Акишина А. А, Формановская Н. И. Русский речевой этикет. М.: Русский язык, 1978.

7. Курцева 3. И. Речевой поступок и речевой этикет. // Проблемы современного образования. 2013.

8.陈松岑, 《礼貌语言》[M], 北京: 商务印书馆, 1989 年。

9.顾曰国，礼貌、语用与文化 [J]，外语教学与研究， 1992 年第 4 期。

10.陈原, 《社会语言学》[M], 北京: 商务印书馆, 2004 年。 
11.汪成慧，俄汉民族礼仪文化差异之诠释 $[\mathrm{J}]$ ，中华文化论坛, 2016 年第 9 期。

12.周民权俄汉社会性别语言的语用对比研究[M], 北京：北京大学出版社，2014 年。

\section{АНАЛИЗ ТЕОРИИ ОБОСОБЛЕНИЯ В СОВРЕМЕННОМ ЯЗЫКОЗНАНИИ}

\section{Н.Г. Содикова (СамГИИЯ)}

Annotation: The article is devoted to the analysis of the existing linguistic literature. The problem of separating the main and secondary members of the sentence is considered and a number of issues are highlighted, from the study of which the general picture of this syntactic-stylistic phenomenon is formed, namely: the essence of syntactic-stylistic isolation.

Key words and expressions: syntactic-stylistic isolation, predicate.

Анализ существующей лингвистической литературы показал, что в проблеме обособления главных и второстепенных членов предложения можно выделить ряд вопросов, из исследования которых складывается общая картина данного синтактико-стилистического явления, а именно: сущность синтактико-стилистического обособления; полупредикативность обособленных компонентов; относительная самостоятельность обособленных компонентов, как в рамках простого, так и в рамках сложного предложений; причины появления всевозможных обособленных компонентов, как в структуре предложения, так и в рамках контекста. В зависимости от того, какие акценты расставляются в ходе исследования вопроса о лингвистической сущности самого явления обособления, можно подойти к рассматриваемому явлению с различных точек зрения.

Основы интонационного подхода к анализируемому явлению содержатся в определении основоположника теории обособленных членов предложения в русском языкознании А. М. Пешковского. Он впервые установил лингвистический термин «обособленные второстепенные члены предложения», который прочно вошел в фонд лингвистической терминологии.

Основным и решающим критерием обособления, по мнению А. М. Пешковского можно" считать его интонационную характеристику и ритм. Вот что по этому поводу он писал: «Обособленным второстепенным членом называется член, уподобившийся (один или вместе с другими, зависящими от него членами) в отношении мелодии и ритма и параллельно - в отношении связей своих с окружающими членами отдельному придаточному предложению» (А. М. Пешковский, 1938, с 306).

В действительности отношение между интонацией и ритмом, с одной стороны, и обособленным второстепенным членом предложения, с другой стороны, нам кажется, представляет несколько иную картину. Именно этот момент находит своё отражение в следующем высказывании А. Г. Руднева: «...интонация и ритм являются лишь одним из многочисленных средств обособления при произношении, а не условием обособления. Вследствие этого указанные грамматические средства решающим критерием обособления служить не могут» (А. Г. Руднев, 1959. с. 11). Действительно, интонация, лишь выражает ритмико-мелодическую сторону речи, то есть повышение или понижение, усиление или ослабление, ускорение или замедление тона, а паузы служат средством обособления членов предложения, но это средство подчинено смысловой стороне высказывания. Подтверждением этому служит следующее высказывание К. Я. Петровской: «Выделение того или иного второстепенного члена предложения связано с особым значением: смысловая роль его возрастает, он приобретает некоторую смысловую самостоятельность, и предикативное значение; но своему содержанию он может приближаться к сочинённому или подчинённому предложению. Таким образом, обособление - это средство выражения особой значимости, экспрессивности второстепенного плена предложения» (К. Я. Петровская, 1953, c. 5). Данный тезис К. Я. Петровской находит своё дальнейшее развитие в работах С.В.Кротевича и А.Г.Руднева. Например, А.Г.Руднев вводит понятие» семантико- 
синтаксическая функция», Под которым понимает синтаксическую роль и грамматическое значение того или другого члена предложения. Например, роль обособленного предикативного обстоятельства со значением времени, условия, образа действия и т. д. (А. Г. Руднев, 1959, с. II). Таким образом, начало «семантико-стилистическому» подходу было положено в работах русских языковедов, таких, как Е. В. Кротевич и А. Г. Руднев, которые исследуют семантические функции обособленных компонентов различного разряда, и считают, что специфика обособления, как правило, обусловливается его смысловыми и стилистическими заданиями.

Для того чтобы правильно представить лингвистическую сущность обособленных синтаксических элементов, нам необходимо, в первую очередь, установить близость части речи и членов предложения.

Подобная близость обусловливается не только общим для них лексическим значением, но и тем, что части речи и члены предложения своим выделением выполняют различную синтаксическую роль в предложении. Например, прилагательные выделяются, как правило, из имен существительных. В качестве морфологического показателя, они выступают в роли прилагательных, а в качестве синтаксического показателя они являются" определением. Но все же полного тождества между определением и прилагательным нет, по сколку в связи с развитием грамматического строя любого языка определение может выражаться не только прилагательным, но и другими частями речи. С другой стороны, прилагательное может служить для морфологического выражения не только предложения, но и сказуемого. Все это свидетельствует о том, что подобные взаимосвязи существуют не только между прилагательным и определением, но и другими частями речи, Это положение дает нам право говорить о том, что между синтаксическими категориями и категориями морфологическими существует определенная связь, но отнюдь не полное соответствие. И попытка классифицировать обособленные члены предложения согласно их морфологическому выражению не может рассматриваться как перемещение морфологии и синтаксиса, или же по выражению А. Г. Руднева как попытка морфологизировать синтаксис, игнорируя смысловые и синтаксические функции обособленных членов предложения. Тем более что живые, действенные члены предложения в современном русском языке устанавливаются на основе анализа предложения и разграничения функций слов и групп в строе предложения.

Подобное утверждение свидетельствует о том» что способы морфологического выражения и всякие другие грамматические параметры при изучении обособленных членов предложения и обособленных конструкций должны учитываться, но не как основа их классификации, а лишь как грамматические средства обнаружения определенных смысловых отношений и синтаксических функций.

Обособленные члены предложения и обособленные конструкции становятся предметом обсуждения ряда лингвистических исследований, в которых затрагиваются их различные аспекты. В первый план обычно выдвигаются кроме интонационных характеристик, и порядок слов, знаки препинания и прочие. М. Н. Петерсон в своей работе «Очерки синтаксиса русского языка» писал: «Под именем обособленных второстепенных членов разумеются те же второстепенные члены с другими порядком слов, паузами, интонацией. В сущности особого способа выражения отношения между словами они не представляют, и нет нужды выделять их в особую труппу» (М. Н. Петерсон, 1923, с 22). Если это высказывание сопоставить с утверждением А. Г. Руднева, попытке морфологизировать синтаксис, игнорируя смысловые и синтаксические функции обособленных членов предложения, то становится ясным, что в данном тезисе автор не учитывает синтаксическую категорию обособленных комплексов.

Рассматривая вопрос о причинах обособления синтаксических элементов предложения, почти все сторонники теории обособления, особо констатируют наличие случаев обязательного употребления запятой (при обособлении используются кроме запятой тире и двоеточие) в предложении, чему способствует ряд факторов. К таким факторам относятся: величина групп слов, принадлежащих обособлению; характер передаваемой информации; 
наличие паузы между обособленными компонентами и остальной частью предложения; инверсия порядка слов, при которой обособленные компоненты предложения помещаются на непривычное для них место в предложениях (здесь имеется в виду препозитивное, интерпозитивное, постпозитивное положение обособленных членов предложения по отношению к обособленным компонентам предложения). Кроме того, определяющим фактором считается стилистический фактор.

\section{Список использованной литературы}

1. Виноградов В.В. Некоторые задачи изучения синтаксиса простого предложения // Вопросы языкознания, 1954, №1.- С.26.

2. Гайлумс К.Я. Обособленное определение в современном латышском литературном языке // Автореф. дисс. на соиск. учен. степ. канд. филол. наук. - Рига, 1956. $-5 \mathrm{c}$.

3. Петровская К.Я. Обособленные второстепенные члены предложения в современном английском языке. Автореф. дисс. на. соиск. учен. степ. канд. филол. наук. Л., 1953. -5 c.

4. Руднев А.Г. Синтаксис осложненного предложения. М., 1959. - 11 с.

\section{“ВАБО” - АЛЬБЕР КАМЮНИНГ АЛЛЕГОРИК РОМАНИ}

H.X. Турсунова (СамДЧТИ)

Annotation: "The plague" is one of the best works of A. Camus. This is a chronicle of the plague year in a small town on the Mediterranean coast. First of all, it is a novel-parable. A terrible disease comes to the city - and people start to die. Residents become hostages of the epidemic, locked in the city. Everyone is faced with a choice: to fight for life, to find a way out, or to accept the domination of the plague, with the inevitable death. Many literary critics compare the events described with those in France during the Nazi occupation.

Key words and expressions: novel-parable, allegory, metaphor, antithesis, personification, chronicle.

1947 йилда А. Камюнинг “Вабо” романи нашр этилади (La Peste, 1947). Роман сўзбошисида адиб шундай ёзади: “Бемаънилик туйғусидан харакатлар учун қоида яратилса, қотиллик хам энг камида лоқайдликка тенглашади, бинобарин, уни амалга ошириш одатий холга айланади. Агар хеч нарсага ишонилса, хеч нарсада мазмун ва қадрият бўлмаса, унда дунёда мухим нарсанинг ўзи йўқ, хеч бир харакат таъқиқланмаган. "Қарши” ёки “тарафдор" йўқ, қотил хақ ёки нохақ хам эмас. Одам жасадини ёқиш учун крематорийларни қиздириш ёки моховларни даволаш билан шуғулланса-да бўлади. Жиноят ва саховат - бариси бирдек, оддий тасодиф ёки инсон феълининг инжиқликларидан ўзга нарса эмас" [2,II,415]. Шунга қарамасдан, адиб ижодининг мазкур босқичи марказида хам яна ўша-ўша - “абсурд”ни кўрамиз. Адабиётшунос Д. Наливайко, Камюнинг "Вабо" романига шундай таъриф берган: “Жанр хусусиятига кўра Камюнинг мазкур асарини энг янги интеллектуал наср жанри бўлмиш роман-масал, дейиш мумкин. Бу жанр универсаль ва кўп маънолилиги билан тавсифланади. "Вабо" - Кафканинг шу жанрдаги “Жараён” ва "Қаср”, Платоннинг “Котлован”, Голдингнинг “Пашшалар хукмдори” номли асарлари қаторидаги энг мухим романлардан бири".

А.Камю ижодини чуқур ўрганган рус адабиётшуноси С.И.Великовский роман хақида шундай ёзади: "Вабо” - “совук” китоб, хатто қашшоқ, унда-мунда чақнаган айрим лирик шуълалар хиссиётсиз хронист томонидан бостирилган, воқеаларни драматик ифода этиш тартиби кўргазмали намойиш усули билан сиқиб чиқарилган, шу боисдан портрет тасвирлар гўё қидирувдаги шахс аломатлари рўйхатига ўхшайди — “шахсий анкета маълумотлари” ва 
қахрамонлар тасвирида жонли харакат хамда рухий қайноқлик етишмайди, шулардан хулоса ўлароқ, китоб жозибаси кам, зерикарлироқ.

Мутлақо тушунарлики, роман воқеалари “194...- йили Жазоирда тўсатдан бошланган эпидемия” хусусида эмас, балки одамлар учун вабодан кам бўлмаган бошқа офат хақида аллегория (рамз) воситасида фикр юритилади. Бундан ташқари, романнинг турли талқиндаги бир қанча номлари хам мавжуд: "Уруш", “Худонинг қахри”, “Инсон айби”, “Офат”. Муаллиф томонидан романнинг илк сахифаларида қайд этилган йилнома (Хронотоп $194 \ldots)$, ва унинг ёзилиш вақти (1940-йил охири ва 1942 йилнинг бахори), хамда асарнинг чоп этилиш санаси (1947), шак-шубхасиз, вабо мазкур контекстда аввало урушни эсга солади. Бутун дунёни ларзага солган ва деярли хар бир одам тақдирига дахлдор Иккинчи Жахон уруши (1939-1945). Илғор тафаккур сохиблари ва ёзувчилар бу аламли ходисани англашга уринадилар, уларнинг кўпчилиги қай даражададир, сиёсий тарафкаш ва ғаразгўй тоифага айланадилар. Романда Иккинчи Жахон уруши ва вабо ўртасидаги параллелга далил бўлувчи деталлар куйидагилардир: “Ёпиқ шахар” («ville fermée») дея кўрсатилган, каламушлар босқинига, алалоқибат, вабога учраган Оран, (муаллиф бунда айнан «invasion» сўзини кўллаган [3, p.p.19,72]). Шахар ортида денгиз деярли кўринмайди. Асар, Франция нацистлар армияси томонидан оккупация қилинган даврдаги реал воқеаларга асосланган. Фашистлар армияси “жигарранг вабо” (немис армияси формаси рангига кўра) дея номланган. Икки офат, миқёсига кўра ўзаро ўхшаш икки фалокат: «Il у a eu dans le monde autant de pestes que de guerres. Et pourtant pestes et guerres trouvent toujours les gens aussi dépourvus» [3, 40]. - Дунёда қанча урушлар юз берган бўлса, шунча марта вабо эпидемияси хам тарқалган. Шунга қарамасдан, уруш хам, вабо хам одамларни доимо ғафлатда қолдирган (Н.Х.Турсунова таржимаси).

Бу икки офатнинг пироварди бир хил: оилаларни барбод этиш, яқинларни қон қақшатиш, этни тирноқдан ажратиш, озодликни чеклаш, халқларни қирғинбарот қилиш, ўзаро нафрат, ғам-алам. Муаллиф тез-тез харбий атамаларни истифода қилади: «vie de prisonniers » («махбуслар хаёти» $[3,77])$, «ville menacée» («шахар хавф остида» [3, 114]), «interminable défaite» («чексиз мағлубият» [3, 128]). Ушбу талқинларга кўра, бош қахрамон доктор Риэ ва унинг дўстлари немис оккупацияси давридаги Франция Қаршилик харакати намоёндалари ўлароқ кўзга ташланади.

Бош қахрамонлардан бири ашаддий дахрий Жан Тару эса вабони адолатсиз жамият учун хақли жазо, дея қабул қилади. Суд одиллигидан хафсаласи пир бўлган (у инсонни қатл қилинишига гувох бўлган - сўз Мерсонинг қатли хақида бораётир), революцион курашданда “кўлини ювиб, кўлтиққа урган”, икки йўлни хам босиб ўтган зот, булар - сароб идеаллар учун жонни тикишдан уззга нарса эмаслигини теран англаганди: қолаверса, инсонга хос барча нарсадан Тару совуган, кўнгли қолган. Унинг фикрича, хар бир инсон охир-оқибат ўзини ўлимга олиб борувчи иш-фаолият билан машғул бўлади. Бас шундай экан, Тарунинг фикрича, бу хаётда гунохга ботмай туриб, Вабога йўлиқиш маъқулроқ. Унингча, одамларга шусиз хам “вабо теккан”: «...C'est cela qui peut soulager les hommes et, sinon les sauver, du moins leur faire le moins de mal possible,et même parfois un peu de bien. Et c'est pourquoi j'ai décidé de refuser tout ce qui, de près ou loin, pour de bonnes ou de mauvaises raisons, fait mourir ou justifie qu'on fasse mourir » [3, 242]. - Фақат шугина одамлар гунохини енгиллаштириши мумкин, майли, улар хаёти сақлаб қолинмас, аммо хеч қурса камроқ залолатга кетар, хатто, бир қадар савобга эришишса, не ажаб! Айнан шу туфайли мен хамма нарсани инкор этишга қарор қилдим, оз ёки кам, яхши ва ёмон, ўлим келтириш ёки уни оқлаш бўладими (Н.X. Турсунова таржимаси).

Вабонинг энг хунук кўринишларидан бири - инсонлар ўртасида бирдамликнинг йўқолишига эътибор қаратамиз. Шунга кўра, муаллиф томонидан Доктор Риэ ва унинг сафдошлари одамларга, бундай холларда қандай бўлиш кераклиги хақида энг ёрқин намуна ўлароқ тақдим қилинган. Кучайиб бораётган хавф-хатар ва оломонни қамраган умидсизликка қарамасдан, Риэ ва унинг яқин сафдошлари эпидемияга қарши курашни асло сусайтирмайдилар, вахоланки, айни дамда кўплаб шахарликлар шубхали худбин ва якка 
холда жон сақлаш пайига тушадилар. "Вабо” рамзли романи юзасидан мулохазаларимиз аввалида муаллиф яна абсурд мавзусига қайтганини айтдик. Гарчи бу асар Камю ижодининг иккинчи даври «Исён» (La Révolte)га мансуб бўлса-да мазкур тенденция яққол кўринади. Бу мулохазани анада кенгроқ кўриб чиқиш мақсадга мувофиқ. “Сизиф хақида афсона” эссеси тахлилида биз абсурднинг туғилиши хақидаги ўзгармас аксиомага дуч келамиз. Бир-бирини тўлдирувчи унсурлар тўқнашуви натижасида “инсон онги - абсурд - дунё” деган учлик (mpuada) хосил бўлади. "Вабо" романида бу унсурлар тўқнашуви мавжудми? Шахар ахли, барча тирик жонзотларга қирон келтирувчи офат - Вабога дуч келгач, дунёнинг абсурдлигини англайдилар. Рухоний Панлю отанинг қавмга омонлик сўраб қилган илтижоли дуоларига қарамай, насронийлар Вабо қаршисида буткул ожиз тутқунларга айланишади. Оран ахли, олдинда уларни фақатгина ўлим кутаётганини англайдилар: «Ils éprouvaient ainsi la souffrance profonde (la métaphore) de tous les prisoniers et et de tous les exilés (l'hyperbole), qui est de vivre avec une mémoire qui ne sert à rien...Impatients de leur présent, ennemis de leur passé et privés d'avenir, nous ressemblions bien ainsi à ceux que la justice ou la haine humaines font vivre derrière des barreaux (l'hyperbole)» [3, 77]. - Улар барча кувғин ва махбусларга хос азобларни бошдан кечирдилар (муболаға), инсон - хотира ила тирик, агар бу хотира кераксиз бўлса, унда яшашдан не фойда? Улар чеккан азоб-уқубатнинг мохияти хам шундан иборат... Бугунги кунидан қониқмаган, ўз ўтмишига душман ва келажакдан мосуво кимсалар - ким? Шу тариқа, адолат ёки нафрат одамларни панжара ортида яшашга мажбур этади (муболаға) (Н.X. Турсунова таржимаси).

"Вабо" романида эса бутун бошли Оран шахри ва унинг ахолиси тутқунга айланишади. Роман ёзилиш жараёнида Камю Жан Гренье билан фикр алмашади: “Сиз мабодо Оранга тушиб қолганингизда, ташқи дунёдан қанчалик узилиб қолишингизни хатто тасаввур хам қила олмасдингиз. Бу хақиқий лабиринт. Хар бир кўча муюлишида фуқаро нохушлик деб аталмиш Минотаврга дуч келади [4, III, 573]». Роман, тўғрироғи, мажозий роман, бизни беихтиёр абсурд ва инсон тақдири хақидаги фикрга қайта етаклайди. Роман хроника услубида битилган. Жазоир қирғоғидаги француз префектураси, Оран номли аллақандай шахарнинг 194... йиллардаги хроникаси: « À première vue, Oran est, en effet, une ville ordinaire et rien de plus qu'une préfecture française de la côte algérienne. La cité elle-même, on doit l'avouer, est laide. D'aspect tranquille, il faut quelque temps pour apercevoir ce qui la rend différente de tant autres villes commerçantes, sous toutes les latitudes. Comment faire imaginer, par exemple, une ville sans pigeons, sans arbres et sans jardins, où l'on ne rencontre ni battements d'ailes ni froissements de feuilles, un lieu neutre pour tout dire ? Le changement des saisons ne s'y lit que dans le ciel...» [3, 10]. - Оран, бир қарашда, оддий шахар, Жазоир қирғоқларидаги француз префектурасининг шахарларидан бири. Шахарнинг кўримсизлигини тан олиш керак. Тинчлик ниқоби остида бир-қанча вақт ўтиб, савдо-сотиқ билан шуғулланадиган бу каби кўплаб шахарларга ўхшамаслигини англаб олишимиз мумкин. Каптарсиз, дарахт ва боғлар йўқ, қушлар қанотларини қоқмайдиган, барглар шивирламайдиган, ўзига жалб қилмайдиган шахарни қандай тасвирлаб бериш мумкин? Фасллар алмашишини эса осмоннинг рангига қараб тушуниш мумкин... (Н.Х. Турсунова таржимаси).

Шундай қилиб, “қизиқарли воқеалар”ни ривожлантириш мақсадида муаллиф қуйидагиларни танлайди: «Cette cité sans pittoresque, sans végétation et sans âme...[3, 12]». Хеч бир белгисиз (нишонаси йўқ), кўклик йўқ ва рухи йўқ бир шахар... (персонификация, жонлантириш) (Н.Х.Турсунова таржимаси). С.И. Великовскийнинг қатъий эътирофига кўра, романда “романтик хаёлпарастликнинг ўзи йўқ... Камю одатий яшаш жойи ўрнига каттаюкичик, Оран ахли қамалган ялонғоч казематни тасвирлайди. Хаммаси ўлим билан юзма-юз, қамалган. Бунда хамма истисносиз, қурбон: зараркунанда бацилла жиноятчи ва тақводор, болалар ва кексалар, рухан тушкун ва жасур инсонларни-да баравар ўз комига тортган. Йилномачи барча ва хар бир кимсани таништириш баробарида, улардан хар бирининг тақдирига дахлдорликни уқтиради. Китобдаги манфаатлар тўқнашуви кенг қамровли: шахснинг атроф-мухит билан тўқнашуви, ўнг ва сўл кучлар билан эмас, балки инсониятнинг шафқатсиз ва қиёфасиз офати — вабо билан тўқнашув (антитеза) [1, 103-104]. 
“Вабо” романида бўлгани каби, “Бегона” қиссасида хам - хақиқатни тан олмаслик ва хар қанча шафқатсиз бўлса-да кўзига тик боқмаслик тилга олинади, илло, айнан шундай дақиқаларда инсон абсурд дунё ва унда кун кўраётган биз - тилга олинамиз.

\section{Фойдаланилган адабиетлар рўйхати}

1. Великовский С.И. Грани несчастного сознания. Театр, проза, философская эссеистика, эстетика Альбера Камю. Москва, «Искусство», 1973.

2. Albert Camus, Essais, Paris, Bibl. de la Pléiade, 1965, p.415

3. Camus A. La peste. Edition Bélin/Gallimard, 2012. 351 p.p.

4. Camus A. Euvres complètes, Paris, Gallimard, Bibliothèque de la Pléiade, 4 vol., 20062008.

5. Camus A. L’Etranger. Edition Gallimard, 1942. Rééditer en 2000. 188p.p.

\section{XITOY TILIDA MAXSUS KISHILIK VA KO`RSATISH OLMOSHLARNING TAHLILI}

O.Z. Tilovov
SamDCHTI

Annotation: In addition to first, second, and third person pronouns, there are several special personal pronouns in Chinese. This article analyzes several specific personal pronouns. In this case, we analyze the 人家, 别人, 别, 别的, 另, 另外, 其中, 其余 and 其他 from the special personal pronouns.

Kalit so`zlar: 人家, 别人, 别, 别的, 另, 另外, 其中, 其余, 其他

Xitoy tilida kishilik olmoshlari birinchi, ikkinchi va uchinchi shaxs kishilik olmoshlaridan tashqari bir nechta maxsus kishilik olmoshlari ham mavjud. Ushbu maqola bir nechta maxsus kishilik olmoshlari tahliliga bag ishlanadi. Bunda biz maxsus kishilik olmoshlaridan 人家, 别人, 别, 别的, 另, 另外, 其中, 其余 hamda 其他 larni tahlil qilib chiqamiz.

人家 rén jiā - ma’nosi ko’p bo 'lib, ham 别人 (boshqa birov, boshqalar)ni, ham 我自己 (men o`zim)ni va yana 他, 他们 (u, ular) ni ma’nosini anglatib kelishi mumkin. 人家 uchinchi shaxsni ifodalaganda aniq bir obyektni nazarda tutib keladi.

(1) 别人 (boshqa birov, boshqalar): so`zlovchi va tinglovchidan tashqari bo`lgan shaxsni ta'kidlash. 人家能做到的, 我们也能做到- boshqalar bajara olishayapti, biz ham bajara olamiz.

（2）他，他们 (u, ular): qaysidir odam yoki odamlarni ta'kidlash. 把信给人家送去 - xatni unga junatib yubor.

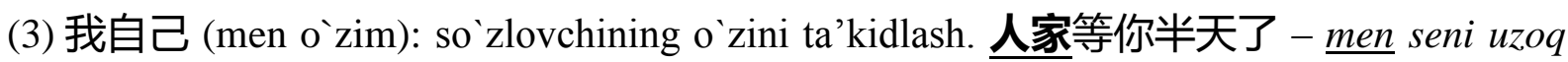
vaqt kutdim.

人家 “rén jiā”ning gapda yakka holatda kelganda gapning egasi yoki to ‘ldiruvchisi bo 'lib ham kelishi, ham shaxslarning ismi oldidan kelib,

别人 bieren - asosan uchunchi shaxsni nazarda tutib kelib, aniq bir obyektni nazarda tutmaydi, umumiylik saqlanadi.

别人都同意, 就你一人反对 - boshqa hamma rozi, birgina sen qarshi.

别, 别的, 另, 另外 bu guruh so`zlar boshqa vaziyatdagi so`zlarni ta’kidlab kelib, ular o`rtasidagi bog 'liqlik ham juda murakkab. Bu yerda eng e’tiborli bo 'lish kerak bo 'lgan tomoni bu “ 别” bo ‘lib, ravish sifatida gapda qatnashganda 不要 bilan ma’nosi bir xil bo 'lib keladi, ya’ni, ta'qiqlash ma'nosini anglatadi. “别” ot bilan qo`shilib kelib, “别的” ning o`rnida ham qo'llanilishi mumkin, masalan 别人, 别国 kabi. 另 bilan 另外 ravish bo lib kelganda ma'no jihatdan bir xil, gapda hol vazifasida keladi; ko`rsatish olmoshi bo`lib kelganda 另 va 另外 ning bir xil o`xshash tomoni mavjud. Ya’ni o`zidan keyin miqdor so`zlar bilan birga kelishi mumkin. Masalan: 另外一 
个/另一个。Farqli tomon esa 另外 o`zi bilan 另外+的+名 shaklida keladi, lekin 另 bunday shaklda kelmaydi. 另外 yakka o`zi kelganda, 此处 bilan ma’nosi va qo`llanilishi bir xil bo`ladi.

你别/不要去那个地方了 (Sen u joyga borma)。

别/别的人不去我也不去 (Boshqalar bormasa, men ham bormayman)。

还有别的问题吗 (Yana boshqa savollar bormi)?

我们另/另外找一个地方吧 (Biz boshqa bir joy topa qolaylik)。

另外, 我们再讨论一下儿明天的旅行计划。(Bundan tashqari, biz ertangi sayohat rejasini yana muhokama qilaylik)。

另两个城市我们也想去参观参观 (Qolgan ikki shaharga biz ham borib sayohat qilishni xoxlaymiz)。

另外一个问题下次再谈 (Boshqa bir muommoni kelasi safar gaplashamiz)。

“另外” yana “以后” “之后” degan ma'noga ega. Masalan: “这个我们另外找时间再说吧” gapning ma'nosi, “我们这次先不聊这个, 之后再说好了” ma'nosi bilan bir xil.

其中, 其余, 其他 bu guruh so`zlar ichidan 其中 ot hisoblanib, maxsus qo`llanilishga ega. Uning oldidan odatda katta sonli miqdor keladi, ortidan esa o`sha katta sonli miqdorning bir qismi keladi, bundan tashqari 其中 meyoriy ko`rinish formasida kelishi mumkin, masalan, 其中之一。

我们班有 20 个同学, 其中有 11 个女生 (Guruhimizda 20 nafar talaba bor, shundan 11 nafari qizlar)。

我有很多好朋友，大卫是其中之一(Juda ko`p yaqin do`stlarim bor, Davei ulardan biri)

其余 va 其他 larning ma’nosi va qo'llanilishi juda ham yaqin, to 'g`ridan to`gri ot bilan bog lana oladi. E’tiborli bo`lish kerak bo`lgan tomoni ko`rsatish olmoshi 其他 ham shaxsni ham predmetni ko`rsatib kelishi mummkin.

你们两个先走, 其余人留下。Siz ikkingiz ketavering, qolganlar shu yerda qoladi.

这些我收下, 其余你们都带回去吧。(Bularni men olaman, qolganlarini sizlar olib ketaveringlar)

玛丽留下，其他同学可以走了。(Mali qolsin, qolgan talabalar ketaversin)

Yuqoridagi tahlil qilingan gaplar va qoidalardan kelib chiqib shuni aytish mumkinki, keltirib o'tilgan bu olmoshlar bir biri bilan ham ma'no jihatdan, ham qo'llanilish jihatdan o'xshash tomonlari va o`z navbatida bir birini o`rnida qo`llab bo`lmaydigan holatlari ham mavjud ekan. O`quvchiga yanada tushunarli bo`lishi uchun biz quyidagi misollar orqali yana bir tahlil qilib o`tamiz.

1. 除了小王，你还有别的/其他中国朋友吗?

Wangdan tashqari, sening yana boshqa xitoylik do`stlaring bormi. (Gapda aniqlovchi fazifasida)

2. 除了中文, 你还会说别的/其他外语吗?

Xitoy tilidan tashqari, yana boshqa tillarni ham bilasanmi. (Gapda aniqlovchi fazifasida) 3. 我们班六个同学过了 HSK 六级考试, 另外/其他两个没过。

Guruhimizda 6 nafar talaba HSK 6 darajasidan o`ta oldi, qolgan ikki nafar o`tolmadi. (bu gapda 别的 ni qo`llab bo`lmaydi)

4. 妹妹有两条黑裙子, 另外一条是白色的。

Singlimning ikkita yupkasi qora, boshqa bir yupkasi oq rangda. (一条裙子 bu yerda bitta yupka bo`lganligi uchun 其他/别的 qo`llanilmaydi)

5. 今天先讨论这个问题, 别的/其他以后再讨论。

Bugun bu muommoni muhokama qilamiz, qolganlarini boshqa safar. (“别的、其他”gapda ega vazifasida kelishi mumkin, “另外”esa yo`q; “别的” yana to `ldirivchi vazifasida kelishi mumkin, “其他、另外”esa yo`q)

6. 要想保持健康, 你最好每天多吃水果蔬菜。另外, 记得适量运动。 
Sen hardoim sog `om bo`lishni xoxlasang, eng yaxshisi har kuni ko`proq meva sabzavot yegin, bundan tashqari, sport bilan shug ullanish ham esingda tursin. (Ushbu gapda faqatgina 另外 此处 ning o`rnida qo`llana olishi mumkin)

7. 我今天晚上另外有安排, 我们找别的/其他时间再一起聚聚吧。

Bugun kechga boshqa bir rejam bor, Boshqa safar vaqt topib ko`rishamiz.

8. 这件衬衫太大了，您还有别的吗?

Bu ko ylak juda ham katta, sizda yana boshqasi bormi. (“别的” yana to 'ldirivchi vazifasida kelishi mumkin, “其他、另外”esa yo`q)

9. 不好意思，您点的啤酒没有了，您想喝点儿别的吗?

Kechirasiz, Siz buyurtma bergan pivo qolmabdi, boshqa biron nima ichasizmi. (“别的” yana to`ldirivchi vazifasida kelishi mumkin, “其他、另外”esa yo`q)

\begin{tabular}{|l|l|l|l|l|}
\hline & $\begin{array}{l}\text { 主 } \\
\text { ega }\end{array}$ & $\begin{array}{l}\text { 宾语 } \\
\text { To’ldiruvchi }\end{array}$ & $\begin{array}{l}\text { 定语 } \\
\text { Aniqlovchi }\end{array}$ & $\begin{array}{l}\text { 逻 连 接 词 } \\
\text { mantiqiy } \\
\text { bog`lanish }\end{array}$ \\
\hline 别的 & $\sqrt{ }$ & $\sqrt{ }$ & $\sqrt{ }$ & $\times$ \\
\hline 其他 & $\sqrt{ }$ & $x$ & $\sqrt{ }$ & $\times$ \\
\hline 另外 & $x$ & $\times$ & + 的 -- $\sqrt{ }$ & $\sqrt{ }$ \\
\hline
\end{tabular}

Adabiyotlar:

1. 现代汉语实用语法分析。清华大学出版社.-北京。

2. 刘珣. 新实用汉语课本. 北京语言大学出版社.-北京 2009

\title{
ХИТОЙ ВА ЎЗБЕК ТИЛЛАРИДА МИЛЛИЙ-МАДАНИЙ ЭКВИВАЛЕНТСИЗ КОННОТАТИВ ЛЕКСИКАНИ ЎРГАНИШГА ДОИР
}

\author{
Х. Тугалов, (СамДЧТИ)
}

Annotation: In this work, we try to show the meaning, national culture in chinese and connotative vocabulary without equivalent Connotation is an additional evaluative, emotional and expressive component of the content, which expresses the main meaning of the word, which gives the word semantically, stylistically, additional meanings, more expressive, expressive and expressive. The study of the linguistic functions of the connotation confirms that it is of a national, social, cultural nature, reflects the linguistic consciousness of the speakers of the language, and that such a connotation is incomprehensible to members of other nationalities.

Таянч сўзлар: ассоциатив, коннотив лексика, коннотатив компонент, эквивалентсиз лексика, миллий-маданий ўзига хослик.

Тил хар қандай жамиятнинг мавжуд бўлишлиги ва тараққиёти, миллатнинг маънавий маданиятини, жамият вакиллари ўртасидаги ўзаро, шунингдек маданиятлараро, миллатлараро муносабатларни ўрнатилишдаги энг мухим восита эканлиги аллақачон исботланган. Тил маданиятни, маданият эса тилни вужудга келтиради ва ўлар ўзаро узвий боғлиқликда ривожланади. Маданият инсониятнинг узоқ даврлар жараёнида тўплаган тажрибаси махсули сифатида нафақат миллатнинг миллий анъаналарида, урф-одатларида, диний эътиқодларида тафаккур ва қадриятларида балки бевосита тилнинг ўзида, одамларнинг нутқ актида мулоқотнинг ўзига хос услуби сифатида акс этиб келаверади. Бу жараёнда лексик бирликлар маъноси муайян лисоний коллективнинг турмуш тажрибаси, нарса ва ходисаларни ассоциатив идрок қилиши, муайян ижтимоий мухитда шаклланган онги туфайли турлича коннотациялар билан тўлдирилиб боради.

Коннотация - бу сўзнинг асосий маъноси ифодалайдиган мазмуннинг кўшимча ифодаланадиган бахоловчи,эмотив ва экспрессив компонентлари бўлиб,улар сўзни 
семантик, стилистик жихатдан қўшимча маъноларини хосил қилиб, фикрни ифодалироқ, тантаналироқ, образлироқ ифодаланишига ёрдам беради. Коннотациянинг лисоний функцияларини тадқиқ қилиниши унинг миллий, ижтимоий, маданий характерда бўлишлигини, тил сохибларининг лисоний онгини акс эттиришини ва бундай коннотация бошқа миллат вакилларига тушунарли бўлмаслигини тасдиқлайди.

Бир тилдаги лексик бирликлар ифодалайдиган коннотатив компонентларни бошқа тиллар билан қиёслаб ўрганилиши улар ўртасидаги семантик фарқлар нафақат сўз ифодалайдиган предметлик маъноларига, балки шу предметнинг физик мохиятига, лисоний бирлик ифодалайдиган ижтимоий,эмоционал ва маданий мухитга хам боғликдир. Демак,бу ўринда тиллараро коннотацияларни ўрганиш эквивалентсиз лексика хисобланмиш хар бир тилдаги миллий ўзига хос сўзлар ифодалайдиган маданий коннотацияларни қиёслаб ўрганишни тақозо қилади.

Ушбу мақоламизда биз хитой ва ўзбек тилларини қиёслаб ўрганишда дуч келинадиган эквивалентсиз лексикалар -яъни хар бир тилга хос бўлган миллий-маданий коннотацияларни қиёслаб ўрганишни мақсад қилиб кўйдик.

Эквивалентсиз коннотатив лексика дейилганида хозирги замон тилшунослигида бир тилга хос миллий-маданий ўзига хос тушунчаларни ифодаловчи лексик маънонинг иккинчи бир тилда аниқ эквиваленти мавжуд бўлмаслиги тушунилади. Хитой ва ўзбек тилларида хар икки тил ва маданиятнинг фарқланувчи белгиларини ифодалайдиган жуда кўп лексик бирликлар мавжуд. Бундай сўзларнинг тушунилиши қийин бўлган семантик компонентлари турлича лисоний ва нолисоний омилларга боғликлиги билан изохланади. Шу сабабли миллий анъаналарни характерловчи бундай коннотатив лексикалар миллий-маданий ва эмоционал маънолари билан бошқа тиллардаги шундай сўзлар семантикасидан фарқланиши мумкин.

Тиллараро мулоқот ёки бадиий асар мутолласи жараёнида коммуникантлар айнан коннотатив маънолари тушунарли бўлмаган мана шундай лексик бирликларга жуда кўп дучор бўлишади. Хитой ва ўзбек халқларининг кўпмиллатли маданиятининг ўзига хос хусусиятлари оламнинг лисоний манзарасини идрок қилишдаги айнан мана шундай эквивалентсиз лексикаларда, фон билимларда ва коннотатив лексикада ўз аксини топади.

Ўзбек тилида хам фақат шу миллатга хос бўлган, миллий колоритни ёрқин ифодалайдиган, бошқа тилларда анологи мавжуд бўлмаган кўплаб сўзлар мавжуд. Масалан, «чопон» сўзи ўзбек эркаларининг кундалик ёки тўй ва маросимларда киядиган қора, кўк рангли матодан ичига пахта солиб қавилиб тикиладиган узун енгли устки кийимини ифодалайди. Табиийки,миллий ўзига хосликни ифодалайдиган бу сўзни ўқиган ёки эшитган хитой миллатига мансуб киши сўзнинг фақат асосий маъноси «кийим»нигина тушунади, у ифодалайдиган юқоридаги коннотатив маънолари англашилмасдан қолаверади. Чунки бундай кийим хитой тили ва маданияти учун эвкиваленти мавжуд бўлмаган бегона сўз ва у махсус изохга мухтож.

Хитой тилини махсус ўрганаётган биз ўзбеклар учун бу тилда бир хил денотантлар билан ифодаланувчи,аммо эмоционал эстетик ассоциацияларга асосланган эквивалентсиз коннотатив лексикани билиш айникса мухим. Хитой тилида ўзбеклар учун тушунарли бўлмаган, одамнинг предмет ва атроф-мухит ходисаларига хиссий субъектив муносабатини ифодалайдиган жуда кўп коннотатив эквивалентсиз лексикалар мавжуд. Масалан, ўзбеклар учун хитой тилидаги сирка идиши маъносини ифодаловчи 醋坛子 сўзи «хасадгўй, ичи қора киши» маъносини англатиши хаёлига хам келмайди ва уни тўғри маънода тушунади. Бундай коннотатив маъно хитойликларнинг урф-одатлари билан боғлиқ. Маълумки сирка шўримтир хидга эга ва хитой ошхонасида энг севимли зиравор хисобланади. Аммо сўз маъноси ўтмишда содир бўлган қизиқарли тарихий воқеа билан хам боғлиқ. Қадимда Фан Сюаньлин исмли киши Тан сулоласига мансуб император Ли Шиминянинг энг яқин вазирларидан бири бўлиб, унингсай-харакатлари туфайли император сиёсати мамлакатда жадал амалга оширилган. Император вазирини мукофатлаш учун пул эмас, гўзал ва ёш канизакни совға қилган. Фаннинг рашкчи хотини буни эшитиб, ўлимни афзал билиб император совға қилган 
захарли шаробдан бирини ичиб юборади. Вазирнинг хотини ўлмай қолади, чунки император рашкчи хотиннинг бу ниятини пайқаб унга захарли шароб ўрнига сиркали идишни юборган бўлади. Шундан бошлаб 醋坛子сўзи халқ орасида кенг тарқалиб «妒忌» «рашкчи» сўзи билан бирга, «хасадгўй киши маъносини англата бошлаган»

Худди шундай хитой тилидаги «竹木» (бамбук) сўзи хам рамзий кўшимча коннотатив маънога эга, у хитой миллатинингқадр-қимматини, соф мухитини ифодалайди. Қолаверса бамбук энг тез ўсадиган дарахт тури бўлиб хитойлдикларнинг қадр-қиммати тобора ортиб бораётганлигини хам ифодалайди.

Хитой тилидаги эквивалентсиз коннотатив лексикага ёрқин мисол сифатида 牡丹 «мудань» сўзини хам келтириш мумкин. У қизил, қирмизи ва оқ рангларда гуллайдиган дарахтсимон гул тури бўлиб пион гулига жуда ўхшаб кетади. У хитойликларнинг энг чиройли ва севимли гули хисобланиб, «барваста қоматли гўзал аёл»ни хам ифодалайди..

Ўзбекча «чинор» ва хитойча «сун шу» (қарағай) дунёдаги хар қандай тилга дарахт тури сифатида денотатив маънода таржима қилиниши мумкин. Аммо турли дарахтлар номи билан хар икала тилда уларнинг «мустахкам соғлик», «узоқ умр кўриш» каби коннотатив маъноларини кўрамиз.Хитой ва ўзбек маданияти билан таниш бўлмаган кишида бундай дарахт турларига боғлиқ бўлган эмоционал-этик ва эстетик коннотациялар бу сўзларнинг номинациясидан ташқари хеч қандай таъсурот қолдирмайди..

Юқорида билдирилган фикрларни умумлаштириб миллий-маданий ўзига хосликни акс эттирадиган лексика тилдаги реалияларнинг ўзига хослигини коннотация орқали ифодаланишидир, деган хулосага келиш мумкин. Хитой ва ўзбек тилларидаги миллиймаданий лексик бирликлар халқ томонидан яратилган, образли коннотацияларда ифодаланган объектив борликдаги нарсалар, воқеалар, урф-одатлар, анъаналар, одамларнинг- одамларга, атроф мухитга турлича муносабатларини акс эттиради ва ўз луғат таркибларида турғинлаштириб, авлоддан-авлодга етказилишида кумулятив функцияни хам бажаради. Буларнинг хисобга олиниши айниқса хорижий тилларни ўргатишда лингвомаданиятшунослик, лингвомамлакатшунослик характеридаги эквивалентсиз коннотатив лексикани ўргатишда мухим ахамият касб этади.

\section{Фойдаланилган адабиётлар}

1. Горелов В.И. Грамматика китайского языка. -М.: Просвещение, 1982.

2. Горелов В.И. Теоретическая грамматика китайского языка. -М.: Просвещение, 1989.

3. Драгунов А.А. Грамматическая система современного китайского разговорного языка. -Л.: Изд-во ЛГУ, 1962.

4. Иванов И.А., Поливанов Е.Д. Грамматика современного китайского языка. -М.: Эдиториал УРСС, 2001.

5. Коротков Н.Н. Основные особенности морфологического строя китайского языка. - M., 1968.

\section{ТИЛДА АКС ЭТГАН СТЕРЕОТИПЛАРНИНГ ТУРЛАРИ}

\section{Маматова Феруза Махаммадона

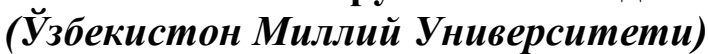

Annotation: This article is devoted to the analysis of the opinions on the classification of stereotypes according to different criteria. Linguists divide them into groups such as national, ethnic, external and sublingual stereotypes. The stereotypes reflected in the language are perceived as a reflexive unit of the national culture.This, in turn, shows that research is an important necessity for comparative linguocultural practice and for the theoretical understanding of such research, as well as for the study of foreign languages. Stereotypes are formed in the human mind 
as signs of a stable mental landscape of the world, but at the same time they are expressed in language: vocabulary, proverbs and sayings.

Key words and expressions: Linguaculturology, stereotype types, national and ethnic stereotypes, linguistic picture of the world, upper and lower stereotypes.

Стереотип бир неча келиб чиқиши, тарқалиши ва бошқа хусусиятларига кўра турларга ажратилади. В.В.Красных таъкидлашича стереотиплар хар доим миллийдир[Krasnykh 2002:194].Улар миллий колоритдан келиб чиққан холда ўзнинг мазмунидаги фарқ билан турли этносларда бир хил тарзда мавжуд бўлиши мумкин. Бироқ, турли лингвомаданий умумийликда фақатгина стереотипнинг мазмунли тўлдирилишига, балки унинг мавжуд ёки мавжуд эмаслигига асосланган фарқлар мавжуд. Бундай холларда стереотипларни билиш мулоқот қилувчиларнинг мулоқотини енгиллаштиради ва соддалаштиради, зеро стереотип маданий мулоқотда шахснинг таянчидир.

Олимлар миллий ва этник стереотипларни автостереотипларга (маданиятнинг ичида мавжуд бўлган ўзлари хақидаги афсоналар) хамда гетеростереотиплар (ташқи, яъни бир миллат маданиятининг вакилларини бошқа миллат маданияти вакиллари хақида юзага келган стереотиплар) ажратади.Стереотиплар, уларда акс этган шундай характер хусусиятларининг уларда шалланишини кучайтириб одамларга етарлича кучли таъсир ўтказади[Krasnykh 2002:55].Мисол тариқасида, ўзбек маданият вакилларини немис, инглиз ёки рус маданияти одамларига нисбатан бўлган тасаввурини келтириш мумкин (юқорида келтирилган таснифлашга кўра улар гетеростереотиплардир). Инглиз маданий меросида обхавога оид кўплаб мақол ва фразеологизмларни ва об- хаво мавзусига оид сўзлар иштирокидаги мақол ва идиомалар мавжуд учратиш мумкин: hether the weather, a bolt from the blue- “қуёшли кун урртасида момақалдироқ", make hay while the sun shines -“темирни қизиғида босиш керак”, а ray of sunshine - “оптимист, тоза хаводан бир ютум”, A foul morn may turn to a fair day "булутли кун, куёшли кунга ўзгариши мумкин”, to weather the stormчидамоқ, яъни қийин вазиятдан сабр билан чиқиб кетиш , After a storm comes a calm - ўзбек тилиннинг ойнинг ўн беши қоронғу, ўн беши ёруғ, сув бир лойқаланиб тинади мақоллига яқин, яъни портанадан кейин, осудалик бўлади деган маънода, After rain comes fair weather яъни ёмғирдан кеин яхши хаво бўлади, Everything is good in its season - хамма нарсанинг ўз вақти соати бор маъносда ёки as right as rain - бу идиома “ёмгирдек яхши" яъни "яхши” деган маънони англатади.

Келтирилган мисоллар инглиз менталитети учун типик бўлган об-хаво, унинг одамнинг кайфиятига таъсири, табиат ходисалари хатто инсон, вазиятнинг белгиларини тасвирлашдаги ахамити бошқа халқларнинг тасаввури эканлигидан далоат беради. Миллий стереотип бир миллий гуруга ёки бутун бир миллатга тегишли ва ўша миллатнинг хар бир вакилиди ўзига хос хусусият борлигини тахмин қилади. Бу фарқланмайдиган мулохаза муқаррар равишда ўзида яширин ёки очиқ холда аниқ бахони сақлайди [Елизарова 2004:291].Миллийстереотиплартурли социология, психология, политология, филология, тарихсохалардаўрганилади. Узбекхалқинингмаънавий-маърифиймаданиятинингнегизида “ўзбекчилиг”, “ўзбекодоб-ахлоқи” каби ахлоқий қадриятлар тизими ётади. Ўзбеклар бошқа миллатлардан очиқ кўнгиллилиги, мардлиги, жиддийлиги, ватанпарварлиги, инсонпарварлиги, мехр-мурруватлиги, мехмондўстлиги, кечиримлилиги, мехнатсеварлиги, она ва аёлларни эъзозлаши, оталарни хурматлаши, яхшилик қилиш каби қадимий анъаналарни сақлаб қолиши билан хам фарқланади. Шу билан бирга ўзбекларнинг «оилавий муносабатларини» асл намуна деб хисобласа бўлади деб ёзади шарқшунос олим [Х.Вамбери 1992: 115]. “Арслон изидан қайтмас, йигит - сўзидан”, “Ботирдан ўлим хам қўрқар", “Бузилган элни ботир тузатар", “Мард айтмас, айтса қайтмас", “Ватанга келган - имонга келар", “Ватанинг тинч - сен тинч”, “Халқ ва тан билан, Ватан халқ билан”, “Мехмон келар эшикдан, ризқи келар тешикдан”, “Мурувват - мехрнинг тузоғи”, “Уят юзда бўлар, мехр кўзда", “Хурматинг - савлатинг, мехнатинг - давлатинг”, “Эр йигит номи билан, мехнатда шони билан”, “Дарё сувини бахор тоширар, одам қадрини мехнат оширар”, “Ота - онасини танимаган тангрисини танимас”, “Яхшилик нур келтирар, ёмонлик - зулмат”, “Яшилик қил, 
дарёга ташла, балиқ билар, балиқ билмаса холиқ (худо) билар”, “Яхшилик қилсанг, яшир, яхшилик кўрсанг, ошир” каби ўзбек халқ мақоллари Херман Вамберининг ўзбек миллати ва маданиятига хос бўлган менталитет белгилари, бошқача қилиб айтганда ўзбеклар хақидаги ушбу стереотипларни қайсидир маънода хақиқат эканлигини исботлайди.

Стереотипларнинг иккика тегориясини белгилайди: сиртки ва қуйи. Сирткистереотиплар - ички сиёсий, тарихий, халқаро вазиятлар хамда вақтинчалик омиллар билан белгиланган у ёки бу халқ хақидаги тасаввурлар. Бу, аниқ тарихий реалиялар билан боғлиқ образли тасаввурлардир [Тер -Минасова 2000:262]. Вақт ўтиши билан бу стереотиплар ижтимоий, сиёсий ва бошқа жараёнлар таъсирида ўзгаришиши мумкин. Бошқа қилиб айтганда, бундай стереотипларнинг давомий яшаши, мавжудлиги жамиятнинг турғунлигига боғлиқ. Сиртки стереотиплардан фарқли ўлароқ, қуйи стереотиплар вақт ўтиши билан ўзгармайди. Улар турғунлик ва давомийлик хусуиятларига эга. Ушбу стереотиплар орасида халқ турмуш тарзи ва хаёт хусусиятлари билан боғлиқ алохида гурухни ташқи стереотиплар ташкил қилади. Халқларнинг турмушидаги мунтазам ўзгаришларга қарамай бундай стереотиплар арзимас даражада ўзгаради [Тер-Минасова 2000:262].

Яна бир тилшунос стерелтипларни этник ва миллий стереотипларга ажратади: этник стереотиплар этноснинг "содда" аъзосининг ўз - ўзини акс эттиролмайди ва жамоа беихтиёрлиги ва хатти-харакатларининг омилидир, буни махсус ўргатишнинг имкони йўқ, маданий стереотиплар ўз-ўзини намоён қила олади ва якка беихтиёрлик ва хаттихаракатларининг омилидир, буни эса ўргатишнинг имкони бор [Ufimtseva 1996:26].

Лакофф ижтимоий стереотипга метонимиянинг мимолларидаг бири сифатида қарайди. Бу холатда, бир категория қисми бутун категорияни бутунлигича намоён қилади, бу эса мулохоаалардан хукм чиқариш жараёнини соддалаштиради [Лакофф 1987:53]. Жамият вакиллари, ижтимоий мухим бўлган категорияларни акс эттирувчи маълум бир тўплам стереотипларга эга. Масалан, она-уй бекаси, маълум бир жамиятда мавжуд бўлган қарашлар туфайли, бу она тоифасининг энг муваффақиятли намунасидир. Бироқ, стереотиплар қисмлардан иборат бўлиш ва субъективлик хусусиятларга эга. Шунда, "working mother" категорияси "housewife mother" “идеал” категориясига қарши қўйилади [Лакофф 1987:51]. Ижтимоий стереотип хақида янада кенгроқ тушунчани У.Хвастхофф таклиф қилди. У стереотипни, нафақат қандайдир тил воситаси билан, балки яширин равишда ифода қилинган, аниқ бир маданият доирасида олам хақидаги билимларни акс эттирувчи когнитив структура сифатида аниқлаб берди [Quasthoff 1989: 181].

Стереотипларни Н.А.Рождественская мазмунига кўра икки категорияга ажратади: одамларни, муайян бир миллат, ижтимоий ва сиёсий гурухларнинг аъзолари сифатида таснифлайдиган стереотиплар ва хатти-харакати, жисмоний сифатлари, ташқи кўринишини белгилаш ва хоказолар бўйича одамларнинг шахсий хусусиятларини характерлайдиган стереотиплар [Рождественская 1986:69].

Донецнинг П.Н. стреотипларни категорияга ажратишда Н. А. Рождественскаяга яқин келади ва унга қўшимча қилади. У бир нечта асимметрик қарама - қаршиликлар асосида таснифлашни таклифқилади:

- шахсларга объекти мамлакатлар, ходисалар, нарсалар ва хоказо бўлган муайяни жтимоий, моддий, ходисаларга бой ва хоказо жамиятларнинг аъзолари сифатида шахсий муносабатга эга стереотиплар;

- соф моддий, рационал (идрокгаасосланган) маълумотни акс эттирувчи, когнитив, хистуйғу, бахова шу кабиларни акс эттириш билан боғлиқ прагматик стереотиплар;

- гетеро стереотиплар, яъни бошқалар хақидаги тасаввур, “ўзгалар” образлари ва авто стереотиплар маълум бир маданият вакили ёки бир этнос аъзоси сифатида ўзи хақидаги тасаввурлар, “ўзи” образлари;

• интенционал (мақсадли) ва спонтан (ўз - ўзидан юз берадиган);

• ижобий ва салбий;

• интенсив (кучли, тез) вамедиал (ўрта) [Донец 2001:183]. 
Л.И.Гришаева ва Л.В.Цурикова фикрича, стереотиплар нафақат ижобий ва салбий, балки нейтрал (бетараф) хам бўлишлари мумкин [Гришаева, Цурикова 2007:58]. Маслованинг таъкидлашича стереотиплар маросимлар, анъаналар, урф - одатлар, афсоналар билан кўп умумий жихатларга эга, лекин стереотиплар, “ўзларининг” мухитида мавжуд яширин хаёллар сатхида қолади [Маслова 2001:95].

Демак, стереотип воқеликнинг этник, лисоний, ақлий манзарасининг шаклланишида мухим ахамият касб этади. Стереотип тушунчасидан ёки унга мазмунан яқин бўлган штамп, клише, стандарт, шаблон, трафарет, эталон ва бошқа тушунчалардан фойдаланмай туриб, тил устида олиб бориладиган лингво маданий тадқиқотлар етарли ва мос бўлиши мумкин эмас. Шунинг учун оламнинг ақлий ва лисоний манзарасининг бўлаги сифатида, стереотип кўплаб тилшунослар ва лингво маданиятшунослар томонидан фаол кўриб чиқилмокда. Лингво маданий стереотипларни ўрганиш жараёнида, ижтимоий - маданий, рухий ва этно маданий жихатлар хам ўрин эгаллайди, холбуки, стереотип -бирор - бир объекнинг, ижтимоий ходисанинг ёки бирор -бир халқ хақидаги тасаввурларнинг умумийлаштирилган, стандарлаштирилган образидир. “Стереотип” тушунчасини илмий иборага айлантирилиши билан “лисоний ва маданий ходисаларнинг умумий талқин қилиниши имкони яралади” [Бартминьский 1997: 12].

\section{Фойдаланилган адабиётлар руйхати}

1. Бартминьский Е. Этноцентризм стереотипа:польские и немецкие студенты о своих соседях// Славяноведение. М.: Индирик, 1997. №1. С. 12-24

2. Гришаева Л. И., Цурикова Л. В. Введение в теорию межкультурной коммуникации. - М.: Академия, 2007

3. Донец П. Н. К типологии стереотипов // Социальная власть языка. - Воронеж: Издво ВГУ, 2001. - С. 183-188.

4. Елизарова Г.В. Культура и обучение иностранным языками. СПб.: Изд- во РГПУ им. А. И.Герцена, 2004.- 291 с.

5. Лакофф Дж. Мышление в зеркале классификаторов // Новое в зарубежной лингвистике. Вып. 23, М.: Прогресс, 1988, с.39.

6. Маслова В. А. Лингвокультурология. - М.: Академия, 2001

7. Рождественская Н.А. Роль стереотипов в познании человека человеком // Вопр. психологии. - 1986. - № 4. - С. 69-76

8. Тер-Минасова С.Г. Язык и межкультурная коммуникация: учеб. Пособие. - М.: Слово, 2000. - 262с

9. Херман Вамбери Ўзбегим. - Тошкент, 1992 й. 115-бет.

10. Krasnykh V.V. Ethnopsycology and cultural linguistics: a course pf lectures. M.: Gnosis, 2002. $284 \mathrm{pp}$

11. Ufimtseva N.V. Russians: the experience of another self-cognition // Ethno-cultural specificity of linguistic consciousness. M.: 1996.P.140.

12. Quasthoff U. M. Social Prejudice as a Resource of Power: Towards the Functional Ambivalence of Stereotypes // Language, Power and Ideology- Studies in Political Discourse. Amsterdam, Philadelphia: John Benjamins Publishing Company, 1989. P. 181 - 196.

\section{CHARACTERISTIC FEATURES OF LEXICAL DERIVATION}

Safarova Dildora (Sam IFL)

Annotation: In this article we review characteristic features of lexical units which formed by the process of derivation, their morphological, semantic categories. More precisely, the article presents derivation as the major type of production of forms with complementary meanings and overviews which are demonstrated. 
Key words and expressions: derivation, lexical derivation, morphology, morphological categories, grammatical categories, suffixes, prefixes.

The weight of derivation in language increases due to the potential of the lexical layer to form new words and the valence of the resulting units to acquire more than one semantic meaning. If we observethe notion from the point of view of lexical units formed within the traditional lexicalderivational pattern, their different semantic meanings, functional approach, we can detect changes in their connotation and syntactic construction. During the latest period many areas of modern linguistics have the characteristics of anthropocentrism, an approach that has influenced the content of each study in recent decades. Anthropocentrism in the concepts of structure and function of language is one of the leading directions in the development of today 'slinguistics. Modern English language is no exception. As human beings develop, new concepts are emerging, but derivation and conversion methods remain the most common and acceptable ways ofdesignation in language. The fact that lexical derivation uses a ready-made stem as a template to form a word using affixes makes it a general method in this regard. As the semantic meaning of the previously existing stems is sealed in the human mind, which paves the way for the assimilation of a new lexical unit into the language.

Scholars such as Balli and Kubryakova were the first among scholars to point out that the transformation of a lexical units from one category into another played a major role in language development. "Linguistic units if remainwithout altering their categories when added other signs would have limited the richness of speech. But due to the ability of characters to transfer from one category to a differentone forming new lexical units by means of derivation enrichesthe language with different semantic colors." ${ }^{1}$ claimsBalliinhiswork" "General linguistics and problems of French language".From this it can be said that the lexical type of derivation plays an important role in word formation. The difference between a derivation in a language and other word-formation methods, and whether it is observed in certain language layers or not, requires the division of derivation into two main types, lexical and syntactic. E. Kurilovich was one of the first linguists to pay attention to this and proposed to distinguish between the lexical derivation and syntactic derivation, to study them as a separate field. The most obvious feature of the lexical derivation type of word formation theory is that the word changes its class. For instance:
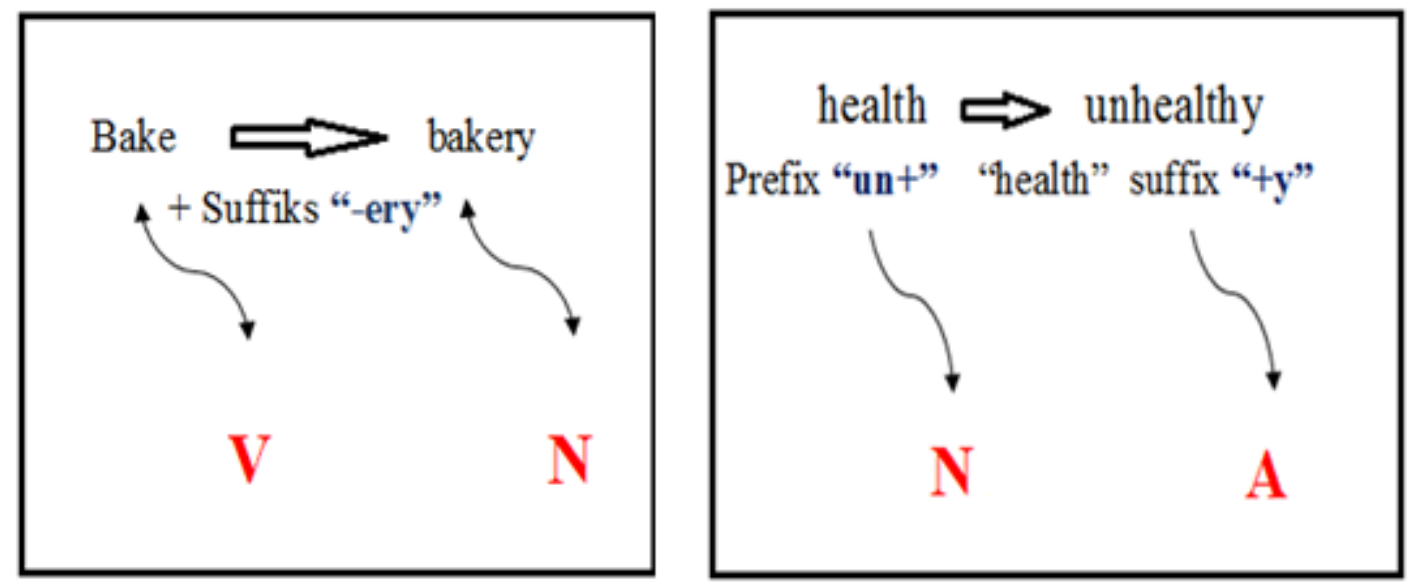

It seems that the study of the relationships between the units formed in the process of derivation in the context of these analytical categories is a key tool for understanding the structure and functioning of the entire language system. Fromthe highest levels of language, such as speech analysis to the lowest word formation models are started with the theory of derivation which is important factor in understanding the whole mechanism of language. Based on the above example, the following features of lexical derivation can be listed:

1) Derivation is the process of the construction of derivative signs, which creates subordinate signs to name the new concept directly

2) the correlationbetween the derivative sign andthe root symbol in terms of form and meaning 
3) lexical derivation includes features of morphological, syntactic and semantic categories

For example, the word "normalize" has a morphological category in the form of suffix "ize", moreover the resulting word "normalize" belongs to the category of verb, that is, the sign of the grammatical class. Lexical procedure provided for derivation, additionally the phonological elementsanddistinct morphological constituent is responsible for phonological comprehension.Phonological elements influence the categoriesof resulting units. Rearrangement of elements presents no disagreement construction, but basically changes a stem from one category to another, at times, and at times not.

For example,observe (V) - observer(N)

Ability (N) - disability (N)

The meaning of outcome word must agree with that of root word in all necessaryesteems.

In general, it seems that "lexical derivation" is not a simple word-formation process, but a re-creation by adding affixes to a core morpheme forming a new unit and, if necessary, continuing to add affixes while current the process goes on. If we compare the core to a tree, derivation is the formation of new branches, that is, the appearance of secondary characters in the language. In lexical derivation, derivatives having the same basis can occur in the following two different morphological environments:

1) both the basic morpheme and the word-changing morpheme have primitive morphological features; in this case, the product is characterized by the structure of "base + morphological index (drink $\rightarrow$ drinkable).

2) modifier morpheme is characterized by a structure similar to the pure base indicator (bike $\rightarrow$ biker)

In short, lexical derivation in English can be regarded as very remarkable and effective way of complementing the vocabulary of a language, with the transformation of common words into new terms and lexical units.The variability of systems that English propositions for the construction of new units, have been discussed in this article, as well as with the conformingsamples, presented what succeeds English as a language standard which iscommonly comprehensible. English therefore endures to have more derivatives to conquer the situation of the world's primary language.

\section{The list of used literature}

1. Sh. Balli, Generallinguistics andproblems ofFrench language,M., (1955),P 143

2.Crystal, D. (2002), The English Language. Second Edition. Penguin Books, London

3.Sanel Jurida. "Word Formation in English:Derivation and Compounding"(2018), P 157-170

4.Svechkareva Ya.V. On the derivational potential as a linguistic category //Bulletin of Tomsk State University. (2007). P. 15-16

\section{O'ZBEK TILINING - DAVLAT TILI SIFATIDA SHAKLLANISHI}

\section{Eshnayeva Feruza (SamDCHTI AL.)}

Annotation: The article deals with the Uzbek language and its importance as a state language, the attention paid to the Uzbek language from the first year of independence, the efforts made to develop the language and increase its prestige in the world as well, the word referred to the important aspects of native language, in addition to scientific and practical work.

Key words and expressions: State language, Uzbek alphabet, State symbols, education system, Uzbek scholars, Abdulla Avloniy, Abdulla Qodiriy, State language status.

1989- yil 21-oktabrda "Davlat tili haqida“gi O’zbekiston Respublikasi Qonuni hamda 1993yil 2-sentabrda “Lotin yozuviga asoslangan o'zbek alifbosini joriy etish to'g'risida”gi qonunlar qabul qilindi. Albatta, bu qonunlar ona tilimizning sayqallanishi va yuksalishi, shuningdek,yosh 
avlodlarimizning ma'naviyatiga bir qadar ijobiy o'sishlar olib kelmoqda desak beixtiyor yanglishmagan bo'lamiz. Chunki, dunyoviy fikrlarga asoslangan holda fikr yuritar ekanmiz, bevosita shunga amin bo'lamizki, hozirgi kunlarda har bir tilning qiymatini boshqa davlatlarning ta'lim tizimiga fan sifatiga kirib birishiga nisbatan, yoki bo'lmasa aholi darajasining qancha miqdori shu tildan kundalik turmushda foydalanishiga qarab uning qanchalik ahamiyatliligini bilib olish ham qiyin emas. Shunga nisbatan fikrlar ekanmiz bizning ona tilimizning o'rni ham davlatimizning obro'siga yarasha kundan kunga yuksalib bormoqda. Misol tariqasida bizning bu qadrli ona tilimizning davlat ramzlari qatorida, yani davlat gerbi, bayrog'i madhiyasi va shu asnosda davlat tili bo'lib qo'shilishi ham, albatta, bejiz emas. Bu tadbirlar guvoh bo'lib turganimizdek davlatimiz rahbarlarining bir muncha sa'y harakatlari tufayli yuz bermoqda. Eslab o'tish joizki, bizning birinchi prezidentimiz bo'lgan Islom Karimovning bir muncha mashaqqatlari orqasidan bu natijalarga erishdek desak mubolag'a qilmagan bo'lamiz. Biz bu haqda birinchi prezidentimizning ona tilimiz borasidagi o'z mulohazalariga nazar tashlasak bevosita yanglish so'zlamaganimizga amin bo'lamiz, yani u kishining quyidagi fikrlari orqali bu so'zlarimizda dalil keltirdik desak ham bo'ladi: 'O'zlikni anglash, milliy ong va tafakkurning ifodasi, avlodlar o'rtasidagi ruhiy-ma'naviy bog'liqlik til orqali nomoyon bo'ladi. Jamiki ezgu fazilatlar inson qalbiga til orqali, ona allasi, ona tilining betakror jozibasi orqali singadi. Ona tili - bu millatning ruhidir" - deya ta'kidlab o'tganlar o'zlarining "Yuksak ma'naviyat -yengilmas kuch" asarlarida.

Qo'shimcha tarzda shuni aytib o'tish joizki, har yili 21-oktabr kuni mamlakatimizda til bayrami sifatida keng nishollanishi an'anaga aylanib qolgan. Chunki, mamlakatimizda ona tilimizni yanada rivojlantirish va takomillashtirish, uning milliy ruhini oshirish, madaniyat va san'atni yuksak pog'onalarga ko'tarish, shuningdek, lotin yozuviga asoslangan o'zbek alifbosini joriy etish sohasida qabul qililngan Davlat dasturi ijrosini ta'minlashdek, ustuvor yo'nalishdagi vazifalarni bajarish tom ma'noda kundalik hayotimizga tobora singib bormoqda. Vaholanki, bu borada bizning yetuk shoir va shoiralarimiz ham o'z hissalarini yetarlicha qo'shishmoqda. Shu o'rinda ma'rifatparvar va zabardast ijotkorimiz bo'lgan Abdulla Avloniyning sehrli qalamlari ila tilimizga mo'jazgina qilib ta'rif etilgan zarhal so'zlarga diqqatimizni qaratamiz: "Har bir millatning dunyoda borligini ko'rsatadurg'on oynai hayoti til va adabiyotdir. Milliy tilni yo'qotmak milliy ruhni yo'qotmakdir"- degan aniq va teran fikrlarini bayon etganda naqadar haq edi. To'gri biz bu haqda o'zimizning va shuningdek, shoir hamda shoiralarimizning lo'nda va ochiq fikrlarini keltirib muhokama qilsakda ozlik qiladi.

O’zbekiston Respublikasining 2004-yil 30 apreldagi” O'zbekiston Respublikasining ayrim qonun hujjatlariga o'zgartirishlar va qo'shimchalar kiritish to'g'risida"gi 621-2 son Qonuni asosida mazkur qonunning ijro muddati 2005-yil 1-sentabrdan 2010-yil 1-sentabrgacha uzaytirilgan. Guvohi bo'lib turganimizdek, davlatimizda kuzatilayotga bu tub islohotlar, albatta, xalqimizning ma'naviy-madaniy manfaatlarini maqsad qilib olgan bo'lib, tilimizningda ahamiyatini chetlab o'tmaydi. E'tirof qilganimizdek, bu islohotlar 1992-yil 7 dekabrda o'z aksini topdi. Ya'ni, O'zbekiston Respublikasi Oliy Kengashi sessiyasida qabul qilingan O'zbekiston Respublikasi Konstitutsiyasining 4-moddasida o'zbek tili davlat tili maqomiga ega ekanligi mustahkamlab qo'yildi.

Shu bilan bir qatorda tarixga bir nazar tashlar ekanmiz, tilshunos olimlar shundan xabar berishadiki,turkey tillarimiz eramizning 4-asrida uch guruhga bo'lingan hamda qarluq,qipchoq,o'g'uz guruhlari vujudga kelgan. Bular orasida eng qadimgi yozuv tili qarluq guruhi zaminida shakllangan azaliy o'zbek tilidir.tarixda eng ko'p adabiy va ilmiy asarlar ham shu tilda ijod qilingan. Lutfiy, Sakkokiy, Navoiy, Bobur kabi so'z ustalari ijodi bilan bu til yanada sayqallangan va rivojlangan. Ma'rifat parvar va donishmand tilshunoslarimizning o'zbek tilining naqadar boy til ekanligi haqida purma'no fikrlari hayotimizda isbotlangan. Shu bois, o'zbek tili ona timizga Asosiy qomusimizda davlat tili maqomi berilganligi shu elning fuqarosi sifatida har birimizga milliy g'urur va iftixor baxsh etadi.

Xulosa qilib aytganda, har bir millatning tili o'z qadimiy hamda hozirgi xalqi uchun doimo qadrli va o'chmas boylik hisoblanadi. Chunki, shu til orqali biz har bir sohada muayyan yutuqlarga erishamiz va shu vosita orqali boshqa qardosh xalqlarimizning yashash tarzi va madaniyatini 
o'rgangan holda o'z dunyoqarashimizni kengaytirib boramiz. Va shuningdek, millatning hamda xalqlarning birligini ham mana shu til birlashtirib turadi, chunki agarda orada tushunmovchilik yuz beradigan bo'lib qolsa beixtiyor ahillik to bora so'nib boradi. Shu maqsadda har bir individual shaxs o'z ajdodlaridan meros singari yodgor bo'lib qolgan ona tilini asrashi uni har qanday ta'na, tamal toshlaridan himoya qilib so'z so'zlashda ehtiyotkorlik bilan, misol tariqasida Abdulla Qodiriyning : “ So'z so'zlashda va ulardan jumla tuzishda chuqur andisha kerak" degan mulohazalari asosida ish tutsa, bizning kundan kunga yuksalib borayotgan tilimiz hech qachon yo’qolib ketmaydi, aksincha, mashhurlashib boraverdi.

\section{Foydalanilgan adabiyotlar ro'yxati}

1. Каримов И.А. Юксак маънавият - енгилмас куч. - Тошкент: Маънавият, 2008.

2. Mirziyoev Sh. Erkin va farovon, demokratik O'zbekiston davlatini mard va olijanob xalqimiz bilan birga quramiz. O'zbekiston Respublikasi Prezidenti lavozimiga kirishish tantanali marosimiga bag'ishlangan Oliy Majlis palatalarining qo'shma majlisidagi nutq $-\mathrm{T}$.: O'zbekiston, 2016. -56-bet

3. Jamotxonov H.A. Hozirgi o'zbek adabiy tili. -T., 2004. (1, 2- qismlar)

4. Nurmonov A. Hozirgi O`zbek adabiy tili. -T.: Sharq, 2002.

\section{OBJECT SYNTAXEMES IN THE ENGLISH AND UZBEK LANGUAGES}

\section{Asadova Gavhar Teshabayevna} (SamSIFL)

Annotation: This article focuses on analyzing sentence structures through syntaxeme analysis and identifying position of object syntaxemes of different categorical and non-categorical signs in English and Uzbek sentences. The article may attract interest of anyone who deals with syntactic semantics and structural syntax.

Key words and expressions: syntactic semantics, deep structure, categorical signs, non-, syntaxeme analysis, instrumentality.

Language is ever-changing and developing all the time. From the very beginning of its history as a science scholars try to investigate it from different approaches. As nations interact it is necessary to learn languages and this process makes it essential to compare languages of the world with one another, whether they are of the same language system or not. The English and Uzbek languages belong not only to different language families but they also differ structurally. In the contemporary world Uzbek linguists are conducting research in all branches of linguistics comparing Uzbek with other languages, one of which is English. It is universally known that there is a considerable amount of disputable problems on the syntax level of linguistics including object syntaxemes in both English and Uzbek syntax. Therefore, I made it the aim of the article to comparatively analyse object syntaxemes in the sentence structure of the two languages.

The study of syntax is the investigation of the rules, principles, and processes which determine the structure of sentences in human languages. Syntax can be seen as the governing principles defining which combinations of linguistic symbols are deemed to be correctly structured by natural language speakers.

The scientific study of natural language syntax can be found as early as the Asțādhyāy 4th-c. BC Sanskrit grammar of the Indian grammarian Pānini. In the Western world, the systematic study of syntax was largely neglected or conflated with other objects such as logic, until the late 1950 s, with the rise of theories of generative grammar developed by Noam Chomsky and others [Szendröi, 2003].

Semantics consists of the study of the relationships between symbols or signs such words, phrases, sentences, and discourses, and what these elements mean or stand in for:- their denotations and senses. 
Semantics has philosophical roots, but since the 1970s linguists have become intimately engaged in this tradition of research, particularly after Richard Montague developed a formalized approach to the semantics of natural language, popularized amongst linguists by Barbara Partee. Montague's formal semantics drew upon the logical system of lambda calculus developed by Alonzo Church, revolutionising the study of meaning in natural language [Kiss, 1998].

Thus syntax is concerned with what makes phrases/sentences well-formed and semantics with how well-formed syntactic structures are interpreted. Yet well-formed sentences bear meaning and meaningful sentences bear structure: that is, syntax and semantics interact, and many of the arguably most interesting linguistic phenomena involve data whose explanation necessarily involves the interaction of syntax with semantics.

In the world linguistics sentences are usually analysed by means of traditional method that is dividing the sentence structure into primary and secondary parts of speech which is based on putting question on the syntactic units of the sentence. In the English language parts of sentences are also defined according to their place in the sentence structure. The usual pattern is subject + predicate + object as in the following examples:

1) Jane has written a book.

2) The book was written by Jan $\underline{\text { Jane. }}$.

In the second sentence by changing the place syntactic units changed their functions as well.

In the Uzbek language parts of sentences have flexible location though usual pattern is subject + object + adverbial modifier + predicate. For instance,

3) Lola gullarni kecha sug'ordi.

This sentence can have the following structures keeping its semantic meaning:

(3a) Gullarni Lola kecha sug'ordi.

(3b) Lola kecha gu $\underline{\text { llarni }}$ sug'ordi.

(3c) Kecha gullarni Lola sug'ordi.

From the above given variations it is obvious that the predicate has a final position. Other parts of the sentence remained in their functions no matter where their position is. If sentence (3) is converted into passive construction then syntactic units change their functions as in the English sentence structure (2):

(3d) Gullar Lola tomononidan sug'orildi.

It can be inferred that the method of putting question and defining positions reveals only surface structure of the sentence and does not indicate anything on its deep structure. In order to open the deep structure we have to refer to syntactic semantics and identify syntaxemes expressed by the syntactic units of the sentence structure.

Studying sentences according to syntactic semantics is considered deep structure of the components, where differential categorical and non-categorical signs of each syntactic unit are revealed. Categorical signs are the ones which express grammatical meaning as a part of speech i.e. substance/substantiality (Sb) - any part of speech having nominative meaning, process/processuality (Pr) - verbs expressing action or state, qualification/qualificativity (Qlf) adjective, adverb, numerals and some pronouns (Asadov, 2018). Non-categorical signs are connotational meaning of words within the sentence structure in connection with other words. So, any word has a categorical sign in language while they can obtain non-categorical sign only in speech. In syntaxeme analysis on the base of the three differential categorical signs more than a hundred non-categorical signs of syntactic units can be identified (Usmanov, 2004).

Object syntaxemes are positioned in different places in the sentence. Below we will analyse English and Uzbek sentences on the base of syntaxeme analysis method.

4) Mr. Witty organized a party for his colleagues.

5) I asked George for ha

6) She liked swimming.

7) The bathroom was carefully cleaned.

In sentence syntactic unit a party_(4), The bathroom (7) express pure object syntaxemes on the base of substantiality, for_.... 


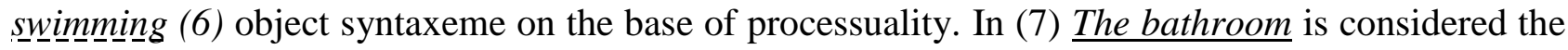
subject of the sentence, however, it expresses object syntaxeme as it is not the agent of the action. Syntaxeme model of these sentences can be visualized as follows:

(4) Mr. Witty organized a party for his colleagues. - SbAg . PrAc. SbOb. SbObDr.

(5) I asked George for help. - SbAg. SbObDr. PrObPur.

(6) She liked swimming. - SbAg . PrSt . PrOb.

(7) The bathroom was carefully cleaned. - SbOb. QlfMn . PrAc.

The results of the analysis indicate the position of object syntaxemes not only after verbs but also before verbs. They are mostly expressed by substantiality and processuality categorical signs.

In the Uzbek language the below given example sentences are analysed:

8) Bobo nevaralarining muvaffaqiyatidan g'ururlandi.

9) Alisher sekingina eshikni ochdi....

10) Azamat pichiqchasi bilan konserva bonkani ochdi.

11) Hovli chinnidek yarqillatib supurilgan edi.

In all these sentences object syntaxemes are expressed by nouns i.e. their differential categorical sign is substantiality whereas they have various non-categorical signs. Sentence (8) contains object causative syntaxeme muvaffaqiyatidan, (9) eshikni - pure object syntaxeme, (10) pichiqchasi bilan instrumental object syntaxeme, (11) Hovli object locative syntaxeme. These sentences get the below syntaxeme analysis model:

(8) Bobo nevaralarining muvaffaqiyatidan g'ururlandi. - SbSt . SbPs . SbObCs . Prst.

(9) Alisher sekingina eshikni ochdi.... - SbAg . QlfMn . SbOb. PrAc.

(10) Azamat pichiqchasi bilan konserva bonkani ochdi. - SbAg . SbInsOb. SbOb. PrAc.

(11) Hovli chinnidek yarqillatib supurilgan edi. - SbObLc . SbCpr. PrMn . PrAc.

The results of the analysis show that in Uzbek sentences object syntaxemes are mainly expressed by nouns, yet their non-categorical signs are not the same. Object syntaxemes have causative, instrumental and locative signs as well.

Similarities of English and Uzbek syntactic units expressing object syntaxemes are that they both have pure object non-categorical signs; they can be in the position of subject and object. The differences are English object syntaxemes have positions after and before verbs while Uzbek ones are always before verbs; English object syntaxemes have semantic meaning of direction and purpose, whereas Uzbek ones possess instrumentality, locativity and causal non-categorical signs.

This article is only a drop from a vast ocean of syntactic semantics which needs further research that consequently leads to the development of computer linguistics.

\section{The list of used literature}

1. Asadov R.M. Functional analysis of monovalency and polyvalence components in the English simple sentence structure. Dissertation abstract of $\mathrm{PhD}$ on philological science. Tashkent: 2018. - 25p.

2. Kiss, Katalin É. (1998). Identificational Focus and Information Focus. Language (74): 245273

3. Szendröi, Kriszta (2003). A Stress-Based Approach to the Syntax of Hungarian Focus. Linguistic Review (20)

4. Usmanov U.U. A new approach to sentence analysis // International scientific theoretical conference (Гап тахлилига янгича ёндашув // Халқаро илмий-назарий анжуман). Samarkand: 2004.- P.105-108. 


\title{
FE'LNING ZAMON KATEGORIYASI TADQIQIGA DOIR
}

\section{Elyor Xonnazarov (Alisher Navoiy nomidagi Toshkent Davlat O`zbek tili va Adabiyoti Universiteti)}

\begin{abstract}
Annatation: This article discusses the study of the category of tenses in Uzbek linguistics, which is one of the most important categories of verbs. The research draws conclusions on issues such as the approach to the form of time, the classification of forms of time. It focuses on aspects of
\end{abstract} this category that need to be explored in the future.

Key words and expressions: forms of tenses, meaning of tense, moment of speech, past tense, present tense, future tense, speech situation

O'zbek tili morfologiyasida fe'l so'z tukumi juda katta o'rinni egallaydi. Fe'l boshqa turkumlarga qaraganda grammatik kategoriya va shakllarga boydir. Fe'lning grammatik xususiyatlari o'zbek tilshunosligida atroflicha o'rganilgan. Ammo fe'l grammatik shakllarining, jumladan, zamon shakllarining xususiyatlarini kognitiv tadqiq qilish hozirgi zamonaviy tilshunoslik yo'nalishlarining maqsad va vazifaridan kelib chiqqan holda juda ahamiyatlidir.

O'zbek tilshunosligi qisqa vaqt ichida grammatik muammolarni ilmiy tekshirish sohasida katta yutuqlarga erishdi: morfologiya va sintaksisga doir bir qancha mavzular monografik tarzda yoritildi. $\mathrm{Bu}$ ishlar, birinchidan, o'zbek tili ilmiy grammatikasining zaminini yaratdi, ikkinchidan, til sohasidagi amaliy ishlarimizning - adabiy tilning holatini takomillashtirish, o'qish- o'qitish sohasida qo'llanmalar yaratish kabi ishlarning sifatini oshirish imkoniyatini berdi.

Morfologiyaning eng yirik markazlaridan bo'lgan, $\mathrm{o}^{6} \mathrm{z}$ grammatik shakllari, shuningdek sintaktik vazifasi va salmog 'ining boyligi bilan ajralib turadigan murakkab fe'l sohasi bo 'yicha ham jiddiy ishlar qilindi: fe'l zamonlari, mayl, fe'lning tarkibi jihatidan turlari, to'liqsiz fe'l, sifatdosh, ravishdosh, harakat nomlari kabi bir qancha mavzular maxsus yoritildi. Bu tipdagi mavzularning kognitiv asosda yoritilishi tilshunoslik uchungina emas, balki adabiyotshunoslik uchun ham juda muhimdir. $\mathrm{Bu}$ yo'nalishdagi tekshirishlar o'zbek tilshunosligi sohasida yaqindagina boshlandi. 1969-yilda Toshkentda bo'lib o'tgan Respublika tilshunoslik konferensiyasi monografik tarzda tekshirilishi zarur bo'lgan dolzarb muammolar qatorida zamon shakllarining uslubiy xususiyatini ham ko'rsatib o'tdi.

Hozirgi o'zbek tili fe'lning zamon formalariga juda boyligi bilan ham xarakterlanadi. Bu formalarning o'zaro umumiy bo'lgan tomonlarini va har birining o'ziga xos xususiyatlarini belgilash ham nazariy, ham amaliy jihatdan muhim ahamiyatga ega. Turli darslik va qo'llanmalar, ayrim monografiyalar, shu- ningdek o'zbek tilidagi fe'l zamonlari mavzusi bo'yicha bir necha dissertatsiyalar yoqlangan. Biroq har bir zamon formasining o'ziga xos xususiyati haqidagina emas, hatto, hozirgi o'zbek adabiy tilida fe'lning qaysi zamoni qanday formalarga egaligi haqida ham shu vaqtga qadar bir xil fikrga kelingan emas. Zamon kategoriyasi jahon tilshunosligida ham, o'zbek tilshunosligida ham keng o'rganilgan mavzulardan hisoblanadi. $\mathrm{O}^{\prime} z$ zek tilshunosligida bu mavzuda A.G'ulomov, A.Hojiyev, J.Jo'rayeva, Sh.Shukurov kabi olimlarning tadqiqotlari muhim ahamiyat kasb etadi. Ayniqsa, Sh.Shukurov tomonidan mazkur kategoriyaning tarixiy planda tadqiq qilinishi orqali zamon shakllarining taraqqiyot yo'li tahlil qilindi [Shukurov 1976:160]. Bundan tashqari o'zbek tilshunosligiga oid turli darslik va qo'llanmalar mualliflari ham fe'l mavzusiga to 'xtalish jarayonida uning kategoriyalaridan biri bo'lgan zamon masalasiga ham munosabat bildirib o'tganlar. Shunga qaramay, o'zbek tilshunosligida zamonni ifodalovchi shakllarni belgilash, va ularni tasniflash masalasida har xil fikrlar bildirilgan. Ayrim zamon shakllariga munosabat bildirishda, mayl va zamon shakllarini farqlashda turlicha yondashilgan o'rinlar juda ko"p. Tilshunos A.Hojiyev "...har bir zamon formasining o'ziga xos xususiyati haqidagina emas, hatto, hozirgi o'zbek adabiy tilida fe'lning qaysi zamoni qanday formalarga egaligi haqida ham shu vaqtga qadar bir xil fikrga kelinmagan" [Hojiyev 1973:128] ligini ta'kidlab, zamon shakllarini tasniflaydi va har bir shakl haqida umumiy ma'lumot beradi. Biroq har bir shaklning nutqiy vaziyat bilan aloqadorlikda ifodalaydigan xususiy ma'nolari tadqiqotlarda to 'la qamrab olinmagan. 
Zamon shakllarini tasniflashda ikki nuqtaga e'tibor qaratilgan: harakat vaqti va nutq momenti. Harakat vaqti nutq momentidan oldin bo'lsa, o'tgan zamon; harakat vaqti va nutq moment bir paytda bo'lsa, hozirgi zamon; harakat vaqti nutq momentidan keyin bo'lsa, kelasi zamon sifatida baholanadi.

Tilshunos A.Hojiyev "Fe'l" kitobida o'sha paytgacha qilingan tadqiqot natijalarini umumlashtiradi va tadqiqotlardagi xilma-xilliklar haqida fikr yuritadi.

Fe'l bildirgan harakatning bajarilishi, albatta, ma'lum bir vaqtda bo'ladi. Demak, harakat vaqt (zamon) tushunchasi bilan aloqador bo'ladi. Fe'l bildirgan harakat obyektiv harakatning tildagi ifodasi bo 'lganidek, fe'llardagi zamon ham harakatning bajarilishi bilan aloqador bo'lgan obyektiv vaqtning tildagi ifodasidir. Lekin obyektiv zamonning tildagi ifodasining o'zi grammatik zamon kategoriyasi hisoblanmaydi. Grammatik zamon kategoriyasi harakatning nutq momentiga munosabatini ifodalaydi. Nutq momenti ham subyekt tomonidan belgilanadigan qandaydir vaqt bo'lagi bo'lmay, obyektiv zamon (vaqt)ning so'zlovchi gapi, so'zi (nutqi) to'g'ri kelgan bo'lagidir. Bunda so'zlash, nutq ham harakat hisoblanadi va uning bajarilishi obyektiv vaqtning biror qismiga to'g'ri keladi. Harakat bajarilish vaqtining nutq momentiga munosabatiga qarab fe'lning uch xil zamoni farqlanadi: 1) nutq momentigacha bo'lgan harakat - o'tgan zamon;

2) nutq momentida ham davom etayotgan (tugamagan) harakat - hozirgi zamon;

3) nutq momentidan keyin bo'ladigan harakat - kelasi zamon.

Fe'lning zamon grammatik kategoriyasi munozarali muammolardan sanaladi, chunki bu kategoriya bilan bog'liq yoki unga uyqash bo'lgan yana mayl, shaxs-son kabi kategoriyalar ham borki, ularning lisoniy maqomi hanuzgacha katta munozaralar va tortishuvlarga sabab bo'lib kelmoqda. Sohaga daxldor ilmiy adabiyotlar tahlili shuni ko'rsatdiki, mavjud ilmiy izlanishlarda fe'lning zamon kategoriyasiga an'anaviy yondashuv ustun bo'lib, ularda ko'proq uning strukturalsemantik va funksional jihatlariga asosiy e'tibor qaratilgan, vaholanki uning lingvokognitiv, kommunikativ-pragmatik va lingvokulturologik jihatlari va unga qiyosiy yondashish masalasi hanuzgacha deyarli tadqiq qilinmagan. Umumiy va qiyosiy tilshunoslik nuqtayi nazaridan olib qaralganda zamon grammatik kategoriyasiga umumlisoniy ta'rif berilishi maqsadga muvofiqdir.

Shunday qilib, grammatik zamon bu fe'lning grammatik kategoriyalaridan biri bo'lib, u gapda kesimdan anglashilgan voqelik (ish harakat, jarayon, holat, daraja, sifat, miqdor kabi) larning ular haqida gapiruvchi shaxs nutqi paytiga nisbatan qanday vaqtda (hozirgi, o'tgan va kelasi zamonda) va qay (oddiy davomsiz, davomli, tugal) tarzda amalga oshirilishi, ya'ni voqelantirilishi yoki kechishini ifodalovchi kategoriyadir. Tillarda fe'lning zamon grammatik kategoriyasi o'ziga xos morfologik-semantik kategoriya bo'lib, u fe'lning zamon shakllari orqali ifodalanadi.

\section{Foydalanilgan adabiyotlar ro'yxati}

1.А.Хожиев. Феъл. Тошкент: Фан, 1973.

2. Ш.Шукуров. Ўзбек тилида феъл замонлари тараққиёти. Тошкент: Фан, 1976.

\section{ADVERTISING AS AN INDEPENDENT DISCOURSE IN LINGUISTICS}

Umida Mahmudova Ural kizi (PhD student of Karshi state university)

Annotation: This article examines the nature of discourse of advertising in linguistics. This article focuses on the interaction of language with advertising, its image and layout, and examines advertising persuasive strategies. It discusses main interrelationship between culture and advertising discourse. This study is not meant to exhaust all the fields of the particular discourse and does not involve to all the problems it poses. This article aims at find the basic elements of the most influential discourse of the $21^{\text {st }}$ century advertising text.

Keys words and expressions: advertising, text, discourse, culture, linguistics, semiotics.

President of Uzbekistan Shavkat Mirziyoyev signed a decree "On Uzbekistan's Development Strategy" in 2017. The Decree has approved Uzbekistan's Five-Area Development 
Strategy for 2017-2021 years. It is important to ensure that new products and technologies are being introduced, thus ensuring the competitiveness of national goods in the local and foreign markets. Developing marketing strategies to protect the local market and active access to foreign market in the context of globalization is one of the most pressing challenges of today. Year by year the development of industry in the Republic and the increase in the demand for various types of services raise the role of the advertising industry. In the beginning, it is important to define advertising itself. What is advertising? Advertising is an extremely multifaceted phenomenon. The term comes from the Latin word to the advertiser to shout loudly or to notify, which reflects the original function of advertising - information are shouted out or read out in squares and in other places where people gather, advertising always carries information, however, if advertising is always information, information not always an advertisement. In fact, advertising is special information that is distributed in accordance with the law by any legal or natural person, products, including trademarks, service marks and technologies for the purpose of direct or indirect profit[1].

The history of advertising technology has evolved from mass advertising to divide the consumer audience into the so-called target groups. Advertising occupies a boundary position between various professional areas and attracts the attention of representatives of various professions. It is therefore not surprising that there are various interpretations this concept and definition of the term itself. The criteria for this concept are not clearly defined. "Dictionary of foreign words" interprets the concept of advertising as "information about goods, various types of services, etc. in order to alert consumers and create demand for these goods, services, etc"[2]. American Marketing Association draws attention to the fact that the filing method information depends on its nature and characteristics of the target audience, and interprets the concept advertising as follows: "Advertising is any paid-for form of non-personal representation of the facts about goods, services or ideas to a group of people. Advertising is distributed in certain form of non-personal information about goods, services or ideas and endeavors intended for a group of individuals (target audience) and paid by a specific sponsor"'[3]. Ph. Kotler interprets the concept of advertising as follows: "Advertising is non-personal forms of communication carried out through paid means dissemination of information with a clearly indicated source of funding"[4]. Researchers identify various types of advertising. So, depending on the purpose of advertising, $\mathrm{Ph}$. Kotler identifies the following types:

- prestigious advertising;

- brand advertising;

- classified advertising;

- sales advertising;

- outreach advertising.

Foreign researchers say the following types of advertising exist:

- brand advertising;

- retail advertising;

- political advertising;

- advertising in directories;

- institutional (corporate advertising);

- social advertisement;

- interactive advertising[5]. Authors of the study "Advertising Language" divide advertising into commercial and non-commercial. Commercial advertising is itself divided into image, industrial and consumer advertising types. Essential in terms of language design of advertising texts is the division of advertising into classified and advertising into. Advertising has long been a main topic for several studies in different disciplines such as marketing, mass media, sociology, linguistics, cultural anthropology and cultural studies. Advertising as a discourse type has been pointed out by many scholars. Thus, marketers are interested in economic efficiency of advertising. Many sociologists reveal patterns that the impact of advertising on various groups of population, taking into account the orientation of the latter. Specialists of culturology learn 
advertising as a manifestation of mass culture. Focus of psychologists is advertising phenomena such as social perception, collective activity, motivation to achieve success, level claims, etc.

\section{ADVERTISING DISCOURSE}

Linguistic study of advertising is the types of the text in advertisement, its description in terms of the basic paradigm "Text is a discourse." The concept of "discourse" has acquired an extraordinary popular in modern linguistics. Van Dijk remarks advertising discourse: "often the most vague and difficult to define concepts become the most popular. Discourse is one of them." According to Goddard, "discourse advertising is a way through which people construct their ideas about the world'[6]. There might be different types of words in advertising text but they do not happen in isolation they occur in complex interaction with music, picture, jingles and other text around them[7]. There are a lot of purposes for using language which determine how the writer or speaker chooses words and how they use figurative language. The language has a very powerful effect over people their thought and actions. According to G.Rahimov: "Unfortunately, although most works contain textual errors in writing process, the practice of developing and implementing practical recommendations to improve the quality of the writing is not satisfactory. In order to achieve a satisfactory level of understanding, first it is necessary to analyze all the phenomena of speech communication, text discourse, textual activities and their intercultural attitudes"[8]. The aim of this work is to consider the modern understanding of discourse from the point of view of the basic paradigm "text - discourse" and features of the advertising language in the context of discursive analysis. Despite the large number of works on various text issues - recognized communicative unit, there is no single universally accepted definition of the concept of "text", which apparently due to the great complexity and versatility of the object. It is indicated that the process of speech itself (oral or written) leads to the generation of a text - speech product, message developing in a sequential description of a number situations. Most characteristic for a similar point view is a definition of text that it was proposed I.R. Halperin: "Text - this is a product of the writing process, possessing completeness, objectified in the form of a written document, literary processed in accordance with the type of this document, a work consisting of the title (title) and a number of special units (superphrase phrases), united by different types lexical, grammatical, logical, stylistic connection, having a certain purposefulness and pragmatic attitude"[9]. Genre specificity of the phenomenon of advertising make up the method of transmitting the advertisement and the purpose of composing the advertising text. A text immersed in a situation of advertising communication is the basis for highlighting the most general meaning of the term advertising - advertising discourse. Discourse, as indicated by A.A.Kibrik and him coauthors, "A discourse is broader concept than text. Discourse is also a process linguistic activity, and its result - and the result is the text"[10]. Cognition of the world is systemic, it is organically linked to the inseparability of knowledge, linguistically expressed through discourse - a dynamic process by which the predicative the connection of the phenomena of the world with its direct expression with the help of language. Definition of discourse in different linguistic sources ambiguous that shows a different attitude of linguists belonging to different linguistic schools to this concept. However, the most original work on advertising language discourse was Cook's work who analysis of the social implications of advertising language. He distinguishes basic differences between text, context, and discourse. He describes: "Text is used to mean linguistic forms, temporarily and artificially separated from context for the purposes of analysis. Context is another theme, it includes; substance, music and pictures, paralanguage(gestures, voice, facial expressions and touch in speech), situation, co-text, intertext, participants(senders, addressers, adressees and receivers), and last function what the text intended to do. Discourse is a text and context together, interacting in a way which is perceived as meaningful and unified by the participants"[11]. In Uzbek linguistics, the term discourse is used in more broadly. We consider the discourse as a coherent text in conjunction with extralinguistic, sociocultural, psychological and other factors. Discourse is a dynamic process, reflects to the functional features of the speech and has an expressive and cognitive properties. It's important for the advertising language to distinguish oral and written discourses. Oral discourse allows for great lexical and grammatical variation, at the same time plays an important role. Many phenomena 
considered to be part of oral discourse, fixed in many dictionaries and became the main part written discourse.

These phenomena can be understood based on context in linguistic and extralinguistic. The use of punctuation in writing, as well as in oral speech which determines the rhythm speech, and its perception of reading and listening. Advertising texts constitute a discourse. They are always dynamic and modern, they are perceived by the participants of communication in the context. Advertising text has its own unique characteristics. In many advertising texts, with verbal elements include audiovisual. These items may belong to different topics and do not have a clear structure. Texts in the structuring of which, in addition to verbal means, iconic (picture, drawing, photograph) are used, as well as other means semiotic codes (such as color, font, size), called creolized. Their texture consists of two homogeneous parts: verbal (language / speech) and non-verbal (belonging to other sign systems than natural language). As a rule, the presence of a non-verbal component is perceived as an indispensable attribute of a full-fledged advertising text. The text is seen as a reflection. Under advertising text means the totality audiovisual media in arbitrary combinations (with the permissible absence of any element) aimed at the recipient in order to provide the planned impact directly or indirectly associated with object of advertising. Mandatory minimum element of the advertising text - the word / digital number / abbreviation or symbol, when decoding outputting the object of impact on the addressee. Studies about the discourse of advertising with a linguistic focus remain rare. In addition to a previous studies of the syntax of headlines, Mardh defines the use made in headlines of some linguistic features such as nouns and nominal groups of articles and verbs. Mardh also remarks the number and length of words, and the number of modifiers in noun phrases and types of clauses. She discusses the readability of headlines by discussing the ways as reader familiarity and text visibility in advertising. Studies of advertising language followed by many scholars, Straumann (1935) in relation to the language of headlines and Leech is concerned with the specialized grammar of advertising. Till today, Leech's researches continues to implement a useful catalog of the defining features of this language variety. All studies include a detailed research of comparatives similes, noun compounds, stylistic features and count versus mass nouns. Some scholars addresses not only in what way advertisers use language but also how consumers are expected to interpret it. Advertising text reveals the main content of the advertising message. Its task is their appearance to attract attention potential buyer, an explanation of interest and the conclusion to convince to buy offered goods. Basic structural elements of advertising texts - this is the title, body text and motto; also used subtitle, inserts and frames, stamps, logos and autographs (signatures). The headline draws attention to the text, interested in the buyer. Therefore, it must be effective and clear. Headings are divided into several types: headers reporting useful properties;

- provocative;

- informative;

- interrogative and containing a team. The subtitle is a kind of bridge between the headline and the body text. The main text fulfills the promise of the title. The main text of the advertising message can be narrative, graphic, stunt (original); it can be written in the form of a monologue or dialogue. The structure of the text is divided into three parts: introduction, main part and conclusion. In the introduction, the advertiser introduces the consumer to the topic. This is appropriate if the consumer is unfamiliar with this problem or may not be aware of it. It's known that the reader of an advertising text is not so much interested in products, how many benefits he can derive from them. Therefore, the main thing in this section is to prove to the consumer logically, using examples, that the advertised product is what it really needs.

Conclusion. In conclusion, summarizes result of the proposed. The final phrase - the slogan - should encourage the buyer to take action ("buy today", "call now", etc.). This is the most strong form of trading offer. In coming up with a slogan, you need to strive for to ensure that it is consistent with the overall advertising theme, is concise, formulated by original pun and contained, by opportunities, company name. When creating advertising text, authors use the entire arsenal of linguistic and non-linguistic means in order to find the most effective form of influence on the 
addressee. As a type of spoken media, advertisements can be one of the most crucial media discourses in terms of manipulated language use and hidden ideologies.

\section{The list of used literature}

1. Law of the Republic of Uzbekistan "On Advertising" Article 4

2. Словарь иностранных слов // Отв. ред. А.Г. Спиркин, И.А. Анчурин, Р.С. Карпинская и др. - М., 1987. - С. 426.

3. Edwards Ch. Mundy., Retail Advertising and Sales Promotion. - N.Y., 1981

4. Котлер Ф., Основы маркетинга. - М., 2001.

5. Vestergaard T., Schröder K. The Language of Advertising / Blackwell Publishers Ltd., 1985.]

6. Goddard, A. (1998). The language of advertising. London \& New York . Routledge.

7. Cook, G. Discourse of advertising. London and New York: Routledge. (1992).

8. Rakhimov G., The English language in Uzbekistan (Sociolinguistic and pragmatic aspects) Tashkent 2018., p-63

9. Гальперин И.Р., Текст как объект лингвистического исследования. М.: Наука, 1981. 139 c.12,

10. Кибрик А.Е., Очерки по общчим и прикладным вопросам языкознания. Гл. 19. Эскиз лингвистической модели текстообразования. - М., 1992. - С. 287-301.

11. Cook, G. Discourse of advertising. London and New York: Routledge. (1992)., p-6.

\section{YAPONIYADA ISH YURITISH TILINING SHAKLLANISHI}

\section{Radjabov Diyor Raxmonberdiyevich (SamDCHTI Yapon tili o'qituvchisi)}

Annotation: The development of the property system had a great influence on the formation of the working style of the Japanese language. It is believed that the formation of Osaka as a trading center in Japan. During the Edo period (1603-1867) gave rise to certain speech methods and strategies in the Japanese business community to achieve the effectiveness of business relations used by Osaka merchants since ancient times.

Key words and expressions: Edo, Osaka, Samurai farmers, craftsmen, merchants, business relations, communication, culture.

Feodal zamonlardan beri yapon jamiyatini to'rt sinfga bo'lingan. Bular

-samuraylar;

-dehqonlar;

•hunarmandlar;

-savdogarlar.

Mulkchilik tizimining rivojlanishi yapon tilining ish uslubini shakllanishiga katta ta'sir ko'rsatdi. Taxminlarga ko'ra, Edo davridagi Osaka shahrining Yaponiyada savdo markazi sifatida shakllanishi (1603-1867) tufayli, Yaponiya biznes hamjamiyatida qadim zamonlardan beri Osaka savdogarlari tomonidan ishlatib kelinayotgan ishbilarmonlik aloqalarining samaradorligiga erishish uchun muayyan nutq usullari, strategiyalari paydo bo'ldi.

Osaka savdogarlarining nutqida keng qo'llaniladigan va natijaga yo'naltirilgan. Ushbu harakatlar to'plamini quyidagicha ajratish mumkin:

-Hazil-mutoiba;

-iltifotdan foydalanish;

- mijozga yoki sherikga qiziqish bildirish;

- va'dalar berish, kafolatlar berish;

-hamjihatlik va fikrning birligini bildirish;

maslahat va ishonchni ifoda etish; 
ifodasi;

-suhbatdoshni xafa qilishni xohlamaslik bilan bog'liq kelishmovchiliklarning yumshoq

-kategorik bayonotlarning yo'qligi;

-javobgarlik hamda masu'liytni namoyish etish;

-taqdim etilayotgan tovarlar va xizmatlarning sifati,

Ushbu strategiyalar hozirgi kunda yapon biznes hamjamiyatida potentsial va mavjud bo'lgan sheriklar o'rtasida barqaror ishonchli aloqalar va kelishuvlarni o'rnatish uchun qo'llaniladi.

Yaponiyaning ishbilarmonlik dunyosida ba'zi o'ziga xos xususiyatlar mavjud. Masalan:

-xudolarga murojaat qilish odati;

-guruhga yo'naltirilganlik;

-kompaniyadagi xodimlarni bir lavozimdan ikkinchi lavozimga ko'tarilishi;

-jarayonlarni muntazam ravishda o'tkazish tartibi;

- shartnomalar tuzmasdan bitimlar tuzish odati va boshqalar.

Bularning barchasi biznes aloqalari sohasidagi og'zaki muloqtga ta'sir qiladi. Yapon tilida kommunikativ shakllaning o'ziga xosligi, madaniy omillarga, hamda yapon tilining sof lingvistik xususiyatlari bilan ham belgilan. Turli sohalarning jadal rivojlanishi va ishbilarmonlik aloqalarining kengayishi tufayli yapon tilida ishbilarmonlik aloqalari o'zlashtirilgan lug'atdan (asosan ingliz tilidan) foydalaniladi. Ayni paytda Inson faoliyatining faqat ma'lum sohalariga xos bo'lgan atamalar soni doimiy ravishda o'sib bormoqda. Buning sababi shundaki, ko'pincha chetdan kirib kelgan so'zlar asl yapon tiliga qaraganda ko'proq va o'ziga xos ma'noga ega.(Fedorishin,1985). Masalan, ingliz tilidan "Claim" (kure: mu) "da'vo, shikoyat" so'zini taqqoslang. "Da'vo" va uning yaponcha sinonimi SHS (seikyu :), bu "da'vo, talab"deb tarjima qilinadi va h.k.

Yusoutchuu hason ni tysuru kure: mu wa ukeireraramasen ("Biz transportirovka paytida etkazilgan zarar shikoyatlarini qabul qila olmaymiz").

Xalqaro ishbilarmonlik aloqalari kengayib, bozor iqtisodiyoti globallashib borishi bilan, yaponlarning umumiy nutq madaniyati ham o'zgarib bormoqda. So'nggi 10 yil davomida yapon nutq madaniyati yanada mazmunli bo'lib, uning imo-ishoralar bilan boyib borishi ko'payib bormoqda. Aksar yaponiyaliklar oxirgi paytlarda Yevropa ritorikasining me'yorlariga amal qilishni boshlashdi.

Og'zaki nutqdagi muloyim shakllardan foydalanishni kamaytirish va yosh etnik yapon xalqlari muloqotida an'anaviy odob-axloq qoidalarining ahamiyati pasayishi tendentsiyasi mavjudligini inkor etish mumkin emas.

Taxminlarga ko'ra, odob-axloq shakllarini yapon tilida ishlatish chastotasi suhbatdoshlar tegishli bo'lgan kompaniyalarning hajmiga, maqomiga va turiga bog'liq. Rasmiylik darajasiga biznes aloqalarining o'zi shubhasiz ta'sir ko'rsatadi, uni ikki turga bo'lish mumkin:

1)mamlakatning ichki bozoridagi aloqa;

2)tashqi iqtisodiy darajadagi xorijiy kompaniyalar bilan aloqa.

Xorijiy kompaniyalar bilan aloqalarni o'rnatishda yaponiyaliklar o'zlarining an'anaviy odobaxloq qoidalariga amal qiladilar. Yaponiyada ishlaydigan chet ellik hamkasblariga nisbatan xushmuomala muloyim shakllar ishlatilmasdan, ularning o'rniga neytrallar qo'llaniladi:

Shunday qilib: soudan ha hitsuyonara enre-naku itte kudassai yo ("Agar sizga maslahat kerak bo'lsa, ikkilanmasdan shunday deb ayting").

1) ma'lum bir faoliyat sohasidagi tajribasiz ishtirokchilar sifatida chet elliklarga homiylik munosabati;

2) chet elliklarning o'zlari orasidagi stereotipli muloqotiga yo'naltirilganligi (yanada ifodali va to'g'ridan-to'g'ri);

3) doimiy munosabatlarni emas, balki vaqtinchalik aloqalarni saqlashga e'tibor qaratishda yordam beradi.

\section{Foydalanilgan adabiyotlar ro'yxati}

1. Alpatov V.M. Zamonaviy yapon tilida xushmuomalalik toifalari. - M.Kom.Book, 2006.

2. Alpatov V.M. Yaponiya: til va madaniyat. - M.: Slavyan madaniyatlari tillari, 2008.206 
3. Fedorishin M.S. Dunyoqarashlarning dialogi. // Yaponiya madaniyatidagi inson va dunyo), Moskva: Nauka, 1985 .-- S. 247-257.

4. Gundling E. yapon sheriklari bilan biznes aloqasi san'ati. JETRO risolasi, elektron hujjat. 2006 yil.

5. Kavato Akio. Yaponiya biznes korxonalarining yangi modellari. Ular o'lmadi. // Moskva davlat universiteti Oliy biznes maktabida nutq stsenariysi (29 iyun 2011 yil)

\section{ИНГЛИЗ ВА ЎЗБЕК ТИЛЛАРИДА НОАНИК ОЛМОШЛАРНИНГ ТАДКИҚИГА ДОИР}

\section{Эгамназаров Қобил (СамДЧТИ)}

Annotation: In this paper, the syntactic role of indefinite pronouns in the speech device of both languages and their differential syntactic units is determined.

Key words and expressions: pronouns, indefinite pronouns, nominative, predicative, component, module.

Хозирги замон тилшунослигида ноаниқ олмошларни аниқлашда ва уларни таснифлашда хар иккала тил мисолида олимларнинг фикрлари бир-биридан фарқ қилиши уларнинг бу борада бир тўхтамга келмаганлигидан далолатдир. Масалан, инглиз тили назарий ва амалий грамматикасида ноаниқ олмошлар Л.П.Винокурованинг фикрича one, each, every, all, either, both, other, another, some, any, everybody, someone, anything, much, many, (a)little, (a) few [1954, 67].

В.Н.Жигадло, И.П. Иванова, Л.Л. Иофик “Хозирги замон инглиз тили” назарий грамматикасида қуйидагиларни ноаниқ олмошлар деб эьтироф этадилар: some, any, somebody, anything, anybody, someone, something, anyone [1956, 64-66].

Инглиз тилшуноси Р.А.Клоуз фақатгина ноаниқ олмошлар some, any, every, no [1979, 146] кабиларни баён этган.

И.П.Иванова, В.В. Бурлакова, Г.Г.Почепцов some, any ва уларнинг ясама шакли хамда no, nobody, no one кабилар ноаниқ олмошлари сифатида тан олган. [1981б 44].

Ўзбек тили грамматикаларида хам ноаниқ олмошлар бир хил эмас. У.Турсунов, Ж.Мухтаров, Ш.Рахматуллаев ноаниқ олмошлар сирасига нимадир, кимдир, аллаким, алланима, аллақандай, аллақачон, аллақанақа, аллақайси, аллақанча, қанақадир, қандайдир, қачондир, қайсидир, қаер(-га, -дан, -да) дир, бир нима, бир нарса, бир қанча, бир неча, биров, бирор, бир кун, бир вақт кўрсатилган [1992, 313-314].

Э. Қиличев гумон олмошлари аллаким, аллақандай, нимадир, кимдир қаергадир, биров, баъзи, алланима, бир нарса, бири кабиларни эьтироф этган. [2001, 189].

Юқорида қайд қилинишича хар иккала қардош бўлмаган тилларда ноаниқ ёки гумон олмошларини таснифлашда олимларнинг бир тўхтамга келмаганликларининг гувохи бўлдик.

Ноаниқ ёки гумон олмошларни тадқиқ қилишда айрим монографик ишлар мавжуд. Яъни Л.А. Сучкова "Синтактическая семантика неопределённых местоимение в современном английском языке" мавзусида some, anybody, somebody, something, someone, every, everything anybody, anyone, any, other, another, each, someday кабиларни гап қурилмасида тутган ўрнига кўра компонентларга ва синтаксемаларга ажратиб тахлил қилган. [1983].

Инглиз ва ўзбек тиллари мисолида М.И. Гадаева ўзининг диссертациясида турли тизимли тилларда ноаниқлик категорияси хақида тўхталиб, инглиз тилида асосан ноаниқ артикль асос қилиб олинса, ўзбек тилида “бир" сонига кўпроқ эътибор берилган [1989]. Ушбу ишда муаллиф ноаниқ олмошларга қисман тўхталсада, уларни инглиз ва ўзбек тиллари гап қурилмасида тутган синтактик ўрни , уларнинг гапдаги бошқа компонентлар билан синтактик алоқалари, дифференциал синтактик-семантик белгилари аниқланмаган. 
Мазкур мақолада хар иккала тиллар гап курилмасида ноаниқ олмошларнинг синтактик ўрни ва уларнинг дифференциал синтактик бирликларини аниқлашдан иборат.

Инглиз тили мисолида ноаниқ олмошлар гап курилмасида қуйидаги синтактик ўринларда келиши мумкин:

1. Ядро предикатив $\left(\mathrm{Np}_{1}\right)$ ўрнида:

I fact, anything come of, It was bound...(M.E.300)

Ушбу гап таркибида ноаниқ олмош “anything” ядро предикатив 1 ўрнида ядро предикатив $2\left(\mathrm{~Np}_{2}\right)$ соте компоненти билан ядро предикатив алоқа асосида боғланади

2. $\quad$ Ядро предикатив $2\left(\mathrm{~Np}_{2}\right)$ ўрнида:

I am not anything... (M.E.289)

3. Ядро бўлмаган тобе предикатив $1\left(\mathrm{NDp}_{1}\right)$ ўрнида:

I saw everyone coming home church (E.H., 277)

Бу гап таркибида "everyone" ядро предикатив 2 (saw) компонентига тобе бўлиб, у билан субординатив алоқа билан боғланса, caming билан эса ядро бўлмаган предикатив асосида боғланади.

4. Ядро бўлмаган аппозитив предикатив $1\left(\tilde{N}_{1} \mathrm{P}_{1}\right)$ ўрнида:

We all knew that being wounded, after all, was really an accident. (E.H., 86)

Аппозитив компонент ўрнида келган ноаниқ олмош “all” бевосита ва билвосита синтактик алоқалар билан боғланади. All гап таркибида ядро предикатив 1 (we) билан бевосита аппозитив алоқа билан боғланса, ядро предикатив 2 (knew) билан билвосита ядро предикатив алоқа асосида боғланади. Буни исботлаш учун тушириб қолдириш трансформациясидан фойдаланиш мумкин:

We all knew ............. allknew

5. $\quad$ Уюшиқ ядро бўлмаган тобе $\left(\mathrm{H}_{1} \mathrm{~N} D \vec{D}\right)$ компонент ўрнида:

He had sold vitality, in one form or another (E.H., 283)

Уюшиқ бўлаклар one form ва another ўзаро координатив алоқа ёрдамида боғланади, ядро предикатив 2 (had sold) компонентига субординатив алоқа асосида боғланади.

6. Ядро бўлмаган тобе компонент (ND) ўрнида:

"Give me bacon and eggs" said the other men (E.H., 64)

Ушбу гапда ноаниқ олмоши the other тобе компонент ўрнида ядро предикатив 1 (men) компонентига субординатив алоқа асосида боғланади. Шу ўринда қайд этиш жоизки, ноаниқ олмошлар гап таркибида тобе компонент бўлиб, у гапнинг ядро предикатив $1\left(\mathrm{~Np}_{1}\right)$, ядро предикатив $2\left(\mathrm{~Np}_{2}\right)$ хамда тобе компонентларга хам тобе бўлиши мумкин [А.М.Мухин, 1968, 164-166]. Юқорида берилган мисолларнинг синтактик алоқаларини юнкцион моделлар ва гап компонентларининг дифференциал синтактик белгиларини хамда уларнинг морфологик хусусиятларини компонент моделлар асосида куургазмали равишда қуйидагича изохлаш мумкин:

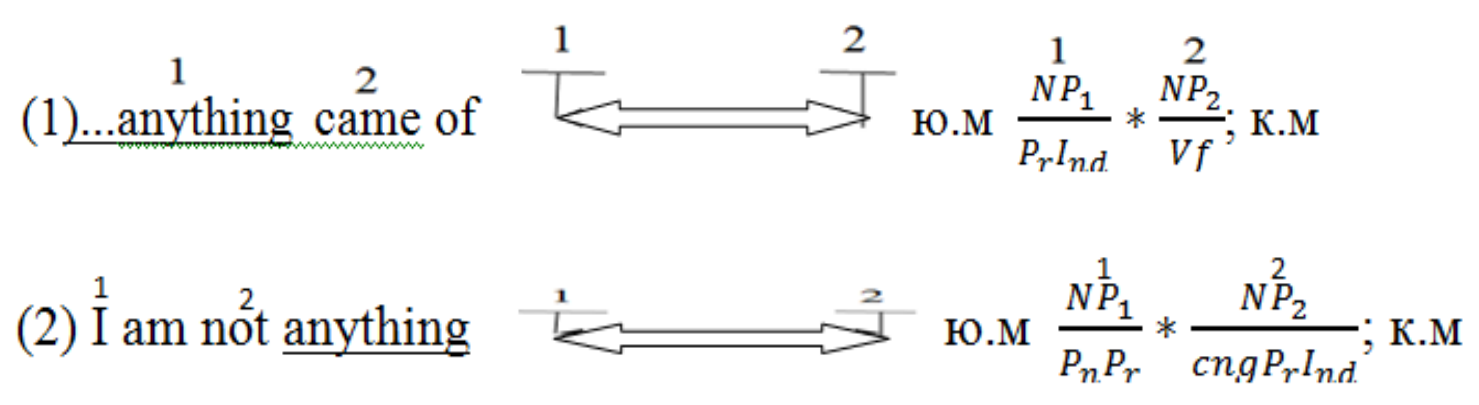

(3) $\stackrel{1}{I}^{2}$ sâw everyone coming .... 
(4) $\underline{W}^{1}$ e all knew ...

(5) He had sold... in one form or another.

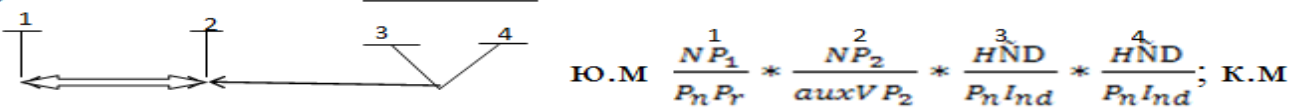

(6) ... said the other

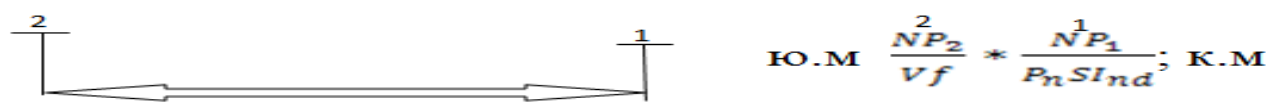

Ўзбек тили мисолида қараганда ноаниқ олмошлар гапда қуйидаги синтактик ўринларда келиши мумкин:

1. Ядро предикатив $1\left(\mathrm{~Np}_{1}\right)$ ўрнида:

Allanarsa "tars" etib urildi (P.Q., 414)

2. Ядро бўлмаган аппозитив предикатив $1\left(\tilde{\mathrm{N}}_{\mathrm{AP}}\right)$ ўрнида:

... Xisravshohmi - birortasi Samarqandni zabt etsa...(P.Q., 92)

3. Ядро бўлмаган тобе ядро предикатив $1\left(\tilde{N}_{1} P_{1}\right)$ ўрнида:

....Allakimlar o'q yoki, tig' zarbidan jon berayotgani... (P.Q.,198)

4. Ядро бўлмаган тобе компонент (ND) ўрнида:

...bir kishi sabrsizlanib yo'taldi. (P.Q., 123)

Мазкур гапларнинг юнкцион ва компонент моделлари қуйидагича:

(1) Allanarsa "tars"s" etib uzzildi.

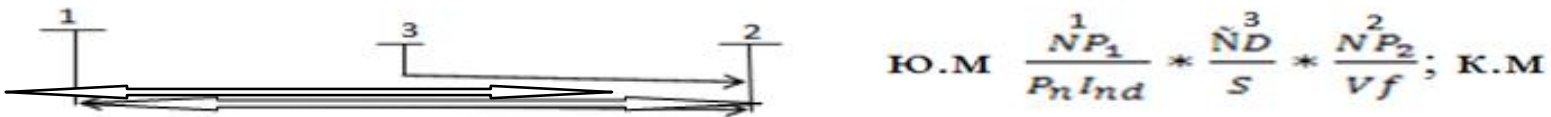

(2)... Xisravishohmi - birortasi Samarảandni zåbt etsa...

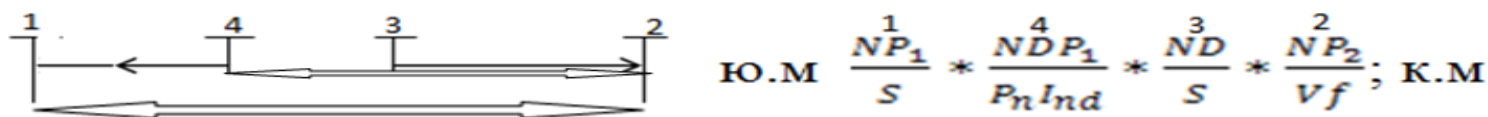

(3) ... Allakimlar o' 4 yoki, ti ${ }^{5}$ ' zarbidan jỏn berał́zotgani...

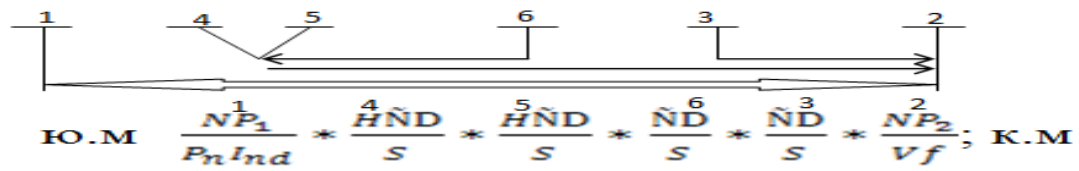

(4)...bir kishi sabrsizlanib yo ${ }^{3}$ taldi.

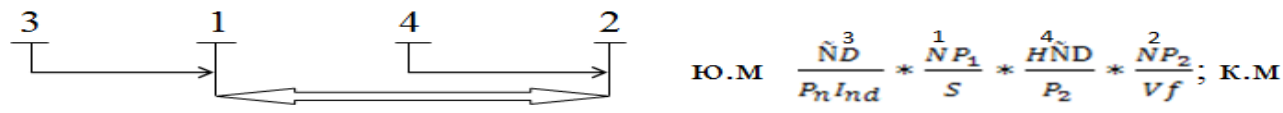

Умуман инглиз ва ўзбек тиллари гап қурилмасида асосан ядро бўлмаган тобе компонент ўрнида кўпроқ учрайди.

1. Аммо ноаниқ олмош ядро предикатив 2 (ND) компонентига тобе бўлиши мумкин:

You know everything. (E.H., 50)

2. $\quad$ Тобе компонентга (Np) тобе ўрнида: 
I can give you any kind of sandwiches. (E.H., 64)

3. Ядро предикатив $1\left(\mathrm{~Np}_{1}\right)$ компонентга тобе:

The other ear should have been there.(E.H. 55)

1. У Узбек тилида хам ноаниқ олмошлар ядро предикатив $1\left(\mathrm{~Np}_{1}\right)$ компонентига тобе бўлиб келиши мумкин:

... qandaydir kuyov topilganga o'xshaydi.(P.Q.,107)

$2 . \quad$ Ядро предикатив $2\left(\mathrm{~Np}_{2}\right)$ компонентига тобе:

Nigoraxonim ...yana nimalarnidir aytmoqchi...(P.Q.,93)

3. Ядро бўлмаган тобе (N) компонентга тобе:

Mulla Fazliddin qandaydir xavf sezib gapirmoqda edi. (P.Q.,67)

Хар иккала тилда хам ноаниқ олмошлар ядро предикатив 1( $\left.\mathrm{Np}_{1}\right)$ ўрнида келганда бошқа компонентларга тобе бўлмайди:

Something has gone out of me (M.E., 402)

...Kimdir qizil boshnovkarga tosh otdi (P.Q.403).

Ядро предикатив $2\left(\mathrm{~Np}_{2}\right)$ ўрнида келганда хам бошқа бирорта компонентга тобе бўлмайди:

I thought you were someone else. (E.H., 18)

Бундай мисоллар ўзбек тилида учрамайди. Мисолларнинг тахлилидан маълумки инглиз тилида ноаниқлик some, anybody, anywhere, anything, anyway, any more, any one, every, sometimes, something, never, everything, nothing, somebody, many кабилар ёрдамида ифодаланса, ўзбек тилида алланечук, бир, бирон, қандайдир, бирор, қачондир, баъзи, бирорта, алланарса, аллаким, кимдир, бир қанчаси, аллақайси, аллақачон, бир неча, нимадир, нечундир, аллақандай, биров, қайёққадир, негадир, аллақанақа, кабилар ёрдамида ифодаланади.

Ишимизнинг кейинги сахифаларида келтирилган ноаниқликни ифодаловчи хар бир синтактик бирликларни гапдаги тутган ўрнига кўра уларнинг дифференциал синтактиксемантик белгиларини аниқлаш, яъни улар иштирок этган гапларни синтаксемаларга ажратиб тахлил қилиш ва аниқланган синтаксемаларнинг парадигматик қаторини, уларнинг вариантларини (коннотатив, факультатив) кўрсатиш ва ноаниқ олмошлар ифодалаган синтаксемалар синтактик алоқалар (ядро предикатив, ядро бўлмаган предикатив, субординатив, координатив, аппозитив) базасида қандай синтаксемалар билан бирикиш холатларини изохлашдан иборат.

\section{Фойдаланилган адабиётлар руйхати}

1. Винокурова Л.П. Грамматика английского языка. - Учпедгиз: Ленинград,1954

2. Жигадло В.Н., Иванова И.П., Иофик Л.Л. Современный английский язык. Изд-во литературы на иностранных языках.- Москва,1956

3. R.A .Close A Reference Grammer for students of English.- "Просвещение".- Москва, 1979.

4. И.П.Иванова, В.В.Бурлакова, Г.Г.Почепцов Теоретическая грамматика современного английского языка. “Высщая школа".- Москва,1981.

5. У.Турсунов, Ж.Мухтаров, Ш.Рахматуллаев Хозирги Ўзбек адабий тили. "Ўзбекистон".-Тошкент, 1992.

6. Э.Қиличев Хозирги ўзбек адабий тили. “Бухоро университети”.- Бухоро, 2001.

7. Л.А.Сучкова Синтаксическая семантика неопределенных местоимений в современном английском языке.// Автореферат дисс. канд. филол. наук.- Ленинград -1983.

8. М.И.Гадоева Типологическая категория неопределенности и способы ее выражения в разоносистемных языках. // Автореферат дисс. канд. филол. наук.Ташкент, 1989.

9. А.М.Мухин Структура предложений и модели.- Ленинград,1968. 


\title{
VALENCY OF SYNTACTIC UNITS WITH NUCLEAR AND NON-NUCLEAR PREDICATIVE RELATIONS
}

\section{Asadov Rustam Muminovich}

(SamSIFL)

\begin{abstract}
Annotation: This article focuses on syntactic valency of the units with nuclear and nonnuclear predicative relations, on the basis of English sentences. The difference between nuclear and non-nuclear predicative relations is stated, the number of valencies of the syntactic units according to their position is classified by functional analysis and component models with some examples. This article may take interest of those who study philology for master's degree, who are making research work on functional syntax and/or syntactic valency and anyone who is interested in linguistic valency.
\end{abstract}

Key words and expressions: valency, nuclear predicative relation, non-nuclear predicative relation, subordinate relation, coordinate relation, junctional analysis, component model.

This article was written as the result of series analysis of English sentences taken from works of modern English and American literature. Though, in this article, I do not look at the sentences themselves but their patterns for analysis.

As it is known, the theory of valency has been the object of research works since the $1940^{\text {th }}$, yet there is no single and definite definition of it. There are different approaches to valency theory in the world linguistics such as semantic, lexical, and stylistic and so on. As to syntactic valency, most linguists base on verb centrism and identify syntactic valency by the verb's lexical-semantic features. That linguistic valency has not been researched completely and in detail makes the subject actual.

Linguistic valency has been under scientific consideration of world linguists and most research works have been done on the base of European languages. The following linguists made valency the object of their research: S.D.Katsnelson, L.Tesniere, R.Longacre, G.Zandau, J.Erben, G. Helbig, K.Zommerfeldt, E.P.Logoceva, V.Bonsio, V.V.Burlakova, N.N.Stepanova, M.V.Vlavatskaya, E.V.Razova, U.I.Yuldasheva and others.

Valency is studied in all linguistic levels: in morphological level M.D.Stepanova, G.Helbig; in lexical level V.Yu.Rozentsveich, E.N.Melnikova, D.J.Allerton, S.M.Kibardina, T.V.Ebert.

In most of these works valency is based on the lexical meaning of the verb, its combinability with other parts of the sentence and according to these features verbs are classified as one-valency, two-valency, three-valency and so on.

Valency in syntactic level is divided into obligatory valency and optional valency [Апресян, 1974; Зоммерфельдт, 1975]. But in all these research works linguists define valency by lexicalsyntactic characteristics of the verb in the position of the predicate. In any language there exist sentences without a verb; in this case how do we define syntactic valency of such sentences? As it is mentioned in some research works done on syntactic valency in English syntax structure any syntactic unit has a valency [Asadov, 2014].

The novelty of my research is that I analyzed monovalency and polyvalency syntactic units in English sentence structure through linguistic methods defining their syntactic relations and positions.

The following linguistic methods are used in the research work: experimental method, distributional method, method of componential and syntaxeme analysis, junctional method. Sentences collected from various English and American fiction books are taken as the material of the research.

Studying a great number of scientific works on linguistics I decided to support idea that any syntactic unit may have valency whether there is a verb in the sentence or not. The number of valances is defined according to the number of their syntactic relation, which means a syntactic unit which has one syntactic relation is a one-valency element and that having two syntactic relations is a two-valency element. 
In the structure of the sentence one can observe the following syntactic relations: predicative relation, subordinate relation, coordinate relation and appositive relation. Predicative relation in itself is divided into two types: nuclear predicative relation and non-nuclear predicative relation.

1. Characteristic feature of the nuclear predicative relation is that it connects the two main components of the sentence which are not dependent on any other component and can be a complete sentence. Nuclear predicative relation has the following sign in the junctional model ( ). As to say in traditional grammar nuclear predicative relation connects the subject and predicate of the sentence.

2. Non-nuclear predicative relation is the relation between the syntactic units which are in predicative relation but are not the subject and predicate of the sentence. In traditional grammar, such components are classified as complex subject and complex object. Non-nuclear predicative relation is in opposition to nuclear predicative relation and is considered in the same level with other relations such as subordinate, coordinate and appositive relations; but there is difference between these relations too. Usmanov U.U indicates the difference between the subordinate and non-nuclear relation as follows: "in subordinate relation one component is subordinate in unilateral direction to the main component, while in non-nuclear relation there is equal connection to both directions" [Usmanov, 1990]. Non-nuclear predicative relation has the following sign in the junctional model ( $\quad$ ). Non-nuclear predicative relation links components which are not the principal parts of the sentence but are in predicate relation with each other. In traditional grammar this relation is seen in objective and subjective constructions with non-finite forms of the verb. In such constructions the participant, which is expressed by a noun in common case or a pronoun in objective case is called non-nuclear dependent predicated component $-\mathrm{NDP}_{1}$, and the other participant expressed by a verb form is called non-nuclear predicating component $-\mathrm{NP}_{2}$.

Participants of the nuclear predicative relation, the subject which is called nuclear predicated component $-\mathrm{NP}_{1}$ and the predicate the one called nuclear predicating component $-\mathrm{NP}_{2}$ can have one, two or three valencies. Whereas non-nuclear dependent predicated component can have two or three valencies and non-nuclear predicating component can have one or two valencies. To prove this theory I define valency of nuclear and non-nuclear syntactic units analyzing the following sentences by componential and junctional models:

\section{He could make them think (RGH, 126).}

There are both nuclear and non-nuclear predicative relations in this sentence. So $\mathrm{He}$ is the nuclear predicated component $-\mathrm{NP}_{1}$, could make is the nuclear predicating component $-\mathrm{NP}_{2}$, them is the non-nuclear dependent predicated component - $\mathrm{NDP}_{1}$, think non-nuclear predicating component $-\mathrm{NP}_{2}$ of the sentence.

Here I would like to mention that componential model of the sentence is limited only by presenting differential syntactic signs and does not demonstrate formal side i.e. morphological characteristics of the components completely. Therefore, I have to use some morphological signs in my research. Signs used to express morphological features: Prp - pronoun personal, $\mathrm{m}$ - modal verb, Vinf - infinitive form of the verb. The junctional model (J.M) and the componential model (C.M) of the above example are as follows:

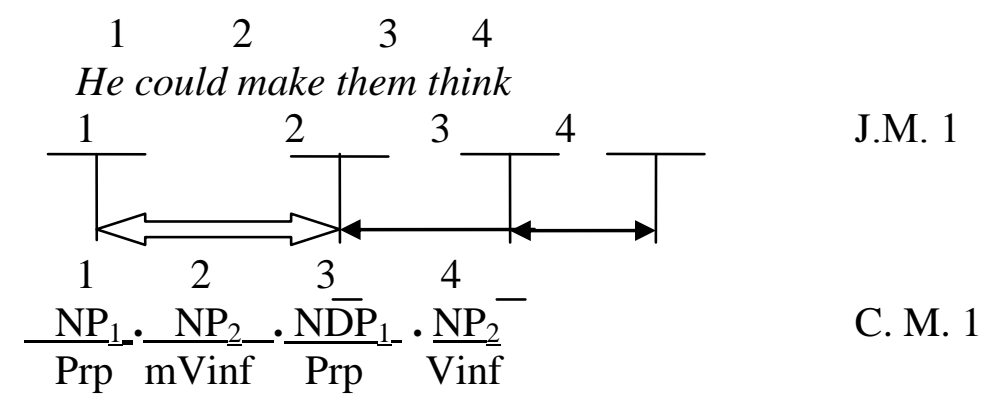

The first, second and fourth components of this sentence are one-valency syntactic units because they get into one syntactic relation with other syntactic units. That is to say $\mathrm{NP}_{1}$ and $\mathrm{NP}_{2}$ 
are in nuclear predicative relation with each other and, $\mathrm{NP}_{2}$ has non-nuclear predicative relation with $\mathrm{NDP}_{1}$. The third syntactic unit of this sentence has two valencies i.e. this component is a bivalence component as it has two syntactic relations: one is subordinate relation with $\mathrm{NP}_{2}$, the other is non-nuclear predicative relation with $\mathrm{NP}_{2}$. In traditional English grammar books, the third and fourth syntactic units of the above given example are considered as "the objective with the infinitive construction" [Quirk, Greenbaum, 1982]. This objective infinitive construction is looked at as one syntactic unit called a complex object. Yet, in English grammar, interpreting this construction as one syntactic unit - complex object - has been one of the argumentative problems among linguists. Because the question by what syntactic relations the second component with the third component as well as the third component with the fourth one are connected has not been answered yet.

That the third component of the sentence (them) is really bivalence can be proved via the method of transformational analysis of omission, that is by dropping out the syntactic unit expressed by the non-finite form of the verb (think):

1) He could make them think $\rightarrow$ He could make them ....

In spite of the fact that the result sentence of this analysis seems grammatically close to the target one, in fact it is semantically not complete. Consequently, it proves that non-nuclear predicative relation is as essential as other syntactic relations. That is why to preserve this relation non-finite form can be transferred into the finite form, which, in its turn, changes the non-nuclear predicative relation into the nuclear predicative one without losing the semantic meaning of the combination:

\section{(1) He could make them think $\rightarrow$... them think $\rightarrow$ they thought}

The result carries the conclusion that converting "objective with the ibfinitive construction" into a sentence indicates the existence of non-nuclear predicative relation between the components of the phrase [Mukhin, 1999; Tikotskaya, 1985]. The difference between nuclear and non-nuclear predicating components is that while the former is always the predicate of the sentence, the latter can never be the predicate in a sentence structure.

We can draw conclusion that a syntactic unit having a nuclear predicative relation can be monovalency or bivalency whereas a syntactic unit with a non-nuclear predicative relation is always bivalency however, it may have three valencies in case of having coordinative relation.

\section{The list of used literature}

1. Apresyan Yu.D. Leksicheskaya semantika. Sinonimicheskiye sredstva yazyka (Апресян Ю.Д. Лексическая семантика. Синонимические средства языка). - Nauka, 1974.$216 \mathrm{p}$.

2. Mukhin A.M. Funksionalny sintaksis (Мухин А.М. Функциональный синтаксис). Sankt-Pitersburg: 1999-184p.

3. Quirk R., Greenbaum S., Leech G., Svartvik J. A University Grammar of English. Moscow, 1982. (Russian publication)

4. Tikotskaya K.E. Stuktura predlojeniy s kauzativnymi glagolami v sovremennom angliyskom yazyke (Тикоцкая К.Е. Структура предложений с каузативными глаголами в современном английском языке. / Автореф. дисс. .. канд. филол. Наук). - Minsk: 1975.-24p.

5. Usmanov U.U. Metodicheskaya rekomendatsiya po teorii sintaksemnogo analiza nulevyx elementov $\mathrm{v}$ strukture nepolnyx predlojeniy $\mathrm{v}$ angliyskoy diologicheskoy rechi (Усмонов У.У. Методическая рекомендация по теории синтаксемного анализа нулевых элементов в структуре неполных предложений в английской диологической речи). - Samarkand: 1990.90p.

6. Zommerfeldt K.E. K voprosu minimum predlojeniya (Зоммерфельдт К.Е. К вопросу минимуме предложения (валентность и ситуативная заверщённость)). // Inostran. yazyki v shkole, 1975, 1.-P.10-19. 


\title{
ТЕРМИН ЯСАЛИШИДА ТАЯНЧ ВА ЯНГИ МАЪНОНИНГ ЎЗАРО МУНОСАБАТИ
}

\section{Саидова Азиза Давлатовна}

(СамДУ)

\begin{abstract}
Annotation: The article analyzes the semantic, derivational and plural meanings of terms, changes in lexical units and meanings.
\end{abstract}

Key words and expressions: primitive meaning, basic meaning, derivative meaning, lexical units, semantic microsystem.

Маълумки, киши онгида нарса ва ходисани муайян синфга киритишга имкон берадиган белги - хоссалар мажмуи мавжуд. Инсон тафаккури хам воқелик асосида шаклланади. Бу жараён нафақат тажриба ва кузатишлар, шунингдек, тил орқали хам содир бўлади. Олам хақидаги билимлар ривожи нисбатан махдуд (ёпиқ) жамиятда содир бўлади [Cherry 2008:14]. Шунинг учун турли тамаддунлар ўз тасаввур тизими ва бахолаш мезонларини хосил қилади.

Бу жараёнда сўзларнинг нафақат туб, балки кўчма маънолари хам шаклланади. Шунинг учун жамиятда янги предмет пайдо бўлганда, у муқаррар равишда бошқа (мавжуд) предметлар билан қиёсланади. Агар бу ерда маълум ўхшашликлар пайдо бўлса, улар, албатта, номинацияга таъсир қилади. Хозирги вақтга келиб, оламнинг илмий манзараси тасвирида жиддий нуқсонлар мавжудлиги кўринди. Билимларни қайтадан англаш ва бахолаш тушунчалар аппаратининг бехад кенгайишига олиб келди [қаранг: Dohan 2009:18]. Натижада илмий терминологиянинг шаклланиши тезлашди ва айни пайтда мавжуд луғавий бирликларнинг маъноларига хам аниқликлар киритилди.

Маълумки фан ривожи билан бир қаторда, янги назариялар пайдо бўлмоқда. Бу эса албатта, луғавий бирликлар маънолариниг ўзгариши,терминологиянинг бойишига сабаб туғдиради. Зотан, терминология тизими илмий кузатувлар ва тажрибага муқобил равишда ривожланади (қаранг: Elmer 2009; Harris 2007).

Айтилганлардан тилнинг луғат таркибида бир сўз бир пайтнинг ўзида илмий назария шакллангунига қадар мавжуд бўлган маънони касб этиши мумкин деган хулоса келиб чиқади. Соха мутахассисларига маълум бўлган бу сўзга жорий илмий тадқиқот натижаси юкланади. Масалан, valve сўзи ўрта асрларда “эшикнинг жойлашуви” маънони ифодалаган. Илмий билимларнинг тараққиёти билан у техника сохасида кенг қўлланадиган бўлди. Хозир бу сўз техникада "клапан”, “вентил”, “кран” ва шу каби маъноларни, океанологияда “малюска чиғаноғи жойлашуви” маъносини англатади. Шунга кўра, термин ясалиши, анъанага биноан икки, яъни синхрон ва диахрон ёндошув асосида шаклланади. Булардан биринчисида у ёки бу маънонинг маълум пайтдаги фаоллиги аниқланса, иккинчисида вақт ўтиши билан маъноларнинг силжиши кузатилади.

Одатда, термин маънолари орасида етакчи (асосий) маъно бўлади ва у кўшимча иккиламчи маъноларни ўзаро мантиқан боғловчи вазифасини бажаради. Умуман, маъноларнинг бир-бири билан семантик алоқаси терминотизим мавжудлигининг шартларидан биридир. У тилнинг лексик тизимида яхлитликни таъминлайди ва семантик микротизим мақомини нисбатан мураккаб тизимларда шакллантиради.

С.Д.Кацнельсон [2010:57], А.А.Потебнянинг бу борадаги фикрларини умумлаштириб, “бир сўз маънолари орасидаги алоқа семантик эмас, балки деривацион характерда бўлади”, - деб ёзади. Шунга асосланиб, сўз - терминлар маъноларини "олдингисининг кейингисига мунособати доирасида қараш”, яъни асосий ва ясама хосилалар сифатида қараш лозим ва бу генетик, яъни тарихан боғлиқ алоқадир" [Канцельсон 2010:46]. Шунингдек, вақт ўтиши билан асосий ва ясама маъно орасидаги алоқа йўқолганда уни қайд этишнинг иложи йўқлигини таъкидлаб бўлмайди. Зеро, маънолар орасидаги алоқа сақланиб қолаверади. Е.В.Падучаеванинг шу муносабат билан билдирилган фикри эътиборга молик: "Полисемантик сўзнинг кўплаб лексик-семантик вариантларида, қоидага кўра, ўзак лексемани топиш мумкин. Қолганлари унинг бевосита ва билвосита семантик 
дериватларидир. Айни пайтда сўзнинг маъноси деривацион структура сифатида намоён бўлади" [Падучаева 2014:398]. Тарихий тараққиёт давомида маънолар структураси ўзгаришларни бошдан кечиради ва бунда деривация тараққиёт сценарийлари жуда рангбаранг бўлиши мумкин. Маъноларнинг яхлит занжиридан бирор халқанинг тушиб қолиши, бир бутун структуранинг бир неча структурага бўлиниши ва х.к. шулар жумласидандир.

Кўпинча бир хил деривацион алоқалар бархам топганда сўз кейинчалик янги алоқаларни кашф этиши мумкин. “Шунинг учун этимологик, яъни тарихан бархам топган ва мазкур даврда сўзда жадал намоён бўладиган фаол (айни пайтда амалда бўлган) деривацион муносабатларни фарқлаш керак” [Кацнельсон 2010:59].

Бироқ хар қандай холатда хам маънолар орасида этимологик муносабатларнинг бўлиши терминни тегишли семантик гурухга киритиш учун замин хозирлайди. Чунки “семантик яккаланишнинг ўзи хам мустақил лексик бирликни хосил қилишда асос вазифасини ўташи мумкин” [Шмельёв 2009:336].

А.А.Филиппова [2008:10] терминологик кўпмаънолилик билан полисемия тушунчаларини қуйидагича фарқлайди: “Агар терминнинг маънолари бир луғат сўзлиги доирасида берилган бўлса, у холда термин полисемияси, термин маънолари матнда аниқлашса ва бир луғат сўзлиги доирасида қайд этилмаса, у холда терминнинг фақат кўпмаънолилиги хақида гапириш мумкин”.

Тил шароитида термин маъноси билимларнинг маълум тизимига нисбатан танланади. Тушунча хам, ўз навбатида, билимнинг муайян сохаси билан чекланади. Бунда ғайрилисоний компетенция ёки билим захираси тил белгисини тўғри идрок этиш ва термин маъносини тўлиқ тушунишнинг зарурий шарти эканини унутмаслик керак.

Терминлар илмий мулоқотнинг асосий ахборот базаси бўлганлиги сабабли хар қандай сохада терминология инсон фаолиятининг турли сохаларида - меъёрий харакатлар, илмий маърузалар, анжуман ва семинарларда олиб бориладиган сўзлашувлар, мақола ва монографиялар ёзиш, ўқув жараёни кабиларда мулоқот қилишга ёрдам беради. Бундай холатларнинг барчасида терминдан турли мақсадларни намоён этиш талаб қилинади. Бу холатлар эса коммуникатив йўналтирилганлик билан белгиланади. Бундан ташқари, мавжуд фанларда тадқиқот объектларига нисбатан турли назария ва концепциялар мавжуд бўлгани холда илмий фаразлар хам турлича талқин қилинади.

\section{Фойдаланилган адабиётлар рўйхати} $470 \mathrm{p}$.

1. Cherry C. Pragmatic Aspects of Human Communication. - Dordrecht: Reidel, 2008. -

2. Dohan, Mary Helen. Our Own Words.-New York: Knopf, 2009.-384 p.

3. Elmer W. A questionnaire for the terminology of coalmining // The history and the dialects of English. - Heidelberg, 2009/ - P.200-252.

4. Harris R. The Language Makers. - London : Duckworth, 2007. - 468 p.

5. Канцельсон С.Д. Содержание слова, значение и обозначение. - М.: Академия, 2010. - C. 112

6. Падучева Е.В. Динамические модели в семантике лексики. - М.: Языки славянской культуры, 2014. - С.608

7. Шмелёв Д.Н. Современный русский язык: Лексика. - М.: Книжнй дом «ЛИБРОКОМ», 2009. - С.336

8. Филиппова А.А. Внутриотраслевая полисемия в русском и немецком методическом дискурсе (на материале концепта ЦЕЛЬ). // Автореф. Дис... канд. филол. наук. Екатеринбург : УГУ, 2008. - С.23 


\section{YAPON TILIDA OLMOSHLARNING LINGVOMADANIY XUSUSIYATLARI}

\section{Urokov Sherbek}

(SamDCHTI)

Annotation: This article explores the linguistic and cultural features of the pronoun in Japanese. It analyzes and comments on over eight linguistic and cultural comparisons of the first person pronoun in Japanese and Uzbek. All theoretical data are confirmed by practical examples.

Key words and expressions: Linguistic comparisons, pronouns, linguacultural examples.

Bugun o'zbek tili bilan bir vaqtda chet tillarni ham o'rganish, ularni zamon talablari darajasiga ko'tarish hayotimizning tarkibiy qismiga aylandi. Ona tilimizning ravnaqi davlat siyosati darajasiga ko'tarilishi tilshunosligimiz oldiga yuksak vazifalarni qo'yish bilan bir paytning o'zida chet tillari bilan chog'ishtirib o'rganish kabi vazifalarni ham qo'ydi.

Tillardagi lisoniy birliklarni yangidan yangi metod va usullar asosida tadqiq etish chet tillarni tobora chuqurroq, teranroq tadqiq etilishiga olib kelmoqda. Biroq bu borada kelajakda amalga oshirilishi lozim bo'lgan yuzlab muammolar, masalalar o'zining to'la to'kis yechimini kutmoqda. Shulardan biri alohida xususiyatlarga ega bo'lgan olmoshlarni stilistik xususiyatlarini tahlil etishdir. Olmoshlarning lingvomadaniy xususiyatlari ayniqsa badiiy matnlarda yaqqol ko'zga tashlanadi. Bunda olmoshlarning badiiy asardagi xususiyatlari har ikka tilda chuqur o'rganilishi lozimligini talab etadi.

Shuningdek bugungi kungacha yapon tilining o'zbek tilshunoslari tomonidan ko'plab jihatlari o'rganilgan bo'lishiga qaramay yapon tilining stilistik vositalari e'tibordan chetda qolib kelmoqda. Umuman olganda tildagi matnning jozibasi bevosita matnning stilistik bo'yoqdorligiga ham bog'liqdir. Yapon tilida ham olmosh o'zining lingvomadaniy xususiyatlariga ega bo'lib, turli badiiy asarlarda turlicha ma'no va mazmun kasb etib keladi. Bunda birgina kishilik olmoshi misolida ham ko'rib chiqishimiz mumkin. Yapon tilida I - shaxs kishilik olmoshining sakkizdan ortiq ko'rinishlar mavjud bo'lib, ularning har biri o'ziga xos ma'no va mazmun kasb etashini takidlab o'tish joizdir.

1. Vatashi(私) - men - bu so’z hozirgi yapon jamiyatida betaraf shakil sifatida qo'llaniladi. Ammo shu bilan birga ayollar nutqining xushmuomalalik shakli sifatida ham qo'llaniladi. olmoshidir.

2. Boku(僕) - men - yapon jamiyatida o'spirinlar tomonidan ko'p qo'llaniluvchi kishilik

3. Ore( 俺 ) - men - yapon jamiyatida o'ziga ishonchi yuoqri bo'lgan jasur yegitlar tomonidan qo'llaniladigan kishilik olmoshidir.

4. Ora (おら ) - men - yaponiyaning Tokoku provensiyasidan bo'lgan kishilar tomonidan qo'llaniluvchi kishilik olmoshidir. Shuningdek bu olmosh yapon jamiyatida ko'cha bolasiga xos jargon ham hisoblanadi.

5. Oira(おいら ) - men - Edo davrinig so'ngi yilllarida ayollar nutqida ham foydalanishgan. Bugungi kunda o'zini muhim sanovchi, kekaygan erkaklar nutqida uchraydi.

6. Atashi(あたし ) - men - odatda iboli, sodda xarakterga ega qizlar tomonidan ko'p qo'llaniladiga kishilik olmoshi bo'lib, asar qahramonini odobli, hayoli jihatdan yoritishga xizmat qiladi.

7. Atai(あたい) - men - yapon jamiyatida boy qizlar tomonidan qo’llaniluvchi kishilik olmoshidir. $\mathrm{Bu}$ kishilik olmoshi yapon tilida yozilgan asar qahramonining o'ziga bino qo'yganiligini ifoda etish maqasadida va shuningdek oliy tabaqaga mansub ayol obrazini yaratishda ham qo'llaniladi.

8. Ashshi(あっし ) - men - bu olmosh asosan yapon adabiyotida hunarman obrazini yaratishda qo'llaniladi

9. Vashshi(わし) - men - yaponjamiyatida kamdan kam qo’llaniluchi kishilik olmoshi bo'lib, asosan keksa yoshdagi erkaklar nutqida uchraiydi. 
Yuqoridagi misollardan ko'rinadiki, o'zbek va yapon tillaridagi olmoshlarning semantik stilistik farqlarini anglamay turib, har ikki tildagi badiiy asarning semantik - stilistik mohiyatini tushinib bo'lmaydi. Buesa tarjima jarayonida bir qancha qiyinchiliklarni yuzada ketiradi.

Shuningdek yapon tilida olmoshlarning lingvomadaniy xususiyatlari tildagi jargonlar hisobiga yanada boyiydi. "Men" olmoshining bir qancha turlari o'ziga xos kinoya darajalariga ega va bu darajalar bir - biridan farq qiladi. Shu o'rinda qizlar va o'g'il bolalar nutqiga ajralishini ham takidlab o'tish joizdir. Ba'zan bu kishilik olmoshlari badiiy asarlarda xarakter jihatdan o'gil bolalarga taqlid qiluvchi qizlar obrazini yaratishda stilistik vosita sifatida qo'l keladi.

Yuqorida yuritilgan fikrimiz ya'ni olmoshlarning lingvomadaniy xususiyatlari o'zbek va yapon tillari misolida keng o'rganilmagan. Bu kabi masalalarga oydinlik kiritish o'zbek tilidan yapon tiliga, yapon tilidan o'zbek tiliga amalga oshirilayotgan badiiy tarjima jarayonida katta ahamiyat kasb etadi. Agar bunday jarayonda yapon tilidagi olmoshlarning lingvomadaniy ma'nolarini e'tibordan chetda qoldirsak asarning jozibadorligiga birmuncha ziyon yetishi ham mumkin.

\section{Foydalanilgan adabiyotlar ro'yxati}

1. Йўлдошев Б. Бадиий нутқ стилистикаси. - Самарқанд: СамДУ нашри, 1982.

2. Йўлдошев Б., Шомуродов Ш. Матнда гумон олмошларининг айрим семантик ва функционал-услубий хусусиятлари хақида // Тил тараққиётининг деривацион қонуниятлари (Тўплам). - Самарқанд, 2009.

3. Киэда М. Грамматика японского языка : пер. с яп.; общ. ред., предисл., коммент. и прил. Н. И. Фельдман. - Изд. 3-е, стереотипное / М. Киэда. - М., 2004. - Т. I

4. Алпатов В. М. О показателях множественности и категории числа в современном японском языке / В. М. Алпатов // Японское языкознание. - 1979.

5. Конрад Н. И. О "языковом существовании" // Японский лингвистический сборник. M., 1959.

6. Matt Fargo "Dirity Japanese" 2007., 150 p

7. フ・ガイフア「日本語における主語省略の条件についての考察」2014 年 現代 社会文化

8. 庵功雄・高梨信乃・中西久実子・山田敏弘『中上級を教える人のための日本語文 法ハンドブック』白川博之監修，2001年

9. 成山重子『日本語の省略がわかる本』明治書院. 2009 年

\section{"是" FE'LINING TAHLILIGA DOIR}

To`xtamishev Abdurasul (SamDCHTI)

Annotation: This thesis discusses details of the verb "是", which is the main component of Chinese grammar, and discusses its basis in building various structures, its appearance in our time and personality, its meaning and functions.

Key words and expressions: the verb to be, the participle of the verb, the function of the form, the participle, constructions, tenses.

Xitoy tili Xitoy - Tibet tillari oilasiga mansub bo`lib, bu tilda Yevropa tillariga xos bo`lgan jihat deyarli uchramaydi. Ammo ayrim hollarda bu ikki til o’rtasida ba`zi o`xshash jihatlarni ko`zimiz ilg`aydi. Bu holatni tillar o’rtasidagi o`xshash jihatlar yoki bir tilning ikkinchi tildagi ekvivalentligi deb atash mumkin.

Ingliz tilini o`rganganlar yoxud o ’rganuvchilarga yaxshi tanishki, bu tilda bo 'lmoq "to be" fe`li o`ziga xos xarakterga ega. Ot-kesimli gaplarni esa ushbu fe`l ishtirokisiz tasavvur etish mumkin emas. Xitoy tili ham o`zining ana shunday "bo 'lmoq" fe'liga ega bo`lib, u juda ko`p va xilma - xil xarakterli xususiyatlarga ega. Yana bir jihati shundaki, xitoyliklar ushbu "bo`lmoq" 
fe `lini universal fe`l deb ham atashadi. Quyida “是 shi” bo`lmoq fe`lining vazifalari, qo`llanilishiga atroflicha to 'xtalib o'tamiz:

Xitoy tilida “bo'lmoq” fe'li “非动作动词 fei dongzuo dongci” deb atalib, harakat fe'llari bo`lmagan fe`llarni o`z ichiga olib, muhokama va tasdiqni ifodalashga xizmat qiladi. Ayrim hollarda o`rganuvchilar “是 bo`lmoq” fe`li ishtirok etgan gaplarning strukturasini osonlik bilan o`rganishlari mumkin. Ammo ayrim hollarda esa, “是” ishtirok etgan gaplarning mag`zini chaqish uchun anchagina tajriba kerak bo 'ladi. “是 bo 'lmoq” fe`li ishtirokidagi gaplarning dastlabki turiga misol qilib, quyidagi $\mathrm{A}+$ 是 $+\mathrm{A}, \mathrm{B}$ 是 $\mathrm{B}$ konstruksiyasiga to`xtalamiz:

Bu turdagi gap A va B ni ta`kidlash uchun ishlatiladi, undan so`ng esa, gapda alohida ta kidlangan A va B ga qisqacha ta`rif ham keltirish mumkin. Ayrim holllarda esa ta`rifsiz ham kelishi mumkin.

“是” ishtirok etgan gaplarning xususiyatiga alohida to`xtaladigan bo`lsak, "saqlash" ma`nosidagi gap tarkibida ega o`rin - joyni ifodalovchi so`z bo`lib, bir vaqtning o`zida to `ldiruvchi ham o`rin - joyni ifodalovchi so`z bolishi mumkin. Yana bir jihati shundaki, gap tarkibidagi to`ldiruvchi aniq ma`noni ifodalab, bir yoki bir nechta ma`noni bildirishi mumkin, masalan:

“学校前边是邮局”.

"Xuexiao qianbian shi youju".

"Maktabning old tarafida pochta".

Yuqoridagi misolda “邮局” - “pochta” so`zi aniq ma`noda kelib, bu gapda “是” maktabning old tarafida aynan pochta joylashganligini ifodalab kelyapti.

“我旁边是两个日本女同学”.

"Wo pangbian shi liangge Riben nu tongxue".

"Mening yonimda yaponiyalik ikki talaba".

Ushbu misolda ham “是” - "bo`lmoq” fe`li yonimdagi talabalar boshqa mamlakatlardan emas, aynan yaponiyadan ekanligini ta`kidlagan.

“是” ning yana bir xususiyati shundaki, u o`zidan keyin sifat hamda ravishni ham olishi mumkin. Bunday hollarda “是” fe'ldan oldin kelib, “haqiqatdan, ayniqsa” degan ma'nolarni ifodalaydi. Misol tariqasida quyidagilarni keltirish mumkin:

“今天的天气是不错”.

"Jintian de tianqi shi bu cuo".

"Bugun havo juda ajoyib".

“太晚了, 咱们是该走了”.

"Tai wan le, zanmen shi gai zou le".

"Kech bo 'lib qoldi, biz ketishimiz lozim va hokazo".

Yuqoridagi qoidalardan kelib chiqib, “是” - “bo`lmoq” fe'li xitoy grammatikasida gap tuzilishining asosiy elementi hisoblanadi, degan xulosaga kelish mumkin. Juda ko`p va xilma - xil vazifalari hamda ishlatilish o`rniga ko`ra, bo`lmoq fe`li haqiqatan sermahsul va bo`yoqdordir. Boshqa tillardan farqli o`laroq, ushbu fe`lning zamon va shaxslarda tuslanmasligidan kelib chiqib, xitoy tilini o`rganuvchilarga qiyinchilik tug`dirmaydi xulosaga kelishimiz mumkin.

\section{Foydalanilgan adabiyotlar ro'yxati}

1. Huang, C.-T James, Logical Relations in Chinese and the Theory of Grammar. NewYork and London. 1998.

2. Zhan Fang Qiong, The Structure and function of the Chinese copula construction. Shanghai. 2016.

3. 现代汉语实用语法分析，第二版，上册，清华大学出版社，北京， 2016.

4. 现代汉语实用语法分析，第二版，下册，清华大学出版社，北京， 2016. 


\title{
LEARNING A LANGUAGE AND ITS ACQUISITION
}

\section{Zumratkhon Shukurova \\ (Master in Uzbekistan State World Languages University) \\ Shakhnoza Juramurodova \\ (a third-year student of $U z S W L U$ )}

\begin{abstract}
Annotation: The remarkable way whether the humankind from his very early age acquires a language faster and easier as fairly more effectively as possible via either language learning process or its acquisition has long captivated linguistics and skilled psychologists through setting out the basic theoretical debates about the topic. To begin with the essential notions, a language is a skill that we have mainly be in the degree of a master by the age of three having some more accessibilities of incredible ease and speed, despite the complexity of the language. Through saying those notices above, one is clear about to come to the anticipation that what factors help him/her in the process of language learning. While language acquisition is supposed to be a subconscious process leading to the person's fluency, learning is a conscious process which presents itself in learning rules, methods with the help of master-apprentice programs. The primary purpose of the article is to consider questions such as what characteristic of humankind makes it possible to acquire a language. Language acquisition tips such as first, second language acquisitions and its approaches and conclusive ideas that which of the two factors is more predominant in the process of learning a language.
\end{abstract}

Key words and expressions: language acquisition, language learning, first language acquisition, second language acquisition: four types of theories.

There is an important distinction made by linguists between language acquisition and language learning. Children acquire language through a subconscious process during which they are unaware of grammatical rules. Similarly, to the way they acquire their first language. They get a feel for what is and what is not correct. In order to acquire language, the learner needs a source of natural communication. The emphasis is on the text of the communication and not on the form. Young students who are in the process of acquiring English get plenty of "on the job" practice. They readily acquire the language to communicate with classmates.

Language learning, on the other hand, is not communicative. It is the result of direct instruction in the rules of language. Furthermore, it certainly is not an age-appropriate activity for young learners. In language learning, students have conscious knowledge of the new language and can talk about that knowledge. They can fill in the blanks on a grammar page. Research has shown, however, that knowing grammar rules does not necessarily result in good speaking or writing. A student who has memorized the rules of the language may be able to succeed on a standardized test of English language but may not be able to speak or write correctly.

Until the nearer times, we have never thought about how it is easy for us to learn our native, first language; about how very quickly we could be able to accommodate in the second, third or fourth languages. Until this time, we had stated our ideas concerning the similarity of language acquisition and learning process. However, after having some more experience about the topic collecting the sufficient valid data and analyzing everyday sophisticated observances and facts, we have come to the solid decision that those two things are a lot more different from each other. Nevertheless, this does not change the idea of the interconnected position of both notions when it comes to language preservation and revitalization. While language acquisition is supposed to be a subconscious process leading to the person's fluency, learning is a conscious process which presents itself in learning rules, methods with the help of master-apprentice programs. Without learning acquisition, there will be no traditional heritage that reminds us of our naturalism and clearness. The reason why our parents teach us our first language, it will be somehow more natural for us to understand them.

Moreover, that is the first symptom of first language acquisition. Without learning, there will not be any history, language literacy and development. Both notions also create continuous 
opportunities for the sake of young learners such as fast accessibility of the language learning process in the real atmosphere in overseas countries through hearing the native speakers' speeches (language acquisition) and improving one's skills through teaching theories practically and theoretically(learning). Besides, admittedly, this article tries to accurately identify and show valuable data and underlying notices of people about the language acquisition and learning: their advantages and disadvantages, drawbacks connection and, mostly, their importance in the lifetime propaganda.

The debate between philosophers and linguistics conveying the idea that which one is much better and more efficient to use and study. Nearly, $70 \%$ of people around the world use everyday English and especially for them, English language atmosphere full of with so many grammatical rules and theories is not needed at all. However, as MihailLomonosov, great Russian grammar founder, physic stated: "Learning without grammar is like unpleasant oratory, stump poetry, unbelievable history and groundless philosophy". Leaning on this explicit confirmation, second language acquisition is set to be learnt through grammar for the novice students, and then it loses its impact towards uselessness as the learners keep concentrating their minds on analyzing and getting involved in the activities. And staff which demand them be absorbed in the atmosphere of daily-life English. Let us see how language is acquired or learnt through the processed diagram:



First language acquisition is acquired from the times of the baby is trying to understand the world he/she came in. It is available among all nations, and we learn our first language with errors through imitation. However, the matter is related to the topic of second language acquisition which belongs to English-training specialists mostly in our country.

\section{Second Language Acquisition (SLA)}

- How do people acquire second languages?

- There are several general approaches to SLA theory: cognitive, constructivist, sociocultural, and behaviourist.

- Under these approaches, there are several theories and hypotheses.

- Each approach EMPHASIZES one place where learning takes place.

- One can think of the differences between these as natural disagreements about the first place where language learning happens.

\section{Behaviourist approach}

- Major theorist: BF Skinner (based off of experiments by Ivan Pavlov).

- Language is a learned behaviour/habit.

- Positive and negative reinforcement.

- Language is conditioning. 
- Suggests language is only learned through imitation.

Zone of proximal development (Learner can do with guidance)
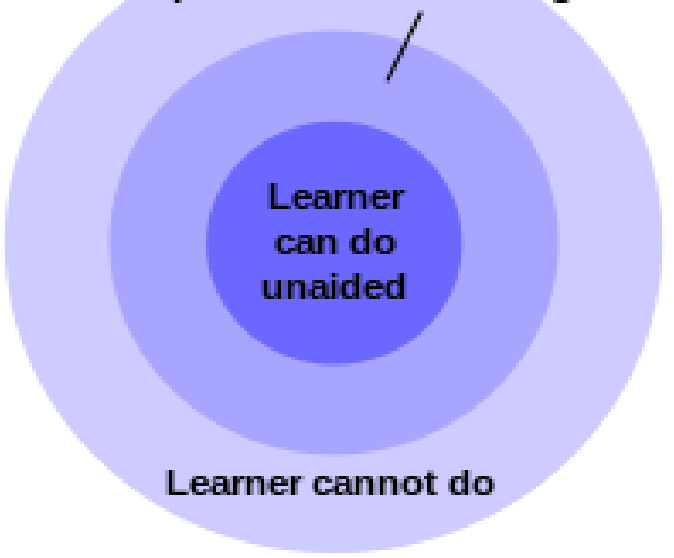

- Language is "nurtured" rather than something the learner learns by him/herself. theory.

- Has more or less been discredited as a

Innatist Cognitive Approach

- Innate $=$ natural or inborn

- Major theorists: Noam Chomsky and Stephen Krashen language

- General cognitive function is used to acquire

- Analyzing language, notice patterns, deduce rues inborn

- Making mistakes and taking chances

Learning by trial and error Innate = natural or

Major theorists: Noam Chomsky and Stephen Krashen

- General cognitive function is used to acquire language

- Analyzing language, notice patterns, deduce rues

Socio-cultural

- Major theorist: Lev Vygotsky

- Language learning occurs as a result of social interaction within a culture

- Learners' capacities/abilities are influenced by the culture in which they develop

- Zone of Proximal Development (ZPD) = learning happens when faced with language that is just a little bit beyond what they can currently do.

A high number of language learners in Uzbekistan has learnt their English as their target or second language from the stage of not acquiring but teaching through grammar patterns. Along with English, Russian is also officially declared as the second language throughout the territory. However, if compared to each other, Russian is learning more effectively with the existence of

\section{Results of survey}

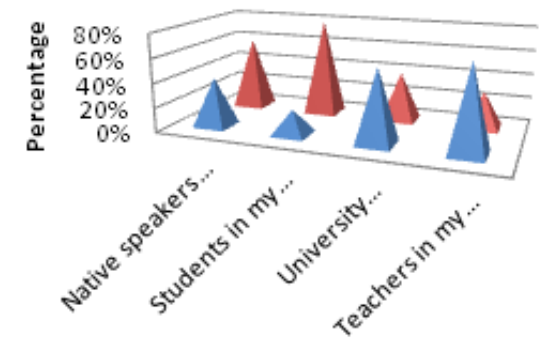

Opinions about communicative Opinions about grammar-translation...

\begin{tabular}{|c|c|c|c|c|}
\cline { 2 - 5 } \multicolumn{1}{c|}{} & $\begin{array}{c}\text { Native } \\
\text { speakersin } \\
\text { my university }\end{array}$ & $\begin{array}{c}\text { Students in } \\
\text { my University }\end{array}$ & $\begin{array}{c}\text { University } \\
\text { applicants }\end{array}$ & $\begin{array}{c}\text { Teachersin } \\
\text { my university }\end{array}$ \\
\hline $\begin{array}{c}\text { Opinions about grammar- } \\
\text { translation method }\end{array}$ & $40 \%$ & $20 \%$ & $60 \%$ & $70 \%$ \\
\hline $\begin{array}{c}\text { Opinions about } \\
\text { communicative language } \\
\text { acquisition method }\end{array}$ & $60 \%$ & $80 \%$ & $40 \%$ & $30 \%$ \\
\hline
\end{tabular}
more and more languagespecialized schools, classes and atmosphere: Nearly just over $5 \%$ of the population belongs to the native speakers all around the country. Lack of teachers, very few numbers of language interacted classes, and far fewer stocks of foreigners also affect the way the language is acquired. Only the aspect of socio-cultural learning theory is apparent in Uzbekistan that the improving degree of the learner is interconnected with the pace of the nation's cognition to be able to know the language. The learner can only do the

requirements of language acquisition and learning with guidance in the zone of proximal development. He or she cannot do, or it is remained unaided, on the contrary.

We have surveyed in order to find out the grouped candidates' attitudes towards language learning by grammar-translation-method and language acquiring by communication in terms of positivity and negativity. As it is seen visibly, the group who has the most negligible attitude 
towards the grammar is the students studying in UzSWLU. They said they had already left this style of learning and they would prefer communicative means in the field. The group who reacted the most positive towards the grammar and did not approve the language acquisition is the teachers in our university. All in all, it is mesmerizing that Communicative language acquisition method has vindicated as sufficiently as expected.

To sum up, it is impossible to avoid traditional approaches when phasing the most nontraditional and modern ones. Both are related to each other, but with some limitations when learning a language. The first stage should still be language acquiring period.

\section{The list of used literature}

1. Brown, H.D (2002). Principles of language learning and teaching. WhitePlains, NY: Pearson.

2. Engin, A.O. (2009). Second language learning success and motivation.

3. Foreign Language. (2013). In the Collins Dictionary. Retrievedfrom www.collinsdictionary.com

4. Genesee, F.(2008). Bilingual first language acquisition. Evidence from Montreal. https://www.psych.mcgill.ca/perpg/fac/genesee/6.pdf

\section{YAPON TILIDA ERKAK VA AYOLLAR NUTQIDA UCHRAYDIGAN LEKSIK VA GRAMMATIK LAKUNALAR}

\section{Shaxnoza Kodirova, (SamDCHTI) \\ Furukawa Midori (SamDCHTI, JICA ko'ngillisi)}

Annotation: Gender concepts are one of the most important concepts in linguistic science. Although much work has been done to date on the various differences that exist in the speech of men and women, such differences are still not sufficiently studied from a general linguistic point of view. Recent research in the field of gender studies has explored the unique gender characteristics of communication. Most of them are specific to the speeches of men and women not only in Japanese but all over the world.

Key words and expressions: “女言葉 - onna kotoba”, “女性語-josey go”, “男言葉 otoko kotoba”, “男性語-dansey go”, わたし (vatashi), わたくし(vatakushi), じぶん(jibun), うち (uchi).

Gender - sotsio-madaniy kategoriya bo'lib, jinslar rolini an'anaviy o'rganishni nazarda tutmaydi. U ijtimoiy va psixologik jarayonlarning yirik majmui, bundan tashqari, jamiyatda vujudga keladigan va milliy lisoniy shaxsning axloqiga ta'sir ko'rsatadigan madaniy ko'rsatmalar, qoidalardir. Gender xususiyat deyilganda, makulinizm va feminizm madaniy tushunchalari hamda, ayollik va erkaklikning o'ziga xos xususiyatlari tushuniladi [Гуревич Т.М., Изотова Н.Н. 2013:116]. Binobarin, gender tushunchasi, yuqorida aytib o'tilganidek, maskulinizm (jasorat) va feminizm (nazokat) bir tomondan psixikaning filogenetik bog'langan xususiyati bo'lsa, boshqa tomondan ontogenezda to'planadigan sotsio - madaniy hosila hamdir. Lekin shuni ham ta'kidlash kerakki, hozirgi zamon faylasuf va sotstologlar "jins" va "gender" tushunchalarini bir - biriga qarama — qarshi tushunchlar deb hisoblashmoqda.[ Звегинцев. В. А. 1972:24].

Erkaklar va ayollar nutqida mavjud bo'lgan turli tafovutlar haqida bugungi kunga qadar ancha ishlar olib borilganiga qaramay, hali-hamon bunday farqlar umumlingvistik nuqtai nazaridan yetarlicha o'rganilgan deb bo'lmaydi. Ayrim tillarda bu omil ochiq namoyon bo'lsa, boshqa tillarda uning lingvistik asoslarini ko'rsatib berish biroz murakkabliklarni keltirib chiqaradi. "Gender" tushunasi ustida tilshunoslik nuqtai nazardan tadqiqot olib borgan olimlardan O.Djesperson, L.Blumfild, U.Labov, L.Milroy va boshqalarning izlanishlari ushbu jihatlarni aniqlashtirishga qaratilganligi bilan ahamiyatlidir. Erkak va ayol nutqidagi farqlanishlar eng qadimgi davrlardan 
mavjudligi taxmin qilinadi va bu jinslar orasidagi mehnat taqsimoti bilan bog'liq bo'lganligi haqidagi qarashlar ehtimoldan xoli emas. Keyingi davrlarda esa, erkak va ayol nutqlari diniy jihatdan chegaralanib, shu jihatdan farqlanishlar yuzaga kela boshlaydi. Nutqning jinslar orasida farqlanishi turli tillarda, turli daraja va ko'rinishda namoyon bo'ladi. Bunday farqlanishlar izlanish olib borilayotgan yapon tilida ham ancha murakkab ko'rinishda namoyon bo'ladi va ular lingvistik izoh talab qiladi. Yapon tilida "gender" xoslik nafaqat leksik, hatto, fonologik sistemada ham namoyon bo'lish holatlari ham uchraydi. Ularning bir - biri orasidagi farqlanishlar shu qadar kattaki, hatto, mazkur ikki tur genderlar alohida - alohida tizim sifaida o'rganiladi. Bu tizim bir - biridan turli jihatdan farqlanadi.

"Gender" kategoriyani grammatik rod tushunchasi bilan adashtirmaslik kerak. Yapon tilida ayollar nutqidagida qo'llaniladigan so’zlar “女言葉 - onna kotoba” yoki “女性語-josey go”, erkaklar nutqi elementlari esa “男言葉 otoko kotoba” yoki “男性語-dansey go” deb ataladi. [井 出幸子、巫女 「1984,: 63].

So'nggi yillarda gendershunoslik sohasida amalga oshirilayotgan tadqiqodlarda, muloqot uslubidagi o'ziga xos gender xususiyatlar o'rganilib kelinmoqda. Ularning aksariyati nafaqat yapon, balki, butun dunyo erkak va ayollar nutqlariga xosdir. Masalan , taniqli sotsiolingvist Robin Lakoff ta'limotiga ko'ra erkak va ayollarning muloqotga kirishish va muloqot jarayonidagi nutqi quyidagicha deferensatsiyalab ko'rsatilgan.

\begin{tabular}{|c|c|c|}
\hline Holat & Erkaklar & Ayollar \\
\hline $\begin{array}{l}\text { Muloqotga } \\
\text { kirishishda }\end{array}$ & $\begin{array}{l}\text { Salomlashishning qisqa bo'lishi va } \\
\text { ba'zan hatto ko'rishish bilan } \\
\text { chegaralanib qolish }\end{array}$ & $\begin{array}{l}\text { Quyuq salomlashish, hol-ahvol } \\
\text { so'rash va hokazolar }\end{array}$ \\
\hline \multirow{4}{*}{$\begin{array}{l}\text { Muloqot } \\
\text { jarayonida }\end{array}$} & $\begin{array}{l}\text { Oldindan rejalashtirilgan fikrlarning } \\
\text { ifodalanishi }\end{array}$ & $\begin{array}{l}\text { Bir xil "navbatchi" fikrlarning } \\
\text { takror qo'llanilishi }\end{array}$ \\
\hline & Dalil va isbot keltirish & $\begin{array}{l}\text { Hissiyotlarni ochiq ifodalash va } \\
\text { ulardan foydalanish (yig'lash, } \\
\text { hushdan ketish) }\end{array}$ \\
\hline & $\begin{array}{l}\text { Buyuk insonlar, olimlar fikrlaridan, } \\
\text { aforizm yoki latifalar foydalanish }\end{array}$ & $\begin{array}{lr}\text { Boshqalarning } & \text { gaplarini } \\
\text { suhbatdoshga } & \text { etkazish, } \\
\text { tanishlarining } & \text { gaplaridan } \\
\text { foydalanish } & \\
\end{array}$ \\
\hline & $\begin{array}{l}\text { Grammatik } \\
\text { uchraydi. }\end{array}$ & $\begin{array}{l}\text { O'ta to'g'ri } \text { grammatik } \\
\text { qo'llanishlar uchraydi. }\end{array}$ \\
\hline
\end{tabular}

Shu jihatdan yapon millati vakillari ustida olib borilgan tadqiqod natijalariga quyidagicha

\begin{tabular}{|l|l|l|}
\hline Erkaklar & Ayollar \\
\hline $\begin{array}{l}\text { Muloqot jarayonida yapon tiliga xos } \\
\text { xushmuomalalik shakllaridan kamdan kam } \\
\text { foydalashiladi }\end{array}$ & $\begin{array}{l}\text { Muloqot jarayonida yapon tiliga xos } \\
\text { xushmuomalalik shakllaridan tez-tez va } \\
\text { ko'p foydalaniladi. }\end{array}$ \\
\hline $\begin{array}{l}\text { Hurmat belgisini ifodalovchi qo'shimchalar } \\
\text { iloji boricha qo'llanilmaydi. }\end{array}$ & $\begin{array}{l}\text { Hurmat belgisini ifodalovchi qo'shimchalar } \\
\text { ko'p uchraydi. }\end{array}$ \\
\hline "Erkakcha" so'zlardan foydalaniladi & "Nazokatli” so'zlardan foydalaniladi. \\
\hline So'zlashuvda “qo'pol” so'zlar qo'llaniladi. & $\begin{array}{l}\text { So'zlashuvda “yumshoq” so'zlar } \\
\text { qo'llaniladi. }\end{array}$ \\
\hline
\end{tabular}

Genderolingvistika o'z tadqiq yo'nalishida ikki muhim jihatga

1. Muayyan tilda erkak va ayol nutqining tafovutlari

2. Muayyan til sistemasida erkaklik va ayollik belgilari bilan bog'liq tushunchalarni ifodalovchi til birliklari tadqiqiga e'tibor qaratdi.

Gender masalasi tilshunoslikning sotsiolingvistika yo'nalishida keng miqyosda o'rganila boshlandi. Sotsiolingvistika doirasida amalga oshirilgan tadqiqotlarda erkak va ayollar nutqidagi aksent, urg'u, ohang, xos so'zlar va so'zlashuv shakllari o'rganildi. Umuman olganda, dunyo 
tillarida erkak va ayollar kommunikativ xulq — atvorini o'rganishda asosiy omil bo'lib xizmat qiladigantayyor qolip yoki andozalar mavjud emas. Lekin bu fikrdan mustasno holatda, yapon tilida aksariyat hollarga nisbatan aynan manashunday qoliplarni uchratishimiz mumkin [Гергерд А.А. 2014:65]. Yapon tilida erkak va ayolning nutqiy muomalasi bir- biridan farqlanadi. Erkaklar "erkakchasiga", ayollar esa "ayolchasiga" gapirishi norma sifatida qabul qilingan va aks holda, muloqot jarayonida o'ta kulgili holat va jiddiy tushunmovchiliklarga olib kelishi mumkin. Yapon tilini o'rganish jarayonida ana shunday holatlarni inobatga olish muhim sanaladi. O'zbekistonda lingvomadaniyatshunoslik fani tadqiqotchilaridan biri SH.Usmonovaning ilmiy ishlaridan birida mavzuga doir quyidagi holat keltirilgan.

“... Los-Anjeleslik bir biznesmen yapon tilini mukammal o'rganishga ahd qilibdi. Buning uchun yapon millatiga mansub o'qituvchi yollabdi va tilni mukammal o'rganibdi. So'z boyligi juda zo'r, grammatikasi benuqson, aksenti esa bilinmas darajaga yetibdi. Ammo u Yaponiyaga borib, mahalliy biznesmenlar bilan yaponcha gaplashishni boshlaganda uning tili g'alatiligi bilan hammani hayron qoldiribdi. Nega? Buning sababi shuki, biznesmen yapon tilini ayol o'qituvchidan o'rgangandi. Ko'p xalqlarda bilinmasligi mumkin, ammo Yaponiyada nutq intonatsiyasi ayollar va erkaklarda bir-biridan juda katta farq qiladi. Erkaklarning nutqi ayollarnikiga nisbatan ochiq (dangal) va agressiv (hatto ayollar o'zaro gaplashganda yapon erkaklari ularni yaxshi tushinishmaydi degan gaplar ham yuradi). Shuning uchun Amerikadan kelgan janobning yapon ayollari manerasida gapirishi g'alati va kulguli holatni keltirib chiqargan.” [Усманова Ш. 2013..56]. Erkak va ayol nutqidagi tafovutlar ko'pgina hollarda asosan kishilik olmoshlarida uchraydi.

\section{1. "MEN" kishilik olmoshi (1 shaxs birlik).}

Har ikkala jins vakillari tomonidan nutqda bir hil tenglikda qo'llash mumkin bo'lgan ko'rinishlari mavjud bo'lib, ular qo'llanilish holati, vaqti va boshqa ba'zi jihatlarga ko'ra bir biridan farqlanadi.

\begin{tabular}{|l|l|}
\hline わたし (vatashi) & $\begin{array}{l}\text { Olmoshning rasmiy va neytral ko'rinishlaridan biri. } \\
\text { Muloyimlik bo'yoqdroligiga ega bo'lganligi uchun } \\
\text { norasmiy hollarda aksariyat erkaklar tomonidan } \\
\text { qo'llanilmaydi. }\end{array}$ \\
\hline わたくし (vatakushi) & $\begin{array}{l}\text { "Vatashi” ga qaraganda rasmiyroq va erkakcha } \\
\text { xususiyati (mujestvennost) yuqoriroq ko'rinishi }\end{array}$ \\
\hline じぶん (jibun) & 1 shaxs birlikdagi o'zlik olmoshi ko'rinishi. (o'zim) \\
\hline うち (uchi) & $\begin{array}{l}\text { Olmoshning “uy" va “oilaga” ga aloqador bo'lgan } \\
\text { hollardagi qo'llanilishi }\end{array}$ \\
\hline $\begin{array}{l}\text { "MEN" olmoshini o'z ismi orqali } \\
\text { ifodalanishi }\end{array}$ & $\begin{array}{l}\text { Har ikkala jins vakillari nutqida uchraydi. Lekin bu } \\
\text { holatda ayollik xususiyati (jenstvennost) yuqoriroq. }\end{array}$ \\
\hline
\end{tabular}

Mazkur olmoshning erkak va ayollar nutqidagi alohida - alohida ko'rinishlari

\begin{tabular}{|c|c|c|c|}
\hline \multicolumn{2}{|c|}{ Erkaklar nutqida } & \multicolumn{2}{|c|}{ Ayollar nutqida } \\
\hline ぼく(boku) & $\begin{array}{l}\text { O'smirlar, yosh va o'rta } \\
\text { yoshli erkaklar nutqida } \\
\text { uchraydi }\end{array}$ & $\begin{array}{l}\text { あたし } \\
\text { (atashi yoki } \\
\text { atasi) }\end{array}$ & $\begin{array}{l}\text { Olmoshning yumshoq va } \\
\text { erkalanishdagi } \\
\text { O'smir qo'rinishi. } \\
\text { nutqida uchraydi. }\end{array}$ \\
\hline おれ (are) & $\begin{array}{l}\text { Norasmiy va qo'pol } \\
\text { olmosh bo'lib, asosan } \\
\text { so'zlashuvda o'smirlar } \\
\text { va o'rta yoshli erkaklar } \\
\text { nutqida uchraydi. }\end{array}$ & $\begin{array}{l}\text { あたくし } \\
\text { (atakushi) }\end{array}$ & \begin{tabular}{lcr} 
"Vatashi" & ga & qaraganda \\
rasmiyroq & va & erkakcha \\
xususiyati & \multicolumn{2}{c}{ (mujestvennost) } \\
yuqoriroq. & Ayollar & nutqda \\
qaysidir & jasoratiga & urg'u \\
bermoqchi & \multicolumn{2}{c}{ bo'lganda } \\
qo'llaniladi. & &
\end{tabular} \\
\hline だいこ (daiko) & $\begin{array}{ll}\text { Olmoshning } & \text { qo'pol va } \\
\text { vulgar } & \text { ko'rinishi. }\end{array}$ & $\begin{array}{l}\text { あたい } \\
\text { (atay) }\end{array}$ & $\begin{array}{l}\text { Olmoshning Nazokatlilikka xos } \\
\text { bo'lmagan, qo'pol ko'rinishi. }\end{array}$ \\
\hline
\end{tabular}




\begin{tabular}{|l|l|l|l|}
\hline & $\begin{array}{l}\text { Manmanlik bo'yog'i } \\
\text { mavjud. }\end{array}$ & $\begin{array}{l}\text { Asosan yoshlar nutqida } \\
\text { uchraydi }\end{array}$ \\
\hline わし (vashi) & $\begin{array}{l}\text { Katta yoshli qatlam } \\
\text { vakillari (qari chollar) } \\
\text { nutqida qo'llaniladi }\end{array}$ & \\
\hline $\begin{array}{l}\text { わ か は い } \\
\text { (vagahay) }\end{array}$ & $\begin{array}{l}\text { Olmlshning arxaik va } \\
\text { patriarxatik ko'rinishi. } \\
\text { お れ さ ま } \\
\text { (oresama) }\end{array}$ & $\begin{array}{l}\text { Olmoshning pafosli } \\
\text { ko'rinishi. }\end{array}$ & \\
\hline われ (vare) & $\begin{array}{l}\text { O'rta yoshdan o'tib katta } \\
\text { yoshga kirayotgan } \\
\text { erkaklar nutqida } \\
\text { qo'llaniladi }\end{array}$ & \\
\hline
\end{tabular}

\section{2. "SEN" kishilik olmoshi (II shaxs birlik).}

"SEN" kishilik olmoshi ko'plik kategoriyasida emas, balki, hurmat yuzasidan "SIZ" kabi tushunilishi mumkin. Bu olmoshning ham 1 shaxs birlik olmoshi kabi har ikkala jins vakillari tomonidan nutqda bir hil tenglikda qo'llash mumkin bo'lgan ko'rinishlari va jinslar bo'yicha alohida - alohida qo'llaniladigan ko'rinishlari mavjud.

\begin{tabular}{|c|c|c|}
\hline \multicolumn{2}{|c|}{ Erkaklar nutqi } & Ayollar nutqi \\
\hline $\begin{array}{c}\tau \text { ま } え \\
\text { (temae) }\end{array}$ & $\begin{array}{l}\text { Olmoshning eskirgan shakllaridan biri } \\
\text { bo'lib, hozirda haqoratlash bo'yoqli } \\
\text { ko'rinishiga aylangan. }\end{array}$ & $\begin{array}{l}\text { Suhbaddoshning ismiga } \\
\text { ism suffikslarini qo'shgan } \\
\text { holda murojaat qilinadi. }\end{array}$ \\
\hline $\begin{array}{l}\text { こいつ } \\
\text { (koitsu) }\end{array}$ & $\begin{array}{l}\text { Olmoshning qo'pol shakli. III shaxs birlik } \\
\text { olmoshiga yaqin. ("bu bola") }\end{array}$ & \multirow{5}{*}{$\begin{array}{l}\text { Boshqa holatlarda "SEN" } \\
\text { olmoshining yuqorida keltirilgan } \\
\text { erkak va ayollar tomonidan teng } \\
\text { tarzda qo'llaniladigan } \\
\text { ko'rinishlaridan foydalaniladi }\end{array}$} \\
\hline $\begin{array}{l}\text { な ん } \\
\text { (nanji) }\end{array}$ & $\begin{array}{l}\text { Olmoshning qadimiy ko'rinishi bo'lib, } \\
\text { hozirda tarixiy matnlar tarjimasidagina } \\
\text { uchraydi. }\end{array}$ & \\
\hline $\begin{array}{l}\text { な } \\
\text { (nare) }\end{array}$ & 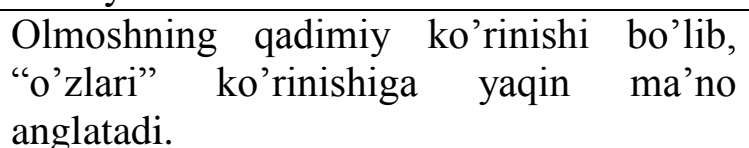 & \\
\hline $\begin{array}{l}\text { お ま え } \\
\text { (amae) }\end{array}$ & $\begin{array}{l}\text { Xotini yoki sevgan qiziga nisbatan } \\
\text { “azizim" ma'nosida ishlatiladi. } \\
\text { Begonalarga nisbatan qo'llanilganda } \\
\text { qo'pol bo'yoqdorlikka ega. }\end{array}$ & \\
\hline $\begin{array}{l}\text { きさ ま } \\
\text { (kisama) }\end{array}$ & $\begin{array}{l}\text { Olmoshning eskirgan shakllaridan biri } \\
\text { bo'lib, ancha rasmiy va hurmatni } \\
\text { ifodalovchi shakli bo'lgan. hozirda esa } \\
\text { ancha qo'pol va haqoratlash bo'yoqli } \\
\text { ko'rinishiga aylangan. }\end{array}$ & \\
\hline
\end{tabular}

Yapon tilida erkak va ayollar nutqidagi qo'shimchalarning ham farqlanish holatlari mavjud bo'lib, ular o'z ichiga ayollarga xos nazokatni va erkaklarga xos mardlikni mujassamlashtiradi. Yapon tilida bunday qo'shimchalar aksar hollarda gap oxirida qo'llaniladi, ya'ni, ular ort qo'shimchalar hisoblanadi. [75]

\begin{tabular}{|c|c|c|c|}
\hline \multicolumn{2}{|c|}{ Ayollar nutqidagi qo'shimchalar } & \multicolumn{2}{|c|}{ Erkaklar nutqidagi qo'shimchalar } \\
\hline わ wa & $\begin{array}{l}\text { Gapda muloyimlik va } \\
\text { xushmuomalalikni ifodalaydi. }\end{array}$ & かい kai & $\begin{array}{lr}\text { か (ka) } & \text { so'roq } \\
\text { qo'shimchasining } & \text { erkakcha } \\
\text { ko'rinishi } & \end{array}$ \\
\hline わよ wayo & $\begin{array}{l}\text { Gapda informativ va rasmiy } \\
\text { ohangni ifodalaydi }\end{array}$ & ぞ zou & $\begin{array}{l}\text { Gapda bajarilgan ish - } \\
\text { harakatga urg'u berilganda } \\
\text { qo'llaniladi. }\end{array}$ \\
\hline わね wane & qo'shimchasining & ぜ ze & ta'kidlangan \\
\hline
\end{tabular}




\begin{tabular}{|l|l|l|l|}
\hline & $\begin{array}{l}\text { vazifasida qo'llaniladi, } \\
\text { nisbatan xushmuomalalikni } \\
\text { ifodalaydi. }\end{array}$ & & ohang \\
\hline の no & $\begin{array}{l}\text { So'roq gaplarda muloyimlik } \\
\text { va xushmuomalalikni } \\
\text { ifodalaydi. }\end{array}$ & よ yo & $\begin{array}{l}\text { Gapda ta'kidlash va biroz } \\
\text { jahlni ifodalaydi }\end{array}$ \\
\hline のよ noyo & $\begin{array}{l}\text { Gapda aniqlik va ishonchi } \\
\text { komillikni ifodalaydi. }\end{array}$ & かな kana & $\begin{array}{l}\text { Ikkilanganlikni yumshoq } \\
\text { tarzda ifodalash. }\end{array}$ \\
\hline のね none & $\begin{array}{l}\text { Ma'lumotni aniqlashtirish } \\
\text { uchun beriladigan so'roq } \\
\text { gaplarda xushmuomalalikni } \\
\text { ifodalaydi. }\end{array}$ & & \\
\hline $\begin{array}{l}\text { Ikkilanganlikni yumshoq } \\
\text { tarzda ifodalash. }\end{array}$ & & \\
kashira
\end{tabular}

Yapon tilida lakunarlik hodisalari nafaqat leksik va grammatik (so'zlar, qo'shimchalar), balki, fonetik va fonologik jihatdan ham namoyon bo'lishi mumkin. O'z navbatida bu hodisa yana genderlik hodisasi bilan chambarchars tarzda ifodalanadi.

\section{Foydalanilgan adabiyotlar ro'yxati}

1. Гуревич Т.М., Изотова Н.Н. Японский язык. Лингвокультурология. М.: Изд-во МГИМО-Университет, 2013. 116 с.

2. Гергерд А.А. Статья «Особенности перевода культурных реалий» Вестник ВолГУ. Серия 9. Вып.-12. 2014।

3. Звегинцев. В. А. Язык и лингвистическая теория. М. 1972. 248 с.

4. Усманова Ш. Маданиятлараро мулоқотда лакуналарнинг ўрни // Лингвист. Илмий мақолалар тўплами. В. - Т.: “Академнашр”, 2013.

5. 井出 幸子、かわなり 巫女 「日本の女性語と世界の女性語」Г.C. 1984, №3

\section{МЕТАФОРАНИНГ ТАБИАТИ ТАЛКИНИГА ЁНДАШУВЛАР}

\section{Улугова Шохида Шохруховна (СамДЧТИ докторанти)}

Annotation: This article deals with the problem of interpreting metaphors by a great number of linguists at the different times. The tradition of convincing metaphor as a means of creating imagery formed in the fields of rhetoric, poetics, stylistics, literary theory to some extent hinders the definition of its linguistic essence. Metaphor is the use of a word or phrase in a figurative sense based on similarity or analogy. There are four types of semantic migration: migration from species to type, from type to species, from species to species and migration by analogy.

Key words and expressions: literary expression, semantic migration, stylistics, rhetoric, speech migration, conceptual, reality, semantics.

Инсон азалдан атрофидаги воқеликни билиш ва "ўз оламини" идрок этишга интилиб келади. Оламнинг метафорик қиёфаси ана шундай интилишларни амалга ошириш воситасидир. Одамзот хар доим олам манзарасини тартиблаштириш, тизимлаштириш ва тавсифлаш йўли билан ўз амалий эхтиёжи учун зарур бўлган воқеликка айлантириш ва тавсифлаш йўли билан ўз амалий эхтиёжи учун зарур бўлган воқеликка айлантириш измида бўлади. Метафоранинг турли сохаларга оид билимни умумлаштириши ва бунда хатто бирбиридан узоқ бўлган сохалар - табиий воқелик ва рухий олам, инсон хаёти ва коинот олами ўзаро муносабатга киришиши мумкинлигини сезган инсоннинг метафоралашув жараёнига бўлган қизиқиши табиийдир. Шу боис, метафора ходисаси қарийб икки минг йилдан буён файласуфлар, адабиётшунослар ва бошқа қатор гуманитар фанлар вакилларининг эътиборини жалб қилиб келмоқда. 
Метафорани кўпроқ бадиий ифода безаги, нутқий кўчим, стилистик восита сифатида талқин қилиш анъанаси хам ўша даврлардан бошланган. "Метафора" (юнон. "ўзгартириш", "кўчириш") Аристотель изидан борганлар бу тушунчани "бир сўзнинг бошқаси билан алмаштирилиши" мазмунида англаб келмоқдалар". Хатто, ушбу ходисанинг шу хилдаги тавсифи луғатлардан мухим ўрин олиб келмокда. Қиёсланг: "метафора-маъно кўчишининг кенг тарқалган турларидан бири, нарса - ходисалар орасидаги ўхшашликка асосланувчи кўчим тури, метафора мохиятан яширин ўхшатиш бўлиб, унда ўхшатилаётган нарса тилга олинмаган холда, унинг маъносини ўхшаётган нарса (яъни уни ифодалаётган сўз) билдиради" (Куронов ва бошқ.2013:170). Инглиз тилида нашр қилинган луғатларда эса метафоранинг безакли нутқ усули эканлиги тўғридан -тўғри изохланади: "Metaphor - a tipe of figurative speech. Typically a metaphor ascribes to an entity a property that it does not, strictly and literally speaking, possess, although not all metaphors fit this definition" (Allott 2010:137).

Аристотель яратган метафора назарияси иерархик турлар назариясидир. Унга биноан метафора шаклланишида икки гурухдаги объектлар билан бир қаторда, уларни хусусиятлари хам иштирок этади. Натижада, метафора бир гурухдаги объектлар белгиларини бошқа гурухдагиларига кўчиради. Одамни "тулки" деб аташ билан ушбу жониворга хос бўлган хислат - айёрлик унга ёпиштирилади. Шу вазиятда инсоннинг табиати изохланиб, унинг тимсолий қиёфаси тасвирланиши билан бир пайтда "тулки" сўзи хам "айёр, ёлғончи" кўчма маъносини олади.

Аммо метафора хосил бўлишининг мазкур модели унинг барча жихатларини акс эттира олмайди. Шунинг учун, Аристотель назарияси метафорани лингвистик ходиса сифатида қарашга у вадар имкон бермайди. Олимнинг хизмати ушбу ходисанинг эвристик функциясини таъкидлаш хамда уни соф қиёслаш харакатидан ташқарида курилиши билан боғлиқ. Файласуф олим, тилни борлиқни тасвирлаш воситаси сифатида қараётиб, метафоранинг тасвирлаш, изохлаш вазифасини таъкидлайди ва бу, ўз навбатда, тадқиқотчиларнинг ушбу ходисага мунособати асрлар давомида бир хилда бўлишига сабаб туғдирди. Метафора, хозиргина айтилганидек, нутвва безак бериш воситаси бўлиб қолаверади. Маънонинг маълум бир даражада чегараланган семантик доирада кўчиши ёки қиёсланиш, метафорик алмашинув қоидалари хамда метафора маъносини тушуниш масалалари адабиётшунослик ва лингвопоэтика кўламида мухокама қилинади.

Метафора тахлилига қиёсий ёндашув узоқт вақт хеч қандай ўзгаришсиз ўз хукумронлигини сақлаб тургани маълум. Унутмаслик керакки, метафорани кўп жихатли ходиса сифатида дастлабки "куртак"лари хам Аристотель ва Платонлар давридаёқ пайдо бўла бошлаган эди. Афсуски, кейинги асрларда риторика фанида юзага келган тушкунлик метафора назариясининг хам турғунликка тушиб қолишига сабаб бўлди. Ўтган асрнинг бошларида инглиз тилшуноси А. Ричардс "Риторика фалсафаси" номли китобида куурсатиб ўтганидек, риторика фани тараққиёти тарихида метафора сўзнинг қайишқоқлигига асосланган, айрим холатлардагина жўяли туюладиган хамда алохида махорат ва эхтиёткорликни талаб қиладиган "қулай найранг" кўринишидаги восита сифатида қараб келинди. Бундан тишқари метафора қандайдир эрмак, ўйинчоқ сифатида қаралиб, тилнинг асосий шакллардан бири эмас, балки қўшимча механизми кўринишида талқин қилинди. (Ричардс 1990:45).

Кейинги тадқиқотларда метафоранинг олам лисоний манзарасини шакллантиришидаги ролига ахамият берилиб, унга дунё хақида фикр юритиш воситаси мақоми берилди. Маълумки, инсон концептуал тизим, яъни унинг психологик билимни ўзлаштириш давомида шахсий маъно-мазмунни хосил қилишга йўналтирилган фаолиятини шакллантирувчи тушунчалар тизимида мавжуд бўлади. Демак, ўзлаштирилаётган билимни концептуаллашув тамойили метафоранинг гнесологик вазифаси фаоллашувида мухим ўринни эгаллайди. Шунга биноан, метафора стилистик троп бўлиб қолавериши билан биргаликда, унинг инсон тафаккури жараёнида аниқланадиган воқелик модели мақоми хам берилади. 


\section{Фойдаланилган адабиётлар руйхати}

1. Allot N. Key terms in pragmatics.-Beijing: Foreign Language Teaching and Research Press, 2010.-289p.

2. Аристотель. Сочинения. Т. Ч.-М.:Мысль, 1983.-830с.

3. Куронов Д., Мамажонов 3., Шералиева М. Адабиётшунослик терминлари. -Т.: Академ нашр, 2013.-408б.

4. Ричардс А.А. Философия риторики//Теория метафоры.-М.:Наука, 1990.-С.44-67.

\section{ИЗМЕНЧИВОСТЬ НОРМЫ В РУССКОМ ЯЗЫКЕ}

\section{ШадиеваДилрабоКурбановна \\ (Термезский филиал Ташкентской Медицинской Академии)}

Annotation: The word is the most important unit of language, the most diverse and voluminous. It is the word that reflects all the changes taking place in the life of our society. The word not only names an object or phenomenon, but also performs an emotionally expressive function. When choosing words, we must pay attention to their meaning, stylistic coloring, usage, compatibility with other words. Since a violation of at least one of these criteria, a violation of the language norm can lead to a speech error. The norm reflects the desire of the language in a given period to stop, solidify, stability, continuity, universality, universality, and at the same time, the desire to go beyond the original, generating new opportunities. Language is an important indicator of social stratification. And my article is devoted to speech errors and language norms.

Key words and expressions: speech, norm, culture, criteria, structure, change.

Языковой нормой обычно понимают совокупность наиболее устойчивых, освященных традицией языковых средств и правил их употребления, принятых в данном обществе в данную эпоху. В соответствии со структурой языка различаются орфоэпические, лексические, грамматические (словообразовательные, морфологические, синтаксические), орфографические, пунктуационные нормы. Все эти нормы важны для обеспечения функционирования русского языка как государственного.

Нормы языка - явление историческое, постоянно меняющееся. Изменение литературных норм связано с развитием языка, социальными изменениями, развитием литературы и др. То, что было нормой в прошлом веке и даже 10 лет назад, сегодня может явиться отклонением от нее. Если посмотреть словари 100-летней давности, то можно увидеть, как менялись нормы, например, произношения и ударения. Неверно думать, что норма неподвижна. Она постоянно расшатывается узусом (от лат. Usus 'употребление'). Норма изменяется и развивается во времени.

Если грамматические нормы более устойчивы, то орфоэпические нормы очень подвижны. В словарях нередко даются произносительные варианты: творо $\square$ - тво $\square$ ог, исчёркать - исчерка \ть, пе Фрчить - перчи \ть.

Вопросам нормирования языка много внимания уделял выдающийся русский ученыйэнциклопедист М.В. Ломоносов. В 1755 г. он обосновал теорию «трех штилей» «высокого», «среднего» и «низкого», которая положила начало научному исследованию стилистического разнообразия русского языка.

Норма - это совокупность наиболее пригодных для обслуживания общества средств языка, складывающихся как результат отбора языковых элементов из числа сосуществующих, наличествующих, образуемых вновь или извлекаемых из пассивного запаса прошлого в процессе социальной, в широком смысле, оценки этих элементов [1].

Понятие нормы распространяется на все уровни языка. В соответствии с уровневой соотнесённостью и спецификой выделяются следующие типы языковых норм [1]: лексические - обеспечивают правильность выбора слов; 
Лексика любого живого языка находится в постоянном изменении - в язык непрерывно входят неологизмы и постепенно уходят старые слова. Выделяются следующие способы пополнения лексики [2]

Словообразование, то есть создание новых словоформ из уже существующих в языке компонентов: так из существовавших в русском языке основ пар и воз(ить) в XIX веке было образовано двухосновное слово паровоз, обозначавшее новое на тот момент понятие.

1. Полисемия - приобретение существующими словами новых значений: так существовавшее слово ворота (проём в стене или заборе, закрываемый при помощи створов) в качестве спортивного термина приобрело новое значение (специальная конструкция на спортивной площадке, куда необходимо направить мяч или иной спортивный снаряд).

2. Конверсия - переход одних частей речи в другие без использования аффиксов: так наречие хорошо преобразовалось в существительное хорош в значении школьной оценки.

3. Заимствования из других языков, такие слова, как компьютер (от англ. computer) или энщиклопедия (от лат. encyclopaedia, которое в свою очередь произошло от др.-греч.

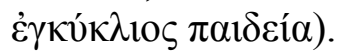

4. Создание аббревиатур: такие, как вуз (из высшее учебное заведение) или БРЭ (из Большая российская энциклопедия).

- Акцентологические - предусматривают правильную постановку ударения;

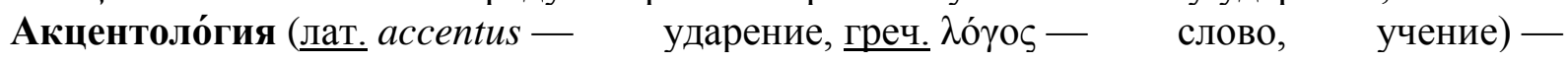
раздел языкознания, изучающий природу, особенности и функции ударения. Иногда к области акцентологии относят также $\underline{\text { тон и }}$ некоторые другие просодические явления. Акцентологией также называют систему явлений языка, связанных с ударением[3].

Изучение ударения в морфонологическом аспекте ставит перед собой следующие задачи: установление связи наличия или отсутствия ударения с разновидностями морфем или их сочетаний (различаются аутоакцентные, требующие ударения, к примеру рус. $6 b l-$

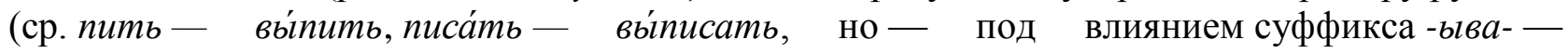
выпи́сывать), преакцентные, располагающиеся перед ударением, и постакиентные морфемы);

Различаются фонологическое ударение, относимое к слогу или море, и морфонологическое ударение, характеризующее тот или иной морфологический элемент. В случаях, когда речь идёт о словоформах с неслоговыми или нулевыми морфемами, говорят об условном морфонологическом ударении, способном падать, к примеру, на нулевое окончание (ср. рус. стол - столу́) [3].

орфоэпические - описывают правильное произношение слов; Орфоэ́пия (от др.греч. ỏ $\theta$ ó «правильный» и ह̌ло «речь») - совокупность правил устной речи, закреплённых в литературном языке. Разные авторы трактуют понятие орфоэпии слегка по-разному, «широкий» подход включает нормы произношения и ударения, «узкий» подход исключает ударение из правил орфоэпии. Орфоэпические нормы весьма важны в речевой деятельности, поскольку неверное произношение или ударение отвлекают внимание от смысла высказывания, затрудняют понимание, а часто просто производят неприятное впечатление на слушающего. [4]В истории русского литературного языка орфоэпическая норма к началу XX века в основном одержала верх над местными произношениями. Так, исчезло диалектальное произношение на о: «м[о]л[о]дой», «х[о]p[o]шо» вместо литературного

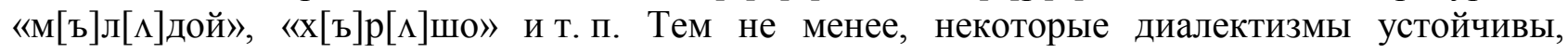
например, твердое произношение звука «ч» на западе и на востоке, произношение «по́ля», «мо́ря» вместо «поле», «море»- в центре и т. п. Но особенно много случаев, когда нельзя уверенно утверждать, какой из вариантов для литературного языка «правилен». На настоящий момент русская орфоэпия ещё не вполне установилась и продолжает развиваться.

- Орфографические - закрепляют единообразие передачи речи на письме;

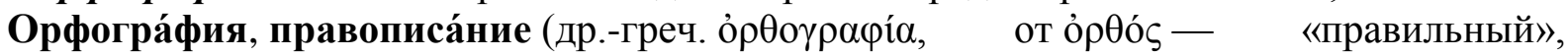
и $\gamma \rho \alpha ́(\varphi \omega-$ «пишу») - единообразие передачи слов и грамматических форм речи на письме. 
Также свод правил, обеспечивающий это единообразие, и занимающийся им раздел прикладного языкознания.

Орфогра́фия - раздел лингвистики, изучающий правила написания слов.

Отражает ослабление безударных гласных (вместо О и Е пишется А и Я), некоторые явления, связанные с согласными (пишется ЦЦА вместо ТСЯ/ТЬСЯ). Не отражает явлений, связанных с согласными (напр., звонкие согласные в конце слова оглушаются, но пишутся всё равно буквы, соответствующие звонким).

-морфологические - правила словоизменения и словообразования, описываемые в грамматиках;

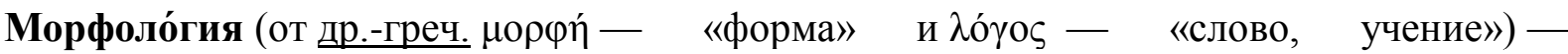
раздел грамматики, основными объектами которого являются слова естественных языков, их значимые части и морфологические признаки. В задачи морфологии, таким образом, входит определение слова как особого языкового объекта и описание его внутренней структуры. Тесная связь понятий морфологии и слова (в этом же значении часто употребляется более точный термин «словоформа») ставит само существование морфологии в зависимость от существования слов в конкретном языке. Между тем, это понятие является одним из самых противоречивых в лингвистике и, скорее всего, не универсальным. Иначе говоря, слово это такой объект, который существует, по-видимому, не во всех языках, а значит, не во всех языках существует и морфология как самостоятельный раздел грамматики. В языках, не имеющих (или почти не имеющих) слов, морфология не может быть разграничена с синтаксисом: у неё не остаётся ни самостоятельного объекта, ни самостоятельной проблематики.

- Синтаксические - регламентируют правильное построение грамматических конструкций.

Си́нтаксис (др.-греч. би́v- $\tau \alpha \xi ı[5]$ «составление», «координация», «порядок») раздел лингвистики, в котором изучаются номинативные и коммуникативные языковые единицы: предложение и словосочетание. Слово в буквальном переводе означает не только составление, но и упорядочивание, координирование, соединение слов в связный текст.

В лингвистике синтаксис - это совокупность правил, теоретических систем и языковых процессов, упорядочивающих и изучающих структуру предложений в каком-либо языке. Целью многих синтаксисов является установление синтаксических правил, общих для всех языков. Предметом изучения в синтаксисе являются синтаксические единицы, или языковые конструкции, в которых элементы речи объединены синтаксическими связями и отношениями[6]. Синтаксис неразрывен с нормами коммуникации, структурой мышления и обозначаемой действительностью, что делает его наиболее универсальной частью языковой структуры. Вместе с тем в каждом языке действуют свои специфические правила синтаксических отношений и способы их применения. Во многих языках цель синтаксиса создать свод правил и систем для процессов, происходящих в языковой среде, которые изучают и упорядочивают способы сочетания слов и многообразную структуру текста:

- грамматический строй языка: слова, являющиеся членами предложения; словосочетания; предложения простые и сложные; тексты;

- раздел науки о языке, изучающий виды синтаксических связей, лексическое и грамматическое значение словосочетаний в предложении.

Морфологические и синтаксические нормы включаются в число грамматических норм.

Заключение

Новое поколение опирается на уже существующие тексты, устойчивые обороты речи, способы оформления мысли. Из языка этих текстов оно выбирает наиболее подходящие слова и обороты речи, берет из выработанного предшествующими поколениями актуальное для себя, привнося свое, чтобы выразить новые идеи, представления, новое видение мира. Естественно, новые поколения отказываются от того, что кажется архаичным, не созвучным новой манере формулировать мысль, передавать свои чувства, отношение к людям и событиям. Иногда они возвращаются к архаичным формам, придавая им новое содержание, 
новые ракурсы осмысления. В каждую историческую эпоху норма представляет собой сложное явление и существует в довольно непростых условиях. Итак, нормы помогают литературному языку сохранять свою целостность и общепонятность, защищают его от потока диалектной речи, социальных жаргонов, просторечия; языковые нормы постоянно изменяются. Это объективный процесс, не зависящий от воли и желания отдельных носителей языка; нормы помогают литературному языку сохранять свою целостность и общепонятность. Они защищают литературный язык от потока диалектной речи, социальных и профессиональных жаргонов, просторечия. Это позволяет литературному языку выполнять одну из важнейших функций - культурную.

\section{Список использованной литературы}

1.Норма языковая. Российский гуманитарный энциклопедический словарь. Архивировано 25 сентября 2015 год

2.А. М. Кузнецов. Лексика . Лингвистический энциклопедический словарь . Гл. ред. В. Н. Ярцева. - М.: Советская энциклопедия, 1990.

3.Касевич В. Б. Акцентология . Лингвистический энциклопедический словарь . Главный редактор В. Н. Ярцева. - М.: Советская энциклопедия, 1990. - 685 с. - ISBN 585270-031-2.

4. Елена Малышева, Ольга Рогалева. Современный русский язык. Часть II. Орфоэпия. Флинта, 2014.

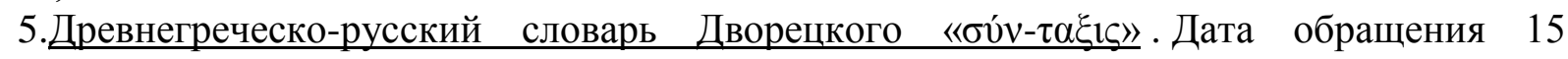
февраля 2020. Архивировано 28 декабря 2014 года.

6. Л. А. Беловольская. Синтаксис словосочетания и простого предложения. http://www.philology.ru. (2001). Дата обращения 1 мая 2019.

\section{СЛОВООБРАЗОВАТЕЛЬНЫЕ АФФИКСЫ В РУССКОГО ЯЗЫКЕ}

\section{Султонмуродова Фарангиз Акрамовна}

(Сам ГУ)

Annotation: This article discusses some features of derivational affixes of the Russian language. And also all morphological ways of word are studied.

Key words and expressions: word formation, affix, suffix, prefix, methods, productive, unproductive, semantics.

Выделяются в русском языке следующие группы продуктивных приставок и суффиксов, при помощи которых образуются прилагательные:

1) Приставка без - (бес) и суффикс -н-: безразмерный, бесплатный, безрезультатный и т.п.;

2) Приставка вне- и суффиксы -н; -ов-, -ск-:внештатныци, внеплановыци, внеевропейский и т.п.;

3) Приставки до-, за-, и за- и суффиксы -н-, -ск-, - ов- и др.:добольничный, доисторический, заоблачный, заполтсный, заоконный, заокский и т.п.;

4) Приставка меж- и суффиксы -н-, -альн; -ическ-:межрегиональный, межконтинентальный, межгалактический и т.п.;

5) Приставки на-, над- и суффикс -н-: нареберный, подарочный, надсводный и т.п.;

6) Приставка по- и суффиксы -н-, -онн-, -енн-:послойный, пореформенный, пожизненныцй и т.п.;

7) Приставка при- и суффиксы -н-, -ск-:пришкольный, приусадебный, приинститутский, приволжский, приобский и т.п.;

8) Приставка пред- и суффиксы -ов-, -н-, -ск- и др.: предпусковой, прединфарктный, предвечерний, предмайский и т.п.;

9) Приставка после- и суффиксы -н-, -онн-:послеуборочный, послебольничный, послеоперациионыий и т.п. 
К малопродуктивным относится, например, способ образования прилагательных при помощи приставки от- и суффикса - н-: отглагольный, отыменный.

При образовании глаголов в различной степени продуктивны три морфологических способа словообразования: префиксальный, суффиксальный и суффиксальнопрефиксальный.

Префиксальный способ образования глаголов является наиболее продуктивным. От любого бесприставочного глагола путем присоединения к нему приставки возможно образовать новый глагол с иным оттенком в лексическом значении (ср.бежать - вбежать, выбежать, прибежать, отбежать и др.).Лексическое значение приставки наиболее отчетливо у глаголов движения.

Характерной особенностью глагольных приставок является наличие в их кругу приставок-антонимов, что облегчает уяснение значения приставки (ср.: заклеить отклеить, а также приставок-синонимов, уточняющих лексическое значение глаголов (ср.: выгнать - изгнать). Некоторые приставки вносят в значение глагола экспрессивные оттенки (ср.:возрадоваться-обрадоваться).

Суффиксальный способ образования глаголов используется при образовании глаголов от существительных и прилагательных а также от местоимений, числительных и междометий. Суффикс -нича-(-ича; -а-) употребляется при образовании глаголов от названий лиц со значением «заниматься чем-либо, действовать как кто-либо»: ло-дыр-ничать, моченнича-ть, сапож-нича-ть. Суффикс -ова- (-ева-) и его производные - ствова-, ирова-, -изирова - образуют глаголы от существительных со значением «осуществлять чтолибо»: совет-ова-ть, господ-ствова-ть, дебатирова-ть, коллектив-изирова-ть. От существительных и прилагательных образуются глаголы посредством суффикса -и- -со значением «создавать известное качество или состояние»: сор-и-ть, бел-и-ть. От прилагательных возможно образование глаголов посредством суффикса - e-, имеющим значение «делаться, становиться таким-то»: стар-е-ть, слаб-е-ть; реже используется суффикс -ну-: cлеn-ну-ть, кpen-ну-ть. От междометий образуется глаголы суффиксом -я- (ох-а-ть, $\mathbf{a x -}$ а-ть) и его вариантом-ка-- от междометий и звукоподражательных слов (мяу-ка-ть, ay-кать), а также суффиксом -ну-(ахну-ть, ияок-ну-ть).

Суффиксально-префиксальный способ образования глаголов менее продуктивен. Разновидностью этого способа является использование суффикса -ыва- (-ива-) и аффикса ся в сочетании с приставками: походить - по-хаж-ива-ть, cnamb - вb-cnamb-ся (в последнем случае можно говорить о префиксально-постсуффиксальном способе).

Среди словообразовательных суффиксов различаются непродуктивные, с помощью которых в настоящее время новые слова не образуюся (например, непродуктивен суффикс нь: боле-знь, жи-знь; суффикс - ух:петух, паст-ух), и суффиксы продуктивные, активно участвующие в современном словообразовании.

Все продуктивные словообразовательные суффиксы делятся на несколько групп:

1) суффиксы, служащие для образования названий предметов;

2) суффиксы, употребляемые для образования названий лиц (мужчин и женщин);

3) суффиксы, служащие для образования слов с отвлеченным значением (абстрактных);

4) суффиксы, служащие для образования существительных, передающих субъективную оценку.

1. Суффиксы и приставки, служащие для образования названий предметов.Среди суффиксов этой группы выделяется ряд продуктивных суффиксов, например:

1) -льник, -лк-а, при помощи которых образуются существительные (чаще всего от глагольных основ) со значением орудия действия, наименования прибора (будильник, холодильник, веялка, грелка, молотилка);

2) -щик (-чик), при помощи которого образуются существительные (как от глагольных, так и от именных основ) с тем же значением (счетчик, тральщикк; слова с этими 
суффиксами употребляются в разных стилях речи, но наиболее характерны для речи научнотехнической;

3) -льн-я, при помощи которого образуются существительные женского рода со значением места действия (читальня, красильня, купальня и др.);

4) -ие (-ье), используемый для образования (чаще всего от именных основ с приставками пространственного значения) существительных со значением места (заречье, предгорье, всполье, подножье и др.);

5) -к-а, используемый для образования существительных (чаще всего основ относительных прилагательных на -ов-, -ев-), являющихся названием предметов по характеризующему их признаку (анисовка, дюймовка, кладовка, жестянка); слова с данным суффиксом употребляются преимущественно в разговорной речи; этот же суффикс используется и при образовании слов, употребляемых в качестве разговорного (или даже просторечного) синонима сочетания прилагательного с существительным:

Третьяковка (Третьяковская галерея), вечерка (вечерняя газета) и др.; суффикса -ыва(-ива-) и аффикса -ся в сочетании с приставками: походить - no-хаж-ива-ть, cnam - вbcnamb-ся (в последнем случае можно говорить о префиксально-постсуффиксальном способе).

\section{Список использованной литературы}

1. Тихонов А.Н. Словообразовательный словарь русского языка. В 2-х тт.Москва «Русский язык», 1990.

2. Земская Е.А. Современный русский язык. Словообразование. М.,1973.

3. Лопатин В.В.Словообразование. Книга о русском языке. М., 1969.

4. Винокур Г.О. Заметки по русскому словообразованию. Избранные работы по русскому языку. М., 1959.

5. Бабакулов И.Т. Словообразовательные системы русского и узбекского языков в аспекте типологической детерминанты. Монография - Самарканд, 2017. 160с.

\section{К ВОПРОСУ ЛИНГВИСТИКИ ЮРИДИЧЕСКИХ ДОКУМЕНТОВ}

\section{Н.Б. Абдурашитова \\ (стариий преподаватель, соискатель Кафедра изучения языков Академии Министерства внутренних дел РУ)}

Annotation: The article raises the problem of the accuracy of the language of the law, which provides for the elimination of conflict situations in the use of regulatory documents in the sociopolitical and economic life of the country. It is no secret that every legal document, first of all, must comply with the requirements of accuracy, strictness of style, as well as specificity and clarity of wording, therefore, failure to comply with these regulations leads to the appearance of corruptiongenerating factors that create a wide corridor for committing various types of offenses, attempts to bypass the letter law to achieve various illegal purposes. To this end, the author examines a number of regulatory documents and gives his assessment of the resolution of problematic situations using linguistic-semantic analysis. The article also raises the problem of discrepancies in legal documents after their implementation into Uzbek or vice versa into Russian, which in turn also serves as one of the factors the possibility of unjustified application of exceptions to the general rules of jurisprudence.

Key words and expressions: conflict situation, language of law, corruption-generating factors, regulatory documents, linguistic-semantic analysis

Известно, что любой нормативно-правовой акт, прежде всего, должен соответствовать требованиям точности формулировок, строгости стиля, конкретности и ясности предписаний, поэтому одним из ведущих качеств языка закона должна быть точность, которая в свою очередь достигается соответствующим использованием языковых средств лексики и терминологии. 
По мнению В.Я. Колдина, «развитие лингвистической экспертизы имеет принципиально важное значение для юриспруденции, поскольку особая роль любой экспертизы в общей системе права обусловлена тем, что экспертиза является инструментом решения коллизионных ситуаций между субъектами права и, следовательно, инструментом защиты охраняемых правом интересов личности, общества и государства».

В частности, статья 24 Закона «О противодействии коррупции Республики Узбекистан» гласит: антикоррупционная экспертиза нормативно-правовых актов и их проектов представляет собой процесс, направленный на: выявление коррупциогенных факторов, создающих возможность совершения коррупционных правонарушений; общую оценку последствий принятия проекта, создающих возможность совершения коррупционных правонарушений; прогнозирование возможности возникновения рисков коррупционного характера в процессе применения нормативно-правовых актов; разработку рекомендаций и принятие мер, направленных на устранение выявленных коррупциогенных факторов. По нашему мнению, в статье правильно использован термин «коррупциогенный» для обозначения признаков, способствующих развитию коррупционных проявлений, которые могут реализоваться благодаря наличию определенных свойств, факторов, условий. Термин «коррупционный» по своей семантике служит для обозначения уже реализовавшихся коррупционных проявлений, например, условий, в которых коррупция уже существует, выявлена, и, следовательно, должна быть устранена [Россинская, 2015: 4].

Представляется, что такой подход соответствует положениям системы противодействия коррупции закрепленной в «Методике проведения антикоррупционной экспертизы проектов нормативно-правовых актов», в которой, во-первых, обозначены главные цели антикоррупционной экспертизы - предупреждение возникновения и выявление в проектах коррупциогенных факторов и их последующее устранение, во-вторых, перечень коррупциогенных факторов, содержащих неопределенные, трудновыполнимые и (или) обременительные требования к физическим и юридическим лицам, расширен. К ним также относится чрезмерная избыточность правового урегулирования отношений, выражаемая в необусловленной и необоснованной регламентации поведения и деятельности юридических и физических лиц, которая может привести к ограничению свободы участников общественных отношений.

Отсюда можно сделать вывод, что «коррупциогенными факторами являются положения нормативно-правовых актов (или их проекты), устанавливающие для правоприменителя необоснованно широкие пределы усмотрения или возможность необоснованного применения исключений из общих правил, а также положения содержащие неопределённые, труднопонятные или обременительные требования к гражданам и организациям и тем самым создающие условия для проявления коррупции».

В нашей республике законы издаются как на государственном, так и на русском языках, и нередко, прослеживаются неточности в смысловом понимании одного и того же положения закона. Данный случай, безусловно, приводит к использованию правовых норм в коррупционных целях. Например, при переводе статьи того или другого закона явно бросается в глаза нецелесообразное использование фраз-клише свойственных юридическому тексту. Для примера сравним ст.1 Гражданского кодекса Республики Узбекистан на русском и узбекском языках. Статья 1 ГК Республики Узбекистан гласит: «Гражданское законодательство основывается на признании равенства участников регулируемых им отношений, неприкосновенности собственности, свободы договора, недопустимости произвольного вмешательства кого-либо в частные дела, необходимости беспрепятственного осуществления гражданских прав, обеспечения восстановления нарушенных прав, их судебной защиты» Данная статья переведена на узбекский язык как: «Fuqarolik qonun hujjatlari ular tomonidan tartibga solinadigan munosabatlar ishtirokchilarining tengligini e'tirof etishga, mulkning daxlsizligiga, shartnomaning erkinligiga, xususiy ishlarga biron bir kishining o'zboshimchalik bilan aralashishiga yo'l qo'yilmasligiga, fuqarolik huquqlari to'sqinliksiz amalga oshirilishini, buzilgan huquqlar tiklanishini, ularning sud orqali humoya qilinishini ta'minlash 
zarurligini asoslanadi». Отсюда видно, что неточный перевод и употребление таких языковых клише как перевод слова признание как e'tirof etish, вместо tan olish, произвольное вмешательство как о'zboshimchalik bilan aralashish вместо хоhlaganicha aralashish (в данном случае именно это имеется ввиду) порождает ряд непростительных неточностей, более того, увеличения объема самой статьи, затруднения ее юридического восприятия, и появления коррупционных толкований.

Вышеизложенные и другие недостатки, связанные с несоответствием нормативноправовых актов требованиям законодательной лингвистики, во многом связаны с недостаточным уровнем ответственности специалистов государственных органов, которые участвуют в правотворческой деятельности. Также серьезное отрицательное влияние на качество правовой базы оказывают изъяны законодательного характера, в том числе неустановление в нормативно-правовых актах, регулирующих правотворчество, некоторых лингвистических требований, предъявляемых к нормативно-правовым актам.

Следовательно, во многом потенциальные условия, порождающие коррупциогенность текста закона, создают злоупотребления законами языка, слабое владение юридическим языком, неумелое обращение с ним при конструировании нормативных предписаний. Ибо текст нормативно-правового акта должен быть не только грамотным с точки зрения юридической техники, но и лингвистически точным.

\section{Список использованной литературы}

1. Гражданский кодекс Республики Узбекистан. - Т., 1997.

2. Собрание законодательства Республики Узбекистан, 2015. Ст. 644 - С. 90.

3. См. Собрание законодательства Республики Узбекистан, 2017 г. Ст. 2 - С. 131

4. Антикоррупционная экспертиза нормативно-правовых актов. Под ред. Е.Р.Россинской. М., 2015.

5. Юрислингвистика -- 3: Проблемы юрислингвистической экспертизы: Межвуз. Сборник научных трудов/Под ред. Н.Д. Голева. Барнаул, 2002.

6. Колдин В.Я. Экспертиза как инструмент права//Проблемы юридической техники: Сборник статей под ред. В.М. Баранова. Нижний Новгород, 2000.

\section{НЕМИС ТИЛИДА ИЛОВА КОНСТРУКЦИЯЛАР БАЖАРАДИГАН ФУНКЦИЯЛАРИ ХАҚИДА}

\section{Рахимов Мирзали Раббимович \\ ( СамДУ)}

Annotation: This article discusses the construction of sentences in German. The basic communicative functions of the applied elements concretize, complement and realize the events that take place within the main expression. The incompatibility of some of the components that make up the elements of the application enhances their syntactic functions in practice, resulting in increased sensitivity to the event being described.

Key words and expressions: construction, communicative function, complement, incompatibility, application enhances, syntactic function, increased sensitivity semantic factors of application connection, stylistic sensitivity, the logical character of event, emotional assessment.

Иловали элементлар асосий коммуникатив функциялари асосий ифода таркибида содир бўлаётган воқеа-ходисаларни конкретлаштиради, тўлдиради ва реаллаштиради.

Иловали элементлар таркибида келувчи баъзи бир компонентларнинг уззига мос ўринда келмаслиги уларнинг синтактик функцияларини амалда кучайтиради, натижада тасвирланаётган воқеа-ходисанинг таъсирчанлиги ошади. Иловали элемент томонидан билдирилаётган коммуникатив функцияларнинг олдин умумлашганини, кейин эса яна конкретлашганини иловали элементларнинг стилистик функцияларини бойитишга хизмат қилади [Бушуй 2004:19]. 
Dativ келишиги билан ифодаланиб келувчи иловали элементларга хос бўлган хусусиятлардан яна бири иловали элементлар коммуникатив функцияларининг инверсияга эга бўлишидир. Бу холни куйидаги мисоллар тахлилида кузатиш мумкин:

1. Fritz spielte nicht mehr. Mit niemandem [Bruns M. 1972:156].

2. Mutli kommt gleich. Sie ist bei Oma. Mit dem Fahrrad [Herbert O. 1972:160].

Кўриниши жихатдан кейинги мисолларда баён қилинган иловали элементлар № 1-, 2 рақамли мисоллардаги иловали элементларни такрорлаб келгандай. Умуман олганда, бу иловали элементлар хам содда структуравий иловали элементлардир. Бироқ, коммуникатив функциялари нуқтаи назаридан қандайдир ўзларига хос хусусиятга эга. Бу хусусият №1рақамли мисолдаги иловали элементнинг конкретлаштириш ва ўша мисолдаги иловали элементнинг умумлаштириш характерига эга бўлиши билан ифодаланди. Иловали элементларга хос бўлган бундай хусусият, уларнинг асосий ифодага нисбатан билдирилаётган коммуникатив фунукцияларини фақатгина конкретлаштирибгина қолмасдан, балки уни умумлаштириши хам мумкин. Иловали элементлар коммуникатив функцияларининг бундай вариантивлиги, асосан баъзи лексик-грамматик компонентларнинг жой алмашиниши билан бевосита боғлиқ бўлиб, бундай вазият иловали элементларнинг хам стилистик, хам синтактик функцияларини кучайтиришга хизмат қилади [Расулова 2004:182].

Dativ келишиги билан ифодаланиб келувчи иловали элементиларга хос бўлган хусусиятлар Dativ келишигини талаб қилувчи предлоглар билан ифодаланиб келган иловали элементларнинг тахлилида такрорланиши ва кенгайтирилиши мумкин, чунки Dativ келишигини талаб қилувчи предлоглар билан ифодаланиб келган иловали элементлар ўзларининг ёйилиш даражаси жихатдан худди шундай табиатга хос бўлган иловали элементлардан кескин фарқ қилади [Турсунов 1993:465]. Шу сабабли бу гурухдаги иловали элементлар илова конструкциянинг турли хил структуравий шаклларини намоён қилиши мумкин.

Фикримизнинг исботи сифатида, энди Dativ келишигини талаб қилувчи предлоглар билан келган иловали элементларнинг тахлилига ўтамиз.

Mit предлоги билан келувчи иловали элементлар.

Mit предлоги билан келувчи иловали элементлар, худди шундай структуравий гурухга мансуб бўлган иловали элементлардан ўзларининг ёйилиш даражасининг юқорилиги билан фарқ қилади ва хар хил шаклга эга бўлган иловали элементларни юзага келтиради.

Mit предлоги билан келувчи иловали элементлар якка холда шаклланади:

1. Dann sprach er langsam, Wort für Wort: Der General fürchtete um sein Zentrum. Mit gutem Grund. [Bredel E. 1981:208].

2. Du, zum Beispiel hast du Kind und Frau. Ja, ich kenne die Blocks auf Klappendorf zu. Mit den blauen Balkons [Herbert O. 1972: 128].

3. Annette hatte eine weite schingende Bewegung. „Auf den Kopf“, sagte sie. Mit einer Flasche [Kleine D. 1972: 270].

4. Ich glanbe schon, sagte Kelly. Mit einem bißchen Glück [Thürk H. 1968: 78].

Бу иловали элементлар тахлили асосида қуйидагиларни таъкидлаш ўринлидир; биринчидан, бу иловали элементлар асосий ифодага нисбатан икки хил муносатда бўлишади: соф (1-4 мисолларда) соф бўлмаган (2-3 мисолларда) иловали элементлар; иккинчидан, иловали элементларнинг коммуникатив функциялари бутун асосий ифоданинг мазмунини (1-мисолда) ва унинг айрим компонентларининг (2-,3- ва 4-мисолларда) мазмунини конкретлаштириб, изохлаб, тўлдириб келади; учинчидан, №1-рақамли мисолда келтирилган иловали элемент фақат иккинчи даражали бўлакларга хос бўлган хусусиятни яна бир бор таъкидламоқда. Бундай хусусият иловали элементнинг юзага келиши билан бевосита боғлиқ бўлади. Масалан, агар асосий ифода таркибида эга ёки кесим келмаса, у холда бош бўлаклардан биронтаси хам иловали элемент функциясида келаолмайди, чунки улар учун имконият яратилмайди. Иккинчи даражали бўлаклар учун эса бундай хусусиятни хеч қандай ахамияти йўқ, чунки асосий ифодада худди шунга ўхшаган тўлдирувчи келадими ёки йўқми (1-,2- мисолларда) тўлдирувчилар иловали элементлар функциясида кела олишлари мумкин. 
Ана шу хусусиятлар туфайли иккинчи даражали бўлаклар билан келувчи иловали элементлар бош бўлаклар билан ифодаланиб келувчи иловали элементлардан кескин фарқ қилади.

\section{Фойдаланилган адабиётлар руйхати}

1. Бушуй А.М., Зияева С. Ажратилган сўз бирикмаси инглиз тили синтактик сатхда деривацион ходиса сифатида. Хорижий филология: тил, адабиёт, таълим. - Самарқанд: СамДЧТИ, 2004, 3(12). -б. 9-19

2. Bredel Willi. Die Söhne. Aufbau -Verlag Berlin und Weimar, 1979. -558 s.

3. Расулова М.И. Соотношение мыслительных и лексических категорий в лингвистических исследованиях. Халқаро илмий-назарий конференция материаллари. (Самарқанд 2004-йил 26-27 ноябр). - Самарқанд: СамДЧТИ, 2004. -б. 182-184.

4. Турсунов Б.Т. Присоединение как особый тип синтаксической связи. Докт.дисс. Санкт-Петербург, 1993, -465 с.

5. Формоновкая Н.И. Стилистика сложного предложения. М., «Русский язык», 1978, 239 c.

\section{ОСОБЕННОСТИ СЕМАНТИКИ ДЕМОНОЛОГИЧЕСКОЙ ЛЕКСИКИ В УЗБЕКСКОЙ ЛИТЕРАТУРЕ}

\section{Садриддинзода Сафия Шахобиддиновна (Преподаватель СамГИИЯ)}

Annotation: A feature of demonological vocabulary is the existence of this vocabulary in the minds of all existing peoples and nationalities, through the literature of the Uzbek people we have a large, priceless database, which reveals the true beauty, uniqueness of the nation, at the same time, literature gives us an understanding of the prejudices, fears and superstitions of the Uzbek people. Demonological vocabulary has been introduced into the Uzbek language since ancient times, since it was at these times that people were inclined to superstition and believed in the existence of such demonological characters as "Dev", "Pari", "Xizr" "Ajdar", etc.

Key words and expressions: Demonological lexicon, denotation, the concept of "evil spirits", national literature, angel, demon.

Литература узбекского народа отражает образ жизни людей, общественную и домашнюю жизнь, труд, природу и общество, верования и религиозные убеждения, чувства к человеку и миру, мир искусства, образование, счастливые и справедливые времена. Развитие литературы неразрывно связано с социально-экономическим развитием. Согласно историческим изменениям в жизни людей они тоже менялись. Некоторые жанры или модели полностью исчезли, и появились новые. Поэтому они многослойны и оставили свой след на протяжении нескольких периодов долгой работы. Мифы, легенды и мифы о племенах и кланах, загадки и пословицы, аплодисменты и проклятия, примеры сезонного фольклора и трудовые песни распространены среди многих народов. Однако в более поздние периоды возникли сказки, архаические формы эпоса. Героические былины писались в период крушения патриархальных отношений и образования первых государств. Позже появились романтические эпосы, лирические и исторические песни, устные драмы, анекдоты и восхваления.

Алишер Навои является ярким представителем узбекской литературы. Он создал бесценные многочисленные романы, стихи, прозы. Поэт в своих произведениях часто обращался к демонологическим персонажам “ Dev" “ajdar" “ pari” устного народного творчества, для передачи настроения и положения главных героев.[5, 55]. В стихах он часто использовал образ “Ajdar”. Мы связываем тесное переплетение этого образа в узбекской литературе с сознанием древних людей, так как в их мировоззрении шла постоянная борьба между добром и злом. Зло являлось символом смерти, распространения чумы, бедствия, 
природных катастроф. Поэт раскрывая истинную красоту волос красавицы сравнивает с демонологическим образом “ ajdar”.

Зулфиқонлих пайкарим ничек типечу хам била, Ул сифатким, тортқайаждарбиравни дам била (Навоий, VІ жилд, 1990:362).

Густые волосы красавицы манят возлюбленного как дракон и ведут его к смерти. Часть произведения, связанные с формой и цветом дракона переносят образ дракона в волосы красавицы, тем самым создавая новое восприятие изображения символа зла. Во время изучения лирики Алишера Навои мы столкнулись с мифологическими образами “ Dev” “ Daxshatlisahromahluqi" . В аннотированном словаре слова "Dev", “ G'ulibiyobon” означают “ Dasht- sahrodevi” в переводе на русский язык это степной великан.

Йўл билур қүофиладин тушма кайрукимэрур,

Бубиёбонарохамвулкўпухзамрахзан (Навоий, II жилд, 1990:386).

Образ "Рari" также часто используется вузбекской поэзии . Образ Пари восходит к первобытным временам. Человеческая фигура - это основная форма фей. Ведущая черта образа пари в этом образе - красота. Обычно такие феи появляются в образе очень красивых, луноподобных девочек или округлых мальчиков (Каюмов, 1999, с. 10).Исходя из вышеописанной легенды образ “Pari” тесно переплетается с образом ангела. Хотя ангелы появились от лучей света, по дороге которых стоят “Pari”, которых назвали “Jin". Позднее исходя из народных представлений и легенд образ “ Рari” часто переплетался с образом “ Jin”. По свидетельствам автора Р. Шариповой узбеки проживающие на территории Хатирчи и Нурота верят мифу о том, что если влюбляется в кого-нибудь "Рari” то этот человек в глазах “Pari' превращается а огонь. Откуда и исходит узбекская поговорка “ Falonchiningqizifalonchiningko'zigaolovbo'libko'rindi”.

В произведения яркого представителя узбекской культуры А.Навои этот образ используется для изображениявозюбленной

Гарпарийларкушкаби рам к̧илсалар мен телбадин, Ғамйўқ, улийхи пари пайкарменингромимкерак (Навоий, Гжилд, 1990:239).

Лирика Алишера Навои берёт начало от фольклорных произведениях, в которых отражается глубокое мировоззрение узбекского народа. Мифический образ Хизра, который также встречается в художественной литературе, изобилуетиспользованием в стихах, произведениях. Хизрявляется вечно живущим образом, который несёт в себе тепло, доброту, бесконечную любовь. Он появляется в жизни людей в трудных минутах или для предостережения от грядущих бед. [6, 70], Все вышеописанные черты присутствуют в возлюбленной героине А.Навои

Хизр хат тингсабзаси, хуайвонсуинуишилабинг, Ул су мавжидин бўлиб бир даври тавқуиабвабинг (Навоий, ІІ жилд, 1990: 307).

Таким образом в итоге нашего анализа мы пришли к выводу, что литература неразрывно связана с народным сознанием, она формируется на протяжении многих веков и каждое историческое или уникальное в жизни народа событие оставляет свой след в ходе развития литературы. На примере А.Навои мы постарались показать функциональность демонологической лексики, которая берёт начало от фольклора и устного народного творчества, что формируется посредством национального сознания и саморазвития узбекской нации.

\section{Список использованной литературы}

1. Навоий Алишер. Мукаммаласарлартўплами. XX жилдлик VI жилд. Фавойидулкибар. -Тошкент: “Фан”, 1990.

2. Навоий Алишер. Мукаммаласарлартўплами. XX жилдлик V жилд. Бадоеьул - васат. Тошкент: “Фан”, 1990.

3. Навоийасарларилуғати. -Тошкент: ҒафурҒуломнимидагиадабиётвасанъатизд. 1972. 755-стр 
4. НурмановФурқат. Хизробразининггенезисиваунингўзбекфольклоридагиталқини. Филол. фанлариномзодидисс. автореф. - Тошкент, 2007.

5. Маллаев Н.М. Алишер Навоийвахалқоғзакиижоди. - Тошкент: Ғ.Ғуломномидагиадабиётвасанъатизд, 1974.

6. ҚаюмовОлим. Ўзбекфольклорида пари образи. Филол. фанлариномзодидисс. автореф. - Тошкент: 1999.

\section{文言 wényán ВЕНЬЯНЬ ТИЛ НОРМАЛАРИ АСОСИДА ТУЗИЛГАН ИБОРАЛАР}

\section{Таир Акимов (ТДШУ катта ўқитувчи)}

Annotation: It takes a great deal of knowledge to fully understand and translate the vast heritage of the Viennese language preserved in the state libraries of the PRC as archival materials in our time. This is the reason why only great Chinese scholars and historians can translate messages written in this language.

Key words and expressions: Phraseology, semantic structure.

Хаммамизга маълумки, фразелогик иборалар халқ оғзаки ижодининг энг кенг тарқалган машхур жанри бўлиб, у авлод-аждодларнинг асрлар тажрибасидан ўтган хаётий кузатишлари натижасида вужудга келган, тилдан-тилга ўтиб сайқал топган панд-насихат рухидаги чуқур мазмун, ихчам шакл, таъсирчан ифодага эга бўлган халқ хикматидир.

Хозирги кунда хитой тилидаги ибораларни урганишгахитойшунос олимларининг қизиқиши тобора ортиб бормоқда.Хитой Халқ Республикасида хам бу борада фундаментал илмий изланишлар йўлга қўйилган.Тарихий бадиий меросни тадқиқот қилиш борасида мазкур мамлакатда Хитой хукуматининг бевосита кўмаги асосида Илмий-тадқиқот институтлари,тадқиқот марказлари ташкил этилиб самарали мехнат қилинмоқда.Масалан: Пекин шахридаги Хитой давлат қадимги ёзувларни ўрганиш илмий-тадқиқотлар маркази,Шанхай шахридаги Фудань Университети,Жилинь Университети,Сичуань давлат университетларида хитойда қарийб 5000 йил илгари пайдо бўлган қадимги Венъянь ёзуви нормалари асосида ёзиб қолдирилган катта маданий,маърифий,тарихий қўлёзма ва босма адабиёт намуналарини илмий тадқиқотлар йўли билан изчил ўрганилмоқда.ХХР хукумати мазкур ишларга алохида эътибор қаратмоқда.Хитойнинг кўзга кўринган етук олимлари,жумладан Фудан университети,Қадимги тиллар ва ёзувлар ўрганиш маркази профессори Лью Джин ва Жилин университети қадимги манбалар билан ишлаш кафедраси мудири профессор Жень Чинлар бу илмий ишларга рахбарлик қилмоқдалар.

Г.Э. Хакимова таъбирича: “ Фразеологик бирликлар образлиликни, экспрессивлик ва эмочионалликни юзага келтирувчи мухฺим воситалар булиб, улар бадиий публицистик матнларнинг ифодавий таъсирчанлигини оширишга хизмат килади. Фразеологик бирликлар ихчам, маъно жихатидан салмоқдорлиги ва таъсирчанлиги туфайли давр рухига мос келади. Бу эса, узз навбатида, фразеологияга доир тадқиқотларнинг хэозирги вақтда долзарб ва мухуимлигини яна бир карра исботлайди"[Г.Э. Хакимова 2018:2].

Хитой тилининг қадимги кўриниши бўлган Венъянь тил нормалари тарихи узоқ ўтмишга бориб тақалади.Венъянь тили тарихий тил бўлиб,даставвал у халқнинг оғзаки сўзлашув тили бўлган.Бу тахминан 5000 йиллар аввал бошланган жараён бўлиб,ёзувнинг пайдо бўлиши мобайнида ёзма ёдгорликлар битила бошланган. Давлатнинг ички ва ташқи сиёсати,фан ютуқлари,давлатлараро муносабатлар ёзишмалари ўша даврларда мазкур тилда олиб борилган.Ўтмиш мероси сифатида кутубхоналарда сақланиб келаётган бу тилдаги адабиётлар ўз замирида хитой халқининг асрлар давомида тўплаган жудда катта маданиймаърифий билимларини асраб турибди.Албатта,Венъян тилида бизгача етиб келган манбаларнинг илк намуналари содда рифмаларда ёзилган шеьрлар,ибораларнинг осон ва тез эсда қоладиган турлари,хикоялар,мақоллар хамда маталлар эканлиги ажабланарли хол эмас.Венъянь тилидаги бизнинг даврда архив материаллари сифатида XXР давлат 
кутубхоналарида сақланиб келаётган улкан меросни тўлиқ англаб етиш,таржима қилиш кучли билимларни талаб этади.Йирик хитойшунос олимлар,тарихчиларгина бу тилда битилган хабарларни мазмунан батафсил ўгириб бера олишлари сабаби хам айнан мана шунда.Баъзи олимларнинг фикрича,бу тилдан 1918 йилларгача қўлланилиб келинган.Венъянь тилида фан-техниканинг замонавий талабларига жавоб бериш борасида қийинчиликлар учрай бошлагач,хозирги замонавий Байхуа тили ишлатилиб келинмоқда.Байхуа тили хам хитой халқининг маънавий-маданий бойликларини ўзида аккумуляция этиш жараёнида халқнинг ўтмиш анъанавий жозибадор оғзаки ва ёзма бойликларидан тўлиқ фойдаланмокда.

Венъянь тили ўзининг махсус тил нормаларига эга.Бу тил нормалари хитой халқининг анъанавий миллий тафаккурини акс эттирувчи туганмас манба эканлиги хитойшунос олимлар тарафидан эътироф этилади.Венъянь тилидаги материаллар халигача илмийтадқиқотлар орқали тўлиқ очиб берилмаган.

Жахон синологияси олдидаги мухим вазифалардан бири тилшунослик сохасига оид Венъянь тил нормалари асосида яратилган улкан мерос ичидаги бебахо лингвистик дурдоналарни бугунги хитой тилининг ривожидаги ахамиятини очиб беришдир.Хитой тилидаги фразеологизмлар мавзусига илмий-тадқиқот мақсадида ёндошилар экан,муболағасиз хозирг тилда ишлатилиб келаётган афоризмлар,мақоллар,маталлар,идиомаларнинг илдизи қадимги Венъянь тилида қолдирилган намуналардан келиб чиқади,дейилса хато бўлмайди.

Тарихий пиллапоялардан ошиб келар экан инсоният тиллари,жумладан хитой тили хам жузъий ўзгаришларга учраганлиги табиий холдир.Ижтимоий тузумлар,давлатчилик шакллари такомиллашуви бевосита тил нормаларининг хам ўзгаришини тақозо этувчи омиллар,бўлиб авлоддан авлодга ўтиб келаётган бадиий адабиётларни тушуниш мураккаблашиб,қийинлашиб боради.Олдинги аждодлар учун тушинарли бўлган фикрлар кейинги авлодлар учун мавхум фикрларга айланиб боради.Тилга оид материалларни ўрганилар экан,ушбу ишда хитой тилининг сермунозара мавзуларидан бири бўлмиш фразеологияларга эътибор қаратилмоқда.Венъянь тил нормалари асосида тузилган, икки бўғинли сўзлардан тузилган бир неча фразеологик бирикмаларни кўриб чиқилади. Венъянь тилида кўлланилган баъзибир иборалар,Байхуа тилида бошқача иероглифлар билан ифодаланса-да, қўлланиладиган ўринлари ва маъноларига тўлиқ мос келиши сақлаб қолинган. Масалан:

“骨瘦如柴 gǔ shòu rú chái”- озиб чўn бўлиб қ̧олмоқ( қурук суяк бўлиб қ̧олмок) иборасини олдинги даврда “骨瘦如訝 gǔ shòu rú chái”-(чиябууридек озиб кетмок) деб кўлланилган. Бу иборада “㑗 chái -чиябўри” билан “柴 chái - ўтин” иероглифлари ўхшаш охангда бўлса хам маънолари хар хил. Ушбу сўзларнинг маънолари хар хил бўлса хам, иборанинг маъносида деярли катта ўзгариш йўқ.Турли иероглифлар орқали ёзувда акс эттирилган муайян бир ибора асл туб мазмунни берувчи,шаклан бир-биридан фарқли жумлаларга ўхшаб қолган,аслида маъно ўшалигича қолган. Иборалардаги хадлар алмаштирилиб ишлатилиб, қўлланиб, аста -секин халқ ичига сингиб турғунлашган .

“信口开河 xìn kǒu kāi hé” ва “信口开合 xìn kǒu kāi hé” ибораларининг маъноси “оzзига келганни гапирмоку" .

“合 hé -бирлашмож” билан “河 hé -дарё” охангдош сўз бўлиб, сўзларнинг маъноси хар хил. Лекин бу икки иборанинг маъноси бир хилдир.

Венъянда “揠苗助长 yà miáo zhù zhăng”-Майсаларни тортиб-тортиб уссишига ёрдам бермоқ(қош қуяяман деб,кўз чиқармоқ) иборасидаги “揠 уа̀- тортмоқ” вақтлар ўтиши билан аста- секин “拔 bá- тортмож̧” маънодош сўзга ўзгарган.Хозирги кунда “拔苗助长 bá miáo zhù zhăng” деб ишлатилади.

Хитой тилидаги “雪中送炭 хuе̌ zhōng sòng tàn- иборанинг маъноси: совуқуда кўмир етқ̧азиб бермоқ”" Ўзбекчаси: бошга овир кун тушганда ёрдам бермоқ;; мухтожларга ёрдам қўлини чўзмоқ;Муқобили:Чанқ̧аганда сув бер, музлаганда кўмир бер. 
Венъянь тилидан олинган“绵里藏针 mián lǐ cáng zhēn-иборасининг маъноси: naxma ичига нинани яшириб қуймоқ̧” ўзбекча муқобили қуйидагидир: “тили иакар, дили захар”. Юқорида мисол қилиб келтирилган иккита турғун иборада одам тана аъзолари иштирок этмаган бўлсада, ўзбек тилига таржима қилганда соматик иборалар тарзида таржима қилинади.

Веъянь тилида икки хатлик иборалар хам учрайди:虚惊 хӣ jīng - ёлгон чақ̧ирув; 默契 mò qì - сукуm аломати ризо; 苦命 kǔ mìng - аччиқ құсмат. Хитой тили изохли луғати нашрдан чиққандан кейин уларнинг хозирги замон тилидаги мавқеи масаласи мунозаралигича қолмоқда.Венъян тилидаги баъзи сўзлар хозирги хитой тилида қўлланилмайди. Кўпгина 成语 chéngyйларда лексик эски маънолар, талаффузи ва лексик элементлар сақланиб қолган бўлиб, хозирги замон хитой тилидаги маъноларга тўғри келмайди, шунинг учун уни тахлил қилаётганда хитойликларнинг ўзлари анча мунча хатоликларга йўл қўяди.

“Баъзибир 成语 chéng уй ларда эски грамматик форма сақланиб келмокда. Масалан:”他 的 tā de-yнин2” ўрнига 其 qí кўлланилган. “莫名其妙 mò míng qí miào- mушунарсиз, ақлл бовар қилмаслик”. 怎么 zěnme-нинг ўрнига 焉 уān кўлланилган. “不入虎穴焉得虎子 bú rù hŭ xué yān dé hŭ zй-йўлбарснинг инига кирмай, йўлбарснинг боласини ушлаб бўлмас; тоққа чиқмасанг дуллана қ̧айда, жон куйдармасанг- жонона”. “不分彼此 bù fên bǐ cǐ-сенинг-менинг демаслик”. 这 zhè нинг ўрнига 此 č̌, 那 nà нинг ўрнига 彼 bǐ қўлланилган бўлсада иборанинг маъносида ўзгаришлар кузатилмайди.

Мустахкам семантик тузилиш 成语 chéng уй ларда сақланиб қолган бўлиб, оғзаки ва ёзма адабиётларни жозибали, таъсирчан иборалар билан безаб келмокда.

触霉头 chù méi tóu - дил сиёхуликка йўлиқмок(йз айби билан); 高名堂 gāo míng táng фойда чиқ̧ади; 摆龙门阵 băi lóng mén zhèn -zan сотмоқ; ; 刮脸皮 guā liăn pí- - уялтирмоқ .

О.В. Чибисова, И.В. Каминская “В русской и китайской лингвокультурах"деган мақоласида 成语 chéng уŭ лар одатда тўрт бўғиндан ташкил топган бўлади, аммо тўрт бўғиндан кўп бўлган 成语 chéng уй лар хам учраб туради. Уларнинг асосий ўзаги қадимги хитой 文言 wén yán ёзувидан олинган, 文言 wén yán хозирги замон тили билан уухшашлиги жуда хам кам бўлганлиги учун кўпгина 成语 chéng уй ларнинг маъносини иегорлифлардан тушуниб олиш қийин,деб ёзган .[О.В. Чибисова, И.В. Каминская 2019]

Хақиқатан,文言 wényánда ёзилган матн ва ибораларни хозирги кунда хитойликлар ўқиб тушуниши қийин бўлиб қолганлиги сабабли хитойлик тилшунос мутахасислар 文言 wényánни хозирги замон хитой тилига таржима қилиб тушунтиришга харакат қилишади.

“成语保留了许多古代汉语的特征。古代汉语的这些特征, 在现代汉语中有的消失了, 有的失去了普遍性 ; 在成语中它们却被继承下来。和现代汉语相比, 成语中“文言”特征格外 明显”[马国凡 1973:30].

Таржимаси: тилшунос олим 马国凡 Măguófán таъбирича,“Ибораларда қ̧адимги хитой тили хусусиятлари сақланиб құлган. Қадимги хитой тилига хос хусусиятлар хуозирги замон хитой тилида сақланиб қолмаган, баъзилари эса умуман йўқолиб кетган; иборалар уиша хусусиятларга ворислик қулиб келмоқуда. Хозирги замон хитой тилига ққараганда, ибораларда “文言wényán” тил хусусиятлари жуда равщан акс эттирилгандир”.

Биз куйида “文言 wén yán”да ёзилган сўзларнинг хозирги кунда хитойликлар кундалик тилда кўлламасликларини кўриб чиқамиз.

a) 保留了许多古代词 : Жуда кўп қадимий сўзлар сақланиб қолган:

一些成语中的构成词, 在现在代语中已不使用 [马国凡 1973:31]. Баъзибир иборалар таркибидаги сўзлар, хозирги кунда кўлланилмайди. Мисол: “不容置喙 bùróngzhìhuì- оzиз очдирмаслиқ; сивдирмаслик”" (喙 huì- 是嘴 shìzuǐ) 嗀 huì олдинлари хитой тилида оғиз деган маънода бўлиб, хозирги кунда 豷 huì ни оғиз деб берилса тушунишмайди . 
“移樽就教 yízūn jiù jiào- салом бериб сабоқ олмож”（樽 zūn- 是酒杯 shì jiǔ bēi）樽 zūn шароб стакани деган маънода, хозирда бу сўз шароб стакани деб кўлланилмайди.

“二坚为虐 èrshùwéinüè- касал бўлмоқ” (坚 shù-是小孩子 shì xiăo hái zi-

坚 shù кичик бола деган маънода). 坚 shù хозир хитой тили ёзув чизиғининг номи бўлиб, «坚 shù I »тик чизиқ маъносида қўлланилади.

б) 一些词的意义有了改变 : Баъзибир сўзларнинг маънолари ўзгариб кетган: Мисол:

“扬汤止沸 yángtāngzhĭfèi-Қайнаётнан қ̧озонни шопириб туххтатмоқ;; масалани умуман хуал құлмислик̧".

固若金汤 gù ruò jīn tāng-мустахฺкам хуимоя қ̧илинган қ̧алъа.

赴汤蹈火 fùtāngdăohuǒ-хавф-хатардан қўрқмаслиқ.

这里“汤”不是今天菜汤的意思, 而是热水或开水 Бу иборалардаги “汤 tāng” бугунки кундаги “ шурва” деган маъносида эмас, балки иссиқ сув ёки қайноқ сув маъносида кўлланилган.

户限为穿 hùxiànwéichuān- кирди-чик̧ди одамлар жуда кўn

家喻户晓 jiā yù hù xiăo-хฺммма одам хабардор бўлмок

千家万户 qiān jiā wàn hù- одамлар билан гавжум; кўп одамлар

这里的“户”是指门。据说，古代双扇开的叫“门”，单扇开的叫“户”。“户枢”是门轴; 一 家一个门，一家也叫一户，“户晓” “万户”就是“家晓”“家万” [马国凡 1973:32]. Бу ерда“户 hù” эиик деган маънода. Айтишларга қараганда, қадимда жуфт қанотли эшикни “门 ménэшик” дейишган, бир қанотли эшикни “户 hù- эшик” дейишган. “户枢 hùshū”эщикнинг ошик--мошиви;

一个门 yígèmén- битma эшик, “一户 yíhù ни бир эшик” хам дейишган, “户晓 hùхiăo хуммла оила”, “万户 wàn hù-кўn оила” деган маънода кўлланилган.

家喻户晓 jiāyùhùxiăo-х̧амма хабардор бўлмоқ̧; 家家户户 jiā jiā hù hù (家至户晓 jiāzhìhùxiăo) -хุамма оила, хฺар бир оила, хฺар бир уй, уйма уй; 千门万户 qiānménwànhù-кy̆n оила деган маънода; 戴高帽子 dàigāomàozǐ[马国凡, 高歌东２000:2] -баланд қ̧алпоқ кийдимоқ;; махтамоқ; ; махтаб иилатмоку.

他这个人就喜欢受人棒承, 别人一给他戴高帽子, 他就找着东南西北了 [汉语成语大全 2017:347]. Бу киши одамларнинг махташини ёқтиради, бошқ̧алар мақтаб қуйса, ўзини қўяр жой топа олмай қуолади.

Хулоса қилиб айтганда, Хитойдаги қадимги Венъянь тил нормалари асосида хозиргача етиб келган юқоридаги иборалар халқнинг ментал мероси хисобланувчи фразеологизмлар тиллар такомиллашуви билан йўқолиб кетмаслигига исбот бўлади.Ёзув шакллари,давлатчилик турлари алмашиб борса-да, халқнинг онгида аждодлардан ўтиб келган ва чуқур илдизларига эга бўлган тафаккур тарзи,унинг жимжимадор безак воситалари ушбу халқнинг оғир-енгил кунларида бархаётлигича яшайверади.

\section{Фойдаланилган адабиётлар руйхати}

1. Г.Э. Хакимова “фразеологик бирликларнинг лингвокультурологик аспекти” Тошкент - 2018 2бет

2. О.В. Чибисова, И.В. Каминская “КОНЦЕПТ «Время»-2019VI Всероссийская научно-практическая конференция «Научная инициатива иностранных студентов и аспирантов российских вузов»

3. 成语 概论 马国凡 内蒙古人民出版社 呼和浩特 1973 年 第 30 页

4. 成语 概论 马国凡 内蒙古人民出版社 呼和浩特 1973 年 第 31 页

5. 成语 概论 马国凡 内蒙古人民出版社 呼和浩特 1973 年 第 32 页

6. 惯用语 马国凡, 高歌东 内蒙古人民出版社 2000 年 2 页

7. 汉语成语大全 北京 2017 年 347 页 


\title{
SOME PARTICULARITIES OF COLLOQUIAL SPEECH OF THE ENGLISH LANGUAGE
}

A.V. Faleyeva

( SamSIFL)

\begin{abstract}
Annotation: The problem of interpretation of term colloquial, main particularities of colloquial speech, features of slang, jargon and colloquial words, the colloquial simplification of words and sentences, the free choice of linguistic means, the usage of emotional coloring of words, the use of exclamation sentences, the indistinct adherence to grammatical structures, logical sequence are analyzed in the article. The article includes analyses of colloquialisms in modern paper and electronic dictionaries. Various examples of colloquialisms as the words of the day and according to thematic groups are given in the article. The peculiarities of different representatives of social and professional groups and the usage of colloquialisms in the speech of this groups are investigated.
\end{abstract}

Key words and expressions: informal speech, colloquial system, conversational language, emotional coloring, grammatical structures

The colloquial speech was investigated by T.M. Belyaev, V.A. Khomyakova, V.D. Bondaletova, W. O Grady, etc. The term colloquialism has no clear boundaries. However, there are some parameters of distinguishing colloquialisms themselves from other components of informal vocabulary.

Let's consider the difference between colloquialisms and slang. Thus, slang refers to words used only by certain social groups. Spoken language is understood more broadly. It may include some slang expressions, but also colloquial words familiar to all native speakers. Thus, colloquial vocabulary can include slang. So, colloquialisms are familiar to the main group of society, while slang is limited to a specific social group. Jargon is used in the speech of people engaged in a certain activity or among people of a certain profession. Jargon includes words used by people working in a specific field or having a common interest.

Let's consider the information about colloquial words from «An Introduction to English Slang A Description of its Morphology, Semantics and Sociology» of Elisa Mattiello: "Consider, for instance, the expressions belly and beer belly: the former is a colloquial term referring to one's 'stomach', while the latter is a slang expression which refers to 'a protruding stomach caused by drinking large quantities of beer', and may also be used as a derogatory definition for people having such a stomach, as in They described $\mathrm{Pa}$ as a beer-belly and said Ma was unfriendly. Similarly, nana is an abbreviation of banana in colloquial English, but, in English slang, it rather refers to 'a foolish or silly person', as in A frank admission that he had made a nana of himself» [Mattiello E. 2008: 38].

The lexicographical sources often show colloquial words and phrases with note colloq as well as infml. as an identifier. There are such definitions of the word «colloquial» as: «1.characteristic of or appropriate to ordinary or familiar conversation rather than formal speech or writing; informal. 2. involving or using conversation» [https://www.dictionary.com/]; «(of words and expressions) informal and more suitable for use in speech than in writing» [https://dictionary.cambridge.org/]; «informal or conversational language, usually culturally specific. Not formal or literary» [https://www.urbandictionary.com/]; «used in or characteristic of familiar and informal conversation; also: unacceptably informal; b: using conversational style a colloquial writer; 2 : of or relating to conversation» [https://www.merriam-webster.com/]. Therefore, despite of different forms of interpretation, the main meaning of the word colloquial «informal, conversational» is general for all definitions. The synonyms of the word «colloquial», such as: «conversational, informal, nonformal, nonliterary, unbookish, unliterary, vernacular, vulgar» are given in the electronic version of Merriam-Webster dictionary [https://www.merriam-webster.com/]. The opinions of scientists about the boundaries of colloquialisms are various.

Spoken language is different from formal speech. Its includes such features as: 
colloquial simplification of words and sentences (details are omitted, repetitions are often used);

free choice of linguistic means (professionalism, jargon, dialects, etc. are included in the spoken language);

the usage of emotional coloring of words;

the use of interrogative and exclamation sentences;

indistinct adherence to grammatical structures, logical sequence.

Dictionaries play an important role in the investigation of colloquial speech. Nowadays there have appeared a lot of printed and electronic versions of dictionaries of colloquial languages. For example, the Urban Dictionary is the electron dictionary that includes colloquial words. Let's enumerate some examples of the words of days:

1) sep 6 word of the day

Steezy - style with ease

For example: Damn that was a steezy ass kickflip son!

2) aug 18 word of the day

Enby (Pronounced (EHN-bee))- based off of the shortening of "non-binary", N.B. A term used by the non-binary/genderqueer community as an alternative to girl/boy.

For example: Are they a girl or a boy?

Neither, they're an enby!

3) aug 16 word of the day

rat-licker - a person who refuses to wear a mask, or take any of the basic precautions to help society prevent an air born illness during an epidemic.(In reference to the bubonic plague being spread by rats.)

For example: I went to the mall for some new underwear, but had to leave. Too many Ratlickers.

The guy's a tiger. Watch out for him [https://www.urbandictionary.com/]

The word of the day helps to investigate more popular colloquial words of the particular time of the English language. These words can have two or more interpretation of the meaning in the dictionary. People are able to vote for the best meaning.

The common words can have other meaning in colloquial language. Let's consider thematic group animals in the electronic version of the Informal ABBYY Dictionary:

1) Tiger in the colloquial language:

What is this tiger juice anyway?

This tiger milk would kill a tiger of any age or disposition.

He was bleary-eyed and shaky after a night of tiger sweat.

2) Cow in the colloquial language:

That cow can hardly get through the door.

She's just a silly cow.

Some tribes use cow chips as fuel.

She is out in the pasture gathering cow flops.

While you're at the store get some more cow juice.

3) Horse in colloquial language:

All the guys wind up hooked on horse.

She is off horse.

I use horse on my vegetables.

They caught him horsing his secretary.

So, colloquialisms are understood as words and idioms of the spoken language used in informal speech and writing, which have an ethical and stylistic degradation of various qualities, which may not entirely appropriate and acceptable in a polite conversation or business correspondence. 


\section{The list of used literature}

1. Mattiello E. An Introduction to English Slang. A Description of its Morphology, Semantics and Sociology.- Milano: Polimetrica International Scientific Publisher, 2008. - 324 p.

2. Informal Dictionary (кверсии ABBY 2006)

3. https://www.dictionary.com/

4. https://dictionary.cambridge.org/

5. https://www.merriam-webster.com/

6. https://www.urbandictionary.com/

\section{ХУШМУОМАЛАЛИК БУЙРУК НУТКИЙ АКТЛАРИНИ ФАОЛЛАШТИРУВЧИ ТУРҒУН ШАКЛДАГИ СЎРОК ГАПЛАР}

\section{Жуманов Вайдулла (Қарии давлат университети)}

Annotation: This article is studied modeled (Will/won't, would/wouldn't/you+Inf..?) interrogative sentences of idiomatical structure which express politeness of imperatives speech acts.

Key words and expressions: modele, interrogative sentences, idiomatical structure, politeness, imperatives, speech acts.

Нутқий фаолиятнинг кечиши мураккаб жараён ва ўз мазмун-мохиятига кўра сўзловчининг тил воситаларидан фойдаланиш жараёни натижасида юзага келадиган ходиса хисобланади. Кўринадики, нутқ онгли мақсад, индивидуал хис-туйғу, муносабатни ифодаловчи жараёндир. Бу жараённинг бажарилишида лисоний бирликлар(гап) структурасида асл маъносидан ташқари, тасдиқлаш, буюриш, маслхат, ижозат, огохлантириш, ваъда бериш, сўраш каби мазмунни ифодалаш имконияти намоён бўлади[Ш.Сафаров,2008,72.б].

Сўроқ гаплар, гап коммуникатив (нутқий актлар) турлари доирасида ўзига хос вазифавий-синтактик тузилиши ва семантик-прагматик хусусиятлари билан алохида худудни эгаллайдилар. Сўроқ гапларининг асосий қисми маълум кўринишдаги структур моделлар негизида эркин таркиб топадиган тузилмалардир.

Аммо сўроқ гаплар тизимида яна бир алохида гурухдаги тузилмалар мавжуд бўлиб, улар таркиби жихатидан турғунлик хусусиятига эгадирлар. Турғун структурага эга бўлган ушбу сўроқ гаплар нафақат тузилиш модели, балки нутқий мулоқот жараёнида бажарадиган вазифалари билан хам эркин таркибли сўроқ гаплардан фарқ қиладилар. Мулоқот жараёнида (матнларда) кенг миқиёсда кўлланиладиган ушбу Will/won't, would/wouldn't/you+Inf..? моделда ясалган турғун шаклдаги сўроқ гаплар матнда буйрук нутқий актлар вазифасида фаоллашади. Ушбу моделдан тузилган турғун шаклдаги сўроқ гаплар сўзловчининг хушмуомалалик, илтимос, таклиф, ижозатни ифодалаб, одатда, адресатнинг истагини хисобга олган холда харакатга ундайди[Хидешели Е.П,2003,16-17.б].

Шуни қайд этиш керакки, ушбу турдаги сўроқ гаплар эмоционаллик нуқтаи назаридан бироз нейтрал хисобланиб, улар одатда хеч қанақа қўшимча прагматик маъноларни англатмайди. Масалан, қуйидаги холатларда назокатли илтимоснинг ифодаланишини кузатамиз: "Will you tell me when we get to the Consulate?" "Will you wait in the hall if I call you next time?"

[Green G-HC, 1987, P. 44].

Бироқ бундай гаплар таркибида for Christ's sake, in God's name каби кириш унсурлари эмоционал охор, ранг- тус бериши мумкин. Масалан: «You are my tower of strength and goodness, Mike,» Antonie said emotionally., "Will you for Christ's sake stop sounding like a literal translation from Racine? " Michael said roughly to hide how deeply Antoine had touched him. [Show I-TH,1983,P. 114]. Ажратиб кўрсатилган гап энди нафақат назокатли илтимосни, 
балки хижолатни, сухбатдошнинг олдинги репликаси туфайли сўзловчида пайдо бўлган саросимани хам ифодалайди.

Will /would/ you +Inf...? модели бўйича тузилган фразеологик таркибли, ижобий маъно англатувчи сўроқ гаплар таркибида kindly, be so kind as to, please каби кириш унсурларини ишлатилиши туфайли ушбу турдаги гаплардаги илтимоснинг назокатлилиги янада ошади. Масалан:

Will /would/ you kindly give me your book?

Will /would/ you be so kind as to give me your book?

Will /would/ you please give me your book?

Will /won't, would, wouldn't/ you+Inf...? модели бўйича тузилган турғун структурали (ижобий шаклдаги) сўроқ гаплар хам коммисив иллокутив кучига хамоханг бўлган таклиф ва тақдим этиш иллокутив кучларини воқелантиради. Мисол учун, агарда адресант олдидан хонада стуллар борлигини билмаса, Will you sit here? таклифи ғалати эшитилиши мумкин эди. Комиссив иллокутив кучи, қоидага кўра, имплицит тарзда хосил бўлади, бироқ муаллиф матнида аниқ воқеланиши мумкин. Масалан:

Instinctively she drew up for woman the comfortable chair. «Will you sit here?» [Pearl S-TN, 1976, P. 356].

Таклиф этиш иллокутив кучининг комиссив иллокутив кучи билан бирикиши қуйидаги гапларда хам намоён бўлади:

«Would you drink a glass of Vermouth? » [Hemingway E-FA, 1976,P. 81];

"Will you have a cigarette?» [Hemingway E -FA, 1976,P. 72].

Won't you + Inf...? модели бўйича тузилган турғун структурали салбий-сўроқ гаплар, will you қабилидаги ижобий сўроқ гаплардан фарқли ўлароқ, ўзининг коммуникативсемантик тузилишида адресатга йўналтирилган харакат хақидаги дастлабки тахмин унсурини сақлайди[В.С.Храковский В.С, 2001, 215.б]. Бошқача қилиб айтганда, сўзловчи адресат томонидан унга буюрилган, айтилган харакатни бажаришга қандайдир ички шай холатида турибди. Масалан, таклиф маъносидаги: Won't you join us? гапини қуйидаги тарзда изохлаш мумкин: Won't you join us $\rightarrow$ I suppose, that you will join us.

Шундай қилиб, турғун структурали салбий-сўроқ гапларни қўллаш орқали адресат ўз таклифи ёки илтимосининг бажарилишига маълум бир ишончини ифодалайди. Ижобийсўроқ гаплар эса бундай ишончни англатмайди. Масалан Will you stay tonight [Green G$Q A, 1983, P .26]$ гапини қуйидаги тарзда ўзгартириш мумкин: I don't know if you stay tonight or not.

Won't you +Inf...? модели бўйича тузилган турғун структурали салбий-сўроқ гаплар айрим холатларда адресант томонидан бир неча марта мурожаат қилиб айтилган илтимосни адресат бажаришни хохламаслигини англатиши мумкин [ Jespersen O, 1958, 304.б].

Масалан:

"We got to go. We can't stand this no more.»

«Just stay till spring,» Ma begged. «Just till spring. Won't you stay till spring? Who'd drive the truck?» [Steinbech J-GW,1976, P.468].

Келажак харакатга тегишли бўлган савол ёрдамида салбий илтимосни ифодалаш имконияти йўқлиги хам қизиқарли фактдир. Бошқача қилиб айтганда, Don't take out the garbage буйруқ маъносини, Won't you take garbage? гапи ёрдамида хам, Will you take out the garbage? гапи орқали хам етказиб бўлмайди[ Кукаркина Н. А, 2011, 60-69 .б].

Шундай қилиб, Will /won’t/ you+Inf.....? модели бўйича тузилган турғун структурали салбий-сўроқ ва ижобий сўроқ гаплар фақат ижобий илтимосни ифодалаши мумкин.

Would /wouldn't/ you like /care/+N/Inf/Ger...? модели бўйича тузилган турғун структурали сўроқ гаплар адресатнинг харакатни бажариш хохиш-истаги тўғрисидаги саволни ифодалаб, таклиф иллокутив кучини хосил қилади: «Would you like to take Francis and go and play with Natta weeks?» [Pearl B-TN, 1976, P. 18]. Кўриниб турибдики, бу турдаги гаплар жуфт иллокутив куч-таклиф ва комиссив иллокутив кучларини хосил қилиши мумкин. 
Хулоса ўрнида шуни таъкидлаш жоизки, маълум моделлар асосида ясалган турғун шаклдаги сўроқ гаплар таркибида биринчи шахс бирлик олмоши мавжуд бўлганида таклиф иллокутив кучини хосил қилади. Бундай гапларда таклиф ва коммисив (ундов) иллокутив кучи уйғунлашиб, иллокутив маъно синкретизм кўринишида фаоллашади ва ушбу турдаги гаплар хушмуомалалик кўлланишидаги нутқий актлар таклиф, ижозат, маслахат, илтимос маъноларида воқеланади.

\section{Фойдаланилган адабиётлар руйхати}

1. Есперсен О. Философия грамматики .-М. Изд-во иностр. Лит-ры. 1958.- 404 с.

2. Кукаркина Н. А. Речевая этика и вежливость. Русская словесность. - 2011. - N 4. - С. 60-69.

3. 3.Сафаров Ш. Прагмалингвистика. «Ўзбекистон миллий энциклопедияси» Давлат илмий нашриёти, -Тошкент: 2008. 286-б.

4. Хидешели Е.П. Функции коммуникативных типов предложения в современном английском языке: Автореферат. Дис . ... канд. Филол. Наук. - Пятигорск 2003. -18 с

5. Храковский В.С., Володин А.П.Семантика и типология императива. Русский императив. Изд.2.2001. 272 .

6. Green G. The Honorary Consul. - Great Britain: Penguin Books Ltd, 1987. - 268p.

7. Greene G. The Quiet American. - Great Britain: Penguin Books Ltd, 1983. 168p

8. Hemingway E . A Farewell to Arms. - Moscow: Progress Publishers, 1976.- 319 p.

9. Pearl S. Buck. The Time is Noon. - N.Y.: John Day Company, 1976. -359p.

10. Shaw I. The Top of the Hill. - London: New England Library, 1983. - 320p.

11. Steinbeck J. The Grapes of Wrath. - USA: Penguin Books, 1976. - 502 p.

\section{РОЛЬ АНГЛИЙСКОГО ЯЗЫКА В ОБОГАЩЕНИИ УЗБЕКСКОЙ ЛЕКСИКИ С ПОМОЩЬЮ ЗАИМСТВЕННЫХ СЛОВ}

\section{Хасанова Камила Бахтиёровна (Термезкий государственный университет)}

Annotation: The lexical composition of the language considered the most variable and constantly changing language component. This change, associated with the enrichment of the language, reflects various historical periods in the development of society. The process of enrichment refers primarily to the process of borrowing words from other languages. The development of science and technology, international contacts in various fields contribute to the emersion of new words into the language. This article discusses the process of lexical enrichment of the Uzbek language with international vocabulary through the English language.

Key words and expressions: language, enrichment, vocabulary, translation, contact, borrowings, English -international words, phonetics, grammatical structure, socio-historical process, borrowed words.

Известный факт что, язык играет важную роль в жизни каждого человека. Невозможно представить, что было бы, если бы на Земле не существовало такого многообразия языков. При помощи языка люди понимают друг друга - язык выполняет коммуникативную функцию. Помимо этого язык отражает менталитет народа. То, что свойственно той или иной национальности, всенепременно отразится и на языке.

Наш родной узбекский язык обладает множеством форм, он очень сложен для освоения. Большинство людей, которые занимается его изучением, отмечают, что он весьма непрост для понимания.

Отмечено что в конце XIX и в течение XX веков в связи с усилением общественноэкономического контакта в среднеазиатские языки как и в узбекский язык поступают слова английской лексики и интернациональной лексики. 
Приток этой лексики (главным образом, связанной глобализацией и научной терминологии) с каждым годом все более и более увеличивается, он продолжается и в наши дни. В современном узбекском языке количество заимствований равняется запасу собственно узбекских слов.

Заимствования слов происходило во все эпохи. Уже в древности существовали так называемые слова путешественники, которые вместе с обозначаемыми предметами переходили от народа к народу, от языка к языку.[6.С.176].

Целью статьи, это рассмотрение некоторых заимствований и их влияния в узбекский язык. Ясно что, лексическую основу современного узбекского языка, составляют несколько языков тюркской группы и также, история возникновения и развития узбекского языка тесно переплетается с историей его носителей. Появление такой нации, как узбекский народ, было обусловлено процессом слияния ряда этнических групп, средством общения которых были тюркские и иранские языки. Этим объясняется большое количество диалектов в узбекском наречии, между которыми наблюдается огромная разница.

Давайте рассмотрим классификацию по популярным тематикам заимствования из русского языка, наиболее прижившиеся в узбекском:

\section{Заимствованные слова использующие в повседневной речи :}

кино, зоопарк, цирк, телевизор, радио, артист, шоколад, журнал, шарф, автобус, центр, клуб, саммит, рейтинг, блендер, шампунь, триллер, троллейбус, трамвай ,ток-шоу, селфи, сквер, саундтрек, репортаж, рейтинг, парковка, кросворд, плейлист, бестселлер,президент

\section{Слова относящие к компьютерным технологиям}

компьютер, инновация, вай-фай, флешка, пайнет, монитор, дисплей, калькулятор, ноутбук, принтер, сканер, CD, DVD, процессор, хакер, Интернет, сайт, блог, , SMS логин, дисплей, ноутбук, пост, трафик,

\section{Слова относящие к бизнесу}

Аутсорсинг, бренд, брокер, дедлайн, дилер, инвестор ,лизинг, менежмент, пиар, прайзлист, релиз, риелтор, стартап, холдинг, бизнес, бизнес план, акция, дивиденд ,кредит,бюджет,банк,корпорация,

\section{Слова относящие к еде}

Фастфуд, хот дог ,джем, крекер, ростбиф, чипсы, фри, гамбургер, чизбургер, поп- корн, йогурт, кола, спрайт, пудинг ,шоколад ,майонез, вино, лимонад, ки-эф -си,

\section{Слова относящие к моде}

Джинсы , клатч, леггинс, свитер, смокинг, стреч, мейкап, жемпер, секондхенд, шарф, шорты, клеш, блуза, кардиган, жакет, поло,туника,блейзер,

Актуальность данного исследования заключается в том что, история заимствований более чем какая-либо другая область словарного состава тесно связана с историей народа в его отношениях с другими народами. При процессе заимствования значение какого-либо слова часто сдвигается. Бывает и так, что заимствованное слово возвращается в своем новом значении обратно в тот язык, из которого оно пришло. Общепринято считать, что для вхождения слова в систему заимствующего языка требуются следующие условия:

передача иноязычного слова фонетически и грамматически средствами заимствующего языка;

- соотнесение слова с грамматическими классами и категориями заимствующего языка;

- фонетическое и грамматическое освоение иноязычного слова;

- словообразовательная активность слова;

- семантическое освоение, а именно, определенность значения, дифференциация значений и их оттенков между существовавшими в языке словами и заимствованиями;

· регулярное употребление в речи.[7.С.58].

Для того чтобы стать заимствованием, пришедшее из чужого языка слово должно закрепиться в новом для себя языке, прочно войти в его словарный состав. 
Согласно статье Давлятовой Э.М. «В современных исследованиях заимствованные слова представляют собой специфическую систему с точки зрения фонетического состава, структуры, смысловой нагрузки, поэтому их правильное использование вызывает затруднение на первых порах. Адаптация заимствованных слов проходит в несколько этапов - фонетический, графический, морфологический и лексико-семантический.» [2.C.355].

Все интернациональные заимствования, принимаемые без каких-либо фонетических изменений, способствуют обогащению не только лексики национальных языков, но также его фонетического и грамматического строя.

Осваивается произношение заимствованных слов со стечением двух или нескольких согласных в разных позициях (например: класс, романс, рентген, регресс, пунктуация, аванс, портрет, астрономия и др.), что не характерно для узбекского языка.

В составе заимствованных слов узбеки усваивают некоторые суффиксы и приставки, отсутствующие в родном языке. Таковы, например, суффиксы -ист (активист, педантист, ра-дист), -изм (идеализм, феодализм, капитализм), -онер (акционер, реакционер), фикация (электрофикация, классификация), -ер (актер, комьпютер, принтер), -тор (директор, администратор , инструктор), -ант (консультант, лаборант); приставки авто(автозаправка, автомашина, автограф), анти- (антибиотик, антифашист,

антигриппин), экс- (экс-чемпион, экскурсия) и др

В заключении можно сделать выводы что, самым изменчивым языковым компонентом, постоянно меняющимся, считается лексический состав языка. В этом изменении, связанном с обогащением языка, отражаются различные исторические периоды в развитии общества. К процессу обогащения относится, прежде всего, процесс заимствования слов из других языков. Развитие науки и техники, международные контакты в различных сферах способствуют притоку новых слов в язык. Таким образом, следует отметить, что под влиянием происходивших различных общественно-культурных событий идет активный процесс развития и обогащение узбекского языка. Что касается лексики вышеуказанных слов, то также требуется постоянная работа над смыслом этих слов. Только в этом случае обучающиеся глубже усвоят значение употребляемых английских и интернациональных слов.

\section{Список использованной литературы}

1. Ахманова О.С., Задорнова В.Я. Лингвистические проблемы перевода. //Сборник статей.- Москва,- МГУ,- 1998. С.73

2. Давлятова Э. М. Заимствование в контексте лингвокультур //Евразийский научный журнал. - 2017. - №. 2. - С. 355-356.

3. Жерибило Т.В. -Словарь лингвистических терминов -Назрань , изд.ООО «Пилигрим»-2010,-С. 107.

4. Крысин Л. П. О русском языке наших дней. URL: http://www.philology.ru/linguistics2/krysin-02.htm,

5. Худайкулов А. Э. Семантическая адаптация некоторых английских заимствованных слов в русских письменных памятниках XVII-XIX веков //Вестник Челябинского государственного университета. - 2011. - №. 28.

6. Шайкевич А.Я. Введение в лингвистику- изд. «Академия»-Москва-2005, С.176.

7. Ярцева В.Н.- Большой энциклопедический словарь- Языкознание - // Научное издательство-«Большая Российская энциклопедия» -Москва 1998.С.158. 


\title{
ҚАРАҚАЛПАҚ ХАЛЫК ЖУМБАҚЛАРЫНДА ЭЛЛИПСИС КОНСТРУКЦИЯЛАР
}

\section{Наўбетуллаева Эльмира (Нукус давлат педагогика институти)}

\begin{abstract}
Annotation: There are ellipsis sentences in the karakalpak folk riddles and there are given their own differences.
\end{abstract}

Key words and expressions: short sentences, ellipsis sentences, rhyme, rhythm, econ.

Эллипсислик толық емес гәплер тилимизде стилистикалық жақтан анықлық хәм сөзлерди үнемлеў ушын қолланылатуғын қубылыс сыпатында белгили. Эллипсислик толық емес гәплерде баянлаўышлар қолланылады яғный баянлаўыш өз хызметин гәптеги басқа сөзге жүклеп. оның орны белгисиз болып қалады хәм турақласып бара береди, бул қубылыс әсиресе сөйлеў тилине тән.

Халық аўызеки дөретпелери де халықтың сөйлеў тили негизинде келип шыққан, соның ишинде жумбақлар да халық аўызеки дөретпелериниң бири болып, оларда эллиптикалық конструкцияларды көплеп ушыратыў мүмкин.

Тил мудамы ықшамлықты талап етеди. Бул айтылажақ пикирдиң дәл айтылыўын тәмийнлейди. «Толық емес гәплердиң баянлаўышсыз қолланылыўы- бул да стильлик жақтан қәлиплескен, мәнилик жақтан түсиникли, структуралық жақтан толық болмаса да гәптиң бул түри ушын әдеттеги нормаль жағдай» болып есапланады ${ }^{33}$. Тилимизде әсиресе, жумбақлардағы эллипсислик конструкциялар айрықша дыққатты аўдарады.

Қарақалпақ халық жумбақларында олардың төмендегише түрлерин көриўимизге болады.

Жайса көлдей, жыйса тенцей (Шатыр)

Аўзы астында, көзи үстинде (Бекире)

Мине, бул жумбақларда «болады» деген сөз яғный баянлаўыш гәп ағзасы түсирилип қалдырылган, бирақ гәптиң улыўма мазмунында кемислик сезилмейди. Сонлықтан, айтылмаған ямаса түсирилип қалдырылған баянлаўышты гәпте қосып айтыўдың хеш қандай зәрүрлиги жоқ хәм оны талап та етпейди. Буның менен гәптиң бир қанша ықшамлығы бузылады, өткирлиги, күшли тәсирлилиги бир қанша кемейеди.

Эллипсислик толық емес гәплердиң өзине тән өзгешеликлери бойынша өзбек тил билиминде Н.М.Махмудовтың [Махмудов: 15]; азербайжан тилинде А.Я.Мамедовтың [Мамедов; 18]; ал рус тил билиминде С.А. Зимнухованың арнаўлы изертлеўлери бар.

Эллипсислик конструкциялар жумбақларда көплеп ушырасады. Буның баслы себеби, халықтың сөйлеў тилинен пайда болған халық аўызеки дөретпелери бир неше әсирлер даўамында қайта исленип халық тәрепинен дөретилип барылған. Халық аўызеки дөретпелеринде соның ишинде жумбақларда да артықша сөз қолланылмай, бир сөз бир неше мәртебе тәкирарланбаўы, айтылажақ пикир тыңлаўшыға анық хәм дәл жетип барыўын тәмийнлеўде әхмийетке ийе.

Қарақалпақ халық жумбақларында эллипсислик конструкциялар өзине тән өзгешеликлер менен ажыралып турады. Әсиресе, жумбақлардағы қатарлардың уйқасларын тәмийнлеў ушын хызмет етеди. Мысалы.

Териси пулдан

Көзлери нурдан

Суў ишпейди құолдан. (сазан)

Бунда 1-2-қатарларда «болады»» баянлаўышы түсирилип қалдырылған, егер толық түрде берилгенде «териси пулдан болады, көзлери нурдан болады» деп айтылып, бир сөздиң өзи еки рет қайталанып көркемликке кери тәсирин тийгизеди. Ал 3-қатарда ишпейди баянлаўышы уйқасты тәмийнлеў ушын гәптиң басына шыққан Негизги гәп ағзаларының

\footnotetext{
33 .Хазирги қарақалпақ әдебий тилиниң грамматикасы. Синтаксис,Нөкис 1992.
} 
орнында турғанда яғный қолдан суў ишпейди болып айтылғанда бул жумбақ уйқасқа қурылмас еди. Нәтийжеде көркемлик бузылады.

Демек, жоқарыда мысал етип алынған жумбақтағы эллипсислик конструкциялар бириншиден, жумбақта қайталаўға жол қоймай турған болса, екиншиден, ықшамлықты тәмийенлеп тур, ал үшиншиден, жумбақ қатарларындағы уйқасқа келтирип ырғақ пайда болыўына жәрдем берип тур. Ал ырғақтың хәм уйқастың болыўы- бул жумбақтың адамның ядында сақланыўында өз тәсирин тийгизеди.

Қарақалпақ халық жумбақларында эллипсислик конструкциялар дүзилиси бойынша төмендегише болады:

1. Баслаўыш пенен толықлаўыштың өз-ара мәнилик байланысынан дүзилген эллиптикалық толық емес гәплер. Мысалы:

Териси пулдан, көзлери нурдан. (сазан)

2. Баслаўыш пенен пысықлаўыштың өз-ара мәнилик байланысынан дүзилген эллиптикалық толық емес гәплер. Мысалы:

Өзи суўдың астында, көзи суўдың бстинде (балық).

3. Баслаўыш пенен анықлаўыштың өз-ара мәнилик байланысынан дүзилген эллиптикалық толық емес гәплер. Мысалы:

Айналасы шардай,

Түси қ̧андай,

дәми палдай (шийе).

Өзи қ̧ара, сөзи ақ (тахта-пор).

4. Пысықлаўыш пенен анықлаўыштың қатнасынан.

Жас күнинде орақтай, орта жаста шөректей (ай).

5. Толықлаўыш пенен анықлаўыштың қатнасынан.

Сүттен тынық, пахтадан ақ

(қ̧ap).

Таўдан бийик, теңчизден терен

(қылл).

Таўдан бәлент, сайдан терен (ақыыл).

6. Пысықлаўыш пенен баслаўыштың мәнилик қатнасынан дүзиледи. Кеште қьысыр, күндиз буўаз (етик)

7. Шәрт пысықлаўыш пенен анықлаўыштың қатнасынан

Жатса жабадай

Турса түйедей. (пемахана)

Жайса көлдей

Жайса теңдей (Шатыр)

8. Айырым жумбақлар өзине уқсас нәрсеге теңелип баслаўыш пенен баслаўыштың мәнилик қатнасынан дүзиледи.

Атасы палўан,

Анасы жорва,

Баласы ойыншы

(көпир, суў, бальюқ, бақ̧а).

Қызыз қосықщшы

Басы тарақ қуйрывы орақ (қ̧ораз).

9. Жумбақта тек ғана анықлаўышлардың қатнасынан дүзилген эллиптикалық толық емес гәплер де ушырасады

Еки басль, алты аяқль,

Бир куйрықлы, еки қ̧олль (атқ̧а минген адам).

Эллиптикалық гәплер айтылыў интонациясы да толық гәплерге салыстырғанда бир қанша күшли хәм тәсирли болады. Баянлаўыш түсирилип қалдырылған сөзден алдыңғы сөз бир қанша көтериңки айтылады. Буның баслы себеби дыққат сол нәрсеге қаратылғанлығында. 
Солай етип, қарақалпақ халық жумбақларындағы эллипсислик гәплердиң қурылысы бойынша ықшамлығы, айтылыўына аңсатлық туўдырыўы, ядлаўға қолайлылығы менен өзине тартады. Өз гезегинде бул жумбақлардағы уйқасты, ритмди тәмийнлейди. Соның менен бирге, сөзлерди қолланыўда тек ғана бир сөзди қайталаныў болмаў, көркемлигин күшейтиў, адам санасына анық, дәл жетиў, жумбақтың шешимин тез табыў ушын қолланылған.

\section{Пайдаланылған әдебиятлар}

1. Зимнухова С. А. Безглагольные эллиптические конструкции в их соотношении с грамматическим строем языка.АКД, Барнаул, 2011.

2. Махмудов Н.М. Эллипсис в узбекском языке. АКД, Т, 1977.

3. Мамедов А.Я. Эллипсис в азербайджанском языке АКД, Баку, 1981

4. Хәзирги қарақалпақ әдебий тилиниң грамматикасы. Синтаксис, Нөкис 1992.

\section{ГАПЛАРНИНГ КОММУНИКАТИВ ТУРЛАРИ. СЎРОК ГАПЛАРНИНГ КОММУНИКАТИВ ТУРЛАРИ ВА УЛАРНИНГ ВАЗИФАЛАРИ}

\section{Жуманов Вайдулла (Қарши давлат университети)}

Annotation: The article deals with the communicative types of sentences, formal-syntactic structure and semantic-pragmatic features, mainly the composition of interrogative sentences on the basis of certain structural models, communicative aspects of interrogative sentences and pragmatic meanings expressed through interrogative sentences, determining the scope of speech acts. functions, regardless of the communicative purpose, they are divided into three general categories, ie message, interrogation, command meaning interrogative buy interrogative and imperative sentences, including the following intermediate communicative type sentences with mixed communicative purpose: interrogation; interrogation; command; command-line; interrogation-command; command is a common phenomenon in the system of communicative types of speech, which includes interrogative sentences, a mixture of grammatical signs and communicative relations within a single sentence. In dialogic interrogative sentences, their main function is to obtain information, and it is observed in the analysis of this article that such statements express command, request, fear, rebuke, advice, message, and wonder in a particular context.

Key words and expressions: communication, interrogative pronoun, interrogative pronoun, imperative pronoun, autative pronoun, formal-syntactic, semantic-pragmatic, syntactic-semantic.

Гап тилнинг коммуникатив бирлиги сифатида, энг аввало, сўзловчи томонидан маълум мақсад билан айтиладиган ахборотни ифодалай олиши билан тавсифланади. Коммуникациянинг аниқ мақсадлари жуда хам хилма - хилдир, бироқ бундай турлитуманликдан қатъий назар улар учта умумий категорияга, яъни хабар, сўроқ, буйрук маъносини англатадиган дарак, сўроқ ва буйруқ гапларга бўлинадилар. Ушбу гаплардаги асосий мақсад маълум бир воқеа, ходиса тўғрисида маълумот бериш, тингловчининг ушбу гапнинг мазмунига боғлиқ бўлган жавоб беришга ундаш ва уни бирор бир харакатини бажаришга чақиришдан иборатдир. Айтиш жоизки, гапларнинг юқорида эслатилган уч тоифали коммуникатив таснифини тадқиқотчиларнинг хаммаси хам тўғридан-тўғри қабул қилавермайди. Анъананавий учлик таснифи турли тамойилларга асосланиб, бир-бирига қарама-қарши кўйилади. Зеро, дарак ва сўроқ гаплар функционал кўрсаткичига нисбатан ажратилса, буйруқ эса соф функционал хусусият бўлмасдан, балки истак модал маъносига хам тегишлидир[Демидова 2005:16]. Шу боис айрим тилшуносларнинг гапларни коммуникатив турдаги дихотомик тизим тарзида тасвирлашга бўлган уринишлари тушунарли. Бинобарин, М.В.Никитин гапларнинг турини эмас, нутқ турларини ажратиб, дарак нутқни буйруқ нутқига қарама - қарши кўяр экан, сўроқ нутқини буйруқ-истак 
нутқининг бир тури сифатида талқин этади, чунки иккала холатда хам бирор бир харакатга ундаш мақсади ифодаланади[Никитин 2007: 517]. Бошқача айтганда, М.В.Никитин хар иккала холатда хам буйруқ ёки истак борлигини таъкидлайди. Масалан: Биринчи холатда сўроқ гапга жавоб бериш истаги мавжуд бўлса, иккинчи холатда ундалаётган харакатни бажариш истаги борлиги назарда тутилади.

Шунинг билан биргаликда, буйруқ ва сўроқ гапларнинг коммуникатив вазифасида хам ўхшашлик мавжуд, яъни уларнинг хар иккаласи хам тингловчини бирор-бир харакатга ундайди. Шу боис бўлса керакки, ушбу турдаги гаплар, дарак гаплардан фарқли равишда, асосан диологик нутқда учрайдилар. Дарак ва сўроқ гаплари ўртасида маълум даражада умумийлик мавжуд, чунки уларнинг иккаласи хам предмет ва ходисалар ўртасидаги муносабатларни тавсифлаш хусусиятига эга. Шу боис бу турдаги гапларда модалликнинг ифодаланиши эркиндир. Буйруқ гапларининг кўлланиши эса доимо имкониятдаги модаллик билан боғлиқ. Айнан шу хусусиятлар ва буйруқ гапларининг субъекти формал ифода топмаслигини инобатга олган холда Л.А.Бархударов буйруқ гапларини бошқа гапларга қарама-қарши кўяди[Бархударов 1966 :172].

Сўроқ ва буйруқ гаплари умумий хислатларга эга бўлишидан қатъий назар, охирги турдаги гапларнинг ўзига хос хусусиятлари айниқса коммуникатив мақсадни воқелантириш шароитида аниқ кўзга ташланади.

Ажратилаётган уч функционал турга кирувчи гапларнинг фарқи коммуникатив мақсад фаоллашувида намоён бўладиган сухбатдошлар муносабатида ўз аксини топади. Сўзловчи дарак гапи воситасида маълум ходисалар ўртасидаги муносабатларни таъкидлайди. Демак, ушбу гапнинг коммуникатив мақсади сухбатдош тамонидан узатилган ахборотни қабул қилишга йўналтирилган. Тингловчининг бошқа хатти-харакатлари гап грамматик маъноси билан боғлиқ бўлмасдан, балки нутқ вазияти, гапнинг аниқ мазмунига тобедир. Буйруқ семантикаси хам бирор бир ходиса, факт таъкидини инкор қилмайди. Лекин талаб қилинаётган жавоб харакати кўпинча мажбурийдир, чунки ушбу харакатнинг бажарилиши ёки олдиндан режалаштирилади ёки унинг ижросига розилик (норозиликни) билдиришни сўрайди. Сўроқ гапларнинг грамматик маъноси эса сухбатдошдан дарак гап шаклидаги ёки паралингвистик элементлар воситасидаги жавобни кутади. Демак, коммуникатив мақсад ифодаси ва қўлланиш қоидалари жихатидан дарак, сўроқ ва буйруқ гапларига бир хил мундарижа хос бўла олмайди.

М.Я.Блох. дарак, сўроқ ва буйруқ гапларни асосий коммуникатив турдаги гаплар деб хисоблаб, улар қаторига аралаш коммуникатив мақсадни кўзловчи оралиқ коммуникатив турдаги қуйидаги гапларни хам киритади: дарак-сўроқ; сўроқ-дарак; дарак-буйруқ; буйруқдарак; сўроқ-буйруқ; буйруқ - сўроқ гаплар [Блох 2000: 108-112]

Ю.А.Егорова хам, судья ва гувох ўртасидаги диалогик мулоқот матнини ўрганаётиб, унинг таркибида ифодаланаётган коммуникатив мақсадни кўзловчи оралиқ коммуникатив турдаги гапларни ажратади: сўроқ-буйруқ; буйруқ-сўроқ; дарак-буйруқ [Ю.А.Егорова 2002:10-13]. Масалага бундай ёндашув дарак, сўроқ ва буйруқ гаплар ўртасидаги чегаранинг харакатчанлигини очиб беради ва маълум даражада гапларнинг нутқда актуаллашиб, ўзининг бевосита туб вазифасини йўқотиб, ўзига хос бўлмаган функцияларда қўлланилиш холатларини тушунишга ёрдам беради. Л.П.Чахоян, М.Я. Блох, Егорова томонларидан таклиф этилган гаплар коммуникатив турлари таснифининг ижобий тарафларидан бири уларнинг анча даражада батафсиллиги бўлиб, бу тил тизимида мавжуд бўлган гапларнинг коммуникатив-семантик гурухларини тасаввур қилиш ва уларнинг коммуникатив мохиятини аниқлаш имкониятини беради. Бироқ, улар, пировард натижада, анъанавий учликка (дарак, сўроқ, буйруқ) асосланган.

Шу боис, бизнинг тадқиқотимизда содда гапларнинг тўртта мустақил тури ажратиладиган тасниф асос қилиб олинган бўлиб, унга биноан дарак, сўроқ, буйруқ ва оптатив гаплар атрофида фикр юритамиз.

Маълумки, хар хил турдаги коммуникатив гапларни ўзаро боғлайдиган туташ нуқталар мавжуд: сўроқ гапларни дарак ва оптатив гапларга ахборот етказиш жараёни 
якинлаштиради, уларни буйруқ гаплар билан эса сухбатдошни қандайдир харакатга кўзғатиш дақиқаси бирлаштиради. Бироқ, улар орасида фарқлар хам мавжуд: оптатив гаплар буйруқ гаплардан фарқли ўлароқ адресатнинг эркинлигига таъсир этмайди; сўроқ ва буйруқ гаплар оптатив гаплардан фарқ қилиб, адресат томонидан лисоний ифодаланган жавоб ёки бошқа бирор кўринишидаги жавоб харакатини талаб қилади.

В.Г.Гакнинг фикрича, модаллик жихатидан гап коммуникатив турлари ўзаро фарқланадилар, хусусан, дарак ва сўроқ гаплар модалликка нисбатан бефарқ, яъни улар истаган майлда бўлиши мумкин. Буйруқ ва оптатив гаплар эса муайян модаллик мазмуни билан боғланган бўлади (буйруқ гаплар-императивда, оптатив эса-истак майлида) [Гак 2000:124]. Бундан ташқари, содда гапларнинг тўртта мустақил тури ажратиладиган тасниф мохияти жихатидан функционал хусусиятли эмас. Улар кўпроқ структуравий жихатдан фарқланадилар. Шунинг учун хам баъзи бир турдаги гаплар коммуникатив мавқеига мос бўлмаган мазмунни ифодалашига хайрон қолиш керак эмас. Хусусан, дарак гаплар ўзига хос интонация орқали саволни ифодалаши хам мумкин: You will come here tonight. You will come here tonight? Ўқитувчининг ўқувчига буйруғи: There's little chalk left- Bring some more chalk ва хоказо.

Сўроқ гаплар таклифни What about a cup of tea? $\rightarrow$ Have a cup of tea; маслахатни: Why don't you take an aspirin? $\rightarrow$ I advise you to take an aspirin; таънани: How dare you to speak with your mother like that? $\rightarrow$ You shouldn't speak with your mother like that ифодалаши хам мумкин.

Гап коммуникатив турлари тизимида ягона гап доирасида грамматик белгилар ва коммуникатив муносабатларнинг чатишиши кўп учрайдиган ходисадир. Бунинг натижасида гап ўзининг коммуникатив мавқеи асосида аралаш белгиларга эга бўлади [М.Я. Блох 2000: 20]. Сўроқ гапи кўп маъноли ва хар хил коммуникатив хусусиятларга эга, маълум бир диологик контекстда буйруқни, илтимосни, кўрқувни, таънани, маслахатни, хабарни, хайратни ифода этиши доимо кузатилади.

\section{Фойдаланилган адабиётлар руйхати}

1. Демидова И.А. Средства выражения побудительной модальности в русском и английском языках (на материале газет): Дисс. канд. филол. наук. - Калининград, 2005.23c

2. Бархударов Л.С. Структура простого предложения современного английского языка.- М. Высшая школа. 1966.-200 с.

3. Блох М. Я. Теоретические основы грамматики Текст. / М. Я. Блох. -М. : Высш. шк., 2000. $160 \mathrm{c}$.

4. Егорова Ю.А. Прагмастилистический аспект коммуникативного контакта: автореф дис... канд. филол. наук. -Тула. 2002-19 с.

5. Никитин М.В. Курс лингвистической семантики. Учебное пособие СанктПетербург Издательство: РГПУ им. А.И.Герцена, 2007-819 с.

6. Чахоян Л.П. О признаках высказывания \ Значение и смысл речевых образований. -Калинин: Изд-во Калининск.ун-ва.1979 а.-С. 121-126.

\section{COMPARATIVE ANALYSIS OF ADJECTIVES IN ENGLISH AND UZBEK LANGUAGES}

\section{P.I.Khotamova (SamSIFL)}

Annotation: Quality refers to the character of the horse and tells us what the horse is like.

1. (what car?) - Yellow car.

2. (what car?) - Small car.

3. (What car?) - Strange car.

4. (what car?) - Useless car. 
The words "yellow," "small," "strange," and "useless" above are called adjectives in grammar. There are 3 different levels of quality: normal level, comparative level and incremental level. Let's put the following three cars in three levels of goodness.

Key word and expressions: suffix, simple sentence, grammar, comparative, adjective.

All three are good cars, but we need to rank these three as good, better, and best cars. Let's start with the simplest: (what car?) This is a good car. "Good" is a simple quality. Better car (what car?) This is a better car. "Better" is a comparative quality. We created this quality by comparing the current machine to the previous machine. One car was better than the other.bestcar (what car?) This is the best car. "The best" is the quality of the sixties. Accumulated quality is created by comparing two or more things and choosing one of the BEST, MOST BEAUTIFUL, MOST BIG, MOST, MOST, MOST.... In English, adjective, as in Uzbek, means a sign of a horse. In English, quality is always used before the horse. For example: small car, important subject. There are two types of adjectives in English: single-syllable and multi-syllable. For example: small car - a singlelink quality; important subject - a multi-link quality. As mentioned above, there are three levels of quality: simple, comparative, and incremental.

\section{LEVEL OF ONE-LINKED QUALITIES}

1. At the simple level of one-syllable adjectives, no addition is added to the adjective, and the adjective itself is written. For example: Small car - a small car. Big garden - big garden. Strong man is a strong man.

2. At the comparative level of one-syllable adjectives, the suffix "-er" is added to the adjective. This suffix corresponds to the Uzbek suffix "-roq". For example: Smaller car is a smaller car. Bigger garden is a bigger garden. Stronger man is a stronger man.

3. To make the accrual level of one-syllable adjectives, the suffix "-est" is added to the adjective, and the definite article "the" is always placed before the adjective at the accusative level. The suffix "-est" in English corresponds to the word "eng" in Uzbek. For example: The smallest car - the smallest car. The biggest garden. The strongest man is the strongest man.

\section{LEVELING OF MULTIPLE-LINKED QUALITIES}

1. At the simple level of multi-syllable adjectives, no addition is added to the adjective, the adjective itself is written. For example:

Important subject - important fan. Beautiful girl - beautiful girl. Difficult task.

2. To make a comparative level of multi-link adjectives, the word "more" is placed before the multi-link adjectives. This corresponds to the Uzbek suffix "-roq". For example: More important subject. More beautiful girl. More difficult task.

3. At the cumulative level of multi-syllable adjectives, the adjective is preceded by the definite article "the" and the word "most". In this sense, it corresponds to the Uzbek word "eng". For example: The most important subject. The most beautiful girl. The most difficult task.

\section{CHARACTERISTICS}

The grading of some adjectives in English does not follow the above rules. Such qualities are created through a complete change in the core of quality.

Conclusion: Superlative does not tolerate any comparison. He stands above all and does not hide it, for he is the most, the most. Before embarking on the formation of new forms of proportion, it is necessary to ask, comparatively and perfectly, how many syllables a word has. Depending on the next answer, two methods of teaching are distinguished: If a word consists of one or two syllables, the exact article is added to it and the ending -est: clean - the cleanest (clean - the cleanest), great - the biggest (great - the greatest), sharp - sharp (sharp - sharp). If a word consists of three or more syllables, an additional word will appear in front of it with the most or least definite article: thin - the thinnest (terrible - the thinnest), terrible - the most terrible (terrible - the most terrible), difficult - the most difficult (difficult - the most difficult). If adjectives consisting of one or two syllables end with a dumb vowel sound, it falls when you add the vowel or -est numbers: cute cute - cute (cute - cute - cute). If the short adjective ends with -y, this letter changes to -i with the addition of -er or -est: hungry - hungry - ochgriest (hungry - opener - hungry). When a short 
consonant ends with a vowel and a vowel consonant, when the vowel adds the number -er or -est, the last consonant is added: fat - fat - fat (thick - thick - thick).

1. https://azamat.uz

\title{
The list of used literature
}

2. https://samarapedsovet.ru

3. The traditional XXV practical conferencing of masters and students

\section{HOZIRGI ARAB VA O'ZBEK TILLARIDA FE'L SO'Z TURKUMINING FARQLARI VA UMUMIY JIHATLARI}

\section{Xoshimova Zarnigor Ibroximovna (СамДЧТИ 2-курс магистранти)}

\begin{abstract}
Annotation: The article provides general and up-to-date information on verb phrases and verb differences in modern uzbek and arabic grammar.

Key words and expressions: verb phrase, stem, verb chapters, verb proportions, inclinations, Abdul Aziz Muhammad Fahir, "توضيحالنحو" (Grammatical commentary), verb tenses, personnumber suffix.
\end{abstract}

O'zbek tili Alisher Navoiy, Ibn Sino, Farobiy va boshqa ko'plab mutafakkirlarning tili hisoblanib, ular o'z asarlari bilan jahon madaniyati xazinasiga beqiyos hissa qo'shganlar. Dunyo xalqlarining uzoq tarixiy jarayonlaridagi o'zaro munosabatlari, turli sohalardagi aloqalari tabiiyki, tillarning boyishiga ham o'z ta'sirini ko'rsatgan. Jumladan, o'zbek xalqining arab olami xalqlari bilan azaliy mustahkam aloqalari o'laroq o'zbek tiliga 50 foizdan ortiq arab so'zlarining o'zlashishiga sabab bo'lgan. [3.3]Lekin grammatik tuzilish jihatdan ikki til ham o'z doirasida o'ziga xos til qonun qoidalari asosida o'rganiladi. Bunga bir asos shuki, ikki xilning "bobo tili" ya'ni tillar oilasi turicha. O'zbek tili bizga ma'lumki, Oltoy tillar oilasining turkiy tillar turkumiga kiradi. Arab tili esa o'z navbatida Somiy tillar oilasiga mansubdir.

Ta'lim sohasida ham arab tilini o'rgatish va o'rganish jarayonida marfologiya va sintaksis masalalarining davrimizga qadar o'z ilmiy qiymatini yo 'qotmaganligi va bu borada nodir arab tilini tilshunoslik nuqtai-nazaridan o'rganish va uni hayotga tatbiq etish ham eng asosiy, hamda, birlamchi vazifalaridan hisoblanadi.Arab tili qadimiy va nodir til bo'lishi bilan bir qatorda o'zining mukammal grammatik qurilishiga, go'zal lahjalariga va betakror so'z boyligiga egadir.

Sharqshunoslikning bir bo'lagi bo'lgan arab tilshunosligini tanlagan ilmutoliblar shu sohaning turli jihatlarini mukammal o'rganishga intilishadi.

An'anaga ko'ra arab nahvshunoslari arab tilidagi barcha so'zlarni asosan uchta katta guruhga bo'lib o'rganadilar. Ular:

Ism - ot, sifat, olmosh, son, ravish, fe'lning harakat nomi, sifatdosh - اسم

$$
\text { فعل - ف }
$$

Fe'l - fe'ning zamonlari, mayllari, nisbatlari, bo'lishli va bo'lishsiz

حرف - Harf- yordamchiso'zlar

Bular orasida fe'llar arab tili grammatikasida asosiy o'rinni egallaydi. Chunki arab tilidagi juda ko'p ismlar ham asosan fe'l o'zagidan yasaladi.

O'zbek tilidagi kabi arab tilida ham predmetningish-harakatini ifodalaydigan mustaqil so'zlar fe'l deyiladi.

Arab tilida fe'l o'zining shaxs va sonda tuslanishi bilan ajralib turadi. Arab nahvchilari fe'lni ism va yuklamalarga qaramaqarshi qo'yadilar.[ 4.116]

Misrlik mashhur nahvshunos olimlardan biri Abdul Aziz Muhammad Fohiro'zining “توضيحالنحو", ya’ni “Grammatikani sharhlash” nomli nahvga oid asarida shunday yozadi: 
و الفعل: ما دل على معنى في نفسه مقترنا بزمان, سواء كان وقوع هذا المعنى في الزمان الماضي, او في الحال ام في

[5.9] المستقبل

Ya'ni: "Fe'l o'zida zamonning ma'nosini dalolat qiladi va bu ma'no o'tgan, hozirgi yoki kelasi zamonda sodir bo'lishi mumkin."

Fe'l turkumiga oid barcha so'zlar uchun umumiy xususiyat zamon bilan bog'liq holda yuz beruvchi hodisani ifodalashdir.Ana shu umumiy xususiyatga ko'ra fe'llarning barchasi bir umumiy so'roqqa nima qildi?,nima qilyapti?, nima qiladi? so'rog'iga javob bo'ladi. Fe'llar boshqa so'zlarga nisbatan leksik-semantik va grammatik xususiyatlari jihatidan nihoyatda murakkabdir.[2.32]

Ish harakat yoki holatni bildiruvchi bu so' $z$ turkumi arab tili grammatikasida juda katta o'rin tutadi, chunki boshqa turkum so'zlari ham asosan, yuqorida aytib o'tganimizdek, fe'l o'zaklaridan yasaladi.

Fe'llar cho'ziq undoshli va to'rt o'zak undoshli bo'ladi. Fe'llarning ko'pchiligini cho'ziq undoshlilar tashkil qiladi.

$\mathrm{Bu}$ o'zak undoshlar atrofidagi unlilarni o'zgartirish, u yoki bu o'zak undoshni kiritish yo'li bilan fe'llarning hosil aboblariyasaladi. Hosila shaklidagi fe'llarning, tabiiyki mazmunida ham o'zgarish sodir bo'ladi. Hosila shakllarni boblar deb atash qabul qilingan.Uch o'zakundoshli fe'llarning 15ta, to'rt o'zakundoshli fellarning 4ta bobi mavjud.

$\mathrm{Bu}$ boblarga ularni o'zaro farqlash uchun nom qo'yilgan. Arab tadqiqotchilari uch

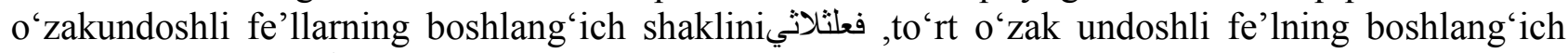
shaklini esa فعلرباعيمجردdeb, qolgan boblarni esa shu bobning harakat nomi (masdari) atamasi bilan ataganlar, masalan: بابالتفعيل “taf'ilbobi”, بابالافتعال “iftialbobi” va hokazo.

Zamonaviy adabiyotlada bu boblarga tartib raqami berilgan va ular rim raqami bilan ifodalanadi, masalan: II bobi, VII bobi, XI bobi va h.k.

O'zbek tilida esa fe'llarning o'zaklariga nisbatan aniq sonda bo'lishi mumkin degan tushuncha mavjud emas.Fe'llardan shaxs-son qo'shimchasini, zamon qo'shimchasini olib tashlagan holda o'zak ajratiladi.

Arab fe'lning barcha boblari o'tgan va hozirgi-kelasi zamonga ega. Ular shaxsda, sonda, jinsda tuslanadi.Fe'llar arab tilida aniq va majhul nisbatga ega. Bundan tashqari fe'llarning 5ta mayillari mavjud: darak mayli, shart, buyruq, istak va kuchaytiruv mayillari.

O‘zbek tilidan farqli o'laroq arab tilidagi fe'llar infinitiv, ya'ni fe'lning noaniq shakliga ega emas. Shuning uchun zamonaviy lug'atlarda fe'lning o'tgan zamon III shaxs, birlik, muzakkar shakli shartli ravishda infinitive sifatida qabul qilingan. Masalan: كتب bu fe'lning asl ma'nosi “ $u$ yozdi", shartli ma'nosi: yozmoq.

Uch o'zak undoshli fe'llar arab tilida fe'llarning asosiy qismini tashkil etadi. Ular o'nbeshta bobda aks ettirilgan. Shulardan o'nta bob hozirgi adabiy tilida ko'p qo'llaniladi. Qolgan beshta bob esa qadimgi arab tilida ishlatilgan, keyinchalik iste'moldan chiqib ketgan. [1.79]

Arab tilida fe'l narsa(shaxs)ning harakat yo holatini ifodalaydi. Bu xususiyatga muvofiq, fe'llarni ikki turga ajratish mumkin: harakat bildiruvchi va holat bildiruvchi fe'llar. Arab tilida fe'llar o'timli va o'timsiz bo'lishi mumkin. Ma'lumki, har bir fe'l shaklida mujassamlangan zamon, undan anglashilgan ish-harakat yoki nutq lahzasiga munosabatini ko'rsatadi. Arab tilida o'zbek tilidan farqli o'laroq fe'lning ikkita zamon shakli mavjud, ular: o'tgan va hozirgi-kelasi zamon.

Arab tilidagi fe'llarni rus va o'zbek nahvchi olimlari to'g'ri va noto'g'ri fe'llarga bo'lib o'rganishadi. Bunda solim fe'llar to'g'ri, qolgan fe'llar esa ikkilangan va hamzali fe'llarni ham qo'shib noto'g'ri fe'llarga kiritilgan.

Arab nahvchi olimlari esa uni o'zlariga xos tarzda صحيح و معتلto'g'ri va illatli fe'llarga ajratishgan. Bunda solim, ikkilangan va hamzali fellar to 'g'ri fe'llar guruhiga kiradi, misol, ya'ni to 'g'riga o'xshash, ajvaf (bo'sh fe'llar) va noqis fe'llar esa illatli fe'llar guruhiga kiradi. Jumladan, hozirgi zamon taniqli tilshunos olimlardan biri Mustafo G'alayiniy o“zining " "Arab tili darslarining majmuasi” asarida fe'llarni tasniflab chiqadi.[6.45]

Xulosa o'rnida shuni ta'kidlash joizki,ikki tilni bir biri bilan qiyoslab o'rganish tilni mukamm alo 'rganish uchun yaxshi metod sanaladi. 
Arab tilidagi mavjud grammatik qoidalarni nafaqat darsliklardan, balki asl manbalar orqali o'rganish va uni amaliyotda qo'llash har birimiz uchun katta ahamiyat kasb etadi.

\section{Foydalanilgan adabiyotlar ro'yxati}

1.Ibroximov N., Yusupov M. Arab tili grammatikasi. -T., 1997

2.Shoabduraxmonov Sh. Xozirgi o'zbek adabiy tili. -T., 1980

3.T.Sh. Qodirov, D.I.Aliyev Arab tilileksikologiyasi. - T., 2010

4.Гранде Б.М. Курс арабской грамматики в сравнительно-историческом освешении. M., 2001.

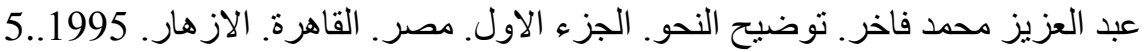

الثيخ مصطفى غلييني. جامع الدروس العربية. مصر .6.2008 الأهر.

\section{THE CONCEPT OF TEACHING ARABIC LANGUAGE IN UZBEKISTAN}

Hashem Ismail Hammam Ali

(Teacher, SamSIFL)

Annotation: Teaching Arabic language in higher education institutions in Uzbekistan is intended to aim at teaching it to achieve the linguistic capabilities of the Uzbek learner so that he can practice it in its natural practical functions a healthy practice by directing the activities of the teacher and the learner towards achieving the four language skills that make them able to understand them if they hear or read them and transfer their thoughts to others orally or in writing.The functional method when teaching the Arabic language was based on a set of principles drawn from several theories developed by different schools which are: including structural, formal, and behavioral principles.

Key words and expressions: the principle of the need, the principle of interest, impact law , repetition law.

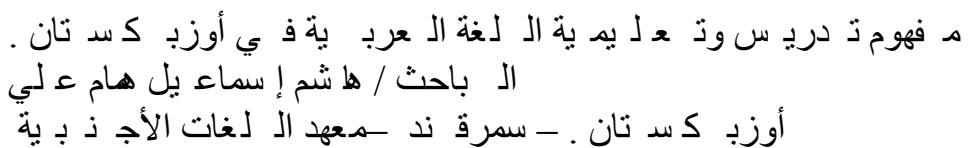

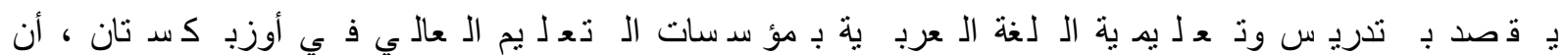

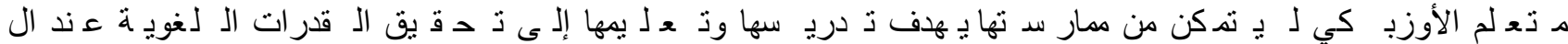

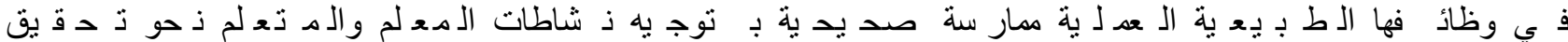

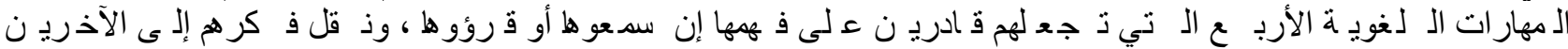

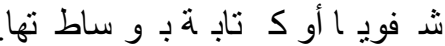

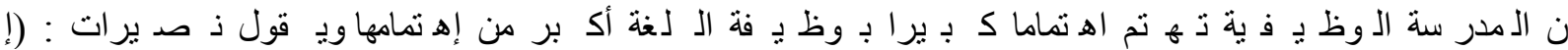

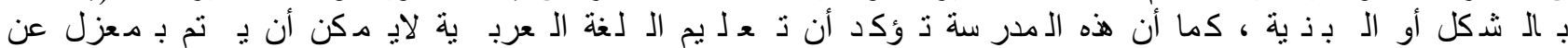

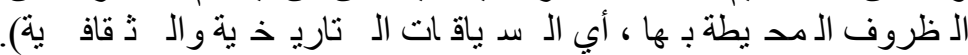

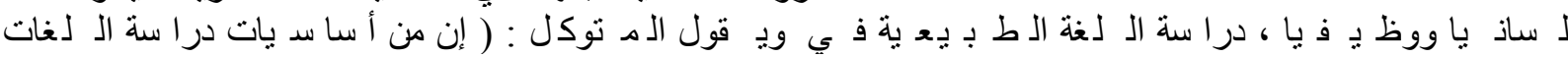

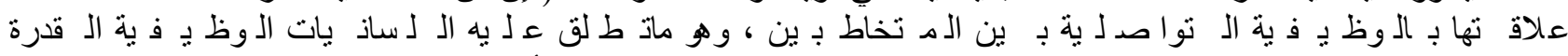

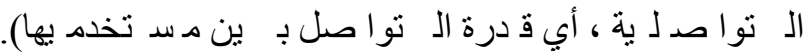

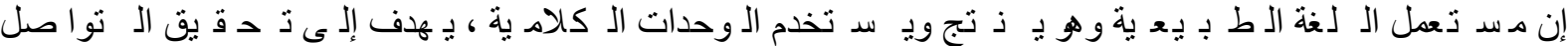

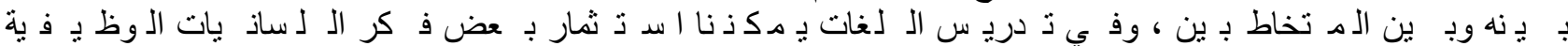

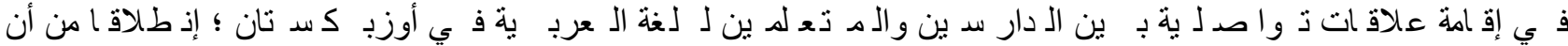

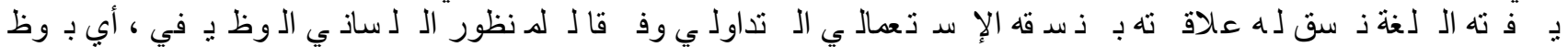

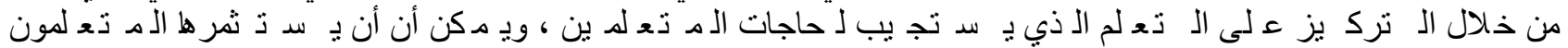

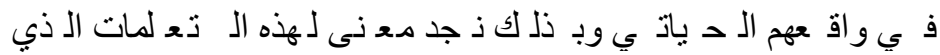

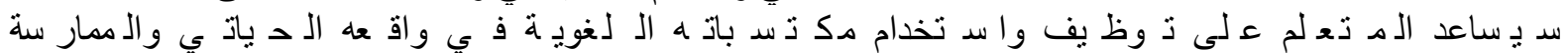

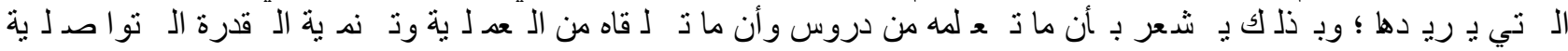

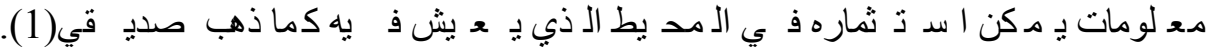




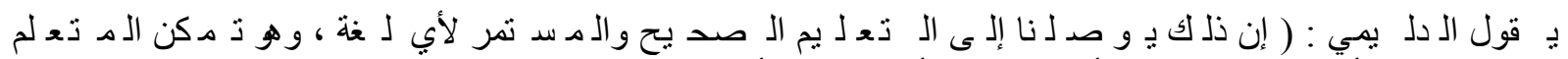

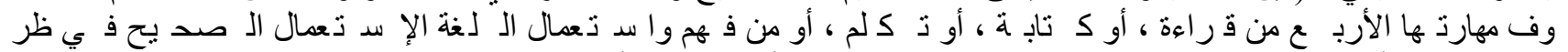

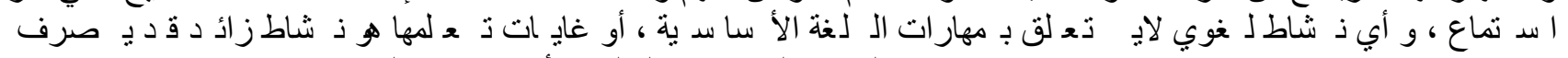

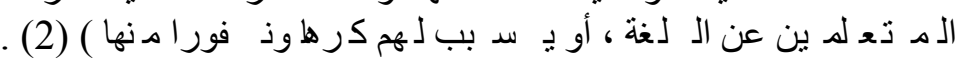

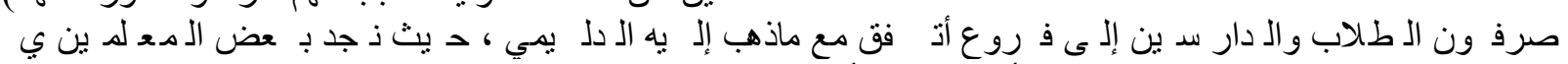

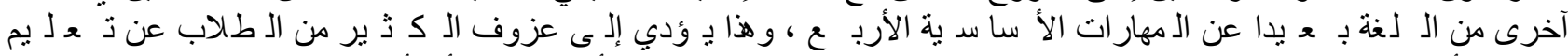

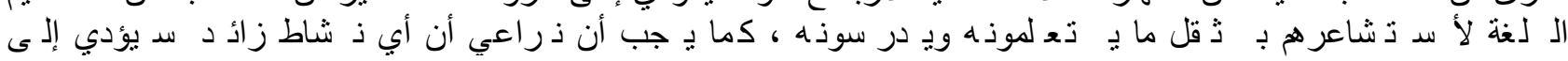

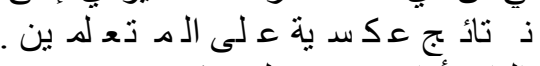

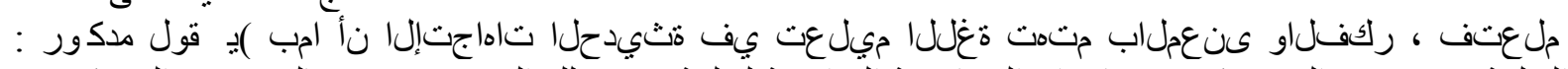

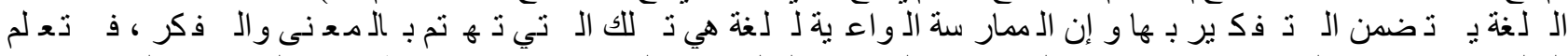

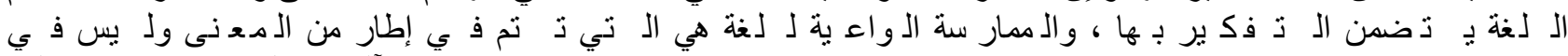

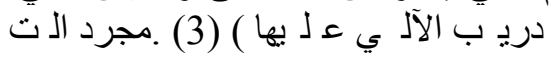

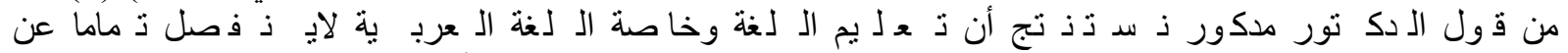

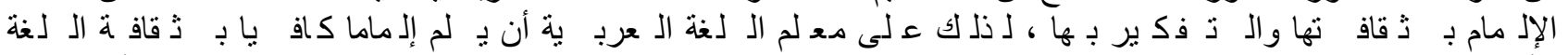

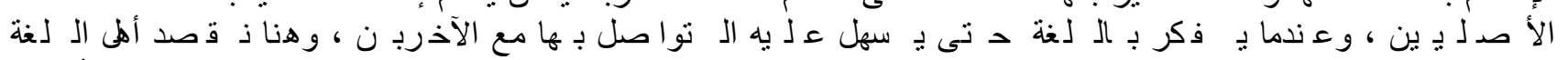

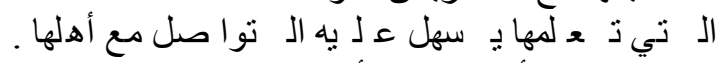

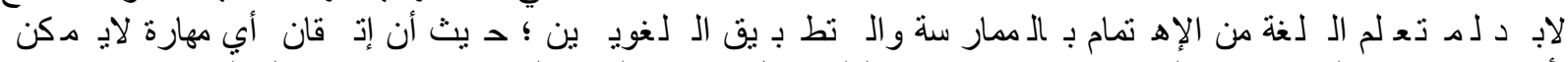

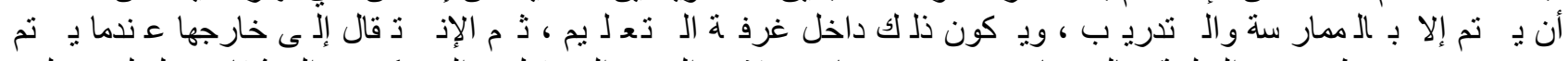

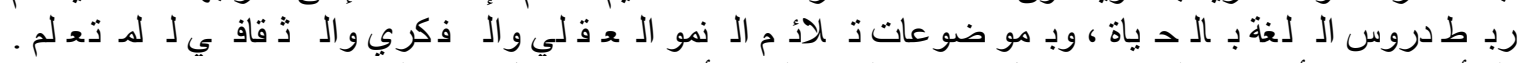

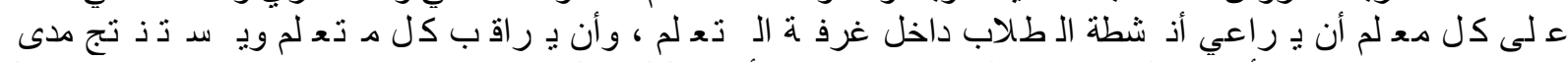

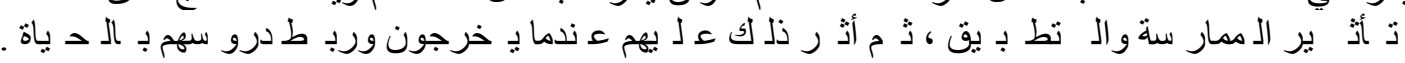

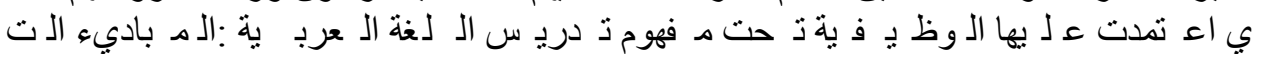

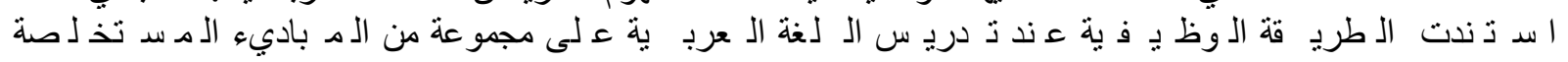

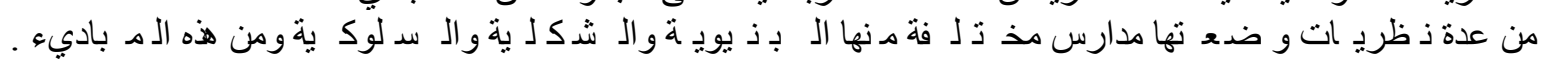

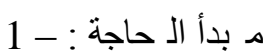

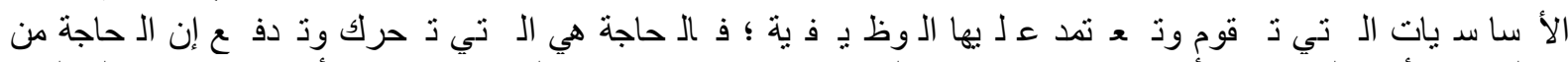

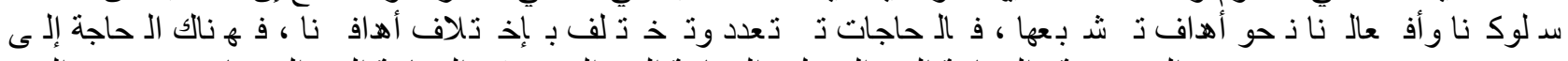
. إل خاج..

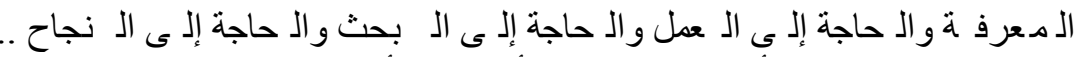

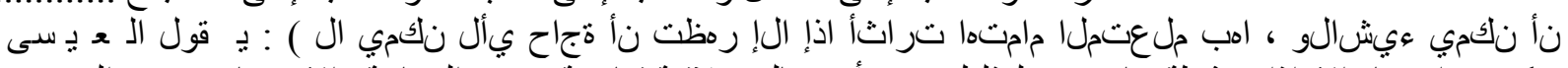

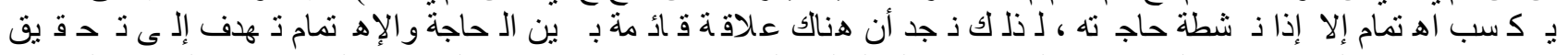

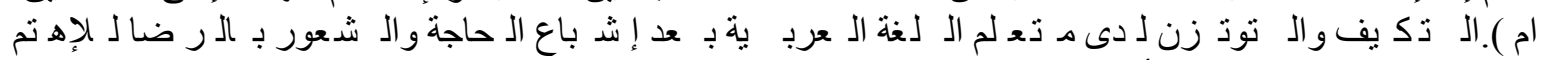

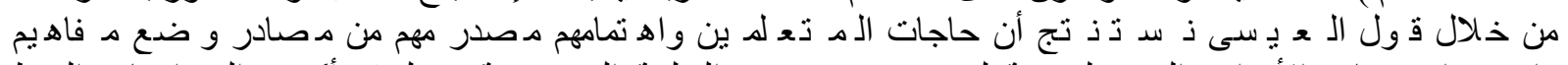

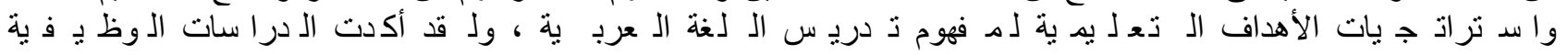

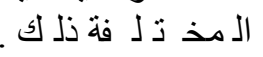

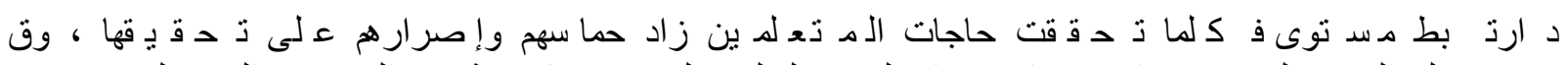

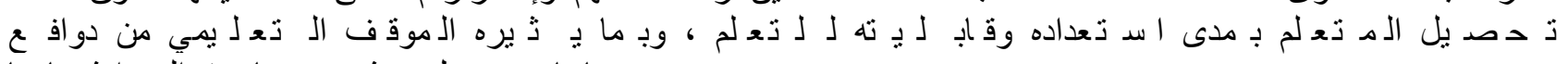

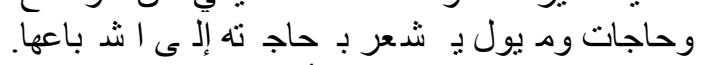

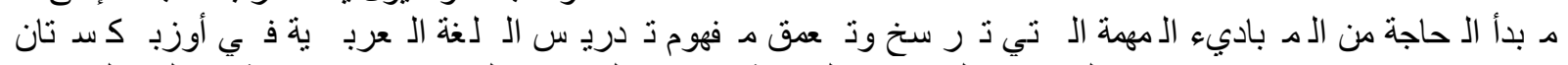

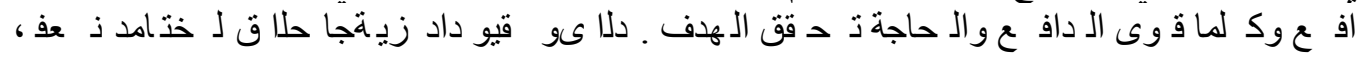

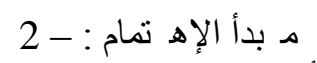

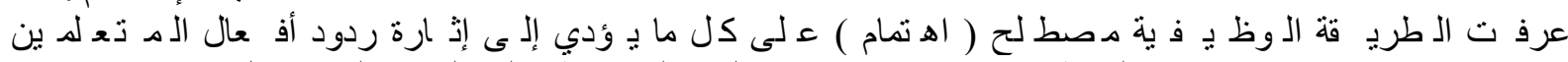

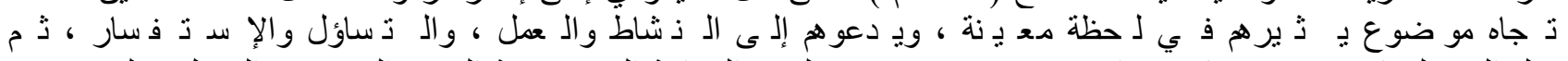

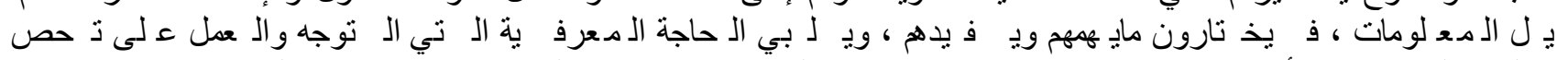

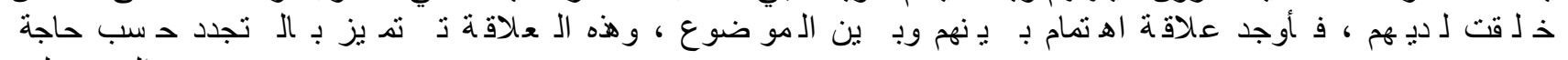

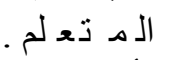

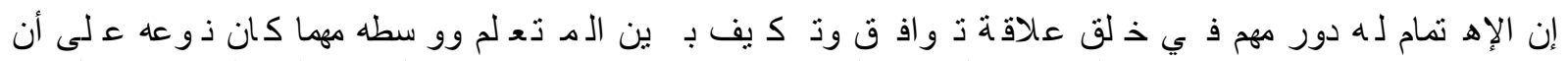

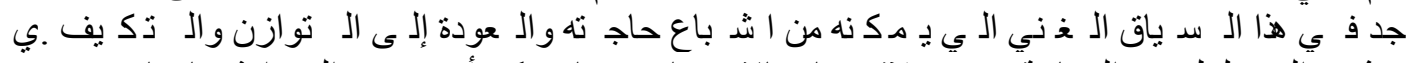

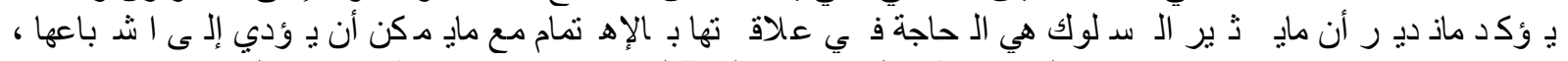

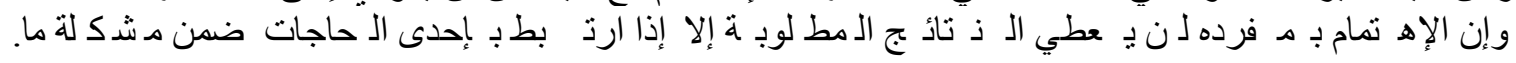




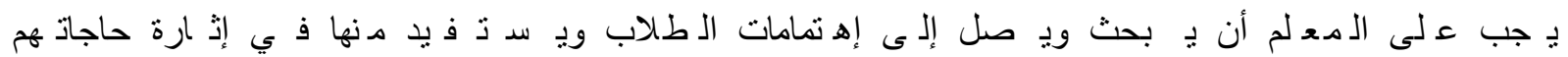

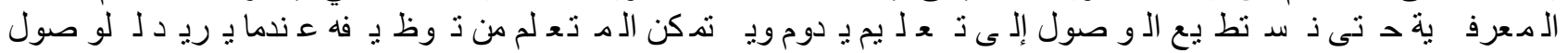

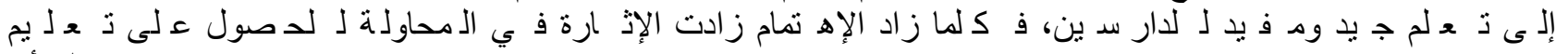
ضل .أف د د

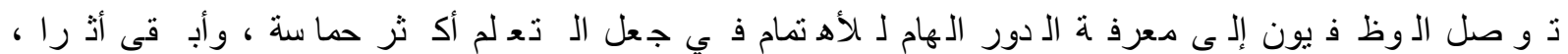

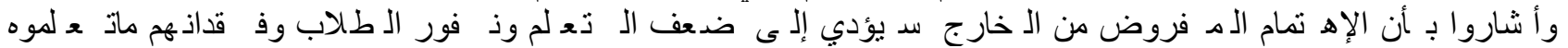

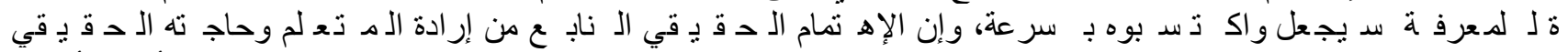

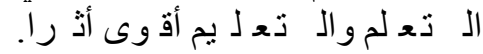

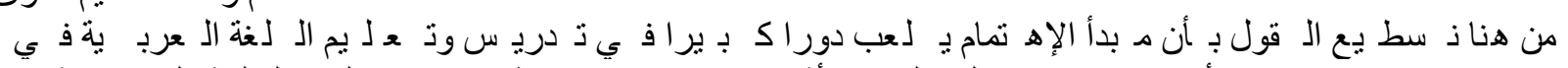

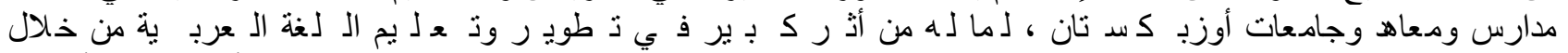

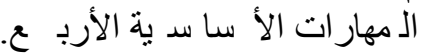

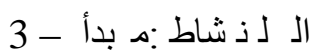

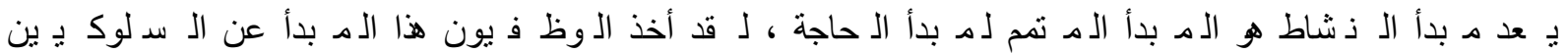

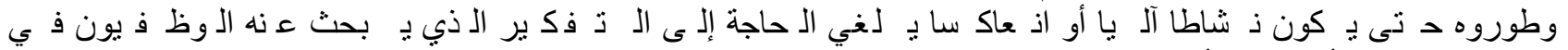

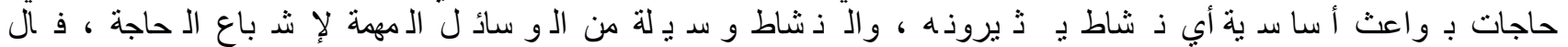

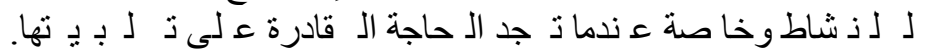

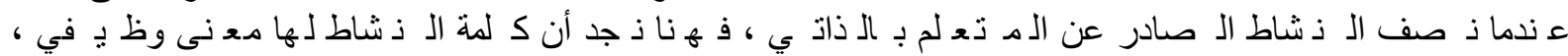

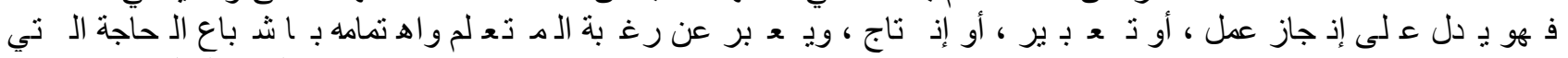

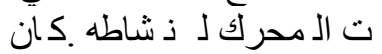

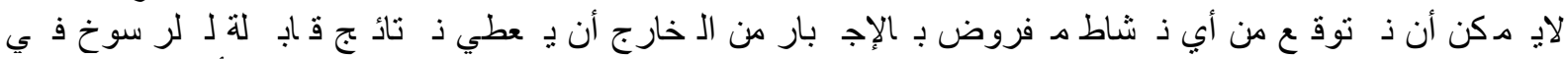

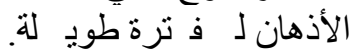

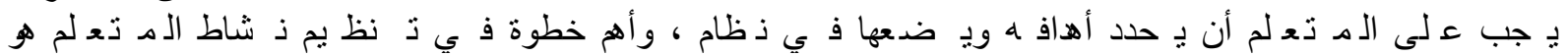

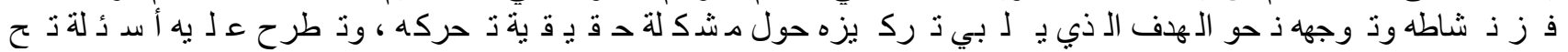
حاج تنه.

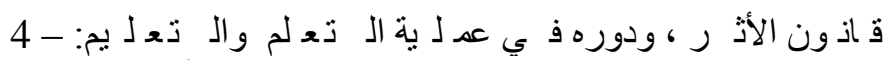

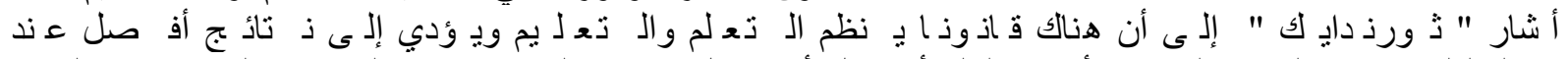

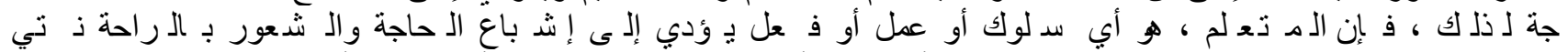

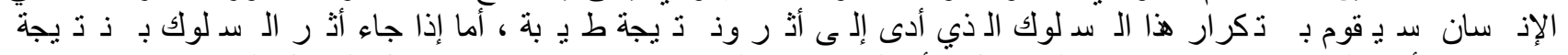

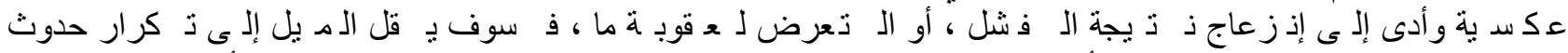

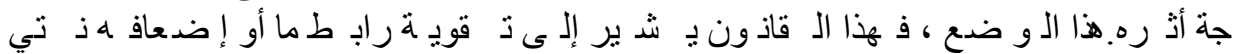

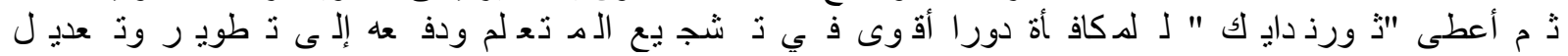

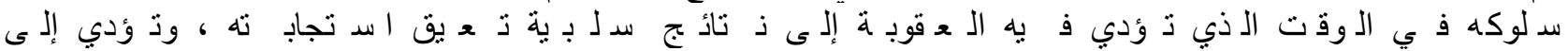

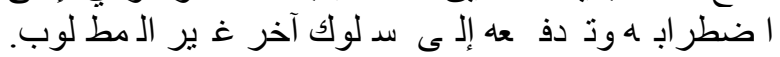

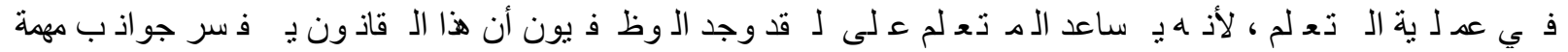

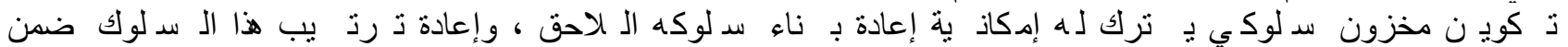

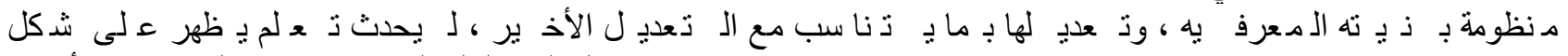

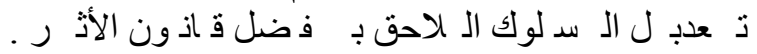

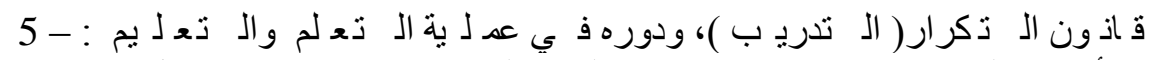

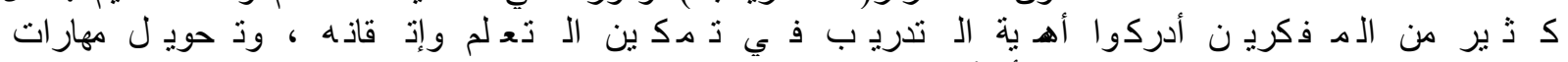

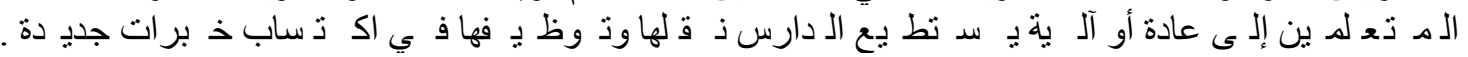

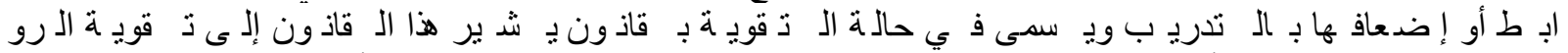

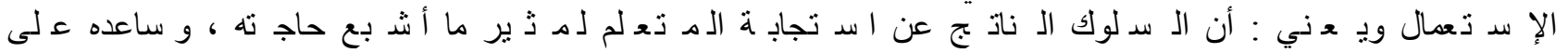

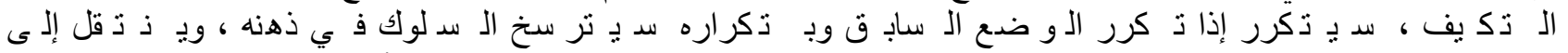

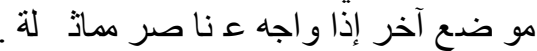

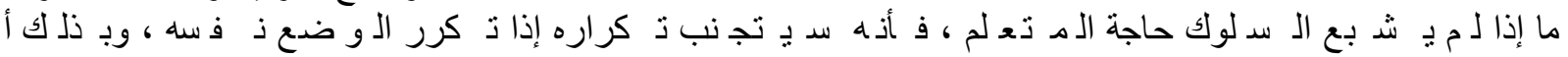

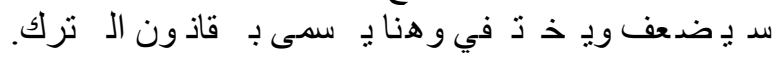




\section{SOME STUDENTS' DIFFICULTIES IN LEARNING PHONETICS OF THE ARABIC LANGUAGE}

\section{Shavkatjon Alamov \\ (Teacher, SamSIFL)}

Annotation: The difference or similarity between the Arabic language and the Uzbek language are in the sounds. The article illustrates differences between Arabic language and Uzbek language in the phonetic system. Also, describe some difficulties that student come across in the process of learning Arabic phonetics, because it is so difficult to pronounce Arabic sounds. There are some arabic sounds explained in the article that are specific to the Arabic language.

Key words and expressions: phonetic sounds, specific features, the process of learning Arabic language, the nature of composition.

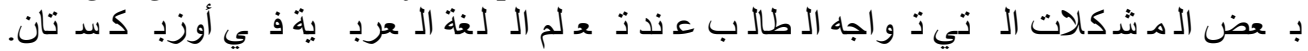

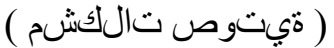

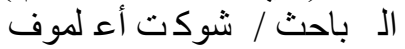

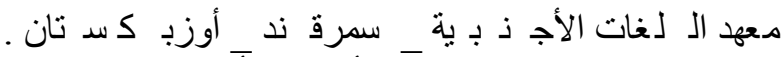

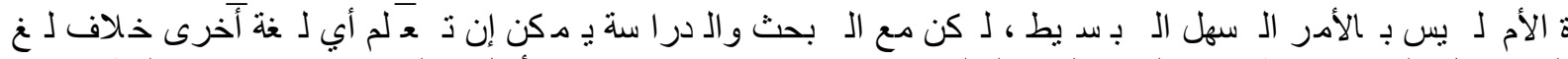

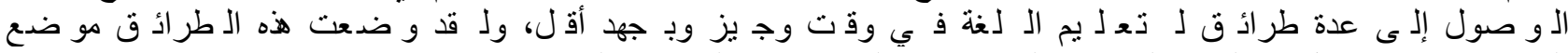

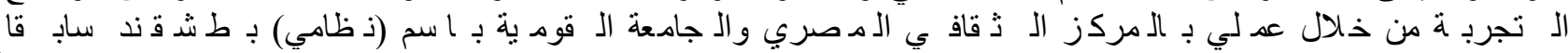

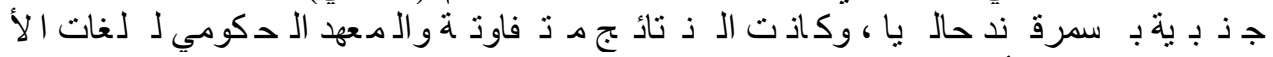

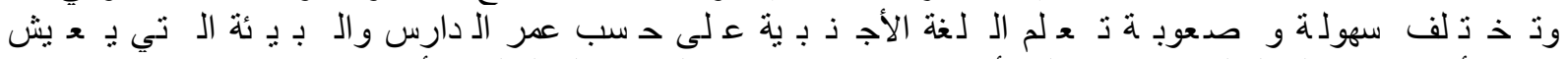

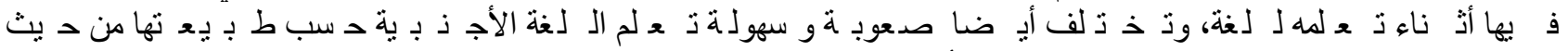

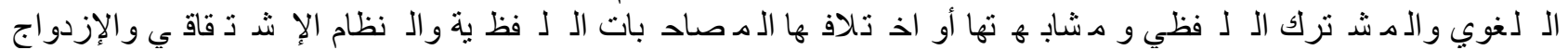

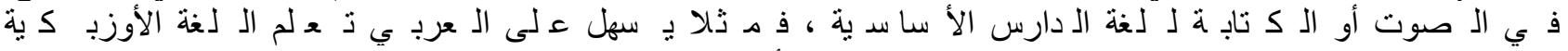

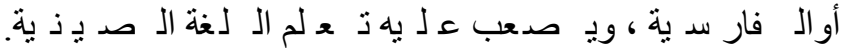

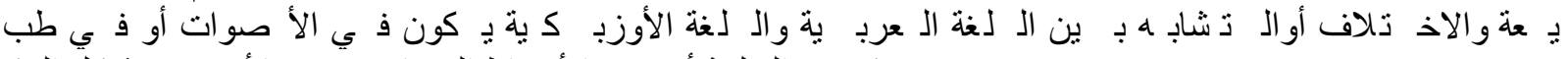

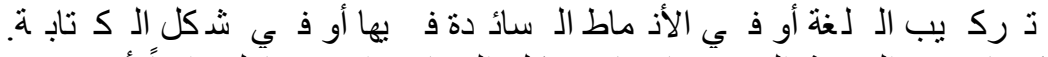

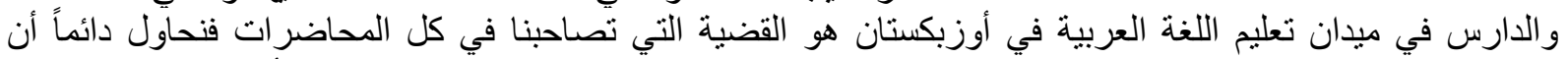

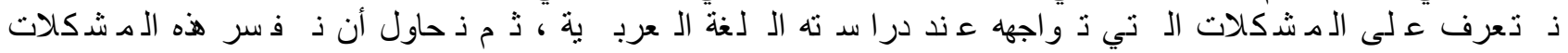

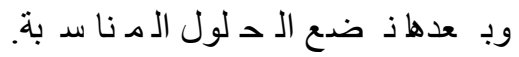

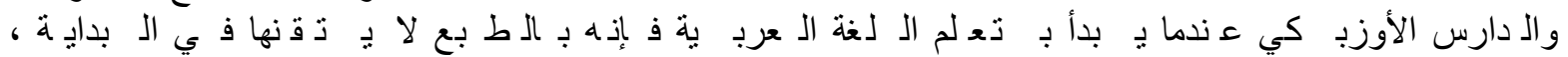

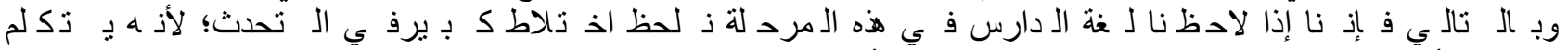

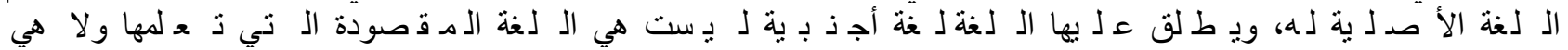

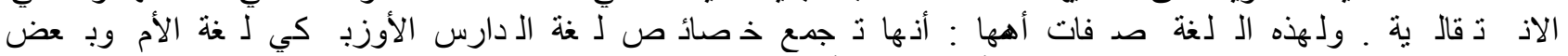

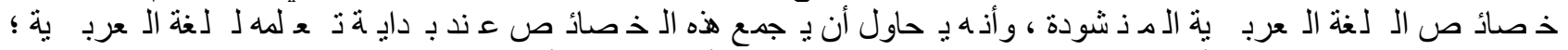

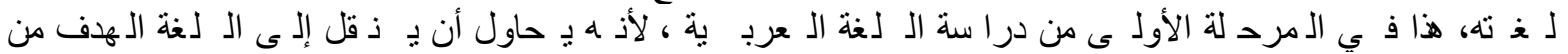

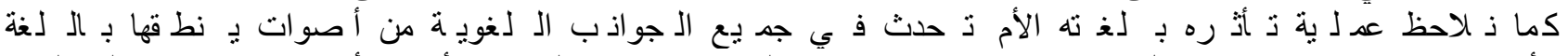

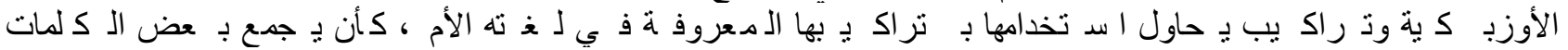

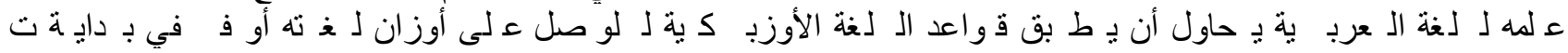

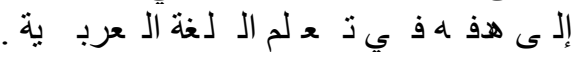

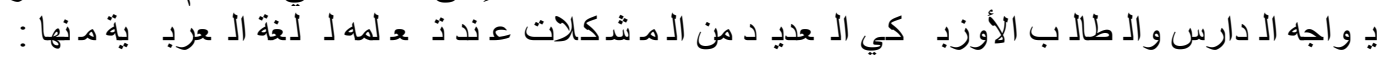

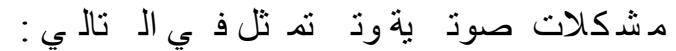

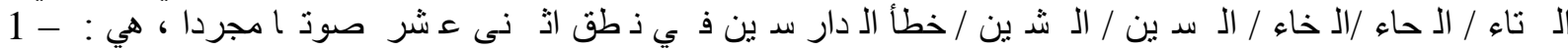

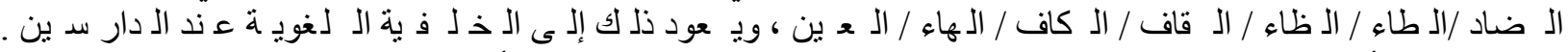

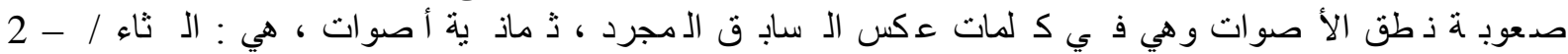

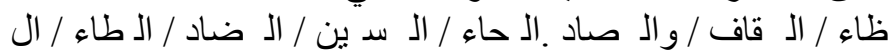

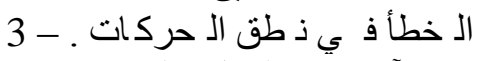

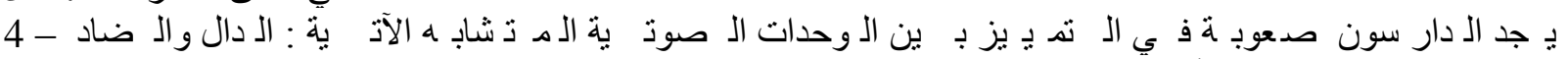

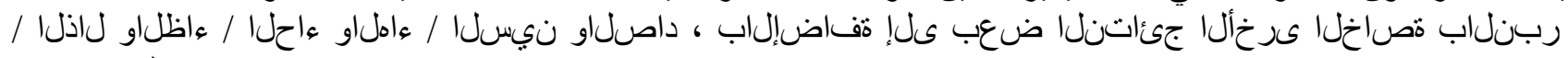
وال ت ذنغ يم. 


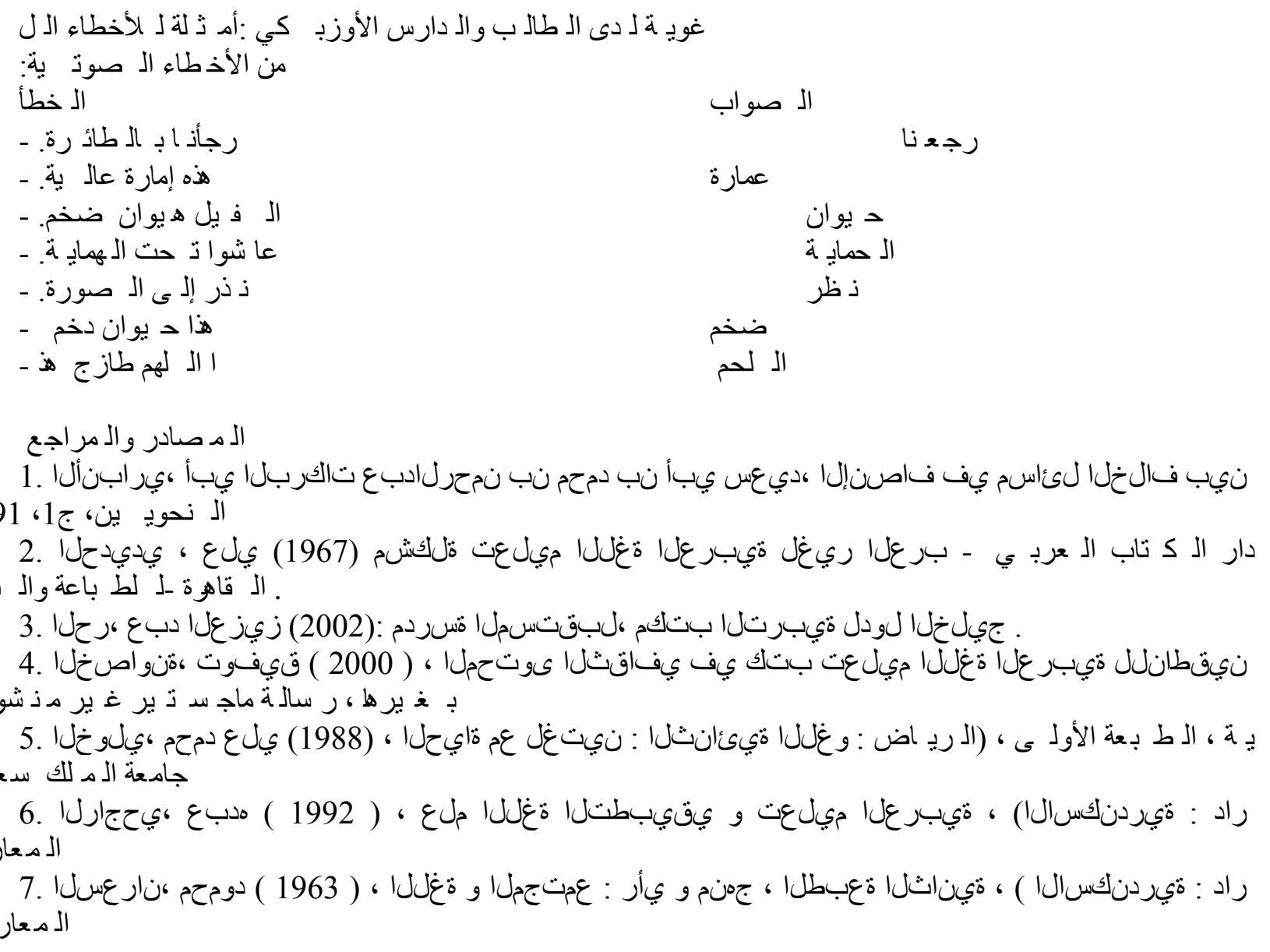

\section{-NI TUSHUM KELISHIGI QO`SHIMCHASINING XITOY TILIDAGI EKVIVALENTI: GRAMMATIK XUSUSIYATLARI, QO`LLANILISHI}

\section{Hamdamova Charos (SamDCHTI magistranti)}

Annotation: In this article discussed, the Chinese equivalent of the suffix, its Grammatical features, application and grammatical rules are proved by examples in two languages.

Key words and expressions: Cases in Chinese language “把”, “以...为...”, “将”.

Xitoy tilida ham xuddi o`zbek tilidagidek, to`ldiruvchi, o`z navbatida vositali va vositasiz (qisman vositasiz deyish maqsadga muvofiq) turlarga bo linadi va bu ikkala turda ham to 'ldiruvchi o`zining yasovchi birliklariga ega bo `ladi. Ammo o`zbek tilidan farqli o`laroq, xitoy tilida vositasiz to`ldiruvchini yasashga xizmat qilgan birlikni tushirib qoldirishning iloji yo`q. Aniqroq qilib aytganda, xitoy tili amorf til bo`lganligi va so`zlar bir - biri bilan bevosita bog`langani bois, bu tilda biror bir qo`shimchani uchratmaymiz. Ammo xitoy tilida o`zbek tilining tushum kelishigi qo`shimchasi (-ni) ni o`rnini bosadigan bir so`z borki, bu so`z orqali yasalgan har bir gap yoki so`z birikmasida to`ldiruvchining kesim gap bo`lagiga bevosita bog`lanishi o`zbek tilining vositasiz to`ldiruvchining yasalish qoidasiga to`g ri keladi.

“把”(ba) li gap [2, 32 - b.], xitoy tilida, ayniqsa, xitoy adabiy tilida ko`p murojaat qilinadigan gap turlaridan biri bo`lib, o`z navbatida xitoy tilini o`rganuvchilar tomonidan ko`plab qiyinchilikka duch kelishga sabab bo`ladigan gaplardan biri hamdir. Shu bois, xitoy tilini o`rganuvchilardan bu tur gapning ma`nosi hamda ishlatilishini o`rganish bilan birga, uning turli xarakterli xususiyatlari, o`zgarishlarini ham yodda tutish talab etiladi. 
“把” ( $b a$ ) li gaplar, asosan, harakatni ifodalovchi fe`llar bilan yasalgani bois, harakatni ifodalamaydigan 有 you bor, 像 xiang o`xshamoq, 属于 shuyu mansub bo`lmoq, 要求 yaoqiu talab qilmoq singari fe`llarni vositasiz to`ldiruvchi bilan qo`llamaymiz.

Xitoy tilidagi“把” ( $b a$ ) li gaplarning o`zbek tilidagi vositasiz to`ldiruvchi ishtirok etgan gaplardan farqlovchi yana bir xususiyati shundaki, o`zbek tilida gap tarkibida to`ldiruvchining qaysi turi ishlatilishidan qat’I nazar, fe `lning bo`lishsiz shaklini ifodalaydigan yo`q, emas, emish singari fe`lning to`liqsiz shakli hamda modal so`zlar kesim bilan ishlatiladi. Masalan, men uy ishini ustozga bermadim, gapini olsak. Ushbu gapda kesim vazifasini fe`lning bo lishsiz shakli ifodalab kelgan. Ammo ushbu gapni to`g`ridan - to`g`ri xitoy tiliga tarjima qilganda 我把作业没有交给老 师[2, 32 - b.] wo ba zuoye meiyou jiao gei laoshi deyish yaramaydi. Chunki “把” (ba) li gaplarning yana bir xususiyati shundaki, bu gap turida inkor yuklamasi yoki inkorni ifodalovchi modal so`zlar “把” (ba) dan oldin ishlatiladi. Ya`ni yuqorida keltirilgan men uy ishini ustozga bermadim, misoli 我没把作业交给老师 wo mei ba zuoye jiao gei laoshi deyiladi.

Shuningdek, inkorni ifodalovchi so`zlar bilan bir qatorda, “想” “xiang”-moqchi, xohlamoq “要” “yao” kerak, xohlamoq, “能” “neng” qila olmoq, “应该” “yinggai” kerak, to’g 'ri kelmoq “可以” “keyi” mumkin, “必须” “bixu” majbur, kerak, “得” “dei” kerak singari modal so`zlari ham “把” $b a$ dan oldin ishlatiladi. Aksincha, o`zbek tilida yuqoridagi singari modal so`zlar xuddi inkor so`zlar singari fe`ldan keyin keladi. Masalan, 我要把钱还给你 wo yao ba qian huan gei ni men pulni senga qaytarib berishim kerak. 你可以把信直接寄给他 ni keyi ba xin zhijie ji gei ta, sen xatni to`g`ridan - to`g`ri o`ziga yuborishing mumkin.

Ba`zi hollarda “把” baning o`rnida 将 jiang ham ishlatilishi mumkin. Bu ikki so`z ham vositasiz to 'ldiruvchini ifodalashga xizmat qiladi, biroq bu ikkisining farqi shundaki, 将 jiang asosan, adabiy hamda kitobiy tilda ishlatiladi. Ammo bu ikki to`ldiruvchi ma`no jihatidan bir biridan deyarli farq qilmaydi. Masalan, 你们必须将 (把) 道理解释清楚[2, 32 - b.] nimen bixu jiang ( ba) daoli jieshi qingchu sizlar albatta tamoyilni aniq tushuntirishingiz lozim. Ushbu gap og`zaki - so`zlashuv uslubdan ko`ra ilmiy uslubda kengroq ishlatilishini inobatga olib, 将 jiang dan foydalanish maqsadga muvofiq. Ammo ushbu gapda 把 badan foydalanish ham hech qanday kamchilik keltirib chiqarmaydi.

Xitoy tilida yana “以........ 为........." “yi.....wei...." strukturasi ham borki, bu struktura yuqoridagi “把” bali gapning o`ziga xos ko`rinishidir. Shuni alohida ta`kidlash joizki, ushbu struktura qadimiy xitoy tiliga oid bo'lgani bois, bugungi kunga kelib, bu strukturani deyarli uchratmaymiz.Ushbu struktura “把 ........当作/看作 / 看成” “ba..........dangzuo/ kanzuo/ kancheng" “...........ni .........deb hisoblamoq/ deb ko'rmoq" ma`nolariga to g`ri keladi va ko pincha ilmiy va falsafiy nazariya hamda tamoyillarni ifodalashda kengroq foydalaniladi. Masalan, 以 $\mathrm{R}$ 为半径 yi $R$ wei banjing, Rni radius deb hisoblamoq va hokazo.

\section{Foydalanilgan adabiyotlar ro'yxati}

1. M.Qodirov, H. Ne`matov, Ona tili, 8- sinflar uchun darslik, Cho`lpon nomidagi nashriyot - matbaa ijodiy uyi, Toshkent 2014.

2. 朱庆明, 现代汉语实用语法分析 ( 第二版) 上册。清华大学出版社 2012 年

3. www.baidu.com

4. www.google.ru 


\section{ПАРАДИГМАТИКА ТУШУНЧАСИНИНГ ФАНГА КИРИБ КЕЛИШИ}

\section{Б.М.Мирзаев \\ (СамДЧТИ магистранти)}

Annotation: The article presents general and preliminary information about the concepts of "paradigmatics", "paradigmatic relations", one of the latest research innovations in modern linguistics.

Key words and expressions: paradigm, paradigmatics, syntagmatics, F. de Saussure, L. Elmslev, paradigmatic relations, morphology, syntax, morpheme

Сўнгги ўн йилликларда тилшунослик фанининг ривожланиши синтактик парадигматика муаммоларининг жадал ривожланиши билан тавсифланади. "Синтактик парадигма" тушунчаси сўнгги лингвистик тушунчалардан биридир. Парадигматик ва синтагматик муносабатларни кўриб чиқиш зарурлиги хақидаги фикрлар хозирда хамма томонидан тан олинган [5. 65]. Аммо замонавий тилшуносликда синтактик парадигманинг умумий қабул қилинган таърифи мавжуд эмас, у қандай мезон асосида ажратилганлиги, унинг қандай тузилмалари борлиги, синтактик парадигма таркибий қисмларини бирлаштирган қандай муносабатлар мавжудлиги хақида аниқ консепция йўқ [4. 249].

Парадигматик муносабат бир парадигма бирликлари доирасидаги - орасидаги муносабатдир, ички жараёндир. Тил ва нутқ дихотомиясига кўра парадигматикапарадигматик муносабат тушунчаси тил билан - тил имконияти билан боғланади. Чунки парадигматик муносабат бирликлари хам аслида имконият сифатида нуткда - нутқ бирликларида воқелашади, муайянлашади, нутқ учун ашё, зарурий материал вазифасини ўтайди, нутққача бўлган жараён хисобланади. Шунга кўра улар синтагматик муносабатдан фарқланади, улар каби бевосита рухий - фикрий таъсир қилиш қувватига - коммуникатив алоқа имконига эга бўлмайди, умумийлик сифатида мавжуд булади [7. 62].

Парадигматика тил бирликларини тил системасининг элементлари сифатида, структурал бирликларнинг жами сифатида текшириш аспектидир [2. 310]. "Синтактик парадигма" тушунчаси сўзларни қамраб оладиган хар қандай грамматик категорияларнинг таъсири натижасида кенг талқин қилиниши мумкин ва тор доирада уларга фақат синтактик муносабатлар табиатида турлича бўлган синтактик таснифларнинг тўпламларини хавола қилиш мумкин.

M. Я. Блох синтактик парадигмани "категорик маънони ифодалашнинг умумлаштирилган ўзгарувчан-инвариант хусусиятига кўра синтактик даражада бир-бирига боғланган ва бирлаштирилган бир қатор тил тузилмалари" деб тушунади [3. 34]. Синтактик парадигма хақида энг кенг тушунча, хеч бўлмаганда битта морфемада ажралиб турадиган корреляция қилинган синтактик тузилмалар мажмуи сифатида аниқланган, синтактик парадигмада жумлалар ва ибораларни хам ўз ичига олади. Дархақиқат, биз синтактик парадигма хақида гапираётганимиз сабабли, унинг аъзолари синтактик даражанинг бирликлари бўлиши керак: жумлалар ва иборалар. Баъзи тилшуносларнинг фикрига кўра [1. 72], жумлалар парадигмалари синтактик эмас, балки морфологик парадигмалар йиғиндисини ифодалайди. Масалан, "ушбу китоб" сўз бирикмаси парадигмалари, "ушбу китоблар" ибораси асосий сўзининг шакллари тизимига асосланган. Синтактик тилшунослик олимлари жумлалар синтактик парадигманинг бирлиги эканлигига кўшилишади. Бироқ, савол туғилади: ушбу таклифлар қай даражада кенгайтирилади? Шубхасиз, хар бир жумланинг тарқалиши хам ўз парадигмасига эга бўлмайди. Акс холда, синтактик парадигматика мутлақо чексиз бўлиб, амалий маънога эга бўлмайди. Шу сабабли, баъзи бир нечта умумий бирликларнинг парадигмаларини тузиш керак, улар Н.Ю. Шведованинг терминологиясидан келиб чиқиб, жумлаларнинг таркибий асослари деб номланиши мумкин [8. 26]. П. Адамец ва В. Грабе хар бир жумла предикатнинг моддалар билан конфигурацияси бўлган маълум бир ядрога асосланишини таклиф қилади. Худди шу ядро семантикага яқин бўлган бир қатор жумлаларда учрайди, аммо улар учун хар хил грамматик дизайн талаб этилади. Битта ва бир 
хил ядро турли аъзолар томонидан турли хил жумлаларда тарқалиши мумкин, аммо ядро кимлиги ушбу жумлаларнинг яқинлигини таъминлайди. Юқорида тилшунослар ядро жумлалари тушунчасини синтактик тизимнинг марказига қўйдилар. Асосий жумлалар - бу феъл ва синтактик категорияларни хаддан ташқари белгилаш билан тавсифланадиган ядро жумласидир. Белгиланмаган ядро жумласи фаол овоз, жумланинг номинатив тури (мавзуни номинатив холатда шакллантириш) ва бирон бир қўшимча лексик-модал воситалар билан мураккаблаштирилмаган белгиларсиз модаллик билан намоён бўлади. Шундай қилиб, синтактик парадигмаларнинг бирликлари жумлаларнинг таркибий асослари, яъни предикат, предмет ва қўшимчалардан ташкил топган маълум бир ривожланиш даражасидаги жумлалардир [1.73].

Умумий парадигма ёки ядро жумласининг асл шаклидаги барча ўзгаришлар битта умумий синтактик парадигмага тегишли. Ядро жумлаларининг барча ўзгаришлари кўпинча ўзгаришлар деб аталади ва пайдо бўлган янги шакллар трансформациялар деб аталади.

Трансформациялар - бу ядровий жумланинг ўзгариши, унда унинг синтактик тузилиши ўзгаради, лекин унинг лексик таркиби ва унинг таркибий қисмлари ўртасидаги умумлаштирилган-семантик муносабатларнинг табиати сақланиб қолади.

Г.А.Золотова модел ўзгаришнинг учта асосий турини тавсифлайди:

1) грамматик модификациялар;

2) таркибий ва семантик ўзгаришлар;

3) синтактик синонимлар.

Биринчи холда, асл структура вақт ва моданинг грамматик маъноларида (Н. Ю. Шведованинг парадигмаси) фарқ қилувчи бир қатор вариантли тузилмалар билан мунтазам алоқада бўлиб, шунингдек, маълум бир қатор тузилиш учун - синтактик шахснинг маънолари билан, яъни предикативлик таркибий қисмларини ташкил этувчи тоифалар. Кўрсатилган грамматик маъноларда фарқ қиладиган тузилмалар моделнинг ўзига хослиги ва типик маъноси билан бир қаторга бирлаштирилган.

Иккинчи холда, бошланғич структура хатти-харакат предметининг харакатга, фазавий маъноларга, экспрессив, сўроқ ва салбий маъноларга модал-ихтиёрий муносабати йўналиши бўйича жумлалар моделларининг бир қатор мунтазам таркибий ва семантик ўзгаришлари асосини ташкил қилади. Шу билан бирга, турли хил йўналишларнинг модификациялари битта модел ичида бирлаштирилиши мумкин. Ва бу ерда вариантли тузилмалар моделнинг ўзига хослигини ва типик маъносини сақлаб қолади. Хизмат ва ёрдамчи сўзлар ёрдамида яратилган семантик фарқлар, шунингдек, интонация, ўзгартиради, лекин жумланинг таркибий ва семантик асосини ўзгартирмайди.

Учинчи холатда асл тузилиш синоним қаторнинг асосини ташкил қилади. Бу ерда муносабатларнинг табиати бошқача: серияли таркибий ва семантик константларга асосланган типик маънонинг ўзига хослиги билан боғлиқ, аммо моделнинг бирлиги сақланмайди, қарама-қаршилик тегишли маънавий соялар билан ушбу маънони ифода этиш усулларига кўра давом этади.

Кўриб чиқилаётган вариацион қаторларнинг хар бирини жумлалар парадигмаси консепцияси остида жамлаш мумкин, аммо уларнинг хилма-хиллиги парадигма горизонтал, синтагматикадан фарқли ўлароқ вертикал ўқ сифатида синтаксис учун қабул қилиб бўлмайдиган холга келтиради. Агар биз геометрик тасвирлардан фойдалансак, айтишимиз мумкинки, жумланинг асл тузилиши вариант тузилмаларининг қарама-қарши йўналтирилган чизиқлари ўтган, кесишган ва ўзаро таъсир қиладиган нуқта бўлади. Марказда ўзгармас, бошланғич тузилишга эга бўлган бу чизиқларнинг таъсир доираси Г.А. Золотова томонидан жумланинг синтактик майдони деб аталади. Бошқача қилиб айтганда, жумланинг синтактик майдони - бу мунтазам грамматик ва таркибий-семантик модификацияларни ва жумланинг асл тузилиши атрофида синоним ўзгаришларни бирлаштирадиган тизим. Турли хил жумлаларнинг маълум бир модификация ва ўзгартирилиш қобилияти жумланинг таркибий ва семантик хусусиятлари, йаъни ушбу тузилманинг маълум тилнинг синтактик тизимидаги бошқалар орасида тутган ўрни билан белгиланади. Моделнинг ўзгариши билан боғлиқ 
бўлган асл тузилишнинг синоним ўзгаришлари ташқи доирада ёки майдоннинг ташқи қатламида жойлашган. Унинг предикатив минималини кўшимча маънолар билан тарқаладиган ва мураккаблаштирадиган жумланинг таркибий қисмлари, аммо асл тузилиши ўзгармайди, майдоннинг четини ташкил қилади.

Кейинчалик жумлалар парадигмаси Н. Ю Шведова консепциясида баён этилган, у жумлалар парадигмасида синтактик вақт ва обектив модаллик жихатидан бир-биридан фарқ қиладиган шаклларни ўз ичига олади. Ушбу турдаги парадигма жумлаларнинг морфологик шаклларини ташкил этадиган бир хил грамматик тоифаларга асосланади. Бироқ, морфологик парадигмага жуда яқин бўлишига қарамай, жумлалар парадигмаси ушбу тушунчада синтактик сифатида тавсифланади: унинг аъзолари жумланинг синтактик (ва морфологик эмас) шаклидир, бунда кескин белгилардаги фарқлар нафақат феълнинг ўзгариши, балки фарқлар билан хам ифодаланади. жумлалар тузилишида. Синтактик парадигма барча мумкин бўлган жумлалар моделлари учун тузилган, морфологик парадигма эса фақат "классик" оғзаки жумлаларга нисбатан кўлланилади [8. 33].

Хозирги вақтда синтактик парадигма доктринасига хар қандай бахо бериш қийин, аммо парадигматик схемаларнинг қурилиши уларни маълум синфларга жалб қилиш учун ўзаро боғлиқ тузилмаларни янада кенгроқ очиб беришга имкон бериши аниқ. Хусусан, инвариант компонентни аниқлаш синтактик парадигма доирасини тартибга солувчи хусусиятлар тўпламини ажратиб олиш ва шу билан трансформацион грамматикани трансформацион усул доирасида семантик эквивалентлигини янада ўрганиш учун назарий асос билан таъминлаш имконини беради. Синтактик парадигманинг ўзгарувчан хусусиятлари, шунингдек, батафсил ўрганишни талаб қилади, чунки уларнинг хилма-хиллиги ва субектив мотивацияси синтагматиканинг асоси сифатида қабул қилинган парадигма тушунчасига қарши. Шундай қилиб, синтактик парадигма замонавий грамматиканинг кам ўрганилган назарий муаммоси бўлиб, унинг ривожланиши, бизнинг фикримизча, ушбу фаннинг назарий асосини кенгайтиради.

\section{Фойдаланилган адабиётлар рўйхати}

1. Адамец П. Трансформационная парадигма предложения и ее соотнесенность с актуализационной парадигмой // Вопросы языкознания. 2000. № 1. С. 66-74.

2. Ахманова О.С. Словар лингвистических терминов. М., 1960.

3. Блох М. Я. К проблеме синтаксической парадигматики // Проблемы синтаксиса английского языка. Ученые записки. М.: МГПИ им. В. И. Ленина, 1970. № 422. С. 20-42.

4. Золотова Г. А. О регулярных реализациях моделей предложения // Вопросы языкознания. 1969. № 1. С. 67-78.

5. Когнитивные категории в синтаксисе: коллективная монография / под ред. Л. М. Ковалевой (отв. ред.), С. Ю. Богдановой, Т. И. Семеновой. Иркутск: ИГЛУ, 2009. 249 с.

6. Лешка О. Место трансформационных отношений в языковой структуре // Сескословенска русистика. Праха, 1966. Т. ХИ. № 2. С. 65-66.

7. Расулов Р. Умумий тилшунослик . 2-қисм. Т. 2006.

8. Шведова Н. Ю. Спорные вопросы описания структурных схем простого предложения и его парадигм // Вопросы языкознания. 1973. № 4. С. 25-36.

\section{НЕМИС ТИЛИДА СИНОНИМЛАР ГУРУХИ ДОИРАСИДАГИ СЎЗЛАРНИНГ МАЬНО ОТТЕНКАЛАРИ}

\section{Ф.Абдухакимова (магистрант СамДЧТИ)}

Annotation: In this work, we try to show the meaning, emotional, expressive and stylistic and other features of words belonging to a synonymous group in the German language on the basis of the analysis of factual materials.

Key words and expressions: synonyms,nouns, verbs. 
“Синоним” атамаси дастлаб лексикага нисбатан ишлатилган бўлиб, бу ерда маънолари бир хил, шакли ва маъно оттенкалари турли хил бўлган сўзлар ёки сўз формалари тушунилади. Синонимларнинг хар хил айтилиши ва турли хил ёзилиши борасида тилшунослар хамжихат бўлсада, улар синонимлар англатган маъносига келиб хар хил фикрларни баён этишади. Натижада тилшуносликда синонимлар хақида хар хил таърифлар пайдо бўлган. ${ }^{1}$

Тилнинг сўз бойлиги ортиши, ривожланиши билан синонимлар доираси кенгая боради. Синонимларнинг тараққиёти, тилда янгидан-янги синонимларнинг пайдо бўлиши сўз бойлигининг ривожига боғлиқ. Синонимлар умумий маънолари асосида ўзаро бирлашиб, битта “синонимик уяни” хосил қилади. Айнан мана шу синонимик уяга кирган хар бир сўзнинг маъно оттенкасини белгилаш ва қай холатда уларнинг бири ўрнига иккинчисини ишлатиш мумкинлигини кўрсатиш хар бир тадқиқот олдида турган мухим вазифа бўлиб хисобланади.

Биз мазкур ишимизда немис тилидаги бир синонимик группага кирувчи сўзларни маъно оттенкалари, эмоционал, экспрессив ва стилистик хамда бошқа хусусиятларни фактик материаллар ${ }^{2}$ анализи асосида кўрсатишга харакат қиламиз.

\section{Angst (f), Furcht (f), Schreck (en) - кўрқинч, кўркув, кўрқиш.}

Ушбу учала сўз хам бирон нарсадан қўрқиш маъносини англатади. Булар ичида Angst умумий маънога эга. Furcht ва Schreck (en) эса ушбу хиссиётнинг юқорироқ даражасини англатади. Schreck (en) сўзи Angst ва Furcht отларига нисбатан узоқ давом этмайдиган бир лахзалик қўрқувни англатади. Мисоллар:

1. Im Hof herrschte die Stille der namenlosen Angst. (L.Frank).

2. Das Gefühl der Furcht sonderte sich von Nebengefühlen. (A.Seghers).

3. Sein Schreck war so gewaltig, daß er nicht länger als eine Sekunde dauern konnte. (L.Frank).

\section{Ding (n), Sache (f), Gegenstand (m) - нapca}

Учала от хам бир хил нарсани, яъни предмет, нарса маъносини англатади. Бироқ Ding ва Sache сўзлари кўпроқ жонли тилга хос бўлса, Gegenstand сўзи одатда ёзма нутқда ишлатилади. Мисоллар:

1. Dann kramte er aus dem Rucksack verschiedene Dinge heraus. (A.Seghers).

2. ... wenn sie ... dumme kleine Sachen kauften, nur um zusammen etwas zu kaufen ... (L.Frank).

3. Für den Metaphysiker sind die Dinge ... ein für allemal gegebene Gegenstände der Untersuchung. (F.Engels).

3. Ende (n), Schluß (m) - тамом.

Хар иккала от хам бирон нарсанинг тугалланганлигини англатади. Бироқ Ende вақт маъносига эга бўлган тушунчаларнинг нихоясини англатса, Schluß сўзи бирон-бир воқеаходисанинг тамом бўлганлигини билдиради. Қиёсланг:

1. Jetzt zwar, Ende Juli, verhalten sie sich still. (A.Seghers).

2. Erst seit dem Ende des 16. Jahrhunderts kennt die deutsche Sprache das Dehnungs - h als Längezeichen.

3. Am Ende des Briefes hieß es ... (A.Wedding).

4. greifen, fassen, packen, ergreifen - ушламоқ.

Бу тўртала феъл хам “бирон нарсани ушламоқ” деган маънони англатади. Packen феъли кучайтирувчи маънога эга. Буларнинг барчаси Akkusativobjekt билан қўлланади. Бироқ уларнинг хар бири турли хил предлоглар билан ишлатилади: greifen an + Akkusativ; fassen, packen an + Dativ; fassen, packen, ergreifen bei + Dativ; greifen und fassen nach + Dativ. Мисоллар:

1. Er griff sich an den Hals. (A.Seghers).

2. Dabei fasste sie Helene am Arm und zog sie mit fort. (W.Bredel).

3. Dann ergriff der Student das Glas und schüttete den Wein Herrn Hut ins Gesicht. (L.Frank). 
4. Die Begeisterung der Gesetzgeber packte das ganze Volk. (L.Feuchtwanger).

5. Junge (m), Knabe (m), Bube (m) - ўғил бола.

Бу отлар бир хил маънога эга бўлиб, улар ишлатиш жихатдан бир-биридан фарқ қилади. Knabe сўзи авваламбор ёзма нутққа тегишли бўлиб, поэзияда кўплаб ишлатилади. Junge ва Bube сўзлари эса жонли тилга хос бўлиб, Junge сўзи Германиянинг шимолида, Bube сўзи эса жанубда, шунингдек Австрияда кўпроқ ишлатилади. Қиёсланг:

1. Siebzehn Knaben standen vor dem Richtertisch. (L.Frank).

2. „Würde auch dir nichts schaden, mein Junge, meint der Onkel“. (F.Wolf).

3. Ich hoffe, du wirst solche Kindereien nicht mehr tun; du bist ja wirklich kein Bub mehr. (St.Zweig).

6. lernen, studieren - ўқимок.

Хар иккала феъл хам бирон жойда ёки бирон нарсани ўқимоқ маъносини англатади. Lernen феъли биринчи навбатда мактабда ўқимоқ маъносини англатса, studieren феъли эса олий ўқув юртида тахсил олмоқ маъносида ишлатилади. Шунингдек у бирон бир фанни (медицина, математика, биология) ўрганиш маъносида хам ишлатилади. Хар иккала феъл хам тўлдирувчисиз ёки турли хил предлоглар билан хам ишлатилади: Lernen in, an + Dativ, studieren an, auf, selten in + Dativ. Мисоллар:

1. Er beschrieb auch die Schule, in der er einen Monat gelernt und gelebt hatte. (A.Seghers).

2. Der Maestro, das ist etwas anders. Er hat auf dem Konservatorium studiert. (H.Mann).

3. „Was studieren Sie denn, junger Mann?“ fragte sie. „Chemie“. (H.Mann).

7. Lohn (m), Gehalt (f), Gage (f) - иш хақи, ойлик.

Бу сўзлар бирон кишининг мехнати учун бериладиган ойлик, хафталик ёки кунлик иш хақини англатади. Бироқ улар ўртасида тафовут мавжуд. Lohn - бу аввалам бор ишчининг иш хақига нисбатан ишлатилади. Gehalt сўзи хизматчининг иш хақини англатса, Gage - бу санъаткорнинг мехнати учун бериладиган суммага нисбатан қўлланади. Мисоллар:

1. Sollte sie immer das letzte Wort haben bei ihrem geringen Lohn als Straßenbahnschaftnerin? (E.Strittmatter).

2. So ein Flesch klaute bestimmt an einem Tage mehr, als ein Zollinspektor bei treuer Pflichterfüllung im Monat an Gehalt verdiente ... (W. Bredel).

3. Sie erhielt am Theater in Wien eine Gage, von dreihundert Kronen. (B.Kellermann).

Юқоридаги мисоллар шуни кўрсатадики, хар бир “синонимик уя” ни ташкил этувчи сўзлар умумий маънолари асосида ўзаро боғланганлар. Аммо улар маъно оттенкалари ва ишлатиш доирасига кўра бир-биридан фарқ қилади. Синонимларнинг ўзларига хос шу хил маъно тафовутлари айрим холларда бирининг ўрнига иккинчиси ишлатишга имкон бермайди (Масалан: Lohn,Gehalt, Gage сўзлари).

Демак, синоним сўзларининг маъно оттенкалари ва қўлланиш доираси бир хил эмас. Бир “синонимик уя” га кирувчи сўзларнинг мухим белгиси уларнинг маъно томондан бирбирига яқинлигидир. Шунинг учун хам улар умумий бир маъно теварагида уюша олади ва бир синонимик группани ташкил қилади.

\section{Фойдаланилган адабиётлар руйхати}

1. Синонимларга берилган таърифлар: Л.М.Скрепина. Грамматическая синонимия. Л.1987, стр.4; Ахманова. Словарь лингвистических терминов. М.,1966, стр. 407; J.Dubuis, M. Giscomo, L. Marcellesi.Dictionnsire de linguistique. F., 1973. C.476.

2. Мисоллар М.Г.Арсеньева, А.П.Хазанович, Д.Б.Замчукларнинг Deutsche Synonyme (Л., 1963) номли китобидан олинди. 


\title{
II ШЎЪБА
}

\section{УМУМИНСОНИЙ ҚАДРИЯТЛАРНИНГ ШАКЛЛАНИШИДА МИЛЛИЙ МАДАНИЯТНИНГ ЎРНИ}

\section{КИТАЙ И ЦЕНТРАЛЬНАЯ АЗИЯ: АКТИВИЗАЦИЯ СОТРУДНИЧЕСТВА В НОВЫХ УСЛОВИЯХ}

\author{
Ян Бо \\ (ШУИЯ, Китай, к.ф.н., профессор)
}

\begin{abstract}
Annotation: The article examines China's relations with Central Asia based on a comparative analysis of Central Asia's relations with the United States, the EU, Japan, and South Korea, and identifies a new quality of China's cooperation with Central Asian countries, in particular within the framework of the Chinese Belt and Road initiative and the SCO

Key words and expressions: Central Asia, China, cooperation, Shanghai cooperation organization, Belt and Road initiative

Начало XXI столетия характеризуетсяперемещением центра тяжести мирового развития в сторону Азии. При этом ощутимо возрастает политическая значимость Центральной Азии, которую все чащеназывают «Сердцем Азии». Китай и Россия исторически и географически тесно связаны с этим самобытным регионом, где, как на оживленном историческом перекрёстке, с древних времён встречались различные человеческие цивилизации.Сотрудничество Китая и Россииносит в регионе характер стратегического партнёрства. Ярким тому примером может служить Шанхайская организация сотрудничества, олицетворяющая собой межгосударственное объединение нового типа.

В 2021 году ШОС будет отмечать юбилейную дату - 20-летие со дня оборазования. За два десятилетия ШОС закрепила за собой авторитет ответственной за регион организации, которая последовательно и неуклонно придерживается линии, исключающей блоковые, идеологизированные и конфронтационные подходы к решению актуальных международных и региональных проблем. Главное, практические результаты даётплодотворное долгосрочное сотрудничество по укреплению экономических и гуманитарных связей, а
\end{abstract} такжевзаимодействие в борьбе с новыми вызовами и угрозами.

\section{Отношения развитых стран с Центральной Азией}

Примечательно, что повышенное внимание к Центральной Азии со стороны ведущих стран мира проявилось еще в 90-х годах. Сегодня столицы государств Центральной Азии стали привычнымместом проведения крупнейших международных форумов, определяющих глобальную повестку дня. Место и роль Центральной Азии на мировой арене существенно изменились. Равно как и стремление ведущих стран мира активно развивать сотрудничество с государствами региона.

Как известно, в 2011 г. США анонсировали идею запуска собственной инициативы «Новый Шелковый Путь», которая ушла в историю, не найдя широкой поддержкив регионе. Вместо неё был предложен формат Диалога «США и Центральная Азия».На первой встрече в формате «5+1» на министерском уровне, ЩД02которая проводилась в г. Самарканд в ноябре 2015 г., министры иностранных дел стран Центральной Азии и государственный секретарь США договорились сосредоточить внимание набезопасности, экономикеи проблемах окружающей среды. 2 февраля 2020 г. в Ташкенте руководители внешнеполитических ведомств сфокусировали внимание на укреплении диалога по террористическим угрозам. Несмотря на остроту ситуации, связанную с COVID-19, 30 июня 2020 г. состоялась внеочередная встреча руководителей внешнеполитических ведомств США и стран Центральной Азии. Были обсуждены вопросы региональной стабильности, торгово- 
экономического сотрудничества и обеспечения продовольственной безопасности в регионе.В новой «Стратегии Соединенных Штатов в Центральной Азии на 2019-2025 годы: укрепление суверенитета и экономического процветания» отмечается, что США за последние 25 с лишним лет предоставили странам региона помощь на сумму более $\$ 9$ млрд, а также обеспечили финансирование более 40 тысяч учебных и профессиональных обменов. ${ }^{34}$

Европейский союз начал взаимодействие со странами Центральной Азии через инициированную им программу ТАСИС, которая охватывала все новые независимые государства на постсоветском пространстве,входившие вСНГ.В ее рамках с 1992 по 2007 годы для поддержания и проведения институциональных реформ Европейская Комиссия предоставила странам центрально-азиатского региона помощь в размере 1,1 млрд евро. ${ }^{35} \mathrm{~B}$ июне 2007 г. ЕС принял Стратегию нового партнерства с Центральной Азией. На период с 2014 по 2020 гг. ЕС выделил 1,1 млрд евро на сотрудничество с Центральной Азией, в том числе свыше 454 млн евро на региональные программы, из которых каждый четвёртый евро - 115 млн - был предназначен для программы обмена студентами и преподавателями Erasmus $+{ }^{36}$ Новая версия Стратегии «ЕС и Центральная Азия: Новые возможности для сильного партнерства» 17 июня 2019 г. документ был утвержден Советом ЕС. ${ }^{37}$

Япония первой предложила центрально-азиатским партнерам «открыть» диалоговый формат регулярных встреч глав внешнеполитических ведомств в 2004 г. По оценке японской стороны со времени обретения независимости свыше 10 тысяч человек из стран Центральной Азии прошли стажировку и обучение в Японии; в свою очередь около 3,5 тысяч японских экспертов за этот период посетили регион. Диалог также активизировал обмены между 8 японскими и 16 центрально-азиатскими университетами и исследовательскими центрами. За период с 2015 по 2019 гг.общий объем финансирования проектов, осуществленных или запланированных между Японией и Центральной Азией, достиг примерно 2,8 триллионов иен. Страна восходящего солнца нацелена последовательно развивать сотрудничество с регионом, несмотря на территориальную отдаленность друг друга.

В 2007 г. в г. Сеул была заложена традиция проведения Форума по сотрудничеству «Республика Корея - Центральная Азия». С каждым годом растет вклад Форума в расширение взаимодействия в сферах, имеющих потенциал для расширения двустороннего и многостороннего сотрудничества.В ноябре 2016 г. на X юбилейной сессии было объявлено о создании Секретариата Форума, который позднее был учрежден при Корейском Фонде международного обмена. ${ }^{38} 12$-й Форум сотрудничества «Центральная Азия - Республика Корея» прошел в г. Нур-Султан, 16 октября 2019 г.29 июня 2020 года в формате видеоконференции состоялось подписание Меморандума о взаимопонимании между ТППстран Центральной Азии и Корейской Ассоциацией международной торговли (KITA) о создании Делового Совета «Корея - Центральная Азия».

Первый диалог «Индия - Центральная Азия» на уровне министров иностранных дел состоялся лишь в январе 2019 г.Встреча прошла с участием Афганистана в формате $1+5+1 . B$ качестве практического шага индийская сторона предложила создать «Группу развития

\footnotetext{
${ }^{34}$ U.S. Department of State. United States Strategy for Central Asia 2019-2025: Advancing Sovereignty and Economic Prosperity (Overview). https://www.state.gov/united-states-strategy-for-central-asia-2019-2025-advancingsovereignty-and-economic-prosperity/.[Последнееобращение: 20.08.2020]

${ }^{35}$ European Commission. EC Technichal Assistance to the Commonwealthe of Independent States and Georgia: The TACIS Programm. https://ec.europa.eu/commission/presscorner/detail/en/MEMO_92_54.[Последнееобращение: 05.09.2020]

${ }^{36}$ EU External Action Service. Central Asia. https://eeas.europa.eu/headquarters/headquarters-homepage/2068/centralasia_en.[Последнееобращение: 05.09.2020]

37 European Council. Central Asia: Council adopts a new EU strategy for the region. https://www.consilium.europa.eu/en/press/press-releases/2019/06/17/central-asia-council-adopts-a-new-eu-strategy-forthe-region/.[Последнее обращение: 15.09.2020]

${ }^{38}$ Секретариат Форума Сотрудничества "Центральная Азия - Республика Корея". https://www.centralasiakorea.org/web/pages/gc85704h.do. [Последнее обращение: 03.09.2020]
} 
Индии и Центральной Азии» для укрепления партнерства, а также начать диалог по воздушным коридорам со странами региона, которые не имеют выхода к морю.

\section{Взаимнодействие Китая с Центральной Азией}

Китай в числе первых признал независимость и суверенитет новых государств Центральной Азии. На рубеже 2021/2022 годов Китай и его центральноазиатские партнеры будут отмечать 30-летие установления дипломатических отношений. Все эти годы сотрудничество развивалось по нарастающей и отличалось крепнущей из года в год дружбой, растущим взаимопониманием и взаимным доверием. Оставшийся от истории пограничный вопрос был полностью и окончательно урегулирован, что открыло самые широкие перспективы для развития добрососедских отношений вXXI веке.

Общим достоянием является и совместно выстроенная за эти годы устойчивая, отвечающая коренным интересам Китая и государств Центральной Азии, архитектура дружескихотношений, отличающаяся прочностью фундамента и мозаикойуглубленного стратегического партнёрства.

За короткий период времени, не имеющая выхода к морским путям Центральная Азия превратилась в крупнейший на планете сухопутный порт и востребованное транзитное пространство. Только через Казахстан за последние два десятилетия проложено 11 автомобильных и 6 железнодорожных международных магистралей, по которым ежегодно проходит около 60\% всех товарных составов, следующих по маршруту Китай-Европа-Китай. На фоне попыток подрыва глобализации, неуклонно растет востребованность Инициативы «Пояс и Путь», расширяется транспортная взаимосвязанность Китая и Центральной Азии. Невозможное стало возможным. На глазах современников в рекордно короткие сроки на новой технологической основебыл воссоздан Великий Шёлковый путь.

Динамика торговли между Китаем и странами Центральной Азии свидетельствует о том, что это далеко не «шоссе с односторонним движением», а полнокровное взаимовыгодное сотрудничество. В частности, за период с 2001 по 2019 гг. товарооборот между Китаем и странами региона увеличился в 30 раз: с 1 млрд 508 млн в 2001 г. до 46,5 млрд в 2019 г. ${ }^{39}$ Стороны успешно преодолели трудности, вызванные мировым финансовоэкономическим кризисом. Его уроки учитываются при координации и принятии совместных мер по смягчению негативных последствий на экономику региона в связи с пандемией коронавируса.Министры иностранных дел Китая и стран Центрально Азии уделили этой теме особое внимание на состоявшейся 16 июля 2020 г. встрече, прошедшей в формате видеоконференции.

\section{Сотрудничество в рамках «Пояса и Пути» и ШОС}

Очевидно, что участие центрально-азиатских государств в совместном продвижении Инициативы «Пояс и Путь» открыло новые широкие горизонты сотрудничества в торговоэкономической сфере, где заложен основательный фундамент, а совместно строящееся на нем здание будет неуклонно подниматься вверх и расширяться по горизонту. Что бы не говорили критики и злопыхатели, многопрофильное сотрудничество Китая и стран Центральной Азии способствует устойчивому социально-экономическому развитию региона. У Китая и стран Центральной Азии во многом совпадают как цели развития, так и озабоченности, особенно что касается проблем обеспечения безопасности и стабильности в регионе.

У Китая и стран Центральной Азии есть надежный друг и стратегический партнёр, Россия, которая тесно и плодотворно взаимодействует с ними в двустороннем и многостороннем форматах, в частности, в рамках ШОС. Очередной Саммит организации, который, как ожидается, пройдёт осенью текущего года под председательством России, вновь подтвердит эту исторически сложившуюся связку Китай-Россия-Центральная Азия, в которой нет «старших» и «младших», «начальников» и «подчинённых». В ней все узлы

\footnotetext{
39 Trade $\quad$ Map $\quad-\quad$ International $\quad$ Trade Statistics. https://www.trademap.org/tradestat/Product_SelProduct_TS.aspx?nvpm=1\%7c\%7c\%7c\%7c\%7cTOTAL\%7c\%7c\%7c2 \%7c1\%7c1\%7c1\%7c2\%7c1\%7c1\%7c1\%7c1\%7c1.[Последнее обращение: 20.09.2020]
} 
равны и каждый играет незаменимую, взаимодополняющую роль, обеспечивая безопасность друг друга и совместное развитие на долгие десятилетия вперёд. А «долгий огонь, - как гласит китайская пословица, - сталь закаляет».

\title{
MADANIYATLARARO MULOQOTNING BA`ZI JIHATLARIXUSUSIDA MULOHAZALAR (Yapon madaniyati va adabiyotining ilk davri misolida)
}

\section{X.A. Mamatqulova ( SamDChTI, dotsent)}

\begin{abstract}
Annotation: The article is devoted to the study of the characteristics of the culture and literature of Japan before the pre-alphabetical period and the era of Nara. Changes in the sociocultural life and literary process of Japan of these periods are described. The formation of the ethnocultural features of Japan from the Paleolithic period to the Heian epoch and their expression in the language and text based on information are investigated.
\end{abstract}

Key words ans expressions: Jomon era, yayoi culture, kofunzhidai, "Three sacred objects", Yamato, Prince Shotoku, "empress" Suiko, Nippon, Nara, literary periodization, Kojiki, Nihonshoki, Himmei, Fudoki.

Xitoy yilnomalarida yaponlar (xitoycha vojen, yaponcha vajin - vaning odamlari) haqidagi ilk ma'lumotlar miloddan avvalgi I asrga to'g'ri keladi. "Xan shu"da (Xan sulolasi tarixida): "Lolan daryosi bo 'ylarida vojenlar yashaydilar.Ular yuzdan ortiq hududlarga bolinganlar [1.20.].

Eramizning I asrida va xalqining koplab mayda hududlari urug'chilik va qabilachilik asosida birlasha boshlaganlar. Urug'(uji) asosiy ijtimoiy tashkilot sifatida qarindoshchilik munosabatlariga asoslanadi. Hududi umumiy, yaratuvchi-ma'budga(ujikami) sig'nadi, yagona sardorga (uji-nokami)bo'ysunadi. Sardor boshqa urug'lar bilan aloqalar olib boradi, urug' a'zolarining ustidan hukm chiqargan hamda urug'ning oliy shamani hisoblangan. Eramizning boshlarida qadimiy yapon urug'lari qondoshchilik va hududiy birlashmalardan iborat edi [1.15.].

III asrning ikkinchi yarmida ilk temir davri boshlanib Yaponiya tarixida "Kofun jiday"qo 'rg'on davri deb nom olgan. Sardorlarni keyinchalik avlodlarning ulug'larini dafn qilganda ham dumaloq shakldagi (V asrning oxirlaridan VII asrning oxirlarigacha kvadrat-dumaloq)qo'rg'onlar qurishgan, keyinchalik ulardan dafn buyumlari: marosimga oid buyumlardan harbiy buyumlargacha topilgan.

III asrda uchta qabilaviy uyushmalar mavjud bo'lgan. Markaziy Kyusyuda Kuna, Shimoliy Kyusyuda Ematay Xonsyu orolining markaziy qismida Yamato. Har biri o'zining sardori tomonidan boshqarilgan va qit'a bilan mustaqil aqloqalar olib borganlar. Xitoy solnomalaridan "Vey ji" da (Vey qirolligi tarixi) keltirilishicha Vey qirolligi hamda Kyusyu orolining shimolida "qirolicha" Fimiko saltanati o'rtasida diplomatik aloqalar o'rnatilgan.

Hunarmandchilik va dehqonchilikning paydo bo'lishi va rivojlanishi immigrant (kikaji) larning yangi oqimini yuzaga keltirgan, ular -xitoylar va koreyslar, yuqori rivojlangan madaniyat vakillari sifatida ularning hunarmandchilik mahsulotlariga ehtiyoj katta bo'lganligi bois Ichki Yapon dengizi qirg'oqlariga ixcham-ixcham guruhlar tartibida joylashtirilganlar.

Qadimgi yaponlarning diniy e'tiqodlari keyingi davrlarda sinto-(ma'budlar yo'li) deb nomlanadi. O'zida animizm, ajdodlar e'tiqodi hamda ikki turdagi shomonlik-shimoliy osiyo va malay-poleziya unsurlarini birlashtiradi. "Yaponiya anallarida"(VIII asr.) Yaponiyaning samoviy mab'udlar tomonidan tashkil topishi haqidagi bo 'limida shunday deyilgan: "O'sha yerda ko"p kamilar mavjud bo'lib, chaqnab turadilar.... Shuningdek, daraxtlar va maysalar ham bor, ular gapiradilar.

Har bir urug' o'zining yasirosiga-muqaddas joyiga ega bo'lgan. U yerda urug'ning ajdodlariga ta'zim bajo keltirganlar. Uji federatsiyalarining tashkil topishi va Yamato urug'ining kuchayishi munosabati bilan shu urug'ning yaratuvchisi hisoblangan quyosh ma'budasi Amaterasuga topinish boshlangan. U boshqa mahalliy topinishlarni siqib chiqarmaydi, lekin ulardan ko'ra ko'tarilib ilk yapon davlatining barcha hududlariga tarqalgan. Ise viloyatida Tinch okeaninig 
qirg'og'ida Amaterasuga topinish uchun bino tiklaydilar. Bu yerning kohini turmushga chiqmagan malika bo'lgan. Davlat barpo bo'lishi haqidagi umum yapon miflari arxaik koreys folkori va marosimlaridagi voqealarga o'xshash. Ildizlari Shimoliy Osiyoga borib taqalsa ajab emas [1.82.].

Ilk davlat tashkilotlarining doimiy poytaxtlari bo 'lmagan. Har bir "qirol" ma'muriy markazini yangi joyga ko'chirgan. Sababi vafot etgan "qirol' hududini la'natlangan degan tasavvur hamda Yamato davlatiga kirgan kuchli qabilaning manfaatlari bo'lgan. Davlat boshqaruvi o'zining ehtiyojlarini keltirib chiqargan: ma'muriy apparatning yaratilishi, markazlashuvning g'oyaviy asoslanishi, davlat tizimining barcha sohalari faoliyati uchun yozuvning qabul qilinishi.

Orolga IV-V asrlarda Xitoy va Koreyadan ko'chib kelgan bir qancha muhojirlar Xitoy ieroglif yozuvini bilganlar. Ma'lumotlarga ko'ra, yozuv VI asrning o'ttizinchi yillarida keng miqyosda kirib keladi [1.17.].

Vakayama viloyatida topilgan bronza oynadagi yozuvga 503 yil deb sana qo'yilgan[1.24.].

Yaponiyada yozuv madaniyatining uzluksiz tarixi VII asrdan boshlangan. Hozirgi kunda buddaviylik ibodatxonalarida eng ko'p qadimiy matnlar mavjud, zero ularda bronzadan yasalgan qadimiy madaniy buyumlar saqlanib qolgan. Yaponiyada buddaviylik tarqalishining asosiy nuqtasi 552 ( boshqa variantda 538 yil) yil koreys davlati Pekchedan qimmatbaho sovg'alar bilan kelgan elchilar bilan bog'liq. Sovg'alar ichida Buddaning haykaltaroshlik tasvirlari, budda yozuvlarining qo'lyozma matnlari, marosimlarda ishlatiladigan qimmatbaho idish ham bo'lgan. 594 yil valiahd shaxzoda Shotoku (574-622) "qirolicha" Suyko (554-628) nomidan buddaviylik ta'limotining uch xazinasi - Buddaga, ta'limotiga (dxarmaga), xizmat qiluvchilar jamoasiga(sangxu) e'tiqod qilishga farmon chiqarib xalqqa e'lon qiladi. "Yaponiya anallarida" imperator Temmu (673)davrida buddaviylik ta'limotining qonunlari xitoycha tarjimasi VII asrda yaponlar orasida keng tarqalganligi, u uch mingdan ortiq o'ramadan iborat ekanligi, qayta ko'chirishga ko 'p odamlar jalb qilinganligi bayon etilgan.

Hukumron urug'ining ilohiyligi to'g'risidagi cintoistik kontsepsiya davlat boshqaruviga qaratilmagan bo'lib, hukumdorning unga tobe urug'lar boshliqlaridan mutlaq ustunligini e'tirof etgan. Davlat boshqaruvida g'oyaviy ta'limotni qabul qilish borasida ta'sirga ega urug'lar orasida uzoq tortishuvlardan so'ng buddaviylikni tarqatishga, keyinchalik konfutsianlik va xitoy siyosiy institutlarini o'zlashtirishga qaror qilganlar. Natijada buddizm davlat diniga aylangan.

604 yilda shaxzoda Shotoku 17 moddadan iborat birinchi Konstitusiyani qabul qilgan. VI asrning oxirlarida Yaponiyaga Markaziy va G'arbiy Osiyodan moddiy buyumlar kirib kelgan. 607 yilda Shotoku Xitoyga Ono-no Imoko boshchiligida keng ko'lamda elchilarni yuborgan. Xitoy imperatoriga yozilgan maktub shunday boshlangan: "Quyosh chiqar mamlakatning samo o'g'loni Quyosh botar mamlakatning samo o'g'loniga murojaat qiladi...”. Shu tarzda Yamato davlati Xitoy bilan mustaqil va teng huquqli munosabatlar o'matishga harakat qilgan. Oradan bir yil o'tib Xitoydan javob tariqasida elchilar kelgan.

Buddizm va konfutsianlikning tarqalishi hamda VII asrda Xitoy andazalaridagi siyosiy institutlarining tatbiq etilishi, fan va texnikaning taraqqiyoti Yaponiyaning mintaqa tamadduniga jalb etilishiga olib kelgan. O‘zlastirilgan (Sharqiy Osiyodan, Hind-buddizmdan, Markaziy Osiyodan ) unsurlar protoyapon madaniyatining o'ziga xos sintetik ya'ni bir tomondan an'nalarni saqlab qolgan, ikkinchi tomondan yangiliklarni faol o'zlashtirib olgan madaniyatga aylanishiga omil bo'lgan. Mazkur xususiyatlar Yaponiya tarixining rivojlangan yozma madaniyatining bosqichlarida yaqqol ko'rinadi.

VII asrning ikkinchi yarmida Yaponiyaning Yamato nomining o'rniga xitoylashgan nom Nippon (Nixon, xitoycha Jiben-Quyoshning ildizi) myomalaga kiritiladi. Bu davrda yapon hukumdorlari Kuyusyu, Sikoku, Xonsyu orolining katta qismida hukumronliklarini o'rnatgan edilar. Xonsyu orolining shimoliy qismida bo'ysunmas ayn qabilalari istiqomat qilganlar. Bir paytlar Yamato federatsiyasini tashkil qilgan yapon urug'lari tinimsiz bo'linishlar va tarkibiga boshqa urug'larni qabul qilishlari natijasida tubdan o'zgarganlar. 664 yil "qirol” Tenji urug'larni tabaqalashtirish xususida farmon chiqargan. Uryg' boshliqlarining mavqesiga ko'ra turli uzunlikdagu qilichlarni joriy etgan. Ilk davlatchilikning tashkil topishi g'oyaviy ta'minotidan tashqari tez sur'atlarda xo'jalikning, hunarmandchilikning, fan va san’atning taraqqiyotiga olib 
kelgan. Qurulish ishlari avj olgan. Saroylar, ibodatxonalar, yo'llar, ko'priklar, bandargohlar, kemalar qurulish shular jumlasidandir. Foydali er qazilmalari ishlari, metallurgiya va mexanika rivojlangan (kompasning, suvda harakatlanadigan g'ildiraklar kabilarning muomalaga kiritilishi). Astronomiya sohasida esa taqvim kiritilgan, yo'l, xitoy tizimiga asoslanib yil oyga, kichik va katta mavsumlarga sutka va soatlarga bo'lingan va hokazo, qishloq xo'jalik ishlarining muddatlari aniqlangan. Matematika, tibbiyot, qog'oz va yozyv jihozlarini ishlab chiqarish, to'qimachilik, rassomchilik, musiqa taraqqiyot etgan. Muayyan hunarmandchilik sohalari uchun alohida korporatsiyalar tashkil etilgan. Saroyda fan va turli ishlab chiqarish sohalarini boshqaradigan bo'limlar tashkil qilingan. 645 yilda Xitoy Tan sulolasi andazasida aholini va qishloq xojaligining erlari ro'yxatdan o'tkazilgan. 646 yilgi farmon bilan me'rosning yangicha tizimi kiritilgan, mamlakatning ma'muriy viloyatlarga va uezdlarga, poytaxtning -dahalarga bo 'linishi belgilangan.

VII asr yapon davlatchiligida yozuv davri bo'lishga ulgurgan edi. Rasmiy xujjatlar, buddaviylik sutralari, ularning izohlari, xo'jalik ko'rsatmalari xitoy tilida olib borilgan.

Tabiatdan ruhlanish "so'z qalbiga" ishonishga (kotodama) olib keladi, ya'ni yaponlar so'z sehriga ishonadilar.

Yapon tarixshunosligida VI asrning oxiri va VII asrning oxirigacha Asuka davri deyiladi. (Ushbu asrda bir qancha "qirollarning" qasrlari joylashgan joyga nisbatan olingan). Mazkur davrda mamlakatning siyosiy va ijtimoiy hayotidagi muhim voqealardan biri Tayka islohoti (645) natijasida iqtisodiy, ijtimoiy, ma'muriy sohalarda, erdan foydalanish tizimida kuchli ijobiy o'zgarishlar bo'lgan[4.212.]. O'zgarishlarning hosilasi sifatida mamlakat hayotini bir necha asrlargacha belgilab bergan Tayxoryo qonunlar to'plamining yaratilishidir (702-718).

VIII asr Yaponiyada yozma adabiyotining vujudga kelishi bilan mashhur.

Yaponiya davlatining mustahkamlanishi va taraqqiyoti yolida tarmoqlangan boshqaruv tizimini yolga qo'yish va doimiy poytaxtga ega bo'lish lozim edi. Poytaxt shahar 710 yil qurib bitkazilgan. Unga Olam Egasi (Nara yoki Xeyjyo) deb nom qo'yilgan. Shahar qurilishida davlat poytaxtini qurishdagi Xitoy me'morlari qabul qilgan tamoyillarga asoslanilgan.

Yaponiya V asrda Koreya orqali Xitoyning iyeroglif yozuvuni qabul qilgan uchta mamlkatdan biri. Ma'lumki, qadimgi xitoy dunyodagi eng qadimgi tamaddunlardan hisoblanadi. Dunyodagi barcha xalqlar madaniyatiga, xususan. Sharqda Yaponiya va Koreyaga ta'siri behisob. Tarixda yapon filologiyasi xitoy yozuvining juda katta ta'siri asosida paydo bo'lganligi ta'kidlangan. Aniqlanishicha, xitoy iyerogliflari Yaponiyada tarqalgungacha ${ }^{\circ} \mathrm{z}$ yozuvi bo'lmagan. Yaponiyada yozuvning paydo bo'lishi V asrning boshlariga borib taqaladi. Buni arxeologik qazilma natijasida topilgan yozuv asoslagan: (Funayama qo'rg'onida topilgan. Kumomoto perfekturasi, Kyusyu oroli) "Kimki ushbu xanjarni olib yursa unga uzoq umr, ko'p farzand va ko'p nabiralar in'om etiladi” deb yozilgan. Aytilishicha o'sha zamonlarda o'yib yozilgan yozuvi bor narsaning qandaydir ilohiy kuchi mavjud deb ishonilgan. Keyinchalik bunday qarash umuman yozuvga nisbatan mavjud bo'lgan. Yaponiyaning eng qadimgi yozma yodgorliklarida ta'kidlanishicha, yapon tiliga xitoy iyerogliflarini kirib kelishi VII asrda tugatilgan.

Yozma yodgorliklardagi ma'lumotlarga ko'ra yapon adabiyoti VII-VIII asrda shakllana boradi, biroq uning ildizlari juda qadimga borib taqalishi kamida eramizning III asrlariga borib taqalishi va xalq og'zaki ijodidan oziqlanganligi sir emas. Shunday qilib yapon yozma adabiyotining vujudga kelishida ko'p asrlik folklor manba bo'ladi. Albatta, folklor keyinchalik ham rivojlanadi. U yapon adabiyotining timsollariga, mavzulariga manba bo'lib qolaveradi. Yozma adabiyot nafaqat xalq og'zaki ijodiyotidan foydalanadi, shuningdek xitoy, koreys kabi o'zidan yuqoriroq rivojlangan mamlakatlarning an'analarini o'zlashtirgan.

VIII asrda yuqoridagi yozma yodgorliklar yaratilgan paytda Yaponiya poytaxt Naraga ega bo'lgan markazlashgan davlat bo'lgan. Davlat boshida yapon tarixiy xronikalarida imperator deb nomlangan dohiy o'tirgan. Ma'muriy va ijtimoiy tartib Xitoy andazasida shakllantirilgan. Amaldagi Tayxoryo kodeksi (701) mamlakatning barcha jabhalarini qamrab olib tartibga solgan. Davlat amaldorlarini tayyorlovchi maktab ta'limi tizimi yaratilgan. Xitoy adabiyotini o'rganish va buddaviylikni targ 'ib qilish tizimning asosini tashkil qilgan. Xitoy yozuvi asosida fonetik bo' ${ }^{\prime}$ 'inli 
alifbo Kana ishlab chiqilgan. Mazkur davrda materik bilan adabiy aloqalar doimiy va rasmiy xususiyatga ega bo'lgan.

Yaponiyadan Xitoyga, Tan saroyiga, Koreyaga maxsus elchilar doimiy yuborilgan. Koreyaning qadimiy davlatlari bilan munosabat Yaponiyaning tili va madaniyatiga ta'sir qilgan. Bu davrga kelib, Xonsyo orolining g'arbiy qismida koreyaliklarning yirik-yirik manzilgohlari mavjud bo'lgan. Koreya va Xitoydan kelganlar hamda sayyor rohiblar mamlakatning madaniy va adabiy hayotida muhim ahamiyat kasb etganlar.

Arxeologik manbalar, qadimiy ibodatxonalar va Naradagi Siyosoin xazinasi Yaponiyaning Xitoy va Koreyadan tashqari boshqa xalqlar va davlatlar madaniyati va tamadduni bilan aloqalari haqida ma'lumotlar beradi. Topilmalardagi naqsh va qadimiy rasmlarning tadqiqotlari yapon ustalariga O'rta Osiyo, Arab mamlakatlari, Yunoniston madaniyati ma'lumligidan xabar beradi. Mamlakatning taraqqiyotida VI asrda kirib kelgan buddaviylikining ahamiyati katta bo'lsada, sintoizm ham o'z ta'sirini saqlab qolgan.

Qadimgi yapon jamiyatida qo'shiqlar muhim ahamiyat kasb etgan. Qo'shiq hayot turmush tarzi bilan chambarchas bog'liq bo'lib, mehnat, marosim, hordiq jarayonida yonma yon tugan. Yapon adabiyotining mazkur qadimiy davri haqida ilk yozma yodgorliklardagi ma'lumotlarda uchraydi. Qadimiy xalq e’tiqodi "Kotoda-mon-sinko", (so‘z qalbiga ishonch ya'ni soz'ning sehriga ishonch) dehqon marosimlarida muhim ahamiytga ega bo'lib, ularning qo"shiqlarida aks etgan. Yapon she'riyatining xususiyatini, mazmunini, o'ziga xosligini ta'minlashda muhim ahamiyat kasb etgan. Nara davrida mamlakatning mustahkamlash va taribga solish maqsadida ilk yozma yodgorliklar yaratilgan. 712 yilda saroy tarixchisi O-no Yasumaro (?-723) "qirolicha" Gemmeyga (707-715) “Kojiki”-“Qadimgi ishlar haqida yozuvlar” ning uch o'ramasini topshirgan. Yodgorlikning yaratilishiga 30 yil sarflangan. "Kodziki" - Qadimgi ishlar haqida yozuvlar (720), tarixiy xronika Nixongi - Yaponiya anallari (720), tarixiy geografik va etnografik yozuvlar Fudoki yerlar va urf - odatlar haqida (713-733) hamda ilk adabiy milliy yodgorlik "Manyoshu"- ilk yozma yodgorliklardir. Yodgorliklarning matnlari xitoycha yozilgan bo'lib, xitoy iyerogliflaridan yapon nutqini berishda qo'shiq, geografik nomlar, atoqli otlarda fonetik belgi sifatida foydalanilgan. Yapon so'zlarini xitoy iyerogliflarida berishda transkripsiyaning turli uslublaridan foydalaniladi. Bu yozuv mayogana ya'ni Manyoshuning bo'g'inli alifbosi deb nomlangan.

\section{Foydalanilgan adabiyotlar ro'yxati}

1. Горегляд В.Н. Японская литература.VIII-XVI веков.Начало и развитие традиций.СПБ. Петербургское востоковедение. 2001. 2-издание.

2. История всемирной литературы в 9 ти томах. 3 том. М.: "Наука".1985.

3. Keen D. Seeds in the heart. Japanese literature from Earlest Times to the late sixsteenth century. N. -Y. 2003.

4. Конрад. Запад и Восток. М.: "Наука".1966.

5. Фужиока Тадахару. Кодза нихон бунгаку. Лекции по японской литературе.том 3. Книга 1. Токио. 2008.

6. ShuichiKato. A History of Japanese Literature (The First Thousand Years) ISBN4-77002934-9., 2002.

7. Черноземова Е.Н. Луков В.А. История зарубежной литературы средних веков и Вожрождения. Практикум - М.: Флинта - Наука 2004.

\section{MILLIY MADANIYATGA OID NEMISCHA FRAZEOLOGIK BIRLIKLARNING SEMANTIK MA’NOLARI XUSUSIDA}

\section{P. J. Nazarov (SamDChTI, dotsent)}

Annotation: This article is dedicated to a problem of German phraseology connected with national culture of old German people. It has been shown some examples of such phrases and their 
semantic meaning with comparing to their Russian or Uzbek equivalents there. The main goal of this article is to identify the degree of influence of German phraseology on building of national culture. The task of this article is to outline the main scientific approach to the problem. As a conclusion of this article has been given some necessary instructions about phraseologies not only as national culture elements but also as richness of the all human race.

Key words and expressions: Culture, national culture, culture elements, idiom, phraseology, proverb, semantic meaning,

Til, tarix, madaniyat tushunchalari bir-biri bilan bevosita bog'liqdir. Shu boisdan har bir millatning dunyo hamjamiyatida tutgan o'rni eng avvalo bu millat aholisining milliy tili, taraqqiyot tarixi va madaniyati bilan o'lchanadi.

"Madaniyat" tushunchasi, arabcha "madina" (shahar) so'zidan olingan. Qadimda dashtu sahrolarda ko'chmanchi holda yashagan arablarga nisbatan "badaviylar", shaharda o'troq holda yashab, o'ziga xos turmush tarziga ega bo'lgan kishilarga nisbatan "madaniylar" so'zlarini ishlatishgan. Keyinchalik "madaniyat" tushunchasi jamiyat, inson ijodiy kuch va qobiliyatlari tarixiy taraqqiyotining muayyan darajasi sifatida kishilar hayoti va faoliyatining turli ko'rinishlarida, shuningdek ular yaratadigan moddiy va ma'naviy boyliklarga nisbatan qo'llanila boshlandi. [Ўзбекистон миллий энциклопедияси. 5-том. 2003:372].

Demak, madaniyat ikki xil ko'rinishda yuzaga keladi: insoniy ehtiyojlarni qondirish maqsadida yaratilgan mehnat mahsulotlari, turli inshoatlar, tabiiy boyliklardan tarkib topgan moddiy madaniyat hamda insonning falsafiy, huquqiy, ilmiy, badiiy, axloqiy, diniy tasavvurlaridan tarkib topgan ma'naviy madaniyat. Madaniyatning har ikki turi jamiyat bilan, kishilarning o'zaro aloqaga kirishuvi bilan vujudga keladi. Shu boisdan ham, ijtimoiy aloqa vositasi vazifasini bajaruvchi til, jamiyat taraqqiyotini belgilovchi tarix kabi madaniy qadriyatlarni ham yakkalikda yaratishning iloji yo'q.

Har bir tilning lug'at boyligi, ayniqsa unda mavjud bo'lgan maqol va matallar, frazeologik birliklar, tasviriy ifodalar, turli xil ko'chimlar kabi badiiy-tasvir vositalari u yoki bu tarzda milliy ma'naviy madaniyatning belgisi vazifasini o'tab beradi.

Shuni ta'kidlab o'tishimiz lozimki, fanda har bir xalqning milliy madaniyatiga taaluqli til birliklari borasida yirik tadqiqotlar olib borish jarayoni endigina boshlangani bois nemis milliy madaniyatiga oid frazeologik birliklarining semantik ma'nolarini tasniflash bo'yicha bajarilgan ishlar miqdori juda ozdir.

Tadqiqot yo'nalishining dolzarbligidan kelib chiqqan holda biz mazkur maqolamizda milliy madaniyat kishilarning birgalikda yashashga va nimanidir yaratishga bo'lgan ehtiyoji orqali yuzaga kelishiga asoslanib, yaratilishi bo'yicha qadimgi germanlarning birgalikdagi mehnat faoliyatiga bevosita bog'liq bo'lgan frazeologik birliklarning leksik-semantik tavsiflari borasida to'xtalib o’tishni oldimizga maqsad qilib oldik.

Manbalarda keltirishicha, miloddan oldingi davrlarda Skandinaviya yarim orolida, Shimoliy dengiz va Boltiq dengizi bo'ylarida yashagan german qabilalari asosan chorvachilik va primitiv dehqonchilik bilan kun kechirishgan. [Руденко 2008:30].

Nafaqat qadimgi germanlarning, balki Xind-Ovropa tillar oilasiga mansub bo'lgan barcha xalqlarning dastlabki hamkorlikdagi faoliyatlari chorvachilik bilan bevosita bo'g'lik bo'lganligi bois, aynan uy hayvonlari, chorva mollarining nomlari asosida yaratilgan frazeologik birliklar va idiomalar, maqol va matallar aholining ilk madaniy qadriyatlari sifatida tan olinadi. Zero hozirgi zamon nemis tilisida "qadriyat, boylik" ma'nolarini anglatuvchi "der Schatz" so'zi ham etimologik tomondan o'rganililganda, Xind-Ovropa tillar oilasiga kiruvchi aksariyat tillardagi aynan "chorva" (masalan, got tilida "scats", qadimgi yuqori nemis tilida "scaz", qadimgi slavyan tilida "скоть", rus tilida "скот") ma'nosini ifodalovchi so'zdan kelib chiqqanligining guvohi bo'lamiz [Руденко 2008:30].

Nemis tilidagi frazeologik birliklarda hayvon va qush nomlarini qollanilish chastotasini o'rganish orqali shunga amin bo'ldikki, yovvoyi hayvonlardan "Affe, Bär, Löwe, Wolf, Fuchs, Hase" (maymun, ayiq, she'r, bo'ri, tulki, quyon) nomlari asosida hosil qilingan, uy hayvonlaridan "Schwein, Hund, Schaf, Pferd, Kuh, Bock, Esel, Katze" (cho'chqa, it, qo'y, ot, sigir, echki, eshak, 
mushuk) nomlari, shuningdek parrandalardan "Hahn, Ente" (xo'roz, o'rdak), mayda jonivorlardan "Maus, Wurm, Fliege" (sichqon, qurt, pashsha) hamda qushlardan "Strauß, Storch, Nachtigall, Taube, Kuckuck, Rabe" (tuyaqush, laylak, bulbul, kaptar, kakku, qarg'a) nomlari ishtirok etgan iboralar nemis tilida yetarlicha miqdorda uchraydi.

$\mathrm{Bu}$ o'rinda shuni ta'kidlab o'tishimiz lozimki, tuyoqli chorva mollarining nomlaridan hosil qilingan frazeologik birliklarning aksariyati nemis milliy madaniyatining timsoli vazifasini ifoda etadi.

Masalan, nemis tilidagi "schwarzes Schaf” (rus tilidagi muqobili “белая ворона") iborasi qilgan ishlari bilan boshqalardan ajralib turishga harakat qiluvchi shaxsga nisbatan ishlatiladi. Bu iboraning kelib chiqishi, Ovropaning bir qator mamlakatlarida, xususan nemislar yashaydigan hududlarda asosan oq rangdagi qo'ylar boqilishi hamda qora rangli qo'ylar deyarli uchramasligi bilan bevosita bog'liqdir [Christa Pöppelmann 2009:49].

Yoki "das geht auf keine Kuhhaut" (ma'nosi: ma'lumotning oshiqchaligi) ifodasini olib qaraylik. Boshqa xalqlarda bo'lgani kabi germanlarda ham qadimda ilohiy fikrlar qo'y, echki, qoramol kabi chorva mollarining terilariga yozilgan. Shu sabab bitta qoramol terisiga sig'may qolgan yozishmalarga nisbatan mazkur ibora o'ylab topilgan. [Christa Pöppelmann 2009:39]

Shuningdek “einen Bock schießen” (ma'nosi: mo'ljalga to'g'ri ololmaslik, xato otish) iborasi esa qadimgi germanlar chorva mollari orasidan echkini otishda qiynalganidan kelib chiqqan [Christa Pöppelmann 2009:82].

Zamonaviy nemis tilida ayniqsa "Schwein" (cho'chqa), "Sau" (urg'ochi cho'chqa) hamda "Ferkel" (cho'chqa bolasi) nomlari bilan hosil qilingan frazeologizmlar ko'p ishlatiladi. Zero bu iboralar qadimda germanlar tomonidan ilk xonakilashtirilgan hayvonlardan birining nomini zikr qilib o'tish sifatida qo'llanilib qolmasdan, ular yana turli kognitiv ma'no buyoqdorligini o'zida mujassamlashtirganligi bilan ham germanlarning tilida, ham ularning milliy madaniyati doirasida munosib o'rin egallaydi.

Quyida "cho'chqa" so'zi bilan bog'liq shunday nemischa frazeologik birliklarning semantik ma'nolariga nazar tashlaymiz:

Mein Schwein pfeift ("lof urmoq" ma'nosida). Bu ibora cho'chqaning hushtak chalganini hech kim ko'rmaganligidan kelib chiqqan [Christa Pöppelmann 2009:113]

Schwein haben ("omadi chopmoq", "ishi yurishmoq"). Bu ibora o'rta asrlarda yaratilgan bo'lib, o'sha davrda yashagan oddiy germanlarning cho'chqasi qancha ko'p bo'lishiga qarab, ularning boylik darajasi shuncha oshib borishi asosida hosil bo'lgan [Christa Pöppelmann 2009:164].

Seine Sau ist fett (“ishi yurishmoq"). Mazkur ifoda cho'chqasi to'ygan odamning kayfi chog' bo'lishidan kelib chiqqan [Christa Pöppelmann 2009:49].

Wie ein Schwein schwitzen ("qoni qaynamoq", "qora terga botmoq). Bu frazeolik birikma cho'chqa quvilganda, uning rosa yugurganidan, junlari xurpayib, pishqirib qolishidan kelib chiqqan [Christa Pöppelmann 2009:49].

Qadimda germanlar urg'ochi cho'chqaning bolalash paytida juda sergak turishgan. Zero bunday paytda ona cho'chqa tashqarida qolsa, ko'p joyni iflos qilib tashlagan. Shu sabab "die Sau rauslassen" (ma'nosi: "o'z holiga tashlab qo'ymoq") ifodasi bilan urg'ochi cho'chqaning bo'shalgani natijasida atrof-muhitni ifloslanishi ko'zda tutilgan. [Christa Pöppelmann 2009:63].

Qadimda germanlarda biror bir ayb ish qilib qo'ygan kishini uy hayvonlaridan it yoki cho'chqasi bilan ko'chada qolishga majburlashgan va bu holat aybdorni uyga loyiq emasligini, el orasida masxara qilinishi lozimligini anglatgan. Shu sabab "zur Sau machen" iborasi bugungi kunda ham "kimnidir urishmoq", "yerga urmoq" ma'nolarini ifoda etadi [Gerhard Wagner 2011:108].

"Ferkel werfen" (salbiy ma'noda: tug'ib tashlamoq, bolalab tashlamoq) iborasi cho'chqaning boshqa chorva mollariga nisbatan tezda ko'payishiga ishora qilinganidan paydo bo'lgan [Лепинг Е.И. и другие 1980:467].

Yuqorida keltirilgan turg'un so'z birikmalarining kelib chiqishi aynan qadimgi germanlarning chorvachilik orqali kun kechirib, uy hayvonlari, shu jumladan chorva mollarini boqish orqali o'z 
milliy, ma'naviy madaniyatlarini shakllantirib borganligidan dalolat beradi. O'z navbatida milliy madaniyatga aylangan bunday qadriyatlar faqat germanlargagina tegishli bo'lib qolmasdan, balki ular vaqt o'tishi bilan umuminsoniy madaniyat darajasiga ko'tarilgan yoki jahon xalqlari tomonidan yaratilgan madaniyatning ta'siriga uchragan. Masalan nemis tilidagi "Mit Kind und Kegel" (so'zma-so'z tarjimasi: bola va tosh sharcha bilan) iborasida qo'llanilgan "Kegel" so'zi 15 asrda chop etilgan lug'atda "nikohsiz tug'ilgan bola", undan keyingi lug'atlarda esa "bolalar o'ynaydigan tosh sharcha" ma'nolarida berilgan. [Gerhard Wagner 2011:122]. Nemis tilidagi bu ibora aslida 4-7 asrlarda butun Ovropa qit'asi bo'ylab yoyilgan va tarixga "Xalqlarning buyuk ko'chishi" nomi bilan kirgan jarayon bilan bevosita bog'liqdir. O'shanda germanlar aravalarga o'z oila a'zolari, oziq-ovqat va qurol-yaroqlarni olgan holda ming mashaqqatlar bilan ommaviy tarzda ko'chishgan va ulardan tirik qolganlari yangi yerlarda o'z milliy madaniyatini yaratishgan. [Руденко 2008:39]. Vaqt o'tishi bilan mazkur ibora o'z semantik ma'nosi, ya'ni "boshqa joyga ko'chib ketish" tushunchasini anglatgan holda boshqa tillarda ham paydo bo'lgan. Jumladan bu iboraning o'zbek tilidagi ma'nodoshlari “bola-chaqasi bilan”, “ko’ch-ko'roni bilan” deb ifoda etiladi.

Milliy ma'naviy madaniyatning umuminsoniy madaniyatga aylanib borishini nafaqat nemis millati shakllanish jarayonida paydo bo'lgan frazeologik birliklarda, balki yana til birliklarining barcha ko'rinishlarida va hattoki barcha xalqlar orasida kuzatishimiz mumkin. Masalan "Chumchuqdan qo'rqqan tariq ekmaydi" maqoli o'zbek milliy madaniyatining mahsuli hisoblanadi. Zero O'rta Osiyo hududida chumchuqlar ko'p tarqalgan hamda qushning bu turi bu mintaqada dehqonchilik qiluvchi kishilarga tariq o'simligining ko'shandasi sifatida ko'p zarar keltirganidan bu maqol milliy ma'naviy madaniyat tariqasida xalq orasida yuzaga kelgan. Shu maqolga semantik jihatdan ma'nodosh bo'lgan rus xalq maqoli mavjud: “Волков боятся, в лес не зойти”. Mazkur rus maqoli ta'sirida o'zbek xalqining ma'naviy madaniyati belgisi sifatida bu maqolning muqobili invarianti paydo bo'lgan, ya'ni: "Bo'ridan qo'rqqan to'qayga kirmas". Faqat tabiiy boylik sifatida rus tilida qo'llangan “o'rmon" so'zi o'rnida cho'l va chala cho'llarga xos bo'lgan "to'qay" so'zi o'zbek maqolida ishlatilgan.

Xulosa sifatida aytish mumkinki, har qanday milliy til va bu milliy tilda yaratilgan purma'no fikrlar u yoki bu tarzda milliy madaniyatni o'zida ifoda etadi. Kishilar tomonidan yaratilgan milliy madaniyat namunalari o'z navbatida yaxshi va yomon unsurlarga ajralib, ularning eng saralari borabora umuminsoniy madaniyat namunalari sifatida qadrlanadi.

\section{Foydalanilgan adabiyotlar ro'yxati}

1. Лепинг Е.И. и другие. Большой немецко-русский словарь. Т.1. -М. 1980.

2. Руденко Е.Н. Введение в германскую филологию. -Харьков. 2008.

3. ัзбекистон миллий энциклопедияси. 5-tom. . -Тошкент. 2003.

4. Christa Pöppelmann. Ich glaub' mein Schwein pfeift!-München. 2009.

5. Gerhard Wagner. Schwein gehabt! Redewendungen des Mittelalters. 2011.

\section{IMPORTANCE OF LEARNING MILITARY TERMS IN STUDYING ENGLISH}

\section{Sh.Bekturdiyeva \\ (Chirchiq oliy tank qo'mondon muhandislik bilim yurti, dotsent)}

Annotation: In the given article the author considers using of military terms in learning foreign languages in the life of military personnel, also regards training functions of foreign languages in military service, knowing of foreign languages stimulate intellectual and speech activities of soldiers, future officers in their developing as militaries. Specialists who know English are support of our Armed forces.

Key words and expressions: Foreign languages, military terms, evolution, communication, process, military career. 
Presence of the army is obligatory feature of any modern sovereign state. The discriminating character of the army is a number and degree of its fighting efficiency. The composition of the army, traditions and attitude society to armies are the most important reason, which influence upon shaping and the further development of the military terminology. Follows to note, that military terminology is renewed not only during different sort of conflicts, but also during military reforms and transformations. Secrecy and shutting of the army forms background for arising and developments of the military language. The notion term derives from Latin terminus and is translated as 'limit, completion'. The main difference of terminological lexicon from nonterminological is its maximum abstructiveness, uniqueness, international, logic and semanticist. Thereby, under term is understood word or word-combination, bolted for concrete notion in system notion given area of the science or technology. V.H. Shevchuk defines military terminology as follows: ordered collections of military term language, which reflect notional device of the military science and, military deal and are connected with forms and ways of conduct of the war, with questions of the strategic use of the armed power, as well as operative-tactical use of the associations, joins, parts and subdivisions, with their organization, arms and technical equipping. Military terms possible to classify as follows: on sphere of the use (different sort of the troops, staff, general tactical, organizing, military-topographical, command- drill). Terms of different sort troops - terms, which are used for description notion in shaping of armed power: parts, joins, associations, institutions, organization and authorities of management, for instance, artillery, infantry, radio technical troops, air force, military-air troops, airborne troops. Staff terms - terms, which are broadly used in organ of military management personal composition, to example, headquarters, staff car, staff coach, personnel.

General tactical terms - terms, which are used at decision of general tactical problems, conduct combined arms and its preparation, to example, defence, corps field gendarmerie, offensive approach.

The organizing terms - terms, which are used in different unit of soldierly power, for instance, unit 'subdivision', battalion, division, company.

Military-topographical terms - terms, which are used in study of terrain, orientation, in instruction of the purposes, production of the measurements on terrain, for example, topographic map, cartography, land survey, aero photography.

Command-drill terms - terms, which are used in drill preparation and command speech of militaries, for example, arms, port!, eyes, right! After the manner formation (morphological wordbuilding, semantic word-building, borrowing, abbreviations).

Morphological word-building is a main way of the word-building and includes the following ways: affixation, stem-composition, reduction and conversion.

Affixation - is such way of the word-building, which allows to create new terms at joining word-buildings, affix to base of the different parts speech, for example, maintainability, surveillance, deterrence, reunion.

Stem-composition- is such way of the word-building, which allows forming new words by join to basis two or more words, for example, aircraft, break-through, battle wise.

Reduction - is a gap of the separate letters and slab in word, but sometimes - removing the much of the word except separate letters, for example, Svc Pit (service platoon), submarine, and radar dome.

The conversion - more wide-spread in military terminology of English type word-buildings, under which belonging to certain portion speech word, not changing source form, gains importance of other part speech. For example, shell > to shell; rocket > to rocket; mortar > to mortar; blockade $>$ to blockade.

The dialect about way of the word-building follows to mention the semantic way, as follows carrying of importance. Surname or name of the inventor can be carried on subject itself. Diesel surname of the inventor and name of the type of the engine, Kalashnikov - surname of the constructor and worldwide known automaton, Sten 'automaton', Bren 'manual machine gun'. Follows to note that basically increase the vocabulary volume term systems is realized to account 
internal resource language (broad use word-building affix stem-composition, reductions) on structure semithentic, polysynthetic.

Base of the military terminology of English form one-component and multi-component nominative units, which is basically presented by substantive joining, for example, battle - battle field - battlefield interdiction - battlefield interdiction line - battlefield air interdiction. On stylistic feature (neutral and emotional- painted lexical units). Follows to note that military terms, as a rule, are presented neutral on emotional colouration lexical unit. However, follows to bring given categorization on stylistic feature, since emotional-painted lexical units of the military sphere mark same notions, as neutral lexical units. Under emotional colouration is meant connected with meaning emotional attitude to notion, named by given word. The example emotional painted military lexicons of English are following words: push-button war, trigger-happy, slick ship.

\section{The list of used literature}

1. Борисов В. В. Аббревиация и акронимия / Военные и научно-технические сокращения в иностранных языках / М., 2004. С. 132-135.

2. Бубнов И. А. Военная топография: учебное пособие. М.: Воениздат, 1969.

3. Данилевич А. А. "Военная терминология современного английского языка"

4. Шевчук В. Н. Военно-терминологическая система в статике и динамике: дис. д-р. филол. наук. Москва, 1985.

\section{ЎЗБЕК ХАЛКИ НИКОХ МАРОСИМЛАРИНИНГ ЭСТЕТИК МОХИЯТИ ВА ТРАНСФОРМАЦИЯСИ}

\section{Р.Р. Комилов (СамДЧТИ, РhD, доцент в.в.б)}

Annotation: This article discusses issues of preservation, transformation, and innovation in the evolution of marriage ceremonies. The problems of preserving the moral and aesthetic nature of Uzbek weddings and their evolution are studied in symbiotic situations, the tasks of transforming Uzbek national wedding ceremonies into aesthetic values in the context of the development of civil society. Emphasis is placed on the study of the specific features of the development trend of marriage ceremonies, and the extent to which the criteria developed above apply in this system is examined. The article analyzes the new social, ethnoesthetic and organizational features and new customs that are being formed in Uzbek weddings today, their compatibility with the traditions of wedding ceremonies and their differences.

Key words and expressions: Family, marriage, ceremony, evolution, transformation, innovation, symbiosis, ethnoesthetic, ethics, tradition.

Ўзбек никох маросими ва унинг асл мохиятини ёш авлодга сингдириш, ёшларда нафис дид хамда юксак ахлоқий фазилатларни шакллантиришга, никох туфайли бу икки жинс вакилларининг бир-бирига бўлган мехр мухаббатини мустахкамлашга хизмат қилади, никохни муқаддаслаштиради. Ахоли орасида никох маросимларини, урф-одатлар рангбаранглигини сақлаб қолиш ва тўйнинг сарф-харажатларини ихчамлаштириш борасида меъёр, вақт бўйича мезон ишлаб чиқилиши, қатъий регламентни ўрнатиш, кудалар томонларида ижтимоий соғлом мухитни, соғлом турмуш тарзини қарор топтириш никохнинг ахлоқийлигини сақлаб қолишга объектив асос бўлади. Ўзбек миллий никох маросимларининг ўзига хос таомиллар билан боғлиқ маданиятнинг ўзгариши, ижтимоийиқтисодий, мафкуравий, диний ва бошқа омиллар таъсирида трансформацияга учраши, шаклланиш ва ривожланиш даврларида симбиоз холатларнинг юзага келиши миллий никох маросимларининг архитектоникасини вужудга келтирган. Айнан урф-одатлар тизимининг трансформацияси қўшни этнослардан турли таомилларнинг кириб келиши ва уларнинг миллий урф-одатлартизимига кўшилиши даражаси билан боғлиқ бўлган. Инновацияларни қабул қилишдаги толерантлик нафақат рамс-русмлар ёки таомил қабул қилинган балки, 
этноснинг ўзбекларга маданий яқинлигига, балки уларнинг муайян ижтимоий қатламга дахлдорлик хиссига хам боғлиқ бўлган. "Никох тўйи куни кечки пайт куёв ўзининг энг яқин дўсти билан бирга устига чопон билан яширинган холда келиннинг олдига олиб келади. Келин турган хонага ўз дўсти томонидан олиб кирилган куёвга танга ва сочқилар сочилган. Ўз навбатида шуни таъкидлаш жоизки, айнан мазкур удумга ўхшаш одат Ўрта Осиёдаги яшовчи бошқа халқлар маросимларида хам учраши хақида этнографик адабиётларда маълумотлар келтирилган.” [Кисляков 1959:113]

Ўзбек никох маросимларининг эстетик жихатдан тахлиллари шуни куурсатдики, аксарият холатларда маросимлар тартиби деярли ўзгармаган. Бу холат у ёки бу маросимий таомилига бўлган хурмат, унинг бир неча асрлик анъаналарни акс эттириши, аждодларнинг нуфузи, ота-боболарининг удумларини муқаддаслаштириш билан ахлоқий императив мохияти сақланиб қолганлиги ва ташқаридаги инновацион ўзгаришлар «шамоли» эстетик хусусият касб этганлиги билан изохлаш мумкин. Ўзбек миллий никох маросимларининг ядроси (ўзак)ни тизимли тахлил қилиб, мавжуд миллий маросимларни хусусий, этник ёки перифериядан таъсир этган инновацияларга бўлиш мумкин. Вақт ва замонлар ўтиши билан айрим перифериядан келган инновациялар ядрога кўчиб ўтган.

Фуқаролик жамиятида қабул қилинган ахолининг турмуш тарзини соғломлаштириш, миллатнинг генафондини яхшилаш сингари хуқуқий хужжатлар никох маросимларининг эстетик қийматини сақлаб қолиб, соғлом турмуш тарзи эстетикасида уйғунлаштирмоқда. Инсоннинг соғлиги ва соғлом наслни яратиш сингари яратувчиликнинг ибтидоси бўлган никох маросимларида айнан шу эзгу қадрият этномаданий асосланади. Ўзбек никох маросимларида фелицитологик мезони, инсоннинг бахтли бўлиши асосий мезон қилиб олинган бўлиб, никохланиш севги, совчилик асосида, стереотип асосида бўлмасин миллий қадриятлар никохни мустахкам бўлишини таъминлаб келган. Ўзбек никох маросимларида бадиий композициянинг кўриниши сифатида маросимда айтиладиган ёр-ёр кўшиқларини келтириш мумкин. Ушбу ёр-ёрлар турли худудларда турлича айтилса хам ритми, нюанси қарийб бир хилдир. Айтиладиган қўшиқ матнида йигит ва қизнинг сифатларининг алохидаалохида эстетик категорияларда ифодаланиши никох маросимини янада гўзаллиштиришга сабаб бўлган. Келин-куёвнинг таърифини беришда, уларни алохида таъкидлаб, янги яхши, ижобий сўзларнинг кўлланилганини кўриш мумкин. Келинни мақташда ширинсўзлиги, қомати ярашганлиги (пластика), қамарюзлиги (ой юзлик), келинни қизлик сифатини беришда жуда ёш, соғлом, ўрта бўйлик, ширин сўз, қаламақош, қизни ташқи гўзаллигини ажратиб кўрсатишда барно, сочи сунбул, зебо сингари йигитларни эстетик аурасига кириб борадиган сўзларнинг қўлланилиши маросимнинг бадиий копозициясини янада бойитади. "Никохдан олдин қизникига тартиб бўйича тўй келишини икки томонлама маъқуллаш мумкин. Биринчиси, қизини хаёли, иболи қилиб тарбиялаган ота-онага хурмат, иккинчиси, куда тарафна тўйда қўллаб-қувватлаш. Хар икки холатда хам ортиқча исрофнинг олди олиниши керак. Демак, қизга тўй келиши унинг бокирилиги, обрўсига берилган тухфадир. Тўйни қиз сотишга тенглаштириш инсофдан эмас, деб ўйлаймиз”. [Мардонова 2011:58]

Социологик тадқиқотларга кўра хам, ўзбекларда никохга кираётганлар ва никох қурганларда турмуш куриш учун асосий мотив сифатида эътиборлидир. Биринчи гурухдагилар севимли, мехрибон инсон ёнида бўлиши, ишонарли, вафодор инсон билан яшашни асос қилиб олган ва иккинчи гурухдагилар эса фарзанд кўриш, зурриёт қолдириш учун никохланишни хохланувчилар хисобланган. Хар иккала мотивдагилар учун умумий 100\% респондент овоз берди. Респондентлар кўпроқ эркаклар учун 18-25 ёш оралиғи, аёллар учун 17-25 ёшдагилар танлаб олинди. Фарзанд кўриш мотивига эркаклардан 40\% овоз берган бўлсалар, аммо умумий аёл ва эркакларнинг $12 \%$ респондентлари уни биринчи ўринга қўйганлар. Умумий овоз, ўринга жойлаштириш бўйича хам севиб никохланувчи мотиви иккинчи ўринда бўлиб, уни биринчи ўринга қўйганлар камчиликни ташкил қилади. Берилган овозларнинг тахлилига кўра, эркаклар учун севги, мухаббат никох учун унчалик мухим эмас, никохдан кейинги севги ва мухаббатга ишониш керак. Умуман олганда, никох қуришда севгининг иккинчи даражада туриши Марказий Осиё халқларига хосдир. 
Фуқаролик жамияти ривожланиши шароитида никохни инсон релаксацияли тушуниши, инсоннинг девиант хулқини, рухий толиқишини мос шароитларда бўшаштириш сингари эстетик тушунчаларда ифодаланмоқда. Ғарбда никохнинг мохияти ўзгараётган бир пайтда мамлакатимизда никохга бўлган муносабат, инсонларнинг ундан хаётий борлиғини топишларига кўмак бериш сингари ишлари, «Оила» илмий-амалий тадқиқот марказининг фаоллашиши кузатилмоқда. Ўзбек никох маросимларининг бадиий композицион, этноэстетик хусусиятларидан тўла фойдаланиш, уларда миллий ўзликни англаш, ўз миллати ва анъаналаридан завқланиши, фахрланиши сингари хиссиётларни шакллантиришда конструктив ахамият касб этишини алохида таъкидлаш керак. Ўзбек никох маросимлари асосида эстетик тадқиқотларни чуқурлаштириш, уни миллий дизайнерлик, ранг-тасвир, бадиий-эстетик идеал сингари тушунчаларда ифодалаш бу сохадаги зарур ишлардир. Халқ оғзаки ва ёзма ижодининг онтологик асоси бўлган никох маросимларида, гўзал кўшиқчилик санъати намунаси, мумтозига айланган ёр-ёрларда қиз, йигит концепти эстетик жихатдан ишлаб чиқилгани, жисмнинг симметрик ва асимметрик хусусиятларини ажратиб кўрсата олгани эстетика илмида катта инқилоб бўлганини эътироф этиш керак. Шу ўринда айтишимиз мумкинки “ўзбеклар никох тўйи маросими таркибида соч силаш удуми хам мавжуд бўлиб, бу одат “чарсиллади” деб аталади. Куёв гўшангага кириб, келиннинг сочини пешонасидан силаб кўяди, бу пайтда қизнинг дугоналари чимилдиқ олдида “ёр-ёр” айтиб турадилар”. [Исмонова 1999:22] Инновациялар мухитида никох тўйлари ва маросимларида янги удумларнинг кириб келиши, диний ва этномаданий эътиқодга тўғри келмайдиган одатларнинг олдини олиш, регламентлар бўйича маълум фармон, қарорлар лойихаси тайёрланиши объектив холатдир. Лекин тўй маросими ва никох маросимларини фарқлаш мухимдир. Никох маросимларида гўзал урф-одатлар, анаъаналар давомийлигини таъминлаш, бу икки жабхани бир-бирига уйғунлаштириш давр талабидир.

\section{Фойдаланилган адабиётлар рўйхати}

1. Кисляков Н.А. Семя и брак таджиков. По материалом конца XIX - начала XX века. -M. 1959. -C. 113

2. Мардонова Г. Нур тўла уй. Тошкент. “Ўзбекистон”. 2011. Б- 58.

3. Исмонова О. Ўзбек тўй маросим фолкьлорида “келин салом" жанри (генезиси, ўзига хос хусусиятлари ва поэтикаси).: Филология фанлар номз. ...дис. - Т., 1999. - Б. 22.

\section{РОЛЬ НАЦИОНАЛЬНОЙ КУЛЬТУРЫ В ФОРМИРОВАНИИ ОБЩЕЧЕЛОВЕЧЕСКИХ ЦЕННОСТЕЙ}

Ф.Б.Мардонова (НавГПИ, РhD)

Annotation: The article makes an analysis of national values and describes the significant role of the revival and development of historical heritage in the upbringing of the youth of Uzbekistan. The importance of the demand to the cultural principles of national spiritual values is evidenced by the fact that over the past decade, formational transformations and democratization of all spheres of life have led to the growth of national, ethnocultural and religious self-awareness. Today it is believed that traditional values are an essential component of national culture which play a vital role as a regulator of public morality. The use of traditional, national and spiritual values needed for the formation of trust and harmony among young people of our country requires a correct attitude: the emphasis should be on cultural and ideological implications and values. It is important to pay attention not to the universal human values, but more to the traditional national values in the pedagogical process. An established scientific fact can be considered that the cultural values that determine the characteristics of the upbringing and education of the younger generation lie at the source of the culture of any nation. 
Key words and expressions: Formation, national culture, universal human values, historical heritage, national values, upbringing of the young generation, harmonious development of the individual.

Каждая культура является выражением духа, потребностей, своеобразия той или иной нации, поэтому она уникальна, самобытна. А богатство мировой цивилизации и, соответственно, мировой культуры, определяется тем, что она представляет собой сокровище общечеловеческих ценностей, единство отдельных, своеобразных, уникальных культур. Диалог цивилизаций и культур, сосуществование различных общечеловеческих ценностей и сохранение всего богатства мировой культуры должны быть наивысшей целью человечества.

Одним из ключевых принципов в формирования общечеловеческих ценностей в мышлении молодого поколения является обращение к культурным корням в вопросах воспитания. Обретение независимости Республикой Узбекистан позволило в полной мере проявиться богатому духовному наследию узбекского народа. Сегодня, в век роботизации и развития высоких технологий, особую актуальность приобретают личностные качества человека - проявление любви и уважения к предкам, Родине, близким людям, отзывчивость, сопереживание, эмоциональный интеллект. Передача нравственных и эстетических норм плодотворна в том случае, когда она согласовано с основополагающими требованиями как общества в целом, так и потребностями молодого поколения. Для молодых людей актуальны потребности в самоутверждении, развитии творческих умений, общении. Педагог должен учитывать потребности учащихся, а также, пополняя багаж знаний и опыта, развивать новые, высокие потребности и идеалы.

Одним из эффективных инструментов развития и реализации потребностей молодого человека считается органичная взаимосвязь обучения с нравственными и эстетическими аспектами национальной культуры. Мыслители Востока Абу РайханБеруни [Умарова Р.Ш. 2019:2], Мирзо-Улугбек, Аль-Фараби, и другие считали, что отсутствие правильного эмоционального развития обучаемого сводит к нулю любые старания педагога в передаче знаний и опыта.

В воспитании патриотизма, любви к Родине, социальной ответственности ключевую роль играет духовное богатство народов, проживающих на территории Узбекистана, их обычаи и традиции, знание истории, художественных произведений, памятников, письменности - всего, что обогатило мировую культурную сокровищницу, а также является свидетельством обширного духовного наследия нашего народа. Благодаря этим ценностям возникает любовь к родному краю, его историческому и художественному наследию. Особую роль играет устное творчество, которое по праву считается исторической памятью народа, передающейся из поколения в поколение и находящей свое отражение в эпосах, сказаниях, песнях, былинах [Ахмедова Н.М., Хамидова Н.У., Алланазарова СХ, Бухорова M.X. 2018:1].

По нашему мнению, необходимо возрождать национальные ценности естественным путём, через осознание национальной идентичности. Культурные традиции, духовное наследие народа на протяжении многих тысячелетий считались первоисточником духовного роста. И сегодня они являются важнейшим фактором воспитания молодого поколения в духе преданности своей стране и идеалам гуманизма.

Для представителей Востока, главное, сохранение семьи, как ячейки общества, и семейных ценностей, почитание нравственных, традиционных и национальных ценностей, так как, XXI век, являясь самым развитым веком науки и техники, в период ускорения процессов глобализации, происходят коренные изменения в жизни общества. Эти изменения приводят к исчезновению некоторых наших ценностей. Поэтому важно понимать суть понятия ценности молодого поколения в защите от различных информационных и моральных посягательств, разрабатывать научные теоретические основы. 
Ценность - понятие, используемое для выражения ценности потребностей и процедур как составная часть человеческого и общинного духовенства, явлений, процессов, обстоятельств, качеств во Вселенной. Понятие ценообразования проявляется в неразрывной связи с историей нации, единством образа жизни, её будущим поколением, социальными слоями, сознанием, языком, духовностью и культурой.

Задача каждого мудрого человека и нашего общества, можно сказать, состоит в том, чтобы воспитывать здоровых детей, воспитывать их в совершенстве как физически, так и духовно, воспитывать их как людей, преданных своим родителям, Родине. Духовное, нравственное совершенство человека - это невероятно широкое, многогранное, глубинное понятие по своей сути. Духовный подъем, нравственное, идейное, политическое развитие человека, происходящее в нашем обществе, неразрывно связано с осуществляемыми в нашей стране процессами национального возрождения.

Общечеловеческие духовные ценности проявляется во всех сферах жизнедеятельности людей. Общечеловеческие духовные ценности - это общие аспекты в традициях и обычаях всех народов, религии и чувствах, взаимоотношениях, их этических и эстетических взглядах, и вообще, в духовной жизни людей. Но когда они выходят за рамки национализма и становятся духовным богатством других народов, они поднимаются до уровня общечеловеческих духовных ценностей и начинают одинаково проявляться для всех народов.

Несмотря на то, что люди живут хотя бы в одном обществе, в одном периоде и в подобных условиях, ценность того или иного предмета по-разному воспринимается, понимается и интерпретируется. Под влиянием социальных процессов меняются представления, взгляды людей на ценности, что связано с изменениями условий жизни, жизни и духовного облика людей в процессе развития. Различные аспекты составляют противоположные стороны любой ценности. Такие понятия, как “доброта" и "зло”, “истина" и “несправедливость", “счастье” и “горе”, “прогресс" и “деградация", “существование” и “отсутствие”, которые кажутся совершенно противоположными друг другу в соответствии с положительностью и отрицанием, оценкой и значением, представляют собой взаимосвязанные аспекты жизни. Ценности имеют различное значение в разные периоды развития общества и жизни людей. В соответствии с исторической необходимостью эти ценности выходят на передний план социального развития, другие кажутся хрупкими. В результате усиливается стремление к социальному развитию и прогрессу в соответствии с законодательством, к стабилизации ценности, которую он получает.

Как известно, понятие оценки формируется при определенных условиях. Поэтому они будут доступны в местных, национальных, региональных формах в универсальном содержании. Общечеловеческие ценности - это понятие, которое выражает систему ценностей общечеловеческого значения, которая является общим критерием оценки для всех людей, народов и государств мира. Общечеловеческие ценности - это невероятно масштабное и многогранное понятие. Оно не состоит из таких понятий, как свобода, тишина, счастье, которые имеют общечеловеческое значение. Егоможно понять не только как культурное богатство, но и как целеустремленность. Вместе с тем, определенные национальные, этнические и частные системы ценностей также не могут заменить общечеловеческие ценности.

Анализ системы общечеловеческих ценностей и образов её проявления - это, по сути, исследование взаимосвязи между ее основными частями общей системы, компоненты которой взаимосвязаны между собой категориями диалектики. Общечеловеческая ценность создает систему, которая является общей для тех, кто живет в определенный период развития общества, проявляется в постоянном необходимом контакте с другими принципами. Проявления общечеловеческой ценности имеют относительную характеристику, но эта относительность не всегда является предсказуемой. В процессе исторического развития (объективно), в результате потребностей общества и людей (субъективно) из образов общечеловеческих ценностей всё это выходит на передний план общей системы, на 
передний план жизни, например, когда возникает угроза независимости страныпатриотизма; в период осознания национального самосознания и национального возрождения - усиливается стремление к изучению исторического и культурного наследия. Таким образом, актуальность той или иной формы общечеловеческой ценности в развитии социальных процессов, когда одни из них приближаются к идеалу, а другие, кажется, отдаляются от них. Нынешняя мировая цивилизация, проблемы и будущее развития, наконец, повысили значение общечеловеческих духовных ценностей и превратили их в жизненную необходимость мировой цивилизации. Потому что эти проблемы могут решаться только тогда, когда все народы и государства на Земле будут вместе в согласии. Общечеловеческие духовные ценности имеют сложную часть, проявляющуюся во всех сферах духовной жизни человека. Это общие аспекты в традициях и обычаях всех народов, религии и чувствах, взаимоотношениях, их этических и эстетических взглядах, в духовной жизни людей.

Таким образом, вышеупомянутая идея является одним из качеств, необходимых для воспитания человека как Человека. Такие высокие качества сейчас ценятся как общечеловеческие ценности.Ведь "ценности-это материальные и духовные ценности, которые формировались и развивались в процессе исторического развития общества, положительно влияющие на социальное развитие как в прошлом, так и в настоящем, и в будущем, приобретают социальное значение, поглощая сознание людей”.[Юсупов Э.Ю., Шермаммедов С.Ш., Аюпов А.Т. 2005:3].

\section{Список использованной литературы}

1. Ахмедова Н.М., Хамидова Н.У., Алланазарова СX, Бухорова MX. Культурологический фактор в современном образовании // Проблемы современной науки и образования, 2018. № 5 (125). С. 90-93.

2. Умарова Р.Ш. Бытие и философские взгляды Абу РайханаБеруни // Достижения науки и образования, 2019. № 3 (44). С. 32-33.

3. Юсупов Э.Ю., Шермаммедов С.Ш., Аюпов А.Т. вабошқ.. Тўлдирилган 2-нашри. Т.: Ўқитувчи, 2005. Б. 228.

\section{俄语教育在吉尔吉斯斯坦的发展历史、现状及前景 QIRG'IZISTONDAGI RUS TA'LIMI TARIXI, HOZIRGI HOLATI VA ISTIQBOLLARI}

\section{夏青, 上海外国语大学 上海 (Xia Tsing, Shanhai)}

Annotation: Russian is the official language of Kyrgyzstan, and its significance for the social function of Kyrgyzstan has been dynamic. During the Soviet era, Russian played a key role in the modernization process in Kyrgyzstan, especially in the fields of economy, industry, science and technology, modern art and culture. The fundamental feature of Russian is that it is flexibly synchronized with the traditional culture of the country, which makes it universally meaningful and fully reflects the world view of the local residents of the country. After Kyrgyzstan became independent, as the country's emphasis on national language and the awareness of the people's nationality increased, education in russian was weakened to a certain extent nationwide. However, in order to develop and improve the system of the balance between the Russian and Russian bilingual, promotethe development of economic in Kyrgyzstan and spread the cultural characteristics of Kyrgyzstan, the status of Russian as the official language and inter-ethnic communication language of the Kyrgyz Republic will not be shaken. The prospects of education in russian are still considerable. Russian is the main official language of the Shanghai Cooperation Organization. Under the framework of the "Belt and Road Initiative" Shanghai Cooperation 
Organization, it is very necessary to study the history and prospects of education of Russia in Kyrgyzstan of the SCO member states.

Key words and expressions: Education in russian; Kyrgyz; Kyrgyzstan; Language policy; Bilingualism

一、俄语教育在吉尔吉斯斯坦的地位变迁

(一) 沙俄时期

众所周知, 中亚地区的资源十分丰富, 自古以来一直都是兵家必争之地。沙俄时期俄 国为夺取中亚的丰富资源，对中亚发起侵略战争，并从中亚各民族的语言、文化等国家软实 力着手，对中亚地区强制性地实施了一系列政策，旨在从根本上将中亚各国“俄罗斯化”。列 宁描述沙俄时期的语言政策：“硬要各民族居民都使用在俄国居民中占少数的大俄罗斯人的 语言, 各个学校都必须讲授俄语。一切文件都必须使用俄语, 不能使用当地民族的语言 40 。” 沙俄在吉尔吉斯斯坦广泛传播俄语和俄罗斯文化, 并在其土地上建立俄语学校, 以增强俄国 在吉尔吉斯斯坦的影响力, 俄语教育从此在吉尔吉斯斯坦生根发芽。

\section{（二）苏联时期}

列宁对于沙俄时期在中亚实行的语言政策持强烈的反对态度，他始终坚持“民族平等” 的原则。十月革命后, 受到列宁指导思想的影响, 苏维埃政府采取一系列政策以废除俄语作 为国语的特殊地位, 把俄语降级为族际共通语, 并允许各民族在当地学校用本民族语言授课 ，这也标志着中亚民族语言教育兴起，而俄语教育相对被削弱。

此外，由于当时苏联的文盲率高，苏联政府在国内展开了一项大规模的“扫盲大运动” ，颁布了《俄联邦人口扫盲法》，规定“8-50 岁的所有不识字的公民必须识字，按其个人意 愿学习俄语或民族语言, 可选其一”。 ${ }^{41}$ 直至 1959 年, 这项长达 30 年的扫盲运动取得重大的 成果一一全国的文盲问题基本已经得到了解决，俄语与民族语言的教育也实现了全民化。

从斯大林一直到戈尔巴乔夫执政前，俄语的社会地位开始逐步提升。斯大林时期，“大 俄罗斯主义”的思潮开始兴起，苏联政府重新提高了俄语的地位，实行“教学俄语化”。此外 ，列宁时期的“民族语言平等”政策令苏联政府担忧国家的统一性遭到破坏以及“民族主义”的 产生, 于是下令所有民族学校必须学习俄语, 俄语在民族学校的教学计划中获得了稳固的地 位。自此，“俄语热”的浪潮在全苏联再次被掀起。在赫鲁晓夫执政期间，他曾规定所有高等 院校必须使用俄语授课, 以至于大多数父母更倾向于从小培养小孩的俄语, 并将他们送入俄 语学校学习。

随后的勃列日涅夫时期, 中亚各国的领导权力机构也开始大力鼓吹俄语教育。吉尔吉 斯共产党中央第一书记乌苏巴利耶夫在吉共的“十七大”报告中指出：“俄语已成为我国各民 族间交往公认的语言。苏维埃吉尔吉斯斯坦劳动人民高度评价, 俄语很好地为苏联大小民族 的国际主义团结事业服务, 为加强国民经济发展、民族文化互相丰富服务, 并有助于顺利解 决共产主义建设的问题，……在共和国吉尔吉斯居民心中加强俄语宣传具有重要的意义 42 。”

\footnotetext{
40 《列宁全集》中文版, 北京: 人民出版社, 1985 年, 第20卷, 第57页。

${ }^{41}$ 《俄朕邦人口扫盲法》, 俄罗斯联邦人民委员会, 颁布丁1919年12月26日。

42 乌兹别克斯坦《东方真理报》，1981年2月4日。
} 
中央颁布的一系列强制性政策使得全苏人民中掌握俄语的人数日益递增, 俄语教育的发展也 越来越有前景。

而到了戈尔巴乔夫时期，苏联政府又重新赋予民族语言重要的地位，使民族语言拥有 在本民族的优先发展权和使用权，从而降低了俄语地位，把俄语将为族际交际语。

\section{（三）苏联解体后}

苏联解体后，吉尔吉斯斯坦颁布了一系列政策以提高本民族语言的法律地位，降低俄 语的法律地位。1993 年 5 月, 吉尔吉斯斯坦通过独立后的第一部宪法, 其中重申了吉尔吉斯 语是吉尔吉斯斯坦共和国的国语地位。吉尔吉斯语在吉国境内被广泛推广, 学校也开始重视 吉语教育，将“吉语化”视为热爱本民族的表现。然而为了应对语言政策导致的俄罗斯人才流 失和本国的经济危机，2000 年 5 月吉尔吉斯斯坦通过了《官方语言法》，其中规定：“俄语 作为吉尔吉斯斯坦共和国的官方语言，在国家管理、司法和诉讼领域以及在吉尔吉斯斯坦社 会生活的其他领域中按本法和其他法律所规定的情况和程序与国语同样使用, 俄语还起着族 际交流的作用, 促进各国在国际社会中一体化。 ${ }^{43}$ 随着俄语作为官方语言地位的提高, 吉尔 吉斯语的地位再次受到冲击。而 2005 年以后的国家领导人来自更加重视吉语南部地区, 于 是要求国民提高吉语的水平, 要求所有想考入国家政府机全的公民必须熟练掌握吉尔吉斯语 。可见，苏联解体后俄语教育的地位发展在吉国相当不平稳。

\section{二、俄语教育在吉尔吉斯斯坦的现状}

如今, 俄语在吉国仍被广泛使用。虽然《语言法》宣布了吉语为吉国国语, 俄语为官 方语言, 俄语的地位并没有因为吉语地位的提高而受到影响。俄语教育在吉尔吉斯斯坦依旧 是教育界的主流。然而, 由于地理位置的差异, 俄语教育在吉尔吉斯斯坦的南北部情况不一 , 在各类学校中的教学情况也各不相同。

\section{(一) 地理位置}

\section{1、南部地区}

吉尔吉斯斯坦的南部地区主要以农业为主 . 经济相对落后。南方的吉尔吉斯人深受伊 斯兰文化的影响, 思想比较传统保守。在教育方面更加重视吉尔吉斯语的教育, 很大一部分 南部地区的居民都不会说俄语, 该地区以吉语学校为主, 但进入大学后必须开始学习俄语, 俄语是大学的一门必修课。

\section{2、北部地区}

吉尔吉斯斯坦的北部地区以工业为主，经济相对发达，人们的生活水平也比南部地区 高，对伊斯兰文化抱有“不屑”的态度，思想比较开放，有“西化”的趋势。在北方，俄语学校 占大多数, 用俄语授课, 从小学到大学俄语都是必修课。而吉语学校占少数, 吉语学校中的 大多数课程虽然用吉语授课, 但也会安排俄语必修课程。

\section{(二) 学校种类}

\section{1、城市俄语学校}

\footnotetext{
${ }^{43}$ 《吉尔吉斯斯坦共和国法律一官方语言法》，2000年5月29日，第52条。
} 
吉尔吉斯斯坦大多数的斯拉夫人、“俄化”的吉尔吉斯族人及其他少数民族人聚集在城 市俄语学校中, 城市中的俄语学校拥有优质的师资力量、教学教材、丰富的文化学习活动以 及俄语生活环境, 但同时吉尔吉斯语也作为一门必修课程。

\section{2、城市吉语学校}

在城市吉语学校中学习的学生大多为吉尔吉斯族人, 他们的父母认为应以精通本族语 言为豪并致力于传承吉尔吉斯文化。城市吉语学校采取吉语和俄语的双语教学, 虽然是吉语 学校, 但是俄语也是城市吉语学校的必修课, 有效地维护了吉尔吉斯斯坦“双语制”的平衡。

3、乡村俄语学校

俄语教育在乡村吉语学校存在弊端。学校紧缺高质量的现代俄语教科书以及优秀的俄 语教师。很多乡村俄语学校仍在使用苏联时期的旧教材, 一些政治、经济、思想等相䏌的文 章已经过时, 一些俄语用语也已经改变, 若依旧使用这些教材会对现代孩子有一定的误导作 用。另外, 在吉国乡村里人们一般使用吉语交流, 学校的老师们受吉语影响, 导致俄语发音 不准确，带偏学生们的俄语标准发音。由于在吉国的乡村地区几乎没有俄语生活环境, 所学 的语言得不到及时的实践, 这类学校的学生的俄语水平不及城市俄语学校的学生。

\section{4、乡村吉语学校}

在乡村吉语学校里, 俄语也是一门必修课, 形式上同样符合吉尔吉斯斯坦“双语制”的 政策, 这就意味着任何一位从乡村吉尔吉斯语学校毕业的学生在理论上都应该能有充足的语 言能力来应付大学里的俄语教学, 然而实际情况却体现了“双语制”的不平衡。乡村吉语学校 的学生无论在课堂上还是课堂外, 都以吉语为主, 整个学习和生活环境都是纯吉语。在这 里, 吉语的“一边倒”一定程度上也违背了“双语制”政策。

\section{三、俄语教育在吉尔吉斯斯坦的前景}

苏联解体后，吉尔吉斯斯坦开始实行“去俄化”进程，努力摆脱百年来俄语在国内的垄 断地位。在教育领域的“去俄化”进程主要体现在缩减学生的俄语必修课、俄罗斯文学课的课 时等。但实际上吉尔吉斯斯坦想在百年内完全实现去俄化并不现实。学习俄语不仅对文化有 意义，而且对于接受经济、科技、建筑和其他领域的吉尔吉斯学习者来说，都是有必要的。

另外，近年来国际局势越来越严峻，在响应“一带一路”倡议的同时，区域安全成了上 合组织各成员国之间的主要问题, 面对这些问题时, 在一个共同的语言环境下才能更迅速高 效地作出反应和决策。

对吉尔吉斯斯坦而言，俄语是获取俄罗斯文化宝库、学习俄罗斯科学和先进技术的渠 道, 也是吉国公民更好地在跨国工作中发挥作用的䏌键。此外, 俄语更是让外界了解吉尔吉 斯斯坦文化历史和民族特色的一个重要媒介。一言以蔽之, 俄语具备着许多吉语没有的特殊 功能，俄语教育在吉尔吉斯斯坦依旧会可持续地平稳发展。

\section{参考文献}

1.《俄联邦人口扫盲法》，俄罗斯联邦人民委员会，颁布于 1919 年 12 月 26 日。

2. 郭卫东、黄小勇、贾静芳 : 吉尔吉斯斯坦共和国不平衡双语制研究 $[\mathrm{J}]$, 载于《新 疆师范大学学报》（哲学社会科学版）,2011 年 5 月, 第 32 卷第 3 期。 
3. 海淑英: 吉尔吉斯斯坦的语言政策及其双语教育 $[\mathrm{J}]$, 载于《民族教育研究》, 2013 年第 1 期第 24 卷。

4. 《吉尔吉斯苏维埃社会主义共和国国语法》, 吉尔吉斯斯坦苏维埃社会主义共和国 最高苏维埃，1989年 9 月 23 日，2220-6。

5. 《吉尔吉斯斯坦共和国法律一一官方语言法》，2000 年 5 月 29 日，第 52 条。

6. 廖成梅: 中亚国家的语言政策论析 $[\mathrm{J}]$, 载于《国际关系学院学报》，2011 年第 6 期。

7. 列宁全集》中文版 $[\mathrm{M}]$ ，北京：人民出版社， 1985 年.第 20 卷，第 57 页。

8. 刘赛, 王新青: 独立后吉尔吉斯斯坦俄语发展现状研究 $[\mathrm{J}]$, 载于《新疆大学学报 》（哲学人文社会科学版），2013 年 5 月，第 41 卷第 3 期。

9. 王尚达、王文：苏联对中亚的语言政策：评论和反思 $[\mathrm{J}]$.载于《俄罗斯中亚东欧研 究》，2005 年第 6 期。

10. 乌兹别克斯坦《东方真理报》[N].1981 年 2 月 4 日。

11. 于沛：苏联扫盲运动(1919-1939)[J]，载于《华东师范大学学报》，1984 年第 1 期

12. 张宏莉 : 中亚国家语言政策及其发展走向分析 [J], 载于《新疆社会科学》, 2015 年。

\section{哈萨克斯坦国家教育发展历程与现状研究 QOZOQISTON DAVLAT TA'LIMI RIVOJLANISH TARIXI VA HOZIRGI DAVRI}

古丽改依·白山

上海外国语大学 讲师, 上海 Шанхай)

哈萨克斯坦列·尼·古米列夫欧亚国立大学 博士生, 努尔苏丹(Гулицзыи Байшань

摘要：本文通过对哈萨克斯坦国家教育政策历史沿革研究，梳理每个历史阶段的主要 教育政策, 深入了解哈萨克斯坦教育发展演变过程, 分析当前教育现状, 反映哈萨克斯坦教 育现代化过程中的改革发展逻辑。

关键词：哈萨克斯坦; 教育政策; 改革发展

Abstract: This paper analyzes the historical evolution of Kazakhstan's national education policy, combs the main education policies of each historical stage, deeply understands the evolution of Kazakhstan's education development, analyzes the current education situation, and reflects the logic of reform and development in the process of education modernization in Kazakhstan.

Keywords: Kazakhstan; education policy; reform and development

教育是培养人力资本的模式、国家发展的基础, 它会直接影响社会、文化、经济的发 展。教育体制是社会发展水平的重要标准。哈萨克斯坦独立以来哈萨克斯坦教育体制经历了 形成-发展-改革等一系列过程。

哈萨克斯坦目前正在实施社会经济和政治现代化的“哈萨克斯坦-2050”战略，该战略的 目标是将哈萨克斯坦发展成世界最发达国家前 30 强 [4]。在实现这一目标的过程中人力资本 演绎着最重要的角色之一, 而人力资本的发展与教育科学的发展有直接的关系, 因此教育的 发展是国家发展不可或缺的部分。

\section{一、哈萨克斯坦独立之前教育政策的历史发展及概况}

哈萨克斯坦独立之前的教育发展历程可分为四个阶段:

\section{（一）第一阶段（1917 年至 1930 年代末）}

苏联政权在哈萨克斯坦实施了公共教育体系的发展和全面扫盲政策。早在 1918 年通过 了“关于统一劳动学校的宣言”和“关于统一劳动学校的规定”, 当时宣布的苏联教育特点为: 免费教育, 男女生联合教育, 不允许教授神学学科, 废除学校自主管理体制等。所有的学校 
分为两个级别, 分别是针对 8-13 岁及 13-17 岁的孩子。并开始将神学院以及俄罗斯-哈萨克 学校转变成苏联学校。1920 年哈萨克斯坦内战结束之际哈萨克斯坦共有 2410 所学校及 14.4 万名学生, 但是 $99 \%$ 的学校没有教学楼、书籍和统一的教学计划。1923 年哈萨克斯坦共有 2025 所学校及 12.8 万名学生。1925 年共有 2713 所学校和 160924 名学生。在这一年哈萨克 斯坦简化了学校结构, 制定了统一的毕业证书、学年、假期以及 5 分制评分系统。在当时严 峻的经济形势下学校和学生数量的增长导致了教育系统质量的下降, 尽管如此, 国家依然致 力于扫除文盲。1930 年宣布普及初等义务教育。1931 年开始普及 7 年义务教育。

20 世纪 20-30 年代哈萨克斯坦教育政策最重要的部分之一是扫除成年人中的文盲。因 此 1921 年哈萨克斯坦政府成立了扫除文盲中央特别委员会, 该委员会领导了所有有关成年 人扫盲的工作并组织了培训学校。1921-1930 年间共有 85 万名成年人在培训学校进行了学 习。

苏联时期哈萨克斯坦开始发展高等教育, 在此之前, 哈萨克斯坦没有任何一所高等学 府。1928 年哈萨克苏维埃共和国建立了第一所高校阿拜哈萨克国立师范学院。1929年建立 了畜牧兽医学院, 1930 年建立了农业学院, 1931 年建立了医学院, 1934 年建立了阿里-法拉 比哈萨克国立大学。

1936 年哈萨克苏维埃共和国简化大学录取制度的决议通过。

1938 年在阿里-法拉比哈萨克国立大学成立了第一个博士点。[2,294-296]

\section{（二）第二阶段（1930 年代末至 1950 年代）}

1930 年代哈萨克苏维埃共和国的扫盲政策开始体现出了效果, 根据 1939 年的普查哈萨 克斯坦识字率达到了 76.3\%。1940 年哈萨克斯坦共有 5289 所小学、1 770 所 7 年制学校、689 所中等学校以及近 114 万名学生。除此之外, 37 所师范类院校, 35 所职业学校, 120 所中等 技术学校。

战争时期哈萨克斯坦高校数量有所增加, 但是教学科研机构的迅速发展是在 1946 年战 争结束, 哈萨克斯坦科学院成立之后, 直到 50 年代末哈萨克斯坦高等学校数量达到了 26 所。[2, 309-311]

\section{（三）第三阶段（1950 年代末至 1960 年代末）}

赫鲁晓夫时代的生产与学校相结合的思想带来了 20 世纪 50 年代末 60 年代初哈萨克斯 坦教育的彻底改革。1958 年通过了 “加强生活与学校的联系法”, 根据该法律取消了 7 年制和 10 年制的教育, 实行了 8 年制义务教育。此后, 毕业生须在中等技术学校学习的同时在工厂 或农村工作三年。此外, 大学录取过程以工作经验为参考依据, 而不是考生的理论知识水 平。哈萨克斯坦于 1962-1963 年间完成了向新的教育体制过度的工作。这项改革带来了一些 影响：1）流动型临时工人数量增加；2）高等教育的地位下降；3）知识分子投身于生产工 作，从而影响他们本专业相关的工作。

1964 年对这项改革进行了修订: 引入了 10 年制中等义务教育, 开始制定新的课程计 划。1966 年哈萨克斯坦在校学生数量达到了 285.2 万。[2,323-324]

\section{（四）第四阶段（1970 年-1980 年代末）}

1970 年批准了“普通中等教育章程”, 根据该章程, 学校有三个阶段: 小学 3 年, 八年 制学校以及 10 年制的中等学校。八年制学校的毕业生可选择在 10 年制学校、职业技术学校 或中等专业学校继续学习。此后, 方可进入大学学习。70 年代末随着人口数量的变化, 学 校和学生数量也发生了变化。1976 年哈萨克斯坦共有 9604 所学校及 334.4 万名学生, 而 1979 年这一数据分别为 8910 所学校及 325.7 万名学生。

此外, 1980 年代哈萨克斯坦高等学校数量达到了 55 所, 并总共培养了 25 万人。

经过苏联时期的教育政策, 哈萨克斯坦教育得到了全面发展。建立了完整的教育体 系、学校在整个国家范围内全覆盖、职业技术和高等学校数量增加、识字率几乎 $100 \%$ 等。

\section{二、哈萨克斯坦独立之后的教育政策发展历程}


苏联教育体系对于哈萨克斯坦教育的发展起到了关键作用。它最基本的特点是基础 性、系统性以及可触及性（免费教育）。苏联解体对于包括哈萨克斯坦在内的后苏联国家经 济带来了巨大困难, 这也体现在了国家教育体系的发展方面。与此同时, 苏联解体的时间也 是哈萨克斯坦教育国际化时代的开始时期。

20 世纪 90 年代的哈萨克斯坦教育是探索的过程, 国家为了建立完整的教育体系，积极 探索社会及教育方面的创新。

独立之后的哈萨克斯坦作为发展中的民主国家给自己设立了两个目标：1）提高人民的 生活质量；2）建立一个更为人道和民主的社会。而教育的发展是实现这两个目标的重要部 分之一, 因此哈萨克斯坦独立以来, 国家一直很重视教育的发展。独立之后的哈萨克斯坦教 育的发展可分为以下几个阶段:

\section{（一）1991-1994 年教育法和管理框架的形成}

哈萨克斯坦独立初期，各方面的法律都不健全，因此在这一阶段的当务之急是根据哈 萨克斯坦本国情况制定立法框架, 在这个过程中面临的主要问题为: 为公民提供教育资助; 为实施对教育领域的经济支持创造法律基础; 为教育领域吸引预算以外的资金并进行监管;

为了形成哈萨克斯坦教育制度的法律基础，1992 年颁布了哈萨克斯坦共和国 “教育 法”，1993 年颁布了“高等教育法”，以此确保了哈萨克斯坦人才培养方面的市场需求。1994 年哈萨克斯坦共和国国家高等教育标准获得批准, 该标准首次在该国引入了高等教育的多层 结构, 学士学位和硕士学位。

与此同时，在这期间对教育系统的概念及规划进行了修订：确立了教育领域国家政策 的概念、国家为教育领域提供支持的计划、为普通教育学校制定了完整的教育计划并编写和 出版了教科书。

制定了教育领域中优先需要改革的方向：扩大教育经费来源；确保地方教育系统的平 衡发展; 在全国范围内建立有效的教育管理系统; 改善和更新教育过程, 增强所学知识和技 能的实践性; 确保教育的国际化, 使国家教育水平接近国际标准; 为教育系统建立有效的法 律基础。

这些改革完善了哈萨克斯坦的教育体系, 确保了教育水平, 并在后来的发展中为哈萨 克斯坦教育逐渐接近国际水平打下了基础。

\section{（二）1995-2000 年教育政策内容更新及教育体系现代化}

自 1995 年以来，由于民主化进程的发展和经济转型，哈萨克斯坦教育改革最为频繁， 哈萨克斯坦教育体系也出现了很多积极的变化。1995 年 8 月 4 日哈萨克斯坦国家政策委员会 批准通过了 “关于高等教育机构活动的法律规定”, 这是哈萨克斯坦第一个高等专业教育标 准。它促进了非政府部门教育组织的积极发展。

1999 年 6 月 7 日哈萨克斯坦修订了“教育法”。根据该法律，教育系统的主要任务之一 是为国家经济的各个领域培养人才。因此按照各领域的人才需求, 国家给各所高校制定了每 一个专业的奖学金名额及人才培养需求。与此同时, 1999 年哈萨克斯坦政府制定并批准了 “哈萨克斯坦共和国国家机构学生群体的形成模式”。该模式旨提高高校报考生评估的客观 性, 选拔更为优秀的青年进入国立大学就读, 并为其提供国家奖学金。从此, 哈萨克斯坦教 育机构的录取原则发生了根本性的变化, 并且开始实施了按照国家需求培养相应人才的新模 式。

\section{（三）2001-2010 年教育领域的战略发展}

在该阶段, 确定了 21 世纪哈萨克斯坦教育持续发展的主要方向, 重点是将国家发展为 世界上最具竞争力的前 50 个国家。因此, 哈萨克斯坦教育政策旨形成符合全球教育空间要 求的教育模式。

自 2001 年起高等学校开始通过考试进行招生, 自 2004 年起开始施行国家统一招生考 试。 
2004 年哈萨克斯坦制定了 2005-2010 年国家教育发展计划。该计划的目标是根据哈萨 克斯坦共和国 2010 年发展战略计划, 对国家多级教育体系进行现代化, 以此提高人力资源 质量, 满足个人及社会需求。此计划分两个阶段实施, 第一阶段为 2005-2007 年间, 目标为 在各地区建立统一的教学管理系统; 第二阶段为 2008-2010 年间, 目标为全面实施发展战略 计划, 并根据积累的经验, 对劳动力市场的发展和社会经济状况进行调整。该计划的方向 为: 过渡到 12 年制的普通中学教育; 建立职业技术教育系统; 根据博洛尼亚进程和国际标 准保障本科-硕士-博士三个级别的教育体系; 建立国家教育评估体系。此计划已获得批准并 编入至 2007 年 7 月 27 日通过的“教育法”条款中。

（四）2011 年至今基于创新发展及全球教育一体化形成新的国家教育模式并培养全球 劳动力市场上具有竞争力的人才

在国际化和国民经济全球化的条件下，国家竞争力的意义日益增长。影响国家竞争力 的指标中教育有着重要地位。因此教育体系的设定对社会发展来说意义非凡。2010 年 12 月 7 日哈萨克斯坦批准了“2011-2020 国家教育发展规划”, 此计划目标为通过提供高质量的教 育，促进可持续的经济增长、提高教育的竞争力和人力资本的发展。该计划分两个阶段实 施, 分别是 2011-2015 年及 2016-2020 年。第一阶段的投入金额为 5097 亿坚戈。该计划确保 了哈萨克斯坦教育现代化的继续发展, 计划将学校和大学、大学和生产相结合, 并指出高等 教育应当符合世界领先水平。

显然，哈萨克斯坦教育体系不断改革发展，走向国际化水平。可以肯定哈萨克斯坦教 育的初步改革已完成, 哈萨克斯坦也出现很多私利或公立以及不同领域的高等学府, 确保了 哈萨克斯坦教育的多样化发展。

\section{三、哈萨克斯坦独立之后的教育现状}

哈萨克斯坦教育是一个持续教育和培养的过程, 其目的为培养学生道德、智力、文 化、生理发展及专业能力。哈萨克斯坦教育体系与教科文组织建议的“国际教育标准分类 ISCED-1997”标准相一致。根据教育规划, 哈萨克斯坦教育分为普通教育和职业教育。其包 含以下阶段: 学前教育, 中等教育, 本科教育和研究生教育。本文中我们将分析哈萨克斯 坦中等教育、本科教育以及研究生教育概况。

\section{（一）哈萨克斯坦中等教育概况}

哈萨克斯坦中等教育为义务教育，包括普通中小学教育及初、中等职业教育。

哈萨克斯坦普通中小学教育为 11 年, 其中小学教育 4 年, 初中 5 年, 高中 2 年。哈萨 克斯坦初等职业教育为 2-3 年, 在职业学校或中学进行学习。中等职业教育为 3-4 年, 在中 等专科学校进行学习。

完成义务教育之后学生可参加国家统一考试, 这既是大学入学考试, 也是学校结业考 试。

考虑到不同民族的教育需求, 哈萨克斯坦学校可使用哈萨克语、俄语、乌兹别克语、 维吾尔语、塔吉克语、乌克兰语、德语等 14 种语言进行授课。

哈萨克斯坦中等教育的重点是信息化和教育内容的更新。

哈萨克斯坦普通中小学教育具有以下任务:

- 保障所有学龄儿童的入学率;

- 实现国家义务教育标准;

- 通过改进教学内容及方法, 引入客观的学生评价和教师评价标准, 以此提高教学质量

- 确保师生身心健康。

哈萨克斯坦初、中等职业教育的主要任务为:

- 制定和执行国家职业教育标准, 并根据劳动力市场和经济结构的变化进行更新;

-为增强职业教育的可触及性创造条件;

- 支持私立职业教育; 
・在职业教育体系中组织和发展社会伙伴关系;

・扩大职业教育机构工作人员培养和培训方面的国际合作。

初等职业教育包括对工人、技工以及失业者的培养、再教育和培训。中等职业教育机 构是中等职业技术学校。它根据国家中等职业教育标准和教学计划培养相应人才。目前中等 职业技术学校引入了新的机制, 根据地方对劳动力资源的需求, 以合同作为基础, 培养相关 领域的人才。此外, 中等职业学校只有在有特定的雇主和地方就业部门确认的情况之下才能 开设新专业。

哈萨克斯坦独立以来，哈中等教育学校和学生数量发生了很大变化。因苏联解体后大 量俄罗斯、德国、乌克兰等民族移民离开哈萨克斯坦, 因此出现了人口大规模减少的现象, 这也体现在了中等教育学校及学生数量上。

如表 1 所示, 1991 年哈萨克斯坦独立之后, 学校数量从 8841 所减少到了 2016 年的 7450 所, 下降了 $15.7 \%$ 。学生数量从 322.6 万减少到了 293.1 万名, 下降了 $9.6 \%$ 。

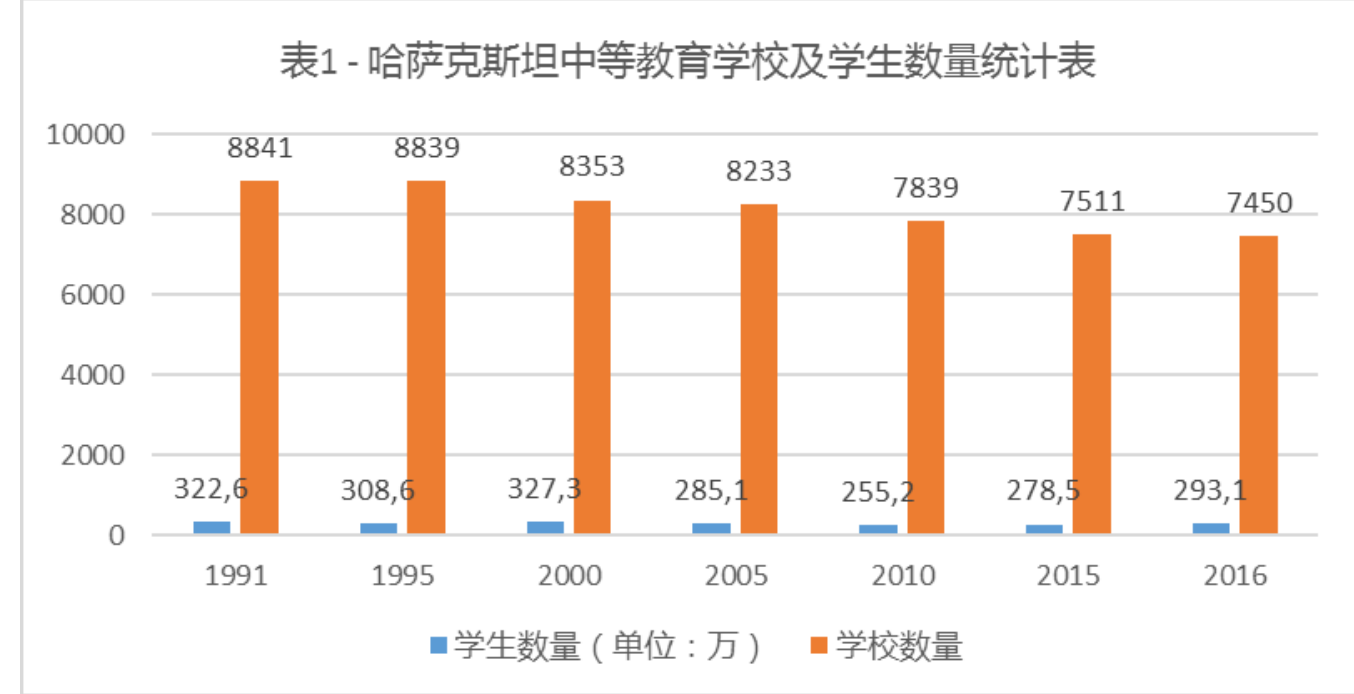

可以看出, 学生数量在独立之后下降至 1995 年的 308.6 万, 而在 2000 年上升至 327.3 万后, 急剧下降。自 2010 年开始又出现学生数量上升的趋势。尽管学生数量有所增加, 但 是学校数量依然减少, 这是因为哈萨克斯坦小型学校逐渐被整合合并, 中等教育改革发展为 精简化，提高教育质量。

\section{（二）哈萨克斯坦高等教育概况}

哈萨克斯坦共和国高等教育机构有以下类型: 国立研究型大学, 国立高等教育机构, 研究型大学, 大学, 科学院, 学院以及同等地位的机构（音乐学院, 道等学校等）。

高等教育的结构有本科, 硕士研究生以及博士研究生三个层次。

哈萨克斯坦高等教育有以下任务:

- 满足个人在智力, 文化和道德方面的发展, 所选专业活动领域获得高等教育和资格方 面的需求;

- 接受高等教育的人才满足社会经济需求;

- 培养合格的专业人士、高层次的教育科研人才;

-组织和进行基础的、勘探的、应用科学的、实验设计的工作和方法研究;

- 对不同领域的领导和工作人员进行再培训或进修;

- 积累, 维护和增强社会道德、文化和科学价值;

-在百姓中传播知识，提高其教育和文化水平。

在经济和教育全球化的大背景下，哈萨克斯坦高等教育面临新的国际化教育体制改 革。高等教育服务市场取决于评估指标, 我们在表 2 中研究了哈萨克斯坦独立以来高校、学 生以及教职工数量动态变化。

表 $2-$ 哈萨克斯坦独立以来高校、学生、教师数量变化表 [5] 


\begin{tabular}{|c|c|c|c|}
\hline 学年 & 高校数量 & 高校在读大学生数量 & 全体教授及教员数量 \\
\hline 1990-1991 & 55 & 287,367 & 21,955 \\
\hline 1991-1992 & 61 & 288,371 & 23,230 \\
\hline $1992-1993$ & 63 & 280,737 & 24,080 \\
\hline 1993-1994 & 89 & 276,715 & 25,036 \\
\hline 1994-1995 & 101 & 275,347 & 31,144 \\
\hline $1995-1996$ & 112 & 272,715 & 31,990 \\
\hline 1996-1997 & 111 & 280,783 & 29,766 \\
\hline 1997-1998 & 133 & 293,465 & 24,678 \\
\hline 1998-1999 & 144 & 318,755 & 27,127 \\
\hline 1999-2000 & 163 & 365,385 & 26,996 \\
\hline $2000-2001$ & 170 & 440,715 & 29,577 \\
\hline $2001-2002$ & 185 & 514,738 & 34,508 \\
\hline $2002-2003$ & 177 & 590,982 & 37,602 \\
\hline $2003-2004$ & 180 & 658,106 & 40,972 \\
\hline 2004-2005 & 181 & 747,104 & 42,333 \\
\hline $2005-2006$ & 181 & 775,762 & 43,382 \\
\hline $2006-2007$ & 176 & 768,442 & 42,788 \\
\hline $2007-2008$ & 167 & 717,053 & 41,207 \\
\hline $2008-2009$ & 143 & 633,814 & 37,814 \\
\hline $2009-2010$ & 148 & 610,264 & 39,155 \\
\hline $2010-2011$ & 149 & 620,442 & 39,600 \\
\hline $2011-2012$ & 146 & 629,507 & 40,531 \\
\hline $2012-2013$ & 139 & 571,691 & 41,224 \\
\hline 2013-2014 & 128 & 527,226 & 41,635 \\
\hline 2014-2015 & 126 & 477,387 & 40,320 \\
\hline $2015-2016$ & 127 & 459,369 & 38,087 \\
\hline 2016-2017 & 125 & 477,074 & 38,241 \\
\hline 2017-2018 & 122 & 496,209 & 38,212 \\
\hline $2018-2019$ & 124 & 542,458 & 38,275 \\
\hline
\end{tabular}

从表 2 中可以看出自 1990-2002 年哈萨克斯坦高校数量每年稳步增长, 自 2002-2018 年 高校数量递减。说明根据哈萨克斯坦相关教育政策，不少高校被合并或关闭。而学生及教职 工数量自 1990-2006 年稳步增长, 自 2006-2007 学年至 2017-2018 学年期间学生数量递减, 教职工数量出现递减-增长-递减的情况。因此可以看出, 自 2006-2007 学年开始哈萨克斯坦 高校开始减少扩招学生数量。值得一提的是, 2018-2019 学年哈萨克斯坦高校、学生、教职 工数量都出现了涨幅, 这说明哈萨克斯坦扩大了对教育的投入，增加了奖学金数量。

目前哈萨克斯坦正在逐步推广将国立大学转变为创新性大学，根据哈萨克斯坦共和国 2020-2025 年教育和科学领域的发展规划, 哈萨克斯坦将加大对教育的投入, 完善基础设 施。未来 5 年将在教育领域投资 14.5 万亿坚戈, 对科研领域的支出将增加 7 倍。教育经费将 达到 GDP 的 7\% [7]。

因此, 可以说哈萨克斯坦的教育体系正在经历一个根本性的转变。为了发展科学和教 育、提高国际影响力，哈萨克斯坦将会加大对教育的投入、引进新的教育技术和教育信息 化。

\section{四、结语}

哈萨克斯坦教育沿着现代化的历程车轮不断发展，积极探索建成哈萨克斯坦特色的世 界水平现代教育。哈萨克斯坦尝试通过人类现代化进入信息时代, 全面加大对教育技术和信 息化的投入，紧跟时代步伐，进行教育改革发展，加快重塑教育的现代化，建设教育强国。 


\section{参考文献:}

1. edu.gov.kz (哈萨克斯坦教育与科学部官网)

2. Кузембайулы А., Абиль Е.А. История Казахстана: Учебник для вузов. / Костанай: Костанайский региональный институт исторических исследований, 2006.-350 с.

3. Государственная программа развития образования в Республике Казахстан на 20052010 годы. Астана, 2004 г.

4. Послание Президента Республики Казахстан - Лидера нации Назарбаева Н.А. народу Казахстана «Казахстан-2050»: новый политический курс состоявшегося государства // Официальный сайт Президента Республики Казахстан: // www.akorda.kz.

5. Министерство национальной экономики Республики Казахстан, Комитет по статистике, раздел «Образование»: // https://stat.gov.kz/official/industry/62/statistic/8 //, 2017.

6. Закон «Об образовании»: // www.zan.kz.

7. Государственная программа развития образования и науки Республики Казахстан на 2020 - 2025 годы, 2019

\section{ВЛИЯНИЕ КИТАЙСКОЙ КУЛЬТУРЫ НА ТРАДИЦИОННУЮ КИТАЙСКУЮ МЕДИЦИНУ}

\section{Л.А.Султанова \\ (ТашГУВ, ст.преподаватель)}

Annotation: As part of the formation of traditional Chinese culture, the ancestors of modern Chinese developed a unique view of the processes associated with life, health and diseases. The methods they used to protect health and counteract diseases gave birth to a comprehensive system of healing, known today as traditional Chinese medicine and pharmacology. The evolution of traditional Chinese medicine is closely linked to the development of Chinese society, economy, science, and culture. In its development, traditional Chinese medicine has passed a long way of development, which began more than 5 thousand years ago in the Neolithic period. The concept of B月-Jin-Yang is at the heart of both traditional Chinese philosophy and traditional Chinese medicine

Key words and expressions: Traditional Chinese culture, traditional Chinese medicine, 阴Jin-Yang concept, harmony, dynamic balance.

Астрономия, математика, агрономия и медицина - четыре наиболее важные науки в древнем Китае. Однако, медицину традиционно считали самой гуманной и культурной наукой. Традиционная китайская культура оказала очень глубокое влияние на традиционную китайскую медицину [ЛянЮнсуань ,ЧжаоСинь, ЧженьСюеянь2015: 1].

В рамках формирования традиционной китайской культуры у предков современных китайцев сложился уникальный взгляд на процессы, связанные с жизнью, здоровьем и заболеваниями. Методы, которые они использовали для охраны здоровья и противодействие болезням, дали жизнь всеобъемлющей системы врачевания, известной в наши как традиционная китайская медицина и фармакология.

Эволюция традиционной китайской медицины тесно связана с развитием китайского общества, экономики, науки и культуры. В своем развитии традиционная китайская медицина прошла долгий путь развития, начало которому было положено более 5 тыс. лет тому назад в период неолита. Формирование теоретической базы ТКМ было завершено уже к периоду эпох ВЁСЕН и осеней (770-476 гг. до н.э.) и Воюющих царств (475-221 гг. до н.э.). К самым ранним классическим трудам по медицине относятся медицинские записи из книги по географии «Шань хай цзин» («Трактат о горах и морях»), «Хуанди нэйцзин» («Трактат Жёлтого императора о внутреннем») и «Шеньнун бэньцао цзин» («Трактат о корнях и травах Шеньнуна»). Дальнейшее развитие протекало в эпоху династии Хань (202 г. до н.э. - 220 г. н.э.), эпоху Троецарствия (220-280 гг. н.э.) и периоды правления всех последующих династий. И на каждом этапе развития традиционной китайской медицины можно обнаружить следы ее тесной связи с развитием всей китайской культуры [ Ли Мусай 1988:2]. 
Традиционная китайская медицина находится в полной гармонии с китайской культурой, неотъемлема от нее, является ее важной составной частью и украшением. На протяжении многих тысячелетий традиционная китайская медицина служила инструментом, помогавшим китайской нации в борьбе с болезнями, охране здоровья и достижении процветания. С наступлением 21-го века в результате стремительного развития науки и технологий происходит фундаментальные изменения в осмыслении человечеством концепции здоровья и средств его обеспечения. Одного предотвращения болезней и телесных повреждений для этого становится недостаточно. На первое место выходит интеграция физического, психического и эмоционального здоровья и достижение качества жизни, обеспечивающего гармонию человека с обществом и окружающей средой. Медицина эволюционирует, превращаясь из науки с чисто биологическим содержанием в научное знание, ориентированное одновременно на общество, психологию, человека и окружающую среду. Эта новая концепция по сути своей совпадает с принципами холизма , являющимися основой ТКМ и включающими такие ее требования, как «превентивное лечение», «единство человека и природы», «единство формы и духа» и «равновесие 阳一阴 ян и инь» [ Юй Хуа ,ЛиньЦянь, 2015:4].

Концепция 阴-阳 инь-ян лежит как в основе традиционной китайской философии, так и в основе традиционной китайской медицины. Обнаружив, что все явления природы состоят из двух противоположных и в то же время взаимодополняющих аспектов, которые находятся в состоянии постоянно изменяющегося динамического равновесия, древнекитайские философы выдвинули концепцию инь 阴-ян 阳 для объяснения этих двух изначальных сил вселенной. Они полагали, что противоположность и взаимодополняемость инь и ян присущи всем вещам, и это является основополагающим законом природы. На основе идей о инь-ян, выдвинутых философскими школами в период, предшествовавшей эпохе династии 秦代 Цинь (до 221 г. до н.э.), авторы «Трактата о внутреннем» выработали наиболее целостную и рациональную, практически свободную от явных нелепостей теорию инь-ян.

Согласно теории 阴-阳 инь-ян, 气 ци, являющееся источником всех вещей, существовало до сотворения мира в виде Великого Хаоса. В процессе движения и преобразования Хаос разделился на инь и ян. Отношения, основанные на противоположности и единстве инь и ян, обнаруживаются во всех вещах, и весь материальный мир является манифестацией их постоянно изменяющихся взаимосвязей.

Инь и ян используются для описания взаимно дополняющих друг друга противоположных вещей и признаков, таких как активность и пассивность, день и ночь, жар и холод, солнце и луна и т.д. В целом, все энергично двигающееся, восходящее, стремящееся наружу, теплое и светлое относится к ян; все находящееся в состоянии относительного покоя, нисходящее, стремящееся к сгущению и концентрации, прохладное и темное относится к инь. Например, вода, холодная, мокрая и стремящаяся к концентрации в одном месте, относится в силу перечисленных свойств к инь. Огонь, сухой, горячий и стремящийся к распространению, относится по названным признакам к ян. Инь и ян могут описывать две формы существования одной вещи. Например, лед и пар являются двумя сторонами воды. Лед как холодная и концентрированная субстанция относится к инь. Пар как горячая и диффузная субстанция - к ян [А.Н.Ахметсафин2007:3].

Соотношение инь и ян во всех вещах является величиной скорее относительной, чем абсолютной. При определенных условиях инь может трансформироваться в ян и наоборот. Переменчивость инь и ян также отражается в бесконечной делимости материального мира, иначе говоря, любое проявление инь и ян допускает дальнейшее внутреннее деление на инь и ян. Относительное соотношение инь и ян постоянно изменяется в соответствии с естественными законами трансформации, включающими взаимодействие, взаимное ограничение, взаимозависимость, динамическое равновесие и взаимопревращение.

Взаимодействие между инь и ян означает, что в процессе движения эти две первичные силы взаимно индуцируют соединение в различных соотношениях. Взаимодействие небесного (ян) и земного (инь) начал породило «десять тысяч вещей», наполняющих 
вселенную, и остается источником постоянного появления новых вещей Взаимное ограничение, означает, что инь и ян преодолевают друг друга. Например, вода (инь) гасит огонь (ян), а огонь испаряет воду. ТКМ использует закон взаимного ограничения в таких принципах лечения, как рассеивание избыточного жара охлаждением и чрезмерного холода согреванием, гиперактивности - покоем, а гиперактивности - возбуждением.

Взаимозависимость указывает на то, что инь и ян экзистеально обусловливают друг друга. Каждый из них является условием существования другого и не может существовать изолированно. Например, 上 верх - это 阳 ян, 下 низ -阴 инь, и не может быть верха без низа, как и низа верха. Аналогичным образом, 热 жара - это 阳 ян, 冷 холод - это 阴 инь, но не бывает жары без холода и наоборот [Юй Хуа ,ЛиньЦянь2015:4].

Динамическое равновесие означает, что

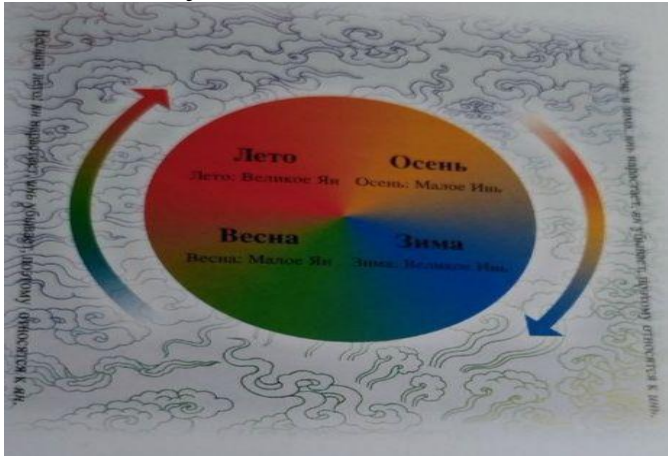

соотношение инь и ян в предмете или явлении не является устойчивым, оно в большей степени представляет собой переменчивую величину, колеблющуюся в определенных пределах динамического равновесия. Примером могут служить: во время зимы инь доминирует над ян.

Приходом весны инь постепенно убывает, а ян по мере развития сезонного цикла нарастает. Другим примером является смена дня и ночи. В течении дня ян усиливается, а инь убывает, а с наступлением ночи происходит обратное. Функционирование человеческого организма сопоставимо с природными явлениями. Днём, когда доминирует ян физиологические функции активизируются, температура тела повышается. Ночью, в периоды доминирования инь, физиологические функции замедляются, температуры тела понижается. Как в природе, так и в человеческом организме чрезмерные изменения инь и ян приводит к нарушению динамического равновесия. В природе утраты равновесия между инь и ян проявляется в стихийных бедствиях, в организме человека - приводит к патологическим изменениям и болезням [ЛянЮнсуань ,ЧжаоСинь, ЧженьСюеянь 2015: 1].

Взаимопревращение инь и ян означает, что при определенных условиях все вещи могут превратиться в свою противоположность. Вещи, относящиеся к ян, постепенно трансформируются в инь, а вещи относящиеся к инь, постепенно переходят в ян. Например, в теченни года лето (ян) естественным образом переходит в зиму (инь), а затем по мере продолжения движения сезонного цикла зима трансформируется в лето. При заболеваниях это означает возможность перехода жара, связанного с ян - патологией и проявляющегося как лихорадка, избыточность ян, дефицит инь и гиперактивность в холод, который связан с инь - патологией и выражается в ознобе, избыточности инь и пониженной активности. При определенных условиях холод как результат инь - патологии также может трансформироваться в жар, обусловленный ян - патологией [Юй Хуа ,ЛиньЦянь 2015: 4].

Европеец, глядя на географическую карту, располагает 北 Север наверху, А 南 Юг внизу. Китаец поступал наоборот Север внизу, а Юг наверху, аргументируя это тем, что 火 «огонь » (Юг, тепло) поднимается

вверх, a 水 « вода» (Север, холод) опускается вниз . Европеец может возразить,что Север наверху, так как полюс мира также наверху, но для китайца это не является серьезным аргументом, а путешествие в Южное полушарие (например, в Австралию) он считает в целом нездоровым предприятием (там все наоборот). Для европейца число 13 является «несчастливым», китаец же будет всячески избегать числа 四 [si]-4,потому что оно созвучно со словом 死 [si]- умереть.

Считая на пальцах, мы загибаем их, обычно начиная с мизинца, китаец

же начнет скорее с большого пальца. Все эти поведенческие особенности

связаны с традиционной установкой и с диссимметричным восприятием. 
Если у европейца правая рука «сильная», следовательно, она « мужская» И даже правильная. Левая рука оказывается «неправильной», а в политической терминологии «левые» связаны с тенденцией к радикализму. Напротив, у китайца правая рука (сторона)Инь (женская, темная, Луна и т. д.), а левая Ян (мужская, светлая, Солнце и т. д.). Такого рода «несоответствия» наводят на мысль о контраверсии культур, а в связи с этим утверждается, что, вероятно, протокитаицы в основе своей являлись левшами. С другой стороны, нередко от китайца можно услышать, что «сердце смещено влево» и поэтому левое это ЯН. На вопрос, почему «сердце смещено влево», обыкновенно ответа нет, или же начинаются пространные «рассуждения» об асимметрии органов. Но вопрос «По чему в таком случае печень находится справа, хотя это Ян», как правило ставит в тупит.

Однако проблема контраверсии легко разрешается, если иметь в виду два обстоятельства: во-первых, традиционную установку культур, геофизические условия в ареале обитания ядра культуры, и, во-вторых, психофизические особенности восприятия [А.Н.Ахметсафин2007:3].

Традиционная китайская медицина использует философскую концепцию инь ян и законы их трансформации для анализа строения, жизненных функций и патологических изменений человеческого организма. Теория инь-ян дает теоретическую базу и практические методы для поддержания здоровья, а также диагностики, лечения и профилактики болезней.

Традиционная китайская медицина находится в полной гармонии с китайской культурой, неотъемлема от нее, является ее важной составной частью и украшением. Заглядывая в будущее, можно утверждать, что традиционная китайская медицина и ее культурологические основы в будущем будут продолжать оказывать сильное влияние на развитие экономики, науки и культуры всего человечества.

\section{Список использованной литературы}

1. 梁永宣, 赵歆, 甄雪燕。《中国医学史》。北京: 五洲传播出版社, 2015 年。 Лян Юнсуань, ЧжаоСинь, Чжень Сюеянь «Традиционная медицина». Пекин, Межконтинентальное издательство Китая. 2015. 211с.

2. 李慕才。《中医知识丛书. 话说中医》。河北: 科学普及出版社.

年。Ли Мусай. Хебэй.1988, 150 с.

3. Ахметсафин А.Н. Китайская медицина. Избранные материалы. Санк-Петербург. Спб: Петербурское Востоковедение, 2007, 160с.

4. 李友华, 林傔。《中国医学》。北京: 2015 年。Юй Хуа, Линь Цянь, Традиционная китайская медицина. Пекин, Министерство культуры КНР. 2015, 101 с.

5. Султанова Л.А. Қисқача хитойча - уузбекча тиббиёт луғати. ТДШИ, 2012. Б. 315.

6. 汉俄医学大词典 - 北京。人民卫生出版社。2006 年。1763 页。

\section{МАКХУЛ НАСАФИЙНИНГ МОТУРИДИЯ ТАЪЛИМОТИ РИВОЖИГА КЎШГАН ХИССАСИ}

\section{A. Muhiddinov (Imam Bukhari International Scientific Research Center, Researcher )}

Annotation: This article mainly deals with the life and scientific legacy of theologian Abu Muti' Makhul ibn Fazl Nasafi, as well as his contribution to the development of theology, and his denials to false and superstitious sects. Information is provided about the works of the scholar, manuscripts of which are now preserved in the funds of the world.

Key words and expressions: Kalam, aqeedah, figh (Islamic law), Maturidi doctrine, mutakallim, scholars, Nasaf and Samarqand, kalam schools, Hanafi school.

Буюк алломалар камолга етган замин Ўзбекистон - буюк алломалар юрти. Заминимизда туғилиб, камол топган мутафаккирларнинг жахон илм-фани ривожига кушшган хиссаси неча асрларки эътироф этилиб, чуқур тадқиқ этилмоқда. Бу табаррук заминдан не-не 
буюк зотлар, олиму уламолар, сиёсатчи ва саркардалар етишиб чиққани, умумбашарий цивилизация ва маданиятнинг узвий қисмига айланиб кетган дунёвий ва диний илмларнинг, айниқса, ислом дини билан боғлиқ билимларнинг тарихан энг юқори босқичга кўтарилишида она юртимизда туғилиб камолга етган улуғ алломаларнинг хизматлари беқиёс экани бизга улкан ғурур ва ифтихор бағишлайди.

Аллох таоло Куръони Каримда буюк неъатларини кимга беришлигини хамда унинг мақоми нақадар юксак эканлиги хақида мархамат қилади: “Аллох кимни хидоятга йўллашни ирода этса, унинг кўкси (қалби)ни Ислом учун (кенг) очиб кўяди. Кимни адаштиришни ирода қилса, кўксини гўё осмонга кўтарилиб кетаётгандек, тор ва сиқиқ қилиб кўяди. Шундай қилиб, Аллох имон келтирмайдиганларга (лойиқ) жазони раво кўргай ",4 .

Бу борада Ибн Умар (р.а) дан ривоят қилинади, Расулуллох соллаллоху алайхи ва валлам: “Албатта Аллох таоло умматимни залолатда бирлаштирмайди" ${ }^{45}$ деб, айтадилар. Шунингдек, Муовия (р.а)дан ривоят қилинади, Пайғамбаримиз Мухаммад Мустафо соллаллоху алайхи ва саллам хадиси шарифларида: “Аллох бир кишига яхшиликни ирода қилса, уни динда фақих қилиб кўяди” 46 деб, айтадилар.

Аллох таоло илмнинг фазилатлари ва унинг мартабаси хақида Куръони Каримда мархамат қилади: “У Ўзи хохлаган кишиларга хикмат (пайғамбарлик ёки Қуръон илми) беради. Кимга (мазкур) хикмат берилган бўлса, демак, унга кўп яхшилик берилибди. Бундан фақат оқил кишиларгина эслатма олурлар"47.

Мазкур оят тафсири хақида буюк муфассир Ибн Аббос розияллоху анхумо фикр ва мулохазалар билдириб, "Ушбу оятдаги хикмат сўзидан мурод, халол ва харом илмини билишликдир”, деганлар.

Тарихдан маълумки хар бир замон ва жамиятнинг қудрати, салохияти ва равнақи унинг илмга бўлган муносабати билан ўлчанган. Шу сабабли бизнинг юртимизда қадимдан илму маърифатга алохида эътибор қаратилган. Жумладан, Ислом оламида IX-XII асрларни илмфанинг олтин даври деб эътироф этилган.

Юртимиздан етишиб чиққан Абу-л-Муъин Насафий (1027-1114), Нажмуддин Умар Насафий (1068-1142), Хофизу-д-дин Абу-л-Баракот Насафий (ваф. 710/1310), Абу-л-Фазл Мухаммад ибн Мухаммад Насафий, Лутфуллох Насафий (ваф. 750/1349) ${ }^{48}$ ва Абдулазиз Насафий (ваф. 533/1138) каби кўплаб диний ва дунёвий илмларнинг дарғаларини тарбиялаб вояга етказган. Мазкур олимлар орасида муносиб мақомга эга бўлган машхур аллома Макхул Насафий бўлиб, у нафақат араб тили грамматикаси, балки ўз даврининг мутакаллим алломаси сифатида хам шухрат қозонган сиймоларидан биридир.

Олимнинг тўлиқ исми Абу Мутиъ Макхул ибн Фазл Насафий бўлиб, унинг таваллуд санаси хақида хозирча манбаларда бирор маълумот учрамайди. Аммо вафот этган йили хақида барча адабиёт ва ёзма асарларда 318/930 сана кўрсатилган. Макхул Насафий юксак илму маърифати билан танилиб, авлоддан-авлодга ўтиб келаётган сулолаланинг асосчиси сифатида хам машхурдир ${ }^{49}$.

Аллохга минг қатла шукрлар бўлсинки, юртимиз мустақиллиги шарофати билан миллий ва диний қадриятларимизнинг тикланиши ва узоқ ўтмишда яшаб ўзларининг сермахсул ижодлари билан ислом динининг турли сохаларига бағишлаб кўплаб асарлар ёзиб қолдирган аждодларимизнинг хаётлари ва сермазмун илмий меросларини хар томонлама чукур ўрганиш энг долзарб масалалардан бирига айланди.

Шу билан бирга айтиш жоизки, шу даврда ислом динининг энг мухим, энг нозик хисобланган ақидавий масалалар билан шуғулланган бир қатор олимлар хам етишиб

\footnotetext{
${ }^{44}$ Қуръони карим маъноларининг таржима ва тафсири. Таржима ва тафсир муаллифи Шайх Абдулазиз Мансур. -Т.: ТИУ, 2004. Анъом сураси, 25-оят. -Б.63.

${ }^{45}$ Имом Термизий ривояти. Сунану-т-Термизий №2167 Хадис.

${ }^{46}$ Муттафақул алайх яъни, Имом Бухорий ва Имом Муслим ривоятлари.

${ }^{47}$ Бақара сураси, 269-оят. -Б. 45.

${ }^{48}$ Абдусаттор Жуманазар. Насаф. -Т.: Алишер Навоий номидаги Ўзбекистон Миллий кутубхонаси нашриёти, 2006. -Б. 167-183.

49 Абдуллох Абдулхамид Саад. Ўрта Осиё олимлари қомуси. -Т.: 2008. - Б. 366.
} 
чиқдики, улар мутакаллим номи билан юритилади. Мовароуннахрда яшаб ижод этган буюк мутакаллимларнинг хаёти ва асарларини ўрганиш борасида бир талай илмий изланишлар амалга оширилганлиги хам барчага маълум. Диний-ақидавий масалаларни илмий асосда чукур ўрганиш хозирги давр учун хам илмий ва амалий ахамиятга эга эканлиги ушбу мавзунинг нақадар мухимлигини кўрсатади.

Шунингдек, юртимиздан чиққан алломалар илмий-маънавий, диний меросида барча диний ва дунёвий билимларга оид намуналарни кузатиш мумкин.

Эътиборлиси, улар орасида калом - ақида илмига бағишланган асарлар хам салмоқли ўрин эгаллайди. Халқимизнинг бебахо маънавий хазинаси хисобланган мазкур асарларни илмий тахлил ва тадқиқ этган холда таржима қилиш, улардан кенг халқ оммаси, айниқса, ёшларни хабардор қилиш хозирги давр учун энг долзарб вазифалардан хисобланади.

Ўзбекистон Республикаси Президенти Шавкат Мирзиёевнинг Термизга ташрифи давомида айтган: "Насафий алломаларлар хаёти ва илмий меросини тўлиқ ўрганиб, жойларда кенг тарzиб этишимиз лозим буулади. Ёиларимизга биз қандай улув боболаримиз уттганлигини етказиб берсак, уларнинг маънавий бойлиги ошади. Шунингдек, улуд олим ва мутафаккир боболаримиз маънавий меросини халқимиз, айниқсса, ёшларимиз онгига синдирсак, уларга муносиб бўлиб ва улардан уррнак олиб яшашига жуда катта ижобий таъсирини кўрсатади, ${ }^{\text {,50 }}$, сузларини келтиришимиз ўринлидир.

Кўриниб турганидек, ташқи тахдидларга қарши курашишнинг энг мақбул ва маъқул йўлларидан бири аждодларимизнинг асрлар оша исботини топган меросига таянган холда олиб борилган ташкилий-амалий харакатлардир.

Халқимизнинг илмий-маънавий мероси, ислом ва унинг ғоялари, диний, миллиймаънавий қадриятларимиз, юртимиздан етишиб чиқиб, бутун дунёда машхур бўлган буюк алломаларнинг хаёти ва калом илмига бағишланган илмий меросларига асосланган холдагина ислом дини ғояларини бузиб талқин қилишга уринаётган оқимларнинг асл мақсадларини фош қилиш мумкин бўлади.

Мовароуннахрда калом илмининг ривожланишида буюк мутакаллим Абу Мансур Мотуридийнинг ўрни нихоятда катта бўлган бўлса-да, Абу Мутиъ Макхул ибн Фазл Насафийнинг хам хизмати беқиёсдир.

Алломанинг "Китобу радд ала ахли-л-бидаъи ва-л-ахва" (“Бидъатчи, адашган ва адаштирувчи ботил фирқаларга раддиялар китоби”) номли учинчи рисоласи бевосита калом илмига алоқадор бўлиб кенг шухрат топган ${ }^{51}$. Ушбу асар калом илми тарихида алохида ўрин эгаллаган бўлиб, шу йўналиш пойдеворини ташкил этган ноёб асарлардан хисобланади Жумладан диний-ақидавий масалаларни илмий асосда чуқур ўрганиш хозирги давр учун хам илмий ва амалий ахамиятга эга эканлиги ушбу мавзунинг нақадар мухимлигини кўрсатади. Шу боис, бу ерда биз уларнинг бидъатини баён қилишни мақсад қилдик ва ўзимизнинг пок ақидамизни асраб-авайлашимиз хар биримизнинг бўйнимиздаги асосий бурч эканлигини яна бир бор таъкидлаймиз.

Макхул Насафийнинг мазкур асари, биринчидан, фирқаларнинг хар бирини мохиятини баён қилиб, сўнг, ахли сунна ва-л-жамоанинг уларга бўлган жавобини баён қилган, уларнинг нотўғри ғояларини очиб ташлаб уларга нисбатан раддиялар келтирган. Аллома ўз асарида олтита - харурийлар, қадарийлар, жахмийлар, рофизийлар, жабарийлар ва муржиъийлар каби асосий оқимларга раддия берган хамда жами бўлиб 72 адашган фирқаларнинг мохиятини тўлиқлигича айтиб ўтган. Ушбу 72 та ботил фирқалар сохта таълимот вакиллари бўлиб, биз уларнинг мохиятини оқилона англашимизда мазкур асарнинг ахамияти каттадир.

Хулоса ўрнида шуни айтиш жоизки, масаланинг ижобий тус олишига маълум маънода бир қатор адашган тоифаларнинг харакатлари жонланиб, ислом дини асосларига таъсир қиладиган даражада хавфли тус ола бошлагани хам сабаб бўлиб, нақлнинг асл мохиятини инсонларга тўғри етказиб берадиган ақида илмига эхтиёж кучайди. Ўша даврларда пайдо бўлган оқимлар ўз қарашларини Қуръон ва хадис билан далиллашга урингани хам масалани

\footnotetext{
${ }^{50}$ Мирзиёев Ш.М. 2016 йил, октябрь. Сурхондарё вилояти, Имом Термизий зиёратгохидаги сухбат.

${ }^{51}$ Абдуллох Абдулхамид Саад. Ўрта Осиё олимлари қомуси. Т - 2008й.- Б. 95.
} 
бирқадар чигаллаштирар эди. Чунки оддий инсонларнинг аксарияти айтилган оятлар ва хадиси шарифларга сўзсиз ишонади хамда уларга амал қилишга шошилади. Хуллас, Куръон тафсири, хадислар шархини тўғри амалга ошириш ва уларни кенг халқ оммасига етказиб бериш давр талаби эди.

Бу давр олимлари, Қуръон ва хадисларда ислом дини таълимоти, эътиқод масалалари муфассал баён этиб берилгани учун калом ахлига эхтиёж йўқлигини таъкидлайдиган аввалги аср алломаларидан фарқ қилиб, калом илмига хам алохида хурмат билан қарай бошладилар.

\section{Фойдаланилган адабиетлар рўйхати}

1. Куръони карим маъноларининг таржима ва тафсири. Таржима ва тафсир муаллифи Шайх Абдулазиз Мансур. -Т.: ТИУ, 2004.

2. Абдуллох Абд ал-Хамид Саад. Ўрта Осиё олимлари қомуси. - Т.: Имом Бухорий республика илмий-маърифий маркази, 2007.

3. Абдулқодир ибн Абулвафо Қураший. ал-Жавохир ал-музийя фи табақот алханафийя. - Байрут: Муассасату-р-рисола, 1993. Т.2.

4. Исфахоний. Салжуқийлар давлати тарихи, - Б. 52.

5. Имом Термизий ривояти. Сунану-т-Термизий №2167 Хадис.

6. Абдусаттор Жуманазар. Насаф. -Т.: Алишер Навоий номидаги Ўзбекистон Миллий кутубхонаси нашриёти, 2006. -Б. 167-183.

7. Имом Бухорий ва Имом Муслимнинг “Сихох” асарлари.

8. Мирзиёев Ш.М. 2016 йил, октябрь, Исо Термизий зиёратгохидаги сухбат. Сурхондарё вилояти.

9. Абдуллох Абдулхамид Саад. Ўрта Осиё олимлари қомуси. - Т.: Имом Бухорий республика илмий-маърифий маркази, 2007.

10. Абдуллох Саъад. Ўрта Осиё олимлари каталоги”дан). Араб тилидан Н.Жабборов таржимаси. // Имом ал-Бухорий сабоқлари. 2006/3. -Б. 174.

11. Абу Мутиъ Макхул ибн Фазл Насафий. Бидъатчи, адашган ва адаштирувчи фирқаларга раддиялар китоби. Араб тилидан Х.Мухидинов таржимаси. -Т.: Тошкент ислом университети, 2012. -Б. 69.

12. Абу Саъд Самъоний. Ал-Ансоб. -Байрут: Дору-л-жанон, 1988. Т. 3. -Б. 375,376;

13. Даминов И.И. Абу-л-Муин Насафий. -Самарқанд: Имом Бухорий халқаро маркази, 2013. - Б. 108.

14. Рудолф У. Ал-Мотуридий ва Самарканд суннийлик илохиёти. -Т.: Имом алБухорий халқаро жамғармаси, 2001. - Б. 86.

15. Ўрта аср шарқ алломалари ва мутафаккир-ларининг тарихий-фалсафий мероси энциклопе-дияси. - Самарқанд. Имом Бухорий халқаро маркази, 2016.

16. Оқилов С. Абул Муъин ан-Насафий илмий мероси ва Мотуридия таълимоти. Монография. - Т.: 2008.

17. Оқилов С. Мовароуннахрда Мотуридия таълимотининг шаклланиш тарихи. Монография. - Т.: 2012. 


\section{俄罗斯东正教会对俄罗斯军队的影响探析 RUS PRAVOSLAV CHERKOVINING ROSSIYA ARMIYASIGA TA'SIRINI TAHLIL QILISH}

王萌

俄罗斯东欧中亚学院(Wang Meng, Rossiya)

摘要: 12 世纪初, 弗拉基米尔·莫诺马赫首次为士兵们举行祝圣仪式, 便预示着在这片 土地上军队与宗教之间的联系将无法分割；18 世纪初, 彼得大帝在俄罗斯军队中建立了军 事神职人员体系, 该体系在沙皇俄国的历史进程中不断被巩固加强, 军事神职人员的自主权 利不断扩大, 逐渐独立于主教, 并在 1812 年卫国战争中做出了突出的贡献; 直至 20 世纪 初, 俄罗斯军事神职人员体系被人民委员军事部取缔, 东正教会暂时退出了军队的舞台。20 世纪末, 东正教逐步走向复兴的道路, 俄罗斯军队与东正教会再次携手合作, 双方签署联合 文件、创建联合机构以解决军队教育体系软弱的问题, 但反对的声音从未停止, 军队东正教 神职人员的存在可能会激化宗教间的矛盾。

关键词：俄罗斯；东正教；军队；神职人员

1994 年 3 月, 俄罗斯国防部部长巴甫洛夫·格拉铸夫与全俄和莫斯科至圣大牧首阿列克 谢二世签署了第一份相互合作的文件, 东正教神职人员再次走入俄罗斯军队, 并对俄罗斯军 人进行精神和信仰指导。多年来, 俄罗斯政府积极致力于提升和保护军人的东正教信仰。为 纪念卫国战争胜利 75 周年, 俄联邦国防部部长谢尔盖.绍伊古倡议为军队人员建立一处宗教 场所一一俄罗斯陆军东正教大教堂 ( 又名: 俄罗斯联邦武装力量主教堂、俄军主教堂、俄罗 斯国防部主教堂, 原名: Главный храм Вооруженных сил Российской Федерации）。2020 年 6 月 14 日, 多名俄罗斯高级军事将领和士兵身穿二战军装, 参加了在莫斯科郊外举行的 俄罗斯陆军东正教大教堂交接仪式, 俄东正教大牧首也在仪式上发表讲话。毫无疑问, 这是 俄罗斯的现代武装力量和东正教会积极恢复相互合作的体现, 也是俄罗斯政府培养军人东正 教信仰的手段。早在沙皇俄国时, 沙皇政府就修建东正教行军教堂, 以强调东正教和军队的 关系, 仅在 1905 年, 沙皇俄国就修建了 686 座东正教行军教堂 ${ }^{[1]}$ 。实质上, 俄罗斯的爱国 主义早就深深烙上了东正教印记, 宗教信仰和爱国热情也早已互相融合。新时期军队中的东 正教复兴是为了唤醒俄罗斯士兵骨子里“为了信仰和祖国”的热血。然而, 新时期的俄罗斯和 沙皇俄国在社会制度、发展模式、宗教与思想等方面大相径庭, 东正教会能否发挥其往日的 作用仍是末知。

\section{理论综述}

中国学界对俄罗斯东正教的研究开始于 20 世纪 30 年代（乐峰观点）或 20 世纪 80 年 代（戴桂菊观点）。经过多年的发展和完善, 国内学者们对俄罗斯东正教的历史、宗教思想 及宗教哲学、东正教的复兴、东正教社会影响等方面均有较深的论述和研究。乐峰的《东正 教史》详细地介绍了东正教的起源、形成、基本内容、基本特点、哲学、伦理学、教堂艺术 和它在世界各地的传播和发展情况等问题, 堪称东正教的“百科全书”。21 世纪以来, 国内学 
者对俄罗斯东正教的研究从宏观向微观发展, 由面到点, 更加细致。其中涉及到俄罗斯东正 教与军队之间的䏌系的研究主要分为以下三种：

第一种是研究俄罗斯政教兊系的学术文章，尤其是苏联解体后，东正教教会开始复 兴, 当代俄罗斯的政教䏌系成为热点话题, 其中包括《无处不在的身影——东正教介入俄罗 斯社会政治生活试析》（林精华：俄罗斯研究，2010 年第 5 期）、《东正教对俄罗斯政治的 作用和影响概述》（邱赤峰：国际资料信息，2004 年 10 月）、《东正教在俄罗斯政治生活 中的作用及影响》（蒋莉：现代国际爸系，2002 年 9 月）等, 但在这些文章中, 东正教与俄 罗斯政治乃至外交的䏍系发展是主要话题, 涉及到俄罗斯军队的基本只有几句话, 阐释教会 负责对军人的精神道德教育和爱国主义教育。《宗教在俄罗斯军队中复兴的原因初探》(王 利亚：空军政治学院学报, 1995 年 2 月）第一次以俄罗斯军队为主要研究对象, 探析东正教 在军中复兴的原因。文中认为, 俄罗斯的东正教会获得了合法的军人教育者和指导者的地 位, 既继承了历史的传统, 也有军队教育体系薄弱的内在原因和东正教会积极宣传的外在原 因。

第二种是分析东正教在世俗中的作用, 即东正教对俄罗斯社会的影响。如《东正教与 俄罗斯社会》（张雅平：社会科学文献出版社，2013 年）运用丰富的资料描述了东正教会 在俄罗斯各个时期的历史及影响, 但对军队涉及的内容仍然较少。《俄罗斯军队东正教神职 人员的作用与影响评析》 (翁泽仁: 军事史林, 2019 年 4 月) 中从法律制度出发, 详细解释 并分析了俄罗斯军队东正教神职人员体系的产生、发展与复兴, 分析了军队东正教神职人员 在俄罗斯历史中扮演着怎样的角色。作者对军队东正教神职人员持积极态度, 认为他们的作 用无论是在战争年代还是和平年代都不可估量。

第三种是从军事教育角度，分析宗教在军队思想教育中的作用和模式，如《创新发展 中的俄军思想教育工作》（王帅：西安政治学院学报, 2010 年）和《俄军宗教工作制度的 形成及发展趋势》（李小燕: 军队政工理论研究,2013 年）。

俄罗斯的东正教研究机构一般都设在东正教会或神学院里, 并由莫斯科牧首公署出版 刊物。除此之外, 现代对东正教会的研究经常会以论文集形式出现, 如《新牧首时代的东正 教会》（Православная церковь при новом патриархе.М.2012.）,该论文集内容涉及目前俄罗 斯东正教会与军队、传媒等领域的相互作用。尼科利斯基所著的《俄国教会史》运用丰富的 资料描述了从公元十世纪到十月革命前的俄国教会史, 其中涉及军队神职人员的发展。格奥 尔吉耶娃所著《文化与信仰》从文化的角度出发, 阐述了东正教在俄罗斯的发展, 以及对俄 罗斯社会产生的重大影响, 包括对军队及战争产生的重大影响。此外, 值得一提的是格里戈 里耶夫海军上校, 他是俄罗斯联邦边防学院教授, 历史学副博士, 文化部与俄罗斯科学院文 化和自然遗产研究所负责人。他著有《信仰与忠诚：俄国东正教会和俄军䏌系史概论》，格 里戈里耶夫上校将分散的历史事实整合在了一起, 从多个方面研究了东正教会对俄国军队的 影响, 书中有多个章节, 如〈俄国军队与宗教〉、〈陆军神职人员历史〉、〈海军中的神甫〉均 讲述了东正教会在俄国军队中的发展过程。

\section{军事神职人员体系变革}


东正教及东正教神职人员对俄罗斯军队的影响历时久远。12 世纪初弗拉基米口尔. 莫诺 马赫首次为士兵们举行祝圣仪式 ${ }^{[15](351)}$ 。在之后的几个世纪 , 东正教神甫人员的身影也一 直出现在军队中, 军队和宗教相结合的思想一直成为各沙皇统治思维中的一环。“寄希望于 上帝、笃信东正教、促使教会帮助前线的战士, 成为历代俄罗斯沙皇不可撼动的行政策略 ${ }^{[15]}$ (351)。

18 世纪初, 彼得大帝建立军事神职人员体系, 象征着国家与军队进行了官方性的联 合。1716 年, 俄罗斯军队的《军法条例》章程中专门设置了《䏌于神职人员》一章, 涉及 神甫在部队中的权力、责任与活动形式。其中 , 《军法条例》规定每一个军团必须配备神 甫, 并首次建立了军团首席神甫的职位。但是需要强调的是, 彼得大帝军事神职体系的建立 有其特殊性和时间性, 这主要表现在 : 战争期间, 军团首席神甫（该名称为德语称呼, 后期 更名为俄语的主神甫、大神甫) 是作战部队所有军事神甫的首领 ${ }^{[3]}$ 。和平时期, 陆军神职人 员却应服从于军团驻扎地的地方主教 ${ }^{[4]}$ 。而且, 军团首席神甫及所有军事神职人员的任命都 是为了在战争期间用以观察作战部队的精神状况 ${ }^{[3]}$ 。此时, 军队神职人员的自主权相对较 小。之后, 叶卡捷琳娜二世为近卫军团修建专门的教堂, 甚至为军事僧侣提供“为居民举行 圣礼获得额外收入”的权力 ${ }^{[4]}$ 。保罗一世对该体系进行了大幅度的变革, 他在位期间大大加 强了军事僧侣的作用, 使军事僧侣的编制和首席神甫的职务固定化与常态化, 权力得以扩大 和集中 ${ }^{[11](60)}$ 。他合并了陆军与海军神职人员, 创建了以首席神甫为首的陆海军军事神职人 员局。陆海军首席神甫直接服从于正教院, 并成为正教院的成员。军队神职人员的自主权扩 大, 他们在任何时候都独立于主教, 脱离了主教的监督, 拥有了自己的权力空间。与此同 时, 军队神职人员也针对军人士兵开展了爱国主义的培养工作和教育工作。在此之后, 军事 僧侣和首席神甫的作用、范围与权力得以进一步加大和扩充。如 1815 年形成了单独的总 司令部和近卫军首席神甫局, 该局涉及的问题几乎独立于主教院 ${ }^{[1]} ; 1888$ 年 11 月 26 日亚历 山大三世制定的《军法条例》规定，在战争期间确立前线部队主神甫的职位。虽然军事神职 人员没有军衔, 但是却会根据其职位给予相应军衔的权力。如军事主神甫相当于中将、前线 部队神甫等同于少将、在职的大司祭 上校、非编制的大司祭 中校、营队的监督司祭

中校、神父一一大尉、在职与非在职的助祭——尉 ${ }^{[11](61)}$ 。

随着俄罗斯不断对外扩张, 战争发生的更加频发, 军队神职人员的数量也越来越多。 1800 年有 140 名在军队的东正教神甫, 1913 年有 766 名, 1914 年底有 1000 名, 1915 年底 2000 名, 而该数量相当于俄罗斯这一时期东正教僧侣总数的 $2 \%{ }^{[1]}$ 。但这仍然不能满足战争 期间的实际需求, 下面是一组东正教军事僧侣与服务对象的数量对比：19 世纪初, 一名军 事僧侣服务于 2500 名军人；一战初期为 $1:: 1300$ 名；到 1917 年秋天为 $1: 3200$ 名 $^{[6]}$ 。这表明 军队神职人员在战争期间的作用是非常重要的, 他们不仅要对军人进行爱国主义教育, 还承 担着多项复杂且繁琐的任务, 包括组织礼拜、忓悔、举行圣事、指导合唱、安抚伤员、安葬 死者、帮助医生包扎伤口、把死者和伤者从战地搬回、向阵亡军人的家属通知其死讯并帮助 他们、维护军人墓地的秩序、设立行军图书馆 ${ }^{[1]}$ 。不仅如此, 他们也在战争中有着不畏牺牲 
的英勇表现, 在 1812 年的“卫国战争”中, 在打败拿破仑的侵略中, 俄罗斯东正教会神职人 员扮演了不可或缺的角色, 俄罗斯学者梅利尼科娃根据获得的随军神职人员的履历表、奖赏 随军神职人员的命令和其他保存在主教公会和俄国国家军史档案馆中的资料将参战神职人员 的信息确定为 200 名 ${ }^{[7]}{ }^{(46)}$ 。

这种东正教神职人员体系一直延续到 1918 年, 1918 年 1 月 16 日, 俄罗斯军事神职人 员体系被人民委员军事部取缔, 并从部队中辞退了 3700 名神甫 ${ }^{[4]}$ 。苏联时期军队中一直进 行的是无神论教育, 在军队中不得组织任何形式的宗教活动, 并有一整套的政治教育体系来 保证军队的凝聚力和战斗力, 即依靠政工体制 (政委和教导员) 来对官兵进行思想道德教 育。

20 世纪 90 年代, 苏联逐步走向解体。宗教的生存空间也有了一定的改善, 1990 年 10 月苏联颁布《爸于信仰自由和宗教组织法》规定现役军人可以在业余时间作礼拜和履行宗教 仪式 ${ }^{[9]}$ (28)。东正教有机会在军队中传播教义, 加强宣传, 密切与军队的关系; 相应的, 军 中的士兵们也并未完全放弃信仰：1992 年 6 月, 苏联国防部军事社会学、心理学及法学研 究中心对本国士兵的宗教信仰状况进行了问询调查。调查结果表明: $25 \%$ 的苏联士兵认为自 己是有信仰的人； $35 \%$ 的在信仰与不信仰上帝之间徘徊； $40 \%$ 的是非信仰者；10\%的认为自 己是无神论者 ${ }^{[8]}$ 。1 1994 年 3 月, 俄罗斯国防部部长巴甫洛夫·格拉铸夫与全俄和莫斯科至圣 大牧首阿列克谢二世签署了第一份相互合作的文件；1997 年 4 月新任国防部长伊戈里·洛基 沃洛夫与阿列克谢二世签署了新的合作条例。在这份新条例中扩大了相互作用的领域及合作 形式；1995 年, 成立了俄罗斯东正教会大牧首公署与武装部及维权机构相互作用事务管理 局。俄罗斯东正教会首先提出重建军事神职人员体系, 同时也获得了一些政党及社会运动的 支持, 如“俄罗斯基督教民主联 盟”和“军队精神复兴运动”等。虽然俄联邦国防部并没有给 予明确答复, 但在 2000 年对抗车臣分裂分子的战争中, 神职人员随军作战, 大大地鼓舞了 军人的士气, 号召他们为了信仰和祖国而战, 最终共同消灭了车臣分裂分子, 东正教神职人 员在军队中的作用和影响力不容小觑。2006 年 4 月 14 日, 俄罗斯东正教会事务管理局与俄 罗斯各宗教委员会倡导“国家、社会及俄罗斯所有传统的宗教联合起来恢复军事神职人员体 系”, 该倡议在 2009 年 6 月 21 日被时任总统的梅德韦杰夫采纳, 军事神职人员体系被再次 恢复。军中神甫的选拔方式十分严格, 截至 2015 年, 俄联邦战略导弹部队、航空航天国防 部队及南部军区分区中配备有约 1000 人的神职人员, 其中 30 名在编 ${ }^{[10]}$ (110)。值得一提的 是, 新时期俄罗斯政府依然通过为军人修筑军事教堂以及为军人配备专职神甫来培养和促进 俄罗斯军人的东正教信仰, 至 2010 年初, 俄罗斯的军队教堂就已达到 530 座 $^{[5]}$ 。

\section{积极影响}

俄罗斯东正教会进入军队, 可以在一定程度上弥补俄罗斯军人的心灵空虚, 并满足军 人的宗教诉求。苏联解体后, 苏共退出了历史舞台, 军中政治工作机全和政治委员制度被取 缔, 俄罗斯军队在意识形态上出现了前所未有的真空状态。士兵们无法找到心灵和精神的寄 托, 失去了信仰的支撑, 士气不振, 精神情况每况愈下。据报道, 2000 年俄军官自杀的人 


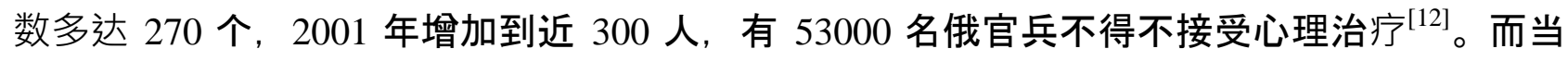
权又重新发现了东正教会的国家性支撑及社会统一作用优势, 并放宽了对俄罗斯东正教会的 管制。《红星报》曾对此报道说. “由于共产主义神话的破产, 人们开始到宗教中寻找精神支 柱。许多人一夜之间就变成了虔诚的教徒, 有的人甚至以信教为自豪, 就象当年加入苏共一 样。”东正教神职人员走进军队, 为军人的宗教信仰服务: 协助军队中的信徒官兵参加洗 礼、婚礼、忓悔、葬礼, 定期进行宗教教育, 提供宗教书籍, 为司令部提供宗教事务次询, 与地方宗教团体及福利机构保持联系等 ${ }^{[13](86)}$ 。

军队神职人员不仅满足了士兵们的宗教诉求, 更为他们提供了心灵的避难所和信仰的 支持力量。

东正教会可以为俄罗斯军人提供良好的精神道德教育, 有助于塑造士兵们的人生观、 价值观和世界观。苏联解体后, 俄罗斯缺乏健全的全民教育体系, 军队的教育机余软弱无 力, 教育工作的缺失或执行力软弱成为影响部队战斗力的重要因素。虽然俄军自 1992 年至 2002 年建立的教育工作体制对改善军队思想教育状况发挥了一定的作用, 但体制本身以及 以实施过程中出现诸多问题, 导致军中人员思想状况依然面临严峻形势[14] (126)，如俄军在 军事改革期出现的理想信念动摇、作风纪律涣散、服役心理压力等问题无法得到有效解决, 此外, 经过两次车臣战争的检验发现俄军教育体制对部队人员的精神心理保障工作远远达不 到要求。从 2002 年起俄军每年开小差的人数约有 5000 人, 而事实上, 比这个数据还要高得 多 ${ }^{[14]}$ (126)。值得注意的是, 军人这一特殊群体的思想道德教育要比普通人民的教育还要重 要和困难。军人时刻面临生死考验, 面临着巨大的压力, 要结合“不可杀人”的诫命与战场上 必须杀的职责, 不能残忍啫血, 却也不能胆小软弱, 战场上的一幕幕极容易成为困扰军人一 辈子的哥梦, 因此解决军人的心理问题, 培养军人的军事道德异常重要。1994 年 3 月俄国防 部长格拉乔夫与东正教全俄大牧首阿列克西二世签署了一项联合声明, 正式宣布“俄罗斯军 队将与东正教会携手合作共同致力于军人的精神道德教育和爱国主义教育, 并做好军人的社 会保障工作”。军队的神职人员在军队中积极开展军人精神道德教育、参与法治和军事纪律 教育, 协助解决日常发生的摩擦与争吵, 并进行军人的军事心理保障。东正教神职人员可以 通过通过祈祷、祝圣等宗教仪式满足军人的宗教需求并缓解军人的心理压力, 也可以与情况 不佳的士兵进行谈话, 以宗教教义鼓舞其士气, 在作战环境或执勤任务比较重的时期, 神职 人员深入到作战一线, 主持宗教仪式、帮助伤员恢复、提供心理疏导服务等, 为官兵在战时 保持良好的精神心理素质起到了积极作用, 如俄军每年夏季和冬季练兵之前, 在各部队和分 队随军神甫都会为官兵主持祈祷和宗教日祷仪式, 以激励官兵投人作战训练任务。在“东方 演习”中, 神职人员与心理辅导员一起定期组织关于军人勇敢精神和保卫祖国事迹的座谈为 训练场官兵提供心理服务和精神支撑 ${ }^{[14]}$ (127)。

俄罗斯东正教会走入军队有利于培养军人的东正教信仰, 促进爱国主义宣传, 并捍卫 国家及军队领导的精神合法化。军人应时刻谨记为什么而战, 应在精神战场上感受到自己是 不可战胜的, 要在敌人面前感受到祖国的优越性和正确性, 军队神职人员运用东正教观点阐 
释军人的天职与义务并激发俄罗斯军人的爱国情绪。实质上, 俄罗斯的爱国主义早已深深烙 上了东正教印记, 宗教信仰和爱国热情也早已互相融合。新时期俄罗斯军队东正教神职人员 体系的重建可以激励士兵、团结稳定和凝聚军队, 使爱国统一战线。军队只有在精神上统 一, 只有坚定不移地为祖国而战, 军队的整体实力和战斗力才会提高, 才会在战场上所向披 靡。

\section{消极影响}

新时期的俄罗斯和沙皇俄国在社会制度、发展模式、宗教与思想等方面大相径庭，军 队神职人员体系在新时期的俄罗斯缺乏相应的社会基础，与之相适应的其他具体制度也还没 有完善, 如随军神职人员的工资待遇法律保障问题、军队教堂的宗教器具供应制度化等细节 问题尚未解决, 现阶段重新确立军队神职人员体系会有不可忽视的消极影响。

宗教本身具有排他性, 俄罗斯军队中并不是所有的人都信奉东正教, 还存在信奉佛教 或者穆斯林的士兵以及无神论者。2011 年夏天俄罗斯联邦武装部社会科学调查中心的问询 资料显示, 现今俄罗斯 $69 \%$ 的军人有宗教信仰, 其中的 $76 \%$ 为东正教徒, $10 \%$ 为穆斯林 [4]。数据表示, 无神论者或者信奉其他宗教的士兵不在少数。虽然 2014 年, 增派的军事僧 侣呈现多样化的特点. 132 名军事神职人员中有 129 名东正教徒、2 名穆斯林及 1 名佛教徒

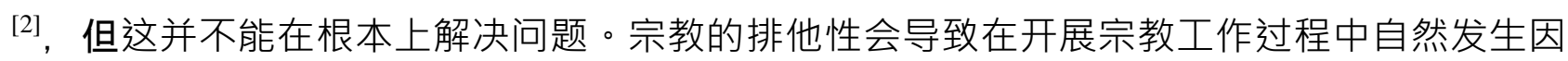
宗教信仰不同而产生的宗教歧视，甚至不睦。如，东正教会为每一位士兵发放《圣经》，在 军队中举行宗教仪式, 对于不信仰东正教的人来说, 可能会起到适得其反的作用。

东正教神职人员不能完全取代军队教育体系。为了推进东正教走入军队, 负责教育工 作的军官职位缩减约 $70 \%$, 空缺职位均由文职人员取代 ${ }^{[14]}{ }^{(128)}$ 。这种压缩教育工作人员, 加大文职人员和神职人员的做法引起了社会的與论矣注。因为文职人员和神职人员在军事事 务和军人心理的掌握方面显然没有教育军官更专业, 虽然他们可以从宗教角度利用教义来教 育俄罗斯士兵, 但是专业的教育人员仍然有存在的价值, 军队神职人员不应完全取代他们, 而如何推进宗教教育和专业教育的融合与合作是一大难题。

无法否认，现阶段的军队神职人员体系仍然具有政治色彩。俄罗斯陆军东正教大教堂 在建设期间就因使用俄联邦总统普京、国防部长绍伊古、联邦委员会主席马特维延科等人的 马赛克像装饰墙壁而引起了社会的批评，后来不得不拆除这部分画像，用手持圣像的东正教 僧侣装饰墙壁。这暴露了军队中的东正教和俄罗斯政治之间存在的矛盾。军队中的东正教并 不是真正意义上独立于政治和意识形态的宗教，而是政府用于管理军队思想的手段之一，所 以在实践中, 二者不可避免地会发生摩擦，不利于军队的思想和精神统一。

此外，东正教神职人员能够发挥预期的作用还未可知，当今，俄罗斯东正教神职人员 对军队生活的参与, 没有令军队中出现士气振奋、纪律提高、违法现象减少、 自杀率下降等状况, 相反的是, 国家军事改革进展缓慢、体系危机逐渐加深、军人数量减 少、官兵的思想政治状况日益恶化、理想及信念缺失、酗酒、吸毒、挪用公款及盗窃军事设 备等事件频发 ${ }^{[13](86)}$ 。 


\section{小结}

虽然重建东正教军队神职人员体系会存在一些弊端, 但现阶段来说, 这是符合俄罗斯 国情、传承国家文化传统的做法。无法否认, 军队神职人员体系不仅为士兵们找到了心灵寄 托, 还有利于提升士兵的爱国主义教育、精神道德和文化修养, 解决军队中出现的摩擦, 促 成统一爱国战线的形成, 并提高俄罗斯军队的战斗力。

\section{参考文献}

1. Константин Капков.Военное духовенство Российской империи / Православие. Ru [EB/OL].http://www.pravoslavie.ru/28242.html

2. Борис Лукичев. Военному духовенству Вооружённых сил России--пять лет / Аналитика / ЖМПиЦВ. [EB/OL]. http://e-vestnike.ru/ analytics/ voennomu_duhovenstvu_rf_5_let_8173/

3. Р.Н.Александрович.Развитие правого регулирования деятельности православных священников в армии за период XVIII--XIX вв.: Портал Богослав. Ru [EB/OL].https://moluch.ru/archive/46/5564

4. Военное духовенство-Древо. [EB/OL].http://drevo-info.ru/artucles/4753.html

5. Перспективы института военных священников в российской армии--Вестник Военного духовенства. Новости епархий. [EB/OL].http://kapol Lan. ru/porspoktivy-institutavoonnyx-svyashhennikov-v-rossijskoj-armii.html

6. Памятная Книга Российской Военного и Морсекого Духовенства XIX--начала XX веков Справочные Материалы Москва Информационной центр “Летопись” По блогасловению Святейшего Патриарха... [EB/OL].http-nauka.x-pdf. ru-17yuridicheskie567244-2-

7. Котков В. М. Коткова Ю. В. Военное духовенство России. [М]. Санкт-Петербург. 2005. С. 46.

8. Тридиционное религиозные объединения РФ.[EB/OL].http: //voenn. info/ docs/ ogp/ogp-k1/2015/2015-08-01. shtml

9. 郑江婷. 苏联解体后俄罗斯东正教的复兴之路[D].上海外国语大学,2012.

10. 胡巍藏. 苏联解体后俄罗斯东正教会社会影响研究[D]. 黑龙江大学, 2015 .

11. 翁泽仁.俄罗斯军队东正教神职人员的作用与影响评析[J].军事史林,2019(04).

12. 章自力、汪宁.东正教与俄罗斯当代社会, 载于《俄罗斯重新崛起》 $[\mathrm{M}]$, 上海外语 教育出版社, 2006 年

13. 胡巍藏. 俄罗斯东正教会与军队合作一随军牧师传统的重拾[J].俄罗斯东欧中亚研究, 2013,(5).

14. 李小燕.俄军宗教工作制度的形成及发展趋势[J].军队政工理论研究,2013,14(03).

15. 申猛. 俄国 1812 年卫国战争中的东正教会研究[D].吉林大学,2020.

16. 王利亚·宗教在俄罗斯军队中复兴的原因初探[J].空军政治学院学报,1995(02)

\section{ХОЗИРГИ ЗАМОН ДАВЛАТ-ХУҚУҚИЙ ВОҚЕЛИКЛАРИ АСОСИДА ХУҚУҚ УСТУНЛИГИ (RULE ОF LAW)НИНГ БУГУНГИ КУНДА ШАХСНИНГ ХУҚУҚЛАРИ ВА ҚОНУНИЙ МАНФААТЛАРИНИ ТАЪМИНЛАШДА АХАМИЯТИ}

\section{П. Кобилов (ТДЮУ ўқитувчиси)}

Annotation: This thesis discusses the concept of the rule of law, the views of scholars on the subject, the historical origin of the rule of law, its features, its role in the development of the state and society based on a democratic civil society, the rights and legitimate interests of individuals 
and legal entities. Special emphasis is also placed on the rule of law in the process of building a democratic society.The rule of law is a measure of justice, and citizens have the same rights regardless of nationality, language, social origin, customs, traditions, values, religious beliefs, gender. As a result, stability will be ensured in the socio-political and economic-spiritual life of the country. Negative attitudes to laws are formed, and in a country where they are not enforced or served as a formality, negative situations such as looting, inequality, injustice, violence occur.

Key words and expressions: Rule of Law, Rule of Law, Avesto, Democratic Society, Human Rights.

Ўзбекистон Республикаси Конституцияси қабул қилинганлигининг

27 йиллигига бағишланган тантанали маросимдаги маърузасида Президент Шавкат Мирзиёев хар қандай демократик ислохотлар самараси, тинчлик ва тараққиётнинг асосий гарови Конституция ва қонун устуворлиги билан бевосита боғлиқлигини алохида таъкидлади: “Қонун устуворлиги - бу давлат хокимияти ва бошқарув органлари чиқараётган хужжатлар, мансабдор шахсларнинг хатти-харакатлари фақат ва фақат Конституция хамда қонунларга мувофиқ бўлиши шарт деганидир".

Қонун устуворлигини таъминлаш мамлакатимизда амалга оширилаётган давлат бошқаруви ислохоти билан боғлиқ. Бир томондан, давлат бошқаруви қандай бўлишлиги қонун устуворлигига боғлиқ бўлса, иккинчи томондан, мукаммал давлат бошқаруви қонун устуворлигини таъминлаш воситасидир.

Қадимий манбалардан бири “Авесто”нинг иккинчи китоби “Ясна”нинг 7-бобида ёзилишича, Ахурамазда юборган қонун-қоида, тартибот, ахлоқий ўгитларга амал қилсалар эзгулик ёвузлик устидан ғалаба қилади6. Бунда аждодларимиз қадимдан турли нопок ишлардан, фирибгарлик, товламачилик, ўғирлик, порахўрлик каби жиноятлардан, бировнинг хақига хиёнат қилишдан ўзларини тийишганлигини кўриш мумкин. Юнон мутафаккири Арасту жамиятда хуқуқнинг ўрнига алохида урғу бериб, қонунлар хуқуқлардан ташкил топиши зарурлигини билдиради. Мажбурий кучга эга қонунлар бўлмаса, жамиятда фуқароларнинг тенгсизлиги, адолатсизлик келиб чиқиши мумкин [Мехамедов 2003:10].

Дархақиқат, жамиятда ижтимоий муносабатлар қонунлар орқали тартибга солинади, адолат қарор топиши учун қонунга мурожаат қилинади. Қонун орқали фуқароларнинг хукуқ ва эркинликлари таъминланади, юзага келиши мумкин бўлган адолатсизликлар бархам топади. Қолаверса, турли жиноятчиликларнинг олдини олинади, қонунларни четлаб ўтиш, уни бузиш каби хуқуқбузарликларга чек кўйилади. Бу эса жамиятда қонунга итоаткорликнинг объектив зарурати хисобланади. Қонуннинг кучи, обрўси, таъсири, амалий ахамияти хаётда унинг халол, хақиқий, одилона татбиқ этилишидадир. Давлат хокимияти ва бошқарув органларининг мансабдор шахслари ўзлари нинг ваколатлари ва бурчларига масъулият билан одилона ёндашса, Ватан, давлат манфаати ва тақдирини ўзлари учун олий мақсад деб хисоблашса, қонунларни турмушга адолатли қўлласалар, жамият равнақ топади. Қонун барчанинг иродаси билан қабул қилинган хужжат ва хаттоки, давлат бошлиғи ундан юқори тура олмайди [Руссо 1969:177].

Демократик жамият қуриш жараёнида қонун устуворлигига алохида урғу берилади. Чунки, қонун устуворлиги адолат мезони хисобланиб, фуқаролар миллати, тили, ижтимоий келиб чиқиши, урф- одати, анъанаси, қадриятлари, диний эътиқоди, жинсидан қатъи назар, бир хил хуқуққа эга бўлади. Натижада, мамлакат ижтимоий- сиёсий ва иқтисодий-маънавий хаётида барқарорлик таъминланади. Қонунларга бефарқ муносабат шаклланган, улар ижро этилмайдиган ёки расмиятчиликка хизмат қиладиган мамлакатда талон-торожлик, тенгсизлик, адолатсизлик, зўравонлик каби салбий холатлар юзага келади. Шу боис, қонун устуворлиги умуминсоний қадрият даража- сига кўтарилган. Президентимиз Ш. Мирзиёев таъкидлаб ўтганидек, «жамиятда хуқуқий маданиятни юксалтириш, фуқароларда қонунга хурмат хиссини кучайтириш ва хукуқбузарликларга қарши курашишда фаол қатнашаётган инсонларни рағбатлантиришга алохида эътибор қаратилиши лозим».

Қонун устуворлиги бугунги кунда хаётий зарур давлат-хуқуқий қадрият бўлиб, унинг қанчалик хаётимизга сингиб боришидан хуқуқий давлат куриш борасидаги саъй- 
харакатларимизнинг натижаси боғликдир. Шу маънода қонунларга риоя этиш - оддий кундалик заруратга айланмоғи керак.

Таъкидлаш жоизки, илмий манбаларда қонун устуворлиги, хуқуқ хукмронлиги, хуқуқ устунлиги каби атамалар ишлатилиб келинсада, уларни аниқ-тиниқ ўзаро фарқлаш ёки айнанлигини асослаш борасида якдиллик кам. Маълумки, “хуқуқ устунлиги” атамаси инглиз тилида "rule of law", рус тилида эса “верховенство права",“правление права" маъноларида қўлланилади Миллий илмий адабиётда қайд этилган атамалар “хуқуқ бошқаруви”, “хукуқ хокимияти” ёки “хуқук устунлиги” сифатида тушунилиб келинмокда.

Рус олимлари олиб борган тадқиқотларда хам хукуқий қонунийлик тушунчасини учратиш мумкин. Масалан, С.С.Алекссевнинг таъбирича, хуқуқ устунлиги ғояси - “ўзининг мохиятига кўра хукуқнинг хокимият, давлатга нисбатан сўзсиз устуворлигини англатади”[ Алексеев: 2001:485.].

Хуқук устунлиги ўз ичига, давлат ва жамият хаётининг барча мухим масалаларига хуқуқ ва қонун нуқтаи-назаридан қараш ва хал этишни, умуминсоний ахлоқий-хуқуқий қадриятлар ва давлат фаолиятини оқилона уйғ унлаштиришни, давлат ва жамоат органларининг хар қандай қарорларини ғоявий-хуқуқий жихатдан асослашни хамда хар қандай давлатда инсонларнинг хуқуқларини таъминлашнинг ишончли воситалари механизми мавжудлиги ўз ичига олади ва тақозо этади [Исломов 2001:354].

Харакатлар стратегияси доирасида, амалга оширилаётган суд-хукуқ тизимини демократлаштириш ва либераллаштириш борасидаги ислохотларнинг мазмун-мохияти қонун устуворлиги ва қонунийликни мустахкамлашга, шахснинг хуқуқ ва манфаатларини ишончли химоя қилиш механизмларини яратишга қаратилган. Шу боис, юртимизда хукуқий давлат асосларини янада такомиллаштириш, суд-хуқуқ ислохотларини давом эттириш, ахолининг хукуқий онги ва маданиятини юксалтириш биз учун хал қилувчи вазифа бўлиб қолмоқда.

Шу билан бирга, инсон хуқуқларини химоя қилишда миллий институт ва марказлар ташкил топганлигини хам қайд этиш зарур. Жумладан:

Ўзбекистон Республикаси Олий Мажлисининг инсон хукуклари бўйича Вакили (омбудсман); Ўзбекистон Республикаси Инсон хукуқлари бўйича Миллий маркази;

Ўзбекистон Республикаси Президенти хузуридаги Тадбиркорлик субъектларининг хуқуклари ва қонуний манфаатларини химоя килиш бўйича вакил ва бошқалар.

Хозирги замон давлат-хуқуқий воқеликлари асосида хуқуқ устунлигининг бугунги кунда жамиятнинг барқарор ривожланишидаги ахамиятини тахлил этар эканмиз, қуйидагиларни тилга олиш мухим саналади Ўзбекистонда миллатлараро тотувлик ва диний бағрикенглик масаласига давлат сиёсати даражасида эътибор қаратилаётганлиги, сўнгги йилларда хуқуқ устунолги ва инсон хуқуқларини таъминлаш бўйича қўлга киритилган ютуқлар халқаро хамжамият томонидан эътироф этилмоқда. Буюк Британиянинг “Тhе Economist" журнали версиясига кўра Ўзбекистон "Country of the Year" - " Йил мамлакати" деб эълон қилиниши унинг халқаро имижини кўтаришга хизмат қиладиган йирик воқелик сифатида бахоланмокда.

Президент Шавкат Мирзиёев ўз нутқида Сохибқирон Амир Темурнинг “Давлат қонунлар асосида курилмас экан, ундай салтанатнинг шукухи, кудрати ва таркиби йўқолади", деган пурмаъно сўзларини келтириб, Ўзбекистонда "Конституция ва қонун устуворлигини таъминлаш биз бунёд этаётган демократик хукуқий давлатнинг бош мезони хисобланади", дея бу ғояни изчил ривожлантирди.

Хуқуқ устунлиги албатта коррупция ва давлатнинг унга қарши курашиш, энг аввало олдини олиш бўйича чора-тадбирлари ва мавжуд қонунчилик ахволи хам назарда тутилади. Шундай қилиб, “Коррупцияга қарши курашиш тўғрисида"ги Қонунда, биринчи навбатда, давлат аппарати ва фуқаролик жамияти институтларининг ушбу иллатга қарши курашдаги куч хамда имкониятларини бирлаштириш мақсади назарда тутилди. 2017 йилда суд, хуқуқни мухофаза қилувчи ва назорат органлари рахбарлари мамлакатимизнинг кўплаб худудларида сайёр қабуллар ўтказди. Бу қабулларда коррупцияга қарши курашиш ва унинг олдини олиш билан боғлиқ муаммолар бўйича 43 минг 127 нафар фуқаро иштирок этди. 
Хулоса қилиб айтганда, хуқуқ устунлиги ва қонунларга риоя этиш ички зарурат, ички ишонч билан амалга оширилиши керак. Шундагина қонун устуворлиги ўзининг ижобий натижасини тўлароқ намоён этади. Бундай даражага эришиш учун жамият аъзоларининг хуқуқий онги ва хукуқий маданиятини янада юксалтириш зарур. Шу муносабат билан қонунга итоаткор шахсни тарбиялаш бўйича ишларимизни изчил давом эттиришимиз даркор.

\title{
Фойдаланилган адабиётлар рўйхати
}

1.Ахмедшаева М.А. Давлат ва хуқуқ ривожининг хозирги замон тенденциялариТошкент: ТДЮУ, 2018.

2.Алексеев С.С. Восхождение к праву. Поиски и решения. “Норма”. М., 2001. С. 485.

3.Мухамедов Ў.Х. Конституция ва қонун устунлиги. - Т.: Ўзбекистон Республикаси ИИВ академияси, 2003.

4.Руссо Ж. Ж. Трактаты. - М., 1969. - С. 177

5.З.Исломов. Обшество. Государство. Право.Т.:Адолат. 2001.

6.Hayek F. A. The Constitution of Liberty. P. 205-206

\section{ШАХС МАЬНАВИЙ КАМОЛОТИ ВА ЖАМИЯТ ТАРАҚКИЁТИДА ДАХЛДОРЛИК ТУЙҒУСИНИНГ АХАМИЯТИ}

\author{
А. Ж. Душаев \\ (ГулДУ ўқитувчиси)
}

Annotation: This article describes in detail the socio-political situation in the cradles of ancient civilizations, which have left a significant mark on the history of philosophical thought, social development, their attention to the issue of sense of belonging and its role in the spiritual development of the individual.

In the regions of ancient civilization, the extraordinary high development for its time and future was due to the sense of spiritual involvement in national development in the presence of progressive, thoughtful, wise philosophers and mature figures, all the material and spiritual foundations of knowledge in the world were discovered by ancestors. Although the social, philosophical theories, advanced teachings, which are the basis for the stages of development, are primarily expressed through the approach of man, the issue of his spiritual maturity, the goal was the spiritual maturity, ascension and development of one person, nation. The importance of national-spiritual involvement in the phenomenon of culture, worldview, governance and development, which emerged in the cradle of philosophical thinking and civilization, shows the high role of highly developed and socialized individuals in solving the spiritual maturity of the individual and the development of the nation.

Key words and expressions: Science, philosophical thinking, spiritual maturity, intellect, sense of belonging, national-spiritual involvement, noosphere, phenomenon, development trends, and so on.

Фалсафий тафаккур тарихига назар ташласак, уларнинг қайси бир қисмини олмайлик, шахс билан, унинг маънавий камолоти билан боғлиқ жихатлар ўша таълимотнинг асосини ташкил этишини кузатамиз:

- Қадимги Миср - астрономия, математика, максимал даражадаги физика ва механика, геометрия, география, архитектура (илмий дахлдорлик), тиббиёт - милоддан аввалги 3600 йилда афсонавий табиб Имхотеб шарафига дастлабки шифохонанинг қурилиши (ижтимоий дахлдорлик), бадиий санъат (шеьр, расм, чизмачилик, тўқувчилик ва бошқалар, (сенинг гўзаллигинг ўзи хаётдир, умр бағишлайди хар бир юракка - айнан ўзаро дахлдорлик) [Абдулла Шер 2010:18]; қишлоқ хўжалиги ва мелиоратив билимлар (хаётий дахлдорлик);

- Қадимги Месопатамия - халқ оғзаки ижоди, бадиий адабиёт, эътиқодий-маънавий, диний масалалар, қадимги ёзувлар, хаёт хақидаги фалсафий ёндашувлар (олам ва одам 
дахлдорлиги), ёруғлик, қуёш, ой билан боғлиқ тушунчалар, юқори чўққига кўтарилган эстетик тафаккур ва дунёқараш (Семирамида осма боғлари), борлиққа, табиатга этикаэстетика нуқтаи назаридан муносабат, табиий ва аниқ йўналишдаги фалсафий-илмий билимлар;

- Қадимги Хиндистон - математика, тиббиёт, жаррохлик, фармацевтика, бадиий ижод, фалсафа (веда, упанишад, Будда, миманса, локаята, ньяя, вайшешика, чорвака ), адабиёт (калила ва димна), дин (ведаизм, брахманизм, буддизм), маданият (эпослар - Рамаяна ва Махабхарата), оламни англашга интилиш билан боғлиқ фан куртаклари (Объектив дахлдорлик);

- Қадимги Хитой - ўзига хос концептуал миллий - маънавий йўналишлар, Даосизм, Конфуцизм ғоялари билан миллий ривожланиш тенденцияларини белгилаб берган феномен (миллий-маънавий дахлдорлик), ижтимоий фалсафа, онтологик, гносеологик, диалектик, синергетик билим элементлари, эътиқод, табиат, жамият, инсон борлиғи;

- Қадимги Юнонистон - Фалсафа тарихида биринчилардан бўлиб антропологик ёндашув (Сукрот, Афлотун, Арасту, Стоиклар - фалсафа, фан хамда унинг тарихи мавжуд экан, - сўнмас дахлдорлик), инсонийлик, инсон ўзлиги, англаш, тафаккур, ақл ва қалб бирлиги, инсон онги ва ғоя, тавхид элементлари, ренессанс даври ғояларининг ўзаги, давлат ва жамият бошқаруви, фалсафий мактаблар, академия;

- Марказий Осиё - Ахлоқ, инсон маънавий камолоти, жисмоний ва рухий баркамоллик, шахс фазилатлари, инсон қадри, ижтимоий тараққиётда инсон омили, эътиқоди ва танлаган йўлида содиқлик ва собитлик, эзгулик ғалабаси, поклик, гўзаллик, эстетика, илохий неъмат хусусиятларини ўзида мужассам этган миллий менталитет, маънавият, маданият, тасаввуф таълимоти [ушбу маълумотлар Юсупов Э 1999, Назаров Қ 2005, Ахмедова М 2006, Чориев А 2007] ва бошқа манбаларда хам келтириб ўтилган] (юксак дахлдорлик).

Таъкидлаб ўтилган минтақаларда ўз даври ва келажак учун фавқулодда юқори ривожланиш қай тариқа бундай поғоналарни забт этди? Албатта, ўша халқлар илғор фикрли, теран тафаккурли, донишманд - файласуф ва етук намоёндалари борлиғида мавжуд бўлган миллий тараққиётга нисбатан маънавий дахлдорлик хисси туфайли эди.

Аслида, жахондаги барча моддий ва маънавий билим асослари аждодлар томонидан кашф этилган, хозирда уларнинг мерослари жамият хаётига татбиқ этиш билан шуғулланилмоқда, десак хато бўлмайди.

Инсоният тараққиётининг кейинги босқичлари учун асос бўлган ижтимоий, фалсафий назариялар, илғор таълимотлар биринчи навбатда инсон, унинг маънавий камолоти масаласини турлича ёндашувлар орқали ифода этсалар-да, мақсад бир йўналиш сари харакат қилган. У хам бўлса шахс маънавий камолоти, юксалиши хамда ўз халқи, миллатининг тараққиёти эди. Шахс маънавий камолоти ва миллат равнақини хал этишда миллий маънавий дахлдорлик туйғуси юксак даражада ривожланган ва ижтимоийлашган шахсларнинг роли юқоридир.

Агар, фалсафий тафаккур тамаддуни бешикларида юзага келган маданият, дунёқараш бошқарув ва тараққиётни харакатга келтирувчи кучлар феноменида миллий - маънавий дахлдорлик туйғуси илдиз отмаганда, замонавий илм - фан, ноосфера босқичи интеллектини хайратга солиш даражасида юксак мақомга етмаган бўлар эди. "Билимсиз куч адли йўқ шохдир, қуввати йўқ илм эса, адолатли, лекин лашкари йўқ шох кабидир” [Кошифий Хусайн Воиз 2011:97]. Таъкидлаш жоизки, ўтмиш аждодлар томонидан яратилган умуминсоний меросларда миллий-маънавий дахлдорлик ва дахлдорлик туйғусининг асослари барпо этилган.

Миллий маданиятига эга бўлиб, мустақил миллат сифатида яшаш - хаётнинг асоси бўлмоғи керак. Бу эса барча миллатларнинг орзусидир.

...Миллат тил, дин, маданият, адабиёт, урф-одатлар бирлигига асосланади. [Тўғон Ахмад Закий Валидий 1997:111] Халқ, миллат мавжуд экан, тил, маданият, қадриятлар тизими, умуман миллий-маънавий мерос ва уларга нисбатан, миллий-маънавий дахлдорлик 
туйғуси мавжуд бўлади. Фақатгина уларга қайта жон бағишлаш, уларни бойитиш, келгуси авлодларга бус-бутун етказиш жамият олдида турган мухим вазифалардан биридир.

Миллий - маънавий дахлдорлик деганда, инсоннинг ўз халқи ва миллатига, аждодлардан қолган бой миллий - маънавий, илмий, фалсафий, тарихий меросига, унинг урф - одат, анъана ва қадриятлар тизимига, халқ қалбида илдиз отган имон - эътиқодига, асрий тафаккурида шаклланган менталитетга таянган холда таълим - тарбия орқали бугун ва келажак ривожи учун самарали бўлган инновациялар, ислохотлар, тараққиёт тенденцияларига нисбатан тааллуқлилик ва тегишлилик нигохи, нуқтаи назаридан муносабатда бўлиш эса хар биримизнинг асосий вазифамиз бўлмоғи шарт.

\section{Фойдаланилган адабиётлар рўйхати}

1. Абдулла Шер. Эстетика. - Т. “Ўзбекистон файласуфлари миллий жамияти нашриёти", 2010. - 18 б.

2. Кошифий Хусайн Воиз. Футувватномаи Султоний. - Т.: “Ўзбекистон миллий энциклопедияси” Давлат илмий нашриёти. 2011. - 97 б.

3. Назаров Киёмиддин. Фалсафа асослари. - Т.: “Шарқ”, 2005.- 46-78 бб.

4. Тўғон Ахмад Закий Валидий. Бўлинганни бўри ер. Туркистон халқларининг миллий мустақиллиги учун кураши тарихидан хотиралар. Бошқирд тилидан Ш.Турдиев таржимаси. - Т.:”Адолат”. 1997. - 111 б.

5. Фалсафа. Ахмедова М тахрири остида-Т.: “ЎФМЖ”, 2006.- 26-51 бб.

6. Чориев Анвар. Инсон фалсафаси. - Т.: “ЎФМЖ”, 2007.- 8-58 бб.

7. Юсупов Эркин. Фалсафа. Иккинчи нашр - Т.: “Ўқитувчи”, 2005. - 37-46 бб.

\section{ДИСКУРСИВ ФАОЛИЯТ ВА ХУРМАТ КАТЕГОРИЯСИНИНГ ВОКЕЛАНИШИ}

\section{М. Бузрукова \\ (СамДУ таянч докторанти)}

Annotation: The article examines the category of respect and discursive activity. The author analyzes in detail the Category of Respect. The thesis considers the works of famous scientists such as P. Brown and S. Levinson and their work - "Universals in Language Usage: Politeness Phenomena" as well as V. I. Karasik, Ye.A. Zemskaya.

Key words and expressions: category of respect, social face, negative face, positive face.

Коммуникатив мақсадга эришишнинг мухим усулларидан бири, сўзсиз, хурмат категорияси тамойилларига амал қилишдир. Чунки фақат шу йўл билан сухбатдошлар ўртасида ижтимоий-маданий ва коммуникатив мувозанатни сақлаб туриш мумкин. Е. А. Земская айтганидек, хурмат тамойили “нутқий хатти-харакатни изга солиб турувчи мухим ускунадир" [Земская 2002:25].

Айтиш жоизки, хурмат категорияси кенг қамровли дискурсив ходисалар қаторига кирганлиги боис, турлича назарий талқинларга эга бўлиб қолмоқда. Бинобарин, хурмат ижтимоий меъёр кууринишида талқин қилинганида у этикет меъёрига тенглаштирилиб, унга амал қилувчи нутқий харакатлар ижобий бахоланади, меъёрдан чекинадиганлари эса кўпол хисобланади. Бундай талқин хурмат категориясини хар қандай жамиятда тарғиб қилинадиган ва одатда одобнома, панднома жанридаги асарларда таърифланадиган қоидалар йиғиндисига айлантиради [Мўминов 2000].

Хурмат категориясини турк тилида ифодаланиш воситаларини ўрганган X. К. Имомованинг қайд этишича, "Мулоқот хулқи муаммосини миллий характер - миллатнинг ўзига хос урф-одати, қадрият ва анъаналарини хисобга олмай, ўрганиб бўлмайди. Мулоқот ахборотнинг мантиқий мазмунига эмас, балки сўзлаётган кимсанинг рухий холати, хиссиёти, истакларини хам ифодалаши мумкин” [Имомова 2017:11].

Хурмат назариясига қаратилган энг машхур иш П. Браун ва С. Левинсоннинг "Universals in Language Usage: Politeness Phenomena" (1978) бўлса, ажаб эмас. Муаллифлар 
кўллашган "fасе" (бу ерда "шахс" маъносида) тушунчаси хар бир кишининг жамиятда ўзлигини, “ўз шахси”ни сақлаб қолишга интилишига нисбатан ишлатилади. Олимларнинг фикрича, ўзликни сақлаш мулоқот мақсадига кирмаса-да, лекин мулоқотнинг меъёрдагидек кечишини таъминлайдиган шартдир.

В. И. Карасикнинг ёзишича, “ижтимоий ўзлик - бу оддий ўз-ўзини хурмат қилишдан иборат бўлмасдан, балки шахс ўз хатти-харакатлари жамият учун фойдали эканлигини намойиш этишга уринишдир" [Карасик 2002:80]. Шунингдек, мулоқот жараёнида кишилар ўзгаларнинг ўзлигига хам зарар етказмасликлари мухимдир. Шунга нисбатан, П. Браун ва С. Левинсон “ижтимоий ўзлик" (social face), “негатив ўзлик” (negative face) ва “ижобий ўзлик” (positive face) тушунчаларини фарқлаш лозимлигини уқтирадилар. "Негатив ўзлик” мустақиллик, фикр эркинлиги, харакат эркинлиги кабиларни назарда тутади. Ушбу турдаги хурмат сухбатдошлар ўртасидаги ижтимоий масофани сақлаш талабини амалга оширади. “Ижобий ўзлик”, ўз навбатида, инсоннинг мақтовга, қўллаб-қувватлашга сазовор бўлиши харакатига ишора қилади. Мулоқот жараёнида унинг иштирокчилари сухбатдошнинг “ижтимоий ўзлиги”ни эътиборга олишга харакат қиладилар ва бунда ходисанинг ижобий ва салбий жихатлари инобатга олинади. Аммо сухбатдошларнинг хар иккаласи хам “ўзлиги”ни йўқотиб қўйиш хавфини келтириб чиқарадиган нутқий харакатлар (face threatening acts) хам йўқ эмас.

Р. Браун ва С. Левинсон таклиф қилишган назария лисоний хурмат категориясининг воқеланишини изохловчи харакат эканлиги (how individuals produce linguistic politeness) тадқиқотчилар томонидан қайд этилган [Watts 2003:85]. Аммо ушбу назариянинг энг катта камчилиги унда тескари холат, яъни сухбатдошга нисбатан хурматсизлик кўрсатиш харакати умуман эътибордан четда қолганлигида кўринади. Холбуки, мулоқот тахдид, қўполлик, хақоратлаш мазмунларига хам эга бўлиши мумкинлигини инкор этиб бўлмайди. Бундан ташқари, хурмат харакати фақат субъект нуқтаи назаридан қаралиб, жавоб харакати ва ушбу харакатга бериладиган бахо назардан четда қолади. Шу аснода, хурмат дискурс фаолиятига тегишли ходиса сифатида қаралиши лозимлиги равшан бўлади ва фақат шундай ёндашув доирасида бажарилаётган харакатларнинг хушмуомила ёки қўпол кечаётганини бахолаш мумкин. Бизнингча, хурмат категориясини хушмуомилалик ва қўполлик билан чегаралаб қўймасдан, балки унинг майдонини кенгайтириш ва унга “ижтимоий ўринлилик” (socially appropriate) тушунчасини хам татбиқ этиш ниятини билдираётган Р. Уоттс хакдир. Олим хурматни хатти-харакатларнинг воқеликда кечаётган ўзаро муносабат мухитига мослашув воситаси сифатида талқин қилиш тарафдоридир [Watts 2003:143].

Унутмайликки, Р. Браун ва унинг хаммуалифи, охир-оқибатда, хурмат категорияси воқеланишида кузатиладиган фарқлар стратегия танлови билан боғлиқ бўлмасдан, балки мазкур вазиятда у ёки бу маданиятда қайси стратегиялардан фойдаланилишига бориб тақалишига боғлиқ эканлигини эътироф этади [Brawn, Levinson1987].

Шундай қилиб, хурмат категорияси коммуникатив категориялар орасида марказий ўринни эгаллайди. Ушбу категория умумлаштирувчи хусусиятга эга бўлиб, ўз атрофига бошқа бир қатор прагматик ходисаларни бирлаштиради. Айнан хурмат тамойилига амал қилиш инсон дискурсив фаолиятини тўғри йўлга солиш учун хизмат қилади.

\section{Фойдаланилган адабиётлар рўйхати}

1. Земская Е.А. Язык как деятельность: морфема, слово, речь. Монография.

2. - М., Языки славянской культуры, 2004. - 25 с.

3. Имомова Х. К. Турк тилида хурмат категорияси. Филол. фани бўйича фалсафа док. (PhD) дисс. автореферати - Т., 2017. - 45 б.

4. Карасик В. И. Язык социального статуса. - М.: И-т Языкознания РАН, 2002. - 80 с.

5. Мўминов С. Ўзбек мулоқот хулқининг ижтимоий-лисоний хусусиятлари. Филол. фан док. ... дисс.- Т., 2000. - 235 б.

6. Brown P., Levinson S. Politeness: Some Universals in Language Usage

7. //Goody E.N. (ed.) / Questions and Politeness. - Cambridge: Cambridge 
8. University Press, 1978. -62 p.

9. Watts P. Politeness. - Cambridge: Cambridge Univer. Press, 2003.

\title{
BIR UMRLIK HAMROH-ISMLARNING KELIB CHIQISHI
}

\author{
Bi Feng Yun 毕风云 \\ (SamDChTI, o'qituvchi) \\ D.A.Quliyeva \\ (SamDChTI, o’qituvchi)
}

\begin{abstract}
Annotation: This scientific article describes the origins and various similarities and differences of the tradition of choosing a name for a child, which is the most important and most active process in the social life of the two neighboring nations, Uzbek and Chinese. A lifelong companion name that is beautiful to the child and gets a positive mood from his name when he grows up has been studied and compared in the context of two languages. Especially, in the Chinese language, which is very interesting and unconventional for many, the representation and origin of names and surnames are given with wonderful stories and facts. What to look for when choosing a name - this process is reflected in the social life of the Chinese people and has now become part of social culture.
\end{abstract}

Key words and expressions: 姓 xing, the traditions of selecting name, Gouzi “狗子”the word meaning dog, 姓名, the most common Chinese names

\section{"Kitobning nima haqidaligi uning nomidan bilinadi. \\ Shuningdek, ism ham nomlangan narsaning unvonidir". \\ Shayx Bakr ibn Abdulloh Abu Zayd}

Ota-onaning farzandi oldidagi eng birinchi va ma'suliyatli vazifasi bu-farzandiga chiroyli ism tanlab qo'yishdir. Hozirgi kunda ism tanlashda yoshlarimiz ko'p o'ylab, ijtimoiy tarmoqlardan izlab, do'st-u oshnolardan so'rab surishtirganliklari sa'y-harakatlari-oiladagi yoshi kattalarning bir og'iz so'zi bilan, ya'ni, aynan ular tanlagan ismni qo'yish bilan yakunlanayapti. Bu qanchalik to'g'ri? Aslida ism tanlashda nimalarga e'tibor berish kerak? Farzandga ismni kim tanlashi kerak? Bizning o'zbek xalqimizda ism tanlash vaqtida ko'pincha quyidagi maslahatli gaplarga duch kelamiz:

Bobosidek bo'lsin deb bobosini ismini qo'ydik

$>\quad$ Onam juda ham yaxshi ayol edilar, onamni ismini qo'yamiz

$>\quad$ Dadasining ismi boshlangan harf bilan boshlansin

$>\quad$ Serial bosh qahramoni juda ham chiroyli edida, o'shaning ismini qo'yaylik.

$>\quad \mathrm{Bu}$ yil mana bunaqa ism urfda, biz ham shunaqa qo'yaylik.....va hokazo shunga o’xshash fikrlar.

Ammo shu kabi gaplarga amal qilib ism tanlash qanchalik to'g'ri unchalik ham o'ylab ko'rmaymiz ba'zida. Farzandga chiroyli, ma'nodor hamda jarangli ism tanlash shak-shubhasiz, yuqorida aytganimizdek ota-onaning burchi. Albatta, ota-ona oila kattalari bilan maslahatlashgan holda farzandiga mos ism tanlashi lozim. O'tmishga nazar soladigan bo'lsak, ota-bobolarimizning ismlari tug'ilgan paytdagi vaziyatdan kelib chiqib qo'yilganligiga guvoh bo'lamiz. Xususan, oilada ikki yoki uchta qiz tug'ilsa keyingisi o'g'il bo'lishini niyat qilib O'g'iloy, ketma-ket farzandlar nobud bo'lsa, yangi chaqaloq eson-omon qolishi uchun Tursun yoki Tursunoy, nor bilan tug'ilgan chaqaloqlarga nori ketsin uchun Anora, Nortoy, Norboy, xoli ko'p bo'lib tug'ilsa Xolboy yokida Xolida va shu kabi vaziyatlarga moslab ism tanlangan. Hozirgi taraqqiy etayotgan zamonda esa yangi tug'ilgan chaqaloqlarga u katta bo'lgandan keyin uyalib qolmasligi uchun, ismi jarangli va xush yoqishi uchun turli xil zamonaviy ismlar qo'yilmoqda. Bizga ma'lumki, har bir millatda o'zining tilidan kelib chiqqan holda o'sha millatga mos ismlar mavjud, aynan inson ismini eshitib u qaysi millat vakili ekanligini ajratish mumkin.Masalan Марина, Анастасия, Марат ismlari rus 
millatining, Bob, Tom, Alisa ismlari inglizzabon millatning, Ayjan, Aynur ismlari qozoq millatiga tegishli shaxslarning ismi ekanligini bemalol farqlay olish mumkin, ammo hozirda zamon taraqqiyoti bilan mana shu farq chegarasi ham millat tanlamayapti, turli millatlar o'zaro jarangdorligini hisobga olib o'z farzandlarini chet tilida ma'no anglatuvchi ismlar bilan bemalol atashmoqda. Bizning o'zbek xalqimizda keying yillarda Sofiya, Milana, Amalya ismlari juda ham ko'payib ketdi.Aynan ismlar almashinuvi millatlararo madaniyatning almashinuvida o'ziga xos o'rin egallaydi.Xo'sh, boshqa millatlarda ism tanlashda nimalarga e'tibor beriladi hech qiziqib ko'rganmisiz?Keling, birgalikda xitoy xalqining ism tanlashda nimalarga e'tibor qaratishi va qanday xitoycha ismlar nisbatan ko'pligini bilib olamiz.

Xitoyliklarning familiyasining kelib chiqishi juda qadim zamonlarga borib taqaladi. Familiya xitoy tilida 姓 xìng deyiladi va mazkur so'zning iyeroglifi 女 nü hamda 生 shēng alohida iyerogliflarining qo'shilishidan paydo bo'lgan. Ya'nikim, 女 nü-ayol hamda 生 shēng-tug'moq iyerogliflari birlashib ayol kishi farzand tug'ishi ma'nosidan kelib chiqqan. Eng qadimgi xitoyliklar familiyalari ham aynan ayol iyeroglifi mavjud 姜 jiāng, 姚 yáokabilar bo’lgan. Xitoyliklarning familiyasi nomlanishi juda ham turli xil va juda qiziq, xususan, ba'zi familiyalar hayvonlarning nomidan-熊 xióng-ayiq, 龙 lóng-ajdarho, 牛 niú-sigir, 马 mă-otkabi, ba’zilari qadimgi hukmron davlatlar nomidan-宋 sòng Sun davlati(960-1279), 齐 qí-Chi davlati (1122-265), 赵 zhào Jao davlati (475-220), 秦 qín Chin davlati(475-220)va boshqalar, ba’zilari o'simliklar nomidan-杨 yáng terak, 柳 liǔ majnuntol, 叶 yè bargkabilardan kelib chiqqan.

Xitoyda qaysi familiya eng ko'pligini bilasizmi? Oxirgi statistik ma'lumotlarga qaraganda, “ 李” Li familiyasi xitoyliklar ichida eng ko’p tarqalgan familiyalardan hisoblanib, mamlakat aholisining 7,9\%, bu deganikim, yuz millionga yaqin xitoylikning familiyasi “李” Li ekan. Bundan tashqari, 王 Wáng, 张 Zhāng, 赵 Zhào familiyalari ham xitoyliklar ichida eng ko'p tarqalgan familiyalardan hisoblanadi.Xitoyliklarning ismiga keladigan bo'lsak, ismi bir xil xitoylikni topish juda ham mushkul, Xitoyda ismlar juda ham turfa va rang-barang desak mubolag'a bo'lmaydi. Sharq millatlariga xos xitoyliklar ham farzandiga ism tanlashda ota-ona yoki oiladagi yoshikatta hurmatli insonlar maslahatiga tayanishadi hamda yaqin do'stlardan yordam kutishadi.Ism qo'yishda sermazmun iyerogliflarni tanlashga katta e'tibor qaratishadi.Xususan, o'g'il farzandga ism qo'yayotganda mard, jasur, azamat, qo'rqmas, yorug'lik, ajdarho, she'r, sog'lik kabi ma'nolarni bildiruvchi so'zlardan foydalanishadi. Qiz farzandga ism qo'yishda esa go'zallik, yoqimtoy, mayin, oy, gul, kuy, xushbo'ylik ma'nolarini bildiruvchi so'zlardan foydalanishadi. keltiramiz:

Xitoyliklarning ismi alohida alohida ma'no anglatuvchi ikki qismdan iborat bo'ladi.Misol

\section{佳欣 Jiā xīn}

佳-ajoyib, xush

欣-xushchaqchaq, xursand 晨旭- Chénxù

晨-tong

旭-kun yorishmoq 华伟-Huá wěi

华-gullab-yashnamoq, ajoyib

伟-buyuk, ulkan

Ikki til o'rtasida ism qo'yishning farqli tomonlaridan yana bir tomoni shundaki, o'zbek tilida ismlar qotib qolgan atama ot bo'lib kelsa, xitoy tilida esa ism tarkibiga kiruvchi har bir qism alohida ma'no bildiradi va grammatik jihatdan alohida gap bo'lagi bo'lib kela oladi.

Ism-insonning to umri oxirigacha yo'ldoshi hisoblanadi, shuning uchun ham xitoyliklar ism tanlashda juda ham e'tibor bilan, chiroyli va ezgu ma'noli iyerogliflar (so'zlar)ni tanlashga e'tibor berishadi. Qadimgi xitoyda ism tanlashda unchalik e'tibor berilmagan, boshida aytganimizdek, ism tanlashda sevimli hayvon, davlat va o'simliklar nomiga tayanilgan, hattoki qadimda, farzandiga ko'z tegib qolmasligi uchun eshitilishi yoqimsizroq bo'lgan ismlar tanlangan. 
一百多年前，有一对夫妻四十多岁才有孩子，他们给孩子取名叫“狗子”，这个名字虽 然不好听, 可是他们觉得能让孩子健康, 平安。。。Yuz yillar oldin bir oilaning bir necha yillab farzandlari bo'lmay, qirqdan oshganlarida farzandli bo'lishibdi, orzuqib kutilgan farzandga ko'z tegmasdan tinch-xotirjamlikda va sog'-salomat ulg'aysin deb unga Gouzi “狗子”(it ma'nosini bildiruvchi iyeroglif (so'z)) deb ism qo'yishibdi.

Ko'rinib turibdiki, avallari uncha ham ahamiyatga ega bo'lmagan ism tanlash odati hozirgi kunda katta e'tibor markazida bo'lib bormoqda. Xitoyda avallari ism tanlashda yozilishi ham aytilishi murakkab bo'lgan iyerogliflar tanlangan bo'lsa, hozirgi kunga kelib eng sodda, ommabop va tushunarli iyerogliflar urfga kirmoqda, shu sababli ismdosh odamlar soni ham ko'payib bormoqda. Statistik ma'lumotlarga qaraganda hozirda Xitoyda eng ko'p qo'yiladigan ismlar qatoridan quyidagi beshtasini keltiramiz:

№ ISM

姓名

1 张伟 Zhāng wěi

2 王伟 Wángwěi

3 王芳 Wángfāng

4 李伟 Lǐwěi

5 李娜 Lĭ nà

\section{AHOLI SONI}

人类

299025

290619

277293

269453

258581

Qaysi millat vakili bo'lmasin tug'ilgan farzandga yaxshi niyatlar bilan chiroyli ism qo'yishadi, ismiga monand o'zi ham chiroyli bo'lishiga umid qilishadi va tanlangan ismdan farzandlar voyaga yetgach mamnun bo'lishini xohlashadi.Shundayekan, ism tanlashda e'tiborliroq bo'lib, umr bo'yi hamroh bo'luvchi ismlarning ma'nosi va jarangdorligiga ahamiyat beraylik.

\title{
Foydalanilgan adabiyotlar ro'yxati
}

1. 《中文读本》, 第一册, Beijing-2001, 67-bet

2.《最有中国味儿的字和词》, Beijing-2010, 138-bet

3. “Ma'naviyat asosiy tushunchalar izohli lug'ati”.-Toshkent: G'afur G'ulom nashriyoti, 2013, 448-bet

4. www.baidu.com

5. www.ziyonet.uz

\section{THE ROLE OF THE CHINESE NATIONAL HOLIDAY-"THE MOON FESTIVAL" AMONG THE CHINESE PEOPLE}

\author{
D.A.Quliyeva \\ (SamDCHTI o'qituvchisi) \\ N.J.Vaxabova \\ (SamDCHTI talabasi)
}

Annotation: The traditional ties of friendship and cooperation between the peoples of Uzbekistan and China, which are the cradles of ancient civilizations, have deep historical roots and are based on mutual respect and interest.This scientific article studies and compares values which are considered to be significant in strengthening friendly relations between these two nations explaining national holidays importance for the uzbek-speaking students studying Chinese. 
Key words and expressions: National holidays, Moon Festival, Hou Yi heroism, Chang E legend, moon cake, melon festival, values similarity.

Har bir xalq o'z madaniyatini turli jabhalarda namoyon qiladi. Turli xalqlarning yashash sharoiti, urf-odatlari, an'analari, hayot tarzini mazkur xalq nishonlaydigan bayramlar orqali ham yaqqol ko'rish mumkin. Har bir xalqning o'z milliy bayrami bo'ladi va mana shu bayramda o'sha xalqning ruhiyati o'z aksini topadi.Har bir mustaqil davlat hozirgi kunda insonlarning ma'naviyatini oshirish, ularga ma`naviy ozuqa berish, yaxshi, farovon turmush sharoitlarini yaratish, o`z yurti, oilasi, kasbini sevish, ularni ilmli, bilimli, ma rifatli, komil inson qilish va boshqa ezgu maqsadlar yo'lida, avvalo, millatining qadriyatlarini insonlar ongiga singdirmoqda. Dunyo ilm-fani rivojlangani sari, o'tmishda mavjud bo'lgan, ammo hozirgi kunda yo'qolib ketgan urf-odatlarni o'rganish jarayonida millatlarning bir-biriga bo'lgan qiziqishlari ortib bormoqda.Bu o'rinda, biz milliy bayramlarni alohida ta'kidlab o'tishimiz zarur. Chunki, har bir milliy bayram o'zida bir xalqning turmush tarzini, tarixi va madaniyatini aks ettira oladi. Milliy bayramlarning asosiy vazifasi - milliy va dunyo madaniyatlarining eng yaxshi namunalarini keng targ ib qilish va ommalashtirish, o`sib kelayotgan avlodni, zamonaviy yoshlarni ma`naviy tarbiyalash, millatiga, tarixiga, insoniyatga bo 'lgan hurmatini uyg`otish va saqlash hisoblanadi. Barcha Osiya xalqlari qatorida, xitoy xalqi ham o'zining milliy bayramlarini hozirgi kungacha keng miqyosda nishonlab kelmoqda.Bu albatta, avloddan-avlodga o'tib kelayotgan qadriyatlarning saqlanib qolishida asosiy rollardan birini o'ynaydi. Xitoy milliy bayramlari har birining o'z kelib chiqish tarixi mavjud bo'lib, afsonaga aylangan qahramonlarning ko'rsatgan jasoratlari va ularning ruhiga bag'ishlab o'tkazilgan marosimlar keyinchalik milliy bayramlarga aylanib ketgan.

Xitoy yangi yili hisoblangan Chun jiedan(春节 Chūn jié) keyingi ikkinchi muhim ahamiyatga ega bo'lgan milliy bayram bu- 中秋节 zhōng qiū jié (Oy festivali) hisoblanib, mazkur milliy xalq bayrami oy kalendari bo'yicha sakkizinchi oyda ya'ni kuzning birinchi yarmida nishonlanadi. Oy festivalini turli xil nomlar bilan atashadi: Oy shirinligi bayrami,O'rta-kuz festivali,Lantern festivali, Reunion festivali shular jumlasidandir.O'rta-kuz bayrami Tan sulolasi davridan boshlab har yili butun Xitoy bo'ylab rasman o'tkaziladigan bo'ldi.Xitoyliklar bu kunda nafaqat, oydan zavqlanishadi, balki hosil yig'ish jarayonining nihoyaga yetganligi, qishki mavsumga tayyor bo'lganligi munosabati bilan ham xursandchilik qilishadi. Bayram kechasida ko'chalar jonlanadi vazavqqa to'ladi. Xitoylik oilalar ertalabgacha bayramdan zavq olib uni nishonlashadi. Yilning eng yorqin va to'lin oyidan aynan, oy festivali kechasida zavqlanish mumkin. Shunisi qiziqarliki, Xitoyning turli hududlaridaoy festivali turlicha an'analar bilan nishonlanadi.Fujian provinsiyasidaayollar uzoq umr ko'rish uchun Nanpu ko'prigidan o'tishadi; Jiangsi provinsiyasida qishloqlarda samovarlar somon orqali qizdiriladi va undan butun qishloq bo'ylab hushbo'y ifor taraladi; Shandong provinsiyasida oyga qurbonlik qilishdan tashqari, ota-bobolar ruhiga ham qurbonliklar qilishadi.

Azaldan xitoy milliy bayramlarida tayyorlanadigan maxsus taomlar mavjud bo'lib, ularning masalliqlari va tayyorlanish jarayoni bayramlarning ramzihisoblanadi. Oy festivalining an'anaviy shirinligi“ 月 饼 "yuè bǐng( Oy shirinligi) deb nomlanadi.Ushbu shirinlikni tayyorlash oy festivalining eng asosiy an'analaridan biri hisoblanadi.Oy shirinligining son-sanoqsiz turlari mavjud.Oyning to'lganligini bildirish maqsadida, shirinlik shaklini dumaloq qilib tayyorlashadi hamda oyning to'rt bosqichini ifodalash uchun to'rtta tuxum sarig'idan foydalanishadi. Oy shirinligi har xil mevalardan tayyorlanadi, ammo eng shirin va xaridorbop turi bu-zanjabilli oy shirinligi hisoblanadi.O'rta-kuz festivali arafasida butun Xitoy do'konlari oy shirinliklari bilan to'ladi.Hattoki, oy shirinligining yaralishi bilan bog'liq afsona ham mavjud ekan.Aytishlaricha, Min sulolasi oy shirinligining yordami bilan tashkil topgan ekan.

Har bir milliy bayramning kelib chiqish tarixi bo'lganidek, Oy festivali ham uzoq o'tmishga va ajoyib afsonlarga borib taqaladi. Xitoyliklar orasida keng tarqalgan afsonalardan biri，嫦娥 cháng éChangE(嫦娥 cháng é)va Hou Yi(后裔 hòu yì)afsonasi bo'lib, har yili oy festivali arafasida oilaviy davralarda aytib beriladi. Hou Yi va Chang E er-xotin bo'lishiga qaramasdan, har birining taqdiri alohida afsonaga aylangan.Birinchi qahramonlik afsonasi Hou Yi haqida bo'lib, "10ta 
quyoshni urib tushirgani" haqida kuylanadi.Qadim zamonlarda 10ta aka-uka quyoshlar har kuni navbati bilan osmonga nur berishga chiqishar ekan.Ammo, kunlardan bir kuni 10ta quyoshning barchasi baravariga osmonga chiqibdi. Ayni yig'im-terim paytida harorat haddan tashqari ko'tarilib ketadi vayer yuzi sahroga aylana boshlaydi. Bundan xabar topgan osmon xudolari mergan kamonchi Hou Yiga 10ta quyoshning aqlini kiritib qo'yishni buyurishadi.Hou Yi 9ta quyoshni urib tushiradi, o'ninchisiga esao'z vazifasini, issiqlik va nur taratishnitayinlaydi. Ana o'shandan buyon xalq orasida hosil yig'imi vaqtida xalqni qutqarib qolgan Hou Yi qahramonligi og'izdan-og'izga o'tib kelmoqda.Ikkinchi afsona esa Hou Yining qahramonligi uchun osmon xudolari tomonidan, abadiy umr elikserini berish bilan boshlanadi.Bir kuni Chang E eliksirni bexosdan hidlaydi va tanasi yengillashib ketayotganini sezadi. U bulut kabi osmonga uchib ketadi.O'shandan beri Chang E osmondagi Oy saroyida yashaydi degan qarashlar mavjud.KeyinchalikChang E o'rta-kuz bayramining ilohiy ma'budasiga aylanadi.Hozirgi kunda oy festivali kechasida barcha insonlar osmonga qarab Oy saroyidagi Chang Ening jilolanishidan zavq olishadi, go’yo.

O'rta Osiyo xalqlarining kelib chiqishi etnik jihatdan bir-biriga aloqador bo'lganligi uchun, ularning urf-odatlari, qadriyatlari va milliy bayramlari o'rtasidaqandaydir darajada o'xshashlik mavjud. Ayniqsa, Buyuk Ipak Yo'li orqali xalqlarning bir-biriga qon-qarindoshligi oshib borgan.Milliylikning o'xshash tomonlari ko'p bo'lgan idek, insonlar o'rtasida o'tkaziladigan milliy bayramlarning ham o'xshashliklari mavjud. Jumladan, xitoyliklarning oy festivali va o'zbeklarning qovun saylini bir-biriga bemalol qiyoslab, taqqoslasak bo'ladi. Bizning yurtimizda keng miqyosda nishonlanadiganqovun sayli shaharlarda, Registon maydonida, Chorsu rastalarida, shahar tashqarisidagi sayilgohlarda, o'tkazilib, bir ikki hafta davom etadi. Sayilgohlarda oshxona, choyxona, nonvoyxonalar quriladi, meva-cheva, attorlik, baqqollik do'konlari ochiladi. Poyga, uloq, ko'pkari, kurash, chavgon musobaqalari, darvoz, hofiz, sozanda, raqqos, masxaraboz, qiziqchilarning chiqishlari, ayiq, ilon o'yinlari, tuya, qo'chqor, xo'roz, it urishtirish, mushakbozlik tomoshalari ko'rsatiladi.Dehqonlar o'zlarining polizlaridan yig'ib olgan turli xildagi poliz ekinlarini ko'rgazmaga olib kelishadi.Qovun sayli yurtimiz bo'ylab qizg'in nishonlanadi.Qovun sayli va oy festivalining o'xshash tomonlariga keladigan bo'lsak, ikkalasi ham kuz fasliga to'g'ri keladi va aynan yig'im-terim vaqtida ushbu bayramlar oddiy xalq orasida zo'r qiziqish va tantana bilan nishonlanadi. Undan tashqari, ikkala bayramning ham boshqa bayramlardan ajralib turadigan xususiyati bor, ya'ni bayram arafasida ham, bayram kunida ham odamlarning xursandchiligi, ularning ko'zlaridagi milliylik ruhi barchasi jam bo'lib o'zgacha muhit kashf qiladi.Yana shuni qo'shimcha qilishimiz mumkinki, qovun saylining an'aniy shirin poliz mevasi qovun bo'lsa, oy festivalining a'nanaviy shirinligi oy shirinligidir. Albatta, bu ikki bayramning bir-biridan farq qiladigan jihatlari ham mavjud.Lekin, asosiy mazmun deyarli bir xil desak, adashmagan bo'lamiz.

Necha ming asrlar davomida, o'zbek va xitoy xalqining qo'shnichilik munosabatlari barqaror bo'lib kelmoqda. Hozirgi kunda, bunday barqarorlikni yanada mustahkamlash maqsadida, biz yoshlar ikki xalqning tarixini, milliyligini o'rganishimiz va bizdan keyingi kelajak avlodga milliyligini saqlagan holda yanada boyitib yetkazishimiz zarur.

\section{Foydalanilgan adabiyotlar ro'yxati}

1. “最有中国味儿的字和词”-Самые "китайские" иероглифы и словаBeijing-2010, 58bet;

2. 新实用汉语课本-北京语言大学出版社, 2003 年 4 月第 1 版.37-bet;

3. “Konfutsiy suhbat va mulohazalar" Lun Yuy "Yangi asr avlodi” Toshkent, 2014,. 33-bet;

4. www.ziyonet.uz

5. www.baidu.com 


\title{
MILLIY SPORT TURLARI VA XALQ O'YINLARI BOLA ORGANIZMNING FUKSIONAL HOLATIGA TA'SIRI
}

\section{S.Xalilova \\ (O’zRes.JTVSVHJTVSBMIMTQTMOM Samarqand filiali o'qituvchisi) \\ Z.Qarshiyeva \\ (Samarqand MOHM o'qituvchisi)}

\begin{abstract}
Annotation:This article provides information on the physiological characteristics of physical activity of children of different ages and the physiological basis of health-improving physical education, the impact of national sports and folk games on the functional state of the child's body.
\end{abstract}

Key words and expressions: physiological characteristics, national sports, folk games, physical education

Jismoniy mashqlar harakatlardan iborat bo'lib,ular yordamida jismoniy tarbiyaning maqsadlari amalga oshiriladi. Bunda eng asosiy maqsad - bu, organizmning mexnat qobiliyatchanligini oshirish va sog'lomlashtirish hisoblanadi. Tarixga nazar tashlaydigan bo'lsak, ota-bobolarimiz azal-azaldan insonni jismonan chiniqtiruvchi, salomatlikka ijobiy ta'sir etuvchi mashqlarga jiddiy e'tibor qaratishganini ko'ramiz. Masalan, ko'pkari musobaqasi har bir ishtirokchidan chavandozlik mahoratidan tashqari jismoniy kuch, o'tkir zehn va yetti o'lchab bir kesish salohiyatiga ega bo'lishni talab qiladi. Ajdodlarimiz shunga mos ravishda tayyorgarlik ko'rib, ham ruhiy, ham jismoniy o'sishga erishganlar. Umuman olganda, milliy sport turlarining barchasi ota-bobolarimizning yashash tarzi, madaniyati va dunyoqarashidan kelib chiqqan holda rivojlangan. O'sha kezlarda kimdir chavandoz, kimdir qilichboz, yana kimdir mergan sifatida tanilgan. Shuningdek, turli o'yinlar va mashqlar tufayli ajdodlarimizda har qanday holatdan olib chiqadigan chaqqonlik, yakkama-yakka olishuvga xos uquv shakllangan.

Bugungi kunda inson salomatligini saqlash va orttirish uchun amaliyotda sog'lomlashtiruvchi jismoniy tarbiyaning turli shakllaridan foydalaniladi. Ular yordamida ta'limga oid, tanishtiruvchi (turizm), qayta tiklovchi (davolovchi gimnastika), ko'ngilochar (o'yinlar), ishlab chiqarish (ishlab chiqarish gimnastikasi) va boshqa yo'nalishdagi maqsadlar amalga oshiriladi. Jismoniy mashqlarning gimnastika, o'yinlar, turizm va sport shakllari farqlanadi. [6]

Ertalabki jismoniy tarbiya uyqudan keyin miyani faollashtiradi, ishlayotgan muskullardan kelayotgan afferent impulslar markaziy asab tizimining tonusini oshiradi, sensor tizim faolligini kuchaytiradi, yurak muskuli ishini faollashtiradi va vena qonini qaytishini kuchaytiradi, nafas harakatlarini chuqurligini ortiradi, to'qimalardagi shishlarni yo'qotadi, limfa aylanishini kuchaytiradi.

Bola 4-5 yoshga to'lganida juda hilma-xil va murakkab harakatlarni: yugurish, sakrash, konkida yurish, gimnastika, akrobatika mashqlarini uddalaydigan bo'lib qoladi. Xuddi shu yoshda u qo'l panjasidagi mayda muskullarning rivojlanishiga aloqador ancha aniq harakatlarni ham o'zlashtira boshlaydi. 6-7 yoshga kelib gavda, son va tizzadagi yozuvchi muskullar kuchi sezilarli darajada ortadi. Mana shu vaqtda butun tayanch-harakat apparatining rivojlanishi uchun funksional jihatdan muhim stimul beradigan narsa - yurishning shakllanishidir. [4]

Maktabgacha tarbiya yoshidagi bolalar juda serharakat bo'lishiga qaramay, xarakatlar tuxtovsiz almashinib turadi. 6 yoshga kelib chidamlilik birmuncha ortadi, shunday bulsada bolalar faollikni tez-tez o'zgartirib turishga xamon moyil bo'ladi. Ular bir joyda turish, o'tirishga qiynaladi, ularning harakatlari tinmasdan almashinib turadi.

Bolalarda harakatlar koordinasiyasining rivojlanib borishi ham harakat analizatorining morfologik jihatdan yetilish prosesslariga bog'liq. Ayni vaqtda nerv tolalarining yaqinlashish jarayoni alohida diqqatga ega bo'ladi, bu prosess nerv sistemasining turli bo'limlarida xar xil muddatda bo'lib o'tadi. Shu bilan birga nerv sistemasining eng murakkab funksiyalarni bajaradigan bo'limlari, xuddi katta yarim sharlar po'stlog'ining neyronlari singari, boshqalardan ko'ra kechroq miyyorlashadi. Maktabgacha yoshdagi va kichik maktab yoshidagi bolalarning jismoniy sifatlari va 
malakalari rivojlanishida o’xshatuvchi (imitasiya) o'yinlarni katta ahamiyatga ega. O'yinlar insonning jismoniy faolligini kuchaytiradi, kuzatuvchanligini rivojlantiradi, miyaning ijodkorligi va vaqt yetishmasligi sharoitida axborotlarni qayta ishlash qobiliyatini oshiradi. Bola hayotida o'yin muhim ahamiyat kasb etadi. O'yin faoliyatiga milliy sport o'yinlarini kiritish milliy sport turlari va xalq o'yinlari o'ziga xos qadriyat sifatida avlodlardan avlodlarga o'tib boradi. Mana shunday o'yinlardan ba'zilarini misol keltirishimiz mumkin.

\section{"KIM TEZ O'RAYDI."}

O’yindan maqsad. Bolalarni tezkorlikka, epchilikka o'rgatish ularning jismoniy rivojlanishini oshirish.

O’yin uchun kerakli jihozlar. Ikki bo'lak arqon, uzunligi 4-5 metr, to'rta chillak, qalinligi 3 sm.

O'yinning borishi. O'yin 6-8 nafar bola, to'rt guruxga bo'linib o'ynashadi.

O'yin uchun ikki bo'lak arqon uzunligi 3-4 m va to'rta chillak kerak bo'ladi. Bolalarni turt tomonda "plyus" shakilda joylashtiriladi. To'rt tomondan bolalar "boshla" deyishi bilan arqoni o'rab markazga qarab kelishadi. Markazga kim birinchi yetib kelsa, o'sha bola g'olib xisoblanadi.

O’yin jarayonidagi erishilgan natija.

Jismoniy: Qo'llarni to'g'ri va tez xarakatlantirish malakasi rivojlanadi, qo'l mayda motorikasi rivojlanadi. iroda charxlanadi. Tezkorlikka, epchillikka o'rganadi.

Ijtimoiy ruhiy: "Lider" bo'lishga intiladi.

Ma'naviy: Xarakatli o'yin orqali milliy ruhni xis qilish, chaqqonlik.

"XO'ROZLAR JANGI"

O'yindan maqsad. Davlat talablarining ijrosi bolalarni chaqqon xarakat qilishga yelka bilan aniq xarakat qilishga o'rgatish, bir oyoqlab sakrash

O'yin uchun kerakli jixozlar: Xo'roz niqobi.

O'yinning borishi. Bu o'yinda 3-4 boladan iborat guruhlar tuziladi. Raqib guruh bola birbirga qarama-qarishi turishadi. Tarbiyachi har bir guruhdan maxsus kiyim kiygan xo'rozchani doira ichiga, ya'ni "kurash maydonchasiga" chaqiradi. Bolalar doira ichidan yelkalari yordamida birbirini turtib chiqarib yuborishga urinadilar yoki muvozanatni yo'qotib ikkinchi oyog'ini yersa tekkizsa ana shu guruh bolasi yengilgan xisoblanadi. G'alabaga erishgan bolani rag'batlantiriladi.

O’yin jarayonidagi erishilgan natija.

Jismoniy: Yelka va oyoq xarakatlari rivojlanadi. Muskullar mustahkamlanadi. Muvozanat saqlash malakasi shakillanadi, sakrash, mo'jalga olish, chaqqonlik,

Ijtimoiy ruhiy: Iroda charxlanadi

Ma'naviy: Jamoa bo'lib ishlash va milliy ruhni his qilish o'rganadi. Milliy xalq udumlarini, urf - odatlar singdirishga, xalq o'yinlariga nisbatan munosabat shakillanadi.

"KURASH"

Kurash bu o'zbek xalqining qadimgi sport turlaridan biri xisoblanadi. Bu o'yin boladan epchillik va chaqqonlik xamda bardoshlilikni talab etiladi. Kurash bu, mard, paxlovon, epchil ikki yigit o'rtasida o'tkaziladigan olishuv, kuch sinashishdir. Yigitlarning xarakatiga qarab ularga bakavul tomonidan "Chala, girrom, xalol, dakki" kabi baxolar berib boriladi.

O’yin jarayonidagi erishilgan natija.

Jismoniy: Epchillikka, chaqqonlikka intiladi, chidamlilikka o'rgatadi, muvozanat saqlashga, epchillikka, qo'l va oyoq xarakatlari rivojlanadi.

Ijtimoiy ruxiy. Bardoshlilikka, irodaviylilikka, yetakchi bo'lishga intiladi.

Ma'naviy: Milliy qadriyatlarimizni xurmat qilishga, mardlikka o'rgatiladi.

\section{Foydalanilgan adabiyotlar ro'yxati}

1. Азимов И.Г.,Собитов Ш.С.,Спорт физиологияси Т:, 1993.

2. Usmonxo'jayev T., Toirova M., Sagfiyev X., Sharipov T "Kichkintoylarga 200 ta harakatli o'yinlar" Yangi asr avlodi Toshkent 2009

3. Проблемы физиологии спорта.Под.общ. ред.В.С. Гиппенрейтра, М., ФиС, 2003.

4. Азимов И.Г.Жисмоний тарбиянинг ёш физиологияси (ўқув қўлланма)Т: 1994. 
5. Сологуб А.С., Солодкова Е.Б. Физиология человека: Общая, Возрастная, Спортивная: Учебник.-М.,2010.

6. Xalilov E.X., Zaynabiddinov A.E., Xushmatov Sh.S. Jismoniy mashqlar fiziologiyasi.

7. Курбонов Ш. Қурбонов А.Ш., Жисмоний машқларнинг физиологик асослари. Т., 2003.
8. www.lex.uz
9. www.ziyonet.uz
10. www.edu.uz
11. http://www.google.uz
12. http://www.sports.uz

\section{RANG-SIFAT BILDIRUVCHI ETNONIMLAR VA ULARDAN SHAKLLANGAN ETNOOYKONIMLAR}

\section{B.A.Sattorov (SamDChTI)}

Annotation: It is known that nature is very rich in colours and dyes: white, black, red, yellow, blue, green, pink and others. Ethnonyms are based on similar colour terms in the vocabulary.

Key words and expressions: etnonim, rang, oq, qora, qizil, sariq, ko ' $k$, yashil, pushti.

Etnonimlarning rang-tus bildiruvchi so'zlar asosida paydo bo'lishining mohiyati haqida K.Shoniyozov shunday yozadi: "Qadimgi davrlarda Oltoy va Janubiy Sibirda yashagan turkiy qabilalar shimol, janub, sharq, g'arbni ranglar nomi bilan ataganlar. Qora rang shimolni, qizil rang

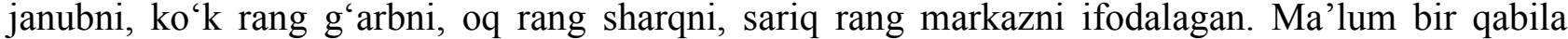
ittifoqida bo'lgan kishilarning tomonlarga qarab joylashishi odat tusiga kirib vaqt o'tishi bilan tomon nomlari rang nomlari etnonim bo'lib qolgan». O'zbek tili toponimlari tarkibida oq, qora, ko'k, qizil, sariq so'zlari bilan aloqador 48 ta etnooykonimlar mavjud. Bu K.Shoniyozov fikrining to'g'riligini tasdiqlaydi.

Joy nomlari sirasida qizil, sariq, ko'k, yangi, oq, qora so'zlari bir xil darajada qo'llanilmaydi. Faktlar ko'rsatadiki, oq, qora so'zlarining qo'llanish miqdori ancha ko'p. Etnonim sifatida ishlatiluvchi va etnooykonimlar tarkibida keluvchi oq, qora, sariq, qizil, ko'k, yangi so'zlari haqida turli xil fikrlar mavjud.

A.N.Kononov oq va qora so'zlarining jug'rofiy atamalar tarkibidagi semantikasi haqida fikr bildirib, u oq so'zi oqmoq fe'li bilan aloqador degan fikrni aytadi.

R.Musin tadqiqotiga ko'ra, «Tabiatda yuzlab minerallar va jinslar oq rangga ega. Biroq Oqtosh Aktasi nomi bilan atalgan bo'lsa, u yerda kvars borligini ko'rsatadi. Shu bilan birga faqat

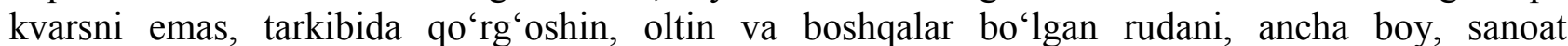
ahamiyatiga ega bo'Igan kon mavjudligiga ishora qiladi. Bunday dalillar E.Begmatov tomonidan ham tilga olingan.

Qora so'zi ko'pchilik olimlar ta'kidlaganidek, u balandroq joy; tekislikdagi kichik balandlik, do'ng joy, kichik tepa; yonidagi boshqa do'nglikdan vertikal ko'lami jihatidan farqligini bildiruvchi; yer, yer osti, buloq, daryo; ulug', buyuk, qudratli, kuchli, katta ma'nolarini ifodalaydi.

Etnonimni ifodalovchi sariq rang sharqda podsholar oilasiga mansub yuqori tabaqa oqsuyak kishilarga nisbatan ishlatilishi to 'g'risida fikr bildiriladi. N.A.Baskakov qirg'iz etnonimi haqida qiziqarli fikrlarni keltirib, ushbu nom tarkibida qizil so'zini topadi va ularni janub o'g'izlari deb izohlaydi. Ba'zi tadqiqotchilar etnonim sifatida ishlatiluvchi ko'k so'zini izohlar ekan, uni «o'rmonli turklar» deb talqin etishadi.

O'zbek tilida oq, qora, sariq, ko'k, qizil, yangi so'zlarini qo'shish orqali yasalgan joy nomlarining lug'aviy-ma'noviy guruhlari turli-tumandir.

a) Aholi punktlari turini bildiruvchi qo'rg'on, qishloq, ovul, guzar, mahalla so'zlari bilan kelgan oq, qora, sariq, ko'k, qizil, yangi so'zlari rang ma'nosini ifodalamaydi: Ko'kdala, Ko‘kgumbaz, Oqbosh, Oqbo‘yra, Oqmang‘it, Oqmanovul, Qorakent, Qoraguzar, Qoraqishloq. Bu 
xil joy nomlarida obyektning hajm, miqdor, ko'rinish, tuzilishi, qarashlilik, qanday toifa kishilar tomonidan yaratilishi va kimlarga xizmat qilishi qator tabiiy hamda ijtimoiy-sosial belgilar nomlanishga mezon qilib olingan;

b) Suvlik turini bildiruvchi daryo, suv, ariq, buloq kabi so'zlar bilan birga kelgan rang bildiruvchi leksemalar o'ziga xos ma'nolarni ifodalaydi. Ular qor suvlari bilan to'yinish, oqim tezligi, oqmoq fe'li, oqish, qizg'ish, yashil, tog' bag'ridan boshlanadigan ma'nolarini bildiradi: Oqdaryo, Qoradaryo kabi;

v) Yer yuza tuzilishi turlarini bildiruvchi tepa, jar, qum, tosh, mula so'zlari bilan birga kelgan rang bildiruvchi so'zlar bilan yasalgan joy nomlari mavjud: Oqtepa, Oqtosh, Ko'ktepa, Ko'kjar, Qoratosh, Qorabayir kabilar. Bu nomlar relyef turlari va tabiatini, tabiiy sharoitini ifodalaydi;

g) Rang-sifat bildiruvchi so'zlar etnonimlar bilan birga keladi va bir etnooykonimni hosil qiladi. Ularning shakllanishida ikki holatni ko'ramiz. Bi-rinchidan, etnonimlarda qalpoq, to' $n$, chakmon so'zlari ishtirok etadi. Etnik birliklar nomlanishida ularning kiyimlari nazarda tutilgan: Qoraqalpoq, Qorachakmon, Ko'kto'nli kabilar. Bu etnonimlardan qishloqlar nomi yuzaga kelgan. Nomlanishda qishloq aholisining qaysi uruqqa mansubligi e'tiborga olingan. Ikkinchidan, rang-tus bildiruvchi so'zlar o'zbek qabila-urug'lari nomi bilan birgalikda etnonimlar yasalgan: oqmang'it, oqchelak, oqtepamitan, oqchuragasi, oqqovun, oqqo'yli, ko'kqarg'a, yangibahrin, yangioqchob,

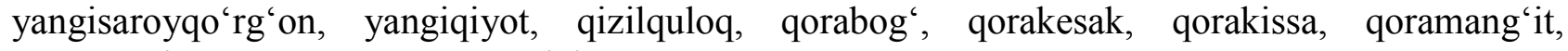
qoramo'yin, qoranayman, qorapichoq, qorasiyroq, qorateri, qoratuxum, qoraunas, qoraupa, qoraxon, qoracha, qorayantoq, qoraqasmoq, qoraqipchoq, qoraqo'yli, qoraguppa, qoraman kabilar.

Sanab o'tilgan etnonimlarning ko'pchiligi etnooykonimlar yasash uchun asos bo'lgan. Quyida ular tahlil qilinadi:

Oqmang'it - Pastdarg'om tumanidagi qishloq Mang'it qabilasining oqmang'it, to'qmang'it, qoramang'it, cholmang'it, olato'n urug'lari mavjud. Qishloq aholining etnik bo'linishiga ko'ra nomlangan. Pastdarg'om tumanida Qoramang'it oykonimi bor.

Qoraxon - Paxtachi, Ishtixon tumanlaridagi qishloq. Ko'lobda yashovchi arablarning sholbof

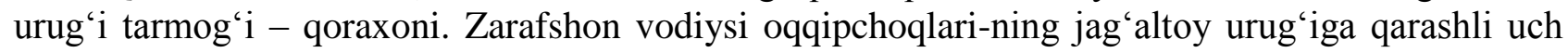
tarmoqning biri qoraxon.

Qadimgi turkiy atama bo'lgan qoraxon etnonimdir. Aslida Qoraxon 927-1212 yillarda Sharqiy Turkistonda tashkil bo'lib, so'ng Movarounnahrdagi o'lkalarni ham o'ziga bo'ysundirgan turk davlatining boshlig'i, asl ismi Abdukarim Sotuq Bug'roxon bo'lgan Ana shu qoraxoniy dinastiyasiga tobe bo'lib, keyinchalik qarluqlar, xo'ja va eshonlar o'rtasidagi urug' yoki tabaqa nomiga aylangan. Qoraxonlarni qoraxoniylar davri (X-XII asrlar) urug'-qabilalarining avlodajdodlari deyish mumkin. Ishtixon tumanida Uchqaramon qishlog'i mavjud. Etnonimni ta'birlashda har xillik mavjud. "Qaramanlar o'zbeklar tarkibiga ham kirgan. Shu bilan qayrog'och daraxtining bir turini Xorazmda qaraman /qora eman/ deyishadi». Ushbu fikrdagi qaraman-etnonim degan mulohazaga qo'shilsa bo'ladi. Chunki respublikamizda Qoramanqal'a, Qaraman, Ozarbayjon, Turkmaniston, Qirg'izistonda shunday joy nomlari mavjud. Qaraman eng qadimgi qabila - urug“ nomidir. Ular qipchoq va $0^{\prime} \mathrm{g}^{6} \mathrm{uz}$ qabilalari tarkibiga kirgan hamda XIX asr oxiri va XX asr boshlarida Farg'ona vodiysiga kelib o'rnashganlar.

Qaraman etnonimi qara va man qismlaridan iborat. Bunda qara so'zi «belgi, holat, nufuz, miqdor, to'da, yig'in, ko'p» ma'nolarini ifodalaydi. Man qismi kishi, odam ma'nolarini bildiradi. Xuddi shu ma'nosi do'rman, nayman, kuman, turkman kabi etnonimlarda ham mavjud.

Turk xoqonligi parchalangandan so'ng VI-XI asrlarda respublikamiz hududiga kelgan qaramanlarning etnik nomini bildiruvchi so'z joy nomlarida saqlanib qolgan. Bu etnonim u aholining qaysi qabila yo uruqqa mansubligini bildirsa, ikkinchidan, ularning yashagan joy nomi hisoblanadi. Demak, qadimiy turkiy nom qaramanni hozirgi qahramon so'ziga nisbat berish to' $\mathrm{g}^{6} \mathrm{ri}$ emas. Chunki uning kechmishi boshqa ma’noda ekanligini unutmaslik lozim.

Foydalanilgan adabiyotlar ro'yxati

中国社会科学院语言研究所词典编撰室编, 现代汉语词典 : 2002年增 325

1. 中国社会科学院语言研究所词典编辑室《现代汉语词典》456 
2. Шаниязов К.Ш.К этнической истории узбекского народа (Историкоетнографическое исследование на материалах кипчакского компонента).Ташкент:Фан,1974.341 с.

3. Горелов В.И. Грамматика китайского языка. -М.: Просвещение, 1982.

4. Горелов В.И. Теоретическая грамматика китайского языка. -М.: Просвещение, 1989

\section{ЖАМИЯТДА МИЛЛИЙ МАДАНИЯТ РИВОЖИДА АХЛОҚИЙ АНЪАНАЛАРНИНГ ФАЛСАФИЙ МАСАЛАЛАРИ}

\section{М. М. Мамадалиев \\ (СамДУ тадқиқотчиси)}

Annotation: In this article, ethical-aesthetic aspects of concept of tradition have been studied philosophically by the object of social science. The studies of the concept of tradition by Uzbek and foreign scientists, its features in the time and space have been analyzed in the context of national and modern aesthetic knowledge.

Key words and expressions: Scientific heritage, the young, spirituality, children, independence, philosophy, relign, worldlines.

Маънавий тараққиётнинг маълум босқичлари аввалги ахлоқий анъаналарни махсулдор имкониятларини ўз ичига олган холда давом этади. Тарихий тараққиёт зинапоясида қадамақадам кўтарилаётган инсоният хар сафар ахлоқий маданият ютуқларини янгидан яратмайди, балки ахлоқий маданият олдин эришган ютуқларига таянади. Шунинг учун ахлоқий маданият тараққиёт тарихидан битта босқични ўчириб бўлмайди. Чунки тараққиёт динамикаси олдинги босқич таъсирида бўлади.

Жамиятда бундай анъаналарни кетма-кетлиги, трасформацион хусусияти бир қатор саволларни юзага келтиради: 1) мавжуд ахлоқий тамойиллар ўтмиш ахлоқий мероси билан қандай алоқадорлик жихати бор? 2) маънавий маданият, ахлоқий мерос хазинасидан нима олиш керак? 3) ўтмиш қадриятлардан қандай фойдаланиш керак. Фақатгина тарихийлик ва мантиқийлик, анъанавий ва замонавийликнинг бирлиги ва қарама-қаршилигини хисобга оладиган бўлсак, бундй ёндашув бу мавзу бўйича объектив манзарани очиб. унинг ривожланишини асосий харакатлантирувчи кучларини аниқлаб олиш мумкин.

Кишилик жамиятида авлодлар алмашиниши ўз-ўзидан анъаналар тизимини яратиб, урф-одат тизимини яратган. Кекса авлод янги авлод билан шу урфлар ва одатлар орқали танишган, бир-бирини англаш жараёни кечган. “Анъанадан фарқли равишда одатлар муайя вазиятда нима қилиш керакли хақида батафсил кўрсатма беради ва шу билан бирга инсонни рухий фазилатларига ортиқча талаб қўймайди. Маросим иштирокчилари одатларни бекамикўст амалга ошириш хақида ўз анъанавий тарбиясида маълумотларни олган бўлиб, у маълум шароитларда ўзгариши мумкин эмас. Инсон хаёти ана шундай урф-одат каби фомулалар асосида тартибга солинган" ${ }^{52}$ [Тейло Э.Б. 2000. 542]. Анъаналар жамият учун дастлабки цензура ролини ўтаган, қонун, қатьий талаблар асносида шаклланган қадриятлар жамланмаси сифатида шаклланган инсониятни дастлабки маънавий-ахлоқий ютукларидандир.

Инсоният умуминсоний ахлоқни ўзлаштириб анъанавийликни ривожлантирган, шу ахлоқий анъаналар таъсирида унинг бадиий-эстетик маданиятини шакллантириб, ўз онгини ривожлантириб юқори босқичга чиқарган. Хар бир жамиятда шахсни ривожлантиришнинг анъаларига риоя этилар экан, уннинг барча омиллари (ахлоқий, эстетик, бадиий в.х)нинг тарихий босиқчларига, ижтимоий мақомига эътибор берилади. Шарқда жамиятлар анъанавий тартиб қоидалар асосида бошқарилгани сабабли шахсиятли тарбиявий ишларда хам шунга эътиқод қилинади. Олдинги авлоднинг ютуқлари панд-насихат (дидактика), ўгит, хаёт фалсафаси сифатида тарбияда гавдаланади, маънавий ютуқларни энг афзаллари

\footnotetext{
${ }^{52}$ Тейлор Э. Б. Миф и обряд в первобытной культуре. - Смоленск: Русич, 2000. - С-542-545.
} 
ўзлартирилади. Бундай трансформацион жараёнга миллий, диний ва худудий тус бериш идеологик ахамиятга эгадир.

Ўтмиш ахлоқий қадриятлари нафақат оддий шахс ижтимоий-маънавий қиёфасида акс этади, балки бутун жамият томонидан максимал даражада ўзлаштириш натижасида бутун миллий-этник ахлоқ назариясида акс этади, такомиллашади. Бу масалалар ахлоқнинг фалсафий масалаларини тўлиқ қамраб олади. Анъана авлоддан-авлодга ўтадиган ва муайян ижтимоий муносабатлар туфайли келиб чиқиб, кишларни хис-туйғуларини, жинслараро, кишилараро фикрларни тартибга солиш тизими, одатлар йиғиндисидир[Яковлева Т.В. 2012. $118]^{53}$.

Анаъаларнинг хусусиятларидан бири бу - узлуксизликдир. Инсонинг маънавий борлиғидаги узулуксизлик ва узлуклилик моддий ва маънавий хаётда акс этади. Унинг маънавий олами турли ижтимоий воқелик туфайли ўз мохияти бутун тизим сифатида ўзгарганда, яъни у бир холатдан иккинчисига ўтганда, хозирни ўтмиш билан боғлаб турганда унинг ташкил этадиган айрим омиллар, унсурларини сақлаб қолиши узулуксизликка мисол бўла олади. Ахлоқий анъаналар ёки анъанавий ахлоқ, норма, меъёрий тузилмалар ўтмиш ва келажакни боғлаб, бу орқали доимийликни бутуннинг барқарорлигини белгилаб беради.

Ўтмишдан аниқки бирор авлод ўз ижтимоий тараққиётини бўш жойда бошламайди. Янги авлод меьрос бўлиб ўтган қадриятлари заминида, бағрида шаклланади ва янги сериотипни яратади. Ўтмиш ахлоқий қадриятлар эвазига авлодлар бир-бири билан генетик яқинлиги, хулқий мансублиги хақида маълумотга эга бўлади. Авлодлар ахлоқий кодлари орқали анъаналар таъсирида “назарий ассимляция”га учрайдилар. Ўтмишдан хозиргача келган ахлоқий қадриятлар синовдан ўтганлиги, кучлилиги туфайли бу хозирги кишилар учун ижодий энергия беради, замонавий ижтимоий тараққиётга мослашиб янги яратувчи кучга айланади.

Жамиятнинг ахлоқий қадриятлари ижтимоий тараққиётни механик йиғиндиси эмас, балки ахлоқий хаётнинг иккитомонлама (узлуклилик ва узлуксизлик) ва кўп томонлама (анъанларнинг синергетик хусусияти) ривожланиши атижасидир. Трансформациялар туфайли ахлоқий қадриятлар жамиятнинг “сақланиш қонуни” каби ўз анъаналарини давом эттириб, янги маданият ва қадриятларни эски билан биргаликда сақлаб, ўзлигидан бегоналаштирмасликка харакат қилади. Демак, ахлоқий анъаналар бир вақтни ўзида жамиятнинг мавжудлигини акс эттириб, миллий-этник, умуминсоний қадриятларини ягоналигини сақлайди ва ўз навбатида вақти вақти билан янги қадриятлар билан бойтиб бориб, эскиларини мазмунан янгиларига бириктириб бораверади. Буни ижодкорлик билан қиёслаш мумкин. Эски ва янгликнинг бирлиги бу - ижодиётда намоён бўлади.

Ижодкорлик оддий фаолиятдан тубдан фарқ қилади. Ўтмиш ахлоқий меросни ўзлаштирмасдан туриб ижодкорликни амалга ошириш имконсиздир. Ижодиёт сохлари (бадиий, илмий в.х) ўз ахлоқий анъаналари атрофида яратилиб, уни таннум қилади, юксак ахлоқий маданият белгиси сифатида кейинги авлод вакилларига кўрсатади. Ижодкорлик ўтмиш ва унинг анъаналарини кейинги, ёш авлодга етказиш, ўтмиш ахлоқий меросини жиддий ўзлаштириб ва ўз навбатида янгилик киритиш каби катта салохиятни билдиради. Ижодкор инсон ўз халқи анъаналарига содиқ қолган холда, ахлоқий маданиятидан четлашмаган холда ижобий позицияни белгилайди. Эзгулик ва ёвузликни англатувчи символик белги, анъанавий ёндашувни чуқур англаб ва замонавий муаммолар тимсолида маънавий қадрият яратилади. Биз ўтмишнинг маънавий меросидаги ахлоқий анъаналарини тадқиқ қилганимизда барча ижодкорларни ахлоқ хақидаги фикрлари, инсон ахлоқини ривожланиб бориши хақидаги ғоялари маълум анъанавий кетма-кетликка бўйсўнишига гувох бўламиз.

Бундан ташқари, анъаналар давомий ва узлуксизлик тушунчалари билан боғлиқ бўлиб, бу ижтимоий ходисала объективдир. Ўтмиш мероси консерватив назарий характерга эга бўлганлги билан, кейинги анъаналар янгилигига муосасиз муносабатда бўлади. Ахлоқий

\footnotetext{
${ }^{53}$ Яковлева Т.В. Традиции как модель системы моральной регуляции.// Вестник КЕМГУКИ 2012 с-118
} 
қадриятларни танқидий бахолаш, қайта кўриб чиқиш ва ўтмиш меросни замонавий мухитга мослаш бу трансформацион жараёнлардир. Агар узлуксизлик объектив бўлса, демак, хар бир янги даврнинг ахлоқий маданиятидаги одамларнинг хохишларидан қатьи назар, дастурлаштирилганда муқаррар равишда янги авлоднинг хулқ-атворига кирадиган таркибий қисмлар, шунингдек нафақат фойдасиз бўлиши мумкин, балки таркибий қисмлар хам ижтимоий тараққиёт учун зарарли бўлиши мумкин.

Шундай қилиб, ривожланиш нуқтаи-назаридан кўриб чиқилаётган маънавий мерос асрлар оша ўзгаришсиз қолмайди, балки хар қандай тарихий даврнинг ўз ахлоқий маданияти мавжуд ва у ўз ичига барча урф-одат, меросни олади ва яратади. Бугунги кунда яратилган ахлоқий қадриятлар, ахлоқий муносабатлар ўтмишдан ривожланиб келаётган меросни бир бўлаги бўлиб, ўтмишдан назарий ва амалий жихатларни қабул қилиб олган бу ижтимой тараққиётни намоён намоён қилади. Ахлоқий қадриятлар анъанаси, тизими диний қадриятлар билан чамбарчас боғланганлиги инсоният ўтмиши қанчалик ижтимоий вазиятларга бой бўлганлигини, тараққиёт босқичларидан мерос бўлиб бизгача етиб келганлиги бу ижтимоий фалсафий тахлил объекти сифатида майдонга чиқади.

Шундай қилиб, узлуксизлик янги авлодларга инсониятнинг ўтмиши томонидан яратилган энг яхши нарсаларни ўзлаштириш ва ривожлантиришга имкон беради. Янги шароитларда жамиятнинг ахлоқий қадриятларининг хилма-хиллигини бойитади. Кейинчалик биз ахлоқий анъаналарнинг асосий функцияларини шакллантиришимиз мумкин. Аввало шуни таъкидлаш керакки, табиийки, турли хил тарихий даврларда урф-одатларнинг функциялари таъсирининг чуқурлиги ва даражаси бир хил бўлмаган. Аммо улар шундай “ёзилмаган қонунлар” асосида кишилар яшаган, тартибни сақлаган, ижтимоий муносабаталарини давом эттирган.

Кишилик жамиятида оддий турмуш тарзида ахлоқий анъаналар бошқалари билан биргаликда пайдо бўлган ва маълум ижтимоий функцияларни бажарган. Бундай ижтимоий функцияларни маънавий қадриятлар деб таснифлаш мумкин. Одатий дунёқарашдан ўтиб, анъаналарда ифодаланган ижтимоий меъёрлар инсон ва одамлар жамоасининг хаттихаракатларини тартибга солувчи кучли восита бўлиб хизмат қилган. Инсон хаётида ахамиятли бўлган ва ахамияти жихатидан турли хил ижтимоий нормалар ёрдамида тартибга солинмайдиган фаолият деярли бўлмаган. Анъаналар худди шу ижтимоий харакатни амалга оширган. Бу ахлоқий анъаналар инсонни оилага, оилани жамоага, жаамоани жамиятга бирлаштирадиган ижтимоий “клей” ролини бажариб келиб, тарихий бурилиш палласида янги замон учун кўприк воситасини ўтаган.

Дархақиқат, маълум бир одат, маросимларини бажариш орқали кишилар ўзларининг хатти-харакатларини тартибга солишди ва фақат ушбу воқеага хос бўлган махсус нормаларга риоя қилишди. Бу вақтда улар бошқа фаолият билан шуғулланмаганлар, чунки бошқа харакатлар, одамларнинг хар хил хатти-харакати жамоатчилик фикри билан қораланган.

Анъаналар одамларнинг хулқ-атворини бошқариш орқали ўзига хос ижтимоий механизмини шакллантиради. Бундай тизим инсоннинг барча фазилатларини, унинг фикрлаш тарзини ва хулқ-атвор табиатини шакллантириш ва амалий равишда амалга оширишга фаол таъсир қилувчи ғоялар, қарашлар, принциплар, қадриятлар ва нормаларнинг бирлашмасидир.

\section{Фойдаланилган адабиётлар рўйхати}

1. Тейлор Э. Б. Миф и обряд в первобытной культуре. - Смоленск: Русич, 2000.

2. Яковлева Т.В. Традиции как модель системы моральной регуляции. // Вестник КЕМГУКИ. 2012. 


\title{
О ЧАСТОТНОСТИ УПОТРЕБЛЕНИЯ ОТДЕЛЬНЫХ ЗАИМСТВОВАННЫХ ЕДИНИЦ В РЕЧИ ПРЕДСТАВИТЕЛЕЙ СТАРШЕГО ПОКОЛЕНИЯ
}

\author{
С.А.Рузметов \\ (УрДУ, базовый докторант)
}

\begin{abstract}
Annotation: The paper considers the issue of the frequency of the use of certain borrowed units in the speech of representatives of the older generation. The materials of the study were videos posted on the website www.youtube.com and demonstrating the speech of representatives of the older generation (more than 60 informants-native Russian speakers). The article provides a detailed description of the identified 1,037 borrowings. For a detailed description of the frequency of the use of foreign words, a table is given, where the frequency of certain borrowings functioning in the speech of representatives of the older generation is compared with articles from the dictionary of O.N. Lyashevskaya, S.A. Sharov. As a result of the study, it was possible to establish that the most frequent borrowed unit in the speech of representatives of the older generation is the word «institute».
\end{abstract}

Key words and expressions: Frequency; a representative of the older generation; speech; borrowing; foreign language word; low frequency; comparison; dictionary entry.

По частотности употребления заимствований представителями старшего поколения можно дать общую характеристику их речи по поводу подбора иноязычных слов. При этом мы обратили внимание не на количество употребления заимствованного слова, а на количество информантов, в речи которых была обнаружена рассматриваемая единица. В целом, мы проанализировали речь более 60 информантов-носителей русского языка. Материалом исследования послужили ролики, размещенные на сайте www.youtube.com и демонстрирующие речь представителей старшего поколения. Нами всего было выявлено 1037 заимствований из разных языков, самые продуктивные из которых были помещены в Таблицу 1.

Итак, самой частотной заимствованной единицей в речи представителей старшего поколения оказалась институт (15 случаев). Как указывается в словаре, к концу ХХ века в художественном тексте у единицы частотность стала уменьшаться, а в публицистике, наоборот, более активизировался.

А мама приехала в Москву. Она окончила гимназию и начальные какие-то курсы в каком-то институте [https://www.youtube.com/ watch?v=Si3H7lz0xr8];

И бабушка, и дедушка окончили Плехановский институт [https://www.youtube.com/watch?v=2PcidcPxvyk];

В 1972 году окончил институm [https://www.youtube.com/ watch?v=qmLfW2WVcHA];

После того, как я закончил техникум, она [мать] заставила меня пойти в институт [https://www.youtube.com/watch?v=Dkyjrsr0aOQ].

Как видим, во всех примерах единица институт употреблена в значении выстее учебное заведение. Из пятнадцати представителей старшего поколения, употребивших данную единицу в речи, только один подразумевает значение совокупность норм права в какой-нибудь области общественных отношений, та или иная форма общественного устройства:

Финансовые институть начали сами создавать себя: из бумажек, которых мы называем деньгами, начали делать деньги... [https://www.youtube.com/watch?v=UJKkMe15X2E].

Таблища 1. Сравнение частотности отдельных заимствований, функиионируюших в речи представителей старшего поколения, с одноименной статьей из Частотного словаря современного русского языка О.Н. Лямевской, С.А. Шарова 


\begin{tabular}{|c|c|c|c|c|c|c|c|c|c|}
\hline \multirow{2}{*}{ 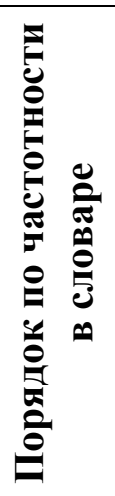 } & \multirow{2}{*}{ 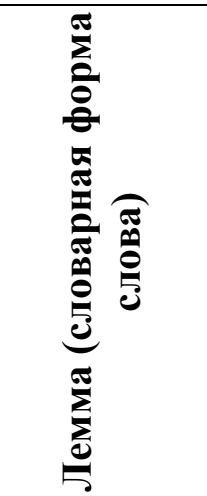 } & \multirow{2}{*}{ 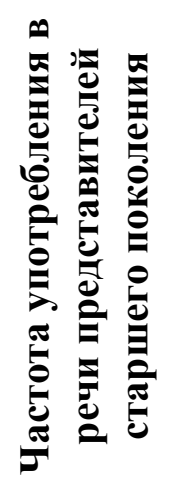 } & \multirow{2}{*}{ 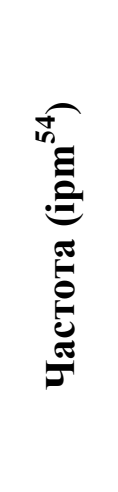 } & \multicolumn{3}{|c|}{$\begin{array}{c}\text { Художественная } \\
\text { литература }\end{array}$} & \multicolumn{3}{|c|}{ Публицистика } \\
\hline & & & & $\begin{array}{l}\frac{8}{8} \\
\frac{1}{1} \\
\text { ஜ̆ } \\
2\end{array}$ & $\frac{\stackrel{8}{\circ}}{\frac{8}{2}}$ & 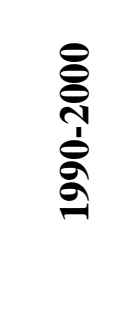 & $\begin{array}{l}\frac{8}{8} \\
\frac{1}{1} \\
\text { ஜ̆ } \\
2\end{array}$ & $\begin{array}{l}\stackrel{8}{\circ} \\
\frac{8}{\grave{\delta}} \\
\frac{\delta}{2}\end{array}$ & 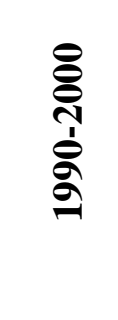 \\
\hline 475 & институт & 15 & 226.5 & 181.5 & 140.3 & 105.6 & 222.4 & 216.4 & 299.9 \\
\hline 187 & машина & 12 & 490.4 & 831.1 & 427.0 & 605.7 & 449.2 & 372.0 & 508.4 \\
\hline 599 & район & 12 & 187.8 & 92.7 & 96.8 & 69.3 & 409.1 & 271.8 & 271.2 \\
\hline 197 & проблема & 11 & 474.9 & 37.2 & 69.8 & 153.2 & 142.3 & 283.9 & 700.7 \\
\hline 315 & школа & 11 & 316.0 & 227.4 & 270.8 & 206.5 & 548.5 & 370.1 & 384.4 \\
\hline 350 & квартира & 10 & 290.9 & 162.0 & 298.9 & 447.5 & 280.2 & 280.3 & 303.5 \\
\hline 603 & класс & 10 & 185.8 & 150.3 & 198.2 & 117.9 & 220.9 & 198.5 & 183.1 \\
\hline 2198 & пенсия & 10 & 53.9 & 27.3 & 36.1 & 37.2 & 22.2 & 34.5 & 89.9 \\
\hline 602 & армия & 9 & 186.4 & 181.8 & 142.6 & 110.2 & 271.3 & 371.6 & 285.4 \\
\hline 449 & газета & 9 & 237.5 & 200.3 & 197.5 & 200.9 & 548.5 & 333.8 & 344.4 \\
\hline 1403 & фронт & 9 & 87.7 & 205.2 & 131.1 & 48.2 & 123.0 & 322.8 & 89.8 \\
\hline 1181 & этаж & 9 & 102.7 & 87.7 & 128.3 & 171.5 & 99.3 & 104.9 & 92.6 \\
\hline 329 & момент & 8 & 306.8 & 164.3 & 203.5 & 264.5 & 149.7 & 274.8 & 348.4 \\
\hline 839 & солдат & 8 & 142.2 & 296.9 & 288.0 & 157.2 & 155.7 & 191.9 & 128.0 \\
\hline
\end{tabular}

Значит, слово институт в речи представителей старшего поколения больше всего употребляется в первом и основном значении (высшее учебное заведение). Если бы было возможности проследить частотность употребительности в речи пожилых людей по показателю IPM (instances per million words), то это продемонстрировала бы более иную картину.

Менее частотными заимствованиями в речи представителей старшего поколения оказались следующие единицы:

- аппарат, министр, операция, организация, офищер, цฺентр (7 случаев);

- журнал,интернет, коллектив,компьютер,магазин,организм,партия, президент,принцип,система,университет, форма,цифрра, электронный(бслучае)

- активный,госпиталь,грамотный,группа, документ, идея, интересный, клуб, командир, культура, лекция, метр, нормальньй, период, пионер, программа, роль, ситуачия, танк, театр, телефон, техникум, фотография (5 случаев);

- альбом бизнес, бомба, газ, директор,журналист,инвалид, интеллигенция, информачия,карточка,коммунист,корпус,курс,лагерь,материал, материальный, медицина, национальнй, поликлиника, политика, практический, продукт, процесс, реакция, революиия, регион, секунда, стандарт, ттанция, темп, территория, тетрадь,техника,трагический,факт фашист, физический, фонд, чай, эксперимент (4 случая);

- администращия, альтернативный, аптека, арестовать, аспирантура, атмосфера, база, библиотека, библия, билет, биография, бригада, бухгалтер, вокзал, врач, глобальный , демобилизаиия, депутат, индивидуальный, инженер, интерес, картина, километр, кино, команда, комиссия, комментарий, коммунизм, консервативный, контролер, концерт, коридор, лаборатория, ликвидировать, линия, литература, медаль, металлургический,

\footnotetext{
${ }^{54}$ Общая частота слова, которая вычисляется путем установления количества употреблений на миллион слов, отсюда и сокращение ipm от «instances per million words». Это общепринятая в мировой практике единица измерения частотности.
} 
метод, метро, милиция, минута, музей, музыка, номер, олимпиада, перспектива, пионерский, план, плита, политический, портрет, пост, профессионал, психологический, пункт, репрессия, роман, спектакль, специалист,специальный,стадион, студент талантливый телевидение,телевизор,телеграмма,тенденщия, транспорт,факультет,фраза,функичия,характер,штаны,эвакуация, экономика, экскурсия, элемент, элита, эмоциональный, эпоха (3 случая).

Единиц, обнаруженных в речи менее трех представителей старшего поколения, мы не сочли необходимым включить в данный список из-за их низкочастотности. Для информации можно добавить, что по два раза было употреблено 162 единицы, остальные все выявленные - случаи единичные (697 единиц).

Таким образом, почти все заимствования, обнаруженные нами в речи представителей старшего поколения, по частотности употребления входят в разряд тысячи самых высокочастотных лексических единиц современного русского языка. Сюда не входят слова фронт, этаж, пенсия, которые по данным словаря [Ляшевская, Шаров 2009] отмечены как менее частотные. Но следует отметить, что и в художественном, и в публицистическом тексте слово пенсия приобретает высокую употребительность. Подобное можно сказать и в отношении данного слова в разговорной речи: в связи с активизацией вопросов социального характера, слово пенсия стала все чаще звучать и в разговорной речи, в частности, в речи представителей старшего поколения.

\section{Список использованной литературы}

1. Ляшевская О. Н., Шаров С. А. Частотный словарь современного русского языка (на материалах Национального корпуса русского языка). - М.: Азбуковник, 2009. - 1087 с. [URL: http://dict.ruslang.ru/freq.php?]

\section{ОИЛА ИНСТИТУТИНИ МУСТАХКАМЛАШДА МАЪНАВИЙ-АХЛОҚИЙ ҚАДРИЯТЛАРНИНГ УРНИ}

\section{Б.Ю.Сайилов \\ (Пайариқ туман 11-сон умумтаълим мактаб ўқитувчиси)}

Annotation: Ethnocultural and national institutions, lifestyles and national values, formed over the centuries, are involved in the vortex of globalization. The system of society-family-human relations, which reflects the existential existence of countries, people and people, in particular, the institution of family-marriage, is affected by global processes, the contradiction of change. On the one hand, the fact that marriage ceremonies as a factor of human self-preservation, reproduction has not lost its ontological and existential character, and on the other hand, the sharp decline in the number of formal marriages in today's world negative developments such as the official registration of same-sex marriages and the increasing diversity of family configurations indicate the relevance of research in this area.

Key words and expressions: Family, marriage, morals, values, rituals, customs, demographic transition.

Инсоннинг хаёти ва турмушида, айниқса, ёш авлоднинг камол топишида, ахлоқий вояга етишида оиланинг ўрни ва вазифаси беқиёсдир. Оилага хос анъаналар, қадриятлар, урф одатлар бола зуваласини шакллантиради. Энг мухими, фарзандлар оилавий хаёт мактаби орқали жамият талабларини англайди, хис этади. Халқимиз тарихига назар ташлайдиган бўлсак, энг қимматли анъаналар: халоллик, ростгўйлик, ор - номус, шарму - хаё, мехру оқибат, мехнатсеварлик каби барча инсоний фазилатлар энг аввало оилада шаклланган. Шундай экан, оила ва никох нима, уларнинг мохияти, мақсади ва ахамиятини билиш хар бир фуқаро, хар бир бўлажак мутахассис, ёш авлоддан тортиб кекса кишиларгача билиши зарур ва мухимдир. 
Қадрият - инсон ва инсоният учун ахамиятли бўлган барча нарсалар эркинлик, тинчлик, адолат, ижтимоий тенглик, маърифат, хақиқат, яхшилик, гўзаллик, моддий ва маънавий бойликлар, анъана, урф-одат ва бошқалар.

Муайян бир элат, миллат, халқнинг хаёти, турмуш тарзи, тили, маданияти, маънавияти, урф-одат ва анъаналари, ўтмиши ва келажаги билан боғлиқ қадриятлар миллий қадриятлардир. Инсон, унинг фаолияти, турмуш тарзи, эътиқоди, умр маъноси, одоби, гўзаллиги билан боғлиқ қадриятлар шахсий қадриятлардир. Қадриятлар комил инсонни тарбиялашда мухим омил бўлиб хизмат қилади.

“Авесто”да оила инсон саломатлиги, камолотининг манбаи, шунингдек муқаддас даргох сифатида қадрли эканлиги, оила барқарорлигида эр ва хотиннинг тенг даражада масъуллиги хақидаги илғор фикрлар баён этилган. Жумладан, асарнинг бош қахрамони Зарадуштранинг заминдаги энг мухтарам гўша қайси гўша?, - деган саволига яхшилик ва эзгуликлар худоси бўлмиш Ахура Мазда: “Агар инсон уй тиклаб, оловга ва оиласига, хотини ва фарзандларига, молларига ўрин ажратиб берса, ем-хашаги кўп бўлиб, чорваси ва итлари тўқ яшаса, уйида ноз-неъматлар мухайё бўлиб, хотини ва фарзандлари фаровон яшаса, уйида эътиқоди собит, олови алангали, бошқа нарсалари хам мўл-кўл бўлса, ўша манзил мухтарамдир" [Йўлдошев 1992:4], дейди.

“Авесто”да оила ва никохнинг инсоният келажаги учун, қолаверса, жамиятнинг ривожланиши учун нақадар мухимлигига алохида эътибор қаратилган. Йигит кишининг уйланиши, аёлнинг турмуш қуриб фарзанд тарбиялаши борасида мухим қарашларни кўришимиз мумкин. Унда айтилишича, “Эркак зурриёд қолдириш қобилиятига эга бўлса-ю, аммо уйланмаса, унга тамға босилар ёки белига занжир боғлаб юришга мажбур қилишган. Баъзан эркакни қопга солиб калтаклашган.

“Авесто”да қариндошларнинг ўзаро оила қуриши ман этилган. Қавм ва уруғ қони тоза, авлодни бенуқсон сақлаш учун шундай қилинган. Кўп фарзандли оилаларга муайян микдорда давлат томонидан нафақанинг берилиши, айниқса, эгизак фарзандли бўлган аёллар мукофотланишга лойиқлиги уқтирилади"

Форобий бахт тушунчасини кишиларнинг турмушдаги саодатга эришуви деб тушунади. Унингча, “Инсонийлик мохияти хақиқий бахт-саодатга эришув экан, инсон бу мақсадни ўзининг олий ғояси ва истагига айлантириб, бу йўлда барча имкониятлардан фойдаланса, у бахт-саодатга эришади" [Форобий 1993:188]. Алломанинг таъкидлашича, оила инсонни яхши хулқли, саховатли ва ақл-идрокли қилишда мухим рол ўйнайди. Инсон оиласиз ўз кўзлаган мақсадига эриша олмайди, деб таъкидлайди. Фаробий билимидан маърифатли етук одамнинг образини тасвирлар экан, бундай дейди: “Хар кимки илм хикматни ўрганмаган деса, уни ёшлигидан бошласин, соғ - саломатлиги яхши бўлсин, яхши ахлоқ ва одоби бўлсин, сўзининг уддасидан чиқсин, ёмон ишлардан сақланган бўлсин, барча қонун - қоидаларни билсин, билимдан ва нотиқ бўлсин, илмли ва доно кишиларни хурмат қилсин, илм ва ахли илмдан мол - дунёсини аямасин, барча реал моддий нарсалар тўғрисида билимга эга бўлсин".

Бу фикрлардан Фаробийнинг таълим - тарбияда ёшларни мукаммал инсон қилиб тарбиялашда хусусан, ақлий - ахлоқий тарбияда алохида эътибор берганлиги кўриниб турибди, унинг эътиқодича, билим, маърифат, албатта яхши ахлоқ билан безатмоғи лозим, акс холда кутилган мақсадга эришилмайди, бола етук бўлиб етишмайди.

“Алпомиш” достонини ўзбек халқининг кўхна никох маросимлари, урф-одатлари, ирим-сирими, таъбуларининг “қомуси” деб аташ мумкин. “Алпомиш” достонидаги қизнинг йигитга қўйган шартлари айнан қадимги никох маросимлари олдидан бўлиб ўтадиган урфодат кўринишидаги этнопсихологик ходисадир. Хозирги кунда хам Бухоро вилояти Ромитан, Жондор, Ғиждувон туманларида (2017 йил июнь-июль ойларида кузатилган), Самарқанд вилоятининг Нуробод, Пастдарғом, Иштихон туманларида (2017 йил сентябрь-октябрь ойларида кузатилган), Қашқадарё вилояти Чироқчи, Шахрисабз туманларида (2017 йил ноябрь-декабрь ойларида кузатилган) никох маросими вақтида қизнинг отаси бўлажак куёвга болта билан “ўтин-кунда” ёрдириш маросими мавжуд[Комилов 2019:76]. 
Қизнинг йигитга кўйган шартлари тадқиқотчиларнинг кўрсатишича [Примова 1999:3450], “никох" билан боғлиқ қадимий урф-одатларга, ижтимоий хаётдаги реал воқеа ва ходисаларга бориб тақалади. Шунингдек, баходир қиз хақидаги анъанавий тушунчаларнинг қадимий илдизлари матриархат даври турмуш тарзига оид реал муносабатлар билан хам боғлиқ. В.Вербицкийнинг ёзишича, тоғли олтойликларнинг қахрамонлик достонларида куёвнинг жасурлиги, чаққонлиги ва кучини синаб кўриш, келин билан куёв ўртасида бўладиган ўзаро рамзий беллашувларга оид маълумотлар келтирилган. Унинг фикрича, “байга” (пойга) баъзи бир олтой халқларида “тууй базми”, “тууй тантанаси” деган маъноларни англатган. Жумладан, “Алпомиш” достонининг олтой вариантида, никох шартларининг 3 та бўлганлиги келтириб ўтилади. Мусобақа шарти "кимнинг камон ўқи тўғри бориб тегади; кимнинг оти кучлироқ; кимнинг кучи кўпроқ”, яъни, “камондан ўқ ўзиш”, “пойга”, “кураш” шартлари тарзида ўз ифодасини топади.

Аслида, никох муносабатларига икки томонлама эътибор берилиши керак бўлган ўринлар хам мавжуд бўлган. Жумладан, йигит томонидан қиз танлашда, йигитнинг онаси, холаси ёки турмушга чиққан опаси мухим ўрин тутган. Бунда қизнинг ўз оиласидаги ўрни, яъни овқат тайёрлай олиши, нон ёпишни билиши, кийим-кечак тика олиши хамда қизнинг соғ-саломатлигига алохида эътибор берилган. Никох йигит ва қизнинг интим муносабатларини тартибга солмай, балки рузғор юмушлари, уй-рўзғор буюмларига эгалик қилиш, уй ўчоғининг оловини ўчирмаслик сингари ахлоқий шартларни хам қўйган.

Биз анъанавий оила турмуш маросимларида қадимий диний эътиқодларни 3 та гурухга ажратишимиз мумкин:

1. Фарзанд туғилиши ва бола тарбияси билан боғлиқ маросим ва урф-одатлар.

2. Никох туйи маросимидаги диний эътиқодлар.

3. Мотам маросимларида архаик диний этиқодлар.

Хар бир халқнинг бошқасидан ажратиб турувчи мухим белгиларидан бири унинг маросимлари хисобланиди. Маросим умум томонидан қабул қилинган рамзий харакатларга эга бўлган хаётий тадбирдир. Инсоният хаётининг мухим бурилиш нуқталари билан боғлиқ тарзда ўтказиладиган тадбирлар оилавий маросимлар деб юритилади.

Кишилар хаёт фаолияти билан боғлиқ анъаналар ижтимоий-сиёсий анъаналарга қараганда бирмунча мутаассиброқ, консервативроқдир. Туғилиш, никох ва ўлим билан боғлиқ маросимлар - бу наинки тафаккурга йўналтирилган, балки хиссиёт ва рух билан боғлиқ мухим босқичлардан иборат бўлиб, уларнинг кўплари келиб чиқиш асосларига кўра қадимий эътиқодлар ва диний қарашларга бориб тақалади.

\section{Фойдаланилган адабиётлар рўйхати}

1. Йўлдошев Ж., Хасанов С. Авестода ахлоқий-таълимий қарашлар. -Т.: Ўқитувчи, 1992.- Б. 4.

2. Форобий Абу Наср. Фозил одамлар шахри (Танланган асарлар): - Т.: Абдулла Қодирий номидаги халқ мероси нашриёти, 1993. - Б. 188.

3. Комилов Р.P. Ўзбек халқи никох маросимларининг генезиси ва эстетик эволюцияси // фалсафа (PhD)... дисс. -Т., 2019. -Б. 76

4. Примова Ф.А. Оилавий муносабатларни шакллантиришда миллий ва диний қадриятларнинг ўрни // Фалс. Фан. номз... дисс. -Т., 1999. -Б. 34-50 


\title{
ЖИСМОНИЙ ТАРБИЯ ВА СПОРТ БЎЙИЧА МАРКЕТОЛОГЛАРНИНГ КАСБИЙ ФАОЛИЯТИ ХУСУСИЯТЛАРИ
}

\section{Ж. А.Самадов \\ (СамДЧТИ ўқитувчиси)}

\begin{abstract}
Annotation: This article is about physical education and sports features of professional activity of marketers are covered.
\end{abstract}

Key words expressions: Sports marketers in the field of sports marketing, physical culture and sports, market economy, utilities.

Иқтисодий ўзгаришлар ва аралаш бозор иқтисодиётига ўтиш, жамиятнинг ахборотлаштириши шароитларида тадбиркорлик фаолиятида спорт маркетингини ташкил қилишни билиш катта ахамият касб этмоқда. Бу ихтиёрий ижтимоий-иқтисодий сохада фаолият юритадиган маркетологларни касбий тайёрлашга бўлган зарурият ва талабнинг кучайишига олиб келди.

Спорт маркетингига ўргатиш мутахасиссининг касбий таълимининг зарурий компонентасидир. Жисмоний тарбия ўқитувчилари учун спорт маркетингини ташкил қилиш билими, кўникмаси ва малакасини эгаллаш мухим хисобланади.

Мутахассисларни ташкилий, иқтисодий ва тадбиркорликка тайёрлаш жисмоний тарбия ва спорт ташкилотлари мутахассислари учун хам мухим хисобланади.

Мутахассиснинг малака талаблари ва махсус касбий таълим мазмунига бозор талабининг фаол таъсири шунда кўринадики, жисмоний тарбия-спорт фаолиятида анъанавий кўринишлардан ташқари хозирги кунда янги кўринишлар хам кириб келмоқда. Хозирда жисмоний тарбия ва спорт сохасида спорт маркетологлари, ташкилотчилар, тадбиркорлар кўп талаб қилинмоқда, анъанавий стандартларда эса бундай мутахассисликлар мавжуд эмас, ОТМ базавий курси етарлича тайёргарликка эга эмас.

Юқорида келтирилганлар, Ўзбекистонда шу мутахассисликлар бўйича талабаларни тайёрлаш учун асосий сабаб бўлади. Чунки ОТМ лар учун спорт маркетологларини тайёрлаш янги йўналиш хисобланиб, кўрсатилган мутахассислик бўйича ўқув жараёнини ташкиллаштириш учун хорижий тажрибаларни ўрганиш ва жорий этиш фойдали бўлар эди.

Берилган муаммо бўйича материалларни умумлаштириш шуни кўрсатадики, спорт маркетологи касб фаолияти сифатида шакллангандан кейин охирги 20 йил давомида тубдан ўзгарган - спорт маркетологи касбга айланиши унинг ривожланиш сохасида табиий жараён хисобланади.

Университетларда ўқув дастурларининг киритилиши ушбу соха касбий тайёргарлигининг заруриятини кўрсатади.

Ғарб давлатларига таққослаганда, Ўзбекистонда спорт маркетингини ривожлантириш бир қанча муаммоларга дуч келмокда. Мутахасисларнинг фикрига кўра, бу муаммолар сифатида қуйидагиларни келтириш мумкин:

- аниқ соха бўйича маркетолог мутахассисларида таълим дастури ё мос назарий билимлар хисобга олинмаган амалий кўникма ва малакага, ёки амалий кўникмаларни шакллантириш хисобга олинмаган назарий билимларга йўналтирилган;

- ОТМларда жисмоний тарбия таълими амалиётида талабалар асосан педагогик тайёрланишга йўналтирилган, бу эса уларнинг кейинчалик замонавий спорт маркетинги принципларига асосланган бозор иқтисодиёти тизимида маркетолог фаолияти билан шуғулланишига қийинчилик туғдиради;

Юқоридаги муаммолар ва камчиликларга қарамасдан Ўзбекистон Давлат жисмоний тарбия университетида дипломли спорт маркетологларини тайёрлашни бошлаб юборишди.

Педагогик ва спорт маркетинги таълимининг бирлаштирилган асосий ёндашуви талабанинг ўзи томонидан натижаси яратилган материални тушуниш ва билиш жараёнида талабанинг фаол иштирокига йўналтирилган дастурни амалга ошириш шакли хисобланади; талабалар ўкув амалиёти доирасида фан бўлимлари ва мавзулари бўйича амалий 
топшириқларни яратишади ва уларни спорт маркетинги асослари бўйича педагогик принципларни қўллаган холда машғулотларда мустақил ўтишади.

Спорт маркетинги мутахассислиги бўйича талабаларнинг амалиёти спорт ташкилотлари хамда маркетинг сохасида ютуқларга эришган тижорат ташкилотларида ўтказилиши назарда тутилади. Унинг дастурига рахбарларнинг муносабатини ёмонлаштирмайдиган ахборотларни йиғиш методлари киритилган. У фаолиятнинг қуйи даражасида маркетолог сифатида аниқ ишларни мустақил бажаришини назарда тутади.

Жисмоний тарбия ва спортни халқ хўжалигининг алохида сохасига ажратиш моддий база билан боғланган ва шу билан биргаликда жисмоний тарбия-соғломлаштириш хизматларини етказиб берувчи сифатида кўриладиган махсулотнинг асосий кўринишини ифодалайди. Хозирда бу сохага нафақат жисмоний тарбия-спорт хизматларини кўрсатувчи ташкилотлар, балки шундай хизматларни кўрсатиш учун ижтимоий-иқтисодий шартларни яратувчи муассасалар, жумладан спорт товарларини тайёрловчи корхоналар, коммунал хўжалик корхоналари, тиббиёт муассасалари, жисмоний тарбия ва спорт бўйича мутахассислар тайёрловчи ўқув муассасалари киради.

Жисмоний тарбия ва спорт тизими доирасида мос равишда микро- ва макроиқтисодий жараёнларни хам кўриб чиқиш керак. Охирги холда гап жисмоний тарбия ва спортнинг иқтисодиёт доирасида бошқа сохалар билан алоқаси хақида кетмокда, яъни жисмоний тарбия ва спорт сохасида иқтисодий фаолиятни макроиқтисодий тартиблаш - инвестицион жараённи шакллантириш, ишлаб чиқариш қувватларининг эскиришини енгиб ўтиш, нархларни яхшилаш ва солиқ тизими хақида.

Жисмоний тарбия ва спорт бўйича маркетологнинг техник малакаси иш фаолияти давомида умумий ва ўзига хос характерга эга бўлган турли методлар, процедура ва техникаларни қўллашни билиши лозимлигини кўрсатади. Умумий техник малакага “маркетологнинг молиявий билими” (бюджет ва сметани ишлаб чиқиш, молиявий хисоботларни тайёрлаш ва ш.ў.) ни киритиш мумкин. Бу маркетлог ишлаётган ташкилот фаолиятига боғлиқ эмас.

Маркетологлар иш жараёнини тубдан билиш ва кутилаётган ходисаларни аниқлашни кўра билиши керак. Шу сифат ёрдамида у муайян (саноат, сиёсат, иқтисодий ва ижтимоий) холатнинг ўзгаришига боғлиқ холда бутун муносабатнинг ўзгаришини олдиндан кўра билади. Юқорида кўрсатилган малакаларга эга бўлган ва уларни бир-бири билан боғлай олган мутахассис спорт маркетинги сохасида муваффақиятли фаолият юритиши мумкин.

\section{Фойдаланилган адабиётлар рўйхати}

1. “Жисмоний тарбия ва оммавий спортни янада ривожлантириш чора- тадбирлари тўғрисида" ПК-3031-сон қарори Тошкент ш., 2017 йил 3 июнь.

2. Кутепов М.Е. Маркетинг в зарубежном спорте. -М.:1993.

3. Veblen T. Theory of the leisure class. T.Veblen-N.Y. 1989.

4. Котлер Ф., Боуэн Дж., Мейкенз Дж. Как удовлетворить клиента качеством предоставляемых товаров и услуг // Маркетинг. Гостеприимство и туризм: чебник для вузов / Пер. с англ. под ред. Р.Б. Ноздревой - М.: ЮНИТИ, 1998.

\section{СИМВОЛИКА ЦВЕТОВ В КИТАЙСКОЙ КУЛЬТУРЕ}

К. Е. Пак

(СамГИИЯ, преподаватель)

Annotation: China is known for its rich culture and centuries-old history. Since ancient times, the Chinese have attached importance to everything around them. The Chinese pay special attention to the symbolism of color, each of which has a hidden meaning. this article is devoted to the study of the uniqueness of color symbolism in the Chinese language. In Chinese, as in other languages of the world, there are many "color" words that reflect not only the national culture, but 
also convey the emotional feelings and experiences of a person, form a special idea of the life of the people and the language as a whole. The study of color symbols will allow you to learn more about the life and culture of the Chinese people and the specifics of the Chinese language.

Key words and expressions: Color, color symbolism, culture, Chinese language

Система цветообозначения представляет собой культурномаркированную ценность нации и часть её культурного наследия. Её формирование тесно связано с разными функциональными свойствами предметов и явлений внешнего мира, с самим восприятием человеком окружающего мира [吴国华 1996., 17].

В языковой картине мира цветовые слова не только рассматриваются как вид информации, который стоит в одном семантическом ряду «цвет - информация - эмоция», но и являются мощным средством эмоционального воздействия на человека, сильно влияют на культуру нации [Комлев 2003].

Все «десять тысяч вещей» в природе имеют свой цвет. В реальной жизни мы встречаем огромное количество цветов и их оттенков. В китайском языке, как и в других языках, слово, обозначающее цвет может вызвать самые различные эмоции и ассоциации. Помимо этого, цветовые слова являются отражением богатой китайской культуры, которая в процессе своего становления менялась и впитывала весь национальный колорит.

С древнейших времен во многих культурах мира цвет постепенно стал приобретать символическое значение и был тесно связан с религией того или иного народа. Издревле люди вкладывали определенный смысл в определенный цвет. Таким образом цветосимволика становится одним из мощнейших средств эмоционального воздействия на человека и является отображением культуры народа.

Цвет несет в себе важную информацию о чувствах и эмоциях. Восприятие цвета в разных культурах может вызывать разные социально религиозные ассоциации [Базыма 2005]. Поэтому у каждого народа имеется свой традиционный национальный цвет, любовь к которому выражается в обычаях и традициях.

Цветовую символику в культуре Китая рассматривают, опираясь на систему пяти элементов под названием 五行 «У Син», что означает «пять движений». Так китайцы разделяют мир на пять его составляющих элементов: дерево, огонь, металл, воду и землю. Каждый из этих элементов является неотъемлемой частью жизненных процессов, происходящих в организме человека и во вселенной. Цвета так же являются частью этой системы. Этипять цветовсчитаются «светлыми, чистыми», а все остальные представляют собой смешение пяти базовых цветов. Китайцы называют такие цвета «смешанными». «Чистые цвета» означают верность традиции, постоянство и благородство, в то время как «смешанные цвета» считаются вульгарными и даже низкопробными. Так, в Древнем Китае по цвету женской одежды можно было определить, кто из женщин является супругой, а кто наложницей. Согласно установлениям, женам следовало надевать одежду только «чистых цветов», а наложницам разрешалось носить наряды «смешанных цветов».

Желтый 黄 («Хуан»), цвет женского начала Инь, символизирует центр мира собственно, сам Китай. Он считается атрибутом императорской фамилии, что подтверждается цветом крыш Запретного города в Пекине, как указывает в своих исследованиях Соколов В. Желтый цвет- обозначает элемент Земли, которая обладает свойствами плодородия. Так же желтый цвет считается цветом осени. Река, протекающая на территории Китая, где зародилась древнейшая китайская цивилизация носит название Желтая река.

Самым любимым цветом китайского народа является 红色 hongse (красный цвет). В Китае этот цвет считается благородным, символизирующим процветание, успех, радость, красоту и счастливую судьбу. Поэтому в Китае торжественные радостные события чаще всего связываются с красным цветом. Праздники также связывают с этим цветом. К примеру китайский Новый год - Праздник Весны или Весенний фестивальпразднуется весь в красной атмосфере: 红灯楼 hongdenglou (красные фонари), 红蜡烛 honglazhu (красные 
свечи), 红对联 hongduilian(красные новогодние парные надписи), 红福字 hongfuzi (красный иероглиф «счастье»); многие женщины одеваются во все красное, так называемое 红装 hongZhuang(красный пышный наряд), носят на голове красные цветы из бархата или шелка и другие аксессуары. В китайском языке распространена такая фраза, как 红红火活过日子 honghonghuohuoguorizi(радостно и счастливо прожить жизнь). Согласно китайской философии, любовь и брак тесно связаны с жизнью и плодородием, в связи с этим вся свадьба сопровождается красным цветом.

Белый цвет 白(«Бай») олицетворяет запад - место, где царят хаос и гибель всего живого. Этот цвет очень противоречив: он указывает на состояние - холод («горячий суп легко растопит белый снег»), обозначает один из элементов - металл (символ начинающегося упадка от Ян к Инь) и ассоциируется одновременно с вероломством и чистотой. Символичным животным запада является Белый тигр Байху, властелин дня, который с одной стороны - владыка губительного для человека мира, с другой - хранитель людей от злых сил, страж страны мертвых. Традиционно белый цвет в Китае означает траур. Если на западе во время траура люди облачаются в черное одеяние, то в Китае наоборот, белые цветы, белые туфли и одежду белого цвета носят в дни траура. Например, фразеологизмом «белое дело» в Китае обозначают похороны.

Черный цвет 黑(«Хэй») в китайской цветовой символике обозначает север, с ним связывают все сокровенное и таинственное, он несет в себе смысловой оттенок смерти и зимы. Элементом этого цвета является вода, обладающая свойствами текучести и прохлады. Черное и белое всегда выступают в паре Инь и Ян как «Белые горы и Черная река».

Зелёный цвет 青 («Цзин») олицетворяет восток. В китайском языке зеленый цвет символизирует природу и плодородие. Элементомзеленого цвета является дерево. Данный цвет ассоциируется с рождением новой жизни, с весной. Следует заметить, что зеленый цвет в различных культурах воспринимается по-разному. Китайцы вкладывают своеобразный смысл в значение данного цвета. Так, например, в китайском языке слово зеленый может означать супружескую измену.

Синий цвет 蓝(«Лан»), как и во многих других культурах мира является символом Неба. Поэтому храм Неба в Пекине покрыт черепицей цвета небесной лазури, и такого же цвета одежда на сановниках, участвующих в поклонении Небу.

Таким образом, в китайском языке существует символика цвета, которая находит отражение в словах, обозначающих цвет. Данные слова, отображают культурные ценности народа и содержат в себе компоненты отражающие национальную специфику. Изучая цветовую символику можно глубже узнать о её особенностях и значении в культуре Китая.

\section{Список использованной литературы}

1. Базыма Б.А. Психология цвета. Теория и практика., Речь 2005, 205 с.

2. 吴国华 Культурная лексикология, Харбин. 1996, 330 с.

3. Комлев Н.Г. Компоненты содержательной культуры слова., Едиториал 2003, 192 с.

4. 言国敦。中国文化概念。天津南开大学出版社 2000, 303

5. studychinese.ru

6. baidu.com

\section{ЁШЛАРДА АХЛОҚИЙ-ЭСТЕТИК ИММУНИТЕТНИ ШАКЛЛАНТИРИШДА САВОДХОНЛИК МАСАЛАСИ}

\section{Д. И. Худайкулов (СамДУ мустақил тадқиқотчиси)}

Annotation: The role of literacy in human life, the role of reading in raising literacy, the definition and sources of youth literacy on the basis of modern criteria, the application of traditional and modern principles, forms and methods of reading to further develop the culture of 
reading in young people's lives. the ability to apply new methods, taking into account the specifics of the information society.

Key words and expressions: Literacy, writing, reading, written and oral creativity, youth education.

Дунё ижтимоий-тарихий тараққиётида авлодлар алмашинуви маълум даврда ўз изини қолдириб келади. Кекса авлод ёш авлод тарбиси билан шуғулланиб, ўзига хос миллий тарбия моделини, дидактикага асосланган маънавий меросни, ёзма ва оғзаки ижод намуналарини яратишади. Ёшларни миллий-ахлоқий намуналар билан қуроллантириб, махсус иммуниетини шакллантириш асосан китоб махсулоти, халқ ижоди (овзаки ва ёзма) намуналари, анъанавий давом этиб келаётган савод чиқариш маданияти орқали амалга оширилган.

Саводхонлик тушунчаси (қадимги юнон тилида "grammata" сўзидан олинган) оғзаки ва ёзма манбаларни алифбода акс эттириш ва шу манбалардан маъноларни ажратиб олиш каби тушунчаларни қамраб олади. ЮНЕСКОнинг 1958 йил Парижда бўлиб ўтган конференциясида саводхонлик тушунчасини дунёда классик маъносини аниқлаш мақсадида махсус таърифи яратилган. Шу сабабли хам хар йили 8 сентябрда Халқаро саводхонлик куни (International Literacy Day) нишонланади [1]. Яъни саводхонлик бу - ўз фикрини адабий тил нормаларига (грамматик, стилистик, орфоэпик) мувофиқ оғзаки ва ёзма равишда ифодалаш қобилиятидир. Ёзувни ихтиро қилиниши саводхонлик бўйича инқилобни юзага келтириб, халқлар маълум белиги, символ ва иероглифларда ў ёзувларини яратдилар. Сопол, дарахт пўстлоғларида ўз кечинмалари, олам хақида қарашлари, хисоб-китоб ишларини қайд қилиб борганлар. Умуман саводхонлик субъектнинг маданий сифати бўлиб, ўз эркинлигини ёзма ва оғзаки намоён қилиши, жамият ва шахс ўртасидаги маданий муносабатларни юзага келиши ва кундалик хаётда уларни қўллай билиши билан асосланади.

Саводхонликни ёзувни кашф этиш билан боғлаш, ёзма манбалар билан боғлаш бир ёқлама қараш хисобланади. Саводхонлик фикрлар хилма-хиллиги, оғзаки ижодни ривожланиши, халқ мақол ва асотирларини пайдо бўлиши билан боғлиқ ижтимоий-маданий вазифаларни бажариб келган. Дастлаб саводхонлик диний матнларни билиб, уни амалиётга қўллай билган инсонга, оғзаки ижодга асосланган, ёдлаш, хотира кучига таянган кишиларга нисбатан айтилган.

Классик давр, аниқроғи ўрта асрларда санъатда дунёни хиссий идрок қилиш йўналишларини ажратиш, фазовий ва вақтли санъатнинг дифференциацияси ва ихтисослашуви амалга оширилди. Санъатнинг янги турлари, жанрлари, янги мусиқа асбоблари яратилди. Санъат, илм-фандаги намойишкоронлик саводхонликни янги шаклларини тақдим қилди. Европада янги миллий адабий тил, шеърият тили, илм-фанинг универсал рамзий белгилари, фанни математик тили ривожлантирилди. Натижада саводхонлик ёзиш ва ўқиш каби тушунчадан визуаллик, мусиқийлик ва бошқа инсон эстетик дидини англатувчи шакллари пайдо бўлди. Бироқ, саводхонлик турли даражада, турли ижтимоий қатламларда турли талабларга эга бўлган. Жамиятнинг сиёсий элита, зиёли қатламлари ва омманинг саводхонлиги борасида бир қанча фарқлар мавжуд бўлган. Масалан, “ўрта аср зиёлилари (рухонийлар, докторлар, хукуқщунослар) учун лотин тилини билиш бу ўрта асрлар саводхонлигининг асослари талабидан бири бўлган. Лотин тили ўрта асрларда Европа маданиятининг ягона интеллектуал, ахборотли маконини ташкил этган” [2; Ле Гофф, 2005]. Ўша даврларда саводхонлик жамиятнинг маданий жараёнларни фақат битта сегментда - фақат интеллектуал элитада тасвирлаб берадиган ва саводхонлик тушунчасининг семантикасида ўқиш ва ёзиш қобилияти тўлиқ акс эттирилган.

Анъанавий жамиятларда ижтимоийлаштириш саводхонлик тартибида эмас, балки бошқа йўллар билан: ижтимоий тажрибани авлоддан авлодга тўғридан-тўғри етказиш (хунармандчилик, дехққонилк ва хуоказоларни тайёрлаш), халқ оғзаки фольклор ёки муқаддас анъаналар, маросимлар ва одатлар, шунингдек. ижтимоий ахамиятга эга тадбирлар ва байрамларда биргаликда иштирок этиш йўли билан етказиб турилган. 
Ғарбда саводхонликни асосан икки давр - классик ва модерн даврларга бўлиб ўрганилиш хам урф бўлган[4; Маклюэн М. 2005]. Яъни классик даврда дунёни хис қилишнинг турли (немис, инглиз, француз каби миллий) йўналишлари кашф қилиниб, санъатни ифодалаш, эстетик муносабатини шакллантириш ва ривожлантириш технологиясини вужудга келтиргани билан ажаралиб туради.

Ғарбда Шаркдан кўра саводхонлик даври эволюциясини тезлашганини, янги кўринишга ўтаётганини кўриш мумкин. Юқоридаги фикрлардан хулоса қилиб айтиш мумкинки, кашф қилинган ёзув, қоғоз, китоб ва китоб мутоааласи даври бир бутун инсоният саводхонлик даврини қамраб олинса, саводхонликдан кейинги (post-literacy) даври - айтиш мумкинки, бу виртуал фазони кенгайиши, визуал ахборотни кўпайиши ва сенсор мутолаани фаоллашган даврни англатади. Бизнинг фикримизча, саводхонликдан кейинги давр яъни янги авлод саводхонлиги даври узлуксиз таълим тизими ислох қилиниши натижасида янги пайдо бўладиган таълим тизими институтлари, электрон маконлари (портал, платформа), таълим технологиялари (интер актив онлайн ва офлайн ахборот узатиш), мутоллани сенсорларга кўчиши (виртуал фазода горизонтал ва вертикал уққиш имкониятлари) даврини асослайди.

Ғарб тадқиқотчидаридан бири Алан Рожернинг фикрича, “...саводхонликдан кейинги давр атамасини ўз муаммоларини қамраб оладиган мукаммал атама хисобланмайди. Аммо ушбу атама билан ўз даврини кишилар маданиятини энг яхши таърифланган, тасвирлаган атама сифатида сифатида тассурот қолдиради. Бу ўқиш ва ёзиш қобилиятига эга, саводсизлигини енгиб ўтган ва ўқиш қобилиятини мустахкамлаган ва шахс сифатида ривожланган ёши катталар учун хосдирдир. Унинг фикрича, саводхонликдан кейинги концепция “узлуксиз таълим”ни қамарб олиши керак” [5; Rogers A.1994]. Саводхонликдан кейинги таълим шаклида ёши катталарнинг янгича саводини ошириш ишларини хам қамраб олмоқда. Бу айниқса, ривожланган Осиё давлатлари таълим тизимида акс этиб бормоқда. Шунинг учун хозирги пайтда саводхонлик кейинги давр хақидаги кўплаб муаммоли мақолалар, илмий ишлар қилинмоқда [3; Jerry van Wyk \& Liezel Frick.2015].

Хозирги кунда саводхонлик манбалари хотирага (табиий ва сунъий хотира), маданиятга (диний, ахлоқ̧ий, санъат, техника ва технология, ижтимоий, сиёсий, хукуқұий), турмуш тарзига (совлиқни сақлаш, молиявий иш юритиш, бизнес, турмушни эстетикаси) хос жихатларни қамраб олмоқда. Саводхонлик манбалари ва саводхонликдан кейинги даврнинг омиллари, объекти, субъекти, функционал ва институционал ўзгаришлари эволюцион тарзда ривожланиб келган. Хулоса қилиб айтиш мумкинки, бундай маданий-тарихий эволюцион давр бир қатор хусусиятлари билан характерланади:

биринчидан, саводли киши ёки саводхонликнинг хар бир тарихий даврга хос талқини мавжуд бўлиб, ягона цивилизация ва маданиятда, бир вақтнинг ўзида турли кўринишларда, яъни саводхонликдан кейинги давр, мультимедиа саводхонлиги даври, медиа саводхонлиги каби акторларга бўлиниши мумкин;

иккинчидан, саводхонликнинг хам турли сохаларга бўлиб ўрганиш хам мумкин: а) тил, нутқ сохалари: кўп тилни билиш, фанлараро метатилни билиш қобилияти, визуал эстетикани тушуниш, теле-радиони тушуниш, ОАВ тилини билиш ва бошқалар; б) ижтимоий сохалар: ахборот олиш ва тарқатиш, умумахлоқни англаш, экологик вазиятни билиш, сиёсий, хукуқий, иқтисодий ва хкларни пухта ўзлаштириш;

учинчидан, саводхонликни билдирувчи учун турли хил манбалар: китоб махсулотига муносабат, мутолаа маданияти, кино махсулоти жанрлари, рақс турлари, архитектура ансамбли, статистика, электротехника, комьпютер дасутрлари билан ишлашни билиши, мобил иловаларни тушуниш, СМС-хабар, пост, блог, ММС хабари ва бошқа ижтимоий тармоқлар билан ишлаш копитенциясига бўлиш;

турртинчидан, мустақил нодавлат ташкилотни ташкил қила олиш, маданий тадбирларда доимий иштирок этиш, ўз саводхонлигини нутқида, ёзма ижодида, хат ёза олишида кўрсатиш, ёшлар уюшмаси ёки бирор ташкилотни ривожлантириш учун креатив фикрларни илгари сура олиш хозирги давр саводхонлигини акс эттиради; 
бешинчидан, ёшларни хозирги давр мезонидан келиб чиқиб саводхонлигини белгилаш ва манбаларини мутолаадан ташқаридан излаш маълум маънода ахлоқий ва эстетик иммунитетини сусайтиради. Бугунги кунда ёшларнинг саводхонлигини нафақат замонавий омилар, балки ўтмиш маънавиятини англатадиган меросларни билиш ва мутолаа қилиш, қадриятларга содиқлик белгилари хам асосий ўрин эгаллайди.

\section{Фойдаланилган адабиётлар рўйхати}

1. http://uchildiz.uz/саводхонлик-дунё-муаммоси/

2. Ле Гофф Ж. Цивилизация Средневековогосредневекового Запада. Екатеринбург, 2005. C-47.

3. Jerry van Wyk \& Liezel Frick. The post-literacy perceptions of newly literate adult learners at a rural community learning centre// Per Linguam 2015 http://dx.doi.org/10.5785/30-3565

4. Маклюэн М. Галактика Гутенберга: становление человека печатающего. Москва, 2005. C. 6-10.

5. Rogers A. Using literacy - A new approach to post-literacy materials // Education Research Paper. 1994. № 10. P. 57.

\section{ЕШЛАРДА ЭСТЕТИК МАДАНИЯТНИ ШАКЛЛАНТИРИШДА МИЛЛИЙ- ЭТНОМАДАНИЙ КАДРИЯТНИНГ ЎРНИ}

\section{С. А. Яхяева}

(СамДУ мустақил тадқиқотчиси)

Annotation: The article reflects the development of aesthetic culture of young people, their modern manifestation in the system of national values. It provides a philosophical and aesthetic analysis of the impact of modern values on the aesthetic culture of young people, the relationship of traditions and ceremonies in society to national thinking.

Key words and expression: Asthetic culture, spirituality, values, philosophy, politics, ideology, state, aesthetic consciousness, moral ideal.

Хар бир давр ижтимоий мухити хаётда бўлаётган ўзгаришларни ёшларнинг ахлоқийэстетик тарбиясига сингиб, жамиятимизнинг юксак маънавий-эстетик маданиятга эришиши ўтмиш этномаданияти билан узвий равишда ривожланиб боради. Бунда аждодларимиз томонидан асрлар давомида яратиб келинган миллий қадриятлар, оилавий анъаналар, этномаданият намуналари мухим ахамият касб этади. Ўзбекистонда ижтимоий-маънавий ва ахлоқий хаётни демократлаштириш жараёни бораётган бир пайтда миллий-этномаданий меросимизни ёшларнинг эстетик дунёқарашига сингдириш, умуминсоний қадриятларни хурмат қилишга ўргатиш, маънавий мерос ва тарихимизни чуқур билишига доир миллий ғояни тарғиб этишлари бугунги кунда долзарб саналади. "Ўзбек этномаданиятидаги умуминсонийлик энг аввало ундаги инсонпарварлик ғояларида, ушбу ғояларни бадиийэстетик воситалар ва усуллар билан ифодаланишида намоён бўлади. Инсонни, ундаги гўзал қиёфа ва фазилатларни улуғлаш, унда келажакка умид билан қараш ибратли ахлоқий-эстетик қадриятлардир" [Нишонова О. 2016. 47].

Жамиятда эстетик маданиятнинг миллий-этномаданий жихатларини давр нуқтаи назаридан ўрганиш ёшлар камолоти билан боғлиқ тарзда янгича талабларни хам қуймоқда. Ёшларда хар қачонгидан кўра кўпроқ ички ва ташқи эстетик маданиятни кучайтириш, унинг ахлоқ билан бирлашувига эришиш долзарб ахамият касб этади. Улардаги фақат ташқи кўринишдан эстетик маданиятнинг яхши бўлишига олиб келмаслиги, балки ички жихатдан хам ахлоқан покиза, маънавий дунёси бой, саховатли, иймонли, муомала маданияти юксак бўлиш каби умуминсоний ахлоқий қадриятлар хам талаб этилади.

Бу жихатдан ота-боболаримизнинг этномаданий тафаккурида шаклланган «Хусн тўйда, ақл кунда керак», деган иборалар барчамиз учун ибратлидир. Дархақиқат, ақл-фаросатдан, 
инсоний ахлоқ ва фазилатлардан махрум бўлган ёшлар хеч қачон юксак қадриятлар тимсоли бўла олмайди. Бундай холатларнинг вужудга келмаслиги учун доимо махаллаларда, таълим масканларида юксак этонмаданий меросимизни тарғиб этишимиз лозим. Хар қандай “жамиятда хукм сураётган ахлоқий мезонларга мос равишда маънавий қадриятлар узоқ вақт давомида сайқалланиб, ривожланиб борган. Қадим даврлардан бошлаб умуминсоний хамда миллий қадриятларга риоя этиш миллатни юксакликка кўтарган, жамиятнинг илдам ривожланишига туртки бўлган” [Эргашев Б., Шарипов М., Жакбаров М. 2002. 25]. Мана шу жараёнда ўзбек халқининг хам ўзига хос этномаданий жараёнлари миллий тафаккур билан диалектик боғлиқликда, турли этник гурухларнинг ўзаро алоқалари асосида шаклланган ва уларни айни дамда бир-биридан ажратиб ташлашнинг иложи йўқ. Халқ, элат ва миллатлар ўз этномаданиятларини яратаркан, бундай ривожланиш ўз навбатида мавжуд этномаданиятнинг уларни янгиланиш жараёнига ўз таъсирини ўтказади ва миллий-этномаданий бирликнинг вужудга келишига олиб келади. Шу боисдан, “этник ва миллатларро муносабатларнинг ижтимоий-сиёсий ва ғоявий жихатдан одилона хал қилиниши энг аввало, хар бир мамлакат ижтимоий-сисий барқарорлиги ва миллий хавфсизлигини таъминлашда асосий омиллардан бири бўлиб хизмат қилади" [Сафарова Н. 2006. 73].

Ўзбекистонда қадимдан шаклланиб келган миллий ва этник жараёнлар бугунги кунда хам ўзининг қадр-қимматини сақлаб келмоқда ва Марказий Осиё худудида ўзига хос этномаданиятни вужудга келтирган. Бу борада давлатимиз рахбари ўзининг фикрларини билдирар эканлар, “Бизнинг минтақамиз халқларини минг йиллик қардошлик ва яхши кўшничилик ришталари боғлаб туради. Бизни тарих, дин, умумий маданият ва анъаналар бирлаштиради” [Мирзиёев Ш. 2018. 264], деб таъкидлайдилар. Бундай азалий ришталар миллий-этномадиний бирликларнинг мутахкамланишига, шу худудда яшаётган турли этносларнинг асрлар давомида эъзозланган диний ва дунёвий ғояларини инновацион тарзда ривожланишига кенг имкониятларни очиб беради. Шу боисдан Ўзбекистон барча сохаларда ислохотларни Марказий Осиё ва жахонда изчиллик билан йўлга кўйган.

Жамиятда эстетик маданиятнинг миллий-этномаданий жихатлари турли этник гурухларнинг муайян маданиятларни биргаликда ривожлантиришида янгиланиб боради. Мана шундай жараёнлар қуйидагиларда акс этади:

-муайян жамиятда яшаётган турли миллат ва элатларнинг бир мақсад йўлида бирлашиб, шу асосда халқнинг, жумладан ёшларнинг ахлоқий-эстетик идеалларини ўтмиш тарихий-маданий мерос билан бойитиши, миллий қадриятларини замон билан хамнафас ривожлантиришида намоён бўлади;

- бирор худуд ахолисининг этник жихатдан кўпчиликни ташкил этишига қарамасдан, шу жойда бошқа миллат ва элатларнинг урф-одатлари, анъаналари, маданияти ва қадриятларини хурмат қилиши хамда жамиятда барчанинг хақ-хуқуқлари тенг қўйилиши асосида миллий-этномаданий омилларнинг эркин амалга ошишига асосланади;

- жамиятда соғлом турмуш тарзини шакллантиришга қаратилган эстетик дунёқараш ривожида ёшларнинг бағрикенглик маданиятига алохида эътибор қаратиш ва улардан туғилиб ўсган юртга нисбатан юксак умуминсоний туйғуларнинг камол топганлиги билан характерланади;

- турли этносларга мансуб инсонларнинг бирлашиб, жамиятда ўзига хос эклектик тафаккур ва турмуш тарзини вужудга келтириши асосида битта оилада икки ёки ундан ортиқ миллатларнинг этномаданиятлари ривожланишига беғараз ижтимоий мухитнинг вужудга келиши билан боғлиқдир.

Жамиятда халқимизнинг ахлоқий-эстетик идеалларига мос келмайдиган келмайдиган бехаёлик, ёлғончилик, тилёғламачилик, ичиқоралик, фирибгарлик, дангасалик, калондимоғлик, мақтанчоқлик сингари қусурлар ёшларнинг камол топиш бориши жараёнида аста-секин йўқолиши, инсоннинг ўзи бу жихатлардан фориғ бўлиши мумкин. Аммо XXI асрда ёшларнинг миллий қадриятлар чегарасидан чиққан холда ахлоқсизлик касаллик аломатлари пайдо бўлмоқдаки, булар энди ўз мохияти жихатидан ижтимоий зарар иллатларга айланиб бормоқда. Ана шундай ахлоқсизлик намуналари гиёхвандлик, диний 
экстремизм ва ақидапарастлик кўринишларида намоён бўлиб, бундай хусусиятлар ёшларни соғлом ижтимоий мавжудотликдан инсоният душмани - экстремизм, кўпорувчилик харакатларига олиб келади. Бу йўлга ёшлар бирдан ва тасодифан кириб қолмайди. Уларнинг орқасида ўз бузғунчи ғоялари ва шахсий ниятларини амалга оширишни истаган рағбатловчилар тургани аниқ. Бу бузғунчи кучлар ёшларнинг онгини захарлаш, уларни ўз томонига оғдириб олиш учун турли маданиятларни бузиб тарғиб қилган холда ўз мақсадларини амалга ошири учун маблағларини аямаслигини хам унутмаслигимиз лозим. Шунинг учун хам доимо азалий этномаданиятимиз намуналарини йўқотмаслигимиз керак.

Ана шундай холатларнинг олдини олиш учун, ёшларимизни мамлакатимизда содир бўлаётган ижтимоий-тарихий воқеаларга лоқайд ва бепарво бўлмасликлари учун тарбия тизимимизни аждодларимиз ўгити, мустақиллигимиз натижалари, умумбашарий инсонпарварлик ғоялари асосида тарбиялаб бориш маънавий-ахлоқий тарбиямизнинг марказида турмоғи лозим. Ёшларимиз имонини бақувват, фикрини тиниқ этиб тарбиялаш уларнинг ахлоқий фазилатларини баркамол айласа, қалбига онгу шуурига ота-она, аждодлар рухи ва мамлакатимиз равнақи хақидаги эзгу ниятларни сингдириш эстетик маданиятларини юксалтиришга олиб келади.

Ёшларнинг она-Ватан ва унинг бугунги ва истиқболдаги хаётидан завқланиши мамлакат қувончу ташвишларини ўзининг шахсий маънавий хаёти тарзида идрок этиши уларнинг эстетик маданияти даражасини белгиловчи мезон бўлиб қолади.

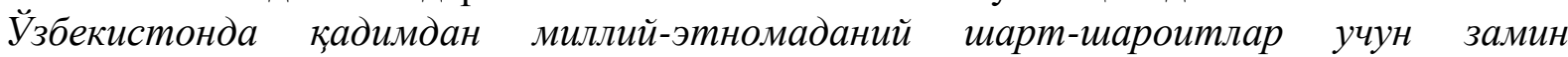
мавжудлиги ва маънавий маданиятнинг қ̧адимий бешиги сифатида халқнинг турмуш тарзи, анъаналари вужудга келганлиги билан характерланади. Бундай қุадриятли шартмароитларни халқнинг кундалик совлом турмуш тарзига тадбиқ этишда, биринчидан, аждодларимизнинг тарихий эволючияси жараёнида ижобий характерга эга моддий ва маънавий ютуқларни қўлга киритганлиги; иккинчидан, халқуииз менталитетида маънавиймаърифий сохадаги илм-фан ютуқьлари, урф-одат, анъана ва расм-русумларнинг миллий қ̧адриятлар сифатида эъзозланиши; учинчидан, азалдан юртимиз Марказий Осиё халқлари учун юксак маънавият ва ахлоқ̧ий идеаллар тарzиботчиси буллганлигига асосланади. Фаробий таъкидлаганидек, "агар инсон яратилишининг мақссади бўлмиш баркамоллик инсонга фақ̧ат табиатан хос бўлганида ва фақ̧ат яхши ният билан амалга омирилганида эди, у хуолда баркамолликка етиштирувчи фаолият ва хуаёт тарзи, фақан чин инсоний фазилат, эзгу ишлар ва аолиятлар, гузал хаёт тарзи бўлур эди” [Фаробий А.Н. 2018. 81].

Эстетик маданият аждодлар томонидан асрлар мобайнида шаклланган ижтимоий, иқтисодий, маънавий-психологик, ахлоқий-эстетик хусусиятлар, одатлар, кўникмалар ва анъаналарнинг бирлигидан иборат этномаданий жараёнлардан ташкил топади. Ана шу тариқа халынинг муайян миллий ғоя тўғрисидаги тасаввурлари турмуш тарзи, хаёт хақидаги тушунчалари, табиат ва коинот тўғрисидаги дунёқараши асосида вужудга келади.

Янги асрга келиб Ўзбекистон халқининг онгу тафаккурида этномаданий янгиланиш, ўзгариш жараёнлари бошланди. Натижада, халқнинг, айниқса, ёшлар эстетик маданиятига зўрма-зўраки равишда мутелик ва қуллик асоратларини пайванд этишга бўлган хаттихаракатлар орқада қолди. Лекин ёшлар онгига турли кўринишдаги этномадний кўринишларга тақлид сифатида маънавий тахдидлар хам озодлик шабадаси, эркинлик туйғуси сифатида кириб кела бошлади. Айрим ёшларнинг қалбини забт этишга интилаётган ахлоқий бузуқлик, диний экстремизм, терроризм инсониятни бошига турли кулфатларни сола бошлади. Мана шундай жараёнда миллий ғоянинг жамият ва халқ хаётидаги ахамиятини англаб етиш, ёшларни вайронкор ғоялардан огох қилиш бизнинг вазифамиздир.

\section{Фойдаланилган адабиётлар рўйхати}

1. Мирзиёев Ш.М. Халқимизнинг розилиги бизнинг фаолиятимизга берилган энг олий баходир. -Т.: Ўзбекистон, 2-жилд, 2018.

2. Нишонова О. Ўзбек этномаданиятининг эстетик мохияти ва функциялари. Фалсафа фанлари доктори (DSc) илмий даражасини олиш учун ёзилган дисссертация. -T.: 2016. 
3. Сафарова Н. Терроризм: манбалар, мақсади ва глобаллашув жараёни (тарихийфалсафий тахлил). -Тошкент: Фан, 2006.

4. Эргашев Б., Шарипов М., Жакбаров М. Жамиятни эркинлаштириш ва маънавият. Т.: Академия, 2002.

5. Форобий А.Н. Фозил оламлар шахри. -Т.: Янги аср авлоди, 2018.

\section{ВОЯГА ЕТМАГАН ЎКУВЧИ-ЁШЛАРНИ ИНТИЗОМСИЗЛИГИНИНГ КЕЛТИРИБ ЧИҚАРУВЧИ САБАБЛАРИ ВА ОМИЛЛАРИ}

\section{Ф.М.Зарипов}

Annotation: The article provides an opinion on the implementation of a model for the prevention of crime and crime among students, provides a system of preventive work aimed at preventing and preventing crime and crime.

Key words and expressions: Students, crime and crime prevention, methods, education, development, national values.

Жамиятда қабул қилинган тартиб-қоидаларни бузиш қачон ва қандай шароитларда юз беради. Биз тадқиқот жараёнида ана шу масалаларга ойдинлик киритиш, муаммонинг илдизини аниқлашга харакат қиламиз. Зеро болаларнинг ёш, яъни ўсмирлик чоғида у ёки бу таъсирларга тезроқ берилиши уларга хос хусусиятдир. Шу сабабли хам вояга етмаганларнинг салбий хатти-харакатларга мойилликларини илгарироқ аниқлаш ва уни тўғрилаш бўйича чоралар кўрилишига алохида эътибор берилиши лозим. Акс холда, кейинчалик вояга етмаган болани нотўғри йўлдан тўғри йўлга солиш учун бир неча баробар ортиқ куч-ғайрат, маблағ сарфлашга тўғри келади.

Хеч бир инсон дунёга мукаммал бўлиб келмайди. Инсон жамиятда, ўзининг қуршовидаги инсонлар орасида, табиат куйнида, турли-туман воқеа-ходисалар ичида, улар билан мулоқотда хамда бевосита аралашув жараёнида ўсиб-улғаяди, камолга етади. Аввало шуни таъкидлаш керакки, вояга етмаган ўсмирлардаги салбий хатти-харакатлар ўз-ўзидан шаклланмайди. Бунинг учун турли миллар таъсир кўрсатади (1-жадвал).

\begin{tabular}{|c|c|c|c|}
\hline № & ap & ip & абаблари \\
\hline 1. & $\begin{array}{l}\text { Tиббий-биологик } \\
\text { (саломатлик холати, } \\
\text { наслий ёки туғма } \\
\text { хусусиятлар, рухий ёки } \\
\text { жисмоний бузи-лиш, } \\
\text { қорин ички қисми } \\
\text { ривожлани-шидаги } \\
\text { жарохатла-нишлар ва } \\
\text { х. к. }\end{array}$ & $\begin{array}{l}\text { Клиник- } \\
\text { патологик } \\
\text { жихатдан } \\
\text { ривожланиши } \\
\text { да } \\
\text { муаммолари } \\
\text { мавжуд } \\
\text { болалар }\end{array}$ & $\begin{array}{l}\text { Саломатлик холатларида меъёрдан оғиш } \\
\text { (болаларнинг жисмоний ёки рухий } \\
\text { саломатлигидаги бузилиш-лар, жисмоний } \\
\text { ўсишдан ортда қолиш, бўйнинг ўсмаслиги, } \\
\text { характерида акцентуация холатининг } \\
\text { кузатилиши кабилар). }\end{array}$ \\
\hline 2. & $\begin{array}{l}\text { Иқтисодий-ижтимоий } \\
\text { (оиланинг } \\
\text { муаммолари, оиладаги } \\
\text { ноқулай рухий } \\
\text { ота-онанинг, } \\
\text { хаёт тарзи, жаслсиз } \\
\text { хаётига } \\
\text { олмаслик ва х.) }\end{array}$ & $\begin{array}{l}\text { Турли } \\
\text { юридик кучга } \\
\text { эга бўлмаган } \\
\text { шарт- } \\
\text { шароитлар } \\
\text { туфайли ота- } \\
\text { она } \\
\text { ғамхўрлиғгид } \\
\text { ан махрум } \\
\text { болалар. }\end{array}$ & $\begin{array}{l}\text { - оилавий тарбиядаги хатолар (“хаддан } \\
\text { зиёд эркалатилган болалик”, “эзилиб, зада } \\
\text { бўлган болалик”, “халокатга махкум } \\
\text { болалик”, “ёлғиз болалик”, “лоқайдликда } \\
\text { ўсган, беэътибор болалик”); } \\
\text { - ота-онада элементар психологик- } \\
\text { педагогик билимларнинг етишмаслиги, } \\
\text { тарбияга оид ташвишларнинг мактаб } \\
\text { зиммасига юклатиши; } \\
\text { - уусмирнинг оилавий юмушлардан }\end{array}$ \\
\hline
\end{tabular}




\begin{tabular}{|c|c|c|c|}
\hline & & & $\begin{array}{l}\text { четлатиб куйилиши; оилавий зиддиятлар } \\
\text { ва х.к.; } \\
\text { - ижтимоий сабаблар (жамият ва } \\
\text { микросоциумдаги қарама-қаршиликлар). }\end{array}$ \\
\hline 3. & $\begin{array}{lr}\text { Психологик } \\
\text { (ўзини } & \text { ўзгалар } \\
\text { томонидан } & \text { қабул } \\
\text { қилинмагандек } & \text { хис } \\
\text { қилиш, } & \text { беқарор } \\
\text { эмоционал } & \text { холатлар, } \\
\text { тенгдошлари } & \text { ва } \\
\begin{array}{lr}\text { катталар билан } \\
\text { мулоқотда }\end{array} \\
\begin{array}{lr}\text { қийинчиликни } \\
\text { қилиш ва х.к.); }\end{array} \\
\end{array}$ & $\begin{array}{l}\text { Ижти- } \\
\text { мойилаш- } \\
\text { маган, нохуш } \\
\text { оилалардан } \\
\text { чиққан } \\
\text { болалар }\end{array}$ & $\begin{array}{l}\text { - шахслараро ўзаро муносабатлар } \\
\text { сохасидаги бузилишлар (эътироф } \\
\text { этилмаган, донгдор бўлмаган, синф } \\
\text { жамоасидан ажралиб, яккаланиб қолган, } \\
\text { азият чекиб юрадиган, эркин мулоқот } \\
\text { гурухлари томонидан рад этилган } \\
\text { (ёшларбоп кўнгилочар кечалардан махрум } \\
\text { қилинган); зиддиятли, назоратсиз, оила } \\
\text { ғамхўрлигидан мустасно); } \\
\text { - рухий зарарланиш холатлари (ота- } \\
\text { онанинг ажралишиши, яқинларининг } \\
\text { вафот этиши, турар жойни алмаштириш ва } \\
\text { х.к.). }\end{array}$ \\
\hline 4. & 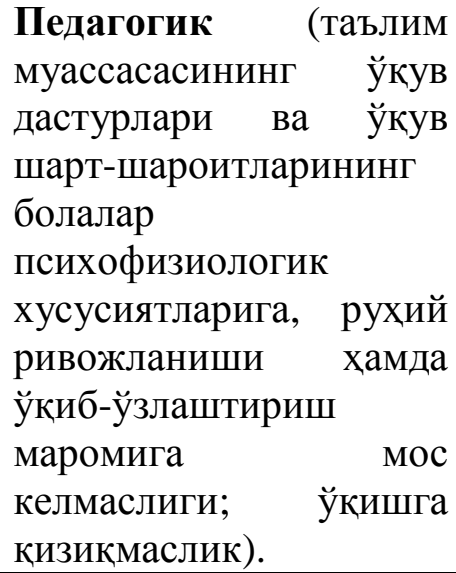 & $\begin{array}{l}\text { Ижтимоий- } \\
\text { иқтисодий ва } \\
\text { ижтимоий- } \\
\text { рухий кўллаб- } \\
\text { қувватлаш } \\
\text { хамда } \\
\text { кўмакка } \\
\text { мухтож } \\
\text { оилалар-нинг } \\
\text { болалари. }\end{array}$ & 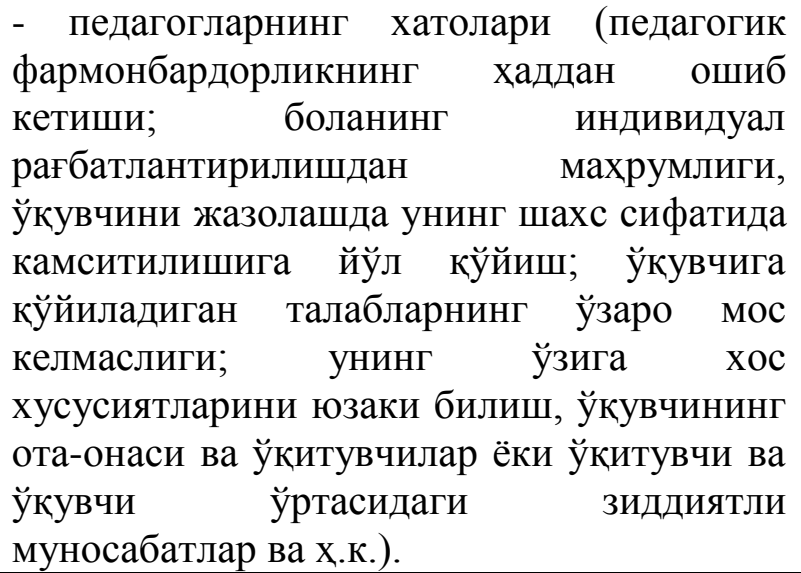 \\
\hline
\end{tabular}

Хозирги узлуксиз таълим-тарбия жараёнида тарбияси оғир, тартиббузарликка мойил, девиант хатти-харакатли болалар билан ишлаш муаммоларига эътибор хар қачонгидан хам кўра кучайтирилиши лозим. Ўкувчилар орасида, умуман ёшлар орасида, педагогикпсихологик нуқтаи назардан қаровсиз қолган, тарбияси оғир, хукуқбузарликка мойил, девиант хатти-харакатли ёшларнинг кўпайиб бориши ўқув-тарбия жараёнига ўз таъсирини кўрсатмай қолмайди, албатта.

Таълим муассасаси қошидаги жамоат кенгаши жисмонан соғлом ва маънавий етук ва хар томонлама ривожланган баркамол авлодни тарбиялашда оила, ота-оналар ва фуқароларнинг ўзини ўзи бошқариш органларининг таълим муассасалари билан хамкорлигини таълим муассасалари томонидан тарбияси оғир, хуқуқбузарлик содир этишга мойил ўқувчилар аниқланганда, улар билан вазирликнинг 2018 йил 6 февралдаги "Умумий ўрта таълим муассасаларда ижтимоий жихатдан хавфли ахволда бўлган вояга етмаганлар билан якка тартибда шуғулланишни ташкил этиш ва назорат қилиш тартиби тўғрисидаги йўриқномани тасдиқлаш хақида"ги 33-сонли буйруғи асосида ишларни тизимли ташкил этиш билан бирга ўкувчи-ёшларни ижтимоий мухофаза қилиш, ижтимоий эхтиёжманд оилалар фарзандларини моддий ва маънавий қўллаб-қувватлаш масалалари билан хам шуғулланмокда.

Шунингдек, умумий ўрта таълим мактабларида давлат ва нодавлат ташкилотлар, отаоналарнинг ўзаро хамкорлигида хар хафтанинг душанба куни “Эрталабки сафланиш", жума куни “Маънавият куни" ва 1-соатда “Синф соат", хар ойда мухим саналарга 
бағишланган “Маънавият хафталиги", педагог ходимлар учун хар ойнинг охирги жума куни “Маънавият соати” тадбирлари ташкил этиш йўлга кўйилган ${ }^{55}$.

"Пайшанба - жиноятчиликнинг олдини олиш ва профилактика куни" тадбирлари доирасида таълимни бошқариш идоралари ва таълим муассасаларининг хуқуқбузарликлар профилактикаси сохасидаги фаолиятини янада кучайтириш, таълим муассасаларида аниқланган ёки ўқувчилар ва ўқитувчилар томонидан хабар берилган хукуқбузарликлар фактлари бўйича ички ишлар органлари билан ахборот алмашинуви тизимини янада яхшилаш вазифалари юклатилди. ${ }^{56}$

Ўспиринлик ёшида ўзликни англашнинг мухим ташкилий қисми бўлиб - ўз хаттихаракатлари учун жавобгарлик ва унинг натижасига фақат ўзи сабабчи эканлигини хис қилиш хусусияти хисобланади. Ўзликни англаш - инсон ички дунёсини кашф қилиш, у хақида яхлит тасаввурга эга бўлиш, ўз-ўзига эмоционал муносабат, ақлий, ахлоқий ва иродавий сифатларини (ўз-ўзини) бахолашдир. Маълумки, ички позиция ўз-ўзидан эмас, балки субъектнинг ташқи мухит билан узлуксиз алоқада бўлиши ва бу мухитнинг унга таъсир этиши жараёнида шаклланади. Педагогик-психологик ташхис бир ёки иккита методикани ўтказиш билан эмас, балки коррекцион ривожлантирувчи хусусиятга эга бўлган узлуксиз жараён сифатида амалга оширилиши зарур.

Шундай қилиб вояга етмаган ўртасида интизомсизликни келтириб чиқарувчи хавфхатар омиллари - бу гурух ёки мухит хамда индивид характерлари ўртасидаги алоқадорлик ва унинг муайян вақт оралиғида бузилиш эхтимолининг юқори даражада бўлиши, деб тавсифланади. Хавф-хатар омиллари турлича кўринишда бўлиши мумкин. Булар:

- оилавий хавф-хатар омиллари (оиладаги келишмовчиликлар ва интизомсизлик, назоратсизлик, оилада жисмоний ва психологик зўравонлик, ота-оналарнинг алкогол ва и наркотик моддаларга ружу қўйиши ва х.к.);

- тенгдошлар гурухуидаги хавф-хатар омиллари (тенгдошларининг салбий таъсири, сархуш ичимликлар истеъмол қилувчи дўстларнинг таъсири, ўқишни истамаслик ва х.к);

- индивидуал хавф-хатар омиллари (ўз-ўзини бахолашнинг куйи даражаси, зўравонлик, гиёхвандликка нисабатан ижобий муносабат, ёмон ўзлаштириш, хулқнинг бузилиши ва х.к);

- мактабдаги хавф-хатар омиллари (ёмон ўзлаштириш, ўқитувчи ва ўқувчиларнинг қуйи ахлоқий даражаси, мактабда тамаки, алкогол ва гиёхванд моддалар истеьмол қилишга олиб келувчи шароитлар мавжудлиги, таълим-тарбия жарраёнига эътиборсиз муносабатда бўлиш ва х.к);

- жамиятдаги хавф-хатар омиллари (жамиятдаги тамаки, алкогол ва гиёхванд моддалар истеъмол қилишга олиб келувчи хаёт шароитлари, жамият аъзоларининг қўллабқувватлашидан четда қолиш, гиёхванд моддаларни топишнинг мумкинлиги ва х.к).

\section{Хулосалар:}

- ўқувчилар хуқуқбузарликлари ва жиноятчилигининг профилактик тадбирлари мухим ахамиятга эга;

- ўқувчилар хуқуқбузарликлари ва жиноятчилигининг профилактикасини оқилона ташкил этишда таълим муассасалари ўқитувчилари, ота-оналар, тегишли идоралар, махалла фаоллари, ижтимоий институтлар ва кенг жамоатчилик хамкорликдаги фаолияти талаб этилади;

55 Халқ таълими вазирлигининг “Умумий ўрта таълим муассасасининг маънавиймаърифий ишлар бўйича директор ўринбосари ва синф рахбарлари фаолияти самарадорлигини 2020 йил 30 июлдаги 180-сон буйруғи;

56 Ўзбекистон Республикаси Президентининг 2017 йил 14 мартдаги "Хуқуқбузарликлар профилактикаси ва жиноятчиликка қарши курашиш тизимини янада такомиллаштириш чора-тадбирлари тўғрисида” ПҚ-2833-сон Қарори; 
- вояга етмаганларнинг қаровсизлиги ва улар томонидан содир этилиши мумкин бўлган жиноятларни олдини олиш, ёшларни турли ёт ғоялар тахдидидан химоя қилиш, соғлом турмуш тарзини тарғиб қилиш, хукуқий саводхонлигини оширишга қаратилган якка тартибдаги машғулотларга мунтазам қатнашишини таъминлаш бўйича аввало, синф рахбарлари, ота-оналар, махалла фаоллари, участка нозирлари билан профилактик тадбирлар самарадорлигини ошириш мақсадга мувофиқ.

\section{Фойдаланилган адабиётлар рўйхати}

1. Халқ таълими вазирлигининг "Умумий ўрта таълим муассасасининг маънавиймаърифий ишлар бўйича директор ўринбосари ва синф рахбарлари фаолияти самарадорлигини ошириш хақида" 2020 йил 30 июлдаги 180-сон буйруғи;

2. Ўзбекистон Республикаси Президентининг 2017 йил 14 мартдаги “Хукуқбузарликлар профилактикаси ва жиноятчиликка қарши курашиш тизимини янада такомиллаштириш чора-тадбирлари тўғрисида” ПҚ-2833-сон Қарори;

3. Х.Ф.Рашидов, Р.Мусурмонов, З.Дехкамбаева, А.А.Зокиров, С.Алимходжаева. Дарс интизомига салбий мунобасатдаги болаларга нисбатан конструктив таъсир этишнинг назарий ва методологик асослари. - Тошкент: "Noshirlik yog'dusi”, 2015. - 202 бет.

\section{“ESTETIKAGA YO'G'RILGAN DUNYO"}

М. А. Абдуллаева

(СамДЧТИ, магистрант)

Annotation: This paper summarizes the sense of aesthetics of the famous Japanese writer Murasaki Shikibu's The Tale of Genji

Key words and expressions: Heian period, Heian aesthetics, Genjimonogatari (The Tale of Genji).

Murasaki Shikibu - yapon qissanavis iva shoiri. Adiba Yaponiya tarixida, siyosatida,davlatchilikning tashkil bo'lishida juda ulkan o'rin tutgan aslzoda Fujiwaralar sulolasiga mansub ayoldir. Murasaki Shikibu 10 asroxirlari - 11 asr boshlarida yashab ijod etgan. Shikibuning tug'ilgan va vafot etgan yili noma'lum, bu haq da yapon tadqiqotchilari turlixil taxminiysanalarnikeltirishadi.

Uning otasi Fujiwara no Tametoki ham o'z davrining mashhur shoirlaridan biri bo'lgan. Murasaki Shikibunin gengtaniqliasari “Genjimonogatari” ["ShahzodaGenjihaqidaqissa” [ 源 氏物語]] romanidir. Asar Murasaki Shikibunin kundaligida keltirilgan ma'lumotlarga asoslanib 1008 yildayozilgan deb taxmin qilinadi. Shiki bu qissanavislik bilan birga

she'riyatbilan ham shug'ullangan.Uning qalamiga mansub"MurasakiShikibushuu"

[“MurasakiShikibushe'riyto'plami”[紫式部集] nomliasariham bizgachayetibkelgan.

MurasakiShikibu [ 紫式部 ]-adibaningtaxallusibo'lib,haqiqiy isminoma'lum, Murasaki“Genjimonogatari” qissasining ayol qahramoni "Murasaki no Ue” [紫の上] sharafiga nomlangan. Shikibu-uning otasining saroydagi unvoni. Heian davridako'pincha saroyda nyobo [女房] bo'lib xizmat qiladigan ayollar o'z otasi yoki aka ukasining lavozimi yunvon atamasi bilan aytilgan. Shikibuning bevosita hayoti bilan bog'liq ma'lumotlar. Shikibuning tarjima iholi, saroydagi hayoti va faoliyati ni yoritishda tadqiqotchilarunin gasarlari - "MurasakiShikibukundaligi" va she'ri y asarlari saqlanib qolgan she'rlarito'plangan "MurasakiShikibushuu" gatayanishadi.

"Genjimonogatari" qissasi-yapon mumtoz adabiyotining eng yirik, muhtasham obidalaridan biri hisoblanadi.Uning dunyoga kelishi X - XI asrlardagi Heian davri madaniyatida giengyuksak cho'qqi-voqealardan hisoblanadi. Asarko' po'qilgan, ham ko'p ko'chirilgan. Shuningdek, keying davr yaponada biy otiga katta ta'sir

k o'rsatgan.

"Genjimonogatari Heian davri zod agonlar jamiyati haqida hikoya qiluvchi saroyada biyot hisoblanadi. Roman voqealari 70 yillik davrni qamraboladi. Asa rmarkazida imperatorning 
farzandi-shahzoda Genjininghayoti, ish qiysar guzash tlario'rintutadi. Tug'ilgan paytidan oq o'zining go'zalchehrasi va boshqa ajoyib xislatlariila ko'zniquvontirgan Genjihammaning ardog'I dabo'lganligi estetik mahorat bilan tasvirlab berilgan.

Asar muallifi Murasaki Shikibux onim bevosita saroyda, imperator Ichijoning rafiqasi Shoshiga xizmat qiluvchi xodima [女房]bo'lganligisababli ham saroy sharoitida o'tkaziladigan birorta bayram yoki marosimni, urf-odatlarni, voqealarni o'tkazib yubormay,ularnisinchiklabo'rganganvao'zasaridayoritibberaolgan.

Shuninguchunbuasarningo'shadavrzodagonlarjamiyati, madaniyati, diniyqarashlari, hayot tarzi, saroy marosimlari,estetikasini o'rganishda ahamiyati juda katta

hisoblanadi. Asarda o'sha zamon zodagonlar hayotini, saroy ahlining turmush tarzini, qalbkechinmalarinibenihoyasergaklikila, butunikir-chikirlarigachaajoyibestetikmahoratbilanyoritib, batafsiltasvirlabberilgan.

Muallifning teran bilimi iqtidori va salohiyatini dunyoga ko'z-ko'zlab kelayotgan muhtasham asarana shutariqayaratildi. Ungachaesa, Yevropamezonlarigako'ra, asarvoqealariniyorqintasvirlagan roman jahon adabiyoti dahali dunyoga kelmaganedi.

Asar bosh qahramon shahzoda Genjining tug'ilishidan to vafotigacha, undan keyin avlodlarining hayotit o'g'risida hikoya qiladi. Ularning unvoni yoki saroydagi darajasi o'sha davrtamoyiliga binoanba'zan ishtirokchi nomi bilan birqatorda, ba'zani shtirokchilarningn omio'rnidaishlatiladi, shunga ko'ra,

xizmatdarajasio'sganisayinharbobdapersonajlarningatalishi ham o'zgaribturadi. Va shu bilan birgalikda ularning bajarayotgan ishlari-yuxatti-harakatlarida, maktub, muloqot, kiygan kiyimlarigacha estetikaning yuksak na'munalarini ajoyib tasvirlab kitobxonga yuksakma daniyat bilan yetkazib berilgan.

Heian davrining estetik mahorati“Genjimonogatari” (Genjihaqidagiqissa) da estetikago'zallikning asardagi qahramonlar obrazi orqali, ularning harakatlari, qolaversa, shunchalik har bir detallariga chago'zal did estetikaga e'tibor berib yaratilganki, unio'qiganodamnio'ziga rom qilibqo'yadi.

Asarda kiyinishga bo'lgan estetika, hatto kifasllarga qarab yorqin yokib o'lmasat o'qrangdagi kiyimlarn itanlab, unga sepiladigan atirlarigacha estetikaning namoyon bo'lishini ko'rib, guvohi bo'lishimiz mumkin.

Heian davri estetik go'zalligining ayollardagi ifodasi mohirlik bilan tasvirlab berilgan. Heian davri go'zalligi, tabiat go'zalligi bilan ham ohang yuradi ganayollarestetikasi haqida va ma'lum joylarida, balkioddiyayolinson sifatida hayotda qandayligini tasavvur qilishimiz

mumkin. Biz bu tasvirlar orqali Shikibuning yozuvchilikdan tortib od diyin soniylikkacha bo'lgan masofada, uning yaratgan asarlarida butunligicha estetika gayo'g'rilganining guvohi bo'lamiz.

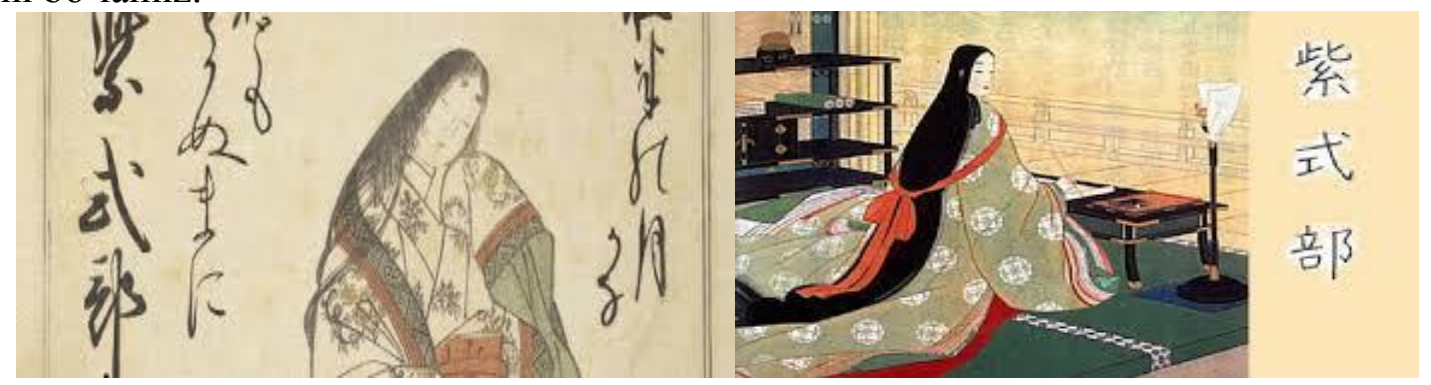

Gigglemug Book Club [MurasakiShikibu Nikki (The Diary of Lady Murasaki) - Gigglemug]

Murasakining "Genjimonogatari" romanidagimuhimg'oyaviy-estetik, ruhiy va ziyatlarni tahlil va tadqiqqilishd ayuqorida tilga olingan asarlarning, ayniqsa, "MurasakiShikibukundaligi" ning ahamiyati juda katta hisoblanadi.

MurasakiShikibuad abiyot, ilm-fan,san'at muhitida kamolga yetgan hamd ayapon va xitoy mumtoz adabiyoti na'munalaridan yaxshigina xabardorbo'lgan. Murasaki Shikibukotoas bobini yaxshi chalgan. 


\title{
Foydalanilgan adabiyotlar ro'yxati
}

1. 今井卓爾ほか編、源氏物語講座 7 『美の世界雅びの継承』勉誠社、1993 年。

2. 小西聖一『紫式部と清少納言一貴族の栄えた時代に』（NHK にんげん日本史、） 理論社、2003 年。

3.与謝野晶子訳『源氏物語』（上中下）角川文庫、1972 年。

4. Muzaffar Ahmad, MurasakiShikibuhaqida, "Jahonadabiyoti” jurnali, 2013-5.

5. Мещеряков А.Н., Герои, творцы и хранители японской старины, «Наука», Москва, 1988.

6. Gigglemug Book Club [MurasakiShikibu Nikki (The Diary of Lady Murasaki) Gigglemug]

\section{РУССКАЯ ДИАСПОРА В ПОСТСОВЕТСКОМ ПРОСТРАНСТВЕ: ОСОБЕННОСТИ ИДЕНТИЧНОСТИ И ЗНАЧЕНИЕ ДЛЯ РОССИИ}

\author{
Хуан Минто \\ (ШУИЯ, Китай, доктор) \\ Ма Хэяо \\ (ШУИЯ, Китай, аспирант)
}

\begin{abstract}
Annotation: After the collapse of the USSR in the countries of the "near abroad" a huge number of compatriots abroad, known in social science as the "Russian diaspora", arose. The article discusses the features of self-identification of the Russian diaspora. This is an important issue for Russia: the Russian diaspora is an important diplomatic tool, is able to alleviate the demographic crisis in Russia, and can contribute to the spread of the Russian language and culture abroad. Russia needs to optimize its policy towards the Russian diaspora in the post-Soviet space. Otherwise, Russia threatens to lose one of the most important sources of influence on neighboring countries.
\end{abstract}

Key words and expressions: Russian diaspora; compatriots abroad; post-Soviet space; Near Abroad; identity

После распада СССР в странах «ближнего зарубежья» России за короткое время возникло огромное количество соотечествеников за рубежом, известных в общественной науке как «русская диаспора», которая до сих пор в большей или меньшей степени испытывает некие духовные связи с Россией, превращающиеся иногда в политическую проблему. Примером тому может служить вопрос Приднестровья, а также проблемы Абхазии, Южной Осетии и Крыма.

Хотя вышеуказанные проблемы уже не являются «горячей точкой»в научном сообществе, но эволюция проблемы русской диаспоры в постсоветском пространстве далеко не закончена. В июле 2017 г. ополченцы так называемой «Донецкой народной республики» провозгласили о создании новой независимой страны под названием «Малая Россия», не подчиненной официальному Киеву. В сентябре 2019 г. президент Южной Осетии выступил с официальным заявлением, что Южная Осетия должна стать частью Российской Федерации. 5 октября 2019г. тысячи русскоговорящих вышли на улицы с протеста против языковой и национальной политики латвийского правительства. Поэтому встает вопрос - почему все это произошло?

Для того, чтобы ответить на этот вопрос, нужно прежде всего разобраться, в чем же особенности русской диаспоры в постсоветском пространстве и каковы ее перспективы. Русская диаспора за рубежом делится на два типа - диаспора в странах ближнего зарубежья и диаспорадальнего зарубежья. Русская диаспора дальнего зарубежья выселяется из России в основном по собственному желанию, и поэтому российская идентичность у них относительно слабая. А что же касается русской диаспоры ближнего зарубежья, то она возникла вдруг и оказалась вне российской территории не по собственному желанию, ведь 
это является результатом распада СССР. Именно поэтому в русской диаспоре постсоветского пространства до сих пор еще сохраняется сильная российская идентичность.

Российские и западные ученые рассматривают вопрос русской диаспоры постсоветского пространства с совершенно разных точек зрения. Российское научное сообщество в основном сосредотачивает свое внимание на конкретной политике в отношении русской диаспоры, в том числе и законах, государственных программах[16] и мерах поддержки для соотечественников, проживающих за рубежом[12], и результативности осуществления этих мер[15]. Однако в работах российских ученых обычно отсутствует теоретическое исследование и достаточно редко можно найти содержание, посвященное особенностям идентичности русской диаспоры и ее значению для российской дипломатии в постсоветском пространстве.

После украинского кризиса 2014 г. проблема с русской диаспорой стала в центре внимания западных ученых, которые углубленно изучали роль русской диаспоры в дипломатической стратегии России. Несмотря на богатые результаты исследования, многие научные работы западных ученых характеризуются явной предвзятостью. Для них существует достаточно общепринятое мнение, что русская диаспора постсоветского пространства является своего рода дипломатическим инструментом, с помощью которого Россия якобы стремится захватить контроль над этими странами, из-за чего Крымская весна еще повторится в других постсоветских странах. Представительно мнение американского ученого Agnia Grigas, которая считает, что меры поддержки российских соотечественников за рубежом включают в себя: гуманитарную политику, политику мягкой силы,паспортизацию, информационную войну и так далее. А окончательная цель этих мер захватить территорию этих стран и тем самым добиться так называемого «возрождения империи»[1]. Wawrzonek тоже считает российскую политику в отношении своей диаспоры империалистической стратегией, целью которой является создание так называемого «антизападного и антидемократического сообщества»[8].

Следует отметить, что русская диаспора, страны ближнего зарубежья и Россия - это треугольные отношения. С этой точки зрения вполне можно сказать, что русская диаспора это уникальные ресурсы в российской внешней политике. А насколько эффективны и результативны эти ресурсы? Это во многом зависит от идентичности русской диаспоры. Каковы особенности идентичности русской диаспоры? На эту тему опубликованно достаточно малонаучных работ. Именно в этом заключается новизна и актуальность данной статьи.

Возникновение русской диаспоры имеет давний исторический корень. Начиная с 16-го века царские власти уже начали целенаправленно вселить на окраины империирусских, чтобы способствовать русификации местных национальностей и тем самым укреплению царского управления. В советский период ряд факторов, в том числе и индустриализация, коллективизация и освоение целины, в значительной степени способствовал увеличению доли русских в Центральной Азии, Закавказье и Прибалтике. Таким образом, согласно всесоюзной переписи населения 1989г.численность этнически русских, проживающих вне РСФСР, составила около 25 млн [11].

Однако с 1989 г. прошло уже свыше 30 лет, и численность русской диаспоры в постсоветском пространстве значительно уменьшилась, составляя 14.2 млн человек. В официальных документах России употребляется совсем другой термин - соотечественник за рубежом, подчеркивая не только этническую принадлежность, но и «лиц, сделавших свободный выбор в пользу духовной, культурной и правовой связи с Российской Федерацией» [22]. Поскольку «духовные, культурные и правовые связи» - это достаточно абстрактные понятия, поэтому официальные данные о количестве соотечественников, проживающих за рубежом, пока отсутствуют. Бывший мэр города Санкт-Петербург Г. С. Полтавченко считает, что общая численность российских соотечествеников составляет 35 млн человек. А бывший глава Россотрудничества полагает, что эта цифра составляет 30 млн [7]. На официальном сайте российского МИД написано, что это 25 млн[20]. Научный круг 
обычно употребляет два понятия для определения численности соотечествеников за рубежом - этнически русские (в узком смысле) и русскоговорящие (в широком смысле). Состояние распределения численности русских и русскоговорящих указано в таблице 1[21].

\section{Таблица1. Численность русских и русскоговорящих в странах ближнего зарубежья (млн)}

$\begin{array}{llllll}\text { Государство } & \text { Численно } & \text { Численно } & \text { Доля } & \text { Численность } & \text { Доля } \\ & \text { сть } & \text { сть } & \text { русских } & \begin{array}{l}\text { русскоговорящ } \\ \text { русскоговорящи }\end{array} & \text { Хх } \\ \text { Закавказье } & \mathbf{1 6 . 5} & \mathbf{0 . 2 1} & \mathbf{1 . 3} \% & \mathbf{0 . 9 5} & \mathbf{5 . 8 \%} \\ \text { Армения } & 3 & 0.02 & 0.5 \% & 0.15 & 3 \% \\ \text { Азербайджан } & 9.5 & 0.14 & 1.5 \% & 0.48 & 5 \% \\ \text { Грузия } & 4 & 0.05 & 1.3 \% & 0.32 & 8 \% \\ \text { Центральная } & \mathbf{6 7 . 5} & \mathbf{5 . 0 5} & \mathbf{7 . 5} \% & \mathbf{1 0 . 3} & \mathbf{1 5 . 3 \%} \\ \text { Азия } & & & & & \\ \text { Казахстан } & 17.5 & 3.68 & 21 \% & 7 & 40 \% \\ \text { Кыргызстан } & 6 & 0.39 & 6.5 \% & 1.2 & 20 \% \\ \text { Узбекистан } & 31.5 & 0.79 & 2.5 \% & 1.58 & 5 \% \\ \text { Таджикистан } & 7.5 & 0.04 & 0.5 \% & 0.3 & 4 \% \\ \text { Туркменистан } & 5 & 0.15 & 3 \% & 0.25 & 5 \% \\ \text { Восточная } & \mathbf{6 1 . 8} & \mathbf{8 . 9 4} & \mathbf{1 4 . 5} \% & \mathbf{3 1 . 5} & \mathbf{5 1} \% \\ \text { Европа } & & & & & \\ \text { Белорусь } & 9.5 & 0.86 & 9 \% & 8.08 & 85 \% \\ \text { Молдова } & 3.6 & 0.24 & 6 \% & 0.8 & 20 \% \\ \text { Украина } & 42.6 & 6.8 & 16 \% & 21.3 & 50 \% \\ \text { Эстония } & 1.3 & 0.33 & 25.5 \% & 0.39 & 30 \% \\ \text { Латвия } & 2 & 0.54 & 27 \% & 0.68 & 34 \% \\ \text { Литва } & 2.8 & 0.17 & 6 \% & 0.25 & 9 \% \\ \text { Итог } & \mathbf{1 4 5 . 8} & \mathbf{1 4 . 2} & \mathbf{9 . 7} \% & \mathbf{4 2 . 7 5} & \mathbf{2 9 . 3} \%\end{array}$

Авторитетный специалист в области глобальных диаспор, ученый Великобритании Robin Cohen разделяет глобальные диаспоры на пять видов - традиционная диаспора (евреи), страдающая диаспора (африканцы, армяне), трудовая диаспора (индейцы), имперская диаспора (англичане) и торговая диаспора (китайские хуацяо, ливанцы)[6]. Русская диаспора не входит ни в одну вышеуказанную группу, поскольку она возникает как прямое последствие распада СССР. С этой точки зрения русская диаспорав странах постсоветского пространства обладает рядом особенностей в плане идентичности:

Во-первых, русская диаспора постсоветского пространства еще находится на стадии динамичной эволюции, ее политическая и духовно-культурная ориентация варьируется по мере изменения окружающих обстоятельств, модель идентичности постоянно подвергается внешним факторам.

С одной стороны, внутренние социальные и политические условия оказывают глубокое влияние на модель поведения русской диаспоры. Согласно результатам одного опроса общественного мнения, проведенного в 2006 г., 20\% опрошенных в юго-восточной части Украины считают, что нужно выбрать другую страну в качестве своей родины[3]. Однако после вступления к власти радикальной администрации Порошенко, права и интересы этнически русских и русскоговорящих часто игнорируются, в результате чего межнациональные и региональные конфликты становятся все более напряженными. На этом фоне в ходе референдума 2014 г.96.77\% крымчан проголосовали за воссоединение к России. 
А с другой стороны, существует ряд внешних факторов, которые также способны оказать некое воздействие на русскую диаспору и ее идентичность. В первые годы получения независимости Казахстанарадикальный национализм практически охватил все регионы, и русская диаспора начала проявлять активность в политике и претендовать на более автономный статус.Примером того может служить митинг казаков Семиреченской области в 1994г. с требованием соединиться к Российской Федерации. В 1996 г. Юрий Антошко и Виктор Антошко, главы Кокшетауских казаков, пытались поднять мятеж и свернуть областную администрацию. Благодаря умеренной национальной и языковой политике администрации Назарбаева порядок в обществе Казахстана восстановился, и центробежная тенденция постепенно утихла. Однако под влиянием украинского кризиса и воссоединения Крыма к России в Казахстане опять же возникло опасение о том, что центробежная тенденция повторится.

Во-вторых, модели идентичности различаются в разных регионах. Для русской диаспоры в странах Центральной Азии характерна умеренная российская идентичность. Они признают свои духовные связи с Россией и в тоже время достаточно рациональны в плане политической ориентации. В Казахстане примерно 58.7\% русских считают Казахстан своей родиной, и только $22.4 \%$ русских считают Россию своей родиной. Похожая картина наблюдается и в Кыргызстане. Там $60.8 \%$ русских предпочитают выбрать Кыргызстан в качестве своей родины, а только 20.7\% - Россию[9]. Русская диаспора в странах Центральной Азии обычно выступают за национальное согласие своей страны и против экстремизма.

Русская диаспора в странах Прибалтики характеризуется явно выраженной российской идентичностью и достаточно активно защищают свою самобытность и интересы, поскольку она считает, что во многих сферах свои права и интересы ущемляются. Согласно результату одного из опросов общественного мнения, проведенного в 2004 г., свыше 60\% русских в Латвии и Эстонии считают себя российскими гражданами[2]. В 1998 г. русские в Латвии подняли массовую акцию протеста из-за пенсионной дискриминации. В 2007г. власти Эстонии решили снести бронзовую статую советского солдата в Таллине, и в результате представители русской национальности и других национальных меньшинств выразили свое категорическое недовольство массовым митингом.

Русская диаспора в Молдове, Грузии и Украине - это достаточно жесткая община, характеризующаяся явным центробежным настроем и устремляющаяся к воссоединению с Россией. В 1992г. администрация Приднестровья отказывалась от использования нового государственного флага Молдовы и это событие даже превратилось в гражданскую войну. В 2006 г. в Приднестровье состоялся референдум и 97\% населения проголосовали за воссоединение к России. Похожая картина и в Украине, где еще в 1994 г. население в юговосточной части уже сделало попытку провозгласить независимость.

Диаспору в Армении, Азербайджане и Белоруси можно описать как «анабиозную общину», которая не очень активно участвует в политическом процессе своей страны и не проявляет центробежный настрой. Это отчасти потому, что доля этнически русских в Армении и Азербайджане невелика и они проживают не совсем компактно. Доля русских в Армении занимает всего лишь $0.3 \%$, а русскоговорящих - 3\%. В Азербайджане русских составляет $1.5 \%$ от общего числа населения, а русскоговорящих - $5 \%$. Что же касается Беларуси, то белорусы и русские входит в одну и туже восточнославянскую подгруппу родословного дерева национальностей. У них схожие языковые, культурные, исторические и религиозные особенности. Причем официальные власти России и Белоруси долгое время сохраняют близкие отношения. На этом фоне и не странно, что русские в Беларуси тоже проявляет анабиозную российскую идентичность. Русские занимают 9\% от всего населения Беларуси, но 75\% граждан этой страны не считают Россию иностранным государством[5].

В-третьих, русская диаспора в постсоветском пространстве является «воображаемым сообществом». «Не может быть, чтобы они знали большинство своих соотечественников, или встречались с ними, или даже слышали о них. Однако образ взаимосвязанности между 
ними существует в сердце каждого из этой общины»[24]. После распада СССР русская диаспора ближнего зарубежья вдруг стала национальным меньшинством. Несмотря на это, данная категория людей все равно считает свою национальную принадлежность гордостью. (См. табл. 2.)[17]

Таблица 2. Валентность этнической идентичности (\%)

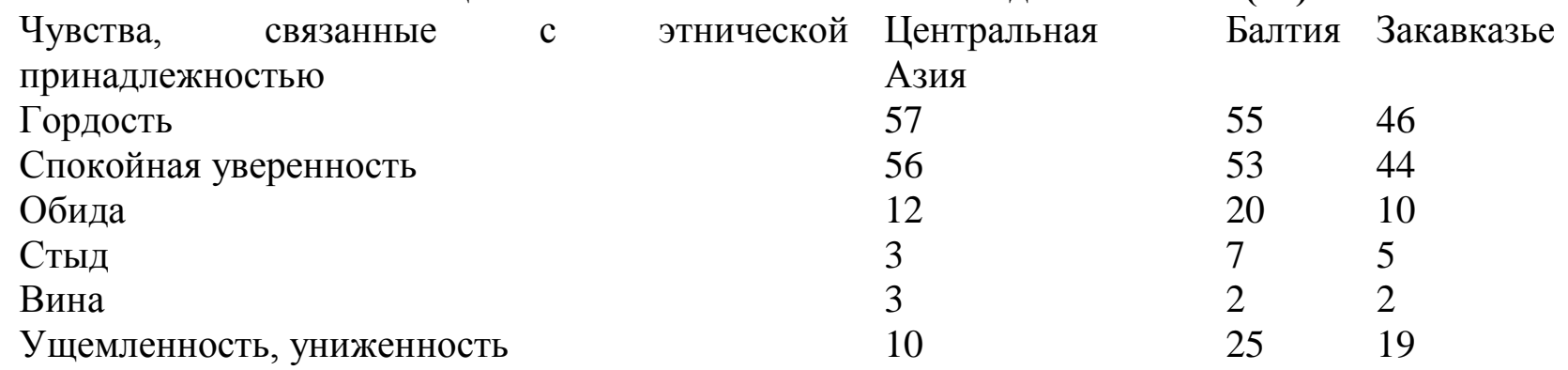

Факт, что в некоторых странах права и интересы русской диаспоры иногда нарушаются в языковой, культурной и политической областях. Однако с такой дискриминацией сталкиваются далеко не все. Русские и представители титульной нации рассматривают этот вопрос совершенно по-разному.Русская диаспора достаточно чувствительна к национальной и языковой политике своей страны и предпочитает считать, что в большей или меньшей степени подвергается реальным угрозам. А большинство представителей титульной нации считает, что такого рода угрозы являются воображаемыми и не имеют никаких оснований, и тем самым не соответствуют реалиям. Такая картина ярко выражена в таблице 3[17].

Таблица3. Оценка различных мнений относительно «проблемы русских» (\%)

Мнения

«Проблема русских» в независимых

выдумана самими русскими и российскими

политиканами

Русские слишком мнительны, их никто не гонит, а они 7.3

«кричат»

Русские в свое время оказали помощь республикам в их 92

развитии и не заслужили неблагодарности в свой адрес

Независимые государства в случае отъезда русских

должны компенсировать им все, что они здесь оставляют

Россия «бросила» русских в республике, и местные 36 власти могут делать с ними все, что захотят
Русские Титульные этносы

$11.5 \quad 56.1$

$7.3 \quad 57$

55

$85.5 \quad 42.4$

11.5

В-четвертых, воображаемые духовные связи с Россией совместно с реальными интересамиопределяют модель поведения русской диаспоры. Нельзя трактовать политическую ориентацию только с точки зрения духовной идентификации, поскольку такой подход имеет ряд ограничений. Для примера можно привести русскую диаспору в странах Прибалтики. Многие русские в этих странах уже приняли гражданство России, однако они все равно предпочитают жить на месте пребывания, даже не имея статуса гражданства своей страны. Почему же такое обстоятельство происходит? Главная причина заключается в том, что такая ориентация максимизирует интересы русской диаспоры, потому что российское гражданство означает приобретение пенсии от России. А остаться на месте пребывания - это означает возможность получить высококачественное образование Европы и относительно высокий уровень жизни. Опрос общественного мнения, проведенный ВЦИОМ в 2009 г., показывает, что чем выше уровень жизни русской диаспоры, чем лучше она интегрированав местную жизнь, тем неохотнее им возвращаться в Россию и поддерживать ее. (См. табл. 4.)[19] 


\begin{tabular}{lllll}
\multicolumn{6}{c}{ Таблица4. Сравнительный анализ мнений русской диаспоры в разных странах } \\
$\begin{array}{l}\text { Страна } \\
\text { пребывания }\end{array}$ & $\begin{array}{l}\text { Довольны } \\
\text { своим } \\
\text { материальным } \\
\text { положением }\end{array}$ & $\begin{array}{l}\text { Владеть языком } \\
\text { титульной нации }\end{array}$ & $\begin{array}{l}\text { Желать остаться в в } \\
\text { стене пребывания }\end{array}$ & $\begin{array}{l}\text { Желать } \\
\text { вселиться } \\
\text { Россию }\end{array}$ \\
Латвия & $24 \%$ & $43 \%$ & & $13 \%$ \\
Украина & $19 \%$ & $49 \%$ & $68 \%$ & $25 \%$ \\
Кыргызстан & $15 \%$ & $18 \%$ & $51 \%$ & $66 \%$ \\
Узбекистан & $3 \%$ & $22 \%$ & $15 \%$ & $86 \%$
\end{tabular}

Кроме того, представители русской диаспоры, прожившие в СССР или России, в большей степени испытывают близость к России по сравнению с теми, кто рождены в странах ближнего зарубежья. По мере развития транспорта и телекоммуникаций многие русские не хотят прерывать связи с Россией. А для нормальной жизни они также проявляют некую лояльность странам пребывания и стараются интегрироваться в местную жизнь. Такая двойная идентичность тоже свидетельствует о том, что реальные интересы оказывают важное влияние на модель поведения русской диаспоры в постсоветском пространстве. В связи с этим лозунг «России нужна сильная диаспора» становится своего рода парадоксом чем сильнее русская диаспора, тем отчужденнее она в отношениях с Россией.

Вышеуказанные специфики проявляют особенные связи между русской диаспорой и Россией, благодаря чему русская диаспора имеет важное потенциальное значение. Ее роль для российской постсоветской политики проявляется в трех аспектах:

Во-первых, русская диаспора является важным дипломатическим инструментом для России. Такая функция уже дала о себе знать в ходе таких геополитических горячих точек, как проблема Приднестровья в 90-е годы, вооруженный конфликт между Россией и Грузией в 2008 г., а также украинского кризиса 2014 г.

На самом деле еще в начале 90 гг. ряд политиков и ученых уже обратили внимание на такую роль русской диаспоры. Сергей Станкевич является одним из первых лиц, призывающих власти России к созданию государственной политики в отношении своих соотечественников в постсоветском пространстве. В 1993 г. он предложил Ельцину доклад под названием «О срочных мерах сотрудничества между российскими гражданами и их соотечественниками за рубежом в социально-культурной сфере», где он считает, что русская диаспора в странах ближнего зарубежья - это не проблема или бремя для России, а наоборот, это источник российского влияния[4]. Такого мнения придерживаются и А. Г. Дугин[14], Д.Е.Фурман[23] и С. А.Караганов[18].

Если отношения между Россией и странами ближнего зарубежья дружественные, то русская диаспора может способствовать политическим, экономическим, культурным и гуманитарным контактам. А если в своей внешней политике страны постсоветского пространства отдаляются от России, то русская диаспора в этих странах может превратиться в центробежную силу, и тем самым стать источником российского влияния, ведь дипломатическое отчуждение от России обычно происходит параллельно и с процессом дерусификации внутри страны - ограничение использования русского языка, ущемление прав русскоговорящих и так далее.

Во-вторых, русская диаспора может облегчить демографический кризис в России. По состоянию на конец 2018 г. общая численность населения России составила 146.9 млн. человек. Этот показатель значительно уступает уровню 1914 г. при царской России. Для такой обширной территории демографический дефицит представляет серьезную угрозу для социально-экономического развития страны. Хотя на официальном уровне уже принят ряд мер, таких, как материнский капитал, снижение кредитной ставки и предоставление налоговых льгот для многодетных семей, но существенных изменений так и не произошло. Начиная с 2000 г. только четыре года в России наблюдался положительный естественный 
прирост населения - 2012-й, 2013-й, 2014-й и 2015-й.Перспектива тревожит. По средним прогнозам Росстат в период 2020-2035 гг. естественный прирост населения страны будет ниже ноля, и тем самым общая численность населения долгое время будет только сокращаться. Статистические данные показаны в таблице 5.[13]

Таблица5. Демографическое развитие в России (с прогнозом)

\begin{tabular}{|l|l|l|l|}
\hline Год & Рождаемость(\%) & Смертность (\%) & $\begin{array}{l}\text { Естественный прирост } \\
(\%)\end{array}$ \\
\hline 2000 & 8.7 & 15.3 & -6.6 \\
\hline 2005 & 10.2 & 16.1 & -5.9 \\
\hline 2010 & 12.5 & 14.2 & -1.7 \\
\hline 2015 & 13.3 & 13.0 & 0.3 \\
\hline 2020 & 10.5 & 12.2 & -1.7 \\
\hline 2025 & 9.6 & 12.2 & -2.6 \\
\hline 2030 & 9.1 & 12.4 & -3.3 \\
\hline 2035 & 9.6 & 13.4 & -3.8 \\
\hline
\end{tabular}

Существует еще один фактор, который усугубляет демографический кризис в России снижение количества трудоспособного населения. В 2002 г. данный показатель составил 21.692 млн. человек. А в 2018 г. этот показатель сократился до 20.149 млн. человек. Кроме того, соотношение числа мужчин и женщин снизилось от 47:53 в 2001 г. до 46:54 в 2018 г.

На таком фоне привлечение русской диаспоры является возможным вариантом для решения проблемы с демографической нехваткой. Такой подход по компенсированию трудовых ресурсов имеет ряд положительных пунктов. Русская диаспора имеет схожую языковую и культурную основу. После вселения в Россию они могут быстро адаптироваться к новым условиям жизни. А самое главное - у них сохранилась российская идентичность, благодаря чему духовная стержень и государственное единство не подвергаются «разбавлению». А обычные трудовые иммигранты этими преимуществами не обладают.

В-третьих, русская диаспора может способствовать распространению русского языка и культуры за рубежом. Русская диаспора - это носитель русского языка и культуры. Она является источником российской мягкой силы в постсоветском пространстве. После распада СССР многие страны ближнего зарубежья продвинули ряд политических курсов по дерусификации, будь то радикальные или умеренные, но с одной и той же целью: создать единую государственную идентичность на основе титульной нации. Такие дерусификационные меры обычно включают в себя: снижение статуса русского языка, проведение латинизации письменности национального языка, противодействие функционированию православных церквей, ограничение доступа населения к российским и русскоязычным СМИ и так далее.

Кроме того, по мере углубления глобализации язык, культура и идеология западных стран во главе с США получили широкое распространение во всем мире. Под влиянием западной культуры и прозападных СМИ возникла тенденция демонизации российской культуры.

Таблица 6[10] отражает удельный вес российских граждан и русскоговорящих в мире, в том числе прогноз до 2050 г. Согласно таблице 6, с 1990 г. доля русского языка в мире непрерывно снижается. На этом фоне не трудно сделать вывод, что ослабление статуса русского языка в мире до 2050 г. - это неизбежная тенденция, которая в конечном итоге ущемит российскую мягкую силу и глобальное влияние, что вызывает озабоченность у российских властей. Поэтому защищать интересы и права русской диаспоры в постсоветском пространстве - это и есть укреплять российскую мягкую силу. 
Таблицаб. Доля российских граждан и русскоязычного населения в мире

\begin{tabular}{|l|l|l|l|l|l|}
\hline Год & $\begin{array}{l}\text { Население } \\
\text { мира (млн.) }\end{array}$ & Население & $\begin{array}{l}\text { Пропорция } \\
\text { Росил.) }\end{array}$ & $\begin{array}{l}\text { Русскоязычное } \\
\text { население мира }\end{array}$ & $\begin{array}{l}\text { Пропорция } \\
(\%)\end{array}$ \\
\hline 1900 & 1650 & 138.0 & 8.4 & 105 & 6.4 \\
\hline 1914 & 1782 & 182.2 & 10.2 & 140 & 7.9 \\
\hline 1940 & 2342 & 205.0 & 8.8 & 180 & 7.7 \\
\hline 1980 & 4434 & 265.0 & 6.0 & 280 & 6.3 \\
\hline 1990 & 5263 & 286.0 & 5.4 & 312 & 5.9 \\
\hline 2004 & 6400 & 146.0 & 2.3 & 278 & 4.3 \\
\hline 2010 & 6820 & 142.7 & 2.1 & 259.8 & 3.8 \\
\hline 2015 & 7200 & 139.0 & 1.9 & 243 & 3.4 \\
\hline 2025 & 7800 & 129.0 & 1.7 & 215 & 2.8 \\
\hline 2050 & 9350 & 110.0 & 1.2 & 130 & 1.4 \\
\hline
\end{tabular}

Из вышесказанного можно сделать вывод, что русская диаспора в постсоветском пространстве еще находится на стадии активной эволюции, ее идентичность пока не окончательно сформирована. Русская диаспора имеет важное значение для России. Хотя Россия уже приняла ряд мер по поддержке своих соотечествеников за рубежом, но эти меры до сих пор не отличаются высокой эффективностью. России необходимо оптимизировать свою политику в отношении русской диаспоры в постсоветском пространстве, чтобы в них укрепилась российская идентичность и духовная близость к России, чтобы она продолжала служить опорой по осуществлению государственных интересов в постсоветском пространстве. В противном случае России грозит потерять один из важнейших источников влияния на страны ближнего зарубежья.

\section{Список использованной литературы}

1. Agnia G. Beyond Crimea: The New Russian Empire. New Haven and London: Yale University Press, 2016.

2. Duvold K., Sten B. Democracy between Ethnos and Demos: Territorial Identification and Political Support in the Baltic States // East European Politics \& Societies and Cultures. 2014. Vol. 28. №2. Pp. 341-365.

3. Loshkariov I. D., Sushentsov A. A. Radicalization of Russians in Ukraine: from "Accidental" Diaspora to Rebel Movement // Southeast European and Black Sea Studies. 2016. Vol. 16. №1. Pp. 71-90. 1995.

4. Melvin N. Russians beyond Russia: the Politics of National Identity.Washington: CSIS,
5. Putin
Comes
Out
On Top
In New
Minsk Agreement.http://www.forbes.com/sites/paulroderickgregory/2015/02/13/putin-comes-out-on-topin-new-minsk-agreement/

6. Robin C. Global Diasporas: An Introduction. London and New York: Routledge, 2002.

7. Souslov M. "Russian World": Russia's Policy Towards Its Diaspora. Paris: Ifri, 2017. P. 10.

8. Wawrzonek M. Ukraine in the "Gray Zone": Between the "Russkiy Mir" and Europe // East European Politics \& Societies. 2014. Vol. 28. №4. Pp. 758-780.

9. Ziegler C. E. The Russian Diaspora in Central Asia: Russian Compatriots and Moscow's Foreign Policy// Demokratizatsiya. 2006. Vol. 14. №1. Pp. 103-126.

10. Арефьев А. Л. Русский язык в мире: прошлое, настоящее, будущее // Слово.ру: Балтийский акцент. 2015. №4. С. 7-21.

11. Всесоюзная перепись населения 1989 года. http://www.demoscope.ru/weekly/ssp/sng_nac_89.php

12. Горяинова М. В. Особенности реализации и защиты личных (гражданских) прав и 
свобод соотечественников, проживающих за рубежом // Юридическая наука и правоохранительная практика. 2011. №4 (18). С. 19-22.

13. Демография.http://www.gks.ru/wps/wcm/connect/rosstat_main/rosstat/ru/statistics/popul ation/demography/\#

14. Дугин А. Г. Основы геополитики Геополит. будущее России Мыслить пространством. М.: АРКТОГЕЯ-центр, 1999.

15. Емельянова Л. Л., Фидря Е. С. Оценка рисков и возможностей реализации Программы оказания содействия добровольному переселению в Калининградскую область РФ соотечественников, проживающих за рубежом // Балтийский регион. 2014. №2. С. 81-96.

16. Кириллова Е. К. Государственная программа переселения соотечественников: четыре года спустя // Балтийский регион. 2010. №4.

17. Лебедева Н. М. Русские в странах ближнего зарубежья // Вестник Российской академии наук. 1998. Т. 68. №4.

18. Мы вернулись в XIX век. https://newtimes.ru/articles/detail/81593

19. Соотечественники за рубежом. (с) ВЦИОМ, 2009 119072, РФ, Москва, https://wciom.ru/fileadmin/file/nauka/ns_doklady/2009/2009-11-06-sootechestvenniki.pdf

20. Статс-секретарь, заместитель Министра иностранных дел Российской Федерации Г.Б. Карасин о важности предстоящего Всемирного конгресса соотечественников и проблемах российских общин за рубежом. http://www.mid.ru/activity/compatriots/min//asset_publisher/evI8J0czYac3/content/id/3413983

21. Тертри Д. Русский вопрос в постсоветский период // Вестник СПбГУ. История. 2017. Т. 62. №1. С. 43-56.

22. Федеральный закон от 24.05.1999 N 99-Ф3 (ред. от 23.07.2013) "О государственной политике Российской Федерации в отношении соотечественников за рубежом". https://legalacts.ru/doc/federalnyi-zakon-ot-24051999-n-99-fz-o/

23. Фурман Д. Е. О будущем «постсоветского пространства» // Свободная мысль. 1996. № 6. C. 36-50.

\title{
24. （美）安德森. 想象的共同体. 上海: 上海人民出版社，2011. 第 6 页.
}

\section{ГЛОБАЛЛАШУВ ШАРОИТИДА ЎЗБЕКИСТОНДА УЗЛУКСИЗ ТАЪЛИМ ТИЗИМИНИ РИВОЖЛАНТИРИШ МАСАЛАЛАРИ}

\author{
О.М.Ғайбуллаев \\ (ф.ф.d, професcop)
}

Annotation: This article discusses the philosophical aspects of the ongoing reforms in the education system in Uzbekistan and modern changes in the national education system. It scientifically reveals the need for a system of continuous education for every citizen in the era of globalization, the importance of educating young people as spiritually mature people.

Key words and expressions: National idea, society, continuing education, youth, spirituality, art, national values, globalization, educational program.

Глобаллашув инсоният тарихий тараққиёти, маданий мероси, ижтимоий тузуми ва мафкуравий қарашларини доимо хилма-хиллигини таъминлаб келган. Бу жараён Ўзбекистонда узлуксиз таълим тизимининг шаклланишида хам янгича кўриниши намоён эта бошлади. Айниқса, оилада вояга етадиган ёш авлодни юксак эстетик идеаллар асосида тарбиялаш, уларни узлуксиз таълим тизимида хар томонлама етук шахс бўлиб етишишини таъминлаш масалаларига алохида эътибор қаратишни талаб этмоқда.

Бугунги кунда жамият ва давлат тараққиётининг барқарорлиги, ўз навбатида юрт тинчлиги ва тараққиётига, умуминсоний маданият ва маънавият ривожига туртки бўлмоқда. Ёшларнинг маънавий-ахлоқий қиёфасини шакллантириш бутун инсоният томонидан тан олинган ва эътироф этилган маънавий қадриятлар хамда ахлоқий тамойилларни фаол ўзлаштириб, хаётга тадбиқ этишлари билан белгиланади. Ўзбекистон Республикасининг 
Президенти Шавкат Мирзиёев таъкидлаганидек, «Маълумки, ёш авлод тарбияси хамма замонларда хам мухим ва долзарб ахамиятга эга бўлиб келган. Аммо биз яшаётган ХХИ асрда бу масала хақиқатан хам хаёт-мамот масаласига айланиб бормоқда «Тарбия қанча мукаммал бўлса, халқ шунча бахтли яшайди», дейди донишмандлар. Тарбия мукаммал бўлиши учун эса бу масалада бўшлиқ пайдо бўлишига мутлақо йўл кўйиб бўлмайди» [Мирзиёев Ш.М. 2017. 505]. Дархақиқат, ёшлар мамлакат келажаги, мамилакатнинг ишонган таянчи, миллат бардавомлиги хисобланади. Шунинг учун хам юртимизда амалга оширилаётган узлуксиз таълим тизимидаги ислохотларнинг мазмун мохияти кўп жихатдан, келажагимиз эртанги кунимиз эгалари - ёшларни хар томонлама етук бўлишларини таъминлайди. Айниқса, хозирги тахликали даврда хар бир ёш авлоддан замон талабларига хозиржавоблик ва фаолликни талаб қилиш билан бир қаторда, уларнинг маънавий-ахлоқий камолоти хар доим долзарб даражага кўтарилмокда. Чунки маънавий-ахлоқий ва миллий қадриятлар, ахлоқ нормаларига кўра, жамият тараққиётига ижобий таъсир кўрсатади. Аксинча, маънавий-ахлоқий ва миллий қадриятлар, ахлоқ нормаларининг бузилиши жамият ва давлатни риаожланишига салбий таъсир этади.

Шу боис «Таълим тўғрисида»ги қонун, Кадрлар тайёрлаш Миллий Дастуримизда миллий ва умуминсоний қадриятларни уйғунлаштириш, ёшларни юксак маънавий-ахлоқий фазилатларни шакиллантириш, ўз Ватанига содиқ ёшларни тарбиялашга алохида ахамият берилган. Хусусан, Кадрлар тайёрлаш тизимини ривожлантиришнинг асосий йўналишларидан бири бўлган маънавий-ахлоқий тарбия ишларида ёш авлодни маънавийахлоқий тарбиялашда халқнинг бой миллий маданий-тарихий анъаналарига, урф-одатлари хамда умумбашарий қадриятларга асосланган самарали ташкилий, педагогик шакл ва воситалари ишлаб чиқилиб амалиётга жорий этилади. Шахсни тарбиялаш ва уни хар томонлама камол топтиришнинг устуворлиги таъминланади. Умумий хамда педагогик маданиятни ошириш мақсадида, мамлакат ахолиси орасидаги маърифий ишлар такомиллаштириб борилади, - деб кўрсатилади.

Ижтимоий тараққиёт жараёнининг жадал суръатлар билан ривожланиб боришида алохида ахамият касб этаётган глобаллашув хар бир давлат, халқ, миллат, ёхуд шахс эстетик маданиятида янгича маъно-мазмун касб этмоқда. Жамият ривожида “хар бир ижтимоий ходисанинг ижобий ва салбий томони бўлгани сингари, глобаллашув жараёни хам бундан мустасно эмас. Хозирги пайтда унинг ғоят ўткир ва кенг қамровли таъсирини деярли барча сохаларда кўриш, хис этиш мумкин. Айниқса, давлатлар ва халқлар ўртасидаги интеграция ва хамкорлик алоқаларининг кучайиши, хорижий инвестициялар, капитал ва товарлар, ишчи кучининг эркин харакати учун қулайликлар вужудга келиши, кўплаб янги иш ўринларининг яратилиши, замонавий коммуникация ва ахборот технологияларининг, илм-фан ютуқларининг тезлик билан тарқалиши, турли қадриятларнинг умуминсоний негизда уйғунлашуви, цивилизациялараро мулоқотнинг янгича сифат касб этиши, экологик офатлар пайтида ўзаро ёрдам кўсатиш имкониятларининг ортиши - табиийки, буларнинг барчасига глобаллашув туфайли эришилмоқда" [Каримов И.А. 2008. 111-112].

Ўзбекистоннинг Харакатлар стратегияси ўзбек халқининг буюк давлат барпо этиш борасидаги мақсад-муддаоларини, таълим тизимидаги замонавий ўзгаришларнинг кенг жамоатчиликка хар томонлама тушунтириш, глобаллашув жараёнининг асл мохиятмазмунини ёшларга аниқ ва равшан қилиб ўргантиш жамиятимизнинг долзарб вазифалардан бирига айланди.

Глобаллашув шароитида таълим-тарбия, тарғибот ва ташвиқотнинг самарали усул ва воситаларидан оқилона фойдаланишни жамият тақозо этмокда. Бугунги кунда глобаллашувнинг ижтимоий хаётимиз билан боғлиқлиги, айниқса, моддий ва маънавий бойликларимизнинг жамият равнақида катта ахамиятга эгалиги хусусида Президент Ш.М.Мирзиёев ўз фикрларини билдирар экан, “Халқимизнинг муносиб хаёт кечириши, фуқароларимизнинг бунёдкорлик салохиятини руёбга чиқариш учун зарур шарт-шароитлар яратди. Айни вактда, бугунги глобаллашув даврида жахон миқёсида чукур молиявийиқтисодий инқироз давом этаётган, рақобат тобора кучайиб бораётган кескин бир шароитда 
биз мамлакатимиз босиб ўтган тараққиёт йўлини хар томонлама тахлил қилиб, давлатимизни барқарор ва жадал суръатлар билан ривожлантириш, олиб борилаётган ислохотлар самарасини янада ошириш мақсадида, 2017-2021 йилларда Ўзбекистон Республикасини ривожлантиришнинг бешта устувор йўналиши бўйича Харакатлар стратегиясини ишлаб чиқдик” [Мирзиёев Ш.М. 2018. 178], деб таъкидлайди.

Ўзбекистон Республикасининг Президент Ш.М.Мирзиёев ташаббуси билан 20172021 йилларда Ўзбекистон Республикасини ривожлантиришнинг бешта устувор йўналиши бўйича Харакатлар стратегияси ишлаб чиқилди. Стратегиянинг тўртинчи устувор йўналиши “ижтимоий сохани ривожлантиришнинг устувор йўналишлари йўналтирилган ахоли бандлиги ва реал даромадларини изчил ошириб бориш, ижтимоий химояси ва соғлиғини сақлаш тизимини такомиллаштириш, хотин-қизларнинг ижтимоий-сиёсий фаоллигини ошириш, арзон уй-жойлар барпо этиш, йўл-транспорт, мухандислик-коммуникация ва ижтимоий инфратузилмаларни ривожлантириш хамда модернизация қилиш бўйича мақсадли дастурларни амалга ошириш, таълим, маданият, илм-фан, адабиёт, санъат ва спорт сохаларини ривожлантириш, ёшларга оид давлат сиёсатини такомиллаштириш" белгиланди. Шу муносабат билан бугунги кунда таълим ва илм-фан, ёшларга оид давлат сиёсатини амалга ошириш, таълимнинг янги, усулларини, жумладан, замонавий ахбороткоммуникация технологияларини жорий этиш сохаси давлат сиёсати даражасига кўтарилиб бормоқда. Бугунги кунда мамлакатимизда ёшларни манавий-ахлоқий, миллий қадриятларимизга хурмат рухида тарбиялаш, маънавий, етук ва баркамол авлодни вояга етказиш, уларнинг хуқуқ ва эркинликларини химоя қилиш, ишлари амалга оширилмоқда.

Ўзбекистонда жахон хамжамияти билан ўзаро алоқаларнинг кўшилиб кучайиб бориши ижтимоий хаётда янгича тафаккур ва онг билан яшашни талаб этмокда. Бу жараён ўз-ўзидан халқимиз турмуш тарзи ва дунёқарашини замонавий ғоялар билан уйғунлашувига кенг имкониятлар яратиб берди. Фуқаролар онгида миллий қадриятлар билан бир қаторда янги кўринишдаги узлуксиз таълимга бўлган эхтиёж шакллана бошлади. Жамиятда узлуксиз таълим асосида ёшларнинг соғлом турмуш тарзини шакллантириш, миллийлик рухиятида жахон халқлари билан алоқаларни ўрнатиш, аждодлар меросини асраб-авайлаш, ўзаро самимийлик, қадриятларга содиқликни тарбиялаш масалалари ифодаланди.

Ўзбек халқи ўзининг бой фалсафий ва эстетик меросига эга. Турмуш тарзимиз шу меросга боғлиқ холда, яъни шарқона миллий тарбия билан боғлиқ равишда ривожланмоқда. Шунингдек, ёш авлодга илму-зиё тарқатишда ўзида нафосат оламини жо этган Қуръони Карим оятлари мазмуни, Хадиси Шарифлар, буюк аллома ва файласуфларимизнинг бебахо нодир китоблари хазинаси нафақат Узббекистондаги узлуксиз таълим тизимида соғлом ижтимоий мухитни, балки жахон халқлари орасидаги таълимни кенг ўрганиш ва ўргатиш хамда яхшилашга қаратилгандир. Бугунги кунда ўз нуфузи ва обрў-эьтибори билан кунданкунга жахонга ном таратаётган Ўзбекистонда глобаллашув жараёни замонавий ва миллий таълимни фақатгина ижобий манфаатлар хамда келажак учун мукаммал турмушни яратишни ўз олдига давр талаби қилиб кўйганидир. Дархақиқат, бу жуда нозик ва қалтис ишни амалга ошириш бутун ўзбек халқининг фарзандларидан сабр-тоқатли, матонатли, интилувчан бўлишни талаб этади. Фарзандларимиздаги иймон-эътиқод, миллий ғурур, ватанпарварлик ва инсонийлик каби хислатлар мустақил Ўзбекистон равнақига ўз таъсирини бевосита кўрсатади.

Бугунги кунда ёшларнинг таълимга бўлган қизиқишлари ва ўзига хос хусусиятлари “миллатнинг жахон глобаллашув жараёнларига ижтимоий, иқтисодий, сиёсий, маънавийрухий кўникиш потенциалига хам боғлиқдир" [Мамашокиров С., Тоғаев Ш. 2007. 32]. Бу боғлиқлик ўз навбатида, жамиятда глобаллашувнинг кенг қамровли эканлигини, хар бир ёш авлоднинг ундан оқилона фойдаланишини, турмуш тарзимизнинг ноёб жихатларига юксак хурмат ва инсонийлик туйғулари билан ёндошишни талаб этмоқда.

Хар бир шахс глобаллашув шароитида ўзининг маънавий камолоти ва эстетик маданияти орқали ижтимоий тараққиётнинг завқли муносабатларини вужудга келтиради. Бу завқли муносабатлар замирида халқимизнинг азалий қадриятларини чукур ўзлаштириш ва 
ўзлигини англаб олиш, воқеликни хиссий ва завқий идрок этиш, тарихимизнинг миллий хамда умуминсоний хусусиятларини теран мушохада этиш кабилар долзарб муаммога айланади. Уларнинг ечими эса, шахснинг юксак маънавий-ахлоқий ва бадиий-эстетик қарашларида ривожланиб бораверади.

Хулоса қилиб айтганда, глобаллашув жараёнида юртимизда узлуксиз таълимнинг узвийлигини таъминлаш, амалга оширилаётган ислохотларнинг хар бир жамият аъзоси учун унумли ва фойдали бўлишини таъминлаш, шунингдек, миллийлик билан умуминсонийликни уйғунлаштирган холда замонавий ютуқлардан бахраманд бўлиб боришни амалга ошириш вазифаси Ўзбекистон халқини буюк келажак ва эзгу мақсадлар сари чорлайди.

\section{Фойдаланилган адабиётлар рўйхати}

1. Каримов И.А. Юксак маънавият - енгилмас куч. -Т.: Маънавият, 2008.

2. Мирзиёев Ш. Миллий тараққиёт йўлимизни қатьият билан давом эттириб, янги босқичга кўтарамиз. 1-жилд. -Т.: «Ўзбекистон» НМИУ, 2017.

3. Мирзиёев Ш.М. Халқимизнинг розилиги бизнинг фаолиятимизга берилган энг олий баходир. -Т.: Ўзбекистон, 2-жилд, 2018.

4. Мамашокиров С., Тоғаев Ш. Эркин ва фаровон хаёт қурилишининг ғоявиймафкуравий масалалари. -Т.: Маънавият, 2007.

\section{ЖАНУБИЙ ОРОЛБЎЙИ ЎЗБЕК ШЕВАЛАРИ ЛЕКСИКАСИНИНГ ЛИНГВОГЕОГРАФИК ХАРИТАЛАШТИРИШ МУАММОСИ}

\section{Ю.М.Ибрагимов (НДПИ, профессор)}

Annotation: In this article, the lexical-semantic, morphological and phonetic features of the Uzbek dialects of the Southern Aral Sea Basin have been interpreted using the most important linguo-geographical method of the present time. Also, the principles of creating a dialectological atlas of Uzbek folk dialects were described in detail. The synchronous materials collected from the dialects were analyzed diachronically.

Key words and expressions: The south Aral kost, linguestic geography, semantic difference, dialektal difference, extralinguistic factor

Жанубий Орол бўйи ўзбек шеваларининг (Бундаан кейин - ЖОБЎШ) худудий (ареали)ни лисоний географик тадқиқ этиш қатор долзарб муаммоларни хал этиш учун ёрдам беради. Шеваларнинг ташқи чегарасини, ички таснифи, тахлил этилаётган шеваларнинг умумўзбек диалектал микрохудуд тизимидаги ўрнини белгилаш; Жанубий Оролбўйи ўзбек, қораалпоқ, қозоқ, туркман каби тўрт туркий тилларнинг ўзаро мулоқат худуди хисобланиши; худуд шевалари тилларининг якинлашуви, архаик ходисаларини сақлаб қолиши хақида маълумот бериш; шу сабабдан шева вакилларининг тили, тарихи, турмуш тарзи, ери, маданияти, урф-одати, дини хақида етарлича маълумот бериш; халқ шеваларини макон доирасида тадқиқ этиш шевалардан денотатларнинг барча хусусиятларига доимий эътиборда бўлишни тақозо этади. Шундай қилиб, лисоний хариталаш ва унинг натижаларини талқин қилишда замонавий хамда самарали услуб - усуллардан фойдаланиш зарур.

Маълумки, тилдаги хар хил диалектал ходисанинг тарқалиш чегарасини, географик ўрнини аниқлаб бериш, янгидан топилган коннинг илгари мавжуд бўлган бўлса хам, қаерда экани номаълум бўлган хазинининг географик ўрнини аниқлаш билан баравардир. Конларни топиб хариталаштириш геологик тадқиқотнинг ютуғи хисобланса, тил ходисаларини йиғиб, харитага жойлаштириш, ареалини аниқлаш, диалектологик атласини яратиш лингвогеографик изланишнинг мувафаққиятидир. Зеро, (ЖОБЎШ) ўзбек шевалари лексиксемантик фарқларнинг аниқ сабабларини лингвогеографик тадқиқ этишдан мақсад, биринчидан, аввало шеваларнинг тарихан вужудга келган тараққиёти динамикасини очиб бериш, шева вакилларининг тарихи орасидаги алоқани хисобга олиш, иккинчидан, шевалар 
воқелигининг хозирги чегараларини тўғри талқин этиш учун бу чегаралар тараққиётининг барча босиб ўтган йўли натижаси, фақат, қадимда эмас, кейинги даврларда хам юз берган лисоний жараёнларнинг натижаси эканлигини унутмаслик [Жирмунский 1963:15-16], учинчидан, шеваларнинг лексик-семантик фарқлари замон ва макондаги лисоний ўзгаришлар хамда ички лисоний омилларнинг мураккаб ўзаро алоқасининг натижаси экани, тугртинчидан, шева худудини қўшни худудлар билан чоғиштириш ва таққослаш асосида кўриб чиқилиши [Взаимодейтв. лингвист. ареалов, 1980:244] лисоний-жўғрофий тадқиқотининг асосий хусусияти эканини хисобга олишдир.

М.А.Бородина: «Лисоний география фақат тилнинг ички таркиби билангина боғлиқ эмас, у баъзан тадқиқотчини мамлакат халқларининг савдо йўллари ва айрим ахоли пунктлари тарихи билан боғлиқ тилнинг ташқи тарихи юзасидан хам кутилмаган натижаларга йўналтиради» [Бородина1966:8], - деган эди. Шу муносабат билан ЖОБЎШ лексикасидан йиғилган синхрон маълумотларни лингвогеографик метод ёрдамида шархлашда, аввало, кенг икки аспектда ёндашишни тақозо этади: 1) умумтуркий ва ўзбек (кейин хосил бўлган) шева ходисалари; 2) ўзбек халқ тили билан яқин алоқада бўлган туркий ва нотуркий тилларнинг таъсири остида вужудга келган шевалар ходисаси. Бу ўрганилаётган шевалар вакилларининг қориндошлигига, географик яқинлигига бевосита алоқадор бўлиб, миллий тил ёки махаллий шеваларга хос ўзгачаликлар унинг маъмурий-географик чегараси билан чекланмайди. Уларни уруғ-қабилачилик даврдаги аталмиш халқларнинг бирлигининг натижаси деб қараш ўринлидир. Масалан, шевалар лексикаси хусусида сўз юритганда форстожик тиллари ва туркий тиллар генетикаси турли хил бўлса хам, уларнинг ўзбек тили билан яқинлигига қадимдан худидий-географик, иқтисодий-ижтимоий, сиёсий-маданий алоқа муносабатлар шароит яратди. Уларнинг ота-боболари ўтмишда Марказий Осиёнинг бой чорвачилик, дехқончилик, хунармандчилик, савдо-сотиқ маданиятига асос солганлар, йирик қурилиш иншоатлари, илм-фан, маънавий-маърифий, маданий бойликларни хамкорликда бунёд этганлар. Шу сабабдан, тадқиқотчилар бу икки халқнинг ўтмиш тарихини бир катта дарахтнинг танасидан ўсиб чиққан иккита қудратли новдага таққослайдилар [Истор. тадж. народ.1933:3[.

Агар ЖОБ минтақасидаги ўзбек шевалари эгаларининг этногенетик жихатига назар ташласак, уларда учрайдиган куингирот, найман, канагас, қиёт, қипчоқ, қангли, қатаган, канагас, киник, чавдир ва бошқа уруғ номлари минтақадаги қорақалпоқ, қозоқ, туркман халқларининг таркибида хам айнан учрайди. Булар хозирги кунда қайси халқнинг таркибига кирмасин ўзларининг уруғчилик даврдаги тил унсурларини ушбу худудларда қисман сақлаб қолган. Уларнинг хар бири тилнинг ички тараққиёт қонуни жараёнида мустақил холда шаклланди, такомиллашди, натижада фонетик, грамматик, лексик-семантик ўзгачиликлар туғилди.

Тадқиқотда шева ва диалектлардан йиғилган синхрон маълумотларни хариталаштиришда диахрон усулдан фойдаланиш умуммиллий ахамиятга молик бўлиб, у тарихий диалектология ва ёзма ёдгорликларнинг маълумотларига таянади. Масалан, хозирги вақтда мавжуд бўлган турғун бирикмалар типи «джав келдимə?», «джав чапқ̧андай», «джав кувzандай», «джав алдылма?», «джав чаппыйды» ва б. қадимда душманнинг хужуми билан боғлиқ юзага келган. Ёйинки, көздиң джәвун алув ибораси бирор нарсанинг чиройли, махлиё этувчи, мафтун этувчи, жоду каби маъноларни ифодалайди. Қиёсланг: қад. турк. тил. жәв ёғ, мой [ДТС.223]. ўзб. ад. тил. ёғ [УзРС.148]. Ўзбек тили қипчоқ лахжасининг джелашган диалектида «й» ундоши сўз бошида «дж) ундошига, сўз охирида «в» ундоши «в» ундоши билан алмашиниши қонуний холдир. Шеваларда иборанинг айнан маъноси кўзингни ёz босишдан асрагин, яъни хаддингдан ошма. Мазкур шеваларда сигирни чақириш. эркалатиш маъносида хзәвкәм-хฺәвкәм, хзав-хฺав ундов сўзи ишлатилади. Хәвкә сигирнинг бўйнидан тўшигача осилиб турган оралиқ жойи. Аслида ўта инжиқ, телба, ўжар, тез айниб турадиган сигирларнинг ўша жойини соғиш олдидан ёки соғиш пайтида хуәвкәм-хзәвкәм деб силайди, эркалатади ва сигир ёввошиб қолади. Қорақалпоғистоннинг Қўнғирот, Шуманай, Қонликўл туманлари, Хўжайли туманининг Қайрангли, Сўкберган қишлоқларида яшовчи 
ўзбеклар нутқида қуртқ̧ачач ўт номи учрайди. Хўжайли-қипчоқ шевасида бу сўз кәмпирчач; беруний-манғит ва тўрткўл-элликқалъа шеваларида мамасач сўзи ишлатилади. Кекса кампирнинг сочига шаклан ўхшашлиги асос қилиб олинган. Қозоқ халқининг «Қўбланди ботир» достонида Кўбланди ботирнинг севган ёрининг исми Куртқа бўлган. Урф-одатлар. ишонимларга кўра, янги туғилган чақолоққа халқ узоқ яшасин деган мақсада унга Курmқа (қари кампир) исмини берган (Ч.Уалиханов). Қадимги туркий ёзма ёдгорликлар тилида қуртқ̧а кампир (ДТС.469). В.В.Радлов Луғатида ва куманлар, уйғур, эски ўзбек тилларида хам қуртққа кампир маъносида қўлланган (ОСТИ.т.ІІІ.ч.1.948-949). Аслида қуртқ̧а сўзи халқ бўлиб ташкил топишидан олдинги даврга тегишли бўлиб, хозирги кўпгина туркий тилларда бу сўзни форс-тожик тилидан ўзлашган кампир сўзи аста-секин истеъмолдан сиқиб чиқармокда.

Ўзбек адабий тилидаги тухум сўзи ЖОБ ўзбек шеваларида йумырта:йумыртқ̧а ва мәйәк:мәйек сўзлари кўлланади. ЖОБЎШнинг джс-ловчи ўзбек шеваларида мәйәк, Кўнғирот, Шуманай, Қалликўл туманларидаги ўзбеклар шевасида мәйек; ўғуз тип шеваларда йумырта:йумыртққа сўзи ишлатилади. Адабий тилдаги туқим сўзи шеваларда урух, авлод, насл, зотдор каби маъноларга эга; шеваларда аканинг хотини тушунчаси Гурлан, Беруний, Янгибозор, Илонли, Тозабозор туманларид: йәнъгə; Хўжайли, Нукус, Кўхна Урганч, Амударё туманининг шимолий қишлоқларида: чечə; Қўнғирот, Шуманай, Қолликўл туманларида джеңзге; Тўрткўл, Элликқалъа туманларида: гәлинбийи:бийи. Мазкур сўз қатор маъноларга эга. Кўнғирот, шуманай, Хўжайли ва Амударё туманининг Қипчоқ мавзесида: 1) джеңзгә:джеңцге - тўй кечаси қиз билан йигитнинг ёнида қоладиган келиннинг янгаси; 2) йигит билан құзни таништирадиган воситачи аёл; қорақапоқ. шеше -эрининг акасининг хотини, катта келин (ҚҚРСЛ.735); Тошкент атрофидаги қозоқлар шевасида: шеше амакисининг хотини; озарбойжон. чичи - ўша маънода. Кейинги йилларда қозоқ, қорақалпоқ шевалари таъсирида Кўнғирот, Шуманай, Қолликўл, Нукус туманларидаги ўзбеклар нутқида ona сўзи ўрнида әджапа атамаси; ЖОБнинг қолган барча қипчоқ тип шеваларида ўзбек адабий тили ва етакчи шахар шевалари таъсирида айапа атамаси ишлатилмоқда. Айапа ва aджапа терминлари фаол истеьмолга кириб, қыз апа эквивалентини сақиб чиқармоқда.

Хулоса ўрнида шуни таъкидлаш жоизки, шеваларни хариталаштириш жараёнида шу нарса аниқландики, тадқиқ этилаётган шевалар бир бутунликка эга эмас. Чунки шева чизиқларининг кўпчилиги ЖОБ худудида турли йўналишлар бўйича тарқалади ва аниқ лисоний жуғрофий тамойилга эга бўлмаган шева худудини ифодалайди. Аммо шу билан бирга шева чизиқларининг маълум боғламларининг муносабати билан ифодаланадиган шевалар лексикасининг лексик-семантик хусусиятларини кўрсатади, Жанубий Оролбўйи ўзбек шевалари учун ранг-баранг кўринишлар хос хусусиятдир.

\section{Фойдаланилган адабиётлар рўйхати}

1. Бородина М.А. О типологии ареальних исследований // В сб. Вопр. изучн. в языкозн. и этногр.: - Л., Наука. 1974 с.43-54.

2. Взаимодействие лингвистических ареалов. Л.,Наука. Ленингр. отдел.// 1980. 276 с.

3. Жирмунский В.М. О диалектологическом атласе тюркских языков СССР.॥ «Вопросы Языкозн.», 1963, № 6, с.15-16.

4. История таджикских народа.Т.1, кн.1. -Душанбе: Дониш.1953. 596 с.

\section{Луғатлар}

1. ДТС.- Древнетюркский словарь.-Л.: Наука,-1969.

2. ККРС. -Каракалпакско-русский словарь.-М.:1958.

3. Узбекско-русский словарь.-М.: 1959. 


\title{
КИТАЙСКАЯ ТРАДИЦИОННАЯ КУЛЬТУРА В КОНЦЕПЦИИ «СООБЩЕСТВА ЕДИНОЙ СУДЬБЫ ЧЕЛОВЕЧЕСТВА»
}

\section{Чжэн Цзелань (ШУИЯ, Китай, старший преподаватель)}

\begin{abstract}
Annotation: At present, the concept of "a community with a shared future for mankind" defines the main direction of China's foreign policy and transforms from an idea to a practical phase. In this article, we analyse this concept based on the Chinese traditional culture.
\end{abstract}

Key words and expressions: China, Xi Jinping, traditional culture, a community with a shared future for mankind, Confucianism, Taoism.

В марте 2013 года председатель КНР Си Цзиньпин во время выступления с докладом в Московском институте международных отношений впервые представил концепцию «сообщества с единой судьбой человечества». В дальнейшем Си Цзиньпин многократно на различных площадках в своем выступлении раскрыл и обогащал данную концепцию. Идея формирования человеческого сообщества с единой судьбой была включена в Устав Коммунистической партии Китая на 19-м Всекитайском съезде КПК в 2017 г., также была закреплена в поправках Конституции КНР в 2018 г.. Очевидно, в настоящее время данная концепция определяет основное направление внешней политики Китая и переходит с идеив практическую фазу.

Концепция «сообщества с единой судьбой человечества»уходит корнями в богатую китайскую традиционную культуру, нацелена на развитие человечества и будущее мира и направлена на достижение общего процветания всех стран.В отличие от «игры с нулевой суммой», данная концепция полна восточной мудрости и придает важное значение миру и совместному развитию. Китай твердо выступает за мирное сосуществование и постоянно расширяет дружественное сотрудничество со всеми странами. В контексте пандемии Китай также активно оказывает гуманитарную помощь другим странам. По данным причинам, концепция, предлагаемая Китаем, находит все более широкую поддержку и одобрение на мировой арене. Она была вписана в резолюции Комиссии социального развития ООН, Совета безопасности ООН и Совета по правам человека ООН в 2017 году.Включение данной концепции в резолюцию ООН свидетельствует о вкладе Китая в глобальное управление.

Содержание концепции «сообщества с единой судьбой человечества» достаточно глубоко и богато, сутью которой является «создание мира, в котором существует прочный мир, всеобщая безопасность, совместное процветание, открытость и толерантность, чистота и красота» 57 , т.е, можно воплощать эту концепцию с таких пяти аспектов, как политика, безопасность, экономика, культура и экология.В аспекте политики требуетсяотказаться от менталитета холодной войны, уважая друг друга, ведя равноправные консультации на основе взаимного понимания. Страны, будь то великие державы или малые страны, должны относиться друг к другу равноправно, устраняя разногласия с искренностью.В аспекте безопасности требуется совместно реагировать на традиционные и нетрадиционные угрозы безопасности, в частности на фоне распространения коронавируса во всем мире. В аспекте экономики требуетсяупрощать торговлю и стимулировать инвестиции, продвигать развитие экономической глобализации в сторону большей открытости.В аспекте культуры следует уважать разнообразие мировой цивилизации, укрепляя дружбу между народами всех стран. В аспекте экологии требуется уважать природу, охранять окружающую среду и совместно реагировать на изменения климата.

Богатое содержание концепции уходит корнями в традиционную культуру тысячелетней давности.Си Цзиньпин также обращает особое внимание на традиционную культуру Китая, на международной научной конференции в сентябре 2014 г., посвященной 2565-й годовщине со дня рождения Конфуция, он выступил с речью о том, что «Лишь помня

\footnotetext{
${ }^{57}$ Полный текст доклада, с которым выступил Си Цзиньпин на 19-м съезде КПК. Сайт правительства Китая. http://www.gov.cn/zhuanti/2017-10/27/content_5234876.htm
} 
прошлое, можно увидеть будущее; лишь бережно храня старое, можно создать новое. Мы должны идти в будущее, черпая силы с прошлого, только таким образом мы сможем решить сегодняшние задачи». Рассматривая ценность китайской традиционной культуры, мы находим источник философии внешней политики Китая.

В традиционной культуре Китая одно важное понятие «Хэ (和)», которое обозначает мир, гармонию и согласие. Понятие «Хэ ( 和)» также представляет собой основу конфуцианства. По словам Конфуция в книге «Лунь Юй ( 论语)», благородные люди находятся в согласии с другими людьми, имея разные взгляды（君子和而不同）. Данная идея произвела на китайскую культуру глубокое влияние. Это не только важный критерий поведения людей в мире, но и принцип совместного развития различных культур человеческого общества. Это толерантный дух уважения и понимания различных культур, является целью стремления, чтобы различные культуры могли достичь идеального и совершенного состояния при равном общении и интеграции. В Китае есть и известные выражения: «Только один вид цветов не создает весны. Когда все цветы зацветут, весна будет в самом разгаре». Мир многокрасочен. Цивилизация одного государства и одной нации является коллективной памятью государства и нации, что требуется уважать различия разных цивилизаций, религиозных верований, социальных систем и идеологий.«Гармония при наличии различия〉 обозначает признание культурных различий и индивидуальностей, подтверждение характеристик и ценностей разных наций, регионов и национальных культур на основе взаимного понимания. Придерживаясь такого принципа, Китайосуществляет дружеский диалог между разными цивилизациями, поддерживает и продвигает культурное разнообразие, содействует различным культурам добиваться беспроигрышного сотрудничества.

В другой классике конфуцианства «Шан Шу(尚书)» гласит: «гармонизировать десять тысяч соседних стран (协和万邦)». Это отражает, что с древних времен Китай уделял особое внимание урегулированию отношений между народами мирным путем. Добрососедская дружба и гармония являются важными понятиями в традиционной китайской стратегической культуре. В классике «Лунь Юй (论语)», «Чжоу Ли (周礼)» древние философы также выступили за гармонию с соседями и против войны. Мэн-Цзы продолжил эту идею и выдвинул идею «покорить других добродетелью». Представитель даосизма Лао-Цзы в своей книге подчеркнул негативные последствия войны. Такая идея в общем отличается от «борьбы» в западной философии. В истории Китай всегда придерживался мирного принципа в процессе обмена с другими народами. Знаменитые исторические события, такие как путешествиеЧжанЦяна в западные регионы при династии Хань, путешествие Сюаньцзана на запад при династии Тани путешествия ЧжэнХэ при династии Мин - все это доказательства мирных обменов в древнем Китае. После провозглашения КНР, китайское правительство выдвинуло основные нормы международных отношений как уважение суверенитета, независимости и территориальной целостности, взаимное невмешательство во внутренние дела и пр., что было широко принято международным сообществом. В сегодняшний день идея Си Цзиньпина о построении сообщества единой судьбы человечества берет свое начало с китайской традиционной культуры и представляет собой продолжение мудрости предшественников.

В китайской древней культуре в понятие «Хэ» ценили не только гармонию между людьми и обществом, но и гармонию между людьми и природой. Идея о «гармонии между человеком и природой» очень влиятельна в китайской традиционной культуре. Конфуцианство подчеркивал «добродетель» и выразил, что следует любить других, также и природу, а даосизм придал важное значение уважению объективному закону природы. Несмотря на различные высказывания, древние философы подчеркивал важность гармонии человека и природы. В концепции «сообщества единой судьбы человечества» также мышление о сохранении окружающей среды.Учеловечества только одна Земля, все нации 
сосуществует в одном мире, перед всеми государствами общие задачи и вызовы, например, изменение климата, и т.д. Если одна странапреследует краткосрочные экономические выгоды за счет потребления большего количества экологических ресурсов, то неизбежно наносит ущерб интересам других соседних стран. Лишь все государства вместе урегулируют политики в сфере экологии и создают международную правовую систему для «зеленого» непрерывного развития, человечество сможет разрешить предстоящие задачи в сфере экологии.

В китайской традиционной культуре своеобразное мировоззрение на «интересы». Конфуций полагал, что можно стремляться к законным интересам, и выступал против незаконно полученной выгоды. В классике конфуцианства «Лунь Юй» написано: «Благородныйчеловек думает о морали, низкий человек думает о выгоде», «Благородный человек зарабатывает честным путем». Все высказывания подчеркивали, что надо получить выгоду законно, честно и справедливо. Такое мышление постепенно стало нормойморали и поведения китайской нации на протяжении тысячелетий, которая не только бессознательно влияет на образ мышления китайского народа и его поведение, но и влияет на отношения между Китаем и другими странами. В древности в обмене с другими странами Китай придал важное значение благородности и справедливости.Принцип «правильного взгляда на выгоду и справедливость» также служит одним из основных компонентов внешнеполитической парадигмы товарища Си Цзиньпина. Он на разных мероприятиях подчеркивал, что надо исходить из интересов не отдельных стран, а всего мирового сообщества, т.е в политическом плане придерживаться принципа справедливости, равенства и приоритета высокой морали; в экономическом плане придерживаться принципа взаимной выгоды и совместного развития.

В классике конфуцианства «Лунь Юй» также гласит: «Не делай другим того, чего не желаешь себе». Эти слова раскрывают важный принцип отношений: поставить себя на место другого и заботиться о других. Всередине XIX века феодальный Китай превратился в полуколонию западных держав и сильно пострадал. На международной арене Китай также не делает другим того, чего сам не желает. Председатель Си Цзиньпин много раз подчеркивал, что Китай не соглашается с логикой устаревшего взгляда, утверждающей, что сильная страна обязательно претендует на гегемонию. Стремлением китайской нации всегда является мир и совместное развитие, а не гегемония.

У Китаядлинная история и блестящая культура.Влияние китайской традиционной культуры на концепции внешней политики всегда ощутимо.Инициатива Китая о создании сообщества единой судьбы человечества отвечает культурно-цивилизационной идентичности китайского народа. В концепции «сообщества единой судьбы человечества» показаны лучшие ценности традиционной китайской культуры, такие, как мирного сосуществование, «гармония при наличии различия», согласие человека и природы, и т.д, также сосредоточены общие культурные идеалы человечества.

\section{Список использованной литературы}

1. 习近平在中国共产党第十九次全国代表大会上的报告(Полныйтекст доклада, с которым выступил Си Цзиньпин на 19-м съезде КПК.) http://www.gov.cn/zhuanti/201710/27/content_5234876.htm

2.钱穆，《中国文化十二讲》，九州出版社，2011年，173页(Цзянь Му，12 лекций по Китайской культурой, Дючжоу изд-во 2011 <173 с.)

\section{БУЮК ИПАК ЙЎЛИ-ТАРИХИЙ ВА МАДАНИЙ ХАМКОРЛИКЛАР ЙЎЛИДИР}

\section{Я.Х.Ғаффоров (ЧДПИ т.ф.н. доцент)}

Annotation: This article presents the history and cultural cooperation of the Great Silk Road, which has served the development of mankind for a long time.

Key words and expressions: Civilization, carvon, elchi, integration, macon, demography. 
Буюк ипак йўлининг тарихи Шарқ ва Ғарб халқларининг кенг миқёсдаги маданий алоқалар ва савдо айрибошлаш тарихидир. Бу тарих ўзаро хамкорлик, алмашиш ва маданиятлар бойитилиши тарихи бўлиб,тинчлик ва тараққиёт асосини ташкил этган.

“Буюк ипак йўли тарихига назар ташлар эканмиз, бу йўл жамият тараққиётини бронза давридан хам илгариги даврлардан бошлаб худудлараро боғловчи восита сифатида унга хос ихтисослашган йўллар бўлганлигини кўрамиз. Ўтмиш тарихда милоддан аввалги VI-IV асрларда Эрон ахамонийлари салтанати даврида унинг худуди буйлаб «шох йўли»ўтган. Ундан илгарироқ Ўрта ва Яқин Шаркда Бадахшон лазуритига бўлган эхтиёж “лазурит йўлининг” вужудга келишига сабаб бўлди. "Буюк Ипак йўли”нинг атамаси қадимда ишлатилмаган. Буюк Ипак йўлини тарихий, географик ва маданий жихатларини илмий ўрганиш амалда кўплаб мамлакат олимлари томонидан XIX-асрнинг II-ярмидан бошланган. Уни тадқиқ этишга Ғарбий Европа, Россия ва Япония олимлари салмоқли хисса қўшдилар. Жумладан бу борада Японияда "Буюк ипак йўли энциклопедияси" нашр

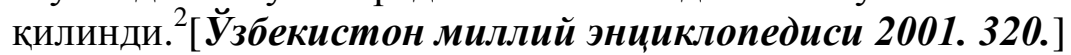

Бу йўл фанга "Ипак йўли” номи билан фақат XIX асрнинг 70-йилларидан бошлаб немис олими Фердинант фон Рихтгофен томонидан киритилган.

Буюк ипак йўли тизимида Фарғона, Хоразм, Самарқанд, Бухоро, Насаф шахарларининг илм-фан ва маданиятлар бирлашувидаги ахамияти катта бўлган.

Марказий Осиёнинг жавохири бўлмиш Фарғона водийси минг йиллар давомида цивилизация бешикларидан бири бўлиб келган. Қадимги Фарғона Бақтрия, Сўғд, Хоразм каби Турон заминнинг йирик тарихий маданий ўчоқларидан бири хисобланиб, умумбашарият маданиятига кўшган муносиб хиссаси туфайли “Фарғона цивилизацияси” деган ном остида жахон тарихига кирган. Жумладан, А.Тойнби уни дунёдаги 20 та цивилизациялардан бири эканини таъкидлаб: “Қадимги Фарғона-жахон цивилизациясининг мухим марказларидан биридир" деб ёзади. Мухим стратегик нуқтада жойлашган водий қадим замонлардан буён яқин қўшнилар ва узоқ ўлкалар билан савдо иқтисодий ва маданий муносабатлар олиб борган. Маданий-иқтисодий алоқалар таъсири ва йўналишни тахлил этишда археология ва этнография фанларининг ахамияти каттадир. Чунки ушбу жараёнлар моддий маданиятда ўз аксини топган бўлади. Жумладан, Хитойликлар Ғарбий ўлкалар деб таъриф берган Фарғона водийси худудида аниқланган айрим археологик комплексларнинг Ғарбий Хитойдаги материаллар билан қиёсий солиштирма ўрганишдаги бир-бирларига ўхшашликлар ва улардан келиб чиқадиган фикр хамда хулосалар қилинади.

Бугунги кундаги ёзма манбалар ва археологик топилмалар Буюк ипак йўлининг Хоразм худудидан хам ўтганлигини ва жуда қадимдан Хитой, Хиндистон, Эрон, Ироқ, Кавказ билан шунингдек шимолдаги кўшни давлатлар билан дипломатик алоқалар йўлга қўйилганлигини тасдиқламоқда.

XVI-XVII асрлардаги буюк географик кашфиётлар муносабати билан Европа ва Осиё давлатларини боғловчи қуруқликдаги қадимий савдо йўлларининг шу жумладан, Буюк ипак йўлининг хам ахамияти пасайиб кетди.Бундан ташқари халқаро майдонда юз берган сиёсий ўзгаришлар ва ихтилофлар хам Хоразмнинг халқаро транзит сохасидаги мавқеига ўз таъсирини кўрсатмасдан қолмасди. Айниқса,XV-XVIII асрларда хонликларда юз берган сиёсий воқеалар, феодал тарқоқлик ва ўзаро ички низолар халқаро алоқаларнинг сустлашишига олиб келди. Бундай кескин ўзгаришларга қарамай, ўзбек хонликларининг кўшни мамлакатлар билан иқтисодий ва маданий алоқалари батамом тўхтаб қолгани йўқ. Ўша даврларда Хива, Бухоро ва Балхнинг савдо карвонларини Хиндистонда, Эрон, Қашқар, Қозоғистон шахарларида, Волга бўйи ва Сибирда учратиш мумкин эди. Буюк Ипак йўлининг халқлар ва миллатлар тарихидаги ахамияти беқиёс. Чунки савдо йўли нафақат савдо карвонларининг балки минглаб ахолининг миграцияси ва эмиграциясини ўз ичига қамраб оладиган жараёндир. Хива хонлигидаги демократик вазиятни ўрганиш учун Буюк Ипак йўли тарихи унинг йўналишлари, қайси давлатлар билан савдо-дипломатик алоқалар йўлга қўйилганлиги, хонлик худудида яшаётган халқларнинг миллий таркибидаги ўзгаришлар, миграция ва урбанизацион жараёнлар,, ахоли бандлиги ва турмуш тарзи масалаларини 
чуқурроқ тахлил этиш мухим вазифа саналади. Ана шулардан келиб чиққан холда Буюк Ипак йўлининг хонликларнинг демографиясига таъсирини куйидагича кўришимиз мумкин.

Биринчидан, Буюк Ипак йўли давлатлар ўртасидаги мухим дипломатик алоқаларни йўлга қўйиш воситаси;

Иккинчидан, божхона орқали ва бозордаги солиқлар орқали тушадиган даромад хонликда иқтисодий кўрсаткичларнинг ўсишига олиб келади.

Учинчидан, махаллий хунармандлар, дехқонлар ва чорвадорлар томонидан етказиб бериладиган махсулотларнинг Жахон бозорига чиқиш имконияти.

Тўртинчидан,Буюк Ипак йўли орқали махаллий ахолининг турмуш тарзи ва яшаш шароитида маданиятлар алмашинуви, такомиллашуви ва умумий алмашувига олиб келади. ${ }^{3}$ [Халқаро илмий-амалий конференция материаллари туиплами.2013.91-94]

Умуман олганда, Буюк Ипак йўли шахарлари бўйлаб, Ўрта Осиёнинг турли тарихий маданий вилоятлар тарихининг энг қадимги давридан бошлаб ўзаро ва кўшни халқлар билан қалин маданий муносабатда бўлиб келдилар. Бу маданий алоқалар ижтимоий-иқтисодий хаётнинг турли сохаларидаги хамкорлик,турли технологик ютукларини кенг миқёсда ўзаро алмашиш, савдо-сотиқ ва элчилик муносабатлари, хунармандчилик, меъморчилик, хайкалтарошлик, тасвирий санъат ва маданиятнинг бошқа сохаларидаги ўзаро таъсир, динийфалсафий қарашлар ва ахлоқий мезонлар алмашинуви, маълумотлар, янгиликлар ва илмфаннинг турли сохалардаги технологик янгиликларнинг, ёзув ва нумизматик жараёнларнинг тарқалиши ва бошқа кўринишларда амалга оширилиб келинди. Бу жихатдан минтақанинг қадимги йўллари, айниқса Буюк Ипак йўли бўйлаб амалга оширилган маданий мулоқотнинг ахамияти нихоятда катта бўлди.Минтақанинг асосий карвон йўлларидаги савдо карвонлари таркибида хунармандлар, олимлар, шоирлар ва мусиқачилар хам бор эди.

Тадқиқотчилар бу жихатдан Илк Ўрта асрларда минтақа халқлари, хусусан, Сўғдийларнинг Шарқнинг улкан худудида турли маданий анъаналар ва динларни ёйиш ва жорий қилишда хам катта ўрин тутганлигини, шу билан бирга бу ўзаро алоқалар бир томонлама бўлмасдан, маданий таъсир Шаркдан Ғарбга-Хитойдан Ўрта Осиёга, Эронга, Олд Осиёга хам тарқалганлиги мухим ахамиятга эгадир. ${ }^{4}$ [Ртвеладзе Э.B.1999.] Ривожланган Ўрта асрларда минтақанинг маданий алоқалари ривожида марказлашган давлатларнинг пайдо бўлиши, илм-фаннинг турли сохаларида моддий ва маънавий хаётда эришилган ютуқлар асос бўлди. ${ }^{5}$ [Хайруллаев М.М 1994.]

Шарқ ва Ғарб халқларининг маданий алоқаларида ўтган тарихий даврлар давомида эзгулик, бунёдкорлик ва умуминсоний тараққиётга хизмат қилиб ғояларни кенг миқёсда тарқалишида асосий омил бўлиб хизмат қилган Буюк Ипак йўлининг тарихий ахамияти янада яққолроқ кўринади. Бу Ўрта Осиё цивилизациясининг бош ғояси сифатида бугунги кунда хам амалда бўлиб келаётганлигини, аждодларимиз асос солган ўлмас ғоялар давом этаётганлигини алохида қайд қилиб ўтишга асос бўлади. Буни Ўзбекистоннинг ташқи маданий алоқалари ва мамлакатимиздаги маданий тараққиёт мисолида хам кўришимиз мумкин.

Айни вақтда аждодларимиз тарихи ва қадриятлари тикланаётганлиги мустақиллигимизнинг ажойиб самарасидир. Халқимизнинг кечмиши, тарихи ва хаётини акс эттирган асарларнинг ўз она тилимизда нашр этилгани қувончимизга қувонч қўшмокда. Эндиликда ўтимишимизнинг кўпгина сахифалари, хужжатлар, кўлёзма материаллари биринчи манбалар асосида ёритилмоқда. Тарихий қадриятлар ва хақиқатлар асл манбаларга таяниб тикланмоқда.Уларнинг хаммаси тарихий адолатнинг буюк ғалабаси тантанасидир. Буюк аждодларимиз томонидан яратилган юксак маданият ва илмий кашфиётлар жамиятимизнинг олий қадрияти бўлган инсон дунёқарашини шакллантириши ва ривожлантиришида катта ахамият касб этади. Президентимиз Ш.Мирзиёев таъкидлаганидек “Буюк тарихда хеч нарса изсиз кетмайди. У халқларнинг қонида, тарихий хотирасида сақланади ва амалий ишларида намоён бўлади. Шунинг учун хам у кудратлидир. Тарихий меросни асраб-авайлаш, ўрганиш ва авлодлардан-авлодларга қолдириш давлатимиз сиёсатининг энг мухим устувор йўналишларидан биридир". 6[ш.Мирзиёев 2019.1/29] 
Хуллас, “Буюк Ипак йўли” Марказий Осиё халқалари сиёсий, иқтисодий, маданий ва савдо сохасидаги хаётида катта ўрин тутган. Бир сўз билан айтганда Буюк Ипак йўли Шарқ ва Ғарб халқлари хаётида ғоятда мухим ва тарихий ўрин тутади. У халқларни сиёсий, иқтисодий, савдо ва маданий сохаларда боғлабгина қолмасдан балки айни замонда бу йўл дунё халқлари ўртасида тинчлик, осойишталик,кўшничилик, дўстлик ва қардошларга биродарлик йўли хам бўлаган.

Ўзбекистон Республикаси Президенти Ш.М Мирзиёев ХХР пойтахти Пекин шахрида бўлиб ўтган “Бир макон, бирйўл”(2017 й, 14-15 май) Халқаро форумида сўзлаган нутқида: “Хитой Халқ Республикаси раиси Си Цзинъпиннинг “Бир макон, бир йўл” концепцияси ажралмас қисми бўлган "Ипак йўли иқтисодий йўналиши”ни ташкил этиш тўғрисидаги ташаббуси, бизнингча, нафақат тарихий рух билан бойитилган, балки узоқ муддатли истиқболга мўлжалланган кенг қамровли ташаббусни ифода этади.... "Ипак йўли иқтисодий йўналиши" ташаббусининг амалга оширилиши нафақат иқтисодий хамкорликни кенгайтириш, мавжуд улкан сайёхлик салохиятидан фаол фойдаланишга қаратилиши лозим. Биз қайта тиклаётган Буюк Ипак йўлида Самарқанд, Бухоро, Хива каби бир неча минг йиллик тарих ва бой маданиятга эга бўлган шахарлар жойлашган"1[ш.Мирзиёв 2019.1/408-410]деган эди.

\section{Фойдаланилган адабиётлар рўйхати}

1. Ртвеладзе Э.В. Великий шелковыйпуть - Т;1999; Цивилизации, культура, государственности Централъной Азии.-Т;2005.

2. Хива хонлигида демографик жараёнларда Буюк Ипак йўлининг ахамияти. "Буюк Ипак йўлининг" ўтмиши ва хозирги куни : ривожланишнинг ижтимоий-маданий, тарихий, сиёсий ва иқтисодий йўналишлари (Халқаро илмий-амалий конференция материаллари тўплами.) Т,25 март, 2013 йил,91,94 бетлар

3. Хайруллаев М.М Ўрта Осиёда илк уйғониш даври маданияти.Т;1994.

4. Ш.Мирзиёев. Халқимизнинг розилиги бизнинг фаолиятимизга берилган энг олий баходир. Т., “Ўзбекистон” 2019 йил, 2-жилд, 483-бет.

5. Ш.Мирзиёев. Таълим ва маърифат-тинчлик ва бунёдкорлик сари йўл. Т., “Ўзбекистон” 2019 йил, 1-жилд, 29-бет.

6. Ш.Мирзиёев. Миллий тараққиёт йўлимизни қатъият билан давом эттириб,янги босқичга кўтарамиз. Т.; “Ўзбекистон”2019, 1-жилд, 408,410- бетлар.

7. Ўзбекистон миллий энциклопедияси.2-жилд.-Т., «Ўзбекистон миллий энциклопедияси» Давлат илмий нашриёти,2001,320-бет.

\section{ХVI-ХІХ АСРЛАРДА ЎРТА ОСИЁ ХОНЛИКЛАРИ ХУДУДИДА ХАРБИЙ САНЬАТ}

ў.Тўхтамишев

(СамИСИ т.ф.н. доценти)

Annotation: Bukhara Emirate, Khiva and Kokand Khanates faced with various historical process in their political, social, economic and cultural life in the XVI-XIX centuries. A number of positive achievements have been made in the fields of science, culture and architecture, artificial irrigation and construction. But the mutual intolerance between the Khanates, political confrontations created a difficult situation. This land, with its innumerable natural resources and vast resources, was in crisis due to the political and military weakness and fragmentation of the Khanates.

Key words and expressions: Bukhara Emirate, Khiva, Kokand, Order of Amir Temur, Order of Jaloliddin Manguberdi, Movarounnahr, Karacherik, Karakazan, Karakaltak, Kilkuyruk, musicians, trumpeters, drummers. 
Бизга ушбу мақоланинг ёзилишида Ўзбекистон Республикасининг Биринчи Президенти Ислом Каримовнинг: “Тарихга мурожаат қилар эканмиз, бу халқ хотираси эканлигини назарда тутишимиз керак. Хотирасиз баркамол киши бўлмаганидек, ўз тарихини билмаган халқнинг келажаги хам бўлмайди" деган сўзлари дастуриламал бўлиб хизмат қилди ${ }^{58}$.

Бугунги кунда бутун дунёда, Марказий Осиё минтақасида хавфсизлик, тинчлик ва барқарорликни таъминлашғоят мухим ахамият касб этмоқда. 1992 йил 14 январда Ўзбекистон Республикаси Олий Кенгаши мамлакатимиз худудида жойлашган барча харбий қисмлар, харбий ўқув юртлари, муассасалар, ташкилотлар ва бошқа харбий тузилмаларни давлат тасарруфига олиш хақида қарор қабул қилди. Кадрларни олий харбий ўқув юртларида тайёрлаш тизими такомиллаштирилди. 1995 йилда Марказий Осиёда биринчи марта Ўзбекистонда Қуролли Кучлар академияси очилди. "Миллий армиямиз бугунги кунда ёшларимизга замонавий харбий билим ва кўникмаларни ўргатадиган, уларни хам жисмоний, хам маънавий жихатдан чиниқтирадиган, рухини, иродасини тоблайдиган, мардлик ва матонат мактабига айланди”.1) Қуролли Қучларимиз сафларида хизмат қилиш эса, том маънода, шон-шараф ишига айланмоқда. Бунда айниқса, Амир Темур ордени (1996 йил 26апрел), Жалолиддин Мангуберди ордени (2000 йил 30-август), “Жасорат” медали (1994 йил 3-май) сингари Ватанимизнинг юксак мукофотлари таъсис этилгани алохида ахамиятга эга бўлди.

Президентимиз Шавкат Мирзиёев ёшларни ватанпарварлик рухида тарбиялаш, юртдошларирмизда ватан тақдири ва келажаги учун масъулият туйғусини янада юксалтириш каби мухим масалаларга алохида эътибор каратмоқда.

Табиийки, Ўзбекистон Куролли Қучлари ўз-ўзидан пайдо бўлгани йўқ. У ўзининг қадимги ва бой тарихий илдизлари, бетакрор анъаналарига эга. Буни мамлакатимиз заминида жуда олис замонлардан бошлаб, шаклланиб, ривожланиб келган харбий санъат ва шу сохадаги урф-одат ва қадриятлар хам тасдиқлайди. Ушбу мақолада халқимизнинг хонликлар даврида харбий санъат борасидаги қадимий тарихи, ўзига хос жанговар анъана ва қадриятлари ўз аксини топган.

Аслида, Ўрта Осиёнинг Марказий худудларида XVIII асрда учта марказлашган давлат вужудга келди. Бу давлатларни йирик ўзбек қавмларидан чиққан хукмронлар бошқариб, учта янги сулолага асос солганлар: Бухоро амирлигида-манғит, Қўқонда-минг, Хоразмдақўнғирот сулолалари ${ }^{59}$.

Сиёсий беқарорлик, парокандалик, иқтисодий вайронагарчиликлар шароитида Мовароуннахр Дашти Қипчоқдан келган янги босқинчиларга қаршилик куурсата олмади. Мовароуннахрга қилинган хужум Шайбонийхон (1451-1510) номи билан боғлиқ бўлиб, у Сирдарёдан Марказий Афғонистонгача чўзилган катта империя хукмдорига айланди. Шайбонийлар давлати маъмурий жихатдан вилоятларга бўлинган бўлиб, бошқарув тизими марказий ва махаллий амалдорлар кўлида бўлган. Марказий бошқарувда хондан кейин кўкалдош, оталиқ, нақиб, парвоначи, вазири азам каби мансабдорлар дунёвий ишларни бошқарган бўлсалар, шайх ул-ислом қози калон, аълам, имом,садр, муфтий, раис (мухтасиб)лар диний ишларни назорат қилганлар, хамда нўён, туғбеги, товочи, жевачи, қутвол, доруға, тўпчибоши каби харбий унвонлар бўлган. Махаллий бошқарув хоким ва беклар қўлида бўлиб, бу жараёнда қози, муфтий, раислар мухим рол ўйнаганлар.

Таъкидлаш жоизки, анъанага кўра, турк-муғул суворийси ўз оила ва уруғаймоқларнинг кўпчилиги харбий юришлардан сўнг тобе мамлакатларда турли вазифаларда қолиб, у ерларда оиласи билан яшарди. Шайбонийхон Мовароуннахрга қўшин тортиб келганда, унинг лашкарларида 92 қавм суворийси хизмат қилган. Демак, хар бир қавмни минг оиладан иборат дексак ва хар бир оила ўртача 6-7 кишидан иборат бўлса, у холда, XVI

\footnotetext{
${ }^{58}$ Каримов И.А. Ўзбекистоннинг ўз истиқлол ва тараққиёт йўли. Т.: “Ўзбекистон” 1992, 71-бет.

${ }^{59}$ Шониёзов К. Ўзбек халқининг шаклланиш жараёни Т., “Шарқ” нашриёти. 2007, 413-бет.
} 
аср бошларидаги Шайбонийхоннинг харбий юришлари муносабатлари билан камида 500-600 минг Даштиқипчоқ ўзбеклари Мовароуннахр ва Хоразмга кириб келган ${ }^{60}$.

Шайбонийлар армияси отлиқ ва пиёдалардан ташкил топган, асосан отлиқ кўшиндан иборат бўлган. Қурол-яроқ асосан ўқ-ёй, узун найза, қилич, гурзи, узун дастали жанг болтаси (табарзин), илгаклардан таркиб топган. Табарзин - чопқувчи қурол. Турли шаклларда бўлган. Баъзилари дурадгорларнинг катта болтасига ўхшаган, бошқалари ёстиқсимон тиғли бўлиб, темир парчасини қирқиш йўли билан шакл берилган.

Шайбонийлар қўшинни ташкил қилиш, жанг олиб боришда Чингизхон ва Амир Темур қўшинлари тактикасига асосланган. Рақибга алохида қисмлар билан хужум қилиш тактикаси, қанотдан айланиб ўтиб қуршовга олиш, орқадан хужум қилиш, сохта харакатлар каби усуллар кўлланган. Жанг олиб боришнинг янги усулларидан бири “Тўлғама" манёври бўлиб, бу усулга кўра рақиб қанотлари айланиб ўтилиб, унинг орқа қисмига энг жанговор отлиқ жангчилар билан кучли зарба берилади.

“Хонлар ва султонлар хамда кабила бошликлари хузурида факат бирнеча юз навкарлар бўларди. Бу навкарлар факат аскарларгина бўлиб колмай, балки ўз хўжайинларининг хонадонларида турли хўжалик юмушларини хам бажарар эдилар ${ }^{61,}$

1510-йилда Шайбонийхон қўшини Эрон шохи Исмоил томонидан тор-мор этилди, Шайбонийхоннинг ўзи эса ўлдирилди. Андижон хокими атоқли саркарда, буюк олим Захириддин Мухаммад Бобур (1483-1530йй.) шайбонийларга қаттиқ қаршилик кўрсатди. У рақиб аскарларини бир неча марта тор-мор келтириб, Самарқандни озод қилди. Аммо куч жихатдан устун душман тазйиқи остида чекинишга мажбур бўлган.

Бобур ночор ахволда қолиб, Амударё томонга чекинган. Бобур янгидан қўшин тўплаб, Афғон ерларини эгаллашга ва Қобулни забт этишга эришган. Ўз даври учун энг яхши саналган артиллерия ва бир-бирига занжир билан боғланган аравалар билан тўсиқлар ясаб, пиёдалар артиллерияни мухофаза қилиш ғанимлар учун жиддий ғов бўлган. Бу унинг оз сонли, атиги 20 минг жангчидан иборат қўшини учун бўлса, техник устунлик эди. Бобур қанотлардан хавф туғдирувчи “Тўлғама" тактикасидан хам фойдаланган. У қўшин марказига пилта милтиқ билан қуролланган ўқчиларни қўйган. '1518-1524 йилларда Бобур Панжобга юриш қилган, 1525 йил декабрда эса Хиндистон худудида пайдо бўлган. 1526йил Панипат жангида Дехли хукмдори Иброхим Лўдий кўшинини тор-мор келтирган, бир йилданг сўнг эса Сикри яқинида ражпутлар хукмдори Рана Санг қўшинини енган. Бобур Хиндистонда 300 йилга яқин хукм сурган кудратли Бобурийлар давлатини барпо этган'.

Бобурнинг Хиндистондаги ютуқларида хоразмлик тўп қуювчи уста Али Кулининг хам ўрни бор. Мохир мерган, европаликларнинг “фаранги” тўпидан ўт очиш хадисини олган Али Кули кейинчалик ўзи тўп (қозон) қуйиб, улардан улкан хажмдаги тошларни отадиган бўлган. Бундай тўпни қуйиш жараёнини Бобур ўзи шахсан кузатган ва бу хақида машхур “Бобурнома" асарида баён қилган. Қозоннинг асосий хусусиятлари порох заряди учун стволдан алохида бўлган камеранинг мавжудлиги эди.

1)Ўзбекистон тарихи Тошкент, 'Янги аср авлоди',2003-йил 301-бет.

Бу қуролнинг “қозон” деб номланишининг ўзи унинг Европадаги бомбардимонларга ўхшаш, мортира типидаги қурол бўлганлигидан далолат беради. Қозонлар қалъаларни қамал қилишда кўлланилган ва ундан қўшинга 8 тадан 16 тагача снаряд тош отиш мумкин бўлган. Қозонлар қалъа миноралар, дарвозаларқаршисига ўрнатилган. Уларга хизмат кўрсатадиган махсус ходим ва қўриқчилар бўлган.

1533-йилда Шайбонийлар салтанатитахтига Шайбонийхоннинг жияни Убайдуллахон ўтиради (1533-1539 йй.). У мохир жангчи бўлиб, эронийларни бир неча бор тор-мор келтирган. Хуросонга талон-тарож юришлар қилган. Убайдуллахон вафотидан сўнг шайбоний хокимлар ўртасида узоқ муддатли урушлар бошланган.

Кучли давлат қуришга бўлган интилиш Абдуллахон II (1557-1598 йй.) номи билан боғлиқ. У Тошкент, Самарқанд, Фарғона, Хирот, Хоразм хокимларига қарши бир неча марта

\footnotetext{
${ }^{60}$ Асқаров А. Ўзбек халқининг этногенези ва этник тарихи. Т., “Университет”, 2007, 271-бет.

${ }^{61}$ Ахмедов Б. Турон тарихи. Оммабоп мажмуа.А.Кодирий номидаги халк мероси нашриёти.Т.1994. 16-бет.
} 
харбий юришлар уюштирган. Абдуллахон II даврида (1557-йилда) пойтахт Самарқанддан Бухорога кўчирилгач, шайбонийлар давлати Бухоро хонлиги деб атала бошлади.

XIX aср бошида унинг таркибига Зарафшон, Қашқадарё ва Сурхандарё вохалари, хозирги Тожикистон ва Туркманистоннинг Мурғоб дарёсигача бўлган қисми, шимолда Туркистон шахригача бўлган барча худуд кирган.

Хоразм ерларида Хива хонлиги барпо этилган. XVIII асрнинг 40 йилларида Ўрта Осиё Нодиршох бошчилигидаги эрон қўшинларининг босқинига дучор бўлди. 1740 йил эронийлар Хивани эгаллашди.

Нодиршох вафотидан сўнг, унинг давлати парчалангач, Бухорода 1920 йилгача хукм сурган манғит амирлари сулоласи қарор топди. Хивада 1804 йилданўзбекларнинг кўнғиротлар сулоласи тахтга ўтирди. XVIII аср бошида Қўқон хонлиги вужудга келди. Хонлик Тошкент, Еттисувнинг бир қисми, деярли бутун Сирдарё хавзаси ва бошқа худудларни ўз ичига олган. XVIII-XIX асрларда хонликлар қўшинлари асосан номунтазам, тажрибали отлиқ жангчилар-навкарлардан уруш холатида тўпланадиган “Қорачерик”, “Қора қозон”, “Қоракалтак”, “Қилқуйрук” каби кўнгилли лашкарлардан ташкил топган. Навкарлар, одатда отда жанг қилишган, лекин зарур бўлса пиёда жангчига хам айланишган.

Хон кўшинлари ўнлик тизими шаклида ташкил қилинган. Хонларнинг шахсий қўриқчилари ва сарой соқчилари отлиқ қисми (пурта, қурчин) мавжуд бўлган. Тиғли қуролларнинг деярли барча турларидан фойдаланилган, XVI аср ўртасида эса ўқ отар қуроллар қўлланила бошлаган.

Бухоро амирлигида Амир Хайдар (1800-1826 йй.) хукмдорлиги даврида харбий кучлар 2 қисмга - мунтазам “Навкария” ва мунтазам бўлмаган “Қорачерик”ка бўлинган. Мунтазам армия - ягона комплектлаш усули, ягона штат ташкилоти, тўлиқ давлат қарамоғида бўлган ягона тарбия тизими, мунтазам таълимга эга доимий армияхисобланган. Армиянинг қуролланиши, аслахалари ва кийими бир хил бўлган. Шахсий таркиби биргаликда жойлашган хаёти ва ўқиши муайян тартибга солинган. Ўзининг жанговар тажрибасини ошириб, сақлаб борувчи мунтазам армия кейинчалик доимий, кадр армиясига айлантирилган.

Номунтазам кўшинлар - бир хил тизимда жамланмайдиган, ягона ташкилий шаклга эга бўлмаган ва жангда тўғри сафланмайдиган қўшинлар. Улар бир хил қуролланишмаган, кийими турлича бўлиб, одатда, ўзларини ўзлари таъминлашган. Номунтазам қўшинлар қадимдан маълум.

Бухоро амири Амир Насрулло (1827-1860 йй.) томонидан ўтказилган харбий ислохотлар натижасида мунтазам қўшин тузулиб, у пиёдалар, сарбозлар ва артиллерия (тўпчилар)дан таркиб топган. Пиёдалар сони тўпчилардан уч ярим баровар кўп бўлган. XIX асрнинг 30 йилларида амирликда 19 мингта харбийлар бўлган. XIX аср ўрталаридаги маълумотларга кўра, сарбозлар батальони 700 кишидан иборат бўлиб, 7 та рота (даста)га, хар бир рота 2 та ярим ротага (ним-даста), 4 та взвод (расад) ва 8 та ярим взвод (бара)га бўлинган. 100 кишидан иборат бўлган харбий қўшилмани юзбоши бошқарган.Юзбеги - юз кишидан иборат қисм сардори. Унинг ёрдамчиси қоровулбеги бўлган, қоровул -разведкачи, суворий гурухи. 50 кишилик расадни панжабоши бошқариб, ўн қишилик сарбозлар гурухига дахбоши бошчилик қилган. Сарбозлар ва тўпчилар кийими қизил, қора ва сариқ сўкнодан тикилган камзул, оқ коленкор шим, қоракўл телпак ва бир жуфт этикдан иборат бўлган. Мунтазам қўшинларни кийим ва қурол-аслаха билан таъминлаш давлат маблағлари хисобидан амалга оширилган.

XIX асрнинг бошида Хива хонлигида 2000 мингта харбийдан таркиб топган мунтазам қўшин тузилган. Хон навкарлари деб аталувчи ушбу қўшилма тинчлик даврида хон ва унинг оиласини қўриқлаган. Уларга маълум бир имтиёзлар берилган. Бухоро ва Кўқон хонликларидан фарқли равишда уларда махсус харбий кийимлар бўлмай, одатда, турли хил чопонлар кийилган. Қўқон хонлигида хам: кўшинлар асосан мунтазам (аскария) ва мунтазам бўлмаган (қилқуйруқ, қоракалтак, Тошкентда қорақозон)дан ташкил топган. Харбий либос қизил ва мовий чопон, сариқшим ва оқ салладан таркиб топган. Барча хонликларда Олий 
бош кўмондон хонлар хисобланган. Харбий кучларга бошчилик вазифасини: Бухоро амирлигида парвоначи, Хивада ясовулбоши, Кўқон хонлигида мингбоши амалга оширган. Харбий харакатларни режалаштириш, харбий кучларни тақсимлаш масалалари нақиблар зиммасида бўлган.

Харбий харакатлар вақтида харбий кучлар қуйидагича тақсимланган: олдинда авангард, унинг ортидан аръергард борган. Уларни чап ва ўнг қанот, марказ ва пистирмадан таркиб топган кўшинлар якунлаган.

Авангард - харбий юриш пайтида қуруқликдаги қўшинлар ва флотда кўриқлаш органи. Юриш пайтида асосий кучларнинг олдида харакат қилган. Авангарднинг вазифаси душманнинг қўққисдан хужум қилишига йўл кўймаслик, асосий кучларни ёйилиб жангга кириши учун шароит яратиб бериш, шунингдек, қўшинлар харакат қилаётган йўлдаги тўсиқларни бартараф этиш.

Кўшинлар жангга байроқлар ва туғлар билан кирганлар. Кўшинларда шунингдек, мусиқачилар, карнайчи, сурнайчи, ноғорачи, найчи, дўлчи ва бошқалар хам бўлган. Кўшинлар билан бирга хунармандлар, савдогарлар, йўлларни тозалаб, кўприклар қурувчи ишчилар хам борган.

Хонликларда мунтазам равишда харбий кўрик ўтказилган. XVI-XVIII асрлар химоя аслахаларининг турли-туманлиги билан ажралиб туради. Улар махаллий анъаналар ва Олд Осиё хамда Ўрта Шарқдан келтирилган янги қуролларнинг уйғунлашувидан иборат бўлган. Шунинг учун Ўрта Осиёлик куролсоз усталар яратган химоя қурол-аслахалари кўшни давлатларнинг жанг кийимларига жуда ўхшаб кетади. Хонликлардаги номдор жангчиларнинг химоя аслахаси турли хилдаги халқа парчинли совутлар, юмалоқ конуссимон дубулғалар, тирсакбандлар, оёқларни химоя қилувчи воситалар ва қалқонлардан иборат бўлган. Дубулға -химоя қуроли тури, бош кийими. Ёғоч, тўқилган навдалар, чарм-теридан қилинган дубулғалар ибтидоий жамиятда пайдо бўлган. Кейинчалик металл кашф этилиши, дубулғалар металл (мис, жез, темир)дан ясалган. Турли шаклга эга бўлган. XVI-XVII асрларда халқапарчинли совутларнинг кенг тарқалган тури бақтарлар, кўкракпўш ва елкапўш бўлиб, улар парчинлардан 3-9 қатор териб тайёрланган, либоснинг енги ва почаси совутдан бўлган. Совут бир-бирига ўтказилган темир халқачалардан ясалган химоя аслахаси. Кўпинча калта кўйлак кўринишида бўлган. Енгил ва ихчамлиги билан ажралиб турган. Оғир бақтарлар парчин билан тўлиқ қопланган. Темир совутлар тез қизиб кетганлиги боис, аскарлар исиб кетмаслиги учун жанг либослари устидан чопон кийишган.

Жанг либосларининг энг кўп тарқалган турлари парчин қопланган зирхлар, машхур куяклар бўлиб, унда парчинлар ички томондан шундай қопланган эдики, ташқаридан фақат парчин қаторларигина кўринарди, холос. Зирхлар -гавдани химоялаш учун кийиладиган қадимги ва ўрта аср жанг либоси. Металл парчалари қадалган қавима пахталик чопон кийилган. Оддий жангчилар -навкарларнинг химоя воситалари орасида совут мухим рол ўйнаган. Совут ичидан одатда, қалин чопон ёхуд чарм-чакмон кийилган.

Шакли ва қопланиш усулига кўра совутнинг бир неча тури бўлган. Ўзбекистон тарихи давлат музейи фондларида XVI-XVIII асрларга оид, енги ва этаги калта кўйлаксифат, пастдан зирх ёқали совутлар сақланмокда. Совутнинг халқачалари қисқич мих билан икки тарафлама махкамланган. Халқачали ва халқа парчинли жанг либослари химоялаш хусусиятларига эгалиги -нисбатан енгил ва қулай бўлганлиги учун кенг тарқалган.

Музей коллекцияларида XVI-XVIII асрларга оид турли бош кийимлар жамланган. Улар орасида юмалоқ конуссимон, яхлит темир куббали, кенг парчинсимон гардишли, тепа қисми конуссимон ва узун парчинли бурунпушши бўлган дубулғалар бор. Қуббага жиға тақиш учун найча ўрнатилган. Дубулғалардан ташқари зирқли бош кийимлар учрайди. Дубулғанинг яна бир тури -юмалоқ, ичи ғовак айлана қуббали ва зирхли темир калтакчалиси бўлган.

Дубулға ва жанг либослари Ўрта Осиёлик жангчилар томонидан XIX асрнинг 2 ярмига қадар кўлланиб келинган. Оддий жангчилар металл жанг анжомларини олиш имконига эга бўлмаганликлари туфайли чарм, намат ва пахтадан кўба, чопқут, кўпу, олпоқ каби жанг анжомларидан фойдаланганлар. Жанговор отлар чингизийлар давридан бери зирхли тўшама 
(жул)лар билан химоялаб келинган. Улар икки ёнлик сағринпўш, кўкракпўш, бўйинбош ва пешона боғдан иборат бўлиб, тизимча билан ўрилган узун чарм тасмалардан жамланган ва пахта тиқиб қавилган. Айрим қисмларига ялтироқ темир парчинлар бириктирилган. XVII асрда отлар боши чарм ва темир ниқоб билан хам химояланган.

XVI-XIX асрларда хумарнадчиликда курол-яроғ ишлаб чиқариш катта ахамиятга эга бўлган. Қурол-яроғ буюмлари орасида турли хил найза, ўқ, камон, қилич, шамшир, ханжар, совут, зирх, қалқон тирсакбанд (билакбанд), тиззабанд, дубулға, бухоролик усталар томонидан нодир тошлар қадаб ясалган, олтин ва кумуш чекмали қимматбахо қурол-яроғлар шухрат қозонган.

Қурол-яроғлар муайян жойнинг ўзидагина тайёрнамасдан, Ўрта Осиёга хориждан: Эрон, Россия, Жунғория, шунингдек, Ғарбий Европа мамлакатларидан хам келтирилган. Ўз навбатида Ўрта Осиё қуролсозлари махсулотлари бошқа давлатларга экспорт қилинган. Руснинг XVI асрда ташқарига чиқарилган ва четдан келтирилган энг мухим буюмлари рўйхатида Ўрта Осиёга қурол-яроғэкпорт қилиш, чарм ва мўйнадан сўнг учинчи ўринни, импортэса газлама, тайёр тўқимачилик буюмлари ва бўёқдан сўнг тўртинчи ўринни эгаллаган.

XVI acp ўртларига келиб, мис ёки темир стволли, дастлаб пилтали, сўнг бурама кертикли (сойли) милтиқлардан мунтазам фойдаланишга ўтилган. Бироқ бундай милтиқлар жуда оз бўлган. Шунингдек, турғун холатдаги лафет (тўп)лардан бир йўналиш бўйлаб, ядро тошлар отадиган артиллерия бўлган. Чор Россияси қўшинлари томонидан 1886 йилда Ўратепа шахри босиб олингач, бу ерда тўп ва ядро тошлар тайёрланадиган металл куйиш заводи, милтиқ ва тиғли қуроллар (найза, қилич, гурзи) ва бир порох заводи борлиги аниқланган.

Ишлаб чиқарилган буюмларнинг сифати юқори бахоланган: бу заводларнинг тузилиши анча содда, хатто, ёмон деб айтиш мумкин. Лекин шунга қарамай, мис тўплар шу қадар яхшики, ўзининг пардози билан артиллерия ишидан оз-моз хабардор бўлган хар бир европаликни лол қолдирган.

XVI-XIX асрларда хонликларда хам, хонликлар ички қисмида хам асосий савдо йўлларида кўплаб қалъалар мавжуд бўлган. Қалъаларда ўқотар ва тиғли қуроллар, турли калибрдаги тўплар билан қуролланган гарнизон жойлашган. Гарнизонда ўнлаб, юзлаб жангчилар бўлиб, уруш вақтида уларнинг сони анча ошган. Йўлак четлари ва ички девор, ғаним қалъа ичкарисига бостириб кирганда хам химояланиш имконини берган. XVI acp мобайнида Бухоро шахри деворининг айрим жойлари қайта қурилган. XVIIaсрда Хивада мудофаа иншоотлари қурилган. Хазорасп Хива хонлигининг энг кучли қалъаларидан бири бўлган. Кўқон хонлигида Туркистон Сирдаёнинг шимолидаги энг кучли истехкомлардан бири эди. Тошкент мухим харбий- стратегик ахамиятга эга бўлган. Бу ерда Бухоро, Хива, Хитой ва Россия савдо йўллари кесишган. Юнусхўжа хукмронлиги даврида (1784 й.) Тошкент мудофаа иншоотларини тиклашга қаратилган тадбирлар амалга оширилган.

Шахарни ўраган девор атрофи йирик хажмдаги хомғишт билан териб чиқилиб, янада мустахкамланган. Кўп жойларда унинг баландлиги кўтарилган, пойдевори эса кенгайтирилиб, тепасидаги майдонча артиллерия тўплари ўрнатишга мўлжалланган. Таъмирдан сўнг шахар деворининг баландлиги 8 метрга яқин бўлиб, қалинлиги таг қисмида 2 метр атрофида, тепа қисмида 90 смга етган. Шахар девори устки қисмидаги парапет (тошдан ясалган деворча) қалин бўлиб, унга 3-4 тўпни ўрнатиш мумкин эди.

XIX асрнинг биринчи ярмига келиб, Ўрта Осиёда уч хонлик ўртасидаги тўхтовсиз урушлар, келишмовчиликлар хонликлардаги иқтисодий, ижтимоий-сиёсий вазиятни танг ахволга олиб келди. Бу худудлардаги маданий хаётни издан чиқарди. Ўлкадаги бундай вазият Россиядек босқинчи давлат учун ўз имкониятларини амалга оширишга қулай шароит яратди. Чор Россияси дастлабки харбий харакатларни бошлаб юборди. Босқинчилар замонавий қурол-аслахага эга бўлиб, уларга Европа урушларида тажриба орттирган генераллар рахбарлик қилдилар. 
Хонликлардаги ички низо, хокимият учун урушлар авж олишига қарамасдан, махаллий ахоли дашхатли ёв билан ўз она юрти, дини, ғурури учун курашганлар. Ахоли узоқ ва қаттиқ қаршилик кўрсатишига қарамай, хонликлар Россия империяси босқинига бардош бера олмаган. Ўз даврида кучли мудофаа истехкомлари ролини ўйнаган шахар деворлари ва қалъалар XIX охири XX аср бошида сўнгги дамларни бошдан кечирди. 1913 йилга келиб Туркистон ўлкасида тиғли ва ўтсочар қурол ишлаб чиқариш деярли бутунлай бархам топди. У Бухоро ва Хива хонликларининг айрим ерларидагина сақланиб қолди.

“XVI-XIX асрларда Бухоро амирлиги, Хива ва Кўқон хонликлари сиёсий-ижтмоий, иқтисоий ва маданий хаётида турли тарихий жараёнларни босиб ўтди. Фан, маданият ва меъморчилик, сунъий суғориш ва қурилиш сохаларида бир қанча ижобий ютуқларга эришилди. Лекин хонликларнинг ўзаро муросасизлиги, сиёсий қарама-қаршиликлар оғир шарт-шароитни вужудга келтирди. Бехисоб табиий бойликлар ва кенг имкониятларга эга бўлган бу ўлка хонликларнинг сиёсий-харбий жихатдан заифлиги ва тарқоқлиги туфайли инқирозга юз тутди".

\section{Фойдаланилган адабиётлар рўйхати}

1. Каримов И.А. Ўзбекистоннинг ўз истиқлол ва тараққиёт йўли. Т., “Ўзбекистон”, 1992, 71-бет.

2. Шониёзов К. Ўзбек халқининг шаклланиш жараёни. Т., “Шарқ” нашриёти. 2007, 413-бет.

3. Асқаров А. Ўзбек халқининг этногенези ва этник тарихи. Т., “Университет”, 2007, 271-бет.

4. Ахмедов Б. Ўзбек улуси. Турон тарихи. Оммабоп мажмуа “А.Қодирий номидаги халқ мероси" нашриёти. Т., 1994, 16-бет.

\section{ИҚТИДОР МУАММОСИНИНГ РИВОЖЛАНИШ ТАРИХИ}

\section{М.М.Абдуллаева \\ (Тош.ш 300-ДИУ мактаби, PhD)}

Annotation: The following article deals with the existence of the problem of power since ancient times, the history of the emergence and development of the concept of talent in the analysis of the history of the development of the problem of power, the ingenuity of talented thinkers and thinkers of the epochs. . Working with gifted children, creating opportunities for talented people to show their natural abilities in the relevant fields of knowledge and science, developing and revealing their unique talents, is a priority of education as a priority. Creating the socio-economic, legal, and organizational conditions for the full realization of the potential of children and talented young people has been studied.

Key words and expressions: Potential, creativity, talented youth, gifted child, history, development.

Республиканинг илмий ва ижодий салохиятини ривожлантирувчи интелектуал салохияти бор ёшларни тайёрлаш, ёрдам бериш, истеъдод сохибларига билимнинг тегишли сохалари ва фаннинг аниқ йўналишлари бўйича ўз табиий қобилиятларини намоён этиш, ривожлантириш ва улардаги ноёб истеъдодини рўёбга чиқариш учун имкониятлар яратишдан иборатдир. Бунда “иқтидорли болалар ва истеъдодли ёшлар билан аниқ мақсадга йўналтирилган ишларни амалга ошириш тизимини яратиш" 62 каби мухим вазифалар белгиланди. Бунда фан олимпиадаларини ўтказиш механизмларини қайта кўриб чиқиш, энг қобилиятли, билимли ўкувчиларни аниқлашда шаффофликни таъминлаш, академик лицейлар билан хамкорликда хорижий тиллар, математика, физика, кимё, биология каби мухим ва талаб юқори бўлган фанлар чуқурлаштириб ўқитиладиган ихтисослашган

\footnotetext{
${ }^{62}$ Ўзбекистон Республикаси Президентининг 2019 йил 29 апрелдаги“Ўзбекистон Республикаси халқ таълими тизимини 2030 йилгача ривожлантириш концепциясини тасдиқлаш тўғрисида"гиПФ-5712-сон фармони.
} 
умумтаълим муассасалари тармоғини кенгайтириш, олий таълим муассасаларининг илмий салохиятга эга педагогик жамоасини умумтаълим мактабларида иқтидорли болалар билан ишлашга ва таълим сифатини бахолашга жалб қилиш мухим ахамият касб этади.

Иқтидор муаммосининг ривожланиш тарихини тахлил қилишда иқтидор, қобилият, талант, истеъдод тушунчаларининг мазмун-мохиятини ўрганишга имкон беради.

Иқттидор инсон психикасининг бутун умр давомида тизимли ривожланувчи сифати бўлиб, инсоннинг бошқа одамларга нисбатан бир ёки бир неча сохада юқори натижаларга эришиш имконига эга эканлиги билан белгиланади. Психологик луғатда иқтидор тушунчаси куйидагича таърифланади:

1) иқтидор бу - фаолиятнинг муваффақиятли амалга оширилишини таъминлайдиган қобилиятларнинг ўзига хос уйғунлашувидир;

2) иқтидор бу - инсоннинг имкониятлари доираси, фаолиятлари даражаси ва ўзига хослигини белгилайдиган умумий қобилиятлар;

3) иқтидор бу - ақлий потенциал, таълим олиш қобилияти ва билиш имкониятларининг бир бутун индивидуал характеристикаси;

4) иқтидор бу - табиат томонидан инъом этилган қобилиятлар, қобилиятлар табиий асосларининг ўзига хослиги ва уларнинг намоѐн бўлиши даражалари;

5) иқтидор бу - истеьдодлилик, фаолиятда юқори натижаларга эришиш учун ички имконият ва шароитларнинг мавжудлиги ${ }^{63}$.

Умумий қобилият эгалари юқори интеллектуал имкониятларга эга бўлиб, муаммонинг ёки бирон-бир масаланинг ечимини тезда топиши, фаолиятига ижодий ёндашиши билан ажралиб туради. Махсус қобилият эгалари эса - бирон-бир аниқ (масалан, математика, мусиқа, расм чизиш, шахмат уй̆наш, спорт) фаолият турига қобилияти бўлган ва мана шу фаолият билан шуғулланишни афзал кўрадилар ${ }^{64}$.

Иқътидор - куч-қувват, қувват, қодирлик, қобилият, холат 65

Қобилият - биринчидан, одамнинг индивидуал хусусиятлари, иккинчидан, одамнинг бирор фаолиятга лойиқлиги, учинчидан, шу фаолиятни муваффақиятли бажаришидир ${ }^{66}$.

Талантнинг асосий белгилари:

1) муваффақиятни таъминлаш;

2) фаолиятни мустақил бажаариш;

3) оригиналлик унсурининг мавжудлиги

4) қобилият хамда истеъдодлар йиғиндисидан иборат эканлиги;

5) индивидуал психологик хислатлиги;

6) ижтимоий турмушни ўзгартирувчи, яратувчи имкониятлиги ${ }^{67}$.

Истеъдод - тайёргарлик, тайёрлик, мойиллик, қобилият. Нихиятда зўр ижодий қобилият, лаёқат ${ }^{68}$

Демак, қобилиятлар мажмуасини талант, қобилиятларнинг ўзига хос уйғунлашуви иқтидор бўлса, истеъдод эса ижодий қобилият деб хисоблаш мумкин. Иқтидор тушунчасининг ривожланиши унинг пайдо бўлиш тарихини ўрганишни талаб қилади.

\footnotetext{
${ }^{63}$ Утепов С.Ш. Информатикадан иқтидорли ўкувчиларни аниқлаш ва уларни иқтидорини ривожлантиришнинг методик асослари: Магистрлик дисс. - Тошкент, 2013. - 116 б. - Б. 18.

${ }^{64}$ Утепов С.Ш. Информатикадан иқтидорли ўкувчиларни аниқлаш ва уларни иқтидорини ривожлантиришнинг методик асослари: Магистрлик дисс. - Тошкент, 2013. - 116 б. - Б. 18-19.

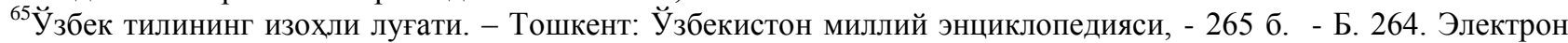
pecypc: http://n.ziyouz.com/books/uzbek tilining izohli_lugati/O'zbek\%20tilining\%20izohli\%20lug'ati\%20-\%20I.pdf. Мурожаат санаси: 06.07.2019.

${ }^{66}$ Умумий психология. Ўкув кўлланма. - Тошкент, 2009. - 172 б. - Б. 157. Электрон ресурс: http://el.tfi.uz/images/Umumiy_psixologiya_b3bae.pdf. Мурожаат санаси: 06.07.2019

67 Умумий психология. Ўкув кўлланма. - Тошкент, 2009. - 172 б. - Б. 157. Электрон ресурс: http://el.tfi.uz/images/Umumiy_psixologiya_b3bae.pdf. Мурожаат санаси: 06.07.2019

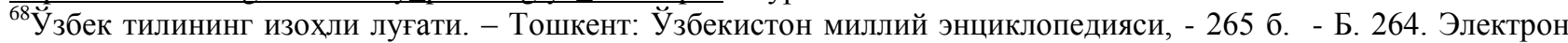
pecypc: http://n.ziyouz.com/books/uzbek tilining izohli_lugati/O'zbek\%20tilining\%20izohli\%20lug'ati\%20-\%20I.pdf. Мурожаат санаси: 06.07.2019. - Б. 237.
} 
Иқтидор муаммоси қадим замонлардан буён мавжуд бўлиб, у қуйидагигича мазмунмохиятни ифодалаган (1.1-жадвалга қаранг):

\begin{tabular}{|c|c|c|c|c|}
\hline № & $\begin{array}{l}\text { Тарихий } \\
\text { даврлар }\end{array}$ & Мутафакк & рлар & $\begin{array}{l}\text { Файласуфларнинг ва даврдаги фикр- } \\
\text { мулохазалари }\end{array}$ \\
\hline 1 & $\begin{array}{l}\text { Қадим } \\
\text { замонда }\end{array}$ & $\begin{array}{l}\text { Платон, } \\
\text { Сенека, } \\
\text { Демокрит }\end{array}$ & Посидонюм, & $\begin{array}{l}\text { Платонгакўра, } \\
\text { иқтидорлиёкиёрқиншахсхақиқийбилим } \\
\text { гаэгабўлганшахсдир. } \\
\text { Қобилиятларнингнамоёнбўлишинингас } \\
\text { осиймезониваайнипайтдаПлатоннингиқ } \\
\text { тидоргаэгабўлишинингкўрсаткичиилхо } \\
\text { мникўрибчикди. } \\
\text { ИқтидорнингнамоёнбўлишиПлатонижо } \\
\text { дкорликишиниуурганибчиқди. } \\
\text { Ижодкорликнингманбаивасабаби, } \\
\text { файласуфнингфикригакўра, } \\
\text { истеъдоддир- } \\
\text { бусанъаткоргаолийватабиатанмавжудб } \\
\text { ўлаганнамуаммо, } \\
\text { наилохийкучларнингхарқандайонглита } \\
\text { ъсирихақидамаълумбўлганилхомнингўз } \\
\text { игахостури. }\end{array}$ \\
\hline
\end{tabular}

2. Антикдав Гераклит, Улар инсоннингиродасиэркинлиги, шу рда

Эпикур, Аристотель жумладан, ўзқобилиятлариниидеалгаривожлантир ишэркинлигихақидагиғоягасодиққолиш ди. Улар учун идеал-доно одам, мукаммалинсон, худоларгаимконқадаряқинбўлганёкихат тохудоларгаайланган. Бундай киши, уларнингфикригакўра, мутлақбилимвамутлақиродагаэгабўлиш икерак

3. Ўртаасрл Европа католик черкови "истеьдод" тушунчаситуғма, арда худотомониданберилганқобилиятларэд и. Иқтидоринсонгахосёки у мавжудэмаслигигаишонишган. Хеч ким истеъдодниривожлантиришбиланшуғул ланмаган
4. Уйғониш Леонардо да Винчи, ижодкорликмуаммосигақизиқишбилан даврида Микеланджело Буонаротти, Мишель дахофеноменигақизиқишпайдобўлди. Монтень, Эразм Вабутасодифэмас.


Роттердамский, Николай

Коперник, Николо

Макиавелли, Данте

Алигьери, Франческо

Петрарка, Вильям

Шекспир

5. Маърифа Джон Локк,

дахонингилохийкелибчиқишиборлигиг

тдаврида

ФрэнсисХатчесон

ашубхақилишди.

Уларнингфикригакўра,

Клод Гельвеций, Дени

Дидро

барчаодамларбир хил

қобилиятларбилантуғиладивафақатхаёт

шароитларихаркимнибошқачақилади

6. XIX ва Френсис Галтон

буажойибқобилият

(дахо)

$\mathrm{XX}$

биринчинавбатдаирсийомиллар,

асрлар

яъниистеъдоднингнатижаситуғмаомилд ир. Шу вақтданбошлаб, эксперимент инсонпсихикаситадқиқотидамустахкам ўрнашиболди, натижадапсихологиянимустақил фанга айлантиришгаёрдамберди ${ }^{69}$.

Иқтидор муаммосининг ривожланиш тарихи 1.1-жадвал.

Иқтидор муаммосининг ривожланиш тарихи, хозирги холати ва тенденцияларини тахлил қилишда иқтидор, қобилият, талант, истеъдод тушунчаларининг мазмун-мохиятини ўрганишга имкон беради. Яъни, қобилиятлар мажмуасини талант, қобилиятларнинг ўзига хос уйғунлашуви иқтидор бўлса, истеъдод эса ижодий қобилиятдир. Иқтидорли болалар билан ишлаш таълимнинг устувор йўналиши бўлиб, унинг мақсади иқтидорлиларнинг ижтимоий шаклланиши ва камол топиши, ижодий иқтидори жамият манфаатлари йўлида имкони борича тўла-тўкис руеёбга чиқиши учун ижтимоий иқтисодий, хукуқий, ташкилий жихатдан шарт-шароит яратиш хамда уларни кафолатлашни таъминлаб беради.

Бугунги кунда дунёда психофизилогик, психогенетик, тестологик, узоқ муддатли тадқиқотлар. умумий психологик, қобилият, ижод ва истеъдод психологияси, ижтимоийпсихологик, таснифловчи, динамик ёндашув каби турли назарий йўналишлар иқтидорли ўқувчи ёшларни аниқлаш, улар фаолиятини илмий ва услубий жихатдан таъминлаб бориш, сохада илғор тажрибаларни оммалаштириш ва улар асосида таълим муассасалари учун тавсия ва кўлланмалар ишлаб чиқишни тақозо этади.

\section{Фойдаланилган адабиётлар рўйхати}

1. Президент Шавкат Мирзиёевнинг Ўзбекистон Республикаси Конституцияси қабул қилинганининг 26 йиллигига бағишланган тантанали маросимдаги маърузаси: Билимли авлод - буюк келажакнинг, тадбиркор халқ - фаровон хаётнинг, дўстона хамкорлик эса тараққиётнинг кафолатидир. $08.12 .2018 . \quad$ Электронный pecypc:https://president.uz/uz/lists/view/2180 Дата обращения: 06.07.2019.

\footnotetext{
69 История развития представлений об одаренности. ттпс://нсатурниа.ру/методика/история-развития-
} представлениж-об-одаренности/ 
2. Утепов С.Ш. Информатикадан иқтидорли ўқувчиларни аниқлаш ва уларни иқтидорини ривожлантиришнинг методик асослари: Магистрлик дисс. - Тошкент, 2013. 116 б. - Б. 18-19.

3. Ўзббек тилининг изохли луғати. - Тошкент: Ўзбекистон миллий энциклопедияси, 265 б. $\quad$ - 264.2 Б. 264 Электрон http://n.ziyouz.com/books/uzbek_tilining_izohli_lugati/O'zbek\%20tilining\%20izohli\%20lug'ati\%20 -\%20I.pdf. Мурожаат санаси: 06.07.2019.

4. Умумий психология. Ўқув қўлланма. - Тошкент, 2009. - 172 б. - Б. 157. Электрон pecypc: http://el.tfi.uz/images/Umumiy_psixologiya_b3bae.pdf. Мурожаат санаси: 06.07.2019
5. История
развития
представлений
об
одаренности.

хттпс://нсатурниа.ру/методика/история-развития-представлениж-об-одаренности/

6. История развития представлений об одаренности.

хттпс://нсатурниа.ру/методика/история-развития-представлениж-об-одаренности/

“建以致用”指导下的《中亚概况》在线课程教学设计 The online course design of "A general introduction of Central Asian

常显敏, 硕士研究生, 讲师 石河子大学, 石河子市, 新疆维吾尔自治区 (Chang Xianmin Shinjon-Uyg'ur avtonom viloyati

Annotation: In the context of the "Great Silk Road", bilateral exchanges and cooperation between China and Central Asian countries have been increasingly frequent. Therefore, it is very necessary to have an in-depth understanding of the national conditions of Central Asian countries. As a very important and "practical" course, the course "General introduction of central Asian countries" keeps up with the needs of the times, with "Constructing for practical purposes" as the fundamental idea, which is an online course based on the characteristics of learners to build up a rich curriculum resources and provide online teaching resources for more learners who want to understand the political, economic, humanistic, and historical situation of Central Asian countries.

Key words and expressions: The course "A general introduction of central Asian countries" , online course, "Constructing for practical purposes", learners, instructional design

《中亚概况》课程教学目标是让学习者掌握中亚国家一一哈萨克斯坦、乌兹别克斯坦 、塔吉克斯坦、吉尔吉斯斯坦、土库曼斯坦的基本国情知识。随着中国和中亚国家多领域交 流与合作的不断深入，对中亚感兴趣的人越来越多，高校师生对于加深中亚认知的需求在不 断增长。《中亚概况》课程应紧跟时代新需求, 建设丰富的在线课程资源, 从而为更多想了 解中亚国家政治、经济、人文、历史等国情现象的学习者提供一个有效的平台和渠道。中国 “十三五”期间高等教育课程改革的纲领性文件：《教育部关于加强高等学校在线开放课程建 设应用与管理的意见（教高 [2015]3 号）》中指出, “建以致用”应成为在线课程的根本思路 “建以致用”要求在线课程的设计和建设要充分考虑学习者的特征。

1. 《中亚概况》在线课程学习者分析

中亚国家从经济体量、政治影响力、文化吸引力方面并不具备明显的优势。人们对中 亚地区的关注动机一定程度上出自学业或行业、工作的现实需要。因此, 《中亚概况》在线 课程的学习者大致可分为两类。第一类为高校师生。在当前中国国内国别和区域学大发展的 背景下, 其人数呈上升态势。这一类学习者有较强的学习能力, 要求课程内容的基础性、系 统性和专业性。第二类为从事与中亚事务相关的社会学习者。这类学习者中的相当一部分具 备俄语背景, 或将进入和中亚国家有业务往来的某一领域, 或已经是某一中亚事务领域的专 才。这一类学习者往往注重学习内容的时效性和实用性, 能现学现用。整体来看。除了从事 中亚研究或教学的专业教师、研究人员, 或经常和中亚有事务往来人之外, 很多学习者的基 础较为薄弱。

\section{2. 以学习者为出发点的在线教学内容设计}


《中亚概况》在线课程以“建以致用”为根本思路，根据学习者特征来设计教学内容和 教学环节。

图 1: 以学习者特征为出发点的设计理念

\section{1 课程内容“专题化”}

《中亚概况》课程是中亚国情学的“入门课程”, 也是后续开展深入学习, 开展国别和 区域研究的基础课程, 其基本目标是让学习者对中亚国家地理、政治、经济、历史等方面有 一个宏观认识。因此，有必要整合教学内容，从“国别学习”改革为“专题学习”，共设政治、 经济、历史、地理、文化、环保、社会、军事 8 个专题。中亚国家在历史、地理、政治制度 、文化传统等诸多方面既有各自的特色, 又有颇多相似之处, 专题学习既有助于认识各国的 国别差异，又能体验中亚的区域特点。

\section{2 教学知识点”精准化”}

设计依据《美国在线教育追踪》对在线课程内容的比例划分和英联邦学习共同体对课 程的定义, 中亚概况在线课程教学和课程资源约占总课程教学内容的 $85.5 \%$, 每一个知识点 视频限 10 分钟以内, 平均为 5-6 分钟。如前文所述, 这门课程的学习多出于学业、工作需 要, 学习或多或少带有“功利性”特征, 因此, 学习者对课程趣味性、实用性的诉求高, 对课 程质量有较高的期待, 要求知识点不仅有碎片化的呈现, 还具有系统性和内部逻辑。在数字 化时代, 未来在线课程将是“数字化融合后的精品”, 能满足各类学习者的个性化产品。课程 的设计始终应该思考、预测、评估学习者的接受能力和兴趣。视频教学遵循两个原则：第一 、依据学习者知识基础和课程内容特点, 选取内容“顾基础”、“重特色”和“讲典型”; 第二、 知识点实现“纽扣式”呈现, 即一个教学视频着重解决一个知识点。

以几个知识点为例:

(1) “1.2 中亚人口与民族”视频教学——提炼重难点, 讲典型

中亚国家的人口增长快是大部分学习者容易得知的，而由于人口增长快、本国无法消 化劳动力而出现的劳务移民现象, 则是大部分学习者的盲点, 从而成为难点和重点。劳务移 民是中亚人口发展速度过快、经济体量有限而导致的独特的社会现象，也成为中亚国家重要 的经济行为，如塔吉克斯坦国民收入的 $1 / 4$ 来自劳务移民收入。另外，中亚多民族分布也为 大家所知，而众多民族的跨界居住并由此引发的民族问题则需要深入思考。

单元视频教学内容选取示例 (1)

\begin{tabular}{|l|l|l|}
\hline 小节内容 & 在线视频内容 & $\begin{array}{l}\text { 时 }{ }^{2} \text { （分 } \\
\text { 1.2 中亚人口与民族视频 1.2_1 快速增长的人口与劳务移民 }\end{array}$ \\
\hline & 视频 1.2_2 跨境民族与民族关系 & $9^{\prime}$ \\
\hline
\end{tabular}

（2）中亚简史一一重视知识的系统性、基础性

根据以往教学经验, 学生对中亚历史的了解较少, 基础薄弱。社会学习者的关注也非 常少 (专业研究者除外)。因此, 这部分的视频教学需要对中亚历史有一个较为系统的呈现 。单元视频教学内容选取示例 (2)

\begin{tabular}{|l|l|l|l|}
\hline \multirow{2}{*}{ 第 4 讲: } & 小节内容 & 在线视频内容 & 时长（分） \\
\cline { 2 - 4 } 中亚简史 & \multirow{2}{*}{4.1 远古至 15 世纪的中亚 } & $4.1 \_1$ 中亚远古社会和土著居民 & $8^{\prime}$ \\
\cline { 2 - 4 } & 4.215 至 20 世纪的中亚 & $4.1 \_2$ 相继登上中亚舞台的外来民族 & $6^{\prime}$ \\
\cline { 2 - 4 } & 4.3 苏联时期的中亚 & $4.2 \_2$ 俄罗斯占领中亚 & $6^{\prime}$ \\
\cline { 2 - 4 } & 4.3 苏维埃政权在中亚的建立 & $6^{\prime}$ \\
\hline
\end{tabular}




\begin{tabular}{|l|l|l|l|}
\hline \multirow{2}{*}{} & $4.3 \_2$ 五个加盟共和国的现代化建设 & $6^{\prime}$ \\
\cline { 2 - 4 } & 4.4 独立以后的中亚五国 & $4.4 \_1$ 独立初期的改革 & $6^{\prime}$ \\
\cline { 3 - 4 } & $4.4 \_2$ 各自走上不同的发展道路 & $6^{\prime}$ \\
\hline
\end{tabular}

\section{3.配套的在线资源链接}

首先, 课程资源建设应与课程教学过程相匹配, 避免在线课程教学设计中普遍存在的 文本资源和视频资源的简单重复; 其次, 课程资源建设要为视频教学服务, 或补充、或深化 、延伸视频教学内容, 两者成互补关系, 一起服务课程目标, 最终形成课程内容的完整性和 系统性。

（1）以“视频 1.1_2 中亚自然资源”为例。视频教学中讲授中亚各类自然资源在各国的 分布、开发、生产及出口情况。配套的课程资源则提供网络视频资源链接: 中央 10 套播出 的专题片: “石油与战争: 抢滩里海”, 通过生动的影片, 让学习者进一步理解中亚油气资源 所具有的重要战略意义, 了解历史上世界对里海油气资源的关注, 加深本节知识点的纵向理 解。

（2）以视频 1.1_1 中亚“两河”、“五湖”、“一盆地”为例。这部分视频教学突出的是中 亚自然地理中的“典型”、“特色”, 突出对中亚国家经济发展起重大作用的地理事物。而在课 程资源则提供完整的单元知识点讲稿, 满足基础薄弱的学习者。

\section{4.多元化、立体化课程评价体系}

设计有效的过程评价机制, 贯穿教学的各个环节。评价体系设计以尊重学习者为基本 前提, 以提高学习者能力培养为根本目的。评价应有利于帮助学生正确认识自己在学习态度 、知识积累和能力培养等方面的表现和潜力, 增加自尊自信, 改进学习方法, 提高学习积极 性和质量。

(1) 评价渗透到教学活动各个环节

图 3: 教学环节

(2) 考核方式多样化

在线课程评价表 (100 分制)

\begin{tabular}{|l|l|l|l|l|l|l|l|l|}
\hline $\begin{array}{l}\text { 考核 } \\
\text { 构成 }\end{array}$ & $\begin{array}{l}\text { 视 频 } \\
\text { 学习 }\end{array}$ & $\begin{array}{l}\text { 单元 } \\
\text { 作业 }\end{array}$ & $\begin{array}{l}\text { 学习 } \\
\text { 时长 }\end{array}$ & $\begin{array}{l}\text { 发 帖 } \\
\text { 次数 }\end{array}$ & $\begin{array}{l}\text { 与 } \\
\text { 活 } \\
\text { 动 }\end{array}$ & $\begin{array}{l}\text { 参与问 } \\
\text { 卷调查 }\end{array}$ & $\begin{array}{l}\text { 单元 } \\
\text { 测验 }\end{array}$ & $\begin{array}{l}\text { 小组 } \\
\text { 互动 }\end{array}$ \\
\hline $\begin{array}{l}\text { 比重 } \\
\%)\end{array}$ & 50 & 10 & 5 & 5 & 5 & 5 & 10 & 10 \\
\hline
\end{tabular}

总之，《中亚概况》在线课程以“建以致用”为设计思路，把学习者接受力和需求放在 第一位, 课程不是停留在简单的国情现象描述和介绍层面, 而要引导学习者透过现象思考本 质, 理解内在缘由; 引导学生由单纯的知识点积累向培养文化素养转变。另外, 应及时把丰 富成熟的中亚国别和区域研究成果、国内外前沿动态和研究方法融入教学, 使之转化成为优 质的教学资源。

\section{参考文献}

\section{The list of used literature}

1. 刘清堂,巴深等.视频课程中教育智能体的社会线索设计研究[J].电化教育研究. 2020(09):55-60.

2. 杨丽娜, 魏永红, 肖克曦, 王维花.教育大数据驱动的个性化学习服务机制研究.电化教 
育研究. 2020(09):68-74.

3. 叶荣荣, 余胜泉,陈琳.活动导向的多种教学模式的混合 式教学研究.电化教育研究, 2012

\title{
O’ZBEK TILI FANINI O'QITISHDA PEDAGOGIC HAMDA INNOVATSION TEXNOLOGIYALARNI QO'LLASH
}

\author{
S.Sh.Xolmirzayeva \\ (TDAU, dots., f.f.n.)
}

\begin{abstract}
Annotation: This article provides information on pedagogical and innovative technologies used in the educational process. In fact, the role of innovative technologies in improving the quality of education is based on several specific instances. At the same time, such complex requirements are set as reading and understanding non-fiction literature, writing a text in the field of specialization and drafting a document, updating the text in terms of form and content, translating the text into a different style of speech. This, in turn, will depend on how students correctly and widely use the possibilities of the Uzbek language, including the lexical and methodological possibilities. All this will be ensured by the liveliness, breadth and interest of the proposed knowledge of the Uzbek language, the correspondence of the chosen profession to its specialization, modernity of teaching methods and techniques, and the effective use of audiovisual means. The article also provides information on the perception map, which is actively used in interactive learning.
\end{abstract}

Key words and expressions: Innovation, pedagogical technology, interactive, cluster, perception map, classification table, international experience, critical thinking, academic association.

Zamonaviy yoshlar innovatsion ta'lim sharoitida boy, keng qamrovli axborot texnologiyalari muhitida tahsil olmoqdalar. Bunday ta'lim tashabbuslar va yangiliklar negizida tug'ilib, o'quvtarbiya jarayonining mazmunini rivojlantirish uchun istiqbolli yo'nalishni boshlab beradi hamda umuman ta'lim tizimi rivojiga ijobiy ta'sir ko'rsatadi. Hozirgi kunda oliy ta'lim muasasalarida talabalarni innovatsion texnologiyalar va ilg'or xorijiy tajribalar asosida o'qitish oldimizga qo'yilgan dolzarb vazifalardan biri hisoblanadi.

Bunda ilmiy-badiiy adabiyotlarni o'qib tushunish, ixtisoslik sohasida matn yaratish va hujjat tuzish, matnni shakl va mazmun jihatdan yangilash, boshqa nutq uslubiga ko"chira olish kabi murakkab talablar qo'yiladi. Bu o'z navbatida talabalarning o'zbek tili imkoniyatlaridan qanchalik to'g'ri va keng foydalana bilishlariga, xususan, leksik va uslubiy imkoniyatlardan o'rinli foydalanishni qanchalik puxta o'zlashtirganliklariga bog'liq bo'ladi. Bularning barchasi ta'limning yuqori bosqichida o'zbek tilidan tavsiya etilayotgan bilimlarning hayotiyligi, kengligi va qiziqarliligi, tanlagan kasbi, mutaxassisligiga muvofiqligi, o'qitish metodlari va usullarining zamonaviyligi, audiovizual vositalarning samarali qo'llanilishi bilan ta'minlanadi.

Biz ham bilimlarni tayyor holda berib bo'lmasligi, talaba $o^{6} z$ bilimlarini tizimli ketma-ketlik asosida takomillashtirishi uchun pedagogik shart-sharoitlarni yaratib berish lozimligi, o'qituvchi talabani uni o'rab turgan borliqning muhim muammolarini izlash, tadqiq qilish va yechimini topishga jalb qila olishi, bu borada interfaol usullarni qo'llash maqsadga muvofiq, degan fikrdamiz. Bizningcha, interfaol o'qitish talaba shaxsiga, an'anaviy o'qitish esa - o'quv fani mazmuniga yo'naltirilgandir. Biroq o'qitishning bu usuli an'anaviy ta'lim muvaffaqiyatlarini inkor etmaydi. Qolaversa, har qanday interfaol o'qitish an'anaviy ta'lim negizida dunyo yuzini ko'radi.

Interfaol degani bu - o'qituvchi va talabaning o'zaro hamkorligi asosida do'stona muhit yaratish, dars samaradorligini oshirish, talabalarda mustaqil fikrlash, fikr - mulohaza yuritish, munosabat bildirish ko'nikmasini shakllantirish demakdir. Bu usulda talaba o'zi faol ishtirok etgan holda, yakka, juftlikda, guruhlarda muammo va savollarga javob topishga harakat qiladi, fikrlaydi, baholaydi, yozadi, so'zga chiqadi, dadil hamda asoslar orqali qo'yilgan masalani yoritib borishga harakat qiladi. $\mathrm{Bu}$ esa talabalarning xotirasida uzoq saqlanadi. Yangi mavzu (axborot)ni 
o'zlashtirishda tanqidiy, tahliliy yondosha oladi. O'qituvchi faqat fasilitator (yo'l-yo'riq ko'rsatuvchi, tashkil qiluvchi, kuzatuvchi) vazifasini bajaradi.

Grafik organayzerlardan ta'lim jarayonida turli maqsadlarda foydalaniladi. Ma'lumotlarni tarkiblashtirish va tarkibiy bo'lib chiqish, o'rganilayotgan tushunchalar (voqea va hodisalar, mavzular) o'rtasidagi aloqa va o'zaro bog'liqlikni o'rnatishning usul va vositalariga "Klaster", "Toifalash jadvali", "Insert", "BBB jadvali" kabi grafik organayzerlar kiradi. "T-jadvali", "Venn diagrammasi" ma'lumotlarni tahlil qilish, solishtirish va taqqoslash maqsadida qo "llaniladigan usul va vositalardir. "Nima uchun?", "Baliq skeleti", "Piramida", "Qanday?" tarkibiy-mantiqiy sxema muammoni aniqlash, uni hal etish, tahlil qilish va rejalashtirish

Tushunchalarg Tavsiflar, toifalar, xususiyatlar, ajralibturadiganbelgilar ayondashuvlar

\section{Vazifaviyuslu Tilxususiyatlari}

bturlari

So'zlashuvusl Shevalarningishlatili ubi

shi,

o'zlug'aviyqatlamiga egaekanligi

Rasmiyishqog Adabiytilme'yorigari

'ozlariuslubi

oyaqilinishi,

leksikvagrammatiko'

zigaxosligi

Ilmiyuslub

Sofilmiyakademizm, atamalarningqo'llanil ishi

Publitistikuslu Gazeta tili, ijtimoiy-

b

siyosiyatamalarningq

o'llanilishi, obrazlilik

Badiiyuslub
Umumxalqtilningbar chalug'aviybirliklari niqo'llanilishi
Amal

qilinishholati

Erkinmuomalada,

badiiyasarlarningq

ahramonlarinutqid

a

Ma'muriyvayuridi

kishlarda

Fan,

texnikavaishlabchi

qarishsohasida

Matbuotda,

ommaviyaxborotv

ositalarida

Badiiyasarlar, badiiymatnlar,asar qahramonlarining nutqida
Qo’llanishdoirasi

Insonlarningkundalikfaoliyatidagiog'

zakinutqshakli

O'quvyurtlarigavaboshqamuassasalrg aishyuzasidanmurojaatqiluvchishaxsl artomonidan

Olimlar, tadqiqotchilar,

kashfiyotchilar, o'qituvchilartomonidan

Jurnalistlar, shoirlar, ijodkorlar, qalamkashlartomonidan

Yozuvchilar,

shoirlartomonidanyaratilganbadiiyasa rlarda

usullari va vositalari.

Interfaol ta'limda faol va samarador vositalardab biri idrok xaritasidir.

Idrok xaritasi - bu har qanday jarayonni yoki hodisani, fikr yoki g'oyani majmualashtirilgan, tizimlashtirilgan, vizual (grafik) shaklda taqdim etish usulidir.

Idrok-xaritasi bir varog'da, muammoni yechish uchun zarur bo'lgan bor ma'lumotlarni yig'ishga va unga yaxlit holda nazar tashlashga imkon beradi. Idrok-xaritalari u yoki bu yechimning salbiy va ijobiy tomonlarini ko'zdan qochirmaslikka ko'maklashadi. Idrok-xaritalari assotsiativ tafakkur qilish jarayonini faollashtiradi va bu an'anaviy tahlil vaqtida yo'1 qo 'yilgan kamchiliklarni keltirib chiqargan muhim omillarni ko'rishga imkon beradi. Bunga qo"shimcha idrok-xaritalarida obrazlar va ranglarni qo'llash intuitsiyani faollashtiradi, bu esa qabul qilinayotgan qarorlarning to'g'riligiga ta'sir ko'rsatishi mumkin. 


\begin{tabular}{|l|l|}
\hline $\begin{array}{l}\text { Konseptualjadval } \\
\text { "Uslubturlari" } \\
\text { mavzusibo'yicha } \\
\text { Nutquslublari }\end{array}$ & Asosiybelgilari \\
\hline So 'zlashuvuslubi & Erkinlik, norasmiylik; oldindantayyorlanmagannutq \\
\hline Ilmiyuslub & Mantiqiylik, aniqlik, xolislik \\
\hline Rasmiyuslub & Aniqlik, qoliplashganlik, rasmiylik, qat'iylik \\
\hline Ommabopuslub & Baho berish, undash, chaqiriq shaklida bo'ladi \\
\hline Badiiyuslub & Obrazlilik, ifodalilik, badiiylik \\
\hline
\end{tabular}

\begin{tabular}{|c|c|}
\hline Nutquslublari & Qo 'llanishsohasi \\
\hline So'zlashuvuslubi & $\begin{array}{l}\text { Norasmiy muomala vositasi, do'stona xatlar, maishiy sohadagi } \\
\text { aloqalar uslubi }\end{array}$ \\
\hline Ilmiyuslub & $\begin{array}{l}\text { Fan, texnika, ta]lim sohasi, Ilmiy ishlar, ilmiy axborot } \\
\text { berishdama'ruza, o'quv qo'llanmalari, lug'at va ilmiy asarlar tili } \\
\text { uslubi }\end{array}$ \\
\hline Rasmiyuslub & $\begin{array}{l}\text { Ma'muruy-huquqiy faoliyat sohasi, turli hujjatlar tili (ariza, } \\
\text { tavsiyanoma, nota, da'vo xati kabi) }\end{array}$ \\
\hline Ommabopuslub & $\begin{array}{l}\text { ijtimoiy-siyosiy doiradagi munosabatlar va adabiyotlar(radio, } \\
\text { chlevideniye, matbuot) omishlarlarda } \\
\text { qo'llaniladigan uslub }\end{array}$ \\
\hline Badiiyuslub & Badiiyasartili \\
\hline
\end{tabular}

Idrok-xaritasining matnli reja oldidagi ustunligi yaqqol ko'rinib turibdi: o'n varog'li matndan ko'ra, o'nta kalit so'zdan iborat suratni eslab qolish juda ham osondir; idrok-xaritasi bilan qurollangan taqdimot notig'ini savol yoki boshqa yo'l bilan fikridan chalg'itish juda ham mushkul; idrok-xaritasini ko'rgazmali qurol (slaydlar, plakatlar) sifatida namoyish etish mumkin, shu tariqa tinglovchilar asosiy g'oyani yaxshiroq eslab qolishadi va har yoqqa qarab chalg'ishmaydi; tadqiqot yakunida idrok-xaritalarining chop etilgan nusxalaridan tarqatma material sifatida foydalanish mumkin.

Ma'ruzalarni konspektlashtirishda, kurs ishlarini (referatlar, diplom ishlar, dissertatsiyalar) yozishda, katta hajmdagi ma'lumotlarni tushunish va eslab qolish jarayonida idrok-xaritalaridan foydalanish juda ham zarur. Kerakli ma'lumotlarni yozib olish, keyinchalik topish va o'qishga juda ham ko'p vaqt ketadi. Idrok-xaritalarini tuzish esa, yaxshi o'zlashtirish va matnni eslab qolish bilan birgalikda, ijodiy va kreativ tafakkur qilish qobiliyatini vujudga keltirib, aqlni tarbiyalovchi o'ziga xos mashq hisoblanadi.O'zbek tili ta'limi mazmunini talabalarning nutqiy savodxonligini grammatikani o'qitish orqali emas, balki turmush va mehnat faoliyatidagi nutq mavzulari doirasini yanada kengaytirgan hamda ixtisoslikka moslashtirgan tarzda o'zbekcha nutqni tinglash, so'zlash, o'qish va yozish amallarini uyg'unlashtirib o'rgatish bilan ajralib turadi.

\section{Foydalanilgan adabiyotlar ro'yhati}

1. Aripov M. Axborot texnologiyalari. - T.: Noshir, 2009.

2. Begimqulov U. Pedagogik ta'limda zamonaviy axborot texnologiyalarini joriy etishning ilmiy-nazariy asoslari. -T.: Fan, 2007.

3. Elektron ta'lim resurslari va axborot texnologiyalari vositalaridan foydalanib darsni loyihalash. Elektron kutubxona. http://lib.tuit.uz/index

4. O`zbek tilining izohli lug'ati. 1-jild. -T.: O`zbekiston milliy ensiklopediyasi, 2006. -B. 228.

5. Umumta'lim fanlari bo`yicha multimedia ilovalarini ishlab chiqish metodologiyasi http://www.ziyonet.uz/ - 261-b.

6. Sultonsaidova S., Sharipova O‘. O`zbek tili stilistikasi. -T.: Yurist-Media markazi, 2009. 


\section{ФОРМИРОВАНИЕ ИСТОРИЧЕСКИХ ВЗГЛЯДОВ СТЕНДАЛЯ}

Д.Ф.Тоирова (Доц., PhD)

Annotation: The article examines the historical knowledge of Stendhal, who, replenishing his first with reading his memoirs, and then more serious historical works, as Stendhal selected for himself only what corresponded to his inner worldview. In which, for example, the republican preference led him to respect and use the works of S. Sismondi in his practice. it is clear that by the time the works of French historians O. Thierry, F. Guizot, F. Mignet appeared, Stendhal had already formed historical and socio-political views, which allowed him to criticize their works.

Key words and expressions: View, historical, realism, historian, revolution, formation, life, literature, part, creativity, historiography, diversity, labor, diversity, thought, basis, periodical, etc.

Несмотря на обширную историографию о жизни и творчестве Стендаля, вопрос о формировании его исторических взглядов в литературе рассматривался мало. Небольшую часть своих работ о жизни и творчестве Стендаля посвятили этому вопросу стендалеведы 70 х годов прошлого века В. Дель Литто, Хайслер М., Р. Андрие ${ }^{70}$ на основании разнообразных источников он показал пути формирования исторического мировоззрения писателя, выяснил, какое место занимала историческая наука в системе его знаний. Источниками для исследования нам послужили дневники, письма Стендаля, его эстетико-историческая работа «История живописи в Италии», исторический труд «Жизнь Наполеона», автобиография «Жизнь Анри Брюлара», критические статьи Стендаля в английской периодической печати, собранные в общий сборник под названием «Английский курьер» ${ }^{71}$. Формирование исторического мировоззрения Стендаля происходило в первой четверти XIX века, с 1800 по 1817 годы. Именно в этот период Стендаль активно учится самостоятельно мыслить, внимательно читать, набирается практического опыта, изучая характер и поведение людей, сравнивая их с характерами людей прошедших эпох. Начиная с 1817 года свои мысли и рассуждения, свой опыт, а также познания в области исторической науки помещает в критические, исторические и литературные произведения ${ }^{72}$. Начальные знания по истории, особенно античной, Стендаль получил в Центральной школе в Гренобле (в которой учился в 1789 - 1799 гг), где преподавателем был Шальве Пьер-Венсан, республиканец по убеждениям $^{73}$ к этому можно прибавить систематическое воспитание деда Анри Ганьона, который постепенно приобщал внука к исторической классике, заставляя читать Плутарха, Полибия на латинском языке.

Но к истории как к науке Стендаль в то время был равнодушен. Математика была его страстью. На выпускных экзаменах летом 1799 году он получает первую награду по математике и решает поступать в Политехническую школу в Париже. Выехав туда осенью для сдачи экзаменов, он в Немуре - 25 милях от Парижа - узнаёт о событиях 18 брюмера, совершившихся накануне - о перевороте Наполеона Бонапарта. Поступление по этой причине откладывается, и Стендаль окунается в светское время провождения: с декабря 1799 года по апрель 1800 года посещает известные в то время в Париже салоны госпожи Кардон, госпожи Ребюфе, госпожи Дарю ${ }^{74}$. Считается, что на формирование взглядов историка немалое влияние оказывает социальная среда, в которой он воспитывался, и что именно отсюда проистекают его сословные, национальные, расовые, конфессиональные интересы.

\footnotetext{
${ }^{70}$ Del Litto V. La intellectuelle vie Stendhal. Paris, 1969; Heisler M. Stendhal et Napoléon. Paris, 1969; Андрие Р. Стендаль или Бал - маскарад. М., 1985. В советской историографии наиболее полно разработал эту тему Реизов Б.Г. в труде «Стендаль. Философия истории. Политика. Эстетика»*, (Сноска. Реизов Б.Г. Стендаль. Философия истории. Политика. Эстетика. Л., 1970.).

${ }^{71}$ Stendhal. Courrier anglais. Le Divan. V. 1-5 Paris. 1936.

72 Реизов Б.Г. Стендаль. Годы учения. Л., 1968.

${ }^{73}$ Стендаль. Жизнь Анри Брюлара// Собр.соч в 15 т. Т.13. С.151.

${ }^{74}$ Там же. С.300.
} 
Стендаль происходил из мелкобуржуазной среды, но с детства пытался из неё выбраться не поддаваться влиянию. Через его творческую деятельность красной линией проходит ненависть ко всему мещанскому, обывательскому и буржуазным порокам, несмотря на то, что он пользовался благами буржуазной цивилизации. Таким образом, социальная среда не оказала практически никакого воздействия на исторические взгляды Стендаля, так как мыслил он не как буржуа, довольный жизнью, не гордился превосходством своей белой кожи, и к религии относился более чем равнодушно.

Сначала он подошёл к истории как начинающей писатель: эта наука была для него тем же, чем она была для философов эпохи Просвещения - повествовательным жанром морального и психологического плана. Благодаря этому жанру можно было познать страсти и характеры, тщеславие великих мира сего. Молодой человек писал 6 августа 1804 года.: «Из всего, что я прочёл и увидел до сегодняшнего дня, я запомнил только то, что мне казалось полезным для таланта, который я хочу развить в себе, - великого живописца характеров. Какую пользу может извлечь из истории тот, кто хочет стать величайшим поэтом?» ${ }^{75}$.

На формирование взглядов будущего историка и на отношение его к историческим трудам не могли не повлиять мысли Сен-Симона о том, что тот, «кто пишет историю своего времени, стремясь только к правде и никого не щадя, всячески старается скрыть, чем занимается. В противном случае чего только не пришлось бы ему опасаться от стольких сильных мира сего, задетых лично или через своих близких сказанной им бесспорной, а значит, беспощадной правдой! Следственно, автор, если только он не решился ума, ни за что не позволит, чтобы его заподозрили в написании истории. Он даст книге созреть, упрятав её под ключ и надёжные замки, так же тайно передаст свои наследникам, а те благоразумно выждут одни - два поколения и выпустят её свет не раньше, чем время станет ей защитой от преследований» ${ }^{76}$. Именно так поступил Стендаль - историк со своей работой «Жизнь Наполеона» и с мемуарами о Наполеоне, спрятав тексты от посторонних глаз надолго, вплоть до своей смерти.

Интересно отметить некоторые сходство в стиле написания мемуаров де Реца и исторического труда Стендаля «Жизнь Наполеона». В обоих случаях у читателя остаётся впечатление, что он слышит живую речь рассказчика. Для авторов характерно прямое обращение к читателю: у Реца это «согласитесь», «судите сами», «вас, без сомнения, удивит», у Стендаля - «не ждите от меня», «предположим», «покончим в нескольких словах» и.т.д. Также присутствует смешение жанров: в обоих произведениях можно найти политические размышления, исторические анекдоты (в значении, которое этому слову придавали в эпоху просвещения), страницы с описанием военных событий, выписки из исторических источников и периодики. Присутствует смена ритма в повествовании: некоторым событиям и Рец и Стендаль отводят несколько страниц, а некоторые сжаты до нескольких строк.

Не случайно исследователь мемуаров Реца А. Бертье в работе «Кардинал де Ретц мемуарист» тонко подметил, что «глубинные выводы, которые можно извлечь из мемуаров, имеют двоякий характер: с одной стороны, личностный, связанный с фигурой самого автора на склоне его лет, с другой - более общий, одновременно исторического и этического плана, относящийся к людям, которые вершили Фронду... Выводы второго рода роднят Реца не столько с Ж.Ж.Руссо, сколько с великолепными романистами XIX века - Бальзаком и Стендалём. Разве они не лучше, чем мемуаристы их эпохи, дают нам понять Францию времён Реставрации?» 77 . То же самое можно сказать и о «Жизни Наполеона» и «Воспоминаниях о Наполеоне» Стендаля.

Две исторические эпохи особенно оказали влияние на формирование исторического мировоззрения - итальянское средневековье и Французская революция.

\footnotetext{
${ }^{75}$ Цит: V. del Litto La vie intellectuelle de Stendhal. Genèse et evolution de ses idees. Paris, 1959. P.188.

${ }^{76}$ Сен-Симон. Мемуары: В 2т.М., 1990.Т.1.С.62.

${ }^{77}$ Цит. по: Виппер Ю.Б. Мемуары кардинала Реца // Кардинал де Рец. Мемуары. М., 1997. С.669
} 
Интерес к средневековой Италии у Стендаля зародился в том же 1808 году в Брауншвейге, когда он знакомится с «Историей средневековых итальянских республик» Симонда Сисмонди. Книга производит огромное впечатление на молодого человека. Сисмонди исследовал историю конституций и свободы в средневековых маленьких городках Италии. Единственным критерием совершенства государственного устройства, по его убеждению, была свобода, а формой её - республика. Но ни в одной итальянской республике не было конституции: ни в аристократической Венеции, ни в демократической Флоренции свобода граждан не была безопасна. Новые правительства удовлетворяли лишь своё честолюбие, из-за которых происходили гражданские войны. Народные конституции, по его мнению, - беспорядочная свобода, от которой различные бедствия. Управлять государством должны самые талантливые, самые богатые и родовитые. Ведь свобода есть равновесие. Чтобы правление было свободное, надо, чтобы в её конституции был аристократический элемент $^{78}$. Стендаль восхищается генералом Бонапартом, видя в нём вождя революции и её защитника, но критикует Наполеона - деспота, который подчинил политику своим честолюбивым интересам. По мнению автора, отказ от революционных традиций обрёк Наполеона на неизбежное поражение. Стендаль никогда не принял бы бонапартизма, утверждавший полезность деспотизма и вред народовластия.

Свои взгляды на исторические изменения, происходящие эпохи Реставрации, Стендаль изложил в своих известных романах «Красное и чёрное» и «Пармская обитель», о чём подробнее будет рассмотрено ниже. В этих произведениях, безусловно, искусно сочетались его историческое мировоззрение и литературный талант.

Таким образом, историческое мировоззрение Стендаля прошло в своём развитии сложный путь. Формирование его не отличалось, на наш взгляд, систематичностью, изучение Стендалём исторической литературы проходило урывками, между выполнением различных служебных обязанностей и без определённого плана. Его исторические взгляды сформировались под влиянием таких мыслителей, как Сен - Симон, Болингброк, Безанваль, Сисмонди. Пополняя свои исторические познания сначала чтением мемуаров, а затем более серьёзных исторических работ.

\section{Список использованной литературы}

1. Del Litto V. La intellectuelle vie Stendhal. Paris, 1969; Heisler M. Stendhal et Napoléon. Paris, 1969; Андрие Р. Стендаль или Бал - маскарад. М., 1985. В советской историографии наиболее полно разработал эту тему Реизов Б.Г. в труде «Стендаль. Философия истории. Политика. Эстетика». Л., 1970.).

2. Stendhal. Courrier anglais. Le Divan. V. 1-5 Paris. 1936.Реизов Б.Г. Стендаль. Годы учения. Л., 1968.

3. Стендаль. Жизнь Анри Брюлара// Собр.соч в 15 т. Т.13. С.151.

4. Цит: V. del Litto La vie intellectuelle de Stendhal. Genèse et evolution de ses idees. Paris, 1959. P.188.

5. Сен-Симон. Мемуары: В 2т.М., 1990.Т.1.С.62.

6. Цит. по: Виппер Ю.Б. Мемуары кардинала Реца // Кардинал де Рец. Мемуары. М., 1997. C.669

7. См.: Реизов Б.Г. Стендаль. Философия политики. С.37.

\footnotetext{
${ }^{78}$ См.: Реизов Б.Г. Стендаль. Философия политики. С.37.
} 


\title{
SYMBOLS AND THEIR ROLE IN THE INTERCULTURAL COMMUNICATON
}

\section{S.I.Khakimova \\ (MA Department, $U z S W L U$ )}

\begin{abstract}
Annotation: This article is focused on the investigation of symbols displayed in diverse cultural spaces, which enables us to reveal not only the universal, but also the national specific features of symbols in language, as well as avoid intercultural misunderstandings in interaction process. Symbols -gestures, signs, objects, signals, words - are, in general, clues helping humanstomake sense of the surrounding world. In this regard, the research emphasizes the problem of "categorization of symbols", which is one of the main provisions of the current investigation. A conceptual and comparative study of symbols in various cultures provide support for an effective communication considered being crucial for professional and spiritual development of the people from different background.
\end{abstract}

Keywords and expressions: Symbols, categorization of symbols, icon, index, conceptual field.

Every nation has their own cultural specifics which is universally accepted or unaccepted in integration process. These cultural differences are embodied in a wide range of phenomenaof thecertain community such as rituals, arts, ceremonies, flora and fauna, dishes, clothes and other specifics. Symbol is a cultural code representinga symbolic world picture of the nation adhering to traditions, customs, beliefs, even some unwritten life norms. As a result, it leads to plain misunderstandings among communicators.

Lich(2001) cites, "There is a big difference between the way that individuals communicate information to each other, using ordinary speech and written words, and the way we communicate with each other using coded conditional forms of verbal and non-verbalbehavior of signs and symbols," [Lich 2001:14].It is seen that communication consists of verbal andnon-verbalelements involving language, a collection of things, images, events applied to socio-status, religious, cultural, psychological,political and legal foundations of a particular culture, in general, signs and symbols around people fascinating their imagination. K. Sitaram and R. Cordell (1976) state that symbol is defined as a linguistic and non-linguistic system of interaction used and developed for communication purposes by members of a given culture and they also claim that people learn symbols through four main sources:

1) through interpersonal communication, observing members of their own community;

2) through mass-media

3) developing their own idiosyncratic methods;

4) as a result of interaction with representatives of other cultures [K. Sitaram and R. Cordell 1976:131].Therefore, symbol is a basis of culture due to the fact that it is created with a help of cultural relationship between form and meaning, not natural. That's why it is important for researchers to consider cultural background of symbols the reason for similarity in appearance, but a drastic distinction in meaning. For instance, in some Western cultures such as Germany, the color "black" is a symbol of power, strength whereas it also depicts the evil, sadnessin some Eastern cultures; black cat, black dress in funeral. Their perception is gained from life experience or culture by their receivers.

People encounters symbols in a daily life. They would be appeared in different way such as objects, figures, colors, pictures, sounds, even words and facial expressions, but all of them show an abstract idea or concept to the addressee.Thus, symbols are differently classified by scientists who are engaged in categorization of symbols. In a sense, symbols are divided into the followings according to Bordon's classification:

* Pictorial symbols include images, icons applied to a real world that shows a generalized manner: e.g. a tree may symbolize a forest or green area for vegetation.

* Functional symbols represent specific activities based on the function of items: e.g. a tent shows a campground or a horse expresses a racing and etc. 
* $\quad$ Conceptual symbols directly demonstrates a concept of a represented feature: e.g. "A Star of David" is a symbol of a Jewish synagogue.

* Conventional symbols are so effective for map readers or passengers so as to find easily their destination or differentiate conventions on the road: e.g. a red line representing "highway or ban", a cross is a "hospital".

* Abstract or geometric symbols are arbitrary shapes representing a particular feature(D.Borden, 1999).

Furthermore, symbols are categorized as follows: universal, nationally specific, individual. It is worthy to explain each of them so as to know main distinctive peculiarities among them.

Firstly, universal symbols are understandable to all the nations. Actually, they are traffic signs, figures in public places (Picture 1).

1. Road signs

Turning to national specific ones, they belong to a certain nation which is a creator of them.For instance, atlas, suzanne is a symbol of Uzbek nationality; sari in Indian nation, language is a national symbol of every culture, gestural language, national flags, emblems, currency and others. It is seen that nationally specific symbols can be material and nonmaterial elements of a certain culture (Picture 2.).

Subsequently, the last type of symbols represents the individual's or a particular group of people's world picture reflecting to the same pragmatic features: age, social, educational status and etc. For instance, E.Hemingway approached the word "rain" in his work to express a symbol of unhappiness, loneliness and suffering; or white fang - a symbol of courage, wisdom and superiority in the works of J. London.[Ashurova D.U., Galieva M.R. 2019:57].

Thus, symbols are a representation of cultural, national and individual world picture of people revealing the complex relationship of "Language-Man-Culture". What's more, It is necessary to be more stressed the distinction of symbols, signs, icons, index, word-symbols.Sign is a much wider and more general notion including words, numbers, sounds, pictures, road signs, and etc. Icons, symbols, index are a part of the sign represented the link between signifier and signified that is fundamental semiotic terms.Icon is something that is applied to signified in physical resemblance like pictures and photographs.Index is an evidence or fact of what's being represented. For ex. a smoke is an image of fire, water is an expression of life, existence.Symbol is something that has no connection in appearance, it is learned culturally, situationally. For instance, the symbol of wisdom is related to a Chinese ancient philosopher, who represented two sides of the world versus each other, yet they do not exist independently without each other as well (Picture 3.)

3. Symbol of wisdom

Symbols give a wide range of meanings to different people in diverse pragmatic acts. It is impossible to predict the concrete meaning of symbol in certain community if
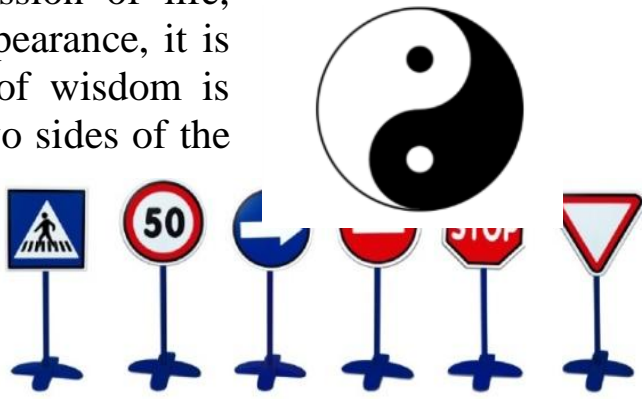
individuals are not a part of this society.Ruth Grains and Stuart Redman quoted, "In order to understand a word fully, one must know not only what it refers to , but also where the boundaries are that separate it from words of related meaning." (www.thoughtco.com). Based on this, symbols

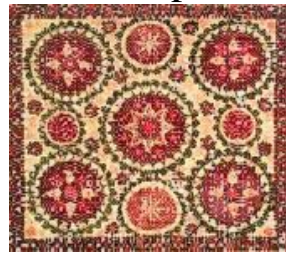
have various conceptual(semantic) fields in different boundaries which keep a deep meaning.

Conceptual field is a combination of a bunch of words under the same concept. Words are meaningful when they are utilized only in its own semantic field that is interrelated with other words[Bin X. and Chunming G. 2013;11]. Theyalso mentioned about denotation that is a core, literal, dictionary meaning of the word contrasting with connotation including figurative, affective meaning based on the subtext. We know that symbolshave figurative meanings that is comprehensive in a certain conceptual field. For instance, art, political, media, computer, sport, religious, science symbols and etc.In this regard, they are so much precise in their own semantic(conceptual) field, in context. Take 
an example symbols in art, an animal, plant, an object, color can be a symbol that stands for something. Mostly, colors in art are found symbolism than other symbolic figures.

- Black represents death or evil;

-White is for life and purity;

- Red standsfor blood, passion, danger, immortal character;

- Yellow can symbolize violence or decay;

- Blue is used for calm, peacefulness.

Studying the concept of symbol in a wide range of cultural environment allowsto make the following conclusion: the identification of the tension about symbols in each culture through finding similarities and differences; to classify them according to pragmatic perspective coincide. By comparing symbolic languagesof various cultures, we can answer a question how to achieve effective cross-cultural communication throughsymbols.

All in all, investigating symbols linguistically and culturally seems to be an interesting attempt to reveal the basic universal and linguo-cultural characteristics of symbols which assists personal and professional development as well as deepens the intercultural communication competence.

\section{The list of used literature}

1. Ashurova D.U., Galieva M.R.(2019). Cultural linguistics. Tashkent: O’zkitobsavdonashriyot, p.57

2. Bin Xu.,Chunming G. (2013).Theory and Practice in language studies, Vol. 3, No. 11, pp. doi:10.4304/tpls.3.11.2030-2035

3. D.Borden. (1999). Carthography: thematic map design. Nyu-York: McGraw Hill-Higher Education.

4. Lich E. (2001). Culture and communication: the logic symbols relationship. M.,p.4

5. Sitaram K.S., Cogdell R.T. (1976). Foundations of intercultural communication. Columbus, p.131

6. www.thoughtco.com

\section{Е.Э. БЕРТЕЛЬС ЎРТА АСР ТАСАВВУФ ПОЭЗИЯСИ ХАҚИДА}

Туробов Б.Н.

(СамДЧТИ Илмий тадқиқот)

Annotation. This article describes the views of medieval mystical poetry in the works of the famous orientalist E.E. Bertels. In several of his works, E.E. Bertels explores the connection of mysticism with Zoroastrianism, neo-Platonism, but sees the main source of the emergence of ideas in social life, social change and material conditions. E.E. Bertels, who studied mysticism, which was interpreted by Western scholars as the first renunciation of the world, "drowning in the inner world", sought from him the qualities of humanity, vivid human emotions, elements of activity. The Orientalist considered it important to find answers to the question of how the mystical movement came into contact with literature, especially poetry, and thus left a number of eternal monuments in world literature. We know that the Sufis attached great importance to the attainment of a state of insanity, which is a special compliment sent by God. Therefore, in the early days, the means of causing ecstasy (madness) within them were sought with great vigor. It was soon recognized that one of these tools would be very effective. It was music, and it was accompanied by an artistic word.

Key words and expressions: mysticism, oriental studies, poetry, sources, inner world.

Тасаввуф ва тасаввуф поэзиясини ўрганаётган Е.Э.Бертельс бир қанча хал қилиниши зарур бўлган муаммоларга дуч келди. Тасаввуф манбалари, ғояларининг пайдо бўлиши, терминларининг маъносини аниқлаш, тасаввуф поэзиясининг ривожланиши асосий йўлини белгилашга харакат қилиш, турли мактабларининг ворисий алоқадорлигини аниқлаш керак 
эди. Йўл-йўлаккай тасаввуф трактати ва поэмасининг композицияси (бадиий асар тузилиши)нинг шаклланиши, тасаавуф шайхининг шахси ва унинг афсонавий таржимаи холи билан муттаносиблиги масалалари келиб чиқди [Бертельс 1965: 6].

Е.Э.Бертельс бир қанча асарларида тасаввуфнинг зардўштийлик, янгиплатончилик билан алоқасини тадқиқ қилади, аммо ғояларнинг вужудга келишининг асосий манбаини жамият хаёти, ижтимоий ўзгаришлар ва моддий шарт-шароитларда кўради. Ғарб олимлари томонидан энг авало дунёдан бутунлай воз кечиш, “ички дунёга ғарқ бўлиш”, деб талқин қилинган тасаввуфни ўргана борган Е.Э.Бертельс ундан инсонпарварлик хусусиятлари, жонли инсоний хиссиётларни, фаоллик унсурларини излайди. Низомийнинг ижоди мисолида у 1923 йилдаёқ, ўтмиш йирик шоирларининг қарийб хаммасини “шайхлар” деб хисобланган, уларни тасаввуфнинг “муйсафид тақвадорлар"и руйххатига ва ибораларини антологияга (турли муаллифларнинг сайланма асарлари) кўшилган, ўрта аср анъанаси, шунингдек, худди Низомийда “зохиднинг хаётидан узоқлик”ни кўрган Европа фани нохақ эканлигига ишонч хосил қилди. У ёки бу шоирларнинг ижодида тасаввуф унсурларининг мавжудлиги тасаввуфнинг умумий тарқалиши билан изохланади, аммо хали шоирни бу тасаввуф назариётчиси қилиб кўймайди. Хусусан, Е.Э.Бертельс бу хақдаги нуқтаи назарини 1929 йилда аниқ кўрсатиб берди. У Навоий ижодидаги инсонпарварлик хусусиятларни эътироф этади ва унинг тасаввуфга нисбатан бўлган муносабатини тўғри таърифлайди. Шу билан бирга бу ерда олим турк тилидаги адабиётларнинг форс тилидаги адабиётга муносабати хақидаги масалани тўғри қўйиш кераклигини уқтиради. Е.Э.Бертельс Низомий ижодинининг прогрессив ва инсонпарварлик характерини кўрсатади. Шу билан бирга бу олим Навоий асарларининг мухим адабий қимматга эга эканлигини бир неча бор таъкидлайди [Бертельс 1965: 7].

Тасаввуф харакати адабиёт, хусусан поэзия билан алоқага қандай киришиб кетди ва шундай қилиб дунё адабиётига бир қатор боқий ёдгорликларни қолдирди, деган масалаларга жавоб топиш мухимдир. Мутасаввифлар худо томонидан юборилган ўзига хос илтифот хисобланган жазавали холатга эришишга катта ахамият берганларликлари бизга маълум. Шунинг учун илк даврларда улар доирасида экстаз (жазава)га сабаб бўлувчи восита катта куч-ғайрат билан изланди. Тезда бу воситалардан бири катта самара бериши тан олинди. Бу музика бўлиб, у бадиий сўз билан кўшилиб олиб борилди. Музикани эшитиш кўпгина шайхларнинг урфига айланди. Тасаввуфнинг мумтоз назариётчиларидан бири ал-Ғаззолий “Кимёи-саодат” асарида кўшиқ айтишнинг жазавага олиб келишдаги бешта сабабини баён қилади. Биз Ғаззолийда бошқа бир мухим кўрсатмани хам учратамиз. У қўшиқ маънавий завқ-шавқ ўрнига, жисмоний кўрқув хам олиб келиши мумкин, деб огохлантиради. Шунинг учун шайхлар томонидан соф рамзий талқин қилинадиган ашулаларнинг танлаб олинишига жиддий эътибор қаратилар эди. Илк даврларда зўрлик билан рамзий талқин қилинмайдиган, балки чуқур ўйланган рамзий маънога эга бўлган махсус поэзияга табиий равишда эхтиёж туғилди, деб тахмин қилиш мумкин. Бундай поэзия VIII асрларда шакллана бошлади, IX асрга келиб унинг араб тилидаги кўп сонли намуналари пайдо бўлди [Бертельс 1965: 45]. Жумлалан, Абу Саид ибн Абу-ал Хайра (967-1049 й.й.) тўғрисидаги маълумотлар шундан далолат берадики, Хуросон тасаввуфининг бу йирик вакили ўзининг ташвиқотларида рубоийлардан кенг фойдаланган. Бу рубоийлар халқники бўлиб, хали бу даврда киборлар доираси бундан анча узоқда эди. Бу даврда мухаббатга оид шеърлардан фойдаланилган. Улар дунёвий лирика сифатида пайдо бўлган, оддий дунёвий мухаббатни тараннум этган бўлса-да, ўзига хос тарзда талқин қилинган. Абу Саид томонидан фақат рубоийлар эмас, ғазаллар хам ишлатилган. Форс тилидаги шеьрлар шайхларнинг сухбатларида $\mathrm{X}$ асрнинг ўрталарида декларация (чиройли ўқиб бериш) қилинган. Бу қўшиқларнинг намуналари бир хил хусусиятлари билан ажралиб туради.Уларга оддийлик, табиийлик, халқ ижодиётига яқинлик хос эди. Чунки шайхларнинг сухбатларида қисман машхур ва бой одамлар қатнашган бўлсалар-да, аммо тингловчиларнинг асосий қисми саводсиз ёки чаласавод хунармандлар ва майда савдогарлардан иборат эди. Шайх ўзининг сухбатларини уларнинг даражаларига мослаштириши зарур эди. Бундан халқ ижодига мурожаат қилишнинг сабаби тушунарли 
бўлади. Бу шеърларда инсоннинг хиссиётига кучли таъсир қилиш асосий мақсад қилиб қўйилган. Шеьрларда омонимлар, чукур рифма, узоқ радифларни соф кўллаш намунасини кўрамиз. Тасаввуф поэзиясини халқ билан алоқаси, халқпарварлиги, феодал аристократияга нисбатан танқидий муносабати сарой поэзиясига қараганда жонли ва хаётбахш қилиб қўйди. Тасаввуф поэзияси қайсидир даражада баъзи даврларнинг халқ ижоди тўғрисида мулохаза юритишига имконият яратади. Бу эса унинг катта қадр-қимматга эгалигидан далолат беради [Бертельс 1965: 50-53].

Тасаввуф муаллифларининг бошқа хизматлари борлигини хам эътироф этиш зарур. Эрон ва Марказий Осиёга монгол босқининг тўфони келганда сарой поэзияси сукут сақлади. Чунки монголларга тушунарсиз тилдаги қасидаларни эшитишга тоқат йўқ эди. Аммо тасаввуф муаллифларининг бу оғир йилларда хам овози ўчмади. Династия йўқолгани билан, халқ йўқолмади. Бу даврга келиб халқ оммаси тасаввуф муаллифларига янада кўпроқ эхтиёж сеза бошладилар, чунки уларга ором бағишловчи сўзлар зарур эди. Тасаввуф шоири тингловчиларда яқинларга мухаббат хақида гапирди, бирлашишга чақирди, ўзаро ёрдам кўрсатишга чорлади, умумий манфаатларни илгари сурди. Шуниси эътиборлики, айнан шу муаллифлар адабиётнинг яхши анъаналарини кутқариб қолдилар ва уларни XIV-XV асрларга етказиб, дунё адабиётининг бойишига имконият яратдилар.

Тасаввуф адабиётини ўрганмасдан, Ўрта Осиё мусулмон Шарқининг маданий хаёти тўғрисида ёрқин тасаввурга эга бўлиш мумкин эмас. Тасаввуф поэзияси XX асрнинг бошигача Шарқ адабиётига таъсир кўрсатиб келди. Мусулмон Шарқининг йирик алломалари тасаввуф адабиёти билан алоқадор бўлганликлари уни истисно қилишга хеч қандай имконият қолдирмади.

Юқоридагиларга асосланиб қуйидаги хулосаларни қилиш мумкин:

1. Дунёвий поэзия, мутассавуфлар хаётига сунъий равишда киритилган бўлиб, жазава(экстаз) холатини енгиллаштиришга қаратилган бўлиши мумкин.

2. Тасаввуф поэзияси терминлардан самарали фойдаланган холда, муаллифнинг дунёқарашини пардага ўралган, яширин тарзда акс эттиради.

3. Дидактик лирика, гарчанд тасаввуфга алоқадор деб хисобланса-да аслида мусулмон диний лирикасидан фарқ қилмайди [Бертельс 1965: 62].

Шуни таъкидлаш лозимки, тасаввуф поэзияси ва унинг рамзий белгиларини ўрганиш учун яна узоқ вақт илмий изланишлар олиб боришга тўғри келади.

\section{Фойдаланилган адабиётлар руйхати}

1. Бертельс Е.Э.Суфизм и суфийская литература. Из-во “Наука”. Главная редакция Восточной литературы. Отв. ред. А.Н.Болдырев. Избранные труды. Том.3. М. 1965. 531 с.

2. Бертельс Е.Э. История персидско-таджикской литературы. Из-во "Наука". Главная редакция Восточной литературы. Отв. ред. А.Н.Болдырев. Избранные труды. Том 2. М. 1965. $561 \mathrm{c}$.

3. Бертельс Е.Э. Избранные труды. Из-во “Наука”. Главная редакция Восточной литературы. Отв. ред. А.Н.Болдырев. Избранные труды. Том 4. М. 1962. 561 с.

\section{УЗБЕКИСТАН-КИТАЙ: СООТРУДНИЧЕСТВО ПРОВЕРЕННОЕ ВЕКАМИ}

\section{O.Ibadulloeva (PhD student)}

Annotation: Today, the Republic of Uzbekistan, has been established friendly relations with many countries of the world, supports effective and fruitful cooperations with many of them. With most of these countries, our country has long maintained friendly relations. The Great Silk Road was the main means linking many nations of the world in close cooperations for our country. China - Uzbek relations is one of these ancient partners. 
Key words and expressions: "Historical Monuments", the history of First Han Dynasty, Uzbek - Chinese Friendship Society.

Первый посол Китая, Чжан Цзян, прибыл в древнюю Фергану (Даван, Деванан) в 128 году до нашей эры. Это стало началом дипломатических отношений между нашими странами.

Ценная информация об истории Туркистана, его людях и экономике, обычаях и традициях, Канге и древнем Ферганско-Даванском государстве до нас дошла через произведения древних китайских историков Си Ма Тян «Исторические воспоминания» и Пан Гун «История Первой династии».

Древние китайские источники сообщают нам, что с первого века до нашей эры из Центральной Азии в императорский дворец отправлялись различные каравана с подарками. Император, в свою очередь, отправлял свои подарки. В 713 году из Самарканда были отправлены вооружения, керамика, страусиные яйца, маленькие человечки и танцоры. C VII по VIII века из Тахаристана были привезены прекрасные лошади, более 200 видов лекарственных трав, изделия из стекла и хрустальные украшения. Было привезено вино, изготовленное по "Иранскому методу". Также в мемориалах Центральной Азии можно найти Бронзовые украшения и другие предметы китайского производства.

Из Китая в Центральную Азию в основном импортировались шелковые ткани, а в Китай - хлопок и шерсть. Например, в 682 году посол Тахаристана подарил императору халат обшитый золотом. В 726 году правитель Бухары прислал, среди прочих подарков, Византийский ковер. Центрально-азиатская музыка повлияла на внедрение новых элементов в китайскую музыкальную и танцевальную культуру, таких как ғижжак, чанг, и флейта. Танцоры и музыканты Бухары, Самарканда, Чача стали очень популярными в Китае в 7-8 веках.

По наблюдениям исследователей, китайская музыка в то время напоминала среднеазиатскую музыку. В период Тана в китайском источнике под названием "хутен" даны сведения о Ташкентском танце.

Политические интересы народов Китая и Центральной Азии имеют много общего и во многом продиктовали характер взаимоотношений. Атаки кочевых племен представляют угрозу для них обоих, поэтому совместная борьба с ними стала жизненно важной.

В 115 г. до н.э. был заключен союз с военными, согласно которому они поставляли солдат в китайскую армию. В период правления империи Тана отношения между странами стали еще больше развиваться. Согласно китайским источникам, с 617 по 648 года в Китай из Самаркандской области

были отправлены 20 послов.

Дипломатические отношения с Китаем были восстановлены во время войны с арабами. Страны Центральной Азии стремились заключить союз с Китаем в борьбе против арабов. С 717 по 731 годы были отправлены из Согдианы -11, из Тахаристана - 5 и из Бухары -12 послов.

Новый этап в развитии дипломатических отношений совпал с правлением Амира Темура. Начиная с 1387 по 1979 годы, Амир Темур отправил в Китай шесть послов.

В 1387 году первое посольство, которое возглавлял Мавлано Хафез, подарило императору 800 лошадей.

В 1394 году Амир Темур направил нового посла в Китай, который в качестве подарка приподнее 200 лошадей и письмо, впервые это письмо было переведено на китайский язык. Даже после того, как Великий Шелковый Путь утратил свое прежнее значение, народы Центральной Азии и Китая сохранили торговые связи.

В XIX веке из Западного Китая в Кокандское, Хивинское и Бухарское ханства были завезены чай, шелковые ткани, фарфор, ковры и продукты животноводства. В Китай были импортированы парча, бархат, золото, мех, кожа, драгоценные камни и другие товары. После завоевания Туркестана царской России стали отгружать железо, медь и другие 
металлические предметы, женские украшения, стекло, посуду, соусы, хлопчатобумажные ткани, спички, сахар.

К началу двадцатого века двусторонняя торговля стала еще больше развиваться. В 1910 году в Китай через Туркестан были отправлены товары на сумму пять миллионов сумов, а из Китая было привезен товар на сумму более восьми миллионов сумов.

Во время Первой Мировой войны торговля между Центральной Азией и Китаем сократилась. Голод в Центральной Азии также изменил структуру двусторонней торговли. Спрос на продукты питания и скот увеличился.

Если в 1915-1916 годах из Синьцзяна в Среднюю Азию было перегнано 10-20 тысяч овец, 500-2000 голов крупного рогатого скота и 200-500 голов лошадей, то в 1917 году 120 тысяч овец, 1200 голов крупного рогатого скота и 3000 голов лошадей.

Торговые отношения продолжались до начала 1930-х годов. Политика большевиков, направленная на разрушение частной собственности и предпринимательства и закрытие границ, опасаясь шпионов и злоумышленников, привела к разрыву связей.

С 1950 года Узбекистан оказывал значительную помощь Синьцзян-Уйгурскому автономному району в Китае в обучении, предоставляя местным жителям литературу и учебники на казахском языке, оказывая медицинскую помощь, минеральные ресурсы и улучшая ирригационные системы.

В 60-70-х годах возникла напряженность между СССР и Китаем. Пограничные проблемы и идеологические разногласия между советскими и китайскими коммунистами ухудшили советско-китайские отношения. В результате Узбекистан потерял возможность сотрудничать с основным государством партнером на протяжении веков.

Так Узбекистан в 1962 году поставил продукцию в Болгарию на 6937,83 тысячи сумов, в Венгрию - 38528,84 тысячи сумов, в Польшу - 33,650,00 тысячи сумов, в Румынию 21808,53 тысячи сумов, а в Китай - всего лишь 339,20 тысячи сум.

К началу 1980-х годов отношения между СССР и Китаем стали улучшаться. В результате усилий направленных на процесс реконструкции в обоих странах, восстановлению взаимоотношений, в целом, привели к восстановлению традиционных связей.

Начиная с 1986 года стали налаживаться торговые отношения между республиками Центральной Азии, Казахстаном и Синьцзян-Уйгурским автономным районом Китая. Между Узбекистаном и Синьцзян-Уйгурским автономным районом наладилось сотрудничество по дальнейшему улучшению производства хлопка, защиты его от различных заболеваний и создания его новых сортов.

17 марта 1989 года в Ташкенте было создано первое советско-китайское совместное предприятие. В тот же день промышленные ассоциации из Урумчи, центра СиньцзянУйгурского автономного района Китая и Министерства местной промышленности Узбекистана подписали соглашение о строительстве завода по производству бытовых термосов в столице Узбекистана.

В январе 1990 года совместное узбекско-китайское предприятие «Ташинтерм» выпустило первую партию термосов. В взаимоотношениях между Узбекистаном и Китаем особое место занимает также общество «Узбекиско-Китайской» дружбы. Оно было создано 30 октября 1958 года, как Общество советско-китайской дружбы (ОСКД). В 1987 году общество было переименовано в общество узбекско-китайской дружбы.

В контексте идеологических конфликтов между СССР и Китаем деятельность общества была очень ограниченной. Только в середине 1980-х годов общество начало устанавливать активные отношения. С 1985 по 1995 год было принято 19 делегаций из Китая, а 12 делегаций были отправлены в Китай.

Несмотря на ограничения и угнетение тиранического режима, народы, входившие в состав СССР, старались поддерживать сотрудничество с иностранными народами.

Только после обретения независимости Республики Узбекистан появилась возможность установить дружественные и основанные на сотрудничестве отношения между 
узбекским и китайским народами, которые формировались на протяжении многих веков и активно проводили многостороннюю внешнюю политику.

Таким образом, народы Узбекистана и Китая придерживались идеалов гуманизма, терпимости, дружбы и добрососедства и эффективно развивали межгосударственные отношения на протяжении многих веков.

\section{Список использованной литературы}

1. Ходжаев А.О трансформатсй "Юечжи” из топонима в этноним// Вопросы истории и археологи Западного Казахстана. Випуск 3. Уралск, 2004.

2.Шефер Э. Золотые персики Самарканда. - Москва: Восточная литература, 1981.

3.Хўжаев А. Буюк Ипак йўли:муносабатлар ва такдирлар. - Т. Ўзбекистон миллий энсиклопедияси,2007.

4.Хўжаев А. Фарғона тарихига оид маълумотлар. Қадимий ва илк ўрта аср Хитой манбаларидан таржималар ва уларга шархлар. - Фарғона: “Фарғона” нашриёти, 2013.

5.Абдухолиқ Абдурасул ўғли Аитбоев. Қадимги Фарғона тарихидан (хитой манбаларида Фарғона хақида илк маълумотлар) -Т: Фан,2002.

6.Хўжаев А. Марказий Осиё халқлари тарихига оид маълумотлар. -Т: Навруз, 2015

7.Крюгер Р.Китай. История страны. М: Эксмо; СПб: Мидгард,2008.

8.Кожин П.М. Китай и Центральная Азия до эпохи Чингисхана: проблемы палеокультуралогии. - М: ИД “Форум”, 2011

9.Ртвеладзе Э. Цивилизации, государства, культуры - Ташкент: Университет мировой экономики и дипломатии, 2005

\section{BUYUK IPAK YO'LI VA UNING AHAMIYATI}

\section{A.Lutfullayev \\ (TIQXMMI Qarshi filiali) \\ S.Mulkamalov \\ (TIQXMMI Qarshi filiali)}

Annotation: The Republic of Uzbekistan has chosen the greatest path as an independent way of life and development, and was one of the first to put forward the idea of restoring the "Great Silk Road" and is working tirelessly to realize this idea. state of affairs. "The Great Silk Road served not only to facilitate trade between regions, but also the exchange of information between nations and continents, and served as an important tool for the spread of new products and crops, the development of cultural values, and thus the conditions for intercultural dialogue. The main results of the restoration of the Great Silk Road are given.

Key words and expressions: Great Silk Road, trade, transport, forum, science and technology, fabrics.

O'zbekiston Respublikasi mustaqil hayot va taraqqiyot yo'lidek eng buyuk yo'lni tanlab, «Buyuk ipak yo'li»ni ham qayta tiklash g'oyasini birinchilar qatori ilgari surgan va ushbu g'oyani ro'yobga chiqarish uchun tinimsiz harakat qilayotgan davlatdir. Shuning uchun ham O'zbekiston qadimiy «Buyuk ipak yo'li»ning yuk ortilgan ot va tuyalardan iborat karvonlarga moslangan «Ipak yo'li»ning o'ta zamonaviy mazmun va darajalarda, eng yangi texnika va texnologiyalar bilan qurollangan ilg'or, murakkab transport va aloqa kommunikasiyalari sistemasi sifatida qayta tiklanish uchun ko'p tadbirlarni ko'rmoqda. Bu tadbirlarga ham mamlakatlarni iqtisodiy rivojlantirish, ham «Buyuk ipak yo'li»ni tiklash vositalari deb qaramoqda."Buyuk ipak yo'li nafaqat hududlar o'rtasida savdo-sotiq aloqalarini, balki davlatlar va qit'alar o'rtasida axborot almashuvini ta'minlashga xizmat qilgan, yangi mahsulotlar va qishloq xo'jaligi ekinlari tarqalishida, madaniy qadriyatlarning rivojlanishida muhim vosita vazifasini bajargan va shu tariqa tsivilizatsiyalar aro muloqot uchun shart-sharoitlar yaratilgan”,- dedi Shavkat Mirziyoyev o‘z nutqida. 
"Bitta belbog' - bitta yo'l" forumida ishtirok etish uchun dunyoning 110 mamlakatidan 1200 nafar vakillark elgan.Ular orasida 29 mamlakat rahbarlari ham bor.

"Bitta belbog' - bitta yo'l" forumi ham hozirgi zamonda dunyo mamlakatlari orasida iqtisodiy hamkorlikni yanada kuchaytirish, savdo va investitsiyalar uchun qulay sharoitlar yaratish, shuningdek turizm, ta'lim va madaniyat sohalarida hamkorlikni rivojlantirishga xizmat qiladi" [Shavkat Mirziyoyev 2017:15], dedi prezidentimiz Mirziyoyev «Buyuk ipak yo'li»ning yangi mazmunda va sifatlarda to'la-to'kis tiklanishi bilan Evropa va Osiyo mamlakatlari xalqlari uchun butunlay yangi taraqqiyot manbalari, omillari va imkoniyatlari vujudga keladi. Ular yanada kengaya borib, ekologik muammolarning eng og'iri -

Orol dengizi muammosini yechishga ham yordam berishi mumkin. «Buyuk ipak yo’li» tiklanishining asosiy samaralari xususida quyidagilarni aytish mumkin.

* «Buyuk Ipak yo'li»nning to'la tiklanishi bilan eng avvalo mamlakatlar o'rtasidagi savdosotiq munosabatlari kuchayadi, savdo hajmi oshadi va ular iqtisodiy taraqqiyotga ijobiy ta'sir etadi.

* Yangi korxonalar, zamonaviy texnik stansiyalari va xizmatko'r sotish shahobchalari vujudga kelib, mamlakatlarning ishlab-chiqaruvchi kuchlari rivojlanadi. Ilmiy-texnik aloqalar hamda yangi texnika va texnologiyalar keltirilishi natijasida fan-texnika taraqqiyoti tezlashadi, xo'jaliklar va tovarlarning raqobat qobilligi kuchayadi.

* Ko'plab yangi ish joylari tashkil qilinadi va ular ko'payib boradi, ishsizlarning ko'pchiligi o’z joylariga ega bo'ladi.

* Har bir mamlakat ichida va xalqaro ko'lamda mehnat taqsimoti chuqurlashadi va kengayadi, mehnatning yangi turlari va yangi kasblar vujudga keladi. Milliy va xalqaro munosabatlar yanada o'zgaradi va takomillashadi. Ekologik muhitni yaxshilash, tovarlar sifatini oshirish imkoniyatlari kengayadi.

* Mahsulot ishlab chiqarish, sotish va xarid qilishnin geksport va import ishlarining arzonlashuviga, iqtisodning o'sishiga ta'sir etuvchi shart sharoitlar, omillar yanada kengayadi. Bular natijasida kishilar moddiy hayoti yaxshilanadi, moddiy farovonligi oshadi.

* Xalqlar o'rtasidagi madaniy, ma’naviy va ma'rifiy munosabatlar, aloqalar, shu jumladan, ma'rifiy turizm yanada rivojlanadi va takomillashadi. Barcha xalqlarning har tomonlama rivojlanishi kuchayadi.

* Iqtisodiy, ma'naviy-ma'rifiy va boshqa munosabatlarning o'sishi, mamlakatlar va xalqlar o'rtasidagi siyosiy munosabatlarga, xalqaro vaziyatga ijobiy ta'sir etadi, xalqaro tinchlik va hamkorlik kuchayadi.

Brinchi Prezidentimiz A. Karimovning quyidagi fikrlarini keltirish o'rinlidir: "Albatta, har qaysi xalq yoki millatning ma'naviyatini uning tarixi, o'zigaxos urf-odat va an'analari, hayotiy qadriyatlaridan ayri holda tasavvur etib bo'lmaydi. Bu borada, tabiiyki, ma'naviy meros, madaniy boyliklar, ko'hna tarixiy yodgorliklar eng muhim omillardan biri bo'lib xizmat qiladi" [I.A.Karimov2008: 29-30].

Brinchi Prezidentimiz I A. Karimov to 'g'ri ta'kidlaganidek, har qanday sivilizatsiya ko'pdan-ko'p xalqlar, millatlar, elatlar faoliyatining va samarali ta'sirining mahsulidir 4. Demak, respublikaning asosiy tub joy aholisi hisoblangan o'zbeklar bilan birga yashayotgan boshqa etnik guruhlarga xos bo'lgan xususiyatlarni o'rganish va rivojlantirish favqulodda dolzarb masalalardan biri hisoblanadi. Xitoylar O'rta Osiyoni o'rganishni aynan Farg'ona vodiysidan boshlagan edi. Qolaversa, O'rta Osiyo xalqlarini Xitoy bilan aloqaqilishlariuchunFarg' onavodiysiningtog'lidavonlarimuhimo'rintutgan.O'rtaosiyoliklar mil. avv. IV-III asrlardayoqdavonva «dashtyo'li» orqaliXitoychegaralargachiqqanlar. Mil. avv. I ming yillik o'rtalaridan to mil. I ming yillikkacha ular, sug'diylar rahnamoligida [А. Хўжаев 2007: 66-70 ]. Amudaryodan to Gansuning Xesi yo'lagigacha yetakchilik qilganlar.

Sopol buyumlarining ko'proq ichki yuzasida qadimgi matolarningizlari qolgan. Eng qadimgi idishlarda qolgan izlarga qaraganda ular juda qo'pol, ko'proqj undan, turli o'simliklarning poyalaridan, paxtadan, to'qilganligi ko'rinib turibdi [Ю. А Заднепровский 1962: 87].Huddi shunday matolarning izlari saqlanib qolgan sopol idishlarining parchalari Qashqadaryoning so'nggi bronza davriga oid Chimqo'rg'on suv ombori zonasidan [М. Х Исамиддинов 2000: 33], 
shuningdek Farg'ona vodiysi arxeologik obidalarining qadimgi davr qatlamlaridan ham ko'plab topilgan [Б. О Абдулгазиева 2004:44]. Shunday ekan, O'rta Osiyo hududida, shu jumladan Farg'ona vodiysida paxta to'qimachilikning eng asosiy manbai-xom ashyosi ekanligini ko'rsatib turgan dalil hisoblanadi. Shuning uchun paxtadan turli matolar tayyorlanib, undan turli kiyimlar tikishganliklari ko'rinib turibdi. Lekin paxtadan tashqari kanop, jun va ipakdan ham turli matolar ham to'qilgan.

\section{Foydalanilgan adabiyotlar ro'yhati}

1. Shavkat Mirziyoyev Pekinda bo'lib o'tayotgan "Bitta belbog' - bitta yo'l" forumida nutq so'zladi. 2017. 29-30.

2. Каримов И. А. Юксак маънавият - енгилмас куч. - Тошкент: Маънавият, 2008. - Б. $66-70$.

3. Хўжаев А. Буюк ипак йўли: муносабатлар ва тақдирлар. - Тошкент: ЎзМЭ, 2007. - Б.

4. Заднепровский Ю. А. Древнеземледельческая культура Ферганы // МИА. Вып.118. Москва-Ленинград,1962. - С. 87.

5. Исамиддинов М. Х., Хасанов М.Х. История древнего и средневекового керамического производстваНахшаба. - Ташкент: Из-во им. А.Кадыри, 2000. - С. 33.

6. Абдулгазиева Б. О ткачестве древней Фергане // Материалы республиканской научно-практическойконференции «Великий шелковый путь и Ферганская долина». Ташкент, 2004. - С. 44-48.

\section{ИЧКИ ТУРИЗМНИНГ ПЕДАГОГИК ЖИХАТЛАРИНИ ТАКОМИЛЛАШТИРИШ.}

Абдуллаева Наргиса (УрДУ)

Annotation: This article discusses the role of domestic tourism in education as well as the pedagogical aspects of domestic tourism.

Key words and expressions: Tourism, domestic tourism, pedagogy,tourism pedagogy.

Қадимдан юксак маданияти ва илм-фани, меъморий обидалари билан кўпчиликни хайратга солиб келган юртимиз истиқлол шарофати билан замонавий сайёхлик марказига айланди. Мустақил Ўзбекистонда туризм халқаро ахамиятга ега бўлган ижтимоий-маданий, маънавий-сиёсий, иқтисодий ва тарбиявий жараён сифатида мавжуддир. Мамлакатнинг географик шароити ва ижтимоий-маданий, иқтисодий тузилмалари асосида туризм икки йўналишга (ички ва халқаро туризм) ажратилган. Мамлакатимиз худудида турли давр ва цивилизацияга дахлдор тўрт мингдан ортиқ қадимий меъморлик ва санъат ёдгорликлари мавжуд. Ана шу бой маданий-тарихий меросимиз, мангуликка дахлдор кўхна шахарларимиздаги ноёб меъморий обидалар, шунингдек, худудларимизда йилдан-йилга такомиллашиб бораётган замонавий инфратузилма Ўзбекистоннинг халқаро сайёхлик бозоридаги юксак салохиятидан далолат беради.

Бугунги кунда мамлакатимиз нафақат сиёсий, иқтисодий-ижтимоий, маданий сохаларда, балки туризмда хам янги ривожланиш босқичига қадам кўйди. Жумладан, Ўзбекистон Республикаси Президентининг 2018-йил 7-февралдаги "Ички туризмни жадал ривожлантиришни таъминлаш чора-тадбирлари тўғрисида" ги ПҚ-3514-сонли қарори [1] , 2019-йил 5-январдаги “Ўзбекистон Республикасида туризмни жадал ривожлантиришга оид кўшимча чора-тадбирлар тўғрисида"ги ПФ-5611-сонли фармони билан тасдиқланган “2019 - 2025-йилларда Ўзбекистон Республикасида туризм сохасини ривожлантириш Концепцияси” [2] да мамлакатимизда туризм салохиятини ривожлантириш учун қулай шартшароитлар яратиш бўйича кўшимча ташкилий чора-тадбирлар амалга ошириш , шунингдек, худудларни барқарор ижтимоий-иқтисодий ривожлантиришнинг энг мухим омилларидан бири сифатида ички туризмни жадал ривожлантириш, фуқароларни мамлакатимизнинг 
маданий-тарихий мероси хамда табиий бойликлари билан таништириш вазифалри белгиланган. Ушбу мухим йўналишлар қаторида юқори малакали мутахассисларни тайёрлаш, хизмат кўрсатувчи ходимларни қайта тайёрлаш ва малакасини ошириш тизимини такомиллаштириш хам алохида ахамият касб етиши алохода таъкидланган. Жумладан, туризм сохасида касб-хунар таълими муассасаларидаги кадрлари ва битирувчиларининг малакасини бахолашни ташкил қилиш; туризм сохасида халқаро талабларга жавоб берадиган узлуксиз, кўп босқичли таълим тизимини яратиш; таълимнинг амалиётга йўналтирилган ва модернизациялашган таълим стандартлари, ўқув-услубий дастурлар хамда илғор ахбороткоммуникация технологияларини жорий этиш; ички ва кириш туризми сохасида бевосита туристик хизматларни кўрсатувчи туризм сохаси ходимлари (гидлар, йўриқчи-кузатувчи, туризм фаолияти субьектлари, умумий овқатланиш ташкилотлари, транспорт ва бошқалар ходимлари) учун мажбурий малака талабларини белгилайдиган стандартлар ишлаб чиқиш; таълим жараёнига хорижий мутахассисларни жалб қилиш орқали туризм сохасида кадрлар малакасини ошириш тизимини такомиллаштириш, шунингдек туризм сохасида кадрлар малакасини ошириш тизимини ташкил этиш учун, шу жумладан худудларда таълим муассасалари сонини ошириш; туризм сохасида кадрлар тайёрлаш учун етакчи хорижий олий ўкув юртлари филиалларини очиш каби мухим ахамиятга эга вазифалар кўйилган .

Хозирда замонавий таълим муассасаларида туризм сохаси учун мутахассислар тайёрлаш бўйича хорижий тажрибани ўрганишнинг асосий йўналишлари белгилаб берилган ва таълим бериш жараёнига хам янги ёндашувларни жорий этиш, соха учун кадрлар тайёрлашнинг илғор махаллий тажрибасини умумлаштириш талаб қилинади. Шу муносабат билан ушбу жараёнларни таъминлайдиган янги технологияларни тадбиқ этиш билан бирга туризм таълимининг инновацион шаклларини фаол излаш зарурати пайдо бўлмокда.

Туризм педагогикаси - таьлим, тарбия ва шахс ривожланишини туризмнинг гуманитар ва ижтимоий функциялари контекстида ўрганадиган фан.Туризм педагогикаси шахсни ватанга бўлган мехр мухаббати, миллий қадриятларимизга бўлган ижобий муносабатни оширади ва шу билан бирга умумжахон маданий қадриятларини англашга хизмат қилади.

Хар қандай фаннинг ўзига хос предмети ва ўрганиш объекти мавжуд ва у ўрганадиган ходисалар хақидаги билимларнинг синтезидир. Шу билан бирга, бу, албатта, бошқа фанлар билан муайян алоқадорлик ва боғлиқликни назарда тутади.

Туризм педагогикасининг предмети - жамиятдаги ижтимоий-иқтисодий ва маданий муносабатларнинг мухим сохасига айланган туристик фаолият давомида шахсни шакллантириш ва ривожлантириш, мақсадли тарзда зарур касбий билим, малака ва кўникмалар билан куроллантиришдан иборат бўлиб, пироварда шахс ва жамиятнинг туристик маданиятини юксалтиришга йўналтирилган жараёндир.

Туризм педагогикаси назарий-методологик жихатдан умумий педагогикага, ёш авлод тарбияси борасидаги турли назарий-концептулал ёндашувларга асосланади. Бунинг сабаби шундаки, инсон хар қандай ёшда саёхат қилади, сайёхга айланади, саёхат пайтида эса мухим маънавий ва жисмоний фазилатлар шаклланади. Турист шахсини шакллантирувчи детерминантларни, ақлий ва жисмоний кучга таъсир этувчи омилларни, дунёқараш асосларини, эътиқодларини, ахлоқий туйғуларини, характер хусусиятларини, эхтиёжларини, қизиқишларини ва афзалликларини очиб бериш жуда ахамиятлидир.

Туризм педагогикаси кўплаб фанлар билан боғлиқ, хусусан фалсафа, эстетика, педагогика, психология, одам анатомияси ва физиологияси, иқтисодий фанлар, этнология, этнография ва бошқалар. Фалсафий фанлар туризм педагогикасига илмий тадқиқотларнинг асосий йўналишларини аниқлашда, одамларнинг борлиги ва тафаккурининг умумий қонуниятлари таъсирини тўғри хисобга олишда, фан ва жамиятдаги ўзгаришлар тўғрисида маълумот беришда ва услубий асосларини аниқлашда ёрдам беради. Психология инсон рухиятининг ривожланиш қонуниятларини, шахснинг эхтиёжлари ва қизиқишларини ўрганади, педагогика эса ички дунёси ва шахс хулқ-атворидаги ўзгаришларни олдиндан белгилаб берадиган таълим таъсирининг самарадорлиги, таълим ва тарбия тамойиллари, 
шакллари ва усулларини шакллантиришга имкон беради. Анатомия ва физиология инсоннинг биологик жихатларини, организмнинг имкониятларини ва унинг чидамлилигини аниқлашга хизмат қилади. Шу билан бирга, иқтисодий фанлар туристик инфратузилманинг ривожланиши қонуниятларини аниқлашга имкон беради. Этнология ва этнография турли хил этник гурухларнинг миллий-маданий хусусиятларини, психологияси, маиший хаёт анъаналари ва ўзига хос жихатларинитадқиқ қилади.

Туризм педагогикасининг асосий дидактик функциялари қуйидагилардан иборат:

- тарбиявий - жамоатчилик туйғусини, маънавий ва ахлоқий қадриятларни шакллантириш, ижтимоий-коммникатив муносабатларни ривожлантириш;

- таълимий - тарих, маданиятшунослик, табиатшунослик, рекреация, валеология ва х.к. бўйича билимларни шакллантириш, тўлдириш ва мустахкамлаш;

- соғлиқни мустахкамлаш - мунтазам равишда жисмоний жихатдан фаол бўлишни таъминлаш, табиий омилларнингорганизм холатига фойдали таъсирини кучайтириш, шахсий ва жамоат гигиенаси қоидаларига риоя қилиш, чиниқтириш ва мослашиш қобилиятларини ривожлантириш.

Туризм педагогикасининг мухим йўналишдан бири бу туристик таълим мазмунини ривожлантиришдир. Мавжуд таълим парадигмаларида таълим мазмуни асосан, ўқув материалларини такомиллаштириш ғояси билан боғлиқ холда, ўқув режалари, дастурлар, дарсликлар, ўқув кўлланмалари, турли хил кўргазмали воситалар, компьютер технологиялари каби таркибий қисмларга ажаратилади. Бироқ, таниқли педагог олим Б.С.Гершунский таъкидлаганидек, таълимнинг бундай соф ўқитиш концепцияси асосан талабалар онгига мурожаат қилади ва интеллектни тобора янги илмий далиллар, тушунчалар, қоидалар, тамойиллар, назариялар ва қонунлар билан тўлдиришга харакат қилади.Вахоланки, таълим мазмуни асосини шахсни ўз-ўзини англашга, ижтимоий ва табиий ходисалар мазмунини, улар ўртасидаги ўзаро алоқаларни яхлит тарзда чуқур тушунишга йўналтирилганлиги хам ташкил қилади. [3, 532-533.]

Туризмнинг мухим педагогик воситалари қаторида туристик фаолиятни ташкил этишнинг қуйидаги усулларини кўрсатиш мумкин:

- дастур, хизматлар, саёхат, маршрут, саёхат, экскурсия;

- харакатланиш усуллари ёки транспорт хизматлари ва ташиш сервиси, алмашинув, туристик харакатлар, туристик транспорт;

- туристик хизмат кўрсатиш усуллари: тураржой, овқатланиш, кўшимча хизматлар кўрсатиш ва х.к.

Шундай қилиб, туризмнинг, шу жумладан ички туристик фаолиятнинг педагогик имкониятларидан самарали фойдаланиш йўллари ва усулларини тадқиқ қилиш бугунги куннинг долзарб илмий-педагогик муаммоларидан бири бўлиб, биринчи навбатда ушбу жараённинг назарий-педагогик асослари ва дидактик концерцияларини янада чуқурроқ тахлил қилишни тақозо этади. kasbiy o'sishi, yuqori malakali mutaxassislarning turizm uchun kadrlar tayyorlashd

\section{Фойдаланилган адабиётлар рўйхати}

1. O’zbekiston Respublikasi Prezidentining 2018-yil 7-fevraldagi“'Ichki turizmni jadal rivojlantirishni ta'minlash chora-tadbirlari to "g 'risida" gi PQ-3514-sonli qarori. https://lex.uz/docs/3551112

2. 2019-yil 5-yanvardagi “O'zbekiston Respublikasida turizmni jadal rivojlantirishga oid qo “shimcha chora-tadbirlar to 'g'risida"gi PF-5611-sonli farmoni bilan tasdiqlangan "2019 - 2025yillarda O‘zbekiston Respublikasida turizm sohasini rivojlantirish Konsepsiyasi”. https://lex.uz/docs/-4143188

3. Гершунский Б.С. ХХІ аср учун таълим фалсафаси - М., 1998 .- 532-533 б. 


\title{
БАРКАМОЛ АВЛОДНИ ТАРБИЯЛАШДА МУЗЕЙЛАРНИНГ ЎРНИ
}

\section{М.Я.Ўринбоева \\ (Самарқанд вилоят ўлкашуносликмузейи)}

\begin{abstract}
Annotation: This article attempts to show the role of museums in the spiritual and moral education of youth. The development of spirituality, self- sufficiency, and pride in the great cultural heritage of our ancestors. And also some suggestions were made about the joint work of public education institutions and museums, especially in significantly enriching the content of lessons, to diversify the types of organization of lessons and educational events not only in public education institutions, but also in secondary special and higher schools.
\end{abstract}

Key words and expressions: self-sufficiency, especially in significantly enriching, museum of local lore, cultural heritage, education institutions, secondary special.

Маълумки хар бир давлатнинг бугунги ва истиқболини унинг маънавиятини юксак наъмуналаридан бўлмиш музейларсиз тасаввур қилиб бўлмайди.

Биринчи Президентимиз И.А.Каримовнинг таъбири билан айтганда "Инсон ўзлигини англагани, насл-насабини чуқурроқ билгани сари юрагида Ватанга мухаббат туйғуси илдиз отиб, улғая боради. Бу илдиз қанча теран бўлса, туғилиб ўсган юртига мухаббат хам шу қадар юксак бўлади". [Каримов 1997:235]. Дархақиқат, Ватанга мухаббат туйғусининг чуқур илдиз отиши учун аввало, тарихни ўрганиш ва ёритиш ғоят мухимдир.

1998-йил 12-январда эълон қилинган “Музейлар фаолиятини тубдан яхшилаш ва такомиллаштириш тўғрисида"ги Фармони Республикамиз ахолисининг барча қатламларини маънавий савиясини оширишга хизмат қилади[Музей 2011: 65]. Шу маънода ёш авлодни маънавий шакллантиришда музейлар мухим восита бўлиб хизмат қилади.

Музейлар - ўқувчи ёшлар учун таълим-тарбия воситаси бўлиб, улар тарихий, моддий, маънавий ёдгорликларни тўплаш, сақлаш, ўрганиш ва намойиш қилиш кабиларни амалга оширувчи илмий, маърифий, маънавий маскандир.

Музейлар ижтимоий вазифасига кўра илмий-тадқиқот, маърифий ва ўкув музейларига, фан ва санъатнинг бирор сохасига ихтисослашган музейларга, ўлкашунослик музейларига, шунингдек, мухим тарихий воқеалар, атоқли арбобларга бағишланган меъмориал музейларга бўлинади.

Узлуксиз таълим тизимининг барча бўғинларида кўзда тутилган ижтимоий-гуманитар, табиий-математика ва махсус фанларни ўрганиш жараёнида тахсил олувчиларни билим, малака, кўникмаларини ўстириш баробарида уларнинг дунёқарашини, маънавиятини юксалтиришда музейларга уюштириладиган экскурсияларнинг ўрнини алохида таъкидлаш лозим.

Шундан келиб чиққан холда таълим муассасаларнинг шаклига қараб, бир қатор омиллар асосида ёндошиш мақсадга мувофиқдир.

1-омил. Мактабгача таълим муассасалари тарбияланувчилари билан олиб борилган экскурсияларда музейлардаги экспонатлар улар назарида тиришқоқлиқ, зукколик, уддабуронлик, озодалик, жасурлик, мехнатсеварлик, тўғрисўзлилик, хақиқий дўстлик каби инсоний фазилатлар болалар тарбиясида мухим ахамиятга эга. Шу сабабдан хам уларнинг эркин фикрлашлари, дунёқарашини шакллантиришда бир қанча омилларга эътибор беришимиз лозим.

2-омил. Музей илмий ходимлари хамда умумтаълим мактаб ўқитувчилари хамкорлигида умумтаълим фанларидан фан ойликларида, мактаб тўгарак фаолиятини янада жонлантириш мақсадларида экскурсиялар, очиқ дарслар, тадбирлар ташкил этишни йўлга кўйиш лозим. Музейларда ўқувчиларни эркин харакат қилиши, фикрлаши, мулохаза юритишлари учун хамма имконият мавжуд.

3-омил. Академик лицей ўқувчилари иштирокида музейларга уюштириладиган мавзувий экскурсиялар, очиқ дарслар талабалар ижтимоий, тарихий ходиса, жараёнларга 
доир экспонатларни бевосита кўриш орқали идрок қилиши туфайли таълим самарадорлиги юқори бўлиши исботланди.

4-омил. Давлатимизнинг таълим сахасидаги асосий хужжатларида олий таълим муассасаларида таълимни ташкил этиш шакллари ва таълим методларини эркин танлаш хуқуқи берилган. Бу масала кафедра, факультет, олий таълим муассасаси ўқув-услубий кенгашларида хал қилиниши лозим. Услубий кенгашлар предметлар ичидаги, предметлараро, туркумлараро боғланишларни хисобга олишлари, такрор ўргатиладиган турли мавзуларни қисман қисқартириш хисобига улардан музейларда ўтказиладиган “Аудитория-музей”машғулотларида ўрганиш йўлларини ишлаб чиқишлари лозим. Шу асосда шахримиз музейларига нафақат алохида фан бўйича, балки фанлараро умумий(комплекс) экскурсиялар уюштириш, кафедра ва факультетда музейларга уюштириладиган экскурсиялар жадвалини тузишга эришиш мумкин. Бу эса таълим муассассаларида ўқув жараёнини модернизациялашга, пировард натижасида таълим самарадорлигини оширишга хизмат қилади.

Музейлардаги таълим-тарбия машғулотларида, таълимнинг оғзаки тушунтириш усуллари билан биргаликда кўргазмали усулининг устувор бўлиши ўз-ўзидан таъминланади. Узлуксиз таълимнинг барча бўғинлари хамкорлик тизимида ижтимоий, тарихий ва табиат ходисаси, жараён, воқеаларни кўргазмали усулда ўрганиш ўқувчи-ёшлар хамда талабалар ўзлаштириш даражасини юқори бўлишини хозирги замон фан ютуқлари исботлаган. Сабаби, бунда ўқув жараёнига одам бош миясининг тасвирий ўнг ярим шари бой имкониятлари қўшилади. Шунингдек, ўқув ахборотини эшитиш канали орқали қабул қилиш қобилияти уни кўриш орқали қабул қилиш каналига нисбатан 3-4 марта пастлиги исботланган. Булардан ташқари, музейларга экскурсияга борганда инсоннинг кўриш орқали қабул қилиши мумкин бўлган ўқув ахборотни қарийиб 90 фоизини ташкил этишини хамда музей экспонатларини бир вақтнинг ўзида кузатиш имконини беришин ёдда сақлашимиз керак.

Шу боис, хар бир таълим муассасалари илмий ва ўкув-методик кенгашларида таълим йўналишлари бўйича ўқув режаларига киритилган фан блокларининг намунавий дастурларини синчковлик билан кўриб чиқиб, уларда музейлар билан хамкорлик қилиш мазмунини киритиш лозим. Бундан ташқари ўқувчи ёшларнинг фан сохасида ўзлаштирган билимларини мустахкамлаш, бойитиш, фан асослари бўйича мустақил ишлаб, мустақил изланишлар олиб боришни ташкил этиш мақсадида мамлакатимиз олий таълим муассасаларида фан, адабиёт, санъат, тарих ва бошқа сохаларда музейлар ташкил этиш тажрибаси мавжуд. Жумладан, Самарқанд давлат университетида Алишер Навоий хаёти ва ижодий фаолиятига бағишланган музей (лаборатория), зоология, археология, геология музейлари, ботаника сохасида эса маъруза, амалий машғулотлар ўтказиш учун иссиқхона (оранжерия) фаолият кўрсатади.

“Алишер Навоий хаёти ва ижодий фаолияти”га бағишланган музей экспонатлари асосида филология йўналишлари талабалари Алишер Навоий асарларига таянган холда ўзларининг фонетика, лексикография, морфемика, морфология, синтаксис каби сохалар бўйича билимларини чуқурлаштириши баробарида Хазратнинг жахон цивилизациясида тутган мавқеи билан танишадилар.

Самарқанд давлат университетининг “Зоология” музейи эса Марказий Осиёда ягона бўлиб, унда 5000 дан ортиқ турли-туман хайвон ва қуш турларига мансуб бебахо экспонатлар, 1000 турдаги турли хашаротларни ўз ичига олган [Жабборов 2003: 12]. Бу ерда 110000 хашаротдан иборат энтомология коллекцияси мавжуд бўлиб, улар “Биология", “Бошланғич таълим" таълим йўналишлари талабалари назарий билимларини чукурлаштириш, мустахкамлаш, маънавий эхтиёжларини қондиришга бўлган интилишларинини таъминлаш учун имконият яратади.

Замонавий педагогик кадрлар тайёрлаш билан шуғулланаётган таълим муассасаларида музейларга уюштириладиган экскурсияларни ташкил этиш, тайёрлаш ва ўтказиш ўқитувчилардан ўрганилаётган умумтаълим фанлари мавзулар бўйича экскурсияларни қандай ташкил этиш, тайёрлаш ва ўтказиш бўйича атрофлича тушунча ва кўрсатмалар 
беришни талаб этади[Шодиев 2005:125]. Масалан, физика фани ўқитувчиси ўқувчиларни “Космос физикаси” (Юлдузлар туркумлари, астраномик тадқиқотлар, Улуғбек астрономия мактаби ва унинг фаолияти) бўлими бўйича уюштириш лозим бўлган экскурсиянинг барча босқичлари билан таништириши мумкин. Математика фани ўқитувчиси “Улуғбек музейи ва расадхонаси"га уюштириладиган экскурсияларнинг барча босқичлари билан таништириб боришни тақазо этади. Ўз навбатида ўкувчилар “Тригонометрия элементлари” бўлими бўйича Беруний ва Улуғбекнинг тригонометрик Зиж (жадвал)лари, тарихий маълумотларга эга бўладилар. Биология фани ўқитувчиси ўқувчилар билан зоология фанидан Ўлкашунослик музейи Табиат бўлимида “Тоғ экотизими”, “Сув-ботқоқ экотизими”, “Тўқай экотизими”, “Адир экотизими”, “Чўл экотизим” ларида мавжуд ўсимликлар қоплами хамда хайвонот дунёси билан яқиндан танишиш имконига эга бўладилар. Тарих фанидан ўқувчилар энг қадимги даврдан XIX-асрнинг 40-йилларигача бўлган Зарафшон вохаси маданияти, этнографиясига оид экспонатлар билан танишадилар.

Шу тариқа барча таълим муассасалари (мактабгача таълим муассасалари, умумтаълим мактаблар, академик лицей ва олий таълим муассасаси) ва вилоятимиз музейлари ўртасидаги алоқадорликни узлуксизлигини таъминлаш, музейлардаги мавжуд экспонатларга таянган холда “Таълим муассасаси-музей” тизимида ўкувчилар тадбирлар, очиқ дарслар, маърузалар, семинар, амалий машғулотларини ташкил этиш, фанлар бўйича олдин тайёрлаб кўйилган ўқув топшириқларини мустақил бажаришлари, илмий-услубий ишларини олиб бориш имконини беради.

Ўқувчи дарс жараёнида қанчалик фаол иштирок этса ва эркин фикрласа, шунча кўпроқ билим ва кўникмага эга бўлади. Музейда олиб борилган дарс жараёнида музей экспонатлари ёки ашёларини “сўзлатиш" нафақат ўша ашёнинг мазмун ва мохиятини очиб бериш, бу орқали ёш авлодни табиат ва унинг неъматларига мухаббат уйғотиш рухида тарбиялашдан иборатдир [Маданиятлараро мулоқот 2019: 258]. Дарс жараёнларини шу тарзда ташкил этиб, юқори натижага эришиш ўз навбатида ўкувчиларнинг келажакдаги касбий махоратининг юқори бўлишини таъминлайди. Бу фаолиятнинг амалга ошиши, шубхасиз, ўқитувчидан етук санъаткорлик қобилиятини ўзида мужассам этишни талаб қилади. Хақиқатан хам бугунги кунда музейлар, асосан ёшларнинг қизиқиши ва талабини қондирувчи, тарих билан юзма-юз туриб эркин мулоқотга киришишга шароит яратувчи ўзига хос масканга айланиб бормоқда.

Хулоса ўрнида шуни таъкидлашимиз керакки, барча таълим муассасалари ўкув режа ва намунавий дастурларини синчковлик билан кўриб чиқиб, улардан музейлар билан хамкорлик қилишга имкон берадиган мавзуларни аниқлашлари мақсадга мувофиқдир. Ана шундагина таълим муассасалари педагог-ходимларида музейлар билан ўрнатилган алоқа таълим-тарбия жараёнини янгиланишининг таркибий қисми эканлиги хақида тушунча том маънода шаклланиши мумкин.

\section{Фойдаланилган адабиётлар рўйхати}

1. И.А.Каримов «Ўзбекистон XXI-аср бўсағасида: хавфсизликка тахдид, барқарорлик шартлари ва тараққиёт кафолатлари» Тошкент,1997 йил. 235 б.

2. Музей-халқ тарихининг кўзгуси. Тошкент, 2011 йил. 65 б.

3. Шодиев Н. “Янги педагогик технологиялар” СамДУ. 2005 й. 125 б.

4. "Маданиятлараро мулоқот Ўзбекистон туризми нигохида: тажриба, долзарб муаммолар ва истиқболлар” Халқаро илмий-амалий анжумани. Самарқанд шахри, 2019 йил, 27-28-июнь, 258-259 б.

5. А.Р.Жабборов, С.Л.Фундукчиев, Б.М.Мухаммадиев "Рол Зоологического музея СамГУ”. В Изучений средний Узбекистана. Самарканд 2003 г. 10-12 б. 


\section{ЖАДИДЛАРНИНГ МИЛЛИЙ ТИЛ ВА ИМЛО МАСАЛАЛАРИГА МУНОСАБАТИ}

Ф.Ф.Ашурова

(ТДАУ)

Annotation: Language is a hallmark of the level of potential and culture of the individual and society. The granting of the status of the state language to the Uzbek language 30 years ago was a truly great and historic event. The enlightened writer Abdullah Avloni wrote, "The mirror life of every nation in the world is language and literature. To lose the national language is to lose the spirit of the nation" and these wise sayings beautifully prove that the future of the country is in language. Indeed, it is inevitable that a nation deprived of its language will not have a spiritual Homeland. The face of the nation, the future of the country is reflected in the language and respect for it. The article discusses the fact that the issue of language and culture has long been one of the most topical issues, and the attention paid to our native language nowadays. It is described that, how the Uzbek language survived on the stage of history, and what the efforts of the Jadids in the process.

Key words and expressions: Language, culture, nation, jadid, "Chigataygurungi", national language, education, dialect, spirituality, sophistication, delicacy.

Тил ва маданият масаласи жуда қадимдан ўта долзарб мавзулардан бири бўлиб келган. Чунки тил орқали хар бир миллатнинг хулқи, одоби, маънавияти, маданияти, қолаверса, миллат сифатида нечоғлик ўрин эгаллаганлиги маълум бўлган. Устоз Навоий айтганидек, “Тилга эътибор - элга эътибор”дир. Демак, хар биримиз ўз она тилимизга эътиборли бўлишимиз, уни ардоқлашимиз, келажак авлодга нафосат ва назокатли тилимизни бутун гўзалликлари билан етказишимиз лозим.

Тил шахс ва жамият салохияти хамда маданияти савиясининг ўзига хос белгисидир. Бундан 30 йил муқаддам ўзбек тилига давлат тили мақомининг берилиши чиндан хам улуғ ва тарихий воқеа бўлган эди. Маърифатпарвар адиб Абдулла Авлонийнинг “Хар бир миллатнинг дунёда борлиғини кўрсатадурган ойинаи хаёти тил ва адабиётидур. Миллий тилни йўқотмак - миллатнинг рухини йўқотмакдур" деган хикматли сўзлари юртнинг истиқболи тилда эканлигини чиройли исботлайди. Дархақиқат, тилидан айрилган халқнинг маънавий Ватани бўлмаслиги муқаррар. Миллатнинг юзи, юртнинг истиқболи тилда, унга бўлган хурматда ўз аксини топади.

Ўзбекистон Республикаси Президентининг 2016 йил 13 майдаги ПФ-4997-сон «Алишер Навоий номидаги Тошкент давлат ўзбек тили ва адабиёти университетини ташкил этиш тўғрисида»ги Фармони, Ўзбек тилига давлат тили мақоми берилганининг 30 йиллигини нишонлаш борасида 2019 йил 4 октябрдаги Қарори, 2019 йил 21 октябрдаги «Ўзбек тилининг давлат тили сифатидаги нуфузи ва мавқеини тубдан ошириш чора-тадбирлари тўғрисида»ги Фармони ва 2020-2030 йилларда ўзбек тилини ривожлантириш хамда тил сиёсатини такомиллаштириш концепциясида белгиланган вазифалар давлат тилининг ривожланишига кенг йўл очиб берди.Бугун ўзбек тилининг бор бўй-бастини, бойлигини кўрсатиш ва келажак авлоднинг ундан тўла бахраманд бўлиши учун изохли ва имло луғатлари, умумий ўрта таълим ўқувчилари учун алохида турли номларда луғатларнинг яратилиши тилимизга бўлган эхтиромнинг ёрқин намунаси саналади.

Тарих сахнасида ўзбек тили не машаққатлар билан омон қолди. Унинг яшаб қолишида не-не инсонлар фидойилик қилмади. Бу жарёнда XX аср бошларидаги жадидлар харакат алохида ўрин тутади.

Маълумки, XX аср бошида ўзбек тили ва унинг услубига форсий, арабий, усмонли турк, татар тилларининг таъсири керагидан ортиқ эди. Бу холат бадиий асарлар, публицистик мақолалар, умуман газеталар тилида хам акс этар эди. Бу табиий равишда хар қандай адабийбадиий матннинг тушунилишини қийинлаштирар, уларнинг таъсир кучини сусайтирар эди.

Илғор фикрли зиёлилар бу салбий холатдан қутулиш борасида жиддий саъй-харакат кўрсатганлар. Чўлпон ўзининг «Тилимизнинг ишланиши» номли мақоласида “Бухоро 
ахбори» газетасининг тилидаги бундай қусур хақида таассуф билан мана буларни ёзган: «Локин йўлдошимизнинг («Бухороахбори» газетасининг) доим кўзга қадалатурғонб итта зўр хатоси бордирки, уни хайрихохлик билан айтиб ўтмасак бўлмайдир. Бизнинг кўрсатмак истаганимиз камчилик - тил, шева камчилиги, тўғриси, тилга ахамиятбермаслик хатосидир. Бош сарлавхаёнида «... адабий жаридаи туркия"деб ёзилган бу газета, маълумдирким, ўзбек шевасида чиқадир. Бухоро хокимиятининг расмий тили хам ўзбекчадир. Бухородек форсэрон таъсирига ортиқ ютулуб кетиб, ўз тилидан ажралиб қолғон бир ўлка учун, у ердаги кўпчилик авом учун тилнинг ахамияти жуда зўрдир. Холбуки, «Ахбор» йўлдошимизда бу жихатга сира диққат этилмайдир ёки этила олмайдир. Унинг ярим татар ва чала-була ўзбек шевасида босила турғон мақола ва хабарларидан бир неча мисол кўрсатай...».

Ўзбек адабиёти, фани ва маданиятининг йирик вакили Фитрат хам тил масалаларига жуда катта эътибор билан қараган. 1918 йил охирида «Чиғатой гурунги» ташкил этилади. Фитрат унинг рахбарларидан ва фаол аъзоларидан бири эди. Бу харакатнинг вужудга келишига зарур сабаблар бор эди: мактабларда усмонли тил ва усмонли адабиёт она тили ўрнида ўқитила бошланади, ўзбек тилинингмавқеи тушиб кетади. Фитратнинг таъкидлашича, «Чиғатой гурунги» ўзбек миллатчилиги: ўзбек тили, ўзбек адабиёти шиорлари остида пантуркист тўдаларга ва шунга берилган жадидларга қарши курашди...

«Тилимиз» мақоласида ўзбек тилининг ашаддий тарғиботчиси ва химоячиси сифатида кўринади. Битта «бил» ўзагидан 98 та сўз ясаш мумкинлигини ва туркий тилнинг сўз бойлиги форс, араб тилларига нисбатан кўпроқ эканлигини таъкидлаб бундай дейди: «Араб, форс, рус, немис, француз тилларидан қай бирининг сарф (морфология демоқчи) китобларини олиб қарасак, кўрамизки, бир сўзни ясамоқ учун бир қанча ёзилғон, ундан сўнг шул қоидадан ташқари қолғон (мустасно) сўзлар деб тўрт-беш сўз кўрсатилган. Турк сўзларида эса бундай сўз топилмайдир... Тилимизнинг авжй тўғрисида хам бойлиги, тугаллиги билиндими? Энди сўзни туркчанинг бахтсизлигига кўчираман. Турк тили шунча бойлиги, шунча тугаллиги билан бахтсизликдан кутула олмамишдир. Турк тили дунёнинг энг бахтсиз тилидир», деб араблар, форслар хукмронлиги даврида бу тилнинг қисилганлигини айтиб, шўролар даврида хам эркин ривожланмаётганига очиқ ишора қилади [Фитрат 2006:125].

1918 йили Туркистон Компартиясининг топшириғига кўра, Фитрат (Шокиржон Рахимий ва Қаюм Рамазон билан хамкорликда) дастлабки она тили дарслигини яратади (бу хақда «Иштирокиюн» рўзномасининг 1918 йил 1 май сонида «Биринчи она тили курси» деган мақола хам чиққан). Кейинроқ олим бу сохадаги ишларини мукаммаллаштириб «Ўзбек тилининг сарфи» (грамматикаси)ни эълон қилади. Ўзбекистон Маориф нозирлиги томонидан тасдиқланган бу дарслик 1925-30 йиллар давомида беш марта нашр этилган.

Фитрат 1919 йилда «Тилимиз» номли мақоласида ўзбек тилининг ўша пайтдаги холатидан бенихоя ёзғириб, куйиб-ёниб мана бундай деган эди: “Туркча бахтсиздир. Минг йилдан бери эзила келмишдир. Лекин, битмамишдир. Битмас, яшамишдир, яшар. Негаким бойдир. Туркча яшамишдир. Яшар, лекин ўзини араб, форс тиллариндан қутқара олурми, йўқми? Сўзни бу ерга етиргач, бармоғимни яранинг ўзагига босмиш бўлдим"[Фитрат 2006:127].

Халқни саводсизликдан қутқариб, маърифатга етиштириш учун харф ва имлони ислох қилиш, ўзбек тилининг қатъий қонун-қоидаларини ишлаб чиқиш, ўзбек адабий тилини ривожлантириш каби олий мақсадларни амалга ошириш ниятида Фитрат томонидан ташкил этилган “Чиғатой гурунги" тўгарагида Элбек хам фаолият юритган.У дастлаб матбуотда босилган шеър ва мақолаларини "Чиғатой гурунги" тахаллуси билан эълон қилган бўлса, 1919 йил “Ўксуз” номли шеъридан бошлаб устози Фитрат танлаб берган Элбек тахаллусини кўллай бошлади. Бизга маълумки, ўтмиш аждодларимизнинг кўпчилиги араб ва форс сўзларидан тахаллус танлашган. Тил софлиги учун курашган “Чиғатой гурунги” аъзолари эса бу анъанадан воз кечиб, соф туркий сўзлардан тахаллус танлай бошладилар. Масалан, юксак билим ва иқтидорга эга бўлган Фитрат гурух аъзоларига Боту, Ўктам, Элхон, Элчи, Чиғатой, 
Ўғуз, Ўктой, Элтузар, Жиғой, Йилдирим каби жасурлик, қахрамонлик бобида донг таратган аждодларимиз номлари асосида тахаллус танлаб берган.

20-30-йиллар ўзбек зиёлилари гарданида ғоят масъулиятли вазифалар турар эди. Шунинг учун улар тор доирада чекланиб қолмасдан, ўз ижодий фаолиятларини кенг қамровда олиб бордилар, ўзбек маданиятини ривожлантириш, юксалтириш учун кўлларидан келганча хизмат қилдилар.

Тил хусусида билдирилган фикрлар турлича, лекин хақиқат шуки, тил бенихоя муқаддас ва мўътабардир. У инсонни шакллантирган, тараққиёт сари етаклаган, унинг ақл неъматларини ифода этиб, тафаккур гулшани дарвозаларини очган тенгсиз бир робитадир. Шундай экан, бугунги кунда уни асраб авайлаш, келгуси авлодларга мерос қилиб қолдириш хар биримиздан катта масъулият талаб қилади. Президентимиз Ш. Мирзиёев уззбек тилига давлат тили мақоми берилганининг утттиз йиллигига бавишланган тантанали маросимдаги нутқида таъкидлаб уттгангларидек:"Хар биримиз давлат тилига бўлган эътиборни мустақьлликка буллган эътибор деб, давлат тилига эхтиром ва садоқ̆атни она ватанга эхттиром ва садоқ̧ат деб билишимиз, шундай құрашни хฺаётимиз қ̧оидасига айлантиришимиз керак. Бу олижаноб хуаракатни барчамиз ўзимиздан,узз оиламиз ва жамоамиздан бошлашимиз, она тилимизга, урф-одат ва қадриятларимизга хурмат, Ватанга мехримизни амалий фаолиятда намоён этишимиз керак” [Халқ сўзи 2019:1].

\section{Фойдаланилган адабиётлар рўйхати}

1. ัззбекистон Республикаси Президентининг 2016 йил 13 майдаги «Алишер Навоий номидаги Тошкент давлат ўзбек тили ва адабиёти университетини ташкил этиш тўғрисида»ги ПФ-4997-сон Фармони.

2. Ўзбекистон Республикаси Президентининг 2019 йил 4 октябрдаги «Давлат тили хақида»ги қонуни қабул қилинганининг ўттиз йиллигини кенг нишонлаш тўғрисида"ги ПҚ4479-сонҚарори.

3. ШІ. Мирзиёев ўзбек тилига давлат тили мақоми берилганининг утттиз йиллигига бавишланган тантанали маросимдаги нутқ̧и. Халқ сўзи. 21 октябрь 2019 йил

4. Абдурауф Фитрат. Танланган асарлар. IVжилд. Тошкент, Маънавият, 2006.

\section{ПОДШО РОССИЯСИНИНГ ТУРКИСТОНДА ОЛИБ БОРГАН КЎЧИРУВЧИЛИК СИЁСАТИ}

\section{У.К.Исмоилов}

(ЧДПИ)

Annotation: Turkestan, located in the center of the world, at the crossroads of the Great Silk Road, has fascinated invaders with its nature and wealth for centuries. Each time it passed from hand to hand, the winners moved in groups and eventually assimilated with the local population. Due to the lack of fertile irrigated land, during the resettlement, the displacement of the local population from their inhabited land was common. Since such cases are repeated every century and a half, Uzbeks, Kazakhs, Kyrgyz, Turkmens, Tajiks, Karakalpaks, Uighurs and other fraternal peoples have formed and developed with almost identical ethnic groups.

From the middle of the 19th century, tsarist Russia began to directly conquer Turkestan. As a result, in 1867, the territories occupied by Russian forces in the country were united into a single administration and the governor-general of Turkestan was established with the center in Tashkent, which included the territories of present-day Uzbekistan, Kazakhstan, Kyrgyzstan, Tajikistan, Turkmenistan, [N. Abdurakhimova, F. Ergashev 2002: 41]

After this event, the country pursued a policy of Russification in order to create a solid social base for the imperial government. The victims of this policy, of course, were the natives. 
Key words and expressions: Resettlement, Position, General G.A. Kolpakovsky, Land Fund, Stolypin, land reform, Verny fortress (Alma-ata), Semipalatinsk, Semirechensky district, Russian peasants.

Туркистон ўлкаси забт этилгач Россия империяси хукмрон доиралари рус дехқонларини мазкур худудга кўчириш сиёсатини олиб борганлар. Кўчирувчилик сиёсати Россиянинг умумий қабул қилинган хуқуқий меъёрлари билан тартибга солинган, аммо бу ўзига хос махаллий хусусиятларга эга бўлган. Рус кўчманчилари махаллий ахоли билан муносабатларда зиддиятлар ва кескинликларга дуч келганлар. Подшо Россияси маъмуриятининг русийзабон ахолини кўчириш бўйича қонунчилик базаси ва аниқ кўчириш режаси бўлмаган. Подшо томонидан чиқарилган Олий Фармонларда хам мавхумликлар кўп учрайди. Мисол учун, 1886 йилги Туркистон ўлкасини идора қилиш буйича муваққат Низомда, империянинг ички худудларидан Туркистон ўлкасидаги бўш ётган ерларга рус дехқонларини кўчириб келтириш хақидаги банди бўлган. Қизиғи шундаки, Низомда айтиб ўтилган “бўш ётган ерлар”га изох берилмаган. Оқибатда эса, аввалига махаллий йирик заминдорлардан, кейинчалик эса бошқа кўплаб дехқон ахолидан суғориладиган ермулкларининг тортиб олиниши ва кўчириб келтирилган русий-забон ахолига тақсимлаб берилишига олиб келган. Иш шу даражага бориб етганки, Россиянинг ички минтақаларидан крепостнойлик тугатилиши натижасида шахсий эркинликка эришган, бироқ ер олишга қурби етмаган дехқонлар, ўз ташаббуслари билан Туркистон ўлкасига кўчиб келиб ўрнашиб, ўзбошимчалик билан махаллий ахолининг ер-мулкларини куч ишлатиб, зўравонлик йўли билан тортиб ола бошлаганлар.

Дастлаб, асосан Еттисув вилоятига рус дехқонлари эркин ва ўзбошимчалик билан кўчиб бориб ўрнашганлар. Бироқ, вилоят худудида бўш ётган, текин суғориладиган экин майдонлари йўқлиги сабаб улар, Верный (Олма-Ота ш.) истехкомини қуриб шу ерда ўрнашиб қолган, казак қўшинлари аскарларидан ерни ижарага олиб фойдаланишган.

Кўчириб келтирилганларни ўлкада жойлаштириш тартиби бўйича вақтинчалик қоидалар дастлаб 1869 йилда Еттисув вилояти харбий губернатори, генерал Г.А.Колпаковский томонидан ишлаб чиқилган. [Научные ведомости Белгородского государственного университета. Журнал. 1 (222) : 113]

Унга биноан кўчириб келтирилганларга яратилган шарт-шароитлар самараси ўлароқ, 1868 йилдан 1882 йилгача Еттисув вилоятида хар бирида 25 минг кишилик ахолига эга 29 та рус қишлоғи ташкил топди. Яъни, 14 йил ичида жами, тахминан 725 минг киши кўчиб келиб ўрнашган.

Ахолиси асосан зич яшаб, ўтроқ зироатчилардан иборат бўлган Сирдарё вилоятида рус дехқонларининг кўчириб ўтказилиши, текин бўш ётган суғориладиган экин майдонларининг йўқлиги сабабли анча кечикди. Мазкур вилоятда дастлабки рус қишлоғи 1875 йилда Авлиёотада ташкил топган. 1891 йилга келиб ахолиси 1300 кишидан иборат бўлган 19 та рус қишлоғи ташкил топган эди. Яъни, 15 йил ичида вилоятга жаъми, тахминан 25 минг киши кўчиб келиб ўрнашган. [Научные ведомости Белгородского государственного университета. Журнал. 1 (222): 113]

1873 йилда Туркистон ўлкасининг биринчи генерал - губернатори К.П. фон Кауфман бутун генерал - губернаторлик худуди рус дехқонлари томонидан ўзлаштирилишининг бош режасини имзолайди. [Ўзбекистоннинг янги тарихи. Том - 1. 2000:192]

Ушбу хужжатда махаллий хамда рус дехқонларининг манфаатларини инобатга олишга харакат қилинган. Мазкур хужжат бўйича, европаликлар, шу жумладан руслар томонидан хам махаллий ахоли вакилларидан ер сотиб олиш таъқиқланган. Чунки, режага кўра, рус дехқонлари кўчиб келиб ўрнашган ахоли манзилгохлари асосан Оренбургдан Тошкентгача ва у ердан Верный (Олма-Ота ш.) қалъаси орқали Семипалатинскка қадар масофада жойлашган катта дарё ва почта йўналишлари бўйлаб жойлаштирилиши шарт эди.

Бироқ кўчириб келтирилган рус дехқонларининг кўпчилиги махаллий иқлимнинг инжиқликлари, тупроқнинг унумсизлиги, хукумат томонидан ўз вақтида моддий ёрдам кўрсатилмаганлиги сабабли ортларига қайтиб кетишга мажбур бўлганлар. 
1886 йилда “Туркистон ўлкасини бошқариш тўғрисида Низом” тасдиқланди. [Ўзбекистоннинг янги тарихи. Том - 1. 2000:216]

Шу муносабат билан Туркистон ўлкасида барча ерлар, тоғлар, ўрмонлар ер усти, ер ости бойликлари билан давлатга тегишли деб эълон қилинди, ер солиғи тизимини жорий қилиш тўғрисида қоидалар ишлаб чиқилди. Низомга биноан ўлкада йирик ер эгалиги ва вақф ерлари тугатилди. Шу орқали йирик ер эгалари хамда мусулмон рухонийларининг мавқеъига путур етди. Мусодара қилинган ерлар янги ташкил қилинган “Ер фонди" ихтиёрига ўтказилди. Фонднинг асосий мақсади, кўчириб келтирилган рус дехқонларини хосилдор ер майдонлари билан таъминлаш эди.

1889 йилнинг 13 июлида кўчириш тўғрисидаги янги қонун қабул қилинди, ва у 1904 йилгача амалда бўлган. Қонунда, кўчириш маъмурият тасарруфига ўтиши ва бу борада ўзбошимчаликка йўл қўйилмаслиги, устувор вазифа сифатида белгиланган. [И.А.Мамадалиев, О.Р. 2018:16]

Бундан буён кўчиб келувчилар ўлкага жойлашиш учун махсус рухсатнома олишлари мажбурий этиб белгиланган. Шу билан бирга, кўчириб келтирилганларга кредитлар ва имтиёзлар берилган. Бироқ бу қонун лойихаси хам рус дехқонларининг ўлкага ўзбошимчалик билан ихтиёрий кўчиб келиб ўрнашишларга тўсқинлик қила олмади.

1900 - 1903 йилларда дунёда иқтисодий инқироз юзага келди, бу Россия қишлоқларига хам жиддий зарар етказди. Вужудга келган ижтимоий - иқтисодий муаммоларни бартараф этиш учун рус дехқонлари оммавий равишда Туркистон, Кавказ ва Сибирга кўчирила бошланди. Энг кўп кўчириб ўтказишлар 1902 йилга тўғри келади. 1906 йилда Столыпиннинг ер ислохоти билан кўчириш сиёсати авжига чиқади. Бироқ империя хукумати кўчириб ўтказилаётганни ваъда қилинганидек шарт-шароитлар, моддий ёрдам борасида таъминлай олмайди. Натижада 1911 йилга келиб бу сиёсат тўлиқ барбод бўлди. Империянинг чекка миллий минтақаларига кўчирилган дехқонлардан 3,5 млн киши ортларига қайтиб кетган. 1911 йилда қайтиб кетганлар сони 81 \% ни ташкил этган бўлса,. 1913 йилга бориб 99 \% га етган.

Хулоса қилиб айтганди, Туркистон ўлкаси Подшо Россияси томонидан забт этилгач, ўлкада империя хукуматининг мустахкам ижтимоий таянчини яратиш учун руслаштириш сиёсати олиб борилган. Метрополиянинг ички музофотларидан кўплаб дехқон оилаларининг ўлкага кўчириб келтирилиши натижасида хосилдор суғориладиган ерлар етишмовчилиги ортиб кетган. 1910 йилга келиб Туркистон ўлкасига кўчириб келтирилган славян халқлари ўлка ахолисининг 10 \% ни ташкил қилган. Уларга ер-жой ажратиш мақсадида махаллий ахоли вакилларидан хосилдор, суғориладиган ерлар турли усуллар ёрдамида тортиб олинган.

Махаллий ахоли ва махаллий маъмурларнинг кўчириб ўтказиш бўйича масъулларига қарши шикоятлари хеч қандай самара келтирмайди. Охир оқибатда Россия империяси хукмронлиги йилларида тўпланиб келган барча норозиликлар 1916 йилда мустамлакачи маъмуриятга қарши йирик халқ кўзғолонига олиб келган.

\section{Фойдаланилган адабиётлар рўйхати}

1. Н.Абдурахимова, Ф.Эргашев. Туркистонда Чор мустамлака тизими. Т. “Академия” 2002.

2. Научные ведомости Белгородского государственного университета. Журнал. Серия: История, Политология. номер - 1 (222) Выпуск 37 УДК 94 (575.4).

3. Ученые записки Худжандского государственного университета им. академика Б. Гафурова. Журнал. Гуманитарные науки 2018 г. УДК 9 (С) 16 ББК 63.3 (2)7-36 И.А.Мамадалиев, О.Р.Махмудов Деятельность комиссии по переселению русского крестьянства в Туркестанский край .

4. Ўзбекистоннинг янги тарихи. Том - 1. Туркистон Чор Россияси мустамлакачилиги даврида. Т. “Шарқ”- 2000 й. 


\section{ТЕМУРИЙЛАР ДАВРИДА ХУРОСОНВИЛОЯТИДА ҚИШЛОК ХЎЖАЛИГИ ВА ИРРИГАЦИЯ ТИЗИМЛАРИ}

\section{М.С.Махмудова (ТИКХММИ doktoranti)}

Annotation: The article describes the development of agriculture and irrigation systems in Khorasan, Merv and Mashhad in the 15th century as a result of reforms carried out by Shahrukh, Abu Said, Hussein Boykaro.

Key words and phrases: Canal, dam, irrigation systems, agriculture, irrigated agriculture, bridge, pool.

Темурийларнинг Хуросонда хукмронлик қилган даврида ободончилик ишларига юксак даражада эътибор берилди. Хуросонда илм-фан ривожланди. Қурилиш ва бунёдкорлик ишларига ахамият ортди. Хуросонда шахарсозлик, хунармандчилик, савдо-сотиқ, қишлоқ хўжалиги ва суғориш тизимлари ривожланди. Мўғуллар томонидан 1220 йилда вайрон этилган Марв шахри қайтадан бунёд қилинди ва Мурғоб дарёсига сув келтирилди. Суғориш тизимига эътиборнинг кучайиши натижасида янги экин ерлари ўзлаштирила бошланди. Амир Темурнинг вафотидан сўнг Хуросонда Шохрух хукмронлик қилди ва Хиротни пойтахтга айлантирди. Унинг хукмронлиги даврида турли сув иншоотлари қурилди ва дехқончилик маданияти янада тараққий этди.

Қадимдан Хуросон минтақаси серсув дарёларга бой бўлиб, Хуросонда экинлар суғорма дехқончилик асосида суғорилган. Харируд, Хилменд, Амударё сувлари суғорма дехқончиликнинг ривожига замин яратди. Ушбу дарёлар суви каналлар орқали барча худуларга кириб бориши натижасида йирик-йирик экинзорлар ва боғлар суғорилиб, гуркираб чаманзорга айланди.

Хуросон ва Харируд шахар ва вохаларининг қишлоқ хўжалиги индувидуал, интенсив ва юқори даражада ихтисослашган эди. Унинг таркибига мева-сабзавотчилик, узумчилик кирарди. Узумчилик нисбатан кичик суғориладиган жойларда ва атрофи девор билан ўраладиган боғларда етиштирилган[1].

Султон Хусайн даврида Хиротда интенсив, суғорма дехқончилик турининг ривожланганлиги ва минтақадаги қишлоқ хўжалигини тасвирловчи қўлланма бу (1515) Қосим Ибн Юсуф Абу Наср Харовийнинг “Иршод ал-зироат” асаридир. Ушбу асарнинг асосий қисми Хиротда машхур бўлган мевали дарахтлар ва узумлар, сабзавотлар, гуллар, тиббиётда кўлланиладиган доривор ўсимликларга бағишланади. Ушбу асарда анор, бехи, нок дарахтларини етиштириш бўйича батафсил маълумотлар берилади. Олма, гилос, анжир, тут, писта ва узумнинг турлари хақида ёзиб қолдиради[1].

Ғарбий Эрон ва Каспий вилоятларидан фарқли равишда бу ерлар қуруқ бўлиб ва бундай ерлар “доимий” деб аталган. Ўрта асрларда Хуросон ерларининг аксариат қисми қурғоқчил ва ярим қурғоқчил бўлган. Қишлоқ хўжалигининг махсулдорлиги учун ерларни суғориш керак эди. Хуросонда ерларни суғориш уч турга бўлинган: 1.Йирик дарёлардан қазилган каналлар. 2.Ер ости каналлари (қанот ёки кориз). 3.Ғиштдан ёки тошдан қурилган тўғонлар. Хуросонда Ғарбий Эронга қараганда дехқончиликда ер усти каналларидан фойдаланиш катта ахамиятга эга эди[1].

Амир Темур вафотидан кейин унинг ворислари ва авлодлари учта асосий худуд Марв, Хирот, Машхадда қишлоқ хўжалигини тиклашни жадаллаштиришга харакат қилишди. 1410 йилда Шохрух Марв вохасидаги каналларни қайта тиклашга буйруқ берди. Мурғобдан оқиб ўтувчи Марв каналини тозалаш ишлари олиб борилади ва Мурғоб тўғони (Султонбанд деб аталади) қайта очилади. Қайта қурилган Марв каналининг энг кенг қисми 20 газ, энг чукур қисми 30 газ, 12 фарсах узунликда ва 12 та сув тарқатиш шахобчасига эга эди. Марв каналини қайта қуриш ишларини Шохрух иккита етакчи амирларига ишониб топширади. Оловиддин Али Кўкалдош, Амир Мусо ва улар билан бирга девон амалдори Амир Али Шаққонийлар ушбу вазифани бир ойдан сал кўпроқ вақт ичида якунлашади. Хофизи 
Абрунинг қайд этишича, тўғон тикланиб сув оқимининг кўпайиши билан бу ерга одамларнинг кириб келиши ва қишлоқларнинг кескин ошиши рўй берди. Биринчи йилда тўғон билан суғориладиган ерда 500 та хўкиз ишлаган[1].

Манбаларда Султон Абу Саид томонидан 1468-69 йилларда Паштан дарёсидан Жуйи Султоний канали қурилгани қайд этилган. Вазир Кутбиддин Товус Симноний бошчилигида канал қурилиши назорат қилинган. Канал қуриш учун икки йил давомида 200га яқин ишчи жалб қилинади ва натижада экин майдонларининг мелиоратив холати яхшиланади[1].Бернард O`Кан хам ўзининг $\mathrm{PhD}$ диссертациясида Абу Саид томонидан хукмронлигини охирида Хиротнинг шимолий ён бағрларини суғорувчи Жуйи Султоний қурилиши хақида ёзади[2].

Султон Абу Саид Шохрух томонидан бошланган Машхад минтақасини қайта куришни ва Машхаддаги Кашаф дарёсининг бир тармоғида Гулистон тўғонини куришни давом эттирди[1].Хусайн Бойқаро Шохрух ва Абу Саид Мирзо амалга оширган ишларни давом эттириб, Марв ва Хирот худудларида янги суғориш иншоотларини қурди ва экин майдонларини кенгайтирди. Бу эса мамлакат ахолисининг турмуш фаровонлигини ошишига замин яратди.

Қосим Ибн Юсуфга Хирот минтақасидаги сув тақсимоти ва қишлоқ хўжалиги хақидаги маълумотлар манбасини Мирак Саид Ғиёс берган. Мирак Султон Хусайн саройининг бош агрономи ва ландшафт архитектори хамда сув тақсимотини назорат қилувчи масъул мироб хам бўлган[1].Бундан кўриниб турибдики, бутун Хуросон худудининг сув хўжалигини бошқариш Мирак Саид Ғиёснинг зиммасига тушган ва унинг фаолияти қишлоқ хўжалигини ривожи учун ахамиятли бўлган.

Бернард О‘Кан Марв вохасини сув билан таъминловчи тўғоннинг Чингизхоннинг ўғли томонидан бузиб ташланганини ва 1409-1410 йилларда Шохрух буйруғига кўра Мурғоб тўғонини қуриш ва магистрал канални қайта куриш хақида ёзади, лекин у тўғоннинг номи “Султонбанд” эканлигини ёзмайди. Бернард О‘Каннинг қайд этишича канал 12 фарсах узунликка эга бўлиб, ушбу канални қуриш учун бир йил давомида кўшиннинг барча ресурсларидан фойдаланилган[2]. Бобур Ғазна яқинида ғазнавийлар хукмдори Султон Махмуд томонидан қурилган деб тахмин қилинган тўртта тўғонни реконструкция қилади, уларнинг биттаси ўша пайтда фойдаланилаётган эди [2].

Темурийлар даврида Хуросонда Ахламад, Кират, Гулистон, Туруқ кабитўғонлар курилган. Гулистон тўғони тахминан Машхаддан 10 км шимолда жойлашган. Гулистон тўғони Туруқ тўғони билан бир пайтда, яъни XV асрнинг охирида курилган[3].Туруқ тўғони Машхад яқинидаги Туруқ қишлоғидан 5 км узоқликда жойлашган[3]. Хондамирнинг буюк ёзувчи ва давлат арбоби Алишер Навоийга бағишланган “Макорим ул-ахлоқ” асарида Алишер Навоий томонидан Туруқ канали ва Туруқ тўғонининг таъмирланганини ёзади[4].

Алишер Навоий Хуросонда вазирлик лавозимида ишлаган пайтларда жуда катта ободончилик ишларини амалга оширади. У ахолини сувга бўлган эхтиёжини қондириш мақсадида жуда кўп ховузлар ва кўприклар қурдиради.

Хондамирнинг “Макорим ул-ахлоқ асари”да Алишер Навоий томонидан қурдирилган ховуз ва кўприклар санаб ўтилади:

Энди қуйида [ул Хазрат] қурдирган ховузларнинг тўлиқ рўйхати келтирилади: Пойи дарахти меросий махалласидаги ховуз, Ихтиёриддин қалъаси олдидаги ховуз, Шолбофон махалласидаги ховуз, Шўрписта ховузи, Чихилгазий махалласидаги ховуз, Хожа Калла ховузи, Пир Қавом махалласидаги ховуз, Қаландарон махалласидаги ховуз, «Шифоия» [мадрасаси] ёнидаги ховуз, хақиқатлар панохи бўлган Хазрати Махдумий қабри ёнидаги ховузssdfghc, Париён ховузи, Фушанж масжиди ховузи, Чарха ховузи, Сахрои боғанд ховузи, Шохони гармоб ховузи, Дизбод ховузи, Зиёратгох ховузи, Андхуд ховузи, Рохи Хоразм ховузи.

[Ул Хазрат томонидан қурдирилган] кўприкларнинг тўлиқ рўйхати куйидагича:Сепулак кўприги, Тулки кўприги, Соқисламон кўприги, Чилдухтарон кўприги, Тарноб кўприги, Қаландарон кўприги, Қозбонон кўприги, Пойи хожа кўприги, Хайробод 
кўприги ва тўғони, Жузжонон кўприги, Нигор кўприги, Фушанж кўприги, Тир кўприги, Нахри араб кўприги, Чахчаронкўприги,Туруккўпригиватўғонитаъмирланди[4].

Темурийлар даврида Хуросон юксак даражада ривожланди. Темурийлар мамлакатда қишлоқ хўжалигига эътибор қаратишди ва сув иншоотлари янги қурилди ва эскилари таъмирланди. Бу эса Хуросоннинг ижтимоий-иқтисодий холатини яхшилади.

\title{
Фойдаланилган адабиётлар рўйхати
}

1. Maria E. Subtenly, “Timurids in Transition".-Boston:BRILL. Leiden,2007.-116-139 б.

2. Bernard O'Kane, "Timurid architecture in Khurasan",PhD dissertation,part I.University of Edinburg,1982.-14-160 б.

3. Bernard O'Kane, "Timurid architecture in Khurasan",PhD dissertation,part II.University of Edinburg,1982.-31-259 б.

4. Хондамир,Ғиёсиддин. “Макорим ул-ахлоқ”:тарихий асар.-Тошкент:Ёшлар нашриёт уйи,2018.-74 б.

\section{XITOYDA TA’LIM TIZIMI}

\author{
M.Atamuradova \\ (SamDChTI talabasi) \\ I.O.Ibragimova \\ (33-o'qituvchisi) \\ F.Atamuradova \\ (SamDU talaba)
}

Annotation: China's tremendous growth rate is not accidental. The tremendous pace of economic development in the People's Republic of China in recent decades has caused a lot of controversy in modern society. There are many speculations and speculations about the origins of China's powerful development. Of course, this could not happen without a pretext from the representatives of the state and the economic sector. If we analyze the history of this country in detail, then this is largely due to a serious approach to the education of every citizen of China, as at the state level. The state not only creates all the conditions for a good education, but also so that people really want to learn. The educational system in China includes basic education (preschool, general primary and secondary), secondary vocational, general higher education.

Key words and expressions: preschool education, primary education, secondary school, higher education, levels of higher education.

Xitoyda maktabgacha ta'lim. Hammasi bolani maktabga tayyorlashdan boshlanadi, chunki uni oldinda ko'p narsalar kutmoqda. O'qishning dastlabki yillaridanoq maktab o'quvchilarining aqliy yuki shunchalik katta ediki, tegishli uquvsiz moslashish qiyin bo'ladi. Shuning uchun maktabgacha yoshdagi bolalar uchun kurslar mavjud bo'lib, bu chaqaloqni keyingi ta'lim uchun poydevor bo'ladigan tayyorgarlik fanlarining kompleksi hisoblanadi. Xitoyda maktabgacha yoshdagi bolalar bog'chaga borishadi. Bog'chalar ikkita asosiy turga bo'linadi: xususiy va davlat maktabgacha ta'lim muassasalari. Shu bilan birga, ular moliyalashtirish uslubida ham, o'qitish uslublarida ham farqlanadi. Xususiy bolalar bog'chalarida o'qitishda bolaga individual yondoshishga, uning ijodiy qobiliyatlarini rivojlantirishga va fan hamda san'atni joriy etishga e'tibor berishadi. Davlat maktabgacha ta'lim muassasalarida bolalarni mehnatga o'rgatishadi, kundalik ehtiyojlarni qondirishga o'rgatishadi va boshlang'ich maktabga tayyorlashadi. Bolalarga bolalar bog'chasidan boshlab xitoyliklarga xos intizom o'rgatiladi. Har kuni ertalab davlat bayrog'ini ko'tarish bilan boshlanadi, barcha o'yinlar o'qituvchilar tomonidan qat'iy nazorat qilinadi va shunchaki bekorchilik uchun bo'sh vaqt sarflanmaydi. Ehtimol, bu xitoyliklarning ajoyib mehnatsevarligi va samaradorligining siridir.

Boshlang'ich ta'lim. Xitoy ta'lim tizimi barcha 6 yoshli bolalarning har kuni maktabga borishini belgilab qo'ygan. Maktabga borishni boshlagan har bir bola: kuniga 9 soat darsni 
o'zlashtiradi; qo'shimcha ravishda qo'shimcha darslarga qatnashadi; kutubxonaga tashrif buyuradi; muntazam ravishda sport bilan shug'ullanadi. Vaqt o'tishi bilan sinflarni taqsimlanadi. Qoida tariqasida, bola uchun eng qiyin fanlar ya'ni matematika, xitoy tili va boshqa shu kabi fanlar kunning birinchi yarmida ya'ni odatda soat 11.30 gacha o'tiladi, undan keyin tushlik uchun tanaffus bo'ladi. Shundan so'ng, oddiyroq ikkinchi darajali mashg'ulotlar boshlanadi (rasm chizish, qo'shiq aytish, jismoniy tarbiya va boshqalar). Boshlang'ich va o'rta maktab ta'limning majburiy bosqichidir. Dasturga xitoy tili, matematika, tabiiy tarix, tarix, geografiya va musiqa fanlarini o'rganish kiradi. Bilim 100 ballik tizimda baholanadi va test tizimidan foydalaniladi.

O'rta maktab. Oltinchi sinfni tugatgandan so'ng, o'quvchilar tegishli imtihonni topshiradilar, natijalari bo'yicha ular o'rta maktabga o'tishadi yoki o'tmaydilar. Ushbu bosqichdagi maktab ta'limi ikki bosqichga bo'linishi mumkin:

O'rta o'rta maktab (majburiy). U uch yil davom etadi va 12 yoshdan 14 yoshgacha bo'lgan bolalarga qaratilgan.To'liq o'rta maktab (ixtiyoriy). Bu barcha ta'lim muassasalarida mavjud emas va Xitoyning ba'zi universitetlariga kirishga tayyorlanayotgan 15 yoshdan 18 yoshgacha bo'lgan bolalar uchun mo'ljallangan.

Tartib-intizomga oid qat'iy qoidalar o'quvchilarga o'qishni munosib ravishda yakunlashga imkon beradi.

Xitoy maktablarida barcha o'quvchilar uchun yagona forma mavjud, kirish eshiklari kuniga ikki marta ochiladi, ta'til paytida ham o'quv jarayoni to'xtamaydi. Dam olishdan keyin talabalar uy vazifalarini o'qituvchilarga topshirishlari shart. Bolalarni chet elga yuborish odatiy holdir. Ammo dam olish uchun emas, balki chet tilini chuqurroq o'rganish uchun. Xitoyda har bir daqiqani o'qish uchun sarflashadi. Kollejda o'qishni istaganlar odatda o'rta maktabga borishadi. Yana bir muhim jihat shundaki, ushbu bosqich boshlanishidan oldin o'quvchilar kasbga yo'naltirilgan testni topshiradilar va yo'nalishni tanlaydilar - kasb-hunar yoki akademik. Akademik yo'nalishdagi o'rta maktabda o'quvchilar universitetga kirish uchun tayyorlanadilar. Maktab o'quvchilari universitetda talab qilinadigan jiddiy va kasbga yo'naltirilgan fanlar bo'yicha mashg'ulotlarni o'tadilar.

Kasb-hunar o'rta maktabi kelajakdagi ishchilarni tayyorlashga qaratilgan.

Oliy ta'lim. Ikki mingdan ortiq oliy ta'lim muassasalari Xitoyda joylashgan. Shuni ta'kidlash kerakki, XXR universitetlarining diplomlari nafaqat ish beruvchilar tomonidan, balki dunyo miqyosida ham yuqori baholanmoqda. Universitetga kirish uchun talabalar universitetga kirish imkoniyatlarini belgilaydigan milliy forma imtihonini topshiradilar. Nafaqat davlat, balki Xitoydagi munitsipalitetlar va xususiy kompaniyalar ham oliy ma'lumotli yoshlar sonini ko'paytirishdan manfaatdor. Shuning uchun universitetda o'qish uchun turli xil grantlar va stipendiyalar mavjud. Talaba uchun kreditlar ham keng tarqalgan. XXRda o'qish tobora ommalashib bormoqda, ammo byudjet joylari uchun raqobat hali ham juda katta. Shuning uchun hatto pullik bo'limga kirish butun oila uchun bayram hisoblanadi. Xitoy universiteti bitiruvchisining diplomi kelajakda muvaffaqiyatli martaba kafolati hisoblanadi.

Xitoyda oliy ta'limning tuzilishi boshqa davlatlarda bo'lgani kabi va uch bosqichdan iborat: bakalavr, magistratura va aspirantura.

Bakalavr bosqichi to'rt yil davom etadi va oliy ta'limning asosiy bosqichi hisoblanadi. Bakalavr darajasi Xitoy va dunyodagi yetakchi kompaniyalarga ishga joylashishga imkon beradi.

Magistr darajasi bu yana ikki yoki uch yillik o'qish va birinchi ilmiy darajadir. Ta'limning ikkinchi bosqichiga kirgan talabalar jiddiy ilmiy ish, tanlangan mavzu bo'yicha o'quv materiallarini nashr etish va nihoyat, magistrlik dissertatsiyasini yozish va himoya qilishni o'z ichiga oladi.

Doktorlik darajasini olish uchun yana uch-to'rt yil aspiranturada o'qish kerak. Odatda bu bosqich to'lov asosida tashkil qilingan bo'ladi, ammo muhim yoki zamonaviy mavzularni o'qiyotgan aspirantlar davlat yordamiga umid qilishlari mumkin, bu esa mamlakatga foyda keltiradigan olimlarning o'sishiga yordam beradi.

\section{Foydalanilgan adabiyotlar ro'yxati}

1. 刘询。新实用汉语课本 3 。北京。 2002 年。

2. 李晓琪。Boya Chinese II. 北京。北京大学。2004 年。 
3. Азитова Г.Ш., Краснова М.Н. ОСОБЕННОСТИ СИСТЕМЫ ОБРАЗОВАНИЯ В КИТАЕ // Современные проблемы науки и образования. - 2017. - № 5.

4. www.edu.uz

5. www.hscake.ru

6. www.studychinese.ru

\title{
СРЕДСТВА ВЫРАЖЕНИЯ «ВЕЖЛИВОСТИ» - преподавание РКИ в КИТайской аудитории
}

\author{
Су Цзумэй \\ (ШУИЯ, Китай, д.ф.н., профессор)
}

Annotation: This article is devoted to the analysis of the expression of "politeness" in Russian.Nowadays we have entered the era of "speakers". Every day we have to employ various forms of verbal expressions to communicate with each other. With the development of computer technology, the means of communication and interaction have been increasingly diverse. Nonetheless, the principle of politeness must be observed in whatever forms of communication. Politeness has multiple significations: it is a term indicative of decency, courtesy, good breeding, or modesty. Politeness is also a manifestation of respect for another person: recognition of the dignity of the individual, showing goodwill for another person. In Russian culture, the concept of politeness occupies an important place. The article focuses on how to politely express gratitude, refusal, request, and how to choose the proper address forms. In addition, the article proffers a pragmatic analysis of address forms related to the violation of the principle of politeness.

Key words and expressions: Politeness, verbal expressions of politeness, gratitude, refusal, request, address forms.

Н.И.Формановская отметила, что наше время надо было назвать «эрой человека говорящего»[Формановская 2010: 7].Действительно, каждый из нас, не говоря ни слова в день, на самом деле занимается речевой деятельностью: слушает радио, читает газету, смотрит телевизор, сидит в Интернете и т.д.И независимо от того, чем мы занимаемся, мы не можем избежать общения с другими. Даже читая книги и газеты, мы тоже общаемся, но лишь только с авторами письменных текстов.

Общение происходит в различных формах: очном и дистантном, прямом и косвенном, устном и письменном, диалогическом и монологическом, межличностном и публичном, частном и официальном и т.д. Но независимо оттипа общения, принцип вежливости всегда соблюдается.

А что такое вежливость? В «Словаре русского языка» [Евгеньева 1981:145] так написано: вежливость — «свойство по значению прилагательноговежливый; учтивость, обходительность». И фиксировано в «Толковом словаре русского языка»[Ожегов 1999:72]такое объяснение слова вежливый: «соблюдающий правила приличия, воспитанный, учтивый». Причем в «Словаре по этикете»сделано такое определение: вежливость - это «...моральное качество, характеризующее человека, для которого уважение к людям стало повседневной нормой поведения и привычным способом обращения с окружающими»[Формановская 2010:81-82].Иными словами, вежливость - это проявление уважения к другому: признание достоинства личности, деликатностьпо другому.По мнению Н.И.Формановской, «вежливость, будучи нравственной и коммуникативной категорией, имеющей разнообразное выражение с помощью многочисленных средств, может быть рассмотрена как концепт»[Формановская 2007:129-130].

Врусском языке очень много слов, выражающих вежливость, например: благовоспитанность, воспитанность, обходительность, любезность, благожелательность и др.А как вежливость отражается в русской речевой деятельности?В ходе преподавания РКИ 
в китайской аудитории мыанализируем этот вопрос в соответствии соследующими ситуациями.

\section{1. Выражение благодарности}

Русские уделяют большое внимание выражению благодарности. Выражая это чувство, они часто говорят «Спасибо», чье исходное значение представляет«Спаси Бог».Кроме слова «спасибо», они еще говорят «Благодарю», т.е. разделить свое счастье с другим, отплатить добром за добро. Например:

1) Правильно. Спасибо, доктор, до свиданья. Все. («Экран и сцена», 2004.05.06)

2) Я благодарю тебя за то, что ты открыл нам такую Кармен! (И. К. Архипова)

Слово «спасибо» выражает не только благодарность, но и уважение к адресату.В общественных местах очень часто звучит теплое «спасибо». Старуха говорит «спасибо», когда кто-то, протягивая руку, помогает ей выходить из переполненного автобуса.Когда люди выходят из тяжелых ворот, и человек впереди тянет дверь, чтобы помочь человеку позади него, последний обязательно будет благодарен и скажет: «Спасибо». Прибыв в пункт назначения и оплатив такси, пассажир всегда скажет таксисту дружеское «спасибо». Все это является проявлением вежливости и благодарности за доброту окружающих, уважения к их труду, а также отражает хорошие моральные качества современных цивилизованных людей.

В таком случае частица бы может играть определенную роль. Слово бы, относящееся к модально-приглагольным частицам, является составным элементом сослагательного и условно-желательного наклонения[Виноградов 2001: 552]. И в сочетании сбыглаголпоблагодаритьможет повысить степень вежливости.Например:

3) Прежде всего хотел бы поблагодарить организаторов конференции за возможность выступить перед столь представительной аудиторией. (А.И. Денисов)

По мнению психологов, «спасибо»- это волшебное слово. Услышав его, люди могут испытывать положительные чувстварадости и мотивировать себя выполнить работу качественно.

\section{2. Выражение отказа}

Выражение отказадолжно быть тактичным и уместным, и уместность также является важной частью вежливости. Если человек хочет отклонить приглашение, разумно не отклонять его сразу, а сначала поблагодарить приглашающего. Например:

4) Спасибо за приглашение, но приехать в ближайшее время я не смогу - другие планы, другие маршруты. (В. Молчанов)

5) Мы живем в Ангарске (это рядом с Иркутском), спасибо за приглашение, но нам далековато. (Наши дети: Дошколята и младшие школьники).

В 4-5 примерах сначала говорящие выражают свою искреннюю благодарность за приглашение, а затем излагают конкретную причину, по которой не могут его принять.Если приглашенный откажетсяпрямо, жестко, то это, скорее всего, повредит лицу приглашающей стороны, и у приглашающего будут отрицательные эмоции.

\section{3. Выражение просьбы}

При просьбе говорящий является бенефициаром, поэтому лучше использовать вежливые слова в предложении, например:

6) - Я хотел бы попросить вас сделать это!

7) - Скажите, пожалуйста, как пройти на Краную площадь?

Или используются вопросительные предложения:

8) У вас есть часы?

9) Вам не трудно подвинуться?

Или используется условноепридаточное предложение типа Если вас не затруднит + пожалуйста :

10)Если вас не затруднит, вы, пожалуйста, поднимитесь ко мне! (Э. Рязанов)

11) Если вас не затруднит, откройте, пожалуйста, эту дверь. (Е. Сухов)

В этих примерах используются соответственно лексические средства (хотел бы, пожалуйста), вопросительные предложения и условные придаточные предложения. Причем 
важно, чтобы поставить себя в такое же положение, как и собеседника, и говорить с ним на равных условиях.Без этого речевогоурегулирования просьба неизбежно звучит как приказ начальника подчиненному, и тогдатрудно себе представить, какойэффект будет иметь речевой акт.

\section{4.Выбор обращения}

Обращения имеют важное значение в повседневной коммуникации.Выбор обращений ограничен многимифакторами, такими как степень знакомства коммуникантов, официальность/неофициальность обстановки общения, взаимоотношения коммуникантов, равенство/неравенство статусно-ролевых позиций партнеров[Формановская 2009: 55-61] и т. $\Pi$.

Выбор обращений в новогоднемпоздравлении президента Владимира Путина 2019 былобразцовым примером. Новогоднее поздравление так начинается: «Уважаемые граждане России ! Дорогие друзья!»Первая форма обращения торжественна и отвечает требованиям официального стиля, в то время как вторая любезна и сближает президента с народом. Сочетание этих двух форм обращенийпередает уважительное и сердечное отношение говорящего к аудитории.

Известно, что в русских семьях родители обычно называют своих детей по именам, дети называют родителей «папой», «мамой», иони обращаются друг к другу на «ты».Однако в жизни при выборе обращений встречаются и случаи намеренного нарушения принципа вежливости. Вот в следующем диалоге мальчик избежал называть своего отца «папой»:

12)[Сын] - Что?

[Отец] - Что, nana!

[Сын] - Что, nana.

[Отец] - Лучше. (Возвращение)

Отец ушел из дома на много лет раньше, чем вернулся домой, сын, когда говорит с ним, уже не привык называть его папой. Отец был не доволен сыноми поправил его,а ребенок был вынужден назвать отцапапой.

Как правило, в России муж и женаобращаются друг к другу по именам и на «ты», но в следующем диалоге жена не называет имя мужа и обращается к нему на «вы»:

13)[Оля] — Алло!

[Саша] - Алло, Оля, это я.

[Оля] - Кто я?

[Саша] — Я, я, Саша.

[Оля]- Какой Саша?

[Саша] — Оля, перестань, Саша, твой муж!

[Оля]- А у меня нет мужа. Ошиблись номером. (Если нам судьба)

Во время телефонного разговора женане называла имени мужа и обращаласьк нему на «вы»,делая вид, что не узнала его. Жена так поступала для того, чтобы разозлить мужа, дать выход своемугневу. Здесь слово «вы» обозначает не уважение, а скорее отвращение. Итак,выбор обращений ярко показывает, каклюди относятся друг к другу.

\section{Заключение}

В русском языке вежливость значит очень много, и так же много средств для ее выражения.Когда люди получаютпомощь от других, они вовремя выражают свою благодарность; отказываясь от приглашения, они стараются говорить как можно тактичнее.Когда человек обращается за просьбой к другим, он будет уделять больше внимания вежливым речевым средствам, чтобы успешно достичь коммуникативной цели.Когда кто-то здоровается с другим, принцип вежливости также соблюдается.Но иногда люди сознательно нарушают принцип вежливости, в результате чеговозникает прагматический смысл. Выражения вежливости в русском языке очень уникальны, и знание ихбудет полезнодлямежкультурной коммуникации между Китаем и Россией. 


\title{
Список исползованной литературы
}

1. Виноградов В.В. Русский язык (Грамматическое учение о слове): Монография. / Под ред. Г.А. Золотовой. 4-е изд. — Москва: Изд-во Русский язык, 2001.— 720 с.

2. Ожегов С.И. Толковый словарь русского языка. / С.И.Ожегов, Н.Ю.Шведова. 4-е изд., доп.-Москва: Изд-во Азбуковник, 1999.- 944 с.

3. Словарь русского языка: В 4-х т. /Под ред. А.П. Евгеньевой. 2-е изд, испр. и доп. Москва:Изд-во Русский язык, 1981.Т.1. А - Й. 1981. —698 с.

4. Формановская Н.И.Речевое взаимодействие: коммуникация и практика: Монография.Москва: Изд-во ИКАР, 2007.- 480 с.

5. Формановская Н.И.Речевой этикет в русском общении. Теория и практика: Монография. - М.: Изд-во ВК, 2009.-334 с.

6. Формановская Н.И. Культура общения и речевого поведения: Монография. Москва: Изд-во ИКАР, 2010.-237 с.

\section{PERSPECTIVE OF PROFESSIONALLY ORIENTED COMPETENCE OF FUTURE ENGLISH TEACHERS}

\author{
Bakiyeva Gulandom \\ (UzSWLU, professor) \\ Makhkamova Komila \\ (Sam SIFL,Phd student)
}

Annotation: This paper introduces perspective of professionally oriented competence of future English teachers during goaling on teaching English as a foregn language. Of course, it gives us to earn professional communicative competence also. As future specialists need communication in target language in order to huge number of factors, to become modern, perspective, professionally oriented teachers. First of all it is significant to increase formation of professionally oriented future teachers according to their willingness and ability employ theoretical knowledge, practical competence and skills in foreign languages, methodological and technical abilities, decision of professional issues, cultural competence.

Key words and expressions: Professionally oriented competence, professional communication, future English teachers, professional competence

Teachers, I believe, are most responsible and important members of society because their professional effort affects the rate of earth [Helen Caldicot 7]. Definitely, their professional efforts affect or effect the rate of earth as it can touch every sphere if the teacher is an English teacher. It can develop or decrease multicultural communication in different spheres. So that, we as English teachers and future English teachers, as a professionals of world language which connect people to communicate also have to do our best to become perspective and have professionally oriented competence.

There comes a time, in Higher Education where our students seem to be unmotivated in their language classes, which implies changes are required in language teaching approaches [Johnson, K.E.Golombek, Paula R., 2016:2]. Sharing the idea of current publications authors sustain the complex process of learning to teach is dependent on the practice. The group of students involved in media activities needed of a specific purpose in an academic environment to provide the best. In accordance with the tendency to develop not only the [Komila Makhkamova, 2020:3]

Modern perspective and educated teachers should effectively organize and realize goals on teaching, facilitating, educating learners to foreign language, in our case English as a foreign language. It's clear that we should not teach only the system of the English language but also forming foreign language communicative competence, education, upbringing, cultural communication and development of learners as well. Bakiyeva mention about forming foreign language communicative competence among student giveb the opportunity to motivate learners to 
lear the language and teachers do it professionally paying attention in all even small details [Bakiyeva G.X, Maxkamova G.t., Qo'ldoshev A. 2007:1].

In order to create the reality it is substantial chance to bring video materials, realias into the classroom. And Sherman presents a convincing argument for incorporating authentic video material into language classrooms. She provides a variety of practical classroom activities showing how to use video to bring real world language and culture into the classroom in contemporary, engaging and productive ways [Sherman, J. 2003:4].

First of all it is significant to increase formation of professionally oriented future teachers according to their willingness and ability employ theoretical knowledge, practical competence and skills in foreign languages, methodological and technical abilities, decision of professional issues, cultural competence. All the above should be integrity of linguistic and methodic training.To effective the activity of the teacher, practical forging use of professional oriented tasks, in general, can be influence the following principles: partner-state, cooperation with students, use the latest achievements of pedagogical science and experience of colleagues, creative ways the ability of the teacher, individual and differentiated approaches to training, provision of students with sufficient quality materials and skills building work with them [Surmin Ju.P. 1997:6]. Usually teachers should be focused on the language, content, and production, so as to meet the objectives of the learning process. For example, some certain situations require a material where the medium is "transferable to real life situations, which students are likely to come across" [Stempleski, S., 1987:4].

If we do our best and have professionaly oriented competence our future English teachers will become better than us, much more perspective and believed teachers of millions and more. We will achieve our goal on target language and our aim in order save and increase our society, our multicultural world and of course our education. It is not less essential teaching English and becoming professionally oriented teachers than to become perspective doctor, lawyer, scientist. Because knowing English well according to all aspects help future English learners to be able to demonstrate and convey to the colleges all over the world in communicatively, lisguistically, culturally correct way,

\title{
The list of used literature
}

1. Bakiyeva G.X, Maxkamova G.t., Qo'ldoshev A. English 3. - Tashkent, 2007

2. Johnson, K.E.Golombek, Paula R. (2016). Mindful L2 Teacher Education: A Sociocultural Perspective on Cultivating Teachers'

3. Komila Makhkamova (2020.) English teachers' professional competence by using realias in teaching. Journal of critical review. ISSN- 2394-5125 Vol 7, Issue 5, 2020,p 206

4. Sherman, J. (2003). Using authentic video in the language classroom. Ernst Klett Sprachen.

5. Stempleski, S. (1987). Short Takes: Using Authentic Video in the English 6.

6. Surmin Ju.P. Chto takoe kejs-metod? Vzgljad teoretika i praktika. M., 1997.

7. https://www.helencaldicott.com Helen Caldicot quotes

\section{БИЛИНГВАЛЬНЫЕ АСПЕКТЫ ОБРАЗОВАНИЯ И ПОВЫШЕНИЕ ЛИТЕРАТУРОВЕДЧЕСКОЙ КОМПЕТЕНТНОСТИ УЧАЩИХСЯ НА УРОКАХ РУССКОЙ ЛИТЕРАТУРЫ В ГРУППАХ С НЕРУССКИМ ЯЗЫКОМ ОБУЧЕНИЯ}

\author{
Д.Х. Алимова \\ (РЦППКРНО, к.ф.н, доцент)
}

\begin{abstract}
Annotation. In the article actual problems of bilingual education in modern methods of teaching Russian literature in the context of "dialogue of cultures" at school with native (nonRussian) language learning, taking into account features of perception of artistic works by students and bilingual.
\end{abstract}


Key words and expressions: Bilingual education, reading culture, language environment, background knowledge, literary relationships, audio-visual components.

Концепция развития системы народного образования Республики Узбекистан до 2030 года поставила перед школой ряд задач, одна из которых - формирование ключевых компетенций, определяющих качество содержания образования. Использование билингвального подхода при преподавании литературы в общеобразовательной школе является одним из условий для развития творческой составляющей, языковой и коммуникативной компетентностей учащихся.

Актуальность темы статьи обусловлена необходимостью грамотной организации работы с двуязычными учащимися для успешного усвоения русской литературы на основе принципа диалога культур. Вспомним строки выдающегося узбекского поэта и государственного деятеля Алишера Навои: «Я знать хотел бы очень много / $-\mathrm{O}$, светоч грёз моих, во имя созиданья / Хотел бы знать я мысли всех людей /И языки всего миросозданья».

Взаимосвязь обучения родному (узбекскому) и неродному (русскому) языкам способствует развитию национально-русского двуязычия. Термином, обозначающим знание двух языков, является билингвизм ${ }^{79}$.

К сожалению, в последние годы наблюдается тенденция уменьшения доли учащихся для которых русский язык является родным, где практически полностью утрачена русская языковая среда, а также понижается уровень владения русским языком у учащихсябилингвов, которым приходится преодолевать языковой и психологический барьеры, затрудняясь высказать свое мнение по той или иной проблеме из-за бедности словарного запаса, сложности проникновения в иную национальную культуру, психологию и мировосприятие, отразившихся в русской и зарубежных литературах.

Достижение должного уровня литературного образования у школьников представляется сложным процессом в силу многих причин. Прежде всего, спад интереса к чтению художественной литературы, низкий уровень читательской культуры у школьников. По утверждению академика В.П. Демина, одной из основных причин снижения качества образования, в том числе и литературного, в том, что «современная ситуация характеризуется как системный кризис читательской культуры» ${ }^{80}$. Государственная значимость этой проблемы подтверждается и тем, что Президент Узбекистана Шавкат Мирзиёев в 2017 году 12 января подписал постановление «О создании комиссии по развитию системы издания и распространения книжной продукции, повышению и пропаганде культуры чтения».

Произведения художественной литературы предоставляют обширные возможности для изучения русской культуры и русского языка, а также вызывают у учащихся стремление к размышлению, обсуждению в классе различных проблем, содействуют созданию коммуникативных ситуаций, в процессе которых происходит активное усвоение лексики, что способствует формированию активного словарного запаса учащихся, повышению их культурологической компетенции. В этом плане значимыми являются тексты, созданные русскими писателями-классиками: А.С. Пушкиным, Н.В. Гоголем, Л.Н. Толстым, А.П. Чеховым и другими об истории, жизни, традициях, культуре русского народа.

Проблема обучения учащихся-билигвов и требует своего решения как на уровне организационном, так и научно-методическом. Традиционная методика обучения к успеху не приводит. Нужно совершенствовать методику билингвального образования, учитывая принципиальные отличия русского и узбекского языка, и, вместе с тем, необходимо изучать русский язык с опорой на родной язык.

\footnotetext{
79 Двуязычие (билингвизм) - владение двумя языками и их попеременное использование в зависимости от условий речевого общения, а носители двуязычия - двуязычные индивиды (билингвы).

${ }^{80}$ Дёмин В.П. Международная научная конференция « Чтение в образовании и культуре». Доклады и тезисы / под ред. акад. РАН и РАО В.А.Лекторского, науч. ред. - 2011. - С.5.
} 
Методологическую базу обучения на билингвальной основе составляют личностноориентированные образовательные технологии, проблемно-поисковая работа с решением предметно-коммуникативных задач (ролевые и деловые игры, проектно-исследовательская и творческая работа.)

Важным методом билингвального образования является личностноориентированное обучение на основе дифференциации и индивидуализации путём организации нетрадиционных уроков (модельных, эвристических, проблемных, дискуссионных, рефлексивных, а также практикумов, экскурсий; коллективной работы на уроке (парной, микрогрупповой); использование в ходе урока русской литературы аудиовизуальных компонентов (иллюстраций, живописи, музыки, кино- и видеоматериалов), способствующих решению воспитательно-образовательных задач урока своими специфическими средствами.

В национальной школе, где преобладает родное языковое окружение, создание доминирующей русской языковой среды невозможно. Значит, нет условий, благоприятствующих успешному развитию мышления на русском языке. Нерусский учащийся - читатель или слушатель, воспринимая неродной текст, не может не мыслить на родном языке, так как у него уже сложившийся с детства родной речевой стереотип.

Практика убедила, что при самостоятельном чтении русской литературы нельзя обходиться без предварительного, а иногда и сопутствующего комментария, который может дать учитель. Необходима и специфическая словарно-фразеологическая работа, которая требует от учителя и учащихся обращения к словарям, составления глоссария. Рекомендуется начиная с 5 по 11 классы заполнение учащимися личных литературоведческих словарей с толкованием теоретических, историко-литературоведческих понятий на русском языке с переводом на родной язык. Основные задачи при этом: а) накопление определенного запаса русских слов и его обогащение; б) изучение лексических и синтаксических оборотов речи; в) постоянное активное использование лексики произведений русской литературы в устной и письменной речи. Только через правильное понимание слов, через воосприятие их эмоционально-оценочных оттенков и звучания можно идти по пути постижения сложной авторской позиции, нравственно-эмоционального мира героев, всей нравственно-художественной природы произведения.

Именно языковыми барьерами (недостаточным знанием русского языка, ограниченностью русской речевой практики, низкой читательской культурой), а также незнанием тех или иных бытовых, историко-культурных реалий русского народа, так называемых «фоновых знаний», которые используются не только для создания образности художественного произведения, нередко осложняется восприятие и понимание, пересказ и трактовка русского литературного произведения. ${ }^{81}$ Рекомендуется при чтении художественных произведений русской литературы паралельное использование их переводов на узбекский язык. Многие произведения русской классической и мировой литературы переведены узбекской научной школой перевода на профессиональном уровне.

Преодолеть трудности, осложняющие изучение русской литературы учащимися нерусской национальности, помогает также использование факторов, свидетельствующих о сходных явлениях в русской и восточной литературах, их взаимосвязях. Предлагается изучать наиболее выдающиеся литературные памятники и явления мирового Востока в сравнении с русской литературой: индийскую драму «Шакунтала» Калидасы (1У-Увек), обрамленную повесть «Панчатантра» (IV-V века), творчество китайских поэтов VIII-Хвек, поэтов Ближнего Востока и Средней Азии X-XIV вв. (Рудаки, Фирдоуси, ИбнСина (Авиценна), Бируни, Омар Хайям, Ибн Рушд (Аверроэс), Саади, Хафиз, Джами, Навои), творчество японских поэта Басе и прозаика Ихары Сайкаку, китайскую прозу Пу-Сун-лина, творчество китайского драматурга Кун-Шан-женя и др.

\footnotetext{
${ }^{81}$ Верещагин Е.М., Костомаров В.Г. Язык и культура: лингвострановедение в преподавании русского языка как иностранного. - М.: Изд-во Московского ун-та, 1973. - С. 129.
} 
При изучении русской литературы во взаимосвязях и перекличках с мировой и национальной (узбекской, таджикской) культурой формируются представления об общности мирового литературного процесса, что способствует лучшему пониманию текста и выявлению его общечеловеческого нравственно-этического начала.

Таким образом, специфика билингвального урока помогает учителю решить ряд задач: создать высокий уровень мотивации на уроке; использовать художественный текст (в том числе на языке оригинала) для развития творческих способностей учащихся; формировать речевую и коммуникативную культуру школьников.

Педагог, работающий в двуязычной среде, должен обладать навыками межличностного общения с учетом особенностей профессии и возрастного подхода к обучению учащихся-билингвов, уметь общаться и организовывать толерантное общение, необходимое для формирования доверительного педагогического стиля в обучении и воспитании; иметь знания о каждой из взаимодействующих в обучении культур.

\section{Список использованной литературы}

1. Постановление Кабинета Министров Республики Узбекистан №124 «Государственный образовательный стандарт системы непрерывного образования. Требования к уровню подготовленности выпускников всех ступеней образования по иностранным языкам».- Ташкент, 2013.

2. Амшоков X.X.Теоретические основы двуязычия и практика взаимосвязанного обучения устной речи на родном и русском языках. Автореферат диссертации.-М., 1999.

3. Верещагин Е.М., Костомаров В.Г. Язык и культура: лингвострановедение в преподавании русского языка как иностранного. - М.: Изд-во Московского ун-та, 1973. - С. 129.

4. Дёмин В.П. Международная научная конференция « Чтение в образовании и культуре». Доклады и тезисы / под ред. акад. РАН и РАО В.А.Лекторского, науч. ред. - 2011. - C.5.

\section{ONA TILI TA'LIMIDA ESHITIB TUSHUNISH MALAKASINI RIVOJLANTIRISHNING AHAMIYATI}

\section{I . Azimova \\ ( Toshkent davlat o'zbek tili va adabiyoti universiteti, f.f.n)}

Annotation: The article is devoted to the problem of teaching listening comprehension in mother tongue classes at secondary school. It gives general overview of psycholinguistic interpretation of listening comprehension explaining the process with the samples in Uzbek. It emphasizes the role of classroom exercises in improving listening comprehension skill.

Key words and expressions: listening comprehension, language teaching, Uzbek, mother tongue classes, language skills

Eshitib tushunish malakasi chet tilini o'rganayotganda muhim deb qaraladi. Ma'lum vaqt davomida mazkur malaka chet tiliga o'qitish darslarida ham e’tibordan chetda bo'lgan. Til o'rgatish darslaridagi asosiy yondashuv grammatik qonun-qoidalarni va tarjima qilishni o'rgatish bo'lgan. Bu kabi yondashuv til o'rganuvchini tabiiy til muhitiga tayyorlay olmagani sabab, shuningdek, tilni tezroq va samaraliroq o'rgatish yo'li sifatida eshitish va takrorlash (audiolingval metod) til o'rgatish amaliyotida qo'llanila boshlagan [Richards 2003, 20].

Psixolingvistik va neyrolingvistik tadqiqotlar insonning lisoniy malakasi to' $r$ t kognitiv malaka: eshitib tushunish, o'qib tushunish, og'zaki nutq va yozma nutqdan tashkil topganligini xususida xulosalarni taqdim etgani ham til o'rgatish darslarida mazkur to'rt malakaga alohida e'tibor berila boshlangan.

“Ona tili darslarida eshitib tushunishga alohida e'tibor qaratish shartmi?” degan fikr ko'plab o'qituvchilarni o'ylantirishi mumkin, chunki inson $o^{6} z$ ona tilisida eshitib tushunishga malakasi 
avtomatik ravishda shakllanadi deb qaraladi. Biroq hammamiz yaxshi bilamizki, bir ma'lumotni hamma bir xil eshitsa-da, har kim har xil tushunadi. Mazkur holatlar eshitish jarayoni passiv shunchaki signalni qabul qilish emas, balki nutqiy signalni qabul qilib, uni qayta ishlab, ya'ni gapning strukturasini to 'g'ri razbor qilish - gap bo'laklarining vazifasini to'g'ri anglash, so'zlarning kontekstual ma'nosini to 'g'ri anglash va ular birgalikda bildirayotgan ma'noni tushunish demakdir.

Eshitib tushunish malakasini shakllantirish uchun mazkur jarayonning tafsilotlarini bilish muhimdir. $\mathrm{Bu}$ o'rinda bizga psixolingvistik tadqiqotlar yordam beradi. I.Azimovaning "O'zbek tilidagi gazeta matnlari mazmuniy persepsiyasining psixolingvistik tadqiqi" nomli monografiyasida matnni eshitib tushunish bo'yicha tajriba bayoni berilgan. Tajribada O‘zMUning O'zbek filologiyasi fakultetining 1-kursida o'qiyotgan 60 ta talaba ishtirok etgan. Ularga matn to'rt marta o'qib eshittirilgan. 60ta talabadan 4tasi matnni to'liq tushungan. 26tasi matnni yaxshi tushungan, biroq ayrim ma'lumotlar tinglovchining e'tiboridan chetda qolgan. 17ta ishtirokchi matnda qo'llangan so'zlarning kontekstual ma'nosini tushungani holda, ayrim gaplarni to'liq tushunmagan. 13 ishtirokchi matndagi so'zlarni tushungan, biroq aksariyat gaplarni tushunmagan [Azimova, 2019, 24-58] . Mazkur holat ona tilini o'rganish jarayonida ham eshitib tushunish malakasiga alohida e'tibor qaratilishi kerakligini bildiradi.

Tushunish jarayoni o'rganilganda shu narsa ma'lum bo'lganki, eshituvchining emotsionalligi va stereotiplari sabab eshituvchi berilgan matnni to'liq eshitmasligi mumkin. Bu ham eshitib tushunishga xalal beradigan holat bo'lgani uchun o'rta maktabdagi mashg'ulotlar davomida alohida e'tibor talab qiladi. Bola tushunishda yo'l qo'ygan xatolari muntazam ravishda ko'rsatilsa va xatoning asosi tushuntirib borilsa, bola tushunish jarayonini ongli ravishda boshqarishga o'rganadi.

Masalan, sevgi haqidagi bir qo'shiqning klipida xonanda va cholg'uchilarning orqasidagi fonda dunyo xaritasi turibdi. "Qo'shiq global masala haqida emas, sevgi haqida bo"lsa, klipda dunyo xaritasiga nima bor?" degan savol kishini o 'ylantiradi. Savolning javobi qo"shiq so 'zlaridan kelib chiqadi: "yuragimni chizib berdim, qaramading, xaritasin tuzib berdim, qaramading..." Ayni vaziyatda xarita so'zi bilan dunyo xaritasi sifatida qabul qilingan.

Matnning bir parchasi (ayni vaziyatda matndagi bir so'z) ta'sirida yuzaga kelgan assotsiatsiya tushunishning boshlang'ich darajasida ongda hosil bo 'ladi va matn mazmuni to 'lig'icha qabul qilinganda u chetga chiqishi kerak. Masalan, kishi "yuragim...xaritasin tuzib berdim" jumlasini eshitish jarayonida xarita so "zini alohida qabul qilganda dunyo xaritasi tushunchasi unga assotsiatsiya bo'lishi mumkin. Ammo xarita so 'zini qo'shiq matni ichida u bog'langan yurak so'zi bilan birga qabul qilar ekan, uning ko'chma ma'noda qo'llanganini xulosa qiladi va "dunyo xaritasi" tushunchasi tushunish jarayonida boshqa ishtirok etmasligi kerak. Keltirilgan misolda "dunyo xaritasi" tushunchasi klipga orqa fongacha yetib borganligidan bilish mumkinki, xaritasi so'zining matn ichidagi ma'nosi retsipiyent tomonidan qabul qilinmagan, balki alohida so' $z$ sifatida qolib ketgan.

Mazkur holatlar bizga tushunish jarayonidagi tafsilotlar haqida ma'lumot beradi. Ona tili o'qituvchisining matnni tushunish jarayonidan to 'liq xabardor bo'lishi, undagi har bir darajada qanday lisoniy birliklar ishlashini bilishi bolaning tushunishiga to'g'ri baho berish va uning tushunish qobiliyatini o'stirishga xizmat qiladi.

Yaqinda 5-sinf o'quvchilarining ona tili darslarida eshitib tushunish malakasining rivojlantirish bo'yicha Toshkent davlat o'zbek tili va adabiyoti universiteti va Toshkent shahri Chilonzor tumanidagi 114-maktab bilan hamkorlikda ilmiy tadqiqot olib borilib, eshitib tushunish malakasiga alohida e'tibor berilib o'qitilganda tajriba guruhida nazorat guruhiga qaraganda ushbu malakaning sezilarli farq bilan rivojlanishi qayd etildi [Murodova 2019, 2020]. Aytish mumkinki, ona tili darslarida bolaning eshitib tushunish malakasiga alohida e'tibor berilib, ta'lim jarayonidan tilning yozma shakli bilan teng o'rin olishiga ehtiyoj mavjudligi birinchi marta ilmiy jihatdan isbotlab berildi.

Eshitib tushunish malakasini shakllantirish uchun avvalo, eshitib tushunish jarayoni qanday kechishi xususida ma'lumotga ega bo'lish zarur. Eshitib tushunishni "yuqoridan pastga" va "pastdan yuqoriga" yo"nalishida kechuvchi jarayon sifatida talqin qilish mumkin. "Yuqoridan pastga" yo"nalishida nutqiy signalning katta birliklardan kichik birliklarga qarab qayta ishlanishi 
nazarda tutiladi, ya'ni umumiy nutq oqimining ohangi, undan gaplarni ajratish, gaplarning ichida sintagmalarni, sintagma ichidan so'z birikmalarni, ulardan so 'zlarni ajratish kabi masalalar hal qilinadi [Dahan, Magnuson, 2006, 249-284]. "Pastdan yuqoriga" yo"nalishida fonemalardan bo'g'inlarga, bo'g'inlardan so'zlarga, so'zlardan birikmalarga, birikmalardan sintagmalarga, sintagmalardan gaplarga, gapdan yaxlit nutqqa qarab mazmun tushunib boriladi. Mazkur ikki yondashuvning unisi yoki bunisi kechadi, deb qat'iy aytib bo'Imaydi. Nutqni anglash jarayonida zaruratga ko'ra ikkala yondashuv ham qo'llanadi. Inson ongining nutqiy signalni qayta ishlashdagi ushbi ikki yo'nalishi tabiatidan kelib chiqqan holda vazifa va topshiriqlarni belgilash mumkin. Masalan, "yuqoridan pastga" yo"nalishi uchun eshittirilgan nutq yuzasidan nutqning maqsadi va xarakterini aniqlash, nutq til uslublarining qaysinisiga xosligini belgilash, nutqning umumiy mazmuni haqida xulosa chiqarish kabi topshiriqlar berish mumkin. "Pastdan yuqoriga" yo"nalishi uchun nutqda qo'llangan so'z va so'z birikmalarini qayd etish, qandaydir xarakterli so'zlarni (masalan, raqamlar yoki sifat turkumiga oid so'zlar yoki notanish so'zlar) eslab qolish yoki yozib olish kabi topshiriqlar berilishi mumkin. Mazkur topshiriqlar ikkala yo'nalishda ham diqqatni kerakli obyektga qaratish ko'nikmasini shakllantiradi.

D.Nunan ham "pastdan yuqoriga", ham "yuqoridan pastga" yondashuvini baravar qo'llaydigan "diktogloss" texnikasi haqida ma'lumot beradi. Unda o"qituvchi matnni odatiy tezlikda o'qib eshittiradi. O'quvchilardan imkoni boricha so'zlarni qayd etish so'raladi. Keyin o'quvchilar guruh bo'lib, o'zlari qayd etgan so'zlariga tayanib eshitgan matnni qayta tiklashi so'raladi [Nunan, 1991, 25-35].

Diktogloss texnikasi quyidagi to'rt bosqichdan tashkil topadi:

1. Tayyorgarlik.

2. Matnni o'qib eshittirish.

3. Matnni tiklash.

4. Tahlil qilish va xatolarni to'g'rilash.

Birinchi bosqichda o'qituvchi o'quvchilarni tayyorlaydi. O'qilishi rejalashtirilayotgan matn mavzusiga aloqador savollar beradi, yoki shunga aloqador rasm ko'rsatadi va hkz.

Ikkinchi bosqichda matn ikki marta o"qib eshittiriladi. Birinchisida o'quvchilar matnni shunchaki eshitadilar. Ikkinchisi marta eshitish davomida o'zlari muhim deb bilgan narsalarni qayd etadilar.

Uchinchi bosqichda guruh bilan birgalikda o'z qaydlari asosida matnni qayta tiklaydilar.

To'rtinchi bosqichda o'quvchilar tiklagan matnlar original matn bilan qiyoslanadi.

Eshitib tushunish malakasini shakllantirishda nutqni turli maqsadlarda eshittirish muhimdir. Buning uchun tushunishni aks ettirishi lozim bo'lgan topshiriqlar turli xarakterda bo'lishi kerak. Masalan, ma'lum joy yoki predmetning tavsifini eshitib, uni rasmda ifodalash, ma'lum sayohat tafsilotlarini eshitib, sayohatchilar marshrutini belgilash (ular borgan joylarni tartib bilan yozish), tushirib qoldirilgan so'zlarni yozish, eshitgan nutqi asosida ma'lumotlarni tavsiflash kabi. Shuningdek, eshittiriladigan nutq ham turli xarakterda bo'lishi lozim: monolog, dialog, suhbat, munozara. Mazkur turfa xillilik o'quvchida nutqning turli jihatlariga e'tibor qaratish ko'nikmasini shakllantiradi. Albatta, nutq mavzusi bolaning yoshiga mos ravishda qiziqarli bo'lishi kerak.

\section{Foydalanilgan adabiyotlar ro'yxati}

1. Azimova I.A. O‘zbek tilidagi gazeta matnlari mazmuniy pertsepsiyasining psixolingvistik tadqiqi. Monografiya. Toshkent, 2019.

2. Dahan, D. Magnuson, J.S. (2006) Spoken Word Recognition. In Handbook of Psycholinguistics. Elsevier Inc.2006.

3. Murodova A. Eshitib qabul qilishda matnda ifodalangan ma'lumot dekodlanishining tajribaviy tadqiqi. Global ta'lim va milliy metodika masalalari. Ilmiy-anjuman materiallari. Toshkent, 2020. B. 179-184

4. Murodova A. Ona tili ta'limida eshitib tushunish malakasining o'rni. Til va adabiyot ta 'limi jurnali. Toshkent, 2019. \# 7. B. 13-14.

5. Nunan, D. (1991) Language Teaching Methodology. Prentice-Hall. Pp. 139. 
6. Richards, J. (2002) Theories of Teaching in Lanugage Teaching. In Methodology in Language Teaching. Cambridge University Press. Pp. 19-26.

\title{
РАЗРАБОТКА ДИСТАНЦИОННОЙ ОБРАЗОВАТЕЛЬНОЙ ПЛАТФОРМЫ ПО ОБУЧЕНИЮ КИТАЙСКОМУ ЯЗЫКУ СТУДЕНТОВ-ФИЛОЛОГОВ ЯЗЫКОВЫХ ВУЗОВ
}

\author{
C. А. Назарова \\ (ТаиГУ, PhD, доцент,)
}

\begin{abstract}
Annotation: In the conditions of the modern post-industrial world, characterized by such active processes as globalization, polyculturalization, the creation of a modern distance educational platform for teaching the Chinese language is becoming its integral part. The development of this training platform provides for the training of students-philologists of language universities based on the methodology for improving intercultural communication, taking into account the cognitive-thinking processes of students. The article discusses in detail the goals and objectives of creating a distance educational platform for teaching the Chinese language within the framework of the concept of cognitive-discursive teaching of intercultural communication among students of philology at language universities.
\end{abstract}

Key words and expressions: Methodology, intercultural communication, concept of cognitive-discursive learning, speech activity, cognitive-thought processes, typology of exercises, distance learning platform.

На этапе динамичного развития Республики Узбекистан большое внимание уделяется сфере образования, культуры, искусства и науки.На сегодняшний день,из-за распространения пандемии, всемирная система образования приобретает новый формат обучения, в этой связи, создание усовершенствованных электронных дистанционных образовательных платформ по обучению иностранным языкам являетсяодной из приоритетных задач в области науки и образования Республики Узбекистан.

Создание дистанционной образовательной платформы по обучению китайскому языку служит выполнению задач, предусмотренных в Постановлении Президента Республики Узбекистан № ПП 4680 от 16 апреля 2020 года «О мерах по кардинальному совершенствованию системы подготовки кадров и повышения научного потенциала в области востоковедения.УП №-5847 «Об утверждении концепции развития системы высшего образования Республики Узбекистан до 2030 года» от 8 октября 2019 года, № ПП-1875, УП4947 «О мерах по дальнейшему совершенствованию системы изучения иностранных языков» от 10 декабря 2012 года, а также в других нормативно-правовых документах, принятых в сфере образования.

Вместе с тем, в Постановлении Президента Республики Узбекистан № ПП 4680 от 16 апреля 2020 года «О мерах по кардинальному совершенствованию системы подготовки кадров и повышения научного потенциала в области востоковеденияотмечены такие важные задачи, как «обогащение содержания образования образовательными технологиями, способствующими креативному мышлению, формированию инновационных идей и разработок».В этой связи, контент электронной дистанционной образовательной платформы по китайскому языку будетразрабатываться в соответствии с предлагаемой нами концепцией когнитивно-дискурсивного обучения межкультурной коммуникации студентов-филологов языкового вуза, глубокого изучения тесной взаимосвязи и интегративного подхода языка и культуры, а также с учетом достижений Китая в сфере науки и образования, в социальноэкономической и политической сферах.

В процессе разработки дистанционной электронной образовательной платформы упражнения и задания будут учитывать все четыре вида речевой деятельности, это аудирование, чтение, письмо, говорение, с учетом распознавания межкультурных 
индикаторов речи носителей языка, являющиеся неотъемлемой частью языка и культуры иностранного языка.

Основное содержание концепции когнитивно-дискурсивного обучения межкультурной коммуникации студентов-филологов языковых вузов представлено тремя основными компонентами содержания обучения (призвано ответить на вопрос: чему учить?): лингвистическим, психологическим и методологическим.

Лингвистический компонент включает языковой материал, который в совокупности представлен темами в рамках диалога культур для обучения студентов в учебных и аутентичных текстах.

Методологический компонент содержания обучения межкультурной коммуникации включает необходимые разъяснения, памятки, и инструкции по использованию печатных словарей, форме ведения индивидуальных словарей и карточек с новой лексикой, лакунами и реалиями о способах реорганизации и систематизации изученной лексики[Соловова 2008:240 ].

Психологический компонент обучения включает в себя следующие аспекты:1) развитие критического мышления студентов; 2) учет когнитивных процессов студентов; 3) в процессе обучения использование стратегии ориентированное на развитие навыков вдумчивой работы; 4) совершенствование коммуникативных и межкультурных навыков и умений общения с учетом их характера взаимодействия; 5) совершенствование языковых способностей таких, как употребления лексической единицей в тексте высказывания, в его грамматической и стилистической структуре, смысловом восприятии в тексте и т.д.

Таким образом, при разработке контента дистанционной обучающей платформы будут учитываться когнитивно-мыслительные процессы студентов. Для более целостного пониманияс когнитивной точки зрениясодержания контента, считаем целесообразным подробно остановиться нанекоторых ключевых понятиях.

Согласно мнению американского педагога-новатора Джон Дьюи, «научить человека мыслить является главной задачей системы образования» [Халперн 2000: 83].

Мышление, являясь высшим проявлением психического, олицетворяет собой процессы познавательной деятельности индивида и моделирования неслучайных отношений внешнего мира. Характеризуясь обобщенным и опосредственным отражением действительности, оно включает анализ, синтез обобщения условий, требований и способов решения задачи[Энциклопедия 2007:543].

С.Л. Рубинштейн дает свое видение: «Наше познание объективной действительности начинается с ощущений и восприятия. Но, начинаясь с ощущения и восприятия, познание действительности не заканчивается ими. От ощущения и восприятие оно переходит к мышлению» [Рубинштейн 2015:309].

С точки зрения Г.Н.Ирмухамедовой, согласно которой«мышление, исходя из самого определения, начинается тогда, когда индивид начинает что-то анализировать, сравнивать, обобщать и т.д. Мышление всегда связано с мыслительным процессом у человека и находит свое отражение в его речи» [Ирмухамедова 2008: 359].

Дайана Халперн, характеризуя критическое мылиление, относит к нему использование когнитивных техник или стратегий, которые увеличивают вероятность получения желаемого конечного результата [Халперн 2000: 83].

Как утверждает Е. Д Климова, для критического мышления характерно построение логических умозаключений, создание согласованных между собой логических моделей и «принятие обоснованных решений, касающихся того, отклонить какое-либо суждение, согласиться с ним или временно отложить его на рассмотрение» [Климов 2013: 21].

В обучающей деятельности подкритическим мышлением понимается совокупность качеств и умений, обусловливающих высокий уровень исследовательской культуры студента и преподавателя, а также «мышление оценочное, рефлексивное», для которого знание является не конечной, а отправной точкой, аргументированное и логичное мышление, которое базируется на личном опыте и проверенных фактах [Заир-Бек и др. 2011:59]. 
На наш взгляд, критическое мышление - это умение мыслить аналитически, строить логическую цепочку, принимать взвешенное,аргументированное решение, выйти на уровень осознанной компетентности студента.

По результатам реализации дистанционной образовательной платформы по обучению китайскому языку будут:

- проведены теоретико-методические исследования по изучению и анализу отечественного и зарубежного опыта по разработкам электронной дистанционной образовательной платформы по обучению иностранным языкам;

- разработана концепция когнитивно-дискурсивного обучения межкультурной коммуникации студентов-филологов при обучении китайскому языку.

разработана собственная электронная образовательная дистанционная платформа основанная на концепции когнитивно-дискурсивного обучения межкультурной коммуникации студентов-филологов.

- $\quad$ разработаны критерии определения уровня сформированностимежкультурной коммуникации студентов-филологов языковых вузов;

- экспериментально доказана эффективность разработанной концепции когнитивно-дискурсивного обучения межкультурной коммуникации студентов-филологов языковых вузов на базе дистанционной образовательной платформы по обучению китайскому языку;

- созданы дидактические материалы в стандартном формате SCORM \{SharableContentObject. ReferenceMode), т.e. учебные объекты \{LearningObject) для использования их в любое время и в любой образовательной среде.

На схеме 1 продемонстрированно содержание концепции когнитивно-дискурсивного обучения межкультурной коммуникации студентов-филологов языковых вузов на базе дистанционной образовательной платформы по обучению китайскому языку.

В заключении следует отметить, что разработка и создание электронной дистанционной образовательной платформы по обучению китайскому языку студентов высших образовательных учреждений Республики Узбекистан будет способствовать скорейшей реализациипоставленных задачперед системой образования Республики Узбекистан. Вместе с тем, в содержание контента обучающей платформы заложена теория критического мышления или осмысленного обучения, в которой студент при обучении сам строит этот процесс, исходя из реальных и конкретных целей, сам отслеживает направления своего развития, сам определяет его конечный результат, а также использует стратегию, ориентированную на развитие навыковвдумчивой работы с информацией испособствовать оптимизации процесса обучения в рамках нашего исследования.

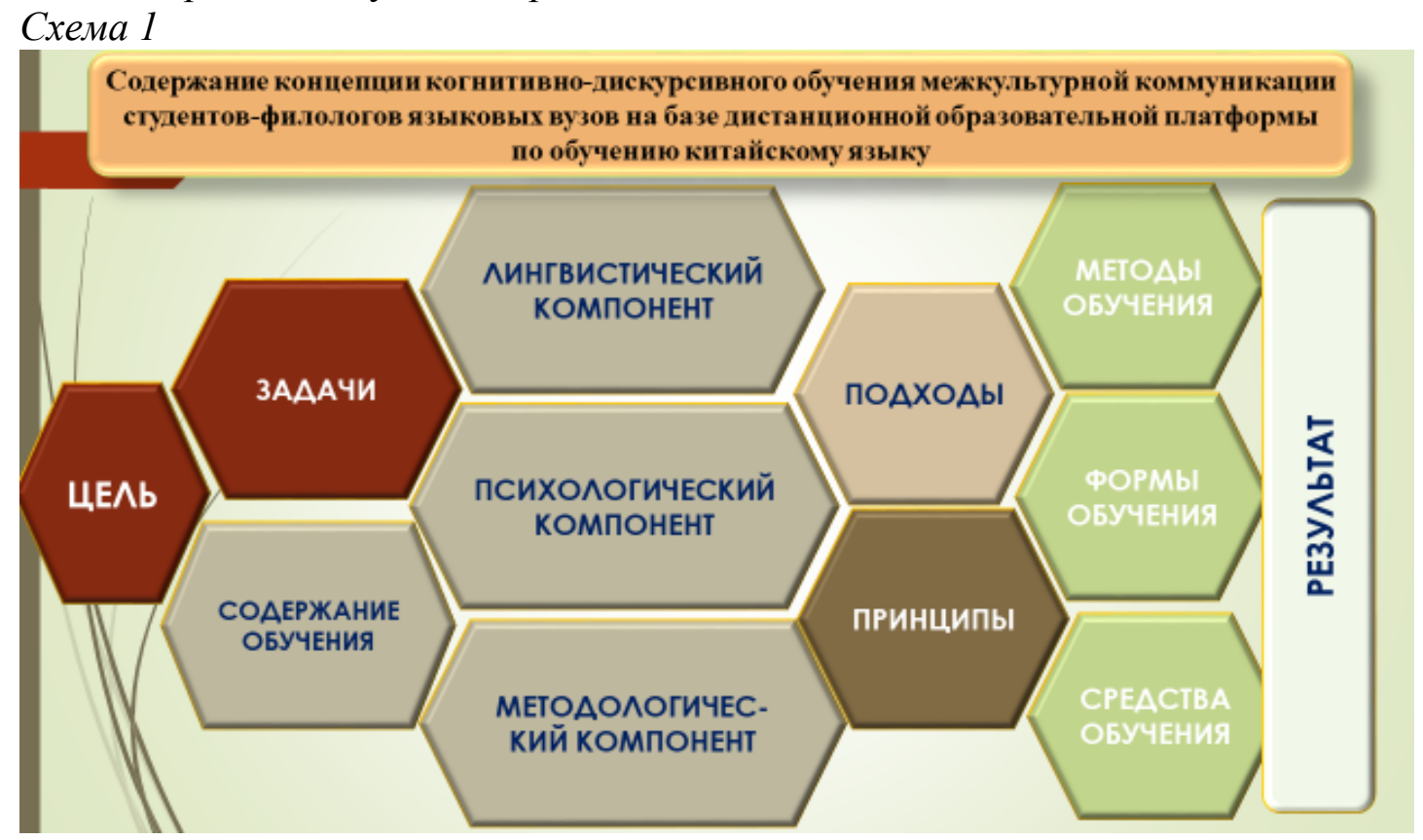




\title{
Список использованной литературы
}

1. Постановление Президента Республики Узбекистан № ПП-1875 “О мерах по дальнейшему соверешенствованию системы изучения иностранных языков” от 10 декабря 2012 года.

2. Постановление Кабинета Министров Республики Узбекистан №124 от 8 мая 2013 г. “Об утверждении Государственного образовательного стандарта системы непрерывного образования по иностранным языкам". www.lex.uz.

3. Постановление Президента Республики Узбекистан № ПП-2909 от 20 апреля 2017 г. “О мерах по дальнейшему развитию системы высшего образования”. www.lex.uz.

4. Постановлении Президента Республики Узбекистан № ПП 4680 от 16 апреля 2020 года «О мерах по кардинальному совершенствованию системы подготовки кадров и повышения научного потенциала в области востоковедения. https://lex.uz/ru/docs/4791179.

5. Большая психологическая энциклопедия. - М., 2007. - 543 с.

6. Дайана Халперн. Психология критического мышления. - СПб.: Питер, 2000. - 512 c.

7. Заир-Бек С.И., Муштавинская И. В. Разитие критического мышления на уроке. М.: Просвещение, 2011. - 223 с.

8. Ирмухамедова Г.Н. Лингводидактические основы обучения критическому чтению аутентичных текстов (На старших курсах экономических вузов): Дис. ... канд.пед.наук.- Т., 2008. - 359 c.

9. Климова Е.Д. Технология развития критического мышления будущих менеджеров в профессионально-ориентированной подготовке к деловому общению: Автореф. дис. ... канд.пед.наук.- Самара, 2013. -24 с.

10. Рубинштейн С.Л. Основы общей психологии. - Спб.:Питер, 2015. - 713 с.

11. Соловова Е.Н. Методика обучения иностранным языкам//Базовый курс. - М.: Издательство «Астрель», 2008. - 240 с.

12. Сян Пинчжу. Когнитивная деятельность методики обучения иностранцев. - Ухан: Изд-во Педагогического университета «Хуа Чжун», 2014. - 238 с. 向平著。对外汉语教学的 实践认知。一武汉：华中师范大学出版社，2014. - 238 页.

\section{СОХАВИЙ ТЕРМИНЛАРНИ ЎКИТИШНИНГ НАЗАРИЙ ВА АМАЛИЙ АСОСЛАРИ}

\author{
Ф.С. Абдуллаева
}

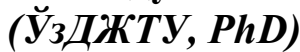

Annotation: Мазкур мақолада сохавий терминларни ўқ̧тишнинг назарий ва амалий асослари ёритилган. Парадигматик муносабатларда юридик терминлар хуолати, исботланган ўзлашма қъатламнинг миқдорий кўрсаткичлари, аффиксал морфлар билан терминнинг туркум вазифалари хзамда аффикслар, синтактик, конверсия, аббревиачия, лексик-семантик усуллар ёрдамида термин ясалиши орқали курсатилган. Шуннигдек, парадигматик ёндашув буйича юридик контекстда терминология этимиологияси ва аффиксал, морфемик-морфологик, лексик-семантик, функиионал-семантик ва синтактик усулда ясалиши аниқлаштирилган.

Key words and expressions: Термин, сохувий термин, методологик, лингводидактик ва технологик даража, лингводидактиканинг тенденциялари, терминологик лексика

Тил ўқитиш методикасининг фан сифатида ривожланиши замонавий босқичини учта: методологик, лингводидактик ва технологик даража изохлайди. Лингводидактика - бу тил ўқитиш назарияси бўлиб, лингвистика ва дидактиканинг интеграциясидан иборат. Лингводидактиканинг объекти тил ўқитиш жараёни ва унинг тадқиқини назарий асослаш, яъни концепция, тил таълими мазмуни, ўқитишнинг ташкилий шакллари, тадқиқот механизми ва жараён лойихасидан иборат. Лингводидактиканинг предмети эса тил ўқитиш 
(ўқитувчи фаолияти), тилни ўрганиш (талаба фаолияти) ва ўкув материали ва технологияси мазмунининг боғлиқлиги қонуниятларини назарий асослашдир ${ }^{82}$.

Чет тилини ўқитишда замонавий лингводидактиканинг тенденциялари қуйидагилардан иборат:

- чет тилини ўқитишнинг мақсади;

- лингводидактика - чет тилини ўқитиш методологияси сифатида;

- чет тилини ўқитишда прагмалингводидактика ${ }^{83}$.

«Чет тилини ўқитиш мақсади» методик тушунча бўлиб, хорижий тилларни ўқитиш методикаси ва лингводидактикасининг асосий талабларини англатади. Хақиқатан хам, ўқув шароитида чет тилини эгаллаш жараёни психолог, психолингвист, лингвист ва методистларни қизиқтириб келган. Фақатгина лингводидактика интегратив фан сифатида тилни ўзлаштириш механизмлари хамда ўкув шароитида мазкур механизмларни бошқаришни амалга оширади. Маълумки, чет тилини ўқитиш назариясини тилни ўзлаштириш назарияси ёки лингводидактика, хорижий тил дидактикаси ва танланган тилни ўқитиш методикаси ташкил этади.

Чет тилини прагматик характер ва касбий фаолиятда ўзга тил компетенциясидан фойдалана олиш қобилияти бўлсагина, мутахассислик талаби бўйича ўзлаштириш мумкин. Прагматика, социолингвистика ва методиканинг интеграцияси ўз навбатида прагмалингводидактикани ташкил этади. Прагмалингводидактика ўзга тил компетенциясини ўқитиш муаммолари, маданиятлараро мулоқотни ўрганади.

Терминларни таснифлаш мезонлари, даражалари ва типологияси умумистеъмол ва суд қарорлари бўйича ўхшаш ва юридик контекст бўйича фарқли хусусиятларини аниқлаштириш имконини беради. Объект миқдори, умумлаштириш, қўллаш, баён этиш, тарқалиш, пайдо бўлиш ва кириб келиш манбаи, воқелик бўйича юридик терминларни таснифлаш мезонлари аниқлаштирилган. Юридик тил, амалиёт ва қонун тили бўйича юридик термин даражалари ажратилган. Шунингдек, кундалик, махсус техник, сунъий, умумий модел типологияси аниқлаштирилган. Умумистеъмолда қўллаш, умумистеъмолда бўлиш, умумий маъно ва умумистеъмолда кўллаш мумкин эмаслиги бўйича кундалик типологияси, махсус техник типологияси, алохида юридик ахамиятга эга, махсус юридик ва махсус юридик эмаслиги бўйича сунъий типологияси, фалсафий, умумназарий, тез-тез учраши бўйича умумий модел типологияси аниқлаштирилган.

Юридик терминларнинг ўзига хос хусусиятлари терминологик номинациялар шакллари, намоён этиш сохалари, илмий терминлар гурухи, лингвистик хусусиятлари, юридик муносабат иштирокчиларининг номланишини, инглизча юридик терминларнинг бевосита номинациялаш усулида ясалган қисмини гурухлаш хамда юридик дискурсда терминологик лексиканинг талаблари бўйича аниқланди.

Фуқаролик, жиноий, тадбиркорлик, сайлов, оила, солиқ, халқаро хуқуқий муносабатлар асосида хуқуқий тизимнинг ўзига хос хусусиятлари юридик терминларнинг типологик таснифини аниқлаштиришни тақозо қилади. Хуқуқ сохасидаги терминларнинг тузилиши ва қўлланиши уларни ясашнинг асосий қонуниятларини ажратиш имконини беради. Термин ясалиши ва терминологик бирликларни яратиш формулалари ва вариантлари хақидаги билимга эга бўлиш, хорижий хукуқий тизимда кўлланиладиган терминлар ва реалияларнинг маъносини тушунишни енгиллаштиради. Маълумки, бир мамлакат хуқуқий тизимида мавжуд бўлган терминлар, бошқа давлат хуқуқий тизимида мавжуд бўлмаслигини кўрсатади.

Тилшунослик, лингвистика - тил хақидаги, унинг ижтимоий табиати, вазифаси, ички тузилиши, таснифи, муайян тилларнинг фаолият қонунлари, тарихий тараққиёти хақидаги фан бўлиб, мақсади, вазифаси ва шаклига кўра тилшунослик бир неча йўналишлар (сохалар) ва бўлимлардан иборат. Тилванутқасосантўрт ярус: фонетика-фонология, морфология,

82 Лингводидактика как теоритеческая основа обучения языку. Электронный ресурс: https://works.doklad.ru/view/NRkF6riOIeo.html. Дата обращения: 22.04.2018.

83 Тенденции современной лингводидактики в обучении иностранным языкам. Электронный ресурс: http://stud.wiki/languages/2c0b65635a2ad78b5d53b88521216d27_0.html. Дата обращения: 22.04.2018. 
лексикология васинтаксисданташкилтопади. Тилшуносликкаоидадабиётларда морфология ва синтаксис ярусларибиратамабилан - грамматика дебаталади.

Парадигматик муносабатларда юридик терминлар холати, исботланган ўзлашма қатламнинг микдорий кўрсаткичлари, аффиксал морфлар билан терминнинг туркум вазифалари хамда аффикслар, синтактик, конверсия, аббревиация, лексик-семантик усуллар ёрдамида термин ясалиши орқали юридик лексикани такомиллаштириш имконини беради.

Аффиксал морфлар ўзакка нисбатан жойлашиши нуқтаи назаридан уч турга бўлинади: префиксал, инфиксал ва постфиксал морфлар. Инфиксал морфлар ўзакнинг ичига жойлашган бўлиб, юридик терминларда кузатилмади 84 .

Терминни шакллантириш жараёнида уни тўғри талаффуз қилиш ва эслаб қолишга эришишда интерфаол методлардан фойдаланиш мақсадга мувофиқ. Бунда метод, унинг тарихи, таълимоти, асосий мазмуни хамда функциясига эътибор қаратиш «метод», «методология», «методика» хамда «интерфаол метод» тушунчаларини уррганишни тақозо этади. Интерфаол методлар лойихасидан фойдаланиб, юридик терминлар талаффузини ўзлаштириш мазкур терминларни билиш, тушуниш, амалда кўллаш ва тахлил қилишни мустахкамлашга имкон беради.

Инглиз тили машғулотларида терминларни талаффуз қилиш кўникмаларига алохида эътибор қаратиш зарур, бу ўз ўрнида касбий мулоқотда терминларни кўллаш кўникмаларини ривожлантириш билан бирга уларни ўзлаштиришни енгиллаштиради. Термин таркибидаги бирор-бир товушни нотўғри талаффуз қилиш оқибатида маъно ўзгариши мумкин, бу, ўз навбатида, оғзаки коммуникация жараёнида қабул қилишни қийинлаштиради. Бу эса фонетик кўникмалар маъно фарқлаш хусусиятига эгалигини исботлайди.

Парадигматик ёндашув бўйича юридик контекстда терминология этимиологияси ва аффиксал, морфемик-морфологик, лексик-семантик, функционал-семантик ва синтактик усулда ясалиши аниқлаштирилган. Аффиксларнинг сўзўзагига нисбатан жойлашиши бўйича юридик терминлар лексикаси тахлили қуйида келтирилди (1-жадвалга қаранг):

er/or: is used for the person who does an activity;

er/or: are also used for things which do a particular.

er/or аффикс ёрдамида юридик терминларнинг ясалиши

\begin{tabular}{|c|c|c|c|c|}
\hline № & Аффикс & Ишлатилиши & Юридик терминлар & Таржимаси \\
\hline \multirow{7}{*}{1.} & \multirow{7}{*}{ er } & \multirow{7}{*}{$\begin{array}{l}\text { is used for the } \\
\text { person who } \\
\text { does } \quad \text { an } \\
\text { activity }\end{array}$} & absentee owner & $\begin{array}{lcc}\text { кўчмас } & \text { мулкнинг } & \text { узоқ } \\
\text { вақтгача бор бўлмаган эгаси }\end{array}$ \\
\hline & & & auctioneer & аукциончи \\
\hline & & & adopters & фарзандликка олувчилар \\
\hline & & & bailsmen, endorser & Индоссант \\
\hline & & & $\begin{array}{l}\text { banker's commercial } \\
\text { credit }\end{array}$ & банк савдо аккредитиви \\
\hline & & & banker's credits & банк кредитлари \\
\hline & & & bona fide purchaser & халол, инсофли харидор \\
\hline \multirow{5}{*}{2.} & \multirow{5}{*}{ er/or } & \multirow{5}{*}{$\begin{array}{l}\text { are also used } \\
\text { for things } \\
\text { which do a } \\
\text { particular }\end{array}$} & abater & $\begin{array}{l}\text { ишни тўхтатиш (бекор қилиш) } \\
\text { учун ариза }\end{array}$ \\
\hline & & & auction in closed tender & $\begin{array}{l}\text { ёпиқ тендер тарзидаги кимошди } \\
\text { савдоси }\end{array}$ \\
\hline & & & boiler room operations & $\begin{array}{lll}\text { шубхали } & \text { қимматга } & \text { эга } \\
\text { қимматбахо } & \text { қоғозларни } & \text { тез } \\
\text { сотиш } & & \\
\end{array}$ \\
\hline & & & broker treatment & воситачилик шартномаси \\
\hline & & & impleader & $\begin{array}{l}\text { учинчи шахсларни судга жалб } \\
\text { қилиш }\end{array}$ \\
\hline
\end{tabular}

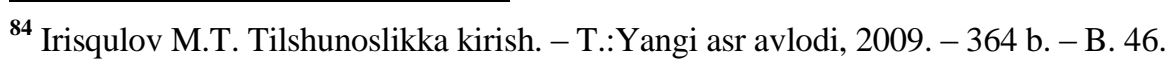




\begin{tabular}{|c|c|c|c|c|}
\hline 3. & or & $\begin{array}{l}\text { are also used } \\
\text { for things }\end{array}$ & abator & $\begin{array}{l}\text { меросга ўтмасдан олдин мол- } \\
\text { мулкни ноқонуний равишда } \\
\text { уззлаштириш }\end{array}$ \\
\hline & & $\begin{array}{l}\text { which do a } \\
\text { particular }\end{array}$ & $\begin{array}{l}\text { administratorof the } \\
\text { bankruptcy estate }\end{array}$ & $\begin{array}{l}\text { танлов } \\
\text { бошқарувчиси }\end{array}$ \\
\hline
\end{tabular}

istused for people's politics, beliefs and ideologies and sometimes their profession: specialist алохида турдаги қимматбахо қогозларга ихтисослашганбиржа брокери.

ness is used to make nouns from adjectives e.g. clearing of responsibility through illness (касаллик туфайли жавобгарликдан озод қүилиш), farm indebtedness (фермерлик хугжалигини олиб бориш билан бовлиқ қарздорлик), fitness (for a particular purpose)маълум мақсадда яроқлилик, genuiness (асллик, хақиқийлик).

able / ible with verbs, means «can be done».

able: acceptable (not acceptable) reasons узрли (узрсиз) сабаблар, actionable давво учун асос берувчи, атоrtizable тууланадиган, қайтариладиган, арреalable хукмдан норозилик туфайли шикоят қилишга лойиқ.

ible: accessible objects хุамма фойдалана олиши/ кириши мумкин бўлган объектлар, accessible information хуамма эркин фойдаланиш мумкин бўлган маълумот, defeasible бекор қилиниши мумкин бўлган.

ise makes verbs from adjectives e.g. advertise реклама бермок, tо authorisеваколатламоқ, рухсат бермоқ, to authorise by a deed ваколат бермоқ, мухрли хужжнат билан ваколатламоқ, to authorise expressly бевосита ифодаланган шаклда ваколатлар бермоқ.

tion/ ion is used to make nouns from verbs бўлганлиги сабабли қуйидаги жадвалда tion/ ion аффикси ёрдамида юридик терминларнинг ясалиши тахлил қилинди (2-жадвалга қаранг):

2-жадвал.

tion/ ion аффикс ёрдамида юридик терминларнинг ясалиши

\begin{tabular}{|c|c|c|c|}
\hline № & Аффикс & Юридик терминлар & Таржимаси \\
\hline \multirow{5}{*}{1.} & \multirow{5}{*}{ ion } & $\begin{array}{l}\text { abeyance of execution of } \\
\text { the decision, abnegation }\end{array}$ & $\begin{array}{l}\text { 1) инкор қилиш; } \\
\text { 2) рад қилиш, воз кечиш }\end{array}$ \\
\hline & & actual possession & фактик (хақиқатан) эга бўлмоқ \\
\hline & & $\begin{array}{l}\text { adjourn the consideration } \\
\text { of the case }\end{array}$ & ишни кўриб чиқишни кечиктириш \\
\hline & & administralion & (мархумнинг) мол мулкини бошқариш \\
\hline & & admission & тан олиш \\
\hline \multirow{5}{*}{2.} & \multirow{5}{*}{ tion } & presentation & далил келтириш, тақдим қилиш, кўрсатиш \\
\hline & & abolition & (бекор қилиш, йўқ қилиш) \\
\hline & & accord and satisfaction & $\begin{array}{l}\text { ижрони алмаштириш хақидаги битим, } \\
\text { ярашиш битими }\end{array}$ \\
\hline & & alienation & $\begin{array}{l}\text { бегоналаштириш, бегона } \\
\text { уткказиш }\end{array}$ \\
\hline & & $\begin{array}{l}\text { abstract } \\
\text { obligation }\end{array}$ & мавхум пуллик мажбурият \\
\hline
\end{tabular}

Other suffixes that can help us recognise the word class (3-жадвалга қаранг): 
Бошқа аффикслар ёрдамида юридик терминларнинг ясалиши

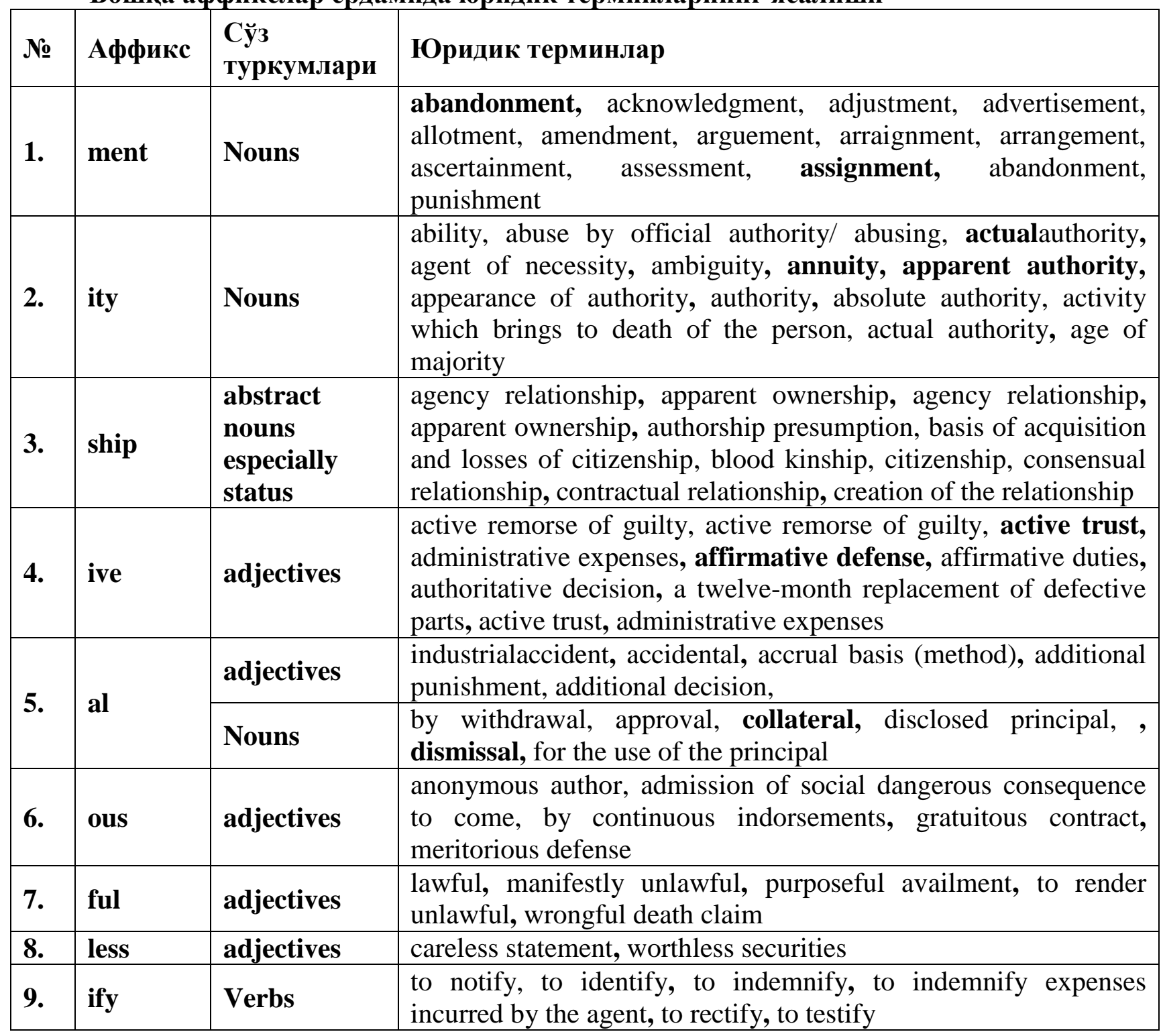

Терминологик лексиканинг ясалишида фаол ишлатиладиган префикслар қуйидаги турларга бўлинади:

1) салбий маъно англатувчи префикслар:

de-destructive, detachment, depersonalization;

dis-disability, discovery, disinhibition, disorder, displacement,

non-conformity nonconformity, un- unlearned, unconditional);

in-insanity, insomnia, incapacity;

2) қайтариш ёки қайта жараённи англатувчи префикслар: re- recoding, recall, reinforcement, reaction;

3) харакатнинг даражасини таснифловчи префикслар: hypo/ hyper-hypo-chondriasis hypersomnia;

4)процессуал кетма-кетликни тавсифловчи префикслар: pre-predisposition, presentencing, premature;

5) бахонинг пасайишини англатувчи префикслар: under-underachievement.

Префикслар ёрдамида юридик терминларнинг ясалиши 4-жадвалда келтирилди (4жадвалга қаранг): 
Префикслар ёрдамида юридик терминларнинг ясалиши

\begin{tabular}{|c|c|c|c|}
\hline № & Префикслар & Маъноси & Юридик терминлар \\
\hline 1. & anti & against & anticipatory breach \\
\hline 2. & auto & $\begin{array}{l}\text { of or by } \\
\text { oneself }\end{array}$ & $\begin{array}{l}\text { autocratic connection to electric, thermal, gas or to water } \\
\text { supply systems, autocratic cutting down of greenplantings in } \\
\text { cities }\end{array}$ \\
\hline 3. & bi & two, twice & bilateral, bilateral deal/agreement \\
\hline \multirow[t]{2}{*}{4.} & \multirow[t]{2}{*}{ ex } & out of & $\begin{array}{l}\text { acquisition/sale of the property extracted by a criminal way, } \\
\text { action of the person in a condition of necessary defencesor } \\
\text { extreme necessities, bill of exchange, bills of exchange } \\
\text { laws, conditional release of the convict before the expire of } \\
\text { his (her) term, except as otherwise provided, excepted risks } \\
\text { алохида таваккалчилик, excess profit tax, exchange of } \\
\text { property, exclusion, exclusive jurisdiction, exclusive } \\
\text { selling rights, expiration, export licence }\end{array}$ \\
\hline & & former & ex-works \\
\hline 5. & $\operatorname{mis}$ & badly/wrongly & $\begin{array}{l}\text { misappropriation, misconduct, misrepresentation, mistake } \\
\text { (of fact, of law) }\end{array}$ \\
\hline 6. & over & too much & conducting / overrule \\
\hline 7. & post & after & posthumous work \\
\hline 8. & pro & in favour of & pro-rata distribution \\
\hline 9. & re & again or back & $\begin{array}{l}\text { redevelopment bonds, redress, reformation, registration } \\
\text { statement, removal, repayment of supplemental } \\
\text { unemployed compensation benefits, replacement fund, } \\
\text { reportedcases, reporting requirement, representation }\end{array}$ \\
\hline 10. & sub & under & $\begin{array}{l}\text { condition subsequent, correspondential subaccount, } \\
\text { subrogation, subscribe for (shares), subsequent authority } \\
\text { (or ratification), subsequent condition }\end{array}$ \\
\hline 11. & under & not enough & undercapitalization, understated, undertaking, underwriting \\
\hline
\end{tabular}

Юридик терминларнинг архаизм, неологизм хамда ўзлашма сўзлар асосидаги тахлили замонавий асосий хуқуқий тизимлар терминлари лотин, юнон, араб, санскрит, япон, хитой, форс, немис, француз, швед ва бошқа тиллардан ўзлаштирилганини кўрсатади. Шу билан бирга баъзи терминлар уч тилдан хам ўзлаштирилган. Масалан: пэр (французча pair, инглизча peer, лотинча - teng).

Фуқаролик-хуқуқий фаолият йўналиши терминларидан сервитут (лот. «servire» - хизмат кўрсатиш), жиноий-хуқуқий фаолият йўналиши терминларидан алиби (лот. alibi - бошқа жойда), экспертиза - (лот. «response» - «жавоб»; «expertus» «тажрибали, тажрибадан билувчи»), (лот. sanctio-қатъий қарор), амнистия (юнон. amnestia - кечириш, гунохдан ўтиш), тадбиркорлик-хуқуқий фаолият йўналиши терминларидан кредит (лот. creditum - ишонмоқ), банкротлик (итал. - синган курси) бошқа тиллардан ўзлаштирилган.

Инглиз тилидан ўзбек тилига ва ўзбек тилидан инглиз тилига таржима қилиш усуллари (калькалаш: тўлиқ калька ва ярим калька, эквивалент таржима, транслитерация, изохли таржима) ёрдамидаюридик терминларнинг синтактик-деривацион хусусиятлари аниқлаштиришни тақозо қилади. Компетенциявий ёндашув асосида юриспруденциянинг давлат-хукуқий, фуқаролик-хуқуқий, жиноий-хукуқий, тадбиркорлик-хуқуқий, халқаро- 
хуқуқий фаолияти бўйича юридик терминларни ўқитиш методикаси махсус сохавий контекстда такомиллаштирилган.

Юридик матнлар хуқуқни ифода этувчи ва мухим юридик ахборотни тарқатувчи, юридик хужжатларни матн хусусиятларига эга бўлган алохида тил бирликларини узз ичига олади. Функционал вазифасидан қатьий назар юридик матнларда алохида тушунчалар қўлланадики, бу тушунчалар фақат шу сохага тегишли бўлади: theft, criminal defense, the witness, the judge, prosecutor, investigator ва х.к.

Изохли таржима аслиятдаги бирор сўз ёки бирикманинг таржима қилинаётган тил лексикасида варианти ёки эквиваленти мавжуд бўлмаган холда таржима жараёнида унинг изохи, яъни ушбу бирлик ифода этаётган тушунчанинг тасвири қўлланиши сифатида тушунилади. Масалан, денонсация - шартноманинг амал қилишини тугатиш ёки шартноманинг ўзида кўрсатилган тартиб ва муддатларда ундан чиқиш усули; инкорпорация давлат ички қонун чиқариш хужжатида халқаро хуқуқ нормаларининг аниқ, айни матн холида акс эттирилиши; деливери ордери (delivery order) - муайян туркумдаги товарни бундай ордерни тақдим этган шахсга бериш лозимлиги хақида омбор эгасига берилган фармойиш (коносамент ёки омбор гувохномасининг сохиби берадиган фармойиш); амнистия - кечириш, хотирдан чиқаришни билдирувчи халқаро атамага айланган; ажрим суд томонидан чиқариладиган процессуал хужжатлардан бири, суд қарорларининг бир тури сифатида қаралади; алиби - айбланувчи ёки гумон қилинувчининг жиноят содир этилган вақтда жиноят жойида бўлмаганлигини ва бу вақтда бошқа жойда бўлганлигини тасдиқловчи факт.

Хулоса қилиб айтганда, хорижий тилларга ўқитишнинг лингводидактик асослари «методология», «лингводидактика» ва «технология» тушунчалари тахлилини тақозо қилади. Лингводидактика тил(лар)ни ўргатиш назариясининг умумий қонуниятларини ишлаб чиқади, тилни ўргатиш/ўрганишнинг методологик асосини изохлайди. Бунда тил таълимининг мақсадлари, мазмуни, методлари, принциплари, воситалари назарий жихатдан тахлил қилинади. Чет тилини ўқитишда замонавий лингводидактиканинг тенденциялари чет тилини ўқитиш мақсади, методологияси, прагмалингводидактикадан иборат бўлиб, таълим олувчининг компетенцияларини шакллантириш ва ривожлантириш имконини беради.

Хуқуқий тизимнинг ўзига хос хусусиятлари хўжалик суд ишларини юритиш, хакамлик судлари фаолияти, халқаро шартномаларнинг таснифланиши, жиноят-ижроия хуқуқий муносабатлари, фуқаролик ишлари бўйича процессуал хужжатлар, фуқаролик хуқуқи, сайлов хуқуқи, оила хуқуқи, адвокатлик фаолияти, тадбиркорлик хукуқий муносабатлар, жиноят процессуал хуқуқи, солиқ хуқуқи, халқаро молиявий-хуқуқий муносабатлар асосида тахлил қилинди. Шунингдек, бакалавриат босқичида юридик кадрларни тайёрлаш соха мутахассисликлари бўйича юридик терминларни ўрганишни тақозо қилади.

\section{Фойдаланилган адабиётлар рўйхати}

1. Лингводидактика как теоритеческая основа обучения языку. Электронный ресурс: https://works.doklad.ru/view/NRkF6riOIeo.html. Дата обращения: 22.04.2018.

2. Тенденции современной лингводидактики в обучении иностранным языкам. Электронный ресурс: http://stud.wiki/languages/2c0b65635a2ad78b5d53b88521216d27_0.html. Дата обращения: 22.04.2018.

3. Irisqulov M.T. Tilshunoslikka kirish. - T.:Yangi asr avlodi, 2009. - 364 b. - B. 46.

\section{THE ROLE OF SOCIOLINGUISTIC IN INTERCULTURAL COMPETENCE}

\section{G. Sh. Salomova $(U z S W L U, P h D)$}

Annotation: Intercultural competence of person is a set of ideas, knowledge about another culture formed through skills, devices, behavioral models that provide a successful system of communication with other cultures. This article is described in the form of highlighting the 
knowledge and skills related to the effective conduct of intercultural competence communication processes. Sociolinguistic skills, like speaking and catching the different languages of society, are very important in multicultural world. This article studied the actual theories about sociolinguistic skills as well. Related disciplines such as social psychology, sociology, linguistics, based on their social, historical, cultural significance and showing a perfect example of linguistic connection. Sociolinguistics is analyzed in intercultural communication as the degree to which a person is able to apply and understand verbal and nonverbal methods.

Key words and expressions: Tonverbal manifestations, nonverbal behavior,intercultural competence, sociolinguistics, sociolinguistic perception, semantic environment, verbal abilities.

Clearly, language and culture are different parts of a whole. They are so closely intertwined that one cannot exist without the other. According to W. Bolton, language should be understandable to everyone in society. Because this phenomenon is an invariable component of the personality factor, it plays a key role in a person becoming a human being. To understand the essence of the universe, it is enough to understand the importance of the languages in it [Bolton; 98-p]. A later hypothesis suggests that speakers of different nationalitiesthe reason they don't understand each other is that their understanding of the world and their interpretation of events are different.According to the English scientist S. Kramsch: "They (people) unite in the understanding of the external and internal essence of concepts" [Kramsch; 66-p]. It is natural that there is, of course, a connection between language and culture. Many scholars have come to a consensus on the subject, that once the custom has been practically applied by all the members of the new language, the use of the symbol, which can give them a sense of belonging to that society, has made it possible. Today, language remains the only means of uniting people with a large number of nationalities.

According to Western scholars, the main basis of intercultural competence is sociolinguistic competence. It is no coincidence that most of the researchers who have conducted research on this issue are linguists. In our opinion, it would be expedient to analyze the issue of sociolinguistic competence from the socio-psychological point of view, as in all social sciences.

Every participant of intercultural relations realizes from the first moment of entering into a relationship that knowledge of foreign languages alone is not enough. In order to effectively continue this relationship and achieve the intended goal, it is necessary to know certain norms of behavior, environmental psychology, the social causes of the situation. Finally, it is important to have a good understanding of the mechanisms of the communication process, which in turn helps partners to avoid the problem of misinterpretation of each other, predict conflicts and misunderstandings [Yankina;132-p]. Russian and Western psychologists, culturologists, linguists have conducted a number of studies on this problem (Liddicoat JSC, 2006; Lapkin., 1995; Swain M., 1995; Stefanenko T.G., 1997; Utalieva J.T., 1997; Hammer MR, 1998; Baker S., 1993; M. Bennet, S.Crozet, 2006; S.Kramsch, 2007).

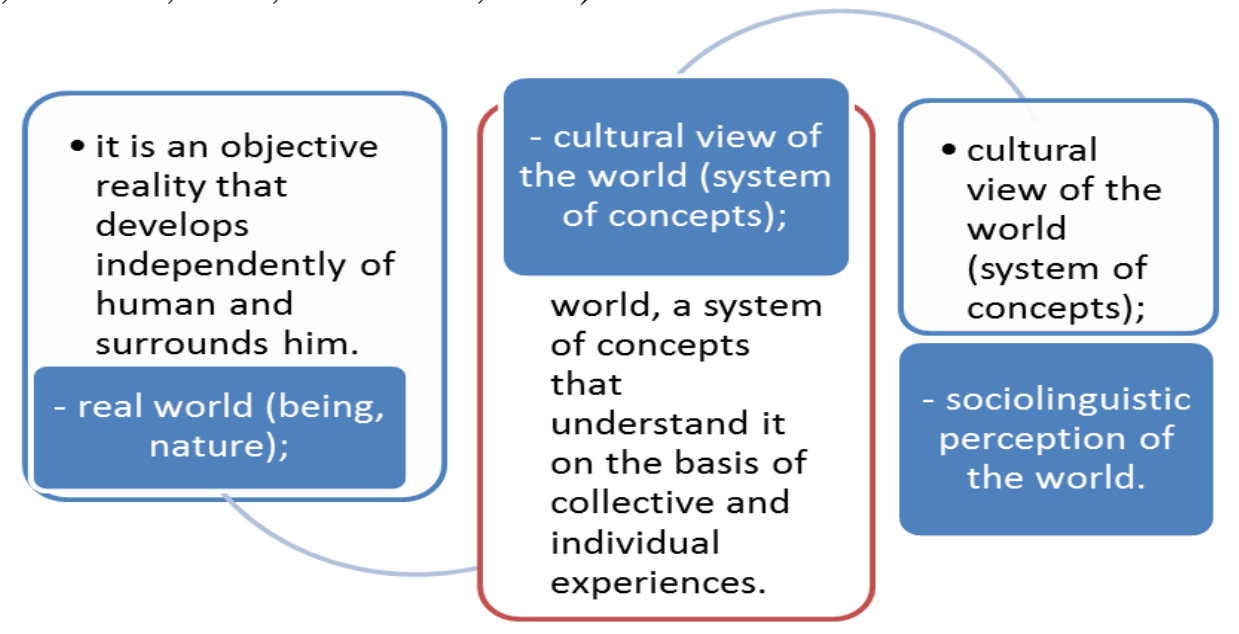

Figure 1. 
When intercultural competence is studied from the sociolinguistic process, the main idea is expressed in the ability to properly organize and effectively communicate between different generations (large and small), different groups, different nationalities. In approaching intercultural competence, the sociolinguistic approach should first focus on the nonverbal form of communication, which is a specific feature of each culture. Sociolinguistic analysis is important in the analysis of the content of nonverbal manifestations in the semantic environment of a particular culture for the development of intercultural competence. In this process, the method of expert feedback emerges as an invaluable resource in the acquisition of competence. Any member of the culture who can interpret its nonverbal behavior and symbolic significance will be an expert.The human environment can be thought of in three ways:

- real world (being, nature);

- cultural view of the world (system of concepts);

- sociolinguistic perception of the world.

Undoubtedly, the cultural view of the world is much richer than its sociolinguistic view. But only in language does culture take on a verbal character. Simply put, language expresses culture through tone. It should also be noted that each nation has its own tone of speech.

This is how the real view of the universe differs from other views. It will be the same for all nations and peoples. That is, nature and being, the events that take place in it, have the same effect on all mankind. It is also worth mentioning the individuality of culture and language, as well as their similarities. Evil and war are condemned in different cultures, both Eastern and Western. The words "family", "child", "loyalty", "responsibility", "duty" are of great importance. Insults that are shouted in different languages also vary in tone, even if the meaning is vague. The word is not just the naming of objects, but a piece of truth that reflects all the existing attributes of cultural life.

\section{The list of used literature}

1. Bolton,W. Language andits study.-Seul: Hyung-SeulPublishing. 1998.- 298 p.

2. Chomsky N. Review of Verbal behaviour by B.F.Skinner. - Language. - 1959. - 426 p.

3. Kramsch.C. Languageand culture. - Hong Kong: Oxford University Press, 1998. -313 p.

4. Янкина Н.В. Формирование межкультурной компетентности студента университета. Автореферат дисс-и на получение докторской степени по педагогики.Оренбург.,2006-42c.

\section{ТQМ - СИФАТНИ ЯЛПИ БОШКАРИШ ТАМОЙИЛЛАРИ АСОСИДА ПЕДАГОГ КАДРЛАРНИ ТАЙЁРЛАШ МАЗМУНИ}

\section{А. А. Мустафақулов \\ ( ЖПИ, PhD)}

Annotation: Inthearticle are considered modern trends of management quality of preparing the pedagogical personnel staff in high educational institutions. As well as, there are enlightened the scientifically-pedagogical essence of quality, quality of education, notions of management quality formation, concepts of TQM-Total quality management, as well as, trends of the practical trainings in high educational institutions, the foreign practice on preparing the pedagogical personnel staff on the base of the trends of the Total quality management and empirical level in this article.Besides, there are given some offers and recommendations on thepreparing the pedagogical personnel staff in the Total quality managementconditionsin this article.

Key words and expressions: TQM - Total quality management, quality, quality of education, the management quality formation, trends of management quality;

Мамлакатимизда таълим ва кадрлар тайёрлаш тизимини жамиятдаги демократик хуқуқий давлат қурилиши, замонавий тенденциялардан келиб чиқиб модернизациялаш, педагогик фаолиятнинг нуфузини ошириш, таълим муассасаларини аттестациядан ўтказиш 
ва аккредитация қилиш тизимини ривожлантириш, таълим даражаси ва сифатини таъминловчи норматив, моддий-техника ва ахборот базасини яратишга йўналтирилган ислохотлар педагогика йўналишидаги олий таълим муассасаларида ўқув жараёнлари сифатини бошқариш механизмлари ва педагог кадрлар тайёрлаш мазмунини тубдан такомиллаштиришдаилғор тажрибаларни кўллаш имкониятларини кенгайтирмоқда. Халқ таълими тизимини 2030 йилгача ривожлантириш концепциясида «педагогика, дидактика, амалий педагогик психология, методика каби фанларга алохида эътибор қаратган холда, ўқув материалларини ва педагогик бахолашни ишлаб чиқиш орқали педагог кадрлар тайёрлаш тизимини такомиллаштириш» каби вазифалар белгиланган [ПФ-5712. 2019:4].

Бу эса педагогика олий таълим муассасаларида таълим сифатини бошқариш тизимини, унинг амалий компонентларига TQM (Total Quality Management) концепцияси тамойилларини кўллашга оид илмий-услубий таъминотини такомиллаштиришни тақозо этади.

Илмий-педагогик адабиётларда таълим тизимини бошқаришнинг методологик ёндашувлари сифатида тизимли-фаолиятли, синергетик, коммуникатив, маданиятшунос-лик, шахсга йўналтирилган ва бошқалар таъкидлаб ўтилади[Лазарев В.С. 2002:304].

Тизимли-фаолиятли ёндашув адаптив таълим тизимининг яхлитлик даражасини аниқлаш имконини бериб, унинг мақсадлари ва мазмуни билан бовлиқ таркибий элементлари уртасидаги ўзаро бовлиқлик ва алоққадорлик даражасини белгилаб беради.

Синергетик ёндащув эса объектнинг табиий уизини ўзи ташкил этиш хусусиятини инобатга олишни тақозо этади. Коммуникатив-диалогик ёндашувга кура самарали натижаларга эришиш учун таълимнинг барча субъект ва объектлари ўзаро тенг муносабатларга асосланган алоқ̧ада бўлиши тавсия этилади.

Маданиятшуносликка оид ёндашув эса аниқ фанлар доирасида таълим жараёнида мутахассислик, умуммаданий ва психологик-педагогик билимлар блокини, маданиятнинг умуминсоний ва миллий асослари, шахс ривожланиши қуонуниятларини бир-бири билан узвий боглаган хуолда урргатишни тақоозо этади.

Шахсга йўналтирилган ёндашув таълим жараёнида хฺар бир шахснинг табиий ўзига хос жихатларини инобатга олиш, ўз қобилият ва имкониятларини юзага чиқариш учун барча шароитларни яратишни билдиради [Толипов Ў., Усмонбоева М. 2005:205].

Илмий-педагогик адабиётларда олий таълим тизимига оид қуйидаги тамойиллар келтирилган:

олий таълим тизимининг бўлажак мутахассис шахсини ривожлантиришга йўналганлик тамойили;таълимнинг узлуксизлик ва узвийлигини таъминлаш тамойили;таълим жараёнини ахборотлаштириш ва техник таъминлаш тамойили;олий педагогик таълим мазмунининг фантехника ва ишлаб чиқариш (технология)нинг замонавий ривожланиш тенденцияларига мослик тамойили;олий таълимда ўқув жараёнини ташкил этишнинг умумий, гурухли ва индивидуал шаклларини оптимал ташкил этиш тамойили;мутахассислар тайёрлашнинг турли босқичларида ўқитишнинг замонавий педагогик технология, метод ва воситаларидан рационал фойдаланиш тамойили;мутахассислар тайёрлаш натижаларининг касбий талабларга мувофиқлик хамда уларнинг рақобатбардошлигини таъминлаш тамойили [Барабанщиков В.А. 1994:88].

Юқорида келтирилган умумпедагогик тамойилларга таянган холда педагогик кадрларни ялпи сифат бошқаруви тамойиллари асосда тайёрлаш жараёнига хос махсус тамойиллар билан бойитишга харакат қилдик. Таъкидлаш жойизки, педагогика фанида таълим сифатини бошқариш тамойилларига етарлича эътибор берилмаган.

Илмий-педагогик адабиётлар хамда илмий тадқиқотларни тахлил қилиш натижасида биз педагогика олий таълим муассасаларида таълим сифатини бошқариш тизими самарадорлигини қуйидаги фалсафий, фанлараро ва хусусий тамойиллар мажмуаси таъминлаши мумкин деган хулосага келдик.

Интегративлик тамойили. Фалсафа фанида интеграция тушунчаси тизимнинг алохида қисмлари ва функцияларининг уззаро бир бутунликка бирлашиши хамда ушбу 
холатга келтирувчи жараённи англатувчи тушунча сифатида талқин этилади [Фатхутдинов P.A. 2005:5].

Интегративлик тамойили,

биринчидан, педагогика олий таълим муассасаларида таълим сифатини бошқариш жараёнининг барча компонентлари яхлитлигини таъминлашга хизмат қилади (таълим субъектларининг хуқуқий муносабатлари, таълим сифатини бахолаш объектлари, таълим сифатини бошқариш мақсадлари, тамойиллари, методлари ва воситалари);

иккинчидан, ушбу тамойил таълим сифатини бахолаш кўп субъектлиги, таълим натижаларининг кўп даражалилиги, таълим сифатини бахолаш экспертларининг субъективлиги ва бошқа таълим сифатини бошқариш жараёнини тарқоқликка олиб борувчи омилларнинг салбий таъсирини бартараф этади.

Фикримизча, интегративлик тамойилини педагогика олий таълим муассасаларида сифатни бошқариш амалиётига жорий этиш ўқув жараёнини компетенциявий ёндашув асосида ташкил этишни юзага келтиради:

таълим модуллари доирасида аниқ компетенцияларни шакллантиришга йўналтирилган билим, кўникма ва малакаларни, фаолият тажрибасини комплекс ўзлаштириш имконини берувчи ўқув материалларини компетенциявий модулли ташкил этиш;

давлат таълим стандартларининг талабаларда компетенциялар мажмуасини шакллантириш, бутун хаёти давомида билим олишга йўналтирилган авлодини яратиш ва амалга ошириш («long life education»).

Шундай қилиб, интегративлик тамойили ўқув жараёнини компетенциявий ёндашув асосида ташкил этишни юзага келтириши билан бир қаторда олий таълим муассасаларида таълим сифатини бошқаришнинг барча даражаларини яхлит холда бирлаштириш имкониятини беради: ОТМда олиб борилаётган илмий-тадқиқот ишларини таълим жараёни ва ишлаб чиқа-риш билан интеграциялаш, таълимнинг анъанавий ва инновацион методлари ва шаклларини, умумий ва касбий билимлар назарияси ва амалиётини, турли хил ўкув фанларини муаммоли-тематик ва мақсадли, бошқаришнинг давлат ва жамоат субъектлари фаолиятини интеграциялаш ва х.к.

Педагогика олий таълим муассасаларида таълим сифатини бошқариш борасида иккинчи мухим тамойиллардан бири бу таълим сифатини бошқаришда экспертларнинг ижтимоий шериклик тамойилидир. Ушбу тамойилни танлашимизнинг сабаблари қуйидагилар билан изохланади:

биринчидан, бу олий таълим муассасаларида таълим сифатини давлат компетент экспертлари томонидан (Таълим сифатини назорат қилиш давлат инспекцияси экспертлари, таълимни бошқариш давлат органлари мутахассислари) бахоланиши;

иккинчидан, бу таълим сифатининг жамоатчилик-касбий институтлар экспертлари томонидан бахоланиши (олий таълим муассасаларида ташкил этилган жамоатчилик кенгашлари);

учинчидан, бу - таълим сифатининг олий таълим муассасаларни бошқариш субъектлари (таълим муассасаси рахбарияти, профессор-ўқитувчилар, таълим олувчилар ва уларнинг ота-оналари) томонидан бахоланиши, бошқача қилиб айтганда, таълим дастурларини амалга ошириш шарт-шароитларининг, таълим эхтиёжларининг қондирилиш имкониятларининг, академик ва касбий мобилликнинг бахоланиши.

Тадқиқотимиз давомида олий таълим муассасаларида таълим сифатини хамкорлик асосида бошқариш тамойили илмий-назарий асосланди.

Олий таълим муассасаларида таълим сифатини хамкорлик асосида бошқариш тамойили. Ушбу тамойил бир томондан, таълимни бошқариш органлари, махаллий давлат бошқарув органлари, ўз-ўзини бошқарув органлари, хукуқ-тартибот органлари, жамоат ташкилотлари ва оилалар манфаатларини мувофиқлаштириб, таълим сифатини амалдаги қонунчилик, давлат таълим стандартлари ва халқаро стандартлар асосида таъминлашдир. Иккинчи томондан, олий таълим муассасаларида ташкил этилган таълим сифатини назорат қилиш бўлимининг жамоатчилик кенгаши, мониторинг ва ички назорат бўлими, ўқув- 
услубий бошқарма, проректорлар, факультет деканлари ва кафедра мудирлари билан таълим сифатини таъминлашдаги хамкорлигини назарда тутади.

Таълим сифатини бошқаришнинг амалий даражасини таъминлашга қаратилган тамойиллар тизими TQM-сифатни ялпи бошқариш концепциясига асосланган бўлиб, ISO 9001:2001 халқаро стандартлари асосини ташкил этувчи маълум саккизта тамойилни ўз ичига қамраб олади: истеъмолчиларга мўлжалланганлик тамойили (customer focus); таълим муассасаси рахбариятининг етакчилик тамойили (leadership); таълим муассасаси ходимларининг барчасини жалб қилиш тамойили (involvement of people); олий таълим муассасаларида бошқарув қарорларини аниқ далиллар асосида қабул қилиш тамойили (factual approach to decision making); тизимли ёндашув асосида бошқариш тамойили(system approach to management); таълим сифатини доимий равишда яхшилаш тамойили (continuai improvement); олий таълим муассасалари ва буюртмачиларнинг ўзаро манфаатдорлик тамойили (mutually beneficial supplier relationships); бошқарувга жараён сифатида ёндашиш тамойили (process approach) [ISO 8402: 1994:38].

Таълим сифатини бошқаришнинг тактик даражасига хос бўлган тамойиллар тизими антропологик ёндашувга асосланган ва талабаларнинг индивидуал хусусиятларини хисобга олиш, креативлик, экологик каби тамойиллар орқали ифодаланади.

Маданиятшунослик, шахсий-фаолиятли ёндашувлар асосида таълим сифатини бошқаришга доир тамойиллар қаторига педагогик жараёнларнинг талабанинг ноёб шахсига мўлжалланганлик, диалогга асосланганлик хамда таълимнинг талабага маданият орқали қаратилганлик каби тамойилларни киритиш мумкин.

Педагогика олий таълим муассасаларида таълим сифатини бошқариш борасида яна бир мухим тамойиллардан бири бу таълим жараёнини мақсадли лойихалаш асосида ташкил этишдир. Ушбу тамойилни танлашимизга, биринчидан, таълимнинг гностик «билимлар»га асосланган парадигмасининг бугунги ахборот асрида замонавий талабларга жавоб бермай қолганлиги ва мақсадли лойихалаш самарадорлигининг тобора ортиб бориши, иккинчидан, олий таълим сохасида инновацион лойихаларнинг қўллаб-қувватланиши билан изохлаш мумкин.

\section{Фойдаланилган адабиётлар рўйхати}

1. Ўзбекистон Республикаси Президентининг 2019 йил 29 апрелдаги «Ўзбекистон Республикаси халқ таълими тизимини 2030 йилгача ривожлантириш концепциясини тасдиқлаш тўғрисида»ги ПФ-5712-сон Фармони.

2. Барабанщиков В.А. Методы окулографии в исследовании познавательных процессов и деятельности. - М.: 1994. -88 с.

3. Фатхутдинов Р.А. Инновационный менеджмент:-СПб.: Питер, 2005.

4. Лазарев В.С. Системное развитие школы. -М: Пед.общество России, 2002 - 304 с

5. Толипов Ў., Усмонбоева М. Педагогик технология: назария ва амалиёт. - Т.: Фан, 2005. - 205 б.

6. ISO 8402: 1994 (E/F/R) Управление качеством и обеспечение качества. Междунар. организация по стандартизации, 1994. - 38 с.

\section{“一带一路”视域下高素质涉俄法律人才培养模式探究 " \\ BIR MAKON - BIR YO'L" NUQTAI NAZARIDAN YUQORI SIFATLI RUSLARGA TEGISHLI HUQUQIY ISTE'DODLARNI TAYYORLASH MODELINI O'RGANISH.}

付国印，硕士研究生 黑河学院 ( 党委 ) 校长办公室(Fu Guoyin, Heilongjia)

\footnotetext{
Annotation: The proposal of the strategic concept of "Belt and Road Initiative" has opened a new window of opportunity for the countries along the route to complement each other's
} 
advantages. At present, the team of foreign-related legal service personnel can not adapt to the high-level opening-up pattern and the increasingly diversified demand for foreign-related legal services, and colleges and universities should enhance their sense of responsibility and sensitivity to the national strategy, according to the needs of the construction of "Belt and Road Initiative" strive to fulfill the mission and responsibility of personnel training. Adhere to the line of training international legal talents and inject more fresh blood into China's "Belt and Road Initiative" initiative.

Key words and expressions: "Belt and Road Initiative", foreign-related, legal talents, training, mode

涉外法律服务人才队伍是我国参与国际治理体系的重要战略资源，“一带一路”战略提 出以来，涉外法治工作快速发展，涉外法律服务人才队伍建设也有了长足的进步，在维护我 国公民和企业海外权益、促进对外开放等方面发挥着越来越重要的作用，这也为中国法律专 业改革带来了极好的机遇，同时也面临着挑战，对相关问题的研究迫在眉睫。在“一带一路” 战略框架下，构建培养高素质涉外法律人才有着重要的现实意义。

一、涉俄法律人才培养目标

高素质涉外法律人才既具有较强的外语能力和扎实的法学功底，未来能够在国际机构 、涉外部门以及处理涉外法律事务的律事务所工作的优秀人才”; “涉外型人才应当具备较高 的外语水准和在国际事务中运用法律知识解决问题的能力，成为在中外交往中传达中国声音 、表达中国立场、维护中国利益、并能够在国际场合自如交往的优秀人才”。上述观点是当 前学界对涉外法律人才培养标准的典型代表。按照这种观点，外语水平和法学功底是基础， 运用所学法律知识处理国际事务是关键。基于此，一种成熟的涉外法律人才培养模式应该符 合上述标准。 [ 张法连,赵永平 2019:13 ] 高素质涉俄法律人才应具备较强的俄语听、说、读 、写、译的言语实践能力，具有扎实的俄语语言基础知识和熟练运用俄语的基本技能，对俄 罗斯原文法律文件及学术论文有较好的阅读理解能力，了解俄罗斯及独联体相关国家的国情 、文化知识，掌握民商法的基本原理，了解中俄两国的主要法律制度和与国际贸易相关的国 际公约，能根据中俄两国的法律规定和国际条约起草、审查中俄贸易合同、合作协议，避免 损失，减少摩擦，能够从法律的视角分析、解决贸易及合作中出现的问题，促进贸易持续发 展。

\section{二、涉俄法律人才基本能力要素}

培养法律功底扎实、俄语能力突出的涉俄法律人才是助推“一带一路”战略的现实需要 。然而，这里必须清楚以下几个问题：第一，如何保证学生的法律功底扎实；第二，如何确 保俄语水平；第三，如何才能做到熟练运用法律技能解决实际问题。如果能够满足上述几个 问题，就能够确保涉俄法律人才培养目标的实现。

（一 ) 法律功底。法律功底必须用母语学习，当学生处于本科阶段时，重点是打好法 学的根基，唯有如此才能保证学生在将来的学习中有坚实的基础。我们知道，时代在发展， 社会在变化，人们的观念也会随之发生改变。世界上任何一个国家的法律都不可能是一成不 变的，而是处于不断的发展变化之中。法律的变是常态，不变才是例外。尽管制定法在变化 ，但隐含于制定法背后的法理却具有相对的稳定性，也就是所谓的万变不离其宗。掌握了基 
本的法理、民事法律的基本精神和原理、刑事法律的基本规则等，可以确保学生能够以不变 应万变。这种法学基本原理的学习，恰恰需要用母语在国内的法科教育中完成。当前，国家 大力推广卓越法律人才计划，按照新的卓越计划制定的培养方案，学生既能掌握基本原理， 又能增强法学的实践能力，这是涉俄法律人才培养之根基。

( 二 ) 俄语水平。在建设中俄经济走廊时，就应该有熟练掌握俄语的法律人才为保障 。毕竟在上述沿线国家中，法律文本的制定是以自己国家的语言为载体的。也就是说，涉俄 法律人才语言方面的培养，应该充分考虑不同法学院校特点，突出语言培养，体现出涉俄法 律人才的特色。[于洋 2019:51] 以黑河学院学院为例，这里毗邻俄罗斯，对俄罗斯的地缘 优势，可以转化成语言优势。那么，如何保证培养的涉俄法律人才具备较高的俄语水平呢? 笔者认为，在本科阶段培养涉俄法律人才时，某一门语言仅仅是基础，俄语的教学不是重点 。俄语水平的提高应该放在国外实现。在笔者提倡的“国内本科+国外硕士”的培养模式中， 俄语学习主要放在了学生选择的相应留学国进行。在具备语言环境的条件下学习俄语，可保 证涉俄法律人才应具有的俄语水平。

(三) 解决问题的能力。至于培养的涉俄法律人才能够熟练运用所学法律知识解决实 际问题，这需要学生在完成上述学业后，在实践中逐渐掌握。毕竟法律是一门实践学科，没 有经过实践的锤炼，不可能成长为一名真正的理论与实践相结合的法律人才。按照“国内本 科+国外硕士”的涉俄法律人才的培养模式，由于学生接受了系统的国内法学教育，其中包括 实践课程方面的训练，已经掌握了实践所需的基本技能，因此，这种培养方式为高素质涉俄 法律人才的培养提供了成功的保障。 [ 吴晓明,孙盛达 2019:127 ]

\section{三、对“国内本科+国外硕士”涉俄法律人才培养新模式的探索}

笔者以黑河学院的实践为例进行阐述如何具体推行“国内本科+国外硕士”的卓越涉俄法 律人才培养模式。

(一) 留学对象。按照“国内本科+国外硕士”的涉俄法律人才培养模式挑选法学专业四 年级的学生出国进行语言培训。法律系学生大四之前，基本上可以修完全部的本科教学培养 计划课程，完成公共课、专业必修课及专业选修课的教学内容，并获得相应的学分。在大四 阶段一般只需撰写学位论文，其他在大四开设的几门选修课，可允许学生在大三时和其上一 届的学生一起完成，这样可以保证学生在大四时，只需完成学位论文就行了。学位论文可以 由指导老师通过邮件的方式对学生进行指导，完成毕业论文后，学生只要按照学校的教学要 求，回国参加答辩即可。并且，按照黑河学院的课程设计，学生在大学的一到三年级，已经 打下了一定的俄语基础。因此，大三结束后既出国参加语言培训，不会对学生本科课程的学 习造成影响，而且还为学生提供了充足的专门学习语言的时间，为其本科毕业后顺利进人俄 罗斯高校从事硕士课程的学习，打下坚实的语言基础。

（二）去俄时间。学生去俄学习的时间通常为每年的 9 月末。这是由以下三个因素决 定的：一是按照司法部的规定，大三结束后，学生便可参加司法考试。国家统一司法考试的 时间大致在每年的 9 月中旬。司法考试对一个法律人而言，有着极为重要的作用，即便是出 
国学习的法科学生，也应该通过该考试，为将来职业的发展创造条件。二是一部分法律专业 的学生同时选修其他专业的双学位，而双学位考试时间为每学期开学的第二个教学周。选在 9 月末，可以兼顾选修双学位学生的考试问题。三是俄罗斯高校一般在 9 月 1 日开学，这样 也兼顾了俄罗斯高校的开学时间。可以说，把去俄时间定在每年的 9 月末。是对多种因素综 合考虑的结果。

(三 ) 法律系课程的调整与学校的政策支持。为了用大四的时间让学生有可能去俄罗 斯提高语言，法律系在课程设置上要尽可能把必修课和选修课排在大三之前，并让打算出国 留学的学生，在大三时将大四开设的选修课程提前修完。这需要法律系和学校政策上的支持 ，为涉外法律人才的培养模式开绿灯。同时，此人才培养模式的实现，需要学校的鼎力支持 。具体而言，一是学校外事处要广泛联系俄罗斯著名院校，为学生提供最为优越的语言学习 环境，同时，也要考虑该院校的法科水平。我们的经验是，学生在某一学校学习语言后，往 往会选择该校继续读研究生。二是为学生争取最优惠的学习条件。尽管国家有支持学生出国 学习的奖学金，俄罗斯也每年为中国学生赴俄学习提供一定的奖学金名额，但这种公费留学 的名额毕竟十分有限。学校一方面要在国内积极争取获得公费名额，另一方面要与俄罗斯合 作方积极联系，争取给前去学习的学生一个最为优惠的学习条件。三是学校在公共选修课程 的开设要突出俄罗斯特色。应开设俄罗斯文化、政治、历史、国情等相关的课程，帮助学生 在去俄之前就已经对俄罗斯有所了解，并能够尽快地融人俄罗斯社会。

“国之交在于民相亲”，通过各院校结合自身实际开展高素质法律人才培养工作，定能 培养出一批能够讲好中国故事、运用法律手段处理好国际事务的涉外法律人才。“国内本科+ 国外硕士”模式的推行，是对高素质涉外法律人才培养模式的新探索，必将为“一带一路”战 略的实施，培养出多元、知识结构合理、实际应用能力较强的高素质法律人才。

\section{参考文献 :}

1. 于洋.“一带一路”倡议下青年法律人才培养研究[J].新长征(党建版). 2019,(12).

2. 吴晓明,孙盛达 浅谈涉外法律人才实践能力培养[J].中国市场. 2019,(34).

3. 张法连,赵永平新时代背景下法律翻译人才培养问题探究[J].译苑新谭.2019,(2)

\section{“一带一路”视域下的经贸俄语课程教学改革与实践 " \\ BIR MAKON - BIR YO'L" NUQTAI NAZARIDAN RUS TILI KURSI ISLOHOTI VA IQTISODIY VA SAVDO AMALIYOTINI O'RGATISH.}

王东敏，硕士研究生 a

\section{黑河学院外国语学院俄语系(Van Dongmin, Heilongjia)}

Annotation: With the deepening of the "Belt and Road Initiative"strategy, the economic and trade cooperation between China and the countries along the route has been deepened, and the demand of enterprises for business Russian talents is also increasing. "Economic and Trade Russian" is a compulsory course for business Russian majors. At present, the teaching concept of this course in many schools is backward, the method is single, and the effect is not good, which is 
far from meeting the needs of employers for business Russian talents. For the reason, we should innovate teaching ideas and contents, strengthen practical teaching and the cooperation between schools and enterprises, so as to train more compound talents of business Russian who can meet the needs of the market, and actively participate in the construction of "Belt and Road Initiative".

Key words and expressions:"Belt and Road Initiative", economic and trade Russian, teaching reform, talent, demand

建设“丝绸之路经济带”和“21 世纪海上丝绸之路”是党中央、国务院洞察全球形势深刻 变化，统筹国内国际两个大局做出的重大战略决策。目前中国已经同 138 个国家和 30 个国 际组织签署 200 份共建“一带一路”合作文件，共同开展了超过 2000 个合作项目 ; 中国与沿 线国家货物贸易累计总额超过了 7.8 万亿美元，对沿线国家直接投资超过了 1100 亿美元。其 中，俄罗斯、土库曼斯坦、哈沙克斯坦等俄语国家与中国关系保持高水平运行，共建“一一带 一路”合作成果丰硕，同时将进一步加强发展战略对接，深化经贸、能源、财金、投资、互 联互通等各领域合作，从“一带一路”建设视角考察经贸俄语教学改革，毕定推动中国与沿线 国家经贸合作提质升级，为“咝绸之路经济带”建设注入强劲动力。

一、“一带一路”视域下经贸俄语人才需求现状

人才是“一带一路”建设的支点和关键。教育的成败关乎人才的成败，进而关系到经济 建设的成败，“一带一路”战略在对 30 多年来我国人才培养进行检验的同时，也为未来新一 轮教育的改革和开放提供了宝贵的机遇。高等院校应提升对国家战略的责任感和敏感性，根 据“一带一路”建设的需要，努力履行人才培养的使命与责任。调查表明，在 2020 届普通高 校外语外贸类毕业生就业洽谈会上，“一带一路”沿线国家的小语种人才需求量加大，结合沿 线国家的经贸交流合作研究金融创新、自贸区建立、通关便利化等，着眼于国际谈判方式差 异及冲突解决，精通外语、通晓国际商务礼仪与国际法律的复合型人才更为缺之，“小语种+ 专业课”成为很多毕业生的竞争优势。“一带一路”发展理念的提出,直接促进着高等院校外语 专业的发展与革新,也为教育工作指明了方向。 [ 安巍 2016:59 ]

从总体上看我国商务外语教学仍处于快速发展阶段，其中经贸俄语是商务外语教学中 的小语种，经贸俄语教学改革远远落后于市场需求，比如许多学校的商务俄语专业都没有引 入俄语电子商务之中，电子商务的俄语教学仍比较少。再如，许多商务俄语专业的人才培养 质量较差，学生往往缺之必要的俄语应用能力，不能很好地适应各种商务活动。在这种情况 下应当从“一带一路”建设的宏观背景出发考察商务俄语教学问题，探索推进商务俄语教学改 革的基本思路。

\section{二、“一带一路”视域下经贸俄语课程教学改革}

《经贸俄语》是俄语专业必选课程，其主要目的在于全面提高学生的俄语综合知识水 平及实践应用能力，提升学生的整体素养，培养俄语专业学生实际运用俄语知识、提高俄语 实践能力，扩展学生的知识面，使学生在毕业后能胜任对俄经贸工作，自如地从事相关业务 。因此从“一带一路”视域考察经贸俄语课程教学问题，推动课程教学理念及内容创新有重要 意义。 
(一) 完善教学理念。当前经贸俄语教学发展滞后与教学理念落后、教学方式不合理 等有着密切联系，所以应当从企业用人需要、俄语教学规律等出发创新课程教学理念，建构 以需求为中心、以学生为中心的课程教学理念。首先，应当从“一带一路”战略的宏观背景确 定人才培养目标，制定教学大纲，满足“一带一路”战略对商务俄语人才的需要。其次，应当 树立以学生为中心、以能力培养为目标的学理念。在应试教育思维和传统教学理念影响下， 许多教师仍以灌输式、讲授式等方式开展教学，忽视了学生的主体性和创造性，不能很好地 促进学生的课堂参与，所以应当树立以学生为中心的教学理念，从学生的学习基础、就业需 要、兴趣爱好等开展教学活动，提高经贸俄语教学的针对性和有效性。 [ 杨柳 2017:45 ]

(二 ) 调整教学内容及方法。当前应当从“一带一路”建设、“一带一路”人才需要的高度 出发调整经贸俄语课教学内容，使其能够很好地适应“一带一路”战略的需要，更好地推动中 国与俄语国家的贸易交往。比如可以从中俄跨境电商快速发展的背景出发，在经贸俄语教学 中增加跨境电商的内容，培养更多精通电子商务的复合型商务俄语人才。此外，应当提高学 生的就业创业能力、俄语应用能力等为加强课程内容建设，建立以能力培养为中心的教学内 容。最后，在教学中教师应当注重案例讲解、实践应用等，通过多媒体技术、虚拟现实技术 以及经贸情景剧等为学生营造生动形象的应用场景，以更好地培养学生的实践能力和应用能 力。

\section{(三 ) 将课程思政融入教学}

将课程思政融入教学，为参与 “一带一路”建设提供理想信念坚定的人才。在教学中， 深度挖掘课程思政内涵，满足俄语专业学生成长发展需求和期待，将学生个人发展与社会发 展、国家发展结合起来，激发学生为民族学习的热情与动力，帮助学生明确自身的价值与定 位。例如，“物流”这一章节，教师上传教学资源，下达学习任务：(1) 相关术语单词与词 组，为本章节讲述打下基础，提高课堂学习效率，同时扩大学生单词量，持之以恒，积微成 著；（2 ）上传“一带一路”、“中欧班列”、“人类命运共同体”理念的相关视频，了解中国方 案，中国外交；上传《中国物流》光影三十年，了解物流发展史，培养学生工匠精神，做到 知识传授与价值引领的结合；（3）通过篮选俄罗斯网站相关资源，上传网页链接： Китайскаялогистика | Жизнь и работа в Китае 了解俄罗斯人眼中的中国物流业; 上传超链接 Rustou，了解对俄跨境贸易综合服务体系俄速通相关情况，了解物流行业前沿，培养职业素 养与理想信念。

\section{三、实践活动改革}

经贸俄语教学是一门实践性很强的教学活动，对教学实践性、应用性等具有较高要求 ，然而在传统教学理念指导下许多教师片面重视理论教学、知识教学等，忽视了学生的实践 能力培养。为此应当强化本课程的实践教学，在形式多样的实践教学中培养学生的俄语应用 能力。

(一) 强化实践教学活动。在经贸俄语教学中，为了更好地培养学生的实践能力、俄 语应用能力等，应当在专业教学中开展创新创业教育，让学生在创业环境中积累经验，不断 
提升学生的社会实践能力和自主创业能力等。 [ 杨立明 2016:78] 比如建立实训基地，完善 实训课程的教学评价标准，通过形式多样的实训课程培养学生的实践能力。在实践活动中应 当让学生学习注册跨境电商账号、设计跨境电商物流方案、搜集跨境电商的商业信息、开展 产品宣传活动等，使学生能够掌握各种商贸知识及技能。此外，应当严格按照自主创业的流 程开展创业教育活动，比如通过笔试、面试等方式选拔学生，并根据专业计划组将工作团队 ，让学生联系真实的工作项目，开展商务俄语活动。在这种真实的情景中培养学生的实践能 力和创业能力，比如可以让学生到外贸公司实习，在实习中掌握俄语的应用场景；还可以鼓 励学生自主探索跨境电商业务，在电商交易中应用自己所学习的理论知识。

( 二 ) 开展形式多样的校企合作活动。校企合作是商务俄语实践教学的重要方式，也 是培养学生的岗位适应能力的重要前提。所以应当将校企合作作为商务俄语教学改革的重要 方向，以顶岗实习、订单培养等方式开展形式多样的校企合作。首先，可以邀请商贸企业对 学生进行教育培训。外贸企业管理人员往往有丰富的管理经验和实践经验，熟悉经贸俄语应 用的各种场景，因而学校可以邀请外贸企业管理人员、商贸人员等对学生进行专业培训，提 高经贸俄语教学的实用性和针对性。此外，应当与外贸企业建立定向培养关系，共同制定培 养计划、培养方案等，让学生到外贸企业进行实习学习，这样才能更好地培养学生的实践能 力。

“一带一路”战略是全面推进对外开放的大战略，所以经贸俄语课程教学应当顺应“一 带一路”战略的发展需要，积极推动教学模式、理念、内容等创新，强化课程教学的实践环 节，以培养更多符合对外贸易需要的复合型商务俄语人才。

\section{参考文献 :}

1. 安巍.“一带一路”国家发展战略背景下的商务俄语人才培养模式研究[J].中国俄语 教学,2016(01).

2. 杨柳.“一带一路”背景下就业创业一体化的商务俄语专业特色建设研究[J].高教学 刊,2017(20).

3. 杨立明.“一带一路”背景下的电子商务俄语课程教学初探[J].中国俄语教学, 2016(03).

ТАРЖИМОНЛИК КОМПЕТЕНЦИЯСИ, ШУ ЖУМЛАДАН, ИСПАН ТИЛИНИ

ЎҚИТИШДА ТАЛАБАЛАРДА ТАРЖИМОНЛИК КОМПЕТЕНЦИЯСИНИ

ШАКЛЛАНТИРИШ МЕТОДИКАСИНИНГ ТУШУНЧАСИ ВА УЛАРНИНГ МОХИЯТИ

\section{С . А .Анорбоева

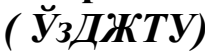

Annotation: The article provides an overview and explanation of learned linguists with brief explanations and recommendations, with theoretical approaches, general principles about the concept of "translation competence", which is currently widely studied and promotes concepts in 
linguistics as well as in preparation for the training of qualified personnel in translation activities, which is currently a relevant topic in the field of Uzbek translation.

Key words and expressions: Translation, translator's competence, types of competence, language norms, semantic content

амонавий тилшуносликда ўрганилаётган кўплаб мураккаб муаммолар ичида тиллараро нутқ фаолиятининг “таржима" ва “таржима фаолияти”ни ўрганиш мухим ўрин тутади. Хар қандай сохада касбий фаолият сифатини бахолаш учун талаб этиладиган мезонлар тўплами мавжуд. Таржима касбида таржимашунос мутахассисларнинг касбий хамда малака даражаларини бахолашда таржимонлик компетенцияси тушунчасига бевосита юзланамиз. Хозирги кунда таржимонлик компетенцияси тушунчасини лингвистика, методология, таржимашунослик, лингвокултурология, психолингвистика ва бошқа чет тиллирини ўқитиш билан бевосита боғлиқ бўлган фанлар таркибида кўп учратмокдамиз.

Жахон амалиётида таржимоннинг касбий компетенсиясини шакллантиришга интергал ёндашув, техник малакалар, тил борасидаги махорат, терминология ва терминографияни такомиллаштириш, таржимон компетенциясини бахолаш, таржима жараёнида икки тил маданиятида сўзлар муқобиллигини топиш, таржимонлар йўл қўядиган типик хатоларнинг олдини олишга қаратилган корректив машқлар тизимини яратиш алохида ахамиятга моликдир. Шу жихатдан таржимон тайёрловчи муассасаларнинг ўқув дастурларида таржимоннинг лингвистик, социолингвистик, прагматик ва маданиятлараро мулоқот компетенцияларини шакллантириш орқали таржимоннинг касбий компетенциясини ривожлантириш заруриятини изохлайди [И.Тўхтасинов 2018:5];

Охирги ўн йиллик давомида таржимонлик компетенцияси тушунчаси таълим сохасида, Европа кенгаши хамда кўплаб чет эл тадқиқотчи олимларининг изланишларида учраб келмокда. Биринчи маротаба “таржимонлик” хамда“компетенция” сўзларини бирлаштириш Исроиллик олим ва таржимон Г.Тури томонидан амалга оширилган бўлиб, у бу ғояни Н.Хомскийнинг “тил компетенцияси”га аналог сифатида яратган[G.Touri 1980];

Таржима компетенциясининг мазмуни тўғрисида олиб борилган анча узоқ мунозаралар жараёнида таржимоннинг ижтимоий, коммуникатив ва матн махоратини тавсифловчи бир нечта субкомпетенциялардан иборат модел пайдо бўлди.

А.Биби ва Д.Энсингерлар томонидан таржимонлик компетенцияларига лингвистик (лексик, грамматик, дискурсив билим, малака ва кўникмалар), таржима назарияси, тил назарияси, маданиятга оид билимлар, таржиманинг махсус сохаларда фойдаланиладиган билимларни ўз ичига олувчи экстралингвистик компетенцияларни, матнни тушуниш, очиш, перефразалаш, шаклини ўзгартиришни ва умуман олганда таржима жараёнини ўз ичига олган замонавий технологияларни билишни, касбий компетенция, диққатни жамлаш, хотирани мустахкамлаш билан боғлиқ, психофизиологик сифатлар - когнитив қобилият, муайян психологик тавсиф, таржима компетенцияси ва бошқаларни киритиш зарурлигини қайд этганлар[И.Тўхтасинов 2018:15];

Ўзбекистонда мустақиллик йилларида таржимашунослик сохасида кескин ўзгаришлар бўлиб келмокда. Хусусан ўз касбининг етук мутахассиси бўлган, замон талабларига тўлиқ жавоб бера оладиган таржимон кадрларни тайёрлашга алохида эътибор қаратилмоқда.Айниқса, Ўзбекистон Республикаси Президентининг 2012 йил 10 декабрдаги ПҚ-1875-сон "Чет тилларни ўрганиш тизимини янада такомиллаштириш чора-тадбирлари тўғрисида"ги қарори қабул қилинганидан сўнг, мамлакатимизда чет тилларни ўқитишга, ўрганишга бўлган эътибор янада кучайди. Шу билан бир қаторда етук таржимон кадрларга бўлган талаб хам ортди. Юртимизда чет тилларни ўқитилишида янгича босқич, янгича давр бошланди. Чет тили дарсларининг ўқитилиши жараёнида илғор педагогик технологияларни, интерфаол, инноватсион усуллардан, коммуникатив-ахборот воситаларидан фойдаланиш талаб қилинмокда. Республикамизда чет тилининг ўқитилиши, чет тили ўқитувчиларининг билим ва кўникмаларини бахолашнинг умумевропа талаблари тавсияномалари (СЕФР) га мос равишда янги усуллар ишлаб чиқилди. Бу эса ўз навбатида таржмашунослик 
мактабининг ривожланишига, яъни таржимоннинг ўзи фаолият олиб борадиган “таржима тили"ни мукаммал даражада билишига олиб келмокда.

Жахонда глобаллашув жараёнлари чуқурлашиб бораётган бир шароитда таржимоннинг касбий компетенсиясини шакллантириш хамда ривожлантиришга бўлган эхтиёж янада ортмоқда. Хар бир сохада профессионал фаолиятнинг сифатини бахолаш учун аниқ белгилаб қўйилган мезонлар тўплами бўлади.

Таржима касбининг вакилларида, хусусан, таржимонларда, профессионал компетенсияга эга малакавий таржимон деб аталиши учун, таржимон ўзида шахсий малакавий компетенсия хамда касбий категорияларнинг малакавий даражасига эга бўлмоғи лозим.

Профессионал компетенсия хамда шахсий малакавий компетенсия, бу хар икки атама дастурий таълим хужжатларида, ва тилшунослик йўналишлари (методология, таржима ишлари, психолингвистика, лингводидактика, лингвокултурология ва х.к.)да кенг қўлланиб келинадиган атамалар бўлиб, одатда синоним тарзида ишлатлиб келинади.

Таржимонлик компетенцияси, шу жумладан, испан тилини ўқитишда талабаларда таржимонлик компетенциясини шакллантириш хозирги кунда етук таржимон тайёрлашда мухим вазифалардан бири хисобланади. Чунки, чет тилини яхши билган хар қандай мутахассис хам таржмон бўлиб қолмайди. Таржимон кенг ампулада ишлай оладиган, ўзида лингвистик, сотсиолингвистик, прагматик ва маданиятлараро мулоқот компетенсияларини шакллантира олган, кенг фикрловчи, нутқи ривожланган, жуда катта сўз бойлигига эга бўлган шахсдир.

Таржимашуносликда олиб борилаётган тадқиқотлар бевосита шуни кўрсатмоқдаки, таржимон таржиманинг лингвомаданий муаммолари, прагматик муаммолар, прогматик ассотсатсия, реалиялар таржимаси, таржимада ассонанс ва диссонанс холатлар, ўқувчига адекват таржимани тақдим этиш долзарб масалалар бўлиб қолмокда.

\title{
Фойдаланилган адабиётлар рўйхати
}

1. И.Тўхтасинов. Таржимон тайёрлашда касбий компетенцияларни эквивалентлик ходисаси асосида ривожлантириш. - Т.: 2018й., - 5 б.

2. Touri G. In Search of a Theory of Translation. - Tel Aviv: Porter Institute, 1980.

3. И.Тўхтасинов. Таржимон тайёрлашда касбий компетенцияларни эквивалентлик ходисаси асосида ривожлантириш. - Т.: 2018й., -156.

\section{ТАЪЛИМ ВА ТАРБИЯ НАЗАРИЯСИДА ДИДАКТИКАНИНГ ТАРИХИЙЛИК ВА ХАЁТИЙЛИК ТАМОЙИЛЛАРИ УЙҒУНЛАШУВИ}

\author{
А.Набиев (ТКТИ Проф. в.б.), \\ К.А.Каримов (ТошДТУ проф.), \\ Б.Каримов (ТошДТУ) \\ Ш.Хайдарова (ТКТИ)
}

Annotation:The article states that the leading factor in creating a favorable innovative environment in the educational process, along with the formation of an environment of didactic and methodological integrity, is education aimed at conformity to the historical and life principles of didactics.

Key words expressions: didactics, competence, independent education, family, maxalla, educational institution, public consciousness, social values, innovative solutions.

Ўзбекистон Республикасини 2017-2021 йилларда ривожлантиришнинг бешта устувор йўналиши бўйича Харакатлар стратегиясида “...талаба-ёшлар таълим-тарбияси учун қўшимча шароитлар яратишга қаратилган комплекс чора-тадбирларни ўз ичига олган бешта ташаббусни амалиётга тадбиқ этиш, жумладан талаба-ёшларни маданият ва санъат, 
жисмоний тарбия ва спортга жалб қилиш, уларнинг компьютер ва интернет технологияларидан фойдаланиш саводхонлигини ошириш, китобхонликни кенг тарғиб қилиш, талаба-қизларнинг касбий кўникмаларини ривожлантириш” устувор йўналиш ва вазифалар белгилаб берилганлиги таълим ва тарбия назариясида дидактик-методологик яхлитлик мухитини шакллантириш билан бир қаторда дидактиканинг тарихийлик ва хаётийлик тамойиллари уйғунлашувига йўналтирилган таълим беришда ғоят мухимдир [1].

Бундай стратегик вазифа-топшириқлар таълим муассасаларида таълим-тарбия борасида қулай инновацион мухит яратиш мақсадида таълимни тарбиядан хеч қачон ажратиб бўлмаслиги, хатто бир лахза хам айри холда тасаввур қилиш мумкин эмаслигини яна бир бор тўлақонли тасдиқлайди. Дархақиқат, таълим-тарбия жараёнлари натижаси кўп миллатли халқимизнинг ўтмишидан далолат бериши билан бир қаторда бугунги ва келажакдаги тақдиримизни хам ўзида тўлақонли мужассам қила олиши билан тавсифланади.

Аслида таълим ёш авлодни назарий билим, амалий кўникма ва малакалар билан куроллантириш, компетенциясини шакллантириш баробарида уларнинг ўқув-билув қобилиятларини ўстириш, дунёқарашларини кенгайтиришга йўналтирилган жараён сифатида педагогика назариясида тавсифланади.

Худди шунингдек, тарбия эса муайян, аниқ мақсад ва ижтимоий тажрибалар негизида ёш авлодни хар томонлама камоллик сари интилишга ундаш, уларнинг она-Ватанга мехрмухаббат ва садоқатли бўлиш, ижтимоий онги, хулқ-атвори, ғурур-ифтихори, дунёқарашини таркиб топтириш жараёни хисобланиб, шахсни мақсадга мувофиқ шакллантириш учун уюштирилган ижтимоий, педагогик-психологик жараёнлар мажмуаси хисобланиб, тарбияланувчиларнинг бевосита шахсига мунтазам ва тизимли таъсир этиш имкониятини яратади.

Ушбу тушунчаларга ижтимоий-педагогик нуқтаи назардан ёндашилса, педагогик жараёнда таълимнинг дидактик воситалари ёрдамида таълим олувчиларга кўрсатилган тизимли (тартибланган, ўзаро узвий боғланган) таъсирини шак-шубхасиз, ижтимоий ходиса деб қараш имконияти яратилади. Табиийки, ушбу ижтимоий ходиса ёки жараённи педагогик технология дейиш хам ўринли ва ғоят ахамиятлидир.

Узлуксиз таълим тизимида янги авлод ўкув адабиётлари “Педагог - услубий ва моддий-техник таъминотлар - таълим-тарбия жараёнлари - ўкувчи ёки талаба”дан иборот яхлит таркибий тузилманинг етакчи компонентларидан бири бўлиб, бир вақтнинг ўзида таълим берувчилар ва таълим олувчилар фаолиятида хам асосий маълумот манбаи хисобланар экан, дарслик яратиш назариясини хеч иккиланмасдан айни вақтда муайян даражадаги таълим-тарбия назарияси сифатида қарашга асос яратилади [2].

Назарийлашган таълим тизимидан бевосита зарурий кўникма-малакалар ва компетенцияларни шакллантиришга қаратилган амалий таълим тизимига ўтилаётган шу кунларда замонавий ахборот ва коммуникация технологияларини таълим-тарбия жараёнларида қўллаш узлуксиз таълим тизимидаги бошқа фанлар сингари умумкасбий фанларда хам ўқув жараёни методик таъминотини ривожлантириш хамда шу ўринда мустақил таълимга эътибор қаратишни талаб этмоқда.

Мустақил таълимнинг асосий мохияти шахс - ўқувчи-талабанинг аудиторияда ва ундан ташқари (Ахборот ресурс маркази, уй, талабалар уйи, кафедра, корхона ва хакоза)ларда бевосита педагог рахбарлигида ёки унинг иштирокисиз якка тартибда ёхуд жамоа бўлиб билим, кўникма-малака, компетенцияларни оширишга қаратилган фаол, босқичма-босқич, йўналтирилган, таркиблаштирилган, тизимлаштирилган хамда бир мақсадга қаратилган фаолиятлар мажмуидан иборат.

Мустақил таълим педагог рахбарлигида ёки унинг иштирокисиз, шунингдек аудиторияда ёки ундан ташқарида амалга ошадими-йўқми, булардан қатъий назар, бу жараёнда педагогик хамкорликнинг роли беқиёсдир. Дарс бериш жараёнини ўқувчиталабаларнинг мустақил ишларига йўналиш бериш тарзида ташкил этмоқ зарур.

Муаллифлар ўзларининг кўп йиллик илмий-педагогик тажрибаларига биноан мустақил таълим самарадорлигига гарчи ўқувчи-талабанинг билим савияси, дунёқараши, масъулият 
билан ёндошуви, фанни ўзлаштириш қобилияти, интилиши, интизомлилиги, фаоллиги, компетентлиги каби инсоний фазилатлари бевосита таъсир кўрсатса-да, бу жабхада педагогнинг фаолияти хам салмоқли эканлигини алохида таъкидлайдилар. Шу ўринда педагогнинг мустақил таълимда тутган ўрнини қисқача изохлаш ўринлидир.

Педагог зиммасига биринчидан, фаннинг асосий мазмун-мохиятини, касб учун мухимлигини ўқувчи-талабаларга аниқ, содда-лўнда тушунтириб, уларда фанга нисбатан қизиқиш уйғотиши, иккинчидан, мустақил таълим учун янги педагогик технологиялар талаблари асосида ўқув-услубий таъминотни яратиш, амалиётда қўллаш ва нихоят, учинчидан эса, мустақил ишларни бошқариш ва назорат мониторингини адолатли, холисона, хаққоний юритиш каби мухим вазифалар юкланган.

Мустақил таълим тарбиявий-таълимий ахамиятга эга бўлиб, ўқувчи-талабанинг умумий ривожланиши ва касбий махоратини ўстиришга хизмат қилади. Тарбиявийлик ахамияти шундаки, таълим олувчи ўзининг билими ва кўникмасини ошириш ва мустахкамлаш баробарида ўзини-ўзини тарбиялаб боради. Таълимий ахамияти эса таълим олувчи бўш вақтдан унумли, самарали фойдаланади. Давлат таълим стандарти ва фан дастурида белгиланган талаблар асосида яратилган фаннинг электрон ўкув-методик мажмуасида мазмунни белгиловчи мажбурий компонентлардан бири ўкувчи-талабага мўлжалланган методик компонентадир. Унинг таркибига мустақил ишларни бажаришга мўлжалланган методик тавсиялар киради.

Энди бевосита мазкур илмий-амалий анжуман доирасида дидактиканинг тарихийлик ва хаётийлик тамойиллари уйғунлашувига таяниб, техника таълим муассасалари мисолида таълим олувчиларда ғурур ва миллий ифтихор туйғуларини уйғотиш мақсадида механика фанининг нафақат мамлакат ижтимоий-иқтисодий-сиёсий ўсишидаги, балки жахон цивилизацияси ривожидаги муносиб ўрнини ғоятда жонли, қизиқарли, асосланган мисолларда ёритилиши, шунингдек фан тараққиётига муносиб хисса кўшган буюк олимлар хаёти ва илмий фаолияти билан ёш авлодни яқиндан таништириш давр талаби эканлиги хусусида фикр-мулохазалар юритамиз.

Таъкидлаш ўринлики, Материаллар қаршилиги фани хам механика фанининг ўзагини ташкил этганлини англаган холда унинг тарихини механиканинг бой тарихи билан чамбарчас боғлиқ холда учта асосий даврга бўлиб ўрганиш мақсадга мувофиқдир.

Қадимий давр механикаси - Аристотел давридан XVI асргача, уйғониш даври механикаси - XVI асрдан XX аср бошигача ва хозирги давр механикаси - XX аср бошидан шу кунгача бўлган даврни ўз ичига олади [3].

Биринчи давр бошида қадимги юнонистонлик қомусчи олим Аристотел (эрамиздан аввалги 384-322-йиллар) ўзининг "Механика" деган асарида механикани бошқа фанлардан ажратган. Юнон олими Архимед (эрамиздан аввалги 287-212-йиллар) ричагга қўйилган кучларнинг мувозанати, жисмларнинг юзаси, хажми, оғирлик марказини аниқлаш усуллари, жисмларнинг сузиш шартлари ва суюқликларнинг гидростатик босими хақидаги таълимотларни яратган.

Шарқ алломаларининг механика ривожига қўшган хиссалари беқиёсдир.

Хозирги замонда ўрта аср шарқ олимларининг биргина статикага оид 50 дан ортиқ асарлари тўғрисида маълумотлар мавжуд. Ўрта аср ислом мамлакатлари олимлари механикани “Илм ал-хиёл” (“Усталик билан ясалган мосламалар тўғрисидаги илм”) деб юритишиб, унда ўша даврга мос механика масалалари кўрилган. Мазмунига мос бўлган энг қадимий асар - Абу Абдуллох ал-Хоразмийнинг (IX acp) “Фанлар калити” китоби бўлиб, унинг алохида боби механикага бағишланган.

Шарқ олимларидан Абу Райхон Беруний (973-1048), Абу Али ибн Сино (980-1037), Улубек Мухаммад Тарағайлар (1394-1449) механика фанининг ривожланишига катта хисса қўшганлар. Беруний ва ибн Сино асарларида харакат (шунингдек, механик харакат), планеталарнинг харакатига оид фикрлар баён этилган. Улуғбек планеталар харакатини, шунингдек Қуёш ва Ойнинг харакатини катта аниқликда хисоблай олган. 
Иккинчи даврда Польшалик улуғ астроном Николай Коперник (1473- 1543) геоцентрик назария ўрнига янги гелиоцентрик назарияни кашф қилиб, унда оламнинг марказида Қуёш жойлашган, Ер хам бошқа сайёралар сингари Қуёш атрофида ва ўз ўқи атрофида айланади, деган фикрларни илмий-назарий жихатдан асослаган. Бу ўринда шуни таъкидлаш мухимки, Абу Райхон Беруний ва Абу Али ибн Синолар хам Н.Коперникдан аввалроқ гелиоцентрик назарияни сифат жихатидан тавсифлаб, улар оламнинг марказида Ер бўлиши мумкин эмас, чунки Ернинг массаси Қуёшнинг массасига нисбатан анча кичик, шу боис оламнинг марказида Қуёш туради ва Қуёш атрофида сайёралар, шу жумладан Ер хам айланиши мумкин, деган фикрларни илгари сурганлар.

Коперник таълимотининг давомчиларидан бири италиялик олим Галилео Галилей (1564-1642) турли хил жисмларнинг бўшлиқ - хавосиз фазода эркин тушишини тажрибалар ёрдамида ўрганган, Ерга нисбатан ихтиёрий бурчак хосил қилиб отилган жисмларнинг харакати хақидаги масалани тахлил этган. Бундан ташқари, моддий жисмлар харакати устида ўтказилган тажриба-кузатишларни умумлаштириб инерция қонунини яратган.

Галилео Галилей биринчи бўлиб ташқи кучлар таъсирига брусларнинг қаршилик кўрсата олишини бахолаш мақсадида ўзига хос хисоблашларни бажарган. Хусусан, кўндаланг кесими тўғри тўртбурчакли бруснинг эгилишга қаршилиги кесим юзасининг баландлиги квадратига тўғри мутаносиб боғланишда эканлигини аниқлаган, аммо материалларнинг физик хоссаларини эътиборга олмаганлиги боис, мутаносиблик коэффициентининг қийматини аниқлашда хатоликларга йўл кўйган. Шунинг учун адабиётларда 1638 йилдан Материаллар қаршилиги алохида фан сифатида пайдо бўлганлиги қайд этилган.

Галилео Галилей ва унинг издошлари ғояларини инглиз олими Исаак Ньютон (16431727) ривожлантириб, тезланиш ва кучнинг мутаносиблиги, таъсир ва акс таъсир тенглиги, бутун олам тортилиши каби механиканинг энг мухим, асосий қонунларини кашф қилган.

Шунингдек, механика фанининг турли сохалари ривожланишига Р.Гук, Т.Юнг, Ж.Д'аламбер, М.Шал, Л.Эйлер, М.Ломоносов, М.Остроградский, П.Чебишев, Ф.Ясинский каби олимлар хам мухим хисса қўшганлар.

Учинчи давр А.Эйнштейннинг (1879-1955) махсус (1905) ва умумий (1916) нисбийлик назариялари пайдо бўлиши билан бошланади. Замонавий конструкциялар яратишда, хусусан Ернинг сунъий йўлдошларини, космик кемаларни учириш, уларни Ой сиртига кўндириш, Марс ва Плутон сайёраларига яқинлашиш, уларнинг фотосуратларини олиш, космик кемалар ёрдамида Ердаги фойдали қазилма бойликларнинг хариталарини тузиш, космонавтика ютуқларини халқ хўжалигининг турли сохаларида қўллашда механика фанининг қонун ва қоидалари беқиёс ахамиятга эга.

Шу жихатдан қараганда механиканинг қонун ва қоидалари асосида яратилган кашфиётлар, хусусан Н.Жуковскийнинг (1847-1921) аэродинамикага оид илмий асарлари, К.Циолковскийнинг (1857-1935) ракета назарияси, суюқ ёнилғида ишлайдиган ракета двигатели назарияси, И.Мешчерскийнинг (1859-1935) ўзгарувчан массали жисмларнинг харакати назарияси, С.Королёв (1906-1966) рахбарлигида яратилган баллистик ва геофизик ракеталар, Ернинг сунъий йўлдошлари ва турли космик кемалар, таниқли ўзбек олимларидан Х.Рахматулиннинг (1909-1988) иншоотлар заминини лойихалаш ва хисоблашда, кема зирхи мустахкамлигини аниқлашда қўлланиладиган "Рахматулин тўлқинлари” назарияси, М.Ўрозбоевнинг (1906-1971) ип механикаси ва иншоотларнинг зилзилабардошлиги назариясига оид илмий изланишлари, В.Қобуловнинг (1921-2008) туташ мухитлар механикаси масалаларини алгоритмлаш, автоматик бошқариш тизимларини яратишга оид илмий ишлари, академик Т.Ширинқулов (1937-2009) ва академик Т.Р.Рашидов (1936 йилда туғилган) ларнинг илмий ишлари механика фанининг амалий ахамиятга эга бўлган кўп тармоқли фан эканлигини тасдиқлайди.

Механиканинг турли йўналишлари ривожига муносиб хисса қўшган Х.Х.Усмонхўжаев, Ж.Ф.Файзуллаев, Я.Н.Мубораков, Р.И.Каримов, Ё.У.Саатов хамда айни пайтда механика сохасида мухим инновацион ечимлар олиб, амалиётга жорий этаётган М.М.Мирсаидов, 
К.С.Абдурашидов, Б.М.Мардонов, Ш.Маматқулов, Ғ.Хожиметов, М.Эргашов сингари таниқли олимларимизнинг хаёти ва илмий-педагогик фаолияти билан ёш авлодни яқиндан таништириш давр талабидир.

\section{Фойдаланилган адабиетлар рўйхати}

1. Мирзиёев Ш.М. Буюк келажагимизни мард ва олижаноб халқимиз билан бирга курамиз. -Т.: "Ўзбекистон" НМИУ, 2017. -488 б.

2. Набиев А. Техника таълим муассасалари учун янги авлод ўқув адабиётларини яратиш технологиялари ва улардан фойдаланиш методикаси // Монография. -Т.: "IQTISODIYOT DUNYOSI", 2020. -352 b.

3. Nabiyev A. Materiallar qarshiligi (nazariyalar va masalalar) // Darslik. Qayta ishlangan va to'ldirilgan 3-nashr. -T.: "Navro'z" nashriyoti, 2019. -412 b.

\section{САДРИДДИН АЙНИЙНИНГ ТАЬЛИМ-ТАРБИЯГА ОИД КАРАШЛАРИ ВА МАКТАБЧИЛИК ФАОЛИЯТИНИНГ ИЖТИМОИЙ МОХИЯТИ}

\section{К.П.Исламова (СамДЧТИ)}

Annotation: The article highlights the social and philosophical essence of Sadriddin Ayni's pedagogical activity, aimed at raising the morale of the people in the context of a complex historical process on the basis of the ideas and directions of Jadidism.

Keywords: "Sifliy", "Muhtojiy", "Jununi", "Aini", Young Bukhara, Jadid schools, Tatar schools, Bukhara Revolution, enlightenment, enlightened reformer, political struggle, progressive, Jadid movement, democratic clergy.

XIX асрнинг сўнги чорагида туғилиб, XX асрнинг ўрталарига қадар яшаб ижод этган Садриддин Айний ўзбек ва тожик адабиётлари тараққиётига муайян хисса кўшган зуллисонайн ёзувчидир. У мансуб бўлган ёзувчилар авлоди халқ ва жамият хаётидан узоқлашиб қолган мумтоз шарқ адабиётига янги тўлқин беришга, уни янги тарихий даврнинг ғоялари билан бойитишга интилди. Маърифатпарвар отаси қўлида дастлабки таълимни олган. Муаллиф хаёти ва фаолияти унинг “Қисқача таржимаи холим”, “Эсдаликлар”, маърифатпарварлик ва жадидчилик фаолияти даври эса "Бухоро инқилоби тарихи учун материаллар" асарида атрофлича баён этилган[1].

Садриддин Айний Бухоро мадрасаларида тахсил олган йилларда (1890- 1891) “Сифлий”(Паст), “Мухтожий” ва “Жунуний”(Телба) каби турли тахаллуслар билан дастлабки шеърларини ёзди. У 1896 йилда илк бор “Айний” тахаллуси билан ижод қила бошлайди. Адибнинг шахсан эътироф қилишича, “Айний” номининг турли китобларда 48 хил маъноси кўрсатилган[2:55].

Садриддин Айний 1890-1899 йилларда Бухородаги мадрасаларда тахсил кўриб, ўз даврига яраша пухта билим эгаллайди. Калкутта, Боғчасарой, Уфа, Оренбург, Қозон сингари шахарларда нашр этилган газета ва журналлар билан танишиш, айниқса, Фитратнинг Туркияда босилиб, Бухорога яширин равишда юборилган-“Мунозара”, “Сайёх хинд қиссаси” сингари асарларини мутолаа этиш бўлажак ёзувчининг дунёқарашида инқилобий ўзгаришларни вужудга келтирди. У амирлик тузумининг чириганини, мамлакатни бошқариш усулини янгилаш, демократик ислохатлар ўтказиш ва халқ оммасини маърифатлаштириш зарурлигини сезди. Садриддин Айний шу тариқа жадидчиликнинг ёрқин намоёндаларидан бирига айланди. Илк жадидчиликнинг асос марказий муаммоси, замонавий мактаб ва замонавий маълумот эди[3:134-136]. Садриддин Айнийнинг XX acp бошида ёзилган қуйидаги шеърида жадидчиликнинг ўша пайтлардаги ижтимоий манзараси ифодаланган:

Мактабсизлик бизни қилди яп-ялонғоч,

Мактабсизлик бизни этди талон-тарож,

Мактабсизлик Турон элини ўлдирди оч, 
Кўзингни оч, бу хурликдан мактабга қоч.

Садриддин Айний Ёш бухороликлар партияси аъзоси сифатида Бухородаги жадид мактабларини ташкил этишнинг дастлабки ташаббускорларидан бири эди. Садриддин Айний “Бухоро инқилоби тарихи учун материаллар” асарида ёзишича, 1908 йил 23 октябрда Бухоро шахрининг Дарвозаи Саллоххона гузарида жойлашган Мирзо Абдулвохид Мунзим (Бурхонов) уйида форсий (тожик) тилида янги усул мактаби очилади ва унга Мирзо Абдулвохид Мунзим муаллим этиб тайинланади[4:32]. Бой болаларни пулли, камбағал болаларни бепул ўқитади.

Садриддин Айнийнинг ўзи то 1908 йил, Мирзо Абдулвохид Мунзимнинг янги усул мактаби очилгунига қадар, Бухородаги татар мактабларида (масалан татар вакилларидан Холид Бурнашев, Низом Собитовларнинг мактаблари) ишлаб, дарс бериш ва ўқитиш йўлларини ўрганган. Садриддин Айний “татар мактабида олти ой ишлаб, тажриба орттирдим”[4:29]- деб, қайд этган эди. XX аср бошларида Бухорода бошланғич мактабнинг тўрт синфдан иборат бўлишини маърифатпарвар адиб Садриддин Айний биринчи бўлиб талаб қилиб чиқади. С.Айний шахснинг камолоти ва жамият тараққиётида маърифат ролини юқори ўринга кўяди. Халқнинг иқтисодий, ижтимоий ахволини ахоли ўртасида маърифат тарқатиш йўли билан яхшилаш мумкин деб хисоблайди. Шунинг учун хам у “Фан халққа бойлик келтиради”[5:26]- деб, ёзган эди.

Бироқ, Мирзо Абдулвохид Мунзим ва Садриддин Айний томонидан очилган янги усул мактаби узоқ фаолият юритмайди. Хар иккала тараққийпарварлар таъқиб остига олинади. С.Айний 1910 йилда Ёш бухороликлар томонидан тузилган “Тарбияи атфол” (“Болалар тарбияси”) яширин жамиятига аъзо бўлади ва унинг ишларида фаол иштирок этади.

“Бухоройи шариф” ширкати муассислигида Садриддин Айнийнинг жадид мактаблари учун ёзган “Тартиб ул-Қуръон” (“Қуръони Карим”ни ўқиш ва талаффуз қилиш қоидаларини ўрганишга бағишланган китоб”), “Заруриёти диния” (“Диний китоб”) ва ижтимоий ва тарбиявий ахамиятга эга бўлган “Тахсиб ус-сибён” (“Болалар тарбияси”) номли ўқиш китоблари дастлаб 1909 йилда Оренбургда нашр этилди. Садриддин Айний “Тахсиб уссибён” дарслигини Исмоил Гаспринскийнинг "Хўжаи сибён” (“Болалар муаллими”) китобидан таъсирланиб ёзади. 1914 йилда Ёш бухороликлар ташкил этган "Маърифат кутубхонаси” томонидан бу китоб 1917 йилда Самарқандда иккинчи марта нашр этилди.

Садриддин Айнийнинг Бухородаги жадидчилик харакати ва жадид мактабларида олиб борган фаолияти мураккаб ижтимоий-сиёсий жараёнлар кечган даврга тўғри келади. Бу пайтда амирликда юзага келган ислохотчилик ва жадидчилик харакатлари унинг дунёқарашида кескин ўзгаришлар ясади. Мутаассиб рухонийлар ва амирлик хукуматининг Ёш бухороликларга қаттиқ қаршилик кўрсатиши кабилар уни ўз ғоя ва мақсадларини қаттиқ туриб химоя қилишга чақирди.

1917 йилда Ёш бухороликларнинг мамлакатда кенг ислохотларни амалга ошириш учун олиб борган курашлари, Бухорода юз берган 1917 йил апрель намойиши ва унинг фожеали оқибатлари, бошдан кечирган азоб- уқубатлари хусусида, Садриддин Айний ўзининг “Бухоро инқилоби тарихи учун материаллар" асарида келтириб ўтади. 1917 йил апрель ойининг бошларида Амир Саид Олимхон Бурхониддин қозикалон ўрнига Ғиждувон қозиси вазифасини бажариб турган тараққийпарвар Шарифжон Махдумни қозикалон мансабига, Чоржўй қозиси бўлган Абдусамадхўжани раис лавозимига, Вобкент қозиси Офоқхўжани муфти аскар лавозимига, Низомиддин Мусаннифни эса Ғиждувонга қози этиб тайинлайди. "Ушбу азм ва мансаблар билан гуёки амир ўз хукумати кабинетини ўзгартирганди". Насрулло қўшбеги топшириғига биноан, 1917 йил 7 апрель куни Бухородаги амир қароргохи бўлган Арки Олийда Амир Саид Олимхоннинг ислохот тўғрисидаги фармони қозикалон Шарифжон Махдум томонидан йиғилганларга ўқиб эшиттирилади. Бироқ орадан кўп ўтмай амир ўз фармонини бекор қилиб, мутаассиб уламолар фикрини қўллаб-қувватлади. 1917 йил Бухородаги апрель воқеалари Садриддин Айнийнинг амирлик ижтимоий-сиёсий тизимига нисбатан нафратини ошириб юборди. 
Ўзи гунохсиз, ўз халқи, миллати учун фидойи бўлган тараққийпарвар ва маърифатпарварларнинг фожиали тақдири, хусусан, укаси Сирожиддиннинг зиндонга солинганлиги ва қатл этилганлиги, ўзининг 75 дарра зарбидан сўнг Когон касалхонасида даволанганлиги, дўсти Мирзо Нарзуллонинг вафот этиши, кўплаб жадидлар, тараққийпарвар ёшларнинг қийноқларга солиши, ўлдирилиши унга қаттиқ рухий таъсир кўрсатди[6:№2209]. Бу фожеали воқеликлар Садриддин Айний хаёти ва фаолиятида туб бурилиш ясади.

Бухорода кечган сиёсий воқеалар туфайли Садриддин Айний 1917 йил июнда Самарқандга кўчиб ўтди. Бу шахарда Махмудхўжа Бехбудий, Саидризо Ализода, Вадуд Махмуд, Сиддиқий Ажзий, Саидахмад Васлий, Абдуқодир Шакурий каби ўз даврининг таниқли маърифатпарварлари ва зиёлилари билан яқиндан танишди. У Самарқандда биринчи педагоглардан Абдуқодир Шакурий ва Рахматулла Исматуллаевларнинг хонадонида яшади, кейинроқ жадидлардан Вадуд Махмуднинг синглисига уйлашиши, жадидлар билан алоқаларининг мустахкамланиши, жамиятни ижтимоий ривожлантириш борасидаги қарашларини кучайтирди.

Садриддин Айний 1918-1920 йилларда Самарқандда таълим сохасида фаолиятини давом эттириш билан бирга инқилобий рухда тарихий ва публицистик мақола хамда шеьрлар ёзди. Унинг мақола ва шеърлари "Хуррият", “Мехнаткашлар товуши”, “Зарафшон” ва “Шуълаи инқилоб” (“Инқилоб шуъласи”), “Болалар йўлдоши”, “Таёқ” каби газета ва журналларда босилган. Бу хақда Садриддин Айнийнинг ўзи шундай ёзган: “Самарқандда тожик тилида "Шуълаи инқилоб" журнали ва "Мехнаткашлар товуши" номидаги ўзбек тилида газета нашр бўларди. Мен буларнинг иккаласига хам хизмат қилардим. Ўша вақтларда махаллий кадрлар етишмас, озчиликни ташкил қилар эди, шунинг учун хам мен бу журнал ва газетанинг кўп қисмини турли имзолар билан мақолалар ёзиб тўлдирар эдим. Икки тилда шеър ёзардим, икки тилда мақолалар ёзардим”[7:91].

Садриддин Айнийнинг қизи, адабиётшунос олима Холида Айнийнинг ёзишича, 1919 йил 13 июлдан бошлаб икки йилу беш ой ичида “Шуълаи инқилоб” журналида Садриддин Айнийнинг 67 та мақоласи эълон қилинган[8:63].

У 1921-1923 йилларда БХСРнинг Самарқанддаги консулхонасида маслахатчи сифатида ишлади. 1923 йилда БХСРнинг Самарқанддаги консулхонаси тугатилгач, 1923 йилнинг охирида Бухгосторг - “Бухоро давлат савдо ташкилоти”га мудир қилиб тайинланди. БХСР хукумати Садриддин Айнийни моддий ва маънавий жихатдан кўллаб турди. Хукумат рахбари Файзулла Хўжаев имзоси билан 1923 йил 13 сентябрда бу борада махсус қарор қабул қилиниб: "Ўртоқ Айнийнинг инқилобий харакатдаги хизматларини ва Бухоро мехнаткаш оммасининг фойдаси учун узоқ йиллик фаолиятини хисобга олиб, шахсий нафақа белгилаш таклиф этилсин. Секретариатга ўртоқ Айнийга хат билан мурожаат қилиш топширилсин, бундан кейин ундан ўзини фақат адабий фаолиятга бағишлаш сўралсин”[9:46] - деб кўрсатма берилганди.

1921-1925 йилларда С.Айний Самарқандда нашриёт ва тахрир ишларида фаол иштирок этади. 1931 йилда Тожикистон Марказий Ижроия Комитети томонидан Мехнат Қизил Байроқ ордени билан мукофотланди. 1935 йилда у адабий фаолиятининг ўттиз йиллиги муносабати билан Тожикистон хукумати томонидан енгил машина билан тақдирланди. 1926 йилдан 1933 йилнинг сентябрь ойига қадар Самарқанддаги Тожикистон нашриёти бўлимида адабий мухаррир, илмий ва адабий маслахатчи бўлиб ишлайди.

1927 йилда Самарқандда Олий педагогика институти (хозирги СамДУ) ни ташкил этишда, айниқса ушбу олий ўқув юртида ўзбек мумтоз адабиёти кафедрасини ташкил этилишида Садриддин Айний ва Абдурауф Фитратнинг хизматлари катта. 1943 йил ноябрь ойида Ўзбекистон ССР Фанлар Академияси ташкил этилиб, академикликка сайланганлар орасида Садриддин Айний номзоди хам бор эди. Ўзбекистон ССР ФАнинг фахрий академиги, 1948 йилдан бошлаб филология фанлари доктори, профессор Садриддин Айний СамДУда 1946 йилдан 1950 йилгача фаолият юритди. У адабиёт кафедрасига мудирлик қилди ва университетда бир қанча олимлар етишиб чиқишига куумаклашди. “Мен ўз ижодимни ёшларга бағишлайман. Мен ёшларга ёрдам беришга хамма вақт тайёрман. Хатто 
ўз ишимни бир ёққа қўйиб, уларга ёрдам бераман. Лекин мен чарчамайман ва ёшларни мусобақага чақираман”[2:87] - деб фаолиятидан чуқур фалсафий мохиятга эга фикрни ёзган эди олим. 1951 йилда Тожикистон Фанлар академияси ташкил этилгач, Садриддин Айний унинг биринчи президенти этиб сайланди. У икки марта СССР Олий Совети депутати (1950; 1954 йилларда), 2-чақириқ Тожикистон ССР Олий Совети депутати бўлиб фаолият юритди.

Садриддин Айний Файзулла Хўжаев билан узоқ йиллар дўстона ва хамкор бўлиб келди.

Файзулла Хўжаев хукумат рахбари сифатида Садриддин Айнийни маънавий ва моддий жихатдан кўллаб-қуватлаб келди. Унинг маслахати ва тавсияси билан Садриддин Айнийнинг қизлар мактаби учун ўзбек тилида тузган “Қизбола ёки Холида” асари 1924 йилда ўзбек тилида Берлинда "Камёвиний” босмахонасида хамда йирик тадқиқоти бўлган "Намунаи адабиёти точик” (“Тожик адабиётидан намуналар”) Москвада 1926 йилда нашр этилган.

Садриддин Айний педагогик фаолиятида алохида ўрғу берилиб ўрганиладиган илм бутарих илми хисобланади. Жумладан, ўзининг “Қуллар” романи орқали кууйидаги чукур фалсафий мушохадага эга бўлган фикрни таъкидлайди: «Мен бу романда халқим тақдири хақида, ўтган аждодлар хаёти хақида ёзганман, аммо менинг назарим хеч хам ўтмишга қаратилмаган. Менинг нигохим келажакка йўналтирилган эди. Бу китоб ўтмиш хақида аммо у келажак авлодга ўгитдир. Чунки тарих фақат келажак учун курашиш қуроли бўлгандагина маъно касб этади»[10].

Садриддин Айнийнинг илмий-ижодий фаолиятида "Бухоро инқилоби тарихи учун материаллар" номли асари алохида ўрин эгаллайди. Ушбу асарнинг салмоқли сахифалари 1918-1919 йилларда Самарқандда тожик тилида ёзилган. Кейинчалик олим асарни қайта ишлаб, янги маълумотлар билан тўлдириб, ўша вақтда СССР халқлари марказий нашриёти мудири вазифасида ишлаган, давлат ва жамоат арбоби Назир Тўрақулов (1892-1939) нинг сўз бошиси билан 1926 йил Москвада араб имлосида ўзбек тилида айрим қисқартиришлар билан (260 сахифа, 3000 минг нусхада) “Бухоро инқилоби тарихи учун материаллар” номи остида нашр эттирди.

Олим шарқшунослик ва адабиётшунослик сохасида “Фирдавсий ва унинг Шохномаси хақида", “Шайх ур-раис Абу Али ибн Сино”, “Шайх Муслихиддин Саъдий Шерозий”, “Камол Хўжандий”, “Устод Рудакий”, “Алишер Навоий”, “Восифий ва асари ў “Бадоеъ ул вақоеъ”, “Мирзо Абдулқодир Бедил” каби асарлар ва илмий-адабий мақолаларини чоп эттирган. Садриддин Айнийнинг адабиётшуносликка кўшган мухим хиссаларидан бири, шубхасиз, унинг “Алишер Навоий” номли монографиясидир[11:18].

Садриддин Айнийнинг тожик тилида ёзган “Одина” номли биринчи қиссаси рус тилига таржима қилиниб, 1930 йилда Москвада чоп этилган. 1932- 1935 йиллар давомида тожик ва ўзбек тилларида "Қуллар” романини ёзиб тугатади. Ушбу роман 1934 йилда ўзбек тилида, 1935 йилда тожик тилида босилди. Садриддин Айний 1939 йилда "Судхўрнинг ўлими" асарини ёзади ва бу асар 1946 йилда ўзбек тилида нашр этилди. Ёзувчи “Судхўрнинг ўлими” асарини 1953 йилда қайта ишлаб унга бир қанча янги образларни киритди.

Садриддин Айний тарихшунос олим сифатида "Муқанна исёни" асарини ёзди. У XX асрнинг 40-йилларида оқ кийимлилар ва унинг рахбари Муқанна хақида махсус рисоласини чоп эттирди. Шунингдек, хорижий мамлакатларда "Бухоро” номи билан машхур бўлган ва кенг тарқалган “Эсдаликлар” (1949- 1954) китоби унинг ижодида марказий ўрин эгаллайди. Бу асар қайта-қайта ўзбек, тожик, рус тилларидан ташқари жахоннинг ўнлаб тилларида чоп этилган. Ўз ижоди билан мактаб яратган Садриддин Айнийнинг илмий мероси ва ижтимоий фаолияти хам дунё илмий жамоатчилиги томонидан муносиб эътироф этилган. Жумладан, Қохирада бўлиб ўтган Осиё ва Африка ёзувчиларининг Халқаро конгрессида Садриддин Айний номи буюк олимлар ва ёзувчилар қаторида тилга олинган. Европа олимлари Садриддин Айнийни “Шарқ маданиятини пухта ўрганган буюк билимдон” деб бахолаганлар.

1978 йилда Ўзбекистонда Садриддин Айний таваллудининг 100 йиллик юбилейи муносабати билан машхур давлат ва жамоат арбоблари, тарихчилар, санъаткорлар, адабиётшунос олимлар унинг хаёти ва ижодига оид хотира парчаларини, мақола, хикоя ва 
шеърларни нашр этишди. 1978 йил ЮНЕСКО томонидан “Садриддин Айний йили” деб эълон қилинди[11:8].

Ўз даврида Бухородаги жадидчилик харакатида фаол қатнашиш баробарида мураккаб тарихий жараёнларнинг иштирокчиси сифатида фаолият олиб борган Садриддин Айнийнинг тарих фани тараққиёти хамда бадиий адабиётни ривожлантиришга кўшган хиссаси ва келажак авлодларга ўрнак бўлувчи хизматлари инобатга олиниб, у 2001 йилда Ўзбекистоннинг “Буюк хизматлари учун” ордени билан мукофотланган.

Хулоса қилиб айтганда, Садриддин Айний ижодининг асосий йўналишлари тахлил қилинар экан, у публицист сифатида долзарб тарихий масалаларга оид мақолалар ёзган, тарихчи, шарқшунос, адабиётшунос ва тилшунос олим сифатида фаннинг кўплаб сохаларида тинимсиз изланишлар олиб борган. Педагогик фаолитида эса ёшларни қайси сохада фаолият юритишидан қатъий назар тўғри ва халол мехнат қилишларини ўқтирган. Садриддин Айний Ўзбекистон ва Тожикистонда илм-фан ва маданиятнинг ривожланишида, кадрлар етиштиришда ўзининг муносиб хиссасини қўшди.

\section{Фойдаланилган адабиётлар рўйхати}

1. Садриддин Айний туғилиб вояга етган Бухоро вилояти Ғиждувон туманига қарашли Соктаре қишлоғидаги Айний уй музейи материаллари.

2. Айний С. Қисқача таржимаи холим / Асарлар. 8 жилдлик. 1-ж. - Тошкент: Тошкент бадиий адабиёт нашриёти, 1963. - Б. 55-87.

3. Хайруллаев М. “Буюк сиймолар”, - Тошкент: Абдулла Қодирий номидаги халқ мероси нашриёти, 1997.-Б.134-136.

4. Айний С. Бухоро инқилоби тарихи учун материаллар. - Москва: СССР халқлари марказий нашриёти, 1926. - Б. 29-32.

5. Айний С. Тахсиб ус-сибён. - Самарқанд, 1917. - Сах. 26.

6. Абдулқодир Ш. Ёш бухоролилар хитоби // Вақт. 1917 йил 18 апрель. № 2209.

7. Айний С. Мухтасар таржимаи холи худам / Куллиёт. 16 чилд. Чилди - 1. Сталинобод, 1958. - Сах. 91.

8. Холида Айни. Жизнь Садриддин Айни (краткий хронологический очерк). Душанбе, 1982. - С. 63.

9. Хасанов М. Файзулла Хўжаев. - Тошкент: Ўзбекистон, 1990. - Б. 46.

10. Айний С. «Бир халқ тақдири», «Янги хаёт»(Новое время) журнали 45-нашр, 1951.йил.

11. Темиров Ф. Садриддин Айнийнинг Бухородаги жадидчилик харакатида тутган ўрни ва ижтимоий фаолияти/ тарих фанлари бўйича фалсафа доктори $(\mathrm{PhD})$ диссертацияси автореферати.- Тошкент, 2020.-Б.8-18.

\section{TEACHING EXTENSIVE READING}

\section{T. Elmurodova} (SamDChTI)

Annotation: This article dedicated to the theme which is very important nowadays how to develop reading fiction books among youth.

Key words and expressions: teaching, multiple choice, literature, text, extensive reading, EFL teaching, book, class, advantage, linguistic, level, novel, misapprehension, writers, students.

Turning now to techniques for encouraging extensive reading it will be found that this territory has already been partly covered, in that setting assignments for skimming, or finding one fact in a substantial body of text, involve one kind of extensive reading at least. The practice of extensive reading needs little justification. It is clearly the easiest way of bringing the foreign learner into sustained contact with a substantial body of English. If he reads, and what he reads is of some interest to him, then the language of what he has read rings in his head, the patterns of 
collocation and idiom are established almost painlessly with a range and intensity which is impossible in terms of oral classroom treatment of the language, where the constraints of lock-step teaching and multiple repetitions, however necessary they may be, impose severe restrictions on the sheer volume of the amount of language with which pupils come into contact. Given properly graded readers whose language and subject matter suit the capabilities of the pupils using them, there is no reason why extensive reading should not form a part of regular EFL teaching from the most elementary stages [F.Grellet 1981:55].

Having class sets has the advantage that the teacher can control the rate of progress of all pupils, it is convenient where the class is taught together; particular linguistic or content difficulties can be tackled with the whole class at once; themes, textual structure, character development and so on can be explored in class discussion; technical or historical background information can be supplied to the whole class as necessary. This is perhaps the best treatment for a book which is likely to present difficulty for the class so that it would not be easy and straightforward for them to read the book entirely on their own. It is probably best to set the reading to be done out of class in terms of specific assignments of certain

nominated chapters or sections. Such assignments do not need to be directly sequential through the book, they may be discontinuous. For example in reading the Arabian Nights if the pupils were to pick out only the story of Scheherazade it might be proper to assign only those sections of the book which dealt with her and omit the sections in which the stories she tells are to be found. In this way the basic framework of the book could be made clear. It is valuable more to set specific questions to which answers must be found; four or five are enough. (What story did Scheherazade begin on the second night? Had she really finished the first one?) It is possible by these means to reduce the amount of class time that needs to be given to checking whether the reading has actually been done and in discussing difficulties that may arise, since these usually are quite closely defined by virtue of the work pupils have done, but it is also of course possible to spend a great deal of time on the discussion. In general this should be discouraged and attention focused on the reading and on deriving meaning over the long term [C.J.Brumfit 1977: 35]. A class library system has the advantage that with limited funds available for the purchase of books it is possible to have four copies of ten different titles - and hence the possibility of exposing the pupils to a greater range of language - instead of forty copies of one title. The books are distributed among the pupils, who read them more or less at their own rate. The teacher can exercise as much or little control over this reading, as he wishes. Cards also have the advantage that they are easy to sort and keep in alphabetical order. The same information can equally well be recorded in an ordinary exercise book of course but this somehow seems to lack the effectiveness of index cards. Many teachers find that keeping a class reading chart for the extensive reading done is useful. This shows pupils' names on the vertical axis of a grid and the titles of the books available in the class library on the horizontal axis. As each pupil takes out a book the date is entered on the intersection of his name and the title, when he returns it that date is entered too. Thus it is easy to see at a glance who is reading many titles quickly, and who is reading few slowly and appropriate encouragement can be offered in each quarter. The demands on class time of this class library system may be a little higher than when using class sets but the sheer volume of reading done is likely to be much higher. The pupils' index cards provide a cross check on this record and allow some of the recording to be done out of class time. Books chosen for use in class libraries like this should on the whole be easy for the pupils to read, preferably with high intrinsic interest and the least possible linguistic difficulty one rough guide is that fewer than one word in every one hundred should be unfamiliar enough to require glossing or the use of a dictionary; that level is the extreme upper limit, ideally the pupil should not need to look up any words at all in the dictionary and provided context and intext definition is used this is quite feasible [R.Isaacs 1968:96]. Obviously for both class sets and class libraries of these kind graded or simplified readers are likely to be required. It must be understood that the kind of extensive reading work being discussed here really has very little to do with the study of 'literature'. It appears to be a very common misapprehension that reading a simplified version of Robinson Crusoe or Oliver Twist has something to do with the study of Defoe 
or Dickens as literary artists the fundamental changes in language and even in the organization of material which simplification may involve clearly mean that this is just not so. The fact that 'Robinson Crusoe' and 'Oliver Twist' are famous names may contribute to the motivation of the reader, but literary study of 'great writers' is clearly something which requires substantially greater experience of all that is written in English than can be expected of most pupils, who need the kind of extended exposure to the written medium in English that graded readers are intended to provide [J.P.B.Allen and S.Pit Corder 1974: 87].

Class libraries of the kind suggested here do require some small amount of storage space. Where this cannot be provided in a classroom it is not difficult to fit all the books needed into a small suitcase which may be no more inconvenient to carry about than the average briefcase. Using a school library for extensive reading has the advantage that no storage space is required for books in the classroom and the range of books available to the pupils can be considerably widened, but it does depend on the school library being well organized, with a good stock of books in English including graded and simplified readers such as those mentioned above it needs to be available and open when the class teacher wants to use it, and it needs to have a librarian who is prepared to cooperate with the teacher in promoting the extensive reading programme. In using the school library even the best organized the control and checking of what is read always seems to become more difficult. If borrowing from the library is done in out-of-class time then class time needs to be used to get the reading record up to date unless the librarian is very co-operative indeed. If borrowing from the library is done in class time then the amount of time taken up always seems to be much more than is ever anticipated and it always seems easy for those who most need encouragement and direction to evade it. The school library is probably most useful for that type of extensive reading which relates to study skills, and where skimming and fact finding assignments are set the resources of even a modest library are likely to be far greater than can be conveniently carried into a classroom.

\title{
The list of used literature
}

1. J.P.B.Allen and S.Pit Corder (eds), The Edinburgh Course in Applied Linguistics, Vol. 3, Techniques in Applied Linguistics, Oxford University Press, 1974.

2. C.J.Brumfit, 'The Teaching of Advanced Reading Skills in Foreign languages with Particular Reference to English as a Foreign Language', survey article in Language Teaching and Linguistics: Abstracts, vol. 10, Cambridge University Press, 1977b.

3. F.Grellet, Developing Reading Skills, Cambridge University Press, 1981.

4. R.Isaacs, Learning Through Language, Tanzania Publishing House, Macmillan, 1968.

\section{CRITERIA FOR THE IMPLEMENTATION OF INNOVATIVE METHODS IN THE EDUCATIONAL SYSTEM}

\author{
Bobokulova H. E. \\ (SamSIFL, teacher) \\ Mirzakulov A.Ch. \\ ( SamSIFL, student)
}

Annotation: The specifics of the introduction of innovative activities in the higher education system today, and barriers to innovation are justified. The purpose and main functions of innovative education have been studied. The modern educational system in our country is the result of huge changes in this area in recent years. From this point of view, education is not only a part of today's community, but also one of the most important factors in its development. Thus, it is clear that education is the key factor to behave and instruct the next generation. Previously, innovation issues were considered only from an economical point of view. However, over time, it became certain that the quality of innovative projects needed to be promoted and assessed. This article argues that the solution of pedagogical problems is related to innovative technologies, and the implementation of a number of innovative methods is the requirement of today's educational system all over the world. 
Key words and expressions: higher education, innovation, education, quality, specialist, teacher, innovative technology, cluster method, Oliy Majlis.

The process of education, the formation of skills and abilities is the main means of preparing a person for life and work. In the process of education, information is obtained and the instruction is carried out. Education is a narrow concept of teaching and nursing. But it refers not only to the process of teaching in different types of universities or institutions, but also to the condition of providing information in family, production, industry and other fields [https://uz.wikipedia.org/wiki].

Education, in essence, refers to the process of teaching, that is, the activity of the pedagogue (teacher), in general, the leadership of the student's cognitive, learning activities, and the learning process, that is, the student's activity. The educational process consists of the sum of the activities of the educator - the teacher and the students. In the process of teaching and upbringing, a person's qualities, outlook and abilities grow. Education ensures spiritual inheritance between generations: people's social-historical experiences are passed on to the younger generation.

There are different type theories about education. Some theories view education as a phenomenon that does not depend on the socio-economic structure of community, while others emphasize that education has sort of characters, aimed at the formation of certain political, philosophical, ethical and legal views in each member of society. The purpose of education varies according to the requirements of objective life. Education is a process of internal contradictions that develops dialectically. Education is a powerful factor that shapes a person's cognitive abilities, emotions, and perceptions.

Education can achieve its results only if it has its roots in science and industry, social life, in short, the life fully integrated with internal and related sectors, the deep interaction of science, education and economics, and the state which is able to conduct uninterrupted communication in all aspects and implement it to all spheres of public life will prosper. In particular, our country is doing a lot in the field of education. Increasingly development of the educational system, identification of target areas for the training of specialists with higher education, especially the continuous improvement of professional skills and knowledge of teachers are among the most pressing issues. It is not coincidence that the address of the President of the Republic of Uzbekistan to the Oliy Majlis on the most important priorities for 2019 emphasizes the relationship between science and education, education and socio-economic life.

The radical changes that have taken place in recent years require a rethinking of new innovative approaches, existing views, concepts and attitudes to all spheres of society with a mirror of development and efficiency criteria. Noting that a lot of positive work has been done in the field of education and training during the years of independence, it should be noted that the goals and methods of achieving them can not be clearly defined, labour market requirements are not studied in depth, inconsistencies between supply and demand, social status and aspirations as a result, many serious errors and omissions were also observed. As a result, the requirements of the Law on Education and the National Training Program have not been fully implemented. Reforms in this area were approved on March 14, 2017 "On measures to further improve the activities of secondary special, vocational education institutions", April 20, 2017 "On measures to further develop the higher education system", May 22, 2017 "Higher education" On Measures to Further Improve the Postgraduate Education System ", on August 8, 2017“ On Improving the Activities of the Ministry of Public Education of the Republic of Uzbekistan ", on September 30, 2017" On Establishment of the Ministry of Preschool Education of the Republic of Uzbekistan ". We can see that these decisions cover almost all types of continuing education system. In addition, the "Strategy for further development of the Republic of Uzbekistan in 2017-2021" focuses on radical improvement of education.[Mirziyoyev 2017: 7];

Given the high social significance of pedagogical education in the sustainable development of society, modern requirements, problems in the system and the provision of links between science and education in solving them require the transfer of continuous pedagogical education to a cluster development system. The innovative cluster of pedagogical education is a whole of all types of 
education, research institutes and centres, practice bases, scientific and scientific-methodical structures in the system of continuing education, the joint activity of which allows to raise the system of pedagogical education to a qualitatively new level. [Hripko. 2011: 36] The cluster system unites the entities, each of which carries out separate activities, around a common goal, and at the same time, each entity operates on the basis of a private interest based on a common goal. [Ermakov. 2011: 84] That is, this process is the basis for the development of competency-based education.

Their interests are the basis of spiritual, intellectual, cultural and professional thinking, and that is why such education is the focus. Innovative education is based on a high level of independence of students, its self-management, and requires a high level of knowledge, initiative and technological knowledge of the teacher. [Ishmuhamedov 2008: 24];

In conclusion, the use of innovative educational methods allows to understand the ways and means of solving professional problems from the social and cultural knowledge and skills of their profession (from profession to culture), to try to master the methodology that leads to qualitative changes in their professional activity (from technology to innovative thinking).

\section{List of used literature:}

1. Sh.M.Mirziyoev. Critical analysis, strict discipline and personal responsibility should be the daily rule of every leader. - T .: Uzbekistan, 2017.

2. Ermakov D.S. Competence approach to education // "Pedagogy" -2011. - № 4 - C. 8-16

3. R. Ishmuhamedov, A.Abduqodirov, A. Pardaev. Innovative technologies in education. - T .: Talent Fund, 2008

4. Khripko V.V.Gorizonty intensification and innovation of teaching in the university // «Alma Master» - 2011 № 9.

5. https://uz.wikipedia.org/wiki/Ta\%CA\%BBlim

\section{КОММУНИКАТИВНЫЙ ПРИНЦИП В ПРЕПОДАВАНИИ РУССКОГО ЯЗЫКА}

\section{Гудзина В.А. \\ (БухГУ, старший преподаватель) \\ Турумова T.X \\ (УрГУ, стариий преподаватель)}

Annotation: This article highlights the issue of the communicative principle in teaching Russian as a foreign language. The purpose of teaching a foreign language at the present stage is the formation of the communicative competence of students. The process of globalization of society, changes in its state requires intensive development of problems associated with teaching communication activities. The dominant idea of teaching is the communicative orientation of all types of speech activity.The organization of the educational process is based on the communicative and cognitive needs of students, their requests and interests, taking into account their real psychological capabilities, individual abilities and perception characteristics. The advantages of the communicative principle are also disclosed. The authors also substantiate the need for the development of communicative training programs and the use of a communicative-activity approach to the educational process.

Key words and expressions: Communicative principle, functional principle, approach, competence, concept, speech activity.

В последние десятилетия передовое мировое сообщество пришло к мнению о необходимости формирования многоязычной личности. Современная ситуация, условия сближения культур, выход на мировую арену предполагают многочисленные контакты. Эти потребности определяют важность изучения иностранных языков. В настоящее время знание иностранного языка - это не только атрибут культурного развития человека, но и условие его успешной деятельности в самых разных сферах производства. В связи с этим 
пересматриваются цели и задачи преподавания иностранных языков. Главным становится функциональный принцип обучения. Необходимо научить студентов не только основам иностранного языка, но и научить их с интересом и правильно общаться на другом языке, как в рамках профессиональной тематики, так и в ситуациях повседневной жизни. Студенты должны не только понимать обращённую к ним речь на иностранном языке, но правильно построить своё ответное сообщение. Инновационный подход к обучению позволяет реализовать современные цели обучения - формирование коммуникативной компетенции учащихся и воспитание толерантности в мультикультурном обществе. Действенным импульсом для появления различных подходов к обучению иностранным языкам на современном этапе стало изменение состояния общества, процесс глобализации. Современный этап развития методики преподавания русского языка как иностранного характеризуется интенсивной разработкой проблем, связанных с обучением коммуникативной деятельности. Следует отметить, что характерной чертой последних десятилетий является всё возрастающий интерес к коммуникативному подходу в обучении иностранным языкам.

Если обратиться к истории возникновения и развития методов обучения, коммуникативный метод имел преимущества по сравнению с грамматико-переводным и «реформистским» методами. Во главу угла при коммуникативном обучении ставятся потребности и интересы обучающихся. По отношению к системе обучения обучающиеся выступают в качестве потребителей, и от их потребностей зависит объём учебного курса, его содержание, методика его преподавания. Суть коммуникативной компетенции в том, что учебный курс направлен на формирование строго определённых умений и навыков общения. Текстовой материал служит основой для построения заданных сфер общения. Речь идёт о специализированном и дифференцированном обучении. Задачами коммуникативного обучения являются решение задач общения и формулирование умений и навыков, обеспечивающих поставленные цели и задачи.

Исходя из вышесказанного, можно сказать, что коммуникативная компетенция в самом начале своего развития имела следующие черты: чёткая ориентированность учебного курса на адресата; специализированность и систематичность. Чтобы овладеть коммуникативной компетенцией, нужна коммуникативная практика. Составление и восприятие аутентичных текстов, характерных для определённой сферы общения, - это и есть владение коммуникацией. По мнению сторонников «современной методики нового подхода», сначала формируется общая речевая компетенция. Она впоследствии может стать предпосылкой для развития специализированных компетенций.

Сторонники коммуникативного метода утверждали обратное: целевые компетенции являются следствием, а не условием коммуникативных умений.

Как нами было уже отмечено, обучающиеся идут к общей компетенции через специфические компетенции. Путь специализации и дифференциации форм и приёмов коммуникативного обучения осуществляется следующим образом:

1) путём дифференциации рецептивных и продуктивных умений, что хорошо прослеживается на материале словаря и грамматики. Чтобы овладеть рецептивной компетенцией, словарь усваивается в объёме, необходимом для узнавания лексических единиц в тексте. А такой уровень узнавания лексических единиц недостаточен, чтобы овладеть продуктивными формами общения. Однако существенным являются не различия в уровне владения учебным материалом, а характер этого владения. И рецептивная компетенция, и продуктивная компетенция владения ИЯ различаются содержанием необходимых умений и навыков. К примеру, обучающийся в национальной группе должен знать род существительного данной сферы общения, уметь правильно выбрать единственно правильную форму слова.

2) путём дифференциации по устной и письменной формам речи. Известно, что для любого языка характерны различия между звучащей и письменной речью. В курсах 
аудирования и говорения необходимо обратить внимание на грамматику устной речи, а в курсах чтения и письма на грамматику письменной речи .

3) путём дифференциации учебных курсов, исходя из их внутренней структуры. В коммуникативном обучении единицами усвоения считаются единицы общения. До эпохи коммуникативного обучения занятия строились по принципу усложнения грамматики. Обучение на коммуникативной основе строит учебную работу на материале текстов, причём тексты даются в том виде, в каком они существуют в культуре изучаемого языка. Эти тексты в письменной и в звучащей форме предназначены для целевых сфер общения. Они содержат языковой и речевой материал, необходимый для формирования умений строить текст из целевой сферы коммуникации.

Исходя из вышесказанного, можно сказать, что коммуникативное обучение представляет собой нечто прямо противоположное современному подходу по всем пунктам.

Доминирующей идеей коммуникативного подхода является коммуникативная направленность всех видов речевой деятельности- говорения, аудирования, чтения и письма. В его основу положена такая организация процесса овладения изучаемым языком, при которой учебно-языковые и учебно-речевые единицы русского языка, а также разнообразные действия, производимые с этими единицами, определяются в соответствии с коммуникативными и познавательными потребностями, запросами и интересами изучающих данный язык, с учётом их реальных психологических возможностей, индивидуальных способностей и особенностей восприятия и использования языка. В настоящее время вряд ли можно найти область преподавания иностранных языков, где коммуникативный подход не стал бы общепризнанным. Особенно в обучении специалистов явно проявляются такие преимущества коммуникативной направленности, как сближение учебной деятельности с практическим пользованием учащимися языком в реальном общении. В центре коммуникативно-направленного обучения находится обучаемый. Он является субъектом учебного процесса. При традиционных методах обучения обычно упускается из виду тот факт, что в реальном учебном процессе преподаватель и учащийся видят практические цели под разным углом зрения. Чтобы избежать подобной рассогласованности учебных целей в рамках коммуникативно-направленного обучения преподаватель должен соотнести их с коммуникативно-познавательными интересами и потребностями учащихся, с их потенциальными способностями, реальными возможностями, особенностями обучения. До начала изучения иностранного языка учащийся имеет в своём распоряжении средство коммуникации - родной язык, который он использует для выражения собственных мыслей и для получения информации извне. Поэтому учащиеся в редких случаях проявляют стойкий и систематический интерес к изучаемому иностранному языку как средству общения. К тому же лингвистическая информация, сообщаемая средствами иностранного языка, не может быть полностью новой для учащегося.

Основным достоинством коммуникативного обучения является широкое использование дифференцированных подходов к подаче учебного материала. Обучаемому могут быть предложены следующие способы презентации нового учебного материала:

1) наглядно-иллюстративный;

2) систематизировано-обобщающий;

3) игровой;

4) индуктивный;

5) дедуктивный;

6) имитативный;

7) эвристический;

8) аналитический;

9) сравнительно-сопоставительный;

10) синтетический.

Стимулятором интеллектуально-мыслительной и коммуникативно-познавательной деятельности учащихся на занятиях русского языка является чётко продуманная система 
речемыслительных задач, которые должны вызвать стремление говорящего выразить свою готовность высказать своё отношение к явлениям, фактам реальной действительности. В сущности, весь процесс общения и состоит из решения мыслительных, коммуникативных задач.

Как установлено, различные цели и задачи, стоящие перед современным учебным процессом, наиболее эффективно можно решить в том случае, если сам преподаватель будет стремиться к активизации интеллектуально-мыслительной и коммуникативнопознавательной деятельности учащихся. Это и приводит к необходимости использования на уроках русского языка элементов программированного и проблемного обучения, а также таких форм организации учебной деятельности, как ролевые игры, игры соревнования, пресс-конференции и т.п. Реальная коммуникативная деятельность учащихся на русском языке, письменные или устные жанры текста, направление общения и их тематизация в соответствии с интересами обучающихся, типы речевых действий представляет коммуникативную программу обучения, соотносится с коммуникативно-деятельностным подходом.

Таким образом, коммуникативно-деятельностное обучение позволяет:

1) вносить по ходу обучения необходимые коррективы в учебный процесс;

2) эффективно справляться с трудностями как субъективного, так и объективного характера, с которыми сталкивается обучаемый при выполнении конкретного проблемнокоммуникативного задания;

3) создать оптимальные предпосылки для осуществления качественного контроля и самоконтроля;

4) моделировать программы овладения иностранным языком;

5) эффективно внедрить в практику обучения ценные достижения смежных наук;

6) преодолеть инертность обучаемых путём внедрения новых форм и способов обучения;

7) максимально учесть различные психологические теории обучения иностранным языкам.

\section{Список использованной литературы}

1. Леонтьев А.А Принцип коммуникативности сегодня // Иностранные языки в школе, 1986, № 2.

2. Митрофанова О.Д. Учебный принцип коммуникативности // Русский язык за рубежом, 1979, №1.

\section{INGLIZ TILI O‘QITISHDA MUSTAQIL TA’LIM SAMARADORLIGIGA KOMPENENTLIK OMILLARI TA'SIRI}

\section{Yo. Beknazarova (SamDChTI)}

Annotation: This article provides an overview of competence and its role in language learning. Competence is a sign of activity that leads to the expected result. It is a product of knowledge and the ability of an expert to apply it in practice. Competence differs from knowledge in that a task cannot be defined or evaluated without practical performance. Competence is an important criterion of competence, which is manifested in repeated application in different situations, as well as in problematic situations.

Key words and expressions: Competence, variability and differentiated character, independent education, integration of knowledge, intercultural and general professional competence

Ingliz tilini o'rganishda talabalarning mustaqil bilim olish tizimi muhim o'rin tutadi. Fan va texnikaning jadal rivojlanishi natijasida axborot oqimining keskin ravishda ortib borishi va bu 
axborotlarning ta'lim oluvchilarga yetkazishda vaqtning cheklanganligi tufayli mustaqil ta'lim olishni tashkil etishga e'tibor tobora kuchaymoqda.

Mustaqil ta'limning kompetentlik nuqtai nazaridan tashkil etilishi qator o'ziga xos xususiyatlarga ega. Ularning mazmunini yoritishga harakat qilamiz. Talabalarning individual xususiyatlarini hisobga olishga yo"naltirilganlik talabalarga mustaqil bajarish uchun taqdim etiladigan ma'lumotlar va amaliy topshiriqlarning variativlik va differensiallashgan xarakterida namoyon bo'ladi. $\mathrm{Bu}$ degani har bir talab $\mathrm{o}^{\prime} \mathrm{z}$ imkoniyatlari va qobiliyatlariga mos bo'lgan darajadagi ingliz tilidagi matn va topshiriqlarni tanlash imkonini beradi.

Talabalar mustaqil ta'limni bajarishi jarayonda bilimlar integratsiyasi, umummadaniy va umumkasbiy kompetentliklar uyg'unlashuvi ro'y beradi. Talabalar ingliz tili haqida yanada to 'laroq tasavvur ola boshlaydi, hamda amaliy va tadqiqot faoliyati tajribasiga ega bo'ladi. Mustaqil ta'limni bajarish jarayonida o'zini mukammallashtirish, talaba shaxsini rivojlantirish orqali professional mustaqil ta'lim yo'nalishi aniqlanadi.

Talaba ingliz tilini to'rt bosqichi (so'zlashuv, gapirish, o'qish va tinglash) bo 'yicha ishlash jarayonida o'quv modullari, o'quv dasturlari fragmentlari, fanni o'rganishda o'quvchilar uchun zarur bo'lgan differensiallashgan individual ta'lim marshrutlari, fanni o'qitishning innovatsion texnologiyalarini ishlab chiqish bo'yicha turli metodik ko'nikmalarni hosil qiladi. Talabalarga individual mustaqil ta'lim vazifalarini loyihalash imkoni har bir talaba haqida to'la ma'lumotlar omborini shakllantirish hisobiga amalga oshiriladi. Bunda mustaqil ta'lim jarayonidagi shaxsiy, kasbiy, o'quv yutuqlari aks etadi va shu orqali talabalarning shaxsiy kasbiy rivojlanishini kuzatish imkonini bo'ladi. Shu yo'sinda talabaga berilgan mustaqil ta'lim mazmunini tahlil qilish keyingi bosqich mustaqil ish topshiriqlari to "plamini aniq tanlash uchun asos bo'ladi. Natijada talabaning kasbiy kompetentligini rivojlanishiga xizmat qiladi.

Mustaqil ta'limning yana bir xususiyatlaridan biri uning natijalarini baholash tizimidagi o'zgarishlarda namoyon bo'lishidir. Bunda ma'lum oraliqdagi ta'lim jarayonida alohida shakldagi bajarilgan mustaqil ta'lim topshiriqlariga baholar qo'yiladi. Bunda baholashni har bir mustaqil ta'lim topshiriqlariga mos individuallashtirishga olib keladi. Natijada natijaviy o'rtachalashga baho olinadi.

Mustaqil ta'limning yana bir muhim xususiyatlaridan biri uning yutuqqa erishishga yo'naltirilganligidir. Chunki ingliz tilida mustaqil ta'lim olishdan asosiy maqsad talaba kasb mahorati va bilim sifatining rivojlantirishdir. Bunda har bir talabaning o'z qobiliyatlari va talantlarini namoyon etishlari uchun keng imkoniyatlar yaratishdan iborat bo 'ladi.

Shunday qilib, kompetentlikni amalga oshirish sharoitida talabalar mustaqil ta'lim vazifalarining xususiyati uning aniq bir talabaga yo 'naltirilganligida; talabalar mustaqil ta'limining shaxsga yo'naltirilganligini ta'minlash imkonini beruvchi ma'lumotlar omborinining mavjudligi zaruratida, yangi o'quv-uslubiy ta'minotini qo'llash imkoniyatini beradigan informatsion ta'lim muhitining mavjudligida va kasbiy individual rivojlanishini ta'minlashda namoyon bo'ladi.

Talablar o'rganiladigan materialni tahlil qilishga qiynalishi ularda informatsion kompetentligi yetarlicha rivojlanmaganligidir. Bunda katta hajmdagi ma'lumotlarni tahlil qilish va qayta ishlashda qiynalishadi, talabalar ijtimoiy tarmoqlarda va internetda ma'lumotlarni qidirish, tanlash va saralash bilan bog'liq muammolarga duch keladi. Chunki talabalar elementar qarorlarni qabul qilishda qiynalishadi, ya'ni ijtimoiy kompetentlikning etarlicha shakllanmaganligi namoyon bo'ladi. Talaba va o'qituvchi orasida teng huquqli kollegial munosabatlarni o'rnatish ko'nikmalarini yetarlicha shakllanmagani, ya'ni talabalar o'z huquq va majburiyatlarini bilmaslik bilan bog'liq muammolar tufayli kommunikativ (muloqot) kompetentlikning yetishmasligi bildiradi.

Ingliz tili darslarida faol ishtirok etishda, masalan ingliz tilidagi mantlarini tarjima qilish diskussiyalarda qatnashishda, individual ishlashda lug'at boyligining kamligidan muhokamada qiynalishadi. $\mathrm{Bu}$ esa $\mathrm{O}^{\prime} \mathrm{z}$ navbatida ingliz tilida erkin gaplashishida jiddiy muammo bo'ladi. Keyinchalik ko'pgina talaballar pedagogik amaliyot davrida amaliy va seminar mashg'o'lotlarini o'tkazish bilan bog'liq qiyinchiliklarga duch kelishadi. 
Xulosa qilib aytganda, ingliz tili o'qituvchilarni tayyorlashda kompenentlikning barcha tashkil etuvchilarini talabalarga qabul qilingandan boshlab, kechiktirmasdan rivojlantirilishi e'tibor qaratish kerak.

\section{Foydalanilgan adabiyotlar ro'yxati}

1. Barkamol avlod - O'zbekiston taraqqiyotining poydevori. - T.: Sharq, 1997.

2. Azizxodjaeva N. N. Pedagogik texnologiya va pedagogik mahorat. - T.: "Fan va texnologiyalar" nashriyoti, 2006.

3. Xodjaev B. X. O`quvchilarning mustaqil fikrlashini shakllantirish yo'llari. - T.: TDPU, 2008. $-65 b$

\section{THE IMPORTANCE OF PRAGMATICS INSTRUCTION IN ESP CLASSROOMS}

\section{Sh.Berdiyorova}

(TSEU)

Annotation: In most EFL classrooms, students are more likely to suffer from lack of communication skills which prevent them from interacting effectively with English speakers. As a result, they are perceived as rude and disrespectful. To overcome the problem, EFL teachers need to make them aware of pragmatics norms.

Key words and expressions: Pragmatics competence, L2 community, cross-cultural misunderstandings, speech act, instruction, overgeneralization, negative transfer.

It is true that, majority EFL teachers mainly focus on the achievement of grammar competence and communicative competence of learners, while the development of pragmatics competence is neglected in EFL classrooms. However, pragmatics competence is very essential skill which guarantees effective communication and immersion into a target language society and culture. One good description of pragmatic competence is "the ability to use language appropriately in order to achieve a specific purpose and to understand a language in a social context." [Jenny Thomas :1983] Knowing the use of sentence structure in the content is not sufficient to master in a second language, learners need to match utterances or sentences with contexts in an appropriate way. If learners wish to avoid cross-cultural misunderstandings, they need to develop pragmatic ability by considering social and cultural norms of the spoken community [Brown and Levenson;1987]. Otherwise, L2 learners fail to interpret intended meaning of speakers and to communicate effectively in a foreign language. Pragmatic incompetence may lead to confusion, embarrassment and cross-cultural misunderstandings and sometimes communication breakdown as well as the stereotyping of the second language learners as rude, insensitive or inept [Thomas:1983]. It is advisable to incorporate pragmatic instruction into English classrooms and give students more choices to practice speech acts.

Discussion and conclusion. L2 learner's pragmatic behaviors diverge from native speaker's norms, which is called pragmatic divergence. Ishihara and Cohen (2010) categorize five common causes of learner's divergence that lead to pragmatic failure: 1) negative transfer of pragmatic norms by relying on L1 norms, 2) limited grammar knowledge in L2 3) overgeneralization of L2 pragmatic norms 4) effects of instruction or instructional materials 5) resistance to using perceived L2 pragmatics norms [Ishihara and Cohen: 2010)]. The first four types of pragmatic divergence can lead to communication breakdown in L2 community. The fifth type of pragmatic divergence depends on learner's choice, although they are aware of pragmatic norms, they resist the L2 pragmatic norms due to the influence of strong sense of identity. I think most frequent divergences might be negative transfer and overgeneralization in pragmatics.

It is apparent that negative transfer of pragmatic norms has mainly impact on learner's pragmatic competence in EFL settings. It is defined that the influence of learner's knowledge of other languages and cultures on the pragmatic use is referred to pragmatic transfer [Kasper 1992]. There are positive transfer and negative transfer of pragmatic norms. Positive transfer relates to a 
learner's pragmatic norms are similar to a member of L2 community. Negative transfer may occur when a second language learner is not familiar with L2 pragmatic norms and apply their L1 knowledgewhen delivering message and discourse in target culture. This transfer of L1 pragmatic behavior might lead to negative communication or misinterpretation where target community is differ from L1 norms. For example, a Japanese learner of English was received a gift from an American friend and saying,"Oh, I am sorry" rather than responding, "Thankyou". Whereas in Japanese culture," thank you" does not express enough sincere and s/he translates literally from what s/he would say in Japanese to English. English speaker would misunderstand why he is apologizing in this situation and hence it creates awkward situation between speakers and even sounds insulting.

As above-mentioned that negative transfer of pragmatic norms diverge learners from L2 norms. When language teacher come across this pragmatic failure in the classroom, teacher should provide more real life situations that help learners how pragmatic behavior differs from one culture to another or how is similar to each other. For example, teacher asks students how you would refuse someone's request in your native language. Students highly benefit from this task as they would get better understanding of literally translation from their native language to second language does not always work. Another task is that teacher should represent sample dialogues or situations and asks them to identify the reason of misconception between speakers. With assistance of this activity, learners realized the influence of negative transfer on communication and cause awkwardness and misunderstandings. It is emphasized that the role of teacher to make sure that students realize to convey delivered message in the community and consequences of their pragmatic behavior [Jiang: 2006].

Another factor of pragmatic failure is overgeneralization of perceived L2 pragmatic norms, which is the same phenomenon with overgeneralization of grammar rules where learners apply a certain rule, which they have learned to context in which it does not apply [Selinker:1972]. In terms of pragmatics, learners of a second language stereotypes or generalize the norms of L2 community and apply wrongly to all situations by neglecting social, geographical and situational variability in the L2. Some learners may apply acceptable pragmatic norms in one situation to another situation where this behavior is not appropriate. For example, American speakers tend to be direct and frank about things and this notion lead to generalize pragmatic norms when a foreign student asks English speaker how much money earns a month. The American would be reluctant to answer the question about asking salary, which seems to him too impersonal question, which results in communication breakdown.

In order to avoid overgeneralization, teacher should incorporate awareness-raising tasks such as role-plays and counter-examples, which allow learners to reflect more authentic language use. Providing contrastive examples activities assist learners to compare two different dialogues in one particular situation through role-plays and to determine pragmatic differences in language use. This activity also offers learners opportunity how to employ appropriate speech acts and speech act strategies and what factors should be considered when performing speech act.

\section{The list of used literature}

1. Brown and Levinson. (1987) Politeness: Some Universals in Language Usage, Cambridge: Cambridge University Press.

2. Gass, S., (1997). Input, Interaction and the Second Language Learner. Lawrence Erlbaum Associates Inc., Mahwah, New Jersey

3. Ishihara N., and Cohen D. (2010) Teaching and learning pragmatics: Where Language and Culture Meet. Longman, Pearson.

4. Jiang, X. (2006). Suggestions: What should EFL students know? System.

5. Kasper, G. and Schmidt, R. 1992: Interlanguage pragmatics and language learning.

6. McCarthy, M. (1998).Spoken Language and Applied Linguistics. Cambridge University Press.

7. Thomas, J. (1983). Cross-cultural pragmatic failure, Applied Linguistics, 4(2), 91-112 
8. Selinker, L. (1972). Interlanguage. Product Information International Review of Applied Linguistics in Language Teaching, 10, 209-241.

\title{
METHODOLOGY OF TEACHING ESP FOR STUDENTS OF HOTEL INDUSTRY MAJOR
}

\author{
N. P. Kurbanova \\ (TSEU)
}

\begin{abstract}
Annotation: Hotel Industry is significantly developed field of modern society, where the collaboration and negotiation play a huge role. Being Lingua Franca-the language of the world, demand for English language acquisition increases noticeably. The people of the target major are required to have English language proficiency. Tourism comes align with English language, due to its world-wide usage and being an official language almost in more than 70 countries of the world. On its turn, English language teachers are specifically needed with their experience, knowledge and teaching skills as well. Current article is to demonstrate the importance of teaching ESP methodology, selecting appropriate techniques for students to learn the languageand be confident in using the language at their work places.
\end{abstract}

Key words and expressions: ESP, language acquisition, proficiency, assessment, evaluation, feedback, alternative assessment.

Introduction. Nowadays, in the rapidly developing century Leaning English as second language is becoming more and more necessary, for various purposes, such as to have better educational background, participate in diversity of exchange programs, have better position at work. It is true that EAP teaching is spread widely, however the brunch of it- ESP, English for Specific purposes, is a little ignored. Consequently, the methods for ESP approach are also in the shade. Tourism and hospitality are categorized as the brunch of ESP, where students of the target major should learn specific language that is about tourism, hospitality, hotel industry. As a result, it is an essential and dynamic specialization within the field of both English language teaching and learning.

Review of the literature. According to some studies English have allocated with focuses such as examining the efficiency of courses and interferences in emerging and expending tourism students' language proficiency. [ Lo \&Sheu, 2008; Zayed, 2009]. Furthermore, there is requirement for language skills of learners and employees. [Choi, 2010]. Brunton, [2009] and Laborda [2005] assessed the coursebooks and materials for teaching ESP from students, employees, trainees' perspectives. In Laborda's [2009] research, it was discovered that the students of hotel industry and tourism, had better input through the computer-based activities, and authentic materials. Diaz and Scholfield [2010] studied students proficiency and compared the results of frequently used words and specific tourism vocabulary, the result of which appeared to have a clear understanding of specific tourism vocabulary better than frequently used vocabulary, due to the authenticity of conducted activities, where students acted relying on their profession and their experience at work.

Discussion and Conclusion. Being an English teacher at the Tashkent State University of Economics, I try to utilize the sessions, using activities from the real-world experience, so students are able to relay on their profession knowledge and acquire the language accordingly. Due to the current pandemic times, the sessions are conducted through zoom platform, which is focused on computer-based teaching. This process even more challenging than teaching in the classroom, with slides on the screen performed with the help of projector. However, teaching skill is another point to take into account, where teacher acts as a facilitator and controls the class online. I would suggest to inspire students to participate in the session activities, and as a teacher I would suggest to involve as many students as possible. Talking to them calling students by name is another approach to involve the students to the process. Nowadays, teachers' digital literacy plays a central role in online teaching process, as to involve the student, teacher should be aware of computer management. Students should be able to write on the whiteboard demonstrated on the screen, presentation slides 
introduced in screen sharing, which is no doubt, controlled by the teacher. One of the most effective activities is role play, where students can act presuming the real state of the current focused field. Peer feedbacks and peer review are another point to take into account. During the collaboration and team work students have an opportunity to listen to each other, assess and work on the errors they make. While teaching ESP, it is important to emphasize the needed language skill, whether the target students need to improve their speaking, reading, writing or listing skill.

\section{The list of used literature}

1. Baban, A. (coord), (2001). Consiliere educationala. Cluj-Napoca: Editura Ardealul.

2. $\quad$ Brookfield, S. (1990). The skillful teacher. Oxford: Jossey Bass Publishers.

3. Brunton, M. W. (2009). An evaluation of hostel employees' attitudes to general and specific English in their coursework. ESP World, 8

4. Delors, J. (2000). Comoaralauntrica. Iasi: EdituraPolirom.

5. Diaz, C. A., \&Scholfield, P. (2010). Reading comprehension and specialized vocabulary: Does tourismvocabulary predict treading comprehension better than general vocabulary? In Proceedings of the Languageat the University of Essex Conference [pp. 1-13]

6. Makhkamova Komila (2019) Perspective of integrating listening and speaking skills in teaching Englishas a foreign language. European Journal of Research and Reflection.

\section{XORIJIY TILLARNI O'RGATISHDA VA O'RGANISHDA ZAMONAVIY METODLAR VA TEXNOLOGIYALARNING O'RNI}

\section{S. S. Bo'riyeva (SamDAQI )}

Annotation: This article provides information on how to use modern methods and pedagogical technologies used in foreign language teaching. It discusses what students should pay attention to when learning a language, as well as the methods that teachers use in the language teaching process. Today, the importance of foreign languages in our society and therefore the importance of language learning among young people is very high. We know that it is difficult to imagine the teaching process without modern technology. Therefore, this article focuses on the role of pedagogical technologies in language learning. There are four aspects to learning a foreign language (reading, writing, speaking, listening) and these aspects are discussed in detail in the article.

Key words and expressions: Method, pedagogical technologies, innovative methods, efficiency, skill, speaker, listener.

Bugungi kunda xorijiy tillarni bilish ko'nikmasi ta'limning ajralmas qismlaridan biri bo'lib kelmoqda. Hozirgi kunda xorijiy tillarni o'rganish dolzarb mavzulardan biri hisoblanadi. Bunga sabab har bir inson o'z ehtiyojidan kelib chiqib til o'rganadi.

Masalan, tadbirkorlar chet ellik hamkorlari bilan hamkorlik o'rnatish uchun, ba'zi yoshlar chet elda ta'lim olishlari uchun va boshqa sabablar tufayli o'rganadilar. Zamonaviy jamiyatda chet tillari kasbiy ta'limning muhim tarkibiy qismiga aylanmoqda. Chet tilini o'rganish uchun, dastlab ona tilini bilmagan o'quvchi chet tilini o'rganishda ba'zi muammolarga duch keladi.

Mamlakatimizda yoshlarning ta'lim olishi, axborot- kommunikatsiya texnologiyalarini faol o'zlashtirish, zamonaviy kasb-hunar, xorijiy tillarni o'rganish uchun barcha imkoniyatlar yaratilgan. Ta'lim olish bilan birga ko'p yoshlarimiz xorijiy tillarni ham o'rganmoqda.

Bizga ma'lumki, chet tillar maktabda, litseyda, oliy ta'limda o'rgatiladi. Mukammal o'rganmoqchi bo'lganlar maxsus kurslarga borib o'rganadilar. Har bir fanni yangi innavatsion pedagogik texnologiyalardan foydalanib talabalarga yetkazib berish bugungi kundagi ta'limning asosiy talablaridan biri hisoblanadi. Shu sababli, chet tili darslarining o'tilishi jarayonida ilg'or pedagogik texnologiyalarni, innovatsion usullardan, kommunikativ- axborot vositalaridan foydalanish talab qilinmoqda. Darslarda pedagogik texnologiyalardan foydalanib olib borishning 
afzallik va foydali tomonlari mavjud. Innovatsion usullardan foydalanib dars olib borishning afzallik va foydali tomonlari mavjud. Innovatsion usullardan foydalanib dars olib borish, darsning samaradorligini yuqori qiladi va o'quvchilarning darsga bo'lgan qiziqishini oshiradi.

Har bir jamiyatning kelajagi uning ajralmas qismi va hayotiy zarurati bo'lgan ta'lim tizimining qay darajada rivojlanganligi bilan belgilanadi.

Hozirgi kunda ta'lim jarayonidagi eng samarali, o'qituvchi pedagoglar ko'zlagan maqsadlarga erishishning kafolatlangan o'qitish uslublari, o'quvchi talabalardan mustaqil fikrlash, turli vaziyatlardan qiynalmasdan chiqib ketishlari uchun zamin hozirlashga qodir bunday o'qitish uslublari pedagogik texnologiyaning eng ilg'or xususiyatidir.

Texnologik vositalardan foydalanish chet tili o'rganishning har bir aspect(o'qitish, yozish, tinglab tushunish va gapirish)ida qo'l keladi.

Masalan, o'qish orqali o'quvchi to'g'ri, xatosiz va tez o'qishni va so'zlarni to'g'ri yozilishini o'rganadi. Qanchalik ko'p matn o'qisa, shunchalik tez va ravon nutqini oshiradi. Yozish orqali esa so'z boyligini oshiradi va to'g'ri, ravon yozishni o'rganadi.

Tinglab tushunish til o'rganishning eng muhim qismlaridan biridir. Bunda o'quvchi bir paytning o'zida so'zlovchining talaffuzi, Grammatik qoidalarga rioya qilganligi, so'z boyligi va ining ma'nolariga e'tibor berish talab qilinadi.

Gapirish orqali so'zlovchi so'zlarni to'g'ri va ravon talaffuz qilishni o'rganadi va so'z boyligini oshirib boradi.

Chet tilini o'qitish jarayonida turli xil jadvallardan foydalanishning ham samarasi yuqoridir. Ta'lim jarayonida jadvallardan foydalanib, o'quvchilar ma'lum bir grammatik qoidani, masalan sifat darajalaridan foydalanib gaplar tuzish, yangi so'zlarni joylashtirib chiqishi mumkin.

Chet tilini o'rganishda maktabdagi 45 daqiqalik dars bilan yoki oliy ta'limdagi 80 daqiqalik mashg'ulotlar bilan o'zlashtirish qiyin. O'quvchi yoki talaba albatta qo'shimcha ravishda chet tili bo'yicha shug'ullanishi kerak. Chunki 50\% bilimni dars jarayonida olsa, 50\% bilimni o'zi mustaqil shug'ullanib oladi.

Har bir o'quvchi til o'rganishda o'z qobiliyatidan kelib chiqib o'rganadi.Ba'zilar 6oyda o'rgansa, ba'zilarga yillar kerak bo'ladi.

Bugun mamlakatimizda yurtboshimiz tashabbuslari bilan til o'rganishga kata e'tibor berilmoqda. Yuqoridagilarga nazar soladigan bo'lsak yurtimiz taraqqiyotida tilning nechog'lik ahamiyatli ekanligiga yana bir karra amin bo'lamiz.

Zamon ilgarilab borgani sari har sohada yangilik ko'payib bormoqda. Til o'rgatishda ham turli uslublar paydo bo'lmoqda. Ingliz tilini o'rgatishda o'rganuvchining salohiyat va darajasi, yoshidan kelib chiqqan holda bosqichma- bosqich o'rgatish yaxshi natija beradi.

Tilni o'rganishni boshlaganlar uchun avvalo to'g'ri talaffuz muhim hisoblanadi. Chunki so'zni bilsa-yu lekin to'g'ri talaffuz qilolmasa, tinglovchi tushuna olmaydi va muloqot jarayonida muammolar kelib chiqadi. Bundan tashqari o'rganuvchi boshidan so'zni to'g'ri talaffuz qilmasa, keyin ham noto'g'ri talaffuzda davom etadi va bu xatolik uning xotirasida shu tarzda qotib qoladi.

So'zni to'g'ri talaffuz qilib, grammatik xatolikka yo'l qo'yilsa, bu tinglovchini tushunib olishi uchun qiyinchilik tug'dirmaydi. Boshlang'ich bosqichda oddiy grammatik qoidalarni o'rganib borish muhim hisoblanadi.

Yuqorida ta'kidlanganidek chet tilini o'rganishda, ona tilini o'rni ahamiyatlidir. Bizga ma'lumki ona tili tabiiy muhitda, chet tili esa sun'iy muhitda o'rganiladi. Chet tilidagi muloqot, asosan darsda muallim rahbarligida kechadi. Chet tillarni samarali o'rgatish uning metodikasini bilishni taqozo etadi. Shu sababli chet tili o'rganish va kelgusida uni boshqalarga o'rgatish uchun chet tili o'qitish metodikasi fani predmetini yaxshi o'zlashtirgan bo'lishi kerak.

Talim berish jarayoni murakkab, ziddiyatli jarayon bo'lib, o'qituvchidan kuchli bilim, kasbiy mahorat, tashkilotchilik qobiliyati va tinimsiz izlanishni talab etadi. Har bir o'qituvchining o'z oldiga qo'ygan maqsadiga erisha olishi uning kasbiy mahoratiga, samara beradigan ta'lim shaklini tanlay olishiga, ta'lim vositalaridan unumli foydalana olishiga, eng muhimi, o'qitish usullarini o'rinli qo'llay olishiga bog'liqdir. O'qitish usullarini to'g'ri qo'llay olinsagina, ta'lim samaradorligi kuchayadi. Ta'lim tizimiga juda ko'p zamonaviy texnologiyalar kirib keldi. Shulardan "KEYS 
STADI" va "KLASTER" metodlarining samarasi yuqori hisoblanadi. Aynan "KEYS STADI" metodi darslardagi muammoli mavzularda qo'llanilsa, mavzuning, muammoning yechimi tez va oson topiladi. $\mathrm{Bu}$ metod qo'lanilganda o'quvchilar mustaqil fikr yuritishga harakat qiladilar. Bundan tashqari "KLASTER" metodidan barcha mavzularni muhokama qilish jarayonida foydalanilsa darsning sifati yuqori bo'ladi.

Darslarning samarali natija berishi o'qituvchining o'quvchilarini qay darajada qiziqtira olishga bog'liq. Hozirgi zamon imkoniyatlari juda yuqoridir. Hozirgi davr chet tillarni o'rganish, samarali egallash davri hisoblanadi. Dars jarayonining bosh bo'g'ini bu o'qituvchi hisoblanadi. Shuning uchun ham pedagoglar zamonaviy pedagogik texnologiyalarning nazariy asoslarini puxta egallashlari va ularni amalda mohirlik bilan qo'llay olishlari ko'zlangan natijaga erishishning zarur kafolati hisoblanadi.

Chet tilini o'rgatish jarayonida ta'lim-tarbiyaning ahamiyati katta hisoblanadi. Chunki tili o'rganilayotgan mamlakatning nafaqat tili, balki uning madaniyati, urf-odatlari ham o'rganiladi. Bunday jarayonda o'qituvchi o'quvchilarga faqat o'z mamlakatining urf-odatlariga, madaniyatiga mos keladigan tomonlarini o'rgatishi lozim. Chunki chet mamlakatlarning hamma urf-odatlari va madaniyati ham to'g'ri kelavermaydi. Bu juda muhim hisoblanadi, chunki o'quvchilarga chet mamlakatlarning urf-odatlari ijobiy ta'sir ko'rsatishi muhim hisoblanadi.

Ta'lim jarayonida usullar to'g'ri tanlansa, ko'zlangan natijaga qisqa yo'l bilan erishish mumkin. Ta'lim-tarbiya sohasining to'xtovsiz takomillashib borishi, o'quv darslarini pedagogik innovatsiyalar asosida tashkil etish oliy ta'lim muassasalari oldida turgan dolzarb vazifalardan bo'lib uni muvaffaqiyatli amalga oshirish oliy ta'lim professor-o'qituvchilari oldida turgan muhim vazufalardan hisoblanadi.

Hozirga kelib pedagogik amaliyotida shunday ta'lim modellari yaratildiki, ular ma'lum sharoitlarda va belgilangan vaqt ichida ko'zlangan ta'limiy maqsadlariga erishishni kafolatlash bunga keng imkoniyatlarni ochib beradi. Bunday ishlarniamalga oshirish turli chet tillarni o'rgatishda ham samarali natijalarni berishi shubhasizdir.

\section{Foydalanilgan adabiyotlar ro'yxati}

1.J.Jalolov. Ingliz tili o'qitish metodikasi, “O’qituvchi” nashriyoti.Toshkent.

2.O'.X.Xoshimov, I.Y.Yokubova. Ingliz tili o'qitish metodikasi. "O'qituvchi”' nashriyoti.Toshkent.

3.Г.В.Рогова. Методика обучения английскому языку. 1997.

4.Adrian Doff. Teach English. A training course for teachers. Cambridge University press. 1988.

5.F.A.Zaripova. Chet tillar o'qitish metodikasidan qo'llanma. Toshkent.2002.

\section{ИЛМИЙ МУЛОКОТ ТАМОЙИЛЛАРИ ВА УЛАРНИНГ ВАЗИФАЛАРИ}

Н. Н. Очилова

(СамДЧТИ)

Annotation: The article studies the features of logic, objectivity, accuracy and consistency in the presentation of the scientific style.

Key words and expressions: Human intelligence,description of events, interpretation, justification of acquired knowledge,systematization of cognition, accuracy, singula

Жамият тараққиётида илм-фаннинг роли алохида эканлиги барчага маълум. Ўтган асрда рўй берган технологик ривож илм сохасида эришилган ютуқлар натижасидир. Бу сирадаги ютуқлар фақат ишлаб чиқариш, иқтисодиёт сохаларидаги туб ўзгаришлар, инқилобий ўсишларга сабаб бўлибгина қолмасдан, балки умуман инсон фаолиятини янги воситалар ва методлар билан бойитиш, ушбу фаолият турларини изчиллаштириш, самарасини ошириш вазифасини хам бажаради. 
Илм-фаннинг энг асосий вазифаси оламни билиш имкониятларини кенгайтириш, табиатни “ўзлаштириш”,унинг сирларидан воқиф бўлиш хамда ривожланиш қонуниятларини очиб беришдир. Фанда ходисалар ўртасидаги боғлиқликлар қонуниятлари аниқланади, хамда нарса-ходисаларнинг мохиятини белгиловчи хусусиятлар тавсифланади. Илмий тадқиқотдан кўзланадиган асосий мақсад-инсоннинг атрофидаги воқеликка муносабати доирасида тўпланган тажрибани умумлаштириш ва қонуниятлар мажмуасини шакллантиришдир.

Инсон фаолияти давомида янги кўриниш олаётган объектларни ўрганиш вазифасини бажараётган фан сохаси жамиятнинг хозирги бажараётган фан сохаси жамиятнинг хозирги ривожи вазиятида кўзга ташланадиган предметлараро муносабатларни ўрганиш билан чегараланиб қола олмайди. Рус методологи академик В.С. Степин фаннинг мақсади объектларнинг истиқболдаги ўзгаришларини ва буларнинг воқелик ўзгаришига таъсирини олдиндан кўриш эканлигини алохида таъкидлайди (Степин 2010: 13).

Ўзбекистонлик файласуф Н.Шермухамедова “Фалсафа ва фан методологияси” номли дарсликда ёзишича, “фан хаёти- инсон хаётининг бир қисми сифатида намоён бўлади.... инсон интеллекти олам хақидаги тугалланган билимни талаб қилади. Интеллект, табиий қизиқувчанлик, билимга ташналик асосида инсонга янги ва янги билимларни етказади" (Shermuhamedova 2008: 15). Дархақиқат, илмий билим, худди барча турдаги рухий-маънавий “махсулотлар" сингари,охир-оқибатда инсон фаолиятини измга солиш учун даркор. Билиш фаолияти турли кўринишга эга ва турли ролларни ўтайди.

Хархолда, фанда амалий фаолият предметларни ривожланиш босқичларини ва улардан юзага келадиган натижаларни олдиндан кўра олиш охирги мақсадлардан бири эканлиги аниқ. Мазкур ривож ва ўзгаришларнинг тагзаминида объектлар ўртасидаги алоқалар мохияти ётади хамда бажарилаётган фаолиятнинг самараси унинг қонуниятларга муқобиллашуви билан боғлиқ (Степин 2010: 17).

Илмий билиш жараёни объект хусусиятлари тахлили билан бир қаторда, қатор ижтимоий-маданий омиллар оғушида кечади. Хар қандай фаолият тури каби, илмий билиш жараёни маълум гурухдаги илмий фаолият мақсади ва унга эришиш усулларини акс эттирувчи меъёрлар назоратида бўлади. Бундай меъёрлар қаторига, одатда, қуйидагилар киритилади: а) илмий идрокнинг турли шакллари доирасида ўрганилаётган объектнинг тасаввур қилинишига йўналтирилган билиш мўлжали; б) фаннинг ижтимоий хаётдаги ўрнини ва тадқиқотчилар ўзаро мулоқотини йўлга қўйишда фаннинг ролини белгиловчи қонуниятлар (Polanyi 1974: 120).

Илмий мулоқотнинг ушбу икки жихати унинг билиш фаолияти ва ижтимоий ходиса сифатида бажарадиган икки вазифаси фаоллашувини тақозо этади.

Фаннинг билиш фаолияти билан боғлиқ вазифалари тадқиқотчи харакатларини турли мўлжаллар бўйлаб йўналтиради: 1) воқеа-ходисаларни тавсифлаш ва изохлаш; 2) олинган билимни асослаш; 3) билишни тизимлаштириш кабилар. Бунда вазифаларни амалга ошириш умумлашган холда тадқиқ усулларини қолиблаштиради ва шу аснода тахлил объекти ўзлаштирилади (Степин 1992; Файзуллаев 2000).

Инглиз файласуфи П.Фейерабенд фанга берилаётган таъриф-тавсифлар унинг мохияти, қандай фаолият кўрсатиши хамда қандай натижага олиб келиши хақидаги саволларга жавоб бериши керак, деб хисоблайди. Олимнинг фикрича, “ушбу саволларга берилаётган жавоблар турлича. Аммо уларнинг хар қандайида фан фаолиятини бошқарувчи илмий метод мавжудлиги назарда тутилади. Мазкур қоидаларга амал қиладиган изланишлар илмийликка мос; улардан чекинадиганлари эса-ноилмийдир” (Фейерабенд 1986: 126).

К. Поппер, А. Эйнштейннинг фикрига изох бераётиб, дедукция йўли билан олам манзарасини ёритиш имконини берадиган универсал қонуниятларни излаш фан учун мухим эканлигини эътироф этади. Унинг хулосасига кўра, “ушбу қонуниятларни мантиқан аниқлаш қийин. Уларни фақат интуицияга биноан, объектни кузатиш асосида ажратиш мумкин” (Поппер 1982: 62).

Илмий фаолиятда турли мақсадлар кўзланиши, меъёрий қоидаларга риоя қилиниши хамда янги марралар сари қадам қўйилиши муносиб кадрлар тайёрланишини хам тақозо 
этади. Махсус тайёргарлик жараёнида бўлажак тадқиқотчилар махсус билимларни эгаллаш, илмий иш методлари билан танишишдан ташқари, илмий фаолият тамойиллари ва ахлоқий нормаси, этикасига хос қонун- қоидаларни хам ўзлаштириши талаб қилинади. Хар бир мутахассис сохасига оид илмий матнларни тез ва оқилона тушуниши, унинг асосий мазмунини оғзаки ва ёзма баён қила олиши шарт. Бундай кўникмаларга эга бўлган мутахассисда касбига оид турли жанрдаги матнларни битиш қобилияти шаклланади (Основа научной речи 2003: 3).

Қайд этилганидек, илмий тафаккур атрофимиздаги оламни матнтиқий категорияларни шакллантириш йўли билан билишга йўналтирилади. Ўз навбатида, мантиқан шакл олган тушунчалар термин-атамалар воситасида тизимлаштирилган холда у ёки бу фан сохасининг мундарижасини ташкил қилади. Шу жумладан, лисоний воситалар танловчи у ёки бу сохадаги инсон фаолиятининг хусусиятлари билан боғлиги боис, ушбу сохага хос харакат турларига таянган холда баён усуллари ва лисоний танлови қонуниятларини аниқлаш мумкин. Шунингдек, илмий асарлар тил ва услубий хусусиятлари тахлили маълум сохага оид тадқиқотлар тарихи ва ривожи хақида хулосалар чиқаришга асос яратади.

Илмий мулоқот вазифалари қаторига маълум кўринишдаги фаразлар, хулосалар, далилларни исботлаш хамда табиий ва ижтимоий ходисаларни тавсифлаш, изохлаш мақсадида долзарб муаммоларни аниқ хамда тушунарли равишда баён қилиш киради. Илмий баён услуби захирасидаги ифода воситаларидан фойдаланган холда мавжуд нарсаходисалар тавсифланиб, хақиқий холат изохланади. Натижада илмий матн фикр-мулохаза ва далиллар мажмуасидан иборат бўлади. Уларнинг ишончилилиги изохловчи нутқий тузилманинг тўлиқлиги ва мазмунан тушунарли бўлишига асосланади.

Илмий ишларда тадқиқотчининг диққат марказида, энг аввало, билдирилаётган фикрмулохазаларнинг мантиқий боғлиқлиги ва мукаммаллиги туради. Ушбу мулохазалар якка ёки тасодифий холатлардан кўра умумий ва қонуний ходисалар тавсифидан иборат бўлиши керак. Фикрий мавхумлаштириш измидан бораётган олим ўз фикрини тизимли равишда баён қилиш йўлларини қидиради.

Буларнинг барчаси адабий тилнинг илмий функционал услуби шаклланишига олиб келди. Илмий усулбнинг турли жихатлари В.В.Виноградов, И.Р. Гальперин, Э.Г.Ризель, М.Н. Кожина, Н.М. Разинкина, А.Н.Васильева, М.Мукарамов, Н.Махмудов, М.Хакимов каби олимлар томонидан ўрганилиб келинмоқда. Ушбу муаллифлар илмий баён услубнинг бадиий баён услубидан фарқли томонларини ёритиш жараёнида унинг мақомини белгиловчи кўрсаткичларни ажратадилар. Бундай кўрсаткичларнинг хозиргача ягона тизими шакллантирилмаган бўлса-да, лекин тадқиқотчиларнинг қарийб барчаси баёндаги қаътий мантиқийлик, изчиллик, умумлаштирилганлик, мавхумлаштириш кабилар асосий экстралингвистик белгилар эканлигини қайд этишади. Айтилган кўрсаткичлар М.Н. Кожина томонидан баённинг далиллаштириш қийматини оширишини қайд этилса (Кожина 1983: 162), И.С..Кауфман буни муаллифнинг “аниқлик ва яккамаънолиликка интилиши” натижаси деб хисоблайди (Кауфман 1968: 199). Р.А.Будаговнинг наздида, бу билдирилаётган фикрга ишонч туғдиради (Будагов 1970: 67).

И.Р. Гальпериннинг таъбирича, хар қандай нутқий услуб алохида бир устувор белгиси билан ажралиб туради (Гальперин 1965: 73). Бундай устуворлик, албатта, баённинг мантиқий асосланганлигида намоён бўлади. Ушбу хусусият илмий баённинг табиатида мавжуд, чунки унинг мақсади ўқувчи онгига таъсир кўрсатишдан иборат. Шунинг учун хам илмий услубнинг “юксак орзуси баёндаги мантиқийлик, объективлик, аниқлик ва изчиллик хусусиятлари” эканлиги хақидаги таъкидни (Разинкина 1972: 28) ўринли, деб хисоблаймиз. Шунингдек, илмий услубнинг экстралингвистик хусусиятларидан яна бири умумлаштириш мақсадининг фаоллашувида эканлиги борасида билдирилаётган фикрга хам қўшиламиз. Умуман, хар бир функционал услуб намунасида унинг коммуникатив вазифаси билан боғлиқ холда ўзига хос кўрсаткичлар намоён бўлади. Бу сирага кирувчи хусусиятлар ва уларнинг кўрсаткичлари тил тизимида ўзига хос ифода воситалари ва уларнинг фаоллашувини назорат қилувчи меъёрлар тагтизимлари шаклланишини тақозо этади. 


\section{Фойдаланилган адабиётлар рўйхати}

1. Степин В.С. Научная рациональность в историческом измерении // Филология познания. - М.: РОССПЭН, 2010. - С. 9-27.

2. Shermuxamedova N. Falsafa ва fan методологияси. - T.: Aloqachi, 2008. - 4006.

3. Polanyi M. Scientific Thought and Social Reality: Essays. - N.Y.: International Univ. Press, 1974. - 279 p.

4. Файзуллаев А.Ф. Исторические методы наблюдения как познания // Классическая наука Средней Азии и современная мировая цивилизация. - Т.: Фан, 2000. 243 с.

5. Степин В.С. Общеметодологические проблемы постнеклассической науки // Проблемы методологии постнеклассической науки. - М.: И-т философии РАН, 1992. - С.316.

6. Фейирабенд П. Избранные труды по методологии науки. - М.: Прогресс, 1986. $236 \mathrm{c}$.

7. Поппер К. Логика и рост научного знания. - М.: Прогресс, 1983. - 391 с.

8. Основы научной речи. Учебное пособие. - СПБ.: Филологический ф-т СПБ ГУ; Издательский Центр “Академия”, 2003. - 391 с.

9. Кожина М.Н. Стилистика русского языка. - М.: Просвещение, 1993. - 222 с.

10. Гальперин И.Р. К проблеме дифференциации стилей речи // Проблемы современной филологии. - М.: 1965. - С. 87-103.

11. Разинкина Н.М. Стилистика английской научной речи. - М.: Наука, 1972. - 168 с.

\section{DIE BEDEUTUNG TECHNISCHER MITTEL FÜR DEN FREMDSPRACHENUNTERRICHT IN DER MODERNEN BILDUNG}

N. T. Ikromov (SamSIFL)

B. T.Qilichev (SamSIFL)

Annotation: This article discusses the importance of technical means for foreign language teaching, which are widely used in modern educational processes, as well as the experience, practical work and reforms based on world experience.

Key words and expressions: Hardware, computer programs, projector, video, interactive tools, animated computer graphics.

Eines der Hauptthemen der nationalen Entwicklung Usbekistans ist heute die Entwicklung einer abgerundeten Persönlichkeit. In Anbetracht dessen ist es wichtig, den Kenntnisstand der Fremdsprachen in unserer jungen Generation zu verbessern, um fließend und fließend sprechen zu können, viele wissenschaftliche und praktische Kenntnisse in Fremdsprachen unabhängig zu studieren und zeitgemäß zu erziehen. Insbesondere im Informationszeitalter müssen wir die Vorteile des Einsatzes technischer Mittel beim Erlernen von Fremdsprachen und beim Unterrichten von Fremdsprachen berücksichtigen. Im Folgenden betonen wir die wichtige Rolle und technische Bedeutung technischer Mittel in der modernen Bildung, ihre Art und die Hauptanforderungen für ihre Verwendung.

Im neuen Jahrtausend, dem 21. Jahrhundert, das als "Zeitalter der Informationstechnologie" bezeichnet wird, dringen Informations- und Kommunikationstechnologien rasch in alle Bereiche unseres Lebens ein. Bildung ist keine Ausnahme. Der Einsatz moderner interaktiver Lehrmittel, multimedialer Bildungsprodukte und multimedialer Anwendungen im Fremdsprachenunterricht trägt Früchte. Sie sind eines der wichtigsten Instrumente zur Verbesserung der Kenntnisse und Fähigkeiten von Sprachlernenden. Der Einsatz von Fernunterricht beim Lehren und Lernen von Fremdsprachen bleibt eines der dringendsten Probleme. In diesem Zusammenhang wollen wir zunächst die Frage beantworten, was Multimedia ist. Multimedia ist ein interaktives System mit Ton sowie animierten Computergrafiken, Videos, statischen Bildern und Text. Das Wort 
Multimedia entstand mit Ausnahme der Computerterminologie, die 1966 erstmals vom amerikanischen Sänger Bob Goldstein in seiner Arbeit verwendet wurde. Der Begriff wurde später verwendet, um die Namen aller Spezialeffektereignisse zu verallgemeinern, und erst in den 1990er Jahren wurde das Wort eingehend analysiert. Früher galten Dias und Tonbandgeräte als Multimedia, jetzt müssen sie spezielle Computersoftware, Projektoren, Videos und andere interaktive Tools enthalten, um den Unterricht multimedial zu gestalten. Multimedia ist eine der effektivsten Möglichkeiten für Lernende.

Es bereichert den Bildungsprozess, steigert seine Effizienz, erhöht die Aktivität von Sprachlernenden und beschleunigt den Erwerb neuer Informationen um ein Vielfaches. Heutzutage kann sich ein Lehrer den Unterrichtsprozess ohne dieses Werkzeug nicht vorstellen. Das Format des Kurses wird sich aufgrund dieser Technologie ebenfalls ändern. Während in der Vergangenheit der Lehrer eine aktive Rolle im Unterrichtsprozess spielte, wird der Schüler heute als die Person angesehen, die zusammen mit dem Lehrer und in einigen Fällen sogar dem Lehrer die passive Rolle spielt. Wenn der Lehrer nur als Erzieher angesehen wurde, ist er jetzt nur noch ein Führer, ein Führer. Die Hauptaufgaben einer Multimedia-Lektion bestehen darin, alle Schüler in den Lernprozess einzubeziehen, ihr Interesse an der Sprache zu steigern, den Schülern die neue Lektion auf verschiedene Weise beizubringen und ihre Sprachkenntnisse zu entwickeln.

Derzeit werden in Usbekistan viele Fremdsprachenprogramme durchgeführt. Die Nationale Fernseh- und Rundfunkgesellschaft Usbekistans, das Staatliche Komitee für Kommunikationsinformations- und Telekommunikationstechnologien, die usbekische Presse- und Informationsagentur und die Nationale Nachrichtenagentur Usbekistans berücksichtigen die Interessen und Interessen von Kindern und Jugendlichen über das Fernsehen, einschließlich lokaler Fernsehkanäle. Vorbereitung und Ausstrahlung von Programmen zum Fremdsprachenunterricht für Jugendliche, regelmäßige Vorführung populärwissenschaftlicher Fremdfeatures und Animationsfilme zur Geschichte und Kultur anderer Völker, Bräuche mit usbekischen Untertiteln. Es ist auch geplant, Bildungseinrichtungen über das Netzwerk "Ziyonet" mit Anwendungen für Geräte zu bereichern sowie pädagogische und künstlerische Literatur in Fremdsprachen, Zeitungen und Zeitschriften mit speziellen Abbildungen $\mathrm{zu}$ veröffentlichen, spezielle Abschnitte und Anwendungen zu erstellen. gefangen. Wie oben erwähnt, heißt es in der Entschließung des Ersten Präsidenten zum Fremdsprachenunterricht: „Durch die Einführung fortgeschrittener Unterrichtsmethoden unter Verwendung moderner pädagogischer Technologien wird die jüngere Generation in Fremdsprachen unterrichtet. das System der Ausbildung von Fachleuten, die diese Sprachen fließend beherrschen, radikal zu verbessern und auf dieser Grundlage Bedingungen und Möglichkeiten zu schaffen, um die Errungenschaften der Weltentwicklung und die weltweiten Informationsressourcen zu nutzen, die internationale Zusammenarbeit und den internationalen Dialog zu entwickeln und dies zu tun. Implementierung wird gezeigt.

Darüber hinaus sieht die Entschließung "Über Maßnahmen zur weiteren Verbesserung des Systems des Fremdsprachenlernens" vor, dass 2013-2016 Fremdsprachenunterrichtsräume in Bildungseinrichtungen mit modernen Informations- und Kommunikationstechnologien und Lehrmitteln ausgestattet werden. Die Notwendigkeit, ein beschleunigtes Programm zu entwickeln, wurde vorgebracht. Das Vorhandensein der erforderlichen technischen Ausrüstung in den Klassenräumen des Fremdsprachenpraktikums erhöht die Qualität des Unterrichts, erhöht das Interesse der Schüler an einer Fremdsprache, und Professoren und Lehrer der Sprache nutzen die geschaffenen Bedingungen gut aus. Sie haben die Möglichkeit, mit neuen pädagogischen Technologien und unter Verwendung ihrer vorhandenen professionellen pädagogischen Fähigkeiten qualitativ hochwertigen Unterricht zu erteilen.

Der Hauptzweck des Einsatzes moderner Technologie im Fremdsprachenunterricht:

- Demonstrationsverbesserung;

- Implementierung von problembasiertem Lernen;

- Bringen Sie den Schülern bei, zuzuhören und die Sprache verschiedener Menschen zu verstehen.

- Erhöhen Sie die Sprachgeschwindigkeit. 
- das Sprachmaterial zum Leben erwecken;

- Ideologische, politische und moralische Erziehung der Schüler;

- Bringen Sie den Schülern bei, selbständig zu arbeiten.

Heute entstehen neue E-Lehrbücher, Lehr- und Lernhilfen. Sie zielen darauf ab, die Alphabetisierung der Schüler zu verbessern, Sprache zu entwickeln, geistige Fähigkeiten zu entwickeln, logisches Denken und kreatives Denken zu entwickeln und die Kontinuität zwischen den Bildungssystemen sicherzustellen.

Es ist bekannt, dass die Computerisierung des Bildungsprozesses nicht nur die Bildungsinformationen verbessert, sondern auch dazu beiträgt, die Elemente neuer Informationstechnologien zu beherrschen. Es ist wichtig zu betonen, dass Computer, insbesondere beim Erlernen von Fremdsprachen, die Arbeit des Lehrers erleichtern und die Effizienz des Unterrichtsprozesses steigern. Gute Multimedia-Programme müssen zielgerichtet sein, da das Lernmaterial ein bestimmtes Thema abdecken muss und das Programm alle Komponenten des Lernprozesses abdecken muss.

Die Einführung moderner Technologien in den Bildungsprozess spielt eine wichtige Rolle bei der Modernisierung des Bildungsprozesses. Unabhängig davon, welche Feldstudenten studieren, ist das Erlernen von Fremdsprachen mit Hilfe moderner technischer Mittel ein intensives Instrument, um ihre Ziele zu erreichen. Heutzutage wartet der Schüler nicht passiv darauf, dass der Lehrer bestimmte Informationen vorbereitet und die Schüler darauf aufmerksam macht, im Gegenteil, es ist unwahrscheinlich, dass er diese Informationen vor dem Lehrer erhalten hat Der Pädagoge muss gründlich vorbereitet sein, bevor er den Unterricht beherrscht und die neuen innovativen Technologien beherrscht.

Apropos neue innovative Technologien in der Bildung, das Gesetz "Über Bildung" und das Gesetz der Republik Usbekistan "Über das nationale Ausbildungsprogramm" sowie das Gesetz des Ersten Präsidenten der Republik Usbekistan "Über Bildung". Alle unsere Bemühungen zur Umsetzung des Dekrets "Zur radikalen Reform des nationalen Bildungs- und Ausbildungsprogramms, zur Erziehung einer harmonisch entwickelten Generation" konzentrieren sich auf so wichtige Themen wie die Ausbildung qualifizierter Lehrkräfte und die Umsetzung von Reformen im Hochschulsystem. Wir achten darauf.

Wie wir oben gesehen haben, besteht die wichtigste Aufgabe eines modernen Lehrers darin, über fortgeschrittene pädagogische Fähigkeiten und ein breites wissenschaftliches Niveau zu verfügen, mit der Zeit Schritt zu halten und die Neuheit zu spüren. Basierend auf diesen Ideen müssen wir in der Lage sein, auf der Grundlage ausländischer Erfahrungen ein eigenes nationales modernes Bildungssystem zu schaffen und umzusetzen, das die fortschrittlichsten pädagogischen Technologien für den Fremdsprachenunterricht unserer Schüler und künftiger Generationen einsetzt.

\section{List of used literature}

1. Karimov I.A. Hohe Spiritualität ist eine unbesiegbare Kraft. Toshkent 2008.

2. Sattarov T. "Technologie zur Bildung methodischer Kompetenz des zukünftigen Fremdsprachenlehrers" Taschkent-2003.

3. Alimov SH. S. Intensive Methoden, interaktive Methoden, nicht traditionelle Lehrmethoden, didaktische Spiele. Andijon 2009

4. Hoshimov O., Yakubov I. "Methoden des Englischunterrichts", die Hauptausgabe der Sharq Publishing and Printing Aktiengesellschaft Tashkent-2003.

5. www.teachinglanguageusing usingcomputertechlonogy. 


\title{
BOSHLANG'ICH TA'LIMDA ZAMONAVIY DARSLARNI TASHKILLASHTIRISH
}

\section{O.Toxtayev (Samarqand, MOHM)}

\begin{abstract}
Annotation: This article discusses the issues of teaching students in primary school using modern methods. The change and expansion of the tasks and objectives of modern education has revealed the essence of improving the content and structure of education and the teaching process.
\end{abstract}

Key words and expressions: Blitz-question, didactic task, "Resume" technology, development, creativity, initiative, teacher, traditional,information, education.

Hozirgi vaqtda ta'lim jarayonida o'qitishning zamonaviy usullarini qo'llash, o'qitish jarayonida yuqori natijalarga olib keladi. Ta'lim usullarini har bir darsning didaktik vazifasidan kelib chiqib tanlash maqsadga muvofiq sanaladi. An'anaviy dars shaklini saqlab qolgan holda, uni turli-tuman zamonaviy usullar bilan boyitish ta'lim oluvchilarning o'zlashtirish darajasini ko'tarilishini ta'minlaydi. Buning uchun dars jarayoni oqilona tashkil qilinishi, ta'lim beruvchi tomonidan ta'lim oluvchilarning qiziqishini orttirib, ularning ta'lim jarayonida faolligi muttasil rag'batlantirilib turilishi, o'quv materialini kichik-kichik bo'laklarga bo'lib, ularning mazmunini ochishda interfaol usullarni qo'llash va ta'lim oluvchilarni ommaviy mashqlarni mustaqil bajarishga undash talab etiladi.

Boshlang'ich sinf darslarida o'qitishning yangi zamonaviy metodlaridan foydalanish jamiyatimiz hayotida yuz bergan ijobiy o'zgarishlar ta'limning maqsadi, mazmuni va vazifalarini ham qayta ko'rib chiqishni taqozo etadi. Buning natijasida o'quvchi dars jarayonida faol ishtirokchiga aylandi, uning fikrlash doirasi kengaydi, undan ijodkorlik, tashabbuskorlik talab etila boshlandi. Zamonaviy usullardan foydalanish: sinf muhitini o'zgartiradi; mavzu qanday o'rganilishi kerakligini belgilab beradi; har bir o'quvchini faollashtiradi.Bugungi kunda o'qituvchi o'qitish uchun faqat zaruriy axborotlarnigina tanlab olishi va o'quvchini bevosita mustaqil bilim olishga o'rgatmog'i zarur. Bu jarayonda o'qituvchining pedagogik mahorati, uning chuqur bilimi, odobaxloqi muhim rol o'ynaydi.Hozirgi kunda zamonaviy usullardan foydalanib dars berishda o'qituvchi mohirlikdan ijodkorlikka intilishi va bu bilan ta'lim sohasi rivojiga hissa qo'shmog'i talab etiladi. Zamonaviy pedagogik texnologiyalarni qo'llashda noan'anaviy dars usullaridan foydalanish orqali iqtidorli o'quvchilarni aniqlash, bo'sh o'zlashtiruvchi o'quvchilarda o' $z$ kuchlariga ishonch hosil qilishlari uchun imkon yaratish, sinfdagi o'quvchilar o'rtasida do'stlik, o'zaro hamkorlik aloqalarini shakllantirishga erishish nazarda tutiladi.

"Rezyume" texnologiyasi. Texnologiyaning tavsifi: $\mathrm{Bu}$ texnologiya murakkab,ko'p tarmoqli,mumkin qadar muammoli mavzularni o'rganishga qaratilgan. Texnologiyaning mohiyati shundan iboratki, bunda bir yola mavzuning turli tarmoqlari bo'yicha axborot beriladi. Ayni paytda ularning har biri alohida nuqtalardan muhokama qilinadi. Masalan, ijobiy va salbiy tomonlari, afzallik va kamchiliklari, foyda va zararlari belgilanadi.

Texnolgiyaning maqsadi: O’quvchilarni erkin, mustaqil, tanqidiy fikrlashga, jamoa bo'lib ishlashga, izlanishga, fikrlarni jamlab taqqoslash uslubi yordamida mavzudan kelib chiqqan holda o'quv muammosini yechimini topishga hamda kerakli xulosa yoki qaror qabul qilishga, jamoaga o'z fikri bilan ta'sir etishga, uni ma'qullashga, shuningdek, berilgan muammoni yechishga o'rgatish.

Texnologiyani qo'llanilishi: Ma'ruza darslarida (imkoniyat va sharoit bo'lsa), seminar, amaliy va laboratoriya mashg'ulotlarida yakka (yoki kichik guruhlar ajratilgan tartibda o'tkazish, shuningdek uyga vazifa berishda ham qo'llash mumkin.

Mashg'ulotda foydalanadigan vositalar: A-4formatdagi qog'ozlarida (guruh soniga qarab) tayyorlangan tarqatma materiallar, flomaster yoki rangli qalamlar.

\section{Mashg'ulotlar o'tkazish tartibi:}

o'qituvchi o'quvchilarning soniga qarab 3-5 kishidan iborat kichik guruhlarga ajratadi.

-o'qituvchi o'quvchilarni mashg'ulotning maqsadi va o'tkazilish tartibi bilan tanishtiriladi va har bir kichik guruhga qog'ozning yuqori qismida yozuvi bo'lgan, ya'ni asosiy muammo, undan 
ajratilgan o'quv muammolari va ularni yechish yo'llari belgilangan, xulosa yozma bayon qilinadigan varaqlarni tarqatadi.

-har bir guruh a'zolari ularga tushgan varaqlardagi muammolarning afzalligi va kamchiliklarini aniqlab, o'z fikrlarini flomaster yordamida yozma bayon etadilar. Yozma bayon etilgan fikrlar asosida ushbu muammoni yechimini topib, eng maqbul variant sifatida umumiy xulosa chiqaradilar.

-kichik guruh a'zolaridan biri tayyorlangan materialni jamoa nomidan taqdimot etadi. Guruhning yozma bayon etgan fikrlari o'qib eshittiriladi, lekin xulosa qismi bilan tanishtirilmaydi.

-o'qituvchi boshqa kichik guruhlardan taqdimot etgan guruhning xulosasini so'rab, ular fikrini aniqlaydi, guruhlar fikridan so'ng taqdimot guruhi o'z xulosasi bilan tanishtiradi;

-o'qituvchi guruhlar tomonidan berilgan fikrlarga yoki xulosalarga izoh berib, ularni baholaydi, so'ngra mashg'ulotni yakunlaydi.

"Blits-so'rov" usuli. Usulning tavsifi: Ushbu usul o'quvchilarni harakatlar ketma-ketligini to'g'ri tashkil etishga, mantiqiy fikrlashga, o'rganayotgan fani asosida xilma-xil fikrlar, ma'lumotlar ichidan keraklisini tanlab olishni, shu bilan bir qatorda, o'zgalar fikrini hurmat qilish va ularga o'z fikrini o'tkaza olish hamda o'z faoliyati, kunini rejalashtira olishni o'rgatishga qaratilgan.

Usulning maqsadi: ushbu usul orqali o'quvchilarga tarqatilgan qog'ozlarda ko'rsatilgan harakatlar ketma-ketligini avval yakka tartibda mustaqil ravishda belgilash, kichik guruhlarda o'z fikrini boshqalarga o'tkaza olish yoki o'z fikrida qolish, boshqalar bilan ham fikr bo'la olish kabi ko'nikmalarni shakllantirish.

\section{Mashg'ulotni o'tkazish tartibi.}

1. O'qituvchi o'quvchilarga ushbu mashg'ulot bir necha bosqichda o'tkazilishi haqida tushuncha beradi. Har bir bosqichga moljallangan vazifalarni bajarishga aniq vaqt berilishi, o'quvchilar esa shu vaqtdan unumli foydalanishlari kerakligi haqida ularni ogohlantiradi.

2. Keyin hammaga alohida-alohida tarqatma material beradi va ushbu materialni sinchiklab o'rganishlarini so'raydi;

- o'qituvchi tarqatma material mazmuni va bajariladigan vazifani tushuntiradi va "o'quvchining ismi va familiyasi" va "sinfi" bo'limlarini to'ldirishni aytadi.

- tarqatma materialda berilgan vazifa dastlab yakka tartibda bajarilishini ta'kidlaydi;

- har bir o'quvchi o'zining shaxsiy fikri asosida tarqatma materialdagi "o'quvchi javobi" bo'limiga berilgan savollardan 3xil variantli javobdan bittasini yozadi, javoblar raqamlar yoki harflar bilan ko'rsatilishi mumkin.

3. Berilgan vaqt ichida yakka tartibdagi ishlar tugagach tarqatma materiallar o'zaro almashinadi.(almashtirishni turlicha tashkil qilish mumkin, masalan yonidagi o'quvchi bilan, kichik guruhlarda yoki orqadagi o'quvch bilan)

4. Tarqatma materiallar almashingach, oqituvchi to'g'ri javoblarni o'qiy boshlaydi, oquvchilar bir-birini ishini tekshira boshlaydi va "to'g'ri javob" bo'limiga "1" balldan, agar noto'g'ri bo'lsa "0" ball qo'yib chiqishadi.

5. O'qituvchi baholash mezonini tushuntirib beradi va tarqatma materiallar qaytadan o'z egalariga almashtirilishi so'raydi,o'z xatolarini ko'rib olishlariga imkon beradi.

6. O'qituvchi tarqatma materiallarni yig'ishtirib olib baholaydi va e'lon qiladi.

Izoh: misol tariqasida "Metallar" mavzusidagi blits-so'rov jadvalini keltirish mumkin (har bir o'qituvchi o'z pretmeti bo'yicha o'tayotgan, avval o'tgan mavzu yoki umumlashtiruvchi darslarda ushbu jadvaldan foydalanib blits-so'rov tuzishi mumkin).

Xulosa qilib aytganda, tajriba-sinov natijalari shuni ko'rsatadiki, agar darslar so'z, tushuntirish orqali olib borilsa, o'zlashtirish $10 \%$ ni, ko'rsatish, namoyishlar orqali tashkil etilsa, $50 \%$ ni, ta'lim jarayoni o'quvchilarning shaxsiy ishtiroki faolligida kechsa, o'zlashtirish sifati va samaradorligi $90 \%$ ni tashkil etadi. 


\section{Foydalanilgan adabiyotlar ro'yxati}

1. Jumayev M.Ye.va b.q. "Boshlang'ich ta'lim fanlarini o'qitish metodikasi” O‘UM. Nizo miy nomidagi TDPU huzuridagi XTXQTUMOHM., 2017.

2. N.Bikbayeva va b. " Matematika o"qitish metodikasi" o'quv qo'llanmasi.T- 1996

3. Yo'ldoshev J.G'., Usmonov S.A. Pedagogik texnologiya asoslari, T.: "O‘qituvchi”, 2004.

4. Ishmuhamedov R.J. Innovasion texnologiyalar yordamida ta'lim samaradorligini oshirish yo'llari.-T.:Nizomiy nomidagi TDPU 2008

5. Ishmuhamedov R. O'quv jarayonida interfaol uslublar va pedagogik texnologiyalarni qo'llash uslubiyati. - T.: RBIMM, 2008

6. Yo'ldoshev. J.G'. Usmonov.S. Ilg’or pedagogik texnologiyalar.- T.:O‘qituvchi,2004.

7. Ochilov M. Yangi pedagogik texnologiyalar. - Qarshi.: Nasaf, 2000

8. Sayidaxmedov N. Pedagogik amaliyotda yangi texnologiyalarni qo'llash namunalari. T.: RTM, 2000.

9. Sayidahmedov N, Ochilov A. Yangi pedagogik texnologiya mohiyati va zamonaviy loyihasi.-T.,1999.

10. Sayidahmedov N. Pedagogik mahorat va pedagogik texnologiya. - T.,2003

\section{БЎЛАЖАК ЎКИТУВЧИЛАР РЕФЛЕКСИВ ПОЗИЦИЯСИНИ РИВОЖЛАНТИРИШНИНГ АЙРИМ МАСАЛАЛАРИ}

\section{Z. Qarshiyeva (Samarqand, MOHM)}

Annotation: In this article, the author highlighted some methodological issues of developing a reflexive position in future teachers. The author revealed the essence of the problem based on the analysis of different approaches.

Key words and expressions: Teacher, reflection, position, reflexive position, formation, development, point of view, method, result

Маълумки, Ўзбекистон Республикаси олий таълим тизимини 2030 йилгача ривожлантириш концепциясида олий таълим муассасаларида ўқув жараёнини босқичмабосқич кредит-модуль тизимига ўтказиш; халқаро тажрибалардан келиб чиқиб, олий таълимнинг илғор стандартларини жорий этиш, жумладан ўкув дастурларида назарий билим олишга йўналтирилган таълимдан амалий кўникмаларни шакллантиришга йўналтирилган таълим тизимига босқичма-босқич ўтиш мухим вазифалар сифатида белгилаб берилди. Ўқитишнинг кредит-модуль тизими компетенциявий ёндашув билан бевосита уйғун амалга оширилиб, модулли ўқитиш технологияларининг натижаси сифатида бўлажак мутахассисларда таркиб топтириладиган компетенциялар акс этади.

Инсоннинг узз фаолияти ва "хаёт сохиби” сифатида ўзига нисбатан онгли муносабати рефлексия орқали шакллантирилади, чунки айнан рефлексия англаб етиладиган воқеликка нисбатан ўз муносабатини идентификациялашга ёрдам беради.

Илғор таълим масаласи биринчи галдаги вазифа деб хисобланса, педагогик тизимни ривожлантиришнинг замонавий босқичи яхлит шахсни ривожлантириш механизми сифатида рефлексияга бўлган лаёқатни шакллантириш ғоясини олға суради. Рефлексив позиция шахснинг бошқа барча нуқтаи назарларини шакллантириш учун асосдир. Шу муносабат билан, бўлажак ўқитувчининг айнан ушбу шахсий-мустақил таълимини шакллантириш жараёнини тахлил этишни мақсадга мувофиқ.

Г.П.Шедровицкий биринчилардан бўлиб “рефлексив позиция” тушунчасини индивид амалга оширилаётган фаолиятга нисбатан уни тахлил қилиш ва келгуси фаолият режасини тузиб чиқиш мақсадида “ташқи” позицияни эгаллаш зарурлигини хис қиладиган вазият сифатида талқин қилган, бунда у рефлексив жараёнларга асосланган. Г.П.Шедровицкий 
инсоннинг ташқи оламга нисбатан нуқтаи назарини рефлексив позиция деб хисоблаган [4, 12-28 б.].

Дастлаб, “рефлексив позиция” тушунчасини аниқлаштириш учун унинг таркибий асоси хисобланган “рефлексив” ва “позиция” атамаларига аниқлик киритиш лозим.

Рефлексия муаммоси турли соха вакиллари томонидан илгари сурилган ва унинг ривожланишида сифат ўзгаришлари юз берган. "Рефлексия" тушунчаси фаннинг кўплаб сохаларида ишлатилади, бу эса ушбу атама билан боғлиқ ходиса мазмунининг кўп маъноли эканлиги билан изохланади.

Рефлексия (лот.reflexio - ортга қайтиш, акс этиш). 1. Кишининг ўз хатти-харакатлари ва уларнинг асосларини тушуниб етиши, фахмлашига қаратилган назарий фаолияти; билишнинг алохида бир шакли; 2) фикрлаш, ўз-ўзини назорат қилиш; 3) ўзининг шахсий харакатлари ва уларнинг қонун қоидаларини фикрлашга йўналтирилган инсон фаолиятининг назарий шакли; 4) ўз рухий холати хақида ўйлаш, хаёл суриш, фикр юритиш, уни тахлил қилишга мойилликни англатади [7, 132-б.].

Бўлажак ўқитувчининг касбий тайёргарлиги жараёнида унинг тадқиқот мавзуси сифатида рефлексив позициясини ривожлантириш педагогик ва психологик адабиётларда “рефлексия” тушунчасининг мохиятини аниқлаштиришнинг долзарблигини кўрсатади.

Тадқиқотимиз учун Қ.Иноқов томонидан таклиф этилган рефлексия таърифи жуда мухимдир: “рефлексия - бу инсоннинг ўз фаолиятини тасаввур этиши, ўзининг муваффақиятлари ва хатоларини кўриш, уларни тўғрилаш ва шу тарзда маданий қадриятларни ўзлаштириш, дунёда ўз ўрнини аниқлаш, ўз имкониятларини билиш қобилияти бўлиб, бу эса қадр-қимматга эга бўлган эркин шахсни камол топтиради" [13].

Агар инсон муайян қадриятларга эга бўлса, у фаолиятдаги воқеликка ўз муносабатини кўрсатишга доимо тайёр бўлади. Ушбу тайёрлик муайян объектлар ва фаолият шароитлари инсон учун қанчалик ахамиятли эканлигига боғлиқ бўлади: агар киши ўз хохиш-истакларини ифода этишга мақсадлар ва фаолият воситаларини танлашга тайёр бўлса, у амалда ўзи учун мухим ва қадрли бўлган нарсани химоя қилишга тайёр бўлади. Бинобарин, позиция фақат фаолиятда, хақиқий харакатда намоён бўлади. Уни амалга ошириш учун усуллар, воситалар, шароитлар зарурдир.

Инсоний қадриятларни руеёбга чиқариш ва уни исботини топиш, ўз фаолиятини аниқлаш ва ривожлантириш позиция орқали содир бўлади, у орқали инсон ўзини фаолият субъекти сифатида намоён қилади.

Шуни таъкидлаш керакки, субъект томонидан рефлексив қобилиятларининг мақсадли ва мустақил равишда намоён бўлиши, шунингдек, рефлексив қобилиятлардан фойдаланиш (воқеликни турли хил холатларда яхлит самарали фаолиятни таъминлаш учун) субъектнинг рефлексияга ички англанган тарздаги тайёргарлиги бўлганда намоён бўлади, рефлексив позиция шахснинг ўз фаолиятига ва ўз-ўзига барқарор, яхлит, онгли муносабатлар тизимини акс эттиради, у шахсий тажрибани шакллантириш ва бойитишга ёрдам беради.

\section{Фойдаланилган адабиётлар рўйхати}

1. ัзбекистон Республикаси Президентининг 2019 йил 8 октябрдаги “Ўзбекистон Республикаси олий таълими тизимини 2030 йилгача ривожлантириш концепциясини тасдиқлаш тўғрисида"ги ПФ-5847-сон Фармони. // Қонун хужжатлари маълумотлари миллий базаси, 09.10.2019 й., 06/19/5847/3887-сон.

2. Вульфов Б.З. Иванов В.Д. Основы педагогики: учебное пособие. - М.: УРАО, 1999. - C. 438-439.

3. Абульханова К.А. Проблема определения субъекта в психологии. Субъект действия, взаимодействия, познания (Психологические, философские, социокультурные аспекты): монография. - М., 2001. - 284 с.

4. Щедровицкий Г.П. Коммуникация, деятельность, рефлексия // Исследование речемыслительной деятельности. - Алма-Ата, 2004. - 125 с. 
5. Хакимова Д.М. Умумий ўрта таълим муассасалари ўқувчиларида рефлексив кўникмаларини шакллантириш жараёнларини ташкил этиш ва бошқариш: педагогика фанлари бўйича фалсафа доктори (PhD). ...дисс. - Тошкент, 2018. - 171 б.

6. Давыдов В.В. Теория развивающего обучения: монография. - М.: ОПЦ ИНТОР, 1996. -541 c.

7. Педагогика: педагогические теории, системы, технологии / Под ред. С.А.Смирнова. - М.: Академия, 1998. - 510 с.

8. Тейяр де Шарден П. Феномен человека. - М.: Наука, 1997. - 136 с.

9. Педагогический энциклопедический словарь / гл. ред. Б.М. Бим-Бад. - М.: Большая Российская Энциклопедия, 2002. - 528 с.

10. Полонский В.М. Словарь по образованию и педагогике. - М.: Высшая школа, 2004. $-512 \mathrm{c}$.

11. Слободнюк Е.Г. Профессионально-ценностные ориентации как фактор становления личности будущего учителя: дис. ... канд. пед. наук. - Магнитогорск, 2000. $192 \mathrm{c.}$

12. Ходжаев Б.Х. Умумтаълим мактаби ўқувчиларида тарихий тафаккурни модернизациялашган дидактик таъминот воситасида ривожлантириш: Педагогика фанлари доктори. ... дисс. -Тошкент, 2016. - 314 б.

13. Иноқов Қ.Қ. Хамкорлик педагогикаси асосида таълим-тарбия сифатини такомиллаштириш: педагогика фанлари бўйича фалсафа доктори (PhD). ...дисс. - Наманган, 2019. - 142 б.

14. Фалсафа. Қисқача изохли луғат. - Т.: Шарқ нашриёт-матбаа акциядорлик компанияси Бош тахририяти, 2004. - 383 б.

15. Акрамов А.А. Шахсга йўналтирилган таълим технологиялари асосида бўлажак ўқитувчиларнинг фуқаролик позициясини ривожлантиришнинг ташкилий-методик асосларини такомиллаштириш: педагогика фанлари доктори. ...дисс. - Тошкент, 2016. - 282 б.

16. Мясищев В.Н. Психология отношений: избранные психологические труды. - М.Воронеж: Изд-во МОДЭК, 1998. - 363 с.

17. Бедерханова В.П. Становление личностно-ориентированной позиции педагога: дис. ... док.пед.наук. - Краснодар, 2002. - 200 с.

\section{"TA'LIMDAGI TEATR" TUSHUNCHASI}

\section{S. S.Pirimkulova}

(SamDChTI)

Annotation: The article discusses the concept of theater in education, the use of innovative technologies, as well as the history of the concept of theater pedagogy, as well as the problem of using theatrical performances in the study of a foreign language, theater work in foreign language lessons. The main purpose of the respective sessions will be discussed. The theater serves not only for teaching speaking skills, but also for teaching various skills.

Key words and expressions: Art technology, pedagogical goal, foreign language, teaching, theatrical pedagogy, creativity.

Ta'lim - bu har bir inson kelajakdagi kasbiga zarur bo'lgan bilim, ko'nikma va malakalarni egallashga intiladigan shakllantiruvchi jarayon. Shaxsni rivojlantirish g'oyasiga asoslanib, o'qituvchilar o'quv jarayonida chet tillarini o'qitishda innovatsion texnologiyalardan foydalanish, shuningdek kundalik va kasbiy faoliyatda chet tili bilimlarini oshirish uchun ulardan foydalanish qobiliyati masalariga to'xtaladilar. Badiiy texnologiyalar innovatsion texnologiyalar sifatida "ko'zda tutilgan pedagogik maqsadga erishish uchun badiiy-ijodiy faoliyatning badiiy vositalari va usullari to'plami" sifatida tobora ko'proq foydalanilmoqda. Badiiy texnologiyalar o'quvchilarning ijodiy 
qobiliyatlarini rivojlantiradi va o'qituvchining kasbiy fazilatlarini amalga oshiradi degan fikrga tayanishadi.

"Teatr pedagogikasi" va chet tilini o'qitishda teatr tomoshalaridan foydalanishning o'ziga xos xususiyatlarini ko'rib chiqsak:

"Ta'limdagi teatr" tushunchasi 1937 yilda Buyuk Britaniyada boshlang'ich maktabda o'ynashga ruxsat berilgan, Berta Vaddell tomonidan kiritilgan. Keyinchalik kontseptsiya Brayan Vay tomonidan ishlab chiqilgan bo'lib, uning kompaniyasining uchta maqsadidan ikkinchisi barcha turdagi maktablardagi o'qituvchilarga dramani ta'limga joriy etishiga yordam berish ekanligini ta'kidladi. So'ngra, ta'lim sohasida teatr butun dunyoga tarqaldi. Tadqiqotlar ushbu amaliyotning o'qitilishi va o'qitish samaradorligini namoyish etadi.

Teatr ta'limi va nemis tilini chet tili sifatida o'qitish kombinatsiyasi ikkita qiyin mavzuni birlashtiradi. Teatr ta'limi, shuningdek, chet tillarini o'rgatish. Teatr pedagogikasi uchun bu erda ijtimoiy, guruhiy dinamik, psixologik va hattoki badiiy maqsadlar keltirilgan. Odatda ikkita asosiy yo'nalish mavjud: jarayonga yo'naltirilganlik va mahsulotga yo'naltirilganlik. Holbuki, mahsulotga yo'naltirilgan asar oxirida birinchi navbatda tomoshabinlar oldida sahnalashtirilgan sahna ko'rinishida bo'ladi va shu bilan asosan badiiy dizaynga e'tibor beriladi, jarayonga yo'naltirilgan ishda esa boshqa maqsadlar birinchi o'ringa chiqadi. Masalan, psixodramada mojaroni hal qilish maqsad bo'lishi mumkin, ijtimoiy tadqiqotlar darslarida esa taqlid qilingan munozaralar faqat ikki xil maqsadni belgilab, siyosiy fikrni shakllantirishga yordam beradi.

Ikki yo'nalish - teatr pedagogikasi va nemis tili darslarini birlashtirgan yondashuv grammatikani o'qitish kabi boshqa uslubiy yondashuvlarni almashtirish uchun mo'ljallanmagan. Aksincha, bu individual o'qituvchi metodlarining umumiy repertuarini boyitishdir. Teatr darslari harakatga yo'naltirilgan darsning bir qismidir. Bu yerda asosiy e'tibor alohida o'quvchi va uning shaxsiga, uning faolligiga qaratiladi, o'qituvchiga o'quv jarayonini tashkil qilish uchun ko'proq vazifalar yuklanadi. Ko'pgina hollarda, ish guruhlarda amalga oshiriladi, fikr almashinadi va faoliyatning umumiy mahsuloti ustida ishlanadidi.

Shuni ta'kidlash kerakki, teatrlashtirilgan va pedagogik yo'naltirilgan nemis tili darslari chet tilidagi didaktika mavzusi bo'lib, bunda dramaturgiyaning turli usullaridan foydalanish mumkin.

Teatr ta'limi chet tili darslariga bo'ysunadi va darslarning asosiy shartlari va maqsadlariga moslashadi.

Chet tili darslarida teatrlashtirilgan tomoshalarga qarshi kelib chiqadigan asosiy dalillardan biri bu o'quvchilarning tilni yaxshi bilmasligidir. Ko'pincha nemis adabiyotida ma'lum bo'lgan asar sahnalashtiriladi. O'z-o'zidan paydo bo'ladigan chiqishlarning boshlang'ich nuqtasi bo'lib xizmat qiladigan sahna improvizatsiyasi aksariyat o'qituvchilar uchun bo'lmaydigan ish bo'lib tuyuladi, chunki aksariyat o'quvchilar og'zini ochmaydi. Shunga qaramay, hatto boshlang'ich darajasida ham teatr elementlaridan foydalanish mumkin.

Chet tili darslarida teatr ishi bilan bog'liq mashg'ulotlarning asosiy maqsadi nutq qobiliyatini rivojlantirish, aniqrog'i, chet tilida muloqot qobiliyatini oshirishdir. Aloqa ko'nikmalarini rivojlantirish uchun mashqlarning 3 turi mavjud: aloqa tayyorlaydiganlar, aloqa o'rnatadigan va tuzadigan va modellashtiradigan mashqlar Ikkinchisiga sahna improvizatsiyasi kiradi. Bu shuni anglatadiki, aksariyat hollarda talabaning avvalgi bilimlari faollashadi yoki yangi lug'at yoki iboralar tegishli kontekstda qo'llaniladi, ammo juda kam hollarda ular qayta kiritiladi. O'qishning bir nechta yo'nalishlari bir-biri bilan bog'liq: grammatika, lug'at va fonetika.

Xususan, chet tili darslarida amaliy tillarni o'rganish uchun voqelik lahzalarini yaratish zarur. Teatr ishi bunga ayniqsa mos keladi, chunki u o'yinchidan yaxlit majburiyatni talab qiladi va shu bilan nafaqat og'zaki, balki og'zaki bo'lmagan ifoda vositalaridan foydalanadigan aloqa jarayonini ta'minlaydi. Shunday qilib, talaba chet tilida va uning ichida improvizatsiya qilish qobiliyatiga ega bo'ladi va tarjima qilinadigan til mamlakatida yuzaga kelishi mumkin bo'lgan kundalik voqelikka tayyorlanadi. Ayniqsa, to'liq erkin, tayyor bo'lmagan improvizatsiyalar bilan, talaba uchun ravonlik va tushunarlilik grammatik jihatdan to'g'riligidan ko'ra muhimroq ekanligi ayon bo'ladi. Bu hech qanday tuzatishlar bo'lmaganligini anglatmaydi. Til darajasiga va ko'rib chiqilayotgan mavzuga qarab, taqdim etilgan sahnalardan keyin aniq xatolarni ko'rsatish mumkin. 
Ikkinchi muhim o'quv maqsadiga chet tilidagi teatr tomoshalari orqali madaniyatlararo mintaqaviy tadqiqotlar erishiladi. Chet tili darslarida sahna improvizatsiyasi maqsadli mamlakatda ijtimoiy voqelikni o'rganishning keng qamrovli usuli sifatida ham xizmat qiladi.

Albatta, teatr nafaqat og'zaki nutq mahoratini oshirishi mumkin. Teatr turli ko'nikmalarni tarmoq orqali o'rgatish uchun ham javob beradi. Masalan, avval matnlar yozilishi va keyin sahnalashtirilishi mumkin. Bu ikkita samarali qobiliyatni - yozish va nutqni birlashtiradi. Tinglash va o'qish bo'yicha topshiriqlar, agar talabalarni kuzatish, improvizatsiya taqdimoti paytida tushunishni nazorat qilish vazifalari berilishi ham mumkin.

Shunday qilib, chet tillarini o'qitish va teatr ta'limi birlashganda, teatr inshootlari chet tillarini egallash maqsadida, asosan og'zaki nutq ko'nikmalarini oshirish uchun ishlatiladi va shu bilan jarayonga yo'naltirilgan yo'nalish amalga oshiriladi.

\section{Foydalanilgan adabiyotlar ro'yxati}

2004

1. Birgit Oelschläger, Szenisches Spiel im Unterricht "Deutsch als Fremdsprache" Berlin.

2. Гальскова Н. Д. Современная методика обучения иностранным языкам - М.: АРКТИ 2000.

3. Goethe Institut 12.07.2019 - Theaterpädagogik Grundlagen/Basics - Theatermethoden zur Sprachförderung

\section{THE ROLE OF PICTURES IN THE TEXTBOOKS IN DEVELOPING STUDENTS' PAREMIOLOGICAL COMPETENCE}

\section{Sh. M.Boykhanov \\ (Nizami TSPU)}

Annotation: Visuals, including pictures are important components of the course books. Teachers employ these additional materials to explain vocabulary, to describe culture elements, and students use them to discuss, to do matching and labeling activities. Despite the available activities in the course books which include proverbs with pictures, and research works on effectiveness of learning proverbs through pictures, there have been no investigations about connecting proverbial discussions with pictures in the course books. For this reason, we aim to study utilizing suitable pictures in the course book and connect them with proverbial activities to differentiate the activity. To discuss the research question we designed a sample proverbial activity and recommended related conclusions.

Key words and expressions: Proverb, image, discussion, simulation, case, differentiate

Introduction. Course books are essential education tool for both learners and teachers because they are designed according to learners' needs. In achieving language skills, pictures, symbols, charts, and tables in the course books are important because by the help of those visuals students understand complex tasks easily. In this article we discuss particularly the role of pictures in the textbooks in developing students' paremiological competence.

Literature review. Some authors scrutinized on using the pictures for different purposes such as associating image and testing students' understandings. J. M. Clark \& A. Palvio stated: "A single mental image can integrate the parts of the events, objects".[Clark \& Palvio 1991:152].Richard P. Honeck, Brenda M. Sowry, \& Katherine Voegtle provided evidence the example of selected group of young learners' (from 7 to 9 year old children) proverbial comprehension level by using pictures. [Honeck, Sowry \& Voegtle 1978:327] Using picture and short wisdom in mass media and advertisement was analyzed by [Mieder 1990]. While Z.Vasiljevic compared the effectiveness of student generated pictures with teacher provided pictures in learning idiomatic language. [Vasiljevic 2012: 75] Another empirical research result was presented by Elham Baharian \& Mohammad Javad Rezai who showed the effectiveness of memorizing proverbs through pictures [Baharian E.\&Rezai M. J.2014:16] Dwi Haryanti utilized 3P (Proverbs-PictureParagraph) learning method, and stated that visualizing proverb helped students develop a 
paragraph [Haryanti 2017: 393], G.Ozbal, D.Pighin, \& C. Strapparava conducted research on "Learning to associate images with proverbs", in doing so, they indicated the connection between features of pictures with the meanings of proverbs. [Ozbal, Pighin, \& Strapparava 2019: 2515]. All above mentioned researchers' suggested using pictures facilitating the learning, but they did not mention about the research problem in this article, that is using suitable pictures in the course book and connect them with proverbial activities to differentiate the activity.

Methodology.We discussed research question qualitatively and analyzed it in several steps. First, research question was identified and reviewed related literature. Second, the proverb a jouney of a thosand miles begins with a single step [Manser 2007: 157] was selected from The Facts On File dictionary of proverbs by Martin Manser, and designed a proverb activity. After discussing findings, relevant recommendations were proposed.

Results. During our research we reviewed some course books and found that pictures were utilized for the following purposes: 1) a tool describing vocabulary, including proverbs; 2) a tool to describe culture elements (Chinese New Year) and 3) a prompt to describe a picture; 4) a clue for matching and labeling activities. Although in some course books, for instance, in Enterprise books by Virginia Evans, pictures were provided, they were only related to the meaning of the proverb or content of the whole unit, but not to the proverbial activity. To fill a gap in this field, we aim to suggest developing students' paremiological competence (knowing and using proverbs in practice) using picture. In terms of using a picture in the activity, Uzbek scholar Jamol Jalolov categorized activities based on their particular features, such as oral and written, receptive and productive activities. He claimed that such word combinations as "activity and text, activity and poem, activity and letter/sound, activity and picture" were inappropriate to methodology due to second word is object of the activity[Jalolov 2012:14-15]. Thus the following proverbial activity is oral and productive.

\section{A jouney of a thosand miles begins with a single step}

The proverb activity that we suggest is "Look at the picture. Advise the unsuccessful learner using proverb "a jouney of a thosand miles begins with a single step". This speaking activity is done after listening and and reading activity. Concerning using the speaking activity, Jamol Jalov stated important suggestion:

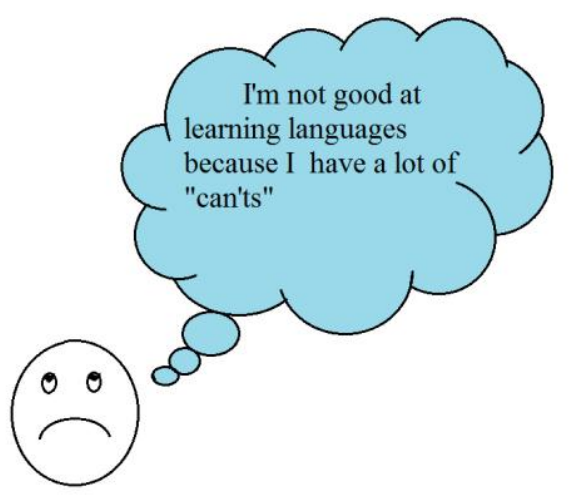

Speaking skill is reinforced through reading and writing skills. Listening and reading texts are one part of the vocabulary and they are repeated in speaking. Speaking activity is done after reading and listening activities. Written exercises are done after oral exercises because of some advantages, that is, the sound is transformed into graphic and they developed equally. [Jalolov 2012:95].

Figure 1: Look at the picture. Advise unsuccessful learner using proverb "a jouney of a thosand miles begins with a single step" Note: Picture is one of the effective tool to differentiate activity.(we drew this picture as a sample and did not adapt from other resourses due to copyright privacy)

This activity is performed in the following stages: 1) First, teacher asks students the relatedness of proverb to the picture and guess the meaning;2) After identifying the meaning, students summarize the reading passage by incorporating the proverb;3) In the next stage, leraners look at the again and visualize similar situatuon in real life;4) Finally, teacher gives feedback and assesses students. It is to note that teacher should choose the technique of speaking activity(role play, discussion, simulation, or case) and apply it based on students' linguistic (using approriate language) and extralinguistic(age, apptitude, motivation) capabilities.

Discussion and conclusion. Teachers cannot always make all students write a paragraph or draw a proverb no matter how learning conditions are facilitated to reach a desired result due to 
learners' incapability. Moreover, proverbial activities are provided in most course books; however, their methodology is not always provided well. We often see such form and meaning based activities as "discuss the following words of wisdom", or "give an equivalent to the following proverb" in the course books. Although the activity Discuss the following words of wisdom has an interactive feature, this does not guarantee that every student is able to do the assigned task successfully. The reason is they need visuals, particularly pictures to think and to elaborate their opinions. Based on this hypothesis, we recommend that course book designers should choose suitable pictures not simply describing some cultural features or vocabulary items, but also related to interactive proverbial activities, so teachers will save their time to search them from other recourses.

\section{The list of used literature}

1. Baharian E.\&Rezai M. J.(2014), The effect of proverbs on learning vocabulary through visual organizers, International Journal of English Language Teaching, Vol.2, No.4, pp. 16-32 http://www.eajournals.org/wp-content/uploads/The-Effect-of-Proverbs-on-LearningVocabulary-through-Visual-Organizers

2. Haryanti, D. (2017), Draw me a proverb: enhancing writing skills through wisdom. The 4th UAD TEFL International Conference, UAD Yogyakarta : pp.179-183 http://seminar.uad.ac.id/index.php/utic/article/view/165Proceedings\%20of\%20the\%204th\%20UAD \%20TEFL\%20International\%20Conference

3. Honeck, R., Sowry, B., \& Voegtle, K. (1978). Proverbial Understanding in a Pictorial Context. Child Development, 49(2), 327-331. doi:10.2307/1128694

4. Clark J. M. \& Palvio A. (1991), Dual coding theory and education, Educational psychology review, Vol.3, p.152. https://steinhardtapps.es.its.nyu.edu/create/courses/2174/reading/dct.pdf

5. Manser, Martin (2007), The Facts on File dictionary of proverbs, Facts On File, Inc. An imprint of InfoBase Publishing: p.157

6. Mieder, Wolfgang. A Picture is Worth a Thousand Words From Advertising Slogan to American Proverb.Southern Folklore; Lexington, Ку. Том 47, Изд. 3, (Jan 1, 1990): 207.

https://search.proquest.com/openview/53a65d6df61e084ba12f781745c0d34e/1?cbl=181982 0\&pq-origsite $=$ gscholar \&login $=$ true

7. Ozbal G., Pighin D., \& Strapparava C. (2019), .A proverb is worth a thousand words:Learning to associate images with proverbs. COGSGI'19: Creavity+Cognition+Computation, Montreal, Canada. https://cogsci.mindmodeling.org/2019/papers/0433/0433.pdf

8. Vasiljevic Z., (2012), Teaching Idioms through Pictorial Elucidation, THE JOURNAL OF ASIA TEFL, Vol. 9, No. 3, pp. 75-105 Bunkyo University, Japan.

\section{ИННОВАЦИОННЫЕ ТЕХНОЛОГИИ ПРЕПОДАВАНИЯ}

\section{С.А.Рахматова (СФ ТУИТ)}

Annotation: In article considers the types of technological innovation, using of training students. Defines perspectives and features by introduction of teaching at establishments.

Key words and expressions: pedagogic technology, innovation pedagogic technology, educational process, innovation, innovation technique.

Образование с одной стороны зависит от процессов, происходящих в нем, реагируя и отвечая состояния научно-технического прогресса, тенденциям развития экономической сферы страны, с другой, безусловно, влияет на все процессы и стороны жизни, поскольку готовит специалистов, развивает личность, формирует определенные жизненные взгляды. Поэтому особого внимания заслуживает современное состояние внедрения инноваций в образование нашей страны. Проблема становления и развития педагогических 
инновационных технологий привлекает внимание многих педагогов-ученых. Однако необходимо отметить, что не хватает комплексного системного подхода к реализации инновационных технологий в педагогическом процессе.

Анализируя технологии обучения, которые применяются в учебных заведениях, отметим их деление на две группы, которые называем традиционными и нетрадиционными. В системе образования выделяем такие инновационные технологии: инновации в содержании образования, инновации в педагогическом процессе, инновации в организационных структурах образования, инновации в деятельности и отношениях между преподавателями и учащимися, инновации и сфере образовательных услуг, инновации в области международного сотрудничества учебных заведений [1]. Рассмотрим инновационные педагогические технологии, которые позволяют усовершенствовать образовательную систему.

Суть проблемного изложения знаний преподавателем заключается в том, что вместо передачи готовых положений (правил, законов) науки преподаватель сообщает фактический материал, дает его описание на фоне систематически создаваемых им проблемных ситуаций, постоянно побуждает учащихся к частичной или полной самостоятельной познавательной деятельности с установлением и решением учебных проблем. В процессе использования информационных технологий учащиеся совершенствуют навыки работы с текстом, создают графические объекты, базы данных, используют электронные таблицы. Доступность глобальных информационных баз позволяет ученику учиться использовать разнообразную информацию, анализировать ее, что, несомненно, расширяет кругозор. Использование информационных технологий повышает мотивацию к обучению, стимулирует познавательный интерес, повышает эффективность самостоятельной работы. Информационные технологии могут стать основными инструментами в сфере образовательной, учебной и творческой деятельности учащихся [2]. Педагогическую основу автоматизированной учебно-контролирующей 45 программы составляют разнообразные тестовые задания.

В связи с тем, что информация в современном мире быстро теряет актуальность, преподавателю необходимо постоянно обновлять материалы учебно- методического комплекса, привлекать к этой работе учеников, еще в большей степени будет способствовать мотивации учебного процесса.

Комбинация, например, двух новейших технологий создает инновационную технологию, которая с одной стороны предоставляет компьютерную поддержку обучения (информационная технология), а с другой - обеспечивает индивидуализацию обучения (модульная технология). Информационно-модульная технология позволяет активно использовать дистанционное обучение, основанное на использовании широкого спектра разнообразных информационных, технологических и технических средств, которые позволяют построить учебный процесс без учета места и времени. К важнейшей черте дистанционного обучения исследователи относят гибкость, модульность, параллельность, полноту информационного доступа, экономичность, технологичность, социальную интернациональность и гуманность. Таким образом, информационно- модульная технология занимает достойное место в общей системе педагогических технологий.

Выводы. Итак, в статье рассмотрены некоторые инновационные и информационные педагогические технологии, которые используются в подготовке учащихся учебных заведений в учебно-воспитательном процессе. Отметим, что одну из представленных педагогических технологий нельзя назвать приоритетной. Они могут быть использованы только в системе, в их комплексном взаимодействии. Поэтому ценность заключается именно в их одновременном и смежном использовании. При выборе технологии необходимо убедиться, что она гарантирует достижение определенного уровня обучения и воспитания. Использование инновационных педагогических технологий зависит также от мастерства преподавателя правильно организовать учебный процесс. Выбирая ту или иную педагогическую технологию необходимо помнить о моральном аспекте. Речь идет, в 
частности, о целесообразности использования известных и создаваемых педагогических технологий. Инновационные технологии - важный фактор учебного процесса. В перспективе становится очевидным широкое использование инновационных педагогических технологий в образовательной системе. Широкий спектр и многовариантность инновационных и информационных технологий обусловливают необходимость их дальнейшего детального анализа и изучения в комплексном взаимодействии.

\section{Список использованной литературы}

1. Ахатова Ж.Е., Абдибекова Л.М. Информационные и инновационные технологии в образовании // Сборник научных трудов по материалам Международной научнопрактической конференции. - 2014. - С. 54-56.

2. Евстратова Т.А. Роль информационных технологий в инновационном развитии муниципальных образований // В сборнике: Государственное и муниципальное управление: инновационные аспекты развития. - 2013. - С. 61- 64.

\section{ПРИНЦИПЫ И СТРУКТУРА МОДУЛИРОВАНИЯ ПРОФЕССИОНАЛЬНОЙ КОМПЕТЕНТНОСТИ У БУДУЩЕГО УЧИТЕЛЯ-БАКАЛАВРА В ПРОЦЕССЕ ПРОФЕССИОНАЛЬНОЙ ПОДГОТОВКИ}

\section{Э.А.ХАЛИЛОВА (ТУИТ СФ)}

Annotation: The article is devoted to one of the pressing topics of our time about the impact of globalization in the political and economic sphere of education. much attention is paid in the article to the formation of the cultural and linguistic personality of a student of a pedagogical university in the process of learning English. The author focuses on the technology of modular training, and the history of the modular discipline "Foreign language". Block-modular structure of a foreign language teaching program.

Key words and expressions: Globalization, sphere, image, process, person, influence, cooperation.

Профессиональная компетенция рассматривается как необходимость постижения человеком окружающей реальности, способствующая становлению личности в течение всей жизни. Развитие общества выдвигает новые требования к личности выпускника вуза, его успешной социализации, которая в значительной степени зависит от сформированности профессиональной компетенции. Согласно моделям, предложенным в документе Совета Европы (1997), профессиональная компетенция состоит из трёх элементов: теоретического, творческого и прагматического.

Процессы демократизации жизни общества Республики Узбекистан вызывают особую необходимость для серьёзных изменений в системе высшего профессионального образования с целью общекультурного, личностного и познавательного развития студентов. Осуществляется значительная работа по дальнейшему совершенствованию системы высшего образования, в частности, принята Программа комплексного развития системы высшего образования в 2017-2021 годах. И как верно отмечено Президентом Республики Мирзиёевым Ш.М. : «Страна, стремящаяся к прогрессу, желающая стать конкурентоспособной, обязательно должна уделять внимание науке. Мы должны развиваться как прогрессивная и инновационная страна. Для этого учёные, исследователи должны усердно работать во благо Родины, внедрять научные разработки и технологии во все сферы, особенно в регионах» ${ }^{85}$.

\footnotetext{
${ }^{85}$ Мирзиёев Ш.М. Встреча с руководителями вузов, учёными и академиками. 6 апреля 2018 год, г. Ташкент.
} 
В современных условиях, развитие и модернизация высшего образования, стало целью комплексного формирования профессиональной компетентности у будущего учителябакалавра. Под профессиональной компетентностью понимается совокупность интеграционных компетенций, которые необходимы для решения множества учебновоспитательных задач на различном уровне. Новые приоритеты в образовании в условиях реализации ГОС побуждают преподавателей к поиску новых современных эффективных технологий преподавания, позволяющих достичь более высоких результатов обучения и воспитания, внедрять новые образовательные технологии в учебный процесс. Передовой опыт практической деятельности преподавателей многих учебных заведений подтверждает их стремление к активному поиску и использованию педагогических технологий в работе с обучающимися. В число современных передовых педагогических технологий входит технология модульного обучения. Модульное обучение - способ организации учебного процесса на основе блочно-модульного представления учебной информации.

Соответственно, модулирование профессиональной компетентности будущего учителя-бакалавра в процессе изучения английского языка становится важнейшим и основополагающим условием эффективного учебно-воспитательного процесса. Профессионально-личностные, качества педагога, также необходимы для работы в педагогической сфере, они являются непременным условием для организации учебновоспитательного процесса в высшем учебном заведении.

Глобализация в политико-экономической сфере, существенным образом усиливая межгосударственные интеграционные процессы и создавая новые сферы социальной активности человека, оказала большое влияние и на сферу образования. Многие отечественные педагогические вузы активно вступили в международное научнообразовательное пространство и приступили к расширению сотрудничества с высшими образовательными учреждениями и организациями за рубежом.

Однако на пути интеграции и глобализации возникло препятствие, связанное с недостаточно высоким уровнем владения иностранным языком. В этой связи многие вузы педагогического профиля встали перед необходимостью осуществлять подготовку специалистов на уровне международных требований, способных эффективно функционировать в международном научно- образовательном контексте и владеющих как минимум одним иностранным языком.

\section{The list of used literature}

1. Furmanova.P. Intercultural communication and cultural-linguistic pragmatics in the theory and practice of foreign language teaching: abstract. dis. ... d RA PED. sciences'. M., 1994.

2. Juceviciene P. A. Theory and practice of modular training - Kaunas: Sviesa, 1989 - 227c.

3. Khutorskoy A.V. Definition of General subject content and key competencies as a characteristic of a new approach to the design of educational standards // Competence in education: design experience: sat. nauch. Tr. / edited by A. V. Khutorsky. M.: Scientific innovation enterprise "INEC", 2007. 327 PP.

4. Gerasimov V. M. Modular training in General technical disciplines of the University. Chita: Chita Polytechnic Institute, 1994-P. 17-20.

5. Zakaryukin V. B., Panchenko V. M., Tardin L. M. Modular design of textbooks on special disciplines of College textbooks. Vilnius : Voronezh state University, 1983. P. 73-74.

6. Markova E. S. Theoretical bases of construction of integrative-modular courses of English for profile school: abstract. dis. ... Cand. PED. Sciences-M., 2004-17-p 


\section{海外における『源氏物語』の翻訳からウズベク語訳へ (FROM TRANSLATIONS OF “THE TALE OF GENJI" OVERSEAS TO UZBEK TRANSLATION)}

\section{G.I.Kurbonova f.n., PhD \\ (SamDChTI)}

Annotation: Masterpiece of Japanese classical literature has been read as 'Japanese Exotic', or as 'Universal' and 'Modern', and are now attracting attention as 'the World's first Novel'. I would like to translate "The Tale of Genji", which is a masterpiece in world novel, into Uzbek language and introduce it to Uzbek people. To that end, I am studying "The Tale of Genji".

In this paper, I summarized the evaluation and translations of "The Tale of Genji" oversease.

Key words and expressions: Heian period, Aristocratic society, Court literature, Universality, Modernity.

『源氏物語』は平安時代（794 年〜1185 年）の貴族社会を舞台とした宮廷文学であ り、54 帖の巻によって構成された長編物語である。後世の日本文学に与えた影響も極め て大きい。

作者は一条天皇中宮上東門院彰子に女房として仕えた紫式部である。作者紫式部の 父は藤原為時、母は藤原為信の娘であり、父も母も嵯峨天皇の時代に左大臣であった藤原 冬嗣の子孫でありながらも、受領階級の家柄であった。父為時は歌人ょり詩人として名高 い。文章生出身者であり、当時の詩文界に活躍していた一人である。「式部」は父の官職 名である。「紫」は『源氏物語』に登場する若紫、後の紫の上に因んで名付けられてい る。

『源氏物語』は 3 部によって構成されている。第 1 部は、桐传帝の皇子として生ま れながら、臣籍に下り、「源氏」の姓を賜った主人公の光源氏が栄華を極める話である。 第 2 部は、光源氏の晚年の苦悩と無常についてである。第 3 部は、光源氏の没後の子孫た ちの物語である。いわば、光源氏と子孫の恋愛や結婚、政治や思想など、王朝貴族の様々 な問題を取り上げながら物語が展開していくのである。

海外において『源氏物語』は日本古典文学の代表的な作品、おょび世界小説史の傑 作の 1 つとして読まれている。また、周知のょうに日本の古典文学作品のなかで、最も多 くの世界の主要言語に翻訳され、紹介されている。海外で読まれる理由として、「一方で は文化圈を越える普遍性があるからであり、他方では、日本的なもの、エクゾチックなも のとして意識されている」（注 1）ことが指摘される。そして現在、古典文学作品である 『源氏物語』の近代性を有する性質が特に注目され、いまは「世界最古の小説」・「世界 最初の小説」として認識されている。例えば、井上英明氏は「この作品じたいの方法・構 造が現在までの世界小説史上もっとも高度で複雑な大規模な形象を達成していることによ って、18・19 世紀における「ノーヴェル,小説」のヨーロッパ的通念を大きく変更させる 内容と迫力をもってい」ると論述し、世界小説史における「本質的に「偉大な小説」」で あると指摘する（注 2）。

現在、世界では以下の言語に翻訳された『源氏物語』が存在する。

アッサム語、アラビア語、イタリア語、ウルドゥ一語、英語、エスペラント語、オ ディア語、オランダ語、クロアチア語、スウェーデン語、スペイン語、スロヴェニア語、 セルビア語、タミール語、チェコ語、中国語、テルグ語、ドイツ語、（トルコ語）、ハン ガリ一語、ハングル語、パンジャービー語、ヒンディー語、フィンランド語、フランス 語、ヘブライ語、ベトナム語、ポーランド語、ポルトガル語、マラヤラム語、モンゴル 語、リトアニア語、ロシア語（注 3 ）。 
それから、『源氏物語』は世界各国の主要な言語に翻訳されているのみならず、完 訳・抄訳をふくめ、例えば、次の通り、同じ言語で何度も翻訳が試みられ、出版されてい ることが注目に值する。

英訳：末松謙澄訳（抄訳） / Arthur Waley 訳 / Edward. G. Seidensticker 訳 / 中村諒一 訳（抄訳） / Helen C. McCullough 訳（抄訳） / Royall Tyler 訳 / Stuart Varnam-Atkin 訳（若 紫巻のみ） / Dennis Washburn 訳。

ドイツ語訳: M. Müller-Jabusch(末松訳) / Herberth E. Herlitschka 訳（ウェイリ一訳の 抄訳）/ Oscar Benl 訳。

フランス語訳: Arvède Barine 訳（末松訳）／Michel Revon 訳（抄訳）／Yamata Kiku 訳（ウェイリ一訳の抄訳）／Charles Haguenauer 訳（桐锓巻のみ）／ René Sieffert 訳／ Michel Revon 訳（抄訳）。

イタリア語訳: Ivo Domenichini 訳（Yamata Kiku 訳） / Piero Jahier 訳（ウェイリ一訳 ・宇治十帖のみ）／Adriana Motti 訳（ウェイリ一訳・幻巻まで）／Maria Teresa Orsi 訳

スペイン語訳: Fernando Gutiérrez 訳（ウェイリ一訳の抄訳）／ Manuel Tabares 訳（ウ エイリ一訳・夕顔巻のみ / Xavier Roca-Ferrer 訳 / Jordi Fibla 訳（タイラ一訳） / Hiroko I. Shimano, Ivān A. P. Romān 訳（抄訳）。

オランダ語訳: Ellen Forest訳（ウェイリ一訳の抄訳）／Hans C. ten Berge 訳（ウェイ リ一訳・夕顔巻、またサイデンステッカー訳の抄訳がある）／Jos Vos 訳（ウェイリ一訳 ) 。

ロシア語訳: Konrad Nikolă̌ 訳（抄訳）／ Sokolova Tatyana 訳。

韓国語訳: 柳呈訳 / 田溶新訳 / 朴光華訳（抄訳）／金鍾徳訳。

中国語訳: 台湾の林文月訳 / 銭稲孫訳 (桐彀巻のみ) / 豊子愷訳 / 殷志俊訳 / 夏元 清訳 / 姚 继 中訳 / 鄭民欽訳 / 康景成訳 / 王烜訳 / 李宏伟訳。（注 4）

『源氏物語』は現代日本語訳の種類も多く、さらに、以上で確認したょうに海外の 多数の言語に翻訳されている。そして、同じの言語にいくつかの種類の翻訳本があること も世界文学としての『源氏物語』の特徽であろう。例えば、ドナルド・キーン氏は、それ ぞれ異なる特徽のある英訳本が存在することについて、次のょうな興味深い指摘をしてい る。

それはとてもいいことだと思います。つまり人の好みによってどういう『源氏物語 』を選ぶかがあります。ほかの国でも、2つ、3つの翻訳があってもょいでしょう。それ ほどすばらしく、世界的な作品です。ひとつだけの翻訳で満足する理由はないです。（注 5)

このょうな多くの翻訳本の出現は、世界各国における『源氏物語』への関心、おょ びそれぞれの国における受容の状況をも示していょう。

各国での翻訳が、アーサー・ウェイリ一訳（1925 年）やエドワード・G・サイデン ステッカ一訳（1976 年）の英語をもとにした重訳であることが多かった。それが最近で は、古語から直接翻訳される時代となった。源氏物語の原文には、自分の国の言語に訳そ うと思わせる鬼力が満ちているようだ。そして、それを読もうとする人々が、世界各国に いるのである。（注 6）

その通りである。『源氏物語』は、初めてアメリカやイギリスの日本研究家によっ て紹介され、現在も『源氏物語』研究についてアメリカが主導的立場を担っており、世界 各国がその研究成果を継承展開している。別の機会に、また、母国ウズベキスタンにおけ る『源氏物語』受容と翻訳の問題について詳しく検討するが、ウズベキスタンの場合は隣 国であるロシアの研究成果を受けており、『源氏物語』のロシア語訳が使われている。 
一般に、『源氏物語』のロシア語訳といえば、Татьяна Соколова -Делюсина 氏（タ チャーナ・ソコロヴァ＝デリューシナ（一九四六年-））による翻訳があげられる（注 7） 。しかし、ロシア出身の日本学者である Николай Иосифович Конрад氏（ニコライ・コン ラッド（1891 年〜1970 年））が『源氏物語』の完訳を目指し、訳業を進めていたことに ついてはあまり知られていない。コンラッド氏には、『伊勢物語』（全訳）の訳業がある 。コンラッド氏は、1924 年に Повесть о Гэндзи, Блистательном принце. Цикада (Уцусэми) と空蝉巻を、続いて 1925 年に Вечерний лик (Югао). Глава из Повесть о Гэндзи と夕顔巻 を、1927 年には Гэндзи-моногатари.дождливую ночь と箒木巻の有名な「雨夜の品定め」 を、そして 1935 年に Фрейлина Кирицубо. Глава из романа Гэндзи-моногатари と桐盇巻を 翻訳・出版している。コンラッド氏は、日本の『源氏物語』を単に歴史上の古典としてで はなく、モダニズムに通じる作品として受け止めていた姿勢がうかがえるとされる（注 8 )。

T. ソコロヴァ=デリューシナ訳は、出版から 2 週間ほどで完売したものの、批評な どがなかったため、当時どのょうに受け入れられたのかは分からないようである。2018 年 3 月号『物語研究』に掲載されたアンダソヴァ・マラル氏による「異言語間における言 説分析一『源氏物語』ロシア語訳の事例から」（注 9）と題した最新の研究があり、ソコ ロヴァニデリューシナ訳の特徴について言及している。

『源氏物語』の解釈、作品の文学的価值についての批評は多種多様であり、時代に よっても、新たに出版される翻訳のもつ特徵によっても変動する。日本古典文学の傑作が 日本的エキゾチックなもの、または普遍性や近代性のあるものとして読まれており、いま や「世界最初の小説」として注目されている。そして、世界のほかの文学作品との関連に おいて鑑賞する可能性さえ期待されている。しかし、残念ながら、母国語のウズべク語訳 はまだ世に出ていない。筆者は『源氏物語』をウズべク語に翻訳することを考えている。 ロイヤル・タイラ一氏が翻訳について、次のょうに言及している。

翻訳にあたっては、正確さだけではなくその文学的な質の高さをも伝えなければな らないと考えた。この 2 つの点は相互に密接に関わっており、ある文学作品が持つ美しさ は、その作品が伝えんとする要素の 1 つであると思われる。（中略）翻訳は子細な読みを 要求してくるもの。（注 10）

翻訳は作品を正確に伝えること、そしてその作品の美しさと価值をも伝えることで あるという。そのため、まず作品の子細な読みが要求される。『源氏物語』の理解を深 め、翻訳の土台を構築するために、まず作品の研究から取り組むべきである。筆者も将来 『源氏物語』を原文からウズべク語に翻訳することを望み、物語の勉強と研究をしはじめ たのである。そして、日本の明治大学大学院（博士前期課程・博士後期課程）で翻訳に向 けての研究をしてきた。世界小説史の冒頭をかざり、世界小説中の傑作とされるこの『源 氏物語』を、ウズベキスタンの人にも翻訳紹介し読んでもらいたい。筆者は、『源氏物 語』の登場人物、特に女性の精細な描かれ方、豊かなあり方、そして多様な生き方に感銘 を受けている。これまでの翻訳研究の成果を参考にしながら、原文を慎重に検討解釈し て、貴族文化社会、自然と人々のあり様、生き方を忠実に再現したいと考えている。

\section{注}

1）ユディット・アロカイ「ドイッ語圈における『源氏物語』受容と翻訳の問題」 (京都大学大学院・文学研究科編『世界の中の『源氏物語』一その普遍性と現代性一』臨 川書店、2010 年 2 月）。

2) 井上英明氏による「世界文学における源氏物語」（山岸徳平、岡一男監修『源氏 物語講座 第 1 巻 主題と方法』有精堂出版、1971 年 5 月）。 
3）京都文化博物館編「源氏物語の外国語訳」『源氏物語千年紀展〜恋、千年の時空 をこえて〜』2008 年 4 月。「日本古典文学翻訳データベース」（伊井春樹編 国際日本文 学研究報告集二『日本文学 翻訳の可能性』風間書房、2004 年 5 月）。また、左記の「海 外源氏情報」サイト『源氏物語』翻訳史略年表を参照した。

http://genjiito.org/genji_infomation/genji_history/

4）前掲（3）「海外源氏情報」・『源氏物語』翻訳史略年表参照。

5) ドナルド・キーン「日本文学の出会いから」（伊井春樹『世界が読み解く日本 海外における日本文学の先駆者たち』學燈社、2008 年 4 月）。

6）前掲（3）『源氏物語千年紀展一恋、千年の時空をこえて一』。

7) Татьяна Львовна Соколова -Делюсина (タチアーナ・リヴォヴナ・ソコロヴァ= デリューシナ）Повесть о Гэндзи（源氏物語）、 Москва Наука（モスクワ、ナウカ社）、 1991-1993.

8）袴田茂樹「ロシアから見た「源氏物語」」。

http://www.tmu.co.jp/feature/hakamada15.html による。

9）アンダソヴァ・マラル「異言語間における言説分析一『源氏物語』ロシア語訳の 事例から」『物語研究』第 18 号、2018 年 3 月。

10）ロイヤル・タイラー 国際日本文学研究報告集 3 「翻訳者として『源氏物語』を 考える」（伊井春樹編『海外における源氏物語の世界、翻訳と研究』風間書房、2004 年 6 月）。

\section{BOLA TARBIYASIDA MILLIY QADRIYATLARNING O'RNI "BAXTSIZLIK SABABI - TARBIYASIZLIKDA. TARBIYASIZLIK MANBAI - HAYOSIZLIKDA. HAYOSIZLIK ASOSI - SUST E'TIQODDADIR"}

\section{N.M.Bekniyozov (DTM, Navoiy viloyati bo'limi boshlig ‘i)}

Annotation: Who is responsible for the upbringing of the child?, What to pay attention to the child-rearing chalk?, What are national values? First the mind is intelligence, then education, then science.

Key words and expressions: national values, intelligence, education.

Dunyoda har bir inson $\mathrm{o}^{6} \mathrm{z}$ farzandining baxtli va saodatli yashashini istaydi. Bola tug'ilganidan boshlab "yaxshi odam bo'lsin" deb duo qilinadi, Allohni tanisin, qalbiga iymon kirsin, deb o'ng qulog'iga azon va chap qulog'iga takbir aytiladi. Bizning yurtda, millatimizda azaldan tarbiya masalasiga bosh masala deb qaralgan. Bolalarni ilmli qilishga alohida e'tibor berilgan. Ota-onalari bolalarini muallimga berayotib «Eti sizga, suyagi bizga. Shu bolamizni savodini chiqarib, odam qilib bersangiz bas»,-deyishgan.

Bola tarbiyasi juda ko'p omillarga bog'liq. Bu omillarning birinchisi homila paydo bo'lishiga tayyorgarlik ko'rishdan boshlanadi. Hozirgi davrda ko'pchiligimiz bu talabga e'tibor bermay qo'yganmiz. Sog'lom, aql-zakovatli chaqaloqni dunyoga keltirish bosh masala hisoblanadi. Buning uchun ota-ona halol, pokiza taomlar yeb yurishi bilan birgalikda Allohdan solih farzand berishini ham o'tinib so'rab borishi kerak. Xotirasi past, beoqibat va noqobil farzandlar qayerdan paydo bo'ladi? O'z-o'zidan ayonki, bunday farzandlar istalmagan, so'ralmagan va kayfu safo orqasidan paydo bo'lgan homiladan dunyoga keladi. Aqli zaif yoki nogiron bolaga tarbiya berish ancha mushkul ish ekanligi hammaga ma'lum. Shu sababli bu masalaga ham alohida e'tibor qaratishimiz zarur.

Ikkinchisi, paydo bo'lgan homilani parvarishlab dunyoga keltirishdir. Biz bu masalaga ham yetarlicha e'tibor beravermaymiz. Yangi tishgan kelinni o'zimizga "buysundirib olamiz" deb, unga azob beramiz. $\mathrm{Bu}$ davr ham kelinning aynan homiladorlik davriga to ' $\mathrm{g}$ ' $\mathrm{ri}$ keladi. Bunday "buysundirish" oqibatida bolaning injiq va nogiron bo'lib tug'ilishi ehtimoldan holi emas. Shu 
sababli homilador kelinlarimiz va qizlarimizni avaylab-asrashimiz, kayfiyatlari yaxshi, ozuqalarining vitaminga boy bo'lishiga e’tibor qaratishimiz kerak ekan.

Uchinchisi, tug'ilgan chaqaloqni kamida 2 yil ona suti bilan ko'krakdan oziqlantirish hamda vitaminga boy va hazmi yengil taomlar bilan taomlantirib, qaddi-qomatini raso qilib voyaga yetkazish talab etiladi.

To'rtinchisi, bolani milliy, diniy va umuminsoniy qadriyatlar, milliy urf-odatlarimiz ruhida tarbiyalashdan iborat. $\mathrm{Bu}$ jarayon juda uzoq muddatli bo'lib, ota-onalardan sinchikovlik, ehtiyotkorlik va bilimdonlik talab qilinadi.

Ota-onalar "Qush uyasida ko'ganini qiladi" degan naqlga amal qilishlari kerak. "Bola otaonasining oynadagi aksidir" degan gap ham bor. Tarbiya - insoniy fazilatlarni jam qilish, xulqatvorni yaxshilik tomon isloh etmoq va shaytoniy xislatlarni o'zidan uzoqlashtirish demakdir.

Endi, duppini olib qo'yib, o'lab ko'raylik: Aql-zakovati bo'lmagan holda tug'ilgan, xotirasi past, noqobil farzandlarga tarbiya kor qiladimi? Shu joyda Mu'iniddin Juvayniyning "Qobiliyat egasining boshini silamaslik - zolimlik, iste'dodi yo "qni tarbiyalash - johillik"- degan hikmatli gapini eslash kifoya. Shu sababli avvalo, aql-zakovatli zurriyotni dunyoga keltirish, undan keyin uning tarbiyasiga alohida e'tibor qaratishimiz kerak bo'ladi.

Bola tug'ilishi bilan bir qator savollar paydo bo'ladi: bolani qanday tarbiyalash kerak, tarbiya asosida nima yotadi, bola odob-axloqli bo'lib o'sishi va yomon odatlarga o'rganmasligi ushun nimalar qilish kerak, bolani albatta gapga kiradigan qilib o'stirish kerakmi, qanday jazo usullarini qo'llash kerak, taltayib ketgan bolani qanday qilib qayta tarbiyalasa bo'ladi,....?

By savollarga javob toppish ushin, avvalo bolaning anatomik-fiziologik xususiyatlarini bilishimiz kerak. Bola kata odamdan farq qilib, o'zining aqliy va jismoniy rivojlanishida takomillashmagan bo'ladi, turli-tuman jismoniy yuklamalarga uncha chidamli bo'lmaydi, tashqi muhitga sust moslashadi. Yosh bolaning tez rivojlanib borishi sababli yuragi va o'pkasi zo'riqib ishlaydi.

Bolaning sezgi organlari tug'ilgan zahotiyoq ishlay boshlaydi, qattiq tovushdan cho'chiydi, ko'z ko'rishi yaxshi rivojlanmagan bo'ladi. Bu jarayonlar vaqt o'tishi bilan tuzalib boradi.

Shu sababli bolani yoshligida qo'rqitmasdan, baqirmasdan, muloyimlik bilan tarbiyalash kerak. Bir narsani to'iq o'rganib olgandan so'ng ikkinchisiga o'tish tavsuya etiladi. Bolani har bir ijobiy hatti-harakatlarini rag'batlantirib, maqtab borish, salbiy hatti-harakatlarini esa noto'g'ri ekanligini muloyimlik bilan tushuntirib, to' $\mathrm{g}$ 'rilab borish kerak.

Tarbiyada shaxsiy namuna asosiy o'rinni egallaydi. Bola ko'zi bilan ko'rganini tez o'zlashtirib oladi. Shu sababli "Qush uyasida ko'ganini qiladi” degan naql kelib chiqqan. Demak, bolamizning tarbiyasi yaxshi bo'lishi uchun o'zimiz yaxshi tarbiyalangan bo'lishimiz kerak ekan.

Bolani erkin harakat qilishga, erkin gapirishga ham o'rgatib borish zarur. Bolaga hamma narsani taqiqlab, so'zsiz buysunuvchan qilib ham quymaslik kerak. Bola bunday vaziyatda fikrlamaydigan, faqat topshiriqlarni bajaradigan manqurtga aylanib qoladi. Bolaning erkin fikrlarini, yaxshi takliflarini rag'batlantirib borish ham muhimdir.

Shu bilan birgalikda bolaning jismoniy rivojlanishiga ham alohida e'tibor berib borish zarur. Chu maqsadda bola rivojlanishi uchun kerak bo'gan vitaminga bou taom bilan ovqatlantirich bilan birga jismoniy mashqlar va jismoniy mehnat qilishga ham o'rgatib boorish zarurdir, toki farzandlarimiz xomsemiz bo 'lib qolmasin, mehnatda toblansin. Ibn Sino bobomiz "aqliy mehnatni jismoniy mehnat bilan muvozanatda olib borish zarur" ligini ta'kidlaganlar.

Sog'lom, aql-zakovatli va tarbiyalangan bolaga ilm berish maroqlidir. Ana shunday farzandlarimiz uchinchi renessans davrini boshlab berishi muqarrardir.

\section{Foydalanilgan adabiyotlar ro'hati}

1. Obiddin Maxmudov. "Farzandnoma". T: "O'qituvchi" NMIY, 2018

2. Shayx Muhammad Sodiq Muhammad Yusuf. "Baxtiyor oila". T: "Hilol-nashr",2020

3. Bahora Bobomurodova. "G'am-qayg'usiz yashay desangiz (o'ksinma)", T: "Sanostandart”, 2016

4. Tohir Malik. "Teng-tengi bilan baxtlidir", T: "Sharq-ziyo-zakovat", 2017 
5. Nurxon Bekniyozov. "Oila, tarbiya, ma'naviyat". T: "HILOL MEDIA", 2013

6. "Tarbiya kitobi: ibratli rivoyat va hikmatlar". T: "Yurist-mediya markazi",2015

7. "Yosh ota-onalarga". T: "Meditsina", 1980

\title{
ХАРБИЙ БИЛИМ ЮРТЛАРИДА ЧЕТ ТИЛЛАРИНИ ЎҚИТИШДАГИ ТАРЖИМАНИНГ ЎРНИ
}

\section{Д. Б. Халмуратова}

(Чирчиқ ОТҚМБЮ)

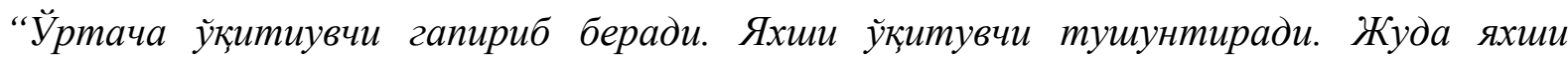 \\ уқитувчи намойиш этади. Буюкустозилхомлантиради” \\ Apmyp Ворд
}

Annotation: The article examines the positive results of learning Russian as a foreign language in military universities through method of translation. It also discusses the difficulties and mistakes that cadets face on the way of learning Russian.

Key words and expressions: Translation, speech, communicative competence, terminology, syntactic unit, general theory of translation.

Марказий Осиё минтақаси, шу билан бирга, собиқ Совет иттифоқи республикалари ўртасидаги муносабатлар ва мамлакатимиз миқёсидаги миллатлараро муносабатлар шароитида, рус тили миллатлар мулоқат тили функциясини сақлаб келмоқда. Айниқса, илмий техник мазмундаги маълумотларни ифодалошда рус тили мухим ўрин эгаллайди.

Дунёнин бошқа тиллари сингари рус тилини ўрганиш юқори малакали мутахассисларни тайёрлаш сифатини ошириш шартларидан биридир. Бу миллий ва жахон маданияти, фан, адабиёти ва санъат ютуқларининг калитидир.

Замонавий тил холатини хисобга олганда, миллий билим юртлари олдида мухим вазифа - мулоқотнинг муайян сохалари ва вазифаларида турли хил коммуникатив мақсадларнитил воситалари ёрдамида хал қилиш қобилиятини шакллантириш турибди.

Ушбу мақсадларга эришиш бевосита самарали услубиятлар, усуллар ва ўкув қўлламалардан фойдаланишга боғлиқ. Ушбу услублардан бири таржима қилиш қобилятини шакллантириш хисобланади.

Харбий билим юртларида қоида тариқасида белгиланган доимий амалий машғулотлар мазкур қобилятни янада юқори даражага кўтаришда мухим ўрин эгаллайди.

Хусусан, чет тилини касбий мақсадлар учун ўргатишнинг вазифаларидан бири, бу мутахассислик бўйича адабиётни тез ва етарли даражада идрок этиш ва тушунишни таъминлайдиган эркин ўқиш қобилиятлари ва кўникмаларини ривожлантиришдир. Аммо, хозирда билим юртида тахсил олиш мақсадида келган аксарият курсантларимизнинг ўқитилаётган чет тили бўйича бошланғич билими даражасини (база даражаси) хисобга оладиган бўлсак, амалдаги таълим стандарти доирасидаги машқлар қаторида фойдаланадиган чет тилидаги матнни таржимасиз тасаввур қилиб бўлмайди.

Таржима ва унинг ажралмас қисми бўлмиш мустақил таълим - матнни тушиниш ва уни визуал идрок этишга чет тилларини ўқитиш жараёнининг илғор босқичларида эришилади. Машғулотлар давомида вақтнинг етишмаслиги, курсантларнинг бошланғич билим даражасиининг пастлиги, уларнинг мотивациясининг сустлиги каби объектив ва субъектив характердаги сабабларга кўра матнни бундай идрок этишнинг хар доим хам имкони бўлмайди. Шу сабабдан курсантлар чет тили компитенциясининг коммуникатив даражасини ривожлантиришни таржимасиз амалга ошириш қийин масала хисобланади.

Бунда, оддий таржима (ўқув машғулотларидаги) ёки профессионал таржимани таълим таржимасидан фарқлаб олиш керак бўлади. Ўкув машғулотларидаги таржима - амалий кўникмаларни машқ қилишга ва таълим мақсадида маълум кўникмаларни ўзлаштиришга қаратилган таржима фаолиятининг тури. Ўкув машғулотларидаги таржима реал шароитлардаги қилинган таржимадан анча фарқ қилади. Шу билан бирга, замонавий техник 
воситалари ўқув машғулотдаги таржимани реал шароитга максимал даражада яқинлаштириш имкониятини яратади. Ўқув машғулотлари давомида қилинадиган таржиманинг асосий турлари курсантлар томонидан дарслар давомида ёки мустақил тайёргарлик жараёнида амалга ошириладиган ёзма таржима, шунингдек, бевосита ўқув хоналарида, дарс мобайнида амалга ошириладиган кетма кет (одатда жумлалар ёки иборалар) таржима қилишдир.

Нофилологик билим юртларида чет тилини ўқитишда машғулотлар давомида таржима мухим ўрин тутади. Шу билан бирга, курсантлар нафақат, мустақил таржима кўникмаларини оширадилар, балки, таржимадан тилни ўрганиш воситаси сифатида хам (грамматик материал ва янги сўз, ибораларни киритиш, икки тилдаги лексик ўхшашликни танлаш, баъзи грамматик тузилмаларни таржима қилиш усуллари) ўқиган ёки эшитган матнни тушунишини текшириш учун кўлланилади. Таржима тинглаш ва гапириш (аудирование, говорение) ёки ўқиш ва ёзишни бирлаштиради, у хар доим икки тилли мухитда амалга оширилади. Нутқ фаолиятининг турли шаклларида чет тилидан фойдаланиш курсантларга билимларни фаоллаштиришга эхтиёж туғдиради.

Икки томонлама таржима услубияти харбий билим юртларида чет тиллари машғулотларида қўлланиладиган таржиманинг яна бир тури хисобланади. Икки томонлама таржима қилиш услубияти тилнинг турли жихатларини ўргатиш, лексик, фонетик ва грамматик кўникмаларини, бир тилдан иккинчи тилга ўтиш қобилиятини мустахкамлаш учун самарали восита сифатида кўлланилиши мумкин. Шу билан бирга, машғулот давомида тили ўрганилаётган давлатнинг халқ оғзаки ижодидан олинган мақоллар, иборалар ва машхур шахсларнинг афоризм ва ибратли сўзларини сўзма - сўз эмас, балки маъновий (семантик) таржима қилиш жараёнида курсантларнинг мантиқий фикрлаш кўникмалари ривожланади.

Таъкидлаш жоизки, услубий адабиётларда таржима масаласи олий билим юртларида тилни ўргатиш воситаси сифатида етарлича даражада ривожлантирилмаган. Таржиманинг тилни ўргатиш жараёнидаги ўрни борасида таржима усулини тўлиқ рад этишдан тортиб, унинг чет тилларини ўргатиш масаласида ўзига хослигини хисобга олишга доир турли фикрлар мавжуд. Амалиёт шуни кўрсатадики, чет тилини ўқитишда таржимасиз усуллардан фойдаланиб, айниқса, нофилолог билим юртларида, самарали натижага эришиш жуда мураккаб вазифа хисобланади. Таниқли тилшунос профессор Бархударов Л.С «Таржимадан чет тили курсининг турли босқичларида фойдаланиш зарур», - деган фикрни билдиради.[Бархударов 2011:1]

Аммо, кўплаб услубчи ва амалиётчи ўқитувчилар таржимадан фақат тилни ўрганишнинг бошланғич босқичида фойдаланиш керак ва юқори босқичларда таълимни таржимасиз амалга ошириш мумкин деган фикрни илгари суришади. [Дубинина 2015:2] Бу нуқтаи назар юзаки хисобланиб, маълум чет тилини ўргатиш курсантларнинг ўз фикрларини ушбу тилда ифода этиш қобилиятини ривожлантиришдан ташқари турли вазифалар мажмуасини ўз ичига олади. Бунда курсант нафақат ўз фикрини чет тилида ифода этиши, балки қандай воситалар орқали ифодалаши, чет тили ресурсларига қанчалик эгалиги, мазкур тилда ифодалаш воситаларининг хилма хиллиги мухим ахамиятга эгадир. Маълумки, тушунчаларнинг маълум доирасини ифодалаш ва махсус бўлмаган мавзу (кундалик ва ижтимоий) бўйича сухбат олиб бориш учун бир яримдан икки минггача лексик биркмалар ва ўта содда бўлган грамматик тузилмалар тўпламига эга бўлса кифоя. [Тер-Минасова 2012:3]

Айнан шу вазиятда кўпчилик курсантларда «луғат доираси торайиши» ходисаси содир бўлади ва ўз фикрини элементар, баъзан ибтидоий шаклда ифода эта оладиган курсантлар, шу билим ва кўникмалар даражасини етарли деб хисоблаб, ўз нутқини янги сўзлар билан бойитиш ва ўзларида мавжуд бўлган сўзларни амалиётда кўллаш кўникмаларини оширишни тўхтатадилар. Чунки, «эркин гапириш» да курсант (талаба) ўзига маълум бўлган тор луғат ва грамматик бирикмалар доираси билан чекланиб қолиши ва ўз фикрларини бехато ифода этиши мумкин. Шу билан бирга, бундай «эркин гапирувчи» курсантлар нутқи ифодасиз ва содда шаклда бўлади. Таржима эса -матнни ёкитўғридан-тўғри нутқни (турли хил соддалаштириш ва алохида тилга мувофиқ иборалар ёрдамида) маъносини етказиб бериш 
бўлса,асл адабий, илмий ва тегишли атамаларга бой матнларни таржима қилиш эса, таржимонданмувофиқлик тамойили асл нусхадаги барча тил бойликларини стилистик тўлик етказишни, турли хил ифодалар, синонимларни ўзлаштиришни талаб қилади. Юқори босқичларда чет тилида нутқни ривожлантиришдаги таржиманинг ахамияти айнан шунда хисобланади.

Таржима компетенцияси эса қуйидаги таржима жараёни учун мухим бўлган кўникма ва малакаларнинг бутун мажмуини ўз ичига олади:

- атамаларни ишлатиш ва тушунишда лингвистик ва нутқий кўникмалари;

-бир тилдан иккинчи тилга ўтишдаги нутқ махорати;

- матн маъносини тахлил қилиш қобиляти;

- асл матннинг инвариантларини топишдаги нутқ қобиляти;

- сўзлаб беришдаги нутқ қобиляти.

Агар ўзбек тилидан рус тилига таржима хақида гапирадиган бўлсак, бунда юқоридаги барча кўникмалардан фойдаланишни талаб қиладиган ўта мураккаб механизм ишга тушади.

Бунда курсантлар нафақат чет тилидаги коммуникатив компетенциясини, балки ўз она тилидан самарали ва етарли даражада фойдаланиш қобилятини ривожлантиради, уларнинг нутқини бойитади, такомиллаштиради ва нотиқлик санъатини намойиш этишга ёрдам беради.

Хулоса тариқасида таъкидлаш жоизки, чет тили, хусусан, рус тилини, унинг грамматик ва семантик мураккаблигини ўрганиш ва ўқувчи-курсантларга ўқитиш амалиётида оғзаки ва ёзма (илмий, адабий матнлар) таржима услубияти нафақат, тилни янада чуқур тушуниб етиш, сўз бойлиги ва коммуникатив компетенцияни ошириш, балки, тилда мукаммал идрок этиш имкониятини яратади ва ўқувчи-курсантларда билингуал идрокни яратиш ва ривожлантиришга хизмат қилади.

\section{Фойдаланилган адабиётлар рўйхати}

1. Бархударов Л.С. Роль перевода как средства развития устной и письменной речи [Электронный ресурс]. - Режим доступа: http://samlib.ru/w/wagapow_a_s/barkhudarov-translrole.shtml, размещено 30/10/2011.

2. Дубинина, Т. Г. Методы обучения переводу на уроках иностранного языка в вузе [Электронный ресурс]. - Режим доступа: www.kgau.ru/img/konferenc/94.doc, размещено 27/11/2015.

3. Тер-Минасова С. Г. Проблемы перевода: MissionImpossible? // Вестник Московского университета. - Сер. 19. Лингвистика и межкультурная коммуникация. - 2012. - № 2. - C. 9

\section{俄语超句统一体构成句类型研究 ИССЛЕДОВАНИЕ ТИПОВ ПРИГОВОРОВ, ФОРМИРУЕМЫХ ЕДИНСТВОМ РОССИЙСКИХ ГИПЕРСЕНТЕНЦИЙ}

\section{上海外国语大学 陈洁(Чен Жиэ)}

摘要：俄语超句统一体（简称超句体）的构成句, 可分为七种类型：小主题句、铺叙 句、引导句、过渡句、兼用句、插叙句、共用句。每一超句体未必包含除铺叙句之外的另外 六种类型的句子, 这是由超句体具体表达内容决定的。

关键词：俄语句法学, 话语语言学, 超句统一体, 小主题句, 铺叙句。

超句统一体（简称超句体）的构成句, 主要依据其与超句体的小主题 ( микротема, 即 核心思想，此乃超句体的基本特征）的关系，分为以下类型。

1. 小主题句 (микротематическое предложение) 
小主题句起点明超句体中心思想的作用, 往往借助各类陈述句及感叹句等表达。它一 般位于超句体起始或结尾，或同时出现于首尾两处，有时也位居超句体中间。

\section{1 位于超句统一体起首的小主题句}

小主题句位于超句体起首时, 时常同启句 ( зачин) 吻合。在此情形下超句体的行文特 点时常是, 由整体到部分, 由抽象到具体, 由综合到分析。如 :

(1) Девушка, которую он назвал своей сестрой, показалась мне очень миловидной. Было что-то своё, особенное, в её смуглом лице, с небольшими чёрными, светлыми глазами. Она совсем не была похожа на своего брата. (Тургенев 《Ася》)

该例首句划下划线部分为小主题句，指明此超句体的核心思想：“我”觉得，这位姑娘 十分可爱。第二个句子具体铺叙姑娘的可爱之处, 最后一个句子作一归纳: 她根本不像自己 的哥哥。

\section{2 位于超句统一体末尾的小主题句}

小主题句位于末尾时, 它往往就是合句（концовка）。在该情况下超句体的行文特征 一般为：由具体、部分到概括、整体。

(2) Старики работали с молодыми, пока были силы. Когда сила кончилась, надо было умирать. Таков был закон жизни. (Лидин 《Олень》)

小主题句为该超句体最末尾一句, 它概括前面句子内容：新老更替乃人生规律。小主 题句位于超句体末尾常起归结作用, 多使用具有归纳、总结意义的句子。

\section{3 位于超句统一体首尾的小主题句}

小主题句同时出现于首尾两处时, 尾句时常照应首句, 并起归纳作用。在此情形下位 于首尾的两个句子分别又是超句体的启句与合句, 它们共同揭示超句体的小主题, 使其意义 得以明晰地尽现。

(3)Естественно, что Иван любил Магнитогорск затаенной, но сильной любовью.Город для него был не просто местом проживания, как старые города для своих жителей, ---- один не мог бы существовать без другого: если бы не город, Иван не стал бы Иваном, если бы не Иван, город не стал бы городом. Отцовская и сыновняя любовь одновременно ---- редчайшее чувство, такое чувство стал питать Иван к Магнитогорску.(Э.Казакевич)

此例小主题写伊万对马格尼托戈尔斯克城市的炽爱, 犹如他们之间是那种父子般的难 舍难分的珍稀情感。这一小主题是通过启句与合句共同揭示的。小主题句同时出现于超句体 首尾时, 其行文特点通常是: 概括 (抽象) ---- 具体 ---- 概括（抽象）。在此情形下, 仅保 留位于首尾的小主题句, 超句体意义也时常是连贯的; 把握位于首尾的小主题句的内容就可 掌握该超句体的主旨含义。

\section{4 位于超句统一体中间的小主题句}

小主题句处于超句体中间, 比其位于超句体首尾情形, 相对较少, 也不及居于首尾时 容易分辨。对这类超句体中心意义的概括需细心揣摩而定。如：

(4) Труппа начала репетировать. Что это были за муки! Даша молча плакала, артисты стыдились глядеть в глаза друг другу. Огрубели, ожесточились, застудили голоса... (А. Толстой) 
该例首句为引导句（参见下文 3.），点明事实背景一剧团开始排练。第二个句子（感 叹句) 为小主题句, 指出排练之艰辛。后续句子写演员排练时的行为、感受等, 从侧面祄托 排练之艰辛。

\section{2. 铺叙句 (повествовательное предложение)}

铺叙句展开小主题句的内容, 并与其通常形成因果、说明和总分等句际意义联系。它 是构成超句体必不可少的主干句子, 是推动情节发展的基本线索（основная линия） [Реферовская 1989: 13]。最典型的铺叙句是各类陈述句。例如：

(5) Мужа своего Марфа не любила, сердце её наглухо было закрыто для него, хотя она и честно несла крест, взваленный на неё отцом и братьями. Да и как она могла любить его? Слабосильный, чуть не на голову ниже её. Ни топор, ни пила в руках не держится. Ему даже бороды бог не дал. Волос рос клочьями ---- где есть, где нету. Как трава на болоте. (Ф. А. Абрамов)

该例首句中《Мужа своего Марфа не любила》为小主题句，其中《сердце её... братьями》属插叙句（参见 6.）， 《Да и как она могла любить его?》是过渡句（参见 4.）

其余句子为铺叙句，陈述玛尔法不爱丈夫的原因。

(6) Погода начала портиться. Волга потемнела, с севера поднялись грядами скучные, холодные тучи, засвистел ветер в тросах низенькой мачты. (А. Н. Толстой)

此例首句为小主题句, 指出天气开始恶化。其后句子解释怎样 портиться, 与小主题 句形成句际说明䏌系。

(7) Зима была трудной. Я плохо зарабатывал, было туго с заказами, и я болел. Рафик потерял ко мне интерес, не знаю уж почему. За всю зиму я не получил у него ни одного гонорара. (Ю.В. Трифонов《Предварительные итоги》)

该例首句亦为小主题句, 指出那年冬季很艰难。后续三个句子阐释如何 трудный，与 小主题句形成说明䏌系。

\section{3. 引导句 (стартное предложение)}

引导句通常位于超句体或某一简单超句体之首, 引出时空背景, 或点出话题, 为展开 小主题作铺垫。充任引导句的通常是表示时空意义的称名句、无人称句及启引话题的疑问句 等, 还时常是指出背景意义的陈述句。引导句一般同于启句。在复合或多项复合超句体中, 两个或若干引导句可构成一个简单超句体。

(8) [1]Вот и лес. [2]Тень и тишина. [3]Статные осины высоко лепечут над вами; длинные, висячие ветки берёз едва шевелятся; могучий дуб стоит, как боец, подле красивой липы. (Тургенев 《Лес и степь》)

该例首句为指示称名句，它作为引导句点明该超句体所讲内容的空间背景----лес。句 子[2]是存在称名句, 它同样用作引导句, 进一步确切空间背景一荫贀而寂静。句子[3]为铺 叙句, 具体描述不同的树木。此超句体中虽无小主题句, 但其核心思想可概括为林中景色。

(9) Стемнело. Едва-едва пламенеет тихая заря. Зелёные сумерки. Чёрны и резки контуры здания с их чуждыми теперь, пустыми, неосвещёнными окнами. Белые фигуры товарищей движутся, точно заворожённые. (Куприн) 
该例为无人称句《Стемнело.》作引导句, 它指出“天黑”这一时间背景；后续句子写这 一时间场合下的景象。该例也无小主题句，但此超句体的核心思想可归结为：黄昏时的景象

(10) [1] Что такое станционный смотритель?[2]Сущий мученик четырнадцатого класса , ограждённый своим чином томно от побоев, и то не всегда (ссылаясь на совесть моих читателей). / [3]Какова должность сего диктатора, как называет его шутливо князь Вяземский?[4]Не настоящая ли каторга?[5]Покою ни днём, на ночью.[6] Всю досаду, накоплённую во время скучной езды, путешественник вымещает на смотрителе. [7]Погода несносная, дорога скверная, ямщик упрямый, лошади не везут ---- а виноват смотритель. (Пушкин 《Станционный смотритель》)

该例为复合超句体，划“处为两个简单超句体的分界。引导句分别为三个疑问句 [1][3][4], 它们分别提出问题一驿站长为何职位? 有何职责? 是不是作驿站长真就是服苦 役? 此超句体内也无小主题句, 但其核心思想可归纳为：作驿站长是一个职卑位贱、受人凌 辱的差使。

\section{4. 过渡句 (переходное предложение)}

过渡句一般用于超句体中间部分，尤其是复合超句体交接处，即 Реферовская 所言前 一超句体的结尾, 或后一超句体的起首。它起衔接句际关系（或简单超句体 ----笔者）的作 用, 即“桥梁”（мост）作用。[Реферовская 1983：97-110] 过渡句可使超句体的核心思想在 连贯的意脉中得以传达, 用作过渡句的时常是陈述句和疑问句。

(11)[1]Однажды мы с сестрой нашли в нашем садике маленького ангорского котёнка.[2]Он был чистенький и пушистый.[3]Откуда он взялся? / [4]Я подхватил котёнка и унёс его домой.[5]Дома мы покормили котёнка. /[6]Потом привязали к ниткам бумажки и стали играть.[7]Но мы мешали друг другу и стали ссориться. / [8]Тогда в комнату вошла мама и велела нам прекратить игру.[9]Мама увидела на полу котёнка и сказала, что это соседкин.[10]Соседка с утра ищет котёнка и у всех спрашивает.[11]Мама взяла котёнка и отнесла его соседке. (Фигуровский)

该例是由四个简单超句体构成的复合超句体（划“”处是其分界，下同）。每一简单超 句体通过时间顺时全系组合起来，表达这种时间顺时全系的手段有，语法手段（动词的完成 体过去时形式）、词汇手段（Потом... Тогда...)。句子[3]《Откуда он взялся?》这一疑问 句位于第一个简单超句体的末尾, 一方面, 它是在与其相邻的两个简单超句体之间起承上启 下的连接过渡作用, 另一方面, 它又为下文 Тогда 引导的最后一个简单超句体的展开埋下伏 笔。(在此将其划入第一个简单超句体是因为, 该简单超句体皆用 он 指代 ангорский котёнок。紧随其后的第二个简单超句体对其的指代已变为 котёнок ---- 指代词的变换是(复 合和多项复合)超句体分界的重要标志之一。)

\section{5. 兼容句 (смешанное предложение)}

兼容句一般指兼有上述两种功能类型的句子, 多属兼有过渡句和小主题句或铺叙句等 作用的句子。该类句子多见诸复合和多项复合超句体交接处。[陈洁 2003:74] 如：

(12) Роли вдруг изменились. Вронский чувствовал его высоту и своё унижение, его правоту и свою неправоту. Он почувствовал, муж был великодушен и в своём горе, а он низок, мелочен в своём обмане. / Но это сознание своей низости пред тем человеком, которого он несправедливо презирал, составляло только малую часть его горя. Он 
почувствовал себя невыразимо несчастным теперь от того, что страсть его к Анне, которая охлаждалась, ему казалось, в последнее время, теперь, когда он знал, что навсегда потерял её, стала сильнее, чем была когда-нибудь. (Л.Толстой 《Анна Каренина》)

该例前一简单超句体主要写渥伦斯基对自己欺骗行为的内心自责, 后一简单超句体写 他这种愧疚心理又是那么无关痛痒, 他感到自己的所为是情有可原。该复合超句体通过 《Но это сознание... 》这一带有复指成分的语句连接起来, 该句子同时点明此超句体的小主 题: 渥伦斯基并不因为意识到自己卑劣的欺骗行径而深感愧疚。此句子兼有过渡句和小主题 句的功能。

\section{6. 插叙句}

插叙（отступление）[Лосева 1980: 69] 句指在行文基本线索展开过程中,中断叙述, 插 入有关的补充说明或细节的交待, 或对表述的评议等。它虽然也可位于超句体内, 但它是与 推动情节发展的基本线索相对应的辅助线索(побочная линия)[Реферовская 1989: 13-16], 若 去掉这类插叙句, 超句体仍为意义、结构和语用的统一体。插叙句一般具有左向交际功能, 说明、解释、评议左面相邻语句, 通常为叙述的支线。右向交际功能的句子在意义上与右面 相邻语句连接, 为叙述的主线, 可推动行文的发展。例如：

(13) ... [1]И рабочие всех стран чествуют теперь Евгения Потье.[2]Его жена и дочь ещё живы и живут в нищете, как жил всю жизнь автор 《Интернационала》. [3]Он родился в Париже 4 октября 1816 года. (Ленин)

此例选自列宁为纪念《国际歌》的作者欧仁. 鲍狄埃逝世 25 周年发表的一篇纪念文章 。该例主要围绕鲍狄埃进行叙述, 但是句子[2]这一插叙句写及他的妻子和女儿当时也同样 生活贫困, 这从侧面突出了鲍狄埃为国际共运事业无私地奋斗终生的品格。这也是纪念鲍狄 埃的原因之一。若不用句子[2]这个插叙句, 该超句体尽管不失连贯, 但缺少句子[2]所言细 节, 影响人物形象的丰满性。

7. 共用句（общее предложение）

共用句只适用于复合或多项复合超句体。共用句的特殊性在于，在复合或多项复合超 句体中它游离于简单超句体之外, 位于复合或多项复合超句体起首、结尾, 与复合或多项复 合超句体的组成部分 --- 各简单超句体形成意义、结构等方面的关联, 对各简单超句体有意 义、结构上的统摄或归纳、概括、引申等作用。下文用“/”表示共用句的界限, 用“//”表示复 合超句体中简单超句体之间的界限。

\section{1 位于复合或多项复合超句统一体起首的共用句}

共用句位于复合或多项复合超句统体起首, 往往指明超句体的小主题, 或点明话题及 时空背景, 起启句作用。

(14) Все мечты твои он растопчет, все надежды оплюёт./ Ты мечтал, что сынишка твой, выросши, станет учёным, инженером, славным человеком на земле, ---- но фашисту не нужны русские учёные, он своих сгноил в собачьих лагерях. Ему нужен тупой рабочий скот, --- и он погонит твоего сына в ярмо, разом лишив его и детства, и юности, и будущего./

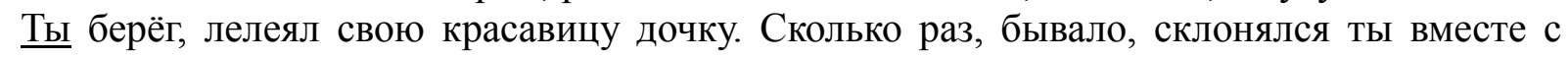
женою над беленькой кроваткой Маринки и мечтал о её счастье. Но фашисту не нужны чистые русские девушки. В публичный дом, на потеху разнузданной солдатне швырнёт он 
твою гордость-Маринку, отличницу, красавицу.../

Ты гордился своей женой. Первой девушкой была у нас на руднике Оксана! Тебе завидовали все. Но в рабстве люди не хорошеют, не молодеют. Быстро станет старухой твоя Оксана. Старухой с согбенной спиной. (Б. Горбатов)

首句为整个超句体的共用句, 指出法西斯践踏、摧灭了一切理想与希望, 是总说。随 后的三个简单超句体以主位平行句式（Ты --- Ты --- Ты）分承说明, 用事实陈述法西斯的 罪行。三个简单超句体之间属联合关系，它们是用主位平行联系相衔接。

\section{2 位于复合或多项复合超句统一体末尾的共用句}

共用句位于复合或多项复合超句体结尾时，其功能相当于合句，起归纳、概括等作 用, 常常揭示超句体的小主题。

(15) [1]Туровского всегда ждут с нетерпением. [2]Надо зимовать в западном секторе Арктики, чтоб понимать, кем был для нас Туровский./

[3]Он был для нас весной, потому что прилетал раньше самой первой посудины.[4]Он был для нас большой землёй, запах которой приносил с собой на крыльях, и семьёй и домом, ---- с ним мы получали вести от них.// [5]Он прилетал к нам первым, а улетал последним, ломая молодой ледок на бухте, и увозил с собой наши письма, просьбы и надежды.[6]Если на зимовке был тяжело-больной, то жил он надеждами на Туровского.[7]Туровский прилетит и спасёт: доставит врача или увезёт в больницу.[8]Если геологическая партия в тундре терпела бедствие, она знала: на выручку к ней пошлют Туровского./

[9]Вот кем был для нас Вася Туровский, линейный лётчик. (Б .Горбатов)

句子[1][2]这一简单超句体引出话题 ---- 图罗夫斯基是“我们”的何人呢? 句子[3][4]构成 的简单超句体直接概述图罗夫斯基曾起到的重要作用; 句子 [5]----[8]这一简单超句体具体陈 述图罗夫斯基的事迹。句子 [9]起鞄尾的合句作用, 指出图罗夫斯基是“我们”赖以生存的飞行 员，并照应了句子[1][2]提出的话题。句子[9]是该三项复合超句体的共用句。

$$
\text { 小结 }
$$

将超句体构成句的功能类型分为七类, 并不意味着每一超句体内都会出现这七种类型 的句子, 但铺叙句是每一超句体必不可缺的主干句子, 是超句体表达内容的主要载体; 小主 题句可隐可现, 通常是超句体主旨信息的承载者。每一超句体构成句的类型, 随表达内容的 繁简程度及作者行文特点等呈现一定的灵活性。将超句体的构成句进行功能分类, 有利于把 握该语言现象的构成规律, 提高驾驭连贯话语的技能。

\section{参考文献}

1. Лосева Л.М. Как строится текст. М., 1980.

2. Реферовская Е.А. Лингвистические исследования структуры текста. Ленинград, 1983.

3. Реферовская Е.А. Коммуникативная структура текста. Ленинград,1989.

4. Чэнь Цзе (陈洁)К вопросу об объёме понятия 《сверхфразовое единство》. ----Язык Сознание Коммуникация, Вып 23, М., 2003. 


\title{
О ТРУДНОСТИ ПЕРЕВОДА ПОЭТИЧЕСКОГО ТЕКСТА ВРАЗНОСТРУКТУРНЫХ ЯЗЫКАХ: НА МАТЕРИАЛЕ ПОЭЗИИ А.ОСМОНОВА
}

\author{
Каландарова Ж.К. \\ (к.ф.н. доц. Международный Кувейтский университет, Биикек, Кыргызстан) \\ Аммар Юнас \\ (к.ф.н. Школа гуманитарных наук, Университет Китайской академии наук, \\ Пекин, Китай)
}

Annotation: During the comparative studies of languages, the historic and geographical similarities and processes of degeneration are observed. Each specific language expresses certain semantics, which is associated with the lifestyle, personal characteristics of an individual and as per its personal values. Recreating a literary text requires transfer of intentions, subtleties of feelings and features of inherent beauty of the original language without compromising the target language. This article highlights the problem of possible difficulties in translating poetic texts from Kyrgyz into English through Russian language.

Key words and expressions: comparative study, semantics, difference and similarity, unrelated languages.

История переводческих учений уходит в глубь истории человечества. Римские писатели и ораторы рассматривали перевод как одно из средств развития родного языка и поэтому меньше всего заботились о точной передаче греческих текстов на латинский язык.Такой перевод получил название вольного.

Позднее, в эпоху Возрождения, были сделаны попытки теоретического обоснования этого переводческого принципа. Так, в 1540 году появился трактат Этьена Доле «О способе хорошо переводить с одного языка на другой». В период средневековья, в связи с переводом Библии на греческий и латинский языки, существенное значение приобрел другой тип передачи иноязычного текста, основанный на тенденции к дословному воспроизведению оригинала.Монахи - переводчики боялись отступить от церковной буквы и переводили слово в слово, в ущерб смыслу, языку, «духу» чужого творения.Борьба двух переводческих принципов - вольного и буквального - продолжалась на протяжении многих веков, все сильнее обостряясь в теоретическом отношении.

В этом отношении работа Роскоммена «Очерк о переводе стихов», «Anessayontranslationverse» (1684), заслуживает серьёзного внимания.Эта дидактическая поэма о задачах перевода и переводчика, где автор советует переводчику при достижении цели быть творцом, а не ремесленником. Он пишет, что иногда по тем или иным причинам следует опустить или добавить что-либо в переводе (но здесь же подчеркивает: скорее опустить, нежели добавить).

Процесс культурного развития общества - процесс двусторонний - это не только создание культурных ценностей, но и переработка их читателями, слушателями.Эти качества находят свое выражение в том, что языковые возможности в процессе перевода с одного языка на другой не всегда, поэтомуодна из основных задач теории перевода - прослеживать закономерности в соотношении между подлинником и переводом.

Известный лингвист А.Швейцер считал, что «теория перевода фактически сопоставляет не грамматические формы как таковые, а наиболее типичные контексты, в которых грамматические и лексические значения тесно переплетаются.Переводчику не следует опасаться обвинений в смешении лексики и грамматики. Именно в том заключается специфика перевода, что в нем лексическое и грамматическое должно рассматриваться в неразрывном единстве, то есть так, как это дано в реальных контекстах» $(6,11)$.

Если сравнивать понятийно-эквивалентные слова в разных языках, они будут отличаться друг от друга в силу того, что каждое из них сопряжено с определенной совокупностью знаний, а весь художественный текст теряет смысл без фонового эффекта. 
Каждый народ одинаково любит, ненавидит, радуется, печалится и надеется на счастье, испытывает чувство долга и т.д. Универсальным для всех людей является тот факт, что для любого индивида: как части универсума характерны два полюса, создающие мир «внешний» - по отношению к человеческому сознанию, и мир «внутренний» - психологическая, субъективная, духовная жизнь.

При переводе мы имеем дело с языком, вернее - с двумя языками, поэтому особое внимание уделяется семантической структуре многозначной лексической единицы, выявлению типов значений слов и критериев их разграничения, а также путям изменения и развития значений слов. Ведь без знания соответствующей коннотаций, присутствующей в языке, невозможно полностью понять весь смысл, заложенный в том или ином высказывании.Поэтому восприятие художественного замысла автора не менее важна, чем буквальное понимание текста.

Слова - это самая яркая часть языка, они связаны со всеми сферами человеческого общества. Большинство слов особенно в поэтических текстах однозначно имеют разные интерпретации. могут означать разные вещи в разных, особенно поэтому перевод такого рода текста имеет более сложный характер, А перевод - это передача красоты, глубины чувств намерений и особенностей присущей языку оригиналу на переводимый язык без ущерба, ведь человек при чтении художественного текста принимает действительность представленный автором-переводчиком.

В поэтической метафоре прямое и непрямое значения могут не только непосредственно примыкать друг к другу, но и быть оторванными друг от друга. В примерах проследим, как функционирует метафора в поэзии А Осмонова:

Көпкөк асман, жерге түшсө жарылып,

Кыян жүрсө жердин үстү тарылып

Ал кыяндан өтөр элем кыйналбай

Бир көз караш кубатынды жамынып $(2,76)($ букв. перев.: Если синее небо упадет и взорвется, над землей будет тесно от дождевого потока (селя), я перешел бы без труда дождевой поток, покрываясь только твоим взглядом, поддержкой).

При переводе переводчик выразил свое отношение к метафоре в языке - оригинале, көпкөк асман, жерге түшсө жарылып, в переводе не небо упало бы, а небесная вода. Вторая строка: метафора кыянжүрсө жердин үстүтарылып - над землей, в переводе города,в языке - оригинале покрываясь взглядом, в переводе - вооружен твоим единым взглядом, в языке - оригинале ал кыяндан өтөр элем кыйналбай, в языке перевода - я перешел бы море без труда.

Как видим в поэтической метафоре прямое и непрямое значения могут не только непосредственно примыкать друг к другу, но и быть оторванными друг от друга.В метафоре көпкөк асман, жерге түшсөжарылып - синее небо упадет и взорвется - Здесь сходства слишком мало, чтобы метафора была приемлемой, небо представлено в виде взрывчатого вещества.А еще поддерживающий взгляд любимой женщины сравнивается с оружием, который поможет перешагнуть дождевой поток.

Русский вариант:

Когда бы вся небесная вода,

Обрушившись, покрыла города,

Вооружен твоим единым взглядом,

Я перешел бы море без труда (перевод М. Синельникова) $(3,109)$

Английскийперевод:

If the heavens burst and poured their waters free,

If mountains streams went lashing across the earth,

I'd swim across that torn twixt you and me,

Made bold by your glance, alone, without fear set forth (переводУ. Мея) $(4,77)$. (букв. перев.: Если небо взорвется и сольёт свою воду свободно, если горные потоки ремнем окружат землю, я выплыву через поток... без страха отправлюсь вперед). 
Для поэтичекого текста характерно удвоение обозначений одной и той же реалии, сосуществование прямого и метафорического слова.Понять метафору - значит разгадать, какие из свойств обозначаемого объекта выделяются в ней и как они поддерживаются за счет ассоциативного комплекса, имплицируемого основным и вспомогательным объектами метафоры.

Не случайно, что в разных языках значения метафор разные.Различия между языками могут проявляться в ономасиологическом плане, то есть один и тот же референт обозначается различными видами метафорических обозначений.Поэтому без знания соответствующей коннотаций, присутствующей в языке, невозможно полностью понять весь смысл, заложенный в том или ином высказывании.

В следующем примере в зависимости от частеречной принадлежности метафора прилагательное, связанное со словом көк - синий,употребляется как существительное (субстантивная метафора):

Алмаз сындуукөккөтийгенмиздери,

Арстандын азуусундай арсайып $(2,92)$ (букв. перев.:Острие, как алмаз, касается сини, клыки торчат, как у льва).

Несмотря на то, что в переводах отсутствует метафора көккө, автор мастерски использует метафору вместо сравнения:

Сгрудились в тес обломки пирамид

Оскалившись, торчат гигантские клыки (перевод В. Потаповой) $(3,85)$.

Английскийперевод:

Their cutting - edge, diamond - sharp, the horizon faces

Their peaks, like lions teeth, seem to pierce the sky(переводУ. Мей) $(4,93)$ (букв. перев.: Их острые концы алмазной остротой касающийся лица горизонта, вершины, как львиные зубы, прокалывают небо).

В языке - оригинале метафора көккө, в русском варианте переводе отсутствует метафора в значении небо, в английском варианте перевода использовано прямое значение the sky - небо

В следующих строчках метафора сен батканда кошо батат употребляется, в значении когда он умрет, то есть звезды не станет, исчезновение звезды на небе ассоциируется со смертью;

Көк түстүу кен асмандын барагынан,

Карайм да кайда экенин таппай жүрөм.

Билип жур, сен батканда кошо батат,

Сөзү ушул бизден дагы мурункунун $(2,16)$, (букв. перев.: Ищу, но не могу найти из страниц синего широкого неба помни; что вместе с твоим закатом уйдет, эти слова наших предшественников).

Русский перевод:

Впиваясь глазами в небесную синь,

Ищу я свою золотую звезду.

Умрешь ты, и в небе погаснет она,

Так мудрые люди считали всегда (перевод И. Волобуевой) $(3,45)$.

Метафора в оригинале кең асмандын барагынан, в переводе превращается в небесную синь, во второй строке автор использует авторскую метафору золотую звезду, вместо простых выражений, и вместо метафоры сен батканда кошо батат авторпереводчик предпочел прямое значение, когда ты умрешь, и в небе погаснет она.

Английский перевод:

On wide open pages of heavens blue I gaze,

But nowhere there my tiny star can I find.

And know that when you one day lie pale and dead,

So our forebears say that star will fade from sight (переводУ. Мей) $(4,17)$. (букв. перев.: Выглядываю в открытые страницы небесной сини, но нигде я не могу найти оловянную 
звезду, и знай: когда станешь бледным, ты умрешь - говорят предшественники, что звезда исчезнет из вида).

Метафора как в языке оригинале и в русском переводе в зависимости предназначения выражается прилагательным синий или существительным синь (небесная синь), английский перевод - heavens blue (небесная синь).

Авторсравнивает конец жизни с закатом, то есть, с закатом и звезда исчезнет, тоже умрет. Синонимичный ряд с доминантным словом умереть (о человеке) - один из наиболее протяжённых и в поэзии, например,:

Чырагымсын, айсыз түндө адашпайм,

Ынагымсын, жан чыкканча тарашпайм $(4,56)($ букв. перев.:Ты мой факел, не заблужусь в темноте, близкий ты мой, не расстаюсь пока душа не уйдет). Метафора в языке оригинале жан чыкканча тарашпайм в русском варианте перевода передается метафорой: до смертного сна, эти выражения похожие даже имеют одинаковые значения. Эти синонимичные метафоры не влияют на значение метафоры, даже в некоторой степени повышают образность, эмоциональность произведения.Нужно отметить, что в поэтической метафоре главные качества - её нестандартность, возможность замены образным эквивалентом.Из пример видно, что метафора в поэзии всегда индивидуальна, неповторима.

Русский перевод:

Ты мой факел, пусть ночь непроглядно - темна.

Я с тобой не расстанусь до смертного сна (перевод М. Синельникова) $(3,35)$.

В следующем примере метафоры в оригинале до смертного сна, автор предпочел пока я живу, то есть использует, простой антонимичный вариант:

My rush light you - on moonless nights not lost,

My precious one, while I live we shall not part (перевод У. Мея) $(4,58)$ (букв. перев.: Ты мой факел безлунной ночи; не заблужусь, мой милый, пока мы живы, не расстанемся).

Важным моментом в рассматриваемых переводах является то, что в разных языках наличествует сходная метафоризация и в каждом конкретном языке процесс метафоризации имеет специфические формы проявления в зависимости от особенностей языка. При переводе переводчик использует языковую локализацию, чтобы правильно адаптировать перевод к целевой культуре.

В следующих строках при помощи удивительных метафорических преувеличений описывается пройденный путь человека:

Миң жылга из калтырып кеткениңди.

Унутпа жылдыз мончок жылдарыңды.

Асмандан ырыс көлүн төккөнүңдү.

Ажалды көк сүбөөгө тепкениңди. $(2,68)$.(букв. перев.: Не забудь, на тысячи лет оставил следы, не забудь годы звездного ожерелья, с неба лили озера счастья, ударил в грудь смерти ногой). Автор заметно преувеличивает человеческие силы, способности, возможности и в русском переводе.

Русский перевод:

Оставил след на сотни лет, века потряс,

Чтоб ожерельем звезд твои года

Как свет сиял родной земле

Победил ты смерть и стал сильнее (перевод С. Липкина) $(3,63)$.

Из примера видно, что метафора в первоисточнике асмандан ырыс көлү в русском переводе превращается в сравнение как свет сиял родной земле. Изменение метафоры в языке перевода еще наблюдается в последней строчке, метафора ударил ногой смерть в грудь заменяется простым выражением победил ты смерть, и стал сильнее.

Английский перевод:

A thousand years the tracks you leave must last.

Don't forget those years of bead like stars

From heaven a lake of kindness on you was spent 
Like deathyou poked in the ribs all lies which passed (переводУ. Мея) $(4,69)$.

(букв. перев.: На тысячу лет ты оставил следы, не забудь те года, как бусы звездные, с небес отправил озеро доброты, как (или похожий на смерти) смерть ты тыкал в ребро прошлой лжи).

Первая строка перевода близка к оригиналу, во второй автор внес частичное изменение. Как видно из примера, что поэтическая метафора живет только в тексте, при повторении поэтической метафоры она угаснет, стирается, вянет.

При переводе поэтичекой метафоры учитываются такие условия в языке, как стилистические, семантические, так как группировка слов, основанная на вышеназванных фактах, отражает закономерные связи и отношения стилистических единиц в развитии всей системы языка под воздействием как лингвистических, так и экстралингвистических факторов. Поэтому успешное выполнение функции переводчика ориентируется на всестороннее знакомство с историей, культурой, обычаями и прочими реалиями современной жизни народа, говорящего на иностранном языке.

\section{Список использованной литературы}

1. 1.Бархударов Л.С. О лексических соответствиях в поэтическом переводе.Тетради переводчика на материале Бунина И.А.- вып №2 с.19.

2. Осмонов А Көл толкуну. - Бишкек. 1995.-148c.

3. Осмонов А Избранное. - М.: Изд-во. худож. лит.,1975. - 272с.

4. OsmonovAWaves of the lake. (translatedbyMayW.) - Bishkek. - 1995. -148c.

5. Каландарова Ж.К.Экспликация метафоры в разносистемныхкыргызском, русском и английском языках Дис...канд.филол...наук.- Б.,2008.- 187с.

6. Швейцер А.Д. Теория перевода - М.: Наука.1988.-214c.

\section{ЗАМОНАВИЙ ИНГЛИЗ АДАБИЁТИДА ШАРКОНА ПОРТРЕТ ИФОДАСИ}

\section{Мухаммедова Нилуфар Элибоевна (РhD., доцент Ч̆зббекистон давлат жсахон тиллари университети)}

Annotation: The following article deals with the analysis of the eastern woman portrait created in the novels, written by English modern writer Margaret Drabble. Women images, created by an English writer, are compared with women images described by Uzbek writers. The novel of the English writer in which the writer successfully created the image of the eastern woman based on the life of Korean queen is evaluated as transcultural novel.

Key words and expressions: portrait, image, queen, west, woman writer, character

Жахон адабиётшунослигида эришилган сўнгги ютуқлар яратилаётган қахрамонлар образини янгича ёндашувлар асосида бахолашга кенг имкониятлар бермокда. Бу мураккаб жараёнда ижодкорнинг истеъдоди, эстетик идеали, дунёқараши, интуицияси, рухий олами, ғоявий позицияси ва ижодий тажрибаси етакчилик қилади. Реал воқелик шу асосда образли тасвирга эга бўлади ва адабиётда хар бир образ инсонга йўл кўрсатади.Замонавий инглиз ёзувчиси Маргарет Дрэббл прозасида аёл культи орқали шарқона образлар ифодаси етакчи ўринни эгаллайди. Асарларда кўтарилган муаммолар, ёзувчининг бадиий услуби, рамз ва мотивларнинг мохияти, образ хулқ-атвори психологиясининг ёритилиши каби мавзулар юзасидан тадқиқотлар олиб борилмоқда.

Муаллифнинг “Қушлар учун қафас" (1963), “Бир ёз мавсуми” (1964), “Тегирмон тоши” (1965), “Олтин Иерусалимим” (1967) ва “Шаршара” (1967) асарлари М. Дрэббл ижодининг илк босқичини ташкил қилса, иккинчи босқичига 1970-йилларнинг биринчи ярмида яратилган “Игна тешиги орқали” (The Needle's Eye, 1972) “Бебахо дунё” (The Realms of Gold, $1975)$ романлари, учинчи босқич эса 1970-йиллар охири ва 1980-йиллар бошларида нашр этилган "Музлик даври" (The Ice Age) ва "Йўл ўртасида" (The Middle Ground) романларини ўз ичига олади. Ушбу асарларда ёзувчи хозирги кунда кенгайиб ва долзарб бўлиб бораётган 
ижтимоий муаммоларни тадқиқ этишни давом эттиради.Адиба хар бир қахрамон тақдирини 80-йилларнинг инглиз хаёти фонида тасвирлади. Оила, ўсмир фарзандлар тарбияси, оналик масъулияти ва таълим-тарбия масалалари асар мазмунини ташкил қилди.1990-2000 йилларда ёзувчи оналар мавзусига мурожаат қилди. Кекса ёшдаги аёллар адибанинг “Эксмур жодугари” (The Witch of Exmoor,1996), “Кулранг капалак”(The Peppered Moth, 2001), “Етти опа-сингиллар" (The Seven Sisters, 2002) асарларининг асосий қахрамонлари сифатида тасвирланди. "Қизил либосли қиролича" (The Red Queen, 2004) романи ёзувчининг шарқ маданиятини қанчалик тушуна олганлигини кўрсатди.

М.Дрэббл яратган аёллар образлари маълум даражада ўзбек адиблари ва адибалари ижодида хам учрайди. Хусусан, ёзувчига замондош бўлган ўзбек адибаси Саида Зуннунова (1926-1977) хикояларида М.Дрэббл аёллар образларининг курашувчанлиги, уларнинг “мен”лиги, журъатлилиги каби қирралари кўзга ташланади. С.Зуннунованинг “Олов қиз” (1963) хикояси қахрамони Мохидил характерида феминистик хусусиятлар кузатилади. Мохидил онасининг ва акасининг хохишига қарши боради, уларга “мен”лигини айта оладиган қиздир. У кимга турмушга чиқишни ўзи хал қилади ва бошқа йигитга унаштирилган куни қишлокдан кетган Ғаффорни излаб топади. Уни кўриб хайрон қолган Ғаффорга "Мохидил кулди: - Нима қилай, ўзинг олдимга тушмагунча қўлимни чўзмайман, деган экансан. Мана келдим" дейди (“Гўдак хиди”, 1986:27). Қизнинг бу хатти-харакати замонавий қизларга хос бўлган шижоатни, мустақил қарор қабул қила олиш хусусиятларини намоён этади. М.Дрэбблнинг оналар мавзуси ўзбек ёзувчиси Ўткир Хошимовнинг “Дунёнинг ишлари” (1982) романидаги мотивларни ёдга солади. М. Дрэббл хам Ў.Хошимов (1941-2013)каби маълум бир асарини онаси хаётига бағишлайди, онаси хаётини тасвирлайди. Аммо ўзбек адибидан фарқли равишда адиба онаси образини идеаллаштирмайди. Онаси Кэтлин Мэри Блурнинг тушкунлик кайфияти сабабларини излайди, она кайфиятининг фарзандларига, оиласига қандай таъсир қилганлигини, унинг оқибатларини тасвирлайди. Ў.Хошимовнинг “Дунёнинг ишлари” романида онанинг фарзандларини қучишида, уни авайлашида, боласи хақида қайғуришларида унинг кучли мехр тафтини хис қиламиз. Адиба асарларида эса она ўз мехрини боласига эркинлик беришида ва унинг муносабатида қолаверса фарзандининг хохиш-истакларини инобатга олишида кўринади.

XXI acp бошларида инглиз адабиётида аёл дунёсининг ўзига хослигини тасвирлай олган адиба яна янги бир аёл портретини яратди.

M. Дрэббл 2000 йилда Сеулга адабиётшунослик масалаларига бағишланган конференцияга таклиф қилинади. Конференцияга тайёргарлик вақтида адиба XVIII асрда Кореяда яшаб ўтган малика Леди Хёгёнг Хонг мемуарлари хақида эшитади. Ушбу давр тахт вориси саналган шахзоданинг рафиқаси маликанинг хотиралари 1795-1805 йилларда саройда кечирган хаётини ўз ичига олади. М. Дрэбблда катта қизиқиш уйғотган малика мемуарининг нусхаси "The Memoirs of Lady Hyeyŏng: The Autobiographical Writings of a Crown Princess of Eighteen-Century Korea” (Леди Хёгёнг хотиралари: ўн саккизинчи аср Корея маликасининг автобиографик ёзмалари) эди. Малика хотираларининг бу нусхасини ЖаХюн Ким Хабош таржима қилади, шархлар билан тўлдириб 1996 йил Калифорния университети нашриётида чоп эттиради. Бутун ижодида аёллар оламини тасвирлаган ёзувчини Леди Хонгнинг саройдаги хавотирга тўла хаёти бефарқ қолдирмади. Леди Хонг саройдаги бахтли ва бахтсиз хаётини, қирол оиласи вакилларининг яхши ва ёмон томонларини мохирона тасвирлай олган аёлдир. У сарой хақида нималарни билса, қандай воқеаларга гувох бўлган бўлса, барчасини ўзгартирмасдан тасвирлайди ва ўз муносабатини билдиради. Тахт вориси бўлмиш турмуш ўртоғи шахзоданинг отаси томонидан ўлимга махкум қилинишига оид тафсилотларининг барчасини кичик деталларгача тасвирлайди. Ушбу мемуарни ўқиган ёзувчи маликанинг тасвирлаш махоратига тан беради. М. Дрэбблнинг назарида Леди Хонг нафақат ўз даврининг, балки хозирги замонда хам топилиши қийин бўлган юксак интеллект сохибасидир. Малика давлат ишларида иштирок этмаган, бунинг устига рухий хаста бўлган шахзоданинг рафиқаси бўлса-да, нафақат саройда, балки Корея тарихида ўз ўрнига эга 
бўлган ва хурмат қозона олган корейс маликасидир. Унинг тимсолида корейс аёлининг итоаткорлигини, сабр-бардошлилигини кўрамиз.

М. Дрэббл 2004 йил Сеулга худди шу конференцияга яна таклиф қилинади. Анжуманнинг бу сафарги мавзуси “Тинчлик учун ижод қилиш” (Writing for Peace. Анжуман хар тўрт йилда Дэсан ташкилоти хомийлигида уюштирилади.) Бу сафар ёзувчи конференцияга Леди Хёнг мемуарларига асосланган янги “Қизил либосли қиролича: Трансмаданий трагикомедия" (The Red Queen: A Transcultural Tragicomedy) асарини олиб келади.

“Қизил либосли қиролича" романида ёзувчи икки аёл, яъни Корея маликаси ва замонавий инглиз аёли образларини гавдалантиради. Леди Хонг тўққиз ёшида тахт вориси бўлмиш шахзодага турмушга чиқиш учун танлаб олинади, ёш турмуш ўртоғининг ва фарзандининг бевақт ўлимини бошидан кечиради. XVIII acp Корея қироли саройида адолатсиз хукмларнинг оқибатларига гувох бўлади. Романда маликанинг хотиралари хозирги замонда яшаётган инглиз олимаси доктор Барбара (Бэбс) Хэлливел кўлига сирли равишда тушади. Барбара Сеулга анжуманда нутқ сўзлаш учун самолётда кетаётганда шу китобни ўқийди ва ундан таъсирланади.

Роман уч қисмдан иборат: “Қадимги замон” (Ancient Times), “Хозирги замон” (Modern Times) ва "Кейинги замон” (Postmodern Times). Мазкур сарлавхалар воқеаларнинг қайси замонга тааллуқли эканлигини англатади. Леди Хонг тарихий шахс, унинг рухи хозирги замонга келади, замонавий адабиётлар билан танишади, мемуарлари Барбаранинг қўлига тушганини билади, доимо унинг ёнида юради. Шу боис романнинг уч қисмга бўлинганлиги қиролича хаётини, Барбаранинг кечинмаларини ва қахрамонларнинг кейинги хаёти ва келажагининг ишончли тасвирланганлигини таъминлайди.

Ёзувчи асарда икки миллатга мансуб аёллар портретини чизади: Леди Хонг ва Барбара Хэлливел. Улар ўз миллатининг, ўз даврининг энг интеллектуал аёлларидир. Барбара хам замонасининг хурматга сазовор олималаридан бири, “илм-фан маликаси”дир. Воқеалар бўлажак маликанинг болалик давридан бошланади. Унинг ўзига хос характер хусусиятлари болалигидан кўзга ташланади ва ўша даврни хотирлаб, шундай ёзади: “My childhood, happy or unhappy, innocent or fearful, did not last long. Shocking things were soon to be expected of me, things that would now be forbidden by law in most nations on earth. I was to be the victim of advancement - Болалигим бахтли ёки бахтсиз, ташвишли ёки беташвиш бўлмасин, узок давом этмади. Ер юзидаги халқұларда хқозир қ̧онун тақуиқлаб куйган хқайратланарли даражадаги ишларни қ̧илишим кутилмоқуа эди. Мен фаровон хуаётнинг қурбониман”[Drabble 2005:13].

Қизалоқ улғаяр экан, таниқли вазирнинг авлоди бўлганлиги учун келажаги қирол оиласи билан боғлиқ бўлиши мумкинлигини ота онасининг, бувисининг сухбатларидан илғаб олади. У сезгир, тезда илғаб оладиган қизалоқдир. У уйида содир бўлаётган бирор-бир хатти-харакатни назаридан четда қолдирмайди. Шу боис у болалигини хам бахтли, хам бахтсиз деб таърифлайди, беғубор болалик даври тезда якун топади ва қизча бўлажак сарой маликаси сифатида шахзода учун муносиб рафиқа сифатида танлаб олинади.

Леди Хонг малика сифатида саройга кириб келади, қироллик оиласи урф-одатларини, сарой маданиятини ўрганади, маликалик бурчини адо эта бошлайди. Леди Хонг ўз вазифаларини кўр-кўрона бажаришни истамайди. Унинг учун хар бир қоиданинг негизида маълум сабаб ётади. Малика саройрасм русумларини амалга оширар экан, уларнинг сабабини англай олмай хайрон. У эндигина сарой мухитига кўникаётган бўлса-да, бу ер ўз хаётидан бутунлай ўзгача эканлигини аста-секин пайқай бошлайди. Сарой маликасига хос тарзда изланади, ўқийди ва ўрганади. Леди Хонгда атрофдагилар илғамайдиган қобилият бор. Унинг жисмида чексиз интеллект яширинган. Мана шу нарса аёлни саройда яшаб кетишига, мухитнинг қонунларига вақтинчалик бўйсунишга, қирол, шахзода, сарой ходимлари, канизаклар ва хизматкорлар билан муросада яшашга туртки бўлади. Малика вақтини ўқишга, изланишга бағишлайди. Шу тарздаги хаётга мослашади, натижада саройдаги воқеаларга ўз муносабатини билдириш мақсадида хотираларини ёзишга 
киришади. Леди Хонгнинг мемуарларини ёзишга қай тарзда ёндашуви хам унинг ўзига хос бўлган хислатларини намоён этади. Малика кузатувчан, унинг мана шу қобилияти хар бир воқеани майда деталларигача тасвирлашида кўринади.

\section{Фойдаланилган адабиётлар рўйхати}

1. Drabble M. The Red Queen. -A Harvest Book: Harcourt, Inc, 2005. -334 p.

2. Rose E. C. Critical Essays on Margaret Drabble.-G. K. Hall \& Co, 1985.- 205 p.

3. Myer V. G. Margaret Drabble: A Reader's Guide. -London: Vision Press,1991. - 174 p.

网络反哺文学的安妮宝贝

Nigina Rasuleva 文学博士 $(\mathrm{PhD})$

UDJTU

Annotation: The article provides an overview of the creative path of the famous Chinese writer Annie Baobei. Looking at her work in dynamics, we came to the conclusion that Annie Baobei entered the Chinese literary arena in 1998 as one of the online writers. Her subsequent literary career appears to us as an evolution from a skilled storyteller who can captivate the reader with her stories, to an observer with a deeply individual opinion and view of Chinese reality.

Key words and expressions: Contemporary literature; network literature; web creation; female writer; internet novel

(一) 作家简介

安妮宝贝，原名励婕，1974 年出生于浙江宁波。1995 年在中国银行宁波市分行营业部 担任职员, 1998 年以安妮宝贝的笔名开始网络文学创作, 1999 年 12 月到上海榕树下文学网 站任内容制作总管。2001 年在杂志开设时尚专栏, 从上海到北京一个出版社担任编辑, 2005 年加入中国作协。2014 年 6 月 16 日, 安妮宝贝在其微博上宣布笔名改为“庆山”。代表 作品有《告别薇安》《八月未央》《彼岸花》《蕫薇岛屿》《二三事》《清醒纪》《莲花》 等。86

安妮宝贝是较早通过网络进行写作的女性作家, 她的创作显得与众不同, 除此之外,她 的写作更接近传统意义上的写作, 网络对安妮宝贝来说就是工具和跳板。1999 年, 安妮宝 贝顶着家人的阻挠, 从银行辞职, 进入中国最早的原创文学网站任职, 要用自己的文字打出 一片新的天空来。功夫不负有心人, 在后来成为网站提升知名度的重要手段的大赛中崭露头 角。当时请来的评委大多是知名的文学作家如贾平凹、王安忆、王朔、阿城等, 这跟网络文 学本身还没有出现自己的大神有很大的全系。 ${ }^{87}$ 从榕树下入职两年时间内, 安妮创作了并电 子出版四十六篇故事。在网上被传播的作品点击量飙升到万余, 紧接着后面的作品又出现了 七八万的点击量, 构成了文学传播前所未有的奇观, 也震惊了作者自己。千禧年首月, 《告 别微安》作为一本短篇出版后, 在网上发表的作品被疯狂的点击, 千禧年的十一月十三日发

\footnotetext{
${ }^{86}[$ 苪渝萍 2004: 2]

${ }^{87}$ [葛红兵2001: 1]
} 
表在工作网站的《八月未央》被阅读十几万次, 《彼岸花》更是接近二十万, 名不见经传的 安妮宝贝被虚拟世界真实的造成了轰动效应。 88

\section{（二）代表作品分析}

安妮宝贝的成功与粉丝经济促进密切相矢。由于网络小说是以网络为基础, 以网络为 交流平台和制作平台, 所以它们的作品也具有网络的特点。由于网络文学的创作者大多是年 轻人, 作品的内容基本上与年轻人的生活密切相余, 这吸引了大量的年轻粉丝。目前, 年轻 人愿意为喜爱的作家付费。对作家明星的崇拜常常使读者愿意接受作家创作或推荐的各种节 目或活动。换句话说，泛娱乐环境中的粉丝经济确保了投资回报。

粉丝, fans 的音译, 对爱好者的统称。在中国, 粉丝是一种食材, 制作粉丝的原料是 红著粉、大米粉等普通原料。尽管原料普通, 但吃起来爽滑可口, 价格能够接收, 为普罗大 众所喜爱。消费者自称粉丝, 一方面表明自己的兴趣爱好, 另一方面也有人多势众的心理优 势在里面, 主人翁意识得以呈现。商家承认并推动消费者的粉丝意识, 是为消费者服务意识 提升和引领消费潮流的可行性操作手段。粉丝经济不是严格意义上的学术概念。公众通常认 为这是一种基于相矢人士和粉丝之间矢系的商业创收行为。它是“以情感资本为核心的情感 资本, 以粉丝社区为营销手段为情感资本增值, 以消费者为主导的粉丝经济, 以消费者为主 导的营销手段, 从消费者的情感出发, 企业利用自身的力量来达到为品牌和偶像的情感资本 增值的目的”。

安妮小说的特点从一开始就与她在互联网上的写作地位密切相矢。在网上冲浪是自由 酒脱的, 可以凭着性子来。历史上从来没有出现过像网络这样给每个普通人发声的机会, 网 络提供空间并鼓励尊重个人和䏌注平等的文化氛围, 为现代人提供了一个居住环境, 他们被 物质欲望包围, 希望进行平等对话并相互发表意见。网络游戏的规则尊重个人的自我意识, 尊重个性的独特性和创造性。安妮小说中的多重声音叙事不仅清晰地展示了她的个人风格, 揭示了她的内在复杂性, 而且成功地为呈现多重声音的小说世界提供了精神交流的领域。

在小说《彼岸花》中，安妮宝贝描述了感官消费文化引起的欲望的满足:“她穿着轨子绣 花裙子、粉色披肩和薄毛皮大衣, 但脚上赤裸着一双细高跟鞋拖鞋, 上面装饰着人造水钻和 金线, 还有一个鳄鱼皮小背包。 ${ }^{89}$ ”这种时髦的服装是上海都市女性的自我表现, 她们是高级、 吃饱喝足、自由意志、个人主义和白领精英。在这里, 消费文化直接指的是感性的物质满足, 这承诺了快乐的生活方式。另一方面, 它将消费对象塑造成一个完整的符号系统。从这个意 义上说, 消费已经成为人们自我表达和认同的主要形式, 它将社会矢系的建构功能从社会生 产领域转移到社会文化领域。在这种情况下, 消费只是一种欲望, 也就是说, 象征着某个社 会阶层, 就像名车和豪华住宅意味着高级社会地位一样。

《莲花》和《春宴》遵循安妮·宝贝擅长的双重故事情节的叙事模式。一条主线是以“写 作女性”为主要角色, 另一条主线是第二个女性主要角色作为双重幻想的反映。这个故事仍 然是关于城市男女的爱和欲望以及女性主角的精神培养, 但它也随着时代的发展添加了一些 新的市场元素: 其中最重要的是增加对中产阶级男性形象的描述以及中产阶级对“精神家园” 的追求。如果说虞丘的江南小镇和文化之旅为中产阶级提供了对中国传统高雅文化和精神家 园的想象需求, 那么安尼宝的现代主义小说则提供了借鉴西方高级文化形式的精神动力。正 如《春宴》中的英雄, 一位事业成功的国际高级白领, “他是这样一个人, 每次出差, 他都 会带一本克劳德·列维-斯特劳斯的《忧郁热带》, 或者尼采哲学书籍, 或者博尔赫斯小说集 这些与他的电话会议工作计划和客户约会无关, 但他需要他们陪着他。即使只是在飞机阅读 灯打开的那一瞬间, 或者只是在入睡前几页, 你最终还是昏昏欲睡。”对于英雄来说, 重要 的不是他所读的内容, 而是一种由西方高级文化规范提供和创造的自我仪式和氛围, 如列维

${ }^{88}[$ 苏晓孛2011: 5]

${ }^{89}$ [黄孝章 张志林, 陈丹. 2010: 3] 
-施特劳斯、尼采、博尔赫斯等。《春宴》再次描绘了一位与中产阶级男人的爱和欲望纠缠 在一起的女作家。清池在一个家庭背景好、相貌平平的妻子和一个年轻漂亮的情人之间穿梭。 然而, 这位女作家不同于那些世俗女性, 对男性主角有不同的吸引力。她提供的是精神渴望 和精神满足。这是超越现实世界和工作压力的出路。一盏灯: “工作的压力, 忘记吃饭和睡觉, 日夜颠倒，欺骗和栬计。90, 不仅如此，生活有时处于被遗弃和停滞的状态。在物质的现实世 界中, 在反复颠簸之后, 有一种焦虑和失落, 当孤独时很难理解。他是一个矛盾的人。一方 面, 他有坚强的意志去赢得并生活在这个世界上。一边是他对一种海拔 4500 米的野生或尾 的向往和理解。他知道这是强烈的, 安静的, 安静的, 丰富的, 也许这是他自己愿望的一部 分。"

安妮宝贝中的主人公都像一对冤家一样相处, 中间夹杂着与各类人等的锅心斗饺和情 感纠缠, 反射着现实人生的各种无奈和悲欢离合。七月和安生是两种截然不同的性格, 但是 却又鬼使神差的走在一起。就像冰与火的存在，一方以另一方的迥异证明彼此的价值和意义。 一旦条件达到了中合的标准, 又可以像亲密的恋人一样不能分开。《彼岸花》中也有这种设 置人物的不同表现构成多声部的精神回响, 故事中人物的纠纠缠缠真是生活中纠纠缠缠的艺 术化再现, 让读者通过阅读实现对生活本身的再次审视, 从而以旁观者的身份从新考虑“他 者”的问题寻求解决的办法。这种置身事外的优越感, 往往带给人一种虚幻的成就, 即世界 在我手, 就是失败了也跟我没有什么太大的矢系, 从头再来不只是口头说说而已, 现实中也 增加了很多面对的勇气。办法总比困难多, 事业如此, 感情如此, 人世间各种事物的道理无 不如此, 正是这种压抑的欲望在幻想中的满足, 让网络文学的读者欲罢不能。 ${ }^{91}$ 安妮宝贝独 特的女性视角, 恰恰满足了年轻人这种充满幻想的浪漫气息, 他们知道痛苦是存在的, 爱也 是真实的, 遇到爱的时候可以忍受痛苦, 认识到这种痛苦的过程不亚于生命的涅槃, 有一神 圣的意味在里面。

\section{(三) 告别网络}

在这样一个多元化、尊重选择、容易陷入虚无的时代, 中国没有统一的信仰和价值标 准可以遵循。因此, 在安尼拜看来, 这个时代是“贫痊的”, 社会的外力无法支撑中国的内在 灵魂。这样中国就可以一直漂走, 随时被带走。在寻找了近乎绝望之后, 中国所能做的就是 承认外在的贫困和内在人性的荣耀。因此, 中国彼此相爱, 彼此相爱, 深深地爱着对方, 见 证着人性中隐藏的邪恶。因此, 中国更加迷失。回顾过去, 中国承认自己的空间, 给予彼此 宽容和理解, 并不断努力压抑内心的欲望。这种平衡使中国的心温暖、安全, 并最终保持和 平。人与人之间有很大的不同。不管占领和过去, 中国都在这条路上经过。安尼拜为中国寻 找源头, 了解一切, 梳理混乱, 反思自己, 同时也反映了一个时代人们的心理历程。文学是 安妮宝贝的心灵家园, 网络只是她抒发个人情感的手段, 从来不是作为目的而存在的。92

安妮小说“告别薇安”，是第一部作品，仿佛隐隐中就在宣誓着自己不会永远在网络的 世界中游七, 当初为了逃离约束二进入自由世界但世界不再自由的时候, 自然而然的选择再 次离开。网络对置身其中的网络作家协助有加, 约束也是明显的, 他们要根据网络的要求进 行创作, 有时候甚至为了点力量违背自己的写作初衷, 去迎合网友的横挑坚拣。这种约束对 追求自由的个体来说是无法忍受的。我知道我的读者很特别。他们存在于互联网上, 可能有 一种更自由和更另类的心态。同样, 也更容易感到孤独...再见微薇安。它在互联网上引起的 骚动证实了我对互联网时代的想象。这确实是一个充满欲望和激情的全新时代。同样, 它也 更加空洞和阴郁。因为中国正面临更多的失踪和告别。安妮宝贝的自我反省也预示着她对写 作和人生有了新的理解, 将要采取新的行动。2002 年后, 安妮“离开”曾经吸引她的注意力的 网络——“我过于迅速和无情地拒绝了他们”, “但不可否认，他们曾经是我的一部分”。

\footnotetext{
${ }^{90}$ [葛红兵 2001：1]

${ }^{91}$ [李碧炎 2008: 6]

92 [马季. 2010: 4]
} 
安妮宝贝离开虚拟世界去远行，脚步走在了真实的土地上。牦牛和咖啡成了她的新视 野。93真实世界是充满未定和诱惑的, 正是这种诱惑让人生存在产生了价值和意义。从哪里 来到哪里去, 真实世界让她有了自我的认知, 让她感觉到生命的美好。网络自然有很多的自 由，但是那种无形的手抓住她，越来越紧几乎窒息。勇敢的安妮宝贝离开这个束缚的“自由”, 更代表着一种新的自由。她后来写的散文几把主题定为“爱和行走”，在路上寻找爱、表达爱， 得到爱。它不那公尖锐和浮泛, 更逼真的肌理和对生活的反思, 文章的形式也更丰富。2004 年初，她在“离开”互联网后出版了她的第一部小说《两三件事》。她以“旅行的态度”讲述了 这件事对于读者和作者来说，书籍有时被用来接近他们的内心世界。为了离开某个地方，到 达某个地方。她以前在处理互联网时没有任何恐慌。同年十月，又有新的作品与大家见面， 散文为主。她的风格逐渐从阴郁和狭窄中走出来, 变得更加清晰和清新。安妮不仅改变了她 怪异、陌生、女性化和荒凉的写作姿态，而且让她认识到把人生寄托在衣食住行上面的理想 是多公的可笑与卑微。人的存在除了活着还应该有生活的趣味, 生活的格调记以及生活的品 味。互联网连起来的精神正逐渐的被物欲所累, 因此在这里已经很难找到个人的愉悦, 精神 的奔放。2014 年她在微博上宣布把“安妮宝贝”的笔名改为“庆山”, 或许表明了她的态度：安 妮宝贝不再回来。

\section{参考文献}

\section{中文作者类}

1. 葛红兵. 《网络文学 : 新世纪文学新生的可能性》社会科学，2001 年。

2. 芮渝萍. 《美国成长小说研究》 [M].中国社会科学出版社, 2004 年。

3. 黄孝章, 张志林, 陈丹. 《数字出版产业发展研究》 [M]. 北京: 知识产权出版社, 2010 年。

4. 马季. 《网络文学透视与备忘》 [M].中国社会科学出版社, 2010 年。

5. 苏晓芳. 《网络与新世纪文学》 [M].中国社会科学出版社, 2011 年。

6. 中文论文类

7. 李碧琰. 安妮宝贝创作论 [D]. 复旦大学, 2008 年。

8. 张伶俐. 安妮宝贝

9. 与外国文学 [D].湖南师范大学, 2013 年。

\section{ИСТИҚЛОЛ ШЕЬРИЯТИДА ЯНГИЧА ТАЛҚИН}

М.А.Халова, доценти Д.М.Худойбердиева (СамДЧТИ)

Annotation: In this article will be non-traditional movement considered that emerged contemporary poetry in our literature, as well as its theoretical aspects. According to several theorists are changes in the national mentality in details clarified and feelings caused by the modern literature.

Key words and expressions: lyrical experience, lyric hero, attitude, literary comparison, comparative analysis, interpretation, inspiration, talent, personality of the poet, world of poetry.

Инсон хаётида кечинмалар мухим ўрин тутади. Бани одам ўз кўнглини тафтиш этиш орқали ўзни ислох қилишга интилиб яшайди. Оний лахзада туйилган бетакрор туйғу - инсон кечинмалари унинг аъмоли, даври, миллатию эътиқодидан қатьи назар, ўзгармас бўлади. Фақат уларнинг келиб чиқиш манбалари ва намоён бўлиш шакллари хар сафар турлича.

Маълумки, Истиқлол йилларида модернга бўлган қизикиш кучайди. Яъни бу борада модернизмни ёқловчилар билан бир қаторда, унга қарши чиқувчилар ва муросали фикр

${ }^{93}$ [张䠲俐 2013: 7] 
билдирувчилар бу бахс-мунозараларни юзага келтиришди. Улардан бири - Шукур Холмирзаевнинг “Жахонбоп асар ёза оламан лекин...” номли Сафар Оллоёр билан бўлган сухбат шундай кечади:

“ - Модернизмга умумий нуқтаи назарингиз қанақа?

- “Модерн» дегани асли “янгилик” дегани. Шу ўринда бир гап. Бир пайтлар Абдулла Қодирийнинг Сотти Хусайн билан савол-жавоби газетада босилган. Шунда Сотти Хусайн Қодирийга асарингиз, хусусан, “Ўткан кунлар” анча жўн дейди ва исботлаб беради. Қодирий буни бўйнига олади ва мен бу асарни достон, эртак эшитиб юрган халқ учун ёзганман, аммо Оврупа модерн услубида ёзиш хам кўлимдан келади" 94 ,-дейди.

Бу билан Шукур Холмирзаев ўқувчилар савиясига эътибор қаратади. Яъни, Абдулла Қодирий айтганидек “достон, эртак эшитиб юрган халқ учун” хам асарлар ёзиш кераклигини таъкидламоқчи бўлади. Албатта, бунда, адиб хақ бўлиши хам мумкин.

“Хозирги адабий давраларда урф бўлган "модерн” сўзининг адабий мохияти хақида сўз юритганда, бизнинг шеьриятга ғарбдан юққан “эпидемия” дебгина қараш нафақат мантиқий хатога йўл кўйиш, балки ўзбек шеьрининг бугунги мушохада табиати ва янги шакллар илинжидаги изланишларни инкор этиш хамдир" ${ }^{95}$. Дархақиқат, давр ўзгарди, одамлар дуёқараши ўзгарди, ижодкорнинг фитратида ўзига хосликлар майдонга келди. Бу эса адабиётга, шеъриятга ўз таъсирини ўтказди.

“Эхтимол, хозирги ўзбек модерн шеьриятида хам, насрида хам Ғарб ёки Шарқ «модерн»чиларига қандайдир тақлидлар учрар. Бироқ яхлит олганда хозирги ўзбек модерн адабиёти миллий заминда, бугунги глобаллашув ва информатика даври тафаккури махсули сифатида дунёни янгича кўриш, англаш эхтиёжи сифатида туғилган, туғилаётган табиий адабий ходисадир" $" 96$. Бу каби фикрлар адабий танқидчиликдан нихоятда салмоқли. Лекин чуқурроқ мушохада юритадиган бўлсак, адабиёт сохасида кўртак ёзган модернизм ўзбек адабиётида анъаналар бағридан сизиб чиққан янгиликдир. Биз бунинг исботини Рауф Парфи учликларида, Абдували Кутбиддиннинг “Изохсиз луғат”ида, Фахриёрнинг “Аёлғу”сида янада яққолроқ кўришимиз мумкин.

Мана шундай янгича ўзгаришлар шоир Абдували Қутбиддин ижодида ўзига хос тарзда ифодаланган. Шоир шеърларида реал воқелик таъсирида туғилган кечинмалар рангбаранглиги, бир сўз билан айтганда туйғулар зиддияти ўзига хос ифодасини топганлиги билан ажралиб туради.

А.Қутбиддин шеъриятида хам поэтик мушохада услубининг ўзига хослигига дуч келамиз. Шоирнинг жуда кўплаб шеърлари модерн шеърият таъсирида ёзилган. Бу шеьрларида мумтоз адабиётимизнинг фалсафий теранлиги, сўзларнинг гўзал тарзда сайқалланиб келиши каби анъаналари, сарбаст шеърнинг қирғоқ бузар мавжлари, туйғу тошқинлиги билан омухталаниб кетади. Натижада замонавий ва мумтоз шеъриятнинг синтезлашган шаклига дуч келасиз:

Чунонам, жононам, сизга пайвандман,

Ииқпарастман, мардуми Самарқ̧андман,

На жамман, на камман, на-да бутунман,

На итман, на одам, на-да туткунман.

Вале сиз учунман

Ёлвиз сиз учунман.

Харгиз сиз учунман, хуар дам сиз учунман,

Чунонам, чунонам, дил тийралашди ${ }^{97}$.

\footnotetext{
94 Холмирзаев Ш. Жахонбоп асарёза оламан лекин...//ЎзАС газетаси, 2002йил, 22 ноябр.

95 Болтабоев Х. Истиқлол имкониятлари: янгиланаётган анъаналар ва постмодернизм. Қаранг: Мустақиллик даври адабиёти. Адабий танқидий мақолалар, бадиалар. - Тошкент: Ғафур Ғулом номидаги нашриёт-матба итжодий уйи, 2006. 283-б.

${ }^{96}$ Норматов У. Тафаккур ёғдуси. - Тошкент: “Янги аср авлоди”, 2005. 65-б.

97 Абдували Кутбиддин. Бор. Шеьрлар ва достонлар. - Тошкент: Ғафур Ғулом номидаги нашриёт - матбаа ижодий уйи, 2011. -Б. 197.
} 
Кўриниб турибдики, бу мисраларда мумтоз шеъриятимиздаги мустазодга хос мисраларнинг ўйноқи, охангдорлиги, бармоққа хос соддалик, ихчамлик ва дилга тез таъсир қилиш, модерн шеъриятга хос чуқур маъно тафаккур теранлиги билан хамоханг бўлиб келаётганлиги кўзга ташланади.

Фахриёр шеъриятини метафоралар асосига курилган шеърият дейиш мумкин. Зеро, у оддий сўз билан эмас, асосан, метафоралар орқали фикрлайди. "Метафора эса иккита белгининг тўқнашувидир"98. Шоирнинг “Қалдирвочлар дарз кетган осмон”, “Соя тикка турар ерга суяниб”, “Ойна каби шаффоф шамол”, “Осмон ёнбошлайди овуз четига”, “Сомон йўли чангларини ювиб олар юлдузлар” каби шеърларда истиоранинг ўзига хос намуналари кузатилади.

Гурлар құсир - тухишдан қолган...

Ёки:

Шеър туцжийман уургимчак каби

Мухаббатнинг толаларидан...

Ўзбек модерн шеъриятининг бош белгиларидан бўлган бундай сўз ўйинлари, ифода тарзидаги шаклий янгиликлар бадиий тахайюли нозик ўқувчиларнинг эхтиёжини қондириши билан бирга, эстетик нафосатни тарбиялашга хам ижобий таъсир кўрсатиши жихатидан эътиборга лойиқдир.

Фахриёр сўзнинг бўёқларини нозик хис этади. Китобхон шоирга хаммаслаклик, хамижодкорлик даражасига кўтарилгани хамоно лирик қахрамоннинг холини тушунади рангдор маъно замиридаги тагдор мазмунни хис этади. Унинг сонетларида модерн услуб устунлик қилади, Хусусан, кечинмалар бадиий тасвир воситаларининг ўзига хос шаклларидан фойдаланган холда ифодаланади. Ташбехлар билан бир қаторда бадиий санъатларнинг аксар турларига намуналар топиш мумкин. Булар шоир изланишлари бадиий жихатдан юксак савиядалигидан далолатдир.

Хуллас, модерн шеъриятда сўзнинг фақат маъно қирраларига эмас, балки шаклий жихатлари - ранги, туси, таъми, бўёғига хам катта эътибор беради. У сўзни шунчаки айтиб қўя қолмайди, балки уч ўлчамли эффектлар кўмагида моддийлаштиради. Бу тоифа шеьр кишини ўйлашга ундайди, бадиий сўздан олинадиган таассуротнинг хилма-хил бўлишига замин яратади.

\section{Фойдаланилган адабиётлар рўйхати}

1. Абдували Қутбиддин. Бор. Шеьрлар ва достонлар. - Тошкент: Ғафур Ғулом номидаги нашриёт - матбаа ижодий уйи, 2011.

2. Болтабоев Х. Модернизм ва янги ўзбек шеьрияти. 2-мақола // Жахон адабиёти. 2007, №2. - Б. 157.

3. Норматов У. Ижод сехри. Т.: Шарқ, 2007.

4. Ильин И.П. Постструктурализм. Деконструктивизм. Постмодернизм. - М.: Интрада. 1996.

5. Рахимжонов Н. Мустақиллик даври ўзбек шеърияти. - Т.: “Фан”, 2007.

6. Фахриёр. Аёлғу. - Т.: Шарқ, 2000.

7. Х Холмирзаев Ш. Жахонбоп асар ёза оламан лекин... //ЎЗАС газетаси, 2002йил, 22 ноябр.

\section{ЎРТА АСРЛАР ДАВРИ ВАЛЬТЕР СКОТТ ТАЛҚИНИДА}

\section{Умарова Махлиё Юнусовна (ф.ф.н., доц. ЎзДжТУ докторанти)}

Annotation: This article gives the analyses of the famous novel "Ivanhoe" which was written by the first outstanding writer of a historical novel in English literature Walter Scott.

\footnotetext{
${ }^{98}$ Огнев В. Книга про стихи. - М.: Советский писатель, 1963. - С. 92.
} 
The artistic image is of the historical figures, heroes and their role discussed. Materials that characterized a broad historical period of the Middle Ages were not sufficient to describe an entire period. The writers looked for elements to express the vitality and reliability of their works.

Walter Scott in his historical works, including the novel "Ivanhoe" vividly depicts everyday details: the architecture of castles, the interiors of dwellings, the costumes of heroes representing different social groups of the population. The article discusses the writer's artistic skills and the expression of history in his works.

Key words and expressions: historicism, art, talent, historical monuments, past, conflict.

Вальтер Скотт (1771-1832) жахон адабиётшунослигида ўзининг тарихий романлари билан мухим ўрин эгаллайди. Унинг Шотландия тарихи воқеаларини хикоя қилувчи “Уэверли ёки олтмиш йил аввал”, “Айвенго”, “Роб Рой”, “Тумор” каби асарлари ўз вақтида жуда машхур асарлардан хисобланган ва халигача жахон адабиётининг ноёб дурдоналаридан хисобланади.

Вальтер Скотт“Айвенго”, “Унаштирилганлар”, “Граф Роберт Парижский”,”Анна Гейерштейн, ёки туман қизи" тарихий романларида Ўрта асрларга мурожаат қилиб, рус романтик ёзувчиларини хам илхомлантирди.Натижада ХІХасрнинг 30-йилларидаЎрта аср воқеаларини ууз ичига олган А.Бестужевнинг "Роман ва Ольга"(1828),Н.Полевойнинг “Симеон хақида қисса”(1828) ва бошқа дастлабки рус тарихий қиссалари пайдо бўлди.

Вальтер Скотт хақлиравишдатарихийроманнингяратувчисихисобланади. Тарихийлик концепцияси, ўздавриучунинновацион, миллийўтмишхақидаги энциклопедикбилим, даврколоритиниқайтатиклашқобилиятибунданташқари, мамлакатучунтарихийсаналган даврларда инсонлартақдиритасвири, миллийхарактергаэга бўлишундаахлоқийидеалнитопишгауринишбуларнинг барчасиСкоттнингасарларига хос хусусиятлардир. Скотнинг эпик хикоя қилиш иқтидори унга муносиб халқаро эътирофга сазовор бўлди. Америка адабиётида, жанр нуқтаи назаридан, унга энг яқин бўлган ёзувчи Жеймс Фенимор Купер эди.

Америкалик ёзувчи Вашингтон Ирвинг бутун умри давомида Скотт ижодидан илхомланиб асарлар яратди. Ирвинг учун Скотт дахо эди ва у билан замондош, сухбатдош бўлишни у ўзи учун тақдирнинг совғаси деб биларди. 1858 йил октябрь ойида ёзувчинингоила даврасида ўтирган 75 ёшли Ирвинг : “Унинг хонадонидаги ўтиришдек бахтга муяссар бўлишдан ортиқ бахтни умрим давомида хис қилмаганман” [Irving 1864:261] дея эътироф этади. Скотнинг :тарихий романларининг ўзига хослиги унинг дунёқараши билан белгиланади.У консерватив қарашларга содиқ қолиб, Тори хукуматини қўллабқувватлаб, конституциявий монархия тарафдори эди. Ёзувчи халқнинг хақ-хуқуқли бўлишини маъқуллагани билан, инқилобий ўзгариш уни чўчитар эди. У хақиқий тарихий романни яратиш шартларидан энг асосийси тарихий аниқлик деб билган. Шунингдек, тарихий асарларини яратиш давомида тарихий ёдгорликларни,хужжатларни,урфодатларни,ўша давр кийим кечакларини диққат билан ўрганиб чикди. "Биз Вальтер Скот тарихий романларини ўқир эканмиз, асардаги воқеа даври замондоши,ўша мамлакат фуқаросига айланамиз ва хар қандай воқеа хақида бизга берадиган нарсалардан кўра кўпроқ тўғри тушунчага эга бўламиз” деб ёзади рус олими В.Г.Белинский. [Белинский 1948:136] Скотнинг романларида асосий тасвир хаёт ва мўъжизалар эмас,балки тарихни харакати ва ривожланишидир.

Вальтер Скоттнинг тарихий ретроспективи салиб юришлари билан боғлиқ. Уларда ёзучи бошқа шахсларни ва жамоатчиликнинг ўзаро боғлиқлигини тарихий жараёнда кўриш ва кўрсатиш имконига эга бўлди. Унинг "Граф Роберт Парижский” ва “Тумор" романларидаги воқеалар айнан биринчи (1095-1099) ва учинчи (1189-1192) салиб юриш вақтига мос тушади. Ушбу асарларда кўплаб хақиқий тарихий шахслар: Византия императори Алексей Комнин, унинг аёли Ирина Дукина, уларнинг тўнғич қизлари Анна Комнин(“Граф Роберт Парижский”асарида); биринчи салб юришлари қатнашчилари Шер юрак Ричард, Филипп Август II, Конрад Монсерратский, Эрцгерцог Леопольд (“Тумор”асарида)кабиларни кўришимиз мумкин.Ёзувчи ўзининг асарларида тасвирланган 
хақиқий тарихий шахсларнинг тақдирини йўқотиш хукуқига эга эмас, лекин у ўзининг тасаввурида хаётга олиб келинган оддий одамларнинг тақдирини хал қилишда эркин фикр юритади. Муаллифнинг дастлабки ва иккинчи харакати орасидаги тафовут йўқолгандан кейингина, уларни хукм қилиш хуқуқига эга бўлади. Яхшилик устидан ғалаба қозониш хар доим хам муқаррар эмас, буни аниқ далиллар билан исботлаш учун Вальтер Скотт, хронологиядан бироз четлашиб, тафсилотларни кўшишга эришган.

Унинг “Айвенго" (1819) асарида тавсирлаган Ўрта асрларнинг “классик” сурати хозирда бир мунча эскирган бўлиши мумкин. Аммо бир вақтнинг ўзида хам хақиқатни очиб берганзамонавийликдан фарқли ўлароқ воқеалар тасвири ўша давр адабиётида хали учрамаган эди. Бу янги давр адабиёти учун бир кашфиёт эди.Аммо Скоттнинг тарихийлиги бу ташқи,эмпирик томон билан чекланиб қолмайди. Унинг хар бир романи маълум бир даврдаги тарихий жараённинг маълум бир концепциясига асосланган. Масалан унинг “Айвенго" романининг кириш қисмида ёзувчи тарихий асарда тарихий ўтмишни қайта тиклаш учун эски ўша давр тилидан фойдаланиш зарурати йўқ деб ёзган. Бу билан асар муаллифи ўз даврининг вакили сифатида тарихни тасвирлаш кераклигини таъкитлайди ва Вальтер Скотт ўзи хам бунга доим риоя қилган.

“Айвенго”романи воқеалари XII аср охири яъни ўрта асрларда Англияда феодал муносабатлар авж олган даврини тасвирлайди. Бир неча асрлар давомида Англия худудида истиқомат қилиб келаётган англ-сакслар ва Англияни XI acp охирида забт этган норман феодаллари ўртасидаги уруш айнан шу асарда яққол ёритиб берилган. Қирол Ричарднинг феодалларга қарши уруши хам шу даврда бўлиб ўтган. [Реизов 1965:497]

Романдаги конфликт, ягона марказлашган давлат ғоясини ўзида мужассам этган қирол хокимиятига қарши, мамлакатнинг сиёсий парчаланишини сақлаб қолишдан манфаатдор бўлган кўзғолончи феодал зодагонлар курашига бориб тақалади. Ушбу конфликт Ўрта асрларга хосдир.Феодаллар давлат ва жамият манфаатларидан фарқли ўлароқ, ўзларининг шахсий хукмронликларини тасдиқлашга интилдилар.Қирол хокимияти эса ўша пайтда Ғарбда шаклланиб келаётган давлатларнинг мустахкамланишига хисса кўшган ва бу жамоат манфаатларига, шу жумладан, жамиятнинг эзилган қисми манфаатларини ўзида акс эттирди. Вальтер Скотнинг талқинида марказлашган қирол хокимияти ғоясини олиб борувчи шер юрак қирол Ричард Робин Гуд ўқлари билан Фрон де Боеуф қалъасига бостириб киради. Халқ феодалларга қарши қирол билан бирга курашиши ушбу эпизоднинг ғоявий маъносини англатади. [ Скотт1962: 717]

Вальтер Скотт Англиядаги қайта қуришнинг мураккаб даврини, тарқоқ феодал мулкларни ягона шодликка айлантириш жараёнларини махорат билан тасвирлаган. “Айвенго" шубхасиз Вальтер Скоттнинг энг яхши романлари сирасига киради. Ёзувчи ўз иқтидорини жуда кўп жихатдан айнан ушбу романда намоён этган. Асарда ёзувчининг ватани бўлган Шотландиянинг ачинарли тарихи ва унинг ачинарли тақдири тасвирланади.

\section{Фойдаланилган адабиётлар рўйхати}

1. Белинский. В. Г. Собрание сочинений в трех томах. Т. II, М., 1948., С. 136

2. Реизов Б. Г. Творчество Вальтера Скотта. - М., Л.: Художественная литература, 1965. -497 c.

3. Скотт Вальтер. Собрание сочинений в двацати томах. Т. VIII, M., 1962. -С. 717

4. Irving, P.M. The Life and Letters of Washington Irving: by His Nephew, Pierre M. Irving / P.M. Irving. - New York: G.P. Putnam, 441 Broadway, 1864. - V. IV. - P.261 (452 p). 


\title{
ЕВРОПА ВА ЎЗБЕК ХАЛК ЭРТАКЛАРИДА ЎХШАШ ОБРАЗЛАР
}

\author{
Мухаммедова Хулкар Элибоевна

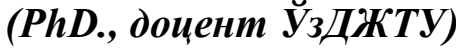

Annotation: The presented article deals with the analysis of similar images, motives and details that exist in the samples of popular fairy tales in the world folklore. The features of similar images observed in Uzbek national and European fairy-tales are analyzed. Certain similar characteristics found in the images are in the samples of Uzbek and European fairy-tales revealed.

Key words and expressions: fairy-tale, image, plot, culture, language, personage

Азалдан эртаклар жахон адабиётида маданиятни кўрсатиб берувчи феномен сифатида талқин этилади. Эртаклар билан бирга тил ва маданият миллатга тегишли бўлган турли деталларда ўз аксини топади. Европа ва ўзбек халқ эртакларида гарчи халқлар тарихан бир хил географик ва маданий шароитда яшашмаган бўлишса-да, жуда хам кўплаб ўхшаш образларни кўришимиз мумкин. Булар ўгай она, ўгай қиз, пари, сехрли ойна ва хомий чол образларидир. Хар бир персонаж эртакнинг хам бадиий-эстетик, хам композитцион қурилмасида мухим ўрин тутади. Жумладан, нуроний чол эртак якунида асосий зиддиятни бартараф этишда хизмат қилса, дев, ялмоғиз кампир, ўгай она каби персонажлар асарда зиддиятларнинг келиб чиқишида, воқеаларнинг шиддаткор ривожида,эртак ғояси очилишида - яхшиликнинг ёмонлик, тўғриликнинг эгрилик, ёруғликнинг зулмат, доноликнинг жахолат устидан ғалабасининг таъминланишида мухим рол ўйнайди.

Ўгай қиз ва ўгай она типидаги туркум эртаклар неча асрлардан буён ўқувчиларни мунгли мотивлари билан ўзига жалб этиб келади. Ўгай қиз типидаги эртакларнинг образ ва мотивлар тизими реал хақиқат, ўгайлик анъаналари ва етимлик билан боғлиқ қадимий тушунчалар атрофида юзага келиб таълимий-эстетик вазифаларни адо этадилар. Мазкур типдаги эртакларнинг ўзига хос хусусиятлари аввало ўгай атамаси хамда ўгай қиз билан ўгай она ўртасида содир бўладиган зиддиятлар тарихи билан ажралиб туради. Ўгай қиз билан ўгай она шахсини бир-бирига “бегона" деб қарши қўйиш ва ажратиш маълум бир замон махсули, аникроғи даврлараро зиддият, турмуш қарама-қаршиликлари, жамиятнинг ибтидоий босқичига оид шарт-шароитларнинг мафкуравий қарашлари замирида вужудга келган[ Имомов 1997: 48].Мазкур типдаги эртакларнинг асосий хусусиятлари аввало ўгайлик мавзуси хамда ўгайликни хикоя қилувчи мотивлар силсиласи, сюжетлар характери, қолаверса иштирок этувчи персонажлар тизими, хар бир персонажнинг айрим жихатлари хамда воқеа-ходисаларнинг хаёлий уйдирмалар асосига қурилганлиги, таълимий дидактик ғоялари билан белгиланади.

Европа ва ўзбек халқларида ўгай қиз туркумли эртакларининг асосий ўхшашлиги шундаки, бу эртакларда хам асосий функцияси тўрт хилбўлган персонажлар иштирок этади. Булар- ўгайқиз, рақиб персонаж- ўгай она, сехрли воситалар билан таъминловчи сехргар пари (“Синдерелла” да), мехрибон момо (“Зумрад ва Қиммат” да)дир.

“Зумрад ва Қиммат” хамда “Синдерелла" эртакларини таққослайдиган бўлсак, иккаласида хам муштарак ғоя яъни ўгай қиз эзгулик тимсоли сифатида намоён бўлади. Зумрад ва Синдерелла образларининг эртакдаги асосий вазифалари ўгайлик ва адолатсизлик, ёвузлик ва инсофсизликка қарши чиқиши билан белгиланади. Мазкур типдаги эртакларнингбошқахрамонларихамодобли, ўтахақгўй, қатьиятли, адолатпарвар, мехнатсевар, гарчи ўгай оналари тазйиқи билан мунгли хаёт кечираётган бўлсалар-да, келажакка ишонч рухи билан йўғрилган покиза қалб эгасидир. Ўгай қизни тахқирлаш турли эртакларда турли хил тасвирланади. “Синдерелла" да бу хол ўгай қизни оғир иш билан банд қилиб кўйиш билан бошланса:

"They took her pretty clothes away from her, put an old grey bedgown onher, and gave her wooden shoes. There she had to do hard work from morning tillnight, get up before daybreak, carry water, light fires, cook and wash'[Jacobs 1994: 131]. 
“Зумрад ва Қиммат” да эса шунга ўхшаш холат узоқ манзилларга адаштириб келиш ёки хайдаб юбориш воситалари билан акс эттирилади:

“Бир куни кампир Зумрадни ёмонлаб, чолга дўқ урибди:- Қизинг беодоб, ишёқмас, уни хуайдаб юбор, ўрмонга обориб адаштириб кел! Бўлмаса сен билан бир нафас хуам бирга турмайман”[ЗЗумрад ва Қиммат 1990: 127].

“Зумрад ва Қиммат” да нуроний ва оқила момо бош қахрамонни синаш ва ёрдам кўрсатиш каби вазифаларни адо этади. “Синдерелла” да пари сехрли кучлар воситасида ўгай қизга ёрдам кўлини чўзади. Шуни айтиш жоизки, “Синдерелла" даги пари сехрни ишга солиб ёрдам кўлини чўзса, “Зумрад ва Қиммат” даги момо ақл ва заковатини ишлатган холда қахрамонга кўмаклашади. “Зумрад ва Қиммат” да момо тимсоли ўгай қизни қимматбахо совғалар билан такдирлайди, айни пайтда дўстлик хамда хамкорлик тимсоли сифатида бош қахрамонни синаш ва ёрдам кўрсатиш каби вазифаларни адо этади, энг мухими ёвузликни қоралаб яхшилик йўлида турган кишиларни рағбатлантиради.Мазкур эртакларда хам ёрдамчи персонажлар бўлиб, унда асосан табиат бўлаги бўлмиш хайвонот олами вакиллари қатнашадилар.

Ёрдамчи образларнинг яна бирига тўхталадиган бўлсак, “Синдерелла" да ёрдамчи персонаж, асосан, парранда ва кушлар шаклида пайдо бўлса, «Зумрад ва Қиммат»да сехрли кучга эга бўлган кийик орқали намоён булиб, ўгай қизни огохлантириш, йўл кўрсатиш каби харакат ва муносабатларни адо этадилар.

Европа ва ўзбек халқ эртакларига бўлган яна бир ўзига хослик шундаки, эртаклар табиати сехрли воқеалар кўламини бўрттиради, жонлантиради:“Зумрад дамолганда гуллар олқишлар, бошларини эгиб салом берар миш,майсалар устида уттриб дамолганда гуллар кувониб унга хуикоялар айтиб бераркан”[Зумрад ва Қиммат 1990: 127].

"Синдерелла" да: "Cinderella, not with standing her coarse apparel, was a hundred times more beautiful than her sisters, although they were always dressed very richly. When she sang all flowers and birds sang with her. "[Jacobs 1994: 131].

Бу хил элементлар етакчи образ табиатидаги ички кечинмаларни белгилайди, ўгай қиз рухиятини кўтаргандек бўлиб эзгулик хар доим ғолиблигини ёш авлодга етказмоқчи бўлади. Қиммат ва Синдрелланинг ўгай опа-сингилларни таққослаш жараёнида хам сехрли бўрттиришларнинг гувохи бўламиз. Масалан: “Қиммат келса бутун гуллар қововини уйиб, майсалар оёzига пояндоз бўлишдан бош тортишаркан, унинг йўлида факат тош-харсанглар учраркан”[ЗЗумрад ва Қиммат 1990: 127].

"Синдерелла" да: "All nature was against her sisters, when they appeared all flowers close andbirds stopred chirping”'[Jacobs 1994: 131].

Айтиш жоизки, ўгай қиз ва ўгай она туркумидаги эртаклар ўзига хосхусусияти, насихатомуз мотивлари ва таълимий-дидактик ғоялари билан ажралиб туради.Яна икки эртакдаги ўхшашликлардан бири шундаки, бош қахрамон идеаллаштириб олинади, бир вақтнинг ўзида идеаллаштириш билан бирга зулм ва зўрлик қораланади, бу оркали ўқувчиларни эзгулик сари этаклашга харакат қилинади.

Эртакларда куйида келтирилган таърифлардан бош қахрамон- ўгай қиз тимсоли нақадар идеаллаштирилганининг гувохи бўлишимиз мумкин:

“Зумрад кўп чиройли, одобли, мулойим, ақлли құиз экан, уни куррганда кўзлар ққамашиб, чиройига хқаттоки ой хуам хқасад килар экан. Бутун табиат унинг яхшилигидан ором олар экан.” - “Зумрад ва Қиммат” [Зумрад ва Қиммат1990: 127]

"She was so kind and looked like as thousand lights shone upon her, Andshe was so beautiful that everyone who saw her was amazed. She was so open hearted and always helped to everybody even to animals - "Синдерелла" [Jacobs 1994: 131]

Гарчи бу икки эртак турли халққа тегишли бўлсада, эртакдаги ғоя адолатнинг қарор топишига, мехнатсеварликка, эзгуликнинг ғолиб бўлишига асосланганлигини хам таъкидлаб ўтиш зарур.

Бу эртаклардаги яна бир ўхшашлик- илохий ёрдамчилардадир. Бу илохий ёрдамчиларга парилар киритилади. Мазкур эртакларда хам парилар эпик кўмакчи ёки қахрамонга ёрдамчи 
вазифасида келади. Синдерелланинг ёрдамчиси унинг чўқинтирган онаси- пари бўлса, Зумрадга ўрмонда яшовчи кампир ёрдам беради. Бироқ кампир хам пари бўлиб, у хам илохий кучлардан фойдаланади. Жахон халқлари адабиёти тарихида париларнинг қахрамонга эпик кўмакчи сифатидаги вазифалари мохиятига кўра куйидаги типга бўлинади.

а) $\quad$ Ўз фаолияти билан қахрамонга бевосита ёрдам берувчи эпик кўмакчи.

Одатда бундай парилар қахрамон эпик мақсадга эришувида кўмаклашади. Масалан, Европа халқ эртаги қахрамони Синдерелла подшох уюштираётган баллга боришни жуда хохлайди. "This godmother of hers, who was a fairy, said to her: "You wish that youcould go to the ball; is it not so?"'Yes," cried Cinderella, with a great sigh"[Jacobs 1994: 131].

Қизнинг баллга бориш иштиёқи қанчалик кучли эканини кўрган пари унга ёрдам беради ва қизни сехр ёрдамида яратилган арава, кийим-кечаклар билан баллга жўнатади: "Well, said her godmother, "be but a good girl, and I will contrive that youshall go." Then she took her into her chamber, and said to her, "Run into the garden, and bring me a pumpkin."Cinderella went immediately to gather the finest she could get, and brought it to her godmother, not being able to imagine how this pumpkin could help her goto the ball. [Jacobs 1994:132]

Турли хайвон ва жисмлардан бу каби кундалик эхтиёждаги нарсаларни сехр ёрдамида яратиш фақатгина париларнинг кўлидан келади, бу эса Синдерелла хақидаги эртакнинг сехрга бой ва одамларни мўжизага ишонадиган қилибт арбиялайди

"Oh, yes," she cried; "but must I go in these nasty rags?"Her godmother then touched her with her wand, and, at the same instant, herclothes turned into cloth of gold and silver, all beset with jewels. This done, she gave her a pair of glass slippers, the prettiest in the whole world. Being thus decked out, she got up into her coach; but her godmother, above all things,commanded her not to stay past midnight, telling her, at the same time, that if she stayed one moment longer, the coach would be a pumpkin again, her horses mice, her coachman a rat, her footmen lizards, and that her clothes would become just asthey were before. "[Jacobs 1994: 132]

Бу жихатлар эртакнинг сехрлилик хусусиятини яққол очиб беради. Бу каби сехрлилик жихатлар Европа эртаклари сюжетини бўрттириб кўрсатиш учун кенгроқ кўлланилади. Болалар оламининг ўзига хослигини кўрсатиш мақсадида кўлланилган бу каби холатлар хаётда мўжизалар бўлиб туришини, одамлар ўзлари уларни пайдо қилишини исботлашга бўлган бир уриниш сифатида кўрсатилган.

Европа ва ўзбек халқ эртакларидаги ўхшаш образлар ўгай она, ўгай қиз, хомий чол, пари, дев, ялмоғиз ва сехрли ойна каби эртакларда учровчи ўхшаш образлар хам эртакда алохида ўрин тутишини хамда уларнинг эртак мазмунмундарижасигатаъсирижудаюқориэканлигиниэртаклар мисолида билиб олишимиз мумкин бўлади.

Фойдаланилган адабиётлар рўйхати

1. Имомов К. Ўзгай қиз типидаги эртаклар. Ўзбек тили ва адабиёти журнали №3, 1997 йил.

2. “Зумрад ва Қиммат. Ўзбек халқ эртаклари.” - Тошкент: Ўзбекистон, 1990.- Б.346.

3. Jacobs J. English Fairy Tales.A Penn State of Electronic Classics Series publication. 1994. -315 p.

\section{浅析佩列文小说《奥蒙·拉》中的太空神话戏仿来源与含义 PARODY OF SPACE MYTHOLOGIES IN VICTOR PELEVIN'S OMON RA: ORIGINS AND MEANINGS}

\section{Hui Zhang, (Ph.D., Instructor Shanghai International Studies University, Shanghai)}

Annotation: Victor Pelevin's novel <Omon Ra>, written in 1991, illustrates the general sentiment of confusion and disillusionment amid the cultural shock following the collapse of USSR. Essentially a satire, it parodies the Soviet space mythologies, showing them as products of 
interaction between Soviet policies, education programs, mass media and individual participation. By creating an absurd image of myth production and reception, Pelevin aims at revealing the underlying semiotic system of Soviet space culture.

Key words and expressions: Pelevin, Omon Ra, space mythologies

维克托·佩列文（В. О. Пелевин）于 1991 年写作的小说《奥蒙·拉》 (ОмонРа) 可以看 作苏联解体时期文化动荡背景下的大众迷惘与虚妄情绪的宣泄产物。作为讽刺小说, 《奥 蒙·拉》的讽刺对象不仅仅是苏联 50-60 年代的官僚主义与形式主义, 还有在此社会风气所主 导下的大众文化。作为戏仿小说，它所戏仿的核心内容不是苏联的航天工程历史，亦非苏联 的官僚与教育体系，而是一个串联了科技、政治、军事、教育与文化诸方面因素的“苏联航 天神话”。从这个角度看，《奥蒙·拉》或许也可以称作一部“元科幻小说”：作者在创作中的 对话对象不是科技本身, 而是科技文化。如果说一般的科幻小说可以定义为以科技为骨架的 现代神话作品, 那么佩列文在《奥蒙·拉》中所塑造的神话世界本身便是建立在一个科技神 话的基础上的, 此神话是由大众共同谱写, 又由国家权力机构认可与宣传的, 它的内容便是 后斯大林苏联时代爸于火箭、人造卫星、宇宙飞船和宇航员的符号系统。换言之，《奥 蒙·拉》是一部从集体正统神话中汲取养分, 却又背离其主旨的个人异端神话。

《奥蒙·拉》并不是唯一一部，也不是第一部以人类太空探索为主题的戏仿艺术作品。 在阿列克谢·费多尔琴科 (А. С. Федорченко) 的伪纪录片《月球初客》（Первые на луне）

（2005）中，苏联早在 1938 年就实现了人类历史上的首次登月，唯一的登月者在返地着陆 时失去了语言能力, 这一事件一直封存于克格勃档案中, 苏联解体后才得以解密。在英国和 美国，类似的“伪史”作品早在六七十年代就已出现，如 1964 年的英国电影《最先登上月球 的人》(FirstMenintheMoon), 1968 年的美国电影《太空登月记》 (Countdown)，1978 年的 美国电影《摩羯座一号》（CapricornOne）等等。（Rogatchevski 2001: 253-259）与《奥 蒙·拉》一样, 这些“伪史”作品多以大国太空竞赛的历史为背景, 利用这一话题的政治敏感 性, 借由太空探索的表面故事编织出其背后的政治斗争、军事竞争和政府阴谋论。透过这些 作品的相似性，不难看出无论是在俄罗斯还是西方（美国为主），航天事业在政治领域都有 丰富的象征功能，有关太空的话语体系是在一个国家的政治诉求和文化定位的框架中打造而 成的。对于上述戏仿作品，我们既可以将它们看作是对于已成定式的“太空话语”的解构，也 可以将它们看作一种对太空竞赛背后冷战思维的文化消费。

然而，较之阿波罗号所代表的阿波罗精神在美国文化中的象征意义，联合号所代表的 苏联精神在苏联文化中有更丰富的所指：它所象征的不仅仅是苏联的科技实力、军事潜力、 工业化程度等指标，还有社会主义、辩证法和“新苏维埃人”的形象。“太空话语”在苏联文化 中的历史维度和哲学维度赋予了它神话的属性, 也意味着它的生产与消费需要遵守严格的典 章与仪式。正如许多学者所指出的，苏联的太空神话并不是凭空造就的，而是自有它的典章 和传承。其典章一部分来自于三十年代的“飞行员神话”，二是同样诞生于三十年代的，以 “斯达汉诺夫运动”为标志的“工人神话”, 三是赫鲁晓夫于苏共二十大上提出的社会前景新设 想。（Gerovitch 2011：81，104-105）太空神话中的词汇、句式、仪式、媒介既是对斯大林时 
代“飞行员神话”与“工人神话”的继承，也是对赫鲁晓夫时代政治与科技动态的反映。小说 《奥蒙·拉》所揤揄的, 绝不仅仅是 60 年代的苏联太空热, 而是贯穿整个苏联历史的神话体 系。在佩列文的世界中, 上述三种神话融为了一体; 推动小说情节发展的, 是来自于这三种 神话的人名、地名、事件、口号和标语。这些符号随着主人公的自我探索一个接着一个浮 现, 逐渐形成一个象征网络, 这个网络的中心便是苏联太空神话的核心一一由新苏维埃人” 建立的乌托邦。

从一开始，小说中就出现了许多苏联航天时代的产物与产品：从“宇宙”电影院到坐落 在莫斯科北部的“宇宙征服者”纪念碑, 从描绘宇航员的室内墙绘到太空科幻题材的流行歌 曲。正是这些无处不在的文化符号造就了一代苏联人的太空理想。正如佩列文所说：“如果 一个人的一半是他现实中的样子, 而一半是他理想中的样子' (王尔德语) , 那么苏联六七 十年代的孩子们都可以称得上是半个宇航员。” (转引自 Smolkin-Rothrock 2011: 159) 然而 佩列文在小说中却有意透过太空文化的现象揭示其内在价值的矛盾。在作家带有犬儒主义倾 向的解析中, 太空理想是虚妄的, 象征这种虚妄的是小说主人公奥蒙·拉在少先队夏令营的 食堂里发现的太空飞船模型。奥蒙·拉发现, 这个飞船有一致命的缺陷——没有舱门。随着 故事的发展, 奥蒙·拉成为了一名真正的宇航员, 拥有了自己的登月飞船。然而他最终却发 现, 这个飞船就像少年时代的模型一样, 是一个劣质的仿造品; 而自己就像模型里的飞行员 一样, 被禁锢在一个精心编造的谎言中——他根本就没有离开地球, 甚至都没有离开莫斯 科。所谓的登月旅行, 只是一场为政治宣传服务的秘密操纵的排演罢了。原型与模型, 人与 玩偶, 现实与虚拟, 理想与妄想的界限在小说中都一一消解了。

选择宇航员作为职业, 对于奥蒙·拉来说是一种道德义务, 因为宇航员是苏联的新时代 英雄, 这一职业是与战争时期的飞行员和模范工人联系在一起的, 它继承了这些旧时代英雄 自我牺牲和挑战极限的精神。这一种传承首先反映在主人公的姓名中。奥蒙·拉的真实姓名 是奥蒙·克里瓦马佐夫。其名, 如主人公所说, 取的是特警部队这一词组的缩写。其姓 ( 直 译为歪脸) 则带来两层联想：一是陀思妥耶夫斯基笔下的卡拉马佐夫 ( 直译为黑脸) , 二是 斯塔汉诺夫运动中的铁路模范工人彼得·克里瓦诺斯 ( 直译为歪鼻 )。与陀氏笔下的卡拉马 佐夫兄弟一样, 奥蒙对于信仰有异常的执着和狂热, 当然与阿廖沙不同的是, 他所信仰的是 科学主义, 于他而言, 太空的末知替代了宗教的神秘。而克里瓦诺斯代表的就是他心中的圣 徒，“新苏维埃人“的典范。奥蒙的假姓“拉”来自于古埃及的太阳神，他选择这个称呼是由于 隼头人身的太阳神使其联想到苏联的战斗机英雄们, 后者经常被比作“隼”。奥蒙对于太空飞 行的想象, 有一大部分素材来自于苏联飞行员的传说、图片和影像。宇航员、飞行员和技术 工人，这三个职业早已在奥蒙的身份想象中融为一体了。

除了奥蒙·克里瓦马佐夫 · 文中出现的其他姓名也指向苏联历史上或是文学史中的传奇 英雄。奥蒙所在的飞行员学校是以马列西耶夫命名的：后者是卫国战争中的飞行员, 受伤后 被截去了双腿, 然而在装上了假肢后在超人般毅力的支撑下重新学会了飞行, 并坚持回归军 队。飞行员学校附近的步兵学校以马特洛索夫命名, 此为二战时期的烈士, 曾在部队遭围困 
时用身体堵住机枪掩护战友。飞行员学校的政治副长姓乌察金, 此姓很容易使读者联想到小 说《钢铁是怎样炼成的》的主人公, 在下肢瘫瘑和双目失明的情况下仍坚持工作的保尔·柯 察金。不论是现实中还是小说里，这些英雄的名字都是少年宇航员们耳熟能详的。

然而在小说中, 英雄的理想被彻底扭曲了。飞行员学校的少年学生们刚入校就被截去 了双腿, 这一举措的唯一目的只是对外制造“国家英雄”的假象。在这一全书最为怪诞的场景 中, 可以看到斯特鲁伽茨基兄弟 ( А. Н. Стругацкий, Б. Н. Стругацкий) 的科幻经典的影 子。在两兄弟的小说《路边野餐》( Пикникна обочине, 1972) 中, 潜行者斯捷尔维亚特尼 克通过禁区中的魔法球实现了自己的梦想, 却因此失去了自己的双腿。小说的最后, 少年阿 尔图尔到魔法球前祈求幸福，却掉进了“绞肉机”的陷阱中。两部小说中的断腿和切割似乎都 是䏌于极权主义的暗喻——代表父权、集体和未来的苏联国家理想只有靠子代个体在此世的 牺牲来维持。如果说在《路边野餐》中, 这牺牲尚能换来乌托邦的希望, 那么在《奥 蒙·拉》中, 它维持的只是苟延残喘的乌托邦的幻影。

在飞行员学生中, 奥蒙·拉和他的朋友米巧克幸运地躲过了截肢手术, 然而这幸运却把 他们拉向更荒诞的悲剧。在成为正式的宇航员之前，他们必须通过一项“转世测试”, 考生会 在测试中进入催眠状态, 讲述自己的前世经历，考官由此判断他们是否有“前世的不良记 录”。奥蒙·拉通过了测试, 而米巧克则因在前世有过背叛和告密的行为而被立即处决。米巧 克的转世自述在小说中犹如神话中的神话, 它记载了叙述者在不同历史文明中的化身一一美 索不达米亚、古希腊、德意志帝国等等。这一章节的东方式魔幻及其跨时代、跨神话的互文 是佩列文小说的惯用手法, 然而在太空神话的语境下, “转世测试”有了更深的历史含义：它 象征着苏联太空文化中的一对内在矛盾。在测试前不久, 乌察金上校曾经告诉奥蒙, 被选中 的宇航员都需要非凡的“英雄精神”才能创造历史。然而，“转世测试”的有效性却意味着宇航 员并没有创造的自由, 他们只是历史的玩偶, 在不同的化身中重复着同样的人生轨迹, 因此 完全可以根据其前世的功过和品格来判定其此世的“英雄”资格。个人能动性与历史必然性 特殊性与普遍性之间的矛盾恰恰体现在苏联宇航员的形象表达上。一方面, 他们被描绘成不 会犯错的“超人”, 勇于探索的“先锋”, “新苏维埃人”的模范（Siddiqi 2011:63）；另一方面, 宇航员的传记和照片又经常侧重他们平凡、居家、亲和的一面，以显示“新苏维埃人”的典型 性, 暗示着苏联社会体系的必胜。（Gerovitch 2011：89; Siddiqi 2011:72）苏联宇航员们常常 感受到自己处于意识形态要求的夹角中, 被迫在大众媒介中切割自己的公共身份, 以满足各 种政治符号代言的需要。

宇航员形象与宇航员本人的分裂、航天史与航天神话之间的距离在小说的高潮部分以 夸张的戏仿形式得以体现。整个这一部分是围绕列宁的名字展开的：奥蒙·拉的任务是驾驶 月球车进入月球背面的列宁峡谷中, 并在峡谷的中点插上带有无线电发射器的旗杆, 发射器 会向太空传输三个单词：“和平”、“列宁”和“苏联”。执行任务前的最后一天，他在列宁墓旁 与乌察金上校进行了最后一场对话。而当他发现整个“月球旅行”只是一场大型摄影棚中的排 演, 并最终逃出工作人员的追捕时，才发现自己并没有走远——棚外是列宁图书馆的地铁 
站。列宁的名字和列宁墓在这一幕的出现不是偶然的, 苏联宇航员接受过的最高荣誉之一便 是在列宁墓后与最高领导人并肩合影。加加林、捷列什科娃、波波维奇与赫鲁晓夫在列宁墓 后交谈的镜头是苏联太空时代最具代表性的画面之一。（Gerovitch 2011：89）与此同时, “列宁墓后的宇航员”也标志着苏联大众传媒对于宇航员以及航天工程形象的严格审查和控 制。苏联历史上, 宇航员和涉及航天技术的照片往往是经过修订审核后才发表的; 宇航员参 加新闻发布会、媒体采访和国际演讲必须遵守严格的措辞限定; 苏联公民在电视上看到的宇 航员工作镜头并非总是真实的记录。如果说苏联宇航员的太空骗局只是佩列文的伪造, 那么 宇航员们在陆地上的影像——例如加加林出发前的演讲, 以及他与科罗廖夫的对话——确实 经常是事前或事后拍摄剪辑而成的。可以说, 奥蒙·拉和他的杜撰人用一种戏谑的方式, 呈 现了苏联太空神话的生产、包装与传播中的荒诞成分。

\section{【参考文献】}

1.Александров, А. А.Путькзвездам: изисториисовет. Космонавтики. М.: Вече, 2006.

2.Бритиков, А. Ф. Русскийсоветскийнаучно-фантастическийроман. Л.: "Наука," Ленинградское отделение, 1970.

3.Пелевин, В. О. Омон Ра. М.: Вагриус, 2000.

4.Gerovitch, S. "Human inside a Propaganda Machine", in Into the Cosmos: Space Exploration and Soviet Culture, ed. James Andrews and Asif Siddiqi. Pittsburgh: University of Pittsburgh Press, 2011.

5.Gerovitch, S. Soviet Space Mythologies. Pittsburgh: University of Pittsburgh Press, 2015.

6.Rogatchevski, A. "Space Exploration in Russian and Western Popular Culture", in Soviet Space Culture: Cosmic Enthusiasm in Socialist Societies, ed. Eva Maurer \& etc. Hampshire: Palgrave Macmillan, 2001.

7.Siddiqi, A. "Cosmic Contradictions", in Into the Cosmos: Space Exploration and Soviet Culture, ed. James Andrews and Asif Siddiqi. Pittsburgh: University of Pittsburgh Press, 2011.

8.Smolkin-Rothrock, V. "Cosmic Enlightenment", in Into the Cosmos: Space Exploration and Soviet Culture, ed. James Andrews and Asif Siddiqi. Pittsburgh: University of Pittsburgh Press, 2011.

\section{ДОСТОН ИЖРОЧИЛИГИДА ЭПИК МАХОРАТНИНГ ЎРНИ}

\section{Насим Очилов \\ (ф.ф.н., доцент, Қарии давлат университети)}

Annotation: Мақ̧олада бахиичилик ва достончилик санъатининг уизига хослиги, достончилик мактаблари, устоз-шогирдлик анъанаси, бахшиларнинг достон ижро этиш махэоратлари, достон куйлари ва ижро усуллари, достон матнларида эпик клише ва формулаларнинг уррни, жамоа ва индивидуал ижод, соз ва суизниг бадиий таъсир кучига амал құилиш, бахшилар эпик репертуарининг бойиб бориш йўллари, эпик махуоратнинг индивидуал ижрода намоён бўлиши, бахшининг эпик клишелардан махуорат билан фойдаланишида анъананинг ўрни масалалари Қурргон достончилик мактабининг исьтеъдодли бахшиси Эргаш Жуманбулбул угли томонидан ижро этилган “Далли” достони матнидаги отни эгарлаш тасвири Шодмон Хўжамбердиев репертуаридан ёзиб олинган “Хон Далли” достони матни асосида қиёсланиб, бахшиларнинг достон ижррочилигида эпик махқорати масалалари хқамда ижро жараёнида бахшининг устозлар анъанасига амал қилиш жараёнлари тахлилга тортилган. 
Key words and expressions: достончилик, эпик махуорат, бахии, анъана, бадихагўйлик, сюжет, мотив, образ.

Достон вадостончилик халқимизнинг қадимий санъат турларидан хисобланиб, унинг этномаданий хаётимизда яшаб, жонли жараёнда ижро этилиши бахши-шоирлар, жировлар, оқинлар қиссахонлар ва халфаларнинг барқарор анъаналар доирасида шаклланган ижодкорона мехнатлари махсулидир.Шундай экан, достончилик санъатининг устоздан шогирдга ўзлашиб, такомиллашиб, қаътий анъаналар асосида ижро ва ижод этилиш жараёнлари эпик махоратнинг мухим белгиларидан хисобланади. Достончилик мактаблари ва бахши-шоирлар ижодий махоратининг йил сайин униб-ўсиши хамда бойиб бориши анъанавий услуб ва поэтик ифодаларнинг ижодий жараёнда мукаммаллашиб бориши билан боғликдир. Демак, бахшининг репертуари ва ижро махорати эпик анъаналар замирида юзага келган ижодий актдир. Мана шундай ижодий харакат достонларда хар гал такрорланувчи эпик клише ва поэтик формулаларни махорат билан кўллаш, уларни қайтадан ижро этиш жараёнида мукаммаллашиб, бахшининг индивидуал ижодкорлик қобилиятини ошириб боради. Чунки "Хар бир ижро этилган асар бир матннинг варианти эмас, балки кенгроқ шеърий захиранинг имкониятидир. Халқ достонларининг эркин ижро этилиши шуни кўрсатмоқдаки, ижрочи биринчи навбатда эпик билимларни сақловчисидир. Достонни кенг миқёсда билиш унинг бир матнини билганга қараганда маъқулдир. Чунки бахши фақатгина бир маротаба ижро қилиш имкониятига эмас, балки бундай имкониятларнинг кўплаб турлари мавжуд. Эпик билимнинг чегараларида турган холда бахши кўпгина муқобил харакатларнинг бирини танлайди, қўшади ёки айрим бадиий парчаларни олиб ташлайди: уларнинг ўрнини алмаштиради, фикрни бошқа сўзлар билан юзага чиқаради, қайта ижод қилиш жараёнида бадиий синонимияларни кўллайди”[Гацак 1971:45].

Одатда хар бир бахши репертуарининг маълум изчиллик асосида шаклланишини устозидан ўрганган достонлар ташкил этсада, талантли достончилар ижодини кузатиш шуни кўрсатдики, бахшиларнинг достончилик мактаблариаро ўзаро алоқалари, бир-бирларига бўлган танқидий муносабатлари хамда “бахшиларнинг ижодкорлиги, яъни уларнинг туб достонларнинг асосий мотивларини ижтимоий-иқтисодий шароит талаблари, эшитувчиларнинг хохиш-истакларини назарда тутиб, янгича комбинацияларда куйлаш орқали"[Мирзаев 2012:10] даврнинг мухим воқеаларини анъанавий йўлларда тасвирлаши хам эпик махорат ва репертуарнинг бойиб боришидаги мухим жихатлардан хисобланади.

Эпик махорат дастлаб, устоз-шогирд анъаналарида кўзга ташланиб, шогирднинг устозидан ўзлаштирган матнга ижодий ёндашуви, бунда анъанавий услуб ва поэтик формулаларни махорат билан ижро эта олиш қобилиятининг шакллана бориш омиллари билан боғланади. Иккинчидан, эпик хотира, билим ва дунёқарашни қабул қилиш ва ўзлаштириш жараёнида бахши улардан махорат билан фойдаланиб, ижодий бадиха қила олиши билан белгиланади. Бахши-шоирларнинг достончилик анъаналари доирасида достонларни ижро этиш малакалари, бунда анъана ва бадиханинг ўрни масалаларида академик В. Жирмунскийнинг туркий халқлар достончилиги борасидаги кузатувлари диққатга сазовор. "Бахши ёдланмаган матнни куйлайди, у хеч бўлмаганда қисман муайян сценарий бўйича импровизация қилади, бунда кетма-кет эпизод ва вазиятларга кўшимча равишда анъанавий одатий жойлар (отни эгарлаш, қахрамонганасихат, жангларни тасвирлаш ва хк) доимий бўлади. Албатта, бундай импровизация фақат маълум бир пухта ташкил этилган анъана доирасида амалга оширилади.Бунда нафақат сюжетлар, мотивлар ва тасвирлар, балки доимий стилистик формулалар, эпитетлар, таққослаш, фразеологик бирликлар ва бошқалар доимий равишда иштирок этади. Бу эса фақат анъана ва импровизациянинг комбинациясидир"[Жирмунский 1974:79].Демак, эпик махорат жонли оғзаки анъаналарда давом этган барча достончилик мактабларида мавжуд бўлиб, бундай жараён бахшиларнинг анъанавий техник формулаларга ижодий ёндашуви ва уни махорат билан ижро эта олиш қобилиятидир. Эпик ижро ва махоратмасаласини кўрсатиш мақсадида Эргаш Жуманбулбул ўғлининг “Далли”[Далли 1972] ва Шодмон бахши Хўжамбердиевнинг 
“Хон Далли”[Хон Далли 2010] достонларида қўлланган отни эгарлаш тасвирини қиёсий тахлилга тортиш асосида кўриб чиқиш мумкин.

“Далли” достони Кўрғон достончилик мактаби бахши-шоирлари репертуарида махорат билан ижро этилган. Жанубий Ўзбекистон достончилигида ушбу достон оммалашмаган. Кейинги йилларда достоннинг китоб холатида чоп эттирилиши бахшилар томонидан ўқиб репертуарида ўзлаштира бошланди. Жумладан, Қодир бахши репертуарида мавжуд бўлган ушбу достон хақида хам шундай фикр билдириш мумкин. Шодмон бахши эса уни устози Қодир бахшидан ўрганганлигини таъкидлайди. Эргаш шоир достонни устозидан оғзаки ўзлаштириб, уни махорат билан ижро этган. Сюжетдаги анъанавий қолипнинг икки бахши репертуаридан ёзиб олинган вариантини қиёслаш анъана ва эпик махорат масаласи, бунда бахшининг достончилик анъаналарига ижодий ёндашиш қобилияти яққол кўзга ташланади. Достонда Хасанхоннинг Даллини излаб Арзрум шахрига сафарга отланиш манзараси мавжуд. Гўрўғлининг топшириға биноан Соқи Ғиротни қахрамонга эгарлаб, уни йўлга тайёрлайди. Эргаш шоир вариантида отни тайёрлаш ва уни Хасанхонга келтириб беришгача бўлган тасвир жами саксон тўрт мисрадан иборат бўлиб, бахши уни Хасанхонга тайёр холатда келтиргунгача бўлган тасвирини бадиий мукаммал тарзда ижро этган. Отни эгарлаш тасвирида анъанавий жихозларнинг от таърифи билан боғлиқ холда ишлатилиши, бунда бахши хар бир детал ва жихозга алохида эътибор билан ёндашганлиги сезилиб туради. Эпик от Ғиротнинг таърифи, Соқининг унга кўмакдошлиги шундан сўнг отни эгарлашда фойдаланувчи жихозлар кетма-кетлик билан тасвирлана боради. Ипакдан босилган “майин терлик”, “бахмал чиргин”, “жахаздирик”, “олтин қошли карсон”, “узанги”, “ипак айил”, “зар чочоқ”, “давир”, “карки қуйишқон”, “чиғатой пуштан”, “қуббали юган” каби жихозлар сифатлашлари билан тасвирни яна бойитади, бахшининг махоратини кўрсатади. Эргаш шоир отни эгарлаш эпизодини шунчаки тасвирлашни эмас, балки достончилик анъаналари доирасида Ғирот ва Соқи биографиясига доир қадимий анъаналарга хам эътибор қаратади, уларга ишлов беради. Шодмон бахши хам Эргаш шоир каби отни эгарлаш тасвирига эътибор қаратса-да, унинг ижросида тасвирнинг торайиб бориш манзаралари кўзга ташланади. Иккинчидан, анъанавий формулалар, халқчил ифодаларга нисбатан индивидуал ёндашув етакчилик қилса, учинчидан, хажм жихатдан хам Эргаш шоир варианти устунликка эга. Эргаш шоирда:

Муллалар ўқийди зеру забарни,

Усталар ишлатар теша табарни,

Боз устидан қўя берди Соқи чол,

Олтин қошли карсон кумуш эгарни (21-бет).

Шодмон бахшида ушбу тасвир қуйидагича:

Мехнат қилган рохатини топади,

Текинхўрлар текин жойга чопади.

От белига қўяберди Соқибек

Карсони тилладан бўлган эгарди (10-бет).

Мантиқ карсоннинг “олтин қошли кумуш эгар” эканлигини талаб этмокда. Эпик клишелар билан боғлиқ бундай тасвирларни кўплаб ўринларда кузатиш мумкин. Шулардан хулоса қилиб айтиш мумкинки, бахшилар ёдланмаган матнни эпик хотирасида мавжуд сценарий асосида импровизация қилиши, эпик клише ва формулалардан махорат билан фойдаланиб, уларга ижодий ишлов бериши бадиий махорат қирраларининг асосий белгиларидан хисобланади. Достон ижрочилигида эпик махоратнинг ўрни қуйидагиларда кўзга ташланади.

Биринчидан, достон ижро этиш жараёнининг ўзи анъаналар доирасида такомиллашган ва маълум қонуниятлар асосида шаклланган ижодий актдир.

Иккинчидан,достон ижро этиш жараёнида бахши устози ва достончилик мактаби анъанлари доирасида достонларни ижро этиш кўникмасини шакллантиради. Бунда достон матнларидаги эпик клише ва формулаларга эьтибор қаратиб, бахши хар гал ижро жараёнида 
уларга индивидуал махорати асосида ишлов беради, такомиллаштиради ва бадихагуйлик сирларини намоён этади.

Учинчидан, Эргаш шоир репертуаридан ёзиб олинган отни эгарлаш билан боғлик анъанавий тасвир жараёни эпик махоратнинг юксак ижро ва ижодкорлик хусусиятидир.Умуман олганда, достон ижрочилигида эпик махоратнинг ўрни катта бўлиб, бахшилар ижодкорлигини ошириб борувчи ва репертуарини бойитувчи омиллардан хисобланади.

\section{Фойдаланилган адабиётлар рўйхати}

1. Гацак В.М. Эпический певец и его текст // Текстологическое изучениеэпоса. - М., 1971. - C.45.

2. Мирзаев Т. Бахшилар эпик репертуарининг шаклланиши ва бойиб бориши масалалари // “Қодир бахши абадияти” мавзусида ўтказилган республика илмий- амалий конференция материаллари. - Қарши, 2012. - Б.10.

3. Жирмунский В.М. Тюркский героический эпос. - Л., 1974. -С. 79.

4. Далли. Достон. Айтувчи Эргаш Жуманбулбул ўғли. Нашрга тайёрловчи М.Алавия // Ўзбек халқ ижоди. Кўп томлик. - Тошкент: Адабиёт ва санъат, 1972.

5. Хон Далли. Достон. Айтувчи Шодмон бахши Хўжамбердиев.- Қарши: Насаф, 2010.

\section{ИСПОЛЬЗОВАНИЕ МЕТЕРИОЛОГИЧЕСКИХ ДИАЛЕКТИЗМОВ В ПРОИЗВЕДЕНИЯХ Н.С.ЛЕСКОВА И СПОСОБЫ ИХ ПОЯСНЕНИЯ}

\section{Эсанов Уктам Джаббарович (Доцент кафедры Узбекского и иностранных языков Ташкентской медицинской академии)}

Annotation: This article examines meteorological dialectisms related to atmospheric phenomena, кура, замять, буран, вьюга, метель which were used by N.S. Leskov in his works and ways of explaining them to a wide range of readers. Examples of meteorological dialectisms from the works of A.S. Pushkin and S.T.Aksakov are given. The research of the famous German scientist V. Girke of the language of works of literary by N.S. Leskov is analyzed.

Key words and expressions: Synonym, interpretation, explanation, dialectism, dialect, example, paragraph, publishers, reader, dialect correspondence, fiction.

Важной составной частью языка художественных произведений Н.С.Лескова являются диалектизмы, составляющее дополнение к словарному запасу русского языка. Объектом нашего исследования в этой статье являются диалектизмы, используемые при обозначении атмосферных явлений. Н.С.Лесков в повести «Житие одной бабы» (1863) использует дополняющие друг другу синонимические диалектизмы кура и замять, которые требуют для современного читателя каких-то пояснений:

«... и по снегу носилась легкая сероватая пыль: можно было ожидать замяти. Настя крепко прозябла в одной свите и пошла к Степанову двору. В избе еще был свет. Настя потихоньку заглянула в окно. Степан сидел на лавке и подковыривал пенькою детские лапотки. В сенях кто-то стукнул дверью. Настя испугалась, отбежала за амбарчик и оттуда продолжала глядеть на окно. В хуторе было тише, чем в поле, но на улице все-таки мелась снежная пыль. Видно было, что кура разыгрывается, ... Настя в ту же минуту завела песенку и, пропев слова три, замолчала и стала смотреть на ворота.

- Ктой-то будто запел? - сказал, ворочась на лавке, Степанов тесть.

- Это тебе показалось, - отозвалась старуха, зевая и крестя рот. - Кто теперь станет петь на дворе? Кура курит, вот и кажется бог знает,что» [3. Т. 1. С. 360].

Этот пример интересен тем, что в одном абзаце используются два синонимичных диалектизма кура и замять.Слова замять и кура незнакомы широкому кругу читателей, но Н.С.Лесков употребил их в таком контексте, где они, дополняя другдруга, становятся более 
понятными широкому кругу читателей. Издатели Собрания сочинений Н.С.Лескова, предвидя затруднения некоторых читателей, решили дать пояснения в примечаниях, хотя при этом ограничились одним из диалектизмов: «замять - метель»[3. Т. 1. С. 504]. По неизвестным причинам слово кура не попало в список поясняемых диалектизмов. Не отмечено оно и среди диалектизмов, относящихся к атмосферным явлениям известного немецкого исследователя языка Н.С.Лескова В. Гирке[10. С. 146].

Различия между словами кура и замять отмечаются в «Словаре ветров», в которомна наш взгляд, составитель словаря дает неправильную форму - заметь (вместо замять).: «Метель ... выделяет общую метель (буран, вьюга, кура, курга, хурта), низовую метель (замет, заметь) и верховую метель (заверть)» [6. С. 110-111.].

Таким образом, диалектизм кура обозначает вообще метель, а замять - только низовую метель. Отношение Н.С.Лескова к диалектным словам и введению их в текст было неодинаковым. Например, в романе «Некуда» 1864 года он вводит орловское слово кура без каких-либо пояснений: «... Он сегодня ехал со следствия, завернул к Помаде, а тут поднялась кура, и он остался у него до утра» [4. Т. 2. С. 117].

Кура для Н.С.Лескова - родное слово, поэтому он, вероятно, не учел, что читатели могли его не понять. В связи с этим издатели дали примечание: «Кура - пурга»[4. Т. 2. С. 730].

В рассказе «Пугало» Н.С.Лесков употребил диалектизм кура в качестве необычного пояснения: «Девушка, Аннушка большая, объясняла это так, что Селиван забрал к себе во время метели (по-орловски - куры) целый господский возок с целым дворянским семейством и медленно отрезал дворянским детям пальчик за пальчиком»[4. Т. 8. С. 17].

Здесь Н.С.Лесков хотел вновь подчеркнуть, что действие происходит в Орловской губернии, но для художественной литературы это не лучший способ поддерживания местного колорита. Скорее всего, в данном случае повлияла журналистская практика автора. Н.С.Лесков употребил в авторской речи слово метель, а затем добавил в скобках орловское диалектное соответствие.

Следует заметить, что широта регионов употребления у диалектизмов кура изамять разные. Вот что дается по этому поводу в «Словаре русских народных говоров»: «Кура. Вьюга, метель. Тульск., Ряз., Курск., Орл., Елец., Брян., Смол., Калуж., Воронеж, Симб., Влад., Новорос., Кубан., Ставроп., Дон., Казаки -некрасовцы, Вост., Северные и центральные области, Сим., Том.» [8. С. 107]; «Замять. Метель, пурга. Орл. Воронеж» [7. С. 272].

Данные, приводимые в «Словаре русских народных говоров», различны. Если диалектизм замять употреблялся в узком регионе, то слово кура было широкопредставлено во многих диалектных областях России. Но в современном русском языке слова кура и замять находятся в пассивном запасе лексики.

Хотя диалектизм кура в некоторой степени был распространён, ни слово кура, ни слово замять в современном русском языке не очень широко известны, а слово буран, который считается оренбургским диалектизмом, на что обращает внимание, например, С.Т.Аксаков в произведении «Записки ружейного охотника»: «... Одни зимние вьюги, пооренбургски - бураны, беспрепятственно владычествуют на гладких равнинах, взрывая их со всех сторон, превращая небо, воздух и землю в кипящий снежный прах и белый мрак. ... O, не дай бог никому испытать жестокость зимних метелей в степях оренбургских.»[2. Т. 6.С. 174] С.Т.Аксаковсначала использует общерусское слово вьюга, при том даёт его местное соответствие с ссылкой на область распространения и буквально в следующем предложении автор употребляетобщерусский синоним диалектизма буран слово метель.

С.Т.Аксаков использует слово буран в одноимённом очерке «Буран», где события происходят в Оренбургской степи:

«Вдруг настала ночь ... наступил буран со всей яростью, со всеми своими ужасами. Разыгрался пустынный ветер на приволье, взрыл снеговые степи, как пух лебяжий, вскинул их до небес». [1. С. 301]. 
Слово буран несмотря на то, что и былвключён в словарь Академии Российской и употреблялся Державиным, С.Т.Аксаков считал его диалектным.

Буран в Оренбургских степях описывает А.С. Пушкин в известном всем эпизоде в произведении «Капитанская дочка»:

... В одно мгновение тёмное небо смешалось с снежным морем. Всё исчезло. «Ну, барин, закричал ямщик, - беда, буран!»

Предположительно, А.С.Пушкин описание оренбургского бурана позаимствовал У С.Т.Аксакова из уже известного нам очерка «Буран». Можно привести ряд параллельных меств описании бурана, у А.С.Пушкина и Т.С.Аксакова. Великий поэт не мог видеть оренбургского бурана, так как единственное посещение А.С.Пушкиным Оренбурга падает на сентябрь 1833 года, когда буранов не бывает. Подробнее об этом написал А.Поляков в работе «Картина бурана у Пушкина и С.Т.Аксакова», «Пушкин в мировой литературе» [5. С. 287-288]. В конце своей работыА.Поляков говорит: «Если признать здесь наличность «заимствования» Пушкиным у Аксакова, то мы имеем типичную пушкинскую переработку, сухую и сжатую в противовес растянутому и эмоционально-насыщенному оригиналу». [5. V. C. 288].

В заключении следует сказать, что В.И.Даль считал диалектизм буран восточным[3. Т. 1 С. 142] в словаре Ушакова оно дано как «обл.»,[9. Т. Стлб. 206].С.Т.Аксаков его считал оренбургским. В настоящее время слово буран стало общеупотребительным и может быть А.С.Пушкин здесь сыграл не последнюю роль.

Н.С.Лесковкак и С.Т.Аксаков употребляют диалектизмы кура, замять, буран для создания местного колорита. Но если диалектизм буран, как мы уже отмечали, вошёл в активный запас русской лексики, то диалектизмы кураи замятьтак и остались в пассивном запасе русской лексики и современном русском языке практически не используются.

\section{Список использованной литературы}

1. Аксаков С.Т. (Денница. Альманах М., 1834, Буран, стр., 301)

2. Аксаков С.Т.Собрание сочинений. Дичь степная, или полевая. Степь. М., 1896, Т. 6.

3. Даль В. И. Словарь живого великорусского языка. Перепечатанный со 2-го издания. - M., 1955.

4. Лесков Н.С. Собрание сочинений в 11- томах. - М.: Художественная литература, 1956-1958.

5. Поляков А. Картина бурана у Пушкина и С. Т. Аксакова. - В кн.: Пушкин в мировой литературе. Л., ГИЗ, 1926, с. 287-288.

6. Прох Л.3. Словарь ветров. - Л., 1983

7. Словарь русских народных говоров. - Л.: Наука, 1974. - Вып. 10.

8. Словарь русских народных говоров. - Л.: Наука, 1980. - Вып. 16.

9. Толковый словарь русского языка: в 4-х томах / Под ред. Д.И. Ушакова - М., 19351940

10. Girke W.StudienzurspracheN.S.Leskows. - Mänchen, 1969. - 221 S.

\section{БОБУР ХУКМДОР ШАХСНИНГ ТИПИК ВАКИЛИ ВА УНИНГ ЎЗИГА ХОС ХАРАКТЕРИ}

\section{Дилора Ражабова (ф.ф.н., доцент, СамДЧТИ)}

Annotation: The given article is devoted to Bobur to the character and his activities as a government leader and a poet. Some extracts were used from "Boburnoma" for.

Key words and expressions: acharakter, a ruler, a typical representative, a harmonic person.

Захириддин Мухаммад Бобур ўзбек давлатчилиги тарихидаги хукмдор шахсларнинг типик вакили, айни пайтда комиллик характерини ўзида мужассамлаштирган буюк инсон 
эди. У ўз давридаги кўплаб етук инсонларга хос бўлган фазилатларни ўзида мужассам этади. Бобурга хос бундай муштарак характер бизнинг замонамизда ўзининг илмий-фалсафий ифодасини топди. «Комил инсон ғояси - хам миллий хам умумбашарий мохиятга эга бўлган, одамзодга хос энг юксак маънавий ва жисмоний баркамолликни мужассам этган, уни хамиша эзгуликка ундайдиган олижаноб ғоядир...

Комил инсон ғояси азал-азалдан халқимизнинг эзгу орзуси, уни маънавиятининг узвий бир қисми бўлиб келган». ${ }^{99}$ Бобур ўз асарларида ана шундай ғояни тарғиб этган ва ўзи тамомила комиллик даражасига етган.

Демак, Бобур эмоционал шоир, синчков олим, жамият ва давр хақида чукур муносабат билдирувчи социолог, дадил курашувчи жангчи, донишманд давлат арбоби, тадбиркор ва камтарин, одамларга мехрибон ва талабчан шахс эди. Бобурда комилликнинг бу қадар шаклланиши ўзига хос ижтимоий асосларга эга.

Бобурнинг «Бобурнома»да яратилган характерини ўрганишда Н.Маллаевнинг кўйидаги фикри эътиборга лойикдир:

«Бобур бошқа тарихий шахсларнинг шакл-шамойили, хулқ-атвори, насл-насаби ва хоказолар билан алохида-алохида таништириб беради. Бироқ «Бобурнома»да Бобурнинг ўзи хақида шу зайлдаги махсус маълумотлар йўқ. Китобхон уни бутун хаёт йўли, иш амаллари, кишиларга ва воқеаларга муносабати, дунёқараши, завқи ва диди, шодлиги ва қайғуси, ғалабаси ва мағлубияти, олқиши ва ранжиши, салтанати ва дарбадарлиги, қаттиқкўллик сиёсати ва мунофиқлиги, ғазаби ва мархамати, рохати ва кўл остидаги йигитлари билан очин-тўкин, отлиқ ва яёв, оёқ яланг ва кулбасиз кечирган кунлари, билими ва донишмандлиги, кузатувчанлиги ва мушохадаси ва бошқа-бошқалар билан мужассамлашади, у гуё бир тарихий романнинг бош қахрамони сифатида гавдаланади. Бироқ фарқ шундаки, тарихий романда ёзувчи қахрамон образини яратар экан, у тарихий шахс билан боғлиқ бўлган хамма фактларни хам олиб, уларни айнан акс эттиравермайди. Балки ўз олдига қўйган мақсади ва вазифасига мувофиқ равишда фактларни танлайди, уларни ижодий қайта ишлаб олади, бадиий фантазиядан фойдаланади. «Бобурнома»да эса Бобурнинг хаёти ва фаолиятига оид фактлар айнан берилади. «Бобурнома»нинг жанр хусусияти, унинг мемуарлиги шуни тақозо қилади». ${ }^{1}$

Бобур гарчи бизга шоирлик қиёфаси билан гавдаланса-да, у энг аввало, даврнинг шохлик маслагини қўлга киритиш учун курашган ва унга эришган хукмдор эди. Бобурда характер шаклланишининг туб асоси нимада? . Бобур хукмдорлар оиласида дунёга келди ва шу мухитда тарбияланиб, болалигидан хукмдорлик идеал мақсадига айланди. Бобур Андижон вилоят хокими Умаршайх Мирзонинг ўғли, Амир Темурга эвара - тўртинчи авлод (Абусаид Мирзо - Султон Мухаммад Мирзо - Мироншох - Амир Темур) эди. Онаси Қутлуғ Нигорхоним ўзбеклашган мўғул уруғидан бўлмиш Тошкент хокими Юнусхоннинг қизи эди. Шу сабабли Бобур «Юнусхон Чингизхоннинг иккинчи ўғли Чиғатойхоннинг наслидандур» ${ }^{2}$ деб таърифлайди.

Демак, Бобур хам ота, хам она томонидан улуғ шохлар Амир Темур ва Чингизхонга авлод саналарди ва аждодлар силсиласига кўра шохлик маслагига даъвогар шахслардан бири эди. Тасодиф туфайли Умаршайх мирзо Ахси қўрғони ёқасидаги каптархонадан қулаб, халок бўлади. Таомилга кўра Умаршайх Мирзонинг тўнғич ўғли Захириддин Мухаммад Бобур отаси ўрнига хоким бўлиб тайинланади. Бу пайтда у 12 ёшга хам тўлмаган эди.

Албатта, бу даврда Бобур хукмдор сифатида тўла даражада шаклланмаган эди. Бобур тахтга кўтарилганча хукмдорлик хизматидан хабари бор, темурийзода хукмдорлар сухбатида бўлган, уларнинг харбий юришларини кўрган эди. Айниқса, у онасининг тарбиясини хурмат билан эслайди: «...менинг волидам - Қутлуғ Нигорхоним эди. Аксар қазоқликларда ва

\footnotetext{
${ }^{99}$ Миллий истиқлол ғояси: асосий тушунча ва тамойиллар - Т.: «Ўзбекистон», 2000 йил, 56-бет.

1 Маллаев Н.M. Ўзбек адабиёти тарихи. Биринчи китоб. Қайта шаклланган учинчи нашри. Тошкент: «Ўқитувчи», 1976 йил, 602-603-бетлар.

2 3.М.Бобур.«Бобурнома».Тошкент. «Юлдузча». 1989й. 12-бет. . «Бобурнома»дан олинган бошқа парчаларда хам шу нашрдан фойдаланилди ва сахифаси қавс ичида кўрсатилди
} 
фатаротларда менинг билан бир эдилар». (13-бет). Демак, Қутлуғ Нигорхоним хар қандай қийин дамларда ўғли билан бирга бўлган, унга маслахатлар берган ёки қуйидаги таьрифда эса темурий хукмдорлар даврасида жуда ёшлигида бўлганлиги эслатилади: «Беш ёшимда Самарқандга келганда манга куйуб эрди».(21 бет.) Бу эслатмада Бобурнинг Султон Ахмад Мирзоникига келгани ва шохнинг унга хурмати ифодаланган.

Султон Махмудхон ва Султон Ахмад Мирзонинг кўшин тортишига, кутилмаганда Умаршайх Мирзонинг ўлими хар икки темурийзодада Андижонни эгаллашга умид ўйғотган эди. Чунки бу пайтда отасининг ўрнига кўтарилган Бобурни улар хали бола деб тушунарди. Отасининг ўлими Бобурга катта изтироб солади ва навкарларини йиғиб, Сирдарёнинг шимоли ва жанубидан хужум бошлаган тоғаларига қарши йўл олади. Бобур бу воқеани шундай тасвирлайди:

«Умаршайх Мирзога бу воқеа даст берганда мен Андижонда чақарбоғда эдим. Сешанба куни рамазон ойининг бешида бу хабар Андижонга келди. Изтироб била отланиб, қошимдаги навкар ва савдор била қўрғон азимати қилдим, Мирзо дарвозасиға етган махалда Ишрим тағойи жиловимни олиб, намозгох сари тебради. Хаёлиға бу келибтурким, Султон Ахмад Мирза улуғ подшохдур, қалин черик била келса, беклар мени ва вилоятни топшурғуларидур. Мени Ўзганд ва Олатоғ доманаси сари олиб борғай. Агар вилоятни берсалар мен бори иликка тушмай тағойиларим Олачахонга ё Султон Махмудхонға борғаймен» (17-бет).

Ёш шахзоданинг юрт душманига қарши отланиши унинг яқинларида шубха ўйғотади. Жумладан, Ишрин тағойи Султон Ахмад Мирзодек улуғ подшохга бахс келиш қийинчилигини уқтиради. Беклар вилоятни хамда Бобурнинг ўзини хам Олачахон - Султон Ахмад Мирзо ва Махмудхонга топшириб юборади деб айтишади. Лекин Бобур ахдидан қайтмайди. Ундаги шижоатни кўриб беклар хам кўллаб-қувватлайди. Ўзи эътироф этганидек, «барча якдил ва якжихат жид ва эхтимол била қальадорлиққа машғул бўлдилар» (18-бет). Бобур бу ўринда Хасан Яъқуб ва Қосим қавчин каби бекларнинг фаоллигини алохида таъкидлайди.

Бобур биринчи зарбани Султон Ахмад мирзога қаратади. Бу пайтда у Ўратепа, Хўжанд, Марғилонни босиб олган ва Қубо (Қува)га хам кириб келган эди. Бобурнинг жанговор хужумига андижонлик арбобларнинг ўзларидан хам «номуносиб сўз айтқон»лар хам топилди. Шулардан бири Дарвеш Гов отли киши эди. У жазолангач Бобурнинг бу сиёсатидан эл босилиб, хукмдорга ишонч билдира бошлади. Султон Ахмад Мирзо камсухан, фақир ва оддий киши эди. Шу сабабдан бўлса керак, у ўз ихтиёрини бериб кўйган эди. Умаршайх Мирзо тасодифий халокатга учраганидек, Султон Ахмад Мирзо қўшинининг хам омади чопмайди. Қуванинг ботқоқликда катта суви оқарди. Катта черик билан тошқинга учраб, кўп от ва туяси билан сувга йиқилиб нобуд бўлади, от ўлати тарқалади. Бунинг устига Бобурнинг сипох ва навкарлари уларни якжихат ўраб турдиларки, «жон тортмоқдин қўймағайлар». Вахимага тушган Султон Ахмад Мирзо сулх тузишга мажбур бўлди. У Самарқандга қайтар экан, Ўратепа навохисида Оқсувга етганда иситмаси чиқиб, оламдан ўтади.

Султон Махмудхоннинг хам жангда омади келмайди. Ахсини озроқ вақт қамал қилсада, кўлга киритолмайди ва Тошкентга қайтиб кетади. Аммо Кошғар ва Хўжан хокими Абобакр дуғлат Кошғарий хеч кимга билдирмай Ўзганд ёнига келиб, урушиш тараддудини кўради. Бобурнинг жами беклари уни даф этишга киришадилар, Кошғарий тавба билан жон сақлайди. Андижон вилояти босқинчилардан тозалангач, Умаршайх Мирзонинг аза расми хурмат билан бажарилди.

Султон Ахмад Мирзо вафот этгач, Самарқанд хокимлигини укаси Султон Махмуд эгаллади. У хам тез орада вафот этди. Хокимликни Султон Махмуд Мирзонинг ўғли Султон Али эгаллади. Акалари Султон Масъуд ва Бойсунғур Мирзолар эса укаси билан хокимият учун кураш бошлаган эди. Бу пайтда Бобур хам Самарқандга хукмдорлик қилишга тайёргарлик қила бошлайди. Лекин Андижонда айрим фитначилар пайдо бўлиб, ундан хокимиятни олиш режасини тузадилар. Бобур Султон Ахмад мирзо хамда Султон Махмудхон босқини пайтида Умаршайх мирзо бекларидан бири Хасан Яьқубни 
фидоийлардан бири, курашишга якжихат бўлганлардан деб хисоблайди. Уруш ғалаба билан тугагандан сўнг эса у Бобурнинг укаси Жахонгир Мирзони шох қилиб кўтариш фикри билан чиқади. Хасан Яъқуб ўз харакати билан Бобурни атрофида фитначи, икки юзли беклар борлигидан огох этади. У Бобурнинг Самарқандга юришига хам хамрохлик қилади, лекин Конибодомгача келиб, яна кўнглида мулкгирлик андишаси туғилиб, Ахсини эгаллаш ниятида орқага қайтади. Қўқонга қайтганида хабар топилиб, у навкарлари билан бирга йўқотилади. Ўзини содиқ санаган бекларнинг Бобурга нисбатан фисқу фужури уни сергакликка чақиради. Бобур ўзида пайдо бўлган сергаклик ва эхтиёткорликни шундай ифодалайди: «Ушбу йил шубхалик таомдан пархиз қила бошладим. Пичоқ ва қошиқ ва дастурхонгача эхтиёт қилур эдим. Тахажжуд хам камроқ тарк бўлур эди» (26-бет).

Бобурнинг хукмдор сифатидаги фаолияти шаклланишида Андижон уруши дастлабки босқич бўлди. Тўғри, урушда Бобур ғалаба қозонди. Лекин хали бу унинг жанговарлик махорати пишиб етишганлигини кўрсатмас эди. Хокимиятни идора этишда, асосан, Шайх Мазидбек, Бобоқули Бобоалибек, Қосим Қавчин каби беклар жипслик билан ёрдамлашишди. Иккинчидан тоғаси Султон Махмудхон ва амакиси Султон Ахмад мирзо урушиш нияти билан келса-да уларнинг ўзида харбий жанговорлик етарли эмас эди. Хатто, Султон Ахмад Мирзонинг навкарлари хаётий тажрибага хам эга бўлмаганликлари оқибатида урушдангина эмас, балки табиий офатдан катта зарар кўрдилар. Бобурни ёш бола деб тушунган, мамлакатдаги вазиятдан фодаланишга уринган Кошғар ва Хўжан хокими хам бекларнинг махкам оёққа туриши билан зарба олди.

Андижон босқинчилари йўқотилгач, Бобур ота мерос мамлакатни бошқариш, уни ободонлаштириш билан чекланса бўларди. Лекин Бобур амакилари хукмдорлик қилаётган Самарқанд сари йўл олади ва шахарни қамал қилади. Бу пайтда шахар хокими бўлган Султон Али ўртадаги қариндошлик ва дўстликни қўйиб, Бобурдан иттифоқчиликни сўрайди. Бобур унинг илтимосини эътиборга олади, лекин тез орада Самарқанд Султон Алининг акаси Бойсунғур Мирзо қўлига ўтади. 1497 йилда, яъни 14 ёшида Бобур мингга яқин кишиси билан Самарқандга отланади. Бобурнинг Андижондан қўшин тортиб, Самарқандга қайта келишининг боиси нимада эди? Унда амакиси Султон Ахмад мирзо ўлиб кетган бўлса-да, ундан ўч олиш, мамлакатни эгаллаш важохати бор эди.

Бунинг туб асоси Самарқанд Амир Темурнинг пойтахти бўлганлигидир. Шу сабабли Бобур хам, бошқа темурийзода хукмдорлар хам шахарни эгаллашни орзу қилишар эди.

\section{Фойдаланилган адабиётлар рўйхати}

1. Захириддии Мухаммад Бобур. Бобурнома,- Тошкент: «Юлдузча», 1989. 12-бет.

2. Абдуллаев В.А. Ўзбек адабиёти тарихи. Иккинчи китоб. Тошкент: Ўқитувчи, 1980. - 345 бет.

3. Абдуғафуров А. Буюк бешлик сабоқлари. Мақолалар. -Тошкент: Адабиёт ва санъат нашрёти, 1995. - 184 бет.

4. Валихўжаев Б. XV-XIX аср ўзбек адабий-танқидий қарашари тарихидаи. «Ўзбек шеърияти ва адабиётшунослиги тарихидан». СамДУ асарлари, янги серия, 138-нашр. Самарқанд, 103-117 бетлар.

5. Валихўжаев Б. Ўзбек эпик поэзияси тарихидан. -Тошкент: Фан, 1974 йил. - 151 бет.

6. Вохидов Р. Биз билган ва билмаган Бобур. Адабий уйлар. Тошкент: «Маънавият», 1999. 18-21 бетлар.

7. Захириддин Мухаммед Бабур. Бабур-наме. Пер. М. Салье.Изд.-2-е. Тошкент: тр.Фан, 1993.463 с

8. Маллаев Н. Ўзбек адабиёти тарихи. Биринчи китоб. Тошкент: Ўқитувчи, 1976 й, 602-603 бетлар. 


\section{NATIONAL PSYCHOLOGICAL CHARACTERISTICS REFLECTED IN CONTEMPORARY RUSSIAN VOCABULARY}

Fu Yu, doctoral postgraduate (School of Russian and Eurasian Studies, Shanghai international Studies University)

Annotation: This paper discusses the national psychological characteristics reflected in the new usage of contemporary Russian vocabulary (Including language innovations in color words, non-standard words, loanwords, newly created words) by giving priority to the general characteristics of Russian vocabulary and the general social psychology of the Russian nation (Including religious, contradictory, extreme, optimistic mentality).

Key words and expressions: Russian; vocabulary; national culture; national psychology; social psychology

\section{Introduction}

The term "contemporary" implies the presentness of language, which is the current and current trend of language and wording. Its basic feature is "new". The public's choice and preference for language expressions within a certain period and in a certain social environment Have specific public habits and tastes. (Ожегов С.И. 2013: 298) This perspective has led us to think: Does the collective vocabulary representation of contemporary Russians reflect their unique national psychological characteristics? Let's discuss it in detail below.

\section{General characteristics of Russian vocabulary}

Before discussing the national psychological characteristics reflected in contemporary Russian vocabulary, we need to briefly describe the overall characteristics of Russian vocabulary.

Combining the words of multiple linguists, we combined Chinese to understand Russian more intuitively, and obtained the following essential differences between Chinese and Russian:

\begin{tabular}{|l|l|l|}
\hline Language Pedigree & Chinese & Russian \\
\hline Types & Sino-Tibetan Language & Indo-EuropeanLanguage \\
\hline Part-of-speech form & analytical and isolated & comprehensive and inflected \\
\hline Morphological changes & no sign & with sign \\
\hline Grammatical means & $\begin{array}{l}\text { mainly word order and } \\
\text { function words }\end{array}$ & mainly morphological changes \\
\hline Part-of-speech determination & based on syntactic functions & based on shape \\
\hline Numberof words & More & less \\
\hline Syntactic connection & meaningful connection & formal connection \\
\hline Ambiguity expression & relatively more & relatively less \\
\hline
\end{tabular}

(1)From the perspective of language lineage, Russian belongs to the Indo-European language family (индоевропейская семья языков), Slavic language group (славянская ветвь), and East Slavic branch (восточнославянская группа).

(2) From the perspective of morphological characteristics, Russian belongs to inflectional language, and there are rich morphological changes: nouns, adjectives, numerals, and pronouns all contain changes in sex, number, and case; verbs have changes in aspects, tenses, form, personality, etc. Therefore, the grammatical form of words is the main means of syntactic connection between content words. In addition to mastering a certain Russian vocabulary, we also have to master many other complex word forms derived from it according to the rules of word formation. It can be said that Russian is a "formal language", and sometimes the form is even greater than the content. In the following, we will give an example of the problem of Russian part-of-speech form and part-ofspeech determination. 
First let 's take a look at the famous example that Л. В. Щерба gave in the 1930s when explaining the course "Basic Linguistics":

Гло́кая ку́здра ште́ко будлану́ла бо́кра и курди́чит бокрёнка. This is a Russian sentence created by the academician. The root of each word is composed of meaningless letters. However, people whose native language is Russian, or foreigners with a certain Russian foundation, can roughly understand the meaning of this sentence: an animal with certain characteristics and grammatically female, in some way acts on another an animal that is grammatically male, and then begins (and continues until the moment of speaking) to perform some kind of behavior on its pups (or smaller animals of its kind).

Coincidentally, in 2015 (2015-11-4) "Language Lunch" WeChat public account launched such a puzzled sentence:

The yinkish dripner blorked quastofically into the nindin with the pidibs. Similar to the sentence of Academician Л. В. Щерба, the editor tried to explain that English is also a formally marked language. Although you cannot interpret the specific meaning of this sentence, you can judge the part-of-speech attributes of these words that you have not seen before or even do not exist at all. They are: "yinkish" is an adjective, "dripner" is a noun, "blorked" is a verb, "quastofically" is an adverb, and "nindin" is a noun.

Everyone knows that nindin and pidibs are nouns, —-why? Because everyone knows that nouns appear after the article the without adjectives and adverbs; into and with are both prepositions. A large number of English sentence analyses tell us that after the article plus the preposition, except for adjectives and adverbs There is a noun. The word quastofically obviously has a derived affix -ly, and -ly generally marks adverbs, so it is easy to see that this word is an adverb. The word blorked has the inflected affix -ed, and -ed can only be used for verbs, so we know that the syntactic category of the word is a verb.

(3) From a phonetic point of view, the pronunciation part of Russian is backward, and we often say that Russian is "hard". Among them, vibrato / Р /, / Ы /, / Ч /, / Ц /, / Щ /, etc. are not available in Chinese and need special training. Many learners from the south, because of local accents, are unable to produce certain sounds or sound groups. However, compared to English, the word form of Russian vocabulary is relatively easy to remember, because as long as you learn the pronunciation of a word, you can basically spell the word, so the special Russian speech system has an impact on the vocabulary recognition and extraction of foreign language learners.

(4) From a semantic perspective, there are many polysemy in Russian vocabulary. For example, the word $u m \partial u$ gives 26 meanings in the 17-volume "Paper Dictionary of Modern Russian Standard Language" (БАС), and "Detailed Russian Paper" edited by Ushakov (Д.Н.Ушаков) Аs many as 40 meaning items are listed in the Quality Dictionary. Complex lexical, syntactic relations, and vocabulary polysemy are important reasons why we cannot accurately understand the meaning of sentences. In addition, there are many loanwords in Russian. We can learn Russian vocabulary by mastering equivalent words in foreign languages such as English.

\section{Russian national psychological characteristics}

National psychology refers to the deep psychological characteristics peculiar to a certain nation formed in a relatively long historical period. Compared with ideology, religion, social politics and other characteristics, the psychological characteristics of a certain ethnic group usually have greater stability, generally not changing for hundreds of years or even a thousand years. Even if some changes have taken place in the national psychological characteristics during the long historical development process, the most fundamental part of it will not change, which allows us to identify the national Cultural characteristics. (赵旭黎 2009: 34-40) For example, during the period of Ross' baptism, during the reign of Mongolian Tatar, during the era of Ivan the Great and Peter the Great, during the age of Pushkin, in the "silver age", even in the Soviet era and Russia Contemporary, you can feel the uniqueness of Russian culture. Therefore, national psychology is a system intertwined by various characteristics, which is determined by relative natural geographical conditions, geopolitical conditions and social living conditions. It includes ways of thinking, ways 
of feeling, norms of behavior, values, common spiritual tendencies, thoughts, and spiritual habits. 朱达秋 2002:52-55)

A deep feature of Russian national psychology is religiousness. The well-known Russian religious philosopher Ny Berdyayev pointed out in his masterpiece "Russian Thought": "Russia's mission is to become a true embodiment and defender of Christianity and Orthodox Church."This psychological feature will undoubtedly be reflected in the national culture and language use. For example, the proverb «Не всё коту масленица, бывает и великий пост. » (A cat can't always celebrate the Festival of maslenitsa ${ }^{100}$, and there will be a Big fast) is a metaphor for good times are not long; «Чего бог не даст, того никто не возьмёт.» (God does not give it, no one can take it) expresses the pious faith of the Russian nation in Christianity.

Contradiction is also an important feature that cannot be ignored at the level of Russian national psychology and language structure, which may stem from Russia 's continuous integration of the historical trends of the East and West. Russia is a huge unity of East and West. In the soul and character of the Russian nation, there are always Eastern and Western forces competing. The contradiction manifests at the language level: «Ангел помогает, а бес подстрекает. » (Angel helper, devil seducer); «Счастье с несчастьем на одних санях ездят. » (Наppiness and unhappiness ride on a sled); «Нет розы без шипов.» (No roses without thorns).At the same time, this conflicting form of language structure also demonstrates the "salience principle" of language cognition proposed in Gestalt psychology. At this time, I have to mention the order iconicity of language output and cognitive things. At the psychological level, people tend to prioritize those with strong objective characteristics, high prominence, and positive elements, that is, the order is first; However, the elements with weak objective characteristics, low prominence, negative, and negative are placed in the second position, that is, the order is second. It can be seen that, whether at the language level or at the psychological level, people generally express the cognitively significant components or the components that attract attention first. For example, «ни много, ни мало» (по more, no less), in public perception, много is more prominent than мало, so naturally put много in the priority language output position; In «Здоров на еду, а хил на работу. », здоров is a positive vocabulary, reflecting the positive attitude of human evaluation, generally placed in the forefront, хил is a negative vocabulary that should be avoided as much as possible and is generally placed behind.

Extremeness is another prominent feature of Russian national culture and psychological characteristics. The Russian nation is influenced by Aristotle 's formal logic and European rationalism, advocating nature as the cognitive object, clear distinction between god and mortal, clear subject and object, focusing on rational thinking, logical thinking and reasoning, and stressing objectivity.Therefore, their expression is more direct, frank, and even too extreme. The extremeness is clearly reflected in the speech acts of the Russians. As the proverbs «Либо грудь в крестах, либо голова в кустах.»(Either there are medals on your chest or your head is in the bushes); «Или цезарь, или ничего.»(Either Caesar or nothing); «Вё просто. Либо ты имеешь своё мнение. Либо чужое мнение имеет тебя.»(Everything is simple, either you have your opinion, or you are included in the opinions of others.); «Чаще всего мне запоминаются события, похожие либо на очень Страшный Сон, либо на очень Блаженный.(Usually I will remember events similar to a very terrible dream or a very happy dream.)

The general social psychology of the "optimistic principle" in the use of language by the Russian nation is mainly manifested in the fact that their use of testimonials is much greater than the use of derogatory terms, that is, to expand testimonials and reduce depreciation. And tend to use most of the neutral words as a commendatory offset, and a small part of the neutral words as a derogatory offset. Psycholinguists Boucher and Osgood (1969) proved through psychological experiments: People always value and pursue the good side, and discard the bad side. This psychological law is called the "optimistic hypothesis". People's expressions of "expanding

\footnotetext{
${ }^{100}$ The Festival of maslenitsa is a winter festival handed down by Mrs. Gusla since the polytheistic era. The Christian church accepted it and celebrated it in the last week before the Big fast.
} 
compliments and reducing derogatory meanings" are usually to maximize the positive effects of compliment words and reduce the negative effects of derogatory words. In Russian, we often use нехорошо (bad) to express the meaning of плохо (bad, poor), and некрасивый (not beautiful) instead of уродливыли (ugly). This way we can communicate our negative emotions and negative evaluations more gently; When we want to express хорошо (good), we will habitually sау очень хорошо (very good), молодец (good job), отлично (great) to deepen the degree of compliment, exaggerate positive meaning and positive evaluation. At the same time, it also follows the "politeness principle" of language communication, and promotes social communication to proceed happily and smoothly. The expression of "neutral words shift to commendation" reflects the social and psychological characteristics of people's optimism and continuous pursuit of development and optimism. In Russian, воздух (air) is a neutral word, but it often means "fresh air" in sentences such as «Пойди с ребёнком на воздух.» (Take the child out to take a breath). There are some similar examples: coбыmие (event) indicates "significant event", качество (quality) indicates "high quality", дело (things) indicates "serious things, right things", мужчина (man) indicates "real man, true man", etc. Of course, in certain contexts, neutral words also have derogatory deviations, such as «горло» ("throat") in $У$ неё горло. (She has a sore throat) means «больное горло» ("sick throat"); «сердце» ("heart") in the sentence У мамы сердие. (Mom has heart disease) means «больное сердце» ("heart disease"). Because positive words are used more frequently, neutral words have more positive meanings and less negative meanings. (张瑶 2014:37-42)

\section{National psychological characteristics reflected in the new usage of contemporary Russian vocabulary}

(1) Color words

Color words not only reflect the attributes of objective things, but color words in a language also reflect a nation's knowledge and understanding of the objective world. The unity of social culture and psychology reflected by the color words of various nationalities. For example,чёрный (black) has the symbolic meanings of darkness, despair, viciousness, mourning in almost all languages of the world, and has a fixed connection with negative, gloomy feelings and associations, such as чёрный рекция (the reactionaries), чёрная работа (rough work); and бельій (white) symbolizes purity, sacred, noble and bright, for example, Russia used to call the nobility-- «белая кость»; legal business --«белый бизнес»; noble work -- «белая работа», in addition, бельй can also mean" irrational, unscheduled ", such as бельй танец (lady invites men to dance), бельле стихи (unrhymed poems), Белая ворона (innovative and unconventional person). (吕莉 2008: 173-175)

The Russian national psychology reflected in красньй (red) is its admiration and love for it. They use «красна девица» (red girl) to refer to "beautiful girl". Red means beauty, masculinity and good luck, which is very similar to China. Different from China, Russian culture does not consider жёлтый(yellow) as a symbol of bright, lively, pleasant and warm, but it has the same negative meanings as black and gray (серый), representing betrayal, jealousy, crazy, parting and sad, so Russian lovers are forbidden to send yellow flowers. Psychiatric hospitals often use the expression «жёлтый дом» (yellow house). With the continuous convergence and integration with Western culture, "yellow" has the meaning of "obscene, pornographic" which is transferred from English in Chinese and Russian cultures, and using жёлтая печать, жёлтая пресса to refer to pornographic publications.

The symbolic meaning of color words is generally established in the process of social development and is a relatively stable cultural phenomenon. However, with the development of the times, the Russian nation 's perception and understanding of color are constantly changing. The psychological associations caused by color words are also gradually changing, in addition to the original meanings, new meanings are derived. For example, розовый (pink) is a very pleasing color, and it is a tender color in people's hearts, representing femininity, beauty, softness and care. Soft colors can eliminate contradictions and conflicts. Pink is designed to soothe people and build a friendly and positive atmosphere. The first rays of dawn lightened the sky with a pink hue, which 
inspired our hope. Seeing this color, many people's aggressive mood and irritability were reduced. Therefore, the Russians use «розовый день» (a pink day) to symbolize a sunny and beautiful day;зелёный (green) has the symbolic meaning of rebirth and prosperity in almost all cultures in the world, which is closely related to the concept of the awakening of natural spring inherent in the subconscious. Since then, the Russian nation has frequently used green in various religious ceremonies and festivals. Green is also related to growth and development. This is the color of life energy and can "nourish" psychology and emotion. The Russian nation tends to use «зелёный парень» (green youth), «зелёный пацан» (green kid), «зелёный человек» (green man) to describe young, naive, inexperienced youth, which can be converted to"Negligent young people, novices" etc. «Зелёный улица» (green street) has two expressions. One is that in the Tsarist era, guilty soldiers passed through two ranks holding sticks and weapons. During the period, they continued to withstand continuous attacks from the ranks. The streets where they are located are called "green streets".Now another meaning of the word is free passage, which means that there is no stopping on the allowed road, meaning "unobstructed street". A similar phrase is «зелёный канал» (green passage).

(2) Non-standard words

Non-standard language (slang, argot, etc.) with anti-normative nature can often reach the expressive power that standard language can't match, and can satisfy people's deep desire for expression. At the same time, it can add freedom, entertainment and novelty to verbal communication. The "vulgar" image of slang and its smaller communication range make it a new language carrier for people. For example, беспредел (Новиков В.И. 2016: 16) means chaos, riot, disorder, and illegal behavior, which originated from the dark language and replaced беспорядок,

беззаконие, etc. (陈欢 2017: 45-50)

(3) Loanwords

Compared with the inherent words in their own language, the novelty brought by foreign words with "exotic style" can always satisfy people's psychological needs for innovation. In addition, Russians 'cult of Western culture has prompted them to always treat loanwords (especially English loanwords) as an advanced form of speech expression. Therefore, in many speech occasions, the speaker replaces the corresponding Russiantraditionalwords with foreign words. To some extent, it not only highlights the self, but also follows the trend. For example: волатильность (Новиков В.И. 2016: 42) means fluctuation, instability, and volatility. It is derived from the English "volatility", replacing изменчивость and other words; фейк (Новиков В.И. 2016: 286) means forgery, impersonation, falsification, and illusion. It is derived from English "fake", replacing подделка, притворство, фальшивка, etc.

(4) Newly created words

People's expression of language is often not satisfied with the old model, and they always pursue the "defamiliarization" of language use. The familiar everyday language has an unconscious automation effect due to a large number of repetitive uses, that is, people are numb to the image and perception evoked by the language. At this time, the image can only play a role of identification, and cannot cause further thinking. In order to eliminate this state of automation and update people's old feelings about the objective world, people tend to replace traditional words with new words, in order to reawaken people's perception of the image of the object, and encourage people to make new discoveries even in the face of oblivious things. "Newly created words" are generally derived from the individual's conscious speech creation activities in specific contexts, which can not only increase the expressive power of the language, but also satisfy the individual's desire to express. For example, the word няшка (Новиков В.И. 2016: 171) was used early among Japanese anime lovers. It was transliterated from the onomatopoeia of the meow in Japanese to «Ня» in Russian, and «Ня» is combined with the Russian suffix -шка to form няшка, which represents the heroine in the anime with a cute and sweet appearance and a soft voice like a cat. The word is now widely used in Russian to refer to "cute people or things", such as «Она такая няшка!» (She is so cute!).

Кронгауз М.A. pointed out in the analysis of няшка that the sound of $н я$ is easy to elicit tender emotions and pleasant moods in people's hearts, and the whole word after the Russian suffix 
is given the "Russian appearance" (Кронгауз M.A. 2013: 310) This constitutes a series of new words ending in -няшка, such as вкусняшкатеans "gourmet", derived from вкусньй("delicious"), on the basis of which derived вкусняшый, also means "delicious";стройняшкатеans "slender woman", derived from стройный("proportionate, good-shaped"), on the basis of which derived стройняшный, also means "have a good figure"; модняшкаmeans "fashionable person", derived from модный ("fashionable and popular"), on this basis of which derived модняшный, also means "fashionable"; умняшкатеans "smart people", derived from умный("smart, reasonable"), on this basis of which derived умняиный, also means "smart". These words are widely used to express positive emotions and generally enter the public's vision of verbal communication.

\section{Conclusion}

Language is a cultural phenomenon. How a language conveys social information and how to act with words, it has its own unique language expression, and can also reflect the unique cultural and psychological characteristics of the nation.This article gives a brief overview of the overall characteristics of Russian vocabulary in terms of language family, morphological features, phonetics, and semantics, as well as the religious, contradictory, extreme, and optimistic mentality of the Russian national language use, and then discusses the national psychological characteristics reflected in the new usage of contemporary Russian vocabulary. Russians 'language innovations in color words, non-standard words, loanwords, and newly created words reflect their freedom and the pursuit and desire for novelty.New forms of language expression are often accompanied by entertainment, enlightenment, and people's desire to express emotions. After people's expression desires are satisfied and a sense of pleasure is obtained, they will continue to integrate with their unique national and social psychology to create new words product.

\section{The list of used literature}

1. Новиков В.И. Словарь модных слов[Z]. М., Словарь XXI века, 2016.

2. Кронгауз M.А. Самоучитель Олабанского[M]. M., АCT: CORPUS, 2013.

3. Ожегов С.И. Толковый словарь русского языка[Z]. М., Мир и Образование, 2013.

4. 陈欢.当代俄语言语时尚初探[J].中国俄语教学,2017,36(01):45-50.

5. 吕莉.谈俄语颜色词所体现的民族文化及心理特点 [J]. 沈阳航空工业学院学 报,2008,25(06):173-175.

6. 许高渝.俄汉词汇对比研究[M].杭州大学出版社, 1997, 811 .

7. 许余龙.对比语言学概论 $[\mathrm{M}]$. 上海外语教育出版社，1992，4.

8. 张瑶. 俄语反义词不对称性及其认知心理特征研究[D].东北师范大学,2014.

9. 赵旭黎.俄罗斯民族心理的几个特点及其在俄语浐语中的反映 $[\mathrm{J}]$. 中国图书评 论,2009(11):34-40.

10. 朱达秋.术语 менталитет 及其内涵[J].解放军外国语学院学报,2002(02):52-55.

\section{文化翻译观视角下的模糊词翻译研究 MADANIY TARJIMA NUQTAI NAZARIDAN TUSHUNARSIZ SO'ZLARNI TARJIMA QILISH BO'YICHA TADQIQOT}

\section{许畅, 博士在读研究生}

\section{上海外国语大学俄罗斯东欧中亚学院，上海市 (Xu Chang, Shanhai)}

Annotation: Since the 1980s, the research on fuzzy linguistics has achieved considerable theoretical results, which are very worthy of reference to translation studies. This article will clarify the feasibility of applying fuzzy theory to translation studies, with the intention of comparing the semantic fuzziness of Russian and Chinese languages, and studying the translation strategies of fuzzy words from the perspective of cultural translation. 
Key words and expressions: Fuzziness, Fuzzy Linguistics, Fuzzy Words, Cultural Translation, Russian-Chinese Language Comparison

一、 引言

“模糊性就是人们认识中关于事物类属边界或性质状态方面的不明晰性、亦此亦彼性、 非此非彼性，也就是中间过渡性。”（黎千驹，2017：19）翻译行为本身实际上也是一种模 糊行为，这一点可以通过历史上一直争论的，即关于原文和译文是否可以实现完全等值问题 的讨论来证明。我们认为, 译文只能是不断逼近于原文, 二者不处于非此即彼的关系, 也就 是说译文和原文的关系并不是要么等值要么不等值, 因为所谓的等值, 实际上更像是一种处 于不断逼近、但不可以到达之间的这么一个区域，翻译活动其实也就是译者对原文内容的一 种综合、模糊的判断的过程。模糊理论可以帮助我们更好的认识翻译这一现象, 更加注重对 翻译行为深层描述和阐释，毕竟：“传统的努力主要是制定“原则”或“标准”，而翻译理论应 该是对翻译现象的一种解释，是对所观察的某些事物的系统和顺序的概念化。”（罗杰.贝 尔，2001）因此，从模糊语言学层面出发来考察翻译活动具有重要意义，值得研究。

\section{二、模糊语言学与模糊词}

模糊语言学作为语言学的分支在中国虽起步较晚, 但发展迅速。查德首次提出的模糊 理论就是从语言范畴入手来观察模糊现象的。语言的模糊性, 指的就是概念外延边界的不确 定性, 或者说是不明晰性。而词语是概念表达的主要形式, 概念是词语的主要内容, 概念的 存在必须通过词语来实现, 如果一个词语不拥有表达概念的能力, 那么它就仅仅只是一些没 有任何意义的符号或者声音。因此, 狭义的模糊语言主要指的是模糊词, 也就是那些能够表 达模糊概念的词语。“自然语言中的词绝大多数都是模糊的。”（文旭，1996，2）因此模糊 语言学领域的语言研究者们一直特别重视对模糊词及其语义的研究, 并对模糊词的分类方式 都发表了自己的观点, 在这里我们就不一一赘述。本文我们主要借助黎千驹教授的观点, 从 语义角度出发将模糊词划分为以下几种类型:

表时间范畴的模糊词（如“上午”、“вечер”等）

表方位范畴的模糊词（如“南”、“наверxy”等）

表称谓范畴的模糊词（如“作家”、“девушка”等）

表事物范畴的模糊词（如“矮子”、“красавица”等）

表动作范畴的模糊词（如“走”、“улыбаться”等）

表心理活动的模糊词 ( 如“爱”、“3нать”等)

表性质状态的模糊词（如“真”、“красота”等）

表颜色范畴的模糊词（如“红”、“белый”等）

表数量范畴的模糊词（如“多”、“мало”等）

表指代范畴的模糊词（如“我们”、“кто”等）

表程度范畴的模糊词（如“很”、“чуть”等）

\section{三、文化翻译观}

翻译不仅是一种语际交际行为，更是一种跨文化交际行为，正如什维策尔所言：“翻译 不单是语言间的相互作用，而且还是文化间的相互作用......翻译不仅是语言现象（或者更确 切地说, 是言语现象), 它还是一个文化现象。实际上, 翻译的过程既“跨越”了语言的界 
限, 又跨越’了文化的界限。在此过程中创造出来的文本不仅被移入另一语言系统, 还被移 入另一文化系统。”[Швейцер1998: 8，14] 翻译过程所获得的译文也不仅是一种言语产品, 更 是一种文化产品, 因此在翻译过程中需要在深入了解原文及本民族语言文化背景的基础之上 来制定相应的翻译策略, 而不仅仅停留在单纯的语言转换层面之上。这就要求译者“必须是 一个真正意义的文化人。译者一方面要深入了解外国文化, 另一方面, 他还得深入了解自己 民族的文化。不仅如此, 他还要不断地把两种文化加以比较, 因为真正对等应该是在各自文 化里的含义、作用、范围、情感色彩、影响等等都相当。”[王佐良, 1989: 18-19]这是因 为: “译者作为跨文化传通的使者, 其任务是促进民族间的文化交流。他应当使不同民族认 识到他们的共同点, 成人彼此间的相异之处并互相理解。[杨仕章, 2003：99]”。总之, 译者 必需充分意识到两种文化语境的重合和相离之处, 并在此基础上, 选择恰当的翻译策略, 促 进文化语境的调节, 从而更好的实现翻译这一跨文化交际行为。

\section{四、文化翻译观视角下的模糊词翻译策略}

翻译不仅是一种语言转换, 翻译时不仅要追求语言层面上的等值, 更要追求文化层面 上的等值。由于原文读者和译文读者处于不同的文化语境之中, 所以他们所拥有的超语言信 息也不相同, 而译者的任务就是为译文读者构建一个可以帮助他们尽量完全理解原文所要表 达内涵的文化背景。语言是文化的反映, 模糊词作为每种语言中的客观存在, 必定会携带有 自身的文化属性。模糊词所表达的概念的模糊区间具有民族文化差异。比如, 俄语中的一词 的词典解释是“часть суток междувечером и утром (примерноотполночидо 4 часов) (晚上到 第二天白天中间的一段时间，大概从半夜到四点）”而汉语中“”一词表示“从零时起到天亮前 的一段时间”, 首先, ночь 和凌晨这两个词的词义是模糊的。其次, 这两个模糊词的语义区 间也不完全吻合，两个词所包含的义位不管在“数量”还是“质量”上都会有所差别。这也就构 成有时原文读者和译文读者产生不同语义联想的原因。语义联想指得是那些在言语交际过程 中临时产生的一种意义, 言语中的联想义是人们在运用语言时而临时产生的一种意义。俄语 读者在看到这个词时联想到的景象同汉语读者所联想到的并不会一直保持一致。对同一个词 语所产生的联想，会由于民族文化习俗和民族文化心理不同而导致不同民族对同一个词产生 不同的联想义。在翻译时我们需要找出原语和译语在语义模糊性方面上的相同之处和相异之 处。而联想义都具有模糊性。

下面我们将以具体实例对比俄汉语中几种不同类型的语义模糊词, 讨论模糊词背后所 展现的民族文化语境差异之处, 在此基础上, 从文化翻译观的角度出发总结可能的翻译策略 和方法。

1. 表时间范畴的模糊词

原文 : Праздновали рождество три дня: в течение этого времени двория разделялась на три смены, из которых каждой предоставлялось гулять на семе по одному дню. (СалтыковЩедрин М.Е. Пошехонская старина)

译文: 圣诞节一共庆祝三天。在这段时间里, 家奴们被分为三批, 每一批可以到村子 里去玩一天。（谢德林《波谢洪泥耶遗风》斯庸 译）

圣诞节一词在第一时间会使译文读者联想到在每年的 12 月 25 日，西方国家基督教天 主教派的节日，然而俄罗斯信仰的是基督教中的东正教，东正教圣诞节在是 1 月 7 日举行。 因此, 在一文中可以选择直译加注释或者加词法 (东正教圣诞节) 的方式来解释东正教的圣 诞节, 以免影响读者对全文的正确理解和接受。

2. 表事物范畴的模糊词

原文: Мне казалось, что горячее её тело пахнет воском и ладаном и что она скоро умрет. (М. Горький, В людях) 
译文：我感觉从她那热乎乎的身上发出一种白蜡和神香的气息。我想, 这个女人快死 了。

译文读者如果仅从字面理解原文的话，有可能会搞不懂“白蜡”“神香”同“死亡”之间存在 着什么样的必然联系。“白蜡”、“神香”这两个词如果在译文中使用注释法, 表明“在为私人 做安魂祭奠的时候会点上白蜡和神香是东正教的习俗。”就会降低译文读者对于译文的理解 难度, 加入新的成分, 确定新的联系, 从而使译者能够对译文的内容与意义做出正确的理 解，为同“死亡”几个词之间搭建起一座桥梁，从而能够更准确地把握原文的涵义。

3. 表动作范畴的模糊词

原文: Всякий делает что хочет до обеда. Обед в семь часов. (Л.Толстой, Анна Каренина)

译文：正餐以前个人想干什么千什么。正餐七点钟开。

从模糊语言学角度来看, 汉语的“午饭”同俄语的“обед”的语义模糊区间是不完全吻合 的, 两者之间存在民族文化差异。在俄罗斯, 午饭时间一般是在傍晚五点至六点, 是一天当 中最丰盛的一餐。正因此就完全可以理解原文“中午饭在七点的情况”。如果直译, 就会是译 文读者产生疑惑。因此, 为了避免这种误解的产生, 这里可以选择规避掉在汉语和俄语中午 饭、晚饭时间点不相对应的表达方法，选取其他可以替代的概念，比如“正餐”。

\section{五、结语}

模糊性是语言的自然属性。因此模糊性表达在语言中的大量存在就会致使译者在实际 翻译过程中有时很难对原文文本中的内容做出精确的“质”和“量”的判断，对于处于同一种文 化中的原文作者和原文读者来说, 模糊语言是不需要对其做精确化处理的, 这是因为携带相 同文化属性的人会形成大致相同的模糊概，具有大致相同的模糊概念鉴别、模糊判断和推理 的方式。而原文作者和译文读者则处于两种文化之中, 这会导致原语和译语中模糊语言单位 的模糊区间有时会出现不完全重合的状况。而对于译者来说, 最终要的任务就是要识别相同 相异之处, 并能够通过恰当的翻译方法调节文化语境, 克服文化差异给两种语言带来的不理 解, 尽可能实现原文和译文的等值。

\section{参考文献.}

1. Швейцер, 1998: 8, 14 Швейцер А.Д. Теория перевода: Статус, проблемы, аспекты 【М】. М::Наука, 1988

2. 罗杰.贝尔, 《翻译理论与实践》外语教学与研究出版社, 2001

3. 黎千驹. 模糊语义学导论【M】. 北京: 社会科学文献出版社, 2017

4. 王佐良. 翻译: 思考与试笔【M】. 北京: 外语教学与研究出版社, 1989: 18-19

5. 文旭. 语义模糊与翻译【J】.中国翻译，1996，(2):5-8.

6. 杨仕章. 文化翻译论略【M】. 北京: 军事宜文出版社, 2003: 99 


\title{
MIGRATION: TEXT CONTACT IN THE TARGET LANGUAGE AN ETHNOGRAPHIC RESEARCH OF ADULT GERMAN L2 LEARNERS
}

\section{Anton Umbach MA (Herder Universität Leipzig, Germany,SamSIFL)}

\begin{abstract}
Annotation: This article is about text contaxt in the target language. The article illustrates theoretical frame and methods with some examples.

Key words and expressions: Second Language Acquisition, Text Linguistics, Ethnography, Adult Education, Migration, The Role of National Culture In Formation Human Values

\section{Theme}

Today societies in contemporary Europe are characterized by ethical diversity and multilingualism. In Germany multilingualism is becoming more and more present in social reality.(Ehlich, 2007a, S. 5). At the same time the increasing complexity of modern society demands a high level of literacy-skills of the individual.To take part in society successfully, reading and writing skills are considered as indispensable cultural techniques(Waggershauser, 2015, S. 9). Because of advancing digitalization and automation low qualified jobs are falling away. Therefore, the demands on the writing/reading proficiency are increasing. Consequently,a high level of reading and writing skill is an important supporting pillar of socio-economic stability of modern society.

Furthermore, due tothe low birth rate in Germany, persistent migration is gaining central importance for the demographic development of the country. For these reasons, Germany benefits of immigrants acquiring literal competences.
\end{abstract}

\section{Subject Area andGoal Setting}

To facilitate the access to German labor market for immigrants, the federal state of Germany is offering a funding program to adults learningGerman as a second language. This program contains language courses from the A1 to B1 Level of the GER with a strong focus to the labor domain.

In these courses teachers are frequently noticing, that the participants are bringing texts into class which they encounter outside the school context in their everyday lives. They are bringing several types of texts like rental agreements, employment contracts, invitations to parents' evenings from the children's school, letters from various authorities, handwritten notes from concerned neighbors, etc.. Because a lot of these texts remain misunderstood the teacher is pleased to give assessments if the presented text has any individual importance for the participant.

This situation shows, that learners have to serve several addressee roles in their everyday lives. They are aware of it but have problems handling it by themselves.

By engaging an inner perspective, this research should reveal the actual need of text type knowledge and strategies to open up an unknown text in a foreign language. This research wants to contribute creating didactic concepts orientating on the individual requirements of people immigrating to Germany.

Against this background this study pursues in which way participants of German funding programs get in touch with German texts outside the formal learning context in their everyday lives.

Therefore this research will answer two central questions

1) How are adult second language learners dealing with texts in the target language German?

2) With which types of texts and theirs functional and thematical dimensions do adultslearning German as a second language get in touch?

\section{Theoretical Frame and Method}

The need of the present research results from the current state of research of sociolinguistic, textlinguistic and reading research. None of these disciplines provided comprehensive knowledge about target language text contact in situations of migration outside the formal learning context.

To get to know more about the texts learners come in contact with, twelve participants of a B1 course of the funding program were partaking in a questionnaire formulated in their native language 
(Arabic and Russian). The questionnaire was followed by a personal interview. By the help of ainterpreter they had the opportunity to speak in their mother tongue and talk about the texts they got in touch with. Furthermore, they had to take photos of the texts they encountered. With all these information a text corpus out of 59 literal artefacts was constructed. In a second step the corpus was analyzed regarding text types and functional and thematical dimensions. (text functions: Fandrych\&Thurmayer, 2011, S.29f)

\section{Results}

The results of the study depict the reality of German-language text contact in context of migration. They allow insights in the everyday lives of learners, which are being shaped by contact with German text types. The study shows a picture of a postmodern, digital communicating Individual which finds itself in a not yet developed foreign text-based meaning system.

\begin{tabular}{|l|l|l|l|l|l|l|l|l|l|}
\hline medium & & Recipient role & & Place & & Function & & theme & \\
\hline printed & 44 & $\begin{array}{l}\text { social } \\
\text { communication }\end{array}$ & 39 & $\begin{array}{l}\text { public } \\
\text { space }\end{array}$ & 14 & $\begin{array}{l}\text { influencing } \\
\text { action }\end{array}$ & 40 & work & 12 \\
\hline digital & 14 & target audience & 18 & at home & 14 & $\begin{array}{l}\text { providing } \\
\text { knowledge }\end{array}$ & 11 & authorities & 9 \\
\hline $\begin{array}{l}\text { hand } \\
\text { written }\end{array}$ & 1 & $\begin{array}{l}\text { personal } \\
\text { addressed }\end{array}$ & 2 & mobile & 14 & evaluating & 4 & living/household & 8 \\
\hline & & & Institution & 13 & entertaining & 2 & commerce & 7 \\
\hline & & & & Take away & 4 & argumentative & 2 & health & 6 \\
\hline & & & & & & & Leisure & 6 \\
\hline & & & & & & & & family/kids & 5 \\
& & & & & & & & & \\
\end{tabular}

Tab.: functional and thematical dimension of German text types L2 Learners come in touch with

The table shows the distribution of several functional and thematical functions of the 59 literal artefacts which adult german-L2-learners came in contact with. The distribution of the dimension of text types which learners encounter in their everyday lives can be an orientation for developing didactical materials. This would ensure a learning process which is closer to the individual world of the learners.

\section{The list of used literature}

1. Adamzik, K. (2016). Textlinguistik: Grundlagen, Kontroversen, Perspektiven (2., völlig neu bearbeitete, aktualisierte und erweiterte Neuauflage ed.). Berlin Boston: de Gruyter.

2. Altmayer, C. (2015). Kulturelle Deutungsmuster in Texten. Prinzipien und Verfahren einer kulturwissenschaftlichen Textanalyse im Fach Deutsch als Fremdsprache. 6(3). Retrieved from https://doaj.org/article/6aaab2a2a84c45c6992c46fc51e8d2ff

3. https://katalog.ub.uni-leipzig.de/Record/ai-28-6aaab2a2a84c45c6992c46fc51e8d2ff

4. Atteslander, P., \& Cromm, J. (2010). Methoden der empirischen Sozialforschung (13., neu bearb. und erw. Aufl. ed.). Berlin: Schmidt.

5. Bärenfänger, O., Lange, D., \& Möhring, J. (2015). Research Papers in Assessment 2015,1: Sprache und Bildungserfolg : sprachliche Anforderungen in der Studieneingangsphase. Leipzig: Universitätsbibliothek Leipzig.

6. Berger, P. L., Luckmann, T., Plessner, H., \& Plessner, M. (2016). Die gesellschaftliche Konstruktion der Wirklichkeit: eine Theorie der Wissenssoziologie (26. Auflage ed.). Frankfurt am Main: Fischer Taschenbuch Verlag. 
7. Crestani, V. (2013). Fandrych, Christian; Thurmair, Maria: Textsorten im Deutschen. Linguistische Analysen aus sprachdidaktischer Sicht. 40(2-3), 192-195. Retrieved from http://dx.doi.org/10.1515/infodaf-2013-2-334

8. https://katalog.ub.uni-leipzig.de/Record/ai-49aHR0cDovL2R4LmRvaS5vcmcvMTAuMTUxNS9pbmZvZGFmLTIwMTMtMi0zMzQ

9. Ehlich, K. (2007a). <Recherche und Dokumentation hinsichtlich der Sprachbedarfe von Teilnehmenden an Integrationskursen DaZ - InDaZ>.

10. Ehlich, K. (2007b). Sprache und sprachliches Handeln (Vol. 1). Berlin u.a.: de Gruyter.

11. Fandrych, C. (2013). Text, Diskurs und Translation im Wandel: Transformationen in der lateinamerikanischen Germanistik.Paper presented at the Asociación Latinoamericana de Estudios Germanisticos, Tübingen.

12. Flick, U. (2009). Qualitative Forschung: ein Handbuch (7. Aufl., [Originalausg.] ed.). Reinbek bei Hamburg: Rowohlt-Taschenbuch-Verl.

13. Haug, S., \& Zerger, F. (2006). Integrationskurse - erste Erfahrungen und Erkenntnisse einer Teilnehmerbefragung. Nürnberg.

14. Hünlich, D., Wolfer, S., Lang, C., \& Deppermann, A. (2018). Wer besucht den Integrationskurs?: soziale und sprachliche Hintergründe von Geflüchteten und anderen Zugewanderten. Mannheim: Institut für Deutsche Sprache

15. Goethe Institut.

16. Karin Birkner, D. M. (2011). InstitutionalisierterAlltag: Mündlichkeit und Schriftlichkeit in unterschiedlichen Praxisfeldern.

17. Kawulich, B. B. (2005). Participant Observation as a Data Collection Method. 6(2). Retrieved from https://doaj.org/article/c7a96bb70c544cc985ad147e452badc9

18. https://katalog.ub.uni-leipzig.de/Record/ai-28-c7a96bb70c544cc985ad147e452badc9

19. Long, M. H. (2005). Second language needs analysis (1. publ. ed.). Cambridge u.a.: Cambridge University Press.

20. Soto-Hinman, I. (2011). Increasing Academic Oral Language Development: Using English Learner Shadowing in Classrooms. Teaching Language Learning, 21-23.

21. Waggershauser, E. (2015). Schreiben als soziale Praxis: eine ethnographische Untersuchung erwachsener russischsprachiger Zweitschriftlernender. Tübingen: Stauffenburg.

22. Weissenberg, J. (2010). Sprachlich-kommunikative Handlungsfelder am Arbeitsplatz. Deutsch als Zweitsprache, 13-24.

23. Weissenberg, J. (2012). Sprachbedarfsermittlung im berufsbezogenen Unterricht Deutsch als Zweitsprache.

\section{O'TKIR HOSHIMOVNING “TUSHDA KECHGAN UMRLAR” ROMANINING BADIIY POETIK XUSUSIYATI}

\section{Dilfuza Rasulmuxamedova \\ $(\boldsymbol{U} \boldsymbol{D} \boldsymbol{D J T U J})$}

Annotation: People's Writer of Uzbekistan Utkir Hoshimov is a writer who has made a significant contribution to the literature and spiritual treasures of our independent Motherland. More than seventy books, published in nearly two and a half million copies in various languages over a period of almost fifty years, have made the writer a respected son of our nation. A number of Hoshimov's works have been screened. He is the author of dramas, comedies, and a number of screenplays, including The "Destroed spring", "Human Loyalty " (1975), "The Medicine of Conscience", "Happy Wedding (1979), and "Repression". The book "Inscriptions in the margins of the notebook" (2001) has left a certain mark on social and spiritual life. An important part of his work in recent years, the novel "Life in a Dream" is deeply rooted in the hearts of readers. In particular, the skill of the writer in creating the image, the skill of using the words in his works is 
recognized by many literary critics. That is why his works have been translated into many languages.

Key words and expressions: image, figurative tool, word usage, lexical tool, grammatical tool

Mashur adibimiz O'tkir Hoshimov, o’zining so'nggi romani "Tushda kechgan umrlar" romanida yigirmanchi-o'ttizinch iyillar, urush davri tozalashlari, urushdan keyingi ziyolilar qatag'oni, afg'on urushi va "paxta ishi”" repressiyalarini xronologik izchillikda yoritadi. ${ }^{101}$ [2. 194] Roman voqealari Rustamning oxirgi kundaligidan boshlandi va asta sekin Qurbanoy xolaning har kungi yumushlariga o'z o'rnini bo'shatib beradi.Asarning asosiy voqealari to'rt oyichida bo'lib o'tadi. Ya'ni Rustamningvafotidan uning o'limi haqidagi ish yopilguncha. Qistirma epizodlarda romanning asosiy voqealariga qahramonlarning kundaligi , xotiralari , xatti -harakatlari ,o'y fikrlari ,estaliklari tarzda mohirlik bilan singdirib yuboriladi. Roman bosh qahramoni Rustam oliygoh talabasi ,Sovuq urush tufayli yuzaga kelgan Afg'on urushi qatnashchisi , ayni chog'da jabrlanuvchisi. U afg'on urushidan kantuzyaga uchragach achinarlisi majruh bo'lib uyiga qaytadi.

Yozuvchi Rustamning kundaliklari orqali afg'on urushi janggohlarini tasvirlar ekan bu ma'nisiz urushning mohiyatini, mohirlik bilan ochadi. Urushdan qaytgan Rustam, o'z hayotini izga tushirishga urinadi. Taassufki, Rustamning hayoti endi o'nglanmaydi . U tirik o'likka aylangan edi. ${ }^{102}$

"Tushda kechgan umrlar" romanidagi o’xshatishga misollar va ularning tahlil talqini. Romanni boshidan oxirigacha o'qir ekanmiz o'xshatishga ko'plab misollar uchratamiz. Albatta orginal ya'ni badiiylik ufurib turgan yoki o'xshatish yaqqol namoyon bo'lgan misollarni tahlil qildik. Ularni ikki guruhga ajratdik:.

1. Leksik vositalar bilan hosil bo'lgan o'xshatish.

2. Grammatik vositalar bilan hosil bo'lgan o'xshatish

Masalan - O'xshatishga misollar: Shaxnozaning qulog'I shang'illar, birov uning miyasiga kirib olib, muttasil to'qmoq bilan o'rayotganga o'xshar edi. O'tkir Hoshimov bu kontekstda iboralar yordamida o'xshatishlar hosil qilgan."urayotganga o'xshar edi" birikmasi orqali leksik o'xshatish ifodalangan va o'x shamoq fe'lining sifatdosh shakli hosil bo'lgan. Oyoqlari ipdek, puf desang uchib ketadigan holi bor-ku, miq etmaydi, eshshak! Nachora, boshqa usulni qo'llashga to'g'ri keladi. Bu misolda yozuvchi - dek o'xshatishni yuzaga keltiruvchi Grammatik vositadan foydalangan va “oyoqlari ipdek" birikmasi sifat yasovchi affiksi orqali o'xshatish hosil bo'lgan. Avtomatni aynan menga o'qtalib turgandek, boshimni ichiga tortdim. Bu misolda ham leksik, ham Grammatik o'xshatishlar bor. Misli, bamisoli aynan ravishlari doim o'xshatish obrazini ko'rsatuvchi so'zdan avval keladi. Yo'q, bu kulgu emas, kalta kesakning tamoq taqillatishiga o'xshagan mudhish birtovish edi. $\mathrm{Bu}$ inkor ma'nodagi o'xshatishlar kaltakesakni tamoq taqillatishini eshitmagan bo'lsakda, o'xshamoq fe'lining sifatdosh formasi ekanligini etirof etishimiz lozim. Mauzerning og'zilang ochilib, basharasi yana ham ahmoqona tusga kirdi. Bu salbiy ma'noli matnda-ona qo'shimchasi o'xshatish obrazini ko'rsatuvchi so'zga qo'shiladi va biror predmet, belgini va holatni shu so'z orqali ifodalab qiyos qilishga yordam beradi va o'xshatish hosil bo'ladi. Bu dunyo muttasil aylanib turadigan murakkab mexanizm.

Yozuvchining bu misolini sof o'xshatish deb qaraymiz. Chunki bu misolda leksik so'zlar yoki grammatik vositalar ishtirok etmagan. Dunyoni mexanizmga o'xshatgan. $\mathrm{Bu}$ bizning tafakkurimizda hosil bo'lgan o'xshatishdir. ${ }^{103}$ [3. 181 b.] Boshini bir tomonga tashlagan ko'yi qopqora kipriklarini gunohkor ona prillatib turushi shuqadar samimiy ediki, boyagi "artisnamo" shopirdan rashk qilganimga o'zimuyaldim. Bu misolda -namo affiksi orqali o'xshatish hosil bo'lgan. U o'xshatish obrazini ko'rsatuvchi “artist" so'ziga qo'shilib holatni ifodalayapti va qiyos qilishga yordam bermoqda. To'laganova qo'y og'zidan cho'p olmagan farishta. Yozuvchi O'tkir Hoshimov bu misolda iboralar orqali To'laganovani farishtaga o'xshatgan. Shaxnoza mening yostig'imni quchoqlab turib, bolalarcha sodda quvlik bilan kuldi. Bu misralarda “bolalarcha” so'zi

\footnotetext{
${ }^{101}$ Rasulov . A. Tanqid,tahlil, baholash-T. Fan 2006 [194b.]

${ }^{102}$ O'.Hoshimov "Saylanma" T. 2003 [203 b.]

${ }^{103}$ Mirzayev . S. XX asro'zbekadabiyoti T. Yangiasravlodi, 2005[181 b.]
} 
orqali o'xshatish hosil qilingan. - cha kuchaytirish formasidan foydalangan va Shaxnozani bolaga o'xshatganligi kontekstdan anglashilib turibdi. Talabalar shaharchasi arining uyasiga o'xshaydi. Bu misolimizda o'xshamoq fe'lining sifatdosh formasi hosil bo'lgan. O'ylab qarasam, o'tgan umrim umir emas, tush ekan. Bu o'xshatish "ekan" o'tgan zamon fe'lida ifodalangan inkor ma'nosini anglatuvchi o'xshatishdir.

Bunda yozuvchi inson umrini naqadar qisqa ekanligini ifodalagan. Mundoq kirish-chiqish qilaylik, bolam, ko'zday qo'shnimiz... Bu misolda -day fe'lning sifatyasovchi formasi sifatida hosil bo'lgan o'xshatish, ibora bilan ifodalangan. "Sabotaj" tashkilotchisi - Rustam degan yigit ekan. Basketbolchilarga o'xshagan baland bo'yli, gavdali... Bu misolda o'xshatish, qiyoslash ma'nosi anglashilib turibdi. Leksik vosita “o'xshagan" so'zi orqali hosil bo'lgan. U doimo o'xshatilgan predmet yoki shaxsdan keyin keladi. Kuz - o'lim to'shagida yotgan bemorga o'xshaydi... Bu misolda ham yozuvchi leksik vosita bilan ko'chim o'xshatish hosil qilgan. Bunda bo'yoqdorlik kuchli tasvirlangan. Bostirmaning qorayib ketgan pastak shiftida olmadek kina lampochka osilib turardi. Bor - yo'q jihoz shu. Bu misolda ham - dek Grammatik qo'shimchasi orqali lampochka olmaga o'xshatilmoqda.

Misolda -kina kichraytirish formasi qo'llangan. Katta yo'l chetida qachonlardir uzilib ketgan tank zanjiri zanglab yotibdi. Xuddi ajdar terisigao'xshaydi. Bu misolda "xuddi" leksik vosita qo'llangan. Misoldagi "xuddi” so'zini bemalol tushurib qoldirishimiz mumkin. U fakultativ xarakterga ega va gap ma'nosiga ta'sir qilmaydi. Bu tushurib qoldirishimizda mazkur gaplar ma'nolariga zarar yetmasligi uchun ularni tuzilishida juz'iy o'zgarish qilishimiz mumkin: Katta yo'1 chetida qachondir uzilib ketgan tank zanjiri zanglab yotibdi. Ajdar terisiga o'xshaydi. O'xshatishda bir soni ham qo'llaniladi. Bunda omonimlik xususiyati paydo bo'ladi. Masalan: uycha, qizcha yigitcha kabi. Sonlarga qo'shilganda chama ma'nosini anglatadi: o'ncha, mingcha, qirqcha vahokozolar. -cha affiksi so'zlarga qo'shilib, urg'u olmaganda sifat va ravishlarni yasaydi va o'xshatish, cho'g'ishtirish ma'nolarini beradi. Bu xususiyat bilan - day, - dek affikslariga juda yaqin turadi. - cha affiksi vositasida sifat yasalganda, asosan, predmet, vaqt, daraja, ko'rsatish kabi ma'nolar bilan bo'g'liq o'xshatish hosil qiladi. Masalan: Ko'z yoshlari daryocha bo'ldi. Bu misolda -cha affiksi yordamida o'xshatish hosil bo'lgan. Bu frazeologik o'xshatish bo'lib, ko'z yoshlarini daryo suviga o'xshatmoqda. Xullas o'xshatishlar badiiy tasvir vositalarida keng o'rinni egallaydi. O’xshatishning ochilmagan qirralari haqida kelgusi kuzatishlarimizda to'xtalamiz. Xulosa Tilshunoslikning asosiy vazifasi til haqidagi bilimlardan kelib chiqqan holda til birliklarini ularning o'zoro sintagmatik, paradigmatik, shakl-mazmun va boshqa munosabatlarida (kelibchqishi, davriga, hududga tegishliligidan) bo'ladigan o'zgarishlarni hisobga olib aniq belgilashdan va ularning nutqda qo'llanilish imkoniyatlarini ochib berishdan iborat bo'lmog'i darkor.

Uslubiyatning asosiy vazifasi til birliklari imkoniyatlarining nutqda namoyon bo'lish qonuniyatlarining, davrga, nutq ko'rinishlariga nisbatan me'yoriyligini belgilab berishdan iboratdir. Biz O'tkir Hoshimovning “Tushda kechgan umrlar" romanida o'xshatish san'ati qo'llanilishi haqida mulohaza yuritar ekanmiz, tasviriy vositaning shakl ko'rinishlarini qo'llanilishini emas, balki yozuvchining o'xshatishni qanday ifodalagani va uning o'quvchiga qanday yetib borishi tushuniladi. Badiiy obraz yaratishda o'xshatishni O'tkir Hoshimovning "Tush da kechgan umrlar" romanidan olingan misollar orqali tahlil qilishga harakat qildik.

Bunda O'tkir Hoshimovning obraz yaratishdagi maxoratini o'rganish bilan birga uning badiiy matnda qo'llangan tasviriy vositalaridan mohirona foydalanganligini isbotini ko'rdik.

\section{Фойдаланилган адабиётлар рўйхати}

1. Sulton. I Adabiyotnazariyasi . T. O'qituvchi,2005

2. Rasulov . A. Tanqid,tahlil, baholash-T. Fan 2006[194 b.]

3. Mirzayev . S. XX asro'zbekadabiyoti T. Yangiasravlodi, 2005[181 b.]

4. Umurov H Tahlilsan'ati. T Adabiyotvasan'at, 1978

5. O’.Hoshimov“Saylanma” T. 2003 [203 b.] 


\title{
ЛУҒАТЛАР ТИПЛАРИ (ТУРЛАРИ) ВА ИЗОХЛИ ЛУҒАТЛАРНИНГ ТУЗИЛИШИ ВА АХАМИЯТИ
}

\author{
Р.С. Шодиев, \\ Ф.Ю. Эргашова, \\ (Чирчиқ ОТҚМБЮ)
}

\begin{abstract}
Annotation: The given article is based on the structure and importance of translation dictionaries (bilingual dictionaries), bilingual differential dictionary, dialect dictionary, multilanguage dictionaries, historical dictionaries, terminological dictionary, dictionary, foreign languages dictionary idiom dictionaries, Phraseological dictionary, synonymic dictionaries, a spelling dictionary, Etymological dictionary and the explanatory dictionary (monolingual dictionaries).
\end{abstract}

Key words and expressions: lexicography, dictionary, lexicology, encyclopedic loot, dialectology lot, lot synonym, antonym loot, orthographic dictionary, etymologic dictionary, terminological dictionary

Лексикогафия тилшуносликнинг бир қисми бўлиб, маълум бир тилга хос сўзларни тўплаш, уларни муайян системага солиш ва луғат тарзда нашр этиш хақидаги хамда луғат ва унинг тузилиши, луғат турлари тўғрисидаги билимдир. Лексикогафиянинг вазифаси жуда кенг бўлиб, у қандай луғат тузиш кераклигини, луғат кандай талаб эхтиёжларига жавоб бериш лозимлиги ни хам ўз ичига олади. Шуни айтиб ўтиш керакки, кишиларни ёдда тутиб қолиш қобилияти нақадар кучли бўлмасин, бир тилдаги барча сўзларни, улар нинг хилма-хил маъноларини эсда сақлаш нихоятда қийин ва мумкин хам эмас. Шунинг учун хам кишиларнинг маданий хаётида турли хилдаги луғатларнинг ахамияти жуда каттадир.

Кишиларнинг ана шундай маданий эхтиёжларини қондириш учун турли хилдаги луғатлар тузилган ва хозирда хам тузилмокда. Демак, лексикогафия лексикологиянинг хам луғат тузиш билан шуғулланадиган бўлимидир.

Анатоль Франснинг ёзишича “Луғат алфавит таркибида жойлаштирилган воқеликдир”. Бундан борлиқдаги жамийки нарса, ходиса ва воқеалар хар бир тилнинг луғат бойлигида акс этади, деган маъно келиб чиқади. Кишиларнинг талаби ва маданий эхтиёжларининг қондириш учун турли хилдаги луғатлар тузиляпти.Хозирги кунда икки тилли таржима луғати, икки тиллик дифференциал луғат, терминологик луғат, тарихий луғат, этимологик луғат, чет тиллардан кирган сўзларнинг луғати, икки тиллик дифференциал луғат, диалектологик луғат, фразеологик луғат, идиоматик сўзлар луғати, орфографик луғат, энциклопедик луғат, антоним луғат, омоним луғат, синоним луғат, махсус луғатлар, имло луғати, талаффуз луғати, немис тилида Grosses Wörterbuch der Deutschen Aussprache ва Langenscheidt Grosswörterbuch der Deutsch als Fremdsprache ( 2003) . ва бошқа луғатлар кишиларнинг маданий эхтиёжини қондириш учун хизмат қилмоқда.

Лексикография назариётидан маълумки, бизнингча уч асосий муаммони масалани хал этиш керак:

1) Луғатларнинг типлари.

2) Луғатлар учун сўзлар тўплаш ва уларни луғатларга киритиш (жойлаштириш).

3) Луғат мақоласининг тузилиши.

Ушбу савол масалаларини хал этишда луғат мақоласи холатига назарий жихатдан қараш керак бўлади ва бу маънода немис тили луғатларини тахлил қилса бўлади. Шуни ёддан чиқармаслик керакки, луғатларни тахлил қилиш тўлиқ маънода назарий ва амалий жихатдан асосий туп масала хар жихатдан хам ёритилавермайди яъни лексикографияда маълум бир мақола, рисола доирасида хал қилиб бўлмайди, албатта, луғатлар тузишда кўпгина сўзлар, иборалар, фактик материаллар тўпланади, алфавитга солинади, классификация қилинади, тартибга солинади. 
Маълумки, хар бир тилнинг хар турли луғатлари мавжуд бўлади. Одатда улар: таржима луғатлари (икки тилли луғатлар), диалектологик луғатлар, кўп тилли луғатлар, тарихий луғатлар, терминалогик луғатлар, чет тиллар луғати, идиоматик сўзлар луғати, фразеологик луғат, синоним луғатлар, антоним луғатлар, орфографик луғат, этимологик луғат ва изохли луғатлар (бир тилли луғатлар).

Луғатлар хар хил мақсадли бўлади (бўлиши мумкин): Норматив (норма бўйича, нормага мувофиқ), бу луғатлар нутқда сўзларни тўғри қўллаш, бошқа луғатлар (айримлари) этимологик луғатлар бўлиб, улар сўзларнинг этимологиясини (келиб чиқиш жихатдан ). Демак, луғатлар олдига хар хил мақсадлар қўйилади, бу мақсадлар: диалектик, фразеологик, синонимик, луғатлар ва бошқалар. Сўзларнинг маънолари луғатларда берилиши ёки берилмаслиги хам мумкин ( масалан: немис тили луғати “Der Grosse Duden" ).

Агар сўзларнинг маънолари берилса (очилса) луғатлар хар хил йўллар (усуллар) билан изохланади (кўлланади), изохли луғатларда изохланади, таржима луғати (икки тилли луғат)да таржима қилинади. Шундан маълумки, ушбу усулларни қўллаш, луғатларда исталган сўз қатламларини қайд этиш мумкин.

Таржима луғатлари. Бу турдаги луғатлар икки ёки ундан ортиқ тилли

бўлиши мумкин. Таржима луғатларидан сўнг энг кўп ва кенг тарқалгани икки тиллик таржима луғатларидир. Бундай луғатлардан бошқа бир тилдаги сўзлар она тилига ёки она тилидаги сўзлар бирор бошқа тилга таржима қилинади.

Масалан: немисча-русча, русча-ўзбекча, немисча-ўзбекча, ўзбекча-русча, французчарусча луғатлар каби. Бундай луғатларни тузиш нихоятда қийин ва мураккаб маъсулиятли ишдир.Бир тилга хос бўлган сўзларни, уларнинг барча маъноларини, сўз маъноларининг ўзгаришини иккинчи бир тилга таржима қилиб бериш жуда қийин ишдир. Бундай луғатларни тузувчилардан хар икки тилни жуда яхши тушунишни, билим даражасининг хар томонлама мукаммал бўлиши талаб килинади. Агар бир тилга хос бўлган сўз ва унинг маъноларини иккинчи тилга биргина сўз билан таржима қилганимизда, шу сўзнинг турли маъноларини, унинг сўз бирикмаларидаги гапдаги хилма-хил маъно нозикликларини ифодалай олмаган, у тилнинг барча имкониятини очиб бера олмаган бўлар эдик.

Масалан; рус тилида войти сўзининг асл маъноси кирмоқдир, бироқ бу сўзни ўзбек тилига таржима қилганимизда, унинг фақат шугина маъносини ифодалаб берсак бу сўзнинг кўчма маъноларини, маъно нозикликларини тушуриб қолдирган бўламиз.Чунки, войти сўзи кирмок маъносидан ташқари, сизмоқ, жсойлаштирмоқ, уурганиб олмоқ, узлаштирмок, мурожаат қилмок, таклиф қилмок, қўлламок, расм одат бўлиб қолмоқ, берилиб кетмок, қизиқмоқ каби маъноларни хам ифодалайди. Мисоллар:

1.Дети вошли в комнату - болалар уйга кирди (бу ерда асл маъносида куилланган).

2.Все вошли в чемодан - хамма нарсалар чемоданга сидди.

3. Войти в суть дело - ишнинг мохиятини, маззини туиуниб олмок.(кириб олмоқ деб бўлмайди).

4.Войти в президиум с предложением - президиумга таклиф ёки тавсия қилмок (кирмок суизи бумисола сунъий бўлиб чиқади).

5.Это слова вошло в употребление - бу сўз ишлатила (кўлланила) бошлади (бу ерда истеъмолга кирди десак сунъий бўлиб чиқади).

6.Войти в привичку - расм бўлмок, одат бўлиб қолмок (бу мисола хуам одатга кирди десак сунъий бўлиб чиқади)

7.Войти в доверие - ишонч қозонмоқ (ишончга кирди деб бўлмайди)

8.Войти а азарт - берилиб (қизиқиб) кетмок. (қизиқишга кирди деб бўлмайди). М.М.Абдурахимов “Ўзбекча-русча, русча-ўзбекча луғат "(2010й) ( 342-343 бетларга қаранг).

Икки таржима луғатлари тузилганда таржима қилинувчи тилдаги хар бир сўзнинг барча маънолари кўзда тутилиб,улар она тили имкониятларидан фойдаланган холда мумкин қадар тўликрок бўлиши, берилиши керак.

Таржима луғатларида бир тилдаги иккинчи тилга таржима қилинганда маъно жихатдан бир бирига яқин синонимлар аввал,бир биридан узоқроқ синонимлар кейин берилади. Бир 
бирига жуда яқин синоним сўзлар вергул билан, озми-кўпми маъно жихатдан узоқ бўлганлари нуқтали вергул билан ажратилади. Masalan: немис тилидаги die Kraft сўзи рус тилига қуйидагича таржима қилинади. Die Kraft сила, усилие; энергия; мощность;

Kräfte $\boldsymbol{p l}$ сила; усилия; äußerste мор самый полный ход; frische Kräfte $\boldsymbol{p l}$ свежие силы; herkömmliche Kräfte $\boldsymbol{p l}$ обычные виды оружия; konventionelle Kräfte $\boldsymbol{p l}$ обычные вооруженные силы; kritische критическая нагрузка; lebende живая сила; militärische военная мощь; mobile Kräfte $p l$ подвижные (мотомеханизированные) части (войска); schwache Kräfte $\boldsymbol{p l}$ небольшие (незначительные) силы; stärkere Kräfte $\boldsymbol{p l}$ крупный (значительные) силы; überlegene Kräfte $\boldsymbol{p l}$ превосходящие силы; vereinigte Kräfte $\boldsymbol{p l}$ объединенные сила; объединенные усилия; vereinzelte Kräfte $p l$ разрозненные (разобщенные) силы; разобщенные усилие; vorgeworfene schnelle Kräfte pl продвинувшиеся(выдвинутые) вперед подвижные (мотомеханизированные) части; Kräfte fesseln сковывать силы (противника); an Kräften abnehmen pl ослабевать, изматываться; außer setzen отменять(напр. решение); außer treten терять силу(о приказе); in setzen утверждать (напр. проект устава); in treten вступать в силу (приказе); seine Kräfte einsetzen $\boldsymbol{p l}$ напрягать свои силы; von Kräften kommen $\boldsymbol{p l}$ ослабевать, изматываться; äußerste voraus (zurück) мор самый полный (аварейный) ход вперед(назад) ! der Kraftaufwand расход (применение) энергии (силы).

проф А.М Таубе, Л.С.Азарх, А.П.Арметов, И.М. Глаголев, Л.Ф. Парпаров ”немецкорусский военный словарь” [9, 514-515 б ]

Таржима луғатларида сўзларнинг кўчма маънолари эса рақамлар билан кўрсатилади. Турғун сўз бирикмалари, идиомалар, фразеологиялар эса алохида белгилар билан ажратилади.

Диалектологик луғат. Диалектологик луғатнинг вазифаси хар бир диалектнинг умумхалк адабий тилидан фарқ қиладиган сўзларини адабий тил билан солиштириб, изохлаб беришдан иборатдир. Рус тилида бир нечта диалектологик луғатлар нашр этилган.Ўзбек тилида Ф.Абдуллаевнинг “Хоразм шеваларининг луғати” ва бошқалар нашр этилган. Диалектологик луғат тузиш масаласи хам ўзбек тилшунослиги олдида турган мухим вазифалардан биридир.

Кўп тиллик луғатлар. Кўп тиллик луғатлар жуда кам учрайди. А.Папов ва В.Поповлар томонидан тузилган. етти тиллик “Французча-инглизча-немисча-испанча-португалчаголландча - русча луғат” ни кўрсатиш мумкин. Бу луғат 1902 йилда Варшавага нашр этилган.

Бироқ бундай луғатлар фойдаланиш учун бир мунча ноқулайлик туғдиради, уларда таржима қилинган тиллардаги сўзларнинг кўп маъноларни бериш имконияти бўлмайди. Кўп тиллик луғатларни тузиш хам нихоятда қийин бўлиб, бундай луғатларни тузувчилардан бир нечта тилни мукаммал билиш талаб қилинади. Шунинг учун хам кўп тиллик луғатларни тузиш ишлари ривож олмаган Икки тиллик дифференциал луғат. Икки тиллик дифференциал луғатларни тузишдан мақсад бир-бирига яқин бўлган икки қардош тилнинг хам маъно, хам шакл жихатдан бир-биридан фарқ қиладиган сўзларни изохлаб беришдир. Тажриба шуни кўрсатдики, бундай луғатларни фойдаси нихоятда оз бўлиб улар икки тиллик таржима луғатидан унчалик фарқ қилмайди. Шунинг учун бундай луғатларни яратиш иши хам у қадар тараққий этмаган.

Тарихий луғатлар.Тарихий луғатлар қадимги ёзув ёдгорликларидаги эскириб қолган, истеъмолдан чиққан сўзларнинг маъносини изохлаб, уларнинг туғри ўқилишига ёрдам беради.Тарихий луғатда сўзлар хронологик тартибда жойлаштирилиб, хозирги тил билан изохлаб берилади. Бундай луғатларни яратиш мураккаб ишдир. Эски ёзувлардаги сўзларнинг маъносини ечиб бериш катта илмий кучни талаб килади. Шунинг учун бу кунгача тарихий луғатлар бошқа луғатларга нисбатан жуда оз яратилган.

Чех олими Ян Гебауэр чех тилининг тарихий луғатини тайёрлаш навбатдаги вазифалардан биридир ўзбек тилининг ёзув ёдгорликлари X асрдан маълум. Махмуд Қошғарийнинг “Девону Луғатит турк “(туркий сўзлар девони), XVI асрнинг биринчи ярмида вужудга келган “Абушка" номли луғат XVIII асрда Нодиршох Махтихоннинг "Санглох" 
(чиғатойча- форсча) луғати, ХІХасрда Шайх Сулаймонинг “Чиғатойча- туркча” луғати ва бошқалар ўзбек тилининг тарихий луғатини яратишга асос бўла олади. П.Шамсиев ва С.Иброхимов тузган “Ўзбек классик адабиёти асарлари учун қисқача луғат" кабилар ўзбек тили бойлигини аниқлашга, шу билан тарихий луғат тузишга ёрдам беради.

Терминалогик луғат. Терминалогик. луғатлар кўпинча бир тилда ёки икки тилда тузилиб, унинг вазифаси хар бир сохадаги терминларни изохлаб, тушунтириб беришдан иборатдир. Бундай луғатлар махсус луғат ёки сохалар луғати деб хам юритилади.Терминалогик луғатлар хар қайси соха бўйича, чунончи, қишлоқ хўжалиги, фалсафа, медицина, тилшунослик, география, физика, математика, харбий ва бошқа сохалар бўйича тузилади.

Ўзбек тилида бирмунча терминалогик луғатлар яратилган. Масалан: Т.Н. Қори Ниёзийнинг "Русча -ўзбекча математик терминлар луғати" (1933), М.А.Собиров, Р.Х.Маллин ва М.Д.Ягудаевларнинг "Русча - уузбекча физика терминлар луғати”, С.Сахобиддиновнинг "Русча -ўзбекча қисқача ботаника терминлари луғати" (1954), А..Ю.Юнусовнинг "Русчаўзбекча қисқача физиологик терминлар луғати", проф А.М Таубе, Л.С.Азарх, А.П.Арметов, И.М. Глаголев, Л.Ф. Парпаров "немисча - русча харбий луғат" ва бошқалар ана шундай терминологик луғатлардир.

Чет тиллардан кирган сўзлар луғати. Кишилик жамиятининг тарихий тараққиёти жараёнида турли тилда сўзловчи халқлар бир- бирлари билан иқтисодий, маданий, илмий муносабатларда ва савдо-сотиқ муносабатида бўлганлар. Халқларнинг ана шундай муносабатлари натижасида бир тилдан иккинчи тилга айрим сўз ва иборалар ўтган. Шундай қилиб хар бир халқнинг тилида четдан кирган сўзлар пайдо бўлган. Бундай сўзлар кўпинча хаммага тушунарли булмайди. Шунинг учун бундай сўзларнинг қайси тилдан кирганлигини кўрсатиб ва уларнинг маъноларини изохлаб беришнинг ахамияти каттадир. Бундай вазифани чет тиллардан кирган сўзлар луғати бажаради .

Чет тиллардан кирган сўзларнинг луғати кишиларнинг иш фаолиятида хам назарий хам амалий жихатдан нихоятда керак бўлганлиги учун кўп тарқалгандир. Масалан: Чет тиллардан рус тилига кирган сўзлар луғати (словарь иностранных слов) йигирма минг сўз ва терминни изохлаб берган.

О. Усмоновнинг ўзбек тилидаги “Интернационал сўзлар луғати “ хам икки ярим минг сўзни ўз ичига олади .

Идиоматик сўзлар луғати . Идиоматик сўзлар луғатининг вазифаси хар бир тилга хос бўлган идиоматик ибораларни тўплаб, изохлаб беришдан иборатдир. Бундай луғатлар жуда хам кам.

Фразеологик луғат. Фразеологик луғат жуда керакли луғатлардан бўлиб, хар бир тилга хос мақол, матал, хикматли (турғун ) сўз бирикмалари-

ни тўплаб, уларнинг қандай холларда ишлатилишишини мисоллар билан изохлаб беради. Баъзи четдан кирган ибораларнинг қайси тилдан кирганлиги кўрсатилиб, параллел берилган. М.И.Умархужаев, К.Н.Назаровнинг "Немисча - русча - ўзбекча фразеологик луғати” хар учала тилга доир бўлган 700 дан зиёд турли хил структуравий тузилишига эга бўлган турғун сўз бирикмаларини ўз ичига олади. Бу фразеологик луғатда берилган хар бир немис тилидаги турғун суз бирикмаси аввал ўша тилда талқин қилинган, сўнгра унинг ўзбек ва рус тилларидаги мос келувчи муқобил таржималари берилган. Бундай луғат тузиш нихоятда оғир ва қийин ишдир, шунинг учун хам бу хил луғатлар кўп тарқалган эмас.

Орфографик луғат. Орфографик луғатнинг бирдан бир вазифаси бир тилдаги сўзларни шу тилнинг грамматик қоидалари асосида тўғри ёзилишини кўрсатиб беришдан иборатдир. Сўзларни бир хил имлода тўғри ёзишда орфографик луғатнинг ахамияти катта. Орфографик луғатлардан С.Иброхимов ва М.Рахмоновнинг “Ўзбек адабий тилининг имло луғати, (1956 ), Ф.Камолов ва З.Маъруфовнинг “Ўзбек тилининг қисқача имло луғати”ни (1969) кўрсатиш мумкин.

Этимологик луғатлар. Луғатнинг бу тури сўзларнинг келиб чиқиш тарихини тушунтириб изохлаб беради. Бундай луғатлар. Хозиргача кам учрайди. Рус тилида бундай 
луғатдан иккитаси бор. С.Бархударов тахрири остида 1961 йилда “Краткий этимологический словаръ русского языка". Г. П Циганенко томонидан ёзилган, 1970 йилда Киевда нашр этилган “Этимологический словаръ русского языка".

Этимологик луғатдан мисол: От сочитания по месту (по участу) Образоваласъ слово поместъе (имение), которое взято из практики пожалования земелслужилым людям на срок несения ими военных обязанностей. От слова поместъе образовалосъ слово (помещица). Қаранг Г. П . Циганенко “Этимологический словаръ русского языка”. [4, 357-358 б].

Луғатлар, асосан, икки турга бўлинади: энциклопедик ва филологик . Энциклопедик луғатларда фан, техника ва маданиятнинг барча сохаларига оид тушунчалар изохланади. Уларда табиат ходисалари, ижтимоий хаётидаги воқеалар, машхур кишилар хақида маълумотлар берилади . Сўзнинг ўзи хақида фақат унинг чиқишини кўрсатиш билан чегараланади. Шунинг учун бундай луғатлар тушунча луғат деб (аталади) юритилади. Одатда, бундай луғатларда расмлар, карта ва схемалар хам келтирилади.

Энциклапедик луғатларда сўз ва иборалар алфавит тартибида мақола -нинг сарлавхаси сифатида кўйилади. Энциклапедик луғатлар мақсад ва вазифасига кўра икки хил бўлади: умумий энсиклопедик луғат ва бирор соханинг энсиклопедик луғати. Умумий энциклопедик луғатларга “ Большая Советская Энциклопедия”, “ Ўзбек Совет Энциклопедияси "мисол бўлади. Бирор соханинг энциклопедик луғатларга “Литературная энцилопедия" “Педагогическая энциклопедия","Техническая энциклопедия”, кабилар киради. Энциклопедик луғат Шарқда “Қомус" деб хам юритилади.

Энциклопедия турли соха, фан, хўжалик ва маориф хақида керакли маълумотлар берувчи илмий асардир. Энциклопедик луғат мухим тарихий воқеалар, фан ва техника сохасида эришилган ютуқлар, турли мамлакатлар ва уларнинг халқлари, тили, иқтисоди, маданияти, давлат, фан, техника санъат адабиёт арбоблари, уларнинг ва илмий қарашлари тўғрисидаги керакли маълумотларни ёритиб беради; Турли терминларни етарли даражада изохлайди. Бундай тирик намунаси сифатида “Большая советская Энциклопедия”ни кўрсатиш мумкин. Эллик томдан иборат бўлган бу нодир асардан хамма сохага оид керакли маълумотларни топиш мумкин. $\quad$ Филологик луғатларда асосий эътибор сўзга ёки сўз бирикмасига берилади ва улар хар томонлама изохланади. Бундай луғатлар хам алфавит тартибида тузилади ва изохланадиган сўз ёки сўз бирикмаси сарлавха сифатида келтирилади. Филологик луғатлар хам икки хил бўлади: умумий ва махсус филологик луғатлар. Умумий филологик луғатларда хамма қўллайдиган сўзларнинг характеристкаси берилади. Булар бир тилли, икки тилли , кўп тилли бўлади.

Кўйилган мақсадга кўра бир тилли филологик луғатлар бир қанча турларга бўлинади. Масалан: изохли луғатлар, махсус лингвистик луғатлар, этимологик луғатлар, морфем луғат, фразеологик луғат, синоним сўзлар луғати, орфоэпик луғат, чаппа луғат, атоқли отлар луғати, жой номлари луғати, машхур ёзувчилар асарлари, луғати ўзлаштирма сўзлар луғати, диалектикал луғат кабилар.

Луғатларда сўзларни ифодаланиши. Маълумки, луғатларда сўзлар алфавит тартибида берилади. Сўзларнинг ишлатилиш доираси, грамматик хусусиятлари хам турли белгилар билан кўрсатилади. Луғатда сўзларнинг ёзилишидан ташқари талаффуз этилиши хам транскрипция орқали берилади.

Хулоса қилиб айтганда ўзбек тилшунослигида хам бу сохада бир мунча ишлар олиб борилмокда. Бундай луғатларни тузиш нихоятда оғирдир, улар бир қанча йилларнинг махсули бўлиб, жуда катта илмий кучлар иштироки билан яратилади.

\section{Фойдаланилган адабиётлар рўйхати}

1. С.Бархударов “Краткий этимологический словаръ русского языка”. 1961 й

2. С.Иброхимов ва М.Рахмонов “Ўзбек адабий тилининг имло луғати". 1956й

3. Ф.Камолов ва З.Маъруфов "Ўзбек тилининг қисқача имло луғати”. 1969 й

4. Г. П. Циганенко “Этимологический словаръ русского языка”. Киев. 1970 й (357358 бетлар). 
5. О. Азизов, 3. Ризаева " Ўзбекча - русча луғат" Тошкент 1989 й

6. Stanislaw Walewski und prof. Dr. Erwin Wedel " Langenscheidt

7. Taschenwörterbuch Russisch-Deutsch, Deutsch- russisch "Berlin und München. 2003.

8. Prof Dr. Dieter Götz, Prof Dr. Günter Haensch, Prof Dr. Hans Wellmann.

9. " Langenscheidt Grosswörterbuch der Deutsch als Fremdsprache" Berlin und München2003.

10. М.М.Абдурахимов “Ўзбекча -русча, русча- ўзбекча луғат ”Тошкент 2010 й (342343 бетларга қаранг)

11. А.М Таубе, Л.С.Азарх, А.П.Арметов, И.М. Глаголев, Л.Ф. Парпаров ”немецкорусский военный словарь” Москва -1964. (514-515 бетлар)

\section{НЕМИС ГАЗЕТА САРЛАВХАЛАРИНИНГ ЎЗИГА ХОС ХУСУСИЯТЛАРИ}

Тагаева 3.C. (Сам ВМИ)

Annotation: This article discusses the specific features of newspaper headlines published in Germany, the functions of reporting, nominative and expressive, the choice of the headline, its lexical-semantic and grammatical structure.

Key words and expressions: newspaper headlines, newspaper headline structure, logicalsemantic structure, lexical-semantic and grammatical structure.

Газеталарнинг бирламчи вазифаси ахборот тарқатиш, хозирги кунда янада тарғибот қилиш, таъсир ўтказиш вазифаси билан боғланиб бормоқда. Газета материалларини тадқиқ қилишда хозирги замон тадқиқотчилари газета сарлавхаларининг структурасига кўпроқ эътибор берадилар. Маълум синтактик моделлар асосида тузилган газета сарлавхалари тил тараққиётида умумий синтактик тенденцияларни ифодалайди. Уларнинг ичида образлилик, маълум холатга бахо бериш, прагматик функциялари алохида ўрин эгаллайди.

Маълумки, матнга қўйиладиган сарлавхалар ўзига хос хусусиятларга ва структурал кўринишларга эга. Немис тилида сарлавхаларни коммуникатив нуқтаи назардан куйидаги ўзига хосликларни алохида ажратиб кўрсатиш мумкин: матннинг комуникатив мақсадини бажаришга қаратилганлиги, матннинг мантиқий - семантик структураларда ифодаланиб келиши, ижтимоий - психологик, коммуникатив вазифаларнинг акс эттирилиши кабилар [Шомаксудова, Тошалиев, Рустамов 1973: 154].

Хар бир матнга кўйилган сарлавха тугалланган фикрни англатувчи гап хисобланади, у коммуникатив бирлик бўлиб унинг мазмуни лингвистик ва лингвистик бўлмаган функционал кўрсатгичлари умумлаштирлади. Сарлавхаларнинг хабар бериш, номинативлик ва экспрессивлик функциялари унинг лингвистик функциялари қаторига киритилади, бу функциялар тилнинг лексик - грамматик воситалари ва турли хил бирликлари орқали амалга оширилади [Попов 1966: 61]. Сарлавхаларнинг реклама қилиш имкониятлари эса лингвистик бўлмаган вазифаларни бажаради.

Немис тилидаги матн ва унинг сарлавхаси ўртасидаги чамбарчас алоқани алохида кўрсатиш лозим. Бунда сарлавханинг танланиши, унинг лексик - семантик ва грамматик таркиби жуда мухим ахамият касб этади. Бизга берилаётган хабарнинг энг мухим қисмини сарлавха ташкил этади. Сарлавхалар оддий матнга қараганда бошқачароқ грамматик ва стилистик қоидаларга бўйсунади. Матн кўйиладиган сарлавхалар сифатида кўпинча мақоллар, хикматли сўзлар, фразеологизмлар ва бошқа тил бирликлари кўлланиб, сарлавхаларнинг маъноларини кучайтиришга, уларнинг прагматик ахамиятини оширишга хизмат қилади.

Ушбу лексик - грамматик бирликлар матнларнинг сарлавхалар сифатида қўлланилганда уларнинг китобхонга нисбатан прагматик таъсир доираси анча кенгаяди, бу сарлавхалар матннинг мазмуни хақида маълум даражада тушунча беради, муаллифнинг 
тасвир этилаётган воқеа - ходисаларга муносабатини ифодалайди. Бу ўринда шуни таъкидлаш лозимки, юқорида қайд этилган лексик - семантик бирликлар турли хил ўзига хос бўлган хусусиятларни намоён этади. Сарлавхаларнинг бундай ўзига хосликлари қуйидаги кўринишда намоён бўлиши мумкин: хабар бериш, аниқлик, фикрни қисқа шаклда баён қилиш, образлилик, китобхонни ўзига жалб қилиш ва бошқалар. Шунингдек, сарлавха орқали китобхон матннинг мазмуни хақида дастлабки тасаввурга эга бўлади. Турли хил стилистик усуллар сарлавхаларнинг янада ёрқинроқ, китобхонлар эътиборини ўзига жалб етадиган, мазмунан теран бўлишини таъминлайдиган воситалар хисобланади .

Ана шу нуқтаи назардан олиб қаралганда муаллиф (шоир, ёзувчи) нинг вазифаси кўзга ташланадиган, тез эсда қоладиган, китобхоннинг диққат -эътиборини тортадиган сарлавхаларни танлашдан иборат, бу вазифани бажариш учун эса тилда мавжуд бўлган ўзига хос лексик -семантик бирликлардан унумли фойдаланиш талаб этилади . Лексиксемантик ўзига хосликларига кўра фразеологизмлар, мақоллар, хикматли сўзлар сарлавха сифатида қўлланиш учун жуда мос келади. Бундай лексик-семантик бирликлар иштирок этган сарлавхалар китобхоннинг диққат - эътиборини ўзига жаб эта олади , матннинг асосий мазмунини англаб етиш имкониятини яратади. Юқорида қайд қилинган бирликлар матн сарлавхалари сифатида ўзларининг асосий (асл) маънолари ва кўчма маъноларини ифода этиб келади [Сатторов 2006: 139].

Ана шу бирликлардан ташкил топган сарлавхалар қисқа структурал шаклда бутун матннинг асосий мазмуни хақида хабар беради, бунда улар маълум коммуникатив прагматик функцияларни бажариб келади.

Одатда сарлавха матннинг номланиши сифатида унинг мазмуни, маълум даражада матн билан боғлиқлиги хақида хабар беради. Ана шу орқали сарлавханинг хабар бериш функцияси амалга оширилади. Дастлаб матн маъно тузилишнинг хилма-хил элементлари сарлавхада қайдаражада ўз ифодасини топишини аниқлаш зарур .

Матннинг маъно тизимига ана шу матннинг асосий ғояси, дастлабки ва ривожланиб борувчи тезислар, вазиятни тахлилий бахолаш, матнда берилаётган хабарнинг мақсади киради. Сарлавхаларнинг кўпчилиги матннинг асосий мавзусини ифода этади. Бундай сарлавхаларни тилшунос олим И.В.Арнолд термини билан “мавзу англатувчи сарлавхалар“ [Арнолд 1988: 74-75] деб аташимиз мумкин.

\title{
Фойдаланилган адабиётлар рўйхати
}

1. Арнолд И.В Стилистика современного английского языка. Л.,1988 С. 76-77

2. Попов А.С Синтаксическая структура современных газетных загалавий и её развитие // Развитие синтаксиса современного русского языка - М $196672 \mathrm{c.}$

3. Сатторов М . Матн, унинг таркибий қисмлари ва бирлаштирувчи воситалари хақида . Таржима жараёни ва хорижий тилларини ўқитишнинг долзарб муаммолари . Республика илмий -назарий конференция материаллари . Самарқанд : СамДЧТИ:нашри , $2006, .138-142$ б

4. Шомаксудова А. Тошалиев И. Рустамов П. Газета сарлавхаларининг струруктурграмматик хусусиятлари.ТашДУ асарлари, ўзбек тили стилистикаси масалалари, Т.,1973.

\section{XITOY VA O'ZBEK TILLARIDA MIKROMATN SINTAKTIK DERIVATSIYASI}

\section{Mamatova Dilshoda (SamDCHTI magistranti)}

\begin{abstract}
Annotation: This article gives a brief overview of the concept of derivation, its emergence, the current important of the field of derivatology, a brief history, the use of derivatology in Uzbek linguistics, syntactic derivation of microtext in Chinese and Uzbek linguages. In the paper, we have mainly tried to analyze the syntactic derivation in the field of derivatology of linguistics. Although
\end{abstract}


the field of derivation has not yet been widely developed and used in our linguistics, we have tried to give a brief overview and information on this article.

Key words and expressions: derivation, derivatio, derivatology, syntactic derivation, microtext, derivation in Uzbek linguistics.

Hozirgi kunga kelib tilshunoslik sohasida derivatsiya hodisasi, derivatsion qonunlar tushunchalari keng qo'llanilmoqda. Derivatsiya nima? Derivatsion qonunlar deganda nima tushuniladi? Derivatsiya atamasi va uning o'rganilish tarixi haqida qisqacha to'xtalib o'tamiz. Derivatsiya so'zi lotin tilidan olingan bo'lib, "derivatio"- biror bir narsaning ikkinchisidan ajralib chiqishini anglatadi. [TIL BIRLIKLARI QO'LLANILISHINING DERIVATSION TAMOYILLARI, O`QUV-USLUBIY MAJMUA,SAMARQAND-2019, 4b.]

Derivatsiya tushunchasi tilshunoslikda oxirgi yillarda kirib kelgan bo'lsa-da, ammo uning qo'llanilishi va derivatsiya haqidagi dastlabki tushunchalar qadimgi hind olimi Panini, o'rta osiyolik olimlardan Mahmud Qoshg'ariylarning asarlarida ham uchraydi. Tilshunoslikda derivatsiyaning sintaktik derivatsiya, leksik derivatsiya, semantik derivatsiya turlari mavjud bo'ladigan bo'lsa, qadimgi dunyo olimlari aynan sintaktik tilshunoslik, hosila struktura masalalariga o'z e'tiborlarini qaratishgan. Derivatsiya atamasining tilshunoslikka kirib kelishida bir qator olimlarning hissasi katta desak, mubolag'a qilmagan bo'lamiz. Xususan, rus olimi V.M.Lomonosov, polyak olimi Eji Kurilovich, Murzin L.N., Sharina O.M. kabi tilshunoslar o'zlarining asarlarida bu soha haqida ma'lumotlar berib o'tdi.

Derivatologiya termini bo'lsa, 1981 yilda Perm universitetida "Derivatologiyaning nazariy muammolari” mavzusida o'tkazilgan nufuzli ilmiy konferensiyada qabul qilindi va tilshunoslik sohasida bevosita qo'llanilmoqda. Undan oldin aynan polyak olimi E. Kurilovich tomonidan yozilgan "Leksik derivatsiya va sintaktik derivatsiya" nomli asarda bu masala tavsifiga keng o'rin berilgan. Ammo bu asar rus tiliga tarjima qilinmagunga qadar, derivatologiya sohasiga e'tibor juda kam edi.1962-yilda bu asar tarjimasi natijasi o'laroq, derivatsiya sohasiga keng e'tibor berila boshladi. Ko'pgina rus olimlari qatorida o'zbek tilshunoslari ham derivatologiya sohasida tadqiqot ishlarini olib borishdi. Aynan derivatsiya maktabining o'zbek tilshunosligidagi asoschilaridan biri professor N.Q. Turniyazov, shuningdek, U.N.Boboyev,A.A. G'afforov kabi tilshunoslar o'zlarining doktorlik dissertatsiya mavzularida derivatologiyaning turli muammolarini ko'tarib chiqardi va natijada o'zbek tilshunosligida derivatologiya sohasining kirib kelishi, o'rganilishi va qo'llailishiga zamin yaratdi. Ammo bu sohada o'rganilmagan jabhalar talaygina.

Sintaktik derivatsiya tilshunoslikda yangi soha hisoblanganigi bois, uning tarkibida sintaktika sohasining qaysi sohalari tahlil qilinishi haqida aniq to'xtamlar mavjud bo'lmasa-da, ammo biz sintaktik derivatsiya nazariyasining qo'llanilish obyektlari sifatida so'z birikmasi va gap, murakkab sintaktik qurilmalarni ham, matn derivatsiyasini ham tadqiq etishimiz taqozo etiladi.

Sintaktik derivatsiyaning asosiy tadqiqot obyektlaridan biri bo'lgan matn derivatsiyasining bir tarmog'i sifatida mikromatnlarni tahli qilamiz. Matn lingvistikasi sohasi tilshunoslikda to'liq o'rganilib chiqqan soha hisoblanmaydi. Matn lingvistikasini o'rganish borasida mikromatn va makromatn tarkibini qamrab oluvchi yo'l-harakati belgilari, so'z birikmasi, gap va uning turlari,murakkab sintaktik qurilma, abzast, yirik asarlarning abzast a boblari kabi bir qator tushunchalarni o'z ichiga oladi. Aynan matn tushunchasini tilshunoslikda tor va keng ma'nolarda talqin qilishini ko'rishimiz mumkin. Agar an'anaviy ma'noda talqin qilinadigan bo'lsak, matn deganda, tugal fikrni anglatuvchi, kommunikativ ma'no kasb qiluvchi har qanday jumlani, hatto grafemani ham matn deyishimiz mumkin. Misol sifatida, "Kutubxona", "Paynet", "Dorixona" kabi so'zlarning peshtoqlardagi yozuvlar, "P"(avtomobillar to'xtash joyi), "M"(metro) kabi belgilar mikromatn maqomiga ega bo'lib, ular bizga aniq tushunchalarni beradi, ya'ni biz u belgilar orqali ma'lum tushunchalarga ega bo'lamiz. Keng ma'noda bo;lsa, matn tushunchasi gazeta, jurnal, ilmiy to'plamdagi maqolalar (xususan, ushbu maqola ham), monografiya, turli xil badiiy asarlar, roman, doston kabi adabiyot janrlarini o'z ichiga qamrab oladi.

N.Turniyozovning ilmiy mushohadalarida matn komponentlari xususida quyidagilar eslatiladi: «Matn komponentlari tasnifi masalasi ham ancha murakkabdir, zotan, mustaqil so'zdan 
boshlab, gap, murakkab sintaktik qurilmalar, abzats, bob kabilarning barchasi matn komponentlari jumlasiga kiradi».[ Турниёзов Н. Матн лингвистикаси. - Самарқанд, 2004, 24-бет.]

Mikromatn sifatida biz talqin etayotgan murakkab sintaktik qurilma abzatsning boshida, oxirida, o'rtasida ham kelishi mumkin (masalan, qo'shma gap, murakkab qo'shma gaplar). Bu, o'z navbatida, abzats bilan murakkab sintaktik qurilma makromatnning fragmentlari sifatida bir-biridan keskin farqlanishini ko'rsatadi.[Пешковский А.М. Русский синтаксис в научном освещении.M.,1956.-C.459.]

Xitoy tilida mikromatnlarning derivatsiyasi, sintaktik derivatsiyalarnin gap tarkibidagi so'zlar, ya'ni operator va operand tushunchalarni tarkibga ajratish yuzasudan ba'zi muammolarga duch kelishimiz mukin, chunki xitoy tili amorf tillari guruhiga kirganligi bois ushbu tilda qo'shimchalar juda ozchilikni tashkil qiladi va ushbu qo'shimchalar gam aynan so'z tarkibida kelmasdan, balki alohida qo'llaniladi. Mikromatn sintaktik derivatsiyasini xitoy tilida talqin qilish jaroyonida yo'l harakati belgilar va avtobus, poyezd, metrolar, bozorlar yoki chiqindi tashlash joylaridagi yozuvlar, ya'ni aynan mikromatnlarni tahlil qilishimiz mumkin. Misol uchun: “禁止吸烟”, “欢迎光缆”,

“入口”，“进口”kabi bir qator nishonlar shular jumasidandir. [https://jingyan.baidu.com/]。

\section{Фойдаланилган адабиётлар рўйхати}

1. Turobov "Til birliklari qo'llanilishining derivatsion tamoyillari”, o'quv-uslubiy majmua, Samarqand-2019, 4b.t.

2. Турниёзов Н. Матн лингвистикаси. - Самарқанд, 2004, 24-бет.

3. Пешковский А.М. Русский синтаксис в научном освещении.-М.,1956.-С.459.

4. https://jingyan.baidu.com/

\section{YAPON TILSHUNOSLIGIDA SHEVASHUNOSLIK TARAQQIYOTI}

\section{Qodirova Mohigul Ihom qizi (SamDCHTI 2-kurs magistranti)}

\section{dialectology.}

Annotation: This article describes the literary language of Japanese and its place in

Key words and expressions: dialect, standard language, International language, Japanese dialect, Kansai dialect.

Yapon tilida so'zlar, grammatika, talaffuzlarning ma'lum bir hududlarga ko'ra turli-tuman shakllari mavjud. Masalan: “umumiy til” (kyoutsugo) da “nega” ma’nosidagi「なぜなのかー (nazenanoka)」so’ziKansaida「ナンデヤネン (nandeyanen)」“mazali”ma’nosidagi「おいしいoishii」Kyushyuda「ウマカ-umaka」“xayrli kech”ma’nosidagi「こんばんはーkonbanwa」so’zi Toxokuda「オバンデスー obandesu」 ${ }^{104}$ kabi shaklda ishlatiladi. Bunday hududlarga ko'ra farqlanuvchi so "zlar "dialekt" deb nomlanadi.

"Dialekt" tushunchasi ma'lum bi rhududning xususiyatlarini o'zida jamlab,

"adabiy til" va "umumiy til"dan farqlanuvchi so "zlarni anglatadi. FuruseJyunichi

(2001)“dialekt"tushunchasiga quyidagicha ta'rif beradi:

1. "Dialekt" juda keng tushuncha hisoblanadi. "Dialekt" tushunchasi keng ma'noda Nagasaki shevasidagi “batten”「バッテン」Osaka shevasidagi“egennai”「エゲッナイ」kabi so’zlarni "dialekt" yohud shevadagi so"zlar deb ataladi. Boshqa hududlar bilan keskin farq qiladigan bunday so "zlar har doim ham "dialekt" deb atash to'g'ri bo'lavermaydi. "Dialekt" so'zi yanada keng tushuncha hisoblanib, ma'lum bir hududning umumiy tilining bir ko'rinishiga nisbatan ishlatiladigan tushunchadir. Umumiy tilning bir ko'rinishi bo'lgani uchun fonetik, grammatik, leksik jihatdan umumiy til barcha jihatlarini qamra bolgan til sistemasiga "dialekt" deb ataladi. ${ }^{105}$

\footnotetext{
104 大西拓一郎（2008）「現代方言の世界」第一章

${ }^{105}$ 古瀬順一( 2001)「国語学概説」 p235-236
} 
2. "Dialekt" - ma'lum bir hududda iste'molda bo'lgan umumiy til sistemasining bir ko'rinishi. Asakura Kunizo (2011/2012) esa "sheva" tushunchasiga ma'lum bir tilde mavjud bo"lgan hududiy yil shakllari - bu "hududiy sheva" deb nomlanadi. Bundan tashqari jamiyatdagi tilshakllari hisoblanmish "ijtimoiy sheva" lar ham mavjud. "Sheva" ning ham "Til"ning ham til sistemasi va xususiyatlari bir xil. Tilda turli xil tilshakllari mavjud. Ma'lum bir tildagi "adabiy til" yoki "umumiy til" ga nisbatan hududiy o'zgarish bo'lib, siyosiy, madaniy omillarning tashqi lingvistik faktorlariga ko"ra nomlangan holatda "sheva" deb atash to 'g'riroq. Ma'lum bir tildagi dialektlar yoki shevalarni tadqiq etishda albatta, shu tilning "adabiy tili" ga murojat etiladi. Yapon tilida adabiy til vazifasini "standart til" (hyoujyungo)bajaradi. Bundan tashqari yapon tilida "standart til" va dialektlar uchun vositachi bo "lgan "umum xalq tili" (kyoutsugo) ham mavjud. Shu o'rinda tilning bu ichki bo"linishlari orasida farqni ajratib olish muhim hisoblanadi. Onishitaku Ichiro (2012) yapon tilidagi "standart tili" va "umum xalq tili" bir-biriga juda o"xshash bo'lib, ba'zida ularni farqlamaslik holatlari ham mavjud. "Standart til" rasmiy til bo'lib, Yaponiya industrial standartlashtirish (JIS) hamda Xalqaro Standartlashtirish Tashkiloti (ISO) tomonidan standartlashtirilgan til shakli bo'lib, o'zbek tilida bu shakl "adabiy til" ga to'g'ri keladi. "Standart til" asosan darsliklar va o"quv qo'llanmalarda, NHK telekanalining axborotlari kabi rasmiy holatlarda foydalaniladi. "Umumxalqtili" esa "standart til" va shevalar oralig'idagi til bo'lib, u turli xil shevada so'zlashadigan aholi uchun umumiy tushunarli bo'lgan ham dastandart til kabi qat'iy qoidalashtirilmagan, rasmiy holatlarda ishlatilmaydigan tilning ko'rinishi hisoblanadi. "Umum xalq tili" barcha shevadagilar uchun umumiy xususiyatlarni o'zida aksettiradi. Masalan, “umum xalq tilidagi”「前」- mae (oldin,old tomon) so’zi Nagoya shevasida「マエデニー maedeni」kabi talaffuz etiladi-yu, shunga qaramasdan boshqa shevada so 'zlashadigan kishilar uchun ham bu tushunarli hisoblanadi. Mana bu "umum xalq tili”ning jamiyatdagi ahamiyati hisoblanadi.

"Kansai” dialekti Tojyo Misaoning G'arbiy dialekti guruhiga, Tsudzuku Tsuneoning G‘arbiy Xonshy guruhiga, Kindaichi Haruhikoning G`arbiy Yaponiya dialekti guruhiga mansub bo'lib, Kansai hududining Osaka, Kyoto hamda Kobe hududlarida ishlatiladigan shevalarini birlashtiradi. Kansai dialekti bir qator o'ziga xos xususiyatlarga ega. Quyida ularning tahlilini keltirib o'tiladi.

\section{Grammatik xususiyatlari「文法」}

a) Inkor shakl「否定表現」

Kansai dialektining eng ko "zga tashlanadigan xususiyati bu-inkor shaklining "umumiy til" va boshqa shevalardan farqlanishi hisoblanadi. Yapon tilining "umumiy til", "kyoutsugo" da inkor

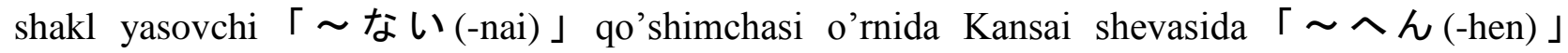
qo'shimchasi ishlatiladi. Masalan, “ketmoq”, “bormoq” ma’nosini beruvchi-iku (行く) fe'lining inkor shakli“ umumiy til”da「行かない(ikanai)」bo’lsa, Kansai shevasida esa「行かへん (ikahen)」 ga o'zgarib ketadi.

b) Inkor so'roqs hakli「否定疑問」

Inkor so'roq shakl「〜じやない」 ya'ni,“-jyanai”Kansai dialektida「〜ちやう」“chyau"ga aylanib ketadi. Masalan: 「行くんじやない?」 $\rightarrow$ 「くんちゃう?」 (ikunjyanai $\rightarrow$ ikunchyau).

\section{Leksik xususiyatlari「語彙」}

Kansai shevasining leksik xususiyatlari o'zigaxos. Undagi so'zlar "umumiy til" va "standart til"dan butunlay farq qiladi. Masalan: "yangi" ma'nosini beruvchi "umumiy til"va“standart til"da

「あたらしい-atarashii」deb talaffuz qilinadigan so’z Kansai shevasida butunlay o’zgarib「さら -sara」so’zi ishlatiladi. Umumiy tilda “rostdan, haqiqatan” ma'nosini anglatuvchi「実際はjissaiva」so’zi o’rnida Kansai dialektida「しょうみ-shyomi」so’zi ishlatiladi.

“Umum xalq tili”danarx ma’nosida “qancha”「いくら-ikura」so’zi o'rnida「なんぼ-nanbo $」$ ishlatiladi. Bu kabi leksik xususiyatlarning muhim bir jihati shundaki, Kansai shevasida bunday leksik birliklar bilan bir paytning o'zida "umum xalq tili"dagi shu so'zlarning ekvivalenti 
ishlatilmaydi. Ushbu dialektning yana bir o'ziga xosligi shundaki, bu shevada ko'proq "mumtoz yapon tili”ning saqlanib qolganligidir. Shu jihatdan Kansai shevasi「伝統性のある」ya’ni, o'zida“an'anaviylikni saqlagan" sheva deb ataladi.

3. Fonetik xususiyatlari「音便」

a) Kansai shevasining fonetik xususiyatlari o'ziga xos xususiyatlarga ega.

Kansai shevasida unli tovushlar aniq talaffuz etiladi. Jarangsiz tovushlar Sharqiy Yaponiya shevalari bilan taqqoslaganda, xususan, shimoliy hududlar (北陸) hamda tog'li hududlarga（山 陰 ) nisbatan kam uchraydi. Yonma-yon kelgan unlilarning qo'shilib talaffuz etilishi kuzatilmaydi. Aynan「う」 unlisi cho’zib talaffuz etiladi. Masalan, おはようございますうー ohayogozaimas emas, balki ohayogozaimasuu tarzida yoki fe'lning kesimlik shakli hisoblanmish $「$ です・ます形-“desu-masu”shakli」“standart til”yoki“umumiy til”da“des-mas”tarzida talaffuz etiladi, ammo Kansai shevasida「ですう・ますう-desuu-masuu」shaklida“u”unlisi cho’zib talaffuz etiladi.

b) ガ行鼻音“ga”qator burun tovushlari mavjud emas. Bu ko’proq sharqiy dialektlarga, xususan, Tokyo shevasiga taaluqli.

c)「せ-se」va「ぜ-ze」tovushlari Kansai shevasida「しえ-shye」hamda じえ-jye」 tarzida talaffuz etiladi. 「せ」va「ぜ」kelib chiqishidan Kanto shevasiga taaluqli bo‘lib, G‘arbiy hudularning barcha shevasida ancha oldindan「しえ -shye」yoki「え -jye」tarzida talaffuz etilib kelgan.

d) ワ行五段動詞の連用形 ya'ni“wa” qatorfe'llariningsifatdoshshakli ウ音便」一 “u”unlisiga aylanadi.Masalan:こーた（買った）、ゆーた（言った）、おもーた（思った） kabi.

e) Kansai dialektida inkorshaklni ifodalaydigan「〜へん- hen 」qo'shimchasi「ヒン hin」 shaklida ham talaffuz etiladi. Masalan:Minami Masahikoning fonetika nalizi natijasida progressive va regressive assimilyatsiya hodisas isodir bo'lishi kuzatilgan. Masalan:Osakada「でけ ヘン -dekehen」 yoki「書けヘン - kakehen」 so'zlarida regressive assimilyatsiya, Kyoto shevasida esa「できヒン - dekihin」 progressiv assimilyatsiya sodir bo'lgan. Buni asoslash uchun adabiy til sifatida vujudga kelgan "umumiy til”, “kyoutsugo” da buso’z「できない -dekinai」 so’zi bilan qiyosiy tahlil qilganimizda o’zak でき+ヘン=でけヘン tarzida shakllangan. Ya’ni tovushlar moslashuvi assimilyatsiya hodisasi sodir bo'lgan. Osaka shevasidagi「でけヘン dekehen」so'zidagi「ヘン」 inkor qo'shimchasi o’zakdagi「き」tovushiga ta'sir qilib,「け」ga o'zgartirib yuborgan. $\mathrm{Bu}$ yerda regressive assimilyatsiya hodisasin iguvohi bo'lish mumkin. Kyoto shevasida esa bu qo'shimcha「ヒン - hin」tarzida talaffuz etiladi. Buning sababi o’zakdagi「き-ki $」$ tovushi「ヘン-hen」qo'shimchasini o’ziga moslashtirib progressive assimilyatsiyani hosil qilgan.

Maskur maqolamda Kansai shevasida Tanaka Tetsuya nazarda tutmagan yana bir qator xususiyatlar mavjudligi ko'rildi. Jumladan, fonetik xususiyatlardan biri bo'lmish ガ行鼻音- “ga” qator burun tovushlarining mavjud emasligi, 「せ-se」va「ぜ-ze」tovushlari Kansai shevasida「 しえ-shye」hamda「じえ-jye」tarzida talaffuz etilishi，ワ行五段動詞の連用形 ya'ni “wa” qator fe'llarining sifatdosh shakli「ウ音便」— “u” unlisiga aylanishi, fe'lning inkor shaklini yasovchi

「ヘン - hen 」 qo'shimchasi qo'shilganda so’zlarda assimilyatsiya hodisasi yuz berishi kabi xususiyatlarni ham ko'rish mumkinligi ham aniqlandi.

\section{Фойдаланилган адабиётлар рўйхати}

1. 大西拓一郎（2008）「現代方言の世界」第一章

2. http://kansaiben.web.fc2.com/jisho.html 東北大学学友会文化系準加盟団体「関西弁 の集い」関西弁辞書（ver.1.3）

3. 古瀬順一 (2001) 「国語学概説」p235-236 


\title{
OMON MATCHON LIRIKASIDA TABIAT TASVIRI VA U BILAN BOG'LIQ POETIK OBRAZLAR TALQINI
}

\section{Abdujabborova Aziza Baxtiyorovna (Urganch davlat universiteti Adabiyotshunoslik mutaxassisligi magistranti)}

\begin{abstract}
Annotation: Analysis and research of spiritual and cultural heritage, critical study, mastery of the events of the current literary process, aesthetic evaluation form the basis of literary science. Accordingly, this article reveals the peculiarities of the poetry of the well-known artist Omon Matjon, describing his philosophical observations, the experiences of the lyrical hero more in relation to nature. Many of his poems are full of spiritual experiences and poetic images related to nature. The poet's poems depict the use of images of nature and poetic images. The originality of Omon Matjon's work, the harmony of creativity and skill will also be covered. The poet's lyrics reflect the existing being, the universe and life, man and his joys, sorrows and pains, nature and society. Omon Matjon's lyrical symphony, which many prose writers fit into short stories and novels, has been composed into lyrics. It is stated that he paid great attention to the language of symbols, the environment in which he lived, the figurative attitude to the realities he felt, the figurative observation. It is widely reported that he approached each image individually and revealed the truth of life.
\end{abstract}

Key words and expressions: Poetic image, stylistic uniqueness, lyrical hero, philosophical observation, social relations, aesthetic taste.

Ma`naviy-madaniy merosni tahlil va tadqiq etish, hozirgi adabiy jarayon hodisalarini tanqidiy o'rganish, o'zlashtirish, estetik baholash adabiyot ilmining asosini tashkil qiladi. Ma'lumki, ijtimoiy-siyosiy, falsafiy tizimlarning o'zgarishi, avvalo, insoniyat dunyoqarashlarning makon va zamondagi o'rin almashunividir. Bu, shubhasiz, yangi tushunchalar, talqinlar, tasavvurlar silsilasini yuzaga keltiradi. "Inson va jamiyat munosabatlarini, ijtimoiy voqelikni yangicha idrok qilayotgan e'tiqodning shakllanishi, o'zligini namoyon etishi ham bu holatning tasdig'idir. Mustaqillik asnosida, umumbashariy qadriyatlarga tayangan, go'zallik-ezgulik-adolat tamoyillariga asoslangan adabiyot ilmi qaror topdi; adabiyotshu-noslik ilmi yangi-yangi talqin va tahlil metodlari, usullari bilan o'z imkoniyatlarini kengaytirib bormoqda.'[Umurov 3:12]

Yurtboshimiz Shavkat Mirziyoyev 2017-yil 3-avgust sanasida ko'plab ziyoli vakillar, fan arboblari, adabiyotshunos olimlar-u ijod vakillari bilan davra suhbati olib borgan. Shunda ushbu purma'no fikrlarini keltirib o'tgan edilar: “ Adabiyot va san'atni, madaniyatni rivojlantirishxalqimiz ma'naviy olamini yuksaltirishning mustahkam poydevoridir. Bizning havas qilsa arziydigan tariximiz bor. Havas qilsa arziydigan ajdodlarimiz bor. Havas qilsa arziydigan beqiyos boyliklarimiz bor. Va men ishonamanki, nasib etsa , havas qilsa arziydigan buyuk kelajagimiz, buyuk adabiyotimiz, san'atimiz ham albatta bo'ladi',. "Yuqorida keltirilgan fikrlarda ayni haqiqat mujassam. "Va men ishonamanki, nasib etsa , havas qilsa arziydigan buyuk kelajagimiz, buyuk adabiyotimiz, san'atimiz ham albatta bo'ladi." Mana shu satrlarga amal qilgan holda, havas qilsa arziydigan adabiyot yaratishda o'zining ijod yo'liga, ijod taktikasiga ega ijodkorlardan biri Omon Matjonning lirikalariga murojaat qilmoqchimiz.

Adabiyotshunoslik ilmida yangi o’ziga xos talqin va tahlil metodlari, usullari bilan o'z imkoniyatlarini o'zgacha uslubda qo'llay olgan ijodkor Omon Matjon asarlariga to'xtalib o'tamiz.

Omon Matjon falsafiy mushohadalarini, lirik qahramonning kechinmalarini ko'proq tabiat bilan bog'liq holda tasvirlaydi. Uning juda ko'p she'rlarida tabiat bilan aloqador ruhiy kechinmalar, shoirona tasvirlar uchraydi. "V.G.Belinskiy "Tabiat, Gyote uchun g'oyalarning ochiq kitobi edi. Pushkin uchun esa u to'liq tavsifga sig'maydigan, ammo sokin va sehrli jonli surat edi...” deydi. “

Ijodkor Omon Matjon asarlarida tabiat jozibalarini, sehrli sir-sinoatlarini ayniqsa, yil fasllarining maftunkor, o’ziga xos holatlarini hamda hodisalaridan foydalangan holda lirik asarlar yaratganligini kuzatish mumkin. Ko'pchilik sohir qalam egalari bo'lmish ijod vakillari maftunkor bahordan ta'sirlanib ijod qilgan bo'lsalar, Omon Matjonga qahraton qish va uning oppoq qorlari, ayozli kunlari ilhom manbai bo'lib xizmat qilganligini uning lirikalaridan ko`rish mumkin. 
Qor bosgan oq-oppoq dalada ko'rdim,

Qimir etmay turar tun qora tulpor,

Qish obdon bekitgan cho'ng qora toshning

Besh-olti joyida erigandek qor.

Shoir o’z asarlarida faqat bu fasldan ta'sirlanib ijod qilgan desak, yanglishgan bo'lamiz, u nafaqat qish balki, tabiatning to'rtta fasli holatlaridan ham unumli foydalangan holda qalam tebratgan. Unga tabiatdagi ko'pgina unsurlar poetik obraz va badiiy tasvir rolini o'tagan: Qish orqali yoritmoqchi bo'lgan asarlarida: qishning ziynati bo'lmish qor, izg'irin shamollar, Xorazm vohasining qattiq sovug'i, billurdek tovlanadigan muz parchalari, Amudaryoning mavjli to'lqinlari, suvlari ; bahorni ifoda qilgan lirikalarida esa nafis gullar, vohaning olovtaft sahrosi-yu, Xorazm vohaga xos bo'lgan gujum daraxti , o'simliklari, sayroqi qushlari, adabiyotda hijron fasli bo'lmish kuz orqali ham sarg'aygan barglar, kabi poetik obrazlar g'oyaviy-badiiy maqsadni to'la gavdalantirishga xizmat qilgan.

Shu yil yoz, To'rtko'lda qayiqda o'tib,

Dilim to'lqinlandi, ko'zim yoshlandi.

Amudaryo suvi sho'r edi, taxir-

Hovuchimdan ko'z yoshidek tashladim. [Matjon 1:309]

Shoir lirikasida mavjud borliq, koinot va hayot, inson va uning shodligi, hasrat-u alamlari, tabiat va jamiat o'z aksini topgan. Ko'pchilik nosirlar qissa va romonlarga sig'dirgan hayon sinfoniyasini Omon Matjon lirikaga jamlay olgan. Ramzlar tiliga katta e'tibor berib, o'zi yashayotgan muhit, o'zi his qilayotgan haqiqatlarga obrazli munosabat bildirishga, obrazli mushohada yuritishga intiladi. Har bitta obrazga alohida yondoshib, hayot haqiqatini ochib beradi. Yuqorida keltirib va to'xtalib o'tgan qish mavzusida yoritgan, hayot, borliq va shu kabi mavzularni qalam ostiga olgan , 1992-yil yozilgan "2-3 -yanvar... Xorazm” sh'erini mushohada qilib ko'ramiz:

Xorazmda qor yukidan og'ochlar sindi.

Kun-tun falak tegirmoni muz sepdi go'yo.

Qurib..., ko'kka uchib ketgan Jayhunning endi

Bulut bo'lib tushishidan bormi bir ma'no?! [Matjon 1:6]

Bu misralardan ko'rinyapdiki, shoir dastlab o'zi tug'ilib o'sgan diyorining iqlimini, haroratini ilk so'zlarida oshkor qilyapdi. Ya'ni, Xorazmda qorning ko'p bo'lishi, hatto daraxtlarni sindirish darajasida yog'ishini, natijada shunga mos ravishda sovuq, izg'irin bo'lishini anglashimizga ishora qilmoqda. Barchaga ma'lumki, hududda qorning ko’p yog'ishi kelasi yil uchun tabiiy suvning ko'p bo'lishiga, kunning sovuq, izg'irinli bo'lishi esa ekinlar zararkunanda hashoratlarining g'umbak (qishlovchi tuxumlari) hamda kasalliklar qo'zg'atuvchi bakteriya, zambrug'larning nobud bo 'lishiga olib keladi, natijada kelasi yil tuproq unumdor, ekinlar hosildor bo ’lishiga zamin yaratiladi. Ijodkor misralarida ana shu misralari orqali voha tabiatining o`ziga xos xususiyatlariga har tomonlama e'tiborini qaratgan deb bilamiz. Ham o'z ma'nosidan ham ko'chma manosidan buni anglab olamiz. Ijodkorning keyingi misralari bilan tanishamiz:

Ko'p davrlardan buyon Jayhunning ( ya `ni, Amudaryo) o`ng va so ‘l qirg'oqlarida joylashgan o`tiroq xalqning tiriklik manbai, insoniyatni boqib kelyotgan ona daryoning suvsiz qolishi-yu, jahon inqirozi bo`lmish Orol dengizining qurishi, endi uning bulutga aylanib yo'qolishidan ijodkorning xavotirda ekanligi bayon qilingan. Hayot haqiqatining nechog'lik teran tafakkurga ega ekanligini keyingi misralarda chuqurroq anglaymiz.

Oyoqlarin muz novdalar qo'yvormay ushlab,

Parvozlari qotishgandek sovuq temirga,

Shoxlar aro panoh topgan junjikkan qushlar,

Daraxtlarga qo'shilishib , qulashdi yerga. [Matjon 1:6]

SHoirni hayratlantirgan, unga zavq bera olgan, mavjud Vatan tushunchasini yanada teran anglashga undagan narsa: shu zaminda yashashi va bu qadim makonning shoirona yurakni bergan tabiati bilan ham bog'liqdir. Ba'zan “...odamda shunday holat sodir bo'ladi. U nimadandir yuragi 


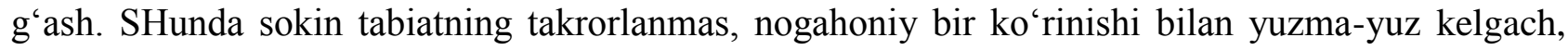
barchasi unut bo'ladi» [Sarimsoqov 4:4]

Kuzning oxirgi oylarida butun tabiatning uyquga ketshini, borliqda sukunat hukmron bo'lishini, ayniqsa kurashdan to'xtab, tin olish uchun qilich va sovutini yechib qo'ygan jangchilarga mengzagani juda takrorlanmas tashbeh bo'lgan. She'rning yaratilgan yiliga e'tibor beradigan bo'lsak, o'z mustaqilligimizni qo'lga kiritganimizdan keyingi dastlabki yilda yozilgan. Bu degani o'zbek xalqi uchun qora tunlarning ortda qolganligini, hamma sinovli, g'alayonli va isyonli, shovqinli kunlar ortda qolib, tinchlik zamoni kelganligini; kuzda bo'ladigan tabiiy jarayonga o'xshatganligi esa ijodkorning mahoratini yana bir bor ochib bera olgan. Tahlikali zamonda, hali atrof-muhit to'la sokinlikni qo'lga kiritmasadan turib,shoirning mustaqillik yillarining ilk pallasida bunday mavzuni ko’tarib chiqqanligining o'zi bir katta jasorat edi.

Kuz. Tunni kutmaymiz. Chunki osmon

Bugun teran va sof. Bugun mukammal.

Taqdir, ehtirosli umr ishlarin

Doim, shunday qo'lla! Va shunday et hal! [Matjon 1:7]

Endi bu yerda ijodkor, butun mavzu ko'lamini kengroq ochib bergan. O'tmishda bo'lib o'tgan hodisalarni, jarayonlarni, mashaqqatli kunlarni yengib o'tshimizda ko'mak bergan yaratgan egamdan minnatdor bo'lish kerakligini, shunday sokin hayotga yetqizgani uchun shukronalik hisini tuyishimizni bizga "Taqdir" so'zi orqali ishora qilmoqda. Taqdiri azalda yozilgan qismatni yashaysan, bizga anashunday fayzli kunlarni ko'rish nasib qildimi, demak biz baxtli insonlarmiz demoqchi nazarimda.

Omon Matjon ijodining o'ziga xos bir jixati muallifning umumlashtirish san'atidir. U o'quvchida xajman ixchamgina parchadan ham bir dunyo ma'no olish imkonini beradi. Tasvir jilosi, lo'ndaligi va undagi fikrlar ko'lami kishini xayratga soladi. Muallifning uslubida asosan to'rt jixat yaqqol ko'zga tashlanadi. Birinchisi, ijodkorning atrof - muhitni teran idrok etishi, mavzuni tanlashi va uni real va hatto naturalistik tasvirda berishi; ikkinchisi, shu mavzuni o'zining bilim doirasida ilmiy - amaliy taxlil qilib, badiiy tarzda ifodalashi; uchinchisi, o'ziga xos uslub har so'zni rostini bitishi; to'rtinchisi, ana shu jixatlarni yuksak badiiy saviyada o'quvchiga yetkazish xusiyatidir. Ijodkorning bu uslubida tabiat manzaralari aloxida o'rin tutadi. Muallifning taxlil uslubi o'zi ko'rgan, kuzatgan narsalarda namoyon bo'lib, ayniksa tabiat manzaralarini yoritishda ulardan keng foydalanilgan. Ijodkorning yana qor obraziga diqqatini qaratganligini ko'ramiz.

To'rt fasl ham xo'bdir O'zbekistonda,

Har biri o'z fe'li, yo'rig'i bilan.

Lekin bu yil qishda ko'p kutdim qorni

Oqligi, sofligi, sovug'i bilan.

Qor obrazi orqali endi bu safar oqlikni, poklikni, beg'uborlikni nazarda tutmoqda. Qor obrazi orqali o'z badiiy niyatini to'la ochib beraolgan. " Badiiy asardagi har bir so'z tasviriy vosita hisoblanishi mumkin, chunki u, albatta, mazkur asar mazmunini ifodalashga xizmat qiladi. Shunga ko'ra, ijodkor voqelikdagi hodisalarni aks ettirish va baholash uchun zarur so' $z$ topa bilishlari lozim. Ulami o'z o'mida qo'llash va ular vositasida ko'zda tutilgan ma'noni to'g'ri ifodalash ustida tinimsiz mehnat qilishlari kerak. Tasviriy-ifodaviy vositalar va tilning maxsus leksik imkoniyatlari nihoyatda ko'p." [Xudoyberdiyev 2:98]

"Adabiy asarlaming badiiy jihatdan mukammal chiqishida epitet, o'xshatish, metafora, metonimiya, giperbola singari tasviriy-ifodaviy vositalar ham muayyan vazifani o'taydi. Ijodkorlar bunday maxsus vositalar yordamida o'zlari tasvirla-yotgan narsa-hodisalarning ba'zi bir tomonlarini yoki belgisini aniq va qisqa xarakterlab berishga erishadilar. Ijodkor har bir hodisani aks ettirganda, uning muayyan sharoitda muhim hisoblangan sifatini ajratib ko"rsatadi." [Xudoyberdiyev. 2:105]

Peyzaj she'riyatda ruhiyat tasviri prinsiplaridan yana biri, - bu «Tabiat bilan bog'liq poetik tafsillar vositasida» amalga oshadi. Ma'lumki, badiiy tasvirda tafsillar, ya'ni detallar muhim ahamiyat kasb etadi. Zotan, «...San'atning barcha shakllarida voqelik obrazlar vositasida aks 
ettirilar ekan, bu obraz voqelikning aynan o'zidan... iborat emas. San'at asarlaridagi har bir obraz ijodkor shaxsining hissiy va aqliy idrokidan o'tgan voqe'lik parchasi» [SHaropov 5:49] sifatida poetik tasvirdan o'rin oladi.

Omon Matjon ijod namunalarida yuqorida keltirilgan o'xshatish, metafra, metanimiya, sinekdoxa-yu giperbalardan unumli foydalangan. Har bitta tabiat tasviriga oid so'zdan mohirona foydalangan. Hayotni, borliqni, tabiat va jamiyatni teran nigoh bilan kuzatgani yaqqol ijod namunalarida nomoyon bo'lgan. Uning nigohidan tabiatning hech bir jihati chetda qolmagan. Omon Matjon ijodida tabiat va undagi obrazlar xuddi o'q va yoydek uning ijodiga xizmat qilgan. Tabiat unga yoy bo'lsa, undagi obrazlar, mayda detallar, elementlar o'q vazifasini bajargan deyish mumkin. Ya'ni, ijodkor nimaniki maqsad qilib, nishonga olgan bo'lsa, anashu obrazlar orqali o'z ijodiy maqsadiga erishgan.

\section{Фойдаланилган адабиётлар рўйхати}

1. Omon Matjon. “Iymon yog'dusi”.- saylanma . Toshkent: G'ofur G'ulom nashryoti, 1995

2. Erkin Xudoyberdiyev. "Adabiyotshunoslikka kirish"- TOSHKENT «Iqtisod»2007

3. Hotam Umurov. "Adabiyotshunoslik nazariyasi" - Abdulla Qodiriy nashryoti-2004

4. Sarimsoqov B. Badiiylik asoslari va mezonlari. T.: O'zR FA, TAI nashriyoti, 2004. 4-bet

5. SHaropov A. YUlduzli osmon sehri. T.: Adabiyot va san'at nashriyoti, 1983. 49-bet.

6. Qobilova Sitora Qobil qizining “ATOYI G'AZALLARIDA TABIAT MANZARALARI TASVIRI" mavzusida yozgan referati.

7. Internet ma'lumotlari: Ziyo.uz.

\section{UNIVERSAL VALUES IN THE STRUCTURE OF UZBEK MEDIA TEXTS (as the sample newspaper Hurriyat)}

\section{Yakhyayeva Navruza Kholbutayevna (Teacher of USWLU, International journalism faculty, department of intensive teaching of the second language)}

Annotation: In this article author shows linguacultural aspects of universal value in meditext.Text Linguistics, which deals with the creation, modeling of its structure

and the study of the process of such activity, is of interest to journalists today as a science. This is due to the fact that linguists describe the modern state of the living language by scientists on the basis of various factors, proceeding from a wide spectrum of linguistic and colloquial traditions.

Key words and expressions: universal values, globalization, mass media, society, text, language, linguaculture.

In recent years in our country, principles corresponding to its model of social, economic, spiritual development, our national self, rich cultural heritage, traditions, customs, traditions and a specific national spirit, formed on the basis of them, have begun to be created. In particular, the media also began to reform its activities again. Modern media is capable of delivering information to a multi-digit audience. In turn, the media should be a specific pulpit, which allows each person to freely express his or her opinion. The ultimate goal of the reforms is to ensure that the mass media serve as a specific framework for the protection of the democratic values of our society and the formation of the political, legal, economic, spiritual consciousness of people.Moreover, it should be borne in mind that traditional spiritual and moral values are "stable values that pass from one generation to another, inherited from previous generations, have a timeless character and are essentially world-preserving" [Dyachkova 2007:141]. Since traditional universal values are expressed in the divine commandments of different religions, they have acquired the character of national and universal values.

The relevance of media linguistics as a new systematic approach to the study of the media language is due to the fact that mass media texts, or media texts, are today one of the most common 
forms of language existence. Indeed, the second half of the XX-beginning of the XXI century is characterized by the rapid growth of a new sphere of speech consumption, mass communication. The dynamic development of traditional media: print, radio, television, the emergence of new computer information technologies, and the globalization of the global information space have a huge impact on the production and distribution of words. All these complex and multi-faceted processes require not only scientific understanding, but also the development of new paradigms for practical research of the media language.

The second half of the XX - beginning of the XXI century is characterized by rapid growth of mass communication and new information technologies. Dynamic development of traditional media - print, radio, television, appearance and distribution. The world wide web - the Internet led to the creation of a single information space, a special virtual environment formed by the combination of many media streams. All this could not but affect the processes of production and distribution of the word, the features of speech use and the nature of language changes.

The main volume of speech use today falls on the sphere of mass communication. Mass media texts, or media texts, are one of the most common forms of modern language usage, and their combined length far exceeds the total volume of speech in other spheres of human activity. At the same time, the body of texts produced and transmitted daily through the media channels continues to constantly increase. This, in particular, can be judged by quantitative indicators: the number of television channels is growing (in the US it reaches seventy-five, including cable TV), their further specialization is taking place - there are mainly news channels (for example, CNN-Cable News Network), entertainment (MTV), sports (Eurosport), educational (Discovery Channel), music, etc.[Joanna Wasiluk 2019:19] There are new radio stations, new Newspapers and magazines designed for a wide audience, as well as to meet the interests of a wide variety of age, professional and social groups.

Communication on the World Wide Web makes a huge contribution to the constant growth of the mass of media speech. The spread of online versions of printed publications, the appearance of online publications - all this contributes to an increase in the total number of texts functioning in the global information space, which is considered by researchers as a special sphere of speech consumption, which has its own characteristics and features.According to uzbek scientists G.Bakieva and

D. Teshabaeva,these new areas of linguistics are united. All of them represent the dialectical integrity of linguistic and mass media characteristics and will have three appearances of the mediaspeech; text consisting of words, video recorder or graphic image scale,sound volume scale (soundscale of harmony)[Bakiyeva G.X., Teshabayeva D.M. 2019:4]

Considering that the fundamental spiritual and moral values that serve as the ideal for most people are truth, kindness, justice, freedom, love and charity, we decided to focus our attention on their use. As it turned out, news reports most often used values such as truth, kindness, and justice. Truth, as a rule, appears in phraseological combinations, as well as in combinations with the words simple and absolute, as well as in combination with time segments.

Analyzing the contexts in which the word "mehr-oqibat" is used, they can be divided into two types. First, these are contexts in which mehr-oqibat is perceived as a value that is part of the culture, as well as a human value to strive for.

1)Ko'plab ziyolilar, ijodkorlar qatorida Toshkentga evakuatsiya qilingan, nasl-nasabi yahudiy bo'lgan atoql ishoira Anna Axmatova o'shanda o'z dil izhorini "Men mehr-oqibat nimaligini Toshkentda o 'rgandim” deya ifodalaganedi. Ha, mehr-oqibat, bag 'ri kenglik hamisha xalqimizning eng ulug' fazilati bo'lib kelgan va budan keyin ham shunday bo 'lib qoladi.[https://uzhurriyat.uz/2018/05/25/o-zbekiston-najot-qal-asi-men-mehr-oqibat-nimaliginitoshkentda-o-rgandim/];

2)Oyna-ko 'ngilni ola bilish, dilga iliqlik baxsh etish, o'z aksiga qarab fikr yuritish tuyg'usi inikosi. Kirishimli, dilxushlik er-xotinning munosabatini bezaydi, mehr-oqibatni bir-biriga bog 'laydi. Har ikkitarafda ushbu fazilat mujassam bo lsa, oila oynasi yorqin, tiniq bo ladi. Tashqaridan ko'rganlar havas qiladi.[https://uzhurriyat.uz/2019/04/03/oila-iroda-sabr-va-sadoqat/]; 3)Ha, bir 
taom bahona ahillik, birdamlik, mehr-oqibat tuyg'ulari yerdan bosh ko'tarayotgan maysalarday gurkirab o'saveradi. Aslida Navro'z shuning uchun ham qadrli emasmi! Shuning uchun ham uch ming yilda necha-necha avlod almashdiyu, bu bayram xuddi mehr kabi, muhabbat kabi hamon bardavomdir. [https://uzhurriyat.uz/2019/03/27/boychechakni-ko-rganlarning-umri-uzun-bo-lg-

usi/];

4) "Bu yer chegara emas, mehr-oqibatning, fayzu barakaning darvozasi bo 'ldi. Xalqni rozi qilaman, deb kunni tunga, tunni kunga ulab mehnat qilayotgan ulug 'larimizdan mingdan-ming rozimiz. Biz et-tirnoq, og 'a-ini qondoshlar qo 'llarimizni ochib hamisha duodamiz", deyishdi ular yakdillik

bilan. [https://uzhurriyat.uz/2018/05/16/el-ham-rozi-ellar-ham-rozi/]; 5)So 'rov o'tkazilgan oilalarning 23 foizi bergan javoblarda ma'naviy-axloqiy qadriyatlarni unutmagan, zamon bilan hamnafas, barchaga ibrat bo 'larli, jamiyatga foydasi tegadigan, otaonasini qadrlovchi, kechirimli, dunyoqarashi keng, vatanparvarlik tuyg'usi shakllangan, o'zaro mehr-oqibatli, kiyinishi badastr, sabr-qanoatli, er-xotin, qaynona-kelin, yaqin qarindoshlar, qudaandalar o'zaro ahilligiga ham alohida e'tibor qaratilgan, [https://uzhurriyat.uz/2019/05/08/zamonaviy-o-zbek-oilasi-qanday-bo-lishi-kerak/].

Second, these are contexts in which kindness is contrasted with negative qualities, such as hatred, envy, and cruelty.

1) Onaman-da, farzandimning ko'proq yonimda bo'lishini, u bilan ko'proq suhbatlashishni, diydoriga to'yishni istardim. U esa «Ona, men hammani sog'inganman. Qishloqda kam bo'laman. Shuning uchun ta'til vaqtida tanish-bilishlardan xabar olib qo'yay, deyman-da. Yana ular meni oqibatsiz bo'lib ketibdi, deyishmasin», degandi. O'shanda xijolat bo'lib qolganman. [https://uzhurriyat.uz/2017/04/18/vatan-uchun-jon-fido-etganlar/];

2) Bunday bemehr va oqibatsiz odamlarni ko'rib, hayron qolasan, kishi. Axir, qaynonasining bu xatti-harakatini ko'rib o'rgangan kelin ertaga atrofidagilarga qanday munosabatda bo'lar ekan-a? [https://uzhurriyat.uz/2017/03/15/oqibat-devorlari-nuramasin/];

3) To'g'ri aytasan, -Jonpo'lat Said shogirdining fikrini ma'qulladi. Men ba'zi bir oqibatsiz odamlarning kimligini bilmagan, behuda o'zimga yaqin tutgan ekanman, deb achinayotganim yo'q, [https://uzhurriyat.uz/2017/02/08/rashidovning-dastxati/].

Analyzing the collected material, we can draw a conclusion about the tendentiousness of most articles aimed mainly at extraordinary events, sensationalism, which subsequently damages the volume of coverage of other topics that accompany the promotion of positive values, a sharp drop in which is noticed by many scientists. Many of these examples show that even if such values do appear, it seems that they are often used for manipulative purposes. This point of view has its own grounds, since, as it is emphasized, at present the form of journalism as an element of the media involves manipulation of the consciousness of the masses.

\section{Foydalanilgan adabiyotlar ro'yxati}

1. Бакиева Г.Х., Тешабаева Д.М. Медиамакондаматн. -Тошкент, 2019. -Б.4

2. D’a ackova M. A., 2007, Pon^ati^acennost' i duhovno-nravstvennyecennosti v pedagogike, «Sibirskijpedagogi`ceskij `zurnal», № 12, Novosibirsk, [Дьячкова М. А.,2007, Понятия ценность и духовно-нравственные ценности в педагоги-ке, «Сибирский педагогический журнал», № 12 , Новосибирск], [online], https://cyberleninka.ru/article/v/ponyatiya-tsennost-i-duhovno-nravstvennye-tsennosti-vpedagogike, [14.08.2017].

3. Добросклонская Т.Г. Вопросы изучения медиа текстов: Опыт исследования современной английской медиа речи. - М.: МАКС Пресс, 2000

4. The Media in Britain. Ed. By Stokes J., Reading A. - London, Macmillan, 1999

5. Mass Media and Society. Ed. By Curran J., Gurevitch M. - London, Arnold, 1999

6. McLuhan M.Understanding Media: Extensions of Man. - London, Routledge, 1994

7. https://uzhurriyat.uz/ 


\section{VATANPARVARLIK RUHIDA YARATILGAN LIRIK ASARLAR TAHLILI}

Zamira Tosheva (SamDCHTI AL)

Annotation: The article deals with a number of attractive lines of patriotic and lyrical poems of the ancient period, created in the spirit of patriotism, as well as examples of the small lyrical poems of our creators.

Key words and expressions: Motherland, Patriotism, creation of Z.M.Bobur, lyrics, poetic, migration of the homeland, artistic heritage, lyrical analysis, lyric pathos.

Bizga sir emaski, asrlar davomida yaratilib xalqimizning umum odatlarini qamrab olgan yagona jamlanma bu - badiiy yoxud ijodiy asarlardir. Mana shu yaratilgan har qanday asarlarni olib tahlil qilishimizdan qat'iy nazar ularda vatan, vatanparvarlik, insoniylik va millatlarning birligi singari ajib hislar bizni bevosita o'z dunyosiga jalb etishiga guvoh bo'lamiz. Nafaqat hozirda yaratilayotgan, balki asarlar osha bizga meros sifatida asralayotgan asarlarda ham biz vatanparvarlik hisslarini o'z asarlari va she'rlariga birinchi maqsad qillib jo qilganlarini ko'ramiz. Albatta, bu maqsadlar samarasiz ketmaganidek, biz yoshlarning shu bilan bir qatorda, har bir insonning yuragida millatimizga bo'lgan hurmat hissini yuksaltirishimizga yoinki sayqallab borishimizga bir poydevor bo'lib kelmoqda deb aytsak ham adashmagan bo'lamiz. Misol tariqasida, buyuk bobokalonimiz bo'lgan va o'zining o'tkir qalami bilan asrlar osha xalqlarimizning qalbiga naqshlanib qolgan Z.M.Boburning asarlarida beixtiyor vatanga bo'lgan sof muhabbat va ayriliq hislari hamda ularning insonga qanchalar ta'sirlari junbushga keltirgan holda mahorat bilan xuddiki, bir rassom singari o'qiguvchi individualning yuragiga o'z prinsipal hislarini ko'rsatmay qo'ymaydi. $\mathrm{Bu}$ zabardast shoirimizning hayot chizgilarini biz bir necha bor takror etganmiz. Shu boisdan hozirda biz u kishining asarlari va ruboiylaridagi purma'no fikrlariga to'xtalib o'tishni joiz hisoblaymiz.

Tole yo'qi jonimg'a balolig' bo'ldi,

Har ishniki ayladim xatolig' bo'ldi .

O’z yerini qo'yib, Hind sori yuzlandim,

Yo Rab, netayin, ne yuz qarolig' bo'ldi.

Ushbu betakror va serjilo hamda hasbi hol tarzida yozilgan misralarni mutolaa qilar ekanmiz, muallifning hayotidagi mashaqqatlarni va asosiysi vataniga bo'lgan yiroqlik iztiroblarini yaqqol guvohi bo'lamiz. Vatanga bo'lgan hijron o'ti hech qanday mubolag'asiz shoirning qalbiga bir on bo'lsada tinchlik va xotirjamlik shukuhini yaqinlashtirmagan. Natijada, quyidagi kabi betakror misralar tug'ilgan va bu qadrli manbaalar, shuningdek, yaqqol ko'rinib turgan hayot tajribasi orqali o'sib borayotgan avlodning ongida ijobiy va sezimli bo'lgan vatanga muhabbat rivojlanib boradi.

Darhaqiqatdan, bizning xazinamiz bo'lgan o'tmishda yozilgan har qanday asar vatan hissining sofligini talqin etadi. E'tirof etganimizdek, Furqat asarlariga nazar tashlar ekanmiz, undagi vatan hijronining naqadar kuchli ekanligini va bu narsa uning hayoti mobaynida hamma asarlariga jo etilayotganligiga amin bo'lamiz. Ayniqsa, bu zabardast va qalami o'tkir ijodkorning "Manam shuurida bulbul" muxammasida talqin etilgan har bir serjilo so'zning zamirida vatanparvarlik ruhi kezib yurdi desak yanglishmagan bo'lamiz. Dalil tariqasida bu shaxsning o'z asarlariga nisbatan tanlagan taxallusi ham vatanga bo'lgan hijron azobini anglatmay qolmaydi,ya'ni "Furqat" so'zining asil ma'nosi ayriliq deganidir va shu sababli Furqatning umri vatanga bo'lgan hijron azobidan tarkib topganligi ham bir ijodiy ilhom bo'lgan deb so'zlasak mubolag'a qilmagan bo'lamiz. Yoinki, bu individual va serqirra yozuvchimiz haqida bizning mustaqillik adabiyotimiz ijodkorlaridan biri bo'lgan A.Oripovning hurmatini u kishiga nisbatan yozilgan bir qancha asarlarida ko'rib o'z isbotini topgan desak ham bo'ladi. Misol uchun "Furqat nidosi" she'rida bir qator tizgin va junbushga keltiradigan talqinlarga bevosita ko'z yugurtirar ekanmiz vatanparvarlik taftining har ikki ijodkorning purma'no so'zlarida mavjlanib, xuddi buloq suvlari singari jimjimador bo'lib turganini ko'ramiz. Modomiki, har bir inson uchun vatan mehri va uning qaynoq tafti shu qadar issiq ekan, uni ta'riflash uchun yoinki, uning hurmati va qadrini ifodalash uchun, bizga shoirlik sir- 
asrorlarining hojati yo'qdir, chunki har qanday inson yoxud hayvon ham o'zi tug'ilib o'sgan diyorini so'zsiz ham o'z quchog'ida, mavjlanib turgan qarashlarida chizib beraoladi.

Biz bir qadar o'zimizning qadimgi xazinamiz hisoblangan o'lmas asarlar vositasida vatanga hurmatni ifodaladik va bu izzatni mustaqillik davrida qay darajada davom etayotganligini yangi davr ijodkorlarining qalam tizginida ko'ramiz va tahlil qilib o'tamiz. Xo'sh, biz kuzatar ekanmiz, har bir badiiy asar, lirik to'plamlar bir vosita orqali yuz beradi, hamda bu aloqa go'yoki, bizning qadimiy udumlar va bobokalonlarimizning serquyosh va serjilo asarlaridir. Shuni hisobga olgan holda, M.Yusuf, A. Oripov, I.Mirzo va shu kabi ijodkorlarning lirikalarida vatan chizgilarini beixtiyor ajdodlar asarlarining vositasi orqali vujudga kelganligini ko'ramiz. M.Yusufning she'rlarini o'qir ekanmiz undagi ajdodlarimizning vatanga bo'lgan mehrini shoirning teran va o'tkir fikrlari bilan birlashib ketganligida va ajib bir go'zallik kashf etganligida ko'ramiz,ya'ni uning "Vatanim " she'rida har bir buyuk bo'lgan ijodkorlarimizning vatan yo'lida qilgan unumdor ishlariga tafsif berilgandir. Dalil sifatida uning bu she'ridan to'rtlik keltirib o'tamiz.

Sen Mashrabsan,

Xalqqa tumor,

Balxda dorga osilgan.

Navoiysan,shoh yonida

Faqirni duo qilgan.

Yassaviysan, meniki deb,

Ko'ringan da'vo qilgan,

Ming bir yog'I ochilmagan

Qo'rig'imsan, Vatanim.

Shak-shubhasiz bu satrlar orqali har bir avlodimizning vatanparvarlik yo'lida ko'rsatgan jo'mardliklarini, shoir o'z muhabbati bilan bir qadar afsonaviy tarzda muhlislar e'tirofiga havola qilgan.

To'g'ri, biz bu satrlar va shu singari baytlardan minglab keltirishimiz va ularning vatan ravnaqi uchun berilgan sernaqsh ta'riflarini aytib o'tishimiz mumkin. Ammo, xulosa o'rnida shuni ta'kidlab o'tish joizki, "Vatanparvarlik" tushunchasi - bu faqat shoir va shoiralarimizning poetik va lirik tizginlaridagina jilolanib qolmasdan, har qaysi insonning tug'ilgan zahoti murg'ak qalbiga kirib boradigan, xuddiki ona allasi singari bir dilbar mehrdir. Haqiqatdan ham vatan mehri ona mehriga o'xshaydi,shu asnoda, qalam sohiblarining "Vatan" so'ziga "Ona " so'zini jipslashtirib,ya'ni "Ona Vatan" deb ta'riflashi ham bejiz emas.Misol uchun M.Yusufning quyidagi satrlari so'zimizning isbotidir.

O, ota makonim,

Onajon o'lkam,

O'zbekiston, jonim to'shay soyangga.

Senday mehribon yo'q,

Seningdek ko'rkam.

Rimni alishmasman bedapoyangga.

Ha, biz bu so'nmas va cheksiz lirik she'rlar orqali Vatanparvarlikning naqadar go'zal mazmunini qiyinchiliklarsiz anglata olamiz. Negaki, bu biz tasavvur qilgandek bir jo'ngina so'z yoxud tushuncha emas. Va shuning uchun, har bir lirik talqinning tagdor zamirida ba'zan biz anglamay qolgan, biroq biz o'qiganda hayajonga tushadigan bir buyuk so'zlar taraladi. Bu so'z Ona Vatan.

\section{Foydalanilgan adabiyotlar ro'yxati}

1. Mirziyoev Sh. Erkin va farovon, demokratik O‘zbekiston davlatini mard va olijanob xalqimiz bilan birga quramiz. O`zbekiston Respublikasi Prezidenti lavozimiga kirishish tantanali marosimiga bag'ishlangan Oliy Majlis palatalarining qo'shma majlisidagi nutq -T.: O‘zbekiston, 2016. -56-bet.

2. Abdulla Oripov. Saylanma. Tanlangan asarlar. 1-4 jildlar. - T.: Sharq, 2000-2001 
3. Normatov U. Ijod sehri. - T.: Sharq, 2007

4. N. Karimov. XX asr adabiyoti manzaralari. -Toshkent: O’zbekiston, 2008.

\section{AXBOROTLASHGAN JAMIYAT TARAQQIYOTINING KONSEPSIYALARI}

\section{Turapov Voxid Mamadiyorovich (SamDCHTI tadqiqotchisi)}

Annotation: It is well known that the formation of factors related to the need of mankind to receive information and its satisfaction has always been the main reason. In this sense, every piece of information disseminated by people has served the interests of the society in which they live, expressing their goals and aspirations. Designed for the convenience and convenience of humanity at a glance, this means of information exchange is now widely used in information attacks between stakeholders involved in various conflicts. That is why life itself requires protection of the population, especially young people, from various harmful influences. It is necessary to be fully aware of the nature of world events, including the development of the information sphere.

Key words and expressions: Information, information society, information culture, civilization, "information revolution".

Har qanday sivilizatsiya insonlar madaniyati va mehnat qobiliyatida ko'rinadi. Ular ilmiy (spekulyativ-dogmatik emas, balki insoniyat tajribasidan kelib chiqqan holda) dunyoqarashga, bilimlarning uzluksiz yangilanishiga asoslanadi. Rivojlangan mamlakatlarni sivilizatsiyaning yangi bosqichiga olib chiqqan taraqqiyotning qudratli lokomotivlari sifatida axborot, boshqaruv mexanizmi va jamoat tashkilotlari edi. Mazkur jarayon XX asrning 60-yillarida boshlanib, 80yillarining o'rtalariga kelib yakunlandi[Абдеев 1994:12].

Axborotlashgan jamiyat mohiyatini o'zida aks ettiruvchi uchta asosiy ilmiy-nazariy yondashuv mavjud bo'lib, ularning birinchisini, amerikalik olimlar F.Maxlup, M.Porat, D.Belning ilmiy yondashuvlari aks ettiradi. Ularning fikricha, axborotlashgan jamiyat mavjudligini asoslovchi mezon - bu axborotlashgan (nomoddiy) sektorning YAIMdagi ulushidir. Ikkinchi ilmiy yondashuv "axborot inqilobi" nazariyasiga asoslanadi. Bu nazariyaga muvofiq, jamiyat qabul qila oladigan axborotning miqdoran oshishi iqtisodiyot taraqqiyotining sifat ko'rsatkichlariga ijobiy ta'sir ko'rsatadi va bu o'z-o'zidan axborotlashgan jamiyatni shakllantiradi. Bunday konsepsiya yapon olimlari T.Umesao, Yu. Xayoshi va Yu.Itolarning ilmiy-tadqiqot ishlarida yoritilgan. Uchinchi yondashuvga ko'ra axborotlashgan jamiyatning asosiy xususiyatlaridan biri - bu AKTning barcha sohalarda keng tarqalishidir. Bunday nazariya yevropalik iqtisodchilar S.Daff, S.Nor va A.Minkalarga tegishlidir[http://uz.infocom.].

Axborotlashgan jamiyat deganda - barcha faoliyat sohalariga intellektual mehnat quroli sifatida dunyoviy bilim manbalariga, kutubxonalariga kirish, ulardan samarali foydalanish, ixtiyoriy (qogozdagi, matn yoki tasvir ko'rinishidagi) axborotni juda qisqa muddat ichida qayta ishlash, jarayonlarni, voqealarni va hodisalarni modellashtirish imkonini beruvchi kompyuterlar va boshqa axborot texnika va texnologiyalar kiritilgan jamiyatni tushunamiz.

Axborotlashgan jamiyatda inson axborotlarni qayta ishlashda zamonaviy vositalar bilan ishlashga o'zini tayyorlashi kerak. Bu shuni ko'rsatadiki inson informatsiyalarga murojaat etishda ma'lum darajadagi axborot madaniyatiga ega bo'lishi kerak.

Axborot madaniyati - axborotlar bilan maqsadga intilib ishlashni bilish va axborotlarni olish uchun, qayta ishlash, kompyuterli informatsion texnologiyani va zamonaviy texnik vositalarni va usullarni qo'llashni anglatadi. Faqat yuqori darajadagi axborot madaniyatiga ega bo'lgan kishilargina tabiiy, ijtimoiy va ekologik resurslarni aniq hisobini qila oladilar. Bu esa barcha tarmoq yo'nalishlaridagi boshqaruv masalalarini tezlik bilan hal etish imkonini beradi va mamlakatni ravnaq topishida muhim o'rin egallaydi.

Axborot jamiyatning eng asosiy mezoni bu har qanday ma'lumotni bir joydan boshqa joyga yuborish va qabul qila olishdir. Texnologiyalar rivojlanib borgan sari, insonlar bir-birlari bilan virtual ma'lumot almashishga moslasha boshladilar. Turli vaqt zonalari orqali ma'lumot almasha 
olishi va boshqa hududda joylashgan axborotlarni topib, qabul qilib ola boshladilar. Bularning barchasi biz uchun odatiy jarayonga aylandi. Biroq, ma'lumot almashish jarayoni orqali ma'lumot vektorlari bizga yanada ko'proq ma'lumot tarqatishimizga imkon berdi. Ushbu vektorlardan foydalanish orqali ma'lumotlar tarqaladi va keyin ularni harakatga keltirgan dastlabki manbalardan ajralib chiqadi. [Wark 1997:24] Shunday qilib, uchinchi tabiat boshqa tomondan "tezlashishi, ko'payishi, bo'linishi, mutatsiyaga uchrashi va nur sochishi" ga qodir. U makon va vaqt chegaralari o'rtasida muvozanatni yaratishga qaratilgan. Buni telegraf orqali ko'rish mumkin, bu insonning ob'ektni siljitishidan ko'ra tezroq ma'lumot yuborishi va olishiga imkon beradigan birinchi muvaffaqiyatli texnologiya edi. Natijada odamlarning turli yo'nalishlari nafaqat madaniyatni shakllantirish, balki jamiyatni shakllantiradigan yangi imkoniyatlarni yaratish qobiliyatiga ega. Shu sababli, ikkinchi tabiat va uchinchi tabiatdan foydalanish orqali jamiyat o'zaro ta'sirning yangi shakllarini yaratish uchun ma'lumot shakllantirilishi mumkin bo'lgan yangi imkoniyatlarni ishlatishi va o'rganishi mumkin. Axborotlashgan jamiyat postmodernizm jamiyat turiga kiradi. Ulrix Bek, Entoni Giddens va Manuel Kastells kabi nazariyotchilar 1970-yillardan boshlab sanoatlashgan jamiyatdan axborotlashgan jamiyatga o'tish global miqyosda ro'y berganligini ta'kidlaydilar.

Bug' kuchi sanoatlashgan jamiyatning asosi bo'lganidek, axborot texnologiyalari ham XX asrning oxirida ro'y bergan samarali mehnatni tashkil qilish, ijtimoiy tuzilish va siyosatdagi o'zgarishlarning katalizatori sifatida qaraladi.

Alvin Toffler jamiyatning ushbu turini tavsiflash uchun super-industrial jamiyat iborasini ishlatgan. Boshqa yozuvchi va mutafakkirlar xuddi shunday ma'noga ega "post-industriyali jamiyat" va "post-industriyali sanoat jamiyati" kabi atamalarni ishlatganlar.

Axborot iqtisodiyoti va bilimlar iqtisodiyoti, mos ravishda, axborot bozori yoki bilim bozori orqali sotiladigan tarkibiy yoki intellektual mulkni ta'kidlaydi. Elektron tijorat va elektron biznes, o'z navbatida, Internet va Butunjahon Internetdan foydalangan holda tranzaksiyalar va biznes yuritish xususiyatiga urg'u beradi. Raqamli iqtisodiyot kosmosdagi atomlarga emas, balki kiberhujumda savdo bitimlariga e'tiborni qaratadi. Tarmoq iqtisodiyotining ta'kidlashicha, korxonalar yakka tartibda emas, balki tarmoqlarda yoki biznes ekotizimlarining bir qismi sifatida birgalikda ishlashadi. Ijtimoiy tarmoqlar ommaviy, global miqyosdagi hamkorlik jarayonini anglatadi. Internet iqtisodiyoti Internet tomonidan faollashtirilgan bozorlarning xususiyatlariga e'tiborni qaratadi. Bilim xizmatlari va bilim qiymati tarkibni iqtisodiy kontekstga qo'yadi. Bilim xizmatlari bilimlar bozorida savdo qiluvchi tashkilotlar tarkibidagi bilimlarni boshqarish tizimini birlashtiradi. Jismoniy shaxslar ko'proq ma'lumot olishlari uchun kuzatuvdan foydalana boshladi. Bu o'z-o'zidan boshqa shaxslarga ma'lumot to'plash uchun foydalanishiga imkoniyat yaratdi.

Axborotlashgan jamiyatning markaziy paradokslaridan biri shundaki, u ma'lumotlarni osongina qayta ishlab chiqarishga imkon beradi, va bu intellektual mulk bilan bog'liq turli xil erkinliklarga olib keladi. Aslida, ma'lumot va bilimlarni ishlab chiqarish va sotish joyiga aylanadigan biznes hamda kapital, ushbu yangi resursni samarali boshqarish, uni axborot iqtisodiyotining asosi sifatida sotish uchun nazorat qilishni talab qiladi.

Axborot almashish erkinligi g'oyasi o'zining falsafiy jihatidan intellektual mulkni himoya qilish va davlat va fuqarolar manfaatlarini himoya qilish, tartib va xavfsizlikni ta'minlashning siyosiy va huquqiy printsiplariga ko'pincha e'tibor bermaydi. Shunday qilib, "ijtimoiy-siyosiy nuqtai nazardan, hamma uchun ma'lumot olish kafolatlanadi; jamiyatning har bir a'zosi telekommunikatsiya tarmoqlaridan foydalangan holda, kosmosda joylashgan joyidan qat'i nazar, har qanday davlatdan har qanday turdagi va maqsadli to'liq va ishonchli ma'lumotlarni o'z vaqtida va tezkor ravishda olish imkoniyatiga ega." [Просвирин 2006:42] Ijtimoiy amaliyotdan ajralib chiqadigan bunday bayonotlar, bilimlar jamiyatining tushunchalariga ijtimoiy utopiya xususiyatini beradi, uning bashorat qilinadigan qiymatini pasaytiradi. 


\section{Foydalanilgan adabiyotlar ro'yxati}

12

1. Абдеев Р.Ф. Философия информационной цивилизации. - М.: ВЛАДОС, 1994. -Б

2. http://uz.infocom.uz/2015/07/30/axborotlashgan-jamiyat-shakllanishining-ilmiy-vanazariy-asoslari

3. Wark, McKenzie (1997). The Virtual Republic. Allen \& Unwin, St Leonards. P-24

4. Просвирин, Ю.Г. Информационное общество и демократия // Вестник ВГУ. Серия «Право». - 2006. - № 1. - С. 42

\section{ИНТЕРПРЕТАЦИЯ СИНТАКСИЧЕСКИХ ТРАНСФОРМАЦИЙ ПРИ ПЕРЕВОДЕ ТЕКСТОВ С КИТАЙСКОГО НА РУССКИЙ ЯЗЫК}

\section{АбдусалямоваТахминаАбдурашидовна (Магистрант, СамГИИЯ)}

Annotation: The article is devoted to the syntactic transformation used in the translation of texts from Chinese into Russian. With in the framework of the topic, the author considered the full translation used at the level of phrases, for example, the book "How the Steel Was Tempered" 钢铁 是怎样炼成的 or "A Dreamin a Red Chamber" 红楼梦 and "Historical Notes" 史记. The purpose of the article is to analyze the syntactic transformations used when translating texts from Chinese into Russian. The author also set several tasks: 1. Consider the types of syntactic transformations during translation; 2. To reveal the place and role of syntactic transformations in translation; 3. Prove the importance of using syntactic transformations when translating newspaper texts from Chinese into Russian. The purpose of the article is to analyze the syntactic transformations used when translating texts from Chinese into Russian.

Key words and expressions: syntactic transformation, translation, transformation, functional replacement, rearrangement, information, translator.

На уровне словосочетаний нередко применяется полный перевод, например, книга 《Как закалялась сталь»钢铁是怎样炼成的 или 《Сон в красном тереме»红楼梦 и «Исторические записки» 史记. Но в большинстве случаев осуществляется неполный перевод, который делится на несколько видов: функциональная замена (изменение лексикосемантического или морфологического статуса одного или нескольких исходных элементов словосочетания); расширение (добавление одного или нескольких элементов в словосочетание); сокращение (пропуск одного или нескольких элементов исходного словосочетания); перестановка (изменение порядка слов в рамках словосочетания или предложения). Рассмотрим более подробно эти виды.

Обзор литературы. Методы. Сокращение: «Путешествие на Запад» 西游记, «Западный флигель» 西厢记. При переводе этих названий произведений опущено слово 记 «записки; история; рассказ»

Расширение: «Цветы сливы в золотой вазе» 金瓶梅, 以史为鉴 (при переводе на китайский язык опущено слово «цветы»), «изучая историю, можно понять причину смены династий» 可以知兴替 (при переводе сократили предложение, опустив слова «причину»и «династий»). При переводе предложений, в которых грамматическая связь является бессоюзной, расширение, или добавление, также необходимо, например: «когда сын уехал далеко, матери неспокойно»儿行千里母担忧, «если кто-то оказался в беде, помощь 
приходит со всех сторон»一方有难, 八方支援, «студент Ли до такой степени беден, что ему даже есть нечего» 李生家贫, 不能举火

Функциональная замена: «Полосатый рейс» (название советского фильма) 运虎记 (букв.: «Рассказ о перевозке тигров»), 贵妃醉酒 «Охмелевшая фрейлина» («Опьянение Гуйфэй), 仰斋志异 «войска еще не прибыли, а тыловое обеспечение уже должно быть впереди» (букв.: «солдаты и кони еще не отправились, а провиант и фураж уже заранее заготовлены») актуальные проблемы филологии и педагогической лингвистики.

Перестановка. Прием используется, вследствие разных речевых традиций определяется последовательность элементов, имея общее значение. Например:

«зерно на приманку израсходовал, а курицу не поймал»; пошли по шерсть, а вернулись стрижеными

偷鸡不着蚀把米.

«после смерти от леопарда остается шкура, а у человека - добрые дела»; оставить добрую память о

себе 人死留名, 豹死留皮;

«для свиньи опасно быть слишком жирной, а для человека - чересчур известным»人怕 出名, 猪怕壮.

Результаты и дискуссия. Перестановка. Кроме речевой традиции, причиной перестановки компонентов предложения могут послужить особенности выражения грамматических отношений, например,

временной связи в русском языке, когда сначала ставится придаточное предложение, а за ним следует главное: «доложить только после того, как приняты меры» (букв.: «сначала отрубить голову, а потом доложить») 先斩后奏;

«Когда правительство выражает волю народа, государство процветает; когда царствует вопреки воле народа, оно терпит фиаско» 政之所兴, 在顺民心; 政之所废, 在逆民心; «чинить овчарню, когда уже обнаружена пропажа овец»; лучше поздно, чем никогда 亡羊补 牢.

Грамматическими причинами перестановок может быть не только разное расположение элементов союзных конструкций в двух языках. Кроме того, к причинам относится разный порядок расположения компонентов атрибутивных сочетаний. В некоторых случаях и в китайском, и в русском языке место определения и определяемого относительно друг друга может совпадать, и тогда перестановка не нужна, например: «естественно-исторический процесс» 自然历史过程; «классово-антагонистическое общество» 阶级对立过程

Но чаще всего причиной применения перестановки является то, что принципы расположения компонентов атрибутивных сочетаний в двух языках различные: в русском языке сначала ставится зависимое от основного элемента определяемое понятие, а затем элемент, выражающий основное, тогда как вкитайском языке этот порядок является обратным. Например:

«неофициальная история конфуцианцев» 儒林外史;

«объективность экономических законов» 经济规律的客观性;

«суверенитет развивающихся стран над своими природными ресурсами» 发展中国家对 自然资源的主权.

Замена 
Осуществление замены возможно как в пределах одной грамматической категории, например, существительного, так и одной категории на другую, например, глагола на существительное. Например,

к первому виду замены можно отнести родовидовую замену:

«Ей немного лет, но язык у нее остер, как бритва» 她年纪不大, 舌头像刀一样尖利. В данном случае видовое понятие «бритва» в переводе заменено на родовое понятие «нож». Такой вид замены обычно называют функциональной заменой. Замена слов, выражающих разные грамматические категории,

встречается довольно часто. Например, местоимение может заменяться на существительное:

«Я представлял себе родину совсем другой. Она казалась мне гораздо лучше» 我所记的 故乡全不如

此。我的故乡好多了 [Павлова 2014, с 74- 87]

Обстоятельство может заменяться подлежащим:

«В феодальном обществе чистые любовные отношения между юношей и девушкой рассматривались как падение нравов» 封建社会把男女间正当的恋爱看成是伤风败俗的事 [Павлова 2014, с 74- 87]

Анализ разных типов синтаксических трансформаций показал, что как их причины,

так и сами приемы, используемые при переводе текста с русского языка на китайский, находят объяснение в рамках функционально-коммуникативной модели перевода. Методологией функционально-коммуникативной теории перевода считается диалектическая природа взаимосвязи и взаимодействия категорий формы и содержания по отношению к языку и речи. Сигнифика высказывания, как и значение всего контекста, рассматривается как форма выражения смысла, что, впрочем, не лишает их значимости в рамках смысловой структуры текста. Иерархические отношения между компонентами смысловойструктуры текста дают возможность смысловой эквивалентности двух текстов при частичном или даже полном изменении их языковых значений. С другой стороны, языковая равнозначность двух текстов еще не является гарантом их смысловой эквивалентности.

В заключение следует еще раз подчеркнуть, что перевод представляет собой сложный речемыслительный процесс, в котором теснейшим образом взаимодействуют лингвистические и экстралингвистические факторы. Умение соразмерять и учитывать эти факторы, творчески используя различные типы переводческих преобразований, свидетельство профессионального мастерства и культуры переводчика.

Несмотря на творческий характер деятельности переводчика, в основе ее лежат объективные закономерности, детерминирующие с той или иной степенью жесткости как само переводческое решение, так и критерии его оценки.

\section{Список использованной литературы}

1. Ван Гохун. Проблемы адаптации китайской и российской систем образования на лингвистическихфакультетах (из опыта преподавания) // Язык и культура. - 2015. - № 4 (32). - C. 94-101.

2. Ваулина Т.А., Сахарова К.Н. Организационные аспекты адаптации иностранных студентов, обучающихся в российском вузе // Вестник Том. гос. ун-та. -2015 . - № 400. - С. 267-272. URL:

3. Гураль С.К., Терешкова Н.С. Обучение техническому переводу студентовлингвистов китайского отделения посредством мультимедийной проектной деятельности // Язык и культура. - 2016. - № 1 (33).

4. Зененко Наталья Викторовна. Диалектика структурных доминант: грамматика и дискурс: на материале иберо-романских языков: автореф. дис. докт. филол. наук: 10.02.19 / H.В. Зененко [Место защиты: Воен. ун-т]. - Москва, 2010. - 40 с. URL: 
http://cheloveknauka.com/dialektika-strukturnyh-dominantgrammatika-i-diskurs (дата обращения: 10.09.2017 г.)

5. Павлова О.В. Классификация межъязыковых фразеологических отношений в китайском и русском языках // Язык и культура. - 2014. - № 3 (27). - С. 74-87.

6. Привороцкая Т.В., Тихонова Е.В. Формирование механизма переключения с китайского языка на русский посредством анализа кинотекста // Язык и культура. - 2015. № 1 (29). - С. 38-44.

7. Щичко В.Ф. Китайский язык. Теория и Практика Перевода: учебное пособие. Москва: Восток-Запад, 2004. - 223 с.

8. Ян Фан Слово «кухня» в русском и китайском языках в лингвокультурологическом аспекте //Язык и культура. - 2011. - № 1 (13). - С. 116-118.

9. 环球时报， 2011 年 8 月 29 日(Китайская газета «Глобальные времена» от 29.08.2011 г. № 2518. C. 6).

10. 环球时报，第 2520 期， 2011 年 8 月 22 日(Китайская газета «Глобальные времена» от 22.08.2011 г.

\section{ГУЛБАДАНБЕГИМНИНГ “ХУМОЮННОМА” АСАРИНИНГ ХОРИЖ МАМЛАКАТЛАРИДА ЎРГАНИЛИШ ТАРИХИ}

\section{Ахмедова Шахноза Насимовна, (НамДУ тадқиқотчиси)}

Annotation: This article tells us about historical events in Movarounnakhr, in the Middle East, in Kabul, in India, wich was reflected in "Humayun-nama" by Gulbadanbegim and shows the scientific researches in translations into English, French and Urdu. The great attention pays to up all the historical moments in period of the life of hero in "Humayun-nama" and masterfully delivers the translations of the work. The article has importance in developing of translation, textmaking and literature.

Key words and expressions: the article, importance, translation, scientific researches, historical events, life of hero.

Шарқ ва Ғарб адабий-бадиий муносабатлари, жумладан адабий хамкорлиги узббек адабиёти ва унинг мумтоз намоёндалари ижоди фақат Осиёда эмас, балки Ғарб мамлакатларида хам катта эътибор қозониб келган. Навоий, Бобурнинг дурдона асарлари шоир ўзи хаётлиги давридаёқ Шарқ мамлакатлари ва Европага тарқалган эди.

Шу боис, таржима ва унинг адабий хамкорликлари ўрни ва мавқеи манбашунослик ва матншунослик, қиёсий адабиётшунослик таржимашунослик масалалари кўп вақтлардан буён кўплаб илмий тадқиқотлар мавзуи бўлиб келмокда.

3.М.Бобурдан сўнг Акбаршох хукмронлигигача бўлган давр Мовароуннахр, Ўрта Шарқ, Қобул , Хиндистон тарихини ўзида акс эттирган Гулбаданбегимнинг "Хумоюннома" асари ўрта аср тарих фани ривожига бебахо хисса қўшган ва ўзининг кўп қирралилиги билан машхур бўлган “Бобурнома”нинг давоми сифатида майдонга келди.

Асарнинг яратилган вақти борасида хозиргача турли фикрлар мавжуд. Бизгача тўла бўлмаган чала холда етиб келган ва хозирда Британия музейида сақланаётган ушбу асарнинг ягона нусхасини инглиз олими Чарльз Ръю XVII асрнинг биринчи ярмида кўчирилган, деб изохлайди. Инглиз таржимони А.С.Беверидж хоним эса мазкур нусха муаллифнинг ўз кўли билан ёзилган ва бу 1585-87 йилларга тўғри келади, дейди. Француз таржимони Б.Граммон хам французча таржиманинг сўз бошида 1587 йилда Акбаршох ўзининг бош вазири ва тарихчиси Абул Фазлга сарой тарихини яратишни буюрган. Шу муносабат билан бобоси Бобуршох хамда отаси Хумоюн подшохни яхши билган олимлар хамда нуфузли саркардаларга мурожаат қилиб, улар хақида билганларини ёзишни буюрган. Бунинг натижаси ўлароқ "Хумоюннома" хам айнан ўша йиллари яратилган, деган фикрни илгари суради. Асарнинг таржималарига келсак, бу асар илк бор 1870 йили форс тилидаги аслидан 
урду тилига хинд олими Рашид Ахтар Надвий томонидан ўгирилган. Европада эса "Хумоюннома"нинг биринчи тўлиқ матни инглиз Шарқшуноси А.С. Бевериж хоним томонидан таржимага яқин 100 сахифалик сўз боши, тўлдирилган қўшимча изохлар, шархлар хамда форс тилидаги нусхаси билан нашр эттирилади. Француз шарқшунослари Жан Пол Ру хамда Жан Луи Бакю Грамонлар “Хумоюннома”ни француз тилига ўгириб, 1966 йили танқидий матнга ўхшаш тўлдиришлар билан китобхонларига тақдим этдилар.

Гулбаданбегимнинг "Хумоюннома" асари Хиндолнинг ўлдирилиши ва Комрон Мирзонинг кўр қилиниши хақидаги хикоя билан узилиб қолади, унинг сўнгги сахифалари ханузгача топилмаган.

Мазкур тарихий асар инглиз шарқшуноси, “Бобурнома” таржимони С.А.Бевериж хоним томонидан биринчи тўлиқ матни сўзбоши, изохлар, расмлар, биографик аппендикслар билан биргаликда 1902 йили Лондонда, 1983 йили эса биринчи бор Хиндистонда, форс тилида ёзилган нусханинг, инглиз тилига қилинган таржимаси билан бирга чоп қилинади.Афсуски, шу вақт ичида на Европа тадқиқотчилари, на бошқа шарқшунослар мазкур асардан тўла равишда фойдалана олмайдилар. Инглиз шарқшуносининг “Британия музейида сақланаётган "Хумоюннома"нинг нусхаси дунёда ўз ахамиятини йўқотган эмас. Шарқшунос олима Сабохат Азимжонованинг шаходат беришича, унинг нусхалари кам тарқалган, шу боис тадқиқотчилар назаридан четда қолган. А.С.Бефериж хонимни таъкидлашича-“Хумоюннома"нинг учта қўлёзмасидан бири Британия музейида сақланади. У 83 варақдан иборат бўлиб, насталиқ хати билан ёзилган, охири йўқ, воқеа узилиб, чала , кемтик холда.

Асарнинг таржималарига келганда шуни айтиш лозимки, бу нодир тарихий асар илк бор 1970 йили форс тилидаги аслидан урду тилига Покистонлик олим Рашид Ахтар Надвий томонидан ўгирилган. 1965 йили катта муқаддима хамда Бобур хаётига доир хронологик кўрсатгичлар билан чоп қилган.

Француз академиясининг профессорлари Жан Пол Ру хамда Жан Луи Бакю Граммонлар томонидан форс йилномачилари, парчалари асосида қайта ишланган ва кемтиклари тўлдирилган нашри, француз Академиясининг Шарқ тиллари ва тарихи бўлими томонидан нашрга тайёрланиб, 1996 йили фаранг китобхонларига тақдим қилинган. "Матнни бобларга, сатрларга ва сарлавхаларга бўлиб ўрганганимизда асарни тўлиқ эканлигига ишонч хосил қилдик. Таржимонлар томонидан-аслиятни тўлдириш, тиклаш жараёнида жуда катта мехнат қилинган. Француз таржимони аслият Комрон Мирзонинг кўзига мил тортилганлиги акс этган сатрдан узилгани хақида изох бериб, Хумоюннинг ўлимигача бўлган воқеаларни таржимада акс эттиришга ўзини масъуллигини таъкидлайди”. Чуқур илмий ижодий изланиш натижаси ўлароқ турли тарихий манбалар асосида тикланган "Хумоюннома"нинг тўлароқ матни дунё юзини кўрди. Асарга сўзбошини икки йирик олим, француз шарқшуноси Жан Луи Бакю Грамон хамда Ўзбекистонда хизмат кўрсатган фан арбоби, профессор С.Азимжоновалар ёзганлар. Таржима матни асар воқеалари баёнидан келиб чиқиб, IX бобни ўз ичига олади ва хар бир боб ўзига хос номланган. Таржимон "Хумоюннома"ни тарихийдаврийлик жихатидан тиклашга уринган ва бундан мақсад аслиятда ёритилмай қолган тарихий воқеаларни, асарнинг бизгача етиб келмаган, йўқолган сахифаларида тарихан асар қахрамони хаётида қандай воқеа-ходисалар содир бўлганлигини аниқлаш ва ўқувчиларга етказиш бўлган. Фаранг таржимони Б.Граммоннинг "Хумоюннома" воқеаларини давр, мазмун ва мундарижа тарафдан ўзига хос тарзда қайта тиклаш (реставрация қилиш) йўлида олиб борган мехнатлари тахсинга сазовор.

Замон-адабиёт-таржима, муаллиф -мутаржим, аслият- кемтик-таржима муносабатлари билан боғлиқ масалаларни ўрганишда “Хумоюннома” , “Бобурнома” каби жуда яхши манба эканлигига шубха йўқ.

\section{Фойдаланилган адабиётлар рўйхати}

1. Gul -badan Begam .Humayun-nama. Beveridge A.S.,London, 1902.

2. Гулбаданбегим. Хумоюннома. Тошкент -1998, Азимжонова С., “Фан”, 1959.

3. Гулбаданбегим. Хумоюннома. Қуронбоев А.Тошкент- 2016. 


\section{ХУСАЙН ВОИЗ КОШИФИЙНИНГ ИЛМИЙ МЕРОСИДА АХЛОК МАСАЛАЛАРИ}

А.Алимов

(СамИСИ)

Annotation: This article described the issues of moral as the national value of the way of life of the peoples of Central Asia. The article substantiates the idea that the concept of tolerance is widely propagated both in religious sources and in the scientific heritage of our scientific thinkers.

Key words and expressions: Central Asia, morol, international good-neighborliness, stable progress, spiritual heritage, Husain Voiz Košifiy.

Хозирги мураккаб глаболлашув шароитида баркамол авлодни тарбиялашда, уларни ахборот хуружлари ва маънавий тахдидлардан химоя этишда маънавий мероснинг ахамияти каттадир. Айниқса комил инсонни тарбиялашда мутафаккир алломаларимиз ўзларининг консептуал ғояларини ишлаб чиққан. Шарқ ахлоқ фалсафасининг нодир намуналарини яратган Хусайн Воиз Кошифийнинг илмий мероси шулар жумласидандир. Хусайн Воиз Кошифий (1442-1505) ислом динининг йирик назариётчиларидан бири бўлиши билан бир қаторда фалсафа, ахлоқ, тилшунослик, адабиётшунослик, сиёсат, тарих, астараномия, нотиклик санъати, тиббиёт каби сохаларга оид 200 дан ортиқ асар ёзган етук алломадир[1;241-245]. Хусайн Воиз Кошифий темурийлар хукмронлиги даврида барқарор ижтимоий мухит ва эркин ижодий фаолият учун яратилган шарт-шароитда яшаб ижод этди. Хирот шахридаги илмий ва ижодий мухит, айниқса, Алишер Навоийдек алломанинг Кошифий ижодий фаолиятини шаклланиши ва юксалишида таъсири катта бўлган. Алишер Навоий Хусайн Воиз Кошифийни ўз химоясига олар экан, унга яқиндан хомийлик қилган хамда унинг истеъдодини юқори бахолар экан, «Мажолис ун нафоис» тазкирасида унга алохида ўрин ажратган.

Хусайн Воиз Кошифийнинг барча асарларида шарқона одоб-ахлоқ масалаларига катта эътибор қаратилади. Хусусан, “Ахлоқи мухсиний” асарининг асосий ғояси инсон фаолиятида яхши хулқни тарғиб этишдан иборатдир. Асар муқаддимасида бу хусусида Хусайн Воиз Кошифий шундай дейди: " Хакимлар чиройли хулқ шундай бир йўлки, бу йўлдан юрмай туриб, иззат ва шариф манзилига етиб бўлмайди ва бу йўлга қадам қўймай туриб вужуд рахтини хайвонот биёбонидан инсоният дорил мулкига етказиб бўлмайди, дейдилар....Одамларнинг қай бирларида чиройли хулқ ва ёқимли хислатлар намоён бўлса, шу кишилар зебо кўринадилар"[2;68]. Кошифийнинг мазкур асари шарқона ахлоқ фалсафасининг нодир намунаси сифатида эътироф этилади.

«Ахлоқи мухсиний» асарида баён этилган барча мавзулар кишини яхши хулққа чорлагани ва бағрикенглик ғояларини кенг тарғиб қилганлиги боис хар бир ўқувчида катта қизиқиш уйғотади. Шахс маънавиятида шукр ва сабр қилишлик ва унинг фазилатлари баён этилиб, хаё, покизалик, олийхимматлик, собитқадамлик, адолатли бўлиш, авф этиш, шафқатли ва мархаматли бўлиш каби ахлоқий фазилатлари зарурлигини уқтириб ўтади. Шуниндек, Кошифий киши фаолиятида чиройли хулқ ва мулойимлик фазилатларининг мохиятини очиб беришга харакат қилади. Омонат ва диёнат, вафо ва ахд, ростгуйлик каби ахлоқий фазилатлар хусусида батафсил тўхталиб ўтади. Охисталик ва шошилмаслик, андишалилик каби хислатларни киши ахлоқ одобида тутган ўрнини баён этади. Шижоат, ғайрат, фурсатни ғанимат билиш киши учун зарур фазилат эканлигига алохида тўхталиб ўтади. Кошифий ўқувчини фаросатлиликка, сир сақлашлик, хукуққа риоя қилишлик, доимо яхшилар билан хамсухбат бўлишликка ва ёмон ишлардан йироқ бўлишга чақиради. Хусайн Воиз Кошифий адаб хусусида шундай дейди: “Адабнинг маъноси ёмон сўздан ва бефойда ишдан нафсни тийиш, ўзини хамда бошқа кишиларни иззатини сақлаб обрўйини тўкмасликдир"'[3;29]. Инсон маънавий баркамоллигида одобнинг ахамиятини таъкидлар экан шундай дейди: “Одобли одам барчага яхши кўринади Улуғлар айтибдурларким, барча сармояларнинг яхшироғи ва жамики зийнатларнинг махбуброғи барча одам учун, хусусан, олам подшолари учун адабдур"[4;29]. 
Хусайн Воиз Кошифий барча ахлоқий фазилатларни баён этар экан хаё хусусида шундай дейди: “Хаёнинг маъноси ёмон иш қилишдан уялишдир. Одамзотга хаё шариф хислат ва мақбул сийратдир". Аллома хаё хусусидаги мулохазаларини баён этар экан, унинг ахамиятини қуйидагича изохлайди: “Агар шарму хаё орадан кўтарилса ва одам хеч кишидан уялмаса, оламнинг тартиби издан чиқади, одамлар орасида яхши расму одатлар битади, кишилар хаётига путур етади. Улар бир-бирлари билан диёнат сақламайдилар, оқибат кучлилар заифларни йўқ қилади. Аммо хаё шундай кучли бир сифатки, у одамларнинг фақат ўзлари хохлаган ишларни қилишга йўл қўймайди”[5;23-24]. Хусайн Воиз Кошифийнинг бу фикрлари, XX асрда Ғарбий Европадаги шарму хаё кўтарилганлиги хамда ахлоқсизлик авжига чиқишиин башорат қилгандек. Аллома хар бир киши хаёга риоя қилиши лозимлигини уқтириб шундай дейди: “Демак, катта-ю кичик-ка хаёдан катта фойда бор, яхши одатларнинг меваси хаё суви ва офтобидан парвариш топмаса, доим хом тураверади" $6 ; 23]$. Кошифий хаёни бир неча турлари борлиги хақида хам тўхталиб ўтади хамда қизиқарли ва ибратли ривоят ва хикоялар орқали ўқувчинит шарм хаёли бўлишга чақиради.

Асарнинг асосий хусусияти шахсда юксак маънавий фазилатларни шакллантириш хусусидаги мулохазалари ва хулосалари мантиқий тафаккур тарзига мувофиқ баён этилади. Содда, равон ва тушунарли тилда баён этилганлиги учун ўқувчида савол ёки эътирозга ўрин қолмайди. Кошифий мазкур асарида хар бир мавзуни ёритишда “Қуръон” оятлари ва хадислардан намуналар келтириш билан чекланмайди, балки, Шарқ халқларининг буюк мутафаккирлари Абулқосим Фирдавсий, Низомий Ганжавий, Жалолиддин Румий, Шайх Саъдий, Бахоуддин Нақшбандларнинг назмларидан лавхалар келтиради. Шунингдек хар бир мавзунинг мохиятини ёритишда ибратли ривоятларни келтириб ўтади. Ривоятларда кўпинча турли хил миллат ва дин вакилларидан иборат тарихий шахслар ва улар хаёти давомида (баён этилаётган мавзуга оид) содир бўлган воқеалар ибрат тарзида баён этилади. Хусусан, Афлотун, Арасту ва Миср, Рум, Форс хукмдорлари хамда вазирлари билан боғлиқ хикоялар асарда ўрин олган. Кошифийнинг ахлоқ фалсафасида диний ва миллий бағрикенглик тамойили мухимлиги тарғиб қилинади. Унинг мазкур асарида келтириб ўтилган ривоят ва хикоятларда қахрамонлар гох насронийлик пайғамбари Исо ёки яхудийлик дини пайғамбарлари Довуд, Сулаймон, баъзан зардуштийлик дини кохини ёки хинд рухонийси бўлиши мумкин. Асарда Қуръондан ташқари Инжил ва бошқа диний манбалардан хам далиллар келтиради. Нуширавон хузурида Рум Қайсари, Хитой хоқони, ва Хинд ройиси бўлиши, албатта бу муаллифнинг хаёлий тасаввури, аммо бунда тўрт хил миллат, тўрт хил дин ва тўрт давлат рахбарларининг бир вақтда, бир жойда, биргаликда ўзаро хамсухбат бўлиши миллий ва диний бағрикенглик тамоилининг тарғиботидир[7;233]. Шунингдек Шом, Яман ва Рум қайсари билан бўлган воқеалар мисолида хам бағрикенглик тамойилини тарғиб қилади.

Исломдан аввалги хукмдорлар, хусусан, Афросиёб, Нуширавон, Искандар Зулқарнайн, Парвиз, Ардашер Бобак, Миср подшохи Паётала, Шеруя каби кўплаб хукмдорларни фаолиятидаги ибратли воқеаларни баён этар экан, кишиларни хамжихатликка даъват этади. Хитой подшохи ва Искандар Зулқарнайннинг, Миср подшохи билан Рум Қайсарининг ўзаро сухбатлари каби келтирилган ривоятлар орқали турли хил миллат ва дин вакилларини ақл фаросат ва яхши одоб ахлоқ орқали тинч тотувликка, бағрикенгликка чақиради. Ўрта асрлардаёқ шахсда юксак ахлоқий фазилатларни шакллантиришда миллий ва диний бағрикенглик мухим тамойил эканлигини Кошифий асослаб бера олган эди. Хусайн Воиз Кошифий «Ахлоқи мухсиний» асарининг илмий ахамияти шундаки, унда шахс маънавий юксалишида зарур бўлган одоб ахлоқ қоидалари мукаммал ишлаб чиқилиши билан бирга турли миллатлар ва динлар вакиллари ўртасида ўзаро хамжихатлик, тинч-тотувлик каби бағрикенглик тамойили илгари сурилган. Хусайн Воиз Кошифий илгари сурган барча миллат ва дин вакилларнинг тенглиги ғояси ханузгача ўз ахамиятини йўқотган эмас. Хулоса қилиб айтадиган бўлсак, аввало, мутафаккир аллома меросининг энг қимматли жихати хозирги даврда турли хил ақидапарастлик ва мутаассибликка қарши курашда назарий манба 
эканлигидадир. Аллома беш аср аввал диний бузғунчи ғояларни, сохта тариқатларни танқид қилган эди. Шу жихатдан Хусайн Воиз Кошифий илмий меросини фалсафий методологик тахлил этиш билан хозирги мураккаб ахборотлашган жамиятда тарбиявий ахамиятини кўрсатиб бериш долзарб ахамият касб этади.

\section{Фойдаланилган адабиётлар рўйхати}

1. Махмудов Р.Ж. Хусайн Воиз Кошифий / Маънавият юлдузлари. Т. 2001. Б.241-245.

2. Хусайн Воиз Кошифий. Ахлоқий Мухсиний. Футувватномаи султоний.Т. 2019. Б .68 .

3. Хусайн Воиз Кошифий. Ахлоқий Мухсиний. Футувватномаи султоний.Т. 2019. Б.29.

4. Хусайн Воиз Кошифий. Ахлоқий Мухсиний. Футувватномаи султоний. Т. 2019 й. Б.29.

5. Хусайн Воиз Кошифий. Ахлоқий Мухсиний. Футувватномаи султоний. Т. 2019 й. Б.23-24. Б.23.

6. Хусайн Воиз Кошифий. Ахлоқий Мухсиний. Футувватномаи султоний. Т. 2019 й.

7. Хусайн Воиз Кошифий. Ахлоқий Мухсиний. Футувватномаи султоний. Т. 2019 й. Б.233.

\section{ТАРЖИМАДА ФРАЗЕОЛОГИК ЛАКУНАЛАРНИ БАРТАРАФ ЭТИШ УСУЛЛАРИ (хитой ва ўзбек тиллари мисолида)}

\section{Исматуллаева Наргиза Расулжановна ( таянч докторант, ТошДШУ)}

Annotation: This article is devoted to several methods of eliminating phraseological lacunas (gaps) in Chinese and Uzbek languages. The peculiarity of phraseological systems in different languages creates phraseological lacunarity. In the process of analysis, it was found that the methods of eliminating phraseological lacunas in Chinese and Uzbek languages in translation are significantly different from lexical lacunas'.

Key words and expressions: lacuna, phraseological lacuna, phraseological lacunar unit, translation methods, calque, explication.

Фразеологизмлар бу халқнинг турмуш хаётида, теварак-атрофида содир бўлаётган табиий хамда ижтимоий ходиса, жараён, хатти-харакатларга бўлган муносабати, уларни кузатишлари натижасида тилда юзага келади.

Таржимашунос Х.Хамидов фразеологизмнинг бошқа тил бирликларидан ажратиб турувчи ўзига хос куйидаги категориал белгилар борлигини кўрсатади: а) лексик маъно; б) компонентлар таркиби; в) грамматик категориялар. Фразеологизм гап ичидаги сўзларга нисбатан алохида, бўлинмас бирлик сифатида намоён бўлади, яъни у сўзлар билан бирлашиб, қисмларга парчалана олмайди (Хамидов 2019:25). Шу маънода, бундай қисмларга парчаланмайдиган фразеологизмларни лакунарлик шароитида таржима тилида тўғри бериш таржимондан лингвистик ва экстралингвистик билимларни талаб этади.

Хитой ва ўзбек тилларида фразеологик лакунарликни бартараф этиш масаласи эквивалентсиз фразеологизмларни таржима қилиш доирасида кичик тадқиқотлар миқёсида ўрганилган. Мазкур икки тил чоғиштирмасида фразеологик лакуналарни аниқлашда, лакунарлик асосан қайси турдаги фразеологик бирликлар улушига тўғри келишини ўрганиш керак бўлади.

Сюй Зонгцай, Йинг Жюнлинг хитой тилида қуйидаги асосий фразеологик бирликларни ажратиб кўрсатади: 1) 惯用 语 guànyòng yǔ - “кўп қўлланиладиган бирикма” (уч иероглифликлар); 2) 成语 chéngyй - “турғун иборалар” (тўрт иероглифликлар); 3)俗语 súyǔ “мақол ва маталлар” (谚语 yànyй - “мақол”, 俗话 súhuà-“матал”) (徐宗才, 应俊玲 2005). 
Фразеологик луғатлар (хатто икки тиллик луғатлар) таржимонга аслиятда кўлланган ибора, мақол, маталлар учун янада муваффақиятли функционал муқобиллар танлашига ёрдам беради (Флорин 1971:344).

Фразеологик луғатлар таржимонга аслиятда қўлланган ибора, мақол, маталлар учун янада муваффақиятли функционал муқобиллар танлашига ёрдам беради. Лекин икки тилли луғатларда хар доим хам ибораларнинг аниқ эквиваленти, баъзи пайтларда луғат ўз ичига қамраб ола олмаган фразеологизмларнинг изохи хам берилмайди.

“Фразеологик лакуна (бўшлиқ)” бирикмасини энг дастлаб қўллаган поляк олимаси Ж.Шершунович ўз ишида фразеологик лакуналарни бартараф этишнинг кўйидаги таржима усулларини таклиф этади: 1) сўзма-сўз таржима; 2) янгилик киритиш; 3) алмаштириш; 4) тушириб қолдириш (Szerszunowicz 2013:339.

Юқоридаги таснифдан фарқли, фразеологик бирликларнинг бир тилдан иккинчи тилга асосан тўрт хил йўл билан таржима қилиниши Қ.Мусаевнинг ишлари (Мусаев 2005:102)да хам кўрсатилади. Унга кўра, аслият тилидаги бирликма компонентлар таркиби, грамматик қурилиши хамда маъно ва услубий вазифаси мос эквивалентлар, бошқа хоссалари фарқ қилгани холда, маъно ва услубий вазифаси ўхшаш муқобил вариантлар, калька усулида ва тасвирий йўсинда таржима қилинадилар.

Ш.Сирожиддинов ишларида эса аслиятдаги фразеологик бирликларни қуйидагича уч гурухга ажратиб ўрганишни ва таржима тилига ўгириш тавсия этилади: 1) бутунлай мувофиқлик; 2) қисман мувофиқлик; 3) мувофиқликнинг йўқлиги (ёки номувофиқлик) (Сирожиддинов 2011:101).

Айнан бизнинг тадқиқот доирамизга кирувчи “мувофиқликнинг йўқлиги”, яъни лакунарлик - аслиятдаги фразеологик бирликнинг таржима тилидаги эквивалентларининг умуман учрамаслиги ва мазкур бирликлар таркибида асл тилга хос бўлган (эквивалентсиз лексик бирликлар) реалияларнинг учрашидир.

Ушбу тадқиқот ишида, хитой тили ва ўзбек тиллари таржимасида фразеологик лакуналарни бартараф этишнинг қуйидаги усуллари таклиф этилади:

1) сўз ёки сўз бирикмаси шаклида бериш;

2) калькалаш;

3) тасвирий таржима (экспликация);

4) маълумот қўшиш;

5) тушириб қолдириш.

1. С̆̈з ёки сўз бирикмаси шаклида бериш

Фразеологизмлар таркибига кирувчи иборалар ўз мохиятига кўра битта сўз ёки иккита сўздан иборат сўз бирикмаларига тенгдир. Икки тил фразеологик бирликлари чоғиштирмасида намоён бўлувчи лакунарликни бартараф этишда айнан битта ёки иккита сўз билан ифодалаш усули қўл келади. Бундай усулни қўллаш натижасида стилистик бадиий бўёқдорликка бир қадар путур етса-да, лекин функциявий жихатдан мазмуннинг сақлаб қолинишига хизмат қилади. Масалан,

我暂时走了。待你洞房花烛之后, 我再与新媳妇比比美丑。

Wǒ zhànshí zǒule. Dài nĭ dòngfáng huāzhú zhīhòu, wǒ zài yǔ xīn xífù bǐbǔ měi chǒu.

Мен хуозир кетаман, сен шу пайтгача турмушга чиқмаган уззингинг суюкли А Сиуингга уйлансанг, шунда уззимни у билан солиштириб кўриш учун яна ққайтаман(Зиямухамедов 2016:203).

Хитой тилидаги жумлада берилган 洞房花烛 dòngfáng huāzhú ибораси турмуш қуришни ифодалайди. Сўзма-сўз “ғорга кирмоқ, шағам ёқмоқ” деб таржима қилинади. Ушбу тўртта иероглифлик ибора мазмуни тагида хитой маданиятида мавжуд бўлган тарихий урфодатлар ётади. 洞房 dòngfáng сўзи қадимги Хитойда турмуш курган жуфтликнинг тўй маросимидан сўнг бир-бирини яхши билиб олишлари учун уч ой давомида ғорда бирга хаёт кечиришлари урф-одатини ифодалаш учун юзага келган. Хитойча чэнгюйнинг иккинчи қисми 花烛 huāzhú эса қадимда янги турмуш курган келин-куёвнинг хонасида аждахо ва 
қақнус сурати ўйилган қизил шағамларнинг ёқилишига нисбатан ишлатилган. Битта иборани ташкил қилувчи икки компонент хам турмуш қуриш маъносини беради. Шу туфайли таржимон томонидан ўзбек тилидаги таржимада бу ибора биргина уйланмоқ сўзи билан ифодаланган. Жумла таржимасида яна хитой тилидаги вариантда кўрсатилмаган маълумот хам кўшиб кетилган. Яъни, контекстга кўра жумла мазмунига аниқлик киритиш мақсадида таржимон томонидан қахрамон йигит уйланиши керак бўлган суюкли ёрининг “А Сиу” исми киритилган.

\section{2. Калькалаш}

Агар аслият таркибидаги фразеологизм ички мазмуни ва образли асоси мантиқий заминга эга бўлиб, бу асос очиқ-ойдин кўзга ташланиб турса, шу билан бирга кишиларнинг хаётий тажрибалари негизида яратилган бўлса, бундай фразеологизм қатор холларда калька усулида таржима қилинадики, бундай холда таржима тилида тегишли фразеологик бирликнинг нафақат мазмуний-услубий хусусияти, балки миллий ўзига хослиги, ижтимоиймаданий хоссаси хам қайта яратилади (Мусаев 2005:240).

Масалан, 井底之蛙 jĭng $d \check{l} z h \bar{l} w \bar{a}-$ қудуқ тагидаги бақа. Қудиқ остидаги қурбақа юқорига қараганида осмоннинг бир парчасинигина кўради. Шу туфайли хитой тилида бу ибора тор дунёқарашли кишилар учун қўлланилади (现代汉语词典 2005:723).

\section{3. Тасвирий таржима}

Муайян фразеологик бирликни гохо на эквивалент, на муқобил вариант ва на калька ёрдамида ўгиришнинг имкони топилади. Бундай холларда санъаткорлар ноилож таржима амалиётининг тасвирий усулига мурожаат қиладиларки, мазкур усул ёрдамида бирликлар маънолари эркин маънодаги сўз бирикмалари воситасида тушунтириб қўяқолинади (Мусаев 2005:205).

\section{耿生打量青凤，见她体态娇美，眼如秋波，聪慧又漂亮。}

Gěng shēng dăliang qīng fèng, jiàn tā tǐtài jiāo měi, yăn rú qiūbō, cōnghuì yòu piàoliang.

Чюй Бинг қ̧изнинг нозик, гўзал ва келишган қ̧адди-қ̧омати, чақнаб турган қора куззларига эътибор берибди(Зиямухамедов 2016:181).

眼如秋波 yăn rú qīūbō ибораси қизларнинг гўзал кўзларига нисбатан ишлатилади. Хитой тилида ўхшатиш учун олинган 秋波 qī̄ $b \bar{o}$ сўзи “куз фасли шамолидан кщтарилувчи дарёдаги енгил тўлқин” маъносини англатади. Бундай ўхшатиш асосан ғамза нигохли кўзларга нисбатан ишлатилади. Ўзбек лингвомаданиятида чиройли кўзлар чаросга, охунинг кўзларига ўхшатилади. Мазкур хитойча иборада ўз аксини топган ўхшатиш шакли ўзбек тили фонида лакунардир. Жумла таржимасида ушбу ибора “чақнаб турган қора кўзлар" тарзида тасвирий усулда, лекин ўзбек ўқувчисига мослаштирган холда берилган.

\section{4. Маълумот кўшиш}

Хитой ва ўзбек тилларидаги таржима материалларини манбалар асосида тахлилига кўра, фразеологик лакуналарни бартараф этишда таржимон томонидан маълумот қўшиш усулини кўллаши хам самарали натижа бериши кузатилди. Таржимада маълумот қўшиш сўз, сўз бирикмаси ва хатто жумла шаклида хам бўлиши мумкин. Бу усулнинг тасвирий усулдан фарқли томони шундаки, тасаирий таржима усули учун фразеологик бирликларнинг изохини икки тилли ёки изохли луғатлардан топиш мумкин. Маълумот қўшиш усулида эса таржимон матн контекстига кўра мақбул хабарни кўшади. Бу ўз навбатида, муаллифнинг услубига таъсир қилса-да, таржима қилинаётган тил сохибининг маълумотни хазм қилишига анча енгиллик яратади. Масалан,

众人神魂颠倒，评头论足，简直要发狂了，唯有孙子楚默默无语。 wúyǔ.

Zhòngrén shénhún diāndăo, píngtóu lùnzú, jiănzhí yào fākuángle, wéi yǒu sūnzi chǔ mòmò

Дустларининг бири «унинг куизлари катта экан» деса, яна бири «у кулганида одамни уззига махлиё қилар экан» деб қизвин сухбатлашишар экан. Фақ̆ат Сун Зичугина бир овиз хуам гапира олмай турар экан(Зиямухамедов 2016:188). 
Жумлада келтирилган 评头论足 píngtóu lùnzú ибораси ўзбек тилида аниқ муқобилига эга бўлмаган лакунар ибора хисобланади. Сўзма-сўз “оёқ-бошини мухокама қилмоқ” дея таржима қилинади. Ушбу ибора бекорчиларнинг аёлларнинг ташқи кўринишини мухокама қилиш харакатига нисбатан ишлатилади. Мазкур жумла таржимасида анча кенгайтирилган таъриф берилган. Яъни қахрамон йигитнинг дўстлари қахрамон қизни ташқи қиёфасидаги жалб қилувчи томонларини кўрсатиб, қизғин сухбат олиб борганликлари кўрсатилган. Хитой тилидаги тўртта иероглифдан иборат фразеологизм, маълумот кўшиш усули воситасида бутун бир жумла кўринишига келтирилган.

\section{5. Тушириб қолдириш}

Тушириб қолдириш усули фразеологик лакунар бирликни таржима матнидан чиқариб ташлашдир. Ушбу техникани кўллашда таржимада йўқотиш бўлиши муқаррар. Шунга қарамай, баъзи бир контекстда агар ибора таржимаси мураккаб характери туфайли таржимани қабул қилишда муаммо туғдирса, берилган лакунар иборани киритмаслик хам натижа беради.

\section{不如跟我回家，吃点粗茶淡饭，家中有床，住上一晚。}

Bùrú gēn wǒ huí jiāa, chī diăn cūchá dànfàn, jiāzhōng yǒu chuáng, zhù shàng ȳ̄ wăn.

Яхииси, ичкарига кир, қорнингни туйгазиб ол, менинг уйимда бир кеча ётиб қ̧ол(Зиямухамедов 2016:256).

Жумладаги 粗茶淡饭 cūchá dànfàn иборасини компонент тахлил қилинса, 粗茶 cūchá оддий, яхши дамланмаган чой ва 淡饭 dànfàn оддий, ночор (суюқ) овқат маъносини беради. Ушбу ибора ночоргина оддий дастурхонни ифодалаш учун кўлланилади. Мазкур хитойча ибора мазмунидаги муқобил фразеологизмларнинг ўзбек тилида мавжуд эмаслиги лакунарликни юзага келтиради. Жумла таржимасида 粗茶焱饭 cūchá dànfàn ибораси тушириб қолдирилган. Бу ерда овқатнинг сифатига эмас, балки овқатланиш харакатга урғу берилган бўлиб, контекст сақланган холда құрин туйзазмоқ феъли орқали фақат овқат ейиш харакати кўрсатилган.

Хулоса ўрнида шуларни кўрсатиш мумкинки, хитой ва ўзбек тилларида фразеологик лакунар бирликларни таржимада беришнинг 5 та усули ажратиб олинди. Булар сўз ёки сўз бирикмаси шаклида бериш, калькалаш, тасвирий таржима (экспликация), маълумот қўшиш, тушириб қолдириш.Таклиф этилган усуллар таржима жараёнида қоришиқ холда қўлланилиши хам кузатилди. Масалан, тасвирий таржима+маълумот қўшиш усули.

\section{Фойдаланилган адабиётлар рўйхати}

1. Зиямухамедов Ж. Пу Сунглинг ва ўрта аср хитой новеллалари. - Тошкент: Чўлпон номидаги НМИУ, 2016.

2. Мусаев Қ. Таржима назарияси асослари. - Тошкент: “Фан” нашриёти, 2005.

3. Сирожиддинов Ш., Одилова Г. Бадиий таржима асослари. - Тошкент: MUMTOZSO`Z, 2011.

4. Флорин С. Необходимое пособие// Мастерство перевода № 8. - Москва, 1971.

5. Хамидов X.X. Турк фразеологияси масалалари. - Тошкент: BAYOZ, 2019.

6. Szerszunowicz J. Phraseological Gaps as a Translation Problem. Research on Phraseology accross Continents. University of Bialustok Publishing House, Bialystok, 2013.

7. 徐宗才, 应俊玲。外国人说熟语 : 汉英对照。- 北京: 北京语言大学出版社, 2005 .

8. 现代汉语词典。- 北京：商务印书馆，2005 年。 


\title{
ВООБРАЖЕНИЕ КАК АСПЕКТ ГНОСЕОЛОГИЧЕСКОЙ ПРАКТИКИ В СУФИЗМЕ
}

\section{Муминов Н.Н. \\ (СамГИИЯ)}

\begin{abstract}
Annotation: The subject of this article is a phenomenon metaphysic imagination in doctrines and practice of modern Sufism. The article is based on data and research results carried out in 2002 in US.
\end{abstract}

Key words and expressions: at-tasavvuf, «perfect man», unique of being, emanation, order, sama', remembrance of God, Gnostics.

К культурному наследию Востока, к которому в настоящее время придается большое значение в Узбекистане, относится философски мистическое течение ат-Тасаввуф. Как мистически аскетическое течение ат-Тасаввуф возник в середине VIII века и играет религиозно-политическую роль в исламском мире до сих пор. Пройдя «институционализацию» в форме суфийских орденов, идеи суфизма широко распространились среди различных слоев и социальных групп мусульманского общества в XII-XIII вв. С этого момента началась интеллектуализация «ат-Тасаввуф». Авторами мистических доктрин признаны ас-Сухраварди ал-Мактул (ум.в 1191г.), Ибн 'Араби (ум. в 1240г.), Ибн Саби’ин (ум. В 1271г.), ‘Абд ар-Раззак ал-Кашани (ум.в 1329г.), 'Абд ал-Карим ал-Джили (ум. в 1428г.) и др. Они сформулировали философско-мистические концепции «совершенного человека» (ал-инсан ал-камил), «единство бытия» (вахдат ал-вуджуд), «самопроявление Абсолюта» (таджалли), «эманации» (файд, судур). Суфийский мистицизм отразился также и на арабской и персидской поэзии: Ибн ал-Фарид, ал-Бусири, ашШуштари, 'Абд ал-Гани ан-Набулуси, Джалал ад-дин Руми, Сана'и, Са'ди, Ираки, Амир ХосровДехлеви, Хавиз, Джами, Ансари, Низами, Алишер Новои, Бедиль и др.

Значимое место в истории суфизма занимает орден (тарикат) Накшбанди, который сформировался и распространился в эпоху Тимуридов. Известные учителя и шейхи этого ордена Баха' ад-дин Накшбанд (1318-1389), ходжа Мухаммад Парс (1345-1420), 'Ала' аддин-'Аттар (ум. в 1400г.) создали систему духовной практики, которая распространилась по всей Средней Азии, Поволжью (Казань), Индии, Османской Турции, в Египете, Йемене, Сирии, Боснии. Сегодня тарикатНакшбанди распространился и в США. Глава ордена Накшбанди в Америке Шейх Мухаммад НазимАдиль аль-Хаккани неоднократно посетил Самарканд и Бухару.

Распространившись на Западе (в Европе и США) антологические и гносеологические идеи суфизма стали не только предметом восточной мудрости, но и предметом духовной практики. Западные адепты суфизма объединяются в братства сохраняя преемственность восходящую к материнским братствам, таким как йасавия, ас-сухравардия, ал-кадирия, рифа'ийа, накшбандия, кубравийа, маулови'а и др.

Глубокий кризис психологического и духовного дисбаланса, который признается многими авторами на Западе, находит свое разрешение в «практике трансовых состояний». Суфийская практика одна из таких.

Известный исследователь ислама ВилльямЧитик отмечал, что «интерес западного общества к восточной традиции, связан с надеждой найти духовные ресурсы, которые были некогда потеряны». В действительности, что ищут европейские и американские адепты в суфийской практике? Ведь молитва в принципе выучивается, сам'a можно просто прослушать, а сухбат может выглядеть как банальный диалог. В конце концов, на постиндустриальном Западном рынке, перенасыщенном информацией, есть всё, что пожелает потенциальный потребитель [ChittickmWilliamC 1989:73].

Отвечая на эти вопросы, в эксклюзивном интервью шейх Пир Зия Хану и Шариф Баба отмечали, что западным адептам не хватает мистического воображения. Ведь в экзистенциональном (онтологическом) существовании нет эзотерического содержания 
ДжалалиддинаРуми. Мистический смысл маснавий понимается лучше когда «ищущий» наблюдает за крутящимися дервишамитариката Мевлеви. Интеллектуальное знание канонов ислама остается всего лишь механическим исполнением, и только тихий и громкий зикр и особенности молитв, практикующиеся в братстве Накшбанди, ставят акценты и вскрывают скрытый смысл намаза. В ат-Тасаввуф практикуется воображение свободное от бытия и дуализма, т.е. метафизическое или гносеологическое созерцание. Более того, многие западные адепты не соблюдают исламский шариат вовсе. В достижении воображения учителя суфизма применяли различные инструменты, например образ «зеркала». «К зеркалу обращались и Ибн Сина, и аль-Газали, и Ибн Рушд, и ас-Сухраварди, и аш-Шахрастани, и аль-Джили». И в сегодняшних проповедях имеет место «зеркальное» отражение: «не имеет значение куда мы идем, давайте смотреть на себя как если, бы мы выдели самих себя, потому что этот мир есть зеркало в котором отражаются всё человеческое. Если вы взглянете на мир, то увидите самих себя». Так выглядит призыв к воображению в ордене РифаиМа'руфи. [Игнатенко А. 1999:102]

Показательным событием в жизни современных западных суфийских течений является ежегодный фестиваль ДжаллалиддинаРуми, который проходит в городе Чапл Хилл (США). Суфийская практика как основной предмет, привлекающий западных адептов уже не экзотика, а реальная духовная эзотерическая работа. Многие формы зикра и сам'a представленные различными суфийскими школами (Бекташи, Рифаи, Мевлеви, Накшбанди) доступны на этом фестивале для каждого. Музыка также остаётся инструментом суфийской практики. Выдающийся мистик - музыкант двадцатого века Хазрат Инаят Хан в своей интерпретации музыки для воображения мистических доктрин говорил: «что самое лучшее по поводу музыки это то, что она помогает человеку сконцентрироваться и медитировать независимо от мышления, и поэтому музыка - это мост через гавань между формой и её отсутствием. Поэзия привносит форму, линии и цвет привносят форму, но только музыка не привносит форму. Она создает резонанс через горнило вибрирующего прикосновения каждого атома целого существования» [HazratInayatKhan 2001:15].

Проповедуя исламский мистицизм западным адептам через практику ордена Накшбанди Шейх Назим Аль-Хакани ставит целью «вывести» человека из экзистенциональной в действительности, от зависимости к мирскому, оставив только созерцание и воображение: «Главное разница между накшбандийским и другими путями в том, что они дают, а мы забираем. Все прибывает в движении, даже ваше отдельное взятое существование. Сначала вы не имеете ничего, потом сами становитесь ничем». Последнее «ничем» интерпретируется как виртуальное. Другими словами лишившись всего мирского, мюрид остается один на один с мистическим созерцанием - воображением. Работа с мюридом для него означает превращение последнего в виртуальное «ничто» как созерцаемое состояние.

Cухбаты - встречи и диалоги с духовным учителем, наставником обеспечивая обратную связь, создают возможность интерпретировать те или иные доктрины суфизма в современном разрезе духовных поисков и проблем отношения человека к гностицизму.

Резюмируя можно отметить, что в число аспектов современного суфизма распространяющегося на Западе имеет место «метафизическое воображение» как психическая и духовная потребность пережить мистический опыт озарения.

\section{Список использованной литературы}

1. Chittickm William C. The Sufi path of Knowledge: Ibn al-'Arabi's metaphysics of imagination,1989 State University of New York Press, Albany, p.IX

2. Игнатенко А, «Зеркало как составляющая спекулятивной парадигмы в арабоисламской мысли эпохи средневековья, Средневековая арабская философия: Проблемы и решения, - М.: Издательская фирма «Восточная литература» РАН, 1998.- под.ред. Е.А.Фролова, стр. 231 
3. Music in the Life of HazratInayat Khan, R.C.Mehta, II. Music, A Perl in Wine, 2001, Omega Publications, ed. By Pirziade Zia Inayat Khan, New Lebanon NY, p.161

\section{«ДИВАН ЛУГАТ АТ-ТУРК» - ПЕРВОЕ ЭТНОЛИТЕРАТУРНОЕ ИССЛЕДОВАНИЕ О ТУРКМЕНАХ}

\section{Мусинова Зебо Турабовна \\ (СамГИИЯ)}

Annotation: The article considers a large ethnographic material about the Turkmens. This material contains information about the material and spiritual culture of the Oghuz-Turkmens in the 11th century, provides material about the life of the Turkmens of the early Middle Ages, contains information about the objects of material culture and life, the origin of the names of tribes and localities, tribal division, the names of food and drink, the terms of animal husbandry, the names of diseases and drugs, and much more.

Key words and expressions: Turklogy, rhymed speech, Turkic tribes, dialectology, linguistic, linguistic, cultural, lexical, phonetic, grammatical, historical and cultural, ethno $\neg$ Graphic, geo-graphic information, dialects, rajaz.

Махмуд Кашгарий написал несколько крупных научных трудов, большая часть которых бесследно исчезла. К счастью, сохранился главный труд его жизни монументальная работа «Диван лугати ат-тюрк»- «Словарь тюркских языков», явившуюся крупным вкладом в развитие мировой культуры.

«Дивани лугати ат-тюрк» явилась результатом многолетних странствий Махмуда Кашгарий по областям, населённым тюркскими племенами. «Хотя я происхожу из тюрок, которые говорят на самом чистом языке, которые по происхождению и роду своему занимают самое первое место - пишет Махмуд Кашгарий в своём Словаре- я пядь за пядью исходил все селения, степи тюрок. Я полностью запечатлел в уме своём и живую и рифмованную речь тюрков, туркмен, огузов, чигилей, ягма, кыргызов. И вот эту книгу после столь долгого изучения и поисков я написал самым изящным образом, самым ясным языком».

«Диван лугат ат-турк» Махмуда Кашгари является единственным памятником тюркской диалектологии раннего средневековья. Впервые этот словарь был переведен на русский язык ученым-востоковедом, кандидатом философских наук Зифой-Алуа Муратовной Ауэзовой.

Материал для книги Кашгарий собирал в течение 15 лет и работу над ней закончил в 1083 году. «Диван лугати ат-тюрк» стал подлинной энциклопедией тюркской народной жизни раннего средневековья, и в настоящее время эта книга является единственным источником обширной информации о жизни тюркских племён того периода времени.

«Диван лугати ат тюрк» - это не просто лингвистическое исследование тюркских языков, а лингвострановедческое, содержащим огромный объём информации по истории, культуре, этнографии, поэзии, фольклору, быту тюркских племён.

Словарь содержит более 9 тысяч слов и словосочетаний, классификацию тюркских языков (рассматриваемых М. К. как диалекты) по фонетико-морфологическим. признакам, обширные лингвистические (лексические., фонетические, грамматические.), историко-культурные, этнографические, географические сведения о более чем 20 тюркских. народах Средней Азии, Восточного Туркестана, Поволжья и Приуралья. Кашгарий наряду с лексическим материалом включил в словарь тексты устно-поэтического творчества тюрок (обрядовые и лирические песни, отрывки из произведений героического эпоса о войне тюрок-мусульман с уйгурами-буддистами, исторические предания и легенды о походе Александра Македонского, пословицы, поговорки, изречения). В нём отражены этические. нормы и ценности, специфическое мировосприятие тюркских народов 11 в. 
О своей книге Махмуд Кашгари пишет: «Эту книгу я составил в алфавитном порядке, украшал ее пословицами, саджами (рифмованная проза), поговорками, стихами, раджазами (стихи воинственного содержания) и отрывками из прозы. Я облегчил трудное, разъяснил неясное и трудился годам. Я рассыпал в нем из читаемых ими стихов для того, чтобы ознакомить с их опытом и знаниями, а также пословицы, которые они употребляют в качестве мудрых изречений в дни счастья и несчастья с тем, чтобы сказитель передавал их передатчику, а передатчик другим. Вместе с этим я собрал в книге упоминаемые предметы и известные слова и, таким образом, книга поднялась до высокого достоинства и достигла отличного превосходства».

Махмуд Кашгари - представитель высших кругов караханидской знати. Отец Хусейн ибн Мухаммад, внук завоевателя Мавераннахра Богра-хана. Кашгари был визирем Барыс-хана (южный берег оз. Иссык-Куль), затем переселился в Кашгар. Там получил образование, продолжив его в Бухаре и Нишапуре. В процессе обучения проявил интерес к языкам, фольклору, этнографии, географии, менталитету тюркских народов. Накопленный опыт и наблюдения он обобщил в своем главном труде «Диван лугат ат-турк» («Словарь тюркских наречий»). Этот труд автора является энциклопедией тюркских народов раннего средневековья. В нем заключены ценные, в некоторых случаях и единичные, сведения о многочисленных тюркских племенах, живших в XI веке. Словарь содержит этнонимы, топонимы, термины родства, различных должностных лиц, названия блюд и напитков, домашних и диких животных, птиц, месяцев и дней недели, народный календарь, названия лекарственных средств, астрономические, военные, медицинские, религиозные и другие термины. Запечатлены этические нормы и ценности, нормы поведения, мировосприятие тюркских народов того времени. Есть важные сведения об историко-культурных связях между различными племенами, упоминания о некоторых исторических событиях, имевших место на территории Казахстана и Средней Азии. Например, о походе Искандера (Александра Македонского). Большой интерес для исследователей представляет сохранившаяся в сочинении самая старая тюркская карта мира. Книга содержит более 400 пословиц, поговорок и устных изречений, которые Махмуд Кашгари собрал в 1072-1074 годы в честь Халифа Аль-Муктади.

Если бы работа была написана только в контексте тюркского языкознания, это явилось бы большим и капитальным исследованием. Но автор приводит в своей работе много сведений о материально-духовной культуре описываемых народов, что делает этот труд своего рода этнографической энциклопедией. «Диван» давно и серьезно исследуется тюркологами, востоковедами, историками и, тем не менее, в книге еще много неизученного. Есть филологическое исследование туркменского ученого С.Ахаллы, в котором проведен сравнительный анализ туркменского языка и материалов «Дивана». Работа ценна тем, что автор перевел множество слов и словосочетаний, пословиц и поговорок из «Дивана» с тюркского на современный туркменский язык, что дает возможность их посредством ознакомиться с материально-духовной культурой огузов-туркмен в XI веке.

\section{Список использованной литературы}

1. Махмуд ал-Кашгари. Диван лугатат-турк (Свод тюркских слов) / пер. с араб. А.Р. Руста-мова / под ред. И.В. Кормушина; прим. И.В. Кормушина, Е.А. Поцелуевского, А.Р. Рустамова. М.: Восточная литература, 2010. Т. 1. 461 с.

2. Кормушин И.В. Введение // Махмуд ал-Кашгари. Диван лугатат-турк (Свод тюркских слов) / пер. с араб. А.Р. Рустамова / под ред. И.В. Кормушина; прим. И.В. Кормушина, Е.А. Поцелуевского, А.Р. Рустамова. М.: Восточная литература, 2010. Т. 1.461 с.

3. Караулов Ю.Н. Русский язык и языковая личность. 1-е изд. М.: Наука, 1987. 264 с.

4. Халеева И.И. Вторичная языковая личность как реципиент инофонного текста // Язык-система. Язык-текст. Язык-способность. М., 1995.

5. Кононов А.Н. Махмуд Кашгарский и его «Диван лугат ат-турк» // Советская тюркология. 1972. № 1. С. 3-17. 


\title{
ХИТОЙДА “АВАНГАРД АДАБИЁТ” ТАЖРИБАЛАРИ ЦАН СЮЭ ИЖОДИ ТАХЛИЛИДА
}

\section{Назирова Шукрия Миадовна, (ТошДШУ)}

\begin{abstract}
Annotation: The article is devoted to the beginning of the formation of the principles of modernism in Chinese literature in China in the late 70s - early 80s. This change manifested itself primarily in poetry. Literary scholars acknowledge that during this period, the stream of "vague verses" that expressed feelings associated with contemplating and evaluating the development of modern society flourished, and its roots are rooted in modern Chinese symbolism. This trend is the first prelude to modernism in the PRC, which also follows prose. Then, by 1985, the trend of modernism became very widespread and reached its peak in the late 1980s. The novels created in this direction are very different from the novels of the past, which are closely associated with ideology.
\end{abstract}

Key words and expressions: Chinese, avant-garde literature, reforms, women's literature.

70-йилларнинг охири - 80-йилларнинг бошлари хитой адабиёти модернизм тамойиллари шакллана бошланганлиги кузатилди. Бу ўзгариш, энг аввало, шеъриятда яққол кўзга ташланди. Адабиётшунос олимлар бу даврда замонавий жамият тараққиётини тафаккур қилиш ва бахолаш билан боғлиқ хис туйғулар ўз ифодасини топган “туманли шеърлар" оқимининг кенг ривож топганини ва унинг илдизлари замонавий хитой символизмига бориб тақалашини эътироф этадилар. Бу йўналиш ХХРда насрни хам ўзига эргаштирган модернизмнинг илк дебочаси хисобланади.

XX асрнинг 80 йиллари хитой адабиётида ўзига хос бир босқич хисобланади. Айнан, 1980-йили Хитойда биринчи марта таржима асарлардан иборат "Модернистик насрий асарлар тўплами" нашр этилди. Бу тўплам хитой адабиётида авангард йўналишининг ривожига туртки бўлди.

Кейинчалик 1985 йилга келиб модернизм йўналиш жуда кенг тарқалди хамда 80йилларнинг охирига бориб ўз ривожининг энг юқори чўққисига кўтарилди. Бу оқим намояндалари асосан XX асрнинг 50-60 йилларида туғилиб адабиёт оламига 80-йилларнинг бошларда кириб келган ёшлар (Ма ань, Цан Сюэ, Гэ Фэй, Юй Хуа, Сунь Ганьлу, Су Тун, Бэй Цунь, Хун Фэн) бўлиб, уларнинг аксарияти ғарб адабиёти таъсиридаги ижодкорлар эдилар. Бу йўналишнинг асосчиси Ма Юань бўлиб, хитой адабиётидаги илк “тажриба роман” ёки “авангард роман” айнан унинг қаламига мансуб. Бу йўналишда яратилган романлар мафкура билан чамбарчас боғланган ўтган давр романларидан кескин фарқ қилади. Бунгача бўлган адабий оқимлар: “чандиқлар адабиёти”, “ислохотлар адабиёти”, “илдизларни излаш адабиёти”нинг барчасида мафкурага бўйсуниш мавжуд эди. Авангард оқимидаги романларда бу хусусият кузатилмайди. Уларнинг бадиий қиммати тамомила бошқа асослар билан белгиланарди. Бу романларда ўтмишнинг тўқима манзарасини яратиш тамойили етакчилик қилди. Бадиий тўқима худди реал воқелик ва хақиқат сифатида намоён бўлди. Шунингдек, модернизмга хос “онг оқими” усулидан кенг фойдаланилганлиги кузатилади. Ма Юаннинг авангард асарлари сирасига кирган “Лхаса дарёсининг илохаси” (1984) ва "Кайлас тоғи васвасаси”(1985) қиссалари унга жуда катта машхурлик келтирди. Ма Юандан сўнг кўплаб ёш ёзувчилар ўзларини “авангард адабиёт” вакиллари сифатида танитдилар.

Эътиборли жихати нафақат ёш ёки ўрта ёшдаги адибалар, балки ёши улуғ ижодкор аёллар асарларида хам абсурд, киноя, кесатиқ орқали тарихий воқеаларни тасвирлаш тамойили кузатилади. Масалан, Цзун Пу (1928й) нинг 80-йилларда чоп этилган "Мен кимман?”, “Ми оиласининг манзаралари”, “Ботқоқдаги бош суяги”, “Лулу” каби бир қатор қисса ва хикояларида Маданий инқилоб даврида дахшатли хўрликларни бошидан кечирган зиёлиларнинг пучга чиққан умидларини тасвирлайди. Лекин бундай адибалар камсонли. Авангард адабиётида “исёнкор” инсоннинг кучли колорити, ғарб қадриятлари ва ижодий методларини ўрганишга мойиллик мавжуд эди. Маданий инқилобдан сўнг йўқолиб кетиш, 
йўқлик кайфияти ғарбнинг модернизм ва постмодернизмдаги бегоналашув, абсурд ва эксизтенциализм адабий назариялари билан қўшилиб кетди.

Авангард адабиёт ўз ичига хам модернизм, хам постмодернизм, плюрализм ва индивидуализмни қамраб олди. Бу йўналишларнинг асосида зиёли ижодкорларнинг давлат позициясига норозилиги ва "интелегенция ва давлат ўртасидаги муносабатнинг барбод бўлиши ва уларнинг қаршилиги ифодаси” турарди. Авангард ёзувчилар ижодининг асосий материали бу: уларнинг шахсий кечинма ва изтироблари, болаликни эслаш, тақдир, умид, севги, нафрат, хаёт ва ўлим хақидаги индивиуал кечинмаларидир.

Ўз ижодида қадимги хитой адабиёти анъаналарини, фалсафасини ва ғарб модернизми тажрибаларини ўзида мужассамлаштирган адибалардан бири 残雪 Цан Сюэдир.Цан Сюэ адабиётга 80 йилларнинг ўрталарида кириб келган бўлиб, адиба сифатида у дастлаб ўз ватани Хитойда эмас, балки хорижда машхурликка эришган. Цан Сюэ таълим олиш имконига эга бўлмаган, заводда мехнат қилган, тикувчилик билан шуғулланган. Ғарб адабиётидан қилинган таржима асарлар билан таниша бошлаганда Цан Сюэ 27-28 ёшда бўлган. Бу таржима асарлар унинг адабиётга бўлган кучли қизиқишини уйғотган ва 31 ёшида унинг ўзи хам илк бор бадиий ижодида ўз иқтидорини синаб кўрган.

Адибанинг барча романлари унинг маънавий оламидан хикоя қилади. У бамисоли шахси иккиланган рассом, бу хақиқат - у халос бўлишни истаган ва бир дақиқа хам тоқат қилолмайдиган воқелик. Тасаввур бу олам ичида ва олам ташқарисида мавжуд. Аммо хақиқатда воқелик қўрқинчли ва чигал бўлиб, инсонлар ундан хеч қачон қочиб кетолмайдилар. Сюэнинг ижодидаги бу услуб қайсидир маънода “сюрреалистик” услубни эслатади. Адибанинг илк асарларида “қўрқинчли воқелик”ни хаддан ортиқ бўртирриб кўрсатиш тамойили кузатилади. Шунингдек, адибанинг илк асарларида қариндошлик, аёл ва эркак, ишқий, қўшнилар ва хамкасблар орасидаги муносабатларда инсоннинг табиатига чуқурроқ назар солиш, инсон борлиғини тасвирлаш кузатилади. Унинг асарларининг асосий

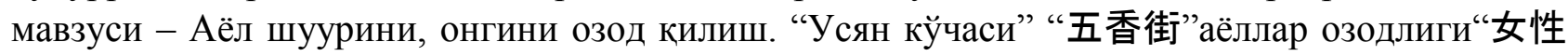
解放” хақидаги энг машхур роман. Асар сюжетини Усян кўчасидаги хиёнат, унинг омиллари билан боғлиқ воқеалар ташкил қилади. Муаллиф асар персонжларининг содир бўлган хиёнатга нисбатан ўз фикрлари, қарашларини очиқ айтишлари учун кенг имконият беради. Уларнинг аксарияти аёллар бўлиб уларни муаллиф аниқ бир исм билан атамайди. Булар $\mathrm{X}$. хоним, Б. хоним, Олтин кампир, оқсоқ хоним сингари шартли лақаблар билан номлайди. Улар хам ижтимоий, хам инсонларнинг шахсий хаётларидаги муаммоларга бефарқ қарамайдилар. Уларнинг хар бирининг ўз фикри ва ғояларида собит бўлиб, хеч кимнингортидан кўр кўрона эргашмайдилар, хеч қандай хукуматга ишонмайдилар. Усянкўчаси сўз эркинлиги, сершовқин нутқлар оламига ўхшайди.

Усян кўчаси аёллари учун бу хатти харакат, бу тарздаги “маданий хаёт” “业余文化生活 "нормал холат хисобланиб, инсонлар шундай бўлишлари керак. Улар ўз харакатларидан заррача уялмайдилар, хижолат бўлмайдилар ва табиий холдек қабул қиладилар. Усян кўчасидаги аёллар ўзларининг хохишларининг асл кўринишларини намоён қиладилар. Усян - бу аёллар олами бўлиб, бу кўча аёлларининг нутқлари ўтмиш аёлларининг тубдан фарқ қилади.

Бир сўз билан айтганда адиба анъанавий адабиётда табу хисобланган, одатда ўта назокат ва эхтиёткорлик билан ёндашиладиган мавзуни тамомила янги ракурсда ўқувчига тақдим қилади.Цан Сюэнинг бошқа асарларининг тадқиқи шуни кўрсатадики, улардаги оналар образи Усяндаги аёллардан тубдан фарқ қилади. Цан Сюэнинг “она”лари сўқувчида мулойимлик, мехр-шафқат туйғуларини уйғотмайди, аксинча нафрат, жирканиш ва иложсизлик хисларини уйғотади. Улар инсон тасаввуридан ташқари, умуман ўзгача характерга эга. Цан Сюэнинг қатор асарларидаги оналар инсонлар асрлар давомида ўрганган образни тамомила ўзгартириб юборди. Цан Сюэнинг бу қарашлари ғарбда XX асрнинг 60йилларидаги Она образига ёндашувни эсга солади. Аёллар эркинлиги масаласида Цан Сюэнинг ёндашуви ўзига хос. Унинг “аёллари” эри учун эмас ўзининг фароғати ва манфаати 
учун уй̆наб куладилар. Унинг аёлларининг онги эркаклар тушунчасидаги аёл онгидан тамомила фарқ қилади. Бу онг аёлни ШАХСИЯТсифатида қабул қилади.

Цан Сюэ асарларини ўрганар эканмиз унинг авангард йўналишдаги баён услуби тадрижий ривожланишда бўлганини кузатамиз. Унинг қахрамонлари ёлғиз, оғриқли бўлишсада, реал воқелик олдида қўрқувга тушмайдилар ва келажакдан умидини узмайдилар. Улар такдирга тан бермайдилар, курашадилар. Цан Сюэ бутун ижоди давомида бу принципдан чекинмайди. Аксинча, асардан асарга ўтгани сари чукурлашиб боради. Ўкувчи тушуниб етадики, қайсидир маънода бу аёллар ўзларининг хатти-харакатлари, оташин ва очиқ ойдин нутқлари билан қайсидир маънода ўзларига ўзлари таскин бераяптилар, ўзларини ўзлари алдаяптилар. Ўзини ўзи алдаш - бу Сарт айтгандек “онгсизлик орқали намоён бўлган озодлик”, ёки Хайдеггер таъбиридек, “ёлғон мавжудлик” хам эмас. Бу тарздаги ТИРИКЛИК - кун кечириш азобларидан қочиш мақсадида ўзини-ўзи алдашдир. Бу билан улар узз сабрларини намоён қилаяптилар. Бошқача айтганда, бу уларниг “сабрга муносабати”. Улар бироз бўлса-да ўз оғриқларини унутадилар. Улар атрофда содир бўлаётган воқеалар мохиятини чукур англаб етмайдилар.

Цан Сюэ 1980-йиллардаги Хитой адабиёт оламидаги энг кучли авангард йўналишидаги ёзувчилардан хисобланади. У ғарб модернизмига оид мавзулар хақида тафаккур қилади, у хитой халқининг хавотир, қўрқув, бегоналашув каби ўзига хос психологиясини ифодалайди. Ва бу психологик нарратив ғарб модернистик нарратив билан айнан мос келади. Унинг Кафка ва Борхес ижоди билан яқиндан таниш бўлганлиги балки қайсидир маънода Цан Сюэ илк асарларининг баён услубида акс этганидир. Лекин бу унинг индивидуал, оригинал ижодий услубга эга эканлигини рад қилмайди.

Хулоса қилиб айтганда бу даврда аёллар адабиётида образлар тизиминиг ўзига хос галереяси шаклланди. Булар: ишчи аёл, сиёсатчи аёл, уй бекаси, журналист, мансабдорларнинг турмуш ўртоқлари, енгилтабиат аёллар ва бошқалар.

Модернизм, постмодернизм техникасидан фойдаланишга уриниш (Цан Сюэ) кузатилсада, аёл ижодкорлар томонидан бу методда яратилган асарлар сони кўп эмас эди.

1990-йил Хитойга ғарб маданияти, қадриятлари ва адабий усулларнинг фаол кириб келган бир давр бўлди. Хитой олиб борган очиқлик сиёсати ижобий таъсир билан бирга сезиларли равишда чиқим қилинишига олиб келди. Маданият ва адабиётни тижоратлашуви холати кузатилади. Баъзи ёзувчилар моддий манфаат туфайли истеъмолчилар талабига мослаша бошладилар. Бу эса ўз навбатида бадиий асарларнинг сифатига таъсир ўтказмасдан қолмади, албатта. Бадиий қимматга эга бўлмаган кўплаб ишқий романлар, интим сахналарга бой хикоялар дунёга келди. “Оммавий маданият” тушунчаси пайдо бўлди.

80-йиллардан фарқли ўлароқ 90-йилларда адабий оқимларнинг кучсизланиши кузатилди. Романчилик жадал ривожланди. Ватан мавзуси етакчи мавзулардан бирига айланди. Инсон рухияти тасвирига ахамият кучайди. Хотира, диалог, бадиий психологизм, рамз сингари бадиий тасвир усулларидан фойдаланиш фаоллашди. Шеьриятга эътибор сезиларли даражада ошди.

\section{Фойдаланилган адабиётлар рўйхати}

1. Дин Фан. Модернистская поэзия в современной китайской литературе. // От национальной традиции к глобализации, от реализма к постмодернизму: пути развития современной китайской литературы. С-Пб, 2004, с.18.

2. Завидовская Е. Постмодернизм и современная китайская литература. // Проблемы Дальнего Востока . - 2003. - №2. - С.146.

3. Чэнь Сяомин. Бяоиды цзяолю: лиши цюймэй юй дандай вэньсюе бяньгэ (Жодуланган тарих ва замонавий адабий ислохот).- Пекин, 2001.- Б.79.

4. Ли Синьмэй. Русский и китайский постмодернизм // Академическиететради. Альманах. Выпуск двенадцатый. Тетрадь шестая. История литературы.М., 2006. // [Электрон. pecypc]. URL: http://independent-academy.net/science/tetradi/12/index.html 
5. Историческиеизменения в литературе Северо-Востока XIX-XX веков / Гл. ред. Ли Чуньянь. -Чанчунь: Цзилинь жэньминь чубаньшэ, 2004.- Стр.300

6. Насимова С. Модернистская направленность произведений Цань Сюэ//“Хитойшуносликнинг долзарб масалалари” мавзусидаги илмий амалий конференция материаллари - Тошкент, 2012. - Б.136-139

7. Китайская проза XX1 века. Перевод с китайского языка. Состовители А.А. Родионов, Н.А.Спешнев. - СПб.:КАРО, 2011. - С.108

8. Виноградов В.В. О теории художественной речи. - М.: Высшая школа, 1971. C.118.

9. Чернец Л.В. Введение в литературоведение. М.: Высшая школа, 1976. С.386

10. Холмуродов А. Ўзбек қиссачилиги: тараққиёт муаммолари. Т.2013//

11. Носирова С. Роль и место китайской женщины в обществе дореволюционного и сегодняшнего Китая.// «Баркамол авлод тарбиясида шарқшунос олимларнинг ўрни” мавзуидаги Илмий мақолалар тўплами. Тошкент, 2016. -79-83

12. Рябченко О.Н. Литература Северо-Востока КНР в период реформ//Ойкумена, 2009, №3. - C.42

13. http://independent-academy.net/science/tetradi/12/index.html// Ли Синьмэй. Русский и китайский постмодернизм // Академическиететради. Альманах. Выпуск двенадцатый. Тетрадь шестая. История литературы.М., 2006.

14. https://ru.wikipedia.org/wiki/ Женская-литература

\section{ШОХ ҒАРИБ МИРЗО(ҒАРИБИЙ) ИЖОДИ ВА ДАВРИ}

\section{Халимов Сулаймон Ғуломович}

(СамДУ)

Annoation: Annotation: The second half of the 15th century was a period of great contradictions in the development of our literature. The literary environment of Navoi's time is characterized by its complexity and peculiarities. It can be said that this period was a period of revival of Turkish literature, further improvement in terms of ideas and content, and ascent to a new stage of development. During this period, more than a thousand poets and writers entered the field of creativity.

The article notes that the spiritual and enlightenment work in the Navoi kingdom, the development of artistic creativity, as well as the Temurid martyrs engaged in creative work, Gharibi and his work were widely covered. In several of his works, it is learned that Shah Gharib Mirza hoped to see in his work and therefore devoted special chapters of many of his works to him.

In addition, the article states that the death of Shah Gharib Mirzo (Gharibi) had a profound effect on Alisher Navoi. It was widely reported that Shah Gharib Mirza wrote a 5-line (60 lines) lament, each consisting of 6 bytes.

Key words and expressions: Timurid kingdom, conflict, contradiction, environment.

\section{Шох Ғариб мирзо(Ғарибий) ижоди ва даври}

Темурийлар салтанатининг ўзаро келишмовчиликлар, зиддиятларга бой бўлган даври хисобланган XV асрнинг иккинчи ярми Мовароуннахр ва Хуросон адабий мухити адабиётимиз тараққиётида йирик ўзгаришларга бой давр хисобланади. Навоий яшаган давр адабий мухити мураккаблиги, ўзига хос хусусиятлари билан ажралиб туради. Айтиш мумкинки, бу давр туркий адабиётнинг ўз қаддини тиклаши, ғоя ва мазмун жихатдан янада мукаммаллашиб, тараққиётнинг янги босқичига кўтарилиш даври бўлди. Бу даврда мингдан ортиқ шоир ва адибларнинг ижод майдонига кириб келди. “Ўша даврларда форс тили поэзия тили, араб тили эса илмий тил сифатида қабул қилинган эди.Расмий ёзишмалар хар иккала тил омихтасидан иборат эди.Туркий тилга эса авом тили сифатида қараш устувор эди. Туркий халқларнинг кўп мингйиллик давлатчилик тажрибаси ва бой маънавий-адабий мероси мўғул босқини оқибатида йўқ қилинганлиги туфайли темурийлар даврида туркий 
халқларнинг шонли тарихи, тили ва қадриятларини тиклаш жуда қийин кечган." 106 Ана шундай қийин шароитда туркий -ўзбек тили ва адабиёти ривожи учун курашган ва ўзлари шу тилда ижод қилиш билан кўплаб ёш ижодкорларга намуна бўлган Султон Хусайн Бойқаро ва Алишер Навоийларнинг хизматлари катта бўлди.Бу она тилида ижод қилувчилар сонининг ортиб, кўплаб кишиларнинг туркий тилда ижод қилиш сари йўналтирди, десак хато бўлмас.Айниқса, “Алишер Навоийнинг "Мухокаматул луғатайн” асарининг яратилиши бу борадаги турли қарашларга узил-кесил нуқта қўйди. Алишер Навоий асарда адабий мухит хақида, туркий адабиётнинг ривожланишига салбий таъсир кўрсатувчи омилларни қуйидагича изохлайди: Биринчи сабаб - туркийгўй ижодкорларнинг туркий ва она тилининг нозиклигини, муркабблигини билдирувчи бир неча маъноли сўзлар ва ифодаларнинг жуда кўплигидан, уларни тушуниш ва шеьриятда махорат билан ишлатиш мехнатидан чўчиб, осонлик сари майл қилишларидир.

Иккинчиси - идрокли сўз санъаткорлари бу йўлдаги бехуда уринишларни кўргач, замонадаги хукмрон анъана доирасида қолишни ўзларига муносиб деб билганликларидир.

Учинчиси - ёш ижодкорларда шундай одат бўладики, ўзига маъқул (бу табиий, албатта) асарларни тажрибали шоирларга, адибларга кўрсатиб, уларнинг эътирофига, мақтовларига сазовор бўлишни истайдилар.Бундай фикрни билдириши мумкин хисобланган сўз санъаткорлари эса туркийдан бебахра эканликлари туфайли энди ижод йўлига кириб келаётганлар форсийга майл кўргазадилар." 107

Демак, шундай вазиятда Навоийнинг туркий тилда ижод қилувчи хар бир ижодкорга алохид эътибор қаратиши табиий эди. Шунинг учун Алишер Навоий «Фарход ва Ширин» достонида Шох Ғариб мирзога махсус боб ажратади ва унинг инсоний сифатларини “Салтанат шажарасининг самараси ва хилофат боғининг шажараси, хидоят авжида манзил этган, тамаллуқнинг нихоятиға етган, риё қасри бунёдин кўнқорғон, балоғат айвонида от чиқорғон, яъни султонзодаи олам Абулфаворис Шохғариб Баходир халлада давлатуху” деб таърифлаш билан бошлайди. ${ }^{108}$ Бобда Навоий Шох Ғариб мирзонинг илмга чанқоқлигидан мамнун эканлигини эътироф этиш баробарида унга илмнинг фойдалари тўғрисида ўгитлар беради. Шоирнинг уқтиришича, “Киши таълимдин торса малолат, Топар илм ахли оллинда хижолат." Навоий шахзодани илм ахлига хурматда бўлишга чақиради:Бировким қилса олимларва таъзим, Қилур гуёеки райвамбарва таъзим. Хадис ўлмиш набийдин бўйла хуодис Ки, олим келди райвамбарва ворис, Кишиким бўлса олам родшохуи, Анинг умматливидиндур мубохуи." 109 Шоир ўз фикрларини давом эттирар экан, Мирзо Улуғбекнинг илм олдидаги хизматларига тўхталиб ўтади, Тахмурас, Жамшид, Заххок каби афсонавий шахслар номларини келтириш билан дунёнинг ўткинччи эканлигига, кишидан фақат яхши ном қолишига ишора қилади: Алар худ кеттилар гар кеч, агар бот, Вале құлди алардин дахр аро от. Бу от гар яхшидур, ёхуд ёмондур, Қилурва они боис куир, не фандур. Қаю фанким шуруъ этмаклик онда, Кишидин яхши от қолzай жахонда. Қила олгонча ул буллсун шиоринг Ки, яхши от қолгай ёдгоринг. ${ }^{110}$

Бунинг учун эса шоир салтанат, халқ ва юрт тақдири учун жавобгар бўлган киши дунёвий илмлардан ташқари илми хикматдан, диний илмлардан хабардор бўлиши, фиқх, хадис ва тафсир илмларини эгаллаган бўлиши лозимлигини таъкидлайди:Чу дин илмива комил бўлди ройинг, Хал этти хотири мушкилкушойинг. Ёки Вагар хуикматқ̧а бўлса илтифотинг Ки, бўлсун Нух умрича хаётинг. ${ }^{111}$

Навоий Шох Ғариб мирзога давлат ва жамоат ишларида қандай бўлиши лозимлиги тўғрисида ўгитлар берак экан, “Нечукким, шохқ тормиш дину дунё, Санга хуам етгай ушбу

\footnotetext{
106 Сирожиддинов Ш. Алишер Навоий: манбаларнинг қиёсий-типологик, текстологик тахлили.Т.: Akademnashr,2011.Б.3.

${ }^{107}$ Суйима Ғаниева “Таъби хуб, каломи марғуб” Темурий шахзода Шох Ғариб мирзо хақида қайдлар.“Ўзбекистон адабиёти ва санъати” газетаси, 1996 йил, 5 июль. №27.

${ }^{108}$ Навоий Алишер “Фарход ва Ширин” достони. Мукаммаласарлартўплами. 8-жилд.Тошкент, 1991.Б.508-516.

${ }^{109}$ Навоий Алишер “Фарход ва Ширин” достони. Мукаммаласарлартўплами. 8-жилд.Тошкент, 1991.Б.510.

${ }^{110}$ Навоий Алишер “Фарход ва Ширин” достони. Мукаммаласарлартўплами. 8-жилд.Тошкент, 1991.Б.508-514.

${ }^{111}$ Навоий Алишер “Фарход ва Ширин” достони. Мукаммаласарлартўплами. 8-жилд.Тошкент, 1991.Б.508-514.
} 
икки маъно. Бу икки ишни гар құлсанг тавақкуъ, Не ишким шах құлур, қилвил татаббуъ” дея айтганларига қатъий амал қилишга ундайди. ${ }^{112}$

Шох Ғариб мирзога доир маълумотлар Навоийнинг бошқа асарларида хам учрайди.Алишер Навоий ўзининг 1491-1498-йиллар давомида яратилган“Мажолис ун нафоис" асарида темурийлар адабий мухитида ижод қилган 459 шоир тўғрисида маълумот беради. Асарнинг "Еттинчи мажлис" деб юритилувчи қисми “Салотини изом ва авлоди вожуб ул-эхтиромлари зикридаким, баъзи яхши махалларда хуб байт ўқубтурларким, филхақиқат ўзлари айтқондек хубдур ва баъзи назм латойифига машғул бўлубтурларким, ул дағи матлуб ва марғубдур" деб бошланади. 7-мажлис Амир Темур ва темурий ижодкорлар тўғрисида бўлиб, унда Сохибқирондан бошлаб Султон Али мирзогача жами 22 темурий хақида маълумот берилган. Бу бўлимга темурийлар сулоласига мансуб бўлган ижодкорлар қатори Шох Ғариб Мирзо тўғрисида хам маълумот бериб ўтади. Навоийнинг Шох Ғариб Мирзони "шўх табълиғ ва мутасарриф зехнлик ва нозук тахайюллуқ ва дақиқ тааққуллуқ йигитдур. Назм ва Ов в ақуш хотириға марғуб ва қурро ва ўкуш кўнглига махбуб” деб таърифлаши унинг Шох Ғариб Мирзони ўзига манзур бўлган инсон ва ижодкор сифатида эътироф этганлигидан далолат беради.Навоий ўз фикрлари исботи учун унинг ижодидан

Қайси бир гулчехра ул гулбарги хандонимча бор,

Қайси бир шамшод қъад сарви хиромонимча бор?

Бу матлаъ хам яхши воқеъ бўлубтурким:

Тарки мехр айлаб агарчи бўлди жонон ўзгача,

То тирикман, құлмавумдур ахуд паймон уззгача.

Буматлаихосхаёлвағарибадотопибдурким:

Порсоёримва май ичмакшиорўлмитяна,

Баски тортарман сабу, эгним фигор ўлмим яна ${ }^{113}$.

каби парчаларни келтиради.Маълумки, Шох Ғариб Мирзо туркий тилдан ташқари форсий тилда хам гўзал сатрлар битган. Навоий унинг форсий тилда хам беназир ижод қилишини эътироф этар экан, қуйидаги парчаларни мисол келтиради: Бу форсий матлаи хам бағоят ошиқона тушубтурким:

Бозамбалоижсовами он мохпорашуд,

Эй вой, он маризкидардашду бора шуд. (яъни, анаўша ой каби гўзалнинг ғамижонимга бало бўлди. Эй вой. Ўша касалликнинг дарди икки баробар ошди.)

Бу матлаи хам бағоят ошиқона ва мухлисона ва муассирона воқеь бўлубтурким:

Дўстон, хуар гах гузар суй мазори ман кунед,

Жои такбирам дуои жони ёри ман кунед ${ }^{114}$. (яъни, дўстлар, гохо мозорим томон келиб туринг. Менга фотиха ўқиш ўрнига ёримнинг дуои жонини қилинг.)

Навоий Шох Ғариб Мирзо ижоди тўғрисидаги фикрларини куйидаги жумлалар билан якунлайди: Девон хам жамъ қилибдур. Яхши матлаълари бу мухтасарға сиғмас, магар яна бир китоб битилгай. ${ }^{115}$

Навоий салтанатдаги маънавий-маърифий ишлар, бадиий ижод ривожини ижод билан шуғулланувчи темурий шаходалар қатори Шох Ғариб Мирзо фаолиятида кўришга умид боғлаган ва шунинг учун ўзининг кўплаб асарларининг махсус бобларини унга бағишлаган эди. Шох Ғариб Мирзо вафоти Алишер Навоийга жуда қаттиқ таъсир қилади. Х.Сулаймоновнинг кўрсатишича, Навоий бундан қаттиқ изтироб чекади. У камтар ва ширинсўз инсон, адолатли ва лутф мархаматли шахзода, қисқа умр кўрса-да, ижод ахли томонидан заковатли шоирсифатида эътироф этилган. Шох Ғариб Мирзо вафотига хар банди 6 байтдан иборат 5 бандли (60 мисраъ) таркиббанд марсия ёзган. ${ }^{116}$

\footnotetext{
${ }^{112}$ Навоий Алишер “Фарход ва Ширин” достони. Мукаммаласарлартўплами. 8-жилд.Тошкент, 1991.Б.508-516.

${ }^{113}$ Алишер Навоий. Мукаммаласарлартўплами. 13-жилд. Тошкент: “Фан”, 1977.Б.162-163.

${ }^{114}$ Алишер Навоий. Мукаммаласарлартўплами. 13-жилд. Тошкент: “Фан”, 1977.Б.163.

${ }^{115}$ Алишер Навоий. Мукаммаласарлартўплами. 13-жилд. Тошкент: “Фан”, 1977.Б.163.

${ }^{116}$ Хамид Сулаймон. Алишер Навоийнинг Ғариб мирзо вафотига ёзган марсияси.-Адабий мерос, 1971, №2.Б.175-178.
} 
Шох Ғариб мирзо зуллисонанйн ижодкор. Унинг форсча 37 ғазал, 1 қитъа ва 1 мухаммаси (умумий хажми 557 мисра) ва ўзбекча 76 ғазал ва 4 мухаммаси (умумий хажми 1210 мисра)ни қамраб олган девонининг қўлёзма нусхаси Гамбург миллий кутубхонасида сақланаётган бўлиб, Олмониянинг шарқшунос олимлари ва Хумболдт университети профессорларининг бебахо ёрдами туфайли Шох Ғариб Мирзонинг форсий ва туркий тиллардаги кўлёзмаларининг нусхалари ва микрофильми Гамбург шахри кутубхонасидан 1999 йилнинг бошларида олиб келинган. Шох Ғариб мирзо ижодининг ғоявий-бадиий хусусиятлари,бадиий санъатлари, унинг сўз қўллаш махорати ўзига хос бўлиб, ўзбек адабиётшунослигида уни тадқиқ этишга эндигина киришилди. Зеро, бу борадаги ишларни изчил давом эттириш темурийлар даври адабий мухитини ўрганишни янги маълумотлар билан бойитиши шубхасиз.

\section{Фойдаланилган адабиётлар рўйхати}

1. Сирожиддинов Ш. Алишер Навоий: манбаларнинг қиёсий-типологик, текстологик тахлили.Т.: Akademnashr,2011.Б.3.

2. Суйима Ғаниева "Таъби хуб, каломи марғуб" Темурий шахзода Шох Ғариб мирзо хақида қайдлар.“"Ўзбекистон адабиёти ва санъати” газетаси,1996 йил, 5 июль. №27.

3. Хамид Сулаймон Алишер Навоийнинг Ғариб мирзо вафотига ёзган марсияси.Адабий мерос, 1971, №2.Б.175-178.

\section{ЗАИМСТВОВАННЫЕ АРХЕОЛОГИЧЕСКИЕ ТЕРМИНЫ BORROWED ARCHAEOLOGICAL TERMS}

\section{Мухтарова Ш.Ф. (СамГИИЯ)}

Annotation: The article discusses the syntactic way of forming terms is very productive in archaeological terminology, since the compound term allows you to most fully reflect the essential features of the concept. Combinations of words allow you to form a number of concepts based on one lexeme using certain types of phrases.

Key words and expressions: labor, medieval, terminology, development, religion, advantage, species, archaeological, character, etc.

Процесс научного взаимообмена обеспечивает непрерывность процесса взаимного обогащения сфер специальной лексики в разных странах. Иноязычные термины появлялись в русской археологической терминологии как в период ее формирования (XIX века кьеккенмединг, 70 - ориняк, террамар, 80 - е мустье, ашель, солютре), так и сегодня - в период ее развития (чоппер, чоппинг, лимас, кливер). Соответственно русские термины входят в состав иностранных терминологии (ср.: фр. un goroditche, англ. Kurgan, Tripolye, Апаи и др.).

Среди причин заимствования следует отметить не только внеязыковые (научный приоритет одной из стран, наличие в ней специфического вида археологических памятников), но и интралингвистические (необходимость номинации новых понятий и реалий, стремление избежать описательных наименований). «Иноязычные элементы ... обычно имеют то преимущество, что при достаточной краткости они легче могут выражать весьма сложные представления, для которых не всегда можно подобрать свой звуковой комплекс равного качества», - отмечал Д.С. Лотте (62, с. 57). Точность, краткость, отсутствие нежелательных языковых ассоциаций у иноязычного термина, его «отстраненность» обусловливают рациональность его заимствования.

Заимствование археологических терминов происходило и письменным, и устным путем. Для археологической терминологии характерно использовании терминов письменных исторических источников, которые в процессе употребления могут уточняться, конкретизироваться. Так, например, термин наус был заимствован из трудов средневековых 
арабоязычных авторов, где он обозначал не мусульманские погребальные постройки, и применен археологами в более узком значении: «В русской и востоковедческой и археологической литературе наусами принято называть склепы, которые зороастрийцы сооружали из глины, саманного кирпича или камня для хранения осуариев или для наземных захоронений».

Процесс заимствования сопровождался ассимиляцией фономорфологической оболочки иноязычных терминов в соответствии с законами русского языка. Как известно, основными способами графической ассимиляции заимствуемых слов является транскрипция и транслитерация. Оформление иноязычных терминов в языке археологии средствами русской графики чаще осуществлялась путём их транскрибирование, то есть передачи произносительной формы слова: ориньяк (aurignak), мадлен (madeleine), мустье (moustier), ашель (acheul), леваллуа (levallois). Реже встречается транслитерация: лингби (lyngby), маглемозе (maglemose), кьеккенментдинг (kjokkenmodding). Возможен и смешанный способ заимствование, когда часть слова транскрибируется, а часть транслитерируется. Так, передача конечного «з» в термине тарденуаз (tardenois) не позволяет считать его полностью транскрибированным. В термине чопnер (chopper) диграф «ch» передается в соответсвии с правилами произношения английского языка [tj] как «ч», но конец слова вопреки

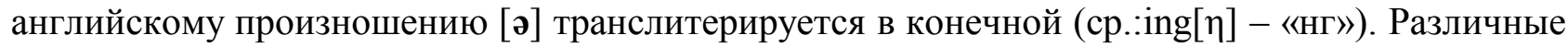
традиции в передаче иноязычных графем обусловливают вариантность заимствуемых терминов (ср.: пальстаб и пальстав, пилкалнис - пилькальнис, лингби и люнгбю, маглемосе и маглемозе)._Колебания в выборе графической оболочке заимствуемого словом характеризуют начальный этап заимствования - стадию «проникновения». Объясняются они также и влиянием языка - посредника. Так появлением варианта термина мадлен магдаленская эпоха на этапе проникновения обусловлено воздействием английской терминологии: Magdalenian (cp.: фp. madeleine).

С точки зрения фонемной субституции заимствованных терминов археологии можно выделить две группы:

1. полностью ассимилированные, произносимые в соответствии с фонетическими законами русского языка (ср.: азиль, оринияк, ашель, шелль);

2. частично ассимилированные, произносимые с отступлением от норм русской орфоэпии. Так, ряд терминов (ср.: солютре, тардэнуаз, аббевиль, тепе, чоппер) вопреки закону о смягчении согласных перед [е] сохраняет твердость согласных.

Часть терминов не освоено в грамматическом отношении (ср.: несклоняемые мустье, mепе, лингби, леваллуа), однако длительный период их употребления обусловил возможность появления их производных (ср.: мустьериьь, мустьерский, леваллуазский).

Освоение иноязычных терминов в семантическом отношении в результате их «укоренения» в заимствующих языке выражается в способности этих терминов развивать новые значения. Так, термин чаатас первоначально обозначал особый тип могильников в Хакасской автономной области. Позднее эти названия было перенесено и на археологическую культуру, для которой было характерно сооружение таких могильников.

Таким образом, немногочисленность иноязычных терминов в археологической терминосистеме, предпочтение семантического калькирования заимствованию свидетельствует о тенденции сохранения национальной основы терминологии, о самостоятельности в выработке понятийного аппарата науки. характерной чертой языка археологии является употреблении региональных терминов, с составляющих большую часть иноязычных терминов.

\section{Список использованной литературы}

1. Ахманова О.С. Словарь лингвистических терминов. - М.: Энциклопедия, 1966. С.9.

2. Реформатский А.А. Термин как член лексической системы языка. - В кН.: Проблемы структурной лингвистики «1967». М.: Наука, 1968, С.123. 
3. Формозов А.А. О термине «мезолит» и его эквивалентах. - Археология, 1970, №3, C.6-11.

4. Даниленко В.П. Русская терминология: Опыт лингвистического описания. - М.: Наука, 1977. С.55

5. Первобытное искусство: Пластика и рисунки древних культур. / Отв.ред. Р.С.Васильевский. - Новосибирск: Наука. Сиб. Отд-ние, 1983. С.45.

6. Археологические открытия 1980 года. М.: Наука, 1981. С.45.

7. Монгайт А.Л., Археология Западной Европы: Каменный век. - М.: Наука, 1973. C.129.

8. Археология: Учеб. /Под ред. В.Л. Янина. - М., 2006. С.19.

9. Горбачев В.Г., Растопчин В.Г., Тищенко В.Н. Культурные ценности: понятие, порядок приобретения, хранения и обращения: Справ. пособие. - М., 1994. С. 3.

\section{“БОШ” СЎЗИ БИЛАН ИФОДАЛАНГАН СОМАТИК ФРАЗАЛАРДА ИНСОН ХОЛАТИ ИФОДАСИ}

Назаров М.М. (УрДУ)

Annotation: This thesis is devoted to the analysis of somatic phraseological units in the Uzbek and English languages that describes human condition with a "head" component.

Key words expressions: Somatisms, phraseology, euphemisms.

Бугунги кунда лингвистик анализларнинг асосий мақсади оддийгина, тилларнинг тил тизими турли хусусиятларини таърифлашдан иборат эмас. Лингвистик бирликларнинг замонавий ёндашувга асосланган анализи тилда инсон омили ролини назарда тутади.

Соматизмлар инсон ва хайвонларнинг тана қисмларини англатади ва сўзнинг тасвирий ифодасини яратиб, унга янги мазмун бағишлайди. Улар фразалар ясалиши ва фразаларнинг маъноси шаклланишида мухим рол уйнайди. Фразеология сохасидаги тил ходисаларини қиёсий ўрганиш бугунги кун олимларига халқлар хаёти, маданияти, тарихи ва психологиясининг хусусиятларини ажратиб олишга ёрдам беради.

Тадқиқотнинг мақсади ўзбек ва инглиз тилларида инсон холатини ифодаловчи инсон тана аъзоси “бош” сўзи иштирокидаги ўзбек ва инглиз тилларидаги фразаларнинг семантик хусусиятларни очиб беришга йўналтирилган.

Биз ушбу тезисда “бош” сўзи иштирок этган, маъновий хусусиятига кўра инсоннинг рухий холати, инсон ақлий фаолияти, жазолаш, касаллик, ўлиш ёки емирилиш билан боғлиқ бўлган холатларни икки тил, яъни инглиз ва ўзбек тилларида солиштириш орқали ўрганиб ўтамиз (А.Исаев). Инсон тана аъзоси “бош” сўзи билан иштирок этиб, семантик мазмун касб этувчи фразалар ўзбек тилида 158 тани, рус тилида 108 та ва инглиз тилида 90 тага яқинни ташкил қилади. Инсон тана аъзоси “бош” сўзи янги фразалар ясашда кўплаб маъновий хусусиятларга эга.

Инсон рухий холатини англатувчи фразалар:

Хуши бошидан учмоқ --- То have someone's head in the clouds

Боши осмонга етмоқ --- His/her head reached into the sky

Мисол:Не has his head in the clouds while the rest of us are trying to figure out how to fix this! (Биз буни қандай тузатишни англашга харакат қилаётганимизда унинг хуши бошида эмас эди)

Инсоннинг ақлий фаолиятини ифодаловчи фраземалар:

Боши ишламайди ---someone's head is not in the game.

Мисол:My head's not in the game.

Жазолаш маъносини билдирувчи соматизмлар:

Бошида данак чақмоқ --- To cut the stone on somebody's head 
Ушбу сўз кўпинча сўзма-сўз таржима қилинган. Айрим соматизмлар иштирокидаги фразаларда асосан тил фразасида иштирок этган тана аъзоси ўрнига бошқа тана аъзоси иштирок этиши орқали таржима жараёнида эквивалентликка эришиш мумкин.

Масалан: Бошига кулфат тушган --- То be heartbroken

Касаллик тушунчасини ифодаловчи фраземалар:

Боши ёрилай деяпти --- Head's gonna to explode.

Мисол:It just feels like myhead'sgonna to explode.

Ўлиш, емирилиш (эвфемизм) маъноларини англатувчи фразалар.

Мисол: Бошидан жудо бўлмоқ --- То lose one's head

One of them loses their head, and one of them goes free.

Инглиз тилида мавжуд эвфимизмларнинг кўпчилиги “кўз” соматизми билан боғлиқ фразалар билан ифодаланади ва ушбу эвфимизмларнинг аксарияти ўлим (биологик) холати билан боғлиқ бўлгани учун ва ушбу холатни мантиқий кўриниши кўзни абадий юмилиш холати яъни ўлимнинг кўриниши сифатида қаралади.

Бу шу нарсага гувохлик берадики, инсон тана аъзоларининг функциялари бир хил ёки ўхшашлик жихатдан қиёсланаётган тилларда акс этади. Ўзбек ва инглиз тилларида “бош”нинг ўзига хос ифодаси мавжуд бўлиб, бош инсоннинг хаётий зарур аъзоси хисобланади. Бош фикрлаш ва идрок қилиш жараёнини бошқаради. Бизнинг қарашимизча бош билимлар, фикрлар ва ғояларнинг жисмоний манбаси, бош шунингдек, инсоннинг турли хил вазиятга ва холатга тушишига сабабчи омиллардан биридир. Хулоса қилиб шуни айтиш керакки, “бош” сўзи билан ифодаланган соматизмларнинг асосий ўзига хос хусусиятлари психолингвистикага оид ишларда чуқур ўрганилиши ва тадқиқ қилиниши зарур. Айнан ушбу тадқиқотлар чоғиштирма тилшуносликда янги даврни вужудга келтиради. Биз ўзимизнинг кейинги мақолаларимизда айнан ушбу мавзуга атрофлича қайтамиз.

\section{Фойдаланилган адабиётлар рўйхати}

1. Аверина М.А. Семантическая организация компонентов-зоонимов в русских паремиях / М.А.Аверина // Инновации в науке. — 2013. — № 21. - С. 29-34.

2. А.Исаев. “Ўзбек тилида соматик фразеологизмлар”, ф.ф.номзодлик автореферати. Ташкент, 1977й.

3. Arnold I.V. Lexicology of modern English. M., 1973.

4. Kunin A.V. English phraseology. M., 1970.

5. Logan P. Smith. The Phraseology of the English Language. Trans.by A. Ignatyev, M., 1959.

6. Shoabdurahmonov Sh. and b. The current Uzbek literary language, T., 1980.

\section{НУРАЛИ КОБУЛ ИЖОДИДА МИЛЛИЙ КОЛОРИТ ТАСВИРИ}

\section{Тўйчиев Абдунаби Худойбердиевич (Гулистон давлат университети)}

Annotation: Only highly spiritual, educated and conscientious citizens can create a developed Uzbekistan. It is no secret that in the current turbulent period, contradictions persist between different ideologies and doctrines. Under the influence of the discrediting of our national values, national restrictions, information attacks and mass culture, some people neglect the centuries-old values. Aimed at destroying people's love for the Motherland, their sense of pride in the rich historical and cultural traditions of their people, the world "eighth miracle" in the ideological struggle against cosmopolitanism, an alien view of foreign culture and life in art and literature, in this regard, artistic literature has a wide range of possibilities.

In this article, we would like to focus on some of our observations of national values and traditions in the narration of events described in the stories of the famous writer Nurali Kabul. 
Key words and expressions: Spirituality, values, traditions, literature, global.spirituality, values, traditions, literature, global.

Сўнгги йиллардаги жамиятимиздаги ислохотлар, ижтимоий-иқтисодий, маънавийахлоқий, сиёсий хаётдаги ўзгаришлар жамият аъзолари тафаккурида хам ўзгаришларга олиб келди. Жамиятнинг ривожланиш даражаси жамият аъзоларининг маънавий-интеллектуал савияси, маданий-ахлоқий қиёфасига кўп жихатдан боғлиқдир. Жамият аъзолари маънавиятини шакллантиришда эса адабиёт беқиёс имкониятга эга.

Атоқли адиб Нурали Қобул асарлари билан адабиёт ривожи ва жамият тараққиётига ўз хиссасини кўшган улкан ижодкордир. Унинг асарларида Ватан мадхи, шу юртда унибўсган одамларнинг қиёфаси, орзу-умидлари, дарду хасратлари, қувонч ва изтироблари тасвири бор. Ёзувчи асарлари баёнида миллий қадриятлар ва урф-одатлар тасвирига оид айрим кузатишларини хам бериб ўтади. Гапимизни асослаш учун мисолларга мурожаат қилсак.

Нурали Қобулнинг “Азоб” хикоясида Алламурод оқсоқол “ку̌зи тиригида супрақ̧оқдисига бошпана қ̧илиб бермоқ̧чи” эканини Хайитбой оқсоқолга айтади [Н.Қобул 2017:59]. Адиб бу ўринда “супрақоқди” деган жуда маънили сўзни кўллайди. Бу сўз, аввало, кенжаси учун қайғураётган ота қиёфасини чизади. Қолаверса, воқеалар кечаётган жойнинг хаёти, табиати ва кишиларга хос хусусиятларни шу биргина сўз ифодалаяпти. Адабий термин билан айтганда “Шарқ колорити” берилган. Адибнинг яна бир асари - “Сариқ қизлар” хикоясида муаллиф миллий менталитетимизга хос урф-одатни асар воқеаларига туртки берувчи деталь сифатида киритиб ўтади [Н.Қобул 2017:9]. Маълумки, уйга узоқрокдан мехмон келганда, мезбон келган мехмоннинг хохиш-иродасига кўра, ундан рухсат сўраб, келган мехмон билан гапи - гапига қовушадиган кишиларни чойга айтади. Бу хайрли одат хозирги кунда хам кўпроқ қишлоқ жойларда сақланиб қолган. Бола дадасининг мехмон олдига айтилиш эпизодида миллий колорит ифодаланган.

Адибнинг “Энам, мен ва бедана” хикоясида эса боланинг дадаси бедана боқиш учун Исмоил бободан бир эски тўрқовоқ олиб келади [Н.Кабул 1987:3]. "Унинг айтишича, бу туррқұовоқ муқ̧аддас эмиш. Қандайдир бир авлиёнинг қ̧абри тепасида ўсган чинорнинг синиб тушган шохидан құлинган эмиш. Дадам бу гапни энамга айтган эди, энам туррқоовоқни ўпиб, қош-кўзларига суртди. Бу менга эриш туюлса-да, бари бир у кишини яхши курраман”. Бу характерли эпизодда махаллий колорит ифодаланган. Аксарият ёши катта онахонлар, айниқса, асар ёзилган ўтган асрнинг 80-йилларида хамда асарнинг автобиографик хусусиятга эга эканлигини назарда тутсак, асар воқеалари кечаётган 60 -йилларда бундай холатнинг рўй бериши табиий бир холдир. Бу асарда табиат, хайвонот дунёси, буюмлар, мухит, уй жихозлари кабилар хам тасвирланади. Бундай тасвирлар асарда махаллий колоритни ифодалашга, образни конкретлаштиришга, воқеага табиий тус беришга, характер қирраларини очишга хизмат қилади. Аммо улар хам, албатта, бош қахрамон Эна образи билан боғлиқ холда берилган.

“Каптарлар қайтмаган кун” хикояси қахрамони кампир бир ўзи яшайди [Н.Қобул 2017:16]. У нимчасининг чўнтагидаги меваларни бежизга асрамайди. Қайси тўй-маъракага бормасин, “илохим, худойим мени хам шундай кунларга етказсин!” дея бир жуфт парвардами, ёнғоқми олади. Сўнг яна бир парвардани олиб тишсиз милкларида айлантириб сўра бошлайди. Атрофида бир-бирига гап бермай чувиллашаётган хотин-халажлар гапини мутлақо эшитмаётгандек одамларнинг боши узра тоғорти уфқига тикиларкан, "Илохим, етказган кунингга, берган ризқингга шукур", дейди.

Унинг яккаю ёлғиз қизи фарзанд кўрмай турмуши бузилгандан кейин ўзидан тўрт ёш чамаси кичик йигитга тегиб кетади. Кампир хар куни сувга борганида балиқларга нон увоқларини бераркан “Дуо қилинглар, худо хам менга эл қатори невара берсин”, - дерди. Яқинда кампирга хушхабар келтиришди... У анчагача тушимми-ўнгимми дегандек ўтирган жойида ағрайиб қотиб қолди. Қизининг бўйида бўлган эмиш.

Нурали Қобулнинг “Салом, тоғлар!” қиссасида хам махаллий колорит, урф-одат, воқеа кечаётган жой хаётига хос турмуш, пейзаж ва тил хусусиятлари акс эттирилган [Н.Қобул 
2017:40]. Яна мисолларга мурожаат қилсак. Асарда учрашувга чиққан Қоракўз Ғойибназардан нега ўнг кулоғи қизларникидай тешик эканлигини сўраганда Ғойибназар ёшлигида йиғлоқи бўлгани учун кулоғини тешишганини айтади. Хақиқатдан хам шундай удум бор. Адиб ўз ўрнида буни асарга сингдира олган. Ёзувчи хаётга қанчалик чукур кириб борса, уни қанчалик чуқур билса, хаёт воқеа-ходисаларини яхши билса у ёзган бадиий асар хам шунчалик хаётий бўлади. У “Салом, тоғлар!”ни ёзганда йигирма тўққиз ёшда эди. Ёш ёзувчининг хаётни теранлик билан кузатгани, илғаганларини махорат билан бадиийлаштиргани тахсинга сазовор. Асарни ўқирканмиз, шунга ўхшаш махаллий колоритни яққол гавдалантирган яна бир қанча эпизодларни учратамиз. Энақиз хола урушга кетаётган куёвининг оғзи тегиши учун “Омонлиқ, омонлиқ, хеч кўрмайлик ёмонлик” деб биринчи пишган ошқовоқдан сомса қилиб келади ёки Ғойибназарни урушга кетишида оналаридан бири қўғирмоч қовуриб, иккинчиси толқон туяётганига шохид бўламиз. Яна Қоракўзнинг дўлана данагидан кўзмунчоқ қилгани, ромчи иштироки, Отақўзи деб исм қўйилиши, Соч олар тўйида сочала қиласан дейишлар ва х.к.лар

Адиб давр колорити (рухи)ни бериш учун хозирги тилда эскириб қолган сўз, ибора ва турли кўшимчалар - архаизмдан фойдаланган. Асарда ғов, чориғ, ун оши, ёғоч коса, зоғора кулча, пуд ғалла, балоқ, оппон-соппон, сумови кууй, шолча, куртова, сочала, “никох суви”, шовуллоқ, паранжи, урчуқ, ромчи, испис пўшта каби кўплаб ўша давр воқеалар тасвирини берадиган сўз ва сўз бирикмалари борки, улар асар қийматини оширишга хизмат қилади. Асарда буюмлар, нарсалар, тасвири хам, мухит, уй жихозлари кабилар хам ўзига хос ўрин эгаллайди. Бундай образлар колоритни ифодалашга, уларга табиий тус беришга, қахрамонлар характер қирраларини очишга йўналтирилган. Ёзувчининг ижодий индивидуаллиги, ўзига хослиги шундаки, хаётда ўзи эшитган, баъзан кўрган воқеаходисаларни, урф-одатларни асарга усталик билан бир эпизодда сингдириб юборган.

Уйғониш даври дахоси Леонардо да Винчи ёзувчиларни муаллимлар деб атаган эди [Э.Худойбердиев 2003:354]. Ёзувчи асари билан кенг халқ оммасига ўз таъсирини ўтказа олади. Адабиёт ёрдамида Шахсни тарбиялаш мумкин, унинг ёрдамида миллий ва умуминсоний қадриятларни киши қалбида шакллантириш мумкин.

Адабиёт илмида катарсис ва каолокогот таълимоти хақида қарашлар бор. “Аристотелнинг "Поэтика" асарида катарсис ва каолокогот таълимоти хақида маълумот мавжуд. Катарсис - рухий покланув таълимоти, каолокогот - маънавий таъсирга берилган шахсдаги рухий- эстетик ўзгаришларни уқиш илмидир. Аристотел санъатнинг инсонга таъсири муаммосини трагедия асарлари тахлили орқали кўрсатган. Инсон қалби нозик, энг таъсирчан, биллурдай покизадир. Қалбга таъсир этувчи восита яна хам нозик, яна хам покиза, олмосдай сержило - серқирра, бебахо бўлмоғи лозим. Халқда “аччиқни аччиқ кесади”, деган нақл бор. Аъзойи баданга тикан кирса, уни (тикандан-да қаттиқ) игна билан чиқарадилар. Энг қаттиқ жисмлар олмос (қаттиқларнинг қаттиғи) билан қирқилади. Нозик, таъсирчан қалбга яна хам нафис, покиза санъат таъсир этиши мумкин. Аристотел яратган катарсис таълимотининг энг ёрқин талқинларидан бири Чўлпоннинг “Адабиёт надур” мақоласидир" [Б.Назаров, 2012:396]. Демак, инсон қалбига “нозик, таъсирчан қ̧албга яна хам нафис, покиза санъат таъсир этиши мумкин” экан. Адабиёт мана шундай “уддалаб бўлмас" вазифани уддалай олади.

Хулоса ўрнида айтиш мумкинки, халқимизнинг кўп асрлик миллий маданияти ва қадриятини асраб-авайлаш умуминсоний қадриятларнинг шаклланишига олиб келади. Яна шуни хам "Унутмаслик керакки, миллий мафкурага хизмат қилиш дегани истиқлол, ватан ва хоказолар хақидагина ёзиш дегани эмас. Чинакам санъаткор нима хақида ёзишдан қатъий назар, - у маънавий муаммоларни бадиий тадқиқ этадими, ўзининг қалб қаърларига нигох ташлайдими, ишқ-мухаббат хақида ёзадими...-ўзи бадиий тасвир ва тадқиқ предмети сифатида олган нарсани умуминсоний қадриятлар, эзгулик, инсонийлик нуқтаи назаридан ёритар ва бахолар экан, у миллий мафкурамизнинг шаклланишига, мустахкамланишига, жамият аъзолари шуурига сингишга хизмат қилаётган бўлади. Зеро, юқорида таъкидлаганимиздек, жамиятимизнинг шаклланаётган мафкураси умуминсоний 
қадриятларга хар жихатдан мувофиқдир" [Қуронов Д. 2004:52]. Ана шундай қадриятларимизни асраб-авайлаш, миллат қадри ва шаъни-шавкатини сақлаш, хозирги глобаллашув даврида ўзлигимизни асраб қолишни таъминлаш кенг зиёлилар қатламининг асосий вазифаларидан биридир.

\section{Фойдаланилган адабиётлар рўйхати}

1. Б.Назаров, А.Расулов, Қ. Қахрамонов, Ш.Ахмедова Ўзбек адабий танқидчилиги тарихи. Олий ўқув юртлари учун дарслик - Т.: Чўлпон номидаги нашриёт-матбаа ижодий уйи, $2012-432$ б.

2. Д.Қуронов Адабиётшуносликка кириш. Олий ўқув юртлари учун дарслик - Т.: Абдулла Қодирий номидаги халқ мероси нашриёти, 2004 - 224 б.

3. Нурали Қобул. Маймунлар мамлакати ёхуд ёввойилар орасида. -T.: “IJOD-PRESS", 2017,- 246 б.

4. Нурали Кабул. Бабушка. Рассказ // -Т.: Пионер Востока, №39, 1987. С.3

5. Нурали Қобул. Жохиллик ва қотиллик -T.: “IJOD-PRESS”, 2017,- 240 б.

6. Э.Худойбердиев. Адабиётшуносликка кириш. Олий ўқув юртлари учун дарслик - Т.: “ЎАЖБНТ”, 2003 - 362 б.

\section{СИДДИҚИЙ-АЖЗИЙНИНГ ИЖТИМОИЙ-АХЛОҚИЙ ҚАРАШЛАРИ}

\section{Хақкулов Набижон Қахрамонович}

(СамДЧТИ)

Annotation: The article analyzes the social and moral views of the enlightener-Jadid Saidakhmad Khasankhoja oglu Siddiki-Ajzi, the need to strengthen the atmosphere of friendship between the peoples of the region, the need to respect universal human values. Also, the role and significance of Ajzi's legacy of social and moral thinking in the development of modern civilization, the formation of independent thinking, a new approach to the world, the ability to evaluate events with deep intelligence and thinking, a deep sense of responsibility, resistance to indifference and indifference. tried to justify it.

Key words and expressions: Enlightenment, Jadid movement, national awakening, friendship, interethnic harmony, mutual cooperation, education, historical and educational heritage.

Маълумки, мамлакатимиз худудида яшаб ўтган мутафаккирларнинг илмий меросини чуқур ўрганиш ва тарғиб этиш, ёш авлодни аждодларимизнинг эзгу анъаналари рухида тарбиялаш буйича ислохотлар изчил давом эттирилмокда. Маънавий - маърифий сохадаги ислохотлар самарасини ошириш зарурати бу йўналишдаги фаолиятни сифат жихатдан янги босқичга кўтаришни талаб қилмоқда. "Биз аждодларимизнинг донишмандлик анъаналарига амал қзилиб, уларнинг вояларини англаган хуолда, қ̧атъий ислохотларни амалга оширмоқ̧дамиз, мамлакатимизнинг янги қ̧еёрасини шакллантириш йўлидан бормоқудамиз ”[1. Мирзиёев Ш.М. 2017. Б.184].

Бу борада жадид мутафаккирларининг мамлакатимиз ва жахон миқёсида эътироф этилган Ватанга мухаббат ва садоқат, бағрикенглик, оилани эъзозлаш ва мустахкамлаш, маънавий огохлик, халқлар ўртасида дўстлик, миллатлараро тотувлик, ўзаро хамкорлик каби ижтимоий-фалсафий ғояларининг мазмунини тадқиқ этиш мухим амалий ахамият касб этади.

Самарқандлик маърифатпарвар-жадидчи Саидахмад Хасанхўжа ўғли Сиддиқий-Ажзий бутун хаётини ана шундай муқаддас ишга сарф этди. Айниқса, Самарқанд минтақасида кўп миллатли ахоли орасида дўстлик мухитини мустахкамлаш, умуминсоний қадриятларга хурмат рухида бўлиш лозимлигини тарғиб қилади.

Ўзи очган мактабда табиий фанлар, араб хамда рус тилларидан сабоқ берди, дарсликлар тузди. Куйида унинг “Миръоти ибрат” достонида келтирилган фикри гувох беради;

Тахсил ўла рус мактабинда, 
Анвои фунун анинг тилинда.

Таълими зироат-у тижорат.

Билгунг ясамоқ одати олот,

Илми хама ихтире-ю хикмат,

Мошин ила ғирмофону соат.

Вопур, шинандафуру телефун,

Хам хикмоту тилғрофу болун.

Хар чоққи, лисони чўх билурсен

Дунёда азизроқ ўлурсен,

Ким давлатининг лисонин билмаз

Таъсиф сўнгинда суд қилмаз. [2; Фаттаев М. 1986.Б.31]

Сиддиқий-Ажзийнинг ахолини маърифатли қилиш борасидаги харакати, ўзбеклар ва тожиклар миллатига мансуб кишилар билан бир қаторда ўзга миллат вакилларига нисбатан олиб борган бағрикенглик фаолияти хар доимо осонликча юз бермади. Кўплаб мутаассиблар томонидан бу фаолият таъқиб остига олинди. Бунга 1914 йилда “Туркистон вилояти газети”да қуйидаги маълумот чоп этилган: “3 январ жумъа 1914 йил. Улуғбек мадрасаси ичидаги жомъеда 5-6 минг мусулмония хузурида муаззин тарафиндан жадидчиларни ва русча ўқитмоққа тарғиб қиладургонларни кофирлиги ва хар ким боласини усули жадидға берса, ўзи кофир, хотини талоқ бўлишини форсий тил ила узун ва баланд бир нутқ ила халойиқға билдирубдир ва хам аларни кофир, ўрус ва хамда кофир ва ўрус билғувчи деб эълон қилибдур”. Гап асосан Халвойидаги Сиддиқий-Ажзий мактаби билан Ражабаминдаги Абдулқодир Шакурий мактаблари хақида гап кетган эди. [3; Қосимов Б. 1994. Б.53]

Шуни хам таъкидлашимиз жоизки, Сиддиқий-Ажзийнинг жамиятда миллатлараро хамжихатлик ва бағрикенгликни таъминлашга қаратилган сайъ-харакати изсиз кетган эмас. Ўз вақтида Туркистон жадидларининг ғоявий етакчиси Бехбудий томонидан Ажзийга “Ойина” журнали орқали ўзини химоя қилишга имконият беради.

Жумладан;

Аз хақигўйи забон кашидан куфр аст,

То жон дорам, каломи Хақ мехонам.

(Маъноси;

Хақ̧иқұатни сўзлаш куфр бўладиган бўлса,

Токи жоним бор экан, хуақ̧иқатни айтаман.)

Ёки,

Хақ сўйлаян инсонлари такфир (кофир) эдажаклар,

Имонли мусумонларинга "шукр" Худоё. - каби чиқишлари билан ўзининг хаёт тажрибаси, билим ва тафаккури орқали мамлакат ва миллат олдидаги масъулиятини тўғри хис этган.

Сиддиқий-Ажзийнинг замондоши, ўз даврининг кўзга кўринган танқидчиси Вадуд Махмуднинг таъбири билан айтганда, “Бизнинг Ажзий хам шу замирдандир. Унинг учун турк, форс, араб, хинд миллати йўқдир. Буларнинг мусулмон бўлғон қисми хаммаси бир миллатдир. Бу фикр мусулмонлар орасида асосан эскидир. Ислом дини хақиқатан шу қадар таъсир эткандирки, уруғ, насл эътибори ила келган айирмалардин айирмаси остида сўнуб, эътибордин тушгандир. Араб қонининг бошқа «ислом» миллатлари қониға кўб кўшилиши хам бунга кўб ёрдам қилғондир. Хозир хам халқдан «кимсан» деб сўралса, «мусулмон» деган жавоб олинади. Бир миллатнинг бу тарзи тараққийси Ажзийнинг ўз даврининг кишиси эканини кўрсатадир"[4; Вадуд М. 2007.Б.42].

Жадидларнинг буюк тарихий хизматлари шундан иборатки, улар етилиб қолган ижтимоий муаммоларни хал қилиш принципларини эволюцион-ислохот йўли асосида ишлаб чиқдилар. Улар дунёқарашининг негизи инқилоб билан эмас, балки ислохот йўлидан бориб, илм-маърифатни, кенг кўламда юксалтириш орқали миллий тараққиётга эришишдан иборат эди. 
Эътибор берган бўлсангиз, кишилар орасидаги муросасизлик хозирги дунёнинг энг катта глобал муаммоларидан бирига айланди. Жамоавий, институционал ва хатто давлат нуқтаи назари даражасига кўтарилган муросасизлик демократия тамойилларини қўпоради хамда инсоннинг шахсий ва жамоавий хуқуклари бузилишига олиб боради [5;Тишков В.А. 1995. С.17].

Дархақиқат, дунёнинг кўпгина худудларида авж олиб бораётган муросасизлик салбий оқибатларга олиб келиши кундай равшандир.

Бу каби холатларни олдиндан кўра билган холда, Ажзий хам ўз халқининг хеч «иттиход, уюшмак, маслахатлашмак» деган маданият муассирларига яқинлашмаслиғидан зорланадир. Хақиқатанда шоирнинг фикри тўғри эмасми? Хар бир иш «қўл бирлиги, уюшмак, кенгаш» билан илгари босмайдирми? Ўз халқининг саодатини Ажзий хам «шуларда» кўрадир:

Гирифтори саводи хатту холи сафхаи дардам,

Асири кулфату ранжу балоу доғи хирмонам.

Давойи захми носурам эмишдир сухбати «ориф»,

Вале махдуми пайкони балойи «қавми нодонам»,- - байтлари биланда ўзининг дардини шарх этадир. Ўзининг «ориф, яъни маърифатли»лар сухбатидан махрум эканини ва «нодон қавм»нинг бало ўклариға «нишон» бўлғонини айтиб, яна ўзига ўзи таскин берадир:

«Рақиб»дан на жафо келса, собир ўл, Ажзий,

Ким ўлмади очи сув ичра беқарор садаф.

«Рақиб» хар қанча жафо қилса хам сан сабр қил, дейдир[6; Вадуд М. 2007.Б.38].

Шунингдек, Сиддиқий-Ажзийга замондош бўлган шоир Турсунқул (Рахим Хошим)нинг «Маориф ва ўқутғучи» журналининг 1928-йил 3-сонида босилган «Сиддиқий тўғрисида мулохазалар» мақоласида олим хақида фикр юрита туриб унга қуйидагича таъриф беради: «Сиддиқий мафкура ва ўйлашда ўз чоғдош (муосир) ва маслакдошларидан юқори туради. Унинг хаёли кенг, дунёни кўриши атрофли, кўзининг уфқи вусъатлидур»[7;]

Таниқли мунаққид Вадуд Махмуднинг «Турк шоири Ажзий» номли мақоласида ўз замондоши Ажзий хақида “Ажзий Шарқ шеърий шаклига ўз ижтимоий- адабий қарашларини олиб кирганлигини, шу орқали миллатни илм-маърифатга, ўзлигини англашга, хуллас, маънавий юксалишга ундаган”[8; Вадуд М. 2007.Б.36], деган фикрлари диққатга сазовордир. Сиддиқий-Ажзийнинг умумий бирликка эришиш, миллатни такомиллаштириш ва исломни ривожлантириш, ўқиш ва мактаб-маориф сохасини ислох қилиш, илм ва хунарни ўрганиш, иқтисодий ва маънавий ахволни яхшилаш тўғрисидаги фикрлари Вадуд Махмуднинг эътиборини тортди ва бу фикрлар ўз даврида илғор фикрлашнинг намунаси, деб эътироф этилди.

Хулоса қилиш айтиш керакки, халқ ишончи ва эътиқодини мустахкамлаш йўлида биз тараққиётимизнинг миллий уйғониш босқичи хисобланмиш - маърифатпарлик-жадидчилик харакатининг йирик намоёндаси бўлмиш - Сиддиқий-Ажзийнинг ижтимоий-ахлоқий тафаккур меросининг замонавий цивилизация ривожидаги ўрни ва ахамияти, мустақиллик тафаккурини шакллантириш, дунёга янгича ёндошув, теран ақл ва тафаккур кучи билан воқеа ва ходисаларни бахолай оладиган, масъулият хиссини чуқур англаб, лоқайдлик ва бефарқликка қарши тура оладиган ёшлар тарбиясида мухим омилларидан бири эканлигини асослашга харакат қилинди.

Ушбу йўналишда олиб борилаётган тадқиқот ишларимиз самараси сифатида кўйидагиларга эришиш мумкин бўлади:

-минтақада XX аср бошиларида миллий уйғониш даврининг ижтимоий-иқтисодий, ғоявий, маънавий-ахлоқий заминлари тўғрисидаги илмий билимлар, хулосалар мустахкамланади;

-Сиддиқий-Ажзийнинг маърифатпарварлик, жадидчилик харакатида тутган ўрни аниқланади; 
-хозирги замон илм-фани, маданияти ривожида маърифатпарвар Сиддиқий-Ажзийнинг маърифий-жадидчилик фаолияти ва унинг ижтимоий-фалсафий меросини мавқеи ва хиссаси белгиланади;

-мустақиллик йилларида мамлакатимизда амалга оширилаётган кенг кўламли ислохатларда Сиддиқий-Ажзийнинг тарихий-маърифий меросини ахамияти ўрганилади;

-маърифатпарвар Сиддиқий-Ажзийнинг тарихий-маърифий мероси, хикматлари ва доно фикрлари баркамол авлод тарбиясида намуна ва ибрат мактаби эканлиги билан белгиланади.

Зероким, Ўзбекистон Республикаси Президенти Шавкат Мирзиёевнинг 2020 йил 24 январдаги Олий Мажлисга Мурожаатномасидаги қуйидаги фикрлари бу борадаги биз каби тадқиқотчи ва илмий изланувчиларга қаратилган ўзига хос чақириқдир: “Биз жадидчилик харакати, маърифатпарвар боболаримиз меросини чукур ўрганишимиз керак. Биз маънавий хазинани қанча кўп ўргансак, бугунги кунда хам бизни ташвишга солаётган жуда кўп саволларга жавоб топамиз. Бу бебахо бойликни қанча фаол тарғиб этсак, халқимиз, айниқса, ёшларимиз бугунги тинч ва эркин хаётининг қадрини англаб етади”.[9]

\section{Фойдаланилган адабиётлар рўйхати}

1. Ўзбекистон Республикаси Президенти Ш.Мирзиёевнинг Бирлашган миллатлар ташкилоти Бош ассамблеясининг 72 - сессиясида сўзлаган нутқи. - Т.: Маънавият, 2017.Б.184.

2. Фаттоев М. Атоқли педагогларимиз. - Т.: Ўқитувчи, 1988. Б.31.

3. Қосимов Б. Маслакдошлар: Бехбудий, Ажзий, Фитрат. -Т.: Шарқ, 1994. -Б.53.

4. Вадуд Махмуд. Танланган асарлар (Нашрга тайёрловчи Баходир Каримов). -Т.: Маънавият, 2007. -Б.42.

5. Тишков В.А. Толерантность и согласие. // Материалы международной конференции “Толерантность, взаимоотношении и согласие”. - Якутск. Июнь. 1995 г. — М., 1997, С.17.

6. Вадуд Махмуд. Танланган асарлар (Нашрга тайёрловчи Баходир Каримов). -Т.: Маънавият, 2007. -Б.38.

7. Жумаев Ж. Жадид мутафаккири Саидахмад Сиддиқий - Ажзий фаолиятини ёритувчи манбалар. (Электрон манба). URL https://www.azon.uz/content/views/ jadidmutafakkiri-saidahmad-siddiqiy-ajz

8. Вадуд Махмуд. Турк шоири Ажзий. // Танланган асарлар(Нашрга тайёрловчи Баходир Каримов). - Т.: Маънавият, 2007. 36-бет.

9. Ўзбекистон Республикаси Президенти Шавкат Мирзиёевнинг Олий Мажлисга Мурожаатномаси. (Электрон манба). URL https://uza.uz/oz/politics/zbekiston-respublikasiprezidenti-shavkat-mirziyeevning-oliy-25-01-2020

\section{ГЕНРИ ЛОНГФЕЛЛОНИНГ “ГАЙАВАТА ХАҚИДА КЎШИК”ДОСТОНИ ТАРЖИМАЛАРИДА ХИНДУЛАР МУАММОЛАРИ ВА УЛАРНИНГ БУГУНГИ КУН АДАБИЙ -ШЕЬРИЙ УСЛУБИГА ХОС ЖИХАТЛАРИ}

Элова Умида Рўзимуродовна

(СамДЧТИ)

Annotation: In this article, the world-famous poem "Song about Gayavata" is dedicated to the life, lifestyle, and culture of the ancient Indians who are Native Americans. At the time of writing, in the nineteenth century, the Indians were completely oppressed and doomed to extinction. The talented poet and scholar Longfello studied Indian folklore, the folklore and mythology of the ancient Hindu tribes, as well as ethnographic and historical materials about the Indians, as evidenced by the poet's many diaries and letters to friends and acquaintances. 
Longfello saw the source of inspiration for the creation of national literature in the oral tradition of the North American Indians - Native Americans. Longfellow's many years of research on the Indians have been reflected in several of his works.

Key words and expressions: Mythology, historical-ethnographic, Hindu epic, onondags, kayaks, tuskarorlar, irokez union, customs.

Таъкидлаш жоизки, хиндулар мавзуси Лонгфеллонинг дастлабки ижод намуналари “Ловелз-Понд ёнидаги жанг”, “Минниенк дафн маросими”, “Хинду-овчи”, "Хинду Юзга ёққан ёмғирнинг қасоси” ва бошқа асарларида хам кузатилади. Уларда шоир хиндулар хаётини, уларнинг озодлик учун курашини хамдардлик билан тасвирлайди, оқ танлиларнинг мустамлакачилик сиёсатига қарши туради.

Оламга яхлит нуқтаи назардан, табиий, табиатдан ажралмаган тарзда нигох ташлаш ва табиатни инсон онгига зид қўймаслик, хаётнинг кенг кўламлилигини хис этиш - халқ поэзияси романтикларининг, жумладан, Лонгфеллонинг хам диққат-эътиборини жалб этган эди. Бир пайтлар А.Шлегель шундай деган эди: “Бизнинг миллатимиз юксак маданиятли тоифаларининг адабиёти йўқ, халқ, оддий одамларда эса бор” [Шлегель 1934:213].

Лонгфеллонинг америка эпоси муаммоларини хал этишдаги вазифаси осон иш бўлмаган, у турли хинду қабилилари тарихида улар маданиятига доир материалларни олиши ва уларни инглиз-европа поэзияси дарахтига пайванд қилиши лозим эди.

У ўз асарига материал сифатида, тили ва маданий қадриятлари европа халқлари меросидан фарқ қиладиган америка хиндулари мифологияси ва қўшиқчилик анъаналарини танлади. Бу борада қийинчилик шундан иборат эдики, хинду фольклори сохасида Лонгфелло, дейлик, фин рун ёки саксон ёрлиқларига ўхшаган ёзма ёдгарликларга таяна олмасди. Унинг ихтиёрида хилма хил айтим-мифологик материаллар бор эди ва у америка адабиёти учун Прометей бўлишга қодир қахрамон излай бошлади.

Шимолий америка хиндуларининг турли қабилалари афсона ва асотирлари "Гайавата хақида қўшиқ" учун асосий манба бўлиб хизмат қилди. Лонгфелло ўзининг поэмасини америкалик тадқиқотчи-этнограф Г.Скулкрафтнинг бир неча китобларидан, жумладан, “Алгик тадқиқотлар”, “Онеота” ва "Қўшма Штатлар қабилалари тарихи, шарт-шароити ва истиқболи” номли [Schoolcraft 1839, 1845, 1859] монографиясидан олинган афсона ва ривоятлар асосига қуради. Хукуматнинг хиндулар иши бўйича ходими бўлган Г.Скулкрафт ўз хаётининг каттагина қисмини хиндулар қабилалари орасида яшаб ўтказган. У 1855 йил 19 декабрда Лонгфеллога йўллаган мактубида қадимги хиндуларнинг поэзия ва адабиётдаги образларини бадиий идроклаш хақидаги ўзининг эстетик нуқтаи назарини шундай баён қилади: "Хиндуни у қандай бўлса шундай - борича тушуниб қабул қилиш керак. У - урушда жасур жангчи, қасос олишда вахший, синовларга бардошли ва эпчилликда, чапдастликда мисоли йиртқич хайвон. Айни пайтда у намунали ота ва оила бошлиғи, ўз юртининг юртпарвари, ўзининг овга берилганлиги билан яхши спорт турларининг ишқибози, бағрикенг ва инсонсевар, ўз дўстлари ва туғишганлари қабрлари бошида чуқур ғам чекувчи. Агар хинду хақида қачондир шеьр ёзиладиган бўлса, бунда у озод, эркин ва ёввойи қиёфада - ўрмонлар ва бепоён чўлларнинг мустақил одами сифатида гавдаланиши лозим..." [Schoolcraft 1956:317].

“Гайавата хақидаги қўшиқ”нинг бош қахрамонига Лонгфелло Гайавата деб исм беради - бу афсонавий-тарихий шахс, айрим манбаларга кўра XV ёки XVI асрларда яшаб ўтган. Ривоятларга кўра, Гайавата Онондага қабиласида туғилган ва унинг номи таржимада “Дарёлар бунёдкори”, деган маънони англатади. Гайаватани 1570 йилда бешта қабилани (онейдлар, могауклар, онондаглар, сенеклар ва каюклар, кейинчалик тускарорларни) бирлаштирган Ирокез иттифоқи ташкилотчиси, деб хисоблайдилар. Бу иттифоқ доимо алконк қабилалари билан курашиб келган, чунки алконк қабилари ирокезларни Шимолий Катта кўллар атрофида кўним топган ердан Жанубга сиқиб чиқаришган уринган [Новиков 1982:27]. Лонгфелло ўз поэмасида воқеалар кечадиган худуднинг, яъни Катта кўллар худудининг жуғрофий ва геологик шарт-шароити билан батафсил танишади, шунингдек, у хиндуларнинг турмуши, урф-одатлари ва маросимлари хақида этнографик маълумотлар 
йиғади - уларнинг хаммасини “Гайавата хақида қўшиқ” асарида муваффақият билан ишлатади.

Асарнинг илк сатрлариданоқ ўқувчини ёввойи америка табиати олами, хусусан, унинг белги-аломатлари ва вакиллари (ўсимликлари, хайвонлари, одамлари) куршаб олади, туб жой халқи - аборогенларнинг, шеърнинг инглиз тили поэтикасига тенг ва мос даражада тушадиган: Шух-Шух-Га(қарқара), Мушкодаза (қарқур-қуш), Тавазонта (водий), Навагада (бахши) ва, албатта, Гайавата каби исмлар берилади. Хатто акс садо хам хиндуча жаранглайди: “Бэм-Вава...”. Хақиқий америкача исмлар хам ўзининг келиб чиқишига кўра аборигенларга бурчли. Лонгфелло ўзининг поэма муаллифи эмаслигига, фақат атиги бошқа хикоячининг “таронасини такрорлагани”га ишора қилади ва кейин табиатининг ўзига жўшқин ва сўнгсиз хилма-хил табиатга сўз беради.

\section{Фойдаланилган адабиётлар рўйхати}

1. Бунин И. Песенъ о Гайавате. Г.У.Лонгфелло. Песенъ о Гайавате. Перевод с англ. И предисловие И. Бунина. -М:Правда, 1982.-196с.

2. Элова У. Жахон адабиёти. Журнал. Генри Лонгфелло ижодида инсон рухияти манзаралари.2020.- 167б

\section{KITOB MADANIYATLARARO MULOQOT VOSITASI (Chesterfildning "Farzandga maktublar" asari misolida)}

\section{S.Saydaliyev (NamDU professori)}

Annotation: The presented article demonstrates the book is a source for intercultural communication, as exemplified by the well-known British statesman and diplomat Chesterfield (Philip Dormen Stenhop) in Letters to a Child. The article describes a survey of students and their analysis. The fact that the book is an instrument of intercultural communication is illustrated by the example of "A letter to a child" by the famous British statesman, diplomat Chesterfield Philip Dorman Stenhop`s. The article describes the survey of students and their analysis.

Key words and expressions: book, letter, ethics, etiquette, culture, communication Book, letters, morality, ethics, culture, communication.

Ma`lumki kitob haqida ko`p va xo`p aytilgan va yozilgan. Bir bog`lam holiga keltirilgan, hajmi 49 sahifa va undan ortiq bo`lgan, lekin vaqtli matbuotga tegishli bo`lmagan, bosilgan, yozilgan, rasm solingan, ba`zan bo`sh qog`ozlar to`plami shaklidagi nashr, kitob deyiladi. 1995 yili YUNESKO tomonidan 23 aprelni kitoblar kuni deb e`lon qilingan.

Kitob bilimlar manbai. U dunyoqarashni shalkkantiradigan va kengaytiradigan vosita. Barcha buyuk kishilar ulug`lik martabasiga kitob mutaalasi orqali erishganlar. Kitoblarning turlari ko`p. Masalan, tarixiy, badiiy, ilmiy, diniy, qovmusiy, fantastik, sarguzasht, ertak va boshqalar. Uning turlaridan yana biri maktublar jamlangan kitoblardir.

Tarixdan Kaykovus, A.Jomiy, A.Navoiy, Javoharla`l Neru va boshqa ko’plab mashhur kishilar qalamiga mansub "noma" janriga misil bo"la oladigan asarlarni keltirish mumkin. Chesterfildning "Farzandga maktublar" asari ham shular jumlasiga kiradi.

1694-1773 yillarda yashab ijod qilgan ingliz davlat arbobi, diplomat Chesterfild (Filip Dormen Stenhop)ning bu kitobi ta lim-tarbiya sohasida alohida ahamiyat kasb etadi. Ushbu asar ma`rifatparvarlik ruhi bilan sug`orilgan bo`lib, XVIII asr Yevropa kishisining qiyofasini tavsiflab berish bilan barobar, davlat xizmatiga o`zini tayyorlamoqchi bo`lgan yosh inson qanday xislatlarni o`zida mujassamlashtirishi kerak, degan savolga javob berishga qaratilgan. Unda Chesterfildning o`zidan ancha olisda yashagan o`g liga qariyb 30 yil davomida yo`llagan 400 dan ortiq maktublari jamlangan.

"Farzandga maktublar" asaridagi 30 dan ortiq maktub zahmatkash pedagog, fidoyi adabiyotshunos, mohir tarjimon p.f.n. NamDU professori Nosirov Qodir Nosirovitsch tomonidan 
o`zbek tiliga ilk bora o`girilib "Jahon adabiyoti” jurnalining 2004 yil mart oyi sonida chop etildi. Odatda biron kitobni nashr qilish uchun muallif yoki tarjimon turli idoralarga murojat qiladi, ko`p ovoragarchliklardan so`ng e`lon qilishga ruxsat olada, natija har doim ham ko`ngildagidek bo 'lavermaydi. Qizig`i shundaki "Farzandga maktublar" asarining Q.N.Nosirov tarjimasidagi jurnal varianti 2008 yilda Toshkentdagi Cho'lpon nomidagi nashryotmatbaa ijodiy uyida "Yoshlar kutubxonasi" seriyasida chop etilib, kitobxonlar e'tiboriga havola qilingan, lekin bundan tarjimonning xabari ham bo`lmagan. Bu ushbu asar kitobsevarlarni qanchalik qiziqtirishi va kitobxonlar uchun zarur ekanligini ko`rsatib turibdi.

Asarda quyidagi mavzular bo yicha umuminsoniy qadriyatlar, ta`lim-tarbiyaga oid masalalar sodda, tushunarli, ko`rsatma, tavsiya, nasihat tarzida qog`ozga tushurilgan. Maktublarda muomala, muomala odobi, xushmuomalalilik, g`urur va noziktablik, xulq-atvor, kiyinish odobi, til o`rganish va inson qalbiga yo`l toppish, yaxshilikka yetaklovchi nasihatlar, to`g`ri so`zlilik, mehribonlik, vaqt, vaqtdan foydalanish, oqillik, suhbatlashish odobi, hayot saboqlari, tajriba, ilm olish yo`llari, inson bo `lish shartlari, fikrni og`zaki va yozma bayon qiliush sirlari, notiqlik san`ati, jamoat oldida ozni tutish, jamoaning ishonchiga kirish, jamoaning xurmatini qozonis, maqsad, maqsad qo`yish va unga erishish sirlari, mehnat, mehnatsevarlik, g'ayrat va shijoat, tartib-intizom va unga rioya qilish, tozalik, tejamkorlik, boyish va boy bo'lish yo`llari, xullas, komillik, komillikka erishish sirlari bayon qilingan.

Ushbu asarning ta`lim-tarbiya jaroyonidagi ahamiyatining beqiyosligini e`tirof etish bilan barobar, u bilan "Psixolingvistika" kursida olib borilgan ish tajribalarimiz bilan o rtoqlashish maqsadida quyidagilarni bayon qilishga jur'at qildik. Chesterfildning "Farzandga maktublar" asaridagi har bir maktub talabalarga bittadan taqsimlab berildi va ularga maktubga oid quyidagi topshiriqlarni bajarish topshirildi.

1. Maktubdan nusxa oling va uni daftaringizga yopishtiring.

2. Maktubni diqqat bilan o`qib chiqing.

3. Maktubga sarlavha qo`ying.

4. Maktubdagi tayanch so`zlarni yozib oling.

5. Maktub mazmunini qisqa yozma bayon qiling.

6. Maktubdan sizga yoqqan jumlalardan uchtasini ko`chirib oling.

7. Maktubdan qanday ibrat olganingizni yozing.

8. Maktubga asoslanib ukangizga nasihat qiling.

Talabalar maktub bilan bajonu dil ishladilar. Ish jaroyonida talabalarning maktubga sarlavha qo`yish malakalari hali yetarli darajada rivojlanmaganligi, va ularning bu sohadagi tajribalari mukammal emasligi ma`lum bo`ldi. Ular bilan sarlavha, uning turlari va xususiyatlari haqida suhbatlashilgandan so`ng, natija ijobiy tomonga o`zgardi. Ko`pchilik talabalar sarlavhani maktubdan izlab topish tajribasini tezda o`zlashtirib oldilar.

"Maktub mazmunini qisqa yozma bayon qilish mashqi"ni bajarish ham bir oz qiyin kechdi. Ayrim talabalar maktubdagi voqealarni uzun, murakkab, qo`shma gapli jumlalar bilan bayon qilishga harakat qilganliklari bois, fikrlarini aniq, sodda va tushunarli izhor qilishga qiynaldilar. Boshqalari maktubdagi jumlalarni shundog`icha ko`chirib qo`yish bilan kifiyalandilar. Natijada topshiriq to laqonli bajarilmay qoldi. Talabalar bilan annotatsiya haqidagi suhbat va bu borada bir qator mashqlar bajarilgandan so`ng, ushbu topshiriqni bajarilish natijasi ham ancha ijobiy baholandi.

"Maktubdan sizga yoqqan jumlalardan uchtasini ko chirib yozing", deb nomlangan topshiriq talabalar tomonidan muvaffaqiyat bilan bajarildi. Ularga asosan ilm olish, kishilarga yaxshilik qilish va yordam berishni o`rganish va boshqa masalalarga oid jumlalarning maqul kelgani, ta`lim jarayonida berilayotgan bilim, ko`nikma va malakalarning talabalarga ijobiy ta`siridan dalolat berib turibdi.

"Aslida maktubdagi har bir jumla kelajakda komil inson bo lish orzusida bo 'lgan kishi uchun foydali va zarur. Shuning uchun faqat uchta emas, balki barcha jumlalar menga yoqdi”, degan fikni ko pchilik talabalar izhor qilganlar. Quyida talabalar ko`chirib olgan va sharxlagan jumlalardan namunalar keltiramiz. 
- Bir sohada yuzaki bilimga ega bo`Igandan, bo`lmagan ma`qul.

- Yuzaki bilim kishiga qoniqish hissi bermasligi bilan bir paytda, kulguga ham sabab bo `ladi.

- Kitobiy bilim va hayotiy bilim - bu bir-birini to 'ldiruvchi, inson uchun eng zarur narsadir.

- Odamning bilimi odamlar orasidagina amalga oshirilishi mumkin, salqin xonada emas.

- Chuqur ilmga ega har qanday odamda ham sog`lom aql bo`lmasa, unda, albatta, mutakabbirlik paydo bo`ladi, dumog`dor, rasmiyatchi bo`lib qoladi.

- Hayotda safsatabozlik bilan bilim orttirib bo`lmaydi.

- Bilmaganingni so`rab bilib olishdan hech tortinmagin, ammo odob doirasidan ham chiqmagin.

- Seni qiziqtirgan narsalarni hech qachon oxirigacha bilmay qaytmagin, bilmaguncha kitob ko`rish doimo odating bo`lsin.

- Fikring oshkor bo`lmasin desang, chehrang ochiq bo`lsin.

- Kishiga o`zni tuta bilishlik, ma`lum darajadagi qat iyat va bir me`yorda kamtarlik zarur.

- Vijdon - insonning o`zi oldidagi javobgarligidir.

- Odamlar do`stlaringga qarab senga baho beradilar. Axir aytishadiku, do`sting kimligini ayt, sening kimligingni aytib beraman, deb.

- Agar senda odamlarga yoqish san `ati bo`lmasa, na amal, na boylik jamoada buning o`rnini bosa oladi.

- Katta majlis nutqning mazmunidan ko`ra so`zlash mahoratingga ko`proq e`tabor beradi.

"Maktubdan qanday ibrat olganingizni yozing", deb nomlangan topshiriqni talabalar mustaqil fikrlarini bayon qilish orqali bajarganlar. "Birgina maktubni o’qib shunchalik ko p ibrat oldimki, o`zim ham xayron qoldim", deb yozadi talabalardan biri. Masalan, "bir daqiqani ham zoye ketkazmaslik, har bir narsa, hodisa, voqeaning foydali tomonlarini ko`rish va undan o`rnak olish, keraksiz va foydasiz narsalardan qochish, har bir narsaning o`rni va vaqti borligini unutmaslik va boshqa masalarda ko`p narsaga e tabor bermasligimni anglab oldim”.

"Men har doim o`z fikrimni ma`qullashga harakat qilardim va uni to’g'ri deb hisoblardim. Buning noto`g’ri va zararli ekanligini bilib oldim. O`zimni tutishim, muomalam, hattiharakatlarimda shunchalik kamchiligim ko'pligidan "ox" deb yubordim. Mening eng katta kamchiligim, tortinchoqligim ekan".

"Maktub matniga asoslanib ukangizga nasihat qiling" nomli topshiriq ham risoladagidek bajarilgan. Talabalar bu topshiriqni bajarishga ijodiy yondoshganlar. Buni quyidagi jumlalardan ham bilib olsa bo`ladi. Masalan, Bilimni mukammal egallagin, lekin bilimli ekanligingni hamma ham bilishi shart emas. Boshqalarning dimog`dorligidan hech qachon nafratlanma, chunki bu nodonlik hisoblanadi. Tili shirali bo 'lgan insonni hamma yoqtiradi. Shuning uchun birinchi navbatda tilni o`rgan. Chet tillarni o`rgan. Til vositasida yoqimli muomala qilishni o`rgan. Har qanday vaziyatda ham xushmuomalalikni saqlab qolishga harakat qil. Taom tanavvul qilayotganingda atrofdagilarga e tabor ber, hech qachon ovqatlanish odobini unutma. Suhbatdoshga hamisha e tiborli bo`l. Sendan gap so 'raganlarida "ha" yoki "yo`q" deb javob qilma. Ko'proq kitob o`qisang, ko`proq o`z ustingda ishlasang mustaqil fikringga ega bo`lasan.

$\mathrm{Bu}$ asar yoshlarni nafaqat ahloq va odobga o`rgatish borasida, balki mamlakatimizda chet tillarni o`rganish va o`rgatish davlat siyosati darajasiga ko`tarilgan bugungi kunda uning mamlakatshunoslik va madaniyatshunoslik nuqtai nazaridan roli va o 'rni beqiyos, deb hisoblashga asos bor. Chunki til o`rganish - bu mamlakatni, kishilarni, madaniyatni, urf-odat va an`analarni o`rganishda o`z ifodasini topadi.

Agar "Farzandga maktublar"ni bir sahifaga inglizcha, o`zbekcha, ruscha variantlarini joylab chop etilsa, tillarni mustaqil o’rganmoqchi bo 'lgan kishilar uchun noyob qo`llanma bo `lgan bo 'lar edi va bu nashr madaniyatlararo muloqotni ta`minlovchi vosita sifatida muhim ahamiyat kasb etsa ajab emas. Bunday qo`llanma bilan ishlash metodikasi haqidagi mulohazalar alohida maqolaning tadqiqot ob`yeti bo`ladi, deb hisoblaymiz. 
Foydalanilgan adabiyotlar ro'yxati

1. Chesterfild. Farzandga maktublar. "Yoshlar kutubxonasi" seriyasi Ruschadan K.H.Hosirov tarjimasi. Toshkent Cho`lpon nomidagi nashryot-matbaa ijodiy uyi. 2008

\title{
ТАЪЛИМ ВА ТАРБИЯ НАЗАРИЯСИДА ДИДАКТИКАНИНГ ТАРИХИЙЛИК ВА ХАЁТИЙЛИК ТАМОЙИЛЛАРИ УЙҒУНЛАШУВИ
}

\author{
Проф. в.б. А.Набиев (ТКТИ), \\ проф. К.А.Каримов (ТошДТУ), \\ катта ўқитувчи Б.Каримов (ТошДТУ), \\ катта ўқитувчи А.Каримова (ТошДТУ), \\ катта ўқитувчи Ш.Хайдарова (ТКТИ)
}

Annotation: The article states that the leading factor in creating a favorable innovative environment in the educational process, along with the formation of an environment of didactic and methodological integrity, is education aimed at conformity to the historical and life principles of didactics.

Key words and expressions: didactics, competence, independent education, family, maxalla, educational institution, public consciousness, social values, innovative solutions.

Ўзбекистон Республикасини 2017-2021 йилларда ривожлантиришнинг бешта устувор йўналиши бўйича Харакатлар стратегиясида “...талаба-ёшлар таълим-тарбияси учун қўшимча шароитлар яратишга қаратилган комплекс чора-тадбирларни ўз ичига олган бешта ташаббусни амалиётга тадбиқ этиш, жумладан талаба-ёшларни маданият ва санъат, жисмоний тарбия ва спортга жалб қилиш, уларнинг компьютер ва интернет технологияларидан фойдаланиш саводхонлигини ошириш, китобхонликни кенг тарғиб қилиш, талаба-қизларнинг касбий кўникмаларини ривожлантириш" устувор йўналиш ва вазифалар белгилаб берилганлиги таълим ва тарбия назариясида дидактик-методологик яхлитлик мухитини шакллантириш билан бир қаторда дидактиканинг тарихийлик ва хаётийлик тамойиллари уйғунлашувига йўналтирилган таълим беришда ғоят мухимдир [1].

Бундай стратегик вазифа-топшириқлар таълим муассасаларида таълим-тарбия борасида қулай инновацион мухит яратиш мақсадида таълимни тарбиядан хеч қачон ажратиб бўлмаслиги, хатто бир лахза хам айри холда тасаввур қилиш мумкин эмаслигини яна бир бор тўлақонли тасдиқлайди. Дархақиқат, таълим-тарбия жараёнлари натижаси кўп миллатли халқимизнинг ўтмишидан далолат бериши билан бир қаторда бугунги ва келажакдаги тақдиримизни хам ўзида тўлақонли мужассам қила олиши билан тавсифланади.

Аслида таълим ёш авлодни назарий билим, амалий кўникма ва малакалар билан куроллантириш, компетенциясини шакллантириш баробарида уларнинг ўқув-билув қобилиятларини ўстириш, дунёқарашларини кенгайтиришга йўналтирилган жараён сифатида педагогика назариясида тавсифланади.

Худди шунингдек, тарбия эса муайян, аниқ мақсад ва ижтимоий тажрибалар негизида ёш авлодни хар томонлама камоллик сари интилишга ундаш, уларнинг она-Ватанга мехрмухаббат ва садоқатли бўлиш, ижтимоий онги, хулқ-атвори, ғурур-ифтихори, дунёқарашини таркиб топтириш жараёни хисобланиб, шахсни мақсадга мувофиқ шакллантириш учун уюштирилган ижтимоий, педагогик-психологик жараёнлар мажмуаси хисобланиб, тарбияланувчиларнинг бевосита шахсига мунтазам ва тизимли таъсир этиш имкониятини яратади.

Ушбу тушунчаларга ижтимоий-педагогик нуқтаи назардан ёндашилса, педагогик жараёнда таълимнинг дидактик воситалари ёрдамида таълим олувчиларга кўрсатилган тизимли (тартибланган, ўзаро узвий боғланган) таъсирини шак-шубхасиз, ижтимоий ходиса деб қараш имконияти яратилади. Табиийки, ушбу ижтимоий ходиса ёки жараённи педагогик технология дейиш хам ўринли ва ғоят ахамиятлидир. 
Узлуксиз таълим тизимида янги авлод ўкув адабиётлари “Педагог - услубий ва моддий-техник таъминотлар - таълим-тарбия жараёнлари - ўкувчи ёки талаба"дан иборот яхлит таркибий тузилманинг етакчи компонентларидан бири бўлиб, бир вақтнинг ўзида таълим берувчилар ва таълим олувчилар фаолиятида хам асосий маълумот манбаи хисобланар экан, дарслик яратиш назариясини хеч иккиланмасдан айни вақтда муайян даражадаги таълим-тарбия назарияси сифатида қарашга асос яратилади [2].

Назарийлашган таълим тизимидан бевосита зарурий кўникма-малакалар ва компетенцияларни шакллантиришга қаратилган амалий таълим тизимига ўтилаётган шу кунларда замонавий ахборот ва коммуникация технологияларини таълим-тарбия жараёнларида қўллаш узлуксиз таълим тизимидаги бошқа фанлар сингари умумкасбий фанларда хам ўқув жараёни методик таъминотини ривожлантириш хамда шу ўринда мустақил таълимга эътибор қаратишни талаб этмоқда.

Мустақил таълимнинг асосий мохияти шахс - ўкувчи-талабанинг аудиторияда ва ундан ташқари (Ахборот ресурс маркази, уй, талабалар уйи, кафедра, корхона ва хакоза)ларда бевосита педагог рахбарлигида ёки унинг иштирокисиз якка тартибда ёхуд жамоа бўлиб билим, кўникма-малака, компетенцияларни оширишга қаратилган фаол, босқичма-босқич, йўналтирилган, таркиблаштирилган, тизимлаштирилган хамда бир мақсадга қаратилган фаолиятлар мажмуидан иборат.

Мустақил таълим педагог рахбарлигида ёки унинг иштирокисиз, шунингдек аудиторияда ёки ундан ташқарида амалга ошадими-йўқми, булардан қатъий назар, бу жараёнда педагогик хамкорликнинг роли беқиёсдир. Дарс бериш жараёнини ўқувчиталабаларнинг мустақил ишларига йўналиш бериш тарзида ташкил этмоқ зарур.

Муаллифлар ўзларининг кўп йиллик илмий-педагогик тажрибаларига биноан мустақил таълим самарадорлигига гарчи ўқувчи-талабанинг билим савияси, дунёқараши, масъулият билан ёндошуви, фанни ўзлаштириш қобилияти, интилиши, интизомлилиги, фаоллиги, компетентлиги каби инсоний фазилатлари бевосита таъсир кўрсатса-да, бу жабхада педагогнинг фаолияти хам салмоқли эканлигини алохида таъкидлайдилар. Шу ўринда педагогнинг мустақил таълимда тутган ўрнини қисқача изохлаш ўринлидир.

Педагог зиммасига биринчидан, фаннинг асосий мазмун-мохиятини, касб учун мухимлигини ўкувчи-талабаларга аниқ, содда-лўнда тушунтириб, уларда фанга нисбатан қизиқиш уйғотиши, иккинчидан, мустақил таълим учун янги педагогик технологиялар талаблари асосида ўқув-услубий таъминотни яратиш, амалиётда қўллаш ва нихоят, учинчидан эса, мустақил ишларни бошқариш ва назорат мониторингини адолатли, холисона, хаққоний юритиш каби мухим вазифалар юкланган.

Мустақил таълим тарбиявий-таълимий ахамиятга эга бўлиб, ўқувчи-талабанинг умумий ривожланиши ва касбий махоратини ўстиришга хизмат қилади. Тарбиявийлик ахамияти шундаки, таълим олувчи ўзининг билими ва кўникмасини ошириш ва мустахкамлаш баробарида ўзини-ўзини тарбиялаб боради. Таълимий ахамияти эса таълим олувчи бўш вақтдан унумли, самарали фойдаланади. Давлат таълим стандарти ва фан дастурида белгиланган талаблар асосида яратилган фаннинг электрон ўқув-методик мажмуасида мазмунни белгиловчи мажбурий компонентлардан бири ўқувчи-талабага мўлжалланган методик компонентадир. Унинг таркибига мустақил ишларни бажаришга мўлжалланган методик тавсиялар киради.

Энди бевосита мазкур илмий-амалий анжуман доирасида дидактиканинг тарихийлик ва хаётийлик тамойиллари уйғунлашувига таяниб, техника таълим муассасалари мисолида таълим олувчиларда ғурур ва миллий ифтихор туйғуларини уйғотиш мақсадида механика фанининг нафақат мамлакат ижтимоий-иқтисодий-сиёсий ўсишидаги, балки жахон цивилизацияси ривожидаги муносиб ўрнини ғоятда жонли, қизиқарли, асосланган мисолларда ёритилиши, шунингдек фан тараққиётига муносиб хисса кўшган буюк олимлар хаёти ва илмий фаолияти билан ёш авлодни яқиндан таништириш давр талаби эканлиги хусусида фикр-мулохазалар юритамиз. 
Таъкидлаш ўринлики, Материаллар қаршилиги фани хам механика фанининг ўзагини ташкил этганлини англаган холда унинг тарихини механиканинг бой тарихи билан чамбарчас боғлиқ холда учта асосий даврга бўлиб ўрганиш мақсадга мувофиқдир.

Қадимий давр механикаси - Аристотел давридан XVI асргача, уйғониш даври механикаси - XVI асрдан XX аср бошигача ва хозирги давр механикаси - XX аср бошидан шу кунгача бўлган даврни ўз ичига олади [3].

Биринчи давр бошида қадимги юнонистонлик қомусчи олим Аристотел (эрамиздан аввалги 384-322-йиллар) ўзининг "Механика" деган асарида механикани бошқа фанлардан ажратган. Юнон олими Архимед (эрамиздан аввалги 287-212-йиллар) ричагга қўйилган кучларнинг мувозанати, жисмларнинг юзаси, хажми, оғирлик марказини аниқлаш усуллари, жисмларнинг сузиш шартлари ва суюқликларнинг гидростатик босими хақидаги таълимотларни яратган.

Шарқ алломаларининг механика ривожига қўшган хиссалари беқиёсдир.

Хозирги замонда ўрта аср шарқ олимларининг биргина статикага оид 50 дан ортиқ асарлари тўғрисида маълумотлар мавжуд. Ўрта аср ислом мамлакатлари олимлари механикани “Илм ал-хиёл” (“Усталик билан ясалган мосламалар тўғрисидаги илм”) деб юритишиб, унда ўша даврга мос механика масалалари кўрилган. Мазмунига мос бўлган энг қадимий асар - Абу Абдуллох ал-Хоразмийнинг (IX acp) “Фанлар калити” китоби бўлиб, унинг алохида боби механикага бағишланган.

Шарқ олимларидан Абу Райхон Беруний (973-1048), Абу Али ибн Сино (980-1037), Улубек Мухаммад Тарағайлар (1394-1449) механика фанининг ривожланишига катта хисса кўшганлар. Беруний ва ибн Сино асарларида харакат (шунингдек, механик харакат), планеталарнинг харакатига оид фикрлар баён этилган. Улуғбек планеталар харакатини, шунингдек Қуёш ва Ойнинг харакатини катта аниқликда хисоблай олган.

Иккинчи даврда Польшалик улуғ астроном Николай Коперник (1473- 1543) геоцентрик назария ўрнига янги гелиоцентрик назарияни кашф қилиб, унда оламнинг марказида Қуёш жойлашган, Ер хам бошқа сайёралар сингари Куёш атрофида ва ўз ўқи атрофида айланади, деган фикрларни илмий-назарий жихатдан асослаган. Бу ўринда шуни таъкидлаш мухимки, Абу Райхон Беруний ва Абу Али ибн Синолар хам Н.Коперникдан аввалроқ гелиоцентрик назарияни сифат жихатидан тавсифлаб, улар оламнинг марказида Ер бўлиши мумкин эмас, чунки Ернинг массаси Куёшнинг массасига нисбатан анча кичик, шу боис оламнинг марказида Қуёш туради ва Қуёш атрофида сайёралар, шу жумладан Ер хам айланиши мумкин, деган фикрларни илгари сурганлар.

Коперник таълимотининг давомчиларидан бири италиялик олим Галилео Галилей (1564-1642) турли хил жисмларнинг бўшлиқ - хавосиз фазода эркин тушишини тажрибалар ёрдамида ўрганган, Ерга нисбатан ихтиёрий бурчак хосил қилиб отилган жисмларнинг харакати хақидаги масалани тахлил этган. Бундан ташқари, моддий жисмлар харакати устида ўтказилган тажриба-кузатишларни умумлаштириб инерция қонунини яратган.

Галилео Галилей биринчи бўлиб ташқи кучлар таъсирига брусларнинг қаршилик кўрсата олишини бахолаш мақсадида ўзига хос хисоблашларни бажарган. Хусусан, кўндаланг кесими тўғри тўртбурчакли бруснинг эгилишга қаршилиги кесим юзасининг баландлиги квадратига тўғри мутаносиб боғланишда эканлигини аниқлаган, аммо материалларнинг физик хоссаларини эътиборга олмаганлиги боис, мутаносиблик коэффициентининг қийматини аниқлашда хатоликларга йўл қўйган. Шунинг учун адабиётларда 1638 йилдан Материаллар қаршилиги алохида фан сифатида пайдо бўлганлиги қайд этилган.

Галилео Галилей ва унинг издошлари ғояларини инглиз олими Исаак Ньютон (1643 1727) ривожлантириб, тезланиш ва кучнинг мутаносиблиги, таъсир ва акс таъсир тенглиги, бутун олам тортилиши каби механиканинг энг мухим, асосий қонунларини кашф қилган.

Шунингдек, механика фанининг турли сохалари ривожланишига Р.Гук, Т.Юнг, Ж.Д'аламбер, М.Шал, Л.Эйлер, М.Ломоносов, М.Остроградский, П.Чебишев, Ф.Ясинский каби олимлар хам мухим хисса қўшганлар. 
Учинчи давр А.Эйнштейннинг (1879-1955) махсус (1905) ва умумий (1916) нисбийлик назариялари пайдо бўлиши билан бошланади. Замонавий конструкциялар яратишда, хусусан Ернинг сунъий йўлдошларини, космик кемаларни учириш, уларни Ой сиртига кўндириш, Марс ва Плутон сайёраларига яқинлашиш, уларнинг фотосуратларини олиш, космик кемалар ёрдамида Ердаги фойдали қазилма бойликларнинг хариталарини тузиш, космонавтика ютуқларини халқ хўжалигининг турли сохаларида қўллашда механика фанининг қонун ва қоидалари беқиёс ахамиятга эга.

Шу жихатдан қараганда механиканинг қонун ва қоидалари асосида яратилган кашфиётлар, хусусан Н.Жуковскийнинг (1847-1921) аэродинамикага оид илмий асарлари, К.Циолковскийнинг (1857-1935) ракета назарияси, суюқ ёнилғида ишлайдиган ракета двигатели назарияси, И.Мешчерскийнинг (1859-1935) ўзгарувчан массали жисмларнинг харакати назарияси, С.Королёв (1906-1966) рахбарлигида яратилган баллистик ва геофизик ракеталар, Ернинг сунъий йўлдошлари ва турли космик кемалар, таниқли ўзбек олимларидан Х.Рахматулиннинг (1909-1988) иншоотлар заминини лойихалаш ва хисоблашда, кема зирхи мустахкамлигини аниқлашда қўлланиладиган "Рахматулин тўлқинлари" назарияси, М.Ўрозбоевнинг (1906-1971) ип механикаси ва иншоотларнинг зилзилабардошлиги назариясига оид илмий изланишлари, В.Қобуловнинг (1921-2008) туташ мухитлар механикаси масалаларини алгоритмлаш, автоматик бошқариш тизимларини яратишга оид илмий ишлари, академик Т.Ширинқулов (1937-2009) ва академик Т.Р.Рашидов (1936 йилда туғилган) ларнинг илмий ишлари механика фанининг амалий ахамиятга эга бўлган кўп тармоқли фан эканлигини тасдиқлайди.

Механиканинг турли йўналишлари ривожига муносиб хисса кўшган Х.Х.Усмонхўжаев, Ж.Ф.Файзуллаев, Я.Н.Мубораков, Р.И.Каримов, Ё.У.Саатов хамда айни пайтда механика сохасида мухим инновацион ечимлар олиб, амалиётга жорий этаётган М.М.Мирсаидов, К.С.Абдурашидов, Б.М.Мардонов, Ш.Маматқулов, Ғ.Хожиметов, М.Эргашов сингари таниқли олимларимизнинг хаёти ва илмий-педагогик фаолияти билан ёш авлодни яқиндан таништириш давр талабидир.

\section{Фойдаланилган адабиётлар рўйхати}

1. Мирзиёев Ш.М. Буюк келажагимизни мард ва олижаноб халқимиз билан бирга қурамиз. -Т.: "Ўзбекистон" НМИУ, 2017. -488 б.

2. Набиев А. Техника таълим муассасалари учун янги авлод ўқув адабиётларини яратиш технологиялари ва улардан фойдаланиш методикаси // Монография. -Т.: "IQTISODIYOT DUNYOSI", 2020. -352 b.

3. Nabiyev A. Materiallar qarshiligi (nazariyalar va masalalar) // Darslik. Qayta ishlangan va to'ldirilgan 3-nashr. -T.: "Navro'z" nashriyoti, 2019. -412 b.

\section{ИННОВАЦИОННЫЕ ПЕДАГОГИЧЕСКИЕ ТЕХНОЛОГИИ КАК ФАКТОР ФОРМИРОВАНИЯ ЧЕЛОВЕЧЕСКОГО КАПИТАЛА}

\section{Г.У.Шамиев (доцент, центра переподготовки и повышения квалификации кадров народного образования Навоийской области)}

Annotation: The best ways of human capital development are effective teaching methods. This article examines the issues of innovative pedagogical technologies, their impact on the quality of education and the formation of human capital, classifies international research and scientific approaches of researchers in this area.

Key words and expressions: Innovation, pedagogy, technology, human, capital, education.

В настоящее время методика обучения переживает сложный период, связанный с изменением целей образования, разработкой государственных образовательных стандартов, 
построенных на инновационном подходе. Все эти обстоятельства требуют новых педагогических исследований в области методики преподавания предметов, поиска инновационных средств, форм и методов обучения и воспитания, связанных с разработкой и внедрением в образовательный процесс инновационных образовательных технологий. Для умелого и осознанного выбора из имеющегося банка педагогических технологий именно тех, которые позволят достигнуть оптимальных результатов в обучении и воспитании необходимо понимать сущностные характеристики современной трактовки понятия педагогическая технология.

Общепринятой классификации образовательных и педагогических технологий в отечественной и зарубежной педагогике на сегодняшний день не существует. К решению этой актуальной научно-практической проблемы различные авторы подходят по-своему. М. Кларк считает, что смысл педагогической технологии заключается в применении в сфере образования изобретений, промышленных изделий и процессов, которые являются частью технологии нашего времени.

Ф. Персиваль и Г. Эллингтонуказывают на то, что термин «технология в образовании» включает любые возможные средства представления информации. Это оборудование, применяемое в образовании, такое как телевидение, различные средства проекции изображений и т.д. Другими словами технология в образовании - это аудиовизуальные средства.Д. Финн заметил, что только наивные люди считают, что технология это просто комплекс аппаратуры и учебных материалов. Это значит гораздо больше. Это способ организации, это образ мыслей о материалах, людях, учреждениях, моделях и системах типа «человек-машина».П.Д. Митчелл в результате анализа более ста источников, связанных с изучаемой дефиницией, считает, что педагогическая технология это область исследования и практики, имеющая связи со всеми аспектами организации педагогических систем и процедурой распределения ресурсов для достижения специфических и потенциально воспроизводимых результатов. ЮНЕСКО, предлагает и широкий подход, - педагогические технологии этосистематический метод планирования, применения и оценивания всего процессаобучения и усвоения знаний путем учета человеческих и технических ресурсов ивзаимодействия между ними для достижения более эффективной формыобразования.С.В. Кульневичсчитает необходимым соотнести понятие педагогическая технология с такими педагогическими категориями как теория воспитания, методика воспитательной работы и педагогическое мастерство. Теория, по мнению данного автора, более общая и содержит систему обоснований. Она содержит аппараты диагностирования и корректировки. Мастерство более субъективно и интуитивно. Технология более объективна и точна. Говоря о воспитании, С.В. Кульневич характеризует его как ненадежный и неточный процесс.Изменить эти его характеристики в положительную сторону можно только в условиях его научной организации, элементом которой является технология.В.П. Беспалько считает, что «...педагогическая технология - это содержательная техника реализации учебного процесса».Это определение ориентировано на использование педагогической технологии только в процессе обучения. Что приводит к резкому сужению этого понятия как педагогической дефиниции и возможностей использования его в практической педагогической деятельности.В.М. Монахов: педагогическая технология- это продуманная во всех деталях модель совместной педагогической деятельности по проектированию, организации и проведению учебного процесса с безусловным обеспечением комфортных условий для учащегося и учителя.М.В. Кларин рассматривает педагогическую технологию как системную совокупность и порядок функционирования всех личностных, инструментальных и методологических средств, используемых для достижения педагогических целей. Такое определение более ёмко, так как речь здесь уже об общих педагогических целях.Г.Ю. Ксензова и Е.А. Леванова трактуют педагогическую технологию в широком смысле как процесс, ориентированный на решение и обучающих, и воспитательных, задач. При этом приобретает множество аспектов.Г.Ю. Ксензова. Педагогическая технология - это такое построение деятельности педагога, в 
котором все входящие в него действия представлены в определенной целостности и последовательности, а выполнение предполагает достижение необходимого результата и имеет вероятностный прогнозируемый характер.Е.А. Леванова. Педагогическая технология - это упорядоченная и задачноструктуированная совокупность действий, операций и процедур, обеспечивающих диагностируемый и гарантированный результат в изменяющихся условиях. Так педагогическая технология может функционировать в качестве науки, исследующей наиболее рациональные пути обучения и воспитания - научный аспект, в качестве системы способов, принципов и регуляторов, применяемых в обучении и воспитании - процессуально - описательный аспект и в качестве реального процесса обучения и воспитания - процессуально - действенный аспект.К инновационным направлениям или современным педагогическим технологиям отнесены: развивающее обучение; проблемное обучение; разно-уровневое обучение; коллективная система обучения; технология решения задач; исследовательские методы обучения; проектные методы обучения; технологии модульного обучения; лекционно-семинарско-зачетная система обучения; использование в обучении игровых технологий (ролевые, деловые и другие виды обучающих игр); обучение в сотрудничестве (командная, групповая работа); информационно-коммуникационные технологии; здоровьесберегающие технологии.В других источниках выделяют:

традиционные технологии: относя к традиционным технологиям различные виды учебных занятий, где может реализовываться любая система средств, обеспечивающих активность каждого обучающегося на основе разноуровневого подхода к содержанию, методам, формам организации учебно-познавательной деятельности, к уровню познавательной самостоятельности, переводу отношений педагога и обучающегося на паритетное и многое другое;

- классно-урочная технология обучения - обеспечение системного усвоения учебного материала и накопление знаний, умений и навыков;

- $\quad$ интерактивные технологии или групповые технологии обучения - работа в парах, группах постоянного и сменного состава, фронтальная работа в кругу. Формирование личности коммуникабельной, толерантной, обладающей организаторскими навыками и умеющей работать в группе; повышение эффективности усвоения программного материала;

- игровая технология - дидактическая игра. Освоение новых знаний на основе применения знаний, умений и навыков на практике, в сотрудничестве;

- $\quad$ технология проблемного обучения - учебный диалог как специфический вид технологии, технология проблемного - эвристического обучения. Приобретение обучающимися знаний, умений и навыков, освоение способов самостоятельной деятельности, развитие познавательных и творческих способностей;

- технология перспективно-опережающего обучения. Достижение обучающимися обязательного минимума содержания образования. Обучение способам решения проблем, навыкам рассмотрения возможностей и использования знаний в конкретных ситуациях. Предоставление возможностей каждому обучающемуся самостоятельно определять пути, способы, средства поиска истины (результата). Способствовать формированию методологической компетентности. Формирование способностей самостоятельно решать проблемы, осуществлять поиск необходимых сведений. Обучениеспособамрешенияпроблем;

- технология мастерских. Создание условий, способствующих осмыслению обучающимися целей своей жизни, осознанию самих себя и своего места в окружающем мире, самореализации в совместном - коллективном поиске, творчестве, исследовательской деятельности;

- исследовательская технология - метод проектов, эксперимент, моделирование или технология решения исследовательских - изобретательских задач. Обучение обучающихся основам исследовательской деятельности - постановка учебной проблемы, формулирование темы, выбор методов исследования, выдвижение и 
проверка гипотезы, использование в работе различных источников информации, презентация выполненной работы.

- электронные образовательные ресурсы, включая ИКТ - технологии. Обучение работе с разными источниками информации, готовности к самообразованию и возможному изменению образовательного маршрута.

- п педагогика сотрудничества. Реализация гуманно-личностного подхода к ребенку и создание условий для осознанного выбора обучающимися образовательного маршрута.

- $\quad$ технология проведения коллективных творческих дел. Создание условий для самореализации обучающихся в творчестве, исследовательской деятельности, коллективе учащихся. Вовлечение обучающихся в обсуждение и анализ наиболее волнующих их проблем, самооценку различных негативных жизненных ситуаций. Формированиеорганизаторскихспособностейобучающихся.

- методы активного обучения - совокупность педагогических действий и приемов, направленных на организацию учебного процесса и создающих специальными средствами условия, мотивирующие обучающихся к самостоятельному, инициативному и творческому освоению учебного материала в процессе познавательной деятельности . К ним относятся коммуникативные технологии, технология портфолио, развитие критического мышления, модульное обучение, дистанционное обучение, тестовые технологии, технология выявления и поддержки одаренных детей.

Таким образом, каждому педагогу необходимо ориентироваться в широком спектре современных инновационных технологий. Сегодня быть педагогически грамотным специалистом нельзя без изучения всего обширного арсенала образовательных технологий. Использование инновационных образовательных технологий является одним из критериев оценки профессиональной деятельности мастера и преподавателя.Поэтому нам необходимо более интенсивное внедрение для наших условий инновационныхтехнологий.

\section{Список использованной литературы}

1. Ишмухамедов Р., Абдуқародиров А., Пардаев А. Тарбияда инновацион технологиялар. Таълим муассасалари ўқитувчилари учун амалий тавсиялар. - Т.: -Истеъдод жамғармаси, 2009.

2. Йўлдошев Ж., Хасанов С. Педагогик технологиялар.- Т.: -Молия-иқтисод॥ нашриёти, 2009.

3. Йўлдошев Ж.Ғ. Хориждатаълим. -Т.: Шарқ, 1995.

4. Муслимов Н.А., Усмонбоева М.Х., Сайфуров Д.М., Тўраев А. Б. Инновацион таълим технологиялари .- Т.: —Сано стандарт нашриёти, 2015.

5. Мухина С.А., Соловёва А.А. Современные инновационные технологии обучения. М.- :ГЭОТАР-Медия, 2008.

6. Мухамедов Ў. Х., Усмонбоева М. Х., Рустамов С. С. Таълимни ташкил этишда замонавий интерфаол методлар. ўқув-услубий тавсиялар.- - Т.: 2012.

7. Омонов Н.T. Pedagogik texnologiyalar va pedagogik mahorat / - T.: - Iqtisod-moliya. 2009.

8. Пирмухамедова М. Педагогик махоратасослари . - Т.: 2008.

9. Рўзиева Д., Усмонбоева М., Холиқова 3. Интер фаол методлар: мохияти ва қўлланилиши. - Т.: Низомий номли ДТПУ, 2013.

10. Холиқов А.А. Педагогик махорат. - Т.: Tafakkur - bo`stoni нашриёти». 2011. 


\title{
ДИСТАНЦИОННОЕ ИЗУЧЕНИЕ КИТАЙСКОГО ЯЗЫКА
}

\author{
Бекниязова С. Н. \\ (преподаватель СамГИИЯ) \\ Тугузов А. X. \\ (студент СамГИИЯ)
}

\begin{abstract}
Annotation: The main purpose of this scientific work is to learn Chinese language from distance learning during global pandemic.
\end{abstract}

Key words and expressions: Innovations, virtual classes and apps.

В настоящее время всем известно, что ситуация во всём мире в критическом положении из-за пандемии. Распространение короновирусной инфекции по всему миру оказала негативное влияние на обучение молодого поколение нашей планеты. В результате ради безопасности учащихсязакрылись все университеты, академические лицеи, колледжи и школы. Вследствии чего были организованы дистанционные обученияво всех сферах.

С каждым днемможно наблюдать изменения в образовательной сфере и в сфере компьютерных технологий. Многие по всему миру учатся онлайн, не выходя из дома. На сегоднешний день в интернете можно найти любую интересующую нас информацию.Главное, чтобы у каждого человека было достаточно мотивации и силы воли изучать что-то полезное и нужное. Вся информация имеется в просторах интернета, там можно скачать любую электронную книгу, нет необходимости на сегодняшний день идти куда-то и стоять в очереди за одной книжкой. Все книги, словари, учебники можно скачать через интернет браузер в электронном варианте. Студенты всего мира имеют возможности пользоваться такими шансами. Это очень удобно, быстро и эффективно.

Многие государственные и коммерческие учреждения перешли на дистанционный вид обучения. Создано огромное количество платных и бесплатных онлайн курсов по изучению иностранных языков. Институт Конфуция, который имеет большинство филиалов по всему миру тоже запустил онлайн курсы китайского языка. Желающие могут получать онлайн обучение через интернет. ConfuciusInstituteOnline предоставляет все нужные материалы для изучения китайского языка. В том числе и для тех, кто хочет получить сертификаты HSK. Не только институт Конфуция создал такие онлайн курсы для обучения, но и компания Яндекс официально объявила интернет сайт, где можно получить бесплатное обучение.RealChinese тоже имеет хорошие электронные материалы, предназначенные в основном для начинающих изучать китайский язык. На сайтеChinesepod, можно найти уроки лексики и грамматики китайского языка. Кроме этого в этой платформе есть ситуационные уроки, на котором учащиеся могут практиковать свое общение.

Многие создатели мобильных приложений тоже объявили о создании разных программ для своих пользователей. Сейчас у многих людей на руках имеются сотовые телефоны, которыми можно пользоваться не только, чтобы поговорить, но, и чтобы отправить сообщение, написать пост, почитать книгу, ну или выучить язык. Пользоваться такими приложениями очень удобно. Это экономит деньги и время, чего так необходимо современному человеку. Например,в приложении ChineseSkill очень много конструкций, грамматических правил, а также 1000 слов для изучения. Следующее приложение это ChineseClass 101. Тут можно выбрать свой уровень по знанию от начального до высшего. Pleco это мобильное приложение даёт возможность тренироваться написанию иероглифов. Ведь правильное написание иероглифов являются одним из основных этапов обучения китайскому языку. Ещё одно мобильное приложение это Китайский 6000 слов. С помощью игр пользователи запоминают новые слова. Все эти интернет платформы и мобильные приложения были созданы для эффективного обучения китайскому языку, а также они дают возможность учить язык дистанционно. 


\section{Список использованной литературы}

1. Методика дистанционного обучения. Марина Эфимовна

2. Избранные главы теории и практики дистанционного обучения. Б. Крук.

3. https://magazeta.com/studying_chinese/

4. https://elenaruvel.com/top-resursov-po-kitajskomu/

\section{$21^{\text {ST }}$-CENTURY TEACHING COMPETENCIES}

S.N.Fazildinova (FSU)

Annotation: The principal aim of this study is to consider the competencies of the modern teacher. To understand $21^{\text {st }}$-century instructional skills, we researched the following issues: students' skills; levels of teachers' professional growth; teachers' pedagogical culture; pedagogical innovations, $2 I^{\text {st }}$-century teaching competencies, teaching through technologies, and the effectiveness of ICT integration in education system.

Key words and expressions: teaching competencies, cultural competency, talent, innovation, creativity, inspire creativity, collaboration and communication, Information, Communication, and Technology (ICT), technology-based teaching.

We often hear about $21^{\text {st }}$-century is the era of new information technologies. In this century learners need more knowledge and skills than ever before. What about teachers? What instructional skills will $21^{\text {st }}$-century teachers need to prepare our students? How are they different from the skills teachers needed in the past?

In recent years, the quality of education has significantly changed. If, previously, the University's major aim was that of providing students with certain types of knowledge that they were expected to apply later, universities today focuses primarily on 'life skills'. Our aim is to teach students to obtain knowledge by themselves and to work in ways that enable them to come up with new ideas.

We must provide students with skills that will help them work collaboratively and sensitively in a team, become decision-makers, plan and manage their time effectively, listen to one another and choose the right communication strategy at the right time. Thereby, we have come to understand that, to meet these new teaching requirements, we need $21^{\text {st }}$-century skills.

Before addressing the meaning of teacher competence, we must first establish the meaning of competence. Competency is a term used extensively by different people in different contexts; hence, it is defined in different ways. Teacher education and job performance are two contexts in which this term is used. Competencies are the requirements of a "competency-based" teacher education and include the knowledge, skills and values a teacher-trainee must demonstrate for successful completion of a teacher education program.

Some scholars see "competence" as a combination of knowledge, skills and behavior used to improve performance, or as the state or quality of being adequately qualified and capable of performing a given role. The Occupational Competency movement initiated by David McClelland in the 1960s sought to move away from traditional attempts to describe competency in terms of knowledge, skills and attitudes and to focus instead on those specific values, traits, and motivations (i.e. relatively enduring characteristics of people) that are found to consistently distinguish outstanding from typical performance in a given job or role.

The main feature of teachers' professional competencies can be:

- Field Competencies

- Research Competencies

- Curriculum Competencies

- Lifelong Learning Competencies

- Social -Cultural Competencies

- Emotional Competencies 


\section{- Communication Competencies}

- Information and Communication Technologies (ICT) Competencies

A competency is more than just knowledge and skills; it involves the ability to meet complex demands by drawing on and mobilizing psychosocial resources (including skills and attitudes) in a particular context. Competency is essential to an educator's pursuit of excellence. Teachers need a wide range of competencies in order to face the complex challenges of today's world. Teaching competency is an inherent element of an effective training process, one that aspires to contribute to the welfare of a particular country or the world, itself.

The central figures in the educational process are teachers. The success of training and education depends on their preparation, erudition and performance quality.

The teaching skills and life-long learning competencies of professional teachers comprise the following: to perform complex pedagogical duties; to be well-spoken, in good mental and physical health, stable and tolerant; to have a propensity to work with the younger generation, good communicative and observational skills, tact, a vivid imagination, and leadership [Shmelev, 2002].

Educational innovation has drawn increasing attention around the world, and many countries have already embarked on educational reforms that aim to change both the goals and practices of education. Expectations that such innovations can be leveraged or supported by incorporating ICT (Information and Communication Technologies) into the learning and teaching process are widespread. Such innovations are fundamentally changing students' learning experiences.

ICT integration in education generally means technology-based teaching and learning process that closely relates to the utilization of learning technologies in schools. Due to the fact that students are familiar with technology and they will learn better within technologybased environment, the issue of ICT integration in schools, specifically in the classroom is vital. This is because, the use of technology in education contributes a lot in the pedagogical aspects in which the application of ICT will lead to effective learning with the help and supports from ICT elements and components [Jamieson-Procter et al., 2013]. It is right to say that almost all ranges of subjects' starts from mathematics, science, languages, arts and humanistic and other major fields can be learned more effectively through technology-based tools and equipment. In addition, ICT provides the help and complementary supports for both teachers and students where it involves effective learning with the help of the computers to serve the purpose of learning aids [Jorge et al., 2003]. Computers and technology does not act as a replacing tool for quality teachers but instead they are considered as an add-on supplements needed for the better teaching and learning. The need for ICT integration in education is crucial, because with the help of technology, teaching and learning is not only happening in the school environment, but also can happen even if teachers and students are physically in distance. However, ICT integration is not a one-step learning process, but it is a continual process of learning that provides proactive teaching -learning environment.

ICT can be used in various ways where it helps both teachers and students to learn about their respective subject areas. A technology-based teaching and learning offers various interesting ways which includes educational videos, stimulation, storage of data, the usage of databases, mindmapping, guided discovery, brainstorming, music, World Wide Web (www) that will make the learning process more fulfilling and meaningful [Finger \&Trinidad, 2002].

On the other hand, students will benefit from ICT integration where they are not bounded to the limited curriculum and resources, instead hands-on activities in a technology-based course is designed to help them to stimulate their understanding about the subject. It also helps teachers to design their lesson plans in an effective, creative and interesting approach that would result in students' active learning. Previous researches proved that use of ICT in teaching will enhance the learning process and maximizes the students' abilities in active learning [Finger \& Trinidad, 2002; Jorge et al., 2003; Young, 2003; Jamieson -Procter et al., 2013].

Beyond basic skill training, schools had used a variety of strategies to provide further professional development for teachers. According to Warwick and Kershner the significance and advantages of ICT should be known by teachers in order to conduct a meaningful lesson with the use of ICT. Indeed, teachers should be sent to attend training courses to learn about 
integration ICT in teaching and learning process. Nonetheless, many schools used peer-tutoring systems. A more skillful teacher in ICT would assist and guide another teacher who has less experience with ICT along the preparation work for teaching and learning process. As what has been discussed, there are many factors to enable the use of ICT in classroom teaching and learning. Begin with policy, follows by the supplement of all the ICT hardware and software facilities, continued by readiness and skills of teacher to integrate it into pedagogical process (Agbatogun, 2012). Besides, technical support and continuous professional development in ICT should be conducted from time to time. In short, all parties must cooperate in order to bring the nation to become a country advance in technology.

In conclusion we can mention that, educators should demonstrate the following competencies:

1) effective classroom management, maximizing efficiency, maintaining discipline and morale, promoting teamwork, planning, communicating, focusing on results, evaluating progress, and making constant adjustments. A range of strategies should be employed to promote positive relationships, cooperation, and purposeful learning. Organizing, assigning, and managing time, space and activities should ensure the active and equitable engagement of students in productive tasks.

2) effective teaching practices, representing differing viewpoints, theories, "ways of knowing" and methods of inquiry in the teaching of subject matter concepts. Multiple teaching and learning strategies should help engage students in active learning opportunities that promote the development of critical thinking, problem solving, and performance capabilities while helping them assume responsibility for identifying and using learning resources.

3) effective assessment, incorporating formal tests; responses to quizzes; evaluation of classroom assignments, student performances and projects, and standardized achievement tests to understand what students have learned.

4) technology skills, knowing when and how to use current educational technology, as well as the most appropriate type and level of technology to maximize student learning. The use of ICT especially in teaching and learning is more about practicality as compared to theories and that is why teachers must be given time to learn and explore it.

Finally, the integration of ICT in classroom needs serious consideration in order to increase the competency of the country's education system. This will help in increasing the world ranking of the national education and produce the better future work force. As the teachers' role is the key role in making any of the new policy to be implemented efficiently and successfully. The changes that is taking place is driven by advanced technology and communication devices that should be available to students wherever they are either at school or home. In addition, the needs for teachers to be literate and have good skills and knowledge in using ICT to improve their teaching methods and approach is desired to promote effective learning as well as to meet the demand of the $21^{\text {st }}$ century teaching skills .

\section{The list of used literature}

1. Agbatogun, A. O. (2012). Investigating Nigerian primary school teachers' preparedness to adopt personal response system in ESL classroom. International Electronic Journal of Elementary Education , 4(2), 377-394.

2. Buharkova, O. V., Gorshkova, E. G. Image of the leader: technology of creation and promotion. Training program. Saint-Peterburg, 2007.

3. Finger, G., \& Trinidad, S. (2002). ICTs for learning: An overview of systemic initiatives in the Australian states and territories. Australian Educational Computing, 17(2), 3-14.

4. Hermans, R., Tondeur, J. , Van -Braak, J., \& Valcke, M. (2008). The impact of primary school teachers' educational beliefs on the classroom use of computers. Computers \& Education, 51(4), 1499-1509.

5. Ivanitsky, A. T. Training of personnel development in the educational collective: methodological guide. Saint-Peterburg, 1998. 
6. Jamieson-Proctor, R., Albion, P., Finger, G., Cavanagh, R., Fitzgerald, R., Bond, T., \& Grimbeek, P. (2013). Development of the TTF TPACK Survey Instrument. Australian Educational Computing, 27(3),26-35.

7. Jorge, C. M. H., Gutiérrez, E. R., García, E.G., Jorge M. C. A., \& Díaz, M. B. (2003). Use of the ICTs and the perception of e-learning among university students: A differential perspective according to gender and degree year group. Interactive Educational Multimedia, 7, 1328.

8. Shmelev, A. G. Psychodiagnosis of personnel characteristics. Saint-Peterburg, 2002.

9. Warwick, P., \& Kershner, R. (2008). Primary teachers' understanding of the interactive whiteboard as a tool for children's collaborative learning and knowledge-building. Learning, Media and Technology, 33(4), 269-287.

\section{ФУНКЦИОНАЛЬНЫЕ ВОЗМОЖНОСТИ ВЕБИНАР ТЕХНОЛОГИЙ В ОБРАЗОВАНИИ}

\section{С. Н. Бекниязова \\ (СамГИИЯ)}

Abstract: The article presents functional opportunities of using webinar technologies in education. The introduction of webinar technologies in education becomes an essential part of life during a pandemic COVID-19.Online learning, in particular webinars are very helpful both for children and for adults.

Key words and expressions: interactive elements; online education; software, webinar technologies, chat; moderator, application.

Из за пандемии COVID-19 онлайн общение, а также онлайн образование стали неотъемлемой частью нашей жизни. Возникла огромная потребность во внедрии онлайн образования в учебный процесс, а также в улучшении и изменении методик преподавания онлайн. Терминвебинар стал часто использоваться в повседневной жизни. И так рассмотрим что такое вебинар, его основные преимущества и как функционирует его программное обеспечение.

Вебинар это “интернет-семинар, исходящий с одного источника с передачей видео и аудиоконтента в режиме онлайн (по интернету) для ограниченной аудитории с целью обучения».

Вебинар можно проводить в прямом эфире или записывать и проводить «по запросу», предоставляя желающим возможность смотреть вебинар в любое удобное для них время.

Однако вместо загрузки, как видеоподкаст, вебинар использует прогрессивный видеопоток на компьютер пользователя, поэтому не занимает места в жестких дисках и не управляет медиа файлами.

Возможность по запросу обмениваться записанными вебинарами и распространять их через интернет или базу данных, играет жизненно важную роль для обучающихся. Это значит, что учебный материал всегда под рукой обучающихся, и возможно егонеограниченное воспроизведение.

Ключевой особенностью хорошего вебинара являются его интерактивные элементы возможность давать, получать и обсуждать информацию. Интерактивная функция может быть выполнена путем обсуждений и через онлайн-чаты на том же сайте, что и вебинар. Это позволяет слушателям обсуждать материал как онлайн-сообщество, либо в некоторых случаях способствует интерактивному обсуждению презентации онлайн, задавая вопросы или делая заявления, которые можно передать напрямую к панели. Поскольку обучаемым предоставляется повышенный уровень интерактивности, позволяя им предоставить информации для обсуждения, (будь то текст, графика, аудио или видео) то учебный процесс станет для них более увлекательным.

Программное обеспечение вебинаров 
Многие компоненты программного обеспечения вебинаров являются интернет приложениями и не требуют установки. Основные части программного обеспечения для вебинаров построены на платформе AdobeFlash, которая является бесплатной и устанавливается на 99 \% устройствах. Еще одно преимущество программного обеспечения вебинарэто то что, помимо отсутствия установки, программное обеспечение будет работать во многих платформах и оперативных системах. Некоторые программные приложения также имеют мобильные версии.

Функциональные возможности вебинар технологий

Существуют различные возможности программного обеспечения, начиная от бесплатного/условно-бесплатного программного обеспечения до платных опций.

Следующие функции присущи для большинства программных обеспечений вебинар технологий:

- Видеосвязь (позволяет тренеру и участникам видеть друг друга);

- Чат (позволяет общаться участникам, набирая текст, не мешая спикеру);

- Просмотр в реальном времени (позволяет рисовать на совместном экране);

- Обмен файлами;

- Обмен заметками;

- Совместное использование экрана (возможность просмотра экрана докладчика / докладчицы);

- Опросы / викторины (онлайн анкеты).

Дополнительные параметры, которые могут быть полезными и доступными в более продвинутых опциях программного обеспечения:

- Возможность переключения модератора / тренера во время сеанса - это может быть полезным для вебинаров с небольшими группами, поскольку позволяет участникам и инструкторам работать совместно, меняя роли;

- Возможность просмотра загруженного файла через ПО - это полезно для обсуждений;

- Возможность записи вебинаров - это может быть очень полезно, поскольку позволяет обучающимся не только просмотреть пропущенный вебинар, но и просматривать содержание и использовать его в виде цифровых заметок. Что в свою очередь дает возможность участникам посвятить все свое внимание вебинару во время живого сеанса. Записанный вебинар должен быть выставлен в сеть тренером;

- Опросное приложение - это отличный способ для оценивания и для набора данных;

- Возможность опубликовать эту анкету - это может быть отличным способом быстро и легко дать участникам обратную связь по этой оценке.

Чтобы определить эффективность функций программного обеспечения вебинара, мы можем задать такие вопросы как:

1. Веб-приложение (на основе браузера) или его установка требует программного обеспечения?

- Какое максимальное количество пользователей?

- Какова стоимость программного обеспечения с точки зрения его затрат и функций?

Pecypcbl

Существует ряд пакетов программного обеспечения, как бесплатных, так и коммерческих, которые могут быть использованы для образовательных целей.

Примерами программных обеспечений для таких вебинаров являются:

- Adobe Connect 8,

- ClickWebinar,

- FastViewer,

- Mikogo,

- TeamViewer 7,

- Saba Webinar,

- RHUBGoMeetNow 4.3 
Итак, мы рассмотрели основные функции и возможности вебинартехнологий. Но даже сегодня считается, что использование этой технологии для обучения все еще находится в зачаточном состоянии, однако, как в случае с новостями и развлечениями, рост их использования в педагогической практике быстро расширяется.

Использованиявебинаров в обучении, особенно для обучения взрослых,открывает огромную возможность для улучшения знаний, а также для повышения квалификации персонала. Кроме того, вебинары могут быть живыми и интерактивными, позволяя имитировать занятия в классе или дает возможность обучающимся смотреть и учить материал в удобное для них время, что делает процесс обучения очень гибким и поэтому эффективным.

Влияние этих технологий может быть максимально эффективным для разработки новых процессов и стилей обучения, специфичных для новых технологий, и в этом статье будет идти речь о потенциальных возможностях вебинаров.

Несомненно, вебинары требуют большей сосредоточенности, технической поддержки в виде компьютер технологий, а также интернет подключения. Оно также ограничивает невербальное общение, но использование вебинар технологий для саморазвития, а также для расширения знаний помогает людям жить и учиться, не подвергая свою жизнь и жизнь близких опасности.

\section{Список использованной литературы}

1. Laurence A. Rowe, Diane Harley, Peter Pletcher, Shannon Laurence, BIBS: Alecture webcasting system, BMRC Technical Report June ,2001.

2. Patricia McKellar, Paul Maharg, Presence, Emergence and Learning Objects:

3. User Interaction in a Virtual Learning Environment.

4. Ashley Deal, A Teaching with Technology White Paper, Carnegie Mellon.

5. The Event Webcasting Toolkit: A Pain-Free Guide to Taking Your Conference

6. Online, Sonic Foundry.

7. Best Practices in Online Video Webcasting, Thomson Financial.

8. Improving the productivity of virtual employees, Citix Online.

9. Mediasite by Sonic Foundry for Distance Education and e-learning, Wainhouse

10. Research.

11. Best Practices: Online Learning. Textbook strategies for video education, Sonic Foundry.

\section{INNOVATSION TEXNOLOGIYALARDAN FOYDALANISH TA'LIM JARAYONIDA - KUNNING DOLZARB MUAMMOLARIDAN BIRIDIR}

\section{O.P.Jiyanov (TATU) A.S.Pardoboyev (TATU)}

Annotation: The article is devoted to the ideas of a new scientific direction in the field of pedagogy today - pedagogical innovation and modernization of the educational process. In particular, the essence of innovative teaching methods and the development of practical ideas in innovative activities are reflected in the logic of academic science and the development of practice as a result of the support of modifications of the development process. Innovations are relevant, important, new approaches formed in one system. They are born on the basis of initiatives and innovations, are promising for the development of educational content, and also have a positive impact on the development of the education system as a whole. Innovation is the end result of a technology, form, or method in a particular field of activity or production, a new approach to solving a problem, or the application of a new technological process that is known to lead to greater success than ever before.

Key words and expressions: Innovation, education, training, teacher, knowledge, teaching methodology, interactive approaches, activities, creative approach. 
Mamlakatimizda amalga oshirilayotgan barcha islohatlar inson manfaatlarini mukammal ravishda ro'yobga chiqarish, xalqimizga farovon turmish tarzini yaratib berishdek ezgu maqsadlarga yo'naltirmoqda. Ushbu vazifalarning qisqa muddatlarda muvaffaqiyatli hal qilinishi bugungi kunda nafaqat davlatimiz, balki o'zimiz yashayotgan jamiyatning har bir a'zosining bu boradagi sobitqadam va ongli faoliyati bilan ham bog'liqdir.

O'zbekiston Respubilkasi xalq ta'limi tizimini 2030 yilgacha rivojlantirish konsepsiyasida "Uzluksiz ta'lim tizimi mazmunini sifat jihatidan yangilash, shuningdek professional kadrlarni tayyorlash, o'qitish metodikasini takomillashtirish, ta'lim-tarbiya jarayoniga individuallashtirish tamoillarini bosqichma-bosqich tadbiq etish" kabi muhim vazifalar belgilangan [3].

Chunki jamiyatning yangilanishi, hayotimiz taraqqiyoti va istiqboli, amalga oshirilayotgan islohotlar samarasi taqdiri, Respublika mustaqilligi va bozor iqtisodiyotiga mos ijtimoiy-iqtisodiy siyosatni shakllantirish-bularning barchasi zamon talablariga javob beradigan yuqori malakali mutaxassis kadrlar tayyorlash muammosi bilan chambarchas bog'liq. Kadrlar tayyorlash milliy dasturini amalga oshirishdagi asosiy tamoyillardan biri - bu ta'lim tizimini tuzilish va mazmun jihatidan isloh qilish uchun o'qituvchi va murabbiylarni qayta tayyorlash, yuqori malakali, raqobatga qodir mutaxassislar tayyorlash bo'yicha ta'lim muassasalarining faoliyatini uyq 'unlashtirish, ilg'or pedagogik texnologiyalarni, pedagogik innovatsiyalarni ta'lim jarayoniga kiritish hisoblanadi. Ammo ilg'or pedagogik texnologiyalar va innovatsiyalar o'z-o'zidan ta'lim tizimiga kirib kelmaydi. Bu o'qituvchi faoliyati va uning motivatsiyasiga boq'liq jarayon. O'qituvchi faoliyatini o'zgartirmay turib, uning mas'uliyati va faolligini oshirmasdan ta'limda bir qadam oldinga siljib bo'lmaydi. Akademik A.N.Leontev «Dunyoni idrok qilishning birinchi sharti faoliyat, ikkinchi sharti - tarbiyadir. Faoliyat jarayonida kishilarning qobiliyati, bilim va malakalari shakllanadi, demak, faoliyat-ijtimoiy hodisa bo'lib, hayotiy kurashning asosiy shartidir»,- deb ta'kidlaydi.

Bugungi kunda pedagogika sohasida yangi ilmiy yo'nalish - pedagogik innovatsiya va ta'lim jarayonini yangilash g'oyalarining paydo bo'lishi natijasida o'qituvchining pedagogik faoliyatida ham yangi yo'nalish «o'qituvchining innovatsion faoliyati» tushunchasi paydo bo'ldi. «Innovatsion faoliyat» tushunchasini tahlil qilar ekanmiz: G.A.Mkritichyanning bu haqdagi fikri diqqatga sazovar: - «Pedagogik tajriba-sinov faoliyatining 3 ta asosiy shaklini ajratish mumkin: xususiy tajriba, tajriba-sinov ishi, o'qituvchining innovatsion faoliyati. Pedagogik faoliyatda innovatsiyalar qancha ko'p bo'lsa, o'qituvchi xususiy eksperimentni shuncha yaxshi tushunadi».

Innovatsion faoliyat - pedagogning o'z kasbini takomillashtirishdagi mavjud shakl va vositalarni egallashga ijodiy yondashuvini nazarda tutadi. Ta'limdagi innovatsiyalar va innovatsion pedagogik faoliyat haqida barqaror va hammaga ma'qul bo'lgan ilmiy tasavvurlar va tasniflar shu paytgacha mukammal tarkib topgan emasligini ham e'tirof etish lozim. Bunday holatning asosiy sabablaridan biri ta'limga yo'naltirilgan ilmiy bilimlar tizimlari o'rtasidagi qiyinchilik bilan engib o'tiladigan uzilishlardir. Yana kattaroq sabab esa ta'limiy bilim va amaliy pedagogik faoliyat o'rtasidagi uzilishdir. O'qituvchi innovatsion faoliyatning sub'ekti va tashkilotchisi sifatida yangilikni yaratish, qo'llash hamda ommalashtirishda ishtirok etadi. U fandagi bilim, an'analardagi o'zgarishlar mazmunini va mohiyatini tahlil eta bilishi kerak. Innovatsion faoliyat tushunchasi innovatsiya, innovatsion jarayon kabi tushunchalar bilan chambarchas boq`liq. Shu sababli bu tushunchalar mazmunini izoqlamasdan turib, innovatsion faoliyat mazmunini anglash mumkin emas. Innovatsiya -amaliyot va nazariyaning muhim qismi bo'lib, ijtimoiy-madaniy ob'ekt sifatlarini yaxshilashga yo'naltirilgan ijtimoiy sub'ektlarning harakat tizimidir . Bu g'oya nazariyasi mohiyatining yaratilishiga nisbatan turli yondashuvlar va fikrlar mavjud bo'lib, uning mohiyati borasida fanda yagona fikr mavjud emas. Innovatsiyalar dolzarb, muhim ahamiyatga ega bo'lib, bir tizimda shakllangan yangicha yondashuvlar. Ular tashabbuslar va yangiliklar asosida tug'ilib, ta'lim mazmunini rivojlantirish uchun istiqbolli bo'ladi, shuningdek, umuman ta'lim tizimi rivojiga ijobiy ta'sir ko'rsatadi. Innovatsiya-ma'lum bir faoliyat maydonidagi yoki ishlab chiqarishdagi texnologiya, shakl va metodlar, muammoni echish uchun yangicha yondashuv yoki yangi texnologik jarayonni qo'llash, oldingidan ancha muvaffaqiyatga erishishga olib kelishi ma'lum 
bo'lgan oxirgi natijadir. Bugun ta'lim tizimidagi innovatsiyalarni quyidagicha tasniflash ma'qullanmoqda:

Ta'lim tizimidagi har qanday yangilik innovatsiya bo’la olmaydi. Shu sababli «novatsiya» va «innovatsiya» tushunchalari o'rtasidagi asosiy farqlarni ko'rsatib o'tish zarur. Buning uchun islohot faoliyatining aniq shakli, mazmuni va ko'lami asos bo'lib xizmat qiladi. Agar faoliyat qisqa muddatli bo'lsa va yaxlit tizim xususiyatiga ega bo'lmasa, o'z oldiga muayyan tizimdagi faqat ba'zi elementlarini o'zgartirishni vazifa qilib qo'ygan bo'lsa, u holda biz novatsiya bilan muloqot qilayotgan bo'lamiz. Agar faoliyat ma'lum kontseptual yondashuv asosida amalga oshirilayotgan bo'lsa va uning natijasi o'sha tizim rivojlanishiga yoki uning printsipial o'zgarishiga olib kelsagina innovatsiya deya olamiz. Har ikkala tushuncha mezonlari quyidagicha: inovatsiya amaldagi nazariya doirasida amalga oshiriladi, ko'lam va vaqt bo'yicha chegaralanadi, metodlar yangilanadi va natijasi avvalgi tizimni takomillashtiradi. Innovatsiya esa tizimli, yaxlit va davomli bo'ladi, ma'lum amaliyotda yangi faoliyat tizimini loyihalaydi, amaliyot sub'ektlari pozitsiyalarini to'la yangilaydi. Bunda faoliyatning yangi yo'nalishlari ochiladi, yangi texnologiyalar yaratiladi, faoliyatning yangi sifat natijalariga erishiladi, natijada amaliyotning o'zi ham yangilanadi [2].

Innovatsiyaning amaliyotga kiritilishi innovatsion jarayonlarda amalga oshiriladi. Innovatsion jarayon deb - innovatsion o'zgarishlarga tayyorgarlik ko'rish va uni amalga oshirish jarayoniga aytiladi. Ta'lim jarayonidagi innovatsion o'zgarishlar, ta'lim tizimiga har qanday yangilikning kiritilishi bevosita o'qituvchi faoliyatini yangilash va o'zgartirish orqali amalga oshirilishi ham muallif tomonidan qayd etilgan. Ta'lim tizimidagi innovatsiyalar, ularni amaliyotga kiritish, innovatsion jarayonlarni boshqarishni tahlil qilish orqali innovatsion faoliyat tushunchasini ta'riflash imkoniyati paydo bo'ldi. Innovatsion faoliyat - pedagogik jamoani harakatga keltiruvchi, olg'a boshlovchi, taraqqiy ettiruvchi kuchdir. «Innovatsion faoliyat - bu yangi ijtimoiy talablar bilan an'anaviy me'yorlarning mos kelmasligi, yoxud amaliyotning yangi shakllanayotgan me'yorining mavjud me'yor bilan to'qnashuvi natijasida vujudga kelgan majmuali muammolarni echishga qaratilgan faoliyatdir», - deb ta'kidlaydi V.I.Slobadchikov.

Innovatsion faoliyat bu amaliyot va nazariyaning muhim qismi bo'lib, ijtimoiy-madaniy ob'ekt sifatlarini yaxshilashga qaratilgan ijtimoiy sub'ektlarning harakat tizimi bo'lib, u ma'lum doiradagi muammolarni echish qobiliyatigina emas, balki har qanday vaziyatdagi muammolarni echish uchun motivatsion tayyorgarlikka ega bo'lishdir. O'qituvchi innovatsion faoliyatining markaziy masalasi o'quv jarayonini samarali tashkil etishdan iborat.

Innovatsion faoliyat - uzluksiz ravishda yangiliklar asosida ishlash bo'lib, u uzoq vaqt davomida shakllanadi va takomillashib boradi. O'qituvchi innovatsion faoliyati xususiyatlarini o'rganib chiqqan pedagog olimlar fikrlariga tayangan holda, quyidagilarni innovatsion faoliyatning asosiy belgilari deb hisoblash mumkin:

- ijodiy faoliyat falsafasini egallashga intilish;

- pedagogik tadqiqot metodlarini egallash;

- mualliflik kontseptsiyalarini yaratish qobiliyati;

- tajriba-sinov ishlarini rejalashtirish va amalga oshira olish;

- o'zidan boshqa tadqiqotchi-pedagoglar tajribalarini qo'llay olish;

- hamkasblar bilan hamkorlik;

- fikr almashish va metodik yordam ko'rsata olishlik;

- ziddiyatlarning oldini olish va bartaraf etish;

- yangiliklarni izlab topish va ularni o'z sharoitiga moslashtirib borish.

O'qituvchilarni innovatsion faoliyatga tayyorlash muammosiga murojaat etish jamiyatda innovatsion jarayonlar dinamikasining o'sib borayotganligini tushunish natijasida vujudga keldi. Uning tahlili faqat fan va texnika erishgan zamonaviy yutuqlardan foydalanishni o'z ichiga olmasdan, balki yangiliklarni izlash, yaratish, moslashtirish, tatbiq etish va olingan natijalarni qayta tekshirish kabi jarayonlarni ham qamrab oladi.

Innovatsion faoliyatning tuzilishini o'rganib chiqqan olimlardan biri V.Slastenin uni quyidagicha tuzilishga ega deb ko'rsatib o'tadi: «Innovatsion faoliyatning tuzilishi-ijodiy yondashuv, ijodiy faollik, yangilikni kiritishga texnologik va metodologik tayyorgarlik, yangicha 
fikrlash, muomala madaniyati. Innovatsion faoliyatning darajalari: reproduktiv, evristik, kreativ bo'lishi mumkin»».

Innovatsion faoliyat davrida yangiliklar, innovatsiyalar, tom ma'noda ta'lim jarayoniga kirib keladi. Shu sababli ta'lim tizimidagi innovatsiyalarni pedagogik jarayonga kiritish 4 bosqichda amalga oshiriladi:

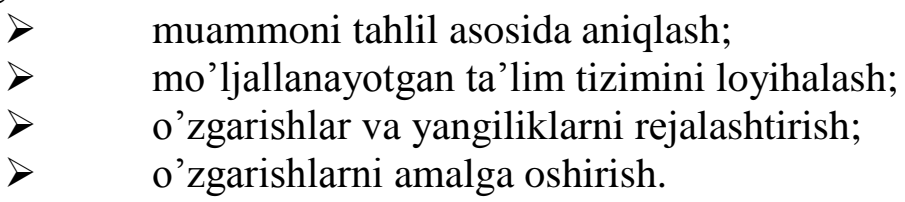

Innovatsion faoliyatga tayyorlashdan maqsad-o'qituvchining yangilikka intiluvchanligini, mustaqil o'z ustida ishlash ko'nikmasi va malakasini shakllantirish, yangi pedagogik texnologiyalar, interfaol metodlardan foydalanib, dars va darsdan tashqari mashg'ulotlarni o'tkazish malakasini takomillashtirishdan iborat [1].

«Innovatsion faoliyat o'qituvchining o'z faoliyatidan qoniqmasligidan kelib chiqadi. U o'qituvchi tomonidan u yoki bu pedagogik vazifani hal qilishda qandaydir to'siqqa duch kelinib, uni muvaffaqiyatli hal etishga intilish asosida yuzaga keladi». Innovatsion faoliyat yangi g'oyani izlashdan boshlanadi. Pedagogik innovatsiya ta'lim-tarbiya jarayonidagi muhim va murakkab masala echimiga yo'nalitirilganligi sababli o'qituvchidan yangicha yondashuvni talab qiladi.

Xulosa qilib aytganimizda, innovatsion faoliyat - bu ilmiy izlanishlar, ishlanmalar yaratish, tajriba - sinov ishlari olib borish yoki boshqa fan-texnika yutuqlaridan foydalangan holda yangi texnologik jarayon yoki yangi takomillashtirilgan mahsulot yaratish bo'lib, uning progmatik xususiyati shundaki, u q`oyalar maydonida ham va alohida bir sub'ektning harakat maydonida ham amalga oshirilmaydi, balki bu faoliyatni amalga oshirish tajribasi kishilar hayotida hammabop bo'ladigan holdagina haqiqiy innovatsion hisoblanadi. Innovatsion faoliyatning asl mazmuni amalda yangi texnologiyaning shakllanishi bo'lib, uning natijasi innovatsiya sifatida yuzaga kelgan ixtironi-loyihaga, loyihani-texnologiyaga aylantirishga yo'naltirilgan faoliyatdir. Innovatsion faoliyatda ilmiy tasavvurlar akademik ilm mantiqi bo'yicha tuq'ilmaydi, balki rivojlanish jarayonining modifikatsiyalari qo'llab-quvatlanishi natijasida rivojlanayotgan amaliyot mulohazasidan paydo bo'ladi.

\section{Foydalanilgan adabiyotlar ro'yxati}

1. F. Zakirova va boshq. Elektron o'quv-metodik majmualar vat a'lim resurslarini yaratish metodikasi. Metodik qo'llanma, T.: OO'MTV, 2010. - 57 b.

2. Uzluksiz ta`lim sifat va samaradorligini oshirishning nazariy-uslubiy muammolar\|l Ilmiy konferensiya materiallari. - Samarqand: SamDU nashri.

3. O’zbekiston Respubilkasi Prezidentining 2019 yil 29 apreldagi “O'zbekiston Respubilkasi xalq ta'limi tizimini 2030 yilgacha rivojlantirish konsepsiyasini tasdiqlash to'g'risida"gi PF-5712-son Farmoni. - Qonun hujjatlari ma'lumotlari milliy ba'zasi , 06/19/5712/3034-son, 29.04.2019

\section{ЧЕТ ТИЛИ ТАЪЛИМИДА ЯНГИ ПЕДАГОГИК ТЕХНОЛОГИЯЛАРДАН ФОЙДАЛАНИШ}

\section{Холмирзаева 3.А. (Сам ВМИ)}

Annotation: The role and importance of pedagogical technologies in foreign language teaching, the views of scholars on pedagogical technologies in foreign language teaching, the solution of some problems in this field as a result of studying foreign language teaching and new pedagogical technologies, as well as relevant recommendations on the use of new pedagogical technologies in foreign language teaching. instructions are explained.

Key words and expressions: pedagogical technology, pedagogical system, foreign language education, educational process, innovative methods, theoretical and practical research. 
Педагогикага оид адабиётлар тахлили шуни кўрсатадики, хозирги даврда педагогик технология тушунчаси чет тили таълимида мустахкам ўрин эгаллади.

Педагогик технология тушунчасининг шаклланиши ва ривожланиши тарихида турли қарашлар мавжуд бўлган: у техник воситалар хақидаги таълимот деб хамда ўқитиш жараёнини лойихалаштирилган холда изчил ва мунтазам ташкил этиш деб талқин қилинган. Хозир педагогик технологияларнинг бир қанча таърифлари мавжуд.

В.П. Беспалко педагогик технологияни амалиётга татбиқ қилинадиган муайян педагогик тизим лойихаси сифатида белгилайди. У педагогик тизим технологиялар ишлаб чиқиш учун асос бўлади, деб хисоблайди. Бунда асосий диққат ўқув-педагогик жараённи олдиндан лойихалашга қаратилади, дидактик вазифа ва ўқитиш технологиялари тушунчасидан фойдаланилади. Шу тариқа В.П. Беспалко ўқув жараёнини лойихалаш ғоясини илгари суради, афсуски, педагогик технология ва лойиха тушунчалари хақида аниқлик йўқ.

Педагогик технология барча йўналишлари қатори чет тили таълими жараёнига жадаллик билан кириб бораётган бўлса хам, унинг мақоми ноаниқлигича қолиб кетмоқда. Тадқиқотчиларнинг ишларида фан ва амалиёт оралиғидан ўрин эгалламоқда.

Н.Ф.Талызина хар бир педагог реал педагогик жараённи ташкил этишдан олдин ўкув жараёни хақида технологик даражада билимлар тизимини билиб олган бўлиши шарт деб хисоблайди. У фан ва амалиёт оралиғида тамойилларни олға сурувчи, методлар ишлаб чиқувчи, уларни изчил қўллаш каби масалалар билан шуғулланувчи -алохида фан бўлиши керак, деб хисоблайди, уларсиз педагогик жараён асосланмай қолади.

Айрим муаллифлар чет тилини ўқитишда педагогик технологияларга фан ва санъат оралиғидаги фан деб қарайдилар, бошқалари уни лойихалаш билан боғлайдилар.

Шундай қилиб, бир ёндашувда ўқитиш технологиялари ўкитишнинг барча воситаларини қамраб олган қандайдир жихозлаш сифатида хам белгиланади. Унда технология ўқув жараёнини техниклаштиришни тақозо қилади.

Бошқа ёндашувда технологияга таълим амалиётини янги ёки замонавийлаштирилган билимлар билан таъминлашнинг усули сифатида қарашга имконият беради. Бунда технологияга таълимнинг илмий тамойиллари ва амалиётини татбиқ этиш сифатида қаралади.

Педагогик технология ўзига хос ва потенсиал яратиладиган педагогик натижаларга эришиш учун педагогик тизимнинг барча ташкилий томонларига алоқадор назарий ва амалий (таълим тизими доирасида) тадқиқотлар сохаси сифатида белгиланади.

Педагогик технология мохиятини ёритиш учун педагог-дидактикачилар томонидан берилган таърифларга тўхталишни мақсадга мувофиқ деб топамиз.

«Педагогик технология - психологик ва педагогик ўгитлар йиғиндиси бўлиб, шакллар, методлар, усуллар, ўқитиш йўллари, тарбиявий воситаларнинг махсус тўпламидир. Айни замонда у педагогик жараённинг ташкилий-методик омилини хам билдиради» (Б.Лихачев).

Бу таърифлар тахлилидан педагогик технология натижани кўлга киритиш учун чет тили таълими доирасида зарур бўлган воситалар тизимини режалаштириш ва татбиқ этиш деган хулосага келиш мумкин.

Чет тили таълими жараёнида ноанъанавий, қизиқарли, фаол, инновацион усуллардан фойдаланиш самарали тизим сифатида ўз ифодасини топган.

Чет тили таълими ва янги педагогик технология муаммоларини ўрганиш натижасида ушбу сохадаги баъзи муаммолар ўз ечимини топади, чет тили таълимида янги педагогик технологиядан фойдаланиш бўйича тегишли янги тавсиялар ва кўрсатмалар баён қилинади.

Хулоса қилиб айтганда, педагогик фанлар асосларини ўқитишга йўналтирилган машғулотлар жараёнини ноанъанавий шаклларда ташкил этиш, таълим жараёнини мукаммал андоза асосида лойихалашга эришиш, мазкур лойихалардан оқилона фойдалана олиш кўникмаларга эга бўлиш таълим олувчилар томонидан назарий билимларни пухта, чуқур ўлаштирилиши, уларда амалий кўникма ва малакаларнинг хосил бўлишининг кафолати бўла олади. 


\title{
Foydalangan adabiyotlar ro'yxati
}

1. Аминов И.Б. Чет тили дарсларида янги информатсион технологиялардан фойдаланиш. Мулоқот шакллари ва хорижий тилларга ўргатиш. Илмий мақолалар тўплами. СамДУ, Самарқанд, 2002 й. 11-12 б.

2. Тўрақулов О.Х. Ўқитишда инновацион усуллардан фойдаланиш// Касб хунар таълими, 2005, 6-сон. -22-23 б.

3. Хошимов Ў. Қ., Ёқубов И.Я. Немис тили ўқитиш методикаси. Тошкент: “Шарк”, 2003.-301 6 .

\section{ON THE ISSUE OF DEVELOPING SPEAKING AND LISTENING SKILLS USING MULTIMEDIATECHNOLOGIES}

\section{ZulfizarKarimova (Tashkent branch of MSU named after M.V. Lomonosov)}

\begin{abstract}
Annotation: The questions of using contemporary computer technologies for educational purposes are risen in this article. Moreover, the work is focused on the issue of developing and improving speaking and listening skills using multimedia technologies. In addition, this article lists the factors that must be taken into account when teaching speaking and listening skills using new computer technologies.The tasks are concretized and some parameters of the use of computer technologies for educational purposes are listed in current work. Some advice of providing effective lessons to develop speaking and listening skills are also given in this article.
\end{abstract}

Key words and expressions: computer technology, educational program, multimedia, specialist, listening and speaking skills, communication, competence, innovation.

Multimedia technologies have undoubtedly become one of the newest educational technologies using computer technologies. The use of multimedia technologies in the educational process allows by means of multimedia, in the most accessible form, to develop the logical thinking of students, to strengthen the creative component of the educational process.

It is assumed that a modern specialist or a person studying a foreign language owns a whole arsenal of technical teaching aids, is fluent in the basics of the information space, is aimed at the formation of an intellectually developed personality, at creative self-development, and applies the acquired knowledge in the future professional sphere. Young staff are ready to use the accumulated knowledge in life, hence it follows that oral competence continues to develop intensively, the ability to carry out interpersonal communication develops.

Having studied the work of researchers in the field of pedagogy and having analyzed the work of information and computer technologies in general, we came to the conclusion that computer technologies for educational purposes can be divided into the following parameters:

For didactic tasks:

- facilities providing basic training (e-textbooks, training systems, knowledge control systems);

- tools for practical training (problem books, workshops, virtual constructors, simulation programs, simulators);

- additional sources (encyclopedias, dictionaries, readers, developing computer games, multimedia training sessions);

- integral means (remote).

On aspects of the educational process:

- information and training (electronic libraries, electronic books, electronic periodicals, dictionaries, reference books, training computer programs, information systems);

- interactive (e-mail, electronic conferences);

- search engines (catalogs, search engines).

By type of information: 
- electronic and informational resources with textual information (textbooks, study guides, problem books, tests, dictionaries, reference books, encyclopedias, periodicals, numerical data, program and educational materials);

- electronic and information resources with visual information (collections: photographs, portraits, illustrations, video fragments of processes and phenomena, demonstrations of experiments, video tours; statistical and dynamic models, interactive models; symbolic objects: diagrams, diagrams);

- electronic and information resources with audio information (sound recordings of poems, didactic speech material, musical works, sounds of animate and inanimate nature, synchronized audio objects);

- electronic and information resources with audio and video information (audio and video objects of animate and inanimate nature, subject excursions);

- electronic and information resources with combined information (textbooks, study guides, primary sources, anthologies, problem books, encyclopedias, dictionaries, periodicals).

By ways of using computer technologies in the educational process:

- lesson;

- extracurricular

By the form of interaction with the student:

- technology of asynchronous communication mode - "offline";

- technology of synchronous communication mode - "online" [LeontievA. A 2001: 536].

When using computer technologies in the educational process, several factors can be emphasized: they are, motivational, information, educational and methodological, organizational, as well as assessing factors.

The motivational factor plays one of the major key roles, as it stimulates an increase in interest and the formation of a stable student's motivation to use computer technologies, since conditions are created:

- a complete analysis of the personal educational abilities and needs of students;

- a wide variety of training sessions, in accordance with the level, content and form;

- discovering the creative possibilities of students.

Information factor. Computer technology tools can be used:

- when creating interactive tables, posters and other digital educational resources on various topics and sections of the academic discipline,

- to develop individual lessons;

- for the implementation of interactive home exercises and simulators used in self-study.

1. Educational and methodological factor. Electronic and information resources can be used as educational and methodological support of the educational process [Segura Alonso2012 :83].

In preparation for the lesson, the teacher can use information resources. For example, directly during the explanation of a new topic, to consolidate the material already covered, to check the quality of knowledge. It is also possible to use computer technology outside the classroom to organize additional material for self-study.

Computer test items can be utilized to implement control and assessment of knowledge. In addition, in preparation for classroom and non-classroom lessons, the teacher is provided with a wide range of information resources. To implement educational and methodological factors, the teacher must have computer skills, the ability to choose the most effective from a huge flow of information resources, in accordance with the level of training of the training group, and then use the resources in the classroom. In short, have computer competence.

Organizational factor. The use of information and computer technologies is possible in different options of the educational process:

- on an individual basis, using a specific selection of didactic material;

- on a group basis: with frontal or subgroup forms of work. 
Assessing factor. In the course of the educational process, a mandatory factor in training is the control and assessment of students' knowledge. There are various types of control, such as intermediate and final. Assessment is carried out using test items.

Tests can be carried out in the on-line mode (carried out on a computer in an interactive mode, the result is automatically assessed by the system) and in the off-line mode (the teacher evaluates the results with comments, correcting errors) [Common European Framework of Reference for Languages Learning, Teaching 2005: 247].

Considering all of the above, we can conclude that the introduction of computer technologies in the educational process, namely in the study of foreign languages, significantly motivates students to study the material provided, increases the productivity of learning, helps to improve various forms and methods of teaching.

However, it should be emphasized that by computer technology we mean not only this devicecomputer, but also the skills of working with information. It would be appropriate here to highlight communication technology. We join the opinion of N.I.Gez that communication technology is based on interconnected complex training in all types of speech activity: listening; speaking; reading; writing.

The main thing in the communicative technology of teaching is the content of speech behavior, which consists of speech actions and a speech situation.

Communicative technology provides for the functionality of learning (student activity): the student asks, confirms the thought, prompts to action, expresses doubts and, in the course of this, actualizes grammatical norms [4].

For the adequate use of communication technology in the classroom, a speech situation should be implemented. Namely, a new speech task, a new communicator, a new subject of discussion, a system of relationships is established, speech material is presented, speech skills are acquired, children's activity and independence of communication develop.

The main activities accompanying the possession of communicative competence are called communication technology. There are the following types of technologies: educational, game, labor. Applying these technologies in the learning process, there is an awareness of the need for communication, the need to use speech, and speech behavior is formed.

Moreover, the communicative technology of the selection of educational material, namely speech structures, vocabulary, a model of speech communication, must correspond to the level of training of students.

It becomes obvious that teaching should stimulate the interaction of thinking, feelings and emotions of students, bring them a sense of satisfaction with the educational process.

Analysis of the methodological literature illustrates that of all types of language activities in a foreign language lesson: speaking, reading, listening and writing, the least amount of time is devoted to the development of listening and speaking, as this requires a certain amount of time and quality resources.

T.L. Stupina in her works emphasized that listening is that unique type of speech activity, in which nothing depends on the person performing it, since while listening to information it is difficult for the listener to correct, avoid, in comparison with the reading or writing, that or adjust in the performed activity, facilitate it, avoid difficulties [Stupina T.L. $2006: 22$ ].

In fact, the process of developing and improving a foreign language and, in particular, oral competence, occurs through listening.

Therefore, teachers in advance should understand how to get the most benefit from the use of modern technical innovations in their pedagogical practice, as well as in what ways and for what didactic purposes they can apply this to develop speaking and listening skills.

\section{The list of used literature}

1. LeontievA. A., Language and speech activity in the general and pedagogical psychology: collected psychological works. Moscow; Moscow Psychological-Social Institute Publishing House, 2001, p. 536. 
2. DOI:https://doi.org/ 10.17853/1994-5639-2017-3-120-141

3. Segura Alonso, Rocío, The importance of teaching listening and speaking skills, Spain, 2012, p.83

4. StupinaT.L., Fundamentals of using podcasting in the educational process: methodological guide / T.L. Stupin. - Irkutsk: IGLU, 2006 .p.22

5. Common European Framework of Reference for Languages Learning, Teaching, Assessment. - M.:Strassburg, 2005. -247 p.

\section{АХБОРОТ ТЕХНОЛОГИЯЛАРИНИНГ ТИЛ МАДАНИЯТИНИ ОШИРИШДАГИ РОЛИ}

\section{Ф.Ф.Саидов (ТАТУ)}

Annotation: Features of information communication in language learning. Methods of learning foreign languages in education through computer-based electronic programs and online platforms.

Key words and expressions: Information technology, language culture, pedagogy and psychology, passive listener, electronic programs, online platform, handouts.

Асрлар давомида ўқитиш деганда маълум билимлар йиғиндисини эгаллаш кўзда тутиларди. Бугун эса таълим жараёнини ахборотлар билан таъминлаш кўлами кенгайиб бормоқда.

Инсон тафаккури шу қадар тараққий этиб бормоқдаки, компьютерлаштириш жараёни нафақат ишлаб чиқаришга, балки таълим сохасига хам киритилиши замон талаби бўлиб қолмоқда. Шунинг учун хозирги вақтда олий таълим муассасаларида янги педагогик технологияларининг илмий асосларини яратиш устида иш олиб борилмоқда.

Дарсни ташкил қилиш жараёнида компьютер технологияларидан фойдаланиш юқори натижалар беради. Чунки компьютернинг овоз, матн, график, расм, видео, интерактив мулоқот каби воситалари таълимнинг эмоционал эстетик таъсирланиш, мақсадга интилиш, тадқиқотчилик каби мотивларини фаоллаштиради.

Тадқиқотлар шуни кўрсатадики, ўқувчи биринчи марта эшитган мавзусини фақат тўртдан бир қисмини, кўрган материалининг учдан бир қисмини, хам кўриб хам эшитса ахборотни 50 фоизини эсда сақлайди. Юқорида айтиб ўтилганидек бугунги кунда компьютер воситасида тил ўргатиш замон талаби экан, хар бир педагок ахборот технологияларининг мохиятини тушуниб етиши, компьютердан фойдаланишнинг педагогик ва психологик ахамиятини англаб олиши керак.

Албатта дарсларни компьютер техногиялари ёрдамида ташкил этишда бир қатор қийинчиликлар мавжуд. Масалан, компьютер хоналарининг барча гурухларда дарс олиб бориш учун етарли эмаслиги электрон ўқув материалларининг мавжуд эмаслиги, айрим ўқитувчиларнинг анъанавий методикадан бошқасини тан олмаслиги, компьютер саводхонлигининг етарли даражада эмаслиги ва бошқа муаммолар.

Бу муаммолар секин-асталик билан хал қилина боради. Мамлакатимизда компьютер ёрдамида иккинчи тилни ўргатиш ишлари жадал олиб борилмокда. Дарсларни компьютер ва ахборот технологиялари ёрдамида ташкиллаштириш ўқув тарбия - жараёнини фаоллаштиради, таълим самарадорлиги ошади, ўқувчиларда катта қизиқиш уйғотади, хотирада яхши қолади, талаба дарс давомида пассив тингловчидан фаол иштрокчига, ўқитувчи билан тенг диалог олиб борадиган хамкорга айланади. Нафақат дарс мазмуни, компьютернинг ўзи хам ўрганиш объектига айланиб, компьютер саводхонлигини оширишга ёрдам беради. Вақтдан унумли фойдаланилади. Дарс давомида бажарилиши мумкин бўлган машқ, вазифалар сони кескин ортади. Компьютер тил ўрганувчи талабалар учун мухим бўлган тил мухитини сунъий равишда яратади.

Албатта, таълим жараёнини компьютерлаштиришда хам баъзи салбий жихатлар учраши мумкин. Китобдан бир оз узоқлашади, компьютер бошида соатлаб ўтириш соғлиққа 
зарар етиши мумкин. Хулоса қилиб айтганда ўқитувчи машғулотларини ташкил этишда компьютер воситаларидан оқилона фойдаланиш керак, шу билан бирга, анъанавий методикани бой тажрибасини уйғунлаштириб кўллаши керак.

Компьютердан фойдаланиш деганда фақатгина мураккаб электрон дастурларни қўллаш тушунилмайди, балки ўқитувчи ўзининг дарси учун тарқатма, кўргазмали, назорат материалларини тайёрлаши мумкин. Тил ўрганаётганда матн устидан ишлар эканмиз, компьютер экранида матнни ўқишга қараганда қоғозда босилган матн билан ишлаш қулайроқ. Шунинг учун матн принтердан чиқарилади ва талабалар сонига қараб ишланади. Албатта дарсликдан фойдаланиш мумкин, лекин бунда ўқувчи машқларни , матнга ўзгартиришларни қоғознинг ўзида бажариши кулайдир.

Тарқатма материалнинг бошқа тури - саволлар мажмуи. Компьютер ёрдамида 10-15 вариантдаги ўқув саволлари тузилади ва барча талабанинг билими бахоланади, бундан ташқари хар бир талаба учун махсус топшириқ ва тестлар тайёрлаш мумкин. Хуллас, компьютер курсини махсус ўрганмаган ўкувчилар хам ахборот технологияларидан фойдаланиш мумкин. Ўргатувчи аудио дастурлар, электрон, лингафон курсларидан фойдаланиши мумкин, улар ўрганувчиларда нихоятда самарали натижа беради. Бироқ, бунда интерактив метод имкониятлари чекланган бўлади.

Яна дарсларда интернет тармоғи орқали ўқитиш усули хам мавжуд, бу масофавий таълим дейилади. Бунда талаба итернет орқали анкета тўлдиради ва ариза ёзиб юборади. Талабалар барча топшириқларни мустақил равишда курс материалларини ўрганган холда бажарадилар, аудиторияда мухокама қиладилар. Масофавий таълим ахборот коммуникация технологияларининг барча ютуқларини қўллайди. Катта хажмда маълумот бера олади, тез ва сифатли назорат қилишга имкон яратади.

Бир гурухнинг ўзида билим савияси хар хил бўлган талабалар ўқийди. Шунинг учун хорижий тил ўрганиш бўйича электрон дастурлар орасида табақалаштирилгани хам мавжуд. Кўпгина дастурлар мустақил таълимга мўлжалланган бўлиб, уларда компьютер ўқитувчиларнинг ролини тўла-тўкис бажаради. Лекин бу дастурларни шундай тузиш керакки, бунда биринчи навбатда ўқитувчини ўрнини белгилаб олиш керак, бу дастурлар мустақил таълим учун кенг йўл очиб бериш билан бирга ўқитувчи бошчилигида ўтказилиши керак. Чунки биз юқорида айтиб ўтгандек талабаларнинг билим даражалари хар хил, шунинг учун уларда хар хил кутилмаган, қизиқарли саволлар туғилиб қолиши мумкин.

Тил ўрганиш аввало жонли мулоқотни тақозо этади. Айниқса, нутқ ўстириш, фикрлашни ривожлантиришда компьютернинг роли катта.

\section{Фойдаланилган адабиётлар рўйхати}

б.

1. ̆̆ўлдошев Ш.С, Ибрагимов, У.М. Компютер графикаси. Тошкент. 2013-йил. 90-98

2. Арипов М, Бегалов У, Бегимқулов У, Мамаражабов М. Ахборот техналогиялари. Тошкент. 2016-йил. 368 б.

\section{ОЛИЙ ТАЪЛИМ ТИЗИМИДА ЗАМОНАВИЙ АХБОРОТ ТЕХНОЛОГИЯЛАРИНИ САМАРАДОРЛИГИНИ ОШИРИШ}

\section{Э.Э.Уришбаев (ЖПИ)}

Annotation: This article discusses the widespread use of information technology in higher education and the radical reform of the education system. Discussions were held on the role of information technology in the further development of employment of graduates of higher educational institutions and cooperation with manufacturing enterprises.

Key words and expressions: Higher education, manufacturing enterprises, information technology, "SMART universities". 
Жамиятнинг хар томонлама равнақ топиши, тараққий этиши таълимнинг ривожланишига ва мазмунан такомиллашиб боришига боғлиқ. Таълимнинг глобаллашуви, инновацион технологияларнинг жорий этилаётгани, айни пайтда кенг кўламли ахборотлар оқими таълим мазмунини мунтазам янгилаб, такомиллаштириб боришни тақозо этади.

Таълим сохасидаги давлат сиёсатини рўёбга чиқариш, кадрлар тайёрлашда ягона давлат талаблари асосида ўқув-тарбия жараёнини такомиллаштириш, ўкув-адабиётлари билан таъминлаш, педагогларга узлуксиз методик хизмат кўрсатиш вазифасини амалга ошириш мухим вазифалардан биридир.

Ушбу йўналишда Жанубий Корея, Буюк Британия, Дания, ва Россия каби давлатларнинг тажрибаси ўрганилганда, ахборотлаштиришнинг асосий мақсади биринчи навбатда таълим сифатини оширишга қаратилган бўлса, кейинги ўринда жараёнларни автоматлаштириш орқали олий таълим муассасаси ходимлари ва профессор-ўқитувчилари фаолиятида кўп такрорланадиган вазифалар учун кетадиган вақтни тежашга қаратилган.

Чет эл тажрибасидан келиб чиққан холда Ўзбекистондаги олий таълим муассасаларининг ўқув жараёни билан бир қаторда фаолиятнинг барча турларига ахбороткоммуникация технологияларидан самарали фойдаланишни инобатга олиб лойихага “SMART” ибораси киритилмоқда. Яъни:

- Specific (ўзига хос);

- Measurable (ўлчаб бўладиган);

- Attainable (эришиб бўладиган);

- Relevant (долзарб);

- Time-bound (аниқ муддатли).

Мазкур лойиха олий таълим муассасаларининг ўкув, илмий ва бошқарув жараёнларини ахборотлаштиришга қаратилган маълумотлар базаларини, ахборот тизимларини яратиш, улардан фойдаланиш, хизматлар кўрсатиш хамда бошқа ахборот тизимлари билан интеграция қилинадин олий таълим муассасасининг "SMART университет" ягона платформасининг асосий тамойилларини белгилаб беради.

“SMART университет” ягона платформасини жорий этишнинг ўзига хос хусусиятлари қуйидагилардан иборат:

- $\quad$ олий таълим муассасасининг ягона ахборот-таълим инфратузилмасини яратиш ва янги инновацион технологияларни жорий этиш;

- ўқув жараёнини бошқариш самарадорлигини ошириш;

- $\quad$ жараёнларни автоматлаштириш эвазига ходимлар фаолиятини енгиллаштириш ва ахборотларни олиш ва йиғиш тезлигини ошириш, ички комуникация ва хужжат алмашиш жараёнини тезлаштириш;

- $\quad$ таълим сифатини ошириш.

“SMART университет” ягона платформасининг асосий вазифалари қуйидагича:

- $\quad$ олий таълим муассасаси ташкилий тузилмаси доирасида талабалар, ходимлар ва ўқитувчиларни шахсий маълумотларини сақлаш ва муассаса контингенти хақидаги ахборотларни рўйхатга олиш;

- шахсий, гурух ва комплекс ўқув режаларини шакллантириш, ўқитувчиларининг ўқув юкламаларини режалаштириш ва юритиш, аудитория фондларининг бандлигини режалаштириш ва назрат қилиш;

- оралиқ ва якуний бахолаш жараёнларини ташкил этиш;

- талабаларнинг ўқув ва илмий фаолиятларини назорат қилиш, ўкув жараёнида уларнинг тайёргарлигини назорат қилиб бориш ва илмий лойихаларга жалб этиш, талабаларнинг муассаса билан молиявий алоқаларини назорат қилиш, ўқишдан ташқари тадбирларга талабаларни жалб этиш;

- битирувчиларни иш билан таъминлаш ва мониторинигини юритиш; 
- хар хил турдаги (тоифадаги) тахлилий маълумотларни яратиш ва зарур хисоботларни шакллантириш.

“SMART университет” ягона платформасининг асосий фойдаланувчилари:

- маъмурият;

- ўқитувчилар ва ходимлар;

- талабалар ва уларнинг ота оналари;

- иш берувчилар хисобланади.

Мазкур платформа, 4та асосий ахборот тизимини ўз ичига олиб, ундан фойдаланиш ва маълумотларни сақлаш учун олий таълим муассасасида замонавий IT-инфратузилма ташкил этилишини хамда хар бир ўқув аудиторияларини замонавий IT-воситалар билан жихозлаш (компьютер, проектор, Интернет ва бошқалар) талаб этади.

Платформанинг асосий ахборот тизимларига куйидагилар киради:

1. “Маъмурий бошқарув” ахборот тизими (МБАТ);

2. “Ўкув жараёни” ахборот тизими (ЎЖАТ);

3. “Илмий фаолият" ахборот тизими (ИФАТ);

4. “Молиявий бошқарув ва статистика" ахборот тизими (МБСАТ).

Мазкур ахборот тизимлари хам ўз навбатида фаолиятдаги бизнес жараёнлар асосида бир нечта қуйи тизимларга бўлинади (1-расм).

1. “Маъмурий бошқарув” ахборот тизими ўз ичига қуйидаги қуйи тизимларни олади:

- Персонални бошқариш тизими: кадрлар тўғрисидаги маълумотлар базаси хамда уни юритиш ахборот тизими.

- Талабаларни бошқариш тизими: талабалар контингенти маълумотлар базаси хамда уни юритиш ва бошқариш ахборот тизими.

- Мониторинг тизими: ички назорат ва мониторингни ташкил этиш тизими, ижро интизомини назорат қилиш тизими, электрон хужжат айланиш тизими.

2. “Ўқув жараёни” ахборот тизими ўз ичига қуйидаги қуйи тизимларни олади:

- Ўкув режаларни яратиш тизими: Давлат таълим стандартлари асосида ўқув жараёнини ташкил этиш, ўқув режа, ишчи ўқув режа ва фан дастурлари базалари хамда уларни бошқариш ахборот тизими.

- Ўув юкламасини яратиш тизими: Профессор-ўқитувчилар ўкув юкламаларини шакллантириш ва тақсимлаш ахборот тизими, Ўкув машғулотлари жадвалини тўзиш, тасдиқлаш ва бажарилишини назорат қилиш, кафедралар ўкув юкламалари ва йиллик хисоботларини тахлил қилиш ахборот тизими.

- у узлаштиришни назорат қилиш ахборот тизими: Талабалар ўзлаштиришини назорат қилиш, курсдан курсга ўтказиш буйрукларини шакллантириш, стипендияларни тайинлаш имконини берувчи ахборот тизими.

- Амалиётни ташкил этиш ахборот тизими: Талабалар ўқув ва ишлаб чиқариш амалиётларини ташкил этиш хамда мувофиқлаштириш ахборот тизими, Магистратура талабалари ўқув-услубий, илмий - тадқиқот, педагогик ва малакавий амалиёт фаолияти бўйича иш режаларини шакллантириш хамда мувофиқлаштириш ахборот тизими. 

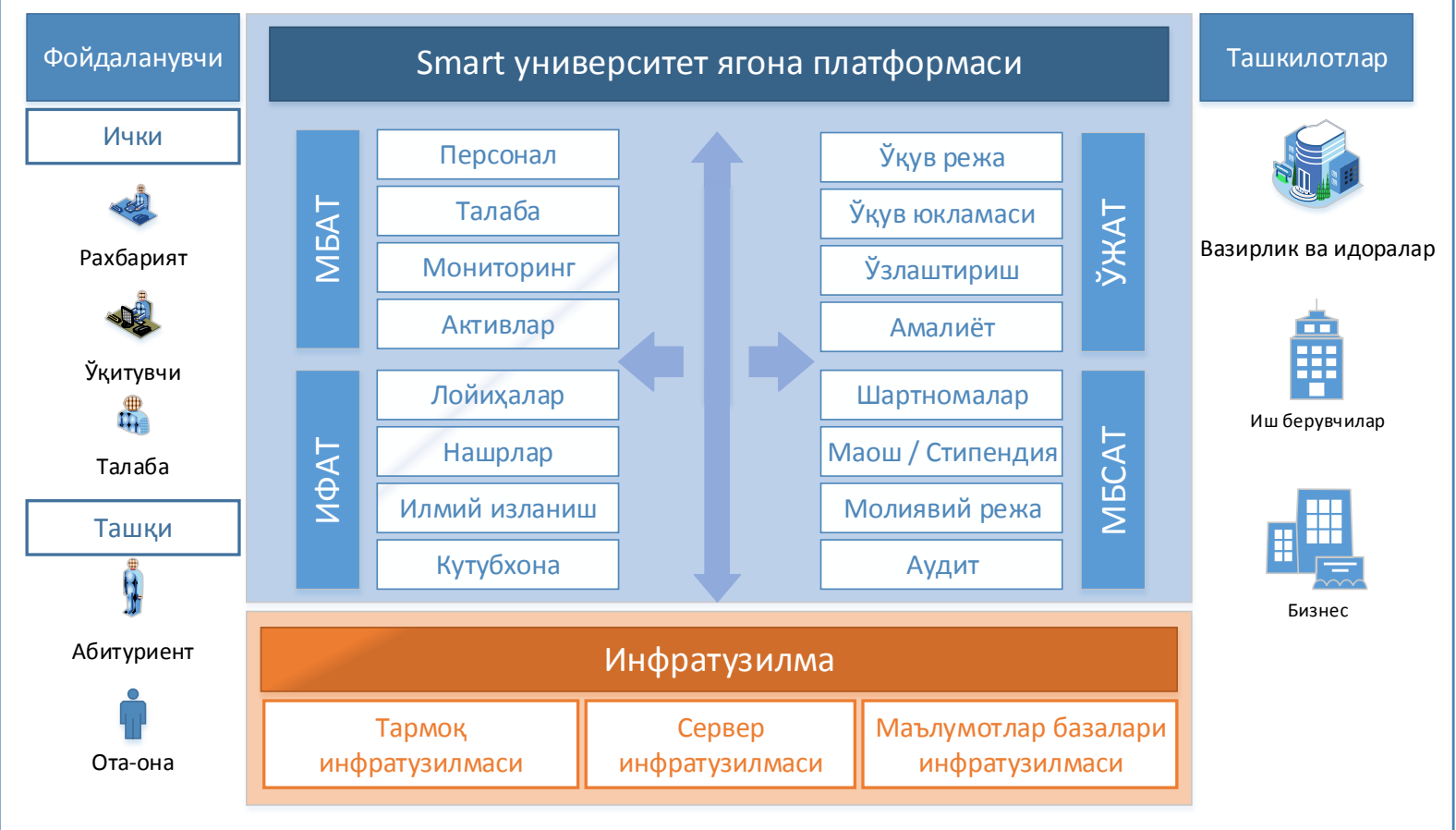

1-расм. Sтагt университет платформасининг асосий компонентлари

3. Илмий фаолият ахборот тизими ўз ичига куйидаги қуйи тизимларни олади:

- Илмий лойихалар ахборот тизими: Илмий лойхалар хамда унда фаолият юритаётган илмий ходимларни хисобга олиш ва назорат қилиш ахборот тизими.

- Нашрларни хисобга олиш ахборот тизими: Ўқув-услубий материаллар, шу жумладан, профессор-ўқитувчилар томонидан илмий мақолаларни тайёрлаш, уларни журналлар ва илмий тўпламларда нашр этиш жараёни назоратини олиб борувчи ахборот тизими.

- $\quad$ Илмий изланувчилар ахборот тизими: Илмий изланувчиларни хисобини юритиш, уларнинг фаолиятини мувофиқлаштириш ахборот тизими.

- Кутубхона ахборот тизими: Ахборот-ресурс марказлари фаолиятини автоматлаштириш, кутубхоналар фондини юритиш, электрон таълим ресурлари базаларини яратиш ахборот тизими.

4. Молиявий бошқарув ва статистика ахборот тизими

- $\quad$ Шартномалар билан ишлаш ахборот тизими: Молиявий шартномалар базасини юритиш ва уларни ижросини таъминлаш ахборот тизими. Тўлов-контракт асосида тахсил оладиган талабалар билан шартномалар тузишни мувофиқлаштирувчи ахборот тизими.

- Маош ва стипендияларни хисоблаш тизими: Муассаса ходимларининг ойлик маошлари ва бошқа турдаги тўловларини хисоблаш ахборот тизими. Талабалар стипендияларини хисоблаш ахборот тизими.

Юқорида келтирилган ахборот тизимларини жорий этиш учун хар бир олий таълим муассасасининг IT-инфратузилмаси талаб даражасида бўлиши шарт. Яъни, олий таълим муассасасининг сервер қурилмалари, локал ва корпоратив тармоқлари зарур қурилма ва дастурий воситалар билан жихозланган бўлиши зарур.

Бундан ташқари, IT-инфратузилманинг асосий компонентларидан бири хисобланган маълумотлар сақлаш учун мўлжалланаган техник воситалар ва уларнинг махсус дастурий иловаларининг мавжудлигига алохида этибор қаратиш керак. Мамлакатда таълим 
сифатининг юқори даражада ташкил этилиши ушбу мамлакатнинг келажак ривожининг асосий омили бўлиб хизмат қилади.

\section{Фойдаланилган адабиётлар рўйхати}

1. Р. Ишмухамедов, А. Абдукодиров, А. Пардаев. “Таълимда инновацион технологиялар: Таълим муассалари педагог-ўкитувчилари учун амалий тавсиялар” Тошкент 2018. Истеъдод, 203 бет.

2. Фан ва таълимда ахборот-коммуникация технологиялари: республика илмийамалий конференция маърузалар тўплами. 04.03.2017|Сон: №1 (65-бет) Тошкент 2015

\section{ИНФОРМАЦИОННЫЕ ОБРАЗОВАТЕЛЬНЫЕ РЕСУРСЫ, НАПРАВЛЕННЫЕ НА РАЗВИТИЕ ВАЛЕОЛОГИЧЕСКОЙ КОМПЕТЕНТНОСТИ БУ ДУЩИХ УЧИТЕЛЕЙ ФИЗКУЛЬТУРЫ}

\section{О. О. Сирожов (НавГПИ)}

Annotation: The article highlights the development of the valueological competence of future physical education teachers through the introduction of information technology in the educational process. The authors believe that the introduction of information technology in the learning process creates favorable conditions for the formation, development and preservation of the physical and moral health of future specialists, taking into account the optimal design of the information space.

Key words and expressions: valeology, competence, information technology, educational process, development, future specialist, health, diagnosis.

Введение. Процесс приобретения валеологических навыков и компетенций у будущих учителей физкультуры объединяет объем знаний, необходимый для специальных видов деятельности будущего педагога. Валеология - изучение формирования, развития и сохранения физического и нравственного здоровья человека в течение всей его жизни. Поэтому, процесс активизации будущих учителей физической культуры на любом этапе обучения, зависит от таких компонентов, как учебная программа, выбор здоровьесберегающих технологий, методов, средств и содержание обучения. В то же время, на наш взгляд, данный подход в обучении несколько устарел, и процесс активизиции студентов должен начинаться не с разработки планов, а с проектирования информационного пространства, которое объединяет валеологическое знание личностного развития обучающихся.

В этом процессе проектирование учебного модуля является последовательным, полным, целеустремленным, профессионально ориентированным; систематизированным, где ведущая роль отводится для общеобразовательных результатов обучения [2].

Как известно, здоровье - динамическое равновесие организма человека и его функций с окружающей средой. Поэтому, так важно при использовании электронных образовательных ресурсов в учебный процесс, учитывать практические исследования в сфере валеологии.

Информационные образовательные технологии, направленные на развитие валеологической компетентности будущих учителей физкультуры имеет важное значение в профессиональном росте будущих педагогов. Как известно, информационные системы, банки данных, учреждения, организации, сайты преподавателей и студентов, центры информационных ресурсов, электронные информационно-образовательные ресурсы, виртуальные лаборатории, медиа и видео уроки, система электронного обмена документами, видеоконференции, которые являются отдельными компонентами современной информационной образовательной среды, онлайн-конкурсы в интранете делают всех участников системы активными пользователями.

Валеологическая компетентность будущих учителей физической культуры-

это результат не только физического развития, но и усвоения валеологических знаний, умений, проявляющихся в осознании важности здоровья, здорового образа жизни для всей 
жизнедеятельности на протяжении жизни, а также, способность и готовность личности контролировать своё самочувствие и состояние физического, психического развития будущих специалистов.

Валеологические компетенщи будущих педагогов физической культуры - это “ готовность к проектированию эколого-ориентированных здоровьесберегающих технологий для дальнейшего физического развития, поддержания функционального состояния систем организма на оптимальном уровне и совершенствования основных физических качеств; готовность работать с информацией о здоровье в научно-популярных изданиях и СМИ; готовность к практическому анализу различного рода рассуждений об эффективности традиционных, новых и инновационных оздоровительных технологий; сформированными навыками публичной речи, аргументации, ведения дискуссии и полемики по вопросам здоровьесбережения; готовность к подготовке и редактированию текстов лекций, статей СМИ для традиционных и виртуальных источников информации; готовность к организационно-управленческой работе при проведении спортивных мероприятий по различным видам спорта и для различных социально-демографических групп населения»[3]. Следовательно, внедрение информационных технологий в современную систему образования требует решения ряда вопросов, а так же ставит перед обществом ряд задач, в том числе этику внедрения цифровых технологий, средства их защиты, правовые аспекты и другие требования.

Анализ показывает, что на сегодняшний день в ряде вузов республики существует необходимость создания электронно-мультимедийных ресурсов электронных образовательных ресурсов (ЭОР) для бакалавров по специальности «Физическая культура».

Принимая во внимание, что процесс приобретения навыков и компетенций валеологической компетентности у будущих учителей физкультуры сочетает в себе объем знаний, необходимый для специальных видов деятельности, мы разработали образовательные электронные ресурсы (ОЭР), такие как «Что такое валеология?», «Валеологический образ жизни будущего педагога». Это создаёт возможность проведению и организации аудиторных и внеаудиторных занятий с помощью визуализации различных педагогических система.

Благодаря ресурсам электронного обучения студенты понимают, что духовное и психическое здоровье являются неотъемлемой частью развития каждого человека и тесно взаимосвязаны между собой. «Здоровье человека - это его здоровый дух, его отношения к людям, его адекватное отношение к событиям в окружающей среде»[4].

В рамках исследования мы сочли необходимым добавить в модель развития валеологической компетентности учителей физической культуры следующие компоненты:

1) применять контент-анализ, разбивая задачи на темы;

2) использование результатов визуализации для оптимального анализа;

4) определить способы решения проблемы при постановке задач.

В рамках исследования выявилось, что использование традиционных методов: словесных, демонстрационных и практических больше ориентированы для усвоения теоретических зананий, тогда как применение инновационных методов обучения значительно повышает уровень развития валеологической компетентности будущих учителей физической культуры. На экспериментальных занятиях нами были использованы технологии, благоприятно влияющие будущим учителям физкультуры развивать валеологическую компетентность. Это:

1. Каркасная технология (Marvin Lee Minsky);

2. Постепенное формирование психических движений (Гальперин).

3. Технологии перевернутой модели обучения (технологии BlendedLearning: J.Graney, J.Bergmann, A.Sams, Overmyer Marshall).

Информационные технологии в образовании - это способ организации современной образовательной среды, основанный на цифровых технологиях. 
Цифровые технологии развиваются с огромной скоростью. Использование цифровых технологий во всех областях жизни - одно из основных требований времени, продиктованных логикой мировых изменений в рамках 4-й промышленной революции.

Как известно, мир меняется, меняются способы работы, меняются цели и практики получения образования в нём.

Методы и результаты. Автоматизация, цифровизация, рост сложности общества, образование сетецентрических сообществ - вот далеко не полный перечень трендов развития современного общества. Как усовершенствовать процесс обучения и добиться более высокой успеваемости обучающихся? На сегодняшний день на помощь придут современные цифровые технологии. Одна из них - скринкаст (screencast) - цифровая видео- и аудиозапись, производимая непосредственно с экрана компьютера, также известная как videoscreencapture (досл. видеозахват экрана). При ее использовании студенты могут спокойно изучать видеоурок дома в свободное время и в комфортном для себя темпе. Если студент пропустил какое-либо занятие, то с помощью видеоуроков он с легкостью сможет нагнать пропущенные темы. На сегодняшний день существуют алгоритмы создания скринкаста (от записи до его сохранения) в программе FreeScreenVideoRecorder, WindowsMovieMaker (ВиндовсМувиМейкер) - популярной бесплатной программы, предназначенной для создания, редактирования и конвертации видео, и MicrosoftPhotoStory 3 для Windows, которая позволяет создавать видеозанятия с изображениями, звуком и музыкой.

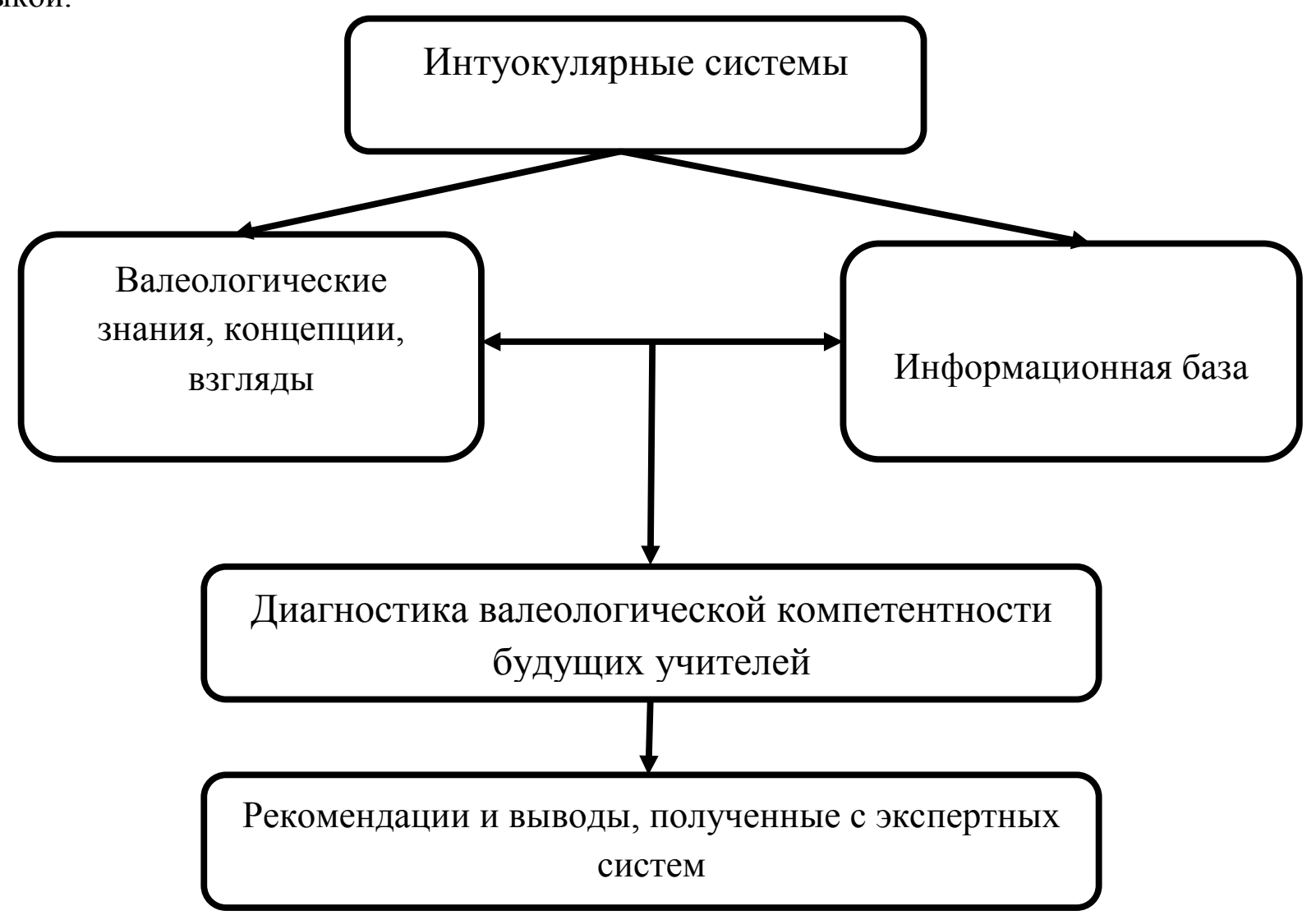

\section{Рисунок 1. Общая структура диагностики валеологической компетентности будущих учителей}

\footnotetext{
Внедрение информационных технологий для развития валеологической компетентности будущих учителей физической культуры требует создания интеллектуальной системы с учетом основных особенностей, требований и показателей этой ссылки. Интеллектуальная система обычно определяется как программное обеспечение, которое способно формировать базу знаний на основе конкретной базы данных и развивать
} 
их взаимосвязи и, как следствие, необходимые рекомендации. Интуокулярные системы - это прежде всего экспертные системы, основанные на знаниях и базах данных (рис.1).

Как показано на рисунке 1, создание интуокулярных систем выполняется с использованием различных программных средств, и их реализация обычно представляет собой сложный процесс, поскольку объекты, на которые применяются экспертные системы, обычно зависят от многих параметров. Кроме того, создание и внедрение экспертных систем требует научного анализа их общей структуры.

Вывод: Таким образом,внедрение информационных технологий для развития валеологической компетентности будущих учителей физической культуры создадут возможность получать помощь через консультации преподавателей с использованием различных средств телекоммуникаций: консультации в прямом эфире (YouTube, Skype); применению в учебном процессе кейсовой и интернет-технологий, электронных ресурсов, блогов, хранилищ и др. А так же, создают возможность иметь доступ к дистанционным образовательным технологиям: учебники с мультимедийными сопровождениями; электронные учебно-методические комплексы, компьютерные практикумы, контрольнотестирующие комплекты, учебные видеофильмы, электронные тренажёры и др.

Внедрение информационных технологий для развития валеологической компетентности будущих учителей физической культуры раскрывают широкие возможности медиаграмотности студентов, т.е. грамотности в области восприятия, понимания, интерпретации текстов, умение как понимать и анализировать медиатексты, так и создавать их.

\section{Список использованной литературы}

1. Постановление Кабинета Министров Республики Узбекистан от 15 августа 2014 года, № 234 «О мерах по дальнейшему совершенствованию системы переподготовки и повышения квалификации работников народного образования. Электронный ресурс: http://www.Lex.uz. 09.10.2015г

2. Абдуллаева Ш.А. Вопросы разработки и внедрения программного обеспечения педагогической диагностики (на примере высших учебных заведений).Ж.: Образовательные ресурсы и технологии.-М., 2019; №3, (28) /https://www.muiv.ru/vestnik/pp/nashi$\frac{\text { avtory } / 6811 / 68840 /}{3 .}$

3. Андрющенко Л.Б., Филатова Е.В.Валеологическая компетентность студентов/ международный журнал прикладных и фундаментальных исследований/ISSN 1996-3955/ИФ РИНЦ = 0,570/https://applied-research.ru/ru/article/view?id=1111

4. Деменок В. В. Моделирование бизнес-инкубирования малых инновационных предприятий // Инновации. - 2008. - №3(113). - С. 65-67.

5. Могилевская Э. В. Учебный бизнес-инкубатор: быть или не быть [Электронный pecypc]. - URL: http://www.relga.ru/Environ/WebObiects/tgu-www.woa/wa/ Main?textid=2359\&level1=main\&level2=articles (дата обращения: 8.06.2014).

6. Рожков В. Д. Самостоятельная профессиональная ориентация: справ.-информ. пособие / под общ. ред. В. Д. Рожкова. - СПб., 2002.

7. Тенетилова В. С. Современные дидактические условия подготовки будущих учителей технологии к предпринимательской деятельности // Известия Российского государственного педагогического университета им. А. И. Герцена. - 2009. - Вып. № 113. - С. 208-211. 


\title{
THE USAGE OF TECHNOLOGY: VARYING THE MEDIUM IN LANGUAGE TEACHING
}

\author{
Kadirxodjayeva D. B. (UWED)
}

\begin{abstract}
Annotation: Following article written by Kadirxodjayeva D.B. gives total information about importance of technology and its usage in language teaching. Present time we cannot imagine language classes without modern technologies, teaching equipments like audio-video sources, projectors and satellites. These gadgets help teachers and students to acquire knowledge better and effectively. Considering the ideas and research results of several scholars we came to decision that besides reading, writing and speaking modern students need to use technologies in order to achieve high levels of acquisition in learning foreign languages. They encourage them to learn more and being able to feel the realia.
\end{abstract}

Key words and expressions: Usage of technology in teaching language, audio-video sources, projectors and satellites, effective language acquisition, modern teaching techniques.

A variety of technologies assume a natural place in language teaching, since language use is itself a multisensory experience. Some technologies permit us to see and hear language in cultural context as well as observe the impact on language meaning of things like real time, word stress, and gestures.

The greetings "How are you today?" can be presented in a variety of mediums:

Print: "How are you today?"

Audio: We hear the phonic chain, with stress and intonation for the particular meaning intended.

Video: We observe one individual greeting another and saying, "How are you today?" with gestures appropriate to the culture.

Methodological considerations

Many developments in language teaching have evolved from a growing awareness of the different mediums with which we can work. Individual teaching styles as well as methodological approaches distinguish themselves in part by the mediums used for presentation of language, production of language, and monitoring of student output. In the Silent Way, for example, the stimulus for language is visual when the teacher points to a color on a chart, and the instructor's feedback to the student is in a paralinguistic medium, by means of hand signals and gestures.

Available technology- tape recorders, slide projectors, overhead projectors, videotape recorders, as well as drawings, pictures, and the ever-trustworthy chalkboard-makes it possible for the language teacher to present language in more forms than just speech and print. We can substitute one medium for another, as when we give feedback in the form of hand signals rather than through verbal correction, or we can alter or eliminate a medium, or we can use three mediums instead of just one (as in the case of captioned television, which uses audio, print, and nonprint visuals).

Language takes many forms: spoken, written, kinesic (body language). We need the many technologies at our disposal to present language effectively in the context in which it occurs. We can present language and monitor our language learning in more than one medium. Charging the usual medium of presentation and feedback is an important key to interesting and creative teaching.

Different approaches tend to urge the use of one medium over another or to the exclusion of others. The dilemma facing language teachers is the fear that perhaps there is one "best way" that is presently unknown to them. Particular methods emphasize specific techniques that draw on a given sensory mode- for example, aural in Suggestopaedia or visual in the Silent Way- and then report an overwhelming success with students that staggers our imagination as we think of our own, more modest achievements.

Choice of medium

The choice of a particular medium depends on several things, including: 
Availability of materials: Audiotapes and radio broadcasts; television programs; commercially produced video; or newspapers and magazines, cartoon books, and the like.

Availability of necessary equipment: Tape recorders, projectors, video-tape recorders, videodisk machines, radios, or satellite dishes.

Type of language lesson planned: does the instructor intend to focus on spoken language or written language? Can use of particular mediums assist the students in transferring their knowledge from, for example, aural to visual recognition of language forms or vice versa? Through which medium will materials best enhance the student's understanding of cultural referents, or of the features of formal and informal language?

The effective use of any medium in language teaching depends on the role the message in that medium plays in the language- learning situation, the content of the materials, and the ways these two interact within each student's language- learning experience. Teacher can use technologies and materials effectively in innumerable ways, depending on the aims of the program and the learning preferences of the students.

Materials in the classroom: as model and stimulus

The point of departure in a language class, from the point of view of materials and the mediums in which they occur, is the words and bits of language played on a tape, written on a chalkboard, or printed in newspapers and on product packages, labels, coupons, flyers, price tags, or hiding in fortune cookies. These act as models, pictures, tapes, articles in newspapers and magazines, and video all give the language learner a feeling for the diversity of use of another language and provide information on the life and habits of the people. All of this provides a context within which to situate language.

Models alone cannot meet the learner's needs, however. Listening to Japanese radio every day for many years will not produce a speaker of Japanese. Only during interaction with the modelreflecting, verifying, clarifying, asking questions, and consulting classmates about it- does the language begin to make sense.

Language can be presented as a stimulus- a springboard for interaction. Language can provoke. A classroom structured so that learners interact with each other as well as with the model will be even more effective if language interactions are structured in different mediums.

How can the teacher structure interactions between students and language in different mediums?

\section{Multimedia tasks}

Students enjoy working on multimedia activities. A group creation of a mock television or print commercial leads students to consult advertisements on the radio, on TV, in newspapers, or in billboards. Much discussion takes place in the planning stages, and students practice the language of negotiations when it comes to the design of the situation, the writing of jingles and dialogues, the reading of first drafts, and finally the use of camera, microphones, or pen and paper when creating the commercial. This activity, as well as the creation of soap operas, newscasts, class newspapers, skits, plays, musicals, and so on, forces the learner to work in more than one medium and practice a variety of language skills, listening, speaking, writing, scanning, browsing, negotiating. The emphasis should be on the process rather than the product.

\section{Video feedback}

A natural extension of the widespread use of tape recording to let students hear their own performance, videotaping of interactions in the classroom is an effective way for students to obtain immediate feedback on their nonverbal as well as verbal behavior. Unlike film, videotape requires no developing, so classroom interactions can be played back immediately.

Since part of the value of video feedback lies in its immediacy, many instructors and students like to place the monitor facing the participants so that all may see exactly what is being recorded on the tape as it is being recorded. This immediate feedback is surprisingly effective in motivating students to monitor their speech and gestures in ways they cannot in a classroom setting. Students should also view their tapes as soon as possible after recording so that they can learn 
immediately from their performance. As with a book, they can skim or ponder, rerunning their performance at will.

\section{The list of used literature}

1. Beatriz, Ch. 1997 Developing Speaking Skills by Creating Our Own Stimulations for the EFL Courses. English Teaching Forum 35,3 pp 54 1991

2. Dick Allwright and Kathleen M.Bailey "Focus on the Language Classroom" Cambridge

3. Wilga M. Rivers “Interactive Language Teaching” Cambridge 1987

\section{ТАЛАБАЛАРНИНГ МУСТАҚИЛ ИШЛАРИНИ РИВОЖЛАНТИРИШДА ТИЗИМЛИ ЁНДАШУВ}

\section{Хайитова Ш.Д. (СамТИ)}

Annotation: This article discusses the conceptual basis for activating students' independent work in the study of general subjects. The importance of a systematic approach in the organization of independent work is also revealed.

Key words and expressions: research, methodology, system integrity, independent learning, systematic approach, independent work, system management, selection of system elements.

Умумкасбий фанларни ўрганишда талабаларнинг мустақил ишларини фаоллаштиришнинг консептуал асосларини аниқлашда мутахассисга қўйиладиган касбий талаблардан, мутахассисни касбий тайёрлашнинг асосий тамойилларидан келиб чиқади. Илмий тадқиқот методологияси ва методикасини танлаш муаммоси тадқиқотимизда мухим ахамиятга эга, методология назарий ва тажриба ишларини ташкил этишда мухим ахамиятга эга.

Бизга маълумки, фанда методология умум билиш усули вазифасини бажаради. Илмий тадқиқотларда икки мухим вазифани бажаради: ўрганиш усули ва жараённи ташкил этиш усули сифатида (бизнинг холатимизда умумкасбий фанларни ўрганишда мустақил ишларни фаоллаштириш).

Педагогикада “тизим” атамаси икки маънода ишлатилади. Биринчиси, педагогик ходисаларнинг сифат холатини кўрсатиш. Демак, педагогик жараён, талаба ва ўқитувчи шахси тизимдир. Иккинчидан, бу атама муайян педагогик тузилмаларни оқлаш учун махсус ишлатилади.

Тизим ёндашуви объектларнинг мохиятини очиб беришга, мураккаб объектнинг турли хил боғланишларини аниқлаш ва уларни ягона яхлит тасвирга туширишга қаратилган тизимлар сифатида ўрганишга асосланган.

Тизим ёндашуви умумий функциялар ва мақсадлар, бошқарув ва фаолият бирлиги билан бирлаштирилган кўплаб ўзаро боғлиқ элементларга эга бўлган объектларни тахлил қилиш учун қўлланилади. Мустақил ишни фаоллаштиришни тахлил қилиш учун ушбу тизимнинг фаолиятига таъсир қилувчи асосий омилларни аниқлаш, ушбу тизимнинг ўрни ва ўрнини бошқа ходисалар контекстида аниқлаш, трансформацион таъсирни амалга оширадиган алохида элементлар ёки гурухларни аниқлаш, бошқарув жараёнларини ўрганиш, мақсадларга эришишни таъминлаш ва олинган натижаларни амалда жорий этиш.

Тизимнинг умумий хусусияти маълум бир элементлар тўпламининг мавжудлигидир. Тизим объектларининг мухим хусусияти-элементлар билан биргаликда тизимнинг яхлитлигини ташкил этувчи улар орасидаги элементларнинг муайян муносабатларининг мавжудлигидир.

Тизимнинг яна бир мухим хусусияти унинг тузилишидир. Тизим тузилишини ўрганиш тизим элементлари орасидаги боғланишларни очиб бериш демакдир. Тузилма тизимнинг барча элементларини ягона ип билан боғлаб, тизимнинг ажралмас характеристикасини ифодалайди. 
Бошқарув цикли, бизга маълумки, бир неча босқичлардан иборат: мақсадни шакллантириш, дастур ва мақсадли режалаштириш, ўқув фаолиятини ташкил этиш, фаолиятни созлаш, фикр-мулохазаларни тахлил қилиш ва ўқувчиларнинг ўқув фаолияти самарадорлигини аниқлаш. Натижаларни кўзланган мақсадга мувофиқлаштириш - таълим жараёнининг энг яхши варианти ва бошқарув мазмунидир.

Шундай қилиб, тизим ёндашуви тизим объектларининг хусусиятларини белгилаш ва уларни яхшилашга ёрдам берадиган қуйидаги қоидаларда ифодаланади:

- тизим яхлитлиги.

- тизим элементларини танлаш;

- тизим элементлари ўртасидаги алоқаларни ўрнатиш;

- тизимнинг тузилишини аниқлаш;

- тизим элементларининг вазифаларини аниқлаш;

- тизимни бошқариш.

Танланган методлар, усуллар, шаклларнинг самарадорлигини текширишда, умумкасбий фанларни ўрганишда талабаларнинг мустақил ишларини рағбатлантириш тадқиқотнинг хар бир босқичида тажриба ўтказиш орқали амалга оширилади, назарий позицияларни илгари сурганимизни тасдиқлаш, инкор этиш ёки аниқлаштириш имконини беради.

Бизнинг назаримизда, талабаларнинг мустақил ишларини фаоллаштириш қурилишига тизимли ёндашув бу тизимнинг турли жихатлари хақида аниқ илмий-назарий билимлар қуриш бўлиб, бунинг учун:

- талабаларнинг мустақил ишларини фаоллаштириш тизимининг асосий элементларини аниқлаш;

- унинг тузилишини аниқлаш;

- тизимнинг алохида даражалари ва элементларининг унинг тўлиқ ишлашини таъминловчи вазифаларини аниқланг.

Бу муаммони тизим ёндашувининг мухим таркибий қисми бўлган моделлаштириш усули ёрдамида хал қилинади. Моделлаштириш - абстракт тафаккурга асосланган назарий ва когнитив жараёндир. Педагогик тадқиқот предмети бўлган педагогик воқеликнинг ўзига хос хусусиятларига қараб педагогикада турли моделлардан фойдаланилади.

Моделга бўлган эхтиёж, объектнинг ўзини ўрганиш имконсиз, қийин бўлса, жуда узоқ вақт талаб қилганда, пайдо бўлади [2]. Шу билан бирга моделлаштириш-ўрганилаётган объект, ходиса ва жараённи акс эттириш ва такрорлашдан иборат бўлган воқеликни билиш усулидир. Модел билан ўрганилаётган тизим ўртасида қандайдир ўхшашлик бўлиши керак.

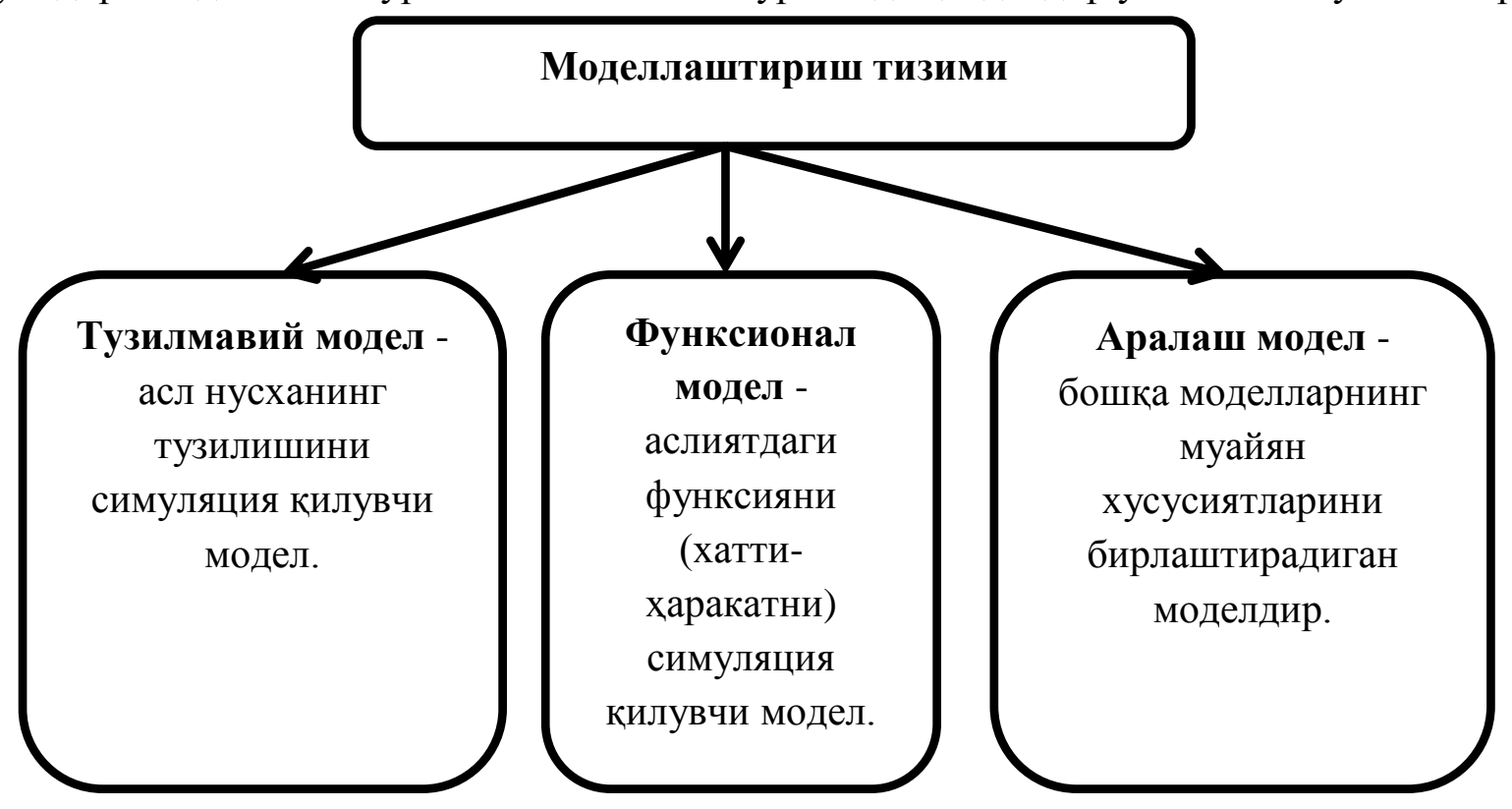

1-расм. Моделлаштириш турлари 
Моделлаштириш умумий илмий метод сифатида, илмий педагогик тадқиқотларда кенг кўлланилади. "Педагогик назариянинг қурилиши ва ундан ўқув амалиётига ўтиш педагогик воқеликнинг моделлари сифатида идеаллаштирилган объектларни шакллантириш билан боғлиқ, яъни педагогик фаолият аспектида олинган ва икки текисликда кўрсатилган воқеликмавжуд ва кабидир. Педагогик амалиётни илмий асослаш тизимида бундай ўтиш назарий моделдан меъёрий сохага фикрни билиш харакати сифатида намоён бўлади...” [1].

Моделлаштириш методини тадқиқотимизда қўллаш, педагогик воқелик каби хилма-хил ва бетакрор, тадқиқотларда топилган моделларнинг хилма-хиллиги хам шундай деб тасаввур қиламиз (1-расм).

Моделлаштириш тартиби бир неча босқичларни ўз ичига олади:

-тадқиқот объекти хақида тўпланган билимларни янгилаш;

- мавжуд моделлар орасидан ўрганилаётган объектнинг мохиятини энг муносиб тарзда акс эттирадиганларини танлаш.

Агар бундай объектни танлаш қийин бўлса, у холда янги модел яратилади. Кейинги босқичда моделни бевосита ўрганиш амалга оширилиб, у ўрганилаётган объект хақида янги билимлар олиш билан якунланади.

\section{Фойдаланилган адабиётлар рўйхати}

1. Полозов В.С. Начертательная геометрия (информационно-параметрический подход в инженерных графических задачах): Учеб, пособие. Нижний Новгород, 2000. 60 с.

2. Юшко Г.И. Научно-дидактические основы организации самостоятельной работы студентов в условиях рейтинговой системы обучения: Авто-реф. дис.... канд. пед. наук. Ростов н/Д., 2001. 25 с.

\section{ONA TILI FANINI O'QITISHDA INTERFAOL USULLARDAN FOYDALANISH}

\section{O.Z.To'xtayeva \\ (Urgut tumani 18-umumta'lim maktabi)}

Annotation: This article provides information on the use of interactive methods in the teaching of mother tongue and how effective these methods are in the classroom. It also looks at how students learn spelling rules. There is also a need to take into account the age and level of education of students, and the need for each student to learn according to their abilities. There is also information that dictations will be recorded from the elementary school so that students do not make spelling mistakes, and more essays and essays will be taken in the upper grades. Experienced teachers are encouraged to organize lessons, reinforce what has already been learned, and prepare the ground for the next lesson.

Key words and expressions: potential, education, skill, method, speaking, purpose, task.

Bizga ma'lumki, xozirgi kunda o'qituvchilarga dars jarayoni puxta, mukammal darajada o'qitish talablari qo'yilmoqda. Shu bilan birga har bir o'qituvchi o'z fani bo'yicha turli xil didaktik materiallar asosida dars olib borish kerakligi aytilmoqda. Bu esa o'z-o'zidan ma'lumki, o'qituvchini o'z fani bo'yicha izlanishga, yanada ko'proq yangiliklar yaratishga undaydi.

O’zbekiston Respublikasi "Davlat tili to'g'risida"gi, “Ta'lim to'g'risida"gi qonunlari hamda "Maktab ta'limini rivojlantirish Davlat umummilliy dasturi"ga muofiq maktablarda ona tili fanini o'qitish oldiga yangi-yangi vazifalar qo'yilmoqda.

Har bir fanni o'qitishning bosh maqsadi bo'lgani kabi, ona tili fanini ham o'qitishda o'z maqsad va vazifalari mavjud.

O'quvchilarga til ta'limini singdirishda ularning yoshi va bilim darajalarini ham hisobga olish zarur. Chunki, har bir o'quvchi o'z salohiyatidan kelib chiqib bilim oladi. Ba'zi o'quvchilarning intelektual salohiyati yuqori, lekin ba'zilariniki sustroq bo'ladi. Bunday vaziyatlarda barcha o'quvchilarga mavzuni yetkazib berishda o'qituvchidan katta mahorat talab etiladi. 
Bundan tashqari 2-sinf o'quvchilariga 3-sinf hajmdagi bilimni berilsa, bu ham o'quvchi buni o'zlashtira olmaydi. Aksincha 3-sinf o'quvchisiga 2-sinfdagi bilimlar berilsa, bu ham o'quvchi uchun zerikarli bo'ladi. Natijada o'quvchilarda tilni o'rganishga bo'lgan havas, qiziqish rivojlanish o'rniga susayadi.

Ona tili fanining bosh maqsadlaridan biri o'quvchilarga imlo qoidalarini o'rgatishdir. O'quvchilar imloviy xato qilmasliklari uchun boshlang'ich sinfdan boshlab diktantlar yozdiriladi va yuqori sinflarda esa ko'proq insho, bayon kabi yozma ishlar olinadi. Insho, bayon kabi yozma ishlar nafaqat imlo qoidalarini balki o'quvchini fikrlashga, dunyo qarashlarini kengaytirishga xizmat qiladi. Psixologik tatqiqotlardan ma'lum bo'lishicha, imlo savodxonlik asta-sekinlik bilan shakllanadi. Barcha yozuv darslarida o'quvchilarga to'g'ri yozish qoidalarini ta'kidlab turish va amaliy ishlarni bajarish orqali ularning imlo savodxonligini oshirish mumkin.

Ona tili darslari oldiga qo'yiladigan vazifalar va ularni amalga oshirish yo'llari samarador usullar bilan o'quvchilar ongiga singdirilgandagina kutilgan natija berishi mumkin.

Bugungi kunda zamon talabi darajasida dars o'tish uchun barcha o'qituvchilarga quyidagi omillarga rioya qilish tavsiya etiladi:

-Innovatsion texnologiyalardan foydalanish;

-O'z fani bo'yicha yangiliklardan boxabar bo'lish;

-Dars o'tishning noananaviy usullarini amaliyotga qo'llash;

-O'qitishda kompyuterlarni joriy etish.

Noananaviy dars tashkil etishda muommoli vaziyat yaratilsa, aniqlansa va bartaraf etish choralari ko'rilsa o'quvchilar mavzuni puxta o'zlashtiradilar. Ona tili darslarida muammoli vaziyat yaratishning usullari xilma-xildir.

-Tilga oid dalillarni tahlil qilish asosida muammoli vaziyat yaratilishi;

-Til harakatlarini qarama-qarshi qo’yish va taqqoslash orqali muammoli vaziyat yaratiladi;

-Innovatsion texnologiyalardan foydalanib, muammoli vaziyat yaratish;

- Tillarni taqqoslash yo'li bilan ham muammoli vaziyat yaratsa bo'ladi.

Muammoli vaziyat yaratishda til materiallarining murakkablik darajasini hisobga olish nihoyatda zarur. Chunki o'qituvchi til materiallarining murakkablik darajasidan kelib chiqib, muammoli vaziyat yaratishning usulini tanlaydi.

O’quvchining olgan bilimini mustahkamlashning yana bir usuli o'tilgan mavzuni takrorlashdir.

Takrorlash bilimlarni aniqlashga, hisobga olish va shu bilan bir vaqtda mustahkamlashga yordam beradi.

Ilg'or tajribali o'qituvchilar darslarni tashkil etishda oldin o'tilganlarni mustahkamlash, yangi bilimlarni o'zlashtirish bilan bir vaqtda keyingi darsda o'tiladigan mavzu uchun zamin tayyorlaydilar.

Ona tili fanini o'qitishning o'ziga xos metodlari haqida gapirilganda, ta'lim jarayonida qo'llaniladigan interfaol usullar muayyan guruhlarda o'qitiladigan o'quv fanining bosh maqsadiga yo'naltirilishi lozimligini ham ta'kidlab o'tish joiz. Aks xolda o'qituvchi tanlagan usul samara bermasligi mumkin.

Ona tili fanini o'qitishda bi qancha interfaol metodlardan foydalanish dars samaradorligini oshirishga xizmat qiladi.

Masalan "case-study" usuli.

"Case-study" inglizcha so'z bo'lib, ("case" - aniq baziyat, xodisa, "study" - o'rganmoq, tahlil qilmoq) aniq vaziyatlarni o'rganish, tahlil qilish asosida o'qitishni amalga oshirishga qaratilgan metod hisoblanadi.

Ona tili darslarida asosan tarbiyaviy ahamiyatga ega bo'lgan matnlar keys topshirig'i uchun tanlanadi.

Xulosa qilib shuni aytish mumkinki, interfaol usullardan foydalanib dars olib borish albatta o'quvchilarda oz samarasini beradi va o'qituvchida ham yetarlicha tajriba, dars o'tish mahoratini oshiradi. 


\section{Фойдаланилган адабиётлар рўйхати}

1.R. Ikromova. Grammatika, imlo va nutq o'stirishdan tarqatma materiallar. "O'qituvchi”. Toshkent. 1993.

2.M. Toshtemirova. Ona tili darslarida o'quvchilarning nutq madaniyatini shakllantirish."Sharq".Toshkent.1999.

3.A.Q.G'ulomov, A.Shukurova. Ona tili darslarida o'quvchilarni mustaqil ishlatish. Yoshkent. 1976.

4.N. Ahmedova. Boshlang'ich sinflarda nutq o’stirish usullari.’Sharq”. Toshkent. 1999.

\section{UMUMTA'LIM MAKTABLARIDA CHET TILI O'QITISH METODIKASI}

\section{A.N.Parmonova \\ (Jomboy tumani 7-umumta'lim maktabi)}

Annotation: This article discusses methods of teaching a foreign language in secondary schools and the needs of students in learning a foreign language. The article also discusses what to look for at each stage of foreign language teaching and how to master it. There is also information about the use of pedagogical technologies in the classroom and their importance in the classroom. The course also covers what the teacher should pay attention to step by step in teaching a foreign language and the students' activities in learning the language. In the upper grades, the teacher also provides information on how to interact with students during the lesson and the process of mastering students in foreign language teaching.

Key words and expressions: pedagogical technology, skill, speech, student, teacher, teaching process.

Har bir jamiyatning kelajagi uning ajralmas qismi va hayotiy zarurati bo'lgan ta'lim tizimining qay darajada rivojlanganligi bilan belgilanadi. Shu jumladan, bizning mamlakatimizda ham ta'lim jarayoniga katta e'tibor qaratilib kelinmoqda. Ayniqsa chet tillarni o'qitish borasida qabul qilingan qarorlar buning isboti bo'la oladi. Nafaqat yurtimizda, balki butun dunyoda chettilini o'rganishga bo'lgan ehtiyoj yuqori hisoblanadi. Chet tilida ravon gapira oladigan insonlarga hamma havas bilan qaraydi. Ta'lim tizimida chet-tilini o'qitish maktablardan boshlanadi va bu o'z navbatida bosqichlarga bo'linadi. Maktablarda boshlang'ich sinflardan boshlab chet tili o'qitiladi. Chet tilini o'qitishda pedagogic texnologiyalarning o'rni beqiyosdir.

Pedagogik texnologiyalarning rivojlanishi va ularning o'quv- tarbiya jarayoniga kirib kelishi, shuningdek axborot texnologiyalarining tez almashinuvi va takomillashuvi jarayonida har bir inson o'z kasbiy tayyorgarligini, mahoratini kuchaytirish imkoniyatlari yaratildi. Ta'lim jarayoniga ilg'or pedagogic texnologiyalarni olib kirish "Kadrlar tayyorlash milliy dasturi" ning bosqich vazifalaridan biridir.

Hozirgi davrda dars jarayonini pedagogic texnologiyalarsiz tasavvur qilish qiyin. Til o'rgatishda avvalo nutqni oshirishga e'tibor beriladi. Chunki o'quvchi so'z boyligini oshirib borgani sari, nutqini ham to'g'ri, ravon o'stirib boradi.

Insonda bolalik chog'idanoq nutq so'zlashga, ya'ni idrok etishga ehtiyoj seziladi. O'z fikrini ifodalash ehtiyoji bola o'sib borishi bilan kengayib boradi va u tobora ko'proq, murakkabroq til birikmalarini o'z nutqida qo'llay boshlaydi. Demak bolaning tilni bilishi nutqiy faoliyat asosida kechadi.

Chet tilini o'rganishni boshlagan kichik yoshdagi o'quvchilarda ona tili shakllangan bo'ladi va ular ona tilida o'z oladilar. Bolalarning dunyo qarashi Nutqiy muloqot jarayonida o'sib boradi.

Bizga ma'lumki maktablarda boshlang'ich bosqich 1-4 sinflar hisoblanadi va chet tili o'rgatishda har bir sinf o'quvchisining yoshiga qarab mavzular tanlanadi.1-sinf o'quvchilariga faqat og'zaki nutq orqali har xil qiziqarli o'yinlar bilan chet tili o'rgatiladi.

Umuman olganda har bir bosqichning o'ziga xos va ularni boshqa bosqichlardan 
Farqli tomonlari o'quv materialini tanlashda va darsni tashkil qilishda hisobga olinmog'i kerak. Aslini olganda ayrim bir bosqichning o'ziga xos tomonlari ikkinchi bosqichga o'tilganda ham ma'lum bir paytgacha davom etishi mumkin.

Ma'lumki chet tili o'qitishda o'quv jarayonini o'quvchilarning yosh xususiyatlarini

Hisobga olingan holda tashkil qilish muvaffaqiyat garovidir.Bu yerda eng muhimi o'quvchi oldiga qo'yilgan vazifa ularning qobiliyatiga yarasha bo'lishi kerak, ya'ni u oquvchiga xaddan ortiq qiyinchilik tug'dirmaslik kerak.

Agar biz 4-5 sinf o'quvchilari bilan 6-7 sinf o'quvchilarini yosh xususiyatlarini o'lchab ko'rsak, u holda shu ma'lum bo'ladiki 4-5 sinf o'quvchilari uchun muhimi o'qishdir. 6-7 sinf o'quvchilari uchun esa chett ilini gapirish.

Dars jarayonida o'qituvchiga ko'p ma'suliyat yuklanadi. Ayniqsa o'quvchi o'z ini hammadan kuchli deb bilsa, o'zining bilganini to'g'ri deb hisoblasa. Bunday paytda o'qituvchi o'quvchi bilan ehtiyotkorlik bilan aloqa o'rnatish lozim.

Ayniqsa 7-8 sinf o'quvchilarida agressivlik kuchli bo'ladi. Ularga nisbatan qattiq qo'llik qilish, nazoratni kuchaytirish, ulardagi agressivlikni kuchaytirib yuborish natijasida o'quvchi bilan o'qituvchi o'rtasida turli xil nizolarning kelib chiqishiga sabab bo'ladi.

O'smirlik - bu shaxsni tarkib toppish va kamolotga yetishishidir. Bu yoshda o'smirlarda tashqi muhitga munosabat va o'z faoliyatiga baho berish xususiyatlari rivojlanadi.

O'quvchilarning xotirasida chet tili predmetiga bo'lgan munosabatlarida ham sezilarli o'zgarish yuz beradi. Masalan, 7-8 sinf boshlarida chet tili o'rganishga bo'lgan qiziqish so'nadi. Lekin 9-10 sinfga kelib o'quvchilar chettili o'rganishga alohida bir qiziqish bilan qaraydilar.

Chet tili o'qitishning natijalari birinchi navbatda mashqlar sistemasi orqali aniqlanadi, chunki chet tili amaliy maqsad ya'ni nutq faoliyatining barcha turlarini egallash mashqlar yordamida amalga oshiriladi. Dars o'quv tarbiyaviy ishlarni olib borishni tashkil qilishning asosiy shaklidir. Bizga kerakli muhim narsa bu qo'yilgan maqsadga erishish vositalarini to'g'ri aniqlash, o'qituvchi va o'quvchi o'rtasidagi munosabatni bir - biriga o'z aro hurmat asosiga qurish va darsni tashkil qilishdir.

Chet tili o'qituvchisi doim izlanishda bo'lmog'I zarur. Har darsda o'quvchilarga biror yangi narsa o'rgatish va yangi usullarini amalda sinab ko'rish maqsadga muvofiqdir.

\section{Foydalanilagan adabiyotlar ro'yxati}

1. J.Jalolov. Ingliz tili o'qitish metodikasi, "O'qituvchi”" nashriyoti. Toshkent.

2. O'.X.Xoshimov, I.Y.Yokubova. Ingliz tili o'qitish metodikasi. "O'qituvchi”" nashriyoti. Toshkent.

3. Г.В.Рогова. Методика обучения английскому языку. 1997.

4. А.П.Старков. Методика обучения английскому языку в средней школе.М.1970.

5. J.Djalolov. O'rta maktabda ingliz tili o'qitish metodikasi. "O'qituvchi" nashriyoti. Toshkent. 1997.

\section{MATN O'QISH KO’NIKMASINING PEDAGOGIK ASOSI HAMDA UNI RIVOJLANTIRISH YO'LLARI}

\section{F.V.Sharopova \\ (Toshkent shahar 195- IDU maktabi)}

Annotation: This article introduces ways in which reading comprehension, one of the language learning skills, is best understood by schoolchildren in their native language, and how this skill is developed. Reading is a secondary linguistic skill based on oral communication skills. Reading comprehension takes place through the human visual organ and the visual information processing system. The majority of those who conducted research on the development of learners' reading comprehension skills comprise of foreign linguists. The article notes that the need to develop students' free-thinking skills in addition to teaching grammar rules in native language 
classes is a current requirement, and methods and techniques for developing this skill is based on foreign methodology which have been developed and proven by analysis of experimental results.

Key words and expressions: language skills, text, reading comprehension, ways of development, program, educational content, linguistic and extralinguistic factors.

O'qish malakasini egallash ancha murakkab jarayon bo'lib, uni shakllantirish uzoq vaqtni talab etadi. Deyarli bir asr oldin (1908) Hyueyning "O'qishning psixologiyasi va pedagogikasi" nomliasari [Richard K. 2005:6] nashr qilingandan so'ng o'qish jarayoniga qiziqish kulminatsiya darajasiga chiqdi. Bu asarda o'qishning pedagogik jihatlari, ya'ni o'qitish va o'qib tushunishning qanda yo'rganilishi olg'a surilib, unda matnni tushunish, bu jarayonda qanday kognitiv mexanizmishlashi haqida gapirilgan.

Matnni o'qib tushunish insonning ko'rish a'zosi va vizual ma'lumotni qayta ishlash tizimi orqali amalga oshadi. Ko'z tekislikdagi grafik chiziqlarni (harflarni) qabul qiladi.

Tushunish - bu o'zida mavjud bo'Igan bilimlarni yangi o'qilayotgan yoki eshitilayotgan xabar bilan solishtirish, taqqoslash orqali sodir bo'ladi. O'qib tushunish haqida ingliz tilshunosi Cheryl J.Gowie o'zining "Psycholinguistic strategies for improving reading comprehension", ya'ni "O'qib tushunish ko'nikmasining psixolingvistik yo"nalishlari” nomli maqolasida, "Bolada mavjud bo'lgan bilimlarga mos matn, bolada uni tushunishga tuynuk ochadi. Berilayotgan ma'lumot uning oldingi bilimini chuqurlashtirishi, aniqlashtirishi kerak" [Cheryl J.Gowie2015: 8], deydi.

F.f.n., dotsent I.Azimovaning "O'zbek tilidagi gazeta matnlarining mazmuniy persepsiyasining psixolingvistik tadqiqi" nomli monografiyasida matnni qabul qilishni "mazmuniy persepsiya" (mazmunni tushunish) termini bilan nomlaydi va uning mohiyati haqida gapirilar ekan, qabul qilishning ikki: qabul qilishning o'zi va tushunish darajasi [Azimova I.2019: 61] mavjudligi, qabul qilishning mohiyati sifatida matn mazmuniy proyeksiyasi (obrazi)ning o'quvchi ongida hosil bo'lishiga aytilishi qayd etiladi. Olimatushunishdaharbirqabulqiluvchiningongiprizmavazifasinibajarishiniaytadi. Harbirodam individual shaxsbo'Iganligiuchun, bujarayonhammadaharxilsodirbo'ladi, ya'nibittamatnni 10 ta o'quvchio'nxiltushunishi (qabulqilishi) mumkin [Azimova I.2019: 221].

O'quvchilarning o'qish savodxonligi boshlang ich sinflarda "O'qish" darsligidan boshlanib, unda o'quvchilarga grafemalarni tanish, yodlash, ularning tovush tomonini yozish bilan birga parallel ravishda o'rgatish, harflarni bir-biriga qo'shib so' $z$ hosil qilish, so' $z$ birikmalarini o'qish va tushunish, kichik matnni o'qish kabi jarayonlar ma'lum qoidalar, usullar yordamida o'rgatiladi. Yuqori sinfda (5-sinfda ham) esa o'qish darsligining o'rnini Adabiyot fani egallab, u badiiy matnlarda badiiy obrazlarni o'rganadi. Bu paytga qadar o'quvchida o'qish ko'nikmasi shakllanib bo'lgan, endi u matn yo asarning badiiy tomonini tahlil qilish, aniqlashga harakat qiladi. Bizga ma'lumki, badiiy matnlar(asarlar) muallif maqsadiga ko'ra tahlil qilinishi, tushunilishi lozim. Ona tili darslaridagi matnlar esa badiiylikdan xoli bo'lishi, uni o'quvchi o'z shaxsiy fikrlash yo'li, mavjud bilimi yordamida qabul qilishi va tahlil qila olishi maqsad qilinishi lozim. Bunda o'quvchilardan bitta xulosaga kelish talab qilinmaydi, bu uning fikrlash va fikrini turli usullarda bayon qilishiga, xulosa chiqarishiga imkon beradi.

Boshlang 'ich sinflar "O'qish" kitobida qisqa hikoya, matnlar berilgan bo'lib, ulardan maqsad kichik maktab yoshidagi o"quvchining o'qish ko'nikmasini shakllantirishdir. Boshlang 'ich sinfdan yuqori sinfga o"tgan o"quvchilar uchun "O"qish" kitobining o"rniga ona tili va adabiyot fanlari kiritilib, ularda o"qish ko"nikmasidan yuqori bo'lgan bosqich, o"qilganlarni "tushunish" darajasini shakllantirish va rivojlantirish maqsad qilinadi. Bu ma'lumotlar maktab ona tili darsliklarida asosan matnlar, ba'zan adabiyot namunalaridan parcha ko'rinishida ham beriladi. Ularni o'quvchiga havola qilishdan maqsad, matnni ona tili fanidan egallagan grammatik qoidalarga ko'ra tahlil qilish, so'zlarning qanday uslubga xosligini aniqlash va shu kabi til shunoslikka aloqador bilimlarni sinash dir. Adabiyot darsliklarida beriladigan badiiy matnlar esa obrazlilikka yo'g'rilgan, so'zlarhardoim ham o'z ma'nosida emas, kontekst ma'nosidan kelib chiqqan holda rango-rang ma'nolarni ifodalaydi. Shu sababli ikkala fanda beriladigan matnlarni o'z xususiyati va maqsadiga ko'ra birbirida nalohida tarzda tahlil qilish va bu ko'nikmai o'quvchilarda ham shakllantirish lozim. 
O‘qish faoliyati yuqorida aytilganidek bosqichma-bosqich shakllantiriladigan jarayon bo'lib, u haqida o'zbek va xorij tilshunos, metodist olimlari o'z fikrlari va tajriba natijalaridan chiqargan xulosalarini, tavsiyalarini berganlar. Amerikalik tilshunos va psixolingvist olim P.Bloom o'qish ko'nikmasini egallash naqadar ulkan yutuqligini e'tirof etadi: "O'qiy olish bu, yozuvchi tomonidan berilayotgan xabarni tushunishdir. O'qish nafaqat alifboni, balki tilni ham o"zlashtirishdir" [Bloom2000:25].

Har bir til o'zi mansub bo'lgan til oilasining xususiyatlariga ko'ra, boshqalaridan farqli holda o'qitiladi, o'rganiladi. Misoltariqasidao'zbek tili, turkiy tillar oilasiga mansub bo'lib, uni o'rganishda harf, bo'g'in, so'z, gap kabi bosqichlarni bosib o'tish, o'rganish lozim. Yevropa tillaridan anglosaks til oilasiga kiruvchi ingliz tilini o'rganishda, o'qish ko'nikmasini egallashda harf, (bo' $\mathrm{g}$ 'in mavjud emas) so' $z$, gap tuzilmasini egallash, grafema va ularning fonemalarini to' $\mathrm{g}^{6} \mathrm{ri}$ tushuna olish talab etiladi. Chet tillarini o'rganish asosan, talaffuz, tovushni o'zlashtirishga asoslanadi.

O'zbek metod istolimasi Q. Abdullayevaning "Savod o'rgatish" uslubiy qo'llanmasida keltirilishicha, ruhshunos olim T. G.Yegorov o'zi ning, Очерки психологи и обучени детей чтению" nomli asarida o"qish malakalarini shakllantirish jarayonini uch bosqichga ajratadi: analitik bosqich, sintetik bosqich va avtomatlashgan bosqich [Abdullayeva Q.1983:18]. Mazkur bosqichlar o'zbek tilida o'qish ko'nikmasi shakllantirish va rivojlantirishda poydevor vazifasini bajaradi.

Analitik bosqich o'qish faoliyatini o'rgatishning ilk bosqichi bo'lib, unda so'zni harf - bo'g' inko'rinishida o"qish malakasi shakllantirila boshlanadi. Keyingi, sintetik bosqichda so "zni ko'rish, talaffuz qilish va tushunish (idrok qilish) orqali o'qish boshlanadi. Bunda harflarni o'rganayotga no'quvchiga shu harf bilan boshlanadigan so'z va uning rasmi bilan, so'zni o'rga tayotganda shu $\mathrm{so}^{\prime} \mathrm{z}$ ifodalaydigan predmetning rasmi va ma'nosi, talaffuzini birgalikda olib borilsa, o'zlashtirish jarayoni samarali kechadi. O'qishni o'rganishning enga sosiy jihati, bu, ma'no farqlashga xizmat qiladigan tovush (fonema) larni ajrata olishdir. Bu bosqichga o'quvchilar 3-sinfda o'tadilar. 4-5sinflarda o'qish avtomatlasha boradi. 5-sinf o'quvchilarida ham matnni o'qish ko"nikmasi avtomatlashgan bo'lib, ular o'zlariga tanish bo'lgan so'zlarni harflab emas, balki bo'g'inlarni qo'shgan holda yoki qisqa so'zlarni butunligicha qabul qiladilar.

Matn o'qishning pedagogik asosi o'qish davomida amalga oshiriladigan bir nechta amallardan iborat. Bulardan biri to $^{\prime} \mathbf{g}^{\prime}$ ri o' $q$ ishdir. Bir nechta metodik adabiyotlarda bu faoliyatga quyidagicha ta'rif beriladi: "To'g'ri o"qish, xato qilmasdan, yanglishmasdan o'qishdir, ya'ni to'g'ri o"qish so'zni grafe maholatidan fonema holatiga to'g'ri o'tkaza olish, qo'shimchalarini to 'g'ri va tartib bilan talaffuz qilish, so'zdagi tovush yoki bo'g'inni tushirib qoldirmay, boshqa tovushni qo'shmay, harflar o'rnini almashtirmay, so'zga urg'uni to'g'ri qo'yib o'qish hisoblanadi [Qosimova K.2009: 30].

Boshlang'ich sinf o'quvchilari so'zlarning ma'nosini chuqur tushuna olmasliklari, ba'zi ko'p bo'g'inli so'zlarning talaffuzidagi qiyinchiliklar sababli gap yoki matnning umumiy mazmunini tahlil qila olmasliklari mumkin. Ammo 5-sinf o'quvchilari yetarli darajada tez va ifodali o'qish, shu bilan birga o'qilgan ma'lumotni tushuna olish ko'nikmasini egallagan bo'ladilar.

O'qish va o'qib tushunishning yana bir asosi - me'yoriy tezlikda o'qish bo'lib, bunda o'qish tezligi matnni tushunish bilan teng holda bo'lishi nazarda tutiladi. O'qishni haddan tashqari tezyoki sekin o'qish matnning umumiy mazmunini to'liq tushunishga xalal beradi.

Matn o'qish ko'nikmasining pedagogik asoslaridan yana biri, bu manbaning ongli o'qilishidir. Ongli o'qish deganda, birinchi navbatda so'zning mustaqil ma'nosini, so'zlarni bir biri bilan bog'lanish munosabatini tushunish, matn mazmunidan xulosa chiqara olish, unda tasvirlangan voqea -hodisalarga $0^{\prime} \mathrm{z}$ munosabatini bildira olish tushuniladi. Matnni o'qituvchi bilan birgalikda qilinadigan tahlillari davomida o'quvchida so'zning kontekstdagi ma'nosini tushuna borish ko'nikmasi shakllanadi.

O'quvchi tomonidan o'qilgan matnning tushunilganligi uning ustida bajariladigan topshiriqlarni qay darajada bajarganligiga ko'ra aniqlanadi. Topshiriqlarga to'g'ri javob bergan o'quvchi matn mazmunini to 'g'ri tushungan hisoblanadi. Yo'l qo'yilgan xatolar esa, o'quvchining matn mazmuni yaxlitligini tushunmagan yoki matn qismlarini mazmun jihatdan bir-biriga bog'lay 
olmaganligini anglatadi. Natijalar tahlilini o'quvchi bilim darajasiga baho bera oladigan mezon deyish mumkin, negaki, matn tarkibidagi leksik, grammatik, semantik qismlar o'quvchi ongida shu paytga qadar mavjud bo'lgan xuddi shunday bilimlar asosiga quriladi, uni to'ldiradi, yangi leksik va informativ bilimlar bilan boyitadi. O'quvchining matnni idrok qila olmaganligi uning ongida bunga asos bo'ladigan bilimning juda pastligi yoki umuman tasavvurga ega emasligini bildiradi.

Ona tili darslari davomida o'quvchilarga tushunishni ta'minlaydigan quyidagi topshiriqlarni berish tavsiya etiladi. Bular: savollarga javob berish; test; nuqtalar o'rniga kerakli so'zlarni topib yozish; matn qismlariga sarlavha qo'yish; jadval ichida berilgan ma'lumotlarni to'g'ri, noto'g'ri, unday ma'lumot umuman berilmaganligini aniqlab belgilangan katakka belgi qo'yish (True, false, not given); matnda tasvirlangan yoki urg'u berilgan jism(lar) rasmini chizish; matnlarni qismlarga bo'lib, har biriga sarlavha qo'yish; matnda urg'u olgan so'zlarning izohini topish; raqamli izohlarga ma'nosi to'g'ri keladigan abzatsni topish; matnda berilgan ma'lumotlarni jadvaldagi savollar asosida tasniflash; boshlangan gaplarni matn ma'nosi asosida davom ettirish; matnga $o^{6} z$ sarlavhasidan tashqari yana qanday sarlavha qo'yish mumkin; matnning eng muhim o'rinlarini o' $z$ so'zingiz bilan yozing kabilar.

O‘quvchilarning matnni o'qib tushunish ko'nikmalarini aniqlash maqsadida olib borilgan tajriba ishlarini tekshirish davomida shunday xulosaga kelindiki, o'quvchilarning o'qigan matnlarining tushunilishini ta'minlash o'qituvchi tomonidan beriladigan topshiriqlarning to ' $\mathrm{g}$ 'ri tanlanishi va tahlil qilinishiga, ularning natijalariga ko'ra faoliyatni yaxshilashga bog'liq. Masalan, testlar o'quvchilarda o'qilgan ma'lumotlarni bir-biriga o'xshash va farqli jihatlariga e'tibor berishga, ularni ajratishga majbur qiladi va $0^{6} \mathrm{z}$ navbatida ularning qay darajada tushunarli bo'l(ma)ganligini aniqlashga yordam beradi. "To'g'ri-noto'g'ri”" metodi yordamida o'quvchilarning matnni qay darajada e'tibor bilan o'qiganliklari, so'zlar ma'nosini tushungan yo tushunmaganliklarini aniqlash mumkin. Predmetlar haqida gapirilganda uning tasvirini chizdirish yaxshi natija beradi, negaki, o'quvchi chizish davomida uning qismlari, vazifalariga qiziqadi, ma'lumotlarni eslaydi, zarurat tug'ilsa qayta murojaat qiladi va uni o'z qo'li bilan yaratadi. Bular esa $0^{6} \mathrm{z}$ navbatida darsga nisbatan qiziqish uyg'otadi.

\section{Foydalangan adabiyotlar ro'yxati}

1. Abdullayeva Q. Savod o'rgatish. Toshkent, 1983.

2. Azimova I. O`zbek tilidagi gazeta matnlarining mazmuni ypersepsiyasining psixoling vistik tadqiqi: monografiya. -T., 2019. - B. 61,66.

3. Azimova I. Ona tili ta'limida lisoniy malaka niri vojlantirishning psixoling vistik asosi. // Global ta'lim va milliy metodika taraqqiyoti. III an'anaviy Respublika ilmiy-amaliy konferensiyasi materiali. - Toshkent. 2019. - B. 221.

4. Bloom, P. How children learn the meanings of words. Cambridge, MA: MIT Press. 2000.

5. Qosimova K., S. Matchonovva b.“Ona tili o"qitish metodikasi” darslik, Toshkent 2009.

6. Richard K. Wagner, Shayne B. Piasta, and Joseph K. Torgesen Wagner, R. K. Reading impairment. In: P. Strazny (Ed.), Encyclopedia of Psycholinguistics. New York: Routledge, Taylor, and Francis. (2005).

7. Umumiy o'rta ta'limning ona tili fanidan davlat ta'lim standartlari va o'quv dasturi. T.: 2017-yil,16-aprel. B. 15-20.

8. Cheryl J. Gowie, Psycholinguistic strategies for improving reading comprehension, The elementary school Journal, Volume 79, number 2. Dec.2015. - B. 8-9. 


\title{
ТАЛАБАЛАРНИНГ ЮТУҚЛАРИНИ БАХОЛАШДА ЭЛЕКТРОН ПОРТФОЛИОНИНГ АХАМИЯТИ ТЎҒРИСИДА
}

\section{К.М.Мамадиёрова (СамДЧТИ магистранти)}

\begin{abstract}
Annotation: Nowadays, the portfolio is widely used, including in the field of education. As a result of the development of the quality control system of education, the Portuguese entered, the learning process as a full-fledged assessment tool. At all stages of the education process in higher education institution, the correct assessment of students' knowledge is of particular. Accurate and systematic assessment is a type of assessment that is mainly used in practice-oriented education and involves the assessment of students' abilities and skills in a situation that is as close as possible to everyday or professional life.In the teaching practices of higher education institutions, teachers often make sure that the interests of students are not fully covered in the formation of a system for assessing the achievements of students in the educational process. From this point of view, the portfolio plays an important role as a tool for objective assessment of students' achievements in the educational process.
\end{abstract}

Key words and expressions: Portfolio entry, university portfolio anamnesis, student portfolio, advantages and disadvantages of portfolio, student portfolio.

Республикамизда илм-фан ва таълим тизими дунё тажрибалари асосида бойитилиб борилмоқда ва шу тариқа глобалашув жаарёнида мамлакатмиздаги олий таълим жахон таълим тизмида ўз ўрнини топиб бормокда десак муболаға бўлмайди. Маълумки, дунёдаги барча олий таълим муассасаларида олий таълим сифати, малакали мутахассислар тайёрлаш хамма вақт долзраб масала бўлиб келган ва бу жараён давом этмокда. Олий таълим муассасасида таълим сифатини таъминлаш билан бир қаторда ўқув жараёнини ташкил қилиш таркиби ва технологиясига, шу жумладан талабаларнинг ўқув натижаларини бахолаш тизимига ўзгартиришлар киритишни ўз ичига олади. Олий таълим муассасасида таълим жараёнининг барча босқичларида талабаларнинг билимларини тўғри бахолаш алохида ахамиятга эга. Тўғри ва тизимли бахолаш - бу асосан амалиётга йўналтирилган таълимда қўлланиладиган ва хаётга, кундалик ёки касбга иложи борича яқинроқ бўлган вазиятга тушиш шароитида талабаларнинг қобилиятлари ва кўникмаларини шакллантирган холда бахолашни ўз ичига олган бахолашнинг тури хисобланади."Тўғри бахолаш" тушунчаси "талабаларнинг хақиқий ютуқларини бахолаш" атамасига тенг келади. Талабаларни бахолаш деганда нафақат фанлараро ўзлаштириш бахолари балки уларни келажакда яхши мутахассислар бўлиб шаклланишида ва ривожланиши учун йўналтирилган прагматик жихатни акс эттиради. Ўзлаштирилган билим ва кўникмалар тизими шахсий хусусиятга эга. Профессионал компетентликни эгаллаган талаба компетентлик нима учун мухимлиги унинг келажакдаги профессионал фаолиятида реал талаблар қай жихатдан ахамиятлилиги каби холатлар билан изохланади. Олий таълим муассасаларининг ўқув амалиётларида ўқитувчилар кўпинча талабаларнинг ўқув жараёни билан боғлиқ ютуқларини бахолаш тизимини шакллантиришда талабаларнинг манфаатлари тўлиғича қамраб олинмаганига амин бўлишади. Айни шу жихатдан олиб қаралганда, портфолио талабаларнинг таълим олиш жараёнида эришган ютуқларини хаққоний бахолаш воситаси сифатида мухим роль эгаллайди. Хозирги пайтда олий таълимни ривожлантириш, таълим сифатини шакллантириш борасида хам бир қанча ишлар олиб борилмокда. Шу йўсинда талабаларнинг эришган ютуқларини бахолаш жараёнида портфолио (электрон портфолио) нинг ўрни беқиёслиги кўзга ташланади. Портфолио (portfolio assessment) олий таълимда аутентик бахолашнинг турларидан бири хисобланади. Ушбу термин мохиятида маълум вақт ичида талабаларнинг ютуқларини хисобга олган холда натижаларга йўналтирилган ўқитишдаги хақиқий бахолаш усули сифатида тилга олинади. "Портфолио (фр. porter-шаклантирмоқ, юритмоқ, folio сахифа, варақ) - ютуқлар, муваффақиятлар тўплами деган маънода ишлатилади. "Portfolioпортфел” каби маъноларда келади[3, 9-11]. Портфолио бизга талабанинг турли хил 
тадбирларда - ўқув, ижодий, ижтимоий, коммуникатив ва бошқа сохаларда эришган натижаларини хисобга олиш имконини беради. Портфолио тушунчаси XV-XVI асрларда ғарбий Европадан кириб келган. Уйғониш даврида фаолият юритган меъморлар буюртмачилар билан ишлаш мобайнида "портфолио" деб номланган махсус папкада тайёр ишлари ва қурилиш лойихаларининг расмларини тақдим этишган. Мазкур папкалардаги хужжатлар буюртмачиларда меъморларнинг профессионал касбий сифатлари хусусида катта таассурот қолдирган. Хозирги вақтда портфолио кўпгина, шу жумладан, таълим сохасида хам қўлланалиб келинмоқда. Таълим сифатини назорат қилиш тизимининг ривожланиши натижасида портфолиолар ўқув жараёнига тўлақонли бахоловчи восита сифатида кириб борди. Портфолиода талабаларнинг таълим жараёнидаги саъй-харакатлари, эришган ютуқлари, бир ёки кўплаб сохаларда кўлга киритган муваффақиятларининг тўплами киритилади. Тўпламда портфолиони бахолаш учун мезонлар ва бахоларнинг акс этиш холатлари киритилса мақсадга мувофиқ. Портфолио ўз ичига "талабаларнинг харакатлари ёки ютуқларини бир ёки бир нечта сохаларда намойиш этадиган мақсадли жамланма, ўқув йили мобайнида талабаларнинг индивидуал фанлар бўйича ўзлаштириш натижаларини аниқлаш, бу шунчаки бажарилган ишларнинг тўплами эмас, балки талабаларнинг харакатлари, динамикаси ва турли сохалардаги ютуқларини кўрсата оладиганва олдиндан режалаштирилган ва махсус ташкил этилган индивидуал хужжатлар йиғиндиси” кабиларни қабул қилади.

Портфолио таълим тизимидаги замонавий устуворликлар нуқтаи назаридан мухим бўлган компетенциялар тўпламини аниқлашга имкон беради, талабаларнинг ўз ютуқларини яхшироқ англашига кўмак беради, вақт ўтиши билан талабаларнинг ўқув ва илмий сохалардаги тайёргарлик даражасидаги ўзгаришларни акс эттирувчи таълим сифатининг назорат қилиш тизимини қўллаб-қувватлайди[1, 46].

Куйида портфолионинг асосий хусусиятлари хақида тўхталамиз[2, 8-9]:

\begin{tabular}{|l|l|l|}
\hline № & Портфолионингвазифаси & Хусусиятлари \\
\hline 1 & Диагностик томондан & $\begin{array}{l}\text { Бунда авваломбор ўзгаришларни, яъни талабанинг } \\
\text { маълум вақт давомида профессионал касбий усишини } \\
\text { аниқлаш ва хисобга олишдан иборат }\end{array}$ \\
\hline 2 & Мақсадли & Таълим мақсадларини кўллаб-қувватлаш билан боғлиқ \\
\hline 3 & Мотивацион жихатдан & $\begin{array}{l}\text { Бунда талабанинг урганилаётган фан сохасида юқори } \\
\text { даражадаги билимларни эгаллаш истагини таъминлаш } \\
\text { билан боғлиқ }\end{array}$ \\
\hline 4 & Мазмундорлиги & $\begin{array}{l}\text { талаба ишларининг кўламини тўлиқ ошкор этишда } \\
\text { намоён бўлади }\end{array}$ \\
\hline 5 & Рефлексив жихатдан & $\begin{array}{l}\text { Талабатомониданўзинингўқувфаолиятитахлилиданамоё } \\
\text { нбўлади }\end{array}$ \\
\hline
\end{tabular}

Портфолио талабанинг ўз-ўзини қадрлаши, таълим жараёнида хар томонлама кучли мутахассис бўлиб етишишнинг самарали усули сифатида хамда хар қандай профессионал ва бизнес мухитида керак. Портфолио нафақат натижаларни, балки хар бир талабанинг олдинги натижаларига нисбатан қандай муваффақиятларга эришганлигини намойиш этишга имкон беради [2, 29-30].

\begin{tabular}{|l|l|}
\hline Портфолионингустунликлари & Портфолионинг камчиликлари \\
\hline $\begin{array}{l}\text { Ноанъанавий жихатдан таълим бериш, таълим } \\
\text { жараёнида бахолаш имкониятларини туғғри олиб } \\
\text { бориш }\end{array}$ & $\begin{array}{l}\text { ууқуда ва талабалар томонидан } \\
\text { бажаришни талаб қилади }\end{array}$ \\
\hline $\begin{array}{l}\text { Талабаларнинг илмий ютуқларини доимий } \\
\text { равишда бахолашга имкон беради }\end{array}$ & $\begin{array}{l}\text { Талабалар илмий ютуқларининг } \\
\text { анъанавий тизимидан кўра амалга } \\
\text { ошириш учун кўпроқ вақт талаб } \\
\text { этилади. }\end{array}$ \\
\hline
\end{tabular}




\begin{tabular}{|c|c|}
\hline $\begin{array}{l}\text { Талабаларнинг ютуқларини динамик холатда, } \\
\text { ривожланишда кўриш эхтиёжларини қондиради }\end{array}$ & $\begin{array}{l}\text { Текшириш ва бахолаш жараёнида } \\
\text { озми-кўпми мехнат талаб қилади }\end{array}$ \\
\hline $\begin{array}{l}\text { Талабаларнинг таълим олиш фаолиятидаги } \\
\text { натижаларни тахлил қилиш орқали миқдорий ва } \\
\text { сифатли бахолашни боғлашга имкон туғдиради }\end{array}$ & $\begin{array}{l}\text { Маълумотларни сақлаш билан боғлиқ } \\
\text { ташкилий қийинчиликларга эга }\end{array}$ \\
\hline $\begin{array}{llll}\text { Талабалар } & \text { фаолиятининг турли сохаларда } & \text { (ўқув, } \\
\text { ижодий, } \text { ижтимоий, коммуникатив) } & \text { қўлга } \\
\text { киритган натижаларни хисобга олишга имкон } \\
\text { беради }\end{array}$ & \\
\hline $\begin{array}{l}\text { Иш берувчиларнинг олий таълим } \\
\text { битирувчиларининг } \\
\text { мусласаси } \\
\text { муваффақиятлари билан онлайн орқали танишиб } \\
\text { бориш ва келажакда иш билан таъминлаш } \\
\text { масалаларини ечиш имконини беради }\end{array}$ & \\
\hline
\end{tabular}

Хулоса қилиб айтганда, таълим жараёнида портфолио талабаларнинг нимага қодирлигини, уларнинг кучли томонларини намойиш этиш, ижодий салохиятини максимал даражада очиб бериш каби имкониятларни очишга туртки бериши ва шу билан биргаликда талабаларни ўқув ва илмий ютуқларини ўзини ўзи бахолашига, натижаларни мушохада қилишига қаратиши муқаррар. Шу билан биргаликда, иш берувчилар билан олий таълим муассасасини тугатаётган битирувчилар ўртасида яқин алоқаларни хам жисплаштирган холда битирувчиларни иш билан таъминланишига замин яратилишига бевосита имкон туғилади.

\section{Фойдаланилган адабиётлар рўйхати}

1. Артемьева Г.Н. Использование портфолио в образовательном процессе вуза // Новые технологии обучения как условие модернизации российского образования. Нижневартовск: Изд-во Нижневарт. гуманит. ун-та, 2011. -С.28-38.

2. Артемьева Г.Н., Зыкова Н.А. Портфолио студента вуза по психологопедагогическим дисциплинма.-Нижневартовск: НВГУ, 2016. -104 с.

3. Панюкова С.В., Гостин А.М., Кулиева Г. Создание веб-портфолио студента. Рязань: РГРУ, 2013. -22 с.

\section{INGLIZ TILINI O‘QITISHDA MUSTAQIL TA’LIMNING SAMARDORLIGINI OSHIRISH}

\section{I.Yo.Beknazarova (SamDChTI) Sh.Mardibekov (SamDChTI 2-kurs talabasi)}

Annotation: This article shows the importance of the organization of independent learning of students in foreign languages and its effectiveness in language learning.

Key words and expressions: information technology, efficiency, consistency, communicative competence, discussion, online courses.

Mustaqil ta'lim malakali kadrlar tayyorlashning muhim omillaridan biri sanaladi. Ingliz tili fani bo 'yicha talabalar mustaqil ta'limini tashkil etishda talabaning qiziqishi va qobiliyatini hisobga olgan holda quyidagi shakllardan foydalanish mumkin: fan mavzularini foydalanish mumkin bo'lgan adabiyotlar ro'yxatidagi adabiyot va o'quv qo'llanmalar yordamida mustaqil o'zlashtirish, adabiyotlar bilan ishlash; amaliy mashg'ulotlariga muntazam tayyorgarlikda borish; alohida berilgan mavzularga ishlanmalar tayyorlash; mavzuni mustahkamlashga doir test larbajarish; amaliyotdagi muammoning bajarish uchun keys topshiriqlarini bajarish; mavzuni mustahkamlash uchun savol va topshiriqlarga tayyorgarlik ko'rish; mavzularga mos tarqatmali va ko'rgazmali vositalar tayyorlash; axborot resurs markazida tanlangan mavzularga mos ma'lumotlarni to'plash, 
qayta ishlash va muayyan tizimlashtirish; kompyuter yordamida berilgan mavzular bo'yicha taqdimotlar tayyorlash; talabalar turar joyidagi imkoniyatlardan foydalangan holda ya'ni talabalar yotoqxonasidagi ma'naviyat va ma'rifatxonasi, kutubxona, zamonaviy axborot texnologiyalar markazida mustaqil o'qish jarayonlarida ishtirok etish. Hozirgi vaqtda axborot texnologiyalarni rivojlanganligi yoshlarimizga xorijiy tillarni o'rganish uchun keng imkoniyatlarni yaratmoqda. Buning uchun o'quvchilardan o'z ustida ishlash ko'nikma va malakalarni shakllantirishlarinitalab etadi. O'quvchilar o'z uylarida turib shaxsiy komputerlaridan foydalang an holda online kurslardan, masalan, British Councilning https://www.britishcouncil.uz/english/mooc, https://www.onestopenglish.com/ kabi online kurslaridan unumli foydalanib nutq faoliyat turlari(o'qish, yozish, eshitish, gapirish)ni shakllantirishlari mumkin. Buning uchun talabalar qo'yidagi malakalarga ega bo'lishi kerak:

a) Berilgan mavzu bo'yicha materiallarni aniq, izchillikda ko'rsatilgan tartibda qayd etish, mashg'ulotlar (activities)ni bajarish uchun zarur bo'lgan mavzuga oid ma'lumotlar topish, o'rganish, tushunish, ularni yozma va og'zaki nutqda tasvirlay (taqdim eta) olish;

b) o'rganganlaridan kelib chiqqan holda mavzu yuzasidan umumiy tasavvurga ega bo'lish;

c) bahs-munozarada talaba oz fikrini erkin bayon etish va himoya qilish, suhbatga kirishish, asosli dalillar keltira bilish, faktlar bo'yicha savollar berish va aniq faktli javoblar berish.

Natijada o'rganuvchilarda chet - tilida kommunikativ kompetensiya shakllanadi. Bundan tashqari yana ular ma'lumotlar izlash, to'plash, qayta ishlash va saqlash jarayonida zamonaviy komputer va axborot texnologiyalarini qo'llashning amaliy malakalari shakillanadi.

Oliy ta'limda talabalar mustaqil ta'lim jarayonida o'quv materialini mustaqil o'zlashtirish, murakkablik darajasi turlicha bo'lgan vazifalar, amaliy topshiriqlarni ijodiy va mustaqil bajarish asosida nazariy bilimlarini, amaliy ko'nikma va ko'nikmalarini shakllantirishadi.

Boshqa fanlar singari Xorijiy til fanlarida ham mustaqil ishlar didaktik maqsad vazifasi, murakkablik darajasiga, kimga berilayotganligiga qarab (ya'ni yakka (individual) yoki kichik guruhlarda) bir - biridan farq qiladi. Mavzular ilmiyligi, izchiligi va o'quv materialini qiziqarliligi, fanlar aro bog'liqligi hamda mustaqil ishlar va topshiriqlarning ijodiy xarakterga egaligi muhimdir.

Mustaqil ishlarni kichik guruhlarda bajarish jarayonida har bir talaba o'z bilim va imkoniyatlarini inobatga olib tanlaydi. O'ziga ishongan iqtidorli talabalar ijodiy va izlanish xususiyatiga ega bo'lgan topshiriqlarni, o'rta darajadagi bilimga ega bo'lganlar soddaroq topshiriqlarni bajaradilar. Shunga qaramasdan topshiriqlar ustida guruh bo'lib ishlash ularga umumiy masalani hal etishda va jamoaviy ruhni shakllantirishga yordam beradi. Talabalar mustaqil ishini ijobiy tashkil etishu chun fan uslubiy qo'llanmalar kerak bo'ladi, Ularda mustaqil ishning batafsil izchilligi, muommoli bahslar uchun mavzular, mustaqil o'rganish uchun adabiyotlar, topshiriqlar, taqdimotni bajarish uchun maslahatlar, o'z-o'zini nazorat qilish uchun savol va testlar keltirilgan nazariy material, amaliy vazifalar, glossariy va h.klardan iborat bo'lishi kerak.

Mustaqil ishlar asosan talabalarga o'quv fanini mustaqil o'rganish, bilimlarini mustahkamlash va o'z ustidaishlashga yordam beradi. Talabani o'quv mashg'ulotiga mustaqil tayyorlanishi uni o'quv jarayoni vaqtida mustaqil fikrga ega bo'lishini ta'minlaydi ya'ni, u o'quv yutuqlarini o'zi nazorat qila boshlaydi va o'ziga nisbatan ishonchi orta boshlaydi. Shuningdek, amaliyot turlari tanishuv, malakaviy va pedagogik amaliyotlar talabalarni mustaqil ishini tashkil etishda katta ahamiyatga ega.

Xulosa qilib aytganda, malakali kadrlar tayyorlash jarayonining sermashaqqat har bir bosqichida, talabalar mustaqil ta'limini sifatli tashkil etish va saviyasini ko'tarish, samaradorligini oshirish ta'limning asosiy vazifalaridan biri bo'lib qoladi

\section{Foydalangan adabiyotlar ro'yxati}

1.O'.Hoshimov. I.Yoqubov. Ingliz tili o'qitish metodikasi.- Toshkent-2003. 


\title{
ЁШЛАР ЭСТЕТИК ТАФАККУРИДА КИТОБ МУТОЛААСИНИ ЎРГАНИШ ВА УНИНГ МЕТОДОЛОГИК АСОСЛАРИНИ РИВОЖЛАНТИРИШ
}

\author{
Тиляева Фотима Зиёдуллоевна \\ (СамДЧТИ мустақил тадқиқотчиси)
}

\begin{abstract}
Аннотация: Ушбу мақолада ёшлар эстетик онгида китобхонлик ва эстетик маданиятни ривожлантириш мезонлари, бадиий адабиёт мутолаасига эга бўлиш афзаллиги, ёшлар интеллектуал савиясини ўстириш хақида фикр юритилган. Китоб мутолаа қилиш ёшларимизда ватанпарварлик, бурчга садоқат, довюраклик, адолатпарварлик, халоллик ва билимдонлик каби фазилатларни камол топишда асосий омил бўлиб хизмат қилади. Китобхонлик инсон дунёқараши, қадриятлар тизими, эх маънавиятини шаклланишида улкан ижтимоий ахамият касб этади. Мазкур мақола ёшлар эстетик тафаккурида китобхонликни педагогик нуқтаи назаридан тахлил этилган.
\end{abstract}

Калит сўзлар ва иборалар: Китобхонлик маданияти, мутолаа, эстетик маданият, маънавий тарбия, инсоний фазилатлар.

Аннотация: Эта статья посвящена развитию чтения и эстетической культуры в сознании молодежи, преимуществам литературного образования и развитию интеллектуального уровня молодежи. Чтение книг является ключевым фактором в поддержании таких качеств молодых людей, как патриотизм, целеустремленность, смелость, справедливость, честность и знания. Чтение играет большую социально-психологическую роль в формировании мировоззрения человека, системы ценностей, духовности потребности среди молодёжи. Развитие книгочтения среди молодежи философски глубоко анализировано в статье.

Ключевые слова и выражения: Культура чтения, книгочтение, культура эстетики, духовное воспитание, человеческие качества;

Annotation: This article is devoted to the development of reading and aesthetic culture in the minds of young people, the benefits of literary education and the development of the intellectual level of young people. Reading books is a key factor in maintaining the qualities of young people such as patriotism, sense of purpose, courage, justice, honesty and knowledge. Reading plays a major socio-psychological role in shaping a person's worldview, value system, and spiritual needs.

Key words and phrases: Reading culture, reading books, aesthetics culture, spiritual education, human qualities;

Тарбия қийин иш ва тарбия шарт-шароитларини яхшилаш - хар қандай кишининг хам муқаддас бурчларидан биридир, зеро ўзини ва теварак атрофдагиларни маълумотли қилишдан хам кўра мухимроқ иш йўқ.

\section{Сукрот}

Ўз истеьдодлари билан донг таратган кишилар вақтларини ўзлари ва авлодларига хурмат келтирадиган қилиб сарфлашлари керак. Агар авлодларга хеч нарса қолдирмасак, улар биз хақимизда нима деб ўйлашлари мумкин. Бўш вақтни оқилона сарфлаш учун, хаётни мазмунли ўтказишда китобнинг ўрни беқиёс. Энг қадрли тортиқ бу китобдир. Илмни пухта эгаллаш, хаётни тўғри йўлга солиш, эзгу амаллар сохиби бўлмоқлик, келажакни тўғри йўлга солиш, донишмандлар қолдирган ўгитларга амал қилиш, барча-барчасининг замирида китобга бўлган мухаббат ва китобхонлик маданияти, эстетик тафаккур асосдир. Китоб бор жойда илм ривожланади, мутолаа, маърифат юксак чўққиларига эришиш калитидир.

Инсонларда эстетик оламга бўлган интилиш табиий холат хисобланади. Чунки инсондаги эстетик сезгилар, эхтиёжлар ва хиссиётларнинг чегараси йўқ. Инсон сезги ва хиссиёт орқали воқеликнинг қонуниятларини эстетик тарзда идрок этади. Турли хил санъат асарлари, бадиий адабиёт, тасвирий санъат, мусиқа кабилар борликдаги гўзаллик тамойилларини ўзида ифода этади. Натижада санъатдаги, адабиётдаги ва ижтимоий хаётдаги гўзалликлар ўзининг янги - янги қирраларини намоён этиб бораверади. 
Маънавий дунёси хар томонлама мукаммал бўлган инсон ўз Ватани учун бор билими, кучини аямасдан келажакнинг буюклигини чин дилдан хис этиб яшайди. Шунинг учун хар бир шахс гўзал фазилатларини, ширин сўзлигини албатта китобдан олади [Ғайбуллаев 2008:126]. Аждодлар меросини, умумбашарий қадриятларни камолотга, саодатга элтувчи юксак йўлда одим қадам ташлашига бадиий асарлар мутолааси орқали эришади.

Инсониятнинг маънавий эхтиёжларини қондиришда диний ғоя ва идеалларнинг йиғиндиси, халқ қўшиқлари, халқ маданий ва маънавий мероси, мақоллари, лапарлари, шеърияти доимо зарурдир. Шунингдек, инсонларнинг маънавий бойликлари ва маънавий маданияти матбуот, китоб, радио, телевидение, турли хил фильмлар, театрлар орқали кенгайиб боради.

Китоб мутолласи, китобхонлик жамиятда улкан вазифаларни бажаради: информацион, интеллектуал, маданий, коммуникатив, билим олмоқлик, таълимий, касбий, сиёсий - ғоявий ва бошқа амаллари билан бир қаторда, вақт ўтиши билан хар бирининг ахамияти ўзгариб боради.

XX acp бошқа олдинги ўтган асрларга қараганда мутолаанинг кенг назарияси имкониятлари ўзининг мақсадлари ва мутолаа вазифалари, мохияти ва методикасини тарғиб қилди. Кўпгина мамлакатларнинг миллий амалиёти, туб маданияти, эстетик қарашларини, умумбашарий қадриятлар таффаккуридан фойдаланмокда. Ўтган асрлар назарий ва амалий қарашлари, тафаккури шундан далолат берадики, хозирги кунда ягона китоб мутолааси назарияси мавжуд эмас. Унинг турфа хил ва йўналишлари мавжуд. Бироқ, алохида холларда ўқитиш интеграцияси, амалиётда ўз аксини топган ва тарқалган китобхонлик бутун холатда педагогика илмини бойитиб бормоқда. Концептуал холатларни тахлил этиш, китобхонликнинг назариясини амалий ўқитиши бугунги куннинг долзарб муаммосидир.

"Мутолаа”, “китобхонлик”, “ўқиш” концептуал тушунчаларининг кўпқирравийлиги унинг роли ва мавқейи инсониятнинг тарихи, цивилизацияси, ижтимоий-сиёсий ва бошқа янгиланишлари, шунингдек, матнларнинг янги ташувчилари пайдо бўлиши билан боғлиқ.

Оммавий тарзда китоб мутолаасининг уч асосий тарихий даври: оммавий ходиса, унинг вазифа ва роли сифатида муайян мақсад, ёндошув ва ўқитиш методикаси ўз ифодасини топган. Оммавий ўқтишининг бирламчи вазифаси - ўқимишли инсонни шакллантириш. Бирничи даврда - диний тарбия асосида, инсон ва Худо, муқаддас илохий китобларни ўқиш мутолаанинг биринчи мақомини ташкил этар эди. Мартин Лютер биринчи ўқитиш услубини кўп карра қайта ўқиш орқали ва диний матнларни овоз чиқариб ўқиш йўли билан изох берди [Ковалло 2008: 11].

АҚШнинг тажрибаси тарихий-педагогик режага мувофиқ жуда қизиқ, Европадан бир аср кейин шаклланиб, ривожланиш босқичи тезроқ кечди, биринчидан Америка кўшма штатлари бошқа давлатлар тажрибаси асосида, ўзининг шароитига мослаштирди (адаптация). Ўзлаштирган тажриба асосида мутолаа Худо билан алоқа бўлса, американча миллий услуби ягона патриотизм мақсадини кўзлаган инглиз тили варианти. Уммуммиллий ўқитиш жараёнида инсоннинг характерини тарбиялаш, ахлоқий сифатларни шакллантириш ва маънавий қадриятларни ўқитиш назарда тутилган. Китобхонликнинг тарбиявий ахамияти унинг мазмун мохиятига айланиб, дунёнинг барча нуфузли таълими тизимларида юксак даражали мутахассисларни чорлаб, жамиятда ўқимишлилик категориясидаги шахсларнинг тарбияси шу методга таянган.

Ўқишнинг иккинчи вазифасига эътибор қаратамиз. ХХ асрга келиб китоб ўқиш, китобхонлик нафақат халқнинг таълими ва маданий хаёти даражаси, балки функциалпрагматик мавқейини ошириш манбайи бўлди. Ушбу ривожланишнинг иккинчи даври инсоннни ўқимишли, саводли ишчи, энг мухим сифатлари мехнат шароитига мослашуви кўникмаларини шакллантирди.

Сўнгги йилларда, буларга арифметика бўйича, орфография, китоб ўқиш, мутолаа, иншо, эссе ёзиш каби қатор шкалалар ишлаб чиқилди ва таълимнинг инструментал бахосининг сифати вужудга келди. 
Прагматизм ғоялари педагогик китобхонликка хам аста секин кириб борди. Хозирги замон мутолааси Б.Скинер, Р.Кателла каби таниқли тадқиқотчилар номи билан жипс боғланган. Ўқиш техникасини ўқитиш, тренинглар, тестлар, матнни ўқишда инсоннинг реакцияси каби долзарб йўналишлар китобхонлик йўналишининг тадқиқот марказига айланди. Ушбу давр жиддий инновациялар жараёни бошланишидир. Ўқитишнинг оммавий тури овоз чиқариб ўқишдан, энди матнни ўз ичида овоз чиқармасдан ўқитишга ўтади. Ўқитиш педагогикасида янги мақсадлар вужудга келди. Ўқиш, мутолаа тезлиги, ўқиш шиддати, қовуштириб ўқиш, тушуниб ўқиш, ўқиганини англаш, қатор методик ёндашувлар ривожланди.

Китоб мутолаасининг функционал-прагматик мақсади, интилиши, инсон ўзининг касбий, профессионал хаётига таъсири ўта мухим палласи хисобланади. Шундай мутолаанинг материалининг асосини илмий, илмий - оммабоп, ўқув, махсус, сохалар буйича мавзули ўқиш ташкил этади.

Китоб мутолаасининг учинчи босқичини ижтимоий-ғоявий деб аташ мумкин, унинг мавжудлиги, ривожланиши оммавий мутолаанинг учинчи даврини белгилаб беради.

$\mathrm{XX}$ acp, икки жамият тизимининг ғоявий қарама-қаршилигининг идеологик куроли бўлди. Тегишли тарзда мутолаанинг ижтимоий-ғоявий роли ошди. “Сўз ўқиб-дунёни ўқийман” деб, таъкидлайди ижтимоий мутолаани ривожланишига асос солган бразилиалик педгог П.Фрйре [Эргашев 2008: 135].

Ёшларни интеллектуал салохият сохибига айланмоқ учун албатта китоб, китобхонлик маданиятини жамиятда, оилавий мухитда ривожлантиришда зиёлилар, донишмандлар, илммаърифат масканлари, кутубхоналар улкан мавқеьга эга. Инсоннинг улуғлиги, ақлий камолоти китобга боғлиқ. Ёшларни хар томонлама ривожлантириш, юксак ахлоқий, эстетик тафаккури, тарбиясида мухим таъсир этувчи куч - бу мақсад сари интилиб, изланиб етук шахс булишида мутолаага, китобхонликка қизиқишини ошириб, рағбатланиб борсак, албатта натижаси йиллар ўтиб намоён бўлади. Таълимга эхтиёж хар бир кишида мужассам, изланиш, мақсад сари интилишда, сўз бойлигини оширишда, тафаккурини ривожланишида китобхонлик маданияти мужассам.

Хозирги даврда асосий мутолаа компетенцияларига қуйидагилар мансуб:

- сиёсий ва ижтимоий;

- маданиятлараро:

• коммуникатив;

- ахборот-технологик

- профессионал;

Бадиий асар қадриятга айланган муайян эстетик яхлитлик. Бадиий асар орқали эстетик ёшларнинг тафаккурини ривожлантириш, зарур маънавий эстетик қониқиш бериш, унинг қалбига чўғ солиш ва мутолаага чорлаш жуда мухим даврнинг талабидир. Шу бадиий хусусиятларнинг жой-жойига куйилганлиги бадиий асар даражаларини белгилаб беради (гўзал шакл, чукур мазмун, пухта композиция, ўзига хос услуб ва.хк.)

-асл истеъдод томонидан яратилган асарларни ёшларга хавола эта билиш;

-мазмуни тарбиявий ахамиятга молик бадиий асарларни тарғботини, шархини уюштириш;

-умумбашарий қадриятларни ёшлар онгида бадиий асарлар орқали сингдириш;

-қисқа маънодор афоризмлар, иқтибослар, фалсафий мушохадаларни йиғиб, ёшларни мантиқан тафаккур этишга йўналтириш;

Том маънодаги санъат намунасига айланган асарда ғоявий ният, илхом, тасаввур, қисқаси, истеъдод ўзини эркин намоён қилади. Мавзу эмас, мазмун долзарблилиги, шаклик пухталик эмас, шакл гўзаллиги, бадиий қиёфалар жонлилиги, бош қахрамонларнинг идеал сифатида идрок этиши учун етарли имконият мавжудлиги биринчи ууринда туради. Инсон такрорланмас олий қадрият, алохида бир олам сифатида асар мехварида туради, бошқа хамма нарсалар ўша мехвар атрофида айланади ва улуғворлигини очиб бериш учун хизмат 
қилади. Муаллифнинг махорати, самимияти, инсонпарварлиги, эркинлиги ўзига ром этади ва асрни қайта - қайта идрок этишдан зерикмаймиз.

Дохиёна асарлари билан бутун дунёни хайратда қолдирган Гомер, Навоий, Фирдавсий, Саъдий, Аттор, Руставели, Данте, Низомий, Шекспир, Бедил, Гёте, Байрон, Шиллер, Гейне, Пушкин, Бальзак, Тагор ва шулар даражасидаги яна ўнлаб номларнигина қўшиш мумкин. Уларнинг дохиёна асрлари ва ижодлари бизни, ўзимиз англамаган холда, каромат каби чорлаб туради, яшашга ўргатади.

Ушбу мутолаа жараёнлари коммуникатив материалларга асосланган, муаллиф билан мулоқот, тил кўрикмаларини хосил қилиш, ёқимли ахборотни онгга жойлаштириш, эстетик лаззатланиш, илмий қониқиш ва шахсни шакллантирувчи, ривожлантирувчи воситадир. Мутолаа жараёнида аста секин китобхонлик техникасини эгаллаш, билимлар, кўникма ва махорат ривожланиб, бутун хаёти давомида турфа холат ва ходисаларга мукаммаллик хосил бўлади.

\section{Фойдаланган адабиётлар рўйхати:}

1. Ўзбекистон Республикаси Президенти Шавкат Мирзиёевнинг 2017 йил 12январдаги "Китоб махсулотларини чоп этиш ва тарқатиш тизимини ривожлантириш, китоб мутолааси ва китобхонлик маданиятини ошириш хамда тарғибот қилиш бўйича комиссия тузиш тўғрисидаги фармойиши. //Халқ сўзи. 1017 йил 13 январ, 9-сон, 1-2 с.

2. История чтения в западном мире: от Античности до наших дней [Текст]/ ред.сост.Г.Ковалло; пер.с.фр. М.А.Руновой, Н.Н.Зубкова, Т.А.Недашковский. - М.ФАИР, 2008. -544c. (Библиотечный бестселлер).

3. Эргашев О, Йўлдошев Е. Кутубхона ва китобхон. Тошкент.: "Ўзбекистон” нашриёти. 2008. 135-136с.

4. Ғайбуллаев О. Шахс маънавий камолоти ва эстетик маданият. Тошкент.: “ЧАШМА ПРИНТ" 2008, 126 с. 


\section{МУНДАРИЖА}

И. М.Тухтасинов. Таржимашуносликда “компетенция” ва “компетентлик” терминларининг

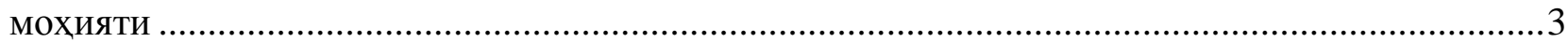

Ш.С.Сафаров. Категоризация и сопоставление языков ................................................6 N.Q.Turniyazov, B.N.Turniyazov Murakkab sintaktik qurilma va gapda kauzativlikning

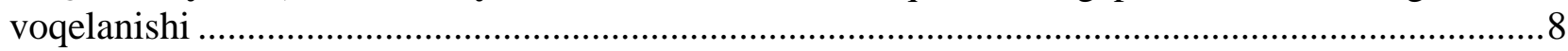

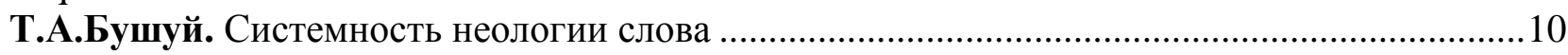

Д.И.Салохи. Творческие принципы Низами Гянджеви и формирование романтизма в

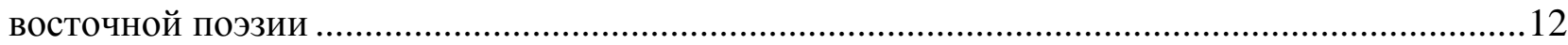

Ш.С.Ашуров. Инкор компонентлар иштирокидаги фразеологизмларнинг ўзбекча

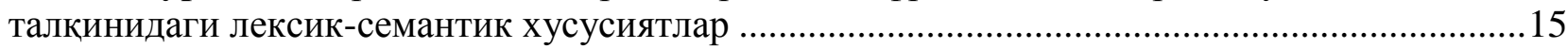

S.Ashirbaev. Lingvistik areal va uning tiplari talqiniga doir ................................................. 17

Ёвкочева 3.М. Виды обращений в стихотворениях А. Ахматовой …................................21

А.Ш.Ибатова. Ўзбек тили терминологиясида "нон" луғавий бирлигининг масалаларини

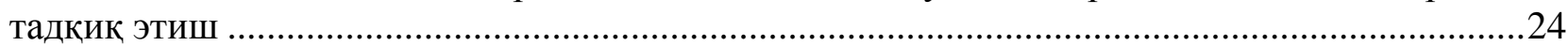

Турниёзов Н.К. Турниёзова Ш.Н. Матн деривациясида ўрин ва пайт равишларининг

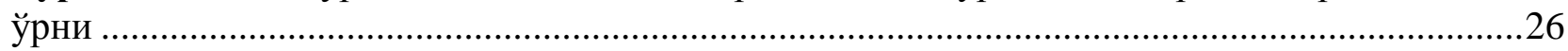

杨明天 Ян Минтянь. “词语 $\Leftrightarrow$ 文本”的分析方法 Метод анализа 《текст слова».................29

Ш.М.Хамроева, Б.Р.Менглиев. Туркий тиллардаги морфологик анализаторлар

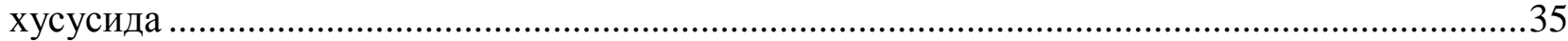

杨仕章 Yan Shizhang. 文化翻译理据性研究 Madaniy tarjima motivatsiyasi bo'yicha

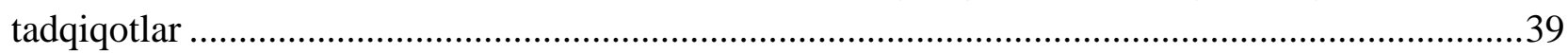

Zh.Ibragimov. Kazak türkçesinin Siri-Derya boyu ağzinda oğuzca unsurlar ............................43

И.Т.Бабакулов, Д.А.Хамраева. О словообразовательных категориях в русском и узбекском языках

Э.А.Алиева, П.Р. Хасанова. Изучение фразеологизмов с зоонимическим компонентом в

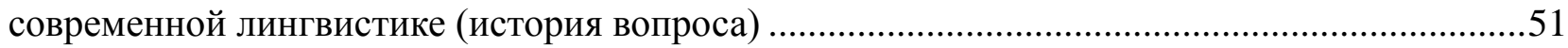

А.К.Омарбекова. Фразеологические единицы с именами собственными казахского языка как отражение национальной культуры ……....................................................................55

R.ASuvonova, A.Boymirzayev. Qipchoq lahjasiga xos harakat fe'llari...................................58

C.А.Насирова. Особенности аббревиации в образовании новых общественно-политических терминов китайского языка 61

Л.Р.Сидоркова, Г.А.Тангриберганова. Об эффективности использования приемов интерактивного обучения в преподавании русского языка (на примере приема «Обучение в

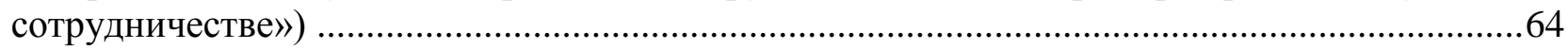

С.С.Нурматов .Қадимги хинд-орий тилларига хос санскрит тилидаги тартиб сонлар деривацияси

LiuYuxin 语言观念学视角下“дружба”观念域研究 - 以俄语浐俗语为例 Lingvistik tushunchalar nuqtai nazaridan " дружба" ning kontseptual sohasi bo'yicha tadqiqotlar - rus maqollari misolida.

Лю Юэлинь. Сопоставление речевого этикета в современном социальном взаимо действии

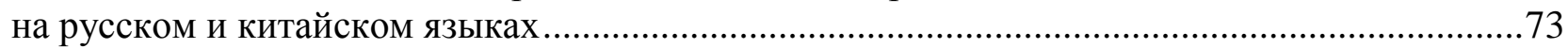

Н.Г. Содикова. Анализ теории обособления в современном языкознании ...........................76

Н.Х. Турсунова. "Вабо” - Альбер Камюнинг аллегорик романи .........................................78

O.Z. Tilovov. Xitoy tilida maxsus kishilik va ko`rsatish olmoshlarning tahlili.............................81

Х. Тугалов. Хитой ва ўзбек тилларида миллий-маданий эквивалентсиз коннотатив

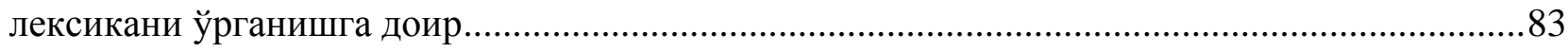

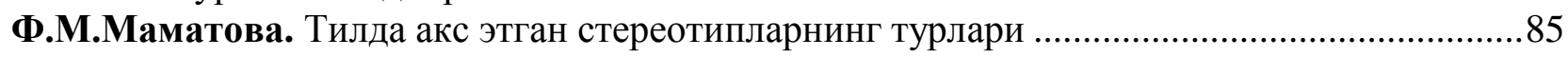

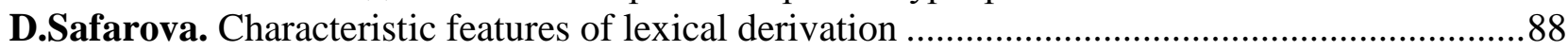

F.Eshnayeva. O'zbek tilining - davlat tili sifatida shakllanishi ..............................................90

G.T.Asadova. Object syntaxemes in the English and Uzbek languages .....................................92 
E.Xonnazarov. Fe'lning zamon kategoriyasi tadqiqiga doir ....................................................95

U.U.Mahmudova. Advertising as an independent discourse in linguistics ...............................96

D.R.Radjabov. Yaponiyada ish yuritish tilining shakllanishi .................................................100

Қ.Эгамназаров. Инглиз ва ўзбек тилларида ноаниқ олмошларнинг тадқиқига доир ..........102

R.M.Asadov. Valency of syntactic units with nuclear and non-nuclear predicative relations .....106

А.Д.Саидова. Термин ясалишида таянч ва янги маънонинг ўзаро муносабати ...................109

Sh.Urokov. Yapon tilida olmoshlarning lingvomadaniy xususiyatlari .......................................111

A.To`xtamishev. " 是" fe'lining tahliliga doir ....................................................................... 112

Z.Shukurova, Sh. Juramurodova Learning a language and its acquisition ............................114

Sh.Kodirova, Furukawa Midori. Yapon tilida erkak va ayollar nutqida uchraydigan leksik va grammatik lakunalar

Ш.Ш.Улугова. Метафоранинг табиати талқинига ёндашувлар ........................................121

Д.К.Шадиева. Изменчивость нормы в русском языке ...................................................123

Ф.А.Султонмуродова. Словообразовательные аффиксы в русского языке .........................126

Н.Б. Абдурашитова. К вопросу лингвистики юридических документов.............................128

М.P.Рахимов. Немис тилида илова конструкциялар бажарадиган функциялари хақида ...130

С.Ш.Садриддинзода. Особенности семантики демонологической лексики в узбекской

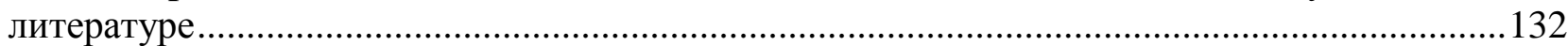

T.Акимов. 文言. wényán венъянь тил нормалари асосида тузилган иборалар .....................134

A.V. Faleyeva Some particularities of colloquial speech of the English language......................138

В.Жуманов. Хушмуомалаликбуйруқ нутқий актларини фаоллаштирувчи турғун шаклдаги

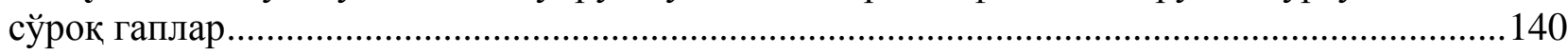

К.Б.Хасанова. Роль английского языка в обогащении узбекской лексики с помощью

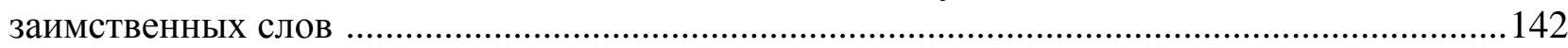

Э.Наўбетуллаева. арақалпақ халық жумбақларында эллипсис

конструкциялар

В.Жуманов. Гапларнинг коммуникатив турлари.Сўроқгапларнинг коммуникатив турлари ва уларнинг вазифалари

P.I.Khotamova. Comparative analysis of adjectives in English and Uzbek languages

Z.I.Xoshimova. Hozirgi arab va o'zbek tillarida fe'l so'z turkumining farqlari va umumiy

jihatlari

Hashem Ismail Hammam Ali. The concept of teaching Arabic language in Uzbekistan...........153

Sh.Alamov. Some students'difficulties in learning phonetics of the Arabic language .................156

Ch.Hamdamova -ni tushum kelishigi qo`shimchasining xitoy tilidagi ekvivalenti: grammatik

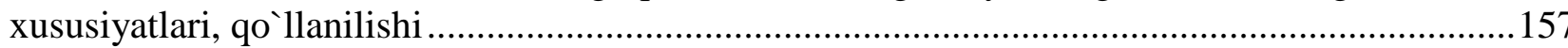

Б.М.Мирзаев. Парадигматика тушунчасининг фанга кириб келиши ................................159

Ф.Абдухакимова. Немис тилида синонимлар гурухи доирасидаги сўзларнинг маъно

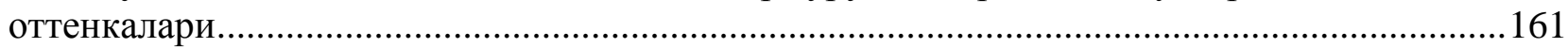

Ян Бо. Китай и Центральная Азия: активизация сотрудничества в новых условиях............164

X.A.Mamatqulova. Madaniyatlararo muloqotning ba`zi jihatlarixususida mulohazalar (Yapon

madaniyati va adabiyotining ilk davri misolida).

P.J.Nazarov. Milliy madaniyatga oid nemischa frazeologik birliklarning semantik ma'nolari

xususida.

Sh.Bekturdiyeva. Importance of learning military terms in studying English............................173

P.P.Комилов. Ўзбек халқи никох маросимларининг эстетик мохияти ва

трансформацияси

Ф.Б.Мардонова. Роль национальной культуры в формировании общечеловеческих ценностей .

夏青 Xia Tsing. 俄语教育在吉尔吉斯斯坦的发展历史、现状及前景 Qirg'izistondagi rus ta'limi tarixi, hozirgi holati va istiqbollari

Гулицзыи Байшань. 古丽孜依·白山哈萨克斯坦国家教育发展历程与现状研究 Qozoqiston davlat ta`limi rivojlanish tarixi va hozirgi davri 
Л.А.Султанова. Влияние китайской культуры на традиционную китайскую медицину ...190 A.Muhiddinov. Макхул Насафийнинг Мотуридия таълимоти ривожига қўшган хиссаси ..193 王萌. Wang Meng. 俄罗斯东正教会对俄罗斯军队的影响探析 Rus Pravoslav cherkovining Rossiya armiyasiga ta'sirini tahlil qilish

П.Қобилов. Хозирги замон давлат-хукуқий воқеликлари асосида хуқуқ устунлиги (rule of law)нинг бугунги кунда шахснинг хуқуқлари ва қонуний манфаатларини таъминлашда ахамияти

А.Ж.Душаев. Шахс маънавий камолоти ва жамият тараққиётида дахлдорлик туйғусининг

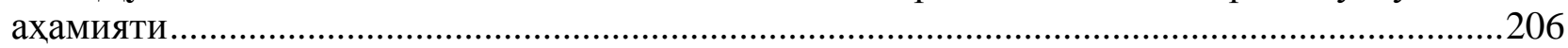

М.Бузрукова. Дискурсив фаолият ва хурмат категориясининг воқеланиши .......................208

Bi Feng Yun 毕风云, D.A.Quliyeva. Bir umrlik hamroh-ismlarning kelib chiqishi ..................210

D.A.Quliyeva, N.J.Vaxabova. The role of the Chinese national holiday-"the moon festival" among the Chinese people

S.Xalilova, Z.Qarshiyeva. Milliy sport turlari va xalq o'yinlari bola organizmning fuksional

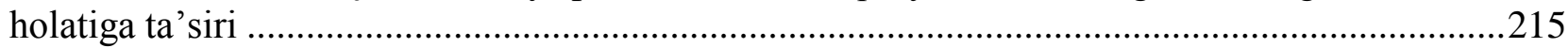

B.Sattorov. Rang-sifat bildiruvchi etnonimlar va ulardan shakllangan etnooykonimlar.............217

M.М.Мамадалиев. Жамиятда миллий маданият ривожида ахлоқий анъаналарнинг фалсафий масалалари

С.А.РузметовО частотности употребления отдельных заимствованных единиц в речи представителей старшего поколения

Б.Ю.Сайилов Оила институтини мустахкамлашда маънавий-ахлоқий қадриятларнинг ўрни

Ж.А.Самадов. Жисмоний тарбия ва спорт бўйича маркетологларнинг касбий фаолияти хусусиятлари

Пак Ксения. Символика цветов в китайской культуре.

Д.И.Худайкулов. Ёшларда ахлоқий-эстетик иммунитетни шакллантиришда саводхонлик масаласи

С.А.Яхяева. Ёшларда эстетик маданиятни шакллантиришда миллий-этномаданий қадриятнинг ўрни.

Ф.М.Зарипов. Вояга етмаган ўқувчи-ёшларни интизомсизлигининг келтириб чиқарувчи сабаблари ва омиллари

М.А.Абдуллаева. "Estetikaga yo'g'rilgan dunyo"

Хуан Минто, МаХэяо. Русская диаспорав постсоветском пространстве: особенности идентичности изначение для России

О.М.Ғайбуллаев. Глобаллашув шароитида Ўзбекистонда узлуксиз таълим тизимини ривожлантириш масалалари ...

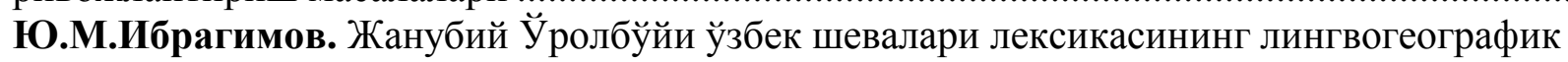
хариталаштириш муаммоси .....

ЧжэнЦзелань. Китайская традиционная культура в концепции «сообщества единой судьбы

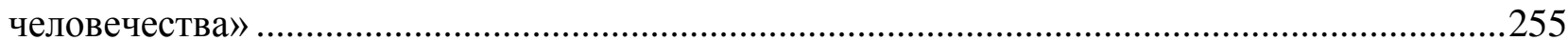

Я.X.Ғаффоров. Буюк Ипак Йўли-тарихий ва маданий хамкорликлар йўлидир .................2257

ў.Тўхтамишев. XVI-XIX асрларда ўрта осиё хонликлари худудида харбий санъат ...........260

М.М.Абдуллаева. Иқтидор муаммосинингривожлаништарихи ........................................266

常显敏 Chang Xianmin. “建以致用”指导下的《中亚概况》在线课程教学设计 The online course design of “A general introduction of Central Asian ........................................................2270

S.Sh.Xolmirzayeva. O'zbek tili fanini o'qitishda pedagogik hamda innovatsion texnologiyalarni qo'llash

Д.Ф.Тоирова. Формирование исторических взглядов Стендаля ....................................2276

S.I.Khakimova. Symbols and their role in the intercultural communicaton ............................2279

Туробов Б.Н. Е.Э.Бертельс Ўрта аср тасаввуф поэзияси хақида …....................................281

O.Ibadulloeva. Узбекистан-Китай: сотрудничество проверенное веками ............................283 
A.Lutfullayev, S. Mulkamalov. Buyuk ipak yo'li va uning ahamiyati .................................286

Н.Абдуллаева. Ички туризмнинг педагогик жихатларини такомиллаштириш. ..................288

М.Я.Ў ринбоева. Баркамол авлодни тарбиялашда музейларнинг ўрни...............................2291

Ф.А.Ашурова. Жадидларнинг миллий тил ва имло масалаларига муносабати ....................294

У.К.Исмоилов. Подшо Россиясининг Туркистонда олиб борган кўчирувчилик сиёсати...296

М.С.Махмудова. Темурийлар даврида Хуросон вилоятида қишлоқ хўжалиги ва ирригация

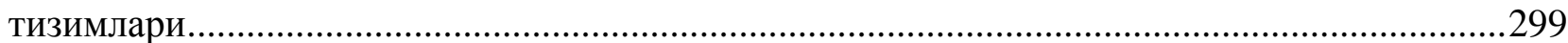

M.Atamuradova, I.O.Ibragimova, F.Atamuradova. Xitoyda ta'lim tizimi ...........................301

Су Цзумэй. Средства выражения «вежливости» - преподавание РКИ в китайской

Аудитории

G.Bakiyeva, K.Makhkamova. Perspective of professionally oriented competence of future English teachers

Д.Х.Алимова. Билингвальные аспекты образования и повышение литературоведческой компетентности учащихся на уроках русской литературы в группах с нерусским языком обучения

I.Azimova. Ona tili ta'limida eshitib tushunish malakasini rivojlantirishning ahamiyati.............310

С.А.Назарова. Разработка дистанционной образовательной платформы по обучению китайскому языку студентов-филологов языковых вузов ...............................................313

Ф.С.Абдуллаева. Сохавий терминларни ўқитишнинг назарий ва амалий асослари ............316

G.Sh.Salomova. The role of sociolinguistic in intercultural competence..................................322

А.А.Мустафақулов. ТQM - сифатни ялпи бошқариш тамойиллари асосида педагог кадрларни тайёрлаш мазмуни

付国印 Fu Guoyin “一带一路”视域下高素质涉俄法律人才培养模式探究 Bir makon - bir yo'l” nuqtai nazaridan yuqori sifatli ruslarga tegishli huquqiy iste'dodlarni tayyorlash modelini o'rganish

王东敏 Van Dongmin “一带一路”视域下的经贸俄语课程教学改革与实践 Bir makon - bir yo'l" nuqtai nazaridan rus tili kursi islohoti va iqtisodiy va savdo amaliyotini o'rgatish ...330 С.А.Анорбоева. Таржимонлик компетенцияси, шу жумладан, испан тилини ўқитишда талабаларда таржимонлик компетенциясини шакллантириш методикасининг тушунчаси ва

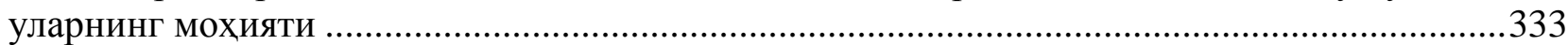

А.Набиев, К.А.Каримов, Б.Каримов, Ш.Хайдарова. Таълим ва тарбия назариясида дидактиканинг тарихийлик ва хаётийлик тамойиллари уйғунлашуви.................................335 К.П.Исламова. Садриддин Айнийнинг таълим-тарбияга оид қарашлари ва мактабчилик

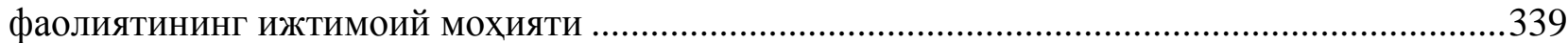

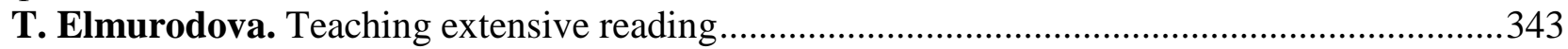
Bobokulova H. E. Mirzakulov A.Ch , Criteria for the implementation of innovative methods in the

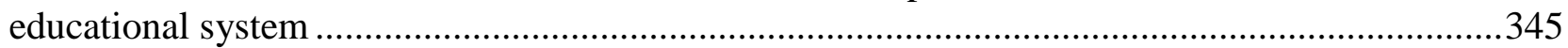

В.А.Гудзина, T.X.Турумова. Коммуникативный принцип в преподавании русского

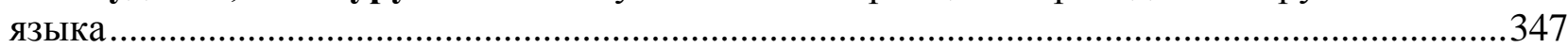

I.Yo.Beknazarova. Ingliz tili o'qitishda mustaqil ta'lim samaradorligiga kompenentlik omillari

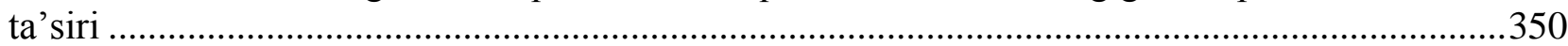

Sh.Berdiyorova. The importance of pragmatics instruction in ESP classrooms .........................352

N.P.Kurbanova. Methodology of teaching ESP for students of hotel industry major .................354 S.S.Bo'riyeva. Xorijiy tillarni o'rgatishda va o'rganishda zamonaviy metodlar va texnologiyalarning o'rni

Н.Н.Очилова. Илмий мулоқот тамойиллари ва уларнинг вазифалари ...............................357

N.T.Ikromov, B.T.Qilichev. Die bedeutung technischer mittel für den fremdsprachenunterricht in

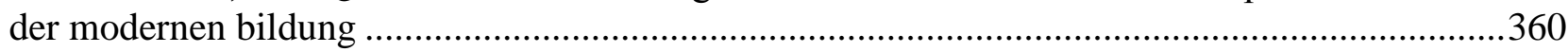

O.Toxtayev. Boshlang'ich ta'limda zamonaviy darslarni tashkillashtirish ..............................363

Z.Qarshiyeva. Бўлажак ўқитувчилар рефлексив позициясини ривожлантиришнинг айрим масалалари 
S.Sh.Pirimkulova. "Ta'limdagi teatr" tushunchasi.

Sh.M.Boykhanov. The role of pictures in the textbooks in developing students' paremiological competence.

С.А.Рахматова. Инновационные технологии преподавания

Э.А.Халилова. Принципы и структура модулирования профессиональной компетентности у будущего учителя-бакалавра в процессе профессиональной подготовки

G.I.Kurbonova 海外における『源氏物語』の翻訳からウズべク語訳へ From translations of “the tale of genji” overseas to uzbek translation.

N.M.Bekniyozov. Bola tarbiyasida milliy qadriyatlarning o'rni"Baxtsizlik sababi - tarbiyasizlikda. Tarbiyasizlik manbai - hayosizlikda. Hayosizlik asosi - sust e'tiqoddadir". .378

Д.Б.Халмуратова. Харбий билим юртларида чет тилларини ўқитишдаги таржиманинг ўрни

陈洁 Чен Жиэ. 俄语超句统一体构成句类型研究 Исследование типов приговоров, формируемых единством российских гиперсентенций .382

Ж.К.Каландарова, Аммар Юнас. О трудности перевода поэтического текста вразноструктурных языках: на материале поэзии А.Осмонова 388

Н.Э.Мухаммедова. Замонавий инглиз адабиётида шарқона портрет ифодаси.....................392

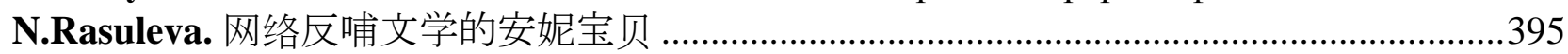

М.А.Халова, Д.М.Худойбердиева. Истиқлол шеьриятида янгича талқин .........................398

М.Ю.Умарова. Ўрта асрлар даври Вальтер Скотт талқинида …......................................400

Х.Э.Мухаммедова. Европа ва ўзбек халқ эртакларида ўхшаш образлар ..............................403

Hui Zhang. 浅析佩列文小说《奥蒙·拉》中的太空神话戏仿来源与含义 Parody of Space Mythologies in Victor Pelevin's Omon Ra: Origins and Meanings ...........................................405

Н.Очилов. Достон ижрочилигида эпик махоратнинг ўрни 409

У.Дж.Эсанов. Использование метериологических диалектизмов в произведениях

Н.С.Лескова и способы их пояснения.

Д.Ражабова. Бобур хукмдор шахснинг типик вакили ва унинг ўзига хос характери ..........414

Fu Yu. National psychological characteristics reflected in contemporary Russian vocabulary ...418 许畅 Xu Chang. 文化翻译观视角下的模糊词翻译研究 Madaniy tarjima nuqtai nazaridan tushunarsiz so'zlarni tarjima qilish bo'yicha tadqiqot .....

Anton Umbach. Migration: text contact in the target language an ethnographic research of adult

German 12learners

D.Rasulmuxamedova. O'tkir Hoshimovning “Tushda kechgan umrlar" romanining badiiy poetik xususiyati

Р.С. Шодиев, Ф.Ю. Эргашова. Луғатлар типлари (турлари) ва изохли луғатларнинг

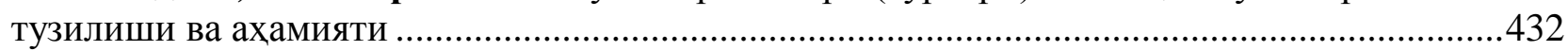

3.С.Тагаева. Немис газета сарлавхаларининг ўзига хос хусусиятлари ..............................437

D.Mamatova. Xitoy va o'zbek tillarida mikromatn sintaktik derivatsiyasi...............................438

M.I.Qodirova. Yapon tilshunosligida shevashunoslik taraqqiyoti .........................................440

A.B.Abdujabborova. Omon Matchon lirikasida tabiat tasviri va u bilan bog'liq poetik obrazlar talqini .....

N.Kh.Yakhyayeva. Universal values in the structure of Uzbek media texts (as the sample newspaper Hurriyat).

Z.Tosheva. Vatanparvarlik ruhida yaratilgan lirik asarlar tahlili.

V.M.Turapov. Axborotlashgan jamiyat taraqqiyotining konsepsiyalari

T.А.Абдусалямова. Интерпретация синтаксических трансформаций при переводе текстов с китайского на русский язык.....

Ш.Н.Ахмедова. Гулбаданбегимнинг “Хумоюннома” асарининг хориж мамлакатларида ўрганилиш тарихи

А.Алимов. Хусайн Воиз Кошифийнинг илмий меросида ахлоқ масалалари .458 
Н.Р.Исматуллаева. Таржимада фразеологик лакуналарни бартараф этиш усуллари(хитой ва

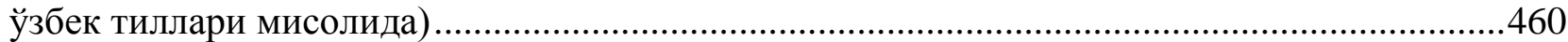

Н.Н. Муминов. Воображение как аспект гносеологической практики в суфизме ..............464 3.Т.Мусинова. «ДИВАН ЛУГАТ АТ-ТУРК» - первое этнолитературное исследование о

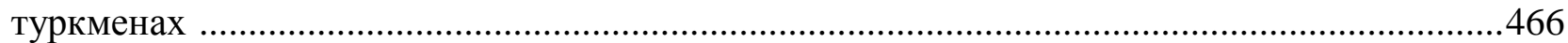

Ш.М.Назирова. Хитойда “Авангард адабиёт” тажрибалари Цан Сюэ ижоди тахлилида .468 С.Ғ.Халимов. Шох Ғариб Мирзо (Ғарибий) ижоди ва даври............................................471

Ш.Ф Мухтарова. Заимствованные археологические термины .........................................474

М.М.Назаров. “Бош” сўзи билан ифодаланган соматик фразаларда инсон холати

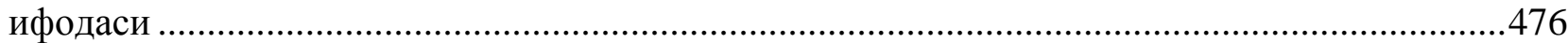

А.Х.Тўйчиев. Нурали Қобул ижодида миллий колорит тасвири ........................................477

Н.К.Хақкулов. Сиддиқий-Ажзийнинг ижтимоий-ахлоқий қарашлари ................................480

У.P.Элова. Генри Лонгфеллонинг “Гайавата хақида кўшиқ” достони таржималарида хиндулар муаммолари ва уларнинг бугунги кун адабий -шеърий услубига хос жихатлари .....

S.Saydaliyev. Kitob madaniyatlararo muloqot vositasi (Chesterfildning "Farzandga maktublar" asari misolida).

А.Набиев, К.А.Каримов, Б.Каримов, А.Каримова, Ш.Хайдарова. Таълим ва тарбия назариясида дидактиканинг тарихийлик ва хаётийлик тамойиллари уйғунлашуви 488 Г.У.Шамиев. Инновационные педагогические технологии как фактор формирования

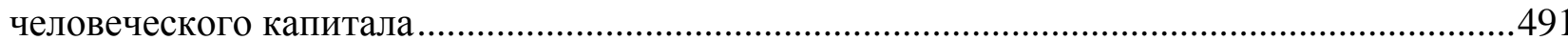

С.Н.Бекниязова, А.Х.Тугузов. Дистанционное изучение китайского языка .....................495

S.N.Fazildinova. $21^{\text {st }}-$ century teaching competencies ........................................................496

С. Н. Бекниязова. Функциональные возможности вебинар технологий в образовании ....499 O.P.Jiyanov, A.S.Pardoboyev. Innovatsion texnologiyalardan foydalanish ta'lim jarayonida -

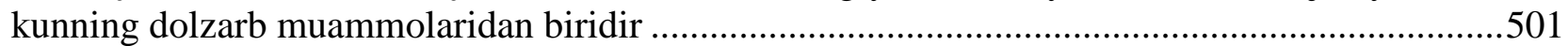

3.А. Холмирзаева. Чет тили таълимида янги педагогик технологиялардан фойдаланиш.504 Z.Karimova. On the issue of developing speaking and listening skills using multimedia

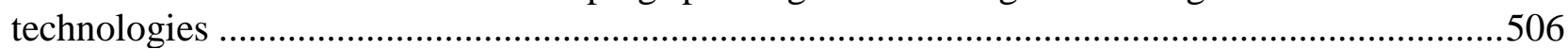

Ф.Ф.Саидов. Ахборот технологияларининг тил маданиятини оширишдаги роли ..............509

Э.Э.Уришбаев. Олий таълим тизимида замонавий ахборот технологияларини самарадорлигини ошириш

O.О.Сирожов. Информационные образовательные ресурсы, направленные на развитие валеологической компетентности будущих учителей физкультуры ..................................514

D. B Kadirxodjayeva. The usage of technology: varying the medium in language teaching ......518 Ш.Д Хайитова. Талабаларнинг мустақил ишларини ривожлантиришда тизимли

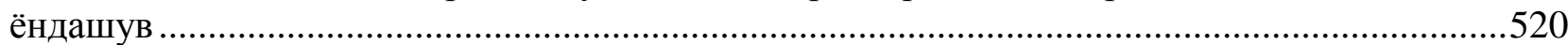

O.Z.To'xtayeva. Ona tili fanini o'qitishda interfaol usullardan foydalanish ............................522

A.N.Parmonova. Umum ta'lim maktablarida chet tilio 'qitish metodikasi................................524

F.V.Sharopova. Matn o'qish ko'nikmasining pedagogik asosi hamda uni rivojlantirish yo"

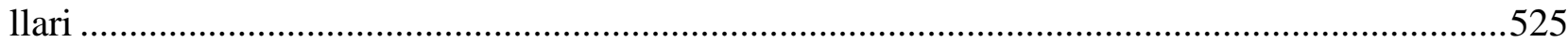

К.М.Мамадиёрова. Талабаларнинг ютуқларини бахолашда электрон портфолионинг

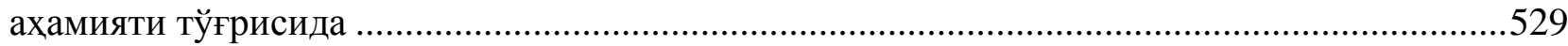

I.Yo.Beknazarova, Sh.Mardibekov. Ingliz tilini o'qitishda mustaqil ta'limning samaradorligini oshirish

Тиляева Фотима Зиёдуллоевна. Ёшлар эстетик тафаккурида китоб мутолаасини ўрганиш ва унинг методологик асосларини ривожлантириш. 
УЎК 4И(075)

КБК $81.2(03)$

Б 90

БУЮК ИПАК ЙЎЛИДА УМУМИНСОНИЙ ВА МИЛЛИЙ ҚАДРИЯТЛАР: ТИЛ, ТАЪЛИМ ВА МАДАНИЯТ. Халқаро илмий-амалий конференция материаллари. Самарқанд: СамДЧТИ, 2020. 542 бет.

\author{
Мухаррир: С. Каримова \\ Техник мухаррир: Х. Амирдинов \\ Компьютерда сахифаловчи: Ш. Абдурахимов \\ Мусаххихлар: Ё. Қаршибоев, 3. Усманова
}

Гувохнома № 10-3512

Босишга 08.10.2020 йилда рухсат этилди.

Қоғоз бичими 60х84 1/16. Офсет қоғози. Шартли босма табоғи 10,0. Нашриёт хисоб табоғи 9,7. Адади 30 нусха. Буюртма № 14/10.

СамДЧТИ нашр-матбаа марказида чоп этилди.

Манзил: Самарқанд шахри, Бўстонсарой кўчаси, 93-уй. 